\title{
Het specialiteitsbeginsel : over de structuur van bestuursbevoegdheden, wetmatigheid van bestuur en beleidsvrijheid
}

Citation for published version (APA):

Schlössels, R. J. N. (1998). Het specialiteitsbeginsel : over de structuur van bestuursbevoegdheden, wetmatigheid van bestuur en beleidsvrijheid. [Doctoral Thesis, Maastricht University]. Sdu Uitgevers. https://doi.org/10.26481/dis.19980409rs

Document status and date:

Published: 01/01/1998

DOI:

10.26481/dis.19980409rs

Document Version:

Publisher's PDF, also known as Version of record

Please check the document version of this publication:

- A submitted manuscript is the version of the article upon submission and before peer-review. There can be important differences between the submitted version and the official published version of record.

People interested in the research are advised to contact the author for the final version of the publication, or visit the DOI to the publisher's website.

- The final author version and the galley proof are versions of the publication after peer review.

- The final published version features the final layout of the paper including the volume, issue and page numbers.

Link to publication

\footnotetext{
General rights rights.

- You may freely distribute the URL identifying the publication in the public portal. please follow below link for the End User Agreement:

www.umlib.nl/taverne-license

Take down policy

If you believe that this document breaches copyright please contact us at:

repository@maastrichtuniversity.nl

providing details and we will investigate your claim.
}

Copyright and moral rights for the publications made accessible in the public portal are retained by the authors and/or other copyright owners and it is a condition of accessing publications that users recognise and abide by the legal requirements associated with these

- Users may download and print one copy of any publication from the public portal for the purpose of private study or research.

- You may not further distribute the material or use it for any profit-making activity or commercial gain

If the publication is distributed under the terms of Article $25 \mathrm{fa}$ of the Dutch Copyright Act, indicated by the "Taverne" license above, 


\section{Het specialiteitsbeginsel}

Over de structuur van bestuursbevoegdheden, wetmatigheid van bestuur en beleidsvrijheid 


\section{Het specialiteitsbeginsel}

Over de structuur van bestuursbevoegdheden, wetmatigheid van bestuur en beleidsvrijheid

\section{PROEFSCHRIFT}

ter verkrijging van de graad van doctor aan de Universiteit Maastricht, op gezag van de Rector Magnificus, Prof.dr. A.C. Nieuwenhuijzen Kruseman volgens het besluit van het College van Decanen, in het openbaar te verdedigen op donderdag 9 april 1998 om 16.00 uur

door

RAYMOND JOHANNES NICOLAAS SCHLÖSSELS 
Promotor:

Prof.mr. F.A.M. Stroink

Beoordelingscommissie:

Prof.mr. A.W. Heringa (voorzitter)

Mr. L.J.A. Damen (Centrale Raad van Beroep)

Mr. M.A. Heldeweg

Mr. H.J. Simon

Prof.mr. B.W.N. de Waard (Katholieke Universiteit Brabant)

(C) 1998 Sdu Uitgevers, Den Haag.

Vormgeving: André Klijsen, villa Y.

Typografie: Tony Claessens .

Van deze studie is een handelsuitgave verschenen bij Sdu Uitgevers onder ISBN 9054091630 
'Het enige wat we hebben om beginselen te funderen zijn argumenten'

(A. Soeteman) 
Aan mijn ouders 


\section{Een woord vooraf}

In het najaar van 1993 verruilde ik mijn baan als gemeentelijk beleidsmedewerker voor een Maastrichtse AIO-onderzoeksplaats naar het 'specialiteitsbeginsel'. Een overstap waar ik geen moment spijt van heb gehad. Het wetenschappelijke en collegiale klimaat bij de vakgroep publiekrecht van de Maastrichtse juridische faculteit stond daar garant voor. Dit boek is dan ook met plezier geschreven. Toch vormde het een opgave waarin uiteindelijk véél 'vrije' tijd is gaan zitten.

Graag wil ik enige personen bedanken die bij de totstandkoming van dit proefschrift betrokken waren. Dat is natuurlijk in de eerste plaats mijn promotor Frits Stroink. Door zijn wijze van begeleiding heeft hij mij veel zelfvertrouwen gegeven om dit boek binnen een periode van ongeveer vier jaar af te ronden.

Verder noem ik de leden van de leescommissie: Aalt-Willem Heringa, Leo Damen, Boudewijn de Waard, Henk Simon en Michiel Heldeweg. Zij vormden zich binnen enkele weken een oordeel over het manuscript, waarvoor mijn dank.

Dank gaat ook uit naar alle leden van de vakgroep Publiekrecht waarmee ik in de wandelgangen stevige discussies voerde over mijn onderzoek. Ofschoon er soms behoorlijke verschillen van mening bleven bestaan, werden mijn gedachten er door gescherpt. Een bijzonder wetenschappelijk klankbord vormde in dit verband de onderzoeksgroep Grondslagen en Beginselen van Publiekrecht (GBP). De discussies die ik in dit verband voerde met onder meer Twan Tak, Jos Teunissen en Henk Simon waren verdiepend. Ook de discussies met mijn kamergenoot en goede collega Eveline van der Linden waren altijd boeiend.

Onmisbaar waren Bregtje Schwenke en Nettie Litjens die dit boek vorm hebben gegeven en de registers hebben verzorgd. Richard Neerhof en mijn zus Martine Schlössels dank ik voor het doorlezen van het manuscript. Wies Rayar vertaalde de samenvatting ervan in het Engels.

Tot slot noem ik het bestuur van de gemeente Susteren. Doordat ik mijn Maastrichtse baan kon combineren met een gemeenteraadslidmaatschap verloor ik de bestuurspraktijk en de 'belangenafwegings'-problemen van iedere dag niet uit het oog.

Een gedeelte van de literatuur ten behoeve van het schrijven van dit boek verzamelde ik aan het Max Planck Institut für ausländisches und offentliches Recht te Heidelberg. Het literatuur- en jurisprudentie-onderzoek werd afgesloten op 1 november 1997. Met latere publicaties en jurisprudentie kon slechts incidenteel rekening worden gehouden.

Maastricht/Nieuwstadt, Januari 1998

Raymond Schlössels 



\section{Inhoud}

Woord vooraf vii

Inhoud $\quad$ ix

Lijst van afkortingen $\quad$ xvii

Hoofdstuk 1

Een eerste verkenning

1.1 Verwarring: één reden voor onderzoek... 1

1.2 Een kennelijk vergeten problematiek als tweede reden... 3

1.3 Last of waarborg? De derde reden...

1.4 Probleemstellingen $\quad 5$

$\begin{array}{lll}1.5 & \text { Afbakening en onderzoeksverantwoording } & 6\end{array}$

1.5.1 Géén horizontale rechtsvergelijking 6

1.5.2 Het communautaire recht $\quad 8$

1.5.3 Coördinatie- en integratievraagstukken 9

$\begin{array}{lll}1.6 & \text { Plan van behandeling } & 10\end{array}$

\section{Hoofdstuk 2}

Bestuursbevoegdheid

2.1 Inleiding 13

2.2 De ruime en enge betekenis van het specialiteitsbeginsel $\quad 13$

2.2.1 Het Franse en Belgische 'principe de (la) specialité 13

2.2.2 Specialiteitsbeginsel en bestuursorgaan 15

$\begin{array}{lll}2.3 & \text { Rechtsbevoegdheid } & 16\end{array}$

$\begin{array}{lll}2.3 .1 & \text { Het bevoegdheidsbegrip } & 17\end{array}$

2.3.2 Het onderscheid tussen 'primaire' en 'secundaire' rechtsnormen 18

2.3.3 Normcondities en toepasselijkheidsdomein 20

2.4 Rechtsbevoegdheid in het publiekrecht $\quad 24$

2.4.1 'Public authority' en beïnvloeding 24

2.4.2 Een nadere juridische omlijning 25

2.4.3 Publiekrechtelijke bevoegdheid en bevoegd handelen 27

2.4.4 Publiekrechtelijke bevoegdheid en het begrip 'uitvoering' 27

2.5 Publiekrechtelijke en privaatrechtelijke '(rechts)bevoegdheid' 29 
2.5.1 Beperktheid, doelgebondenheid en traceerbaarheid 29

2.5.2 Relativering van het onderscheid? 33

2.5.3 Windmill en het specialiteitsbeginsel 35

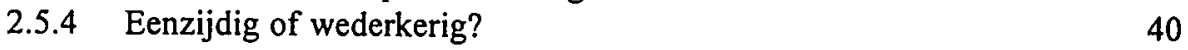

2.5.5 De 'subjectiveringstendens' in het bestuursrecht 41

2.5.6 Het 'wederkerigheids'-concept en het specialiteitsbeginsel 42

2.6 Definitie bestuursbevoegdheid 48

2.7 Bestuurstaak en bestuursbevoegdheid $\quad 49$

$\begin{array}{lll}2.8 & \text { Conclusie } & 54\end{array}$

\section{Hoofdstuk 3}

Een rechtsstatelijk beginsel

$\begin{array}{lll}3.1 & \text { Inleiding } & 57\end{array}$

3.2 De publieke rechtsorde $\quad 58$

3.2.1 De ontsluiting van de publieke rechtsorde 59

3.2.2 De publieke bevoegdheidsdifferentiatie en doelbinding 63

3.2.3 Rechtsvorming en rechtsbeginselen 65

3.2.4 De normzijde en feitelijke zijde van het recht 68

3.2.5 Het specialiteitsbeginsel als publiekrechtelijk structuurbeginsel $\quad 69$

3.2.6 Het rechtsvormingsproces binnen de publieke rechtsorde 70

$\begin{array}{lll}3.2 .7 & \text { Twee naar hun aard verschillende belangensferen } & 71\end{array}$

3.2.8 Het rechtskarakter van het 'publieke' recht 73

$\begin{array}{lll}3.3 & \text { Het algemeen belang } & 74\end{array}$

3.3.1 Het algemeen belang als grondslag voor alle overheidsactiviteit $\quad 74$

$\begin{array}{ll}\text { 3.3.2 Een materieel of formeel criterium? } & 76\end{array}$

$\begin{array}{lll}3.4 & \text { Specialiteitsbeginsel en democratiebeginsel } & 78\end{array}$

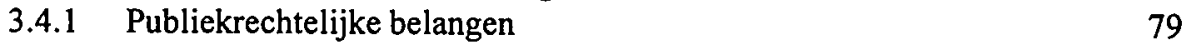

3.4.2 Het democratiebeginsel als normatief uitgangspunt $\quad 80$

$\begin{array}{ll}3.4 .3 & \text { Inhoudelijke democratische legitimatie } \\ \end{array}$

3.5 Het specialiteitsbeginsel in de Nederlandse literatuur 85

3.5.1 Hernieuwde aandacht voor een oud beginsel 86

$\begin{array}{ll}\text { 3.5.2 Legaliteit en specialiteit } & 88\end{array}$

3.6 Tot slot: nogmaals doelgebondenheid $\quad 89$

$\begin{array}{lll}3.7 & \text { Conclusie } & 92\end{array}$

Hoofdstuk 4

Legaliteit en specialiteit

4.1 Inleiding 93

4.2 Legaliteitsbeginsel en wetsbegrip 95

$\begin{array}{ll}\text { 4.2.1 Het formele wetsbegrip } & 95\end{array}$ 
4.2.2 Het materie̋le wetsbegrip 98

$\begin{array}{lr}\text { 4.2.3 De negentiende eeuw } & 99\end{array}$

4.2.4 Borhtlingk en het algemeenheidspostulaat 103

4.2.5 De verzorgingsstaat en het wetsbegrip 105

4.2.6 De naoorlogse theorievorming in Duitsland 107

4.2.7 Herijking van het wetsbegrip in Nederland 110

$\begin{array}{lll}4.3 & \text { Eigen visie inzake de omvang van de legaliteitseis } & 112\end{array}$

4.4 Specificiteit van bevoegdheidsnormen in democratisch-rechtsstatelijk perspectief $\quad 114$

4.4.1 Het specialiteitsbeginsel als beginsel van behoorlijke wetgeving 114

4.4.2 Het Duitse 'Bestimmtheitsgebot' (Art. 80.1 Grundgesetz) 115

4.4.3 Bestimmtheitsgebot en specialiteitsbeginsel 118

$\begin{array}{lll}\text { 4.4.4 Jurisprudentie Bundesverfassungsgericht } & 119\end{array}$

$\begin{array}{lll}\text { 4.4.5 Relevantie jurisprudentie Bundesverfassungsgericht } & 122\end{array}$

4.4.6 'Prescribed by law' 123

4.5 Meer aandacht voor de inhoudelijke normering van bestuursbevoegdheid in Nederland 124

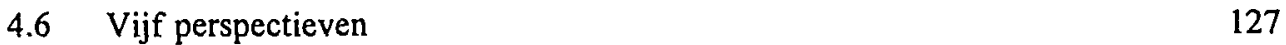

$\begin{array}{lll}\text { 4.6.1 Het democratisch perspectief } & 127\end{array}$

4.6.2 Het legitimatieperspectief in ruime zin 128

$\begin{array}{ll}\text { 4.6.3 Het rechtsbeschermingsperspectief } & 129\end{array}$

$\begin{array}{ll}\text { 4.6.4 Het organisatieperspectief } & 130\end{array}$

4.6.5 Het doelmatigheids- en besluitvormingsperspectief 131

4.6.6 Enige opmerkingen over coordinatie en integratie 132

4.6.7 De 'grote' projecten 136

$\begin{array}{ll}\text { 4.6.8 Tot slot: een kwestie van bestuurscultuur? } & 137\end{array}$

\section{Hoofdstuk 5}

Het verbod van détournement de pouvoir

5.1 Inleiding 139

5.2 Het Franse 'recours pour excès de pouvoir' 140

5.3 De ontwikkeling van het leerstuk van détournement de pouvoir 142

$\begin{array}{ll}\text { 5.3.1 Pariset en Laumonnier-Carriol } & 142\end{array}$

5.3.2 Objectivering 143

5.3.3 Het Pagès-arrest: géén behartiging van private belangen 144

5.4 Het leerstuk van détournement de pouvoir in de Franse doctrine 145

$\begin{array}{lll}\text { 5.4.1 Laferrière } & 145\end{array}$

5.4.2 Het interbellum: Rolland, Hauriou en Duguit 146

$\begin{array}{ll}\text { 5.4.3 De naoorlogse Franse literatuur } & 148\end{array}$

5.4.4 Soorten en gradaties van détournement de pouvoir 149 
5.5 De 'contrôle des motifs' (causa) en détournement de pouvoir (le but)

5.5.1 Enige kenmerken van de 'contrôle des motifs' 151

5.5.2 Concurrentie? 152

5.5.3 Een 'déclin' van het verbod van détournement de pouvoir? 153

5.6 Het leerstuk van détournement de pouvoir in het Nederlandse bestuursrecht 155

5.6.1 Franse origine 155

5.6.2 Toch Nederlands? 156

$\begin{array}{lll}5.6 .3 & \text { Literatuur } & 157\end{array}$

$\begin{array}{lll}5.6 .4 & \text { De wetgeving } & 159\end{array}$

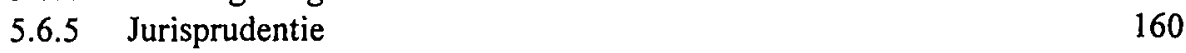

5.6.6 Een bevoegdheidsgebrek? 161

$\begin{array}{lll}5.7 \text { Conclusie } & 163\end{array}$

\section{Hoofdstuk 6}

Het specialiteitsbeginsel en beleidsvrijheid

6.1 Inleiding 165

6.2 Beoordelingsruimte en beleidsruimte 166

$\begin{array}{ll}\text { 6.2.1 Objectieve beoordelingsruimte } & 167\end{array}$

6.2.2 Subjectieve beoordelingsruimte 168

6.2.3 Een gedifferentieerde 'subjectieve' beoordelingsruimte? 169

$\begin{array}{ll}\text { 6.2.4 Variëren op Duk } & 172\end{array}$

6.3 Het rechtskarakter van beleidsvrijheid 175

6.3.1 Belangenafweging en rechtsvorming 176

$\begin{array}{ll}\text { 6.3.2 Drie visies inzake beleidsvrijheid } & 176\end{array}$

6.3.3 Subjectief of objectief? 178

6.3.4 Wat valt er af te wegen? 181

$\begin{array}{ll}\text { 6.3.5 De grondregel van minimale belangenaantasting } & 182\end{array}$

6.3.6 Beoordelingsruimte en beleidsvrijheid 184

6.3.7 Een tweetal 'belangenafwegings'-karakteristieken 185

$\begin{array}{ll}6.4 & \text { Rechtsbelang en belangenafweging in concreto } \\ \end{array}$

$\begin{array}{lll}\text { 6.4.1 Het begrip 'belang' } & 187\end{array}$

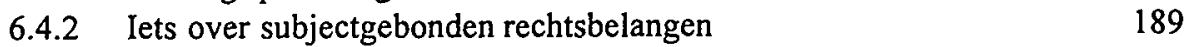

6.4.3 Rechtsbelang en belanghebbende 193

6.4.4 Een monochrome opvatting? 195

6.4.5 Complicaties voor de bestuurspraktijk 197

6.4.6 De materiële bestuurlijke besluitvorming 197

6.5 Het specialiteitsbeginsel en bestuurlijke belangenafweging 198

$\begin{array}{ll}\text { 6.5.1 De veronderstelde selectiefunctie } & 198\end{array}$

6.5.2 Artikel 3:4 lid 1 Awb en het specialiteitsbeginsel 199

$\begin{array}{ll}6.6 \text { Conclusie } & 202\end{array}$ 


\section{Hoofdstuk 7}

De meningen in de literatuur

$\begin{array}{lll}7.1 & \text { Inleiding } & 203\end{array}$

7.2 'Preciezen', 'rekkelijken' en 'gematigden' 204

$\begin{array}{lll}7.2 .1 & \text { Stellinga } & 205\end{array}$

$\begin{array}{lll}7.2 .2 & \text { Tonnaer } & 207\end{array}$

7.2.3 Stroink en De Waard 210

7.2.4 Helder en Jue 213

7.2.5 Vakgroep staats- en bestuursrecht UU 215

$\begin{array}{lll}7.2 .6 & \text { Simon } & 216\end{array}$

$\begin{array}{lll}7.2 .7 & \text { Stout } & 222\end{array}$

7.2.8 Goldschmidt 223

7.2.9 De Planque 225

7.2.10 Messer en Heldeweg 227

7.2.11 Van den Berk 228

$\begin{array}{ll}7.2 .12 \text { Heldeweg } & 229\end{array}$

7.2.13 Damen 230

$\begin{array}{ll}7.2 .14 \text { Nicolaï } & 232\end{array}$

7.2.15 Van Male 236

$\begin{array}{ll}7.2 .16 & \text { Drupsteen } \\ 7.239 & 236\end{array}$

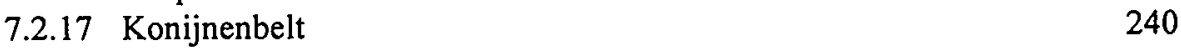

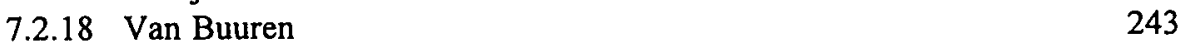

7.2.19 Tak 243

7.2.20 Van Hall 246

$\begin{array}{lll}7.3 & \text { Conclusies } & 249\end{array}$

7.3.1 Publiekrechtelijke belangen 249

7.3.2 Belangen van de direct-belanghebbende 250

$\begin{array}{ll}\text { 7.3.3 Belangen van derden } & 250\end{array}$

\section{Hoofdstuk 8}

Het specialiteitsbeginsel in de jurisprudentie

8.1 Inleiding 253

8.2 Een nadere onderzoeksverantwoording 254

$\begin{array}{lll}8.3 \text { De Kroon } & 257\end{array}$

8.3.1 Speciale publiekrechtelijke belangen 257

8.3.2 Een soort 'Schutznorm'-theorie? 259

8.3.3 De scheiding van publiek- en privaatrecht 260

8.3.4 De verhouding tussen de administratieve regelingen 261

8.3.5 Bestemmingsplan en milieuwetgeving 263

8.3.6 Bestemmingsplan en andere 'grensconflicten' 266 
$\begin{array}{lll}\text { 8.3.7 Tussenconclusie } & 270\end{array}$

8.4 De Afdeling rechtspraak van de Raad van State (ARRS) 270

8.4.1 Belangenafweging en doelgebondenheid 271

8.4.2 De verhouding tussen administratieve regelingen 276

$\begin{array}{ll}\text { 8.4.3 Belangen van derden } & 280\end{array}$

8.4.4 Toch een ruime afwegingsplicht? 286

$\begin{array}{ll}\text { 8.4.5 De 'onzuivere' schadebeschikking } & 287\end{array}$

8.4.6 Het meewegen van 'privaatrechtelijke' belangen 291

$\begin{array}{ll}\text { 8.4.7 Toelaatbaarheid van voorschriften } & 292\end{array}$

8.4.8 Tussenconclusie 294

8.5 De Afdeling geschillen van bestuur van de Raad van State (AGRS) 295

8.5.1 De verhouding tussen administratieve regelingen 295

$\begin{array}{ll}\text { 8.5.2 Belangen van derden } & 297\end{array}$

8.5.3 Een vérstrekkende uitspraak? 298

8.5.4 Toedeling van bezwaren aan de juiste bevoegdhedenkaders 299

8.5.5 Het meewegen van 'privaatrechtelijke' belangen 301

$\begin{array}{ll}\text { 8.5.6 Toelaatbaarheid van voorschriften } & 302\end{array}$

8.5.7 Tussenconclusie 303

8.6 De Afdeling bestuursrechtspraak van de Raad van State (ABRS) 304

8.6.1 Belangenafweging en doelgebondenheid 304

8.6.2 De verhouding tussen administratieve regelingen 306

$\begin{array}{ll}\text { 8.6.3 Belangen van derden } & 310\end{array}$

$\begin{array}{ll}\text { 8.6.4 Het Velpse Duivenhok } & 314\end{array}$

8.6.5 De Buttervliet-uitspraak: een anomalie? 318

$\begin{array}{ll}\text { 8.6.6 Toelaatbaarheid van voorschriften } & 320\end{array}$

$\begin{array}{ll}\text { 8.6.7 Tussenconclusie } & 321\end{array}$

8.7 Het College van beroep voor het bedrijfsleven $(\mathrm{CBb}) \quad 321$

8.7.1 Doelbinding van bestuursbevoegdheid 321

8.7.2 Het meewegen van 'privaatrechtelijke' belangen 322

8.7.3 Belangen van derden 323

$\begin{array}{lll}8.8 & \text { De burgerlijke rechter } & 325\end{array}$

8.8.1 De Waalbrug te Ewijk 325

8.8.2 Het gefragmenteerde karakter van administratieve regelingen 327

8.8.3 Het specialiteitsbeginsel in stelling tegen de overheid? 329

8.8.4 Het leerstuk van de vrijwarende werking van vergunningen 330

8.8.5 De relativiteits- of 'Schutznorm'-leer (art. 6:163 BW) 331

8.8.6 Specialiteitsbeginsel en relativiteitsleer 333

$\begin{array}{lll}8.9 & \text { Enige conclusies } & 339\end{array}$ 


\section{Hoofdstuk 9}

Het specialiteitsbeginsel: een rechtspolitiek dilemma?

$9.1 \quad$ Inleiding

9.2 Enkele uitgangspunten vooraf

9.3 De betekenis van het specialiteitsbeginsel voor de bestuurlijke rechtshandeling

9.4 Bestuurlijke bevoegdheidsstelsels nader beschouwd 346

9.4.1 De karakteristiek van een (discretionair) bevoegdheidsstelsel $\quad 347$

9.4.2 Bindende (gedrags)voorschriften en voorwaarden 348

9.4.3 Publiekrechtelijke regulering en 'reflex'-rechten 351

9.4.4 Relevante ontwikkelingen en theorievorming in Duitsland 352

9.4.5 Een 'subjectief' recht op een bepaalde modaliteit van bevoegdheidsuitoefening?

9.5 Rekkelijken, preciezen én rechtspolitiek? 359

9.5.1 De 'klassiek-precieze' stroming 360

9.5.2 De 'postmodern-rekkelijke' stroming(en) 361

9.5.3 Bindende bemiddeling door het bestuursorgaan? 362

9.5.4 Kater Napoleon en nogmaals Buttervliet 364

9.5.5 Een aantrekkelijk perspectief? 366

9.6 De rechtsgevolgen van een bestuurlijke bevoegdheidsuitoefening 369

$\begin{array}{ll}\text { 9.6.1 Rechtsbelangen: twee hoofdgroepen? } & 370\end{array}$

9.6.2 Het specialiteitsbeginsel en nadeelcompensatie 371

9.6.3 Civil rights and obligations: een bredere invalshoek 373

9.6.4 Het specialiteitsbeginsel en de grond- en verdragsrechten 377

9.6.5 Fricties tussen grondrechten en publiekrechtelijke belangen 379

9.7 Het specialiteitsbeginsel en belangenafweging: eigen visie 383

$\begin{array}{ll}9.8 \text { Slotopmerkingen: een confronterend beginsel... } & 389\end{array}$

$\begin{array}{ll}\text { Samenvatting (Engels) } & 391\end{array}$

$\begin{array}{ll}\text { Literatuurlijst } & 397\end{array}$

$\begin{array}{ll}\text { Jurisprudentie } & 423\end{array}$

$\begin{array}{ll}\text { Trefwoordenregister } & 437\end{array}$

$\begin{array}{lll}\text { Curriculum vitae } & 443\end{array}$ 



\section{Lijst van gebruikte afkortingen}

$\begin{array}{ll}\text { AAe } & \text { Ars Aequi } \\ \text { AB } & \text { Administratiefrechtelijke Beslissingen } \\ \text { ABkort } & \text { Administratiefrechtelijke Beslissingen kort } \\ \text { ABRS } & \text { Afdeling bestuursrechtspraak van de Raad van State } \\ \text { A-G } & \text { Advocaat Generaal } \\ \text { AGRS } & \text { Afdeling geschillen van bestuur van de Raad van State } \\ \text { AMvB } & \text { Algemene Maatregel van Bestur } \\ \text { AöR } & \text { Archiv des offentlichen Rechts } \\ \text { APV } & \text { Algemene Plaatselijke Verordening } \\ \text { ARRS } & \text { Afdeling rechtspraak van de Raad van State } \\ \text { art. } & \text { artikel } \\ \text { a.w. } & \text { aangehaald werk } \\ \text { Awb } & \text { Algemene wet bestuursrecht } \\ & \\ \text { B en W } & \text { Burgemeester en wethouders } \\ \text { BNB } & \text { Beslissingen Nederlandse Belastingrechtspraak } \\ \text { BR } & \text { Bouwrecht } \\ \text { BVerfG } & \text { Bundesverfassungsgericht } \\ \text { BVerfGE } & \text { Entscheidungen des Bundesverfassungsgerichts } \\ \text { BW } & \text { Burgerlijk Wetboek } \\ \text { CBb } & \text { College van Beroep voor het bedrijfsleven } \\ \text { CE } & \text { Conseil d'Etat } \\ \text { CRvB } & \text { Centrale Raad van Beroep } \\ \text { curs. } & \text { cursivering } \\ & \\ \text { Dgr. } & \text { Deltawet grote rivieren } \\ \text { diss. } & \text { dissertatie } \\ \text { e.a. } & \text { en anderen } \\ \text { EG } & \text { Europese Gemeenschap } \\ \text { EHRM } & \text { Europees Hof voor de Rechten van de Mens } \\ \text { EK } & \text { Eerste Kamer } \\ \text { EL Review } & \text { European Law Review } \\ \text { EV } & \text { Eindverslag } \\ \text { e.v. } & \text { en verder } \\ & \end{array}$


EVRM Europees Verdrag tot bescherming van de Rechten van de Mens en de fundamentele vrijheden

$\begin{array}{ll}\text { GG } & \text { Grundgesetz } \\ \text { GS } & \text { gedeputeerde staten } \\ \text { Gst. } & \text { de Gemeentestem } \\ \text { Gw } & \text { Grondwet } \\ \text { Hof } & \text { Gerechtshof } \\ \text { HR } & \text { Hoge Raad } \\ \text { HvJ } & \text { Hof van Justitie van de Europese Gemeenschap } \\ \text { JB } & \text { Jurisprudentie Bestuursrecht } \\ \text { jo. } & \text { juncto } \\ \text { Jur. } & \text { Jurisprudentie van het Hof van Justitie } \\ \text { JZ } & \text { Juristenzeitung } \\ \text { KB } & \text { Koninklijk besluit } \\ \text { KG } & \text { Kort Geding } \\ \text { m.a. } & \text { met aantekening } \\ \text { m.nt. } & \text { met noot } \\ \text { M\&R } & \text { Milieu en Recht } \\ \text { MvT } & \text { memorie van toelichting } \\ \text { NA } & \text { Nieuwsbrief Algemene wet bestuursrecht } \\ \text { NEV } & \text { Nota naar aanleiding van het eindverslag } \\ \text { NJ } & \text { Nederlandse Jurisprudentie } \\ \text { NJB } & \text { Nederlands Juristenblad } \\ \text { NJV } & \text { Nederlandse Juristen-Vereniging } \\ \text { NJW } & \text { Neue Juristische Wochenschrift } \\ \text { nr. } & \text { nummer } \\ \text { NTB } & \text { Nederlands Tijdschrift voor Bestuursrecht } \\ \text { NTBR } & \text { Nederlands Tijdschrift voor Burgerlijk Recht } \\ \text { o.m. } & \text { onder meer } \\ \text { p. } & \text { pagina } \\ \text { PG Awb I } & \text { Parlementaire Geschiedenis van de Algemene wet bestuursrecht Eerste } \\ \text { Pres. } & \text { Tranche, samengesteld door E.J. Daalder en G.R.J de Groot. } \\ & \text { President } \\ & \\ & \end{array}$


RAwb Rechtspraak Algemene wet bestuursrecht

$\mathrm{Rb}$.

RDP

Rec.

red.

RMTh.

r.o.

$\mathrm{R} \& \mathrm{R}$

RvdW

SEW

Stb.

Stcrt.

$\mathrm{tB} / \mathrm{S}$

TK

TvO

TwK

UCB

VAR

vgl.

VNG

VwGO

VwVfG

$\mathrm{Vz}$

wb

Wca

Wet Arob

Wet Bab

Wm

WPNR

WRR

WRO

Wvo

Ww
Arrondissementsrechtbank

Revue de Droit Publique

Receuil Lebon

redactie

\section{Rechtsgeleerd Magazijn Themis}

rechtsoverweging

Nederlands Tijdschrift voor Rechtsfilosofie en Rechtstheorie

Rechtspraak van de Week

Sociaal Economische Wetgeving

Staatsblad

Staatscourant

Ten Berge/Stroink losbladige jurisprudentie Wet Arob

Tweede Kamer

Tijdschrift voor Openbaar bestuur

Tijdelijke wet Kroongeschillen

Uitspraken College van beroep voor het Bedrijfsleven (red. de Ru/Simon)

Vereniging voor Administratief Recht

vergelijk

Vereniging van Nederlandse Gemeenten

Verwaltungsgerichtsordnung

Verwaltungsverfahrensgesetz

Voorzitter

Waterschapsbelangen

Wet chemische afvalstoffen

Wet administratieve rechtspraak overheidsbeschikkingen

Wet Beroep administratieve beschikkingen

Wet milieubeheer

Weekblad voor Privaatrecht, Notariaat en Registratie

Wetenschappelijke Raad voor het Regeringsbeleid

Wet op de Ruimtelijke Ordening

Wet verontreiniging oppervlaktewateren

Woningwet 


\section{Hoofdstuk 1}

\section{Een eerste verkenning}

'Het bestuur is een ambtenorganisatie, dat wil zeggen het bestaat uit een veelheid van ambten, ieder met eigen taak en gebied. Dat wordt door bestuurders wel eens als lastig ondervonden en dan spreekt men van "verkokering" en roept om meer "coördinatie", doch hoe gegrond deze klachten soms mogen zijn, men moet er niet te snel van onder de indruk komen. Het zgn. "specialiteitsbeginsel" is nl. het behoud van de bestuurden en het behoort tot het wezen van het rechtsstatelijk bestuur."

\subsection{Verwarring: één reden voor onderzoek...}

Dit boek gaat over het specialiteitsbeginsel in het staats- en bestuursrecht. Voor de beoefenaren van het publiekrecht is dit geen onbekend beginsel. Het specialiteitsbeginsel brengt, kort gezegd, met zich dat een administratieve wet uitsluitend op haar eigen afgebakende terrein mag worden toegepast en bijgevolg niet mag dienen tot het bereiken van daarbuiten gelegen doeleinden. ${ }^{2}$ Bovendien mogen de in die wet neergelegde bestuursbevoegdheden niet voor een ander doel worden aangewend dan voor het doel dat de wetgever bij de toekenning van deze bevoegdheden voor ogen stond. ${ }^{3}$ Op het eerste gezicht gaat het hier om een bekend en duidelijk gegeven dat geen aanleiding lijkt te geven voor een omvangrijk onderzoek. Maar dit is slechts schijn.

Het specialiteitsbeginsel is in het hedendaagse Nederlandse bestuursrecht - verworden tot - een uiterst omstreden beginsel. Met name de vraag welke grenzen dit beginsel stelt aan de bestuurlijke plicht om in het kader van een discretionaire bestuursbevoegdheid belangen af te wegen houdt de gemoederen bezig. Ik sprak over een uiterst omstreden beginsel. Een korte greep uit de vele opmerkingen en verzuchtingen van auteurs kan deze uitspraak adstrueren. ${ }^{4}$

Schreuder-Vlasblom stelde bijv. '...dat er in het Nederlandse bestuursrecht weinig kwesties zijn waarover méér verwarring bestaat dan over de betekenis van het specialiteitsbeginsel'. Van Buuren is een vergelijkbare mening toegedaan. Volgens hem is het specialiteitsbeginsel 'Eén van de meest omstreden beginselen in het bestuursrecht... ${ }^{6}$ Simon, die zelf veel over het beginsel heeft gepubliceerd, signaleerde in dit verband een 'kakofonie

1. A.M. Donner, Nederlands bestuursrecht, Algemeen deel, vijfde herziene druk, Alphen aan den Rijn 1987, p. 109.

2. Ik ontleen deze algemene definitie aan: Van der Burg/Cartigny/Overkleeft-Verburg, Rechtsbescherming tegen de overheid, vijfde druk, Nijmegen 1985, p. 109-110.

3. Vgl. F.A.M. Stroink, Algemeen bestuursrecht. Een inleiding, tweede druk, Zwolle 1996, p. 13.

4. De cursiveringen in de navolgende twee alinea's zijn van mijn hand.

5. M. Schreuder-Vlasblom, Het nieuwe bestuursprocesrecht, VAR-reeks 113 (verslag), Alphen aan den Rijn 1995, p. 56.

6. P. van Buuren, Belangen afwegen en het specialiteitsbeginsel, Awb-notities (11), NJB 1995/12, p. 460. 
van meningen'? Lambers sprak over een 'worsteling' om te komen tot een juiste toepassing van het specialiteitsbeginsel. ${ }^{8}$ En tot slot rekende Damen de interpretatie van het beginsel tot de 'lastige actuele problemen van het bestuursrecht'. 9 Het gegeven dat omstreden is welke belangen een bestuursorgaan in een belangenafweging op basis van een discretionaire bevoegdheid mag en moet betrekken ontlokte hem de uitspraak '...dat we veel meer aandacht zouden moeten besteden aan het specialiteitsbeginsel... ${ }^{10}$ Aan deze oproep van Damen is gevolg gegeven, want het specialiteitsbeginsel doet véél inkt vloeien. "Ook dit boek is daarvan een tastbaar bewijs. ${ }^{12}$

Dát de discussies over de uitleg van het specialiteitsbeginsel als zeer wezenlijk worden ervaren, blijkt o.m. uit de rechtsstatelijke impact van het onderwerp. In dit kader zijn nogal ferme uitspraken gedaan. Zo zou volgens Van Male het loslaten van het beginsel '...een ongebreidelde uitbreiding van de bevoegdheden van het bestuur betekenen'. ${ }^{13}$ En Stroink stelde onomwonden dat het loslaten van dit beginsel er al gauw toe zou leiden dat wij in een totalitaire maatschappij terechtkomen. ${ }^{14}$ In dezelfde trant benadrukte Donner dat het bestuur geen 'albedil' mag worden. ${ }^{15}$ Het zal dan ook weinig verbazen dat het specialiteitsbeginsel in de literatuur is omschreven als '...een van de meest wezenlijke grondbeginselen uit het bestuursrecht'. ${ }^{16}$ Maar er kunnen kritische tegengeluiden worden waargenomen. Sommige auteurs lijken de rechtsstatelijke betekenis van het specialiteitsbeginsel in het hedendaagse bestuursrecht te relativeren. ${ }^{17}$ Backes suggereerde bijv. een afzwakking van dit beginsel. ${ }^{18}$ Pragmatische en rechtspolitieke uitgangspunten spelen hierbij een belangrijke rol. Zo stelde Konijnenbelt zich zonder veel omhalen op het stand-

7. Zie zijn noot onder ARRS 5 juni 1991, AB 1992, 444, m.nt. H.J. Simon.

8. C. Lambers, De cén-loket-gedachte: ofwel het wieltje van de rolstoel, in: In wederkerigheid (Scheltemabundel), Deventer 1997, p. 312.

9. Zie zijn noot onder HR 18 december 1992 (Kuunders), Gst. 6970, p. 410.

10. L.J.A. Damen (interventie), De belanghebbende, VAR-reeks 109 (verslag), Alphen aan den Rijn 1993, p. 26.

11. Zie bijv. de omvangrijke oratie van Van Hall. A. van Hall, Het specialiteitsbeginsel in het waterstaatsrecht. Over kringen van belangen, Zwolle 1995.

12. Vgl. ook enige voorpublicaties: R.J.N. Schløssels, Wederkerigheid en specialiteit in het bestuursrecht, in: Eenzijdig en wederkerig? (red. E.C.H.J. van der Linden en A.Q.C. Tak), Deventer 1995, p. 153-190 en R.J.N. Schlossels, Het specialiteitsbeginsel en derde-belangen: een frisse benadering of rechtsstatelijk drijfzand?, NTB 1996/3, p. 81-96.

13. R.M. van Male, Rechter en bestuurswetgeving, diss. KUB, Zwolle 1988, p. 334.

14. F.A.M. Stroink, Reflecties op de verschillende bevoegdheden, in: Recht in het water. De juridische aspecten van watersnood, Antwerpen/Apeldoorn 1995, p. 124.

15. A.M. Donner, Nederlands bestuursrecht, a.w., p. 110.

16. H.J. Simon en A.Q.C. Tak, Het BW als 'Zwart gat'. De onttakeling van het publiekrecht door een 'gemene' rechter, NTBR 1994/8, p. 178.

17. Vgl. bijv. R. de Winter, Oud zeer, in: Azen op tegenslag, Lelystad 1994, p. 4-16.

18. Ch. W. Backes, Juridische bescherming van ecologisch waardevolle gebieden, diss. UU, Zwolle 1993, p. 526. 
punt dat het vasthouden aan een 'orthodoxe' (precieze) opvatting over het specialiteitsbeginsel 'maatschappelijk moeilijk verkoopbaar is'. ${ }^{19}$

De aanhoudende controversen tussen verschillende auteurs leidden ertoe dat in de bestuursrechtelijke literatuur al snel werd gesproken over een 'scholenstrijd'. In dit kader wordt een 'rekkelijke' en een 'precieze' stroming onderscheiden, afhankelijk van de betekenis die men toekent aan de doorwerking van het specialiteitsbeginsel in het proces van bestuurlijke belangenafweging. ${ }^{20}$ De gesignaleerde meningsverschillen in de literatuur - de scholenstrijd - alsmede het feit dat er nog geen proefschrift aan het specialiteitsbeginsel is gewijd, lijken op zichzelf reeds valide redenen voor een studie. Maar er is meer...

\subsection{Een kennelijk vergeten problematiek als tweede reden...}

Ofschoon de discussies over de interpretatie van het specialiteitsbeginsel reeds geruime tijd in de literatuur werden gevoerd ${ }^{21}$, besteedde de Awb-wetgever er vreemd genoeg géen aandacht aan. Dit is zeer opmerkelijk. De uitleg van het specialiteitsbeginsel raakt immers het hart van de bestuurlijke plicht tot belangenafweging, zodat aandacht van de zijde van de wetgever in de rede had gelegen. In de parlementaire stukken die de eerste tranche van de Algemene wet bestuursrecht vergezellen wordt, toegespitst op de bestuurlijke belangenafwegingsplicht (vgl. artikel 3:4 lid $1 \mathrm{Awb}$ ), evenwel met geen woord over het specialiteitsbeginsel gerept. ${ }^{22}$ Voor de omvangrijke discussies in de literatuur is evenmin enige aandacht. In dit kader dringt zich de vraag op of hier sprake is van een simpelweg 'over het hoofd zien' of van een bewust mijden van een complexe problematiek.

Intussen wordt artikel 3:4 lid $1 \mathrm{Awb}$ in de literatuur wél met het specialiteitsbeginsel in verband gebracht. Volgens Drupsteen bevat deze bepaling nl. een 'eigen problematiek' die verband houdt met de werking van het specialiteitsbeginsel. ${ }^{23}$ Het verbaast dan ook niet dat verschillende auteurs genoemd artikellid - waarvan de redactie overigens niet uitblinkt door helderheid - in hun 'voordeel' interpreteren. ${ }^{24}$ Hiervoor is ook alle ruimte, temeer omdat de rechtspraak er (nog) niet in is geslaagd het specialiteitsbeginsel op een heldere

19. W. Konijnenbelt, Het specialiteitsbeginsel in het Nederlandse en het Franse administratieve recht, NTB 1994/10, p. 308.

20. Zie in dit kader o.m.: E. Helder en R.J. Jue, Belangenafweging in het bestuursrecht, Bestuurswetenschappen $1987 / 1$, p. 25 ; M.A. Heldeweg, Het specialiteitsbeginsel: bel voor de laatste ronde?, in: Rechtspraak bestuursrecht 1994/1995. De annotaties, i.h.b. p. 179 e.v. en Nicolaï e.a., Bestuursrecht, zesde geheel herziene druk, Amsterdam 1997, p. 15.

21. De discussies over het beginsel nemen in volle omvang hun aanvang naar aanleiding van een publicatie door Stroink en De Waard in 1984. Zie: F.A.M. Stroink en B.W.N. de Waard, Het specialiteitsbeginsel, in: Burger en overheid (Steenbeek-bundel), 's-Gravenhage 1984, p. 231 e.v.

22. Het specialiteitsbeginsel kwam wél kort ter sprake in het kader van de discussies over het 'belanghebbende'-begrip en de ontvankelijkheidsvraag. Vgl. PG Awb I, EV en NEV, p. 152-153.

23. Th. G. Drupsteen, En de gemeenteraad maar belangen afwegen, in: In de sfeer van administratief recht (Konijnenbelt-bundel), Utrecht 1994, p. 71.

24. Vgl. de verschillende visies van Van Buuren en Konijnenbelt. P. van Buuren, Belangen afwegen en het specialiteitsbeginsel, a.w., p. 461 en W. Konijnenbelt, Het specialiteitsbeginsel in het Nederlandse en het Franse administratieve recht, a.w., p. 309-310. 
wijze te operationaliseren. Michiels verzuchtte in dit verband dat '...helaas moet worden geconcludeerd dat de reikwijdte van het specialiteitsbeginsel in de jurisprudentie niet hepaald duidelijk en voor één uitleg vatbaar is ${ }^{25}$. Onduidelijkheid van de zijde van de wetgever én tegenstrijdige jurisprudentie vormen een tweede reden voor een onderzoek.

\subsection{Last of waarborg? De derde reden...}

Er is nog een reden voor het schrijven van dit boek. In de literatuur is erop gewezen dat de werking van het specialiteitsbeginsel heeft geleid tot het verschijnsel van 'verkokerde' administratieve wetgeving. ${ }^{26}$ Door de doelbinding van bestuursbevoegdheden en de spreiding van deze bevoegdheden over vele overheidsambten is er binnen de democratische rechtsstaat een complex stelsel van gefragmenteerde bestuurswetgeving ontstaan. Binnen een bepaalde administratieve wet staat $\mathrm{nl}$. steeds de behartiging van specifieke publieke belangen door de bestuursorganisatie centraal. Er is bijv. een Woningwet, een Wet milieubeheer, een Jachtwet, een Ontgrondingenwet, een Wet op de telecommunicatievoorzieningen, een Veewet, een Landbouwwet, een Drank- en Horecawet, een Warenwet, een In- en Uitvoerwet, een Verkeerswet tegen lintbebouwing en een Wet inzake bloedtransfusie. Zo maar een greep uit de vele wetten die samen het zgn. bijzondere deel van het bestuursrecht vormen. Al deze wetten kennen nog meer bevoegdhedenstelsels, bijv. in de vorm van vergunningplichten. Uit empirisch onderzoek van de Algemene Rekenkamer uit 1994 bleek dat er alleen al op Rijksniveau 544 verschillende vergunningstelsels vigeren die in 112 administratieve wetten zijn neergelegd. ${ }^{27}$ Over de hoeveelheid vergunningstelsels op decentraal niveau zijn mij geen onderzoeksgegevens bekend, maar het aantal zal ongetwijfeld zeer groot zijn.

De burger kan de 'gefragmenteerde' of 'gedeelde' overheid als een last ervaren. Dit geldt overigens óók voor de bestuursorganisatie zelf. Soms is er immers voor éen en dezelfde activiteit een heel scala aan - deels met elkaar samenhangende - vergunningen vereist. Dit roept bij de burger niet zelden associaties op met bureaucratie. ${ }^{28}$ Doordat nu het verschijnsel van de 'gedeelde' overheid inherent is aan de staatsrechtelijke werking van het specialiteitsbeginsel is dit rechtsstatelijk structuurbeginsel bij sommigen in een minder goed daglicht komen te staan. Scheltema heeft er bijv. op gewezen dat door de werking van het legaliteits- en specialiteitsbeginsel de rechtsrelatie tussen bestuur en burger in

25. Zie zijn noot onder ABRS 1 maart 1996, AB 1996, 359.

26. Vgl. J.B.J.M. ten Berge, Besturen door de overheid, Nederlands algemeen bestuursrecht 1, tweede druk, Deventer 1997, p. 51-53. Ten Berge brengt dit verschijnsel i.v.m. de karakteristieke 'doelgebonden normstelling' in het bestuursrecht.

27. Zie het rapport 'Vergunningen' van de Algemene Rekenkamer. TK 1995-1996, 24656, nr. 2, p. 12.

28. Voor het verbouwen van een historisch pand tot cafe/dancing zijn bijv. al gauw de navolgende vergunningen en vrijstellingen vereist: een bouwvergunning, een planologische artikel 19-vrijstelling, een monumentenvergunning, een milieuvergunning, een drank- en horecawetvergunning en een terrasvergunning. Vgl. over deze problematiek: C. Lambers, De één-loket-gedachte, a.w., i.h.b. p. 309/311. 
onoverzichtelijke partjes wordt geknipt $t^{29}$ en Konijnenbelt riep reeds eerder het beeld op van 'verbrokkeld' bestuur als ware het een Kafkaiaans labyrint. ${ }^{30}$ Dergelijke denkbeelden hebben in het hedendaagse bestuursrecht o.m. voeding gegeven aan de gedachte dat in de rechtsrelatie tussen bestuur en burger de betekenis van de - éénzijdig uit te oefenen doelgebonden bestuursbevoegdheid diende te worden gerelativeerd. ${ }^{31}$

Toch nemen andere auteurs de 'ongemakken' van het specialiteitsbeginsel op de koop toe; zij stellen juist de grote rechtsstatelijke betekenis van dit principe centraal. In dit kader kan bijv. het relativerende - maar stellige - citaat van Donner worden gepositioneerd, waarmee dit inleidende hoofdstuk werd geopend. En Damen heeft er de aandacht op gevestigd dat de 'gedeelde' overheid uiteindelijk ook wel iets aantrekkelijks heeft. ${ }^{32} \mathrm{De}$ administratie kan bij vergunningverlening bijv. niet van argument naar argument springen en de 'deling' van het bestuur bevordert de 'checks and balances' binnen de overheidsorganisatie.

Het voorafgaande doet de vraag rijzen of de rechtsstatelijke impact van het specialiteitsbeginsel van zodanige aard is dat de gesignaleerde 'ongemakken' voor de burgers en de bestuursorganisatie op de koop moeten worden toegenomen. Hierbij dient men zich ók af te vragen of het relativeren van genoemd beginsel wel een adequate en weldoordachte reactie is op het verschijnsel van 'verkokerde' bestuursrechtelijke wetgeving.

\subsection{Probleemstellingen}

In het voorafgaande zijn drie argumenten aangevoerd die een aanleiding vormen voor het schrijven van dit proefschrift. In deze argumenten liggen ook de twee centrale probleemstellingen besloten die in de beschouwingen centraal zullen staan. Deze luiden:

1. Welke betekenis moet aan het specialiteitsbeginsel als - verondersteld - rechtsstatelijk beginsel worden toegekend?

2. Welke grenzen stelt dit beginsel aan het proces van belangenafweging door het bestuur in het kader van een discretionaire bevoegdheidsuitoefening?

29. M. Scheltema, Van rechtsbescherming naar een volwaardig bestuursrecht, NJB 1996/33, p. 1359. Vgl. de kritische reacties van Tak (Een volwaardig bestuursrecht, NTB 1996/9, p. 299 e.v.), alsmede Heldeweg en Van der Linden (Een volwaardig bestuursrechtelijk debat, of rechtsbescherming tegen de burger als juridisch tekort, NJB 1996/43, p. 1818-1821).

30. W. Konijnenbelt, Rechtsverwerking door het bestuur: het vertrouwensbeginsel in het administratieve recht, Geschriften van de Vereniging voor Administratief Recht LXXIV, Groningen 1975, p. 70. In gelijke zin ruim twintig jaar later: M. Scheltema, De wondere wereld van het bestuursrecht (afscheidsrede), Deventer 1997, i.h.b. p. I en 13-15.

31. Ik kom hier in hoofdstuk 2 uitvoerig op terug. Gedoeld wordt op de tendens van 'horizontalisering' van de rechtsrelaties tussen bestuur en burger. Zie hierover bijv. De Haan/Drupsteen/Fernhout, Bestuursrecht in de sociale rechtsstaat I, Ontwikkeling, Organisatie, Instrumentarium, vierde geheel herziene druk, Deventer 1996, p. 12 e.v.

32. Zie zijn noot onder HR 18 december 1992 (Kuunders), Gst. 6970, p. 411-412. 
In paragraaf 1.6 van dit hoofdstuk, waar het plan van behandeling wordt besproken, zullen deze probleemstellingen worden uitgewerkt. In de volgende paragraaf zal ik eerst het onderzoeksterrein afbakenen, alsmede een korte verantwoording geven voor de opzet en inhoud dit boek.

\subsection{Afbakening en onderzoeksverantwoording}

De belangrijkste begrenzing van het onderzoeksterrein vloeit voort uit de geformuleerde probleemstellingen. Primaire doelstelling van dit boek is het positioneren van het specialiteitsbeginsel als rechtsstatelijk structuurbeginsel (probleemstelling 1). Als rechtsbeginsel heeft het specialiteitsbeginsel gevolgen voor andere juridische verschijnselen. In dit boek wordt de aandacht geconcentreerd op één van die verschijnselen, nl. de begrenzing van het proces van belangenafweging dat plaatsvindt in het kader van de uitoefening van een discretionaire bestuursbevoegdheid (probleemstelling 2). De aandacht van de meeste auteurs die in hun publicaties het specialiteitsbeginsel analyseerden spitst zich ook op deze problematiek toe.

Tijdens de voorstudies bleek evenwel dat het specialiteitsbeginsel als algemeen rechtsstatelijk structuurbeginsel verband houdt met vele staats- en bestuursrechtelijke leerstukken. Zo is er in de literatuur terecht de aandacht op gevestigd dat dit beginsel een belangrijke bijdrage kan leveren aan de beantwoording van de fundamentele vraag in hoeverre de overheid op basis van haar 'privaatrechtelijke' bevoegdheden typisch publieke belangen mag behartigen. ${ }^{33}$ Ook is erop gewezen dat het beginsel in algemene zin ten grondslag ligt aan de verhouding tussen 'Iagere' (bijv. een gemeentelijke verordening) en 'hogere' regelgeving. ${ }^{34}$

Van een analyse van deze leerstukken is in dit boek goeddeels afgezien. ${ }^{35}$ Het betreft hier nl. leerstukken waaraan belangrijke zelfstandige onderzoeken kunnen worden - en ook reeds zijn - gewijd. ${ }^{36}$

\subsubsection{Géén horizontale rechtsvergelijking}

Dit boek behandelt de problematiek van het specialiteitsbeginsel naar Nederlands recht. Ofschoon op diverse plaatsen verwezen wordt naar Duitse en Franse literatuur, is er géén

33. A.Q.C. Tak, Terugtocht van twee wegen, NTB 1989/9/10, p. 304-305.

34. Zie de noot van H.J. Simon onder VzARRS 26 februari 1990, AB 1991, 566. Signaleer in dit verband de verwantschap tussen het specialiteitsbeginsel en de bekende 'motiefleer' van de Hoge Raad. Vgl. bijv. HR 4 maart 1952, NJ 1952, 365, m.nt. B.V.A.R. (Emmense baliekluivers).

35. In hoofdstuk 2 zal ik wêl stilstaan bij het principiële verschil tussen privaatrechtelijke en publiekrechtelijke bevoegdheid en enige opmerkingen plaatsen bij de 'Windmill'-jurisprudentie van de Hoge Raad (paragraaf 2.5.3).

36. Vgl. bijv. de omvangrijke studie van Van der Veen, die o.m. de problematiek van de 'privaatrechtelijke' verplichtingen bij bijzonder gebruik van openbare zaken - mede in het licht van het specialiteitsbeginsel ter sprake brengt. G.A. van der Veen, Openbare zaken. Betekenis van het aloude publiek domein na vestiging van het primaat van het publiekrecht, diss. UU, Deventer 1997, p. 402 e.v. 
sprake van een rechts-'vergelijkende' studie in de strikte zin van het woord. Er vindt immers géén horizontale vergelijking van verschillende rechtsstelsels plaats op basis van een bepaalde methodologie die erop gericht is om de verschillen en de overeenkomsten tussen deze stelsels systematisch in kaart te brengen. ${ }^{37}$

Op deze plaats wil ik kort aangeven waarom hiervan is afgezien. In dit kader is primair van belang dat de intensieve discussies in de Nederlandse literatuur over het specialiteitsbeginsel - voorzover kon worden nagaan - niet worden aangetroffen in bijv. de Duitse of Franse literatuur. ${ }^{38}$ Dit zou er natuurlijk op kunnen duiden dat men in deze landen de 'specialiteitsproblematiek' op een interessante wijze heeft opgelost en dat zou dan een reden kunnen zijn voor intensieve rechtsvergelijking. ${ }^{39}$ Maar dit is onwaarschijnlijk. Het heeft er nl. de schijn van dat het wetenschappelijk discours juist in Nederland ver gevorderd is en momenteel op scherpst van de snede wordt gevoerd. Indien men nu zou willen analyseren hoe in Duitsland en Frankrijk de specialiteitsproblematiek in de rechtspraktijk wordt benaderd, dan is men aangewezen op een uiterst gedetailleerde analyse van de jurisprudentie die echter moeilijk toegankelijk zal zijn. ${ }^{40}$ Een dergelijke analyse kan immers enkel op een verantwoorde wijze worden uitgevoerd indien men een uitstekende en gedetailleerde kennis bezit van de vele bijzondere delen van het betreffende

37. Zie over de methodologie van rechtsvergelijking in het publiekrecht o.m.: E.M.H. Hirsch Ballin en N. Verheij, Rechtsvergelijking in het bestuursrecht, in: Rechtsvergelijking, AAe 1994/5, p. 371 e.v. en N. Florijn, Rechtsvergelijking in de bestudering van het publiekrecht. Een stilistische benadering, Preadvies voor de Nederlandse Vereniging voor Rechtsvergelijking nr. 53, Deventer 1996, p. 81 e.v.

38. Daar de bestuursrechtelijke rechtsvergelijking in Nederland zich in de regel richt op Frankrijk en Duitsland is het verkennend onderzoek tot deze landen beperkt. Uit dit onderzoek bleek dat achter de Duitse en Franse vertalingen van 'specialiteitsbeginsel' in die rechtsstelsels andere leerstukken verborgen gaan. Het Franse 'principe de spécialité' ziet bijv. niet op de begrenzing van het proces van bestuurlijke belangenafweging, maar op (een aspect van) het bestuurlijk organisatierecht (zie hoofdstuk 2 van dit boek). In de Duitse literatuur treft men sporadisch het begrip 'Spezialitatsprinzip' aan. Dit beginsel houdt evenmin verband met de begrenzing van het bestuurlijke belangenafwegingsproces maar met het constitutionele 'Bestimmtheitsgebot' dat eist dat bevoegdheidsnormen door de wetgever inhoudelijk afdoende worden genormeerd (zie hoofdstuk 4 van dit boek). Uiteraard werd de buitenlandse literatuur ook via andere ingangen doorzocht. Het meest voor de hand lag in dit verband een benadering via het thema 'beleidsvrijheid' (Ermessen, pouvoir discrétionnaire). In de Duitse en Franse handboeken bestuursrecht werd met het oog hierop echter géén fundamentele discussie waargenomen die vergelijkbaar is met het Nederlandse discours over het specialiteitsbeginsel.

39. Vgl. bijv. Konijnenbelt (Het specialiteitsbeginsel in het Nederlandse en het Franse administratieve recht, a.w., p. 312-313) die heeft gesuggereerd dat in Frankrijk met het oog op de specialiteitsproblematiek een interessante oplossing voor handen zou zijn in de vorm van de algemene bestuurlijke politiebevoegdheid die toekomt aan de minister, de prefect en de burgemeester (de 'police administrative'). Het bestaan van deze 'police' - die overigens ó6k gebonden is aan een bepaald belang, nl. dat van de 'ordre public' - lost de belangenafwegingsproblematiek, welke zich voordoet in het kader van specifieke discretionaire bestuursbevoegdheden, m.i. echter geenszins op. Zie over de 'police administrative': R. Chapus, Droit administratif général, tome 1, 10e édition, Paris 1996, p. 634 e.v.

40. Vgl. in dit kader de onderzoeksverantwoording die vooraf gaat aan de jurisprudentie analyse in hoofdstuk 8 van dit boek. Een belangrijk probleem is dat 'specialiteitsproblematiek' in de regel impliciet (d.w.z. verborgen) in de jurisprudentie aan de orde komt. 
buitenlandse bestuursrecht (bijv. het ruimtelijk ordeningsrecht, het waterschapsrecht, het milieurecht, het economische bestuursrecht enz.). Een analyse door wetenschappers uit die landen, waarop buitenlandse onderzoekers vervolgens kunnen voortbouwen, ligt mijns inziens dan ook primair voor de hand.

Dit doet er niet aan af dat uit het Duitse en het Franse rechtsstelsel belangrijke, voor Nederlandse wetenschappers toegankelijke, informatie kan worden geput die van belang is voor de verdere operationalisering van het specialiteitsbeginsel.$^{41}$ Hiervan wordt in dit boek gebruik gemaakt. ${ }^{42}$ In dit kader is van belang dat het specialiteitsbeginsel verband houdt met het verbod van détournement de pouvoir. Dit verbod is, zoals reeds uit de benaming blijkt, ontleend aan het Franse bestuursrecht. ${ }^{43}$ Het ligt bijgevolg voor de hand om in het Franse recht op zoek te gaan naar de oorsprong van dit leerstuk. Dit gebeurt in hoofdstuk 5. In het Duitse constitutionele recht wordt veel aandacht besteed aan de inhoudelijke normering van bevoegdheidsnormen (Bestimmtheitsgebot). Het Duitse Bundesverfassungsgericht heeft in dit verband een omvangrijke jurisprudentie ontwikkeld die verband houdt met de rechtsstatelijke werking van het specialiteitsbeginsel. In hoofdstuk 4 van dit boek, waar het specialiteitsbeginsel als beginsel van behoorlijke wetgeving wordt gepositioneerd, zal aan deze jurisprudentie aandacht worden besteed.

\subsubsection{Het communautaire recht}

Het communautaire besluitvormingsniveau, d.w.z. de uitoefening van de beperkte en doelgebonden verdragsbevoegdheden door de EG-instellingen én de samenhang tussen deze bevoegdheden, komt in dit boek niet aan de orde. Dit onderwerp levert voldoende stof op voor een afzonderlijk proefschrift. ${ }^{44} \mathrm{Ik}$ vestig er op deze plaats enkel de aandacht op dat het specialiteitsbeginsel op communautair niveau als structuurprincipe van bevoegdheidstoedeling min of meer erkenning vindt. Men spreekt dan over het beginsel van 'specifieke competentie-attributie'.45 Vermeldenswaardig is dat het beginsel in het gemeenschapsrecht onder invloed van instrumentele tendensen niet al te precies lijkt te worden uitgelegd. Dit heeft enerzijds te maken met de vaak algemene (doel)normering van de

41. In dit boek wordt $6 \delta k$ inspiratie geput uit de jurisprudentie van het Europese Hof voor de Rechten van de Mens (EHRM).

42. Het gaat hier om een analyse van enige afgebakende democratisch-rechtsstatelijke leerstukken van algemene aard zodat gevaar voor rechtsvergelijkende 'versnippering' - waarvoor Van der Veen terecht waarschuwde - nihil is. Vgl. G.A. van der Veen, Openbare zaken, a.w., p. 11. Waar in dit boek ter adstructie of verduidelijking naar Duitse en Franse literatuur wordt verwezen is in de regel gebruik gemaakt van gangbare handboeken en toegankelijke tijdschriftartikelen.

43. Het principe is ook uitdrukkelijk verankerd in het Duitse bestuursrecht. Vgl. $\S 36.3$ en $\S 40$ van het Verwaltungsverfahrensgesetz.

44. Volgens Dashwood overigens niet alleen voor een proefschrift maar zelfs voor een levenswerk. A. Dashwood, The limits of European community powers, E.L. Review, 1996/21, p. 116.

45. Vgl. art. 3b van het EG-verdrag. Zie voorts: $R$. Barents, Milieu en interne markt. Enkele opmerkingen over de betekenis en de gevolgen van het rechtsbasisvereiste in het communautaire recht, SEW 1993/1, p. 5 e.v. alsmede R. Barents, De communautaire rechter tegenover burocratie en politiek. De interactie tussen algemene rechtsbeginselen en discretionaire bevoegdheden, RMTh. 1995/5, p. 219. 
'Europese' bevoegdheden ${ }^{46}$, en anderzijds met het feit dat de grenzen van deze bevoegdheden (door het Europese Hof van Justitie) ruim worden uitgelegd tegen de achtergrond van de gehele structuur van het betreffende verdrag en zijn doelstellingen. ${ }^{47}$

Voor de nationale (Nederlandse) rechter, die doorgaans opereert binnen een meer gestructureerd kader van bestuursbevoegdheden, kan de communautaire bevoegdhedenstructuur vanuit specialiteitsoogpunt aanleiding geven tot onduidelijkheden ${ }^{48}$ Het verbaast dan ook niet dat in de Europeesrechtelijke literatuur wordt gepleit voor een duidelijker afbakening van de bevoegdheden van de gemeenschapsorganen. ${ }^{49}$

Ik vestig er tot slot de aandacht op dat het primaire en secundaire EG-recht uiteraard (de doelstelling van) nationale bevoegdhedenkaders kan beïnvloeden. ${ }^{50}$ Het spreekt voor zich dat een nationale doelgebonden bestuursbevoegdheid in voorkomende gevallen overeenkomstig de communautaire 'doorwerkings'-regels moet worden uitgeoefend. Hierbij zal onder omstandigheden bijv. een nationaal bevoegdhedenkader richtlijnconform moeten worden geïnterpreteerd. Deze problematiek laat $\mathrm{ik}$ in dit boek verder buiten beschouwing. ${ }^{\text {s1 }}$

\subsubsection{Coördinatie- en integratievraagstukken}

In dit proefschrift is tenslotte afgezien van uitvoerige beschouwingen over juridisch-technische aspecten inzake coördinatie en integratie van bijzondere bestuurswetgeving. De coördinatie- en integratieproblematiek zelf levert eveneens afdoende stof op voor afzonderlijke onderzoeken op het gebied van het bijzondere bestuursrecht. ${ }^{\text {s2 }}$ Wél wordt in hoofdstuk 4 enige aandacht besteed aan de coördinatie- en integratieproblematiek in het licht van de rechtsstatelijke functie van het specialiteitsbeginsel. Bij het zoeken naar wetgevings-

46. R. Barents, De communautaire rechter tegenover burocratie en politiek, a.w., p. 221.

47. Zie: Gev. zaken 188-190/80 (Frankrijk, Italie en VK vs. Commissie), Jur. 1982, 2545 (r.o. 5). Vgl. voor een m.i. fraaie toepassing Zaak C-180/96R (r.o. 62) betreffende het communautair kort geding van het Verenigd Koninkrijk tegen de 'indammings'-beschikking van de commissie inzake de gekke koeienziekte (BSE). Aan de orde was o.m. de rechtsvraag of de omstreden beschikking van de commissie niet steunde op louter economische overwegingen in plaats van op het gemeenschappelijke volksgezondheidsbelang. Zie voor deze uitspraak en commentaar: K.J.M. Mortelmans, Gekke koeien: in dubio pro sanitate, AAe 1996/11, p. 712 e.v.

48. Vgl. bijv. ABRS 1 november 1994, AB 1995, 437, m.nt. E. Steyger (IJssel-Vliet Combinatie BV).

49. Vgl. de inaugurele rede van Dashwood d.d. 13 november 1995. A. Dashwood, The limits of European community powers, a.w., p. 128.

50. Vgl. HvJ 20 september 1988, Jur. 1988, 4635 (gebroeders Beentjes BV). Het betrof hier de rechtsvraag of, en in hoeverre, in het kader van een nationale 'Europese' aanbesteding het algemene werkgelegenheidsbelang een rol mocht spelen. Zie hierover uitvoerig: $\mathrm{H}$. Nijholt, Op weg naar een bestuursrechtelijke normering van het gemeentelijk aanbestedingsbeleid in de bouw, diss. RL, Maastricht 1996, p. 126 e.v.

51. Ik verwijs naar: R.J.G.M. Widdershoyen, Naar een bestuurs(proces)rechtelijk Ius Commune in Europa, VAR-reeks 116, i.h.b. p. 126-130.

52. Vgl. de studie van J. Struiksma, Verwant zonder verband. De coördinatie van de bouw- en milieuvergunning, Deventer 1993. Ik wijs ook op het VAR-preadvies van Stroink inzake de besluitvorming over 'grote projecten' dat in het voorjaar van 1998 verschijnt. F.A.M. Stroink, Complexe besluitvorming: een opgave voor burger, bestuur en rechter, VAR-reeks 120, Alphen aan den Rijn 1998. 
technische oplossingen voor fricties tussen de diverse administratieve wetten, kan de rechtsstatelijke analyse van het specialiteitsbeginsel in dit boek als randvoorwaarde fungeren.

\subsection{Plan van behandeling}

De centrale probleemstellingen worden uitgewerkt in acht hoofdstukken. De hoofdstructuur van dit boek valt uiteen in drie delen. De hoofdstukken 2 tot en met 6 zijn algemeen-theoretisch van aard. In deze hoofdstukken wordt het specialiteitsbeginsel in verband gebracht met enkele centrale leerstukken en themata op het terrein van het algemeen deel van het bestuurs- en staatsrecht. De aandacht gaat uit naar een analyse van het begrip bestuursbevoegdheid, de karakteristieken van de rechtsverhouding tussen bestuur en burger, de rechtsgrond en doelbinding van bestuursbevoegdheden, het proces van gerichte rechtsvorming in het publiekrecht, het beginsel van wetmatigheid van bestuur, het verbod van détournement de pouvoir en het verschijnsel beleidsvrijheid. In de hoofdstukken 7 en 8 vindt er vervolgens een analyse plaats van de relevante literatuur en de jurisprudentie over het specialiteitsbeginsel. Op basis van de inzichten welke ontleend worden aan het eerste deel (de hoofdstukken 2 tot en 6), alsmede aan het literatuur- en het jurisprudentie-onderzoek (de hoofdstukken 7 en 8) wordt in hoofdstuk 9 van dit boek een eigen visie over de specialiteitsproblematiekuiteen gezet. Dit hoofdstuk vormt het derde en tevens afsluitende deel.

Ter afronding van dit inleidende hoofdstuk, zal ik kort aangeven hoe de verschillende hoofdstukken inhoudelijk zijn opgebouwd:

\section{Hoofdstuk 2 Bestuursbevoegdheid}

Het specialiteitsbeginsel is een beginsel dat ten grondslag ligt aan de (interne en externe) structuur van bestuursbevoegdheden. In hoofdstuk 2 wordt daarom eerst de "bestuursbevoegdheid' aan enige beschouwingen onderworpen. Hierbij komen tevens enkele normtheoretische aspecten aan bod. Van belang is dat een bestuursbevoegdheid - te onderscheiden van een bestuurstaak - binnen een rechtsstelsel toekomt aan bijzondere dragers: de bestuursorganen. Deze organen vormen in bestuursrechtelijke rechtsverhoudingen de 'counterpart' van de (actieve) rechtssubjecten, de dragers van zelfstandige rechten, rechtsbelangen en rechtsplichten. Binnen de bestuursrechtelijke rechtsverhoudingen neemt de bestuursbevoegdheid - en bijgevolg het specialiteitsbeginsel - een centrale plaats in. De theoretische onderbouwing die ten grondslag wordt gelegd aan de rechtsverhouding tussen bestuursorgaan en rechtssubject(en) is medebepalend voor de interpretatie van het specialiteitsbeginsel. Daarom wordt in hoofdstuk 2 aandacht besteed aan deze rechtsverhouding, waarbij kritisch stelling wordt genomen tegen de idee van 'wederkerige' rechtsbetrekkingen in het bestuursrecht. Tevens wordt de publiekrechtelijke bestuursbevoegdheid duidelijk gepositioneerd ten opzichte van rechtsbevoegdheid in het privaatrecht. 


\section{Hoofdstuk 3 Een rechtsstatelijk beginsel}

In het derde hoofdstuk wordt het specialiteitsbeginsel in een historisch-theoretisch perspectief geplaatst. Nagegaan wordt hoe de publiekrechtelijke structuur van doelgebonden bestuursbevoegdheden tot ontwikkeling kwam ingevolge een geleidelijk cultuurhistorisch ontsluitingsproces. Dit proces leidde tot een scheiding van de publieke staat en de burgerlijke maatschappij. Vervolgens wordt aandacht besteed aan het gerichte rechtsvormingsproces binnen de publieke rechtsgemeenschap (de staat) tegen de achtergrond van beginselrecht. Hierbij nemen het principiële verschil tussen enerzijds de behartiging van publiekrechtelijke belangen en anderzijds de respectering van private belangen, alsmede de notie van handelen in het algemeen belang, een centrale plaats in. Tot slot zal nagegaan worden hoe het specialiteitsbeginsel zich als rechtsbeginsel verhoudt tot andere typisch publieke rechtsbeginselen, waarbij in het bijzonder de aandacht uitgaat naar het democratisch postulaat en het legaliteitsbeginsel.

\section{Hoofdstuk 4 Legaliteit en specialiteit}

Nadat het specialiteitsbeginsel in hoofdstuk 3 als rechtsstatelijk beginsel is gepositioneerd, wordt in het vierde hoofdstuk de relatie tussen het specialiteitsbeginsel en het legaliteitsbeginsel uitgediept. Voordat deze relatie aan de orde wordt gesteld, zal eerst ingegaan worden op de (actuele) betekenis van het uitgangspunt van wetmatigheid van bestuur. Vervolgens zal aan de hand van relevante jurisprudentie van het Duitse Bundesverfassungsgericht (BVerfG) en het Europese Hof voor de Rechten van de Mens (EHRM) aandacht worden besteed aan de implicaties van het specialiteitsbeginsel op wetgevingsniveau. Hierbij gaat o.m. de aandacht uit naar de wettelijke specificering, in het bijzonder de doelbinding, van bestuursbevoegdheden. Vanuit een vijftal perspectieven zal worden verdedigd dat bestuursbevoegdheid, afhankelijk van de in het geding zijnde rechtsbelangen van burgers, aan eisen van specificiteit zal dienen te voldoen. Het gaat hier om: het democratisch perspectief, het legitimatieperspectief, het rechtsbeschermingsperspectief, het organisatieperspectief en het doelmatigheids- of besluitvormingsperspectief.

\section{Hoofdstuk 5 Het verbod van détournement de pouvoir}

In het vijfde hoofdstuk vormt de wettelijke doelbinding van bestuursbevoegdheden het uitgangspunt. Als algemeen aanvaard bestuursrechtelijk principe geldt binnen de democratische rechtsstaat dat een bestuursorgaan een bestuursbevoegdheid niet voor een ander doel mag uitoefenen dan voor het doel dat de wetgever bij de toekenning van die bevoegdheid voor ogen stond. Het betreft hier het 'klassieke' verbod van détournement de pouvoir dat inherent is aan de rechtsstaatgedachte (vgl. artikel 3:3 Awb). In dit hoofdstuk wordt de historische ontwikkeling van genoemd verbod, dat door de Franse Conseil d'Etat in de negentiende eeuw werd geïntroduceerd, aan een analyserende beschouwing onderworpen. Hierbij zal eerst aandacht worden besteed aan het Franse recht en vervolgens aan het Nederlandse. 


\section{Hoofdstuk 6 Het specialiteitsbeginsel en beleidsvrijheid}

Eerst indien een bepaalde bestuursbevoegdheid aan een bestuursorgaan ruimte laat voor concretiserende rechtsvorming (in de zin van 'beleidsvrijheid') wordt de specialiteitsproblematiek in volle omvang zichtbaar. Hier komt de tweede probleemstelling in zicht: met welke belangen mag en/of moet het bestuursorgaan in het kader van het concretiserende rechtsvormingsproces rekening houden? Voordat deze vraag kan worden beantwoord zal eerst duidelijk dienen te zijn wanneer er sprake is van discretionaire ruimte en in welke gevallen deze discretie een plicht tot 'belangenafweging' voor het bestuur impliceert. In hoofdstuk 6 wordt in dit verband het rechtskarakter van 'beleidsvrijheid' geanalyseerd. Tevens wordt kort aandacht besteed aan het nogal vage 'belang'-begrip, waarna de vraag aan de orde komt wat nu de betekenis is van het verhullende begrip 'belangenafweging'. Tot slot wordt in algemene zin een relatie gelegd tussen bestuurlijke 'belangenafweging', rechtsvorming door het bestuur en de werking van het specialiteitsbeginsel. Hierbij wordt ók aandacht besteed aan artikel 3:4 lid $1 \mathrm{Awb}$.

\section{Hoofdstuk 7 De meningen in de literatuur}

In dit hoofdstuk wordt uitvoerig aandacht besteed aan de verschillende visies die in de literatuur worden aangetroffen inzake het specialiteitsbeginsel en (de grenzen van) bestuurlijke belangenafweging. De literatuur wordt zoveel mogelijk in chronologische volgorde besproken. Aan het eind van het hoofdstuk worden de verschillende visies geordend.

\section{Hoofdstuk 8 Het specialiteitsbeginsel in de jurisprudentie}

Hoofdstuk 8, dat tevens het meest omvangrijke hoofdstuk van dit boek vormt, omvat de analyse van de relevante jurisprudentie. In dit hoofdstuk, dat wordt ingeleid door een aparte onderzoeksverantwoording, komt achtereenvolgens de jurisprudentie van de Kroon, de voormalige Afdeling rechtspraak van de Raad van State (ARRS), de voormalige Afdeling geschillen van bestuur van de Raad van State (AGRS), de Afdeling bestuursrechtspraak van de Raad van State (ABRS), het College van Beroep voor het bedrijfsleven $(\mathrm{CBb})$ en de burgerlijke rechter aan bod.

\section{Hoofdstuk 9 Het specialiteitsbeginsel: een rechtspolitiek dilemma?}

In dit slothoofdstuk wordt op basis van de voorafgaande hoofdstukken een eigen visie inzake de 'specialiteitsproblematiek' uiteen gezet. Hierbij vormt een analyse van de bestuurlijke bevoegdheidsuitoefening enerzijds als rechtshandeling, en anderzijds - in ruimere zin - als rechtsfeit het uitgangspunt. Nagegaan zal worden op welke wijze deze bevoegdheidsuitoefening 'ingrijpt' in de wereld van de subjectgebonden rechtsbelangen. Tegen de achtergrond van de beginselstructuur van het publiekrecht zal vervolgens worden bepaald op welke wijze een bestuursorgaan met de verschillende rechtsbelangen van burgers rekening dient te houden. Ook in dit verband gaat aandacht uit naar de jurisprudentie van het Europese Hof voor de Rechten van de Mens (EHRM). 


\section{Hoofdstuk 2}

\section{Bestuursbevoegdheid}

\subsection{Inleiding}

In dit hoofdstuk worden de begrippen 'bevoegdheid', 'bestuursbevoegdheid' en 'bestuurstaak' aan enige algemene beschouwingen onderworpen. Het betreft hier een verkenning die ertoe strekt om de bespreking van het specialiteitsbeginsel (hoofdstuk 3) en het legaliteitsbeginsel (hoofdstuk 4) van een begripsmatige en theoretische basis te voorzien. Beide rechtsstatelijke beginselen structureren, samen met het democratiebeginsel en de idee van handelen 'in het algemeen belang', de grondslag van rechtsbevoegdheid in het publiekrecht. Voordat op deze beginselen wordt ingegaan is het zinvol om 'bestuursbevoegdheid' eerst vanuit een meer normtheoretische invalshoek te beschouwen. Hierbij gaat de aandacht uit naar de procedurele en materiële kenmerken van bevoegdheidsnormen in het publiekrecht.

In het navolgende wordt de 'bestuursbevoegdheid' tevens gepositioneerd ten opzichte van rechtsbevoegdheid in het privaatrecht (in het bijzonder in het vermogensrecht). Een punt van aandacht vormt in dit verband de stellingname tegen de tendens in het bestuursrecht om bestuursbevoegdheid dogmatisch in te bedden in de idee van een 'wederkerige rechtsbetrekking' (paragraaf 2.5.4). Aangegeven zal worden dat de werking van het specialiteitsbeginsel, als rechtsstatelijk structuurprincipe, moeilijk met een dergelijke benadering kan worden verenigd.

\subsection{De ruime en enge betekenis van het specialiteitsbeginsel}

Het specialiteitsbeginsel is een typerend structuurbeginsel van bestuursbevoegdheid. Genoemd beginsel wordt in dit boek, overeenkomstig de gangbare opvattingen in de Nederlandse literatuur, beschouwd in relatie tot doelgebonden discretionaire bestuursbevoegdheden en het proces van bestuurlijke belangenafweging. ${ }^{1}$ Het gaat hier om - wat ik aanduid als - de 'enge' betekenis van het specialiteitsbeginsel. Naast deze 'enge' betekenis kan een 'ruime' betekenis worden onderscheiden.

\subsubsection{Het Franse en Belgische 'principe de (la) specialité'}

Deze 'ruime' betekenis wordt met name aangetroffen in het Belgische en Franse publiekrecht. Het specialiteitsbeginsel ('principe de (la) specialité' of 'beginsel van specialiteit') wordt aldaar in verband gebracht met de taakuitoefening van rechtspersonen en gespecia-

1. Het specialiteitsbeginsel houdt bijgevolg verband met het leerstuk van détournement de pouvoir. Dit leerstuk staat in hoofdstuk 5 van dit boek centraal. 
liseerde instellingen in het publiekrecht. ${ }^{2}$ Het beginsel stelt in dit verband grenzen aan het werkterrein van functionele onderdelen van de bestuurlijke organisatie die belast zijn met typische overheidstaken zoals academische ziekenhuizen, Rijksmusea en Rijksuniversiteiten. Het betreft hier een begrenzing naar instellingsdoel (publieke taak). Deze taakbegrenzing dient uit het objectieve publiekrecht te worden afgeleid. ${ }^{3}$ Dujardin ${ }^{4}$ omschrijft het beginsel van specialiteit naar Belgisch recht als volgt: 'De wet, het decreet of de ordonnantie verleent de rechtspersoonlijkheid slechts voor een bepaald doel waarvoor de vereniging, instelling of dienst is opgericht. Krachtens dat beginsel - het zgn. beginsel van specialiteit - kan de rechtspersoon, onverschillig zijn publiek- of privaatrechtelijke aard, alleen met het oog op het verwezenlijken van zijn doel handelen.'

Kort samengevat brengt dit 'principe de (la) spécialité' met zich dat gespecialiseerde instellingen in het publiekrecht en (privaatrechtelijke) rechtspersonen, die belast zijn met een typische overheidstaak, in principe uitsluitend werkzaam mogen zijn op hun eigen functionele werkterrein en niet daarbuiten. ${ }^{5}$ De taakstelling begrenst in dit kader tevens de bevoegdheden van de instelling. ${ }^{6} \mathrm{Ik}$ wijs er overigens op dat hier een relatie ligt met het Nederlandse leerstuk van het specialiteitsbeginsel. Ook naar Nederlands recht begrenst de (specifieke) taakstelling van een 'publiekrechtelijke' rechtspersoon immers in globale zin de discretionaire bestuursbevoegdheden die aan de organen van die persoon zijn toegekend. ${ }^{7}$ Een specifieke taakstelling van een organisatorische entiteit krachtens publiekrecht

2. Zie: W. Konijnenbelt, Het specialiteitsbeginsel in het Nederlandse en het Franse administratieve recht, NTB 94/10, p. 311; Van Wijk/Konijnenbelt/Van Male, Hoofdstukken van administratief recht, tiende geheel herziene druk, 's-Gravenhage 1997, p. 333-334.

3. Vgl. in dit verband Vegtings algemene definitie van 'overheidsorgaan'. Hieronder verstaat deze auteur 'een in het objectieve recht geregelde functie met een bepaalde taak in de verzorging van de gemeenschapsbelangen'. W.G. Vegting, Het algemeen Nederlands administratief recht, eerste deel, Alphen aan den Rijn 1954, p. 169.

4. Mast/Dujardin, Overzicht van het Belgisch administratief recht, dertiende geheel opnieuw bewerkte en aangevulde uitgave, Brussel 1994, p. 71 en 72.

5. In Frankrijk wordt het 'principe de (la) spécialité ' reeds sinds lang gezien als een essentieel principe van het bestuurlijke organisatierecht. Zie hierover reeds: G. Jèze, Les principes genéraux du droit administratif, deuxième édition, Paris 1914, p. 317. Op gemeenten rust bijv. een typisch publieke bestuurstaak die met zich brengt dat zij in principe niet op een commerciële wijze mogen participeren in privaatrechtelijke energiebedrijven. Zie voor het hedendaagse Franse administratieve recht: De Laubadère/Venezia/Gaudemet, Droit administratif, tome 1, 13e édition, Paris 1994, p. 257 t/m 260 en R. Chapus, Droit administratif général, tome 1, 10e édition, Paris 1996, p. 344 e.v.

6. Vgl. De Laubadère/Venezia/Gaudemet, Droit administratif, a.w., p. 258: 'La règle de spécialité est ainsi une règle d'interprétation des compétences de chaque établissement public: parce que celui-ci ne possède qu'un personnalité fonctionnelle, son intervention est d'interprétation stricte, comme une exception à la compétence générale de l'Etat ou, dans leurs circonscriptions et pour les affaires locales, des collectivités territoriales.'

7. Hier treedt op de voorgrond dat een openbaar lichaam in het publiekrecht als organisatorisch gemeenschapsverband van bestuursorganen fungeert. Zie: J.A.F. Peters, Publiekrechtelijke rechtspersonen, diss. KUB, Deventer 1997, p. 82-83. Zie ook de bespreking van dit proefschrift door Stroink (NTB 1997/6, p. 241). In dit kader wijs ik er op dat ók naar Nederlands recht voor zelfstandige bestuursorganen het uitgangspunt van taakspecificiteit geldt. Zie: M.M. den Boer, Zelfstandige bestuursorganen uit de zelfkant 
(vgl. het specialiteitsbeginsel in 'ruime zin') kan op zijn beurt verder met zich brengen dat aan deze entiteit géén integrale afweging van publiekrechtelijke belangen mag worden toevertrouwd. ${ }^{8}$ Aldus beschouwd, is er $\delta 6 \mathrm{k}$ naar Nederlands recht een aanwijsbare relatie tussen de taakstelling van een openbaar lichaam en de belangenafweging die de bestuursorganen van dat lichaam op basis van de aan hen toegekende discretionaire bestuursvoegdheden dienen te verrichten.

\subsubsection{Specialiteitsbeginsel en bestuursorgaan}

Omdat de 'enge' betekenis van het specialiteitsbeginsel in dit boek centraal staat behoeft het ruime bestuursorgaanbegrip van artikel 1:1 lid 1 Awb niet te worden gehanteerd. ${ }^{9}$ Onder bestuursorgaan wordt in dit proefschrift verstaan de ambtelijke drager van bestuursbevoegdheid of, om in de woorden van artikel 1:1 Awb te spreken, 'een persoon of college met enig openbaar gezag bekleed'. Dit criterium impliceert dat het moet gaan om een orgaan met een publiekrechtelijke bevoegdheid tot het éénzijdig bepalen van de rechtspositie van rechtssubjecten. Het vaststellen van de aanwezigheid van bestuursbevoegdheid zal in de meeste gevallen niet moeilijk zijn; de aanwezigheid van een dergelijke (specifieke) bevoegdheid zal nl. doorgaans blijken uit een wettelijk voorschrift ${ }^{10}$, alhoewel de Awbwetgever deze eis niet glashard stelt."

De dragers van 'openbaar gezag' kunnen, zoals bekend, zowel 'a-orgaan' als 'b-orgaan' in de zin van de Algemene wet bestuursrecht zijn. Dit onderscheid is voor een analyse van

van de democratie?, VAR-reeks 118, Alphen aan den Rijn 1997, p. 200-201; Vgl. J.A.F. Peters, Zbo's, verzelfstandiging en privatisering. Een korte beschouwing over de VAR-preadviezen 1997, NTB 1997/4, p. 141 en 143.

8. Vgl. ABRS 21 januari 1997, AB 1997, 136, m.nt. ChB; Gst. 7052, p. 243, m.n. J.M.H.F. Teunissen (exploitatiemaatschappij Bedrijvenpark Drachten).

9. Ik doel in dit kader op de Awb-hoofdregel waaraan het criterium van 'organisatorische grondslag' - en dus niet de publiekrechtelijke bevoegdheidseis - ten grondslag ligt. Als bestuursorgaan werd door de Awb-wetgever, met een beroep op de schakelbepaling van art. 3:1 lid l Awb, primair aangemerkt een orgaan van een rechtspersoon welke is ingesteld krachtens publiekrecht (r.i.k.p). Zie: PG Awb I, MvA, p. 136. Vgl. in kritische zin J.A.F. Peters, Bestuursorgaan in de Awb. Kanttekeningen bij een opmerkelijke inhoud, JB 1995/297, p. 1075 en F.A.M. Stroink, De schaduwzijden van de Algemene wet bestuursrecht, JB $1995 / 147$, p. 548. Zie voor een meer uitvoerige bespreking van het 'bestuursorgaan'-begrip onder de Awb het NTB-artikel van M. Bense en S. Zijlstra (Het begrip bestuursorgaan. Betekenis en strekking van art. 1:1, eerste lid, Algemene wet bestuursrecht, NTB 1994/9) en H.J. Simon, Handboek bestuurs(proces)recht volgens de Awb, 's-Gravenhage 1997, p. 13-20. Zie tot slot mijn noten onder Rb. 's-Gravenhage 21 augustus 1995, JB 1996/89 (Algemene woningbouwvereniging Leiderdorp) en ABRS 3 oktober 1996, JB 1996/231 (Luchthaven Schiphol NV).

10. Vgl. L.J.A. Damen, De assistent-kampbeheerder die graag ambtenaar had willen zijn, AAe 1995/4, p. 294 (noot onder Pres. Rb. Amsterdam 13 april 1994). Goorden stelt in dit verband als uitgangspunt centraal dat 'openbaar gezag' dient te worden ontleend aan attributie of delegatie van een bestuursrechtelijke bevoegdheid. C.P.J. Goorden, Verzeifstandiging: naar een doorzichtig en geregeld bestuur, VAR-reeks 118, Alphen aan den Rijn 1997, p. 76. Zie tot slot: Nicolar e.a., Bestuursrecht, zesde geheel herziene druk, Amsterdam 1997, p. 93: 'Publiekrechtelijke bevoegdheid wordt in het algemeen toegekend bij wettelijk voorschrift' (curs. R.J.N.S.). 
het specialiteitsbeginsel verder niet zo relevant. Van belang is wél dat de bestuursorganen de exclusieve dragers vormen van bestuursbevoegdheden. ${ }^{12}$ Het bestuursorgaan is in bestuursrechtelijke rechtsrelaties ${ }^{13}$ derhalve de publiekrechtelijke 'wederpartij' van rechtssubjecten. Het gegeven dat een bestuursorgaan partij is bij een rechtsbetrekking maakt deze tot een door publiekrechtelijke normen en beginselen beheerste rechtsbetrekking. ${ }^{14} \mathrm{De}$ nauwe relatie tussen bestuursorgaan, bestuursbevoegdheid en specialiteitsbeginsel staat daarmee vast.

Aan de uitzonderingen op het begrip 'bestuursorgaan', zoals neergelegd in artikel 1:1 lid $2 \mathrm{Awb}$, wordt in dit boek vastgehouden. De belangrijkste uitzonderingen op het gedefinieerde bestuursorgaanbegrip vormen de wetgever in formele zin en de organen binnen de staat die met rechtspraak zijn belast. Deze worden niet als bestuursorgaan aangemerkt, ook al oefenen zij 'openbaar gezag' uit.

\subsection{Rechtsbevoegdheid}

Het specialiteitsbeginsel houdt dus, zoals gesteld, verband met 'de structuur' van bestuursbevoegdheid. Hierbij kan zowel gedacht worden aan de interne structuur van bevoegdheidsnormen, als aan de externe samenhang van de verschillende bevoegdheden in het bestuursrecht. In dit laatstbedoelde verband kan gesproken worden over de externe structuur van de bestuursbevoegdheden binnen de overheidsorganisatie, welke organisatie zich manifesteert als een gedifferentieerd publiekrechtelijk gemeenschapsverband op democratische grondslag met specifieke bevoegdheidstoedelingen. ${ }^{15}$ In het verdere verloop van dit hoofdstuk zullen met name de interne structuur en het rechtskarakter van bestuursbevoegdheid worden verkend. Hierbij komt o.m. de vraag aan de orde op welke wijze het specialiteitsbeginsel tot uitdrukking komt in de conditionele structuur van een bevoegdheidsnorm.

11. Zie: PG Awb I, MvT, p. 133, waar wordt gesteld: 'De publiekrechtelijke bevoegdheid tot het bepalen van de rechtspositie van andere rechtssubjecten behoeft niet altijd op een uitdrukkelijke bepaling te berusten.' In dit kader speelt o.m. de 'publieke taak'-jurisprudentie waaraan ik in paragraaf 2.7 van dit hoofdstuk enige aandacht besteed. Zie bijv. ABRS 30 november 1995, JB 1995/337, m.nt. F.A.M.S. (Stichting Silicose).

12. Zie bijv. F.A.M. Stroink, Algemeen bestuursrecht, tweede druk, Zwolle 1996, p. 88; C.P.J. Goorden, Rechtsbevoegdheid in het bestuursrecht, diss. KUB, Zwolle 1990, p. 56; Nicolaĩ e.a., Bestuursrecht, a.w., p. 47.

13. Ik hanteer hier bewust het neutrale begrip 'rechtsrelatie'. Het gebruik van het begrip 'rechtsbetrekking', toegespitst op de relatie bestuursorgaan-rechtssubject en, zal in paragraaf 2.5 .4 e.v. van dit hoofdstuk kritisch worden beschouwd.

14. Vgl. M. Bense en S. Zijlstra, Het begrip bestuursorgaan, Betekenis en strekking van art. 1:1, eerste lid, Algemene wet bestuursrecht, NTB 94/9, p. 253. Het specialiteitsbeginsel vormt een fundamenteel bestuursrechtelijk beginsel dat aan de typische rechtsrelaties tussen bestuur en burger ten grondslag ligt. Zie hierover: R.J.N. Schlossels, Wederkerigheid en specialiteit in het bestuursrecht, in: Eenzijdig en wederkerig? (red. E.C.H.J. van der Linden en A.Q.C. Tak), Deventer 1995, p. 153. e.v.

15. Ik kom hier in hoofdstuk 3 op terug. Vgl. over de gemeenschapsidee als organisatorische grondslag van de overheid bijv. De Haan/Drupsteen/Fernhout, Bestuursrecht in de sociale rechtsstaat, Deel I, Ontwikkeling, Organisatie, Instrumentarium, vierde geheel herziene druk, Deventer 1996, p. 148-149. 


\subsubsection{Het bevoegdheidsbegrip}

In deze paragraaf zal ten behoeve van de verdere beschouwingen eerst aandacht worden besteed aan het begrip 'rechtsbevoegdheid'. Het gaat hier om een globale verkenning van de structuur van bevoegdheidsnormen vanuit een positiefrechtelijke invalshoek. Vervolgens zal de aandacht uitgaan naar het begrip 'rechtsbevoegdheid' in het publiekrecht, en meer in het bijzonder naar het begrip bestuursbevoegdheid.

Bevoegdheid is een begrip dat zowel in de spreektaal als in de juridische literatuur met een bepaalde vanzelfsprekendheid wordt gehanteerd. Het lijkt een duidelijkheid in zichzelf te bezitten, aldus Van Maarseveen. ${ }^{16}$ Deze vanzelfsprekendheid is slechts schijn. Het begrip bevoegdheid wordt in diverse betekenissen gehanteerd, terwijl ook de definities in de literatuur verschillen.

Van Dale's Groot Woordenboek der Nederlandse Taal omschrijft 'bevoegd' als 'door de wet of enig erkend gezag of uit hoofde van een functie tot iets (dat genoemd wordt of uit het verband blijkt) gerechtigd'. Het begrip 'bevoegdheid' wordt omschreven als: 'het recht tot het uitoefenen van bepaalde handelingen'. In algemene zin kan gesteld worden dat een persoon ${ }^{17}$ die over een bepaalde bevoegdheid beschikt, gerechtigd is om bepaalde handelingen te verrichten die zonder de betreffende bevoegdheid niet mogen worden verricht.

Bevoegdheid is een normatief begrip. Bevoegdheid in juridische zin staat gelijk aan 'rechtsbevoegdheid'. ${ }^{18}$ Toegespitst op een juridische context houdt bevoegdheid een geoorloofdheid, een toestemming of een machtiging in om iets te doen, of juist na te laten, ten opzichte van andere deelnemers aan het rechtsverkeer. Binnen de kaders van dit boek is met name het 'machtigings'-aspect van belang. Het machtigingsvraagstuk vervult een belangrijke functie binnen het normtheoretische denken. Kelsen omschrijft dit als volgt:

\footnotetext{
'Die normative Funktion des Ermăchtigens bedeutet: einem Individuum die Macht verleihen, Normen zu setzen und anzuwenden. (...) Eine Rechtsnorm ermăchtigt bestimmte Individuen Rechtsnormen zu erzeugen oder Rechtsnormen anzuwenden. In diesen Fällen sagt man: das Recht verleihe bestimmten Individuen eine Rechtsmacht. 19
}

Kelsen benadrukt het belang van het machtigingsvraagstuk door te stellen:

16. H. van Maarseveen, Bevoegdheid, in: Algemene begrippen Staatsrecht, derde geheel herziene druk, Zwolle 1991, p. 64.

17. Het begrip 'persoon' wordt hier gehanteerd in de algemene betekenis van drager of toerekeningspunt van bevoegdheid.

18. Vgl. C.P.J. Goorden, Rechtsbevoegdheid in het bestuursrecht, a.w., p. 53.

19. H. Kelsen, Allgemeine Theorie der Normen, Im Auftrag des Hans-Kelsen-Instituts aus dem Nachlaß herausgegeben von: K. Ringhofer und R. Walter, Wien 1979, p. 82. Door de machtiging centraal te stellen t.a.v. het bevoegdheidsvraagstuk is overigens nog géén antwoord gegeven op de vraag waaraan een entiteit (persoon) een bepaalde machtiging ontleent. Het vraagstuk van de bevoegdheidsverkrijging blijft op deze plaats (nog) buiten beschouwing. 
'Da das Recht seine eigene Erzeugung und Anwendung regelt, spielt die Normative Funktion der Ermächtigung im Recht eine besonders wichtige Rolle. Nur Individuen, denen die Rechtsordnung diese Macht verleiht, können Rechtsnormen erzeugen oder anwenden. ${ }^{20}$

Deze normtheoretische bevoegdheidsnotie van Kelsen is tamelijk vaag, en biedt (nog) niet veel houvast voor een concrete beschouwing van het bevoegdheidsbegrip in een typisch publiekrechtelijke context. Uit de omschrijving van Kelsen blijkt wél reeds dat bevoegdheid in juridische zin uit een rechtsnorm dient te worden afgeleid.

\subsubsection{Het onderscheid tussen 'primaire' en 'secundaire' rechtsnormen}

Om nu tot een nadere omlijning van het bevoegdheidsbegrip in het (publiek)recht te komen, zal de bindende rechtsregel die een (publiekrechtelijke) bevoegdheid in het leven roept - d.w.z. toekent - nader worden bezien. In het kader van een positiefrechtelijke benadering van een rechtsstelsel ${ }^{21}$ is het gebruikelijk om een tweetal basis-normtypen te onderscheiden. Het betreft hier het onderscheid tussen primaire en secundaire rechtsnormen. ${ }^{22}$ Het eerste basis-normtype kan worden aangeduid als gedragsnorm. Dit normtype richt zich rechtstreeks tot rechtssubjecten door middel van een verbod, een gebod of een toestemming. Gedragsnormen beogen primair het gedrag van rechtssubjecten te reguleren. ${ }^{23}$ Deze primaire normen kunnen op een tweetal wijzen tot gelding komen binnen een rechtsorde. In de eerste plaats kunnen gedragsnormen door een (langdurig) proces van

20. H. Kelsen, Allgemeine Theorie der Normen, a.w., p. 82.

21. Tot de kern van een 'positivistische' denkwijze over rechtsstelsels reken ik de volgende uitgangspunten (1) het ontkennen van een noodzakelijk verband tussen - bindende - rechtsregels en regels van moraal (2) het beschouwen van rechtsregels naar hun formele geldigheidsaspect en (3) het beschouwen van een rechtsstelsel als een logische normenhiěrarchie die zijn uiteindelijke geldingsgrondslag vindit in een hoogste (niet positiefrechtelijke) norm, aangeduid als een ultieme 'Rule of recognition' (Hart) of 'Grundnorm' (Kelsen). Zie voor een schets van 'het positivisme': R. Dworkin, Taking Rights Seriously, zesde druk, Cambridge/ Massachusetts 1979, p. 17 Vm 22. Overigens gaat het hier om enkele gemeenschappelijke uitgangspunten, die onvoldoende recht doen aan alle nuances binnen het 'rechtspositieve denken'. Vgl. bijv. P.W. Brouwer, Rechtsbeginselen en rechtspositivisme, in: Rechtsbeginselen, AAe $1991 / 10$, p. $50 \mathrm{t} / \mathrm{m} 52$.

22. Zie i.h.b. de normentheorie van Hart. H.L.J. Hart, The concept of law, tiende druk, Oxford 1992 (eerste druk 1961). Het onderscheid tussen 'primaire' en 'secundaire' normen wordt uitgewerkt in Hoofdstuk V (Law as the union of primary and secondary rules, p. 77 e.v.). Vgl. ook de normentheorie van Kelsen, zoals uitgewerkt in zijn standaardwerk 'Reine Rechtslehre'. Kelsen beschouwt in deze studie de positieve rechtsorde als een hierrarchisch geordend stelsel van rechtsnormen, waarbij de geldigheid van een 'lagere' norm steeds aan een hogere norm kan worden getoetst (Normstufenbau). Aan de top van de normenpiramide plaatst hij de 'vorausgesetzte' Grundnorm, die zelf géén positiefrechtelijke norm is, maar als ultieme (transcendentaal-logische) norm aan het positieve recht ten grondslag ligt. Zie $\mathrm{H}$. Kelsen, Reine Rechtslehre, zweite vollstăndig neu bearbeitete und erweiterte Auflage, Wien 1960, i.h.b. p. 196 e.v. en p. 228 e.v.

23. In de terminologie van Hart is hier sprake van een 'rule of obligation'. Naleving van dergelijke regels rust volgens Hart in beginsel op sociale druk uit de samenleving en het geloof in de noodzaak van naleving van de regel door het individu, resulterend in verplichting (obligation) en plicht (duty). Zie: H.L.A. Hart, The concept of law, a.w., p. 84 en 85 . 
acceptatie deel gaan uitmaken van een 'positief' rechtsstelsel. ${ }^{24}$ Een samenleving met uitsluitend primaire normen wordt volgens Hart echter gekenmerkt door een voortdurende onzekerheid over de inhoud van normen (er is nl. géén specifiek juridisch referentiekader), het statische karakter van het recht en de inefficiëntie van de rechtshandhaving (er is geen hogere autoriteit belast met handhaving). ${ }^{25}$

Gedragsnormen worden binnen een samenleving met een meer ontwikkeld (lees: complexer) rechtsstelsel dan ook voor een belangrijk deel langs een andere weg gevormd, vastgesteld en gehandhaafd. Vorming, vaststelling en handhaving geschiedt hier $\mathrm{nl}$. door competente organen. ${ }^{26}$ Deze organen ontlenen hiertoe een specifieke machtiging aan zgn. secundaire normen. Primaire en secundaire normen veronderstellen elkaar binnen een ontwikkeld rechtsstelsel. ${ }^{27}$ Hart merkt over de relatie tussen beide normtypen het volgende op:

'..in the sense that while primary rules are concerned with the actions that individuals must or must not do, these secundary rules are all concerned with the primary rules themselves. They specify the ways in which the primary rules may be conclusively ascertained, introduced, eliminated, varied, and the fact of their violation conclusively determined. ${ }^{28}$

Secundaire normen, die ook wel aangeduid worden als competentienormen ${ }^{29}$, verlenen aan een orgaan het juridische vermogen om nieuwe gedragsnormen te vormen (of vast te stellen) binnen de grenzen van zijn specifieke competentie. ${ }^{30}$ Gesteld kan nu worden dat de gerichte vorming van nieuw positief recht ('positivering') binnen een ontwikkeld rechtsstelsel in belangrijke mate plaatsvindt op grond van een hiërarchisch gestructureerd

24. Zie: H.L.A. Hart, The concept of law, a.w., p. 89 en 90 . Vgl. ook het onderscheid dat Kelsen maakt tussen 'statische' en 'dynamische' Normsystemen. H. Kelsen, Reine Rechtslehre, a.w., p. 198/199.

25. H.L.A. Hart, The concept of Law, a.w., p. 90 en 91 .

26. Nl. organen die belast zijn met wetgeving, bestuur en rechtspraak.

27. Van Eikema Hommes heeft in dit kader benadrukt dat de aanduidingen 'primair' en 'secundair' niet erg gelukkig zijn, omdat zij een zekere rangorde impliceren. Beide normtypen zijn echter gelijkwaardig en komen gelijktijdig in iedere (ontwikkelde) rechtsorde voor. H.J. van Eikema Hommes, De samengestelde grondbegrippen der rechtswetenschap, Zwolle 1976, p. 55.

28. H.L.A. Hart, The concept of law, a.w., p. 92.

29. Vgl. de opmerking van bijv. Van Eikema Hommes over Harts secundaire normen: 'Deze secundaire rechtsregels verschaffen, zo zouden wij in onze eigen terminologie kunnen zeggen, de competentie tot rechtsvorming van de rechtsorganen, en geven aan, op welke wijze en binnen welke grenzen deze organen hun rechtsmacht kunnen uitoefenen' (curs. R.J.N.S.). H.J. van Eikema Hommes, De samengestelde grondbegrippen der rechtswetenschap, a.w, p. 54.

30. Hart onderscheidt drie soorten 'secundaire normen', $\mathrm{nl}$. (1) 'rules of recognition', (2) 'rules of change 'en (3) 'rules of adjudication'. De eerste soort 'rules' biedt een normatief referentiekader aan de hand waarvan kan worden vastgesteld of bepaalde primaire normen tot een rechtsstelsel behoren (en derhalve 'gelding' hebben). Op basis van de tweede soort kan worden vastgesteld wie - en onder welke voorwaarden primaire normen kan veranderen of vormen. 'Rules of adjudication' verschaffen tenslotte helderheid omtrent de vraag wie mag vaststellen of primaire normen zijn geschonden. Zie: H.L.A. Hart, The concept of law, a.w., p. $92 \mathrm{t} / \mathrm{m}$ 96. In dit kader zijn de statelijke hoofdfuncties van wetgeving, bestuur en rechtspraak te herkennen. 
stelsel van competentienormen (de typische 'Normstufenbau'). Vanuit normtheoretisch oogpunt is een dergelijk stelsel van competentienormen van bijzonder belang voor de dynamiek van een positief rechtsstelsel. Hierbij dient overigens direct de kanttekening te worden geplaatst dat deze 'positivering' niet verabsoluteerd mag worden in die zin dat alle op formeel geldige wijze tot stand gebrachte rechtsnormen ook geacht kunnen worden in overeenstemming te zijn met de materiële rechtsgrondslagen en beginselen van een rechtsorde. ${ }^{31}$ Zoals in hoofdstuk 3 van dit boek zal worden betoogd dient het proces van gerichte (publieke) rechtsvorming - en het daaraan ten grondslag liggende proces van belangenafweging door competente statelijke (bestuurs)organen - steeds beschouwd te worden tegen de achtergrond van materiële rechtsbeginselen die aan het positieve recht ten grondslag liggen. Deze materiële rechtsbeginselen structureren het statelijke rechtsvormingsproces, en verankeren genoemd proces in de typische - cultuurhistorisch bepaalde aard van de publieke rechtsorde. ${ }^{32}$

\subsubsection{Normcondities en toepasselijkheidsdomein}

Indien de notie van beperktheid van rechtsbevoegdheid ${ }^{33}$ in het licht van het bovenstaande nader wordt beschouwd, dan kan worden vastgesteld dat de vorming van nieuw positief recht door een orgaan in beginsel uitsluitend kan plaatsvinden op basis van een specifieke (objectiefrechtelijke) bevoegdheids- of competentienorm. ${ }^{34}$ Deze bevoegdheidsnorm vormt

31. Ook door 'positivisten' wordt wel erkend dat er naast geldig positief recht enerzijds en moraal anderzijds bepaalde fundamentele uitgangspunten zijn die ten grondslag liggen aan positief recht. Vgl. bijv. Hart, The concept of law, a.w., p. $199 \mathrm{t} / \mathrm{m}$ 195. Hart onderscheidt hiertoe een aantal 'truisms' (onbetwiste waarheden) die nauw samenhangen met fundamentele rechtsbeginselen, waaronder het gelijkheidsbeginsel, het respecteren van de menselijke waardigheid en het erkennen van eigendom. Vgl. ook: C.A.J.M. Kortmann, Positivisme, soevereiniteit en recht (rede), NJB 1997/11, p. 484.

32. Zie: R.J.N. Schlðssels, Wettelijk onrecht en bovenwettelijk recht: een reactie, Anti-Nomoi, RegelMaat $1997 / 2$, p. 80 e.v. Zonder diepgaand in de controverse tussen natuurrechtsleer en rechtspositivisme te treden, zal in dit boek als uitgangspunt worden genomen de idee dat rechtspositivering (het formele geldingsaspect) en rechtsbeginselen (het materikle geldingsaspect) elkaar veronderstellen. De inhoud van het positieve recht is derhalve in deze optiek niet exclusief afhankelijk van niet-juridische factoren (politiek, waarden en moraal) zoals het rechtspositivisme in essentie leert. Het positieve recht vindt zijn fundament en verankering daarentegen in materiele rechisbeginselen. Vgl. H.J. van Eikema Hommes, De samengestelde grondbegrippen der rechtswetenschap, a.w., p. 25. Idem: H.J. van Eikema Hommes, De elementaire grondbeginselen der rechtswetenschap, Deventer 1972, p. 355 en 356. Vgl. ook het bekende standaardwerk van Dworkin (Taking rights seriously, a.w.) waarin de complexe relatie tussen positiefrechtelijke regels enerzijds en rechtsbeginselen anderzijds uitvoerig wordt geanalyseerd. Zie voor een heldere en beknopte schets van deze problematiek: A. Soeteman, Hercules aan het werk. Over de rol van rechtsbeginselen in het recht, in: Rechtsbeginselen, AAe 1991/10, p. $28 \mathrm{t} / \mathrm{m}$ 40. Zie voorts hoofdstuk 3 van dit boek.

33. In deze paragraaf wordt in algemene zin over 'rechtsbevoegdheid' gesproken. Het gestelde vormt evenwel i.h.b. een normtheoretische basis voor de hiema te bespreken 'rechtsbevoegdheid' of 'competentie' in het publiekrecht.

34. Waarmee nog niet vaststaat dat een competentienorm steeds op een specifiek wettelijk voorschrift dient te berusten (het legaliteitsaspect). Zie in dit kader hoofdstuk 4 van dit boek. 
de primaire determinant voor het indelen van nieuw gevormde gedragsnormen in geldige en ongeldige. Met andere woorden: de geldigheid van primaire rechtsnormen dient getoetst te worden aan de secundaire bevoegdheidsnorm, die hiervoor het primaire en tevens speciale toetsingskader aanreikt. Dit toetsingskader ligt besloten in de structurele kenmerken van de (secundaire) competentienorm, die als formele geldingsgrond fungeert.

Rechtssubjecten hebben als adressaten van (mogelijke) gedragsnormen belang bij een geldigheidstoets. Ruiter ${ }^{35}$ merkt hier het volgende over op:

\begin{abstract}
'Adressaten van wettelijke competentienormen worden niet onmiddellijk met deze normen zelf geconfronteerd, maar met krachtens haar geschapen gedragsnormen. Als adressaten van gedragsnormen hebben zij slechts belang bij competentienormen waarop deze berusten voorzover zij - of anderen ten behoeve van hen - aan de hand van die competentienormen kunnen nagaan of de tot hen geadresseerde gedragsnormen onaantastbaar geldig zijn. Voor hen biedt de wettelijke competentie op grond waarvan gedragsnormen zijn vastgesteld, een maatstaf om te beoordelen of de besiuiten tot vaststelling van die gedragsnormen de voor onaantastbare geldigheid benodigde eigenschappen hebben.'
\end{abstract}

In navolging van rechtstheoreticus Ross ${ }^{36}$ verdeelt Ruiter ${ }^{37}$ de structuurkenmerken van competentienormen in een drietal hoofdgroepen: (A) personele, (B) formele en (C) materiële. ${ }^{38}$ De structuurkenmerken kunnen worden gezien als de condities waaraan voldaan dient te zijn voordat de op grond van een competentienorm tot stand gebrachte gedragsnormen als geldig kunnen worden aangemerkt. ${ }^{39}$

35. D.W.P. Ruiter, Bestuursrechtelijke wetgevingsleer, Assen/Maastricht 1987, p. 243.

36. A. Ross, Directives and norms, London 1968, p. 130. Ross stelt in dit kader: 'The norm which establishes this ability is called a norm of competence. It states the conditions necessary for the exercise of this ability. These conditions usually fall into three groups: (1) those wich prescribe what person (or persons) is qualified to perform the act which creates the norm (personel competence); (2) those which prescribe the procedure to be followed (procedural competence); and (3) conditions which prescribe the possible scope of the created norm with regard to its subject, situation, and theme (substantial competence).'

37. D.W.P. Ruiter, Bestuursrechtelijke wetgevingsleer, a.w., p. 233 e.v.

38. Andere indelingen zijn ook mogelijk. Zo maken Addink en Steenbergen een onderscheid tussen materiele beperkingen (d.w.z. beperkingen die zien op de inhoud van het te nemen rechtsbesluit) en formele beperkingen (d.w.z. beperkingen die zien op de procedure van de bevoegdheidsuitoefening). Daarnaast onderscheiden zij algemene beperkingen van de bevoegdheid. Hieronder rekenen zij o.m. de vorm waarin rechtsbesluiten genomen moeten worden (bijv. algemene regels of beschikking), en de voorwaarden waarvan de uitoefening van een bevoegdheid afhankelijk is gesteld. Zie: G.H. Addink en J.D.M. Steenbergen, Beperkingen van bevoegdheden: Een onderzoek van administratieve wetgeving, Bestuurswetenschappen, 1985/7, p. 434. Vgl. in dit verband ook: R.J. Jue, Grondbeginselen van het recht, Groningen 1990, p. 39 en R.J. Jue, Vrijheid van besturen, R\&R, 1986/15, p. 143 e.v.

39. Deze indeling van de 'geldigheidscondities' voor de uitoefening van een bestuursbevoegdheid is zeker niet nieuw. Zo bespreekt C.W. van der Pot in zijn bekende artikel 'De vormen van het besturen' reeds de voorwaarden voor de rechtsgeldigheid van beschikkingen. Hij verdeelt deze in een viertal categorieën. (1) een beschikking moet afkomstig zijn van het bevoegde orgaan (personeel kenmerk); (2) de zich in de beschikking openbarende wilsverklaring moet zijn tot stand gekomen, zonder dat aan de wilsvorming gebreken hebben gekleefd; (3) de beschikking moet in de voorgeschreven vorm zijn gegeven (formeel kenmerk); (4) de beschikking moet een inhoud en doelstelling hebben, welke met de algemene regeling, waarop zij gebaseerd is, overeenstemt (materieel kenmerk). C.W. van der Pot, De vormen van het 
Het personele kenmerk ziet op de vraag aan wie rechtsbevoegdheid is toegekend. Rechtsbevoegdheid wordt binnen een rechtsstelsel steeds aan een speciale drager toegekend. In het bestuursrecht is dit het bestuursorgaan. ${ }^{40}$ Alleen deze drager, en niemand anders ${ }^{41}$ kan op grond van een competentienorm, die aan de betreffende rechtsbevoegdheid ten grondslag ligt, geldig recht vormen. Bijgevolg is het uitgesloten dat eenzelfde bevoegdheid tegelijkertijd toekomt aan verschillende dragers. ${ }^{42}$

De formele (of procedurele) kenmerken zien op de eisen die de competentienorm procedureel inkaderen. Een geldige uitoefening van een bevoegdheid kan bijv. afhankelijk zijn gesteld van het inwinnen van advies, het voeren van overleg, het verlenen van inspraak of het aanvragen van een verklaring van geen bezwaar bij een ander orgaan. Ook eisen die verband houden met de bekendmaking en afkondiging van besluiten kunnen gerekend worden tot de formele structuurkenmerken van competentienormen. Formele structuurkenmerken van een competentienorm zien in het bijzonder op de wijze waarop de bevoegdheid dient te worden uitgeoefend; zij kunnen niet gerekend worden tot de materiële 'harde kern' van een bevoegdheid. Formalisering van de bevoegdheidsuitoefening heeft met name tot doel een zorgvuldige uitoefening van een bevoegdheid ten opzichte van rechtssubjecten te waarborgen.

De materiële structuurkenmerken beperken het toepasselijkheidsdomein van de competentienorm daarentegen naar aard en inhoud van de vast te stellen gedragsnormen. In navolging van Addink en Steenbergen dient in dit verband het begrip 'beperking' niet zozeer te worden opgevat als het 'kleiner maken van de bevoegdheid' maar meer als het verduidelijken, het specificeren en het nauwkeurig omschrijven (van het toepassingsdomein) hiervan. ${ }^{43}$

De materiële kenmerken worden door Ruite ${ }^{44}$ in een drietal subcategorieën verdeeld. De eerste subcategorie omvat volgens Ruiter materiële kenmerken die zien op de structuureigenschappen van de gedragsnormen die op grond van de competentienorm tot stand kunnen worden gebracht. Zo kunnen gedragsnormen algemene regels inhouden, dan wel voorschriften toegespitst op een concreet geval. Ook kan de competentienorm aangeven of gedragsnormen het karakter dienen te hebben van verboden of geboden (de normmodaliteit).

De tweede subcategorie omvat materiële kenmerken waaruit begrenzingen voortvloeien ten aanzien van de inhoud van de tot stand te brengen gedragsnormen. De inhoud van de

besturen, in: Nederlandsch bestuursrecht, Alphen aan den Rijn 1932, p. 204 t/m 214.

40. Vgl. C.P.J. Goorden, Rechtsbevoegdheid in het bestuursrecht, a.w., p. 56.

41. Behoudens uiteraard in geval van geldige delegatie (overdracht) of mandaat van een bevoegdheid. Mandaat wijzigt overigens de bestaande bevoegdheidsstructuur niet.

42. Uiteraard kan aan verschillende dragers tegelijkertijd wel een soortgelijke bevoegdheid toekomen.

43. G.H. Addink en J.D.M. Steenbergen, Beperkingen van bevoegdheden, a.w., p. 433.

44. D.W.P. Ruiter, Bestuursrechtelijke wetgevingsleer, a.w., p. $235 \mathrm{t} / \mathrm{m} 238$. 
mogelijke gedragsnormen kan door de competentienorm begrensd worden naar plaats ${ }^{45}$, tijd en onderwerp (het 'normobject'). ${ }^{46}$ Addink en Steenbergen wijzen er in dit verband op dat een beperking naar onderwerp in bijna alle bevoegdheidsverlenende bepalingen voorkomt. ${ }^{47}$

De derde en laatste subcategorie van de materiële kenmerken omvat volgens Ruiter de 'functionele eigenschappen' van de bestuurlijke competentienorm. Voor het onderwerp van dit boek zijn dit de meest interessante beperkingen. Ruiter merkt hierover het volgende op: 'Tot deze subcategorie reken ik allereerst kenmerken die aangeven tot welk doel of ter behartiging van welk belang normzinnen kunnen worden vastgesteld met een beroep op de betrokken wettelijke competentie. (...) Zulke wettelijke specificaties vormen uitwerkingen van het beginsel van specialiteit van publiekrechtelijke competenties' (curs. R.J.N.S.). ${ }^{48}$

Binnen de interne structuur van een competentienorm wordt het specialiteitsbeginsel volgens Ruiter derhalve geoperationaliseerd door de aanduiding van het doel met het oog waarop de bevoegdheid mag en moet worden uitgeoefend. ${ }^{49}$ Het doel van een competentienorm geeft de richting aan waarin het bestuursorgaan zich in het kader van de bevoegdheidsuitoefening (de gerichte rechtsvorming) dient te begeven. ${ }^{\text {so }}$

45. Vgl. bijv. de vrijstellingsbevoegdheid van art. 19 Wet op de Ruimtelijke Ordening (WRO) die door burgemeester en wethouders uitsluitend kan worden uitgeoefend t.a.v. gebieden waarvoor een voorbereidingsbesluit geldt, dan wel een ontwerp bestemmingsplan ter inzage is gelegd. In dit kader kan voorts gewezen worden op de (bestuurs)bevoegdheid van organen van decentrale lichamen (bijv. gemeenten en waterschappen) die in de regel tot het eigen territoir is beperkt. Zie voor een uitzondering echter: HR 7 mei 1957, NJ 1957, 516 (polder Gelkenes). Vgl. ook: art. 8.2 lid 1 Wet milieubeheer. Burgermeester en wethouders van een gemeente waarin een inrichting geheel of in hoofdzaak is gelegen zijn vergunningverlenende instantie.

46. Het gaat hier om de klassieke indeling van (on)bevoegdheid naar 'ratione loci', 'ratione temporis' en 'ratione materiae'. Zie hierover: W.G. Vegting, Het Nederlands administratief recht I, a.w., p. $229 \mathrm{t} / \mathrm{m}$ 235.

47. G.H. Addink en J.D.M. Steenbergen, Beperkingen van bevoegdheden, p. 439. Zie voor een fraai voorbeeld uit de jurisprudentie waarin de beperking van een bevoegdheid naar onderwerp in het geding was: ABRS 7 oktober 1994, AB 1995, 12 (wijkcontainer Rheden). In casu was de vraag aan de orde of het plaatsen van een nieuwe afvalcontainer een activiteit was waarop een APV-ontheffingsbevoegdheid die o.m. zag op het opslaan van aan hun bestemming onttrokken voer- en vaartuigen en oude materialen - betrekking had. De Afdeling overwoog: 'Het gaat hier om een, als bouwwerk aan te merken, voorziening waarin huisvuil en gft-afval kan worden gedeponeerd. Die voorziening dient te worden onderscheiden van het daarin te werpen afval, voorzover dat al tot de in voornoemd artikellid genoemde zaken kan worden gerekend. Het voorgaande leidt tot de conclusie dat het bestreden besluit is genomen met miskenning van de reikwijdte van het in meergenoemd art. 147 eerste lid, neergelegde verbod.'

48. D.W.P. Ruiter, Bestuursrechtelijke wetgevingsleer, a.w., p. 237.

49. Tot deze derde subcategorie rekent Ruiter ook de materièle kenmerken van een competentienorm die de hiërarchische plaats van de tot stand gebrachte gedragsnormen bepalen ten opzichte van andere gedragsnormen binnen een rechtsstelsel. Simon ziet de hiermee verband houdende rangordebepalingen (voorrangsregels) ook als een uitwerking van het specialiteitsbeginsel. Zie zijn noot onder Vz. ARRS 26 februari 1990, AB 1991, 566. 
Resumerend kan op deze plaats worden vastgesteld dat het beperkte karakter van bevoegdheidsnormen in belangrijke mate tot uitdrukking komt in wat Ruiter noemt het toepasselijkheidsdomein van een competentie. De materiële kenmerken van een competentienorm specificeren dit toepasselijkheidsdomein op een normtypische, norminhoudelijke en normfunctionele wijze. ${ }^{51}$ Ruiter leidt uit deze conclusie tevens een opdracht aan de wetgever af om bij het ontwerpen van competentievestigende bepalingen steeds na te gaan in hoeverre de omschreven elementen van het toepasselijkheidsdomein expliciet behoren te worden gemaakt. ${ }^{52} \mathrm{Ik} z a l$ in hoofdstuk 4 nader op deze specificeringsplicht voor de wetgever ingaan:

\subsection{Rechtsbevoegdheid in het publiekrecht}

$\mathrm{Na}$ deze globale normtheoretische verkenning van competentienormen kan het 'rechtsbevoegdheid'-begrip in het publiekrecht nader worden omlijnd. In de literatuur worden vele definities van publiekrechtelijke bevoegdheid aangetroffen die hier niet uitputtend besproken worden. ${ }^{53}$ Volstaan wordt met enige representatieve opvattingen.

\subsection{1 'Public authority' en beïnvloeding}

Rechtstheoreticus Ross omschrijft 'competence' als '...the legally established ability to create legal norms (or legal effects) through and in accordance with enunciations to this effect'. ${ }^{\text {s4 }}$ Bevoegdheidsnormen die 'public authority' creëren onderscheiden zich volgens Ross van andere bevoegdheidsnormen doordat zij slechts macht (power) in het leven roepen voor bepaalde personen: 'The substance of this power is a capacity to create rules that bind others.' Van belang is dat publiekrechtelijke bevoegdheid volgens Ross steeds dienstbaar is aan de (publieke) gemeenschap ('common weal'), doordat de bevoegdheid wordt aangewend om bepaalde doelstellingen voor die gemeenschap te verwezenlijken. ${ }^{5 s}$ Volgens Ross is voorts kenmerkend voor publiekrechtelijke bevoegdheid dat deze niet 'transferable' is. Hiermee bedoelt hij niet dat delegatie (overdracht) niet tot de mogelijkheden behoort, maar dat rechtsbevoegdheid in het publiekrecht niet vervreembaar is aan een willekeurige kring van personen.

50. Vgl. Addink en Steenbergen die de doelstelling van een bevoegdheid beschouwen als een zeer wezenlijke beperking: 'De doelstelling vormt $\mathrm{nl}$. een criterium waaraan het bevoegde orgaan zijn voorgenomen besluit moet toetsen, een richtsnoer dat het moet toepassen.' G.H. Addink en J.D.M. Steenbergen, Beperkingen van bevoegdheden, a.w., p. 438.

51. D.W.P. Ruiter, Bestuursrechtelijke wetgevingsleer, a.w., p. 238.

52. D.W.P. Ruiter, Bestuursrechtelijke wetgevingsleer, a.w., p. 238.

53. Het begrip 'publiekrechtelijke bevoegdheid' kan o.m. vanuit normtheoretische, sociologische en juridische invalshoek worden benaderd. In deze paragraaf ligt de nadruk op de juridische betekenis.

54. A. Ross, Directives and norms, a.w., p. 130.

55. Hier is de legitimerende functie van het (staats)recht in het geding die met zich brengt dat feitelijke (politieke) heersmacht wordt getransformeerd tot publieke, ambtelijke bevoegdheid. Ik kom hier in de hoofdstukken 3 en 4 op terug. Vgl. C.A.J.M. Kortmann, Constitutioneel recht, geheel herziene derde druk, Deventer 1997, p. 6-7. 
Van Maarseveen ${ }^{36}$ analyseert het begrip (rechts)-bevoegdheid in het publiekrecht aan de hand van een drietal aspecten: (1) het aspect van de invloedsuitoefening als inhoudelijke kern, (2) het aspect van de fundering, d.w.z. de rechtsgrondslag of het juridische fundament van de bevoegdheid en (3) het aspect van de rechtmatigheid, d.w.z. de juridische normering van de invloedsuitoefening en het voldoen bij de bevoegdheidsuitoefening aan die normering.

In deze paragraaf gaat met name de aandacht uit naar het eerste aspect. Volgens Van Maarseveen is de kern van het bevoegdheidsbegrip in het publiekrecht gelegen in het uitoefenen van invloed op het gedrag van anderen met de opzet dat daardoor de verwerkelijking van een bepaalde doelstelling dichterbij wordt gebracht. ${ }^{57}$ Het wezen van publiekrechtelijke bevoegdheden is volgens deze auteur gelegen in de mogelijkheid om gedragsalternatieven van rechtssubjecten - de dragers van zelfstandige rechten en plichten - te beïnvloeden.

Deze definitie van Van Maarseveen is ruim en meer sociaalwetenschappelijk dan juridisch omlijnd. Voordeel van deze definitie is dat geabstraheerd wordt van de relatie bevoegdheidsuitoefening-vrijheidsbeperking, zoals Van Maarseveen zelf signaleert. Bevoegdheidsuitoefening kan immers zowel vrijheidsverruiming als vrijheidsbeperking met zich brengen. ${ }^{58}$ Zo wordt door de toekenning van subsidie bijv. een publiekrechtelijke randvoorwaarde gecreëerd om bepaalde gewenste (feitelijke) activiteiten beter te kunnen ontplooien. Bovendien zijn er diverse bevoegdheden die in het geheel geen direct gevolg hebben voor de vrijheid van rechtssubjecten. In dit verband kan bijv. gedacht worden aan typische adviesbevoegdheden.

\subsubsection{Een nadere juridische omlijning}

Steenbeek benadert in zijn proefschrift de rechtsbevoegdheid in het publiekrecht meer juridisch, waarbij hij het typische karakter van publiekrechtelijke bevoegdheid als volgt karakteriseert:

\footnotetext{
'De grenzen van publiekrechtelijke bevoegdheden worden in beginsel door het positieve recht aangegeven en vormen een integrerend deel van de staatsinrichting.(..) Nu kan men een bevoegdheid uiteraard nooit op zichzelf bezien. Bevoegdheid betekent in rechte altijd een relatie tot een bepaalde rechtsmaterie. Bevoegdheid tot rechtshandelen wil dan ook zeggen bevoegdheid tot het teweegbrengen van bepaalde rechtsgevolgen. ${ }^{59}$
}

Stroink en Steenbeek definiëren het begrip (overheids)bevoegdheid als de bevoegdheid om positief recht vast te stellen en te handhaven. Het begrip bevoegdheid in juridische zin wordt door hen omschreven als een ingevolge de wet toegekend vermogen om rechtsge-

56. H. van Maarseveen, Bevoegdheid, a.w., p. 66 e.v.

57. H. van Maarseveen, Bevoegdheid, a.w., p. 65.

58. In hoofdstuk 4 kom ik hier bij de bespreking van het legaliteitsbeginsel op terug.

59. J.G. Steenbeek, Rechtshandeling en rechtsgevolg in het staats- en bestuursrecht, diss. UU, Amhem 1958, p. 19 en 20. 
volgen te bewerkstelligen.$^{60}$ In zijn dissertatie omschrijft Stroink het begrip bevoegdheid als 'het juridisch vermogen van een persoon' ${ }^{61}$ In vervolg hierop wordt door hem onder publiekrechtelijke bevoegdheid verstaan het juridisch vermogen van een ambt. Vanuit deze optiek bezien ligt de kern van het publiekrechtelijke 'bevoegdheidsbegrip' in de mogelijkheid om de positie van rechtssubjecten ten opzichte van het objectieve recht bindend vast te stellen of te wijzigen. Evenals Van Maarseveen onderscheidt Stroink het vraagstuk van de inhoudelijke kenmerken van bevoegdheid van de leerstukken van bevoegdheidstoekenning en bevoegdheidsuitoefening. ${ }^{62}$ In dit verband is van belang dat Stroink onder de bevoegdheid van een ambt niet alleen verstaat de publiekrechtelijke rechten van een ambt, maar ook de publiekrechtelijke plichten. Kenmerk van een publiekrechtelijke bevoegdheid is dat deze altijd meer of minder gebonden is aan geschreven en geheel gebonden aan ongeschreven recht. Stroink definieert publiekrechtelijke bevoegdheid als het geheel van publiekrechtelijke rechten en plichten van een ambt, waarbij het (rechts)handelen krachtens publiekrecht centraal staat. ${ }^{63}$ Het betreft hier - wat kan worden aangeduid als - 'de ruime betekenis van bevoegdheid' in het publiekrecht. ${ }^{64}$

Goorden gaat in zijn proefschrift uit van wat hij, in navolging van Stroink, noemt de 'beperkte betekenis' van het begrip publiekrechtelijke bevoegdheid. Publiekrechtelijke (rechts)bevoegdheid heeft in deze visie betrekking op het éénzijdig bepalen van de rechtspositie van rechtssubjecten. In Goordens optiek gaat het hierbij om de totstandkoming van bestuursrechtelijke rechtsbetrekkingen. ${ }^{65}$ Stroink spreekt in dit verband van 'de bevoegdheid tot het verrichten van publiekrechtelijke rechtshandelingen' ${ }^{66}$ Goorden sluit zich in wezen bij deze definitie aan door voorop te stellen dat 'door de uitoefening van bestuursrechtelijke bevoegdheden positief recht voor andere rechtssubjecten wordt gecreëerd' ${ }^{67}$

60. F.A.M. Stroink en J.G. Steenbeek, Inleiding in het staats- en administratief recht, vierde herziene druk, Alphen aan den Rijn 1989, p. 30.

61. F.A.M. Stroink, Het leerstuk der deconcentratie, diss. UU, 's-Gravenhage 1978, p. 20.

62. F.A.M. Stroink, Het leerstuk der deconcentratie, a.w., p. 20; Stroink onderscheidt ook nog het leerstuk van de rechtsgevolgen van de bevoegdheidsuitoefening. Hieronder verstaat hij "het geheel van rechten en/of plichten dat op een burger, groep van burgers, of ambt(en) komt te liggen'.

63. F.A.M. Stroink, Het leerstuk der deconcentratie, a.w. p. 21.; zie in dit verband ook C.P.J. Goorden, Rechtsbevoegdheid in het bestuursrecht, a.w., p. 55. Goorden vestigt er de aandacht op dat een bevoegdheid zodanig kan zijn genormeerd, dat er in feite alleen nog maar sprake kan zijn van een publieke plicht tot uitoefening.

64. Vgl. De Haan/Drupsteen/Fernhout, Bestuursrecht in de sociale rechtsstaat, Deel I, a.w., p. 205.

65. C.P.J. Goorden, Rechtsbevoegdheid in het besturursrecht, a.w., p. 54. Zie over de bruikbaarheid van het begrip 'rechtsbetrekking' in het bestuursrecht paragraaf 2.5 .4 e.v. van dit hoofdstuk.

66. F.A.M. Stroink, Het leerstuk der deconcentratie, a.w., p. 21. Een iets afwijkende definitie, die wél in dezelfde lijn ligt, wordt aangetroffen bij Addink en Steenbergen, die publiekrechtelijke bevoegdheid definieren als 'het vermogen van een bestuursorgaan tot het geven van rechtsbeslissingen, dus van beslissingen die het vaststellen, wijzigen, ongedaan maken van rechtsposities van burgers of ambten kunnen inhouden'. G.H. Addink en J.D.M. Steenbergen, Beperkigen van bevoegdheden: een onderzoek van administratieve wetgeving, Bestuurswetenschappen, 1985/7, p. 433.

67. C.P.J. Goorden, Rechtsbevoegdheid in het bestuursrecht, a.w., p. 59 . 
Vervolgens beschrijft hij in zijn proefschrift een drietal hoofdkenmerken van publiekrechtelijke bevoegdheid onder de kopjes 'openbaar belang', 'openbaar gezag' en 'wetmatigheid'. ${ }^{68}$ Bestuursrechtelijke bevoegdheden zijn volgens Goorden steeds gebonden aan de behartiging van openbare belangen. Bijgevolg kan bij de uitoefening van deze bevoegdheden nooit sprake zijn van een volledige vrijheid. Voorzover er al sprake is van 'vrijheid' in het kader van de bevoegdheidsuitoefening geeft hij er de voorkeur aan om te denken in termen als 'plichtgemäßes Ermessen' of 'rechtlich gebundenes Ermessen'. De uitoefening van bestuursrechtelijke bevoegdheid impliceert volgens Goorden dat er sprake is van 'openbaar gezag'. Hiervan is sprake indien overheidsmacht tot het éénzijdig en bindend vaststellen van rechtsposities van rechtssubjecten op het recht steunt of door het recht wordt gereglementeerd. Tot slot brengt Goorden het rechtskarakter van de publiekrechtelijke bevoegdheid expliciet in verband met het wetmatigheidsbeginsel. Dit beginsel geldt traditioneel voor alle bestuursbevoegdheden met gebruikmaking waarvan kan worden ingegrepen in de rechten en vrijheiden van burgers (Eingriffsverwaltung). Maar ook ten aanzien van typische 'Leistungsverwaltung' concludeert Goorden dat wetmatigheid hier vanuit een oogpunt van rechtszekerheid en gelijkheid wenselijk is.

\subsubsection{Publiekrechtelijke bevoegdheid en bevoegd handelen}

Op deze plaats is het, gelet op het voorafgaande, voor een goede definitie-afbakening van het publiekrechtelijke bevoegdheidsbegrip zinvol om een onderscheid te maken tussen een juridische bevoegdheid en feitelijk bevoegd handelen. Bevoegd handelen kan in algemene zin omschreven worden als handelen in overeenstemming met geschreven en ongeschreven regels en beginselen van het positieve recht. Een persoon die bijv. op basis van de Wet wapens en munitie een verlof heeft verkregen tot het voor handen hebben van een bepaald vuurwapen oefent géén (publiekrechtelijke) bevoegdheid uit, maar handelt bevoegd. Het feit dat bevoegd wordt gehandeld is dan overigens wél het gevolg van een bevoegdheidsuitoefening op grond van artikel 28 van de genoemde wet door het Hoofd van de plaatselijke politie. Deze kan immers het verlof verlenen of weigeren.

\subsubsection{Publiekrechtelijke bevoegdheid en het begrip 'uitvoering'}

Soms is het onderscheid tussen bevoegd handelen door het bestuur ter uitvoering van algemeen verbindende voorschriften en het daadwerkelijk uitoefenen van een zelfstandige publiekrechtelijke bevoegdheid niet helder. Onduidelijkheid ontstaat indien uitvoeringshandelingen welke door bestuursorganen worden verricht bepaalde kenmerken aannemen van het uitoefenen van een zelfstandige publiekrechtelijke bevoegdheid. In dit kader dient de aandacht te worden gevestigd op het nogal verwarrende jurisprudentiële begrip 'uitvoe-

68. C.P.J. Goorden, Rechtsbevoegdheid in het bestuursrecht, a.w., p. $60 \mathrm{t} / \mathrm{m} 66$. 
ring'. ${ }^{69}$ Als 'uitvoering' wordt in dit verband aangemerkt het rechtens toelaatbare 'regelgevende' of 'beschikkende' handelen door een bestuursorgaan ter concretisering en detaillering van bepaalde algemeen verbindende voorschriften om de vereiste werking van deze voorschriften te verzekeren, zonder dat deze uitvoeringshandelingen - ook wel genoemd uitvoeringsbevoegdheden ${ }^{70}$ - bij de wet in formele zin zijn voorzien. ${ }^{71}$ Derks $^{72}$ omschrijft - in meer beperkte zin - 'uitvoeringsregels' als 'regels die een bestuursorgaan stelt bij de uitvoering van wettelijke voorschriften, niet zijnde algemeen verbindende voorschriften' (curs. J.D). Hiermee beoogt zij kennelijk 'uitvoeringshandelingen' met een regelgevingskarakter te ecarteren. Deze beperkte definitie sluit echter niet geheel aan bij het jurisprudentiële 'uitvoerings'-begrip. Ook in de literatuur is het begrip wel anders gedefinieerd. Zo merkt Kortmann bij zijn bespreking van de Grondwettelijke delegatieterminologie over 'uitvoering' het volgende op: 'Daar waar een ambt door de wetgever gebonden bevoegdheden tot het geven van regelen of het nemen van besluiten met concrete werking krijgt toegekend is er geen sprake van delegatie, doch van uitvoering. Aldus hangt het antwoord op de vraag of er sprake is van delegatie dan wel het toekennen van uitvoeringsbevoegdheden af van de mate van gebondenheid van het ambt waaraan bevoegdheden worden overgedragen of worden toegekend' (curs. R.J.N.S.). ${ }^{73}$

Het fenomeen 'uitvoeringsbevoegdheid' is in rechtsstatelijke nevelen gehuld. Stroink kenschetste de constructie van uitvoering als 'een uitzondering op, of zo men wil, een verbijzondering van het beginsel van wetmatigheid van bestuur'. ${ }^{74}$ Door de uitvoeringsconstructie kunnen bepaalde 'bevoegdheden' voor het bestuur overeind blijven zonder dat de wetgever deze (expliciet) heeft beoogd toe te kennen. Wil een uitvoeringsbevoegdheid toelaatbaar zijn, dan mag zij in ieder geval niet het karakter hebben van een zelfstandige discretionaire beschikkingsbevoegdheid of een (niet gebonden) regelgevende bevoegdheid. Voor het bewerkstelligen van de burgers bindende normstelling ${ }^{75}$ door middel van regels of door voorschriften in concreto, geldt binnen het Nederlandse recht immers in essentie het vereiste dat (bestuurs)bevoegdheden hiertoe herleidbaar moeten zijn tot een formeel-

69. Zie over het begrip uitvoering: F.A.M. Stroink, Het leerstuk der deconcentratie, a.w., p. 112 e.v. (paragraaf 6.2); zie voorts: J.M.E. Derks, De Grondwet en delegatie. Het delegatievraagstuk in constitutioneel perspectief, diss. RL, Maastricht 1995, m.n. hoofdstuk 7 dat geheel aan het onderscheid regelgeving-uitvoering is gewijd.

70. Vgl. F.A.M. Stroink, Beginsel van wetmatigheid van bestuur en het begrip uitvoering, Afd. RRvS contra HR?, TvO 1983/9, p. 204. Zie ook Stroinks annotatie onder HR 25 januari 1926, NJ 1926, p. 246, m.nt. L. Besier (Petroleumkachels Jamin) in AB Klassiek, derde druk, Deventer 1997, p. 45.

71. Vgl. Burkens/Kummeling/Vermeulen/Widdershoven, Beginselen van de democratische rechtsstaat, vierde druk, Deventer 1997, p. 78.

72. J.M.E. Derks, De Grondwet en delegatie, a.w., p. 162 en 163. Derks hanteert hier, zoals zij zegt, een beperkte definitie van dit begrip. In haar optiek staat 'uitvoering' tegenover 'regelgeving'. Onder regelgeving verstaat $z \mathrm{ij}$ het stellen van algemeen verbindende voorschriften (zie ook a.w., p. 8 en 9).

73. C.A.J.M. Kortmann, Constitutioneel recht, geheel herziene derde druk, Deventer 1997, p. 319-320.

74. F.A.M. Stroink, Beginsel van wetmatigheid van bestuur en het begrip uitvoering, a.w., p. 204.

75. Ik reserveer het begrip '(rechts)norm' in dit boek niet exclusief voor het aanduiden van een 'algemeen bindende rechtsregel in abstracto'. 
wettelijke grondslag. ${ }^{76}$ Rechtsnormen die door een bestuursorgaan ter 'uitvoering' van regels worden gesteld lijken bijgevolg een praktische restcategorie, maar tegelijkertijd een rechtsstatelijke anomalie. De erkenning van niet-wettelijke 'uitvoeringsbevoegdheden' blijft vanuit rechtsstatelijk oogpunt dubieus. Stroink liet zich in dit kader de uitspraak ontvallen dat wij de uitvoeringsconstructie kunnen missen als kiespijn. ${ }^{77}$ Het begrip is bijzonder vaag en werkt een onduidelijke bestuurlijke bevoegdhedenstructuur in het publiekrecht in de hand. ${ }^{78}$

\subsection{Publiekrechtelijke en privaatrechtelijke '(rechts)bevoegdheid'}

Publiekrechtelijke bevoegdheid dient strikt onderscheiden te worden van privaatrechtelijke 'rechtsbevoegdheid'. Het specialiteitsbeginsel wordt in dit boek beschouwd als een typisch beginsel dat ten grondslag ligt aan publiekrechtelijke bevoegdheid. Naar algemeen wordt aangenomen ligt genoemd beginsel niet ten grondslag aan privaatrechtelijke 'bevoegdheid'. ${ }^{79}$ Ik kom hier op terug.

Het onderscheid tussen publiek- en privaatrechtelijke bevoegdheden kan gemaakt worden aan de hand van een aantal onderscheidende criteria, die hierna worden toegelicht.

\subsubsection{Beperktheid, doelgebondenheid en traceerbaarheid}

Een algemeen kenmerk van publiekrechtelijke bevoegdheid is de inherente beperktheid ervan. Rechtstheoreticus Ross brengt dit als volgt onder woorden: 'Power is not assigned to public authorities to be exercised as they chose, but only in accordance with established

76. Vgl. hoofdstuk 4. Zowel voor bindende normstelling in de vorm van 'regelgeving' als in de vorm van 'beschikkingsvoorschriften'. Vgl. HR 26 november 1957, NJ 1958, 53 (Vuurwerkarrest) en HR 25 januari 1926, NJ 1926, p. 246, m.nt. L. Besier (Jamin). Vgl. t.a.v. beschikkingsbevoegdheid ook nog het Methadonbrief-arrest (HR 27 juni 1986, NJ 1987, 898, m.nt. MS). In beginsel omdat in de jurisprudentie ook wel (regelgevende) bevoegdheid is aangenomen zonder een overtuigende herleidbaarheid tot de wet in formele zin. Zie bijv. HR 8 mei 1953, NJ 1953, 614 (Distributiewetarrest).

77. In zijn noot onder het arrest inzake de 'Petroleumkachels Jamin' in AB Klassiek, a.w., p. 47.

78. Ter illustratie van deze stelling kan het bekende 'Bromfietsvalhelm-arrest' dienen waarin de Hoge Raad - op de keper beschouwd - een onbevoegd door de Kroon ge(sub)delegeerde 'regelgevende bevoegdheid' van de minister op grond van het Reglement Verkeerstekens en Verkeersregels (oud) sauveerde dopr middel van de uitvoeringsconstructie. HR 11 januari 1977, NJ 1977, 467 (Bromfietsvalhelm-arrest). Vgl. de conclusie van A-G Kist bij dit arrest, die er kennelijk van uitging dat er sprake was van ongeoorloofde (sub)delegatie van regelgevende bevoegdheid door de Kroon aan de minister.

79. Vgl. B. van der Meulen, De normering van het feitelijk handelen der overheid, NTB 1991/9, p. 268. Zie voor een meer uitgebreide bespreking van het 'legaliteits- en specialiteitsgebrek' in het privaatrecht: M.H. Kobussen, De vrijheid van de overheid, diss. KUB, Zwolle 1991, p. 103 t/m 118; idem: M. Kobussen, Een privaatrechtelijke legaliteitseis? De wissel(werking) tussen het legaliteitsbeginsel en het ongeschreven recht bij privaatrechtelijk overheidshandelen, NTB 1989/4, m.n. p. 100/101 en p. 105/106. Vgl. voorts A.Q.C. Tak, Terugtocht van twee wegen, NTB $1989 / 9,10$, p. 304 en 305 , alsmede A.Q.C. Tak, De overheid in het burgerlijk recht, 's-Gravenhage 1997, p. 111. Zie tot slot: De Haan/Drupsteen/Fernhout, Bestuursrecht in de sociale rechtsstaat I, a.w., p. 446. 
rules or presupposed general principles. ${ }^{80}$ Zoals vermeld, vormen publiekrechtelijke bevoegdheden volgens Steenbeek een integrerend deel van de staatsinrichting. ${ }^{81}$ Dit blijkt in het bijzonder uit het feit dat publiekrechtelijke bevoegdheid zich hecht aan ambten die uitdrukkelijk van de ambtsdragers dienen te worden onderscheiden:

'Deze ambtsdragers oefenen bevoegdheden uit, die behoren tot het ambt, en waarvan daarmede tevens de begrenzing is gegeven. Een algemene bevoegdheid is daar dan ook niet de regel, doch de beperktheid is inherent aan het ambt. ${ }^{82}$

Rechtsbevoegdheid in het publiekrecht wordt niet in algemene zin verondersteld, zoals bijv. handelingsbekwaamheid in het privaatrecht, doch dient in de regel expliciet - door de wetgever - aan een publiekrechtelijke drager te zijn toegekend voor een speciaal (publiekrechtelijk) doel. ${ }^{83}$ De aard en omvang van bevoegdheid verschilt in het publiekrecht bijgevolg per ambt. ${ }^{84}$ Hiermee houdt verband dat, zoals Goorden het in zijn proefschrift treffend uitdrukte, overheidsinstanties bij hun taakvervulling niet verder kunnen springen dan de polsstok van hun bevoegdheid lang is. ${ }^{85}$ Publiekrechtelijke rechtsbevoegdheid is ambtelijke bevoegdheid die zonder vooringenomenheid op een onpartijdige wijze (vgl. artikel 2:4 Awb) dient te worden uitgeoefend ter behartiging van specifieke publieke belangen ${ }^{86}$ De psychologische wil van de ambtsdragers mag in het kader van de bevoegdheidsuitoefening géén rol spelen; de 'wilsuiting' door het bestuur wordt door het objectieve (geschreven en ongeschreven) publiekrecht bepaald en begrensd. ${ }^{87}$

80. A. Ross, Directives en norms, a.w., p. 131. Ross lijkt hier met name de gebondenheid van de overheidsorganen aan het recht in ruime zin op het oog te hebben. Onderdeel hiervan vort de bevoegdheidseis. Ik vestig in dit kader de aandacht op een heel treffende karakterisering van de beperktheid van publiekrechtelijke bevoegdheid in de democratische rechtsstaat door het Duitse Bundesverfassungsgericht: 'Die Erfullung offentlicher Aufgaben durch juristische Personen des offentlichen Rechts vollzieht sich in aller Regel nicht in Wahrnehmung unabgeleitener ursprunglicher Freiheiten, sondern auf Grund von Kompetenzen, die vom positiven Recht zugeordnet und inhaltlich bemessen und begrenzt sind (BVerfGe. 31 oktober 1984,68 , nr. 6).'

81. J.G. Steenbeek, Rechtshandeling en rechtsgevolg in het staats- en bestuursrecht, a.w., p. 19.

82. J.G. Steenbeek, Rechtshandeling en rechtsgevolg in het staats- en bestuursrecht, a.w., p. 19.

83. Vgl. art. 1:2 lid 2 Awb en art. 3:3 Awb.

84. Zie bijv.: W.G. Vegting, Het Nederlands administratief recht I, a.w., p. 174.

85. C.P.J. Goorden, Rechtsbevoegdheid in het bestuursrecht, a.w., p. 54.

86. Vgl. A.M. Donner, Nederlands bestuursrecht, Algemeen deel, vierde herziene druk, Alphen aan den Rijn 1974, p. 221 en 222. Donner karakteriseerde bestuursbevoegdheden als 'droits-fonction'; of om in de bekende woorden van Van der Hoeven te spreken 'De vrijheid van de burger is, althans in onze samenleving, in belangrijke mate cen 'vrijheid van'; vrijheid van het bestuur is altijd een 'vrijheid tot'. J. van der Hoeven, De grenzen van de rechterlijke functie in de administratieve rechtspraak, RMTh. 1974, p. 671.

87. Vgl. HR 26 juni 1964, AB 1965, p. 647 e.v. Zie voorts: R.M. van Male, Onvoltooid recht. Over rechtsbetrekking, bestuursrecht en bestuursprocesrecht (oratie), Zwolle 1993, p. 15. Van Male stelt hier: 'De bestuursrechtelijke besluitvorming ontleent zijn (haar R.J.N.S.) rechtskarakter aan de wet en deelt daarom in zijn objectiefrechtelijke karakter.' Daar de objectieve 'ordenende rechtswil' of 'ambtswil' van 
Op dit punt verschilt publiekrechtelijke bevoegdheid principieel van privaatrechtelijke bevoegdheid in het vermogensrecht. Tak en Simon ${ }^{88}$ hebben dit verschil mijns inziens treffend geanalyseerd vanuit de autonomie-gedachte. Rechtsbevoegdheid in privaat- en publiekrecht berust op twee verschillende rechtsgronden. In het privaatrecht fungeert de autonomie, d.w.z. de originaire vrijheid van de burger, als rechtsgrond voor handelingsbevoegdheid. Deze manifesteert zich, toegespitst op rechtshandelingen, als handelingsbekwaamheid. Daarnaast zijn er privaatrechtelijke rechtsbevoegdheden welke samenhangen met subjectieve (vermogens) rechten (bijv. de bevoegdheden van zakelijk gerechtigden). Rechtsbevoegdheid in het privaatrecht wordt niet expliciet toegekend doch is inherent aan de autonomie van ieder rechtssubject. Van bijzonder belang is dat het Burgerlijk Wetboek de uitoefening van privaatrechtelijke bevoegdheid erkent en reguleert, doch deze niet vestigt. ${ }^{89}$ Rechtssubjecten zijn in het privaatrecht in beginsel bekwaam en vrij om hun 'bevoegdheden' naar eigen inzicht uit te oefenen en om zo uitdrukking te geven aan hun eigen autonomie..$^{90}$ De belangrijkste grens van privaatrechtelijke bevoegdheden wordt gevormd door de autonomie van mede-rechtssubjecten. Zo is het bijv. ongeoorloofd om zich jegens hen onrechtmatig te gedragen, dan wel misbruik te maken van een eigen bevoegdheid waardoor de autonomie van medesubjecten op rechtens ontoelaatbare wijze wordt aangetast. In dit autonomie-kader kunnen ook de leerstukken van zaakwaarneming, ongerechtvaardigde verrijking en onverschuldigde betaling worden gepositioneerd. Vermogensverschuivingen zonder een afdoende materiële private rechtsgrond (d.w.z. rechtvaardiging vanuit de autonomie-gedachte) worden in het vermogensrecht niet toelaatbaar geacht.

een bestuursorgaan niet vergelijkbaar is met de subjectieve wil van een persoon (vgl. art. $3.33 \mathrm{BW}$ ), is de concipierring van een bevoegdheidsuitoefening in het publiekrecht als publiekrechtelijke 'rechtshandeling' (vgl. art. 1:3 Awb) dan ook minder gelukkig. Vgl. in dit kader o.m. J.G. Steenbeek, Rechtshandeling en rechtsgevolg in het staats- en administrief recht, a.w., p. $16 \mathrm{t} / \mathrm{m} 17$ en p. $32 \mathrm{vm} 34$; A.Q.C. Tak, Overheid en burgerlijk wetboek. Naar een invullende rechtsleer, Recht en kritiek 1993/2, p. 180 en A.Q.C. Tak, De overheid in het burgerlijk recht, 's-Gravenhage 1997, p. 55-56; H.J. Simon, Publiekrecht of privaatrecht?, diss. VU, Zwolle 1993, p. 114; Van der Burg/Cartigny/Overkleeft-Verburg, Rechtsbescherming tegen de overheid, vijfde druk, Nijmegen 1985, p. 102. Anders: W.G. Vegting, Het algemeen Nederlands administratief recht, eerste deel, Alphen aan den Rijn 1954, p. 238.

88. H.J. Simon en A.Q.C. Tak, Het BW als 'Zwart gat', De onttakeling van het publiekrecht door een 'gemene' rechter, NTBR 1994/8, p. 178. Voor een diepgravender analyse verwijs ik naar: H.J. Simon, Autonomie en 'verbintenis' in het publiekrecht: cen intern-rechtsvergelijkende analyse, In: Eenzijdig en wederkerig? (red. E.C.H.J. van der Linden en A.Q.C. Tak), Deventer 1995, m.n. p. $69 \mathrm{t} / \mathrm{m} 76 \mathrm{en} 83 \mathrm{t} / \mathrm{m}$ 93 en voor wat betreft het privaatrechtelijke autonomiebeginsel naar H.J. Simon, Publiekrecht of privaatrecht?, a.w., p. 88. Vgl. De Haan/Drupsteen/Fernhout, Bestuursrecht in de sociale rechtsstaat I, a.w., p. 96. Deze auteurs brengen het specialiteitsbeginsel i.v.m. het principiele verschil tussen privaatrechtelijke autonomie en publiekrechtelijke bevoegdheid.

89. Vgl. de visie van Teunissen die na een uitvoerige en gedetailleerde historische analyse tot deze conclusie komt. J.M.H.F. Teunissen, Het burgerlijk kleed van de staat. Beschouwingen over de tweewegenleer, diss. RL, Zwolle 1996, p. 114. In soortgelijke zin H.J. Simon, Publiekrecht of privaatrecht?, a.w., p. 88.

90. Gesignaleerd dient te worden dat een en ander niet geldt voor (interne) privaatrechtelijke 'bevoegdheden' binnen rechtspersonen. Voor de organen van privaatrechtelijke rechtspersonen geldt dat $\mathrm{zij}$ steeds gebonden zijn aan de interne aard en structuur van dit rechtsverband. 
Rechtsbevoegdheid in het publiekrecht wordt daarentegen, zoals vermeld, niet aanwezig verondersteld. De onbekwaamheid van de overheidsorganen staat in het publiekrecht centraal. Publiekrechtelijke rechtsbevoegdheid kan in beginsel ${ }^{91}$ uitsluitend verkregen worden door een expliciete toekenning van deze bevoegdheid volgens vaste regels en procedures van constitutioneel recht. Aan deze toekenning gaat in de regel een democratisch proces van belangenafweging vooraf. ${ }^{92}$ Simon en Tak merken in dit verband op: 'De "autonomie" van de overheid (voorzover dit woord in het bestuursrecht al op zijn plaats is) ontstaat niet van rechtswege, maar eerst door attributie door een daartoe constitutioneel bevoegd orgaan. ${ }^{.93}$ Aan de toekenning van publiekrechtelijke rechtsbevoegdheid in de democratische rechtsstaat liggen volgens de genoemde auteurs typisch structurerende rechtsbeginselen ten grondslag, waaronder het specialiteitsbeginsel: 'Een van de meest wezenlijke grondbeginselen uit het bestuursrecht is het specialiteitsbeginsel.(..) Het schrijft voor dat vrijheidsbeperkingen door het bestuur steeds dienen te rusten op expliciete, beperkte, specifieke bevoegdheidsgrondslagen' (curs. R.J.N.S.). ${ }^{94}$

Publiekrechtelijke bevoegdheden vormen de juridische kern van bijzondere en organieke publiekrechtelijke wetgeving. Hierdoor zijn publiekrechtelijke bevoegdheden in de regel duidelijk traceerbaar binnen het (objectieve) publiekrecht. Uit de bekende uitspraak inzake het 'Rotterdamse volkstuinencomplex' blijkt dat de voormalige Afdeling rechtspraak van de Raad van State deze traceerbaarheid van publiekrechtelijke bevoegdheid aanmerkte als essentieel..$^{95}$ Met de traceerbaarheid van publiekrechtelijke bevoegdheid hangt het aspect van de beperkte overdraagbaarheid (delegatie) ervan samen. Omdat publiekrechtelijke bevoegdheden expliciet voor het staatsgezag in het leven zijn geroepen om dienstbaar te zijn aan specifieke publiekrechtelijke belangen ${ }^{96}$ kunnen $z i j$, zoals vermeld, niet aan een

91. Zie voor de uitzonderingen op deze hoofdregel paragraaf 2.7 van dit hoofdstuk. Daar komt o.m. de vraag aan de orde in hoeverre op publieke (beheers)taken bestuursbevoegdheid kan worden gefundeerd.

92. Zie uitvoerig: M.A. Heldeweg, Publiekrechtelijke autonomie. Over exclusieve behartiging van het algemeen belang en de wederzijdse onvrijheid van burger en overheidsbestuur, in: Eenzijdig en wederkerig?, a.w., m.n. p. $127 \mathrm{t} / \mathrm{m} 131$.

93. H.J. Simon en A.Q.C. Tak, Het BW als 'Zwart gat', a.w., p. 178; zie over het verschil tussen het autonomiebegrip in het publiek- en privaatrecht ook: H.J. Simon, Autonomie en verbintenis in het publiekrecht: een intern-rechtsvergelijkende analyse, in: Eenzijdig en wederkerig?, a.w., m.n. p. 83 e.v.

94. H.J. Simon en A.Q.C. Tak, Het BW als 'Zwart gat', a.w., p. 178 en 179; de auteurs beperken de werking van het specialiteitsbeginsel in dit kader tot de sfeer van de 'Eingriffsverwaltung'. In het verdere verloop van dit boek zal het standpunt worden ingenomen dat het specialiteitsbeginsel ten grondslag ligt aan zowel 'belastende' als 'begunstigende' bestuursbevoegdheden.

95. ARRS 20 juni 1980, AB 1980, 567 (volkstuinencomplex Rotterdam). In casu had het college van Rotterdam toestemming geweigerd om een tweede tuinhuisje in stand te houden in een volkstuintje dat de gemeente in eigendom toebehoorde (Dit in afwijking van het advies van de wederverhuurder). Volgens de Afdeling lag aan deze weigering geen specifieke publiekrechtelijke bevoegdheid ten grondslag: 'De in het publiekrecht toegekende bevoegdheden zijn immers duidelijk omlijnd of te herleiden. Voor het geven van de onderhavige toestemming, zoals deze tot stand is gekomen, is een dergelijke bevoegdheid niet aan te wijzen' (curs. R.J.N.S.). Vgl. ook: ARRS 16 juli 1993, AB 1994, 293, m. nt. R.M. van Male (adviesbevoegdheid Nederlek).

96. Vgl. J.M.H.F. Teunissen en A.Q.C. Tak, Recht ist was der Umwelt nutzt ?, NJB 1994/18, p. 610. 
willekeurige kring van dragers worden vervreemd. Dit zou immers de 'externe' bevoegdhedenstructuur binnen de democratische rechtsstaat ernstig kunnen verstoren. Dat een dergelijk gevaar niet uitsluitend theoretisch van aard is blijkt uit de uitspraak van de (voormalige) Afdeling rechtspraak van de Raad van State inzake de vispromotiedagen in Den Helder. ${ }^{97}$ In casu verleenden burgemeester en wethouders van Den Helder op grond van de Algemene Politieverordening 'een algemene standplaatsontheffing' aan de plaatselijke V.V.V. voor het houden van een vispromotie-evenement. Individuele visverkopers dienden zich ter verkrijging van een toestemming tot het innemen van een standplaats, zonder verdere tussenkomst van het gemeentebestuur, te wenden tot de V.V.V. die de plaatsen zou verdelen. De Afdeling rechtspraak achtte deze constructie echter niet aanvaardbaar en overwoog: '(..) Gelet op de hun bij en krachtens de gemeentewet toevertrouwde publiekrechtelijke taken en bevoegdheden zijn verweerders geplaatst in een bijzondere positie als administratief orgaan met de daarbij behorende verantwoordelijkheden. In dit verband bestaat uitsluitend voor verweerders de taak een aanvraag om een standplaatsontheffing op haar eigen merites te bezien, onder toetsing van die aanvraag aan de desbetreffende publiekrechtelijke regelen en beginselen. Verlening van een standplaatsontheffing op de wijze als door verweerders in het onderhavige geval is gevolgd, waarbij de beslissingsbevoegdheid in wezen is overgedragen aan de V.V.V., is hiermee niet verenigbaar.'

\subsubsection{Relativering van het onderscheid?}

In de bestuursrechtelijke literatuur is getracht om het fundamentele verschil tussen publiekrechtelijke en privaatrechtelijke bevoegdheid - met name wat betreft het aspect van doelgebondenheid en de bevoegdheidsgrondslag - te relativeren. Zo benadrukt bijv. Kobus$\operatorname{sen}^{98}$ in haar proefschrift dat (de uitoefening) van zowel privaatrechtelijke als publiekrechtelijke bevoegdheden van de overheid steeds gebonden is aan de behartiging van het algemeen belang. Weliswaar zijn bepaalde bestuursbevoegdheden volgens haar gebonden aan een specifiek algemeen belang, maar dit sluit niet uit dat ook privaatrechtelijke bevoegdheden een algemeen belang tot doel kunnen hebben. ${ }^{99}$ Bovendien kunnen privaat-

97. ARRS 22 april 1989, Gst. 6887, p. 447. Zie voor een vergelijkbare uitspraak: VzARRS 18 mei 1993, Gst. 6971, p. 431 (Pinkpop-zaak). Hier overwoog de voorzitter: 'Een zodanig stelsel komt neer op een ingevolge de Gemeentewet niet toegestane overdracht van bij en krachtens die wet aan burgemeester en wethouders opgedragen publiekrechtelijke taken en bevoegdheden.' In casu was de uitgifte van standplaatsen voor een pop-evenement uitbesteed aan een particulier buro.

98. M.H. Kobussen, De vrijheid van de overheid, a.w., m.n. p. $114 \mathrm{t} / \mathrm{m} 116$.

99. M.H. Kobussen, De vrijheid van de overheid, a.w., p. 115-116. De voorbeelden die zij in dit kader aanvoert zijn echter niet bepaald overtuigend. Zo impliceert maatschappelijke 'collectieve belangenbehartiging' door burgers m.i. nog géén publiekrechtelijke belangenbehartiging. Vgl. bijv. E.-W. Böckenforde, Die Bedeutung der Unterscheidung von Staat und Gesellschaft im demokratischen Sozialstaat der Gegenwart, in: Staat, Gesellschaft, Freiheit, Erste Auflage, Frankfurt am Main 1976, p. 202; vgl. tevens J.M.H.F. Teunissen, Het burgerlijk kleed van de staat, a.w., m.n. p. $233 \mathrm{t} / \mathrm{m} 240$. Evenmin toont het gebruik van de figuur van de overeenkomst in het kader van de Onteigeningwet en de Natuurbescher- 
rechtelijke bevoegdheden volgens Kobussen door middel van beleidsregels (alsnog) aan specifieke algemene belangen worden gebonden. Hierbij verliest Kobussen mijn inziens volledig uit het oog dat het stellen van beleidsregels niet heteronoom is bepaald. Het bestuursorgaan zelf, en niet de democratisch gelegitimeerde wetgever, bepaalt immers de inhoud daarvan. Daarom kunnen beleidsregels - nog afgezien van het feit dat deze 'regels' zijn gerelateerd aan een reeds bestaande bestuursbevoegdheid - een privaatrechtelijke 'bevoegdheid' nooit op gelijke wijze normeren zoals de democratisch gelegitimeerde wet een specifieke bestuursbevoegdheid inhoudelijk normeert. ${ }^{100}$ Hierbij dient tevens te worden gesignaleerd dat rechtsnormen die enkel in algemene zin het overheidshandelen normeren (zoals abbb's en grondrechten) de specifieke wettelijke normering van een bestuursbevoegdheid niet kunnen vervangen. ${ }^{101}$

De nadruk wordt in 'nivellerende' rechtsvisies ${ }^{102}$, welke het beginsel van wetmatigheid van bestuur beogen af te zwakken, met name gelegd op de wijze van het overheidshandelen. Zolang overheidshandelen maar als rechtmatig ${ }^{103}$ kan worden aangemerkt en bovendien gericht is op de behartiging van 'het algemeen belang' (zonder enige nadere specificatie), dan wordt dit toelaatbaar geacht. ${ }^{104}$ Een zwak punt van deze visies is gelegen in het feit dat zij het fundamentele rechtsstatelijke machtigingsvraagstuk, dat ziet op de vraag of het bestuur wel rechtsvormend mag handelen ter behartiging van publieke belangen (het bevoegdheidsbeginsel), onvoldoende onderkennen. ${ }^{105}$ Bijgevolg raakt de democratische component van het legaliteitsbeginsel op de achtergrond. ${ }^{106}$ Ook erkennen

mingswet - waarop Kobussen zich beroept - aan dat privaatrechtelijke bevoegdheid doelgebonden is. De doelbinding vloeit in deze voorbeelden m.i. juist voort uit de genoemde specifieke publiekrechtelijke wetgeving.

100. Vgl. Tak die erop gewezen heeft dat (o.a.) Kobussen in dit verband het democratisch aspect van de legaliteitseis miskent. A.Q.C. Tak, Terugtocht van twee wegen, a.w., p. 313-314, noot 111.

101. Zie over 'speciale' en 'algemene' normering van bevoegdheden R. Bergamin, Rechten jegens de overheid, Het begrip publiekrechtelijke subjectieve rechten, diss. UvA, Nijmegen 1995, p. 222.

102. Vgl. J.M.H.F. . Teunissen, Strategisch concept voor nivellerende rechtswetenschap?, in: Eenzijdig en wederkerig?, a.w., i.h.b. 289 en 290.

103. Vgl. Tak die opmerkte: 'De bevoegdheidsvraag lijkt 'uit', de wetmatigheidsleer (bevoegdheidsleer) is ingeruild voor een rechtmatigheidsleer (controle-leer) zo lijkt het.' A.Q.C. Tak, Inleiding bij de Maastrichtse bundel 'Eenzijdig en wederkerig?', a.w., p. 3 en 4. Het sterke vertrouwen op rechterlijk activisme en de normerende werking van algemene beginselen van behoorlijk bestuur (abbb's) en grondrechten springt hierbij in het oog. Vgl. in dit kader de indringende waarschuwing van Hoekema die opmerkte: 'Ik geloof niet dat verhoogd rechterlijk aktivisme en een verdere uitbouw van beginselen van behoorlijk bestuur kompensatie kan bieden voor het gemis aan zelfstandig normerende betekenis van rechtsregels.' A.J. Hoekema, Het rechtskarakter van doelmatig onderhandelend bestuur, in: Recht, Rechtvaardigheid en Doelmatigheid (red. Maris/Bos/Hoekema/Van Peijpe), Arnhem 1990, p. 124.

104. Gebrek aan 'legaliteit' tracht men te compenseren door de mogelijkheid van toetsing aan ongeschreven (publiek)recht te benadrukken. Volgens Kobussen kan het bestuur zo aan de 'essentie' van het legaliteitsbeginsel, volgens haar het rechtszekerheidsbeginsel, worden gebonden (a.w., p. 117-118). Vgl. ook H.D. Stout, De betekenissen van de wet. Theoretisch-kritische beschouwingen over het principe van wetmatigheid van bestuur, diss. RUL, Zwolle 1994, p. 100 en 164. 
deze visies in onvoldoende mate de essentie van het specialiteitsbeginsel als structuurbeginsel van bestuursbevoegdheid.

De Haan, Drupsteen en Fernhout zien één en ander zuiver wanneer zij in dit verband opmerken: 'Autonomie van partijen in het privaatrecht is nu eenmaal iets wezenlijk anders dan de beleidsvrijheid die de overheid binnen het kader van wettelijke bevoegdheden is gegund. In beginsel is die autonomie onbeperkt en niet doelgebonden, terwijl publiekrechtelijke bevoegdheden zowel aan het legaliteits- als aan het specialiteitsbeginsel moeten voldoen en ook aan speciale bestuurlijke en rechtswaarborgen plegen te worden onderworpen' (curs. R.J.N.S.). ${ }^{107}$

\subsubsection{Windmill en het specialiteitsbeginsel}

De 'gemengde rechtsleer'108 die aan de hiervoor bedoelde 'nivellerende'- of 'rechtseenheid'-visies ${ }^{109}$ ten grondslag ligt, is pragmatisch van aard en mist mijns inziens een duidelijk theoretisch fundament. ${ }^{110}$ Dit komt o.m. tot uitdrukking in de jurisprudentie van

105. Vgl. J.M.H.F. Teunisssen en A.Q.C. Tak, Recht ist was der Umwelt nutzt?, a.w. p. 609: 'Voor een publiekrechtelijke bevoegdheid moet daarentegen steeds een titel kunnen worden aangewezen die deze bevoegdheid vestigt; de uitoefening ervan dient steeds te geschieden met inachtneming van het doel waarvoor zij is verleend.' Zie ook A.Q.C. Tak, De overheid in het burgerlijk recht, a.w. p. 104.

106. Zie: L.J.A. Damen, boekbespreking M. Kobussen 'Devrijheid van de overheid', RMTh. 1992/10, p. 467.

107. De Haan/Drupsteen/Fernhout, Bestuursrecht in de sociale rechtsstaat I, a.w., p. 446.

108. Deze leer gaat er - kortgezegd - vanuit dat indien de overheid gebruik maakt van privaatrechtelijke bevoegdheden ter behartiging van publiekrechtelijke belangen, hetgeen onder voorwaarden toelaatbaar wordt geacht, de uitoefening van deze bevoegdheden mede door publiekrechtelijke normen wordt genormeerd (bijv. door abbb's en de grondrechten). Vgl. HR 27 maart 1987, NJ 1987, 727, m.nt. MS; AB 1987, 273 m.nt. FHvdB (Amsterdam/IKON) en HR 24 april 1992, NJ 1993, 232, m.nt. MS; AB 1992, 542 (Zeeland/Hoondert). Wat betreft de gebondenheid van de overheid aan de grondrechten in het 'privaatrecht' wijs ik op: HR 26 april 1996, JB 1996, 159, m.nt. HIS (Rasti/Rostelli). Deze 'gemengde' leer komt $66 \mathrm{k}$ tot uitdrukking in de schakelbepalingen van het BW (art. 3:14 BW) en de Awb (art. 3:1 lid 2 Awb). Zie over de 'gemengde rechtsleer' o.m. het VAR-preadvies van D.A. Lubach, De verhouding privaat-publiekrecht in het licht van het NBW, Geschriften van de Vereniging voor administratief recht XCIV, Alphen aan den Rijn 1986, p. 13 t/m 16 en diens proefschrift Beleidsovereenkomsten. Een onderzoek naar juridische aspecten van het gebruik van de overeenkomst als beleidsinstrument door de overheid' (Deventer 1982, o.m. p. 145-146). Ik wijs ook op J. van der Hoeven, De magische lijn. Verkenningen op de grens van publiek en privaatrecht, in: Honderd jaar rechtsleven, Zwolle 1970, p. 201 e.v. (i.h.b. p. 218) alsmede op J. van der Hoeven, Publiek- en privaatrecht, in: Osmose tussen publiek- en privaatrecht, AAe 1987/5, p. $277 \mathrm{t} / \mathrm{m} 280$. Zie voor een analyse van de gemene- en gemengde rechtsleer tot slot: J.C.E. Ackermans-Wijn, Contracten met de overheid. Een onderzoek naar de contractsvrijheid van publiekrechtelijke rechtspersonen en het toepasselijke materielle recht, diss. KUN, Deventer 1989, p. 40 e.v.

109. Vgl. bijv. Bloembergen die de éénheid van recht als systeem centraal stelt. Zijn visie van éénheid van recht is uitvoerig verwoord in een reeks WPNR-bijdragen uit 1977. A.R. Bloembergen, De eenheid van privaatrecht en administratief recht, WPNR 5372 (p. 1-5), 5373 (p. 17-23), 5374 (p. 33-36 en 5375 (p. 4954). Vgl. ook A.R. Bloembergen en P.A. Lubach, Burgerlijk recht en adminsitratief recht: twee gelijkwaardige rechtsgebieden, open verbonden in én rechtsorde, WPNR 5885, p. 446 e.v. 
de Hoge Raad over de toelaatbaarheid van het behartigen van publiekrechtelijke belangen door de overheid op basis van 'privaatrechtelijke' bevoegdheden.

Aan deze jurisprudentie, die sinds het bekende Windmill-arrest ${ }^{111}$ in het teken staat van de doorkruisingsdoctrine, ligt de door de gemengde rechtsleer 'gecorrigeerde' gemene rechtsleer ten grondslag. Deze gemene rechtsleer, en de daarmee verweven 'twee-wegen' doctrine, gaat er in essentie vanuit dat aan de overheid obk algemene privaatrechtelijke bevoegdheden ter beschikking staan om typisch publiekrechtelijke belangen te behartigen. De belangrijkste beperkende voorwaarde vormt in dit kader de eis dat behartiging langs privaatrechtelijke weg enkel toelaatbaar is indien de wet dit niet expliciet uitsluit en hierdoor géen publiekrechtelijke weg op een onaanvaardbare wijze wordt doorkruist. ${ }^{112}$ Of er sprake is van een zodanige doorkruising dient volgens de Hoge Raad in het licht van de in het geding zijnde publiekrechtelijke regeling (de wet), alsmede tegen de achtergrond van de geschreven en ongeschreven regels van het publieke recht, te worden beantwoord. ${ }^{113}$ Deze laatste eis lijkt in het bijzonder geïnspireerd te zijn door de gemengde rechtsleer (vgl. artikel 3:14 BW) die immers de algemene rechtmatigheids-vraag van privaatrechtelijk overheidshandelen in het licht van publiekrechtelijke normen centraal stelt.

Gelet op het specialiteitsbeginsel manifesteert zich evenwel onmiddellijk een zwak punt in de leer van de Hoge Raad. Behoren tot de 'ongeschreven regels' 114 van het publieke recht immers niet óok de respectering van het specialiteitsbeginsel alsmede het bevoegdheidsbeginsel en het democratiebeginsel? Ik zou menen van wel. Aanvaardt men dit, naar mijn oordeel vanuit publiekrechtelijk oogpunt nauwelijks te weerleggen, uitgangspunt dan wordt eerst in volle omvang duidelijk dat de doorkruisingsleer een aantal staatsrechtelijke complicaties ${ }^{115}$, die inherent zijn aan de behartiging van publiekrechtelijke belangen door de overheid langs privaatrechtelijke weg, geenszins kàn ondervangen. Privaatrechtelijke bevoegdheden worden $\mathrm{nl}$. niet gestructureerd door het publiekrechtelijke specialiteitsbeginsel en missen bijgevolg, wat hun grondslag betreft, ten principale een

110. Vgl. Stroink die in dit kader spreekt over de 'vlees-noch-vismethode'. F.A.M. Stroink, Algemeen bestuursrecht, a.w., p. 90. In kritische zin ook: A.Q.C. Tak, De overheid in het burgerlijk recht, a.w., p. 102.

111. HR 26 januari 1990, AB 1990, 408, m.nt. G.P. Kleijn (Windmill).

112. Deze 'doorkruisingsleer' is naar mijn oordeel gefundeerd in de idee dat het publieke recht een uitzonderingskarakter heeft en derhalve aan het algemene privaatrecht kan derogeren. Aldus beschouwd, geeft de 'doorkruisings'-doctrine van de Hoge Raad uitdrukking aan het gedachtengoed van de gemene rechtsleer. Vgl. over deze laatstgenoemde leer Asser/Scholten, Algemeen deel, Zwolle 1974, p. 30 en J. van der Hoeven, De drie dimensies van het bestuursrecht, VAR-reeks 100, Alphen aan den Rijn 1989, p. $158-159$.

113. Waarbij het op instrumentalistische wijze toepaste criterium van het 'vergelijkbare resultaat' wordt gehanteerd. Vgl. HR 22 oktober 1993, AB 1994, 1, m.nt. G.A. van der Veen (Staat/Magnus).

114. Waaronder de Hoge Raad - getuige het Amsterdam/lkon-arrest - ók de algemene beginselen van behoorlijk bestuur rekent.

115. Zie ook de opmerkingen van Simon naar aanleiding van het Kabayel-arrest (HR 18 februari 1994, AB 1994, 415 m.nt. G.A. van der Veen). H.J. Simon, Publiekrecht en burgerlijk recht. Het arrest Staat/Kabayel, WPNR 1994/6, p. 755. 
doelbinding met de democratisch-juridische structuur van de publieke rechtsorde. ${ }^{116}$ Het is daarom maar zeer de vraag of dergelijke bevoegdheden, zoals de Hoge Raad toch suggereert, een zelfstandige bevoegdheidsgrondslag mogen bieden om publiekrechtelijke belangen te behartigen. ${ }^{17}$ Het valt hierbij op dat ingevolge de doorkruisingsleer van de Hoge Raad in het midden blijft of de overheid ook dan langs 'privaatrechtelijke' weg publieke belangen mag behartigen indien er helemaal gén publiekrechtelijke weg voor handen is.

In dit verband wijs ik erop dat het zowel vanuit normlogisch als vanuit rechtssociologisch oogpunt moeilijk te begrijpen is dat men enerzijds veel waarde zou moeten hechten aan een specifieke en doelgebonden publieke bevoegdhedenstructuur binnen de overheidsorganisatie (waaraan dan het specialiteitsbeginsel ten grondslag ligt), en anderzijds accepteert dat deze overheidsorganisatie jegens zijn leden/burgers gelijktijdig nog zou beschikken over algemene en open geredigeerde 'privaatrechtelijke' bevoegdheden ter behartiging van typisch publiekrechtelijke belangen. ${ }^{118}$ Wat is dan immers nog de functie

116. Vgl. De Haan/Drupsteen/Fernhout, Bestuursrecht in de sociale rechtsstaat $I$, a.w., p. 48. Onbegrijpelijk acht ik dan ook hoe de aanhangers van de heersende 'gemengde' rechtsleer de 'privaatrechtelijke' bevoegdheden van het bestuur - met het oog op het behartigen van publieke belangen - aan het verbod van détournement de pouvoir denken te kunnen binden (vgl. bijv. Burkens/Kummeling/Vermeulen/Widdershoven, Beginselen van de democratische rechtsstaat, a.w., p. 102). Het verbod van détournement de pouvoir veronderstelt naar mijn oordeel immers steeds een voorafgaande publieke doelgebonden bevoegdheidsgrondslag. Vgl. in dit kader: H.J. Simon, De directe toetsing getoetst, over publieke normen in het privaatrecht, BR 1988, p. 6 en 8.

117. Tak sprak in dit kader over het 'axioma' van Windmill. De vraag naar de principiële toelaatbaarheid van 'privaatrechtelijk' overheidshandelen wordt door de aanhangers van de gemene (en gemengde) rechtsleer éénzijdig vanuit het Burgerlijk Wetboek beantwoord (vgl. art. 2:1 BW). Ik wijs op A.R. Bloembergen, OVerheidsprivaatrecht: schets van een algemeen deel, WPNR 6074, p. 953. De vraag naar de publiekrechtelijke toelaatbaarheid - de publieke bevoegdheidsvraag - wordt niet beantwoord. Zie: A.Q.C. Tak, Overheid en Burgerlijk Wetboek. Naar een invullende rechtsleer, Recht en kritiek 1993/2, p. 178. De fundamentele bevoegdheidsvraag lijkt in de literatuur door aanhangers van de gemengde rechtsleer inderdaad vaak te worden ontweken. Indien men er wel aandacht aan besteedt dan wordt niet zelden een beroep gedaan op de cirkelredenering dat indien de overheid publiekrechtelijke belangen behartigt op basis van privaatrechtelijke bevoegdheden de legaliteitseis niet geldt juist omdat er privaatrecht in het geding is. Zie bijv. G.A. van der Veen, Primaat van het publiekrecht en grondrechtelijke beperkingen op de contractsvrijheid, NTBR 1996/8, p. 197. Vgl. ook Kobussen die in haar proefschrift ruime aandacht besteedde aan het legaliteits- en specialiteitsbeginsel in het privaatrecht. Om het gebriik van privaatrechtelijke wegen te sauveren komt $\mathrm{zij}$ - m.i. noodgedwongen! - tot een sterke relativering van beide beginselen. M.H. Kobussen, De vrijheid van de overheid, a.w., m.n. p. $103 \mathrm{t} / \mathrm{m} 107$ en p. $114 \mathrm{tm} 118$.

118. Vgl. J.M.H.F. Teunissen, Het burgerlijk kleed van de staat. Beschouwingen over de tweewegenleer, diss. RL, Zwolle 1996, p. 261. Waarbij met name de actie ex art. 6:162 BW (onrechtmatige daad) ter behartiging van publiekrechtelijke belangen in het oog springt. Teunissen is van mening dat deze actie zich in ons land, met name sinds het Kabayel-arrest (HR 18 februari 1994, AB 1994, 415), ontwikkelt in de richting van een ongewenste 'para-wettelijke Generalklausel' (a.w., p. 182-183). Dit houdt o.m. verband met het feit dat in de (privaatrechtelijke) praktijk en theorievorming momenteel te gemakkelijk over de vraag wordt heengestapt welke belangen art. 6:162 BW beoogt te beschermen. In mijn optiek zijn dat in ieder geval de private (subjectgebonden) rechtsbelangen van burgers en niet de typisch publiekrechtelijke belangen die het bestuur moet behartigen. Vgl. de exemplarische - typisch privaatrechtelijke opvatting van bijv. Lankhorst die deze problematiek m.i. onvoldoende onderkent. G.A. Lankhorst, De 
van de beperkte, doelgebonden en met typische waarborgen omklede publieke bevoegdhedenstructuur?

Tegen de achtergrond van het specialiteitsbeginsel is in de literatuur, en in sommige 'lagere' jurisprudentie, naar mijn oordeel terecht gewaarschuwd tegen uitholling van een specifieke publiekrechtelijke belangenafweging lang 'privaatrechtelijke' weg. ${ }^{119}$ Ofschoon ook de Hoge Raad dit gevaar (soms) lijkt te onderkennen, is de bestrijding ervan door dit rechtscollege echter (nog) niet principieel ter hand genomen. ${ }^{120}$ Theorievorming die in essentie gebaseerd is op de gemene rechtsleer nodigt hier uiteindelijk ook niet toe uit. Symptomatisch is, naar mijn oordeel, bijv. het gegeven dat ingevolge deze leer nog steeds géen bevredigende theorievorming heeft plaatsgevonden ter zake van het probleem van de (aanvullende) 'privaatrechtelijke' verplichtingen bij bijzonder gebruik van openbare zaken (publiek domein). ${ }^{121}$

Het geschetste gevaar kan naar mijn mening enkel ten principale worden ondervangen indien men ervan uitgaat dat de overheidsrechtspersonen enkel over 'privaatrechtelijke' bevoegdheid beschikken ter behartiging van vermogensrechtelijke belangen en dan nog uitsluitend tegen de achtergrond van hun interne publieke bestemmingsfunctie. ${ }^{122}$ Als

relativiteit van de onrechtmatige daad, diss. RUL, Deventer 1992, p. 81.

119. H.J. Simon en A.Q.C. Tak, Het BW als 'zwart gat', a.w., p. 176. Dit naar aanleiding van HR 20 mei 1994, NJ 1995, 691, m.nt. CJHB (De Negende van OMA). Vgl. in dit kader - in andere zin - Pres. Rb. Maastricht 13 mei 1994, Gst. 7002, nr. 5, m.nt. B, RAwb 1995, 17, m.a. G.A. van der Veen (Pinkpop): 'Het gaat evenwel niet aan dat een gemeente de vereiste publiekrechtelijke belangenafweging op privaatrechtelijke gronden dusdanig uitholt, dat een vergunninghouder geen feitelijk gebruik van zijn recht meer kan maken.'

120. Vgl. de werelden van verschil tussen HR 9 juli 1990, AB 1990, 547, m.nt. G.P. Kleijn (De Pina/Helmond) en HR 8 juli 1991, AB 1991, 659, m.nt. FHvdB (Kunst- en antiekstudio Lelystad BV).

121. Vgl. bijv. G.A. van der Veen, Openbare zaken, a.w., p. 415. Uit de beschouwingen van Van der Veen kan worden afgeleid dat hij in dit verband ondanks de werking van het publiekrechtelijke specialiteitsbeginsel in essentie nog steeds de mogelijk openhoudt voor aanvullende 'privaatrechtelijke' normstelling mits hieraan een ander motief ten grondslag ligt dan aan de publiekrechtelijke regeling. Dit standpunt vloeit voort uit het feit dat Van der Veen de typisch doelgebonden - en dus volledig aan het specialiteitsbeginsel onderworpen - eigen aard van het publieke domein onvoldoende wenst te onderkennen. Vgl. voor een uiterst 'gemeenrechtelijk' georiênteerde visie op dit punt eveneens: J.C.E. Ackermans-Wijn, Contracten met de overheid, a.w., p. 189-191. In mijn optiek zal een beperking van het reguliere gebruik van zaken ten openbare nutte, alsmede bijzonder gebruik, zijn grondslag in een specifieke en doelgebonden wettelijke regeling dienen te vinden. T.a.v. het reguliere gebruik schuilt deze doelbinding reeds in de aard van het publiek domein. Zie over het doelgebonden karakter van het publiek domein: G.E. van Maanen, Van de vogelen des hemels en de stranden der zee. Publiek domein en ander overheidseigendom, WPNR (1992) 6074, p. 975.

122. De publiekrechtelijke activiteit van de overheid omvat noodzakelijkerwijs een vermogensrechtelijke component. Om deze component uberhaupt te kunnen vervullen zal de overheidsorganisatie zich in bepaalde gevailen als burgerlijke rechtspersoon in het vermogensrechtelijke verkeer dienen te begeven. Vgl. H.J. Simon, Autonomie en 'verbintenis' in het publiekrecht: een intern-rechtsvergelijkende analyse, a.w., p. 98. Het gaat hier i.h.b. om situaties waarin de overheidsorganisatie zich goederen ten nutte van de openbare dienst moet verwerven ('potloden en PC's'). Zie: A.Q.C. Tak, De overheid in het burgerlijk recht, a.w., p. 242. Als juist dient in dit kader bijgevolg te worden aanvaard dat 6́bk de overheidsorganisatie participeert in het 'private' rechtsverkeer, maar deze participatie mag naar mijn oordeel dan nooit 
vermogensrechtelijke rechtspersoon zijn zij gén drager van publiekrechtelijke belangen die zij jegens de burgers zelfstandig kunnen behartigen op basis van het materiele privaatrecht. Publiekrechtelijke belangen zijn immers binnen het publieke gemeenschapsverband- meestal door de wetgever - op democratische wijze toevertrouwd aan de statelijke (bestuurs)organen; zij zullen dan ook overeenkomstig het geschreven én ongeschreven publiekrecht door deze organen dienen te worden behartigd op basis van geconditioneerde doelgebonden bevoegdheden. ${ }^{123}$

Dit gegeven sluit overigens niet geheel uit dat de overheid, indien een publieke bevoegdheidsnorm aanwezig is, zij in dat kader eventueel gebruik mag maken van burgerrechtelijke rechtsvormen in situaties waarin het geschreven publiekrecht (nog) tekortkomingen vertoont, op voorwaarde dat het ongeschreven publiekrecht zich daar niet tegen verzet. ${ }^{124}$

In het licht van het specialiteitsbeginsel, en gelet op het voorafgaande, neem ik het standpunt in dat de machtiging tot specifiek (énzijdig) rechtsvormend handelen door het bestuur ter behartiging van publiekrechtelijke belangen in een democratische rechtsstaat - uitzonderingen daargelaten ${ }^{125}$ - herleidbaar dient te zijn tot een besluit van de wetgever in formele zin (de formele bevoegdheidsgrondslag). ${ }^{126}$ Alleen door een dergelijke machtiging kan de traceerbaarheid (ook voor derden) van bestuursbevoegdheid en de

gericht zijn op de behartiging van specifieke publiekrechtelijke belangen. Vermelding verdient i.h.b. dat de overheid oók in dit private rechtsverkeer steeds overheid is, en zal blijven, gelet op haar bestemmingsfunctie, $\mathrm{nl}$. de verwezenlijking van het algemeen belang. Dit wordt ook in de privaatrechtelijke literatuur erkend. Vgl. bijv. G.E. van Maanen, Van de vogelen des hemels en de stranden der zee, a.w., p. 971. Tot slot wijs ik erop dat ik de (beheers)bevoegdheden die de overheid aan het 'publiek domein' ontleent niet als (materieel) privaatrechtelijk aanmerk (zie paragraaf 2.7).

123. In dit verband kan ik mij goed vinden in de strekking van het betoog van Teunissen, zoals uitvoerig uitgewerkt in diens proefschrift. Zie: J.M.H.F. Teunissen, Het burgerlijk kleed van de staat, a.w., i.h.b. hoofdstuk 6. In soortgelijke zin: H.J. Simon, Autonomie en 'verbintenis' in het publiekrecht: een internrechtsvergelijkende analyse, a.w., p. 98.

124. Hier is dan sprake van, wat Tak aanduidt als, 'invullend' gebruik van burgerlijk recht. A.Q.C. Tak, De overheid in het burgerlijk recht, a.w., p. 116-117. Vgl. in dit kader de conceptuele benadering in het Duitse recht. Maurer formuleert dit uitgangspunt als volgt: 'Das schließt nicht aus, daß sich auch der Staat der Formen des Privatrechts bedient; aber das ist nur ausnahmsweise zulässig und beschrănkt sich auf die Verwendung der privatrechtlichen Formen, ohne daß der Staat damit auch der Privatautonomie teilhaftig wurde' (curs. R.J.N.S.). H. Maurer, Allgemeines Verwaltungsrecht, 11. Auflage, Munchen 1997, p. 43. In de lijn van een dergelijke gedachtengang m.i. ABRS 21 oktober 1996 (JB 1996/232, m.nt. HJS), waarin het in het burgerlijke recht uitgekristalliseerde leerstuk van de onverschuldigde betaling wordt herleid tot een algemeen rechtsbeginsel en vervolgens in het kader van een publieke bevoegdheidscontext wordt toegepast. In dit kader wordt wel gesproken over een 'vernieuwde' gemene rechtsleer op basis waarvan wordt erkend dat privaat- en publiekrecht twee geheel zelfstandige, naast elkaar staande rechtssferen zijn, zij het met sommige gemeenschappelijke beginselgrondslagen. De pretentie van algemene gelding van 'het' privaatrecht of 'het' Burgerlijk Wetboek is echter verlaten. Vgl. J.M.H.F. Teunissen, Afrekening met de gemene rechtsleer en de tweewegenleer (1), Gst. 7048, p. 88-91 en W.J.J. Beurskens, Hoeveel toekomst heeft de 'doorkruisingsleer'?, NTBR 1997/9, m.n. p. 280.

125. Vgl. het in paragraaf 2.7 van dit hoofdstuk gestelde over het 'publieke taak'-criterium.

126. Vgl. L.J.A. Damen, boekbespreking M. Kobussen 'De vrijheid van de overheid', a.w., p. 469. 
voorspelbaarheid van de bevoegdheidsuitoefening optimaal worden gegarandeerd, waardoor uiteindelijk ook een effectieve rechtsbescherming wordt gewaarborgd. Verder zal iedere bevoegdheid van het bestuur op basis waarvan publiekrechtelijke belangen worden behartigd steeds dienen te wortelen in de typische aard van de publieke rechtsorde, en de daaraan ten grondslag liggende materiële rechtsbeginselen (zie hoofdstuk 3).

\subsubsection{Eenzijdig of wederkerig?}

Het énzijdigheidsaspect is, naast de doelgebondenheid, een ander belangrijk kenmerk van de publiekrechtelijke bevoegdheid(suitoefening) ${ }^{127}$ Eenzijdigheid impliceert dat de bevoegdheid in beginsel ${ }^{128}$ zonder medewerking van rechtssubjecten, ja zelf tegen de wil van rechtssubjecten, kan (en soms ook moet) worden uitgeoefend. Ook in dit opzicht verschilt publiekrechtelijke bevoegdheid van privaatrechtelijke bevoegdheid. In het privaatrecht is éenzijdigheid van bevoegdheidsuitoefening geen regel maar uitzondering. In het contractenrecht overheerst de meerzijdigheid, in die zin dat instemming van de wederpartij ten aanzien van de inhoud van een obligatoire overeenkomst is vereist (wilsovereenstemming). Privaatrechtelijke bevoegdheden die ontleend worden aan zakelijke rechten kunnen weliswaar éénzijdig worden uitgeoefend, maar zij hebben slechts een afweerkarakter, gericht op het handhaven van de vermogensrechtelijke 'status quo'. Uitoefening hiervan strekt er met andere woorden niet toe om doelgericht - ter regulering van gedrag - een wijziging in de rechtspositie van andere rechtssubjecten te bewerkstelligen, maar uitsluitend om eigen (subjectieve) rechten te beschermen. Eenzijdige uitoefening van bevoegdheden is binnen het privaatrechtelijke vermogensrecht een nagenoeg onbekend verschijnsel. ${ }^{129}$ Men zou in dit kader kunnen tegenwerpen dat een op grond van onrechtmatige daad verkregen verbod de rechtspositie van een wederpartij wijzigt zonder dat deze daarmee instemt. Ook deze 'bevoegdheid' op grond van artikel 6:162 BW kan evenwel uitsluitend worden uitgeoefend ter bescherming van de eigen autonomie van een rechtssubject na rechterlijke tussenkomst. Indien een rechtssubject niet onrechtmatig handelt tegenover een ander rechtssubject, kan het niet tegen zijn wil geconfronteerd worden met een verbod (of gebod) ingevolge artikel 6:162 BW. ${ }^{130}$

127. Zie bijv.: F.A.M. Stroink, Algemeen bestuursrecht, a.w., p. 13 e.v.

128. De 'publiekrechtelijke overeenkomst' laat ik hier buiten beschouwing. Afgezien van het feit dat deze rechtsfiguur - niet te verwarren met het 'bloot' gebruik van burgerrechtelijke rechtsvormen door de overheid - wat betreft de relatie overheid-burger in het Nederlandse recht nog niet tot (volle) wasdom is gekomen, geldt m.i. ook hier het uitgangpunt dat deze 'publiekrechtelijke overeenkomst' wortelt in een publiekrechtelijke rechtsgrond, en bovendien éénzijdig publiekrechtelijk ingekaderd wordt door een specifieke publieke bevoegdheidsgrondsiag. Vgl. J.M.H.F. Teunissen, Strategisch concept voor nivellerende rechtswetenschap?, a.w., p. 331 en 314 . (Zie. bijv. art. 42 WRO i.v.m. de exploitatie-overeenkomst; vgl. in dit kader HR 16 februari 1996, JB 1996/87, m.nt. HJS/RJNS).

129. Binnen het private personen- en familierecht kan men wél enige voorbeelden aantreffen. Bijv.: de erkenning van kinderen als wettig respectievelijk natuurlijk kind (artt. 2:214 en 2:221, lid I BW). 


\subsubsection{De 'subjectiveringstendens' in het bestuursrecht}

In de bestuursrechtelijke literatuur wordt door sommige auteurs gewezen - op wat wordt genoemd - de 'subjectiveringstendens' in de relatie bestuur(sorgaan)-burger. ${ }^{131}$ Niet meer de éénzijdigheid, doch de wederkerigheid in deze rechtsbetrekkingen wordt centraal gesteld. ${ }^{132}$ Deze conceptie is blijkens de memorie van toelichting ${ }^{133}$ ók ten grondslag gelegd aan de Algemene wet bestuursrecht. ${ }^{134}$ De kern van dit 'wederkerigheidsdenken' vormt het uitgangspunt dat burger en bestuur permanent in een volledig door het recht beheerste relatie tot elkaar staan, binnen welke relatie zij rekening moeten houden met de belangen van de andere partij. Minister Hirsch Ballin bracht dit uitgangspunt binnen de vaste commissies voor Justitie en Binnenlandse zaken als volgt onder woorden: 'Die bestuurlijke rechtsbetrekking komt niet tot stand zoals men zich in de 19de eeuw kon voorstellen: een beschikking kwam tot stand en werd afgevuurd op de burger als ware het een kanonskogel die ergens insloeg en definitief effecten had. Zij komt tot stand in een procedure die zelf reeds het karakter draagt van een rechtsbetrekking in ontwikkeling, waarin het bestuur en de burger aan elkaar verschuldigd zijn dat met de relevante belangen rekening wordt gehouden. ${ }^{135}$

Binnen het wederkerigheidsdenken is de uitoefening van publiekrechtelijke bevoegdheid, zoals gesteld, ingekaderd in een permanente rechtsverhouding tussen de drager van deze bevoegdheid en het rechtssubject dat geconfronteerd wordt met, dan wel verzoekt om, bevoegdheidsuitoefening. Deze rechtsverhouding wordt volledig beheerst door rechtsregels, en is voortdurend in ontwikkeling. ${ }^{136}$ De rechtsbetrekking komt niet tot stand op het moment van de bevoegdheidsuitoefening (de éénzijdige rechtshandeling van het bestuursor-

130. Hier is het 'civiele delictenrecht' in het geding, waarbinnen de bescherming van private rechtsbelangen centraal staat. Vgl. H.J. van Eikema Hommes, De elementaire grondbegrippen der rechtswetenschap, a.w., p. 308 en 309.

131. Zie bijv. J.P. de Jong, Bestuursrecht van vreemde herkomst, diss. KUB, Zwolle 1988, i.h.b. p. 81.

132. Zie o.m R.M. van Male, Onvoltooid recht, a.w., p. 10 e.v.; J.L.M. Gribnau, De wederkerige rechtsbetrekking als nieuw paradigma, R\&R 1993, p. 87 e.v.; C.P.J. Goorden, Rechtsbevoegdheid in het bestuursrecht, a.w., p. 114 e.v.; R.J.B. Bergamin, Publieke subjectieve rechten in: Algemene begrippen staatsrecht, Zwolle 1991, m.n. p. 97 e.v.; R.J.B. Bergamin, Rechten jegens de overheid, Het begrip publiekrechtelijke subjectieve rechten, diss. UvA, Nijmegen 1995, m.n. p. 75 t/m 78 en 205 e.v.; E.M.H. Hirsch Ballin, Wederkerig bestuursrecht, RMTh. 1989/1, p. I e.v. en D. Pessers, Wederkerigheid: het rechtsbeginsel van de informatiesamenleving?, NJB 1996/22, p. 836 e.v. Sommigen lijken de kool en de geit te willen sparen. Vgl. J.R.C. Tieman, Wederkerige rechtsbetrekking en bestuursdwang, NTB 1997/6, p. 226 e.v. Overigens is het 'rechtsbetrekking'-concept in Nederland niet nieuw. Ik verwijs naar het handboek van Vegting (m.n. het eerste deel) uit de jaren vijftig dat grotendeels rondom dit concept werd opgebouwd. W.G. Vegting, Het Nederlands administratief recht, a.w., i.h.b. p. $169 \mathrm{t} / \mathrm{m} 189$.

133. PG Awb I, MvT, p. 39 en 40.

134. PG Abw I, MvT, p. 39; weliswaar wordt hier erkend dat bestuur en burger naar hun aard verschillende partijen zijn, maar centraal wordt gesteld de wederkerige relatie die de basis vormt voor de rekenschap die beiden zich moeten geven van de positie en de belangen van de andere partij.

135. PG Awb I, UCV, p. 45.

136. Zie over dit dynamische karakter van de 'wederkerige rechtsbetrekking' bijv.: E.M.H. Hirsch Ballin, Wederkerig bestuursrecht, a.w., p. 4. 
gaan), doch is reeds vóór dit moment in abstracte vorm aanwezig. Brenninkmeijer benadrukt in dit verband expliciet het verschil tussen het ontstaan van de rechtsbetrekking en het beschikkingsmoment. Hij verstaat onder rechtsbetrekking een door rechtsnormen gevormde betrekking tussen twee of meer (rechts)subjecten (waaronder het bestuursorgaan). De totstandkoming van de beschikking is relevant voor de inhoud van een bepaalde rechtsbetrekking, doch valt hiermee niet volledig samen. ${ }^{137}$

\subsubsection{Het 'wederkerigheids'-concepten het specialiteitsbeginsel}

Zoals ik reeds betoogde in een bijdrage aan de Maastrichtse bundel 'Eenzijdig en wederkerig?' staat de aanvaarding van het 'wederkerigheids'-concept naar mijn oordeel op gespannen voet met het specialiteitsbeginsel. ${ }^{138}$ Daarom is het zinvol om dit 'nieuwe ${ }^{\prime 139}$ basisconcept in het bestuursrecht kritisch onder de loep te nemen. Naar mijn stellige overtuiging is $\mathrm{nl}$. de visie die men huldigt ten aanzien van het denken over de rechtsverhouding tussen burger en bestuur - en de daarmee samenhangende visies inzake het legaliteitsbeginsel en het rechtskarakter van beleidsvrijheid - bepalend voor de betekenis die men uiteindelijk toekent aan het specialiteitsbeginsel. De meningsverschillen inzake de interpretatie van het specialiteitsbeginsel wortelen naar mijn oordeel in principieel tegenstrijdige opvattingen over de wezenlijke grondstructuren van het rechtsstatelijke bestuursrecht. ${ }^{140} \mathrm{Op}$ deze plaats dient daarom het 'wederkerigheids'-concept gemarkeerd te worden ten opzichte van het 'bevoegdheids'-concept dat sinds de opkomst van de democratische rechtsstaat ten grondslag lag (en mijns inziens ligt) aan de rechtsrelaties tussen bestuur en burgers. ${ }^{141}$

In dit verband dient voorop te worden gesteld dat de relatie bestuur-burger sinds het einde van de vorige eeuw zeker een wijziging heeft ondergaan. Besturen is niet langer 'mechanische' wetsuitvoering. Het bestuur heeft op grond van vele bestuursbevoegdheden een eigen verantwoordelijkheid binnen het statelijke rechtsvormingsproces. Waar het

137. A.F.M. Brenninkmeijer, Een leerstellig cliché, in: In de sfeer van administratief recht (Konijnenbeltbundel), Utrecht 1994, p. 19. Anders bijv.: R.J. Jue, Vrijheid van besturen, R\&R 1986/2, p. 143: 'Dergelijke rechtsbetrekkingen (overheid-burger R.J.N.S.) kunnen slechts ontstaan indien zij het resultaat zijn van de toepassing van een in de rechtsregel welomschreven bevoegdheid.'

138. R.J.N. Schlossels, Wederkerigheid en specialiteit in het bestuursrecht, a.w., p. 153 e.v.

139. Dat dit concept niet nieuw is, maar kwam 'overwaaien' uit het Duitse bestuursrecht - waar het niet onbestreden is gebleven - is m.i. voldoende door Teunissen belicht. Zie: J.M.H.F. Teunissen, Strategisch concept voor nivellerende rechtswetenschap?, a.w., m.n. p. 303 e.v. Zie ook: De Haan/Drupsteen/Fernhout, Bestuursrecht in de sociale rechtsstaat, a.w., p. 30. en R.J.B. Bergamin, Rechten jegens de overheid, a.w., p. 78 .

140. Ik kom hier in hoofdstuk 9 op terug, nadat de verschillende visies over het specialiteitsbeginsel in de literatuur (hoofdstuk 7) en de jurisprudentie (hoofdstuk 8) zijn geanalyseerd. Op deze plaats wijs ik de lezer reeds op de m.i. verhelderende analyse van Heldeweg inzake 'precieze' en 'rekkelijke' stromingen. M.A. Heldeweg, Het specialiteitsbeginsel: bel voor de laatste ronde?, annotatie onder Pres. Rb. Maastricht 24 februari 1995 in Rechtspraak bestuursrecht 1994/1995, De annotaties, i.h.b. p. 191 t/m 196.

141. Zie over de controverse tussen deze hoofdstromingen in het bestuursrecht: De Haan/Druptseen/Fernhout, Bestuursrecht in de sociale rechtsstaat, a.w., p. $26 \mathrm{t} / \mathrm{m} 36$. 
bestuur vrijheid van handelen toekomt in het kader van de uitoefening van bevoegdheden, wordt deze (beleids)vrijheid niet alleen begrensd door de wet, maar bók door algemene rechtsbeginselen, de beginselen van behoorlijk bestuur en de grondrechten. Het bestuur is volledig onderworpen aan het recht, en mag niet naar willekeur handelen. Het dient tevens waar mogelijk - d.w.z. binnen de grenzen van zijn bevoegdheid - rekening te houden met de relevante rechtsbelangen ${ }^{142}$ van burgers. Door deze belangen van burgers serieus te nemen, en door deze op een adequate wijze te inventariseren en in kaart te brengen - waar nodig in samenspraak met diezelfde burgers - kan de acceptatie van bestuurlijke besluitvorming positief worden beïnvloed. ${ }^{143}$ In zoverre kan met het concept van de 'rechtsbetrekking' worden ingestemd ${ }^{144}$, ofschoon men zich kan afvragen of hier sprake is van iets nieuws onder de zon. ${ }^{145}$

Volgens Van Male vormt de volledige binding van het bestuur aan het recht de kern van bedoeld concept. Er wordt beoogd aan te geven dat de gedragingen van het bestuur en de burger ten opzichte van elkaar worden beheerst door rechtsnormen waaraan de wederpartij aanspraken kan ontlenen. ${ }^{146}$ Juist in dit laatste aspect - het ontlenen van wederzijd$s e$ aanspraken - schuilt evenwel een aanzienlijk rechtsstatelijk gevaar. De achterliggende gedachte van het denken in 'rechtsbetrekkingen' treedt hier pas volledig in het daglicht. Uit een betoog van Gribnau kan worden afgeleid dat de overheid binnen het 'wederkerigheidsdenken' wordt gezien als een actor die te midden van de burgers optreedt in de 'publieke ruimte' met het oog op bestuurlijke belangen, taken en verantwoordelijkheden. ${ }^{147}$ Het bestuursorgaan wordt in dit kader met nadruk als rechtssubject gepositioneerd $^{148}$, waarbij de indruk wordt gewekt alsof het bestuur gemeenschapsbelangen dient

142. Zie over het berip '(rechts)belang' hoofdstuk 6 van dit boek (m.n. paragraaf 6.4 ).

143. Vgl. de opmerkingen die Scheltema reeds in 1975 in zijn VAR-preadvies maakte over de ontwikkelingen in de rechtsverhouding burger-bestuur. M. Scheltema, Gebondenheid van overheid en burger aan eigen voorafgaand handelen (rechtsverwerking), Geschriften van de Vereniging voor Administratief Recht LXXIV, Groningen 1975, p. 9.

144. En dit is m.i. ook de betekenis die Donner aan het begrip 'rechtsbetrekking' in het bestuursrecht wilde toekennen. Vgl. paragraaf 1 van hoofdstuk VII 'Het bestuur en de burger' in zijn Nederlands bestuursrecht, Algemeen deel, vierde herziene druk, Alphen aan den Rijn 1974, p. $221 \mathrm{t} / \mathrm{m} 226$. Het gaat hier m.i. om de idee van de erkenning van de burger als volwaardig rechtssubject, het positioneren van de relatie burger-bestuur als een rechtsrelatie en om het uitgangspunt van individuele rechtsbedeling. Overigens werd het betreffende hoofdstuk niet meer opgenomen in de vijfde herziene druk van Donners Algemeen deel (Alphen aan den Rijn 1987); Vgl. ook de visie van De Haan/Drupsteen/Fernhout, Bestuursrecht in de sociale rechtsstaat, a.w., p. $30 \mathrm{t} / \mathrm{m} 32$.

145. Vgl. bijv. Bergamin die in dit verband in het 'rechtsbetrekking'-concept een precisering ziet van de visie dat het bestuursrecht gebaseerd is op het beginsel van de rechtsstaat (iets nieuws ?). R.J.B. Bergamin, Rechten jegens de overheid, a.w., p. 206.

146. R.M. van Male, Onvoltooid recht, a.w., p. 10.

147. J.L.M. Gribnau, De wederkerige rechtsbetrekking als nieuw paradigma, a.w., met name p. 92 en 93 . Vgl. R. Foqué, De ruimte van het recht (oratie), Amhem 1992, p. 36.

148. Het uitdrukkelijk positioneren van het bestuursorgaan als rechissubject, gelijk een burger, is naar mijn mening typerend voor het 'wederkerigheids'-denken. Vgl. bijv. C.P.J. Goorden, Rechtsbevoegdheid in het bestuursrecht, a.w., i.h.b. p. 109 e.v. en R.J.B. Bergamin, Rechten jegens de overheid, a.w., p. 63 en 64. 
te behartigen als zouden het 'eigen' belangen zijn. Het bestuursorgaan wordt gekarakteriseerd als drager van rechten en plichten. ${ }^{149}$ Met het oog op de belangen van het bestuur zouden ook voor de individuele burger verplichtingen jegens dat bestuur gelden. Ik wijs in dit verband op Nicolaïs opvatting inzake ongeschreven burgerplichten. ${ }^{150}$ Anderzijds zou de burger beschikken over 'publiekrechtelijke subjectieve rechten' jegens de overheid, welke rechten rechtstreeks gerelateerd worden aan de rechtsbetrekking tussen bestuur en burger. ${ }^{151}$

De 'wederkerigheids'-gedachte beoogt mijns inziens een basis te bieden om rechtstreeks op het algemene concept van de rechtsbetrekking (dan wel de aard van de verhouding bestuur-burger) redelijkheids- en/of zorgvuldigheidsnormen te funderen waarop ook de overheid zich kan beroepen tegen de burger, zonodig buiten de wet om. Derhalve gaat het niet uitsluitend om de positionering van de burger als rechtssubject, maar om de relativering van het onderscheid burger-bestuur in zijn algemeenheid. Door een vermeende gelijkwaardigheid ${ }^{152}$ van beiden te benadrukken wordt getracht te abstraheren van de objectieve publiekrechtelijke bevoegdheidsnorm die primair bepalend is voor de rechtsrelaties tussen rechtssubjecten en een bestuursorgaan. Gribnau deed in dit kader de volgende veelzeggende uitspraak: 'Alfa en omega van het bestuursrecht is derhalve niet meer een overheid die de door het legaliteitsbeginsel ingekaderde bevoegdheid heeft de burgers te beperken in de uitoefening van hun rechten en vrijheden, met andere woorden de burgers op basis van een wettelijke grondslag - eenzijdig - te binden. ${ }^{153}$ De abstrahering van het bestuursrechtelijke 'bevoegdheids'-begrip, dat vaak gepaard gaat met de eerder aangestipte relativering van de rechtsstatelijke wetmatigheidsleer en het specialiteitsbegin-

Zie ook reeds Vegting die over de bestuursrechtelijke rechtsbetrekking opmerkte: 'Gelijk in iedere rechtsbetrekking staan in een administratiefrechtelijke rechtsbetrekking twee subjecten in een relatie tot elkaar zo, dat een jegens de ander gerechtigd is tot een praestatie en deze laatste jegens de eerste tot deze praestatie verplicht is.' W.G. Vegting, Het algemeen Nederlands administratiefrecht, eerste deel, a.w., p. 181. Door bestuursorganen te positioneren als rechtssubjecten, zijnde zelfstandige dragers van rechten en plichten, wordt evenwel de typische orgaanfunctie (d.w.z. de actieve subjectfunctie) binnen het recht die van de passieve subjectfunctie dient te worden onderscheiden - onvoldoende onderkend. Zie in dit verband over de orgaanfunctie: H.J. van Eikema Hommes, De elementaire grondbegrippen der rechtswetenschap, Deventer 1972, i.h.b. hoofdstuk X, p. 219 e.v.; zie ook p. 240. Ik kom hier in de hoofdstukken 3 en 9 op terug.

149. R.J.B. Bergamin, Rechten jegens de overheid, a.w., p. 64.

150. P. Nicolar, De stiekeme citoyen, in: De Awb-mens: boeman of underdog?, (Damen-bundel), Nijmegen 1996, p. 179 e.v. Opgemerkt zij dat Nicolail weliswaar de 'wederkerigheidsnotie' expliciet verwerpt (a.w. $180 \mathrm{t} / \mathrm{m} \mathrm{183)}$, maar m.i. desalniettemin op het algemene rechtskarakter van de relatie bestuur-burger (wederkerige) rechten en plichten fundeert, hierbij appellerend aan de idee dat ieder 'mens' ook 'staatsburger' (citoyen) is.

151. Ik verwijs kortheidshalve naar het proefschrift van Bergamin. R.J.B. Bergamin, Rechten jegens de overheid, a.w., m.n. hoofdstuk 3 en 4.

152. In hoofdstuk 3 zal betoogd worden dat er nooit sprake kan zijn van (normatieve) 'gelijkwaardigheid' tussen overheid en burger, omdat deze entiteiten per definitie ongelijksoortige belangen behartigen.

153. J.L.M. Gribnau, De wederkerige rechtsbetrekking als nieuw paradigma, a.w., p. 91 en 92. 
sel, opent de weg naar onderhandelend en horizontaal bestuur ${ }^{154}$ alsmede naar het daarin passende fenomeen van een 'open' bestuursbevoegdheid ${ }^{155}$ die een forum zou bieden voor open en vrije belangenharmonisatie in het publiekrecht. Bestuursbevoegdheid lijkt in dit kader steeds meer te worden opgevat als enkel een instrument voor het bestuur om - zonodig bindend - te bemiddelen in privaatrechtelijke relaties tussen burgers onderling. ${ }^{156}$ Door bovendien de nadruk te leggen op globale en open normering van bestuursbevoegdheid wordt de (omvang van) publieke belangbehartiging opgerekt. Deze ontwikkeling kan leiden tot een steeds verdergaande bestuursinterventie in de autonome rechtssferen tussen burgers onderling. ${ }^{157}$

In het licht van het bovenstaande zal het niet verbazen dat de 'nieuwe' visie inzake de relatie tussen bestuur en burger niet onbestreden is gebleven. ${ }^{158}$ Hoekema heeft bijv. een serieuze waarschuwing doen uitgaan tegen de tendens van 'horizontalisering' in de relaties tussen bestuur en burgers, en met name tegen onderhandelend bestuur. ${ }^{159}$ Hierin schuilen naar zijn oordeel, mede gelet op het specialiteitsbeginsel, rechtsstatelijke gevaren:

'Vanwege het feit dat in onderhandelend bestuur een apart forum wordt geschapen of benut dat geen heldere verbinding heeft met bekende representatieve fora, zoals het parlement of een gemeenteraad, wordt ernstig afbreuk gedaan aan de helderheid van de structuur der bevoegdheden resp. verantwoordelijkheden in het openbaar bestuur. Daarom roept dat bestuur vragen op die zich aftekenen tegen de achtergrond van de

154. Zie over het verschil tussen 'horizontaal' en 'wederkerig' bestuur: L.J.A. Damen, Bestaat de Awbmens?, in: Aantrekkelijke gedachten, beschouwingen over de Algemene wet bestuursrecht, Deventer 1993, p. 110 Um 115.

155. De idee van 'open bestuursbevoegdheid' die ruimte biedt voor communicatieprocessen tussen burgers en bestuur is o.m. uitgewerkt door Stout in haar proefschrift. Zie: H.D. Stout, De betekenissen van de wet, diss. RUL, Zwolle 1994, p. 229 e.v.

156. Vgl. R.J.N. Schlossels, Het specialiteitsbeginsel en derde-belangen: een frisse benadering of rechtsstatelijk drijfzand?, NTB 1996/3, p. 82.

157. Dat dergelijke ontwikkeling door de administratieve rechter - vanuit proceseconomisch oogpunt - wordt gestimuleerd blijkt m.i. uit: ABRS 10 mei 1995, RAwb 1995, nr. 72, m.a. BdW (telefooncel Buttervliet) VzARRS 28 juni 1993, AB 1994, 422 (kater Napoleon). Deze jurisprudentie komt in hoofdstuk 8 en 9 aan bod.

158. Ik bespreek hier niet uitvoerig alle bedenkingen die in de literatuur zijn geuit. Verwezen zij o.m. naar de tien bijdragen in de Maastrichtse bundel 'Eenzijdig en wederkerig?', a.w.; De Haan/Drupsteen/Fernhout, Bestuursrecht in de sociale rechtsstaat, a.w., p. 26 e.v.; H.J. Simon, Publiekrecht of privaatrecht?, diss. VU, Zwolle 1993, p. 201 e.v. en J.M.H.F. Teunissen, Het burgerlijk kleed van de staat, a.w., p. $190 \mathrm{t} / \mathrm{m}$ 194. Ik wijs ook nog op het Utrechtse proefschrift van Schueler. Schueler spreekt over het aangehangen 'dogma' van 'wederkerig bestuur', en merkt bondig op: 'Mijns inziens is 'wederkerig bestuur' als dogma de juridische ontkenning van de machtsrelatie die bestaat in alle gevallen waarin het bestuur een rechtsbetrekking heeft gecreěerd tegen de wil van een burger die daarop geen enkele invloed heeft uitgeoefend.' B.J. Schueler, Vernietigen en opnieuw voorzien. Over het vernietigen van besluiten en beslechten van geschillen, diss. UU, Zwolle 1994, 172.

159. A.J. Hoekema, Het rechtskarakter van doelmatig onderhandelend bestuur, a.w., m.n. p. $122 \mathrm{t} / \mathrm{m} 126$. Nadelen die volgens Hoekema kleven aan 'onderhandelend bestuur' zijn o.m. lastenafwenteling op niet vertegenwoordigde belangen, gebrek aan rechtszekerheid/rechtsgelijkheid, alsmede een gebrekkige (democratische) controleerbaarheid van het bestuur en het risico van privilegevorming. 
maatschappelijk integrerende betekenis die toekomt aan klassieke beginselen van gelijkheid en zekerheid (en het beginsel van specialiteit). ${ }^{160}$

Ook Stroink heeft er in een vroeg stadium op gewezen dat de term '(wederkerige) rechtsbetrekking' in het bestuursrecht versluierend werkt. ${ }^{161}$ Het hedendaagse bestuursrecht in de democratische en sociale rechtsstaat wordt juist in overwegende mate gekenmerkt door éénzijdig overheidsoptreden in de vorm van de publiekrechtelijke bevoegdheidsuitoefening. Hieraan doet niet af dat ten aanzien van deze bevoegdheidsuitoefening geschreven en ongeschreven regels en beginselen gelden die een juist en zorgvuldig gebruik van de bevoegdheid waarborgen (bijv. het inwinnen van relevante informatie, inspraak en vooroverleg). Ook De Haan, Drupsteen en Fernhout nemen in hun handboek een zekere afstand van het denken in termen van 'wederkerige rechtsbetrekkingen' in het bestuursrecht. Volgens deze auteurs verdient het $\mathrm{nl}$. geen aanbeveling om aan de algemene verhouding burgeroverheid concrete rechten en verplichtingen te verbinden, los van die welke zijn gepositiveerd of berusten op erkende regels van ongeschreven recht. Evenmin achten zij het begrip 'subjectief publiek recht' bruikbaar als funderend begrip voor het staats- en bestuursrecht. ${ }^{162}$ Deze opvatting deel ik goeddeels. In dit verband kan niet worden ontkend dat een burger als rechtssubject specifieke rechten heeft in het publiekrecht, maar deze rechten zijn, naar hun (uit)werking, naar mijn mening niet vergelijkbaar met de subjectieve rechten in het privaatrecht ${ }^{163}$; het gaat in het publiekrecht om een volwaardi-

160. A.J. Hoekema, Onderhandelend bestuur, Recht der werkelijkheid, 1994/1, p. 104.

161. F.A.M. Stroink, boekbeschouwing C.P.J. Goorden, Rechtsbevoegdheid in het bestuursrecht, NTB 1990, p. 296; hierin bijgevallen door: H.J. Simon, Publiekrecht of privaatrecht?, diss. VU, Zwolle 1993, p. 202. Zie ook: F.A.M. Stroink, De algemene wet bestuursrecht en het sociale zekerheidsrecht, Tijdschrift voor Sociaal Recht, 1989/10, p. 256 en 257. Hier benadrukt genoemde auteur de verticale verhouding tussen overheid en burger. Door Burkens en Stroink is overigens reeds in 1980 op de mogelijke rechtsstatelijke gevaren van de 'horizontaliseringstendens' in de relatie overheid-burger gewezen. Zie: Sociale verzorgingsstaat en consensuele besluitvorming, NJB 1980/29, p. 743 e.v. (met name p. 749) Tak en Teunissen zijn op dit punt nog kritischer. Zij merken op: 'Dit beeld van de 'wederkerige rechtsbetrekking' is echter niet alleen modieus maar ook vals; in een rechtsstaat is o.i. juist de eenzijdigheid een kenmerk van het overheidsoptreden en een waarborg voor de burgers.' J.M.H.F. Teunissen en A.Q.C. Tak, Recht ist was der Umwelt nutzt ?, NJB 1994/18, p. 614.

162. De Haan/Drupsteen/Fernhout, Bestuursrecht in de sociale rechtsstaat, a.w., p. 32. In kritische zin ook: Nicolaï e.a., Bestuursrecht, zesde geheel herziene druk, Amsterdam 1997, p. 7

163. Bepaalde overeenkomsten kunnen uiteraard niet worden ontkend. Zo vertegenwoordigt bijv. een 'vergunning' niet zelden een bepaalde vermogenswaarde in het private rechtsverkeer, doordat een dergelijke vergunning een essentiele publiekrechtelijke randvoorwaarde kan zijn om van privaatrechtelijke subjectieve rechten in volle omvang gebruik te kunnen maken. Vgl. het bekende Benthem-arrest EHRM 23 oktober 1985, NJ 1986, 102; AB 1986, 1, m.nt. E.M.H. Hirsch Ballin en HR 16 mei 1997, JB 1997/148, m.nt. HJS. Dit gegeven brengt naar mijn oordeel echter nog niet met zich dat er op een vergunning een afdwingbare aanspraak bestaat (zie voorts hoofdstuk 9 van dit boek). Zie ook: De Haan/Drupsteen/Fernhout, Bestuursrecht in de sociale rechtsstaat I, a.w., p. 34. In de sfeer van de sociale zekerheid en subsidies lijken bepaalde 'aanspraken' (nadat bestuurlijke besluitvorming in concreto heeft plaatsgevonden) moeilijk te kunnen worden ontkend, maar deze zijn in ieder geval niet vrij overdraagbaar. 
ge, grondrechtelijke, erkenning als juridische persoon. ${ }^{164}$ Ten aanzien van de concreetheid (of bepaaldheid), de vrije overdraagbaarheid, de vrije genotsbevoegdheid alsmede de juridische afdwingbaarheid verschillen de publieke rechten van hun private tegenpool. ${ }^{165}$

Onjuist naar mijn oordeel is verder de gedachte dat het bestuur in het kader van typisch publiekrechtelijke orgaanfuncties zou beschikken over subjectieve rechten jegens de burgers. Aan publiekrechtelijke bevoegdheden kunnen door het bestuur géen subjectieve rechten worden ontleend. Publieke bevoegdheid is - zoals eerder werd gesteld - publieke plicht. ${ }^{166}$ De onbruikbaarheid van het privaatrechtelijke begrip 'subjectief recht' in het publiekrecht vloeit voort uit het objectieve karakter van dit recht en de centrale positie die hierbinnen toekomt aan de 'afweging' van publiekrechtelijke belangen en subjectgebonden rechtsbelangen ${ }^{167}$ onder de regulerende werking van het algemeen belang, d.w.z. de typisch publiekrechtelijke harmonisatie- en integratiefunctie. Voorzover beoogd wordt om het begrip 'subjectief recht' autonoom in het publiekrecht tot ontwikkeling te brengen ter versterking van de rechtspositie van de burger, stel ik mij op het standpunt dat bedoeld begrip niet zoveel toevoegt aan de normerende werking van het (objectieve) publiekrecht, nl. de wet, de algemene rechtsbeginselen en de algemene beginselen van behoorlijk bestuur. ${ }^{168}$ Ook de grondrechten, die men naar mijn oordeel wél kan zien als een soort 'subjectgebonden' rechten in het publiekrecht, versterken de rechtspositie van de burger ten opzichte van het bestuur reeds in belangrijke mate. ${ }^{169}$

In mijn opvatting over de bestuursrechtelijke 'rechtsbetrekking' hebben verder de conceptie van de bestuursbevoegdheid en de daarmee samenhangende typisch publiekrechtelijke beginselen van legaliteit, democratie en specialiteit niet aan belang ingeboet. ${ }^{170}$

164. Ik wijs erop dat naar Duits recht in de (juridische) erkenning van de menselijke waardigheid en persoon ook de grondslag voor het 'subjektive offentiche Recht' is gelegen. Zie: H. Maurer, Allgemeines Verwaltungsrecht, a.w., p. 150.

165. Anders: F.J. van Ommeren, De verplichting verankerd. De reikwijdte van het legaliteitsbeginsel en het materiêle wetsbegrip, diss. VU, Deventer 1996, p. 278.

166. Ik verwijs in dit kader naar de m.i. gedegen beschouwing van Teunissen over 'publieke subjectieve rechten'. Zie: J.M.H.F. Teunissen, Strategisch concept voor nivellerende rechtswetenschap?, a.w., p. 303 $\mathrm{t} / \mathrm{m}$ 311. Teunissen heeft zich in dit kader o.m. gebaseerd op Z. Giacometti, Allgemeine Lehren des rechtsstaatlichen Verwaltungsrechts, 1. Band, Zurich 1960, i.h.b. p. 306-310.

167. Vgl. H.J. Simon, Publiekrecht of privaatrecht?, a.w., i.h.b. p. 208 en 209. Zie voorts hoofdstuk 3 van dit boek.

168. Vgl. de vaststelling van Bergamin in zijn proefschrift: 'Het bestuursrechtelijke subjectieve recht is aldus beschouwd op te vatten als grondslag voor een aantal normatieve uitgangspunten voor de behoorlijkheid van het overheidsgedrag t.a.v. de burger. Het geeft er rechtvaardiging aan dat bijv. uit gewekt vertrouwen, rechtszekerheid of geleden nadeel een overheidsverplichting wordt afgeleid.' R.J.B. Bergamin, Rechten jegens de overheid, a.w., p. 268.

169. Vgl. hoofdstuk 9 van dit boek (i.h.b. paragraaf 9.6).

170. Vgl. in dit verband bijv. ook: R.J. Jue, Vrijheid van besturen, a.w., p. 143. Ofschoon deze auteur kennelijk het concept van de 'rechtsbetrekking' hanteert, wordt de welomschreven bevoegdheid centraal gesteld. Anders, vanuit een typisch privaatrechtelijke en weinig problematiserende optiek: R.P.J.L. Tjittes, Herbezinning op de grondslagen van de overheidsaansprakelijkheid, preadvies voor de Vereniging voor burgerlijk recht, Lelystad 1996, p. 53-54. 
Zij vormen mijns inziens nog steeds het noodzakelijke fundament voor de 'rechtsbetrekking' tussen bestuur en burger. ${ }^{171}$ Dit brengt met zich dat binnen het hedendaagse bestuursrecht naar mijn oordeel weer meer aandacht naar de bevoegdheidsleer dient uit te gaan. Deze leer is bij lange na niet 'failliet' of 'ouderwets', maar wel toe aan een nieuwe impuls. Genoemde leer biedt mijns inziens ook het primaire - maar niet enige ${ }^{172}-$ referentiekader voor de interpretatie van het specialiteitsbeginsel en de daarmee samenhangende begrenzing van de bestuurlijke belangenafwegingsplicht 'in concreto'. Tevens bieden (discretionaire) bevoegdhedenstelsels de ideaal-typische normatieve structuur om publiekrechtelijke belangen en private rechtsbelangen met elkaar te harmoniseren. In het vervolg van dit boek kom ik hier nog uitvoerig op terug.

\subsection{Definitie bestuursbevoegdheid}

Gelet op het voorafgaande wordt in dit boek van 'bestuursbevoegdheid' gesproken indien een publiekrechtelijke bevoegdheid toekomt aan, en uitgeoefend wordt door, een bestuursorgaan. Hiermee wordt het begrip bestuursbevoegdheid gedefinieerd als een species van het ruimere begrip publiekrechtelijke bevoegdheid. ${ }^{173}$ De essentie van 'rechtsbevoegdheid' in het bestuursrecht is gelegen in de mogelijkheid van een orgaan om éénzijdig (gericht) rechtsgevolgen in het leven te roepen die de rechtspositie van rechtssubjecten vaststellen of wijzigen, waarbij bestuursbevoegdheid steeds wordt uitgeoefend in het algemeen belang ter exclusieve behartiging van speciale publiekrechtelijke belangen (de eis van publieke doelbinding). ${ }^{174}$ De exclusieve machtiging voor het uitoefenen van een bevoegdheid dient een bestuursorgaan te ontlenen aan het objectieve publiekrecht. ${ }^{175}$

Het gedefinieerde bestuursbevoegdheidsbegrip is ruim van aard. Het omvat zowel bevoegdheden met een 'beschikkings'-karakter als bevoegdheden met een 'regelgevings'-karakter. ${ }^{176}$ Voorts ziet het op bestuursbevoegdheden die ten aanzien van burgers kunnen worden uitgeoefend (externe bestuursbevoegdheden), als ook op bevoegdheden die ten

171. Vgl. R.J.N. Schlossels, Wederkerigheid en specialiteit in het bestuursrecht, a.w., p. 153 e.v.

172. Met de De Haan, Drupsteen en Fernhout (a.w., p. 35) ben ik van mening dat óbk aan een eenzijdige benadering van het bestuursrecht vanuit de formele wetmatigheids- en bevoegdheidsleer tekortkomingen kleven. Daarom dient, zoals in hoofdstuk 3 zal blijken, de uitoefening van bestuursbevoegdheid altijd tegen de integrerende achtergrond van alle typische rechtsbeginselen van de publieke rechtsgemeenschap te worden beschouwd.

173. De publiekrechtelijke bevoegdheden van de wetgever in formele zin ên de bevoegdheden van de onafhankelijke organen welke binnen de staat met rechtspraak zijn belast vallen, zoals reeds in paragraaf 2.2 werd gesteld, buiten deze definitic (vgl. art. 1:1 lid 2 Awb).

174. De begrippen 'handelen in het algemeen belang' en '(speciaal) publiekrechtelijk belang' komen in de hoofdstukken 3 en 6 nader aan bod. Op basis van de definitie-eis van specifieke 'doelbinding' kunnen de algemene autonome verordenende bevoegdheden van decentrale regelgevers (die rechtstreeks aan de Grondwet worden ontleend) buiten beschouwing blijven.

175. Op deze plaats wordt nog in het midden gelaten in hoeverre voor bestuursbevoegdheden het legaliteitsbeginsel (beginsel van wetmatigheid van bestuur) geldt. Dit aspect komt in hoofdstuk 4 van dit boek aan de orde. 
aanzien van bijv. ambtenaren - dus binnen de bestuurlijke organisatie - kunnen worden uitgeoefend (interne bestuursbevoegdheden). ${ }^{177}$

Het gestelde in dit boek is óók relevant voor de zgn. 'indirecte' bestuursbevoegdheden. Hieronder worden verstaan die bestuursbevoegdheden die worden uitgeoefend ter beïnvloeding van de uitoefening van bestuursbevoegdheden van andere bestuursorganen. ${ }^{178}$ Ook deze 'indirecte bestuursbevoegdheden' zijn aan het specialiteitsbeginsel gebonden. Zo kan bijv. een goedkeuringsbevoegdheid van een 'hoger' bestuursorgaan slechts worden uitgeoefend in het belang van de wettelijk omschreven publiekrechtelijke belangen. Bij het ontbreken daarvan dient aansluiting te worden gezocht bij de belangen die de betreffende wet, waarop de goedkeuringsbevoegdheid is gebaseerd, beoogt te beschermen. ${ }^{179}$

Ofschoon een ruime definitie van 'bestuursbevoegdheid' in dit boek gerechtvaardigd is omdat het specialiteitsbeginsel als structuurbeginsel van bestuursrecht van belang is voor publiekrechtelijke bevoegdheidsnormen in hun algemeenheid, zal waar nodig een onderscheid worden gemaakt tussen bepaalde typen bestuursbevoegdheid. Zo zal in hoofdstuk 5 (détournement de pouvoir) en hoofdstuk 6 (belangenafweging) onderscheid worden gemaakt tussen bestuursbevoegdheden met een regelgevings- en een beschikkingskarakter. De hoofdstukken 7, 8 en 9 zullen in hoofdzaak in het teken staan van discretionaire bestuursbevoegdheden met een beschikkingskarakter. Ten aanzien van dit type bestuursbevoegdheid doen zich $\mathrm{nl}$. in de rechtspraktijk de meest pregnante specialiteitsproblemen voor.

\subsection{Bestuurstaak en bestuursbevoegdheid}

In dit hoofdstuk dient tot slot een onderscheid gemaakt te worden tussen bestuursbevoegdheid en bestuurstaak. Uitgaande van het gedefinieerde bevoegdheidsbegrip kan gesteld worden dat een bestuursorgaan aan een bestuursbevoegdheid de legitimatie ontleent om nieuw positief recht te vormen waaraan rechtssubjecten gebonden zijn. Het vormen van nieuw positief recht bij wijze van bevoegdheidsuitoefening zal dienen te geschieden met het oog op bepaalde - objectief vaststelbare - publiekrechtelijke doelstellingen. Deze doelstellingen worden, zoals in het volgende hoofdstuk zal blijken, in de democratische rechtsstaat geformuleerd binnen kenbare constitutionele procedures en structuren. Het

176. Waarmee mijn definitie past in de structuur van de Algemene wet bestuursrecht (Awb). Ik wijs er overigens uitdrukkelijk op dat het begrip 'bestuursbevoegdheid' in de literatuur ook in een engere betekenis wordt gebruikt, namelijk als synoniem voor wat ik aanduid als 'beschikkingsbevoegdheid'. Vgl. J.M.E. Derks, De Grondwet en delegatie, Het delegatievraagstuk in constitutioneel perspectief, diss. RL, Maastricht 1995, p. 6.

177. Zie over dit onderscheid: F.A.M. Stroink en J.G. Steenbeek, Inleiding tot het staats- en bestuursrecht, vierde herziene druk, Alphen aan den Rijn 1989, p. 31.

178. Voorbeelden van dergelijke bestuursbevoegdheden zijn bijv. goedkeurings- en aanwijzingsbevoegdheden. Vgl. F.A.M. Stroink, Het leerstuk der deconcentratie, 's-Gravenhage 1978, p. 86.

179. Zie bijv.: Koopmans' Compendium van het staatsrecht, bew. door Th.L. Bellekom e.a., zevende druk, Zwolle 1994, p. 216. 
primaat van doeldeterminatie ligt binnen de publieke rechtsgemeenschap bij de vertegenwoordigende organen. Ter behartiging van de geformuleerde doelstellingen en/of taken kunnen aan bestuursorganen specifieke bestuursbevoegdheden worden toegekend. In navolging van Kortmann dient te worden opgemerkt dat taakstelling en bevoegdheidsverlening nauw met elkaar samenhangen. ${ }^{180}$ Publieke taakstelling kan leiden tot attributie (of delegatie) van bevoegdheden door de wetgever aan bestuursorganen. Uit publieke taakstellingen - die de uitkomst zijn van een politiek-democratisch proces van prioriteitstelling en belangenafweging ${ }^{181}$ - kan bijgevolg in ieder geval de ratio achter de toekenning van bevoegdheden aan het bestuur worden afgeleid. ${ }^{182}$

In dit kader is het relevant om vast te stellen welke taken binnen de democratische rechtsstaat kunnen worden aangemerkt als taken van het openbare bestuur. Een aanknopingspunt voor de beantwoording van deze vraag zou gevonden kunnen worden in de memorie van toelichting bij artikel 1:2 lid $2 \mathrm{Awb} .{ }^{183}$ Ten aanzien van de vraag welke belangen aan een bestuursorgaan zijn toevertrouwd werd door de regering het volgende opgemerkt: 'Of gesproken kan worden van een aan een bestuursorgaan als zodanig toevertrouwd belang, moet beoordeeld worden aan de hand van de taken die aan het bestuursorgaan in kwestie zijn opgedragen. Daarvoor is in de eerste plaats de wetgeving bepalend, waaruit voor sommige bestuursorganen (bijv. ministers) ruime en voor andere bestuursorganen beperkte takenpakketten afleidbaar zijn' (curs. R.J.N.S.). Publieke taken worden in deze optiek door de wetgever (in formele zin) aan het bestuur opgedragen. ${ }^{184}$

Schreuder ${ }^{185}$ maakt in dit verband een zinvol onderscheid tussen 'publieke taken' en 'publiekrechtelijke taken'. ${ }^{186}$ Een publieke taak kan volgens haar worden omschreven als een taak waarmee het algemeen belang is gemoeid. Deze omschrijving is evenwel, zoals zij zelf reeds vaststelt, weinig verhelderend. Ten aanzien van het kernvraagstuk, nl. hoe een publieke taak herkend kan worden, zoekt zij aansluiting bij de publiekrechtelijke

180. C.A.J.M. Kortmann, Constitutioneel recht, a.w., p. 37.

181. Vgl. Kortmann die het begrip 'bevoegdheid' relateert aan '(constitutioneel) recht', en 'taak' aan 'politiek'. C.A.J.M. Kortmann, Constitutioneel recht, a.w., p. 37.

182. Het mag voor zich spreken dat de wetgever aan het bestuur afdoende bevoegdheden dient te verlenen om de opgedragen publiekrechtelijke taken naar behoren te kunnen vervullen. Vgl. H.D. Stout, Doelmatige bestuurlijke belangenafweging: een speciaal terrein, in: De rechtsstaat herdacht (red. J.W.M. Engels e.a.), Zwolle 1989, p. 240.

183. PG Awb I, MvT, p. 149.

184. Deze visie vond ook steun in de jurisprudentie van de (voormalige) Afdeling rechtspraak van de Raad van State inzake art. 4 van de Wet Administratieve rechtspraak overheidsbeschikkingen (Wet Arob). De vraag of een bestuursorgaan als 'belanghebbende' kon worden aangemerkt in de zin van genoemde wet, werd primair beantwoord aan de hand van de aan het betreffende orgaan opgedragen wettelijke taken. Vgl. bijv.: ARRS 11 februari 1982, AB 1983, 317, m.nt. JHvdV (inspecteur RIVM); ARRS 4 november 1983, AB 1984, 64 (culturele raad Dordrecht); ARRS 24 januari 1984, AB 1984, 239, m.nt. CLR; ARRS 31 januari 1985, AB 1986, 280, m.nt. JHvdV (Drank- en Horecawet Landgraaf) en ARRS 27 augustus 1985, AB 1987, 74, m.nt. JHvdV (taxivergunning Maasland).

185. C.A. Schreuder, Publiekrechtelijke taken, private rechtspersonen, diss. RUG, Deventer 1994, p. 33.

186. Vgl. voor de hantering van deze begrippen door de Hoge Raad bijv. HR 11 december 1992, NJ 1993, 301 (Vlissingen/Rize, r.o. 3.5). 
grondslag van een taak binnen het rechtsstelsel. Van een publiekrechtelijke grondslag is sprake wanneer de taak een basis heeft in een democratisch gelegitimeerd besluit van de statelijke organen. ${ }^{187}$ Hieruit kan worden afgeleid dat de politiek het verrichten van de betreffende werkzaamheid in het algemeen belang acht. ${ }^{188}$

Intussen biedt noch het begrip 'publieke taak' noch het begrip 'publiekrechtelijke taak' veel inzicht in de juridische potenties van het bestuur. Goorden merkt op dat uit een algemene publieke taak (die ook 'publiekrechtelijk' kan zijn) geén bestuursbevoegdheid mag worden afgeleid. Volgens hem vloeit de taak voort uit de bevoegdheid en niet omgekeerd. ${ }^{189}$ Inzicht in de juridische potenties van het bestuur kan volgens hem het best verkregen worden op basis van een analyse van de bestuursbevoegdheden die aan de bestuursorganen zijn toevertrouwd. ${ }^{190}$ Ook Stroink stelt zich op dit standpunt. Volgens hem zijn functie, taak en doel(stelling) géén specifiek juridische begrippen. De taak- en doelstelling ligt besloten in de bevoegdheidsverlening en wordt verwezenlijkt in de bevoegdheidsuitoefening. ${ }^{191}$

Als juist moet worden aanvaard dat de wetgever met de codificatie van wettelijke taken in beginsel ${ }^{192}$ géén bestuursbevoegdheid in de eerder gedefinieerde zin beoogt toe te kennen. Veeleer gaat het bij de codificatie van een taak om de algemene afbakening van het gebied waarbinnen een bestuursorgaan, dan wel de publiekrechtelijke rechtspersoon waartoe dat orgaan behoort, zijn specifieke bestuursfunctie dient te vervullen. ${ }^{193}$ In het

187. Enige voorbeelden van publiekrechtelijke taken: art. 1 Waterschapswet; art. 2 Wet op de Bedrijfsorganisatie; art. 2 Politiewet.

188. C.A. Schreuder, Publiekrechtelijke taken, private rechtspersonen, a.w., p. 34.

189. C.P.J. Goorden, Rechtsbevoegdheid in het bestuursrecht, a.w., p. 66. Vgl. ook: B. van der Meulen, De normering van het feitelijk handelen der overheid, NTB 1991/9, p. 268.

190. C.P.J. Goorden, Rechtsbevoegdheid in het bestuursrecht, a.w., p. 54. Vgl. ook de opvatting van Michiels: 'Het begrip (algemene) publieke taak is te vaag om bruikbaar te zijn, behoort niet alles wat de overheid doet tot de (algemene) publieke bestuurstaak.' F.C.M.A. Michiels, De Arob-beschikking, diss. KUN, Nijmegen 1987, p. 183. Van der Meulen, die een wettelijke taakopdracht vergelijkt met een bevoegdheidsgrondslag, wijst eveneens op de principięle verschillen. De grondslag van een geattribueerde (bestuurs)bevoegdheid dient preciezer te zijn geformuleerd. Zie: B. van der Meulen, De normering van het feitelijk handelen der overheid, a.w., p. 271.

191. F.A.M. Stroink, Het leerstuk der deconcentratie, a.w., p. 20.

192. Een 'beruchte' uitzondering op deze hoofdregel vormt art. 2 Politiewet (art. 28 oud), dat bepaalt: 'De politie heeft tot taak in ondergeschiktheid aan het bevoegde gezag en in overeenstemming met de geldende rechtsregels te zorgen voor de daadwerkelijke handhaving van de rechtsorde en het verlenen van hulp aan hen die deze behoeven.' Op basis van dit artikel kunnen onder omstandigheden aan de politie vergaande bevoegdheden - in de zin van (feitelijk) bevoegd handelen -, toekomen i.v.m. het daadwerkelijk handhaven van de rechtsorde. Uitoefening van bestuursbevoegdheid in de gedefinieerde zin (vgl. paragraaf 2.6) is hier m.i. echter niet aan de orde. Zie bijv. HR 24 oktober 1961, NJ 1962, 86 (Zeijense nachtbraker); HR 22 februari 1977, NJ 1977, 288, m.nt. Th. W. van Veen (inbeslagname vlaggestok) en HR 14 oktober 1986, NJ 1988, 511, m.nt. Th. W. van Veen (schaduwen).

193. Vgl. D.W.P. Ruiter, Normscheppende bepalingen in bestuursrechtelijke wetten, Bestuurswetenschappen 1980/4, p. 270. Wettelijke taakomschrijvingen, door Ruiter aangeduid als 'competentievestigende' bepalingen bakenen slechts de 'werkkring' van overheidsambten af zonder dat zij al uitdrukkelijk aangeven welke specifieke bevoegdheden en plichten daarbinnen aan het ambt toekomen. Dit in tegenstelling tot de 
algemeen zijn wettelijke taakomschrijvingen te vaag én te ruim geformuleerd om binnen een rechtsstelsel als specifieke bevoegdheidsgrondslag te kunnen fungeren. ${ }^{194}$

Een relativering is hier op zijn plaats. Opgemerkt dient te worden dat door administratiefrechtelijke colleges meer dan eens op grond van het zgn. 'publieke taak'-criterium 'besluiten' worden aangenomen, zonder dat deze besluiten herleidbaar zijn tot een specifieke bevoegdheidsgrondslag in een specifiek staats- of administratiefrechtelijk voorschrift. ${ }^{195}$ Daar het 'publieke taak'-criterium in de literatuur uitvoerig is belicht laat ik een analyse ervan in dit boek achterwege, en volsta met enige opmerkingen. ${ }^{196} \mathrm{De}$ 'publieke taak'-jurisprudentie, die de nodige kritiek heeft geoogst ${ }^{197}$, dient naar mijn mening tegen een tweetal achtergronden te worden geprojecteerd: een materieelrechtelijke en een strategisch-procestechnische. ${ }^{198}$

Gelet op de bijzondere karakteristieken van de publieke rechtsgemeenschap ${ }^{199}$ kan naar mijn mening allereerst niet volstrekt worden uitgesloten dat er bepaalde bestuursbevoegdheden krachtens ongeschreven publiekrecht kunnen bestaan. ${ }^{200}$ In dit kader dient niet alleen aan 'onvoorzien' staatsnoodrecht te worden gedacht, maar ook aan 'traditioneel' publiekrecht, aan bepaalde impliciete of inherente bevoegdheden ${ }^{201}$ alsmede aan typische bevoegdheden die gerelateerd zijn aan het beheer van het publiek domein door de overheid

echte 'bevoegdheidscheppende' bepalingen.

194. Vgl. art. 170 van de Gemeentewet: 'De burgemeester bevordert een goede behartiging van de zaken van de gemeente.' Zie voorts hoofdstuk 4 van dit boek.

195. Het gaat hier in de eerste plaats om uitspraken van de voormalige Afdeling rechtspraak van de Raad van State (ARRS). Het 'publieke taak'-criterium mag echter ook onder de vigeur van de Algemene wet bestuursrecht op belangstelling van de administratieve rechter rekenen. Vgl. Rb. Roermond 18 april 1995, JB 1995/135; Pres. Rb. Breda 26 april 1995, JB 1995/168, m.nt. R. Schlossels en Pres. Rb. 's-Gravenhage 8 december 1995, JB 1996/5, allen met noot R. Schlössels. Zie ook: Rb. Maastricht, 21 april 1995, JB 1995/116, m.nt. F.A.M.S. (Stichting Silicose). Ook de Afdeling bestuursrechtspraak hanteert het citerium (zie hierna).

196. Ik verwijs naar de uitvoerige jurisprudentie-analyses in de proefschriften van Goorden, Stout en Van der Veen. C.P.J. Goorden, rechtsbevoegdheid in het bestuursrecht, a.w., p. $66 \mathrm{t} / \mathrm{m}$ 77; H.D. Stout, De betekenissen van de wet, a.w., p. $114 \mathrm{Vm} 130$ en G.A. van der Veen, Openbare zaken, a.w., p. 276-291. Tot slot kan nog gewezen worden op de kroniek 'bestuurshandelingen' van F.J. van Ommeren in NTB $1995 / 5$ p. 127 en $1996 / 2$ p. $72 / 73$.

197. Deze kritiek is voor een belangrijk deel terug te voeren op de vermeende inbreuken op het beginsel van wetmatigheid van bestuur. Vgl. G.A. van der Veen die de betreffende jurisprudentie als 'enigszins obscuur' karakteriseert (noot onder ABRS 10 april 1995, AB 1995, 498).

198. Vgl. G.A. van der Veen, Openbare zaken, a.w., p. 277-278.

199. Ik kom hier in hoofdstuk 3 uitvoerig op terug.

200. Vgl. Van Wijk/Konijnenbel/Van Male, Hoofdstukken van administratief recht, a.w., p. 147.

201. Zie bijv. J.M.H.F. Teunissen, Afrekening met de gemene rechtsleer en de tweewegenleer (1), a.w., p. 8990. In dit kader kan gedacht worden aan de ontwikkelingen inzake de 'zelfstandige' besluiten in het bestuursrecht $0 . \mathrm{m}$. wat betreft de onverschuldigde betaling, de nadeelcompensatie en de schadevergoeding. Vgl. o.a. ABRS 21 oktober 1996, JB 1996/232, m.nt. HJS (onverschuldigde betaling); ABRS 18 februari 1997, JB 1997/47, m.nt. HJS (Vierlingsbeek) en ABRS 6 mei 1997, JB 1997/118, m.nt. HJS (Van Vlodrop BV). Zie voorts hoofdstuk 9 (paragraaf 9.6.2). 
(de beheersbevoegdheden). ${ }^{202}$ Soms lijkt - in dit laatste verband - wel eens over het hoofd te worden gezien dat het legaliteitsbeginsel - de formele bevoegdheidsgrondslag - in het Nederlandse constitutionele recht ten aanzien van dit publieke beheer niet in volle omvang is geoperationaliseerd, hetgeen echter niet met zich brengt dat het bestaan van publiekrechtelijke bevoegdheid dan zonder meer dient te worden ontkend, of als 'privaatrechtelijk' moet worden bestempeld. ${ }^{203}$ Typische beheersbevoegdheden worden begrensd door de aard van het doelgebonden beheer van het publiek domein. Dit beheer impliceert het doen beantwoorden van de publieke zaak aan haar reguliere bestemming ten openbare nutte. ${ }^{204}$ Aldus beschouwd, zijn deze bevoegdheden onderworpen aan een cruciale publiekrechtelijke waarborg, nl. het specialiteitsbeginsel. ${ }^{205}$ Een gedeelte van de bedoelde 'publieke taak'-jurisprudentie kan mijns inziens in deze 'beheers'-context worden gepositioneerd. ${ }^{206}$

Daarnaast wordt het 'publieke taak'-criterium door de administratieve rechter strategisch gehanteerd om op een adequate wijze administratiefrechtelijke rechtsbescherming te kunnen bieden. ${ }^{207}$ Het besluit-begrip van de Awb (en voorheen het beschikkingsbegrip

202. Vgl. het schoolvoorbeeld HR 12 januari 1923, NJ 1923, p. 307, W 11060 (Schielands Hooge Zeedijk).

203. Ik wijs in dit verband op de uitvoerige analyses van Teunissen in zijn proefschrifh waarbij ik aansluit. J.M.H.F. Teunissen, Het burgerlijk kleed van de staat, a.w., m.n. p. $121 \mathrm{t} / \mathrm{m} 134$ en p. $252 \mathrm{t} / \mathrm{m} 259$. Teunissen gaat ervan uit dat het legaliteitsbeginsel t.a.v. het beheer van het 'publiek domein' alleen geldt indien er (1) algemene (beheers)regels worden gesteld, (2) dan wel beperkingen worden gesteld aan het normale functionele gebruik (a.w., p. 255). Vgl. ook: A.Q.C. Tak, De overheid in het burgerlijk recht, a.w., p. 241-242. Tak wijst erop dat ook de beheersbevoegdheden democratisch zijn gelegitimeerd. Principieel anders: G.A. van der Veen, Openbare zaken, a.w., i.h.b. p. 261 e.v. Van der Veen, die m.i. de neiging heeft het legaliteitsbeginsel in het publiekrecht te verabsoluteren, is gekant tegen het erkennen van ongeschreven publiekrechtelijke beheersbevoegdheden; deze bestempelt hij tot 'privaatrechtelijk' waardoor het legaliteitsprobleem kennelijk als sneeuw voor de zon verdwijnt (vgl. a.w., p. 8-9).

204. Vgl. G.E. van Maanen, Van de vogelen des hemels en de stranden der zee, a.w., p. 975.

205. Vgl. mijn noot onder Pres. Rb. Utrecht, 9 oktober 1997, JB 1997/287.

206. Deze beheerstaak kan grotendeels 'ongeschreven' zijn, of tot uitdrukking komen in een wettelijke taakomschrijving en/of opdracht. Vgl. VzARRS 6 mei 1991, AB 1992, 414, m.nt. H.J. Simon (Staatsnatuurmonumenten Krammer-Volkerak en Zoommeer); ABRS 10 april 1995, AB 1995, 498, m.nt. G.A. van der Veen (Long Lin). Soms is de publieke beheerstaak maar gedeeltelijk in het geding. Vgl. de inmiddels klassieke uitspraak inzake de wateraansluitingen Groningen (ARRS 1 december 1977, AB 1978, 208, m.nt. M. Scheltema). Sommige uitspraken zijn minder goed te plaatsen. Zie bijv. ARRS 29 september 1993, AB 1995, 144, m.nt. AFMB (tracé elektriciteitsnet).

207. Enige fraaie voorbeelden in dit kader bieden de uitspraken inzake de Regeling Opvang Asielzoekers (ROA): VzARRS 8 augustus 1991, AB 1992, 354, m.nt. R. Kluin; VzARRS 26 augustus 1993, AB 1994, 199, m.nt. Van Male en Pres. Rb. Breda 26 april 1995, JB 1995/168, m.nt. R. Schlossels (anders: Pres. Rb. Zutphen 22 december 1995, JB 1996/65 m.nt. R.J.N.S./HJS). Vgl. voorts: ABRS 30 november 1995, JB 1995/337, m.nt. F.A.M.S. (Stichting Silicose). Een wel erg gewrongen 'publieke taak'-constructie kan worden aangetroffen in VzARRS 17 januari 1992, tB/S 1992, nr. 9 (LPG-installaties). Tot slot in afwijzende zin: ABRS 13 maart 1997, JB 1997/88, m.nt. R.J.N.S. 
van de Wet Arob) biedt hiervoor een legitieme voedingsbodem. ${ }^{208}$ Het gaat hier in hoofdzaak om pragmatische jurisprudentie, waaraan naar mijn oordeel géén zware dogmatische conclusies van rechtsstatelijke aard behoeven te worden verbonden. ${ }^{209}$ Niet het erkennen van ongeschreven bestuursbevoegdheden, maar het vestigen van administratiefrechterlijke rechtsmacht stond - en staat - in dit kader centraal. Hierbij dient overigens te worden opgemerkt dat de administratieve rechter steeds pogingen onderneemt om waar mogelijk aansluiting te zoeken bij wettelijke (dus: publiekrechtelijketaken). Ook gaat in de relevante jurisprudentie de aandacht uit naar het traceren van het materieelrechtelijke karakter van rechtsverhoudingen waarbinnen een bestreden 'besluit' is genomen. ${ }^{210} \mathrm{De}$ (publiekrechtelijke) aard van de betrokken belangen speelt hierbij een rol. ${ }^{211}$

Resumerend kan worden gesteld dat bestuursbevoegdheden naar hun rechtsaard van (publiekrechtelijke) bestuurstaken dienen te worden onderscheiden. Dit is niet alleen relevant voor de bestuursrechtelijke theorie, maar óok voor de rechtspraktijk. Uit vage publieke taken kunnen - behoudens de hiervoor vermelde uitzonderingen - géén (specifieke) bestuursbevoegdheden worden afgeleid. De rechtszekerheid, alsmede het publiekrechtelijke legaliteits- en specialiteitsbeginsel verzetten zich daartegen.

\subsection{Conclusie}

In dit hoofdstuk is gebleken dat binnen een rechtsstelsel aan normen die bestuursbevoegdheden in het leven roepen een bijzondere betekenis dient te worden toegekend. Op basis van deze bevoegdheidsnormen kunnen bestuursorganen de rechtspositie van rechtssubjecten éénzijdig vaststellen en/of wijzigen. Bestuursbevoegdheden zijn belangrijke generatoren voor het proces van gerichte rechtsvorming binnen de publieke rechtsorde. In dit kader is het van belang dat een doelgebonden publieke bevoegdheidsnorm binnen een rechtsstelsel een normerende en legitimerende functie vervult. Een dergelijke bevoegdheidsnorm kent een bestuursbevoegdheid toe en bakent deze zowel in procedureel als inhoudelijk opzicht

208. Art. 2 lid 1 Wet Arob eiste voor het aannemen van een 'beschikking' géen specifieke grondslag in enig staats- of administratiefrechtelijk voorschrift. Hetzelfde geldt voor art. 1:3 lid 1 Awb en het 'besluit'begrip. Vgl. Van Kreveld/Scheltema, Parlementaire geschiedenis van de Wet Arob, Groningen 1976, p. 142 en PG Awb I, MvT, p. 154. Zie ook: PG Awb I, MvT, p. 133.

209. De kritiek die bijv. Crasborn in zijn aantekening onder ARRS 18 september 1980 (tB/S V, nr. 195 , p. 759; parkeerplaatsen Rotterdam) uitte lijkt vanuit dit perspectief bezien dan ook zwaar aangezet. Hier is - wat G.A. van der Veen noemt - 'transformerende publiekrechtelijke taak-jurisprudentie' in het geding (zie over het onderscheid tussen 'transformerende' en 'genererende' publiekrechtelijke taak-jurisprudentie zijn noot onder ABRS 10 april 1995, AB 1995, 498).

210. Simon heeft in dit kader een instructief onderscheid gemaakt tussen de 'publiekrechtelijke grondslag' (formeel 'legaliteits'-criterium) en de 'publiekrechtelijke rechtsgrond' (materieel criterium) die samen de noodzakelijke 'publiekrechtelijke titel' vormen voor het aannemen van een beschikking/besluit. Zie zijn noten onder: VzARRS 21 augustus 1986, AB 1988, 193 en VzARRS 12 oktober 1987, AB 1988, 448.

211. Vgl. H.J. de Ru, noot onder VzARRS 19 maart 1981, AB 1982, 41l. De Ru legt in deze noot expliciet een verband met de 'magische lijn' van Van der Hoeven. Zie: J. van der Hoeven, De magische lijn. Verkenningen op de grens van publiek en privaatrecht, in: Honderd jaar rechtsleven, Zwolle 1970, p. 201 e.v. 
af. Beperktheid en doelgebondenheid zijn wezenlijke kenmerken van iedere bestuursbevoegdheid.

Deze beperktheid komt tot uitdrukking in het 'toepasselijkheidsdomein' van de betreffende competentie. Niet het bestuur zelf, maar het objectieve publiekrecht geeft het doel aan waarvoor een bepaalde bestuursbevoegdheid mag en moet worden uitgeoefend (de 'ambtsplicht'). Doordat gerichte énzijdige rechtsvorming vanwege de statelijke organen op grond van kenbare en traceerbare (bestuurs)bevoegdheden plaatsvindt, wordt dit rechtsvormingsproces voorspelbaar en voorzienbaar voor rechtssubjecten.

Publiekrechtelijke bevoegdheid, en bijgevolg bestuursbevoegdheid, dient strikt onderscheiden te worden van privaatrechtelijke bevoegdheid. Het specialiteitsbeginsel ligt niet ten grondslag aan (vermogensrechtelijke) bevoegdheden in het privaatrecht. Deze bevoegdheden mogen weliswaar niet in strijd met de wet of op onrechtmatige wijze worden uitgeoefend, maar zij worden niet vooraf door een norm van objectief recht toegekend en afgebakend. Van belang is in dit verband dat publiekrechtelijke bevoegdheid en privaatrechtelijke bevoegdheid - benaderd vanuit de 'autonomie-gedachte' - berusten op verschillende en onvergelijkbare materiële rechtsgronden. Publiekrechtelijke bevoegdheid wortelt in de typische aard van de publieke rechtsorde en is per definitie dienstig aan de behartiging van publiekrechtelijke belangen. Privaatrechtelijke bevoegdheid staat daarentegen in het teken van de behartiging van eigen (subjectgebonden) rechtsbelangen door rechtssubjecten. Dit brengt o.m. met zich dat, gelet op het specialiteitsbeginsel, serieuze vraagtekens geplaatst moeten worden bij de rechtspraktijk die aanvaardt dat de overheid typisch publiekrechtelijke belangen mag behartigen op grond van privaatrechtelijke bevoegdheden.

De exclusieve dragers van bestuursbevoegdheid zijn de statelijke bestuursorganen die, binnen de publieke rechtsorde, onderscheiden dienen te worden van de rechtssubjecten. Binnen de rechtsrelatie(s) tussen bestuursorgaan en rechtssubject(en) staat de bevoegdheid centraal. De bestuursrechtelijke 'rechtsbetrekking' is hieraan gerelateerd. Het karakteriseren van de rechtsrelatie tussen bestuursorgaan en rechtssubject(en) als een 'wederkerige rechtsbetrekking' (de 'subjectiveringstendens' in het hedendaagse bestuursrecht) verdient vanuit democratisch-rechtsstatelijk oogpunt géen aanbeveling. Het concept van de 'wederkerige rechtsbetrekking' biedt een voedingsbodem voor onderhandelend en horizontaal bestuur, waardoor typisch publiekrechtelijke rechtsbeginselen en waarborgen zoals het specialiteitsbeginsel in het gedrang dreigen te komen.

Van bestuursbevoegdheden dienen tot slot bestuurstaken te worden onderscheiden. Ofschoon wettelijk gecodificeerde bestuurstaken - publiekrechtelijke taken - een indicatie geven van het terrein waarop het bestuur binnen de democratische rechtsstaat activiteiten mag ontplooien, geven zij nog géén duidelijk inzicht in de juridische potenties van het bestuur. 



\section{Hoofdstuk 3}

\section{Een rechtsstatelijk beginsel}

\subsection{Inleiding}

In het voorafgaande hoofdstuk heeft in algemene zin een verkenning van het begrip 'bestuursbevoegdheid' plaatsgevonden. In dit derde hoofdstuk wordt dit begrip in een ruimere publiekrechtelijke context geplaatst. Hierbij zal in het bijzonder de aandacht uitgaan naar de vraag waarom beperkte en doelgebonden bevoegdheden juist kenmerkend zijn voor het publiekrecht. ${ }^{1}$ Om deze vraag te kunnen beantwoorden zal de rechtsgrond van bestuursbevoegdheid aan een nadere beschouwing worden onderworpen. Hierbij zal onderscheid worden gemaakt tussen de formele wettelijke bevoegdheidsgrondslag en de materiële rechtsgrond waarop overheidsactiviteit berust. Van belang is dat de beperktheid van bestuursbevoegdheid weliswaar in het positieve publiekrecht tot uitdrukking komt in de wettelijke bevoegdheidsstructuren (de 'wetmatigheid van bestuur'), maar dat de diepere rechtsgrond van deze beperktheid is gefundeerd in de interne aard van de publieke rechtsorde en de hiermee verband houdende - cultuurhistorisch bepaalde - scheiding tussen de staat als publieke rechtsgemeenschap enerzijds en een vrije burgerlijke 'maatschappij' 2 anderzijds.

De beschouwingen in dit hoofdstuk beogen het specialiteitsbeginsel als een typisch publiekrechtelijk structuurbeginsel in een historisch ontwikkelingsperspectief te plaatsen. Hierbij zijn de nodige beperkingen in acht genomen gelet op de primaire strekking van dit boek, nl. een analyse van het specialiteitsbeginsel zoals dit momenteel tot uitdrukking komt in de literatuur, de jurisprudentie en de administratiefrechtelijke wetgeving. Enige historische verdieping is echter wenselijk daar een louter positiefrechtelijke analyse van het specialiteitsbeginsel een te geringe waarborg inhoudt om - waar nodig - afstand te nemen van de juridische praktijk. Voorts is het van belang om de relaties tussen het specialiteitsbeginsel en andere publieke rechtsbeginselen in kaart te brengen. Hierbij gaat in het bijzonder de aandacht uit naar het democratiebeginsel (paragraaf 3.4), het legaliteitsbeginsel (paragraaf 3.5.2) en de idee van 'handelen in het algemeen belang' (paragraaf 3.3).

1. Sommige auteurs tonen zich in dit kader sceptisch. Zo heeft R. de Winter zich afgevraagd of de publiekrechtelijke bevoegdheidsnotie niet een achterhaald 'negentiende eeuws' concept is dat wellicht in onze hedendaagse samenleving - waar de intervenierende staat immers alom aanwezig is - gemist kan worden. R. de Winter, Oud zeer, in: Azen op tegenslag, Lelystad 1994, p. 14 t/m 19.

2. Het begrip 'maatschappij' wordt tussen aanhalingstekens geplaatst omdat hier geen sociologische totaalstructuur in het geding is. Binnen 'de maatschappij' kunnen verschillende sociale en - daaraan gerelateerde - normatieve verbandsstructuren worden onderscheiden. Evenmin mag het begrip 'maatschappij' vereenzeivigd worden met het ruimere begrip 'samenleving'. Zie: H. van Erp, Het politiek belang. Over de politieke orde in een pluralistische samenleving, Amsterdam 1994, p. 15 t/m 21. 


\subsection{De publieke rechtsorde}

Aan dit boek ligt de idee ten grondslag dat een complex rechtsstelsel géén normatieve eenheid vormt (de idee van rechtspluriformiteit). ${ }^{3}$ Een rechtsstelsel, zoals dit in al zijn nuances en schakeringen tot ontwikkeling is gekomen tegen de achtergrond van de conceptie van de democratische rechtsstaat ${ }^{4}$, wordt gekenmerkt door de aanwezigheid van verschillende materiële rechtssferen die geordend kunnen worden aan de hand van typerende interne structuurprincipes. ${ }^{5}$ Deze interne juridische structuurprincipes vinden hun grondslag in de (rechts)sociologische aard van de betreffende verbanden en zijn cul-

3. Ik ga derhalve uit van een 'pluriforme' visie op het recht en niet van een 'rechtseenheid'-visie. Vgl. over deze tegenstelling bijv. A.R. Bloembergen, De eenheid van privaatrecht en administratief recht, WPNR 5372 , p. 3. De door mij voorgestane pluralistische rechtsvisie erkent i.h.b. als uitgangspunt dat er aan de onderscheiden materielle rechtsgebieden - waaronder het publiek- en privaatrecht - typische rechtskarakteristieken in de vorm van beginselrecht ten grondslag liggen. Niet ontkend wordt dat aan een rechtsstelsel als geheel ook gemeenschappelijke rechtsbeginselen ten grondslag kunnen liggen, maar een dergelijk gegeven mag nooit leiden tot het verwaarlozen of wegrelativeren van de fundamentele kenmerken van de verschillende rechtssferen. Vgl. De Haan/Drupsteen/Fernhout, Bestuursrecht in de sociale rechtsstaat I, vierde geheel herziene druk, Deventer 1996, p. 47.

4. Een diepgaande analyse van het concept van de 'democratische rechtsstaat' gaat het bestek van dit boek te buiten. Verwezen wordt naar de constitutionele ontwikkelingsleer van bijv. Couwenberg die het liberaaldemocratische staatsmodel uitvoerig heeft geanalyseerd en gepositioneerd ten opzichte van het recel bestaande socialisme, de monarchale machtsstaat en de moderne autoritaire staten. S.W. Couwenberg, Modern constitutioneel recht en emancipatie van de mens, deel III, Constitutionele ontwikkelingsmodellen, Assen 1984, i.h.b. p. 23 e.v. Vgl. ook: S.W. Couwenberg, Gezag en vrijheid, Inleiding in de constitutionele rechts- en ontwikkelingstheorie, Zwolle 1991, p. 102 e.v.

5. Zie voor een analyse van de hier gehanteerde 'verbandsrechtelijke' visie op het recht uitvoerig het proefschrift van Teunissen. J.M.H.F. Teunissen, Het burgerlijk kleed van de staat. Beschouwingen over de tweewegenleer, Zwolle 1996 (i.h.b. hoofdstuk 6 'Het juridisch pluralisme. De constitutieve betekenis van het dualisme Staat-'maatschappij'. De rol van de staat in de rechtsvorming'). De verbandsrechtelijke rechtsvisie voert i.h.b. terug op het standaardwerk van O. von Gierke, Das deutsche Genossenschaftsrecht (I $\mathrm{t} / \mathrm{m}$ IV), Berlin 1913. Op deze plaats dient er - wellicht ten overvloede - op te worden gewezen dat de rechtssociologische 'verbands- of rechtssferentheorie' niet vereenzelvigd mag worden met de bekende denkbeelden uit de anti-revolutionaire traditie (de idee van 'soevereiniteit in eigen kring'). Verwante denkbeelden worden immers ók aangetroffen in het Thorbeckiaans liberalisme waaraan een organischidealistische filosofie ten grondslag ligt, o.m. leidend tot de aanname van een principiele scheiding tussen privaat- en publiekrecht. Zie hierover uitvoerig: E. Poortinga, De scheiding tussen publiek- en privaatrecht bij Johan Rudolph Thorbecke (1798-1872). Theorie en toepassing, diss. UU, Nijmegen 1987, hoofdstuk II en III. Ook wijs $i k$, ter adstructie, op de rechtspluralistische denkbeelden van de interpretatiefilosoof $M$. Walzer. M. Walzer, Spheres of justice. A defense of pluralism and equality, New York 1983. Tot slot verdient vermelding dat waar in dit hoofdstuk verwezen wordt naar de diverse werken van Van Eikema Hommes dit geschiedt op grond van het feit dat in deze werken - die op de theorievorming van Dooyeweerd terugvoeren - m.i. op treffende wijze een pluralistisch-verbandsrechtelijke visie op het recht uiteen wordt gezet. De verbandstheoretische benadering van het recht biedt goede mogelijkheden om het belang van het specialiteitsbeginsel als structuurbeginsel van publieke rechtsvorming duidelijk te positioneren. Geenszins wordt beoogd aansluiting te zoeken bij de methode van de 'transcendentale zelfkritiek' en de daarmee verweven aspectenleer van genoemde auteur. Zie hierover uiterst kritisch: N.H.M. Roos, Enige opmerkingen over de grondslagenproblematiek in de rechtsfilosofie van H.J. van Eikema Hommes, R\&R 1980, p. 26 e.v. 
tuurhistorisch bepaald. De verschillende rechtsverbanden of rechtssferen (gedacht kan bijv. worden aan de publieke staat, de burgerlijke maatschappij, het bedrijfsleven, het verenigingsleven, de vakbonden, het schoolwezen en het gezin) worden gekenmerkt door specifieke interne rechtsstructuren die - in normatieve zin - niet tot elkaar herleidbaar zijn. Het spreekt in dit verband voor zich dat een individu gelijktijdig binnen verschillende van deze rechtsverbanden als rechtssubject kan fungeren. Zo kan een individu als rechtssubject worden erkend binnen de rechtsstructuur van de burgerlijke maatschappij en tevens als staatsburger fungeren binnen de publieke rechtsorde (de staat). Ook is het denkbaar dat een individu gelijktijdig als lid van een vakbond én als werknemer van een bedrijf drager is van rechtssubjectiviteit.

Kenmerkend voor bepaalde rechtsverbanden is nu dat de leden van dat verband door een hogere interne organisatie-eenheid met elkaar zijn verbonden. In dit geval kan gesproken worden over een typische gemeenschapsverhouding. ${ }^{6}$ Een juridische gemeenschapsverhouding is bijv. de vereniging waarbinnen de leden (als rechtssubjecten) van de interne verenigingsorganen dienen te worden onderscheiden. Ook de staat is, als publieke rechtsgemeenschap, een specifiek gemeenschapsverband dat zijn leden (de staatsburgers) naar het publieke aspect van het recht verenigt. Met het oog hierop is, ingevolge een cultuurhistorisch ontsluitingsproces, geleidelijk een hogere institutionele organisatie-eenheid in het leven geroepen. Het publieke gemeenschapsverband, dat overigens uniek is omdat het in het algemeen belang een geweldsmonopolie beoogt te realiseren, kent bijgevolg zijn eigen interne rechtsvormingsprocessen die zich voltrekken op basis van een structuur van typische rechtsbeginselen. Voordat ik hier aandacht aan besteed, zal eerst de historische ontwikkeling van de Westerse staat kort worden belicht.

\subsubsection{De ontsluiting van de publieke rechtsorde}

Binnen de democratische rechtsstaat, zoals deze in de Westerse wereld ${ }^{8}$ gedurende de achttiende en negentiende eeuw tot ontwikkeling kwam, is de scheiding tussen de staat als publiek gemeenschapsverband en de vrije burgerlijke 'maatschappij', met al zijn bijzondere gedifferentieerde private verbanden, typerend. ${ }^{9}$ Ook in de complexe hedendaagse sociale rechtsstaat, die kan worden aangemerkt als een ontwikkeling en verfijning van de

6. Vgl. H.J. van Eikema Hommes, De samengestelde grondbegrippen der rechtswetenschap. Een juridische methodologie, Zwolle 1976, p. 137.

7. Van der Hoeven, die eveneens de aandacht vestigde op de 'verbandenleer', wijst nadrukkelijk op het feit dat de staat als complex (gemeenschaps)verband als enige over (legitieme) fysieke handhavingsmiddelen beschikt. Zie: J. van der Hoeven, De grenzen van de rechterlijke functie in de administratieve rechtspraak, RMTh. 1974, p. 672.

8. De hierna weergegeven schets van de ontwikkeling van de 'Westerse' staat is slechts een schets op hoofdlijnen. Uiteraard verschilt de staatsontwikkeling in concreto per land. Desalniettemin ligt er aan het ontstaan van 'de' democratische rechtsstaat een vrij uniform cultuurhistorisch ontsluitings- en secularisatieproces ten grondslag waarin bepaalde ontwikkelingsfasen kunnen worden onderscheiden. Vgl. Van der Pot/Donner, Handboek van het Nederlandse staatsrecht, dertiende druk, Zwolle 1995, p. $121 \mathrm{tm} 124$. 
negentiende eeuwse liberale rechtsstaat, is dit onderscheid nog altijd van belang. ${ }^{10}$ Weliswaar is genoemd onderscheid in de praktijk - gelet op de complexe structuur van de hedendaagse maatschappij - niet altijd even helder ${ }^{11}$, uitgangspunt blijft dat de staat de (eind)verantwoordelijkheid draagt voor de behartiging van publieke belangen. Door deze belangen te behartigen vervullen de statelijke rechtsorganen een typisch publiekrechtelijke integratiefunctie die gericht is op het reguleren van de rechtsverhoudingen tussen subjecten in het licht van het algemeen belang. ${ }^{12}$ De publiekrechtelijke belangen dienen overigens goed onderscheiden te worden van collectieve en zgn. 'algemene' belangen die binnen de maatschappelijke structuren door verschillende groeperingen en rechtsverbanden (bijv. ideële belangenverenigingen) worden behartigd. Deze belangen zijn géén publiekrechtelijke belangen daar zij niet op basis van het interne recht van de publieke rechtsgemeenschap, maar juist op basis van ander intern verbandsrecht (bijv. verenigings- of stichtingsrecht), worden gedetermineerd. ${ }^{13}$

9. Zie bijv. S.W. Couwenberg, Gezag en vrijheid, a.w., p. 104. Couwenberg spreekt in dit kader over de 'externe machtenscheiding', in tegenstelling tot de machtenscheiding binnen de staat. Vgl. voorts: $\mathrm{H}$. van Erp, Het politiek belang, a.w., hoofdstuk 1 (Staat en maatschappij).

10. Vgl. Böckenforde die op een m.i. overtuigende wijze heeft aangetoond dat het onderscheid tussen 'staat' en 'maatschappij' (Gesellschaft) óbk binnen de kaders van de hedendaagse sociale rechtsstaat van grote betekenis blijft. E.-W. Böckenförde, Die Bedeutung der Unterscheidung von Staat und Gesellschaft im demokratischen Sozialstaat der Gegenwart, in: Staat, Gesellschaft, Freiheit, Studien zur Staatstheorie und zum Verfassungsrecht, Frankfurt am Main 1976, p. 185 e.v.

11. Van belang is met name dat in de hedendaagse sociale rechtsstaat 'de maatschappij' in belangrijker mate is georganiseerd dan in de negentiende eeuwse 'liberale rechtsstaat'. Couwenberg spreekt hier over de ontwikkeling van 'een nieuwe intermediaire machtsstructuur tussen staat en individu'. Zie: S.W. Couwenberg, Constitutionele ontwikkelingsmodellen, a.w., p. 120. Binnen 'de maatschappij' zijn vele organisaties en instellingen tot stand gekomen die o.m. gericht zijn op collectieve belangbehartiging (vakbonden, consumentenorganisaties, milieubewegingen). Ofschoon de publieke besluitvorming door deze maatschappelijke ontwikkeling ('neo-corporatisme') complexer wordt, gaan volgens Couwenberg de soevereiniteit van de staatsmacht en de burgerlijke vrijheid hierdoor in essentie niet teloor: 'In de verzorgingsstaat geldt die burgerlijke vrijheid nog onverminderd, maar zij komt hierin nu vooral tot gelding in het soevereine recht van de burgers en hun organisaties op eigen verantwoordelijkheid en zoveel mogelijk naar eigen inzicht mede te werken aan het overheidsbeleid, gericht op actieve bevordering van het burgerlijke emancipatieproces' (a.w., p. 131).

12. Op de betekenis van het complexe begrip 'algemeen belang' zal in paragraaf 3.3 van dit hoofdstuk nader worden ingegaan.

13. Niet ontkend kan worden dat de behartiging van typisch 'publiekrechtelijke belangen' door de organen van de publieke rechtsgemeenschap momenteel een problematische vertroebeling ondergaat door de opkomst van zogenoemde 'collectieve-' en 'algemeen'-belangacties die gel̆nitieerd worden door diverse maatschappelijke verbanden. Jurisprudentiele (vgl. HR 27 juni 1986, NJ 1987, 743 (Nieuwe Meer) en HR 18 december 1992, NJ 1994, 139 (Kuunders)) alsmede 'wettelijke' ontwikkelingen (vgl. art. 305a BW) ondersteunen dit nivellerende proces van belang-behartiging, waardoor m.i. typisch publiekrechtelijke verantwoordelijkheden (bijv. integrale en evenwichtige belangenafweging) en beginselen (bijv. het democratiebeginsel) onder druk komen te staan. Ik verwijs kortheidshalve naar het betoog in het proefschrift van Teunissen, waarbij ik op dit punt goeddeels aansluit. J.M.H.F. Teunissen, Het burgerlijk kleed van de staat, a.w., hoofdstuk 8. 
Inherent aan de onderscheiding tussen staat en 'maatschappij' is de erkenning van de scheiding tussen overheidsmacht als publiek ambt (bevoegdheid) enerzijds en private vermogensrechten anderzijds. ${ }^{14}$ Deze scheiding was - en is - een noodzakelijke voorwaarde voor de erkenning van autonome en vrije rechtssferen van geëmancipeerde rechtssubjecten en maatschappelijke rechtsverbanden. Het is zinvol om in vogelvlucht bij het ontstaan van deze scheiding stil te staan.

Aan de basis van de hedendaagse Westerse staten stonden tribale leefgemeenschappen. ${ }^{15}$ Hieronder worden verstaan (juridisch) ongedifferentieerde leefgemeenschappen die het individu op een totalitaire wijze omsloten naar zijn gehele bestaan (bijv. geloof, handel, arbeid en recht). Individuen (de stamleden) werden in deze gemeenschappen nog niet op een volwaardige wijze erkend als autonome rechtssubjecten en van een erkenning van zelfstandige rechtssubjecten binnen verschillende rechtsverbanden was evenmin sprake. Het recht dat het gezin, de leefgemeenschap als geheel én de onderlinge relaties tussen 'stamleden' beheerste was nog ongedifferentieerd (stam- of tribaal recht).

De hedendaagse scheiding tussen een publieke samenleving (de staat) en verschillende zelfstandige maatschappelijke rechtsstructuren werd eerst mogelijk door een voortschrijdend secularisatieproces ${ }^{16}$ dat zich op basis van een cultuurhistorische ontsluiting van de samenleving gedurende eeuwen voltrok. ${ }^{17}$ De ongedifferentieerde samenleving ontwikkelde zich in onze contreien via de door geloof gesloten vroegmiddeleeuwse samenleving en de feodale standenstaat - uiteindelijk - van een 'societas cum imperio' tot een 'societas sine imperio'. Kenmerkend voor dit langdurige ontsluitingsproces was dat typische brokken 'overheidsmacht' (bijv. de overdraagbare heerlijke rechten met de daaraan inherente 'publieke' bevoegdheden) langzaam uit maatschappelijke structuren, die zich geleidelijk vormden, werden verwijderd. De overheidsmacht die tijdens de Middeleeuwen, maar ók nog tijdens de Republiek der Verenigde Nederlanden, onlosmakelijk was verbonden met de persoonlijke economische macht van weinigen (denk aan het grootgrondbezit en het

14. Tevens implicerend een fundamenteel-principiele scheiding tussen publiekrecht enerzijds en privaatrecht anderzijds. Zie: H.J. van Eikema Hommes, De elementaire grondbegrippen der rechtswetenschap, a.w., p. 485 en 486 . Zie ook H.J. van Eikema Hommes, De wijsgerige grondslagen van de rechtssociologie, Deventer/Zwolle 1986, p. 198 en 199. Zie voorts: E.-W. Bockenforde, Die Bedeutung der Unterscheidung von Staat und Gesellschaft im demokratischen Soziaistaat der Gegenwart, a.w., p. 187.

15. Zie: R.C. van Caenegem, Geschiedkundige inleiding tot het publiekrecht, Uitg. E. Story-Scientia 1985, p. 27 e.v.

16. Zie over dit voortschrijdend secularisatieproces en de vorming van de Westerse staat bijv. E.-W. Böckenforde, Die Entstehung des Staates als Vorgang der Sakularisation, in: Staat, Gesellschaft, Freiheit, Studien zur Staatstheorie und zum Verfassungsrecht, Frankfurt am Main 1976, p. 42 e.v. In dit kader is het zinvol erop te wijzen dat ook de 'antieke' samenlevingen van de Grieken en Romeinen, ondanks hun prominente statelijke structuur, nog niet in burgerlijke zin ontsloten waren. Zie: H. van Erp, Het politiek belang, a.w., p. 26.

17. Zie over dit ontsluitingsproces uitvoerig: H.J. van Eikema Hommes, De wijsgerige grondslagen van de rechtssociologie, a.w., i.h.b. p. 176 e.v. 
leenstelsel ${ }^{18}$ ), verkreeg geleidelijk een zelfstandig en gedepersonaliseerd publiekrechtelijk karakter. ${ }^{19}$

Het geleidelijke proces van concentratie van publieke macht, dat een centrale plaats innam binnen het voortschrijdende differentiatieproces binnen de samenleving ${ }^{20}$, leidde ertoe dat zich een zelfstandige publieke rechtsgemeenschap kon ontwikkelen. In een later ontwikkelingsstadium werd de door bepaalde machthebbers geconcentreerde macht veelal verder gemonopoliseerd door een soeverein (de vorst) waardoor uiteindelijk een 'Zwangsmonopol' kon worden gerealiseerd. ${ }^{21}$ Deze ontwikkeling resulteerde in vele Westeuropese landen in de typerende staatsvorm van het 'ancien régime', welke gekenmerkt wordt door het vorstenabsolutisme. ${ }^{22}$ Hiermee was de basis gelegd voor - wat nu in de twintigste eeuw - wordt aangeduid als de 'politiestaat'. Dit staatstype kenmerkt zich door een algemene aan de vorst toekomende 'bestuurs- of politiebevoegdheid' die nog niet was gespecificeerd en gedifferentieerd. ${ }^{23}$

Deze politiestaat vormde in de Westerse wereld de directe voorloper van de hedendaagse democratische rechtsstaat. De transformatie van politiestaat tot dit laatstgenoemde staatstype voltrok zich doordat de statelijke bestuursmacht in de achttiende en negentiende eeuw verder onder het beslag van het recht werd gebracht (de rechtsstaat-conceptie)en uit-

18. Zie over de verweving van de publieke en private rechtssferen onder invloed van het feodale (leen)stelsel uitvoerig: R.C. van Caenegem, Geschiedkundige inleiding tot het publiekrecht, a.w., o.m. p. 29-30, 40-42 en p. 49 e.v. Zie voorts: De Haan/Drupsteen/Fernhout, Bestuursrecht in de sociale rechtsstaat I, a.w., p. 8. Overigens dient erop te worden gewezen dat men niet door onze hedendaagse bril van scheiding tussen publiek- en privaatrecht naar het feodale bestel mag kijken. De heerlijke rechten en (bestuurs)bevoegdheden (de 'regalia') waren naar hun rechtsaard zeker niet vergelijkbaar met de vrij overdraagbare vermogensrechten zoals wij die heden kennen. Het beeld van de patrimoniele staat waarin heren 'publieke' bevoegdheden uitoefenden als waren het vermogensrechten is dan ook niet geheel zuiver. Vgl. C.C.J.J. van den Bergh, Iets over publiek- en privaatrecht, in: Ter recognitie (Van der Linden bundel, red. C. Streefkerk en S. Faber), Hilversum 1987, p. 16-17 alsmede E. Poortinga, De scheiding tussen publiek- en privaatrecht bij Johan Rudolph Thorbecke (1798-1872), a.w., p. 97-101 en 147-149.

19. Zie: S.W. Couwenberg, Constitutionele ontwikkelingsmodellen, a.w., p. 12. Zie ook: C.A.J.M. Kortmann, Constitutioneel recht, geheel herziene derde druk, Deventer 1997, p. 7-8.

20. H.J. van Eikema Hommes, De wijsgerige grondslagen van de rechtssociologie, a.w., i.h.b. p. 186.

21. De ontwikkeling van de modeme rechtsstaat, en het daaraan ten grondslag liggende proces van cultuurhistorische differentiêring, is door Van Eikema Hommes beschreven in zijn werk 'De wijsgerige grondslagen van de rechtssociologie', a.w., i.h.b. p. 150 en 151, alsmede hoofdstuk XI. Zie voorts: H. van Erp, Het politiek belang, a.w., p. 27.

22. Zie over dit staatstype R.C. van Caenegem, Geschiedkundige inleiding tot het publiekrecht, a.w., hoofdstuk V.

23. Vgl. J.M.H.F. Teunissen, Het burgerlijk kleed van de staat, a.w., p. 59. Deze 'politiestaat' (der Polizeistaat) vormde zich in vergaande vorm in de achttiende eeuw in de Duitse contreien. Zie voor een fraaie analyse: $O$. Mayer, Deutsches Verwaltungsrecht, Dritte Auflage, erster Band, Munchen/Leipzig 1924, p. 38 e.v. Mayer merkt in dit verband over de macht van de vorst op: 'Der Furst ist der eigentliche Träger der ungeheuren Aufgabe der Verfolgung des Staatszweckes. Wäre es nach Menschennatur moglich, so wurde er alles allein tun. (..) Dem Untertanen gegenuber hat seine Macht keine rechtlichen Grenzen; was er will, ist verbindlich '(a.w., p. 39). 
eindelijk werd gedemocratiseerd (de democratische rechtsstaat) ${ }^{24}$ Hierna volgden in de twintigste eeuw vervolgens nadere correcties op de liberaal-rechtsstatelijke conceptie, waarbij de sociale emancipatie van het individu én van maatschappelijke collectiviteiten centraal stond (de sociale rechtsstaat-gedachte).

\subsubsection{De publieke bevoegdheidsdifferentiatie en doelbinding}

Zoals in hoofdstuk 4 zal blijken, kunnen ook de (19e eeuwse) staatkundige ontwikkelingen in Nederland voor een belangrijk deel in deze grove constitutionele ontwikkelingsschets worden ingepast. Na de Franse tijd vormde het constitutioneel monarchale stelsel in ons land het uitgangspunt voor de verdere staatsrechtelijke ontwikkelingen. ${ }^{25}$ Uitgangspunt binnen dit stelsel vormde de eigen (regelgevende) bevoegdheid van de koning die niet expliciet door de wet werd gevestigd doch door de Grondwet (impliciet) - als originair werd erkend. ${ }^{26}$ De opkomst van het parlementaire stelsel (o.a. door de invoering van de politieke ministeriële verantwoordelijkheid in 1848 en de vestiging van de vertrouwensregel tussen regering en parlement in de jaren 1866-1868), alsmede het Meerenberg-arrest ${ }^{27}$ leidden in de negentiende eeuw tot een vergaande reductie van de zelfstandige "bestuursmacht' van de koning. Deze werd hierdoor als staatshoofd geleidelijk buiten het centrum van de politieke macht geplaatst. ${ }^{28}$ De verdere ontwikkeling van het kiesrecht ${ }^{29}$ vervol-

24. Zie: H.J. van Eikema Hommes, De wijsgerige grondslagen van de rechtssociologie, a.w., p. 151. Vgl. E.W. Bockenforde, Verfassungsfragen der Demokratie, in: Staat, Verfassung, Demokratie, Studien zur Verfassungstheorie und zum Verfassungsrecht, Frankfurt am Main 1991, i.h.b. p. 344 e.v. Bockenforde heeft o.m. gewezen op een aantal noodzakelijke randvoorwaarden voor een volwaardige democratie waaronder o.a: emancipatie van de maatschappij, afwezigheid van theocratie, afwezigheid van sterke sociale en economische tegenstellingen, scholing alsmede vrije communicatie en informatiestromen binnen de maatschappij. Het staatkundige gedachtengoed van de Franse revolutie (i.h.b. Rousseau en Montesquieu) vervulde bij bedoeld transformatieproces, 6ók in ons land, een katalysator-functie. Vgl. bijv. voor de invloed van dit gedachtengoed op de denkbeelden van Thorbecke: E. Poortinga, De scheiding tussen publieken privaatrecht bij Johan Rudolph Thorbecke (1798-1872), a.w., p. 108 e.v.

25. In dit kader dient in navolging van Couwenberg te worden opgemerkt dat zich in Nederland nooit een vorstenabsolutisme in extreme vorm heeft ontwikkeld, maar dat ook vóor de Franse tijd - tijdens de Republiek der Verenigde Nederlanden - het Oranjehuis al zekere monarchale trekken en tendenties vertoonde. S.W. Couwenberg, Constitutionele ontwikkelingsmodellen, a.w., p. 21 . In ons land nam de ontwikkeling van het concept van de democratische rechtsstaat sedert de restauratie (1813/1814) nog ruim een eeuw in beslag. Zie voor een beknopte ontwikkelingsschets: Burkens/Kummeling/Vermeulen/Widdershoven, Beginselen van de democratische rechtsstaat, vierde druk, Deventer 1997, p. 23-24.

26. Vgl. o.m. de annotatie van Van der Burg onder het Meerenberg-arrest in AB Klassiek, derde druk, Deventer 1997, p. 9. De Nederlandse Grondwet gaat niet uit van het beginsel van volkssoevereiniteit (zoals bijv. de Belgische). De Grondwet van 1848 vertoonde - wat betreft de relatie regering parlement een zekere verwantschap met bijv. de (latere) Pruisische Grondwet van 31 januari 1850 die eveneens de samenwerking tussen koning en parlement centraal stelde. Zie over deze Pruisische Grondwet E.-W. Bockenforde, Gesetz und gesetzgebende Gewalt. Von den Anfangen der deutschen Staatsrechtslehre bis zur Höhe des staatsrechtlichen positivismus, Zweite Auflage, Berlin 1981, p. 220-221.

27. HR 13 januari 1879, W4330 (Meerenberg). Het Meerenberg-arrest komt in hoofdstuk 4 nader aan de orde.

28. Zie voor een heldere schets van deze ontwikkelingen: D.J. Elzinga/H.G. Warmelink, Het Nederlandse parlementaire stelsel, Nijmegen 1993, p. 15 t/m 23. 
maakte vervolgens de 'eerste fase ${ }^{30}$ van het democratiseringsproces dat in ons land resulteerde in de vestiging van een - parlementaire - democratie.

Tengevolge van deze ontwikkelingen maakte de geconcentreerde algemene bestuursmacht (van het staatshoofd) binnen de publieke rechtsorde plaats voor een gedifferentieerde ambtelijke bevoegdhedenstructuur. De voortschrijdende democratiserings- en juridificeringsprocessen leidden tevens tot inhoudelijke begrenzing en doelbinding van deze bestuursmacht die hierdoor werd getransformeerd tot een volwaardig - d.w.z. overeenkomstig vaste constitutionele procedures - toegekend en gecontroleerd overheidsgezag. Niet de originaire bestuursmacht van het staatshoofd vormde langer het uitgangspunt, maar de uitdrukkelijk op democratische wijze gevestigde bevoegdheden van het openbare bestuur. ${ }^{31}$ De basis voor een explosieve groei van de administratieve wetgeving in de twintigste eeuw, en de daaraan inherente complexe structuur van bestuursbevoegdheden, was hiermee gelegd. Gelijktijdig won noodzakelijkerwijs de opvatting terrein dat specifieke bevoegdheden van het bestuur uitsluitend mochten worden aangewend ter behartiging van de speciale publieke belangen met het oog waarop ze door de wetgever in het leven werden geroepen. Het verbod van détournement de pouvoir, dat in de negentiende eeuw door de Franse doctrine en jurisprudentie werd geoperationaliseerd, deed in dit verband óók zijn intrede in het Nederlandse administratieve recht. ${ }^{32}$

In dit verband kan gesteld worden dat de specifieke doelbinding van overheidsbevoegdheid en administratieve wetgeving wortelde in de grondstructuur van de tot ontwikkeling gekomen democratische rechtsstaat. Böckenförde merkt over deze - mijns inziens cruciale - constatering het volgende op:

'Diese Bindung und Begrenzung erfolgt durch die Aufstellung und Verbindlichmachung grundlegender Staatszwecke; diese Staatszwecke begleiten die Errichtung und den Ausbau der Staatsgewalt von Anfang an. Sie sind es, die das "Um-willen" des Staates ausmachen, die die Unterwerfung der einzelnen unter die konzentrierende staatliche Macht und Entscheidungsgewalt sinnvoll begrunden und den Staat als Institution der Allgemeinheit von einer zufalligen Machtzusammenballung unterscheiden. Es ist die Funktion dieser Staatszwecke, die Ziele und die Reichweite der organisierten staatlichen Entscheidungsgewalt gegenuber den einzelnen und der freigesetzten Gesellschaft zu bestimmen und zu begrenzen' (curs. R.J.N.S.). ${ }^{33}$

29. Zie in dit verband de nog steeds fraaie uiteenzetting van Donner. A.M. Donner, Iets over kiesstelsels, Amsterdam 1967.

30. In dit kader zij opgemerkt dat het denken over democratie ook in de twintigste eeuw uiteraard verder evalueerde. Het is hier geenszins de plaats om hierover uit te wijden. Ik verwijs naar $\mathrm{H}$. Koning, Directe democratie in Nederland, diss. RL, Maastricht/Den Haag 1995.

31. Vgl. J.M.H.F. Teunissen, Het burgerlijk kleed van de staat, a.w., p. 146-147.

32. Zie hoofdstuk 5 waar de ontwikkeling van het leerstuk van détournement de pouvoir nader wordt belicht. Aan de (Franse) controle door de Conseil d'Etat op détournement de pouvoir lag de controle op de aanwezigheid van bestuursbevoegdheid ten grondslag. Ik wijs er overigens - terzijde - op dat vél oudere (Middeleeuwse) vormen van rechterlijke 'controle' op de aanwezigheid van overheidsbevoegdheid gevonden worden in Engeland in het kader van de 'judicial review' (de 'public law remedies'). Zie hierover: N. Verheij, Publiekrecht en privaatrecht in Engeland: singin' the continantal blues, NTB 1990/1, i.h.b. p. 2-5. 
Ik wijs ook op Van Wijmen die over dit (wettelijke) proces van doelbinding nog het volgende opmerkte:

\begin{abstract}
'Elke wettelijke regeling - en alleen daaruit vloeit, zij het soms indirect, bestuursbevoegdheid voort - heeft een bepaald doel. Zodra de samenleving zich geroepen voelt om als zodanig de behartiging van een zeker belang veilig te stellen, zal daartoe in een staatsvorm als de onze een daad van wet- of althans regelgeving worden gesteld. Het te behartigen belang vormt er de kern, het doel van en het is ondenkbaar, dat zonder zulk vóórgegeven en als behartigenswaardig erkend belang een wet tot stand komt. Door aldus dat belang tot een algemeen belang te maken en tot doelstelling in de betrokken wet op te nemen - rechtschepping bij uitstek dus, namelijk door de wetgever zelf - wordt zulk een doelbelang binnen de grenzen van wet en recht getrokken. Vóordien kon het weliswaar een ethische categorie zijn of een sociaal cultureel gegeven; het bevond zich nog buiten de rechtssfeer. ${ }^{34}$
\end{abstract}

De concentratie, doelbinding én expliciete democratische vestiging van 'bestuursmacht' binnen één publieke rechtsgemeenschap, alsmede de controle van deze macht door de leden van deze gemeenschap zelf, vormden noodzakelijke voorwaarden voor de ontwikkeling van een burgerlijke maatschappij waarbinnen individuen en private rechtsverbanden op basis van burgerlijke vrijheid en gelijkheid naar eigen inzicht invulling konden gaan geven aan hun onderlinge rechtsbetrekkingen. Deze originaire burgerlijke vrijheid diende echter te worden uitgeoefend binnen de publieke randvoorwaarden welke door de statelijke gemeenschap werden gesteld. Het publiekrecht kon hierdoor zijn bovenindividueel-regulerende functie in volle omvang gaan vervullen.

\title{
3.2.3 Rechtsvorming en rechtsbeginselen
}

Voordat het rechtsvormingsproces binnen de publieke rechtsgemeenschap nader wordt beschouwd is het nuttig om eerst enige algemene opmerkingen over (gerichte) rechtsvorming te maken. Rechtsvorming impliceert, zoals in hoofdstuk 2 werd gesteld, de positivering van (nieuw) recht door competente rechtsvormers. Positivering van recht vóoronderstelt derhalve steeds de aanwezigheid van een bevoegdheid op basis waarvan geldige rechtsnormen tot stand kunnen worden gebracht. Deze normen hebben, mits zij herleidbaar zijn tot een (geldige) competentienorm, formele gelding. ${ }^{35}$

Dit positiefrechtelijke uitgangspunt verdient nuancering, daar het in zuivere vorm te kort schiet. ${ }^{36}$ Rechtsvorming door competente rechtsvormers dient, op straffe van verabsolute-

33. E.-W. Bockenforde, Die Bedeutung der Unterscheidung von Staat und Gesellschaft im demokratischen Sozialstaat der Gegenwart, a.w., p. 189; Vgl. over de (groeiende) publiekrechtelijke belangbehartiging en de daaraan inherente ontwikkeling van een structuur van bestuursbevoegdheden: De Haan/Drupsteen/Fernhout, Bestuursrecht in de sociale rechtsstaat I, a.w., p. 39.

34. P.C.E. van Wijmen, Recht, belang en rechtsbescherming. Actie en belang, forum en toetsingsgrond; een dwarsdoorsnede van de rechtsbescherming tegen overheidsbestuur, diss. UU, 's-Gravenhage 1981, p. 478.

35. Zie in dit kader hoofdstuk 2, paragraaf 2.3 .

36. Op deze plaats kan verwezen worden naar het bekende rechtspositivistische standpunt van Kelsen, die in zijn 'Reine Rechtslehre' opmerkte: 'Eine Rechtsnorm gilt nicht darum, weil sie einen bestimmten Inhalt hat, das heißt: weil ihr Inhalt aus dem einer vorausgesetzten Gundnorm im Wege einer logischen 
ring van het positiveringsmoment én het formele bevoegdheidsaspect, beschouwd te worden tegen de achtergrond van materiële rechtsbeginselen die aan het proces van positivering ten grondslag liggen. Materiële rechts-beginselen en gepositiveerd recht veronderstellen elkaar en zijn op elkaar aangewezen. ${ }^{37}$ Enerzijds wordt aan de inhoud van de materiële rechtsbeginselen door het proces van positivering een - noodzakelijke - concrete en bindende vorm gegeven, anderzijds vloeien uit deze rechtsbeginselen de juridische randvoorwaarden voort voor het rechtsvormingsproces. Anders uitgedrukt: rechtsbeginselen verankeren een (positief) rechtsstelsel terwijl zij tevens in dat zelfde rechtsstelsel hun neerslag vinden. ${ }^{38}$

Het moment van rechtsvorming is derhalve van cruciaal belang voor de dynamiek van een rechtsstelsel, maar deze rechtsvorming mag niet indruisen tegen de (ongeschreven) materiële rechtsbeginselen die een normatieve 'basis'-invulling geven aan de materiële competentiesfeer van een rechtsverband. In dit boek wordt dan ook tot uitgangspunt genomen de idee dat het geldende positieve recht is verankerd in typisch beginsel-recht. ${ }^{39}$

De gelding van materiële rechtsbeginselen kan gefundeerd worden in - wat Cliteur heeft aangeduid als - het 'cultuurrecht' ${ }^{40}$ Een cultuurrechtelijke visie op het recht gaat ervan uit dat er binnen een rechtsstelsel naast bewust gevormd recht ook onbewust gevormd recht

SchluBfolgerung abgeleitet werden kann, sondern darum, weil sie in einer bestimmten, und zwar in letzter Linie in einer von einer vorausgesetzten Grundnorm bestimmten Weise erzeugt ist. Darum und nur darum gehört sie zu der Rechtsordnung, deren Normen dieser Grundnorm gemåß ezzeugt sind. Daher kann jeder beliebige Inhalt Recht sein' (curs. R.J.N.S.). H. Kelsen, Reine Rechtslehre, Zweite vollstăndig neu bearbeitete und erweiterte Auflage, Wien 1960, p. 200-201.

37. Zie over de relatie en de wisselwerking tussen positivering en materiele rechtsbeginselen o.m. H.J. van Eikema Hommes, De elementaire grondbeginselen der rechtswetenschap, a.w., p. 355-356. Een fraaie analyse over dit onderwerp treft men aan in het proefschrift van Cliteur dat hierna nog ter sprake zal komen. P.B. Cliteur, Conservatisme en cultuurrecht. Over de fundering van recht in rechtsbeginselen, diss. RUL, Amsterdam 1989. Ik wijs voorts op: B.W.N. de Waard, Beginselen van behoorlijke rechtspleging, met name in het administratief procesrecht, diss. UU, Zwolle 1987, i.h.b. p. 84 e.v. Ofschoon De Waard ervan uitgaat dat rechtsbeginselen een (sterk) ethische lading hebben, rekent hij ze tot de wereld van het recht; hij acht bijgevolg verankering van het positieve recht in cultuurhistorisch bepaald beginselrecht mogelijk (a.w., p. 92). Zie tot slot: R.J.N. Schlossels, Anti-nomoi: Wettelijk onrecht en bovenwettelijk recht: een reactie, RegelMaat 1997/2, p. 80 e.v.

38. Met De Waard ben ik dan ook van mening dat typische rechtsbeginselen vanuit een extern (d.w.z. geobjectiveerd) standpunt beschreven kunnen worden. Het bestaan van dergelijke beginselen kan m.a.w. daadwerkelijk aan de hand van het geldende recht worden vastgesteld. B.W.N. de Waard, Beginselen van behoorlijke rechtspleging, a.w., p. 92. Dit geldt, zoals uit de jurisprudentie-analyse in hoofdstuk 8 nog zal blijken, zeker voor het specialiteitsbeginsel.

39. In een rechtspositivistische opvatting ontbreekt doorgaans de op deze plaats beoogde normatieve 'beginsel'-schakel tussen enerzijds het - door competente organen - gepositiveerde recht, en anderzijds ethiek, politiek en moraal. M.a.w. het zuivere rechtspositivisme verankert het geldende recht niet in beginsel-recht. De meest bekende rechtstheoretische beschouwing over de beginselfundering van het recht is wellicht die van R. Dworkin, Taking rights seriously, zesde druk, Cambridge/Massachusetts 1979. Ik wijs erop dat bijv. Van Eikema Hommes zijn theoretische opvatting op dit punt in verband heeft gebracht met Dworkins visie. H.J. van Eikema Hommes, De rechtsbeginselen volgens de transcendentaal-empirische methode, in: Rechtsbeginselen Zwolle 1980, p. $59 \mathrm{t} / \mathrm{m}$ 62. Het rechtsbeginsel heef, anders dan de scherpe regel, géén 'alles of niets' karakter; het rechtsbeginsel is een normatief richtsnoer. 
kan worden onderscheiden. Het gaat hier, om in de woorden van Cliteur te spreken, om het geheel van algemene rechtsprincipes dat oprijst uit de interactie tussen mensen gedurende een lang tijdsbestek en dat voortdurend aan kritiek en verfijning blootstaat van de jurisprudentie, de rechtswetenschap en de publieke opinie. ${ }^{41}$ Het cultuurrecht, dat gekenmerkt wordt door een materiële beginselinhoud, is het resultaat van een gedurende vele eeuwen voortschrijdend cultuurhistorisch ontsluitingsproces dat - wat het recht betreft wordt gekenmerkt door een cumulatie van rechtskennis, rechtsevolutie, rechtsdifferentiatie en rechtsverfijning. ${ }^{42}$ In de Westerse wereld kristalliseerde dit proces uit in de typische beginselen en de kenmerkende rechtsstructuur van de democratische rechtsstaat.

Cliteur merkt over de beginselfundering van het positieve recht het volgende op: 'Die beginselen zijn de filtered experience of mankind. Zij vormen de rechtspolitieke wijsheid die nooit achter welke sluier van onbekendheid dan ook maar te bedenken zou zijn. Beweren dat zo iets mogelijk zou zijn, getuigt van een naïeve overschatting van het menselijke verstand. Die beginselen zijn mensenwerk, zeker. In die zin zijn zij ook niet bovenwillekeurig. Die beginselen zijn nl. niet met gods vinger aan de hemel geschreven. Maar zij zijn wél bovenwillekeurig in de zin dat zij de wijsheid van het individu transcenderen. $\mathrm{Zij}$ zijn niet het product van één generatie en juist daarom overstijgen zij de perfectie en rationaliteit waartoe éen generatie in staat is. ${ }^{13}$

In dit kader kan gesproken worden over 'de rechtsidee' die binnen een lange tijdsperiode aan de geldende rechtsorde ten grondslag ligt en die tevens het normatieve referentiekader biedt voor het geldende recht. In het vervolg van dit hoofdstuk zal het standpunt worden ingenomen dat het specialiteitsbeginsel als fundamenteel rechtsbeginsel dient te worden aangemerkt dat binnen de democratische rechtsstaat inherent is aan de publiekrechtelijke bevoegdheidsstructuur, alsmede aan de scheiding tussen typisch publiekrechtelijke belangen en private (vermogens)belangen.

Door de aanvaarding van het uitgangspunt dat aan rechtsvorming materiële rechtsbeginselen vooraf gaan, is tevens het noodzakelijke onderscheid tussen formele bevoegdheid (het legaliteitsaspect) en een materiële rechtsgrond voor (publiekrechtelijke) bevoegdheid gegeven. Teunissen merkt over dit onderscheid het volgende op: 'Een formele bevoegdheid kan slechts bestaan binnen een materiële bevoegdheidssfeer, die bepaald en begrensd wordt door de typische aard van de desbetreffende samenlevingskring.(..) Als er binnen één materiële rechtskring een hiërarchie bestaat van hogere en lagere trappen van rechtsvorming, dan is de rechtsvorming door het hoogste rechtsvormende orgaan de formele geldingsgrond van afgeleide (gedelegeerde) vormen van (formele) bevoegdheid binnen het

40. P.B. Cliteur, Conservatisme en cultuurrecht, a.w., m.n. de hoofdstukken 7 en 8 . Zie ook: S.W. Couwenberg, Gezag en vrijheid, a.w., p. 199 en 200.

41. P.B. Cliteur, Conservatisme en cultuurrecht, a.w., p. 422 en 423 . Zie voor een fraaie uitwerking toegespitst op de ontwikkeling van mensenrechten: P.B. Cliteur, What developments can we expect in the field of human rights for the coming decades?, Rechtstheorie (Duncker \& Humblot, Berlin), 1996 (27), p. 177 e.v.

42. P.B. Cliteur, Conservatisme en cultuurrecht, a.w., p. 426 e.v.

43. P.B. Cliteur, Conservatisme en cultuurrecht, a.w., p. 455 en 456. 
materiële rechtsgebied van het verband. De rechtsvormende bevoegdheid van het hoogste orgaan is een materiêle, omdat zij slechts wordt afgebakend door de materiële bevoegdheidssfeer van de desbetreffende samenlevingskring zelf. ${ }^{, 4}$ Ook de rechtsvorming door de rechtsorganen van de publieke rechtsgemeenschap wordt, zoals hierna nog zal blijken, begrensd en beheerst door een materiële competentiesfeer.

\subsubsection{De normzijde en feitelijke zijde van het recht}

Het recht kan in zijn algemeenheid worden omschreven als een door (objectieve) rechtsnormen geregeld evenwicht van belangen van rechtssubjecten (de 'rechtsbelangen') ${ }^{45}$ Het recht vóóronderstelt met het oog hierop steeds een normzijde en een feitelijke zijde. ${ }^{46}$ Aan de normzijde van het recht zijn competente organen verantwoordelijk voor de positivering van nieuwe rechtsnormen (het rechtsvormingsaspect) binnen hun materielle competentiesfeer. In het publiekrecht komen deze orgaanfuncties goed tot uitdrukking in een duidelijke formele competentiestructuur. De rechtsorganen kunnen hier eenvoudig onderscheiden worden van de leden-rechtssubjecten van de publieke rechtsgemeenschap. ${ }^{47}$ Deze ledenrechtssubjecten, de zelfstandige dragers van rechtsbelangen, vormen als zodanig het gegeven waarop het publieke rechtsvormingsproces zich toespitst (de feitelijke zijde van het recht). Het publieke rechtsvormingsproces wordt gekenmerkt door een regulerende functie vanuit een bovenindividueel perspectief (nl. de behartiging van het algemeen belang ${ }^{48}$ ). De normzijde van het recht wordt binnen de publieke rechtssfeer primair gevormd door cultuurhistorisch bepaald beginselrecht (vgl. paragraaf 3.2.3). Op basis van dit beginselrecht, en de daarin gefundeerde constitutionele procedures wordt de publieke normzijde van het recht door de statelijke organen gepositiveerd. Deze positivering komt in belangrijke mate tot uitdrukking in de Grondwet, de organieke wetgeving, de typisch doelgebonden bestuurswetgeving en de concretiserende rechtsvorming die zich op basis van deze wetten voltrekt.

De bestuursorganen zijn binnen de statelijke structuur bij uitsluiting belast met de rechtsvorming ter behartiging van specifieke publiekrechtelijke belangen. Het publiekbestuurlijke rechtsvormingsproces is gerelateerd aan de belangposities van de rechtssubjecten (de staatsburgers). De bestuurlijke rechtsvorming staat volledig ten dienste van

44. J.M.H.F. Teunissen, Het burgerlijk kleed van de staat, a.w., p. 210.

45. Vgl. H.J. van Eikema Hommes, De elementaire grondbegrippen der rechtswetenschap, a.w., p. 221.

46. Rechtsnormen (i.h.b. 'regels') hebben, zo bleek reeds in hoofdstuk 2, een conditioneel karakter. Normcondities kunnen door feiten worden vervuld waardoor bepaalde rechtsgevolgen intreden.

47. Het onderscheid geldt $66 \mathrm{k}$ voor het burgerlijke privaatrecht, zij het dat hier de belangrijkste juridische orgaanfunctie (de handelingsbekwaamheid) in beginsel aan ieder natuurlijk rechtssubject toekomt mits het een bepaalde leeftijd heeft bereikt en niet onder curatele is gesteld, alsmede aan rechtspersonen. Zie: H.J. van Eikema Hommes, De elementaire grondbegrippen der rechtswetenschap, a.w., p. 234. In algemene zin kan men stellen dat het onderscheid tussen de rechtsorganen en de rechtssubjecten, zijnde de dragers van eigen rechtsbelangen en rechtsplichten, in het burgerrechtelijke verkeer niet zo duidelijk op de voorgrond treedt als in het publiekrecht.

48. Zie over dit begrip uitvoerig paragraaf 3.3 van dit hoofdstuk. 
deze subjecten. Aldus beschouwd, zijn de normzijde van het recht en de feitelijke zijde van het recht steeds op elkaar aangewezen. Rechtsnormen, en derhalve ook (discretionaire) bevoegdheidsnormen, hebben nl. géén zin zonder dat blote feiten en belangposities deze normen activeren. Rechtsvorming impliceert daarom per definitie rechtsvorming met betrekking tot bepaalde feiten en rechtsbelangen. ${ }^{49}$ Dit geldt ook voor de gerichte bestuurlijke rechtsvorming die, zoals in dit boek nog zal blijken, weliswaar exclusief gestuurd wordt door de werking van het specialiteitsbeginsel maar gelijktijdig onlosmakelijk gerelateerd is aan de individualiseerbare belangposities van de betrokken rechtssubjecten.

\subsubsection{Het specialiteitsbeginsel als publiekrechtelijk beginsel}

Voordat de typische karakteristieken van het rechtsvormingsproces binnen de publieke rechtsorde worden beschouwd, is het tot slot zinvol om nog stil te staan bij de rechtsbeginselen die aan dit rechtsvormingsproces ten grondslag liggen. Van Eikema Hommes heeft mijns inziens deze rechtsbeginselen op een heldere wijze ingedeeld in modale (d.w.z. algemene) en typische rechtsbeginselen enerzijds, en constitutieve en regulatieve rechtsbeginselen anderzijds. ${ }^{50}$ Deze indeling kan naar mijn mening ook worden gehanteerd om het specialiteitsbeginsel te positioneren.

Onder de modale rechtsbeginselen worden begrepen beginselen die gegrond zijn in de algemene aard en de normatieve structuur van het recht. Deze beginselen zijn derhalve voor een rechtsstelsel als geheel relevant. Een voorbeeld van een dergelijk modaal rechtsbeginsel is het rechtszekerheidsbeginsel. Dit rechtsbeginsel is algemeen van aard en bijgevolg van belang voor zowel het privaat-, het publiek- als het strafrecht. Typische rechtsbeginselen zijn daarentegen slechts relevant voor de rechtsvorming binnen bepaalde rechtssferen. Zo zijn bijv. in de speciale juridische bestemmingsfunctie van de staat typische rechtsbeginselen gegrond. Gedacht kan bijv. worden aan het beginsel van de machtenscheiding, het democratiebeginsel en de idee van het handelen in het algemeen belang. Teunissen heeft erop gewezen dat deze typisch publieke rechtsbeginselen de samenstelling, inrichting en bevoegdheden van de overheidsorganen, alsmede de rechtsverhouding tussen overheid en burgers beheersen. ${ }^{51}$

Zowel de modale als de typische rechtsbeginselen kunnen op hun beurt onderverdeeld worden in constitutieve en regulatieve rechtsbeginselen. De constitutieve beginselen zijn bepalend voor de structuur van het recht als zodanig. Constitutieve rechtsbeginselen kunnen niet worden ontkend zonder de aard van het recht zélf te ontkennen; zij zijn met andere woorden bepalend voor het rechtsbegrip. Van Eikema Hommes positioneert bijv. de begrippen juridische wil en juridische competentie tegen de achtergrond van (modale)

49. $\mathrm{Vgl}$. art. 3:2 Awb dat bepaalt dat het verantwoordelijke bestuursorgaan de nodige kennis dient te vergaren omtrent de relevante feiten en de af te wegen belangen.

50. Zie bijv. H.J. van Eikema Hommes, De samengestelde grondbegrippen der rechtswetenschap, a.w., p. 28 t/m 30 en meer uitvoerig H.J. van Eikema Hommes, Hoofdlijnen der rechtssociologie en de materielle indelingen van het publiek- en privaatrecht, Zwolle 1975, p. 52 e.v.

51. J.M.H.F. Teunissen, Het burgerlijk kleed van de staat, a.w., p. 211. 
constitutieve rechtsbeginselen. ${ }^{52}$ De regulatieve rechtsbeginselen daarentegen ontsluiten, verdiepen en verfijnen de constitutieve beginselen; zij kunnen worden opgevat als rechtsethische principes. ${ }^{53}$ Een regulatief beginsel van publiekrecht is, volgens Van Eikema Hommes, bijv. de eerdergenoemde idee van handelen in 'het algemeen belang'. Zelf zou ik (aspecten van) de 'algemeen belang'-notie overigens eerder kwalificeren als constitutief (de materiële publieke bevoegdheidsgrondslag).

Beziet men de door Van Eikema Hommes omschreven constitutieve rechtsbeginselen voor het staats- en administratiefrecht ${ }^{54}$, dan kan worden geconcludeerd dat ók het specialiteitsbeginsel tot deze beginselen dient te worden gerekend. Zoals hierna zal blijken vormt $\mathrm{nl}$. het specialiteitsbeginsel, toegespitst op bestuursbevoegdheid, de 'beginsel'schakel tussen het typisch-constitutieve democratiebeginsel en het modale rechtszekerheidsbeginsel. Tevens verfijnt het specialiteitsbeginsel de idee van de machtenscheiding, die (o.m.) beoogt om het bestuur én de rechter aan het primaat van de wetgevende macht te binden. ${ }^{55}$

\subsubsection{Het rechtsvormingsproces binnen de publieke rechtsorde}

$\mathrm{Na}$ deze algemene opmerkingen over rechtsvorming en rechtsbeginselen kan het rechtsvormingsproces binnen de publieke rechtsorde nader worden beschouwd. De publieke rechtsgemeenschap vormt, zoals gesteld, één van de gedifferentieerde rechtsverbanden ${ }^{56}$ met een typische interne rechtskarakteristiek. Doel van dit publieke rechtsverband is het bewerkstelligen van een optimale (materiële) vrijheid en gelijkheid voor rechtssubjecten op basis van het typisch publiekrechtelijke uitgangspunt van de behartiging van het algemeen belang. Binnen de publieke rechtsorde worden ter realisering van dit doel aan de statelijke bestuursorganen belangen ter exclusieve behartiging toevertrouwd. Dit geschiedt in de regel expliciet overeenkomstig vaste en kenbare (constitutionele) procedures, die gefundeerd zijn in het interne structuurprincipe van de staat. Naar hun aard zijn deze publieke gemeenschapsbelangenbelangen welke door individuele rechtssubjecten niet, of niet op een

52. H.J. van Eikema Hommes, Hoofdlijnen der rechtssociologie en de materièle indelingen van publiek- en privaatrecht, a.w., p. 54.

53. H.J. van Eikema Hommes, Hoofdlijnen der rechtssociologie en de materiele indelingen van publiek- en privaatrecht, a.w., p. 53.

54. Van Eikema Hommes noemt de volgende negen (hoofdgroepen van) typisch-constitutieve beginselen van het staats- en administratief recht: (1) het representativiteitsbeginsel; (2) het beginsel van scheiding en evenwicht van de staatsmachten; (3) het beginsel van 'rule of law'; (4) het beginsel van een onafhankelijke rechterlijke macht; (5) het decentralisatiebeginsel; (6) de grondrechten; (7) het beginsel van de aansprakelijkheid van de staat jegens zijn onderdanen wegens 'risque exceptionnel' (samenhangend met het égalité-beginsel); (8) - kort samengevat - het beginsel dat het algemeen belang contractbreuk door de overheid kan rechtvaardigen en (9) de diverse algemene beginselen van behoorlijk bestuur. H.J. van Ejkema Hommes, Hoofdlijnen der rechtssociologie en de materielle indelingen van publiek- en privaatrecht, Zwolle 1975, p. $56 \mathrm{t} / \mathrm{m} 69$.

55. Zie in dit kader uitvoerig hoofdstuk 4 van dit boek.

56. Op deze plaats dient te worden opgemerkt dat binnen de publieke rechtsgemeenschap ook deelverbanden kunnen worden onderscheiden (bijv. provincies, gemeenten en waterschappen). 
gelijke wijze, kunnen worden behartigd. ${ }^{57}$ Ook is het mogelijk dat het belangen betreft waarvan de gemeenschap heeft geoordeeld dat het niet wenselijk is dat individuele rechtssubjecten ze behartigen. ${ }^{58}$

Het publieke gemeenschapsverband heeft nu als bijzondere functie om publieke gemeenschapsbelangen te behartigen, maar tegelijkertijd de eigen rechtssfeer van andere (private) rechtsverbanden, alsmede de autonomie van individuele rechtssubjecten en hun rechtsbelangen, te respecteren en zoveel als mogelijk te ontzien. ${ }^{59}$ De typisch integrerende functie van het publiekrecht treedt in dit kader op de voorgrond. De positie van de overheid als deelnemer aan het publieke integratieproces verschilt principieel van de andere deelnemers, gelet op de unieke functie die de overheidsorganen dienen te vervullen. Van der Hoeven merkte hierover op: 'En zelfs wanneer men aan de overheidsorganen uitsluitend een dienende functie toekende, bleef en blijft toch altijd de situatie bestaan dat de opdracht aan de overheid weliswaar van het volk wordt afgeleid, maar dat het geheel nu eenmaal staat boven de delen en dat de overheid en haar organen optreden met het gezag van dat geheel en ter behartiging van het belang van dat geheel. ${ }^{10}$

\subsubsection{Twee naar hun aard verschillende belangensferen}

In dit verband dient men goed voor ogen te houden dat binnen de publieke rechtsorde twee principieel verschillende belangensferen met elkaar in aanraking komen. ${ }^{61}$ Van 'gewone' belangenconflicten, zoals kenmerkend voor het burgerlijk privaatrecht, kan daarom géén sprake zijn. Van Erp schetst dit als volgt:

'Bij gewone belangenconflicten kan vaak worden volstaan met een afweging van de belangen tegenover elkaar, waarbij verondersteld wordt dat ze qua gewicht met elkaar vergelijkbaar zijn, en dat de verschillen kunnen worden vereffend en gecompenseerd. Deze belangenconflicten dienen volgens de normen van ruilrechtvaardigheid te worden opgelost. Er bestaan echter ook conflicten tussen belangen van verschillende categorieěn: tussen algemeen belang en bijzondere belangen; tussen staatsbelang en bijzondere belangen; tussen staatsbelang en algemeen belang. Bij dergelijke intercategoriale belangenconflicten kan er niet van een eenvoudige belangenafweging sprake zijn, omdat algemeen belang en staatsbelang andere typen van belang aanduiden dan bijzondere belangen, en met hen niet in een eenvoudige concurrentieverhouding staan' (curs. H.v.E.). ${ }^{62}$

57. Het gaat hier, om in de termen van Simon te spreken, om de opheffing van 'meta-privaatrechtelijke' tekorten binnen de samenleving of om de behartiging van naar hun aard 'bovenindividuele' belangen. H.J. Simon, Publiekrecht of privaatrecht? Een geschiktheidsonderzoek aan de hand van het nutsmaximalisatiebeginsel toegespitst op het gebruik van privaatrecht door het bestuur, diss. VU, Zwolle 1993, p. 110.

58. Zie: A.Q.C. Tak, Overheidsbestuur en privaatrecht, Alphen aan den Rijn 1978, p. 85. In dit kader kan bijv. gedacht worden aan 'klassieke' overheidstaken zoals defensie, waterstaat en buitenlands beleid.

59. Vgl. H.J. van Eikema Hommes, De wijsgerige grondslagen van de rechtssociologie, a.w., p. 188.

60. J. van der Hoeven, De drie dimensies van het bestuursrecht, VAR-reeks 100, Alphen aan den Rijn 1989, p. 149.

61. Vgl. Simon die erop gewezen heeft dat verschillende 'autonomie-sferen' elkaar hier ontmoeten. Hierdoor wordt de complexe vraag opgeworpen welke autonomie mag (of moet) prevaleren. H.J. Simon, Autonomie en 'verbintenis' in het publiekrecht: een intern rechtsvergelijkende analyse, in: Eenzijdig en wederkerig? (red. E.C.H.J. Van der Linden en A.Q.C. Tak), Deventer 1995, p. 84. 
De belangenconflicten tussen de belangen van de publieke rechtsgemeenschap en private rechtsbelangen kunnen per definitie niet worden opgelost aan de hand van de regels en beginselen van het burgerlijke privaatrecht, dat in belangrijke mate gebaseerd is op het uitgangspunt van de iustitia commutativa (ruilrechtvaardigheid). ${ }^{63}$ De intercategoriale belangenconflicten, welke zich veelvuldig voordoen in het publiekrecht, vragen om normering door specifieke rechtsnormen die zijn toegespitst op deze publiekrechtelijke belangenconflicten. De typische beginselnormen die ten grondslag liggen aan de publieke rechtsorde zijn met het oog hierop geënt op de principiële rechtsongelijkheid tussen burger en overheid. Deze rechtsongelijkheid mag niet vereenzelvigd worden met de feitelijke (d.w.z. economische of maatschappelijke) ongelijkheid zoals deze tussen burgers onderling voorkomt. ${ }^{64}$ De hier bedoelde ongelijkheid vloeit voort uit de onvergelijkbaarheid van de $b i j-$ zondere (vermogens)belangen van private rechtssubjecten en de publieke gemeenschapsbelangen die door het bestuur dienen te worden behartigd.

Het proces van belangen-'afweging' en publieke rechtsvorming krijgt in het bijzonder zijn beslag binnen de typische structuur van de bestuurswetgeving. Deze wetgeving biedt, anders dan het (gepositiveerde) burgerlijke privaatrecht ${ }^{65}$, de ideaal-typische rechtsstructuur om intercategoriale belangenconflicten te harmoniseren. ${ }^{66}$ Met name de bestuursbevoegdheden, waaraan het specialiteitsbeginsel ten grondslag ligt, vervullen in dit verband een bijzondere functie. Simon ${ }^{67}$ merkt hier het volgende over op:

62. H. van Erp, Het politiek belang, a.w., 74 .

63. De behartiging van private belangen door rechtssubjecten staat hier centraal. Zie: J.M.H.F. Teunissen, Het burgerlijk kleed van de staat, a.w., p. 208.

64. Het argument van de maatschappelijke ongelijkheid wordt nogal eens in stelling gebracht om de exclusieve machtspositie van de overheid te betwisten. In dit kader wordt evenwel uit het oog verloren dat de 'machtspositie' van de overheid niel wortelt in maatschappelijke of economische factoren, maar in het verschil tussen bijzonder belang en algemeen belang. Vgl. J. van der Hoeven, De drie dimensies van bestuursrecht, a.w., p. 162 en 163 . Vgl. ook Nicolail e.a., Bestuursrecht, zesde geheel herziene druk, Amsterdam 1997, p. 7.

65. Het burgerlijk privaatrecht is immers primair toegespitst op conflictbeheersing in rechtsgelijke situaties tussen burgers onderling. Zie in dit kader: H.J. van Eikema Hommes, De elementaire grondbegrippen der rechtswetenschap, a.w., p. 308 en 309 . Vgl. ook: J. van der Hoeven, De drie dimensies van het bestuursrecht, a.w., m.n. p. 159, 163, 167 en 225.

66. Hierbij dient men in het oog te houden dat de publiekrechtelijke bevoegdheidsuitoefening vaak 'multipolair' van aard is. Intercategoriale belangenconflicten binnen de publieke rechtsgemeenschap worden niet zelden gekenmerkt door complexe belangentegenstellingen tussen burgers onderling (denk aan derden!) één en ander in het licht van speciale publiekrechtelijke belangen. De inhoudelijk én procedureel genormeerde bestuursbevoegdheid biedt - anders dan open 'privaatrechtelijke bevoegdheid' - een effectief kader om deze belangenconflicten in goede banen te leiden. Vgl. H.J. Simon, Publiekrecht of privaatrecht?, a.w., p. 225. Het feit dat de overheid complexe belangentegenstellingen in goede banen dient te leiden heeft soms merkwaardige consequenties indien er gebruik wordt gemaakt van burgerlijk recht. Vgl. HR 20 mei 1994, NJ 1995, 691, m.nt. CJHB (De Negende van OMA), waarin de Hoge Raad in essentie aanvaardde dat onder omstandigheden de eisen van redelijkheid en billijkheid met zich kunnen brengen dat de overheid van een (wederkerige) overeenkomst moet afwijken in het belang van derden (!).

67. H.J. Simon, Publiekrecht of privaatrecht?, a.w., p. 143. 
'Publiekrechtelijke bevoegdheden worden vanuit meta-, meso en micro-niveau inhoudelijk en procedureel sterk gestructureerd. In het bestuursrecht spreekt men van gelede normstelling en zich verbijzonderende belangenafweging. De kern van dit stelsel is dat het de uitvoerende overheid in belangrijke mate bindt aan de realisering, zo mogelijk, van de autonomie van het rechtssubject. In dezelfde richting wijst het specialiteitsbeginsel dat de belangenbehartiging door het bestuur in hokjes dwingt met name de behartiging van openbare belangen, daarmede vrijheid van rechtssubjecten beschermend' (curs. H.J.S.).

In dit kader dienen ook Van der Hoevens 'tweede' en 'derde' dimensie van het bestuursrecht in herinnering te worden geroepen. Van der Hoeven benadrukte immers dat het bestuursrecht - in tegenstelling tot het privaatrecht - niet alleen waarborgen aan burgers beoogt te bieden tegen bestuurshandelen, maar ók (op exclusieve wijze) de instrumentatie aan het bestuur verschaft om publiekrechtelijke belangen te behartigen: 'Het wettelijk bestuursrecht heeft, zoals hiervoor een en ander maal betoogd, geenszins als enige functie het beschermen van de burger tegen onrechtmatig optreden van de overheid, maar het is tevens en zelfs in de eerste plaats bestemd om de overheid, die tegenover de particulier in beginsel in een andere positie verkeert dan particulieren tegenover elkaar, de instrumenten te bieden die speciale taak voor de gemeenschap te verrichten. Dat is trouwens de enige taak die de overheid heeft: daarbuiten heeft zij geen eigen belangen. ${ }^{.68}$

\subsubsection{Het rechtskarakter van het 'publieke' recht}

Binnen het bestuursrecht vormen (discretionaire) bevoegdheidsnormen, zoals gesteld, de typisch normerende kaders waarbinnen intercategoriale belangenconflicten tussen publieke gemeenschapsbelangen enerzijds en rechtsbelangen van rechtssubjecten anderzijds in concreto door de statelijke bestuursorganen kunnen worden geharmoniseerd. Dit harmonisatieproces wordt binnen de publieke rechtsorde derhalve begrensd door normatieve kaders die voor het bestuur vóóraf vaststaan. Het primaat van de democratisch gelegitimeerde wetgever speelt hierbij, zoals in het vervolg van dit boek zal blijken, een belangrijke rol. De wetgever is $\mathrm{nl}$. verantwoordelijk voor de vaststelling van publiekrechtelijke belangen, alsmede voor de afweging van deze belangen tegen rechtsbelangen van burgers in algemene zin. ${ }^{69}$ De bestuursorganen zijn vervolgens belast met een nadere - individualiserende - belangenafweging. Ik laat Simon nogmaals aan het woord:

'De overheid is geen monoliet. Realisering van vrijheid door de overheid is een proces van zich verbijzonderende keuzen en afwegingen. Die keuzen worden vastgelegd in recht. Dat is de rol van de rechtszekerheid. De gelaagde structuur van het overheidshandelen, gevoegd bij de scheiding van de aan de overheid toekomende bevoegdheden en de in dat kader te betrekken belangen (specialiteitsbeginsel), maakt het mogelijk optimaal recht te doen aan de realisering en respectering van de vrijheid van de rechtssubjecten. 70

68. J. van der Hoeven, De drie dimensies van het bestuursrecht, a.w., p. 163.

69. Vgl. H.J. Simon, Publiekrecht of privaatrecht?, a.w., p. 67.

70. H.J. Simon, Publiekrecht of privaatrecht?, a.w., p. 271. 
Tegen deze achtergrond kan het publiekrecht worden omschreven als het specifieke interne recht van de publieke rechtsgemeenschap dat ziet op het proces van determinatie én behartiging van publieke gemeenschapsbelangen. Het is tevens het typische recht dat de conflicten tussen de (private) rechtsbelangen van burgers - en hun private verbanden - enerzijds en publieke rechtsbelangen anderzijds tracht te reguleren, onder erkenning van fundamentele burgerrechten, éen en ander in het licht van typisch publieke rechtsbeginselen.

\subsection{Het algemeen belang}

Naar algemeen in de rechtsliteratuur wordt aangenomen vormt de leidraad en ongeschreven rechtsgrond voor alle overheidsactiviteit het algemeen belang ('res publica'). Handelt de overheid in een democratische-rechtsstaatniet in het algemeen belang, dan treedt zij buiten haar natuurlijke werkkring.

\subsubsection{Het algemeen belang als grondslag voor alle overheidsactiviteit}

Het algemeen belang vormt de rechtsgrond waarop overheidsactiviteit berust; het 'algemeen belang' begrenst met andere woorden de materiële competentiesfeer van de publieke rechtsgemeenschap en kan daarom worden opgevat als een normatief begrip. ${ }^{71}$ Dit uitgangspunt staat nauwelijks ter discussie. ${ }^{72}$ Polak bracht dit als volgt onder woorden:

'Elke beschouwing over het "algemeen belang", als rechtsbegrip kan uitgaan van de stelling, dat de overheid in een land als het onze, uitsluitend tot taak heeft het algemeen belang te behartigen en dat alle overheidsbevoegdheden, uitgezonderd die van de rechterlijke macht, alleen ter invulling van die taak mogen worden aangewend. Over de wezenlijke grondslag, de rechtvaardiging van dit beginsel moge men verschillend denken, hier kan worden volstaan met de vaststelling dat in de practijk van ons staatsleven dit beginsel door een ieder pleegt te worden aanvaard. (curs. R.J.N.S.) ${ }^{73}$

Handelen in het algemeen belang impliceert in ieder geval het gebod van onpartijdigheid en het verbod van vooringenomenheid van het bestuur (vgl. artikel 2:4 Awb). ${ }^{74}$ Daarnaast

71. Vgl. Simon die de (materiele) rechtsgrond voor het handelen van de overheid onderscheidt van wat hij noemt de (materiěle en formele) bevoegdheid(sgrondslag). H.J. Simon, Financiele voorwaarden en voorschriften. Een blik vanuit de theorie op de praktijk, NTB 1994/6, p. 150; Meer uitvoerig zijn dissertatie: H.J. Simon, Publiekrecht of privaatrecht?, a.w., m.n. p. 117 e.v. Zie over het 'algemeen belang' als normatief begrip: $\mathrm{H}$. van Erp, Het politiek belang, a.w., p. 53 en p. 57 e.v.

72. Wel is het 'algemeen belang' als normatief begrip problematisch. Dit vloeit voort uit het feit dat het begrip in een complexe pluriforme samenleving gevoelig is voor subjectieve (politieke) inkleuring door belangengroepen, waardoor het begrip aan betekenis verliest. Vgl. H. van Erp, Het politiek belang, a.w., p. 53 en 58.

73. C.H.F. Polak, Het begrip 'algemeen belang' in de verschillende onderdelen van het administratieve recht, preadvies VAR, Geschriften van de VAR XIX, Haarlem 1950, p. 43. 
wordt handelen in het algemeen belang in verband gebracht met de idee van de 'verdelende rechtvaardigheid' (iustitia distributiva). ${ }^{75}$ Het betreft hier de égalitaire dimensie van het begrip, welke met zich brengt dat de lasten voor de leden van de publieke rechtsgemeenschap die in het belang van die gemeenschap dienen te worden gedragen, ook evenwichtig over alle leden worden verdeeld.

De enigszins magisch aandoende - en verhullende - notie dat de overheid per definitie 'het algemeen belang' dient te behartigen wordt van oudsher erkend als grondslag van het bestuursrecht. Zo vestigde Boasson reeds in 1911 indringend de aandacht op dit uitgangspunt toen hij zijn drie normen voor het bestuurshandelen formuleerde. De eerste twee normen zagen volgens hem op de eis van plichtmatigheid van het bestuur: 'De ene norm verlangt van de administratie in de eerste plaats, dat ze zich steeds gedrage als gemeenschapsorgaan, dat ze zich niet laat leiden door luimen, antipathie, wrok, zucht tot bevoorrechting, eigenbelang, kortom persoonlijke bedoelingen.(..) De andere norm stelt haar tot eisch, dat ze zich van hare gemeenschapstaak met de noodige zorg kwijt, met andere woorden, dat zij niet lichtzinnig te werk gaat en zich van de feiten, die hare gedragingen bepalen, behoorlijk rekenschap geeft. ${ }^{76}$ Als derde basisnorm voor bestuursactiviteit zag Boasson de eis van rechtswaardering door de overheid. Deze norm brengt tot uitdrukking dat het algemeen belang niet zomaar nagestreefd wordt, maar dat dit uitsluitend kan met inachtneming van de betrokken particuliere belangen:

'De derde algemeene norm, die de practijk van ons rechtsleven aan de administratie oplegt, houdt in, dat zij bij het bevorderen van de gemeenschapsbelangen eene behoorlijke afweging moet verrichten van de waarde van het speciale algemeene belang, dat ze telkens wil behartigen en van de waarde der belangen van de natuurlijke en rechtspersonen, die ten bate van de gemeenschap zullen worden aangetast' (curs. R.J.N.S.). ${ }^{77}$

Over de precieze betekenis en inhoud van het 'algemeen belang'-begrip wordt intussen verschillend gedacht. Zo kan men zich afvragen of het algemeen belang materieel of formeel dient te worden opgevat. Is het algemeen belang met andere woorden definieerbaar als een inhoudelijke (materiële) grootheid die een indicatie geeft van de ideaal-typische overheidsfunctie, of ziet het begrip meer op een formele eis die ten grondslag ligt aan het (rechts)handelen binnen de publieke rechtsgemeenschap?

74. De bestuursmacht in de democratische rechtsstaat is derhalve onderworpen aan het non-identificatie principe. Hierin onderscheidt dit staatsconcept zich van de oude feodale (ongedifferentieerde) rechtsorde waar openbare functies en ambten uiteindelijk dienstig waren aan particuliere belangen en doeleinden. Zie: S.W. Couwenberg, Constitutionele ontwikkelingsmodellen, a.w., p. 26/27.

75. Vgl. J.M.H.F. Teunissen, Het burgerlijk kleed van de staat, a.w., p. 208 en 209.

76. J.J. Boasson, De rechter tegenover de vrijheid der administratie, diss. RUL, Groningen 1911, p. 377.

77. J.J. Boasson, De rechter tegenover de vrijheid der administratie, a.w., p. 379. 


\subsubsection{Een materieel of formeel criterium?}

Indien wordt uitgegaan van een 'materiële' invulling van het 'algemeen belang'-begrip, dan ontkomt men er niet aan om een bepaalde subjectieve lading aan dit begrip ten grondslag te leggen. Groenendijk ${ }^{78}$, die het begrip 'algemeen belang' uitvoerig heeft geanalyseerd, signaleerde dat auteurs die aan dit begrip een inhoudelijke invulling geven deze zoeken in een beperkte categorie van fundamentele belangen. Het betreft hier belangen die volgens hen essentieel zijn voor het voortbestaan van een gemeenschap, voor de bescherming van het naakte bestaan of belangen die verband houden met wezenlijke menselijke behoeften. ${ }^{79}$ Een materiële invulling van het begrip 'algemeen belang' is waarde-georiënteerd en bijgevolg als legitimatiegrondslag voor overheidsactiviteit enkel zinvol indien er een brede overeenstemming over bestaat.

Van $\operatorname{Erp}^{80}$ onderscheidt in dit verband aggregatieve en distributieve concepten. De eerstgenoemde concepten zijn gericht op een verbetering, optimalisering of maximalisering van het algemeen welzijn of de algemene behoeftebevrediging. Deze nutsmaximaliserende theorieën veronderstellen dat ten aanzien van ieder afzonderlijk besluit binnen het publieke rechtsverband steeds kan worden vastgesteld of er sprake is van zowel een verbetering voor de gehele publieke rechtsgemeenschap als voor de rechtsstreeks betrokken rechtssubjecten. ${ }^{81}$ De distributieve concepten gaan uit van het nastreven van een bepaalde verdeling van rechten, plichten, goederen en lasten tussen burgers. Het bewerkstelligen van een optimale materiële gelijkheid van rechtssubjecten staat hierbij centraal. Beide concepten ${ }^{82}$, die als verdedigbare waarde-overtuiging een materiële basisinvulling kunnen geven aan het algemeen belang (en derhalve de aard van het publiekrecht), missen echter een sluitende legitimatieverklaring; onduidelijk blijft waarop hun normatieve gelding berust. Genoemde concepten postuleren daarom slechts de inhoudelijke fundamenten voor overheidsgezag.

Dit behoeft mijns inziens gén reden te zijn om deze concepten als richtsnoer voor overheidshandelen te verwerpen, zolang men zich realiseert dat inhoudelijke staatsdoelen (te onderscheiden van de beginselgrondslagen van de staat) primair binnen een demo-

78. C.A. Groenendijk, Bundeling van belangen bij de burgerlijke rechter, diss. KUN, Zwolle 1981, p. 54.

79. In deze zin wordt 'het algemeen belang' bijv. opgevat door Van Male wanneer hij stelt: 'Het bestuur maakt immers deel uit van de algemene staatsorganisatie die het behartigen van het algemeen belang naar zijn aard tot doel heeft, waarbij ik het algemeen belang nader zou willen omschrijven als het concretiseren van de algemene rechtvaardigheidsidee.' R.M. van Male, Onvoltooid recht. Over rechtsbetrekking, bestuursrecht en bestuursprocesrecht, oratie EUR, Zwolle 1993, p. 5.

80. H. van Erp, Het politiek belang, a.w., p. 63 en 64.

81. Zie voor een duidelijk aggregatief concept het proefschrift van Simon. Hij plaatst de overheid in de rol van maximalisator van maatschappelijk nut. H.J. Simon, Publiekrecht of privaatrecht?, a.w., p. 50/51. Ook in latere publicaties heeft Simon zich expliciet uitgedrukt over de inhoudelijke invulling van het 'algemeen belang'-begrip. Dit impliceert volgens hem: 'Primair de erkenning van ieders gelijke aanspraak op respect als rechtssubject. En op die basis, de bevordering van het gemeenschappelijke welzijn en de sociale rechtvaardigheid.' H.J. Simon, Financiële voorwaarden en voorschriften, a.w., p. 150

82. Uiteraard zijn invullingen van het algemeen belang denkbaar waarbij elementen van beide concepten worden aangetroffen. 
cratisch-constitutioneel proces van publieke besluitvorming worden gedetermineerd. ${ }^{83} \mathrm{Dit}$ sluit overigens niet uit dat de rechtsgrond voor overheidsactiviteit in een bepaald staatstype - zoals de democratische rechtsstaat - een meer permanente inhoudelijke (of materiêle) inkleuring kan ondervinden die voldoende steun vindt in de heersende sociaal-culturele en politieke opvattingen. In dit kader kan men de staat bijv. positioneren als maximalisator van materiële individuele vrijheid, algemeen welzijn en sociale rechtvaardigheid. De conceptie van de 'sociale rechtsstaat' kan tegen deze achtergrond worden beschouwd als een historisch bepaalde invulling van het concept van de democratische rechtsstaat. ${ }^{84}$

Tegenover een materiële invulling van het 'algemeen belang'-begrip kan een meer formeel georiënteerde variant worden geplaatst. De formele invulling van genoemd begrip ziet volgens Groenendijk op een criterium voor de wijze van besluitvorming. ${ }^{85}$ In deze optiek bestaat 'het algemeen belang' niet als een inhoudelijk in te vullen entiteit, maar als een saldo-begrip. Het algemeen belang ziet op een bepaalde uitkomst van een belangenafwegingsproces waarbij de overheid betrokken is. De overheid vervult binnen dit belangenafwegingsproces een dubbele functie. Enerzijds dient zij namens de publieke rechtsgemeenschap de aan haar toevertrouwde belangen optimaal te behartigen (de overheid als 'belanghebbende') ${ }^{86}$, anderzijds dient zij de belangen van de betrokken rechtssubjecten zoveel mogelijk te ontzien. Het algemeen belang refereert dan aan een juiste - d.w.z. evenwichtige - afstemming van het staatsbelang en de verschillende maatschappelijke belangen op elkaar. ${ }^{87}$

83. De postulering van een gesloten-materieel staatsdoel draagt het risico in zich dat een bepaalde (waardegeorienteerde) 'politicke' visie bij voorbaat wordt verheven boven een andere. Vgl. Heldeweg die op grond hiervan tot een afwijzing komt. M.A. Heldeweg, Publiekrechtelijke autonomie. Over exclusieve behartiging van het algemeen belang en de wederzijdse onvrijheid van burger en overheidsbestuur, in: Eenzijdig en wederkerig? (red. E.C.H.J. van der Linden en A.Q.C. Tak), Deventer 1995, p. 128. Vgl. ook E.-W. Bockenforde, Verfassungsfragen der demokratie, a.w., p. 325. Bockenforde wijst erop dat de democratische rechtsstaat, die onder de regulatieve werking van 'het algemeen belang' staat, in beginsel 'formal und inhaltsoffen' is. Dit sluit niet uit dat de werking van het democratieprincipe begrensd wordt door (andere) grondrechtelijke en constitutionele (beginsel)kaders.

84. Zie bijv. S.W. Couwenberg (Constitutionele ontwikkelingsmodellen, a.w., p. 73 e.v.) die de ontwikkeling van de 'sociale rechtsstaat' als een burgerlijke zelfcorrectic (o.m. gericht op een égalisatie-streven) gedetailleerd belicht. Zie in dit kader ook: E.-W. Bockenforde, Die Bedeutung der Unterscheidung von Staat und Gesellschaft im demokratischen Sozialstaat der Gegenwart, a.w., p. $203 \mathrm{t} / \mathrm{m}$ 206. De vrijheid en gelijkheid die door de scheiding van staat en 'maatschappij' werden verwezenlijkt, leidden noodzakelijkerwijze tot (bepaalde) economische ongelijkheid en sociale spanning. De publieke rechtsgemeenschap reageerde op deze ontwikkeling door het garanderen van (minimale) materiele randvoorwaarden voor de maatschappelijke vrijheidsontplooiing van ieder individu. Vanuit dit perspectief bezien zijn de uitgangspunten die ten grondslag liggen aan de sociale rechtsstaat dienstig aan het basisconcept van de democratische rechtsstaat en leiden zij niet tot een 'osmose' tussen staat en 'maatschappij'. Ook de interventies binnen de sociale rechtsstaat dienen immers steeds beperkt en doelgebonden van aard te zijn. De staatstaak blijft ook hier gericht op het verwezenlijken van publiekrechtelijke randvoorwaarden.

85. C.A. Groenendijk, Bundeling van belangen bij de burgerlijke rechter, a.w., p. 55.

86. Vgl. art. 1:2 lid 2 Awb.

87. Zie: H. van Erp, Het politiek belang, a.w., p. 70. 
Hier treedt de legitimerende functie van het 'algemeen belang'-begrip op de voorgrond. Als legitimerend grondbeginsel voor overheidsactiviteit kan het niet gelijk gesteld worden aan de publieke belangen die door rechtssubjecten ter behartiging aan de publieke rechtsgemeenschap worden toevertrouwd. De behartiging van deze laatstbedoelde belangen is $\mathrm{nl}$. onderworpen aan het grondbeginsel, maar zij kunnen niet met 'het algemeen belang' worden vereenzelvigd ${ }^{88}$ Terecht relateert Simon ${ }^{89}$ daarom het 'algemeen belang'-begrip, aan het proces van belangenafweging. Hij merkt hierover op:

'Het complex van normen dat ziet op de materiêle bevoegdheidsvraag zou ik tezamen willen aanduiden als het vereiste van evenwichtigheid. Evenwichtigheid heeft betrekking op de door de overheid te maken belangenafwegingen en de door haar te kiezen criteria voor het maken van keuzen. Bij beslissingen ter zake dient de overheid te letten op noodzakelijkheid, subsidiariteit (onmisbaarheid) en proportionaliteit.'

De materiële bevoegdheid tot overheidshandelen houdt verband met wat door anderen wel is aangeduid als de principieel dienende functie van de overheid binnen de democratische rechtsstaat. ${ }^{90}$ Deze principieel dienende functie van de overheid verplicht haar tot een voortdurende objectieve en onpartijdige zoektocht naar de balans tussen publieke rechtsbelangen enerzijds en belangen van (private) rechtssubjecten anderzijds. Deze plicht, die de complexe publieke integratiefunctie tot uitdrukking brengt, is, aldus opgevat, géén 'formeel' en inhoudsloos begrip. ${ }^{91} \mathrm{Zij}$ geldt voor de wetgever én het bestuur ${ }^{92}$, zowel voor feitelijke als voor rechtshandelingen.

\subsection{Specialiteitsbeginsel en democratiebeginsel}

De materiële bevoegdheidsgrondslag binnen het publieke rechtsverband (nl. het handelen in het algemeen belang) is te vaag en te weinig gestructureerd om te fungeren als recht-

88. Vgl. A.Q.C. Tak en J.M.H.F. Teunissen, Wie zorgt er voor de rechtsstaat? Een voortgezet debat, Recht en kritiek, 1994/4, p. 345. Genoemde auteurs stellen: 'Wij wijzen erop dat het algemeen belang als leidend beginsel van het publiekrecht niet gelijk dient te worden gesteld aan de specifieke publieke belangen die de overheid met haar regelingen dient te behartigen (het publiekrechtelijke specialiteitsbeginsel). De doeleinden van het overheidsoptreden wisselen immers naar gelang van de historische omstandigheden waaronder de overheid haar taak heeft te vervullen.'

89. H.J. Simon, Publiekrecht of privaatrecht?, a.w., p. 119

90. Zie over het uitgangspunt van de dienende overheid i.h.b. Scheltema, die dit uitgangspunt ziet als een rechtsstatelijk beginsel. M. Scheltema, De rechtsstaat, in: De rechtsstaat herdacht, Zwolle 1989, p. 20 e.v.

91. Vgl. Van Erp die aan het 'algemeen belang' een performatief karakter toedicht: 'Het algemeen belang heeft aldus een performatief karakter: door het te onderscheiden van particulier belang en eigen belang wordt een stijl van politiek handelen en argumenteren in het leven geroepen die een groot gewicht hecht aan zedelijke verantwoording van het politieke handelen. In die zin kan het zeker zinvol zijn een beroep te doen op het algemeen belang, ook wanneer de discussie over wat het algemeen belang inhoudt nog volledig open staat, of wanneer de inhoudelijke invulling zelf problematisch is geworden.' $H$. van Erp, Het politiek belang, a.w., p. 59 .

92. Ik wijs erop dat $\delta$ ók de rechterlijke macht binnen de staat in dienst staat van het algemeen belang (als materiele rechtsgrond voor alle overheidsactiveit), zij het dat dit belang in dit verband tot uitdrukking komt in de onafhankelijke en onpartijdige geschilbeslechtende rechterlijke functie. 
streekse grondslag voor éénzijdig dwingend overheidshandelen. ${ }^{93}$ De notie van handelen in het algemeen belang begrenst overheidsactiviteit slechts op een globale wijze. Dit geldt eveneens voor de 'klassieke' en 'sociale' grondrechten die respectievelijk de vrijheidssfeer van de burgers beogen te beschermen tegen inbreuken, dan wel juist een minimale omvang aan materiële vrijheid beogen te garanderen. Met de notie van handelen 'in het algemeen belang' én de erkenning en respectering van grondrechten wordt nog géén antwoord gegeven op de vraag waarop het overheidshandelen in positieve zin gericht dient te zijn. ${ }^{94} \mathrm{Om}$ een specifieke invulling te geven aan overheidshandelen zal daarom een nadere determinatie dienen plaats te vinden van de speciale publiekrechtelijke werkkring van de overheid. Een duidelijke scheiding tussen statelijke en maatschappelijke taken is in dit verband een minimale voorwaarde om een dergelijke werkkring te kunnen vaststellen. ${ }^{95}$ Daarom zal binnen de publieke rechtsgemeenschap in de regel expliciet, overeenkomstig kenbare constitutionele procedures, vastgesteld dienen te worden welke de publieke taken en belangen van de staat zijn.

\subsubsection{Publiekrechtelijke belangen}

Anders dan particuliere rechtssubjecten kunnen de statelijke (bestuurs)organen zich niet in vrijheid belangen ter behartiging aantrekken. Binnen de publieke rechtsorde ontbreekt hiertoe het (privaatrechtelijke) autonomiebeginsel dat als legitimerende rechtsgrond kan fungeren. Waar in het (burgerlijk) privaatrecht de kring van belangbehartiging samenvalt met de autonomie van de betrokken rechtssubjecten, daar ontbreekt deze 'natuurlijke' autonomie bij de organen van het publieke rechtsverband. Voorzover het 'autonomie'begrip in het publiekrecht al bruikbaar is, dient men dan ook te denken in termen van 'publiekrechtelijke autonomie'. Deze 'publiekrechtelijke autonomie' kan uitsluitend op basis van constitutionele beginselen en binnen vaste statelijke besluitvormingsprocedures worden gegenereerd. ${ }^{96}$

Slechts op basis van een proces van determinatie van publieke belangen kan zich binnen de staat een gedifferentieerd en hiërarchisch geordend stelsel ('Normstufenbau') van speci-

93. Vgl. bijv. H.J. Simon, Publiekrecht of privaatrecht?, a.w., p. 94.

94. Ook positieve grondrechtelijke opdrachten (bijv. sociale grondrechten) zijn in de regel te weinig concreet om zelfstandig richting te geven aan het statelijke rechtsvormingsproces. Vgl. bijv. art. 19 lid $1 \mathrm{Gw}$ dat luidt: 'Bevordering van voldoende werkgelegenheid is voorwerp van zorg der overheid.'

95. Zie: E.-W. Bøckenforde, Die Bedeutung der Unterscheidung von Staat und Gesellschaft im demokratischen Sozialstaat der Gegenwart, a.w., p. 202.

96. Het begrip 'publiekrechtelijke autonomie' is in de literatuur wel beproefd als pendant van het privaatrechtelijke autonomiebeginsel. Publiekrechtelijke autonomie wordt dan gelijkgesteld aan het algemeen belang-begrip (en de materiele invuling daarvan), of aan de ruimte die aan statelijke organen toekomt om binnen de kaders van hun (formele) bevoegdheid belangen af te wegen. Zie in dit kader respectievelijk: H.J. Simon, Autonomie en 'verbintenis' in het publiekrecht: een intern-rechtsvergelijkende analyse, a.w., p. 83-84 en M.A. Heldeweg, Publiekrechtelijke autonomie, a.w., p. 121 e.v. Vgl. ook Bockenforde die op de individuele democratische participatierechten de 'kollektiv-autonomen Freiheit' binnen de democratische staat fundeert. E.-W. Bockenforde, Verfassungsfragen der demokratie, a.w., p. 324. 
fieke en begrensde bestuursbevoegdheden ontwikkelen (specifieke competentie-attributie). Hierbij geldt als uitgangspunt de herleidbaarheid van iedere bestuursbevoegdheid tot een hoogste rechtsvormende macht (de Grondwetgever). Een dergelijk stelsel van bestuursbevoegdheden is een belangrijke voorwaarde voor een controleerbare behartiging van publieke belangen. De publiekrechtelijke bevoegdheid is in dit verband wel omschreven als een 'kristallisatie-punt' binnen het proces van afnemende publiekrechtelijke autonomie. Door de statelijke bevoegdhedenstructuur (en de gelaagdheid daarbinnen) wordt het publieke rechtsvormingsproces en het daaraan ten grondslag liggende belangenafwegingsproces - steeds verder - normatief gebonden. ${ }^{97}$

De publieke belangen, welke overeenkomstig constitutionele procedures worden vastgesteld kunnen het best worden aangeduid als publiekrechtelijke belangen. Teunissen en Tak spreken voor deze aanduiding een voorkeur uit:

\begin{abstract}
'Wat de specifieke, door de overheid te behartigen belangen betreft, verdient het overigens o.i. aanbeveling om - i.p.v. publieke belangen - te spreken van publiekrechtelijke belangen. Daarmee wordt duidelijker aangegeven dat het niet de overheidsadministratic zelf is die bepaalt welke belangen zij heeft te behartigen, maar dat een belang eerst dan een door de overheid te behartigen belang is, indien door het objectieve (publiek)recht dit belang ter behartiging is opgedragen aan die administratie en daartoe bevoegdheden zijn verleend. Essentieel is hier het democratiebeginsel' (curs. A.Q.C.T. en J.M.H.F.T.). ${ }^{98}$
\end{abstract}

Bedoelde - democratisch gedetermineerde - publiekrechtelijke belangen dienen gesitueerd te worden aan de eerder in dit hoofdstuk omschreven normzijde van het recht. Zij zijn geenszins vergelijkbaar met de (private) rechtsbelangen van rechtssubjecten. $\mathrm{Zij}$ vormen nl., zoals vermeld, een nadere invulling en specificatie van de (materiële) competentiesfeer van de overheid. Publiekrechtelijke belangen liggen uiteindelijk ten grondslag aan alle overheidsactiviteiten $^{99}$, zowel aan feitelijk handelen (bijv. op basis van beheerstaken) als aan publiek rechtshandelen (bijv. op basis van bestuursbevoegdheden).

\title{
3.4.2 Het democratiebeginsel als normatief uitgangspunt
}

Naar wordt aangenomen is binnen de democratische rechtsstaat het democratiebeginsel dienstig aan de verwezenlijking van de interne structuur van de staat. ${ }^{100}$ In de meest

97. Zie: M.A. Heldeweg, Publiekrechtelijke autonomie, a.w., p. 131.

98. A.Q.C. Tak en J.M.H.F. Teunissen, Wie zorgt er voor de rechtsstaat? Een voortgezet debat, Recht en kritiek, 1994/4, p. 345.

99. Vgl. E.-W. Bockenforde, Verfassungsfragen der Demokratie, a.w., p. 299 en 230.

100. Het uitgangspunt in dit bock vormt, zoals gesteld, de conceptie van de 'democratische rechtsstaat' zoals deze in de Westerse wereld sedert het einde van de 18 de eeuw tot ontwikkeling is gekomen. Typerend voor dit staatsverband is de spanning tussen de erkenning van een fundamentele (staatloze) vrijheidssfeer van het individu enerzijds (liberaal element), en het democratisch postulaat anderzijds (volkssoevereiniteit). Het individu functioneert binnen de democratische rechtsstaat daarom niet uitsluitend als vrij 'mens' (homme) maar obk als 'burger' (citoyen). In deze laatste hoedanigheid komen aan het individu als lid van de publieke rechtsgemeenschap naast 'afwerende' grondrechten ók fundamentele rechten toe om aan het politieke besluitvormende 'discours' binnen die gemeenschap deel te nemen en zo mede de na te streven 
ruime zin opgevat beoogt dit beginsel, in al zijn verschillende verschijningsvormen en uitwerkingen, de deelname van de rechtssubjecten aan het rationele publieke discours binnen de staat te bevorderen. ${ }^{101}$ Doel van dit (abstracte) discours is o.m. gelegen in het determineren van de interne doeleinden van de staat ${ }^{102}$, onder gelijktijdige erkenning én optimale respectering van de bijzondere (rechts)belangen en subjectieve rechten van de leden van deze gemeenschap. ${ }^{103}$ Met het oog op dit determinatieproces van publieke gemeenschapsbelangen dient niet uitsluitend te worden gedacht aan het geformaliseerde debat binnen de vertegenwoordigende staatsorganen, maar tevens aan meer informele structuren binnen het staatsverband waar openbare meningsvorming plaatsvindt.

Typerend voor de hedendaagse democratische rechtsstaat is evenwel dat een aantal rechten om aan het publieke discours deel te nemen voor rechtssubjecten formeel zijn gewaarborgd. Hierbij kan gedacht worden aan het actieve en passieve kiesrecht, het Grondwettelijke petitierecht, de vrijheid van meningsuiting, het uitgangspunt van openbaarheid van bestuur en diverse geformaliseerde inspraakrechten. Eerst indien de verschillende deelnamerechten op basis van politieke (rechts)gelijkheid voor rechtssubjecten zijn gewaarborgd, wordt de algemene notie van een noodzakelijk 'rationeel publiek discours', getransformeerd tot een legitimerend democratiebeginsel. Habermas merkt hier hetvolgende over op: 'Das Diskursprinzip soll erst auf dem Wege der rechtsformigen Institutionalisiering die Gestalt eines Demokratieprinzips annehmen, welches dann seinerseits dem Prozess Rechtsetzung legitimitătserzeugende Kraft verleiht. ${ }^{104}$

Binnen het publieke debat wordt een inhoudelijke invulling gegeven aan de specifieke werkkring van de overheid. Habermas, die in dit verband de term 'kommunikative Macht'

publieke doelstellingen te bepalen. Couwenberg heeft in dit kader gesproken over een 'ideologisch' compromis waarin liberale en democratische opvattingen van het emancipatiemotief continu om de voorrang strijden. S.W. Couwenberg, Constitutionele ontwikkelingsmodellen, a.w., p. 29.

101. Het ligt buiten het bestek van dit boek om principiele beschouwingen te wijden aan het democratiebeginsel en aan de verschillende uitwerkingen daarvan. Ik hanteer in dit boek een normatief uitgangspunt waarbij het aspect van de 'belinvloeding' van het politieke besluitvormingsproces door de burgersrechtssubjecten centraal staat. Hierbij wordt niet uit het oog verloren dat door vele auteurs (vanuit sociologische en politicologische invalshoek) kritiek is geuit op deze normatief-juridische democratieconceptie (o.m. door J. Schumpeter en R. Dahl). Zie voor een beknopt overzicht van de verschillende democratie-theorieën bijv. W. van der Burg, Het democratisch perspectief, diss. UU, Arnhem 1991, m.n. hoofdstuk 2. Zie ook: H. Koning, Directe democratie in Nederland, a.w, p. $7 \mathrm{tm} 20$. Met Van der Burg moet in dit kader worden opgemerkt dat het erkennen van participatiegerechtigdheid niet impliceert dat ieder individu ook daadwerkelijk invloed heeft op de politieke besluitvorming. Van der Burg stelt in dit kader: 'Hoe men de democratische procedures ook uitbreidt en verfijnt, van rełle en significante invloed van ieder afzonderlijk individu kan geen sprake zijn.' W. van der Burg, Het democratisch perspectief, a.w., p. 97 en 98 . De democratisch politieke werkelijkheid en het normatieve uitgangspunt staan bijgevolg voortdurend op gespannen voet met elkaar.

102. Vgl. Scheltema die het democratiebeginsel dienstig oordeelt aan de positieve invulling van de staatstaak. M. Scheltema, De rechtsstaat, a.w., p. 19.

103. Het democratische determinatieproces wordt derhalve op rechtsstatelijke gronden begrensd door de erkenning van een fundamentele vrijheidssfeer voor de burgers die tot uitdrukking komt in de erkenning van typische vrijheidsrechten. Vgl. E.-W. Bockenforde, Verfassungsfragen der Demokratie, a.w., p. 372. 
hanteert, gaat ervan uit dat de uitkomsten van genoemd debat getransfomeerd dienen te worden tot bruikbare taakopdrachten aan de administratie (het bestuur). De uitkomsten van het democratische debat dienen hiertoe door rechtsnormen te worden ingekapseld in de vorm van (statelijke) bevoegdheden:

'Deshalb schlage ich vor, das Rechts als Medium zu betrachten, uber das sich kommunikative Macht in administrative umsetzt. Den die Verwandlung von kommunikativer Macht in administrative hat den Sinn einer Ermăchtigung im Rahmen gesetzlicher Lizenzen. ${ }^{105}$

Hiermee kent Habermas aan het begrip bevoegdheid een belangrijke functie toe met het oog op de legitimatie van administratieve macht. Bestuursmacht kan zich uitsluitend als legitiem gezag manifesteren in de gedaante van geconditioneerde bevoegdheden die materieel gefundeerd zijn in het statelijke 'discours' (het democratische aspect). ${ }^{106}$ Binnen de democratische rechtsstaat heeft dit uitgangspunt volgens Habermas een aantal belangrijke consequenties voor de macht van het bestuur: 'Die Idee des Rechtsstaates läßt sich dann allgemein als die Forderung interpretieren, das uber den Machtkode gesteuerte administrative System an die rechtsetzende kommunikative Macht zu binden und von den Einwirkungen sozialer Macht, also der faktischen Durchsetzungskraft privilegierter Interessen freizuhalten. ${ }^{.07}$ Het primaat van de 'Kommunikative Macht' sluit het genereren van eigen rechtsmacht door de administratie derhalve uit. Habermas benadrukt in dit verband de noodzaak van een geconditioneerde bevoegdheidstoekenning aan het bestuur:

'Die Logik der Gewaltenteilung verlangt vielmehr, dass dic Administration zu einer moglichst professionellen Erfullung ihrer Aufgaben nur unter Prämissen ermächtigt wird, die ihrer Verfugung entzogen bleiben: die Exekutive soll auf die Verwendung administrativer Macht im Rahmen des Gesetzes beschrănkt werden. ${ }^{108}$

In feite vestigt Habermas hier mijns inziens de aandacht op het specialiteitsbeginsel dat als rechtsstatelijk structuurprincipe een specifieke en inhoudelijk begrensde bevoegdhedentoedeling aan het bestuur vereist.

\subsubsection{Inhoudelijke democratische legitimatie}

In dit kader is het geen vergaande gevolgtrekking dat het specialiteitsbeginsel kan worden opgevat als een typisch beginsel dat het democratiebeginsel ondersteunt. In meer precieze

104. J. Habermas, Faktizităt und Geltung. Beitrage zur Diskurstheorie des Rechts und des demokratischen Rechtsstaats, Frankfurt am Main 1992, p. 154.

105. J. Habermas, Faktizităt und Geltung, a.w., p. 187.

106. Vgl. in dit verband ook E.-W, Bøckenforde, Verfassungsfragen der Demokratie, a.w., p. 389. Bockenforde acht eveneens de binding van staatsmacht door begrensde (ambtelijke) bevoegdheden noodzakelijk om te voorkomen dat machtsuitoefening zich loskoppelt van de democratische grondslag.

107. J. Habermas, Faktizitat und Geltung, a.w., p. 187.

108. J. Habermas, Faktizităt und Geltung, a.w., p. 231. 
zin kan gesteld worden dat het specialiteitsbeginsel dienstig is aan het bewerkstelligen van het proces van democratische legitimatie. Hierbij is het zinvol om erop te wijzen dat 'democratische legitimatie', een verzamelnaam is voor een aantal legitimatievormen.

Böckenförde hanteert hier een driedeling. Hij onderscheidt een: institutionele, personele, en inhoudelijke vorm van democratische legitimatie. ${ }^{109}$ De eerste vorm ziet volgens hem op de democratisch-constitutionele erkenning van de verschillende 'machten' binnen de staat (wetgever, bestuur en rechter). Deze vorm van abstracte legitimatie biedt op zich onvoldoende garanties om de statelijke machtsuitoefening voor burgers controleerbaar te maken. De 'institutionele' legitimatie dient aangevuld te worden door een 'personele' democratische legitimatie. Deze legitimatievorm vereist dat ambtsdragers direct of indirect democratisch gelegitimeerd zijn en derhalve verantwoording verschuldigd zijn aan de vertegenwoordigende statelijke organen. Tot slot is er de inhoudelijke democratische legitimatie die vereist dat statelijke machtsuitoefening door het bestuur is terug te voeren op, dan wel gebonden is aan, een speciale inhoudelijke machtiging van de vertegenwoordigende statelijke organen (en uiteindelijk de burgers).

Tussen de beide laatstgenoemde legitimatievormen bestaat nu een interessante wisselwerking die Böckenförde op heldere wijze belicht. ${ }^{110}$ Naarmate de personele democratische legitimatie van een ambtsdrager zwakker (lees: indirecter) van aard is, vereist het democratiebeginsel dat de inhoudelijke democratische legitimatie strikter is. In dit verband kan gesteld worden dat deze inhoudelijke democratische legitimatie verband houdt met de werking van het specialiteitsbeginsel dat binnen de democratische rechtsstaat een specifieke bevoegdheidstoedeling aan het bestuur vergt. Gesteld kan voorts worden dat daar waar het democratiebeginsel een binding van de bestuurlijke bevoegdheidsuitoefening aan de 'wil van het volk'"' vereist, het specialiteitsbeginsel tegelijkertijd verplicht om het fictieve karakter van deze binding te minimaliseren. De binding van een bestuurlijke bevoegdheidsuitoefening aan de 'fictieve' volkswil geschiedt binnen de democratische rechtsstaat uiteindelijk door de erkenning van het primaat van de wetgever. ${ }^{12}$

Simon heeft met het oog hierop een verband gelegd tussen het democratiebeginsel en het specialiteitsbeginsel:

109. Zie. E.-W. Bockenforde, Verfassungsfragen der demokratie, a.w., p. $301 \mathrm{t} / \mathrm{m} \mathrm{308.} \mathrm{Böckenforde} \mathrm{spreekt}$ over: (1) 'funktionelle und institutionelle', (2) 'organisatorisch-personelle' en (3) 'sachlich-inhaltliche demokratische Legitimation'.

110. E.W. Böckenforde, Verfassungsfragen der Demokratie, a.w., p. 307 en 308.

111. Essentieel is het inzicht dat 'de wil' van de wetgever geenszins gelijk gesteld kan worden aan de psychologische wil van de meerderheid van de volksvertegenwoordigers. Er is slechts sprake van een 'ordenende rechtswil' van competente statelijke rechtsorganen die gezamenlijk 'de wetgever' vormen. Zie in dit kader: H.J. van Eikema Hommes, De elementaire grondbegrippen der rechtswetenschap, a.w., i.h.b. p. 240 en 244. De 'wetgever' dient opgevat te worden als een constitutionele procedure die het mogelijk maakt om de werkkring van het publieke rechtsverband bindend te determineren. Een bijkomstig probleem dat het moeilijk maakt om 'de wil' van de wetgever vast te stellen hangt samen met het feit dat 'de wetgever' uit verschillende organen bestaat en dat vele actoren bij het (langdurige) wetgevingsproces zijn betrokken. Vgl. de fraaie noot van A.C. ' $t$ Hart onder het bekende 'Jodiumhoudend broodzout'-arrest (HR 10 april 1984, NJ 1984, 612, m.nt. 't H). 
'Het democratiebeginsel fingeert de toestemming van de betrokkene, voegt daaraan evenwel het vereiste toe dat die bevoegdheidsgrondslag zijn basis moet vinden in de formele wet. Het "specialiteitsbeginsel" (als beginsel van behoorlijke wetgeving) voegt daar aan toe dat, afhankelijk van het gewicht van het in het geding zijnde belang, die grondslag in de wet aan bepaalde eisen van specificiteit zal moeten voldoen. Ook deze eis kan in verband gebracht worden met het fictieve karakter van de democratische legitimatie. Het vereiste van specialiteit kan gezien worden als de uitdrukking van de verplichting van de formele wetgever het fictieve karakter van de toestemming zo veel mogelijk terug te dringen door die aantasting in de rechtspositie zo beperkt (voor wat betreft de aan te tasten belangen) en zo voorzienbaar mogelijk te maken., 113

Van bijzonder belang is dat Simon hier het specialiteitsbeginsel als een zelfstandig publiekrechtelijk rechtsbeginsel ten tonele voert dat samen met het democratiebeginsel de grondslag voor bevoegdheid binnen het publieke rechtsverband structureert. Hierbij koppelt Simon het specialiteitsbeginsel los van het (formele) legaliteitsvereiste. Het specialiteitsbeginsel richt zich weliswaar tot de wetgever en stelt, afhankelijk van de in het geding zijnde rechtsbelangen, eisen aan de specificiteit van de (wettelijke) bevoegdheidsgrondslag maar genoemd beginsel wordt door hem niet vereenzelvigd met het uitgangspunt van wetmatigheid van bestuur.

Ik wijs in dit verband ook op de visie van Tak die de legaliteitseis enkel ziet als een hulpmiddel voor legitimatie van overheidsmacht. ${ }^{114}$ Het legaliteitsvereiste is in zijn opvatting dienstig aan een tweetal doeleinden die beiden zijn terug te voeren op het specialiteitsbeginsel. Tak ziet het specialiteitsbeginsel nl. als de bindende schakel tussen de algemene en specifieke bevoegdheden van het bestuur. De algemene (materielle) bevoegdheid van het bestuur fundeert Tak in het behartigen van het algemeen belang. Deze algemene bevoegdheid ligt steeds ten grondslag aan de specifieke (wettelijke) bestuursbevoegdheden en vormt ten aanzien van deze bevoegdheden (en de uitoefening daarvan) tevens een correctiemaatstaf. ${ }^{115}$ Over de functie van het specialiteitsbeginsel binnen het publiekrecht merkt hij het volgende op:

'Het evenwicht tussen beide (bevoegdheden R.J.N.S.) wordt betracht door het specialiteitsbeginsel, dat tweerrlei functie vervult: 1 . bewaking van de gezagslijn tussen volkswil en machtsuitoefening: toegekende bevoegdheden mogen niet worden gehanteerd in afwijking van de door de volksvertegenwoordiging beoogde doeleinden (democratisch aspect), en 2 . aan de burger mogen op grondslag van bepaalde

112. Zie in dit kader bijv. Heldeweg die stelt: 'Een primaire bevoegdheid (curs. M.A.H.) is een op de 'expliciete wil' van de volksvertegenwoordiging terug te voeren machtiging tot rechtsvorming, c.q. tot burgers bindende overheidsinterventies in de samenleving. (..) Zulks vloeit ook voort uit het specialiteitsbeginsel, dat de bevoegdheidsuitoefening bindt aan het primaat van de wetgever en de burgers beschermt tegen lasten of vrijheidsbeperkingen anders dan uit hoofde van het krachtens (het desbetreffende) algemeen verbindend voorschrift te behartigen belang' (curs. R.J.N.S.). M.A. Heldeweg, Beleidsregels: naar een nieuwe catechismus voor 'ambtelijke bijbels'?, NTB 1995/4, p. 84 en 85.

113. H.J. Simon, Publiekrecht of privaatrecht?, a.w., p. 273.

114. A.Q.C. Tak, Het moment X, TvO 1990/6, p. 134.

115. Tak ziet het in acht nemen van 'het algemeen belang' als een 'hardheidsclausule', teneinde waar nodig rekening te kunnen houden met andere aspecten van het algemeen belang dan waarin de wettelijke regeling voorziet. A.Q.C. Tak, Het moment X, a.w., p. 135. 
bevoegdheden geen lasten worden opgelegd die met de toekenning van die bevoegdheden niet werden beoogd (rechtsbeschermingsaspect), bekend als verbod van détournement de pouvoir. 116

Het democratiebeginsel vereist bijgevolg dat, alvorens een nieuwe bestuursbevoegdheid in het leven wordt geroepen, er een integrale en zorgvuldige afweging van de betrokken belangen plaatsvindt. ${ }^{17}$ Deze belangenafweging 'in abstracto' is gericht op de beantwoording van de vraag of een specifieke bevoegdheidstoekenning met het oog op een bepaald publiekrechtelijk belang noodzakelijk is. Tevens zal uit het democratisch-politieke debat moeten blijken hoe het (nieuw) te behartigen publiekrechtelijke belang zich verhoudt tot andere publiekrechtelijke belangen die reeds an het bestuur ter behartiging zijn toevertrouwd. In het democratisch-politieke proces vindt derhalve een ordening en prioriteitstelling van publieke belangen plaats. ${ }^{118}$ Het bestuur is aan de uitkomst van deze democratische afweging en prioritering gebonden ${ }^{119}$, en draagt - op basis van specifieke (wettelijke) bevoegdheidsgrondslagen - verantwoordelijkheid voor de publieke belangbehartiging. ${ }^{120}$ Hiermee staat vast, dat het bestuur geén volledig 'open' belangenafweging behoeft te verrichten. Sterker, het bestuur kàn binnen de democratische rechtsstaat geen volledige belangenafweging meer verrichten daar het steeds gebonden is aan 'in abstracto' gedetermineerde bevoegdhedenkaders. ${ }^{121}$

\subsection{Het specialiteitsbeginsel in de Nederlandse literatuur}

De aandacht in de Nederlandse literatuur voor het specialiteitsbeginsel als zelfstandig rechtsstatelijk structuurbeginsel neemt toe. ${ }^{122}$ In de meeste handboeken en inleidende werken wordt tegenwoordig wel enige aandacht besteed aan het fundamentele karakter van 'dit rechtsbeginsel, dat.de rechtsrelaties tussen het bestuur en de burgers beheerst. ${ }^{123} \mathrm{De}$

116. A.Q.C. Tak, Het moment X, a.w., p. 135.

117. Vgl. ook: A. De Moor-Van Vugt, Maten en gewichten, Het evenredigheidsbeginsel in Europees perspectief, diss. KUB, Zwolle 1995, p. 10 en 11.

118. Vgl. A.Q.C. Tak, Overheidsbestuur en privaatrecht, Alphen aan den Rijn 1978, p. 89.

119. Vgl. H.J. Simon, Publiekrecht of privaatrecht?, a.w., p. 119.

120. Zie: D.W.P. Ruiter, Normscheppende bepalingen in bestuursrechtelijke wetten, Bestuurswetenschappen, 1980/4, p. 267.

121. Addink en Steenbergen brengen dit als volgt onder woorden: 'De belangenafweging, waarmee elk regelgeven gepaard gaat, is voor het orgaan in abstracto al gemaakt, hem rest het interpreteren van de gegeven doelstelling en het invullen daarvan in de concrete situatie.' G.H. Addink en J.D.M. Steenbergen, Beperkingen van bevoegdheden: Een onderzoek van administratieve wetgeving, Bestuurswetenschappen 1985/7, p. 438. Zie voorts mijn opstel 'Wederkerigheid en specialiteit in het bestuursrecht', in: Eenzijdig en wederkerig? (red. E.C.H.J. van der Linden en A.Q.C. Tak), Deventer 1995, m.n. p. 157 t/m 169.

122. De discussies in de literatuur spitsten zich aanvankelijk uitsluitend toe op de grenzen die het specialiteitsbeginsel stelt aan de bestuurlijke belangenafivegingsplicht in het kader van een discretionaire bevoegdheidsuitoefening. In hoofdstuk 7 wordt de relevante literatuur op dit punt uitvoerig geanalyseerd.

123. Zie o.m. De Haan/Drupsteen/Fernhout, Bestuursrecht in de sociale rechtsstaat I, a.w., p. 96; J.B.J.M. ten Berge, Besturen door de overheid, Nederlands algemeen bestuursrecht, deel 1, tweede druk, Deventer 1997, p. 51-53; Nicolar e.a., Bestuurșrecht, zesde geheel herziene druk, a.w., p. 13-16 en F.A.M. Stroink, Algemeen bestuursrecht, tweede druk, Zwolle 1996, p. 13. 
aandacht voor het beginsel lijkt overigens van recente datum. Pas tegen het einde van de jaren zeventig begint het specialiteitsbeginsel zich immers in de literatuur onder deze benaming te manifesteren. Een verklaring hiervoor kan wellicht worden gevonden in de alsmaar complexer wordende administratieve wetgeving met zijn talrijke vergunning- en ontheffingsstelsels. Van der Burg en Cartigny zijn, voorzover ik kon nagaan, de eersten geweest die het beginsel expliciet onder deze benaming onder de aandacht brachten. In de eerste druk van het boek 'Rechtsbescherming tegen de overheid' ${ }^{124}$ uit 1979 omschrijven zij het beginsel als volgt:

\footnotetext{
'Ter afsluiting moet hier nog iets worden opgemerkt over een problematiek die verband houdt met het verbod van détournement de pouvoir en die men in het administratieve recht op ruimer schaal tegenkomt. Gedoeld wordt op het zgn. "specialiteitsbeginsel". Dit is geen a.b.v.b.b. (algemeen beginsel van behoorlijk bestuur R.J.N.S.) maar cen beginsel dat ten grondslag ligt aan administratieve wetgeving. De strekking ervan is dat iedere administratieve wet alleen op zijn eigen "speciale", door die wet zelf afgebakende terrein mag worden toegepast en niet mag dienen tot het bereiken van daarbuiten gelegen doeleinden.'
}

Het specialiteitsbeginsel wordt in de visie van deze auteurs opgevat als een structurerend beginsel dat ten grondslag ligt aan administratieve wetgeving. Bijzondere administratieve wetten worden door de wetgever steeds voor een speciaal doel in het leven geroepen. Bijgevolg reguleren deze wetten, zoals ook in de inleiding werd vermeld, steeds een speciaal segment van de rechtsrelatie tussen burgers en overheid. ${ }^{125}$

\subsubsection{Hernieuwde aandacht voor een oud beginsel}

Ofschoon de belangstelling voor het specialiteitsbeginsel van recente datum lijkt, dient benadrukt te worden dat de aandacht voor dit beginsel - of aspecten ervan - geenszins nieuw is. Daarom kan wellicht beter gesproken worden over hernieuwde aandacht. Het specialiteitsbeginsel, dat verband houdt met de gedifferentieerde organisatie van het openbare bestuur, wordt immers sinds jaar en dag in de staats- en bestuursrechtelijke literatuur onderkend, zij het niet onder deze benaming. ${ }^{126}$ Zo bracht Boasson ${ }^{127}$ reeds in het begin van deze eeuw de bestuursorganisatorische implicaties van dit beginsel treffend onder woorden:

124. Van der Burg/Cartigny, Rechtsbescherming tegen de overheid, Utrecht 1979, p. 89. In dit kader dient erop gewezen te worden dat Cartigny het specialiteitsbeginsel twee jaar eerder als zodanig noemt in een noot onder ARRS 30 juni 1977, AB 1977, 392.

125. Het gaat hier om het verschijnsel van de 'verkokerde' administratieve wetgeving. Zie: J.B.J.M. ten Berge, Besturen door de overheid, a.w., p. 52.

126. Vgl. bijv. F.J.A. Huart, Misbruik van burgerlijk recht door de administratie, in: Verspreide geschriften, Alphen aan den Rijn 1949, p. m.n. p. 21 en 28. Ik wijs ook nog op Donner die in zijn proefschrift het specialiteitsbeginsel impliciet onderkende. A.M. Donner, De rechtskracht van administratieve beschikkingen, diss. VU, Alphen aan den Rijn 1941, p. 75.

127. J.J. Boasson, De rechter tegenover de vrijheid der administratie, a.w., p. 371. 
'Ieder orgaan, iedere tak van dienst behoort te waken voor de speciale belangen, dic hem zijn toevertrouwd en uitsluitend voor deze. Gaat elke autoriteit zich op grond van hare formeel ongebonden bevoegdheid als handhaver van het algemeen belang in den ruimsten zin opwerpen, dan verliest de differentiatie van bestuur voor een belangrijk deel hare waarde. Men bedenke ook, dat het hier niet alleen om eene vraag van recht te doen is, maar tevens om een beginsel van orde en organisatie.'

Het belang van deze opmerkingen van Boasson mag niet worden onderschat. De toepassingsgebieden van de diverse administratieve wetten mogen door het bestuur zelf niet 'dooreen' worden gemengd. Op deze wijze zou immers de door de wetgever doelbewust in het leven geroepen rechtsstatelijke bevoegdhedenstructuur, die tevens een belangrijke organisatiewaarborg inhoudt, teniet worden gedaan. Uitsluitend de wetgever bepaalt het doel dat het bestuur binnen een bepaalde regeling mag nastreven.

Met oog hierop stelt Van Male ${ }^{128}$ in zijn proefschrift: 'Kenmerkend voor de specifieke wetgeving op het terrein van het bestuursrecht is dat zij doelbepaald is; iedere regeling is gericht op realisering van een bepaald doel. Men spreekt in dit verband wel van het specialiteitsbeginsel, dat niet een beginsel van behoorlijk bestuur, maar een beginsel van administratieve wetgeving is. De strekking ervan is, dat iedere regeling op het gebied van het bestuursrecht zijn eigen doel heeft en dat de in de wet of krachtens de wet toebedeelde bevoegdheden alleen ter bereiking van dat doel mogen worden uitgeoefend' (curs. R.J.N.S.). Dat Van Male het specialiteitsbeginsel fundamenteel acht voor het administratieve recht blijkt uit de waarschuwing die hij er onmiddellijk aan toevoegt: 'Het loslaten van het specialiteitsbeginsel zou een ongebreidelde uitbreiding van de bevoegdheden van het bestuur betekenen. Het zou de deur openzetten voor wat De Winter in ander verband chargerend wetgeving van het type "alles is verboden, behoudens" heeft genoemd.'

De Haan, Drupsteen en Fernhout doen een waarschuwing uitgaan in dezeifde richting: 'Aanwending van een bevoegdheid buiten het aangegeven doel ondermijnt zo de rechtsstaat. Meer specifiek voor bestuurswetgeving wordt in dit verband wel gesproken over het specialiteitsbeginsel. Dit houdt in dat wij in het bestuursrecht geen algemeen werkende wetten kennen, maar iedere wet gericht is op een bepaald doel. ${ }^{129}$ Ook in de vierde geheel herziene druk uit 1996, wordt een principiële passage aangetroffen waarin genoemde auteurs het specialiteitsbeginsel treffend karakteriseren en bovendien duidelijk positioneren als typisch publiekrechtelijk beginsel:

'Het specialiteitsbeginsel kan in verband worden gebracht met het principiele onderscheid tussen privaatrechtelijke autonomie en publiekrechtelijke bevoegdheid. In beginsel is een burger autonoom in het aangaan van burgerrechtelijke rechtsbetrekkingen. Daartegenover kan een bestuursorgaan alleen rechtsverhoudingen in het leven roepen, wanneer het daartoe bevoegd is. Deze bevoegdheid ontleent het bestuursorgaan aan wettelijke regelingen, op grond waarvan bevoegdheden doorgaans specifiek, dat wil zeggen met het oog op een bepaald doel en omgeven door condities worden toegekend. De nadruk die op

128. R.M. van Male, Rechter en bestuurswetgeving, diss. KUB, Zwolle 1988, p. 334.

129. De Haan/Drupsteen/Fernhout, Bestuursrecht in de sociale rechtsstaat, deel 1, Ontwikkeling, Organisatie, Instrumentarium, derde geheel herziene druk, Deventer 1986, p. 76. 
het specialiteitsbeginsel wordt gelegd is een nadruk op de begrenzing van bestuursbevoegdheden. Als zodanig hangt het specialiteitsbeginsel samen met de rechtsstaatgedachte. ${ }^{130}$

Tot slot kan in dit kader nog worden gewezen op Tak die het publiekrecht schetst als een gesloten, specifiek wettelijk en onvrij bevoegdhedenarsenaal waarbij deze publiekrechtelijke bevoegdheden altijd door het specialiteitsbeginsel en het verbod van détournement de pouvoir zijn 'ingesnoerd' in het specifiek wettelijke keurslijf, met als kompas de 'richtige' uitvoering van de wet. ${ }^{131}$

Gelet op het bovenstaande kan vastgesteld worden dat het specialiteitsbeginsel in de Nederlandse bestuursrechtelijke literatuur meestal direct in verband wordt gebracht met de rechtsstaatidee. Hierbij wordt het beginsel opgevoerd als een fundamenteel rechtsbeginsel dat een waarborg biedt tegen een almachtige overheid. ${ }^{132}$

\subsubsection{Legaliteit en specialiteit}

Indien het specialiteitsbeginsel wordt beschouwd als een ongeschreven rechtsstatelijk beginsel dat ten grondslag ligt aan administratieve wetgeving, dan dringt zich de vraag op hoe dit beginsel zich verhoudt tot het legaliteitsbeginsel. ${ }^{133}$ In dit verband valt het op dat de auteurs die het specialiteitsbeginsel als rechtsstatelijk beginsel beschrijven, genoemd beginsel direct of indirect in verband brengen met het uitgangspunt van wetmatigheid van bestuur. Tonnaer acht beide beginselen kennelijk synoniem:

\footnotetext{
'De achtergrond van dit beginsel (het legaliteitsbeginsel R.J.N.S.) dat - toegepast op bestuursorganen - ook wel het "specialiteitsbeginsel" wordt genoemd, is duidelijk: de legitimiteit van het optreden van bestuursorganen is het best gewaarborgd als de wetgever het bestuur tot dat optreden machtigt.(..) Ook in het Nederlandse rechtsstelsel neemt het specialiteitsbeginsel een fundamentele plaats in.(.) Het specialiteitsbeginsel vindt zijn positivering in de administratieve wetgeving. Als zodanig treffen wij het in de Grondwet niet aan. ${ }^{134}$
}

In de visie van Tonnaer lijken legaliteit en specialiteit één, voorzover er sprake is van de toekenning van bestuursbevoegdheden aan bestuursorganen. Opvallend is wêl dat Tonnaer aangeeft dat het specialiteitsbeginsel eerst in de wetgeving wordt gepositiveerd. Dit duidt

130. De Haan/Drupsteen/Fernhout, Bestuursrecht in de sociale rechtsstaat, a.w., p. 96.

131. A.Q.C. Tak, De overheid in het burgerlijk recht, 's-Gravenhage 1997, p. 111.

132. Vgl. ook de interventie van Stroink bij het VAR-preadvies van Tonnaer: 'Ik hecht waarde aan de benadering van het specialiteitsbeginsel, ook al omdat het waarborgen inhoudt. Het voorkomt dat de bestuurlijke overheden zich, zoals vroeger in de politiestaat, met alles kunnen gaan bezighouden en het geeft de burger de waarborg dat dat niet zomaar zal gebeuren.' Geschriften van de Vereniging voor Administratief Recht XCII, Vergunningverlening in stroomversnelling (verslag), Alphen aan den Rijn 1984, p. 151.

133. De visie van Tak kwam hiervoor reeds ter sprake (paragraaf 3.4.3).

134. F.P.C.L. Tonnaer, Legaal besturen; het legaliteitsbeginsel, toetssteen of struikelblok? in: Bestuur en Norm, (Crince le Roy-bundel) Deventer 1986, p. 270. 
erop dat ook hij dit beginsel ziet als een zelfstandig structurerend rechtsbeginsel dat ten grondslag ligt aan de bevoegdheidstoedeling in het publiekrecht.

Schreuder zoekt in de eis van gerichtheid van de publiekrechtelijke bevoegdheid de essentie van het specialiteitsbeginsel. Het specialiteitsbeginsel is in haar opvatting een uitwerking van het legaliteitsbeginsel..$^{135}$ Ook zij benadrukt het fundamentele karakter van zowel het legaliteits- als specialiteitsbeginsel door er expliciet op te wijzen dat beide beginselen de burger beogen te beschermen tegen overheidsmacht. Messer en Heldeweg zien het specialiteitsbeginsel blijkbaar ook als een verlengstuk of een aspect van het bij de rechtsstaatsidee behorende legaliteitsbeginsel. In hun visie wordt het specialiteitsbeginsel gezien als een aanscherping van het legaliteitsbeginsel. ${ }^{136}$

Ofschoon het specialiteitsbeginsel in verband kan worden gebracht met het vereiste van legaliteit (opgevat als 'wetmatigheid van bestuur'), is het mijns inziens toch zinvol om beide rechtsstatelijke beginselen te onderscheiden. Stroink en De Waard beproefden in dit kader een onderscheid door de werking van beide beginselen te illustreren aan de hand van de begrippen bevoegdheid en onbevoegdheid. Het specialiteitsbeginsel kan volgens hen alleen een rol spelen in gevallen waarin een bestuursorgaan een bevoegdheid daadwerkelijk bezit, maar daar een onjuist gebruik van maakt. ${ }^{137}$ Dit onderscheid is evenwel toegespitst op het niveau van de uitoefening van een bevoegdheid en is bijgevolg minder bruikbaar om beide beginselen op constitutioneel niveau ten opzichte van elkaar te positioneren.

Om te komen tot een bruikbaar onderscheid tussen beide beginselen kan naar mijn oordeel het beste aansluiting worden gezocht bij de eerder besproken opvattingen van Simon en Tak die ervan uitgaan dat het legaliteitsbeginsel - toegespitst op de grondslag van bestuursbevoegdheid - o.m. het democratiebeginsel en het specialiteitsbeginsel vóronderstelt. Het legaliteitsbeginsel, opgevat als het uitgangspunt van wetmatigheid van bestuur, is vanuit deze optiek bezien 'slechts' een hulpmiddel om de betrokkenheid van rechtssubjecten bij de toekenning en afbakening van bestuursbevoegdheden binnen de democratische rechtsstaat te waarborgen.

\subsection{Tot slot: nogmaals doelgebondenheid}

Aan het slot van dit hoofdstuk is het zinvol om het belang van de doelgebondenheid van bestuursbevoegdheid nog wat nader te beschouwen. In dit kader dient kort stilgestaan te worden bij de constitutionele implicaties van doelgeoriënteerd (rechts)handelen door het bestuur. Een blik op juridisch onderzoek van Duitse origine is in dit verband waardevol. Met name in het licht van het constitutionele 'Verhältnismäßigkeitsprinzip"138, is in Duitsland fundamenteel onderzoek gedaan naar het primaat van de 'Zwecksetzung' binnen

135. C.A. Schreuder, Publiekrechtelijke taken, private rechtspersonen, diss. RUG, Deventer 1994, p. 115: 'Een uitwerking van het legaliteitsbeginsel is het specialiteitsbeginsel. Dit beginsel houdt in, dat een verkregen bevoegdheid gekenmerkt wordt door gerichtheid.'

136. E.A. Messer en M.A. Heldeweg, Bestuurscompensatie en het specialiteitsbeginsel, RMTh, 1990/4, p. 156.

137. F.A.M. Stroink en B.W.N. de Waard, Het specialiteitsbeginsel, in: Burger en overheid (Steenbeek-bundel), 's-Gravenhage 1984, p. 235. 
de (sociale) rechtsstaat. In dit verband bevat bijv. het Habilitationsschrift van Haverka$\mathrm{te}^{139}$ belangwekkende informatie.

Gelet op het onderwerp van dit boek is met name van belang dat Haverkate het ontstaan van de democratische rechtsstaat expliciet in verband brengt met de determinering van specifieke doelen ('Handlungszwecke') waarop het handelen door de overheid dient te zijn gericht. ${ }^{140} \mathrm{De}$ specificering van doelen draagt bij aan de rechtvaardiging (legitimatie) van het statelijk handelen. Naarmate doelen vager zijn geformuleerd, neemt $n l$. de mogelijkheid tot 'doel-middel'-controle af:

'Je abstrakter Zwecke gefaßt sind, um so eher können sie als Handlungsrechtfertigungen verwand werden, ohne $\mathrm{da} B$ eine wirkliche Kontrolle erfolgen könnte, ob een bestimmtes Handeln tatsachlich einem vorausgesetzten Zweck dient oder nicht."14I

Van vage statelijke doelstellingen gaat daarom slechts een geringe legitimerende werking uit. Om een effectieve juridische controle van de uitvoerende overheidsorganen te bewerkstelligen, zal derhalve eerst het doel waarop het handelen is gericht duidelijk dienen te zijn. Ook binnen de hedendaagse sociale rechtsstaat brengt het democratiebeginsel met zich dat het primaat van 'Zwecksetzung' bij de vertegenwoordigende statelijke organen dient te liggen. Zowel het bestuur ${ }^{142}$, als de rechter ${ }^{143}$ zijn aan dit primaat gebonden. Doelen die in het politiek-democratische debat aan rechtsnormen ten grondslag zijn gelegd vormen bijgevolg onmisbare referentiepunten voor nadere rechtsvorming, rechtsconcretisering en rechtsvinding.

Haverkate komt met het oog hierop aan het einde van hoofdstuk 4 van zijn Habilitationsschrift tot de volgende conclusie:

138. Dit beginsel vereist binnen het Duitse constitutionele recht dat overheidsmaatregelen steeds beperkt van aard en omvang zijn en niet verder ingrijpen in de rechtsbelangen van burgers dan strikt noodzakelijk om een bepaald doel te bereiken; het omspant het 'Ubermaßverbot' en de eisen dat overheidsmaatregelen 'Erforderlich' en 'Geeignet' behoren te zijn. Het beginsel is verwant aan het Nederlandse evenredigheidsbeginsel (vgl. art. 3:4 lid $2 \mathrm{Awb}$ ). Zie over het Duitse 'Verhăltnismaßigkeitsprinzip' meer uitvoerig: A. de Moor-Van Vugt, Maten en gewichten, a.w., p. 19-39.

139. G. Haverkate, Rechtsfragen des Leistungsstaats, Verhaltnismaßigkeitsgebot und Freiheitsschutz im leistenden Staatshandeln, Tubingen 1983, m.n. Kapitel 1.IV en Kapitel 4.

140. G. Haverkate, Rechtsfragen des Leistungsstaats, a.w., p. 20. Vgl. de eerder geciteerde visie van Bockenforde. E.-W. Bockenforde, Die Bedeutung der Unterscheidung von Staat und Gesellschaft im demokratischen Sozialstaat der Gegenwart, a.w., p. 189.

141. G. Haverkate, Rechtsfragen des Leistungsstaats, a.w., p. 24.

142. G. Haverkate, Rechtsfragen des Leistungsstaats, a.w., p. 133.

143. G. Haverkate, Rechtsfragen des Leistungsstaats, a.w., p. $135 \mathrm{Vm}$ 137. Haverkate merkt over (zelfstandige) 'rechtsvorming' door de rechter nog het volgende op: 'Von dieser Sicht des Richterrechts aus durfen wir vermuten, daß die richterliche Pflicht zur Rechtsschöpfung nicht zur Setzung von Zwecken legitimiert, sondern der Orientierung an vorgegebenen Zwecken bedarf. (...) Der richterrechtliche Beitrag ist der zu allen Rechtssätzen hinzuzudenkende Faktor der Rechtsverwirklichung, sozusagen das X vor der Klammer, die alle anderen Rechtsquellen umschließt. Dieser eigenstăndige Beitrag des Richters ist ein Element der Rechtssetzung. Eine Zwecksetzungskompetenz des Richterrechts ergibt sich daraus aber nicht' (curs. G.H., a.w. p. 137). 
'Wir kommen zu dem vorlaufigen Ergebnis: Der Richter kann und darf keine Zwecke des Staatshandelns setzen; er kontrolliert das Staatshandeln mit Hilfe der diesem Handeln vorgegebenen Zwecke. Gleiches gilt fur die Verwaltung. Die traditionelle Anschauung ging dahin, der Gesetzgeber sei zur Rechtsetzung berufen, die Rechtsprechung und die Verwaltung zur Rechtsanwendung. Dieses Modell ist zutreffend kritisiert worden; der Gesetzgeber hat kein Rechtssetzungsmonopol, sondern eine Rechtssetzungsprărogative. Der Gesetzgeber setzt Zwecke, dem Richter und der Verwaltung sind diese Zwecke vorgegeben. Alle rechtsschupferische Tatigkeit des Richters steht, nicht anders als die der Verwaltung, unter der Prämisse, dass die Zwecksetzungen normativ vorgegeben sein mussen.144

Ook Dombrowski ${ }^{145}$, die eveneens de behartiging van publiekrechtelijke belangen door het bestuur vanuit een sociaal-rechtsstatelijke optiek analyseerde, vestigde de aandacht op het 'doelstellingsprimaat' van de wetgever. Dombrowski maakt in dit verband een strikt onderscheid tussen 'Gesetzlich genannten Zwecke' en 'Gesetzesfremden Zwecke'. De eerste groep doelstellingen vormt voor het bestuur de leidraad bij de uitoefening van een (discretionaire) bestuursbevoegdheid. Vanuit democratisch-rechtsstatelijke optiek is het in hoge mate onwenselijk dat het bestuur zelf bepaalt welke belangen het wil behartigen. Volgens Dombrowski is bijgevolg géén andere conclusie mogelijk dan dat de wetgever minimaal het doel dient aan te geven waarop de bestuursactiviteit zich dient te richten. ${ }^{146}$ Gebeurt dit niet, of niet in afdoende mate, dan belandt de rechtsstaat op een hellend vlak:

'Es ist auf die Dauer eine nicht gering zu schătzende Gefahr fur die Rechtsstaatlichkeit, wenn fur das Handeln der Verwaltung nicht das Gesetz letzte Richtschnur ist, sondern tatsachliche oder auch nur vermeintliche Bedurfnisse der Praxis. Wenn im Bereich der freien Verwaitung schon eine Bindung an genau umrissene Tatbestănde nicht in Betracht kommt, dan soll die Verwaltung wenigstens an die Zwecke des Gesetzes oder des betreffenden Instituts gebunden sein, so daß fur eine "selbstschøpferische" Verfolgung gesetzesfremder Zwecke durch die Verwaltung kein Raum bleibt..147

Met deze woorden van Dombrowski, die benadrukken dat de (wettelijke) doelbinding van bestuursbevoegdheden ók in de hedendaagse interventiestaat van groot belang is, wordt dit hoofdstuk afgesloten. In het volgende hoofdstuk zal de aandacht nader gericht worden op de relatie wetgever/bestuur. Nagegaan zal worden welke betekenis toekomt aan het beginsel van wetmatigheid van bestuur (het staatsrechtelijke legaliteitsbeginsel). Tevens zal worden bezien in hoeverre er uit het specialiteitsbeginsel een rechtsstatelijke plicht kan worden afgeleid voor de wetgever om bestuursbevoegdheden inhoudelijk te normen. Het gaat hierbij om de functie die het specialiteitsbeginsel als beginsel van behoorlijke wet- of regelgeving vervult.

144. G. Haverkate, Rechtsfragen des Leistungsstaats, a.w., p. 143.

145. H. Dombrowski, Mißbrauch der Verwaltungsmacht. Zum Problem der Kopplung verschiedener Verwaltungszwecke, Mainz 1967.

146. Vgl. in Nederland I.C. van der Vlies, Handboek wetgeving, tweede herziene druk, Zwolle 1991, p. 150154 (Het beginsel van duidelijke doelstelling).

147. H. Dombrowski, Mißbrauch der Verwaltungsmacht, a.w., p. 30. 


\subsection{Conclusie}

In dit hoofdstuk werd de interne rechtskarakteristiek van de publieke rechtsorde globaal verkend. Vastgesteld werd dat aan het ontstaan van de hedendaagse 'democratische rechtsstaat' een cultuurhistorisch ontsluitingsproces ten grondslag ligt dat zich gedurende vele eeuwen voltrok. Kenmerkend voor dit proces was het ontstaan van een scheiding tussen staat en 'maatschappij'. Door deze scheiding werd overheidsmacht in een publieke rechtsgemeenschap geconcentreerd en onderworpen aan de normerende werking van typisch publieke rechtsbeginselen. Hierdoor ontstond een doelgebonden ambtelijke bevoegdhedenstructuur. Aldus beschouwd, kan men stellen dat het specialiteitsbeginsel een fundamenteel structuurbeginsel is van de democratische rechtsstaat dat inherent is aan de scheiding tussen privaat- en publiekrecht, tussen private rechtsbelangen en publiekrechtelijke belangen en tussen de publieke staat en de 'vrije' burgerlijke maatschappij. Het loslaten van dit beginsel zou een volledig open bestuursbevoegdheid met zich brengen waartegen burgers enkel nog vanuit algemeen grondrechtelijk perspectief fundamenteel verweer zouden kunnen voeren.

Op basis van de doelgebonden publiekrechtelijke bevoegdhedenstructuur kon zich het specifieke publieke rechtsvormingsproces, dat exclusief gericht is op de behartiging van publiekrechtelijke belangen, gaan voltrekken. Dit 'interne' rechtsvormingsproces van de publieke rechtsorde is steeds onderworpen aan de idee van "handelen in het algemeen belang'. Daarnaast geeft het specialiteitsbeginsel in belangrijke mate richting en structuur aan dit proces. Het specialiteitsbeginsel kan derhalve worden opgevat als een fundamenteel rechtsstatelijk structuurbeginsel dat nauw verband houdt met andere publiekrechtelijke beginselen, waaronder in het bijzonder het democratiebeginsel en het legaliteitsbeginsel; desalniettemin is het een zelfstandig publiek rechtsbeginsel dat eist dat het (gerichte) statelijke rechtsvormingsproces vanwege het bestuur zich voltrekt op basis van een duidelijke en doelgebonden structuur van bestuursbevoegdheden. 


\section{Hoofdstuk 4}

\section{Legaliteit en specialiteit}

'De legaliteitseis is echter een rechtsbeginsel en daarmee onderworpen aan de kenmerkende beperkingen van rechtsbeginselen: zij bekleden zelden een monopoliepositie en hun contouren zijn doorgaans allesbehalve scherp."

\subsection{Inleiding}

In de literatuur wordt het specialiteitsbeginsel in verband gebracht met het staatsrechtelijke legaliteitsbeginsel. ${ }^{2}$ Sommige auteurs stellen beide beginselen, toegespitst op bestuursbevoegdheid, zelfs op één lijn. ${ }^{3}$ Deze opvatting wordt in dit boek niet gedeeld. In het voorafgaande hoofdstuk werd gesteld dat het specialiteitsbeginsel zich manifesteert als een zelfstandig rechtsstatelijk structuurprincipe dat in de democratische rechtsstaat inherent is aan de scheiding tussen de publieke rechtsorde enerzijds, en de verschillende maatschappelijke (private) rechtsstructuren anderzijds. Bestuursbevoegdheid is doelgebonden bevoegdheid die door de bestuursorganen wordt uitgeoefend ter behartiging van typisch publiekrechtelijke belangen. Deze bevoegdheid berust meestal op een wettelijke grondslag.

Als juist kan worden aanvaard dat het specialiteitsbeginsel eisen stelt aan deze wettelijke grondslag. In dit vierde hoofdstuk wordt daarom ingegaan op de staatsrechtelijke legaliteitseis. Hierbij dient men voor ogen te houden dat in het Nederlandse constitutionele recht bezwaarlijk over 'het' legaliteits-beginsel kan worden gesproken. ${ }^{4}$ Bedoeld beginsel heeft géén nauwkeurig omlijnde betekenis, terwijl evenmin duidelijk is in hoeverre de legaliteitseis deel uitmaakt van het positieve staats- en bestuursrecht. ${ }^{5}$ Dát er binnen de Nederlandse

1. J.H. Nieuwenhuis, Vechten met de beer? De strijd om het legaliteitsbeginsel, RMTh. 1997/9, p. 351

2. Goed te onderscheiden van het strafrechtelijke legaliteitsbeginsel dat $0 . \mathrm{m}$. tot uitdrukking komt in art. 16 van de Grondwet en in art. 1 lid 1 van het Wetboek van Strafrecht. Zie over de samenhang tussen het specialiteitsbeginsel en de legaliteitseis bijv. M. Scheltema, Van rechtsbescherming naar een volwaardig bestuursrecht, NJB 1996/33, p. 1359. Vgl. ook Simon die het specialiteitsbeginsel in zijn handboek karakteriseert als een 'uitwerking' van het legaliteitsbeginsel. H.J. Simon, Handboek bestuurs(proces)recht volgens de Awb, 's-Gravenhage 1997, p. 139. Tot slot wijs ik erop dat ook in het privaatrecht een 'legaliteitsprincipe' wordt onderkend waarvan de strekking, $\mathrm{nl}$. het bieden van rechtszekerheid door codificatie, enkel verwantschap vertoont met én aspect van de staatsrechtelijke eis. Vgl. J. Smits, Privaatrecht en postmodernisme. Over recht en tijdgeest, toegelicht aan de hand van enige civielrechtelijke fenomenen, Recht en kritiek 1997/2, p. 164.

3. Bijv. F.P.C.L. Tonnaer, Legaal besturen; het legaliteitsbeginsel, toetssteen of struikelblok? in: Bestuur en Norm (Crince Le Roy-bundel), Deventer 1986, p. 270.

4. Volgens Scheltema is er geen sprake van een echt beginsel. De legaliteitseis pretendeert volgens hem dienstig te zijn aan de onderliggende beginselen van rechtszekerheid, gelijkheid en democratie. M. Scheltema, Van rechtsbescherming naar een volwaardig bestuursrecht, a.w., p. 1358.

5. Zie: F.H. van der Burg, Regelgeving en bestuur, Zwolle 1993, p. 108. 
blijkt, zij het op een fragmentarische wijze, uit de Grondwet ${ }^{6}$ en uit de jurisprudentie. ${ }^{7}$ Met Verheij kan worden ingestemd wanneer hij stelt dat de eis van wetmatigheid van bestuur een levend en dynamisch ideaal is. ${ }^{8}$

Ik beperk mij in dit hoofdstuk tot de vraag in hoeverre het publieke rechtshandelen door het bestuur (de 'bevoegdheidsuitoefening') dient te steunen op een (Grond)wettelijke grondslag. Het legaliteitsbeginsel vat ik op als de eis van wetmatigheid van bestuur. Deze eis ziet in het staatsrecht in het bijzonder op de formele grondslag voor bestuursbevoegdheid. Het legaliteitsvraagstuk houdt in mijn optiek verband met de 'normatieve' behartiging van publiekrechtelijke belangen door het bestuur. ${ }^{9}$

In het eerste gedeelte van dit hoofdstuk zal de aandacht met name uitgaan naar de vraag in hoeverre éénzijdig publiekrechtelijk rechtshandelen door het bestuur herleidbaar dient te zijn tot een formeelwettelijke grondslag. Een korte historische schets van de ontwikkelingen in het denken over het legaliteitsbeginsel kan hierbij niet worden gemist. In dit verband zal ik het dogmatische onderscheid tussen 'Eingriffsverwaltung' en 'Leistungsverwaltung' kritiseren. ${ }^{10}$ In het tweede gedeelte van dit hoofdstuk staat vervolgens de vraag centraal aan welke inhoudelijke kwaliteitseisen de wettelijke grondslag voor bestuursbevoegdheid vanuit een oogpunt van specialiteit en rechtszekerheid dient te voldoen. Ik put in dit kader inspiratie uit de constitutionele jurisprudentie van het Duitse Bundesverfassungsgericht (paragraaf 4.4.2) en uit de jurisprudentie van het Europese Hof voor de Rechten van de Mens (paragraaf 4.4.6).

6. De Grondwet eist in diverse gevallen een wettelijke - of tot de wet herleidbare - basis voor inbreuken op eigendom (art. $14 \mathrm{Gw}$ ) en grondrechten. Voorts verplicht de Grondwet de wetgever uitdrukkelijk om bepaalde onderwerpen of aangelegenheden bij (of krachtens) de wet te regelen of te bepalen (vgl. bijv. art. 23 lid 3 en art. $104 \mathrm{Gw}$ ). Vgl. tot slot art. 89 lid 2 en $4 \mathrm{Gw}$, dat een wettelijke basis eist voor de op Rijksniveau vast te stellen algemeen verbindende voorschriften voorzover deze door straf (kunnen) worden gehandhaafd.

7. Vgl. HR 22 juni 1973, NJ 1973, 386, m.nt. A.R.B. (fluoridering); HR 27 juni 1986, AB 1987, 241, m.nt. FHvdB (methadonbrief) en - toegespitst op belastingheffing - HR 8 oktober 1993, AB 1994, 299, m.nt. FHvdB (toeristenbelasting Marken). In dit laatstgenoemde arrest hanteert de Hoge Raad zelfs expliciet het begrip 'legaliteitsbeginsel'. Zie voorts paragraaf 4.2.3.

8. N. Verheij, Deuken in het ideaal. Over wetmatigheid van bestuur II, Publiek Domein 1989, p. 242.

9. In hoofdstuk 2 en 3 nam ik het standpunt in dat typisch publiekrechtelijke belangen, die m.i. principieel verschillen van private (vermogens)belangen, op basis van doelgebonden bestuursbevoegdheden behoren te worden behartigd. De behartiging van publieke belangen door feitelijk overheidshandelen laat ik buiten beschouwing. Hier ligt overigens vaak een bevoegdheidsuitoefening aan ten grondslag.

10. Deze onderscheiding is afkomstig uit het Duitse recht. Waar met het oog op 'Eingriffsverwaltung' (belastend bestuur) het 'Gesetzesvorbehalt' (staatsrechtelijk legaliteitsbeginsel) volledig wordt erkend, is dit t.a.v. 'Leistungsverwaltung' (begunstigend bestuur) omstreden. Zie bijv. N. Achterberg, Allgemeines Verwaltungsrecht, 2. vøllig neubearbeitete und erweiterte Auflage, Heidelberg 1986, p. 239 e.v.; Zie voor een omlijning van deze begrippen ook: I. von Münch en D. Ehlers, Verwaltung und Verwaltungsrecht im demokratischen und sozialen Rechtsstaat in: Allgemeines Verwaltungsrecht, 9. Auflage, Berlin/New York 1992, p. 33 e.v. en H. Maurer, Allgemeines Verwaltungsrecht, 11. Auflage, Munchen 1997, p. 109-113. 


\subsection{Legaliteitsbeginsel en wetsbegrip}

De beschouwingen in de Nederlandse literatuur over het legaliteitsbeginsel gaan meestal samen met analyses van het materiële wetsbegrip. ${ }^{11}$ Aan dit verschijnsel ligt de gedachte ten grondslag dat indien men er in slaagt de inhoudelijke kenmerken van het begrip 'wet' vast te stellen, bijgevolg tevens vaststaat dat alleen de wetgever deze 'wet' tot stand mag brengen. De interpretatie van het wetsbegrip, de definiëring van de staatsrechtelijke legaliteitseis én de competentie-afbakening tussen wetgever en bestuur vloeien bijgevolg samen. Omdat het hier een benaderingswijze betreft die in ons staatsrecht steunt op een lange traditie, is het zinvol om de hoofdlijnen van de historische en hedendaagse discussies over het wetsbegrip in kaart te brengen.

Voordat ik mijn aandacht op dit wetsbegrip richt, is een algemene opmerking over 'het' legaliteitsbeginsel op zijn plaats. Uit de literatuur blijkt dat de legaliteitsvlag vele ladingen dekt. Door sommigen wordt het beginsel vereenzelvigd met de rechtsstaatidee of met een algemeen rechtmatigheidspostulaat ('de overheid behoort overeenkomstig het recht te handelen'). Anderen spitsen de legaliteitseis juist toe op het machtigings- of bevoegdheidsvraagstuk ('de grondslag voor overheidsgezag'). Ik zelf volg deze laatste koers. In het belang van de overzichtelijkheid kan worden gewezen op de door Van Ommeren ${ }^{12}$ gehanteerde driedeling tussen het rechtsstaatbeginsel, het consistentiebeginsel en het legaliteitsbeginsel (in enge zin). Waar het rechtsstaatbeginsel de onderwerping van de overheid aan het recht in zijn algemeenheid tot uitdrukking brengt en het consistentiebeginsel ${ }^{13}$ het vereiste dat overheidshandelen overeenkomstig algemene regels dient plaats te vinden, daar brengt het legaliteitsbeginsel met zich dat de overheid slechts bevoegd is tot een bepaald soort handelen indien dit handelen berust op een (formeel)wettelijke grondslag.

\subsubsection{Het formele wetsbegrip}

Over het wetsbegrip in 'formele zin' bestaat in de literatuur weinig verschil van mening. Hieronder wordt verstaan elk besluit afkomstig van de organen die overeenkomstig de in

11. Zie de navolgende dissertaties uit de jaren negentig van de twintigste eeuw: F.J. van Ommeren, De verplichting verankerd. De reikwijdte van het legaliteitsbeginsel en het materiële wetsbegrip, Deventer 1996, i.h.b. p. 196-198; J.M.E. Derks, De Grondwet en delegatie. Het delegatievraagstuk in constitutioneel perspectief, Maastricht 1995, p. 249-250 en H.D. Stout, De betekenissen van de wet. Theoretisch-kritische beschouwingen over het principe van wetmatigheid van bestuur, Zwolle 1994, i.h.b. p. 85 .

12. F.J. van Ommeren, De verplichting verankerd, a.w., p. 200.

13. Van Ommeren doelt hier m.i. op het fundamentele rechtsstatelijke verbod van willekeur dat verband houdt met het legaliteitsbeginsel en volgens sommige auteurs hier zelfs aan vooraf gaat. Vgl. A.Q.C. Tak en R.E. Bakker, De centrale rol van het willekeurverbod bij de toetsing van overheidshandelen, in: Publiekrechtelijke bewegingen (red. Heringa/Verheij), Deventer 1990, i.h.b. p. 218. Vgl. voorts C.A.J.M. Kortmann, Constitutioneel recht, geheel herziene derde druk, Deventer 1997, p. 50 en M.A. Heldeweg en R.J.N. Schlठssels, Willekeur getoetst; terug naar Doetinchem?, JB 1996/212, p. 907. 
de Grondwet geregelde procedure van artikel 81 e.v. ${ }^{14}$ gerechtigd zijn tot het tot stand brengen van wetten. ${ }^{15}$ Het begrip 'wet' wordt in dit kader niet inhoudelijk gedefinieerd maar enkel als een product van een Grondwettelijke procedure. Een dergelijke formele opvatting van het wetsbegrip brengt met zich dat géén (regelgevend) gebied wordt afgebakend dat tot de exclusieve competentie van de wetgever behoort. ${ }^{16}$ Weliswaar bevat de Grondwet een aantal uitdrukkelijke opdrachten aan de formele wetgever, maar deze zijn niet limitatief van aard en er kan mijns inziens géén materieel wetsbegrip uit worden afgeleid. ${ }^{17}$ Binnen de grenzen die voortvloeien uit het internationale en communautaire recht, de Grondwet, de grondrechten en de algemene rechtsbeginselen, kan de wetgever in formele zin zich - onverminderd Grondwettelijke opdrachten - willekeurig onderwerpen ter regulering aantrekken. ${ }^{18}$ Het formele wetsbegrip geeft bijgevolg nauwelijks houvast bij de afbakening van de staatsrechtelijke legaliteitseis. ${ }^{19}$

De Grondwettelijke wetgevingsprocedure beoogt intussen wél belangrijke aspecten van het democratiebeginsel, dat (mede) ten grondslag ligt aan de legaliteitseis, te operationaliseren. ${ }^{20}$ In dit verband kan worden gewezen op de uitvoerige voorbereidingsprocedure van voorstellen van wet (o.m. advisering door de Raad van State) en in het bijzonder op de openbare behandeling in het parlement. In de hedendaagse literatuur wordt het belang van de wetgevingsprocedure voor de verwerkelijking van het democratieprincipe onderkend. Damen ${ }^{21}$ heeft bijv. een duidelijk pleidooi gehouden voor democratische legitimatie van besluiten met overheidsgezag. Democratische legitimatie kan volgens hem bij uitstek bereikt worden op basis van de Grondwettelijke wetgevingsprocedure, daar het parlement in dit verband beschikt over vergaande en duidelijke beïnvloedingsmogelijkheden.

14. De inhoud van art. 81 van de Grondwet van 1983 wordt in eerdere Nederlandse Grondwetten aangetroffen in art. 119 (Grondwet van 1953 en 1972), 112 (Grondwet van 1938), 110 (Grondwet van 1922), 109 (Grondwet van 1887) en 104 (Grondwet van 1848).

15. Zie bijv. P.J. Oud, Het constitutioneel recht van het Koninkrijk der Nederlanden II, tweede druk, Zwolle 1970, p. 91; I.C. van der Vlies, Het wetsbegrip en de beginselen van behoorlijke regelgeving, diss. UvA, 's-Gravenhage 1984, p. 85 e.v.

16. Vgl. I.C. van der Vlies, Het wetsbegrip en de beginselen van behoorlijke regelgeving, a.w., p. 85. Zie ook: H.D. Stout, De betekenissen van de wet, a.w., p. 85.

17. Hier is wel onderzoek naar gedaan. Zie: J.M.E. Derks, De Grondwet en delegatie, a.w., i.h.b. paragraaf 9.2. Overigens leefde deze gedachte al bij Thorbecke. Vgl. J.R. Thorbecke, Aanteekening op de Grondwet, (nieuwe) tweede uitgave, eerste deel, 's-Gravenhage 1906, p. 283.

18. Vgl. F.A.M. Stroink en J.G. Steenbeek, Inleiding tot het staats- en bestuursrecht, a.w., p. 33. Zie verder: F.H. van der Burg, Regelgeving en bestuur, a.w., p. 37.

19. Ofschoon tijdens de parlementaire behandeling van aangehaald Grondwetsartikel wel summier gesproken is over een materieel wetsbegrip, geeft de tekst van art. $81 \mathrm{Gw}$ toch uitsluitend uitdrukking aan de wetgevingsprocedure. Vgl. J.M.E. Derks, De Grondwet en delegatie, a.w., p. 252-254.

20. Vgl. bijv. M.H. Kobussen, De vrijheid van de overheid, diss. KUB, Zwolle 1991, p. 118; Vgl. voorts: Orde in de regelgeving, Eindrapport van de commissie wetgevingsvraagstukken (commissie Polak), 'sGravenhage 1985, p. 42. De commissie Polak sprak in dit verband over én van 'de voornaamste verworvenheden van onze parlementaire democratie'.

21. L.J.A. Damen, Ongeregeld en ondoorzichtig bestuur, diss. RUG, Deventer 1987, p. 271. 
Van der Vlies zit op eenzelfde lijn. ${ }^{22}$ In een openbaar debat kan het parlement volgens haar de regering verplichten om voorstellen van wet toe te lichten en te verdedigen zodat de strekking ervan duidelijk wordt. Hiermee hangt het aspect van de beïnvloeding en mobilisatie van de openbare mening (middels de media), die op haar beurt weer van invloed kan zijn op het electoraat, samen. Op grond van deze overwegingen, en de hieruit voortvloeiende waarborgen, verdedigde Van der Vlies dat de wetgever alle ingrijpende besluiten binnen het nationale rechtsstelsel dient te nemen. ${ }^{23}$ Ook de commissie Polak opteerde in haar eindrapport 'Orde in de Regelgeving' voor het 'primaat van de formele wetgever' ${ }^{24}$ Hierbij hechtte de commissie bijzondere waarde aan het waarborgen van het democratisch gehalte van regels.

Inmiddels staat de Grondwettelijke wetgevingsprocedure aan kritiek bloot, die op deze plaats niet onvermeld mag blijven. De kritiek spitst zich toe op de vraag of de Grondwettelijke procedure daadwerkelijk garant staat voor een democratische meerwaarde. Exemplarisch is een betoog van Jurgens in het Nederlands Juristenblad. ${ }^{25}$ Jurgens verzet zich tegen, wat hij noemt, 'de sacrosancte positie van wetten in formele zin'. De hiërarchische positie van wetten wordt nog steeds afgeleid van de wijze waarop zij geacht worden te ontstaan, nl. als een uitdrukkelijk besluit van de regering en de volksvertegenwoordiging. Hierin ligt volgens hem naar aloude fictie de democratische legitimatie besloten die inhoudt dat wetten tengevolge van de medewetgevende taak van de volksvertegenwoordiging tevens het rechtsbewustzijn van het volk weerspiegelen.

Ik ontken niet dat de representatieve democratie legitimatietekorten vertoont. Betrokkenheid en inzet van het parlement als medewetgever mag naar mijn oordeel evenwel niet ten principale worden ontkend. Wél kan de vraag worden gesteld of het parlement als medewetgever zijn aandacht wel op essentiële (juridische) punten richt. Zo werd bijv. in het eindbericht van de commissie vermindering en vereenvoudiging van overheidsregelingen $^{26}$ (als minpunt van het wetgevingsproces) opgemerkt dat: '...de Tweede Kamer zich bij de behandeling van de wetgeving die in diep ingrijpende bevoegdheden voor het bestuur voorziet, zich de belangen van de betrokken justitiabelen pleegt aan te trekken. Zij doet dit echter minder door de uitoefening van die bevoegdheden aan materiële normen te binden, als wel door die aan procedurele waarborgen(...) te onderwerpen' (curs. R.J.N.S.).

Ook uit het betoog van Jurgens kan worden afgeleid dat hij zijn pijlen niet zozeer richt op het parlement als medewetgever maar op het wetgevingsproces zelf en op de rol die het parlement binnen dat proces momenteel vervult. Hij ontkent niet de noodzaak van parle-

22. I.C. van der Vlies, Het wetsbegrip en de beginselen van behoorlijke regelgeving, a.w., p. 101 en 102.

23. I.C. van der Vlies, Het wetsbegrip en de beginselen van behoorlijke regelgeving, a.w., p. 103. In het vervolg van dit hoofdstuk zal nog nader aandacht worden besteed aan de opvatting van Van der Vlies.

24. Toegespitst op het uitvaardigen van algemeen verbindende voorschriften. Orde in de regelgeving, a.w., p. 42.

25. E.C.M. Jurgens, De mythe van Meerenberg, Over de betrekkelijke legitimatie die uitgaat van medewetgeving door de Staten-Generaal, NJB 1993/39, p. 1381 e.v. (Themanummer Zorgen om Wetgeving), a.w., p. 1382.

26. TK $1983 / 1984,17931$, nr. 9 , p. 60. 
mentaire betrokkenheid bij de totstandkoming van regelgeving, maar vraagt mér aandacht voor de wijze waarop aan deze medewetgevende taak inhoudelijk invulling kan worden gegeven. Door te pleiten voor politieke betrokkenheid van de kamer(s) op hoofdlijnen ${ }^{27}$ erkent ook Jurgens in dit verband het belang van het democratiebeginsel. Hij wil de parlementaire betrokkenheid evenwel in omvang beperken en toespitsen op de toetsing aan rechtsstatelijke criteria en de interne kwaliteit van regelgeving. ${ }^{28}$ Dit lijkt mij zeker geen onjuist uitgangspunt. In dit hoofdstuk zal ik met het oog hierop verdedigen dat de wetgever met name bijzondere aandacht zal dienen te besteden aan de materiële normering van bevoegdheidsnormen. Ik volg Jurgens evenwel niet voorzover hij pleit voor het loslaten of vergaand afzwakken van de democratisch-rechtsstatelijke bevoegdheidsleer. ${ }^{29}$

\subsubsection{Het materiële wetsbegrip}

Een formele opvatting inzake het wetsbegrip brengt met zich dat omtrent de omvang van het staatsrechtelijke legaliteitsbeginsel weinig duidelijkheid wordt verkregen. Verheij stelde zelfs, in wel erg krasse bewoordingen, dat een ieder die voor een zuiver formeel wetsbegrip opteert het legaliteitsbeginsel reduceert tot de inhoudsloze en politiek onschadelijke eis dat alleen de wetgever besluiten van de wetgever mag stellen. ${ }^{30}$

In dit verband dient men goed voor ogen te houden welke de strekking is van het staatsrechtelijke legaliteitspostulaat. De Duitse terminologie brengt deze strekking mijns inziens helder onder woorden door te spreken over het 'Vorbehalt des Gesetzes'. ${ }^{31}$ Toegespitst op de grondslag van bestuursbevoegdheid ziet het legaliteitsbeginsel in het bijzonder op de afbakening van het normatieve werkterrein tussen de wetgever en de verschillende statelijke bestuursorganen. Centraal staat hierbij de vraag welk aspect van de gerichte publieke rechtsvorming binnen de statelijke rechtsorde aan de wetgever is voorbehouden en welk deel van dit rechtsvormingsproces bij wijze van (sub)delegatie van regelgevende bevoegdheid, dan wel op basis van (discretionaire) beschikkingsbevoegdheden, kan worden overgelaten aan de bestuursorganisatie.

Deze vraag kan, zoals vermeld, zinvol worden beantwoord door een inhoudelijke - materiële - invulling aan het wetsbegrip te geven. Hierdoor wordt het mogelijk om tot een

27. E.C.M. Jurgens, De mythe van Meerenberg, a.w., p. 1383.

28. E.C.M. Jurgens, De mythe van Meerenberg, a.w., p. 1386.

29. In die zin dat hij kiest voor een 'omgekeerde Meerenberg-doctrine' (Het bestuur is bevoegd, tenzij de wetgever anders bepaalt.). Zoals uit het navolgende zal blijken stel $\mathrm{ik}$ mij op het standpunt dat bevoegdheden van het openbare bestuur in de regel op de wet in formele zin dienen te berusten. Zie: E.C.M. Jurgens, De mythe van Meerenberg, a.w., p. 1386. Overigens zijn de denkbeelden van Jurgens niet nieuw. Vgl. reeds: C.A.J.M. Kortmann, Het eeuwfeest van Meerenberg, NJB 1974/40, i.h.b. p. 1282-1285.

30. N. Verheij, Alleen de wet heerscht over ons. Over wetmatigheid van bestuur I, Publiek Domein 1989, p. 189.

31. Te onderscheiden van de 'Vorrang des Gesetzes', die met zich brengt dat de overheid - zoals iedere burger - niet in strijd met de wet mag handelen. Vgl. H. Maurer, Allgemeines Verwaltungsrecht, a.w., p. 104. 
competentie-afbakening te komen tussen de wetgevende en de uitvoerende macht (het bestuur). ${ }^{32}$

\subsubsection{De negentiende eeuw}

De discussies over het wezen van het wetsbegrip hebben de rechtswetenschap in ons land langdurig beziggehouden, zonder dat dit resulteerde in consensus. 'Er openbaart zich daaromtrent in de wetenschap heel wat verschil van gevoelen', verzuchtte Oud in zijn handboek. ${ }^{33}$ Ook momenteel levert het wetsbegrip nog voldoende stof op voor omvangrijk juridisch onderzoek, welk onderzoek ik niet beoog te herhalen. ${ }^{34} \mathrm{Ik}$ schets enige hoofdlijnen.

In de negentiende eeuw werden de discussies, zoals bekend, beheerst door een aantal strijdvragen over de regelgevende bevoegdheid van de Koning. Enerzijds spitsten deze zich toe op de positie van de 'zelfstandige' algemene maatregel van bestuur (AMvB) ${ }^{35}$, anderzijds was de vraag naar het materiële karakter van wetgeving onderwerp van een aanhoudend wetenschappelijk discours. De eerste vraag spitste zich er in hoofdzaak op toe of aan de Kroon een zelfstandige regelgevende bevoegdheid toekwam wanneer noch de Grondwet, noch de wet (in formele zin) het staatshoofd hier expliciet toe machtigde. ${ }^{36}$ Ofschoon de Grondwetgever van 1815 in dit verband een staatsrechtelijk hiaat kon worden aangewreven ${ }^{37}$, werd deze vraag in de praktijk desalniettemin bevestigend beantwoord. Een aanzienlijk aantal zelfstandige AMvB's kwam vanwege de Koning op diverse terreinen van het staatsbestuur tot stand. Deze praktijk werd gesteund door de zgn. 'Blanketwet' van 6 maart 1818 die - o.m. - op regels, gegeven bij zelfstandige AMvB, vóóraf straf stelde. ${ }^{38}$ De Blanketwet verschafte echter géén specifieke staatsrechtelijke bevoegdheidsgrondslag voor AMvB's. Het wetje beoogde enkel tegenmoet te komen aan het strafrechtelijke legaliteitsbeginsel. ${ }^{39}$

32. Hier is het machtigingsvraagstuk of het formeel-positieve aspect van wetgeving in het geding. $\mathrm{N}$. Verheij, Alleen de wet heerscht over ons, a.w., p. 192.

33. P.J. Oud, Het Constitutioneel recht van het Koninkrijk der Nederlanden II, a.w., p. 94.

34. Vgl. de eerder aangehaalde proefschriften van Stout, Derks en Van Ommeren.

35. Of correcter, in negentiende eeuws jargon: 'algemeene maatregelen van inwendig bestuur van den Staat' (zie art. 73 van de Grondwet van 1815).

36. Deze vraagstelling werd (mede) ingegeven door het feit dat een poging om in het kader van de totstandkoming van de Grondwet van 1815 te komen tot een afbakening tussen enerzijds de uitvoerende macht van de Koning en anderzijds de wetgevende macht was gestrand. Zie: J.R. Thorbecke, Aanteekening op de Grondwet, a.w., p. 283. Uitgangspunt leek te zijn de zelfstandige regelgevende bevoegdheid van de Koning voorzover deze niet in strijd met de wet of de Grondwet werd uitgeoefend. Vgl. in dit kader: H.T. Colenbrander, Ontstaan der Grondwet (Bronnenverzameling), tweede deel 1815, 'sGravenhage 1909, p. 141 e.v., i.h.b. p. 145.

37. Vgl. J.T. Buijs, De Grondwet, Toelichting en kritiek, eerste deel, Arnhem 1883, p. 327.

38. Zie: J.T. Buijs, De Grondwet I, a.w., m.n. p. 327 en 328; R. Kranenburg, Het Nederlandsch staatsrecht, eerste deel, zesde druk, Haarlem 1947, p. 94 en 95; Van der PotDonner, Handboek van het Nederlandse staatsrecht, bewerkt door L. Prakke, J.L. De Reede en G.J.M. van Wissen, dertiende druk, Zwolle 1995, p. 495 en F.H. van der Burg, Regelgeving en bestuur, a.w., p. 40-41. 
Gedekt door deze Blanketwet kon de Koning gestalte geven aan zijn (vermeende) 'zelfstandige' regelgevende bevoegdheid. Over de Grondwettigheid van de 'besluitenpraktijk' bestond verschil van mening ${ }^{40}$ De meningsverschillen werden aangewakkerd door het feit dat óók de Grondwetgever van 1848 géén beslissende uitspraken deed over de staatsrechtelijke verhouding tussen 'wetten' en 'AMvB's'. ${ }^{41}$ Het Grondwettelijke begrip 'wet' werd in formele zin begrepen ${ }^{42}$ en het regelgevende terrein waarop de Koning zich zelfstandig bij AMvB mocht bewegen bleef in dit verband slechts begrensd door de Grondwet en de wet in formele zin, voorzover deze laatste zich uitdrukkelijk een bepaald onderwerp ter regulering had aangetrokken. Opmerkelijk was deze situatie temeer, daar de voorzitter van de Grondwetscommissie van 1815, Van Hogendorp, zich reeds over de staatsrechtelijke status van de AmvB had uitgelaten: '...Zulke algemeene maatregelen kunnen geen ander oogmerk hebben dan de verzekering van de uitvoering der wetten. De wet heerscht alleen over ons; de wet behelst haar eigene sanctie, en zij bepaalt de straffen op hare overtreding' (curs. R.J.N.S.). ${ }^{43}$

Het duurde tot 1879 voordat de positie van de zelfstandige AMvB binnen het Nederlandse constitutionele bestel werd bepaald. Niet de Grondwetgever ${ }^{44}$ of de wetge$v^{45}{ }^{45}$ maar de Hoge Raad nam in de befaamde Meerenberg-kwestie ten aanzien van dit punt principieel stelling. ${ }^{46}$ Deze stellingname kwam overigens na een periode waarin de

39. O.m. gelet op de door Napoleon ingevoerde Code d'instruction criminelle die voorschreef om in geval van een strafveroordeling de wet aan te halen waarop de veroordeling berustte. Zie: J.T. Buijs, De Grondwet I, a.w., p. 341. Zie verder: Van der Pot/Donner, Handboek van het Nederlandse staatsrecht, a.w., p. 495.

40. De Blanketwet werd reeds bij de totstandkoming door Van Hogendorp bestreden. Volgens hem zou de Koning door deze wet een vrijbrief krijgen om zich een gedeelte van de 'natuurlijke' taak van de wetgever toe te eigenen. Zie: J.T. Buijs, De Grondwet I, a.w., p. 339.

41. Vgl. R. Kranenburg, Het Nederlandsch staatsrecht, a.w., p. 92. Overigens had Thorbecke wél bepleit om in de Grondwet te bepalen dat Algemene Maatregelen van Bestuur op de wet zouden dienen te berusten. J.R. Thorbecke, Bijdrage tot herziening der grondwet, 1848, tweede druk 1948, p. 16 e.v., 65. Hierbij had hij tevens bepleit dat de wet 'het onderwerp en gebied bepaalt' waarop de besluitgever zich mocht begeven. Dit pleidooi kwam echter te laat. Zie: J.T. Buijs, De Grondwet I, p. 328.

42. Zie: Kranenburg, Het Nederlandsch staatsrecht, a.w., p. 95. Thorbecke was in dit kader zeer duidelijk: 'De Grondwet ontleent het begrip wet enkel van den persoon, die haar maakt. Zij heeft de vraag opengelaten, wat moet bij ons door eene wet, en wat kan op eene andere wijze worden vastgesteld?' J.R. Thorbecke, Aanteekening op de Grondwet, a.w., p. 283. Deze opvatting was echter geen gemeengoed. Vgl. bijv. de 'materiele' definitie van J. de Bosch-Kemper: 'Het begrip van Wet is het algemeene voorschrif, waaruit regten en verpligtingen worden geboren.' J. de Bosch-Kemper, Handleiding tot de kennis van het Nederlandsche staatsregt en staatsbestuur, Amsterdam 1853, p. 87.

43. Aangehaald bij: J.T. Buijs, De Grondwet I, a.w., p. 327.

44. In dit kader is nog van belang dat de Grondwetgevers van zowel $1814 / 1815$ als 1848 aanzienlijke bevoegdheden inzake het landsbestuur juist aan de Koning hadden toevertrouwd. Vgl. Van der Pot/Donner, Handboek van het Nederlandse staatsrecht, a.w., p. 494-495.

45. Vgl. Buijs die erop wees dat de wetgever door het intrekken van de wet van 6 maart 1818 - een deel van - de 'besluitenpraktijk' (indirect) een halt had kunnen toeroepen. J.T. Buijs, De Grondwet I, a.w., p. 338-339.

46. HR 13 januari 1879 , W4330 (Meerenberg). 
politieke macht van de Koning ingevolge een aantal staatsrechtelijke ontwikkelingen reeds aanzienlijk was gereduceerd. ${ }^{47}$

In het licht van de systematiek van de Grondwet van 1848 overwoog de Hoge Raad in het Meerenberg-arrest:

\begin{abstract}
'...immers, dat, ingevolge vorenvermeld stelsel der Grondwet, het niet de vraag is of die bevoegdheid den Koning door eenige uitdrukkelijke bepaling is ontzegd, maar of zij hem toegekend zij, en alzoo steunt hetzij op eenig bestanddeel van 's Konings in de Grondwet omschreven magt, hetzij op eenige directe of indirecte delegatie des wetgevers, in verband met 's Konings bevoegdheid als uitvoerende magt;

Overwegende, dat ook de wet van 6 maart 1818, in artikel 1 niet kan geacht worden eene algemeene en onbepaalde bevoegdheid aan het uitvoerend gezag te verleenen, maar alleen kan worden opgevat in die zin, dat zij voor al de gevallen, waarin enige wet aan den Koning de bevoegdheid verleent, om de daarbij bijzonder aangewezene bepalingen te maken, aan de overtreding dier bepalingen eens voor al de in het artikel genoemde straffen verbindt; ...'
\end{abstract}

Het Meerenberg-arrest was een constitutionele mijlpaal in de geschiedenis van het Nederlandse staatsrecht. ${ }^{48}$ De Hoge Raad ging in het genoemde arrest in feite uit van een drietal eisen waaraan de grondslag voor regelgevende bevoegdheid van het bestuur in de democratische rechtsstaat diende te voldoen. Kort samengevat kwamen deze eisen op het volgende neer 1. regelgevende bevoegdheid van het bestuur kan uitsluitend bestaan indien deze uitdrukkelijk is toegekend, 2 . deze toekenning dient herleidbaar te zijn tot een besluit van de Grondwetgever of de wetgever (in formele zin), en 3. de toekenning dient in die zin speciaal te zijn, dat de regelgevende bevoegdheid uitsluitend strekt tot het maken van 'bijzonder aangewezen bepalingen'. Hiermee legde de Hoge Raad het primaat van regelstelling in de handen van de wetgever. Regelstelling door de Kroon werd alleen toelaatbaar geacht, op voorwaarde dat de regelstellende bevoegdheid hiertoe berustte op - of te herleiden was tot - een expliciete delegatiebepaling in de wet in formele zin, dan wel rechtstreeks steun vond in de Grondwet.

Donner en Prakke ${ }^{49}$ merken op dat aan het Meerenberg-arrest een 'materieel wetsbegrip' ten grondslag lag, dat dogmatisch alle 'regelstelling' als wetgeving beschouwde. Belangrijker is dat aan het Meerenberg-arrest, naar mijn oordeel, de staatsrechtelijke idee ten grondslag werd gelegd dat (regelgevende) bevoegdheden van het bestuur per definitie

47. Ik wijs op de introductie van de politieke ministeriele verantwoordelijkheid in de Grondwet van 1848 en de vestiging van het parlementaire stelsel (1853-1868) waarin de vertrouwensregel een spilfunctie ging vervullen. De beteugeling van de regelgevende macht van de Koning werd in ons land derhalve primair gerealiseerd via de politiek-staatsrechtelijke weg. De technisch-juridische operationalisering van het legaliteitsbeginsel volgde later. Vgl. A.A.H. Struycken, Administratie of rechter?, Arnhem 1910, p. 19.

48. Teunissen brengt dit arrest bijv. i.v.m. het einde van de politiestatelijke opvatting ingevolge welke opvatting staatsinterventie in de burgerrechtelijke rechtssfeer op basis van een open en algemene bestuursbevoegdheid nog toelaatbaar werd geacht. Zie: J.M.H.F. Teunissen, Het burgerlijk kleed van de staat. Beschouwingen over de tweewegenleer, Zwolle 1996, p. 118-120. Zie voorts hoofdstuk 3 paragraaf 3.2.1.

49. Van der Pot/Donner, Handboek van het Nederlandse staatsrecht, a.w., p. 496. Vgl. ook R. Kranenburg, Het Nederlandsch staatsrecht, a.w., p. 97. 
beperkt, omlijnd en traceerbaar dienen te zijn. Hierbij stelde de Hoge Raad zich expliciet op het standpunt dat regelgevende bevoegdheid uitdrukkelijk aan het openbare bestuur dient te worden toegekend, en dat dit bestuur in dit kader dus niet beschikt over een originaire bevoegdheid. ${ }^{50}$

Ofschoon het Meerenberg-arrest leidde tot meer duidelijkheid inzake de competentieafbakening tussen de wetgever in formele zin en de Kroon, bewerkstelligde dit arrest gén bevredigende helderheid over het inhoudelijke rechtskarakter van regelstelling. Het was Buijs die in de tweede helft van de negentiende eeuw een bepalende bijdrage leverde aan de meningsvorming over het 'materielle wetsbegrip' in Nederland. Uitgangspunt van Buijs' betoog was dat het begrip 'wet', zoals bedoeld in de Grondwet van 1848, in beginsel formeel diende te worden opgevat. ${ }^{51}$ Dit betekende volgens hem echter niet dat het begrip 'wet in materiëelen zin' iedere betekenis miste. Om tot een afgrenzing tussen de macht van het bestuur en de wetgever te komen was het volgens hem evenwel noodzakelijk een omschrijving te geven van 'het natuurlijk terrein dat den wetgever toebehoort' ${ }^{52}$ In dit kader wenste Buijs niet mee te gaan met de Meerenberg-doctrine van de Hoge Raad, die volgens hem onhoudbaar was omdat zij steeds een expliciete (Grond)wettelijke machtiging vereiste voor het bestuur (lees: de Kroon) om regels uit te vaardigen. Het speciale terrein dat aan de wetgever toebehoort moest volgens Buijs enger worden gedefinieerd. Hiertoe kwam hij tot de volgende definitie van het wetsbegrip, waarbij hij aansluiting zocht bij de Duitse rechtsgeleerde Laband:

\footnotetext{
'En wat verstaat men nu onder wetgeven? Ik zoude het liefst met Laband willen antwoorden: "het uitvaardigen van een voor de burgers bindenden rechtsregel". Elke daad van het staatsgezag waardoor het gebiedend of verbiedend tegenover onderdanen optreedt, hun plichten oplegt, welke zonder dat gebod niet zouden gelden, hunne door de wet gewaarborgde vrije beschikking over persoon en goed wijzigt en beperkt, elk zodanig voorschrift is ene wet'.53
}

De omvang van het legaliteitsbeginsel, zoals Buijs' dat zag, was op de keper beschouwd beperkt tot het bereik van de 'Eingriffsverwaltung'. Vanuit de juridisch-politieke optiek van de negentiende eeuwse liberale rechtsstaat was dat begrijpelijk. De naar buiten werkende regels van de 'nachtwakersstaat' beperkten zich immers in hoofdzaak tot ge- en verboden ten opzichte van de 'vrije' burger.

De grondwetgever van 1887 nam de leer van Buijs inzake het materiële wetsbegrip in aangepaste vorm over. ${ }^{54} \mathrm{Zijn}$ leer is in deze gewijzigde vorm nog steeds terug te vinden in artikel 89 lid 2 van de huidige Nederlandse Grondwet.

50. Vgl. de korte historische schets over de ontwikkeling van de democratische-rechtsstaat in hoofdstuk 3 van dit boek. Van der Burg heeft er overigens op gewezen dat de door de Hoge Raad in het Meerenberg-arrest gehuldigde visie eigenlijk niet goed overeenstemde met de ontstaansgeschiedenis van de Nederlandse Grondwet, die in feite de originaire macht van de Koning erkende en constitutioneel inkapselde. Zie: F.H. van der Burg, Regelgeving en bestuur, a.w., p. 43.

51. J.T. Buijs, De Grondwet I, a.w., p. 344.

52. J.T. Buijs, De Grondwet I, a.w., p. 348.

53. J.T. Buijs, De Grondwet I, a.w., p. 336. 
Van belang is dat het wetsbegrip van Buijs de wetmatigheidseis postuleerde voorzover er sprake was van 'Eingriffsverwaltung'. Dit leidde tot een theoretische invulling van het wetsbegrip die niet aan de Grondwetgever(s) van 1815 en 1848 kan worden toegeschreven. Buijs' wetsbegrip had uiteindelijk niet alleen gevolgen voor de regelstellende bevoegdheid van de Kroon maar voor 'belastende' bestuursbevoegdheden in hun algemeenheid. Van der Burg ${ }^{55}$ heeft in dit kader bijv. gewezen op de legaliteits-eis voor beschikkingsbevoegdheid door op te merken dat: '...indien men de lijn van de Grondwetsherziening van 1887 consequent doortrekt men wel moet aannemen dat ook voor concrete bevelen die ingrijpen in de rechtstoestand van de burger de eis van een grondslag in de formele wet moet gelden'.

Dit laatste uitgangspunt werd in de eerste heift van deze eeuw door de Hoge Raad bevestigd. Op deze plaats wordt volstaan met een verwijzing naar het bekende Jamin-arrest uit 1926, waarin de Hoge Raad het beginsel van 'wetmatigheid van bestuur' ook voor belastende beschikkingsbevoegdheden erkende. ${ }^{56}$ Vanaf dat moment kan gesteld worden dat in het Nederlandse staatsrecht het legaliteitsbeginsel integraal gold voor bestuurshandelen voorzover er sprake is van typische 'Eingriffsverwaltung'. Deze invulling van het legaliteitsbeginsel vindt in de Nederlandse literatuur - soms in bijgestelde vorm ${ }^{57}-$ nog steeds steun. ${ }^{\text {s8 }}$

\subsubsection{Böhtlingk en het algemeenheidspostulaat}

In Nederland krijgt de gedachtenvorming over het 'materiële wetsbegrip' in de twintigste eeuw nieuwe impulsen. Hierbij blijkt dat de discussie over de invulling van dit wetsbegrip niet per definitie gekoppeld behoeft te worden aan de rechtsstatelijke verhouding tussen

54. Buijs' term 'de burgers bindende rechtsregel' werd door de in 1883 ingestelde staatscommissie voor de herziening van de Grondwet omgezet in 'voorschriften door straf of politiedwang te handhaven'. Uiteindelijk werd het handhaven door 'politiedwang' geschrapt. Zie in dit kader: F.H. van der Burg, annotatie onder het Mecrenberg-arrest in AB Klassiek, derde druk, Deventer 1997, p. 10. Overigens wordt in de literatuur en rechtspraktijk wél aangenomen dat AMvB's die uitsluitend door politiedwang zouden kunnen worden gehandhaafd eveneens een wettelijke basis behoeven. Vgl. F.J. van Ommeren, De verplichting verankerd, a.w., p. 30. Anders m.i. C.A.J.M. Kortmann, Constitutioneel recht, derde druk, Deventer 1997, p. 317.

55. F.H. van der Burg, Is het wenselijk dat de overheid maatregelen neemt tot ordening en publicatie van bestaande subsidievoorwaarden?, preadvies NJV 1977, deel I tweede stuk, Zwolle 1977, p. 27.

56. HR 25 januari 1926, NJ 1926, p. 246, m.nt. L. Besier. In casu stond de vraag centraal of de op grond van art. 59 lid 1 onder $c$ van het toenmalige Arbeidsbesluit aan de hoofdinspecteur van de arbeid toekomende bevoegdheid tot het stellen van 'eisen' zijn grondslag vond in de Arbeidswet van 1919. De Hoge Raad beantwoordde deze vraag ontkennend.

57. Vgl. bijv. Van Wijk/Konijnenbelt/Van Male, Hoofdstukken van administratief recht, tiende geheel herziene druk, 's-Gravenhage 1997 , p. 71.

58. Een uitputtende literatuurverwijzing kan hier m.i. achterwege blijven. Ik wijs op het proefschrift van Van Ommeren die een 'klassieke' invulling van de legaliteitseis (n!. voor éénzijdig opgelegde verplichtingen die betrokkenen binden) verdedigt. F.J. van Ommeren, De Verplichting verankerd, a.w., o.m. p. 153-154, 200-201. 
wetgever en bestuur. ${ }^{59}$ In dit kader kan in het bijzonder gewezen worden op het werk van Böhtlingk: 'Het wetsbegrip in Nederland'. ${ }^{0}$ Voor Böhtlingk stond vast dat de Nederlandse Grondwet steeds een materieel wetsbegrip heeft gehuldigd. Het bewijs hiervoor diende volgens hem - o.m. - gezocht te worden in artikel 119 van de Grondwet (het huidige artikel $81 \mathrm{Gw}$ ): 'Het kent de formele wetgever de bevoegdheid toe tot het maken van wetten van een zekere inhoud; men kan er slechts nog over twisten welke inhoud.' 61 Over de inhoud van het wetsbegrip liet de Grondwetgever zich volgens Böhtlingk bewust nooit uit. Hij liet dit over aan de wetenschap, die voor een historisch verantwoorde invulling van het begrip zorg diende te dragen. ${ }^{62}$

Hoe zag Böhtlingk nu dit materiële wetsbegrip? In ieder geval achtte hij het algemeenheidsvereiste een essentiale van het wetsbegrip. Onder wet verstaat Böhtlingk de door de wetgever vastgestelde algemene (naar buiten werkende) rechtsregels die iets gebieden of verbieden. ${ }^{63}$ Het algemeenheidsvereiste heeft een ruimtelijke en temporele dimensie, terwijl het vereiste ook meebrengt dat de rechtsregel zich steeds - bij herhaling - tot een in abstracto te bepalen groep van rechtssubjecten dient te richten. ${ }^{64} \mathrm{De}$ algemeenheidseis levert een belangrijke bijdrage aan de verwezenlijking van het gelijkheidsbeginsel en het verbod van willekeur.

Volgens Böhtlingk en Logemann vormde het begrip 'rechtsregel' (naast het belangrijke algemeenheidsvereiste) de kern van het wetsbegrip. ${ }^{65}$ Een regel kan pas als rechtsregel worden bestempeld indien hij bepaalt waartoe deelnemers aan het rechtsverkeer jegens elkaar verplicht zijn. De regel is als het ware de bindende factor in het rechtsverkeer, die zorgt voor de stabilisering van (rechts)verwachtingen. ${ }^{66}$ Het wetsbegrip, en derhalve het legaliteitsbeginsel, behoeft volgens Böhtlingk daarom niet beperkt te blijven tot bepalingen inzake ge- en verboden. Ten aanzien van publiekrechtelijke subsidieregelingen merkt hij bijv., in het kader van zijn beschouwingen over het wetsbegrip van de Franse revolutie, op dat '...indien men deze regelingen gekend had, men ze zeker onder het wetsbegrip zou

59. Vgl. het Rogge-arrest van de Hoge Raad (HR 10 juni 1919, NJ 1919, p. 650). In dit arrest kwam de interpretatie van het wetsbegrip aan de orde in het kader van de beantwoording van de vraag of een ministeriele regeling als een wet in de zin van het (toenmalige) art. 99 RO kon worden aangemerkt.

60. F.R. Bohtlingk/J.H.A. Logemann, Het wetsbegrip in Nederland, Alphen aan den Rijn 1966. Zie voor een uitvoerige analyse van de denkbeelden van Bohtlingk ook: F.J. van Ommeren, De verplichting verankerd, a.w., p. $38-46$.

61. Böhtlingk/Logemann, Het wetsbegrip in Nederland, a.w., p. 49.

62. Böhtlingk/Logemann, Het wetsbegrip in Nederland, a.w., p. 50.

63. Böhtlingk/Logemann, Het wetsbegrip in Nederland, a.w. p. 24.

64. Bohtlingk/Logemann, Het wetsbegrip in Nederland, a.w., p. 19,23, 24 (het algemeenheidsvereiste tijdens de Franse revolutie), p. 29 e.v.; Logemann analyseert het algemeenheidsvereiste nader in Hoofdstuk 24, p. 105 e.v. Hij vangt zijn beschouwingen aan met de stelling dat het 'algemeenheidsvereiste' geen noodwendig element is van de rechtsregel, maar een politiek postulaat, een postulaat nl. van de rechtsstaat.

65. Bohtlingk/Logemann, Het wetsbegrip in Nederland, a.w., p. 111.

66. Vgl. in dit kader ook: M. Scheltema, Bestuursrecht: Is het bestuur wetgever in eigen zaak ?, in: Problemen van wetgeving, Deventer 1982, p. 132: 'De bevoegdheden en verplichtingen van bestuursorganen en de rechten en verplichtingen van burgers zijn een uitgangspunt, op grond waarvan zij van elkaar bepaalde gedragingen kunnen verwachten'. 
hebben gevat, omdat zij, in niet mindere mate dan de ge- of verbiedende regelingen, de positie van de vrije onderdaan beheersen' ${ }^{67}$

Ofschoon de analyses van Böhtlingk een belangrijke bijdrage leverden aan de karakterisering van het wetsbegrip, droegen zij niet bij aan het verhelderen van de afgrenzing tussen de bevoegdheden van de formele wetgever en het bestuur. Hierbij dient wél uitdrukkelijk te worden vermeld dat dit ook niet de intentie van Böhtlingk was, die reeds zelf aankondigde zich niet te richten op 'het competentievraagstuk' dat volgens hem de discussie rond het wetsbegrip beheerste. ${ }^{68}$

Het belang van Böhtlingks beschouwingen is met name gelegen in het feit dat aandacht werd gevestigd op belangrijke inhoudelijke kenmerken van wetgeving. Böhtlingks werk geeft blijk van een duidelijk pleidooi voor rechtszekerheid in de vorm van voorzienbaar en voorspelbaar overheidsgedrag op basis van duidelijke regels. Deze rechtsregels dienen de afwezigheid van willekeur te garanderen en de gelijke behandeling van burgers te bevorderen.

\subsubsection{De verzorgingsstaat en het wetsbegrip}

In de loop van de twintigste eeuw, en met name na de Tweede Wereldoorlog, ontstaat er door de groei van de verzorgingsstaat steeds meer kritiek op het klassieke negentiendeeeuwse wetsbegrip dat de legaliteitseis beperkte tot de sfeer van de 'Eingriffsverwaltung' Deze kritiek, die niet door de denkbeelden van Böhtlingk kan worden ondervangen ${ }^{69}$, is allerminst eenduidig, doch kan voor een belangrijk deel worden teruggevoerd op het feit dat de publieke regelstelling in deze eeuw niet langer beperkt bleef tot de ge- en verboden van de liberale rechtsstaat. De verzorgingsstaat bracht een actief handelende, sturende en presterende overheid op velerlei terreinen, die zich niet meer in het oude keurslijf van het 'Buijsiaanse' wetsbegrip liet dringen. ${ }^{70} \mathrm{Er}$ worden dan ook verschillende pogingen ondernomen om dit begrip te herijken. ${ }^{71}$

Kranenburg ${ }^{72}$ keerde zich tegen het dogmatische karakter van de 'klassieke' wetsdefinitie van Buijs. Volgens hem was er voorhands geén theoretische aanleiding om aan te nemen dat het wetsbegrip uitsluitend gedefinieerd dient te worden als 'een rechtsregel, een norm, de burgers bindende'. Kranenburg koos voor een meer pragmatische invalshoek door uit te gaan van de veronderstelling dat er onder de regels die voor 'het toekomstig leven der groep' gemaakt worden sommigen zijn die van uitzonderlijke betekenis zijn voor de burgers van de staat. Met name regelingen die de vrijheid ordenen en beperken springen in

67. Böhtlingk/Logemann, Het wetsbegrip in Nederland, a.w., p. 25; zie ook p. 53 en 54.

68. Bohtlingk/Logemann, Het wetsbegrip in Nederland, a.w., p. 44 en 45; essentieel in dit kader is dat Bohtlingk met kracht de stelling verdedigt dat de formele wetgever niet het enige orgaan is dat wetgeving in materiele zin kan uitvaardigen. Zie i.h.b. p. 54 e.v. Vgl. in dit kader: F.J. van Ommeren, De verplichting verankerd, a.w., i.h.b. p. 40.

69. Vgl. Ter Spill en Tak die in hun preadvies voor de Vereniging voor Administratief Recht constateerden dat het pleidooi van Bohtlingk voor een verruiming van het materiłle wetsbegrip tot alle algemene regels nooit goed is aangeslagen. F.W. ter Spill en A.Q.C. Tak, Onwetmatig bestuur, Geschriften van de VAR nr. 86, Alphen aan den Rijn 1981, p. 43. 
het oog. ${ }^{73}$ Volgens Kranenburg ontwikkelde zich in het juridisch spraakgebruik echter een wetsbegrip dat slechts zag op een bepaald onderdeel der ordeningen van het groepsleven, $\mathrm{nl}$. die, welke rechten en verplichtingen der burgers regelen. ${ }^{74}$ Impliciet verwierp Kranenburg hiermee mijns inziens de beperking van het wetsbegrip tot 'ge- en verboden'.

De verzorgingsstaat bracht ook op grote schaal een type bestuurlijke wetgeving voort dat in steeds geringere mate de inhoudelijke algemene rechtsregels omvatte zoals die door Böhtlingk werden omsthreven. De wetgever legde steeds meer de nadruk op (discretionaire) bevoegdheidsscheppende en toedelende bepalingen, waardoor de taak van inhoudelijke normstelling in belangrijke mate verschoof van hem naar het bestuur. ${ }^{75}$ Het algemeenheidspostulaat maakte plaats voor het uitgangspunt van concrete normstelling door de 'uitvoerende macht' op basis van (discretionaire) bestuursbevoegdheden. En waar nog algemene inhoudelijke regels werden gesteld, daar gebeurde dit steeds vaker bij wijze van gedelegeerde bevoegdheid door de regering, de ministers of organen van gedecentraliseerde lichamen. De wetgever zelf trad, wat betreft de inhoud van het normstellingsproces, terug. ${ }^{76}$

Koopmans heeft in zijn bekende opstel 'De rol van de wetgever' op indringende wijze de aandacht gevestigd op dit verschijnsel. Volgens Koopmans is de verzorgingsstaat zoals wij die nu kennen goeddeels een schepping van de wetgever. Deze richtte zich in de twin-

70. Vgl. F.R. Bohtlingk in zijn oratie 'De rechtsstaat Nederland' (p. 6): 'Deze rechtsstaat Nederland is intussen in dezelfde crisis geraakt, die overal in West-Europa het klassieke rechtsstaatbegrip aan het wankelen heeft gebracht. De staatsonthouding maakte plaats voor de welvaartsstaat, de staat die behalve als nachtwaker ook optreedt als uitdeler van diensten, als ondernemer, als controleur van de nationale economie, als arbiter tussen de verschillende belangengroepen en tenslotte als consument van bijv. gasmaskers, helmen en gewone kantoorbehoeften.'

71. Pogingen in die zin dat géén genoegen wordt genomen met een zuiver 'formeel wetsbegrip'. De louter formele interpretatie van art. 81 (art. 119 oud) van de Grondwet wint wél sterk terrein. Zie bijv. E.M.H. Hirsch Ballin, Rechtsstatelijke subsidieverhoudingen, preadvies VAR, Geschriften van de Vereniging voor Administratief Recht XCIX, Alphen aan den Rijn 1988, p. 65.

72. R. Kranenburg, Het Nederlandsch staatsrecht, a.w., m.n. p. 76. e.v.

73. R. Kranenburg, Het Nederlandsch staatsrecht, a.w., p. 77.

74. R. Kranenburg, Het Nederlandsch staatsrecht, a.w., p. 79.

75. Zie 0.m.: Orde in de regelgeving, a.w., p. 7; Ph. Eijlander, De wet stellen, diss. KUB, Zwolle 1993, o.a. p. 31 en 46; T. Koopmans, De rol van de wetgever, in: Honderd jaar rechtsleven, Zwolle 1970, p. 229 en 230; C.A.J.M. Kortmann, Het eeuwfeest van Meerenberg, a.w., p. 1278 en N. Verheij, Deuken in het ideaal, a.w., p. 237-238.

76. Deze ontwikkeling is bekend geworden onder de benaming 'terugtred van de wetgever'. Dit begrip werd in 1910 door Struycken geïntroduceerd. Zie: A.A.H. Struycken, Administratie of rechter?, Amhem 1910. Struycken introduceerde het begrip in zijn betoog tegen de wetsontwerpen van Loeff inzake een nieuw algemeen stelsel van administratieve rechtspraak. Hij benadrukte in dit verband de eigen verantwoordelijkheid van het bestuur binnen het proces van statelijke rechtsvorming. Het begrip werd verder uitgewerkt door Van Wijk in zijn rede 'Voortgaande terugtred'. H.D. van Wijk, Voortgaande terugtred, opgenomen in: Besturen met recht, 's-Gravenhage 1974, p. 99 e.v. (zie i.h.b. p. 102 en 103, a.w.). Ik wijs ook nog op: M.C.P.M. van Schendelen, Terugtred van de wetgever, Groningen 1976 en op A.M. Donner, Nederlands bestuursrecht, Algemeen deel, Alphen aan den Rijn 1987, p. 80. Volgens Donner kan men de wettelijke regelingen in het bestuursrecht soms eerder vergelijken met 'kapstokken'. 
tigste eeuw steeds minder op de codificatie van rechtsregels. In plaats daarvan beschouwde hij als zijn belangrijkste taak de modificatie en sturing van de samenleving. ${ }^{77} \mathrm{Om}$ deze nieuwe taak te kunnen vervullen drong de wetgever zich als het ware in een machtigingsrol. Tot zijn primaire taak rekende hij het creëren van bevoegdheden, waardoor hij in de eigenlijke zin van het woord 'wet-(..) gever' werd. ${ }^{78}$ Ondanks deze ontwikkeling blijft de rol van de wetgever volgens Koopmans evident: 'De wet blijft (..) tenslotte het juridische fundament waarop het gevoerde overheidsbeleid rust; d.w.z. de geldigheid van alle handelingen wordt aan de wet afgemeten. De wet is als het ware in juridische zin de constitutie van het beleid. ${ }^{79}$

De opkomst van de verzorgingsstaat had een gigantisch effect op het denken over wetmatigheid van bestuur. In de tweede helft van de twintigste eeuw blijken nl. steeds meer auteurs het legaliteitsbeginsel te willen uitbreiden in die zin dat zij óok voor de sfeer van de 'Leistungsverwaltung' (o.m. uitkeringen en subsidies) een - aangepaste - eis van wettelijke grondslag stellen. ${ }^{80}$ De Awb-wetgever heeft deze ontwikkeling niet onbeantwoord willen laten. ${ }^{81}$

\subsubsection{De naoorlogse theorievorming in Duitsland}

Het is zinvol om in dit verband ook een blik te werpen op de gedachtenvorming over het legaliteitsbeginsel in het naoorlogse Duitsland. Niet ontkend kan immers worden dat juist de Duitse denkbeelden over het wetsbegrip veel invloed hadden, en hebben, in Nederland. ${ }^{82}$

Principiële kritiek op het 'klassieke wetsbegrip' wordt in de jaren '50 en '60 o.m. aangetroffen bij de Duitse auteurs $\operatorname{Imboden}^{83}$ en Mayer ${ }^{84}$, alsmede bij de Zürichse hoog-

77. Vgl. voorts K.F. Schuiling en H.B. Winter, De pretenties van de wetgever, Openbaar Bestuur 1992/1, p. 2.

78. T. Koopmans, De rol van de wetgever, a.w., p. 230.

79. T. Koopmans, De rol van de wetgever, a.w., p. 231; ondanks deze vrij 'instrumentele' benadering blijft ook Koopmans m.i. de waarborgfunctie van de formele wet erkennen, wanneer hij ervoor pleit dat het toepassingsgebied voor elke legislatieve maatregel in de wet dient te worden bepaald (p. 233-234).

80. Vgl. bijv. E.M.H. Hirsch Ballin, Rechtsstaat, grondrechten en subsidieverhoudingen, in: Rechtsstatelijke subsidieverhoudingen, Geschriften voor de VAR XCIX, Alphen aan den Rijn 1988, p. 67-69.

81. In de derde tranche van de Awb (Titel 4.2 subsidies) wordt in principe uitgegaan van een wettelijke grondslag voor subsidiebevoegdheden. De volgende passage uit de MvT spreekt boekdelen: 'Om de met de subsidieverlening beoogde doelen te kunnen bereiken en enerzijds misbruik en oneigenlijk gebruik van subsidies te kunnen tegengaan, anderzijds subsidie-ontvangers voldoende rechtszekerheid te verschaffen, dienen rechten, plichten en bevoegdheden van subsidiegevers en subsidie-ontvangers op heldere wijze te worden afgebakend, een evenwichtig geheel te vormen en goed kenbaar te zijn. Daarvoor is een wettelijke regeling nodig' (curs. R.J.N.S.). TK 1993/1994, 23700, nr. 3, p. 18 en 19.

82. Buijs gaf reeds aan dat hij zijn visie inzake het materielle wetsbegrip ontleende aan de Duitse rechtsgeleerde Laband. Zoals hierna nog zal blijken is ook de theorie van de 'ingrijpende besluiten' (o.a. in Nederland uitgedragen door Van der Vlies) verwant - of zelfs ontleend - aan de Duitse 'Wesentlichkeitstheorie'.

83. M. Imboden, Das Gesetz als Garantie rechtsstaatlicher Verwaltung, Basel/Stuttgart 1954, p. 19 en 20.

84. F. Mayer, Das verfassungsrechtliche Gebot der gesetzlichen Ermächtigung, in: Festschrift zum 75. Geburtstag von Hermann Nottarp, Karisruhe 1961, p. 191. 
leraar Giacometti. ${ }^{85}$ Hun kritiek spitst zich in essentie toe op het feit dat aan het legaliteitsbeginsel, zoals dat in de sfeer van de 'Eingriffsverwaltung' werd geoperationaliseerd, historisch-liberale uitgangspunten ten grondslag liggen die inmiddels achterhaald zijn. Deze uitgangspunten reduceerden de betekenis van het legaliteitsbeginsel volgens genoemde auteurs ten onrechte tot een waarborg tegen ingrepen in de vrijheid en eigendom van individuele rechtssubjecten door de staat. Gevolg van deze nogal éénzijdige benadering was dat het legaliteitsprincipe niet meer werd gezien als een ordeningsprincipe dat centraal staat in de leer van de scheiding van de verschillende staatsfuncties. Volgens Mayer dient het beginsel van 'wetmatigheid van bestuur' juist gezien te worden als een gevolg van de statelijke machtenscheiding: 'Das Prinzip der Gesetzmäßigkeit der Verwaltung ist insoweit ein Ausfluß, eine unmittelbare Folge des Gewaltenteilungsprinzips. ${ }^{86} \mathrm{Op}$ grond hiervan $k a n$ het legaliteitsbeginsel volgens Mayer niet beperkt blijven tot de sfeer van de typische 'Eingriffsverwaltung': 'Ergibt sich aber der Grundsatz der Gesetzmäßigkeit der Verwaltung nicht als Folge eines allgemeinen Freiheitspostulats, sondern unmittelbar aus dem Prinzip der Gewaltentrennung, dann kann dieser Grundsatz nicht auf die Eingriffe in Freiheit und Eigentum des Burgers, also auf die belastenden Verwaltungsakte beschrankt sein, sondern beansprucht Geltung für die gesammte Verwaltung, jedenfalls soweit sie rechtlich verbindliche Entscheidungen zu treffen hat. ${ }^{, 87}$ Het belang van de stellingname van Mayer is met name gelegen in het feit dat het legaliteitsbeginsel wordt gedefinieerd als een democratisch-rechtsstatelijk principe dat het rechtsvormingsprimaat van de wetgever binnen de democratische-rechtsstaat tot uitdrukking brengt.

Giacometti, die het legaliteitsbeginsel eveneens fundeerde in de staatsrechtelijke scheiding van machten, legt hierbij de nadruk op het feit dat de wet steeds een essentiële positieve (d.w.z. richtingevende) voorwaarde is voor bestuursactiviteit. ${ }^{88}$ De langs democratische weg tot stand gekomen wet dient de taken en belangen te omschrijven die het bestuur mag en moet behartigen (de 'gesetzlich zugelassenen Aufgaben'). Deze specifieke functie van de wet kan volgens Giacometti niet vervangen worden door een meer algemene binding van het bestuur aan het recht (d.w.z. aan grondrechten en aan algemene rechtsbeginselen).$^{89}$ Giacometti stelt bijgevolg ók voor de sfeer van de 'Leistungsverwaltung' de legaliteitseis:

'Gleich wie bei der Eingriffsverwaltung ist das Gesetz auch auf diesen anderen Verwaltungsgebieten als Garant vorab der Rechtsgleichheit, Rechtssicherheit und politischen Freiheit der Burger unentbehrlich. Denn das Gesetz schutzt auch hier das Individuum vor Willkürakten der verwaltenden Behorden, es gewăhrt ihm auch auf diese Gebieten die notwendige Rechtssicherheit und gestaltet auch diese Verwaltung entsprechend der Rechtsstaatsidee zu einer demokratischen Verwaltung' (curs. R.J.N.S.). ${ }^{90}$

85. Z. Giacometti, Allgemeine Lehren des rechtsstaatlichen Verwaltungsrechts, 1. Band, Zürich 1960, i.h.b. p. 250-251.

86. F. Mayer, Das verfassungsrechtliche Gebot der gesetzlichen Ermăchtigung, a.w., p. 193.

87. F. Mayer, Das verfassungsrechtliche Gebot der gesetzlichen Ermăchtigung, a.w., p. 193.

88. Z. Giacometti, Allgemeine Lehren des rechtsstaatlichen Verwaltungsrechts, a.w., i.h.b. p. 246-247, 251 en 254. 
Het gedachtengoed van de hiervoor genoemde auteurs komt naar mijn oordeel tot uitdrukking in de latere jurisprudentie van het Duitse Bundesverfassungsgericht. Deze constitutionele rechter ontwikkelde in de jaren ' 70 van de twintigste eeuw een nieuwe visie inzake het 'Gesetzesvorbehalt' die bekend zou worden onder de benaming 'Wesentlichkeitstheorie'. Van belang is dat het Bundesverfassungsgericht zich met name heeft laten inspireren door de idee van de statelijke machtenscheiding en het democratiebeginsel. Hierbij koppelde het Bundesverfassungsgericht los van het verouderde negentiende-eeuwse 'Eingriffscriterium' en beperkte de omvang van het legaliteitsbeginsel niet langer tot belastende bestuurshandelingen. Het primaat van de democratisch gelegitimeerde wetgever werd gelijktijdig opgewaardeerd. Dit blijkt duidelijk uit een standaarduitspraak van 28 oktober $1975 .{ }^{91} \mathrm{Ik}$ citeer de relevante rechtsoverwegingen hier, vanwege hun belang, integraal:

'Der Grundsatz des Vorbehalts des (allgemeinen) Gesetzes wird im Grundgesetz nicht expressis verbis erwahnt. Seine Geltung ergibt sich jedoch aus Art. 20 Abs. 3 GG. Die Bindung der vollziehende Gewalt und der Rechtsprechung an Gesetz und Recht, der Vorrang des Gesetzes also, wurden ihren Sinn verlieren, wenn nicht schon die Verfassung selbst verlangen wurde, daß staatliches Handeln in bestimmten grundiegenden Bereichen nur Rechtens ist, wenn es durch das formliche Gesetz legitimiert wird. (...) Die von der konstitutionellen, burgerlich-liberalen Staatsauffassung des 19. Jahrhunderts gepragte Formel, ein Gesetz sei nur dort erforderlich, wo "Eingriffe in Freiheit und Eigentum" in Rede stehen, wird dem heutigen Verfassungsverstandnis nicht mehr voll gerecht (vgl. BVerfGE 8, 155 [167]).Im Rahmen einer demokratisch-parlementarischen Staatserfassung, wie sie das Grundgesetz ist, liegt es naher anzunehmen, daß die Entscheidung aller Grundsatzlichen Fragen, die den Burger unmittelbar betreffen, durch Gesetz erfolgen $\mathrm{mu}$, , und zwar losgelöst von dem in der Praxis fliessenden Abgrenzungsmerkmal des, Eingriffs'. Staatliches Handeln, durch das dem Einzelnen Leistungen und Chancen gewahrt und angeboten werden, ist fur eine existenz in Freiheit oft nicht weniger bedeutungsvoll als das Unterbleiben eines ,Eingriffs'. Hier wie dort kommt dem vom Parlament beschlossenen Gesetz gegenuber dem blossen Verwaltungshandeln die unmittelbar demokratische Legitimation zu, und das parlamentarische Verfahren gewahrleistet ein hoheres $\mathrm{MaB}$ an Offentlichkeit der Auseinandersetzung und Entscheidungssuche und damit auch grossere Moglichkeiten eines Ausgleichs widerstreitender Interessen' (curs. R.J.N.S.).

89. Z. Giacometti, Allgemeine Lehren des rechtsstaatlichen Verwaltungsrechts, a.w., p. 285. Giacometti merkt over de algemene normering door grondrechten en rechtsbeginselen op: 'Diese können jedoch als allgemeine, das gesamte staatliche Leben beherrschende Rechtsgrundsatze die gesetzesfreie Verwaltung nicht so intensiv inhaltlich ordnen wie das Gesetz, sondern vermogen dies nur in allgemeinster Weise zu tun' (curs. R.J.N.S.). Zie voorts hoofdstuk 3 van dit boek, waar ik de relatie tussen het specialiteits- en democratiebeginsel heb besproken.

90. Z. Giacometti, Allgemeine Lehren des rechtsstaatlichen Verwaltungsrechts, a.w., p. 251.

91. BVerfG 28 oktober 1975, BVerfGe 40, nr. 22. Eerst in latere uitspraken hanteert het Bundesverfassungsgericht de zinsnede 'wesentliche Entscheidung im Sinne des Vorbehalt des Gesetzes'. Een belangrijke uitspraak: BVerfG 8 augustus 1978, BVerfGe 49 , nr. 6 (Kalkar-BeschluB). Van belang is nog dat het Gericht de beantwoording van de vraag of er sprake is van een 'wesentliche Entscheidung' i.h.b. laat afhangen van de 'Grundrechtsrelevanz' van statelijke regelgeving (vgl. BVerfG 21 december 1977, BVerfGe $47, \mathrm{nr} .2$ (Sexualkunde). Zie voor een meer uitvoerige analyse van de Duitse Wesentlichkeitstheorie: Ph. Eijlander, De wet stellen, a.w., p. 96 e.v. 


\subsubsection{Herijking van het wetsbegrip in Nederland}

Sinds de jaren ' 70 en ' 80 van de twintigste eeuw gaat ók in Nederland de aandacht uit naar een nieuw 'wetsbegrip' dat geïnspireerd lijkt te zijn door de Duitse 'Wesentlichkeitstheorie'. Eijlander omschrijft deze theorie in zijn proefschrift als '...een opvatting omtrent het "Gesetzesvorbehalt", die inhoudt dat het nemen van alle wezenlijke besluiten is voorbehouden aan de wetgever in formele zin. Dit ongeacht het gegeven of het betreft de "Eingriffsverwaltung", de "Leistungsverwaltung" of de "besondere Gewaltsverhaltnisse"'.92

Ofschoon de eerste aanzetten voor een dergelijke theorie in ons land reeds vóor de Tweede Wereldoorlog kunnen worden gesignaleerd ${ }^{93}$, doet zij eerst na het bekende Fluorideringsarrest van de Hoge $\mathrm{Raad}^{94}$ in de literatuur haar intrede. Ter Spill en Tak hebben mijns inziens - zij het niet onder deze benaming - de 'Wesentlichkeitstheorie' voor het eerst in ons land verdedigd. ${ }^{95}$ Beide auteurs fundeerden het nieuwe wetsbegrip op een tweetal pijlers. Volgens Ter Spill en Tak zijn voor wetgeving zowel het democratisch als het rechtspostulaat wezenlijk. Het democratisch postulaat brengt met zich dat de wetgever zelf (en niet het bestuur) dient te oordelen welke belangen als algemene (of publiekrechtelijke) belangen dienen te worden aangemerkt. De wetgever is tevens verantwoordelijk voor het afwegen van deze belangen tegen elkaar. Ingevolge het democratisch postulaat dient aan het bestuur, zeker onder normale omstandigheden, géén ruimere beslissingsbevoegdheid te worden gelaten dan die inzake de gedelegeerde afweging van algemene belangen, en wel binnen de objectieve grenzen welke gesteld worden door de volksvertegenwoordiging. Voorts kan aan het bestuur (de plicht tot) belangenafweging worden opgedragen inzake die kwesties, waar bijzondere belangen van particulieren (kunnen) conflicteren met belangen van erkend algemene aard. ${ }^{96}$

92. Ph. Eijlander, De wet stellen. Beschouwingen over onderwerpen van wetgeving, Zwolle 1993, p. 96; de theorie gaat niet uit van een onderscheid tussen 'algemeen-bijzonder' (het algemeenheidspostulaat), en hecht evenmin beslissende kracht toe aan het criterium 'naar buiten werken'.

93. Zie: I.C. van der Vlies, Het wetsbegrip en de beginselen van behoorlijke regelgeving, a.w., p. 93.

94. HR 22 juni 1973, NJ 1973, 386, m.nt. A.R.B. (Fluorideringsarrest). In casu was de vraag aan de orde of een drinkwatermaatschappij op grond van art. 4 lid 1 van de (toenmalige) Waterleidingwet bevoegd was om - in het belang van de volksgezondheid - fluorverbindingen aan het drinkwater toe te voegen. Genoemd artikel bevatte een algemene omschrijving van de taak van het waterleidingbedrijf. Deze bestond uit het leveren van deugdelijk drinkwater aan verbruikers. De Hoge Raad overwoog: '...dat de toevoeging van stoffen aan het drinkwater teneinde daarmee een geheel buiten de eigenlijke drinkwatervoorziening gelegen doel te dienen daarom een maatregel is van zo ingrijpende aard dat, zonder wettelijke grondslag, niet kan worden aangenomen dat een waterleidingbedrijf daartoe bij de vervulling van de hem in art. 4 lid 1 van de Wet opgedragen taak de vrijheid heeft' (curs. R.J.N.S.). In dit arrest werd dus voor bepaald feitelijk overheidshandelen een expliciete grondslag in de wet in formele zin vereist, gelet op de ingrijpendheid van dit handelen. Van belang was in dit kader dat de fluoridering niet plaatsvond op basis van de leveringsovereenkomst en dat de overheid zich bovendien in een monopoliepositie bevond.

95. F.W. ter Spill en A.Q.C. Tak, Onwetmatig bestuur, a.w., p. 49. 'De wetsvorm dient daarom te worden gereserveerd voor de als zeer wezenlijk ervaren rechtsregels' (curs. R.J.N.S.).

96. F.W. ter Spill en A.Q.C. Tak, Onwetmatig bestuur, a.w., p. 49 en 50. 
Het primaat van publieke belangenafweging op hoofdlijnen berust in deze optiek bijgevolg bij de formele wetgever, die het bestuur tot concretisering kan machtigen. Het rechtspostulaat brengt vervolgens met zich dat alleen diè materie bij wet in formele zin wordt geregeld die een zodanig rechtsgehalte heeft dat voor de zware wetsvorm gekozen dient te worden. Ter Spill en Tak stellen voor om als richtsnoer het rechtszekerheids- en gelijkheidsbeginsel te hanteren. ${ }^{97}$ Bepaalde materie dient volgens hen bij wet in formele zin te worden geregeld indien zowel het democratisch als het rechtspostulaat dit eisen.

In 1984 verschijnt de dissertatie van Van der Vlies waarin een soort 'Wesentlichkeitstheorie' wordt verdedigd. In de aanloop naar de definiëring van het wetsbegrip verwerpt Van der Vlies expliciet het onderscheid tussen belastend en begunstigend bestuur aan de hand van een analyse van het karakter van subsidieregels. Tegenover het vermeende 'begunstigende karakter' van subsidie staat volgens haar niet zelden de (sterk) afhankelijke positie van de subsidie-ontvanger die gebonden is aan vele bepalingen en voorschriften. In sommige situaties is subsidie zelfs een essentiële voorwaarde voor een aanvaardbaar bestaan. Bovendien heeft elke subsidieregeling, strikt genomen, een keerzijde aan de inkomstenkant van de overheid. ${ }^{98}$ De middelen om subsidies te genereren worden in belangrijke mate bepaald door belastinginkomsten. Het ligt dan voor de hand dat de belastingbetalers in een democratische staat invloed kunnen uitoefenen op de uitgaven. Volgens Van der Vlies is het derhalve niet juist '...om een tegenstelling tussen het opleggen van burgers bindende bepalingen en het verlenen van gunsten te creëren ten einde aan de hand daarvan de competentie van de wetgever te bepalen'. In vervolg hierop pleit zij ervoor de vraag naar de wettelijke grondslag afhankelijk te stellen van de vraag of de te regelen materie een ingrijpend karakter draagt. ${ }^{99}$

De definiëring van 'ingrijpende besluiten' leidt Van der Vlies in hoofdzaak af uit de overwegingen van de Hoge Raad in het reeds aangehaalde fluorideringsarrest. Na enige inleidende beschouwingen wordt het begrip door haar als volgt afgebakend. Er dient voldaan te zijn aan een drietal criteria. Ingrijpend van karakter zijn besluiten: 1. aangaande de eerste levensbehoeften dan wel fundamentele rechtsbeginselen (waaronder het verlenen van bevoegdheden aan andere organen om ze uit te werken); 2. waardoor (nagenoeg) onontkoombare dwang zal ontstaan om conform het besluit te handelen, en 3a. waarover diepgaande meningsverschillen in de samenleving blijken te bestaan, of $3 \mathrm{~b}$. waarbij fundamentele zaken geraakt worden die de staatsorganisatie betreffen en waarbij het bestuur een eigen belang heeft dan wel de schijn daarvan bestaat. ${ }^{100}$

97. F.W. ter Spill en A.Q.C. Tak, Onwetmatig bestuur, a.w., p. 51 en 52; de auteurs erkennen dat de vraag naar het rechtsgehalte van de materie moeilijk is te beantwoorden. Juist daarom dient deze keuze primair aan de volksvertegenwoordiging te worden overgelaten.

98. Vgl. M. Imboden, Das Gesetz als Garantie rechtsstaatlicher Verwaltung, a.w., p. 42; Imboden spreekt in dit kader over een 'Verteilungsproblem'.

99. I.C. van der Vlies, Het wetsbegrip en de beginselen van behoorlijke regelgeving, a.w., p. 98; Vgl. ook: F.W. ter Spill en A.Q.C. Tak, Onwetmatig bestuur, a.w. p. 46. 
De 'Wesentlichkeitstheorie', die in zowel de Duitse als de Nederlandse literatuur ook wel aan kritiek blootstaat ${ }^{101}$, klinkt tot slot ook duidelijk door in het Eindrapport van de commissie Polak ${ }^{102}$, wanneer wordt gesteld:

\begin{abstract}
'Gegeven de noodzaak van delegatie en rekening houdend met het belang van overzichtelijke regelgeving, kan uit het axioma van het primaat van de wetgever de algemene norm worden afgeleid dat de wet tenminste zowel de reikwijdte en de hoofdlijnen van een regeling alsmede de belangrijkste naar buiten werkende voorschriften behoort te bevatten, terwijl aan de lagere wetgever de nadere uitwerking en de regeling van details kan worden overgelaten.'
\end{abstract}

Tot de belangrijkste naar buiten werkende voorschriften in de hedendaagse bestuursrechtelijke wetgeving dienen mijns inziens in ieder geval die bepalingen te worden gerekend welke bestuursorganen machtigen tot énzijdig publiekrechtelijk rechtshandelen, alsmede die voorschriften die deze bevoegdheidsnormen inhoudelijk en procedureel normeren. ${ }^{103}$

\title{
4.3 Eigen visie inzake de omvang van de legaliteitseis
}

Gelet op het voorafgaande zal het duidelijk zijn dat ik de legaliteitseis voor bestuursbevoegdheid stel ongeacht of er sprake is van 'Eingriffs-' of 'Leistungsverwaltung. ${ }^{104}$ Dit ligt voor de hand indien de ratio achter het staatsrechtelijke legaliteitsbeginsel mede wordt

100. I.C. van der Vlies, Het wetsbegrip en de beginselen van behoorlijke regelgeving, a.w., p. 105 en 106. Als voorbeeld van een besluit dat volgens haar op grond van deze criteria uitsluitend in de vorm van een formele wet dient te worden genomen noemt $z \mathrm{ij}$ de plaatsing van kruisvluchtwapens op Nederlands Grondgebied. Een in die tijd zeer actueel onderwerp in de Nederlandse samenleving. Het mag zeer opvallend worden genoemd dat juist het Bundesverfassungsgericht in het 'Mittelstreckenraketen-Urteil' (BVerfG 18 december 1984, BVerfGe 68, nr. 1) tot de uitspraak komt dat voor een dergelijk besluit - ofschoon zeer wezenlijk - géén wet in formele zin noodzakelijk is. Voldoende wordt geacht dat het parlement (gelet op het democratieprincipe) gekend wordt in het regeringsbesluit (het zgn. 'Parlamentsvorbehalt'). Hierbij wijst het Bundesverfassungsgericht uitdrukkelijk op de parlementaire rechten.

101. De belangrijkste kritiek op de 'Wesentlichkeitstheorie' is het verwijt dat achter het begrip 'ingrijpende' of 'wezenlijke' besluiten een inherente vaagheid schuilgaat. Dit dwingt tot casulstische jurisprudentie. Vgl. N. Achterberg, Allgemeines Verwaltungsrecht, 2. vollig neubearbeitete Auflage, Heidelberg 1986, p. 338339; A. Bleckmann, Staatsrecht I, Staatsorganisationsrecht, Koln/Berlin/Bonn/München 1993, p. 225; H. Maurer, Allgemeines Verwaltungsrecht, a.w., p. 108-109 en N. Verheij, Deuken in het ideaal, a.w., p. 240.

102. Orde in de Regelgeving, a.w., p. 43; zie ook p. 19 van het rapport: 'Zonder tenminste een machtiging daartoe van de wetgever, behoren geen algemeen verbindende voorschriften tot stand gebracht te kunnen worden.' Een en ander brengt de commissie tot de conclusie dat het legaliteitsbeginsel ook in volle omvang geldt voor subsidie-regelingen.

103. Vgl. aanwijzing 24 van de Aanwijzingen voor de regelgeving 1993 zoals laatstelijk gewijzigd bij besluit van de Minister-President d.d. 20 december 1995 (voor de doorlopende tekst wordt verwezen naar de Sduteksteditie van de Aanwijzingen, Den Haag 1996: 'Gereedschap voor de wetgevingspraktijk', deel vier). Deze aanwijzing wordt door Konijnenbelt overigens in verband gebracht met de jurisprudentie van het Duitse Bundesverfassungsgericht. Van Wijk/Konijnenbelt/Van Male, Hoofdstukken van administratief recht, a.w., p. 74 (noot 19). 
gefundeerd in de scheiding van de statelijke machten, de hieraan inherente 'ondergeschiktheid' ${ }^{105}$ van het bestuur aan de democratisch gelegitimeerde wetgever en in het rechtszekerheidsbeginsel. Eénzijdige rechtsvorming door het bestuur dient mijns inziens, voorzover deze van invloed is op de rechtspositie van rechtssubjecten, te berusten op een democratische grondslag. Deze grondslag dient in ieder geval in positieve zin, d.w.z. doelbestemd, richting te geven aan het rechtshandelen van het bestuur (de specialiteitseis). De wet biedt mijns inziens uiteindelijk de beste waarborg om een bestuursbevoegdheid inhoudelijk en procedureel te normeren. Het spreekt voor zich dat de legaliteitseis (de wet-matigheid), vanuit dit perspectief bezien, niet vereenzelvigd kan worden met een algemene rechtmatigheidsnotie.

De onderliggende vraag, nl. wanneer - en op welke wijze - het gerichte bestuurlijk rechtshandelen (de 'bevoegdheidsuitoefening') de rechtspositie van rechtssubjecten beïnvloedt, komt in hoofdstuk 9 van dit boek nog aan de orde. Op deze plaats volsta ik met de stelling dat de rechtspositie van een rechtssubject door een bevoegdheidsuitoefening wordt beïnvloed indien de betreffende bevoegdheidsuitoefening van invloed is op de materiële rechts-belangen van dat subject. In de hoofdstukken 6 en 9 zal ik deze materiële rechtsbelangen herleiden tot typisch vermogensrechtelijke belangen en grond- en mensenrechten. Hierbij wordt aansluiting gezocht bij de jurisprudentie van het Europese Hof voor de Rechten van de Mens. ${ }^{106}$ Bij aantasting, beperking of vaststelling van rechtsbelangen door het bestuur stel ik derhalve de formele eis van wetmatigheid.

104. Ik benadruk overigens dat dit onderscheid m.i. uiteindelijk bijzonder moeilijk kan worden gemaakt, daar ook begunstigend bestuurshandelen vaak leidt tot (bijkomende) verplichtende normstelling voor rechtssubjecten. Dit gegeven vormt op zich een reden om een 'ruime' bevoegdheidseis te stellen. Vgl. wat betreft de uitbreiding van de bevoegdheidseis De Haan/Drupsteen/Femhout, Bestuursrecht in de sociale rechtsstaat I, a.w., p. 14-15.

105. Ik plaats hier het begrip 'ondergeschiktheid' bewust tussen aanhalingstekens omdat het hier geen echte hiërarchie betreft. Het gaat veel meer om staatsrechtelijk te onderscheiden organisatiefuncties die op elkaar zijn aangewezen, maar desalniettemin, wat betreft het publieke rechtsvormingsproces, een eigen taak hebben te vervullen. Vgl. H. Dreier, Hierarchische Verwaltung im demokratischen Staat, Genese, aktuelle Bedeutung und funktionelle Grenzen eines Bauprinzips der Exekutive, Tubingen 1991, p. 163-164, waar deze auteur opmerkt: 'Das Gesetz ist kein selbstgenugsames Endprodukt des Prozessus rechtlicher Steuerung und Lenkung des politischen Gemeinwesens, sondern eine erganzungsbedurftige, modifizierungsfahige ,Zwischenstufe' im Gesamtvorgang verfassungsgebundener, sozialgestaltender Rechtsverwirklichung: zwar Ende der kontroversen politischen Willensbildung, aber zugleich Anfang der Realisierung des nun temporăr verbindlich festgelegten Mehrheitswillens.'

106. Ik kan mij dan ook goed vinden in de suggestie van Tak om op basis van de jurisprudentie van het Europese Hof voor de Rechten van de Mens inzake de 'determination of civil rights and obligations' (vgl. art. 6 EVRM) - naar analogie - een 'modeme' wetmatigheidsleer te ontwikkelen. Zie: A.Q.C. Tak, Boekbespreking F.J. van Ommeren, De verplichting verankerd. De reikwijdte van het legaliteitsbeginsel en het materiele wetsbegrip, RMTh. 1997/6, p. 255. Hierbij stel ik mij voor dat, mede in het licht van de verwante Duitse theorievorming, een meer gedifferentieerde wetmatigheidseis tot ontwikkeling kan komen die afhankelijk van de in het geding zijnde rechtsbelangen (denk o.m. aan de 'Grundrechtsrelevanz'), specifieker van aard kan zijn. De fundamentele beginselbouwstenen voor een dergelijke wetmatigheidseis worden, toegespitst op bestuursbevoegdheid, gevormd door het democratiebeginsel, het specialiteitsbeginsel en de algemene rechtszekerheidseis. 


\subsection{Specificiteit van bevoegdheidsnormen in democratisch-rechtsstatelijk perspectief}

Intussen ziet het legaliteitsbeginsel - opgevat als bevoegdheidsbeginsel - op een formele rechtsstatelijke eis: bestuursbevoegdheden dienen in de regel herleidbaar te zijn tot de wet in formele zin en uiteindelijk tot de Grondwet. Met deze vaststelling is echter nog weinig aandacht besteed aan een andere vraag: aan welke kwaliteitseisen dient een dergelijke grondslag te voldoen? Strekt de staatsrechtelijke legaliteitseis ten aanzien van bestuursbevoegdheden zover dat de wetgever iedere bevoegdheid uiterst nauwkeurig en gedetailleerd dient af te bakenen, of kan (soms) volstaan worden met een meer globale doelbinding? In hoofdstuk 2 werd reeds gesteld ${ }^{107}$ dat bevoegdheden in het publiekrecht soms op een meer globale publiekrechtelijke grondslag (bijv. een wettelijke taakopdracht) kunnen steunen. Evenmin werd uitgesloten dat er zelfs - impliciete - bestuursbevoegdheden denkbaar zijn die niet steunen op een expliciete grondslag in de wet. Als uitgangspunt geldt mijns inziens dat ten aanzien van de noodzakelijke specificiteit van de formele grondslag voor bestuursbevoegdheid een genuanceerde en gedifferentieerde benadering noodzakelijk is. De aard van een bevoegdheid is in dit kader van belang.

\subsubsection{Het specialiteitsbeginsel als beginsel van behoorlijke wetgeving}

$\mathrm{Nu}$ komt de dimensie van het specialiteitsbeginsel als beginsel van behoorlijke wetgeving duidelijk in beeld. Aan deze dimensie van genoemd beginsel is in Nederland (nog) niet veel aandacht besteed. ${ }^{108}$ Debet hieraan is wellicht dat het specialiteitsbeginsel naar Nederlands recht moeilijk geoperationaliseerd kan worden als een beginsel dat zich rechtstreeks tot de wetgever richt. Ons land kent immers gén geschreven Grondwettelijke plicht die de wetgever in formele zin opdraagt om zich rekenschap te geven van het specialiteitsgehalte van bevoegdheidscheppende bepalingen in administratieve wetten. ${ }^{109}$

In dit kader kan o.m. uit het Duitse constitutionele stelsel, alsmede uit de rechtspraak van het Europese Hof voor de Rechten van de Mens (EHRM), inspiratie worden geput. De Duitse Grondwet kent bijv. een bepaling die de wetgever in formele zin verplicht om in geval van delegatie van regelgevende bevoegdheid de 'Ermächtigungsnorm' afdoende te specificeren. Hier is het zgn. 'Bestimmtheitsgebot' of de 'Bestimmtheitsgrundsatz' in het geding. Op basis van de bedoelde bepaling heeft het Bundesverfassungsgericht (BVerfG)

107. Vgl. paragraaf 2.7 .

108. Simon heeft bijv. wél aandacht besteed aan deze functie van het specialiteitsbeginsel. Zijn visie zal in hoofdstuk 7 worden besproken. Vgl. ook Van Ommeren die in zijn proefschrift spreekt over het 'wettelijk specialiteitsbeginsel'. F.J. van Ommeren, De verplichting verankerd, a.w., p. 115 (noot 304). Zie verder paragraaf 4.5 van dit hoofdstuk.

109. Afgezien daarvan blokkeert art. $120 \mathrm{Gw}$ (vgl. HR 14 april 1989, AB 1989, 207, m.nt. FHvdB (Harmonisatiewet)) een adequate sanctionering van een dergelijke plicht, die ook op basis van ongeschreven constitutioneel (beginsel)recht binnen ons staatsrecht zou kunnen worden erkend. 
in de naoorlogse periode een omvangrijke jurisprudentie ontwikkeld die het bestuderen waard is. ${ }^{110}$

Ook de jurisprudentie van het Europese Hof voor de Rechten van de Mens (EHRM) is in dit verband relevant vanwege de toetsing aan het vereiste of een bepaalde inbreuk op een verdragsrecht op een afdoende wettelijke grondslag steunt (de 'prescribed by law'-eis).

\subsubsection{Het Duitse 'Bestimmtheitsgebot' (Artikel 80.1 Grundgesetz)}

De Duitse Grondwet (Grundgesetz, afgekort GG) kent een tweetal artikelen die in het bijzonder van belang zijn voor de relatie tussen wetgever en bestuur. Het betreft artikel 20 GG (Rechtsstaatsprinzip) en artikel 80 lid 1 GG (Bestimmtheitsgebot). ${ }^{111}$ In artikel 20 GG liggen de principes van de Duitse democratische-rechtsstaat verankerd. Lid 1 van dit artikel bepaalt expliciet dat de Bondsrepubliek Duitsland 'ein demokratischer und sozialer Bundesstaat' is, terwijl uit lid 2 volgt dat alle statelijke macht uitgaat van het volk. Lid 3 van artikel $20 \mathrm{GG}$ bepaalt vervolgens: 'Die Gesetzgebung ist an die verfassungsmäßige Ordnung, die vollziehende Gewalt und die Rechtsprechung sind an Gesetz und Recht gebunden.'

Uit artikel 20 GG volgt dat het primaat van 'staatliche Rechtsetzung' is gelegen bij de wetgevende organen binnen de staat. De bevoegdheid tot éénzijdige rechtsvorming door bestuursorganen (die 'Exekutive') is niet uitgesloten, doch is als afgeleide van de wetgevende macht (die 'Legislative') per definitie beperkt van aard en omvang. De wetgever zal de bevoegdheid tot éénzijdige rechtsvorming expliciet aan het bestuur dienen toe te kennen, waarbij hij een aantal grondwettelijke eisen in acht dient te nemen. ${ }^{112}$ Enige belangrijke elementen van deze eisen zijn gecodificeerd in artikel 80 lid $1 \mathrm{GG}^{1{ }^{13}} \mathrm{Dit}$ artikel vormt de centrale bepaling binnen de structuur van de Duitse Grondwet wat betreft de competentieverdeling tussen de (Bonds)wetgever en het bestuur op het gebied van de regelstelling. De bepaling vormt de basis binnen het Duitse constitutionele bestel voor delegatie van regelgevende bevoegdheid. In dit opzicht vertoont bedoeld artikel enige verwantschap met artikel 89 van de Nederlandse Grondwet. Omdat artikel 80 lid 1 GG echter belangrijke inhoudelijke grenzen stelt aan de delegatie van regelgevende bevoegdheid, is de constitutionele 'impact' van deze bepaling beduidend groter.

Voordat ik op de inhoudelijke aspecten van deze bepaling inga, dienen enige opmerkingen te worden gemaakt over het toepassingsbereik ervan. In dit kader is het van belang dat

110. In dit kader is Eijlander mij overigens voorgegaan. Zie: Ph. Eijlander, De wet stellen, a.w., p. 96-102.

111. Ik wijs erop dat dit 'Bestimmtheitsgebot' een uitwerking is van de meer algemene constitutionele 'Bestimmtheitsgrundsatz' die bijv. ook is geoperationaliseerd in artikel 103 lid 2 GG (de strafrechtelijke legaliteitseis).

112. Maunz/Durig/Herzog, Grundgesetz Kommentar (losbladig), Band II, 80/5.

113. Art. 80 lid 1 van het GG luidt: 'Durch Gesetz kønnen die Bundesregierung, ein Bundesminister oder die Landesregierungen ermächtigt werden, Rechtsverordnungen zu erlassen. Dabei müssen Inhalt, Zweck und Ausmaß der erteilten Ermächtigung im gesetze bestimmt werden. Die Rechtsgrundlage ist in der Verordnung anzugeben. Ist durch Gesetz vorgesehen, daB eine Ermächtigung weiter Ubertragen werden kann, so bedarf es zur Übertragung der Ermăchtigung einer Rechtsverordnung.' 
men zich realiseert dat Duitsland een Bondsrepubliek is met autonome landen. Artikel 80 lid 1 GG ziet in beginsel uitsluitend op delegatie van regelgevende bevoegdheid door het 'Bundesgesetz' 114 aan de bondsregering, de bondsministers en de landsregeringen. Op grond van artikel 80 lid 1 GG kunnen de genoemde organen van de uitvoerende macht door de bondswetgever gemachtigd worden om 'Rechtsverordnungen' uit te vaardigen. Onder 'Rechtsverordnung' dient te worden verstaan een bindende rechtsregel waardoor rechten en/of plichten van een abstracte groep van rechtssubjecten in het leven worden geroepen, worden gewijzigd dan wel worden opgeheven. ${ }^{15}$ Het begrip 'Rechtsverordnung' ziet bijgevolg op wetgeving in materielle zin. Het directe toepassingsgebied van artikel 80 lid I GG ziet, indien men dit transformeert naar Nederlandse maatstaven, in het bijzonder op de Algemene Maatregel van Bestuur (AMvB) en de ministeriële verordening. Hierbij maakt het artikel géen principieel onderscheid tussen 'Leistungs'- en 'Eingriffsverwaltung'. ${ }^{116}$

Uit de constitutionele verhouding tussen de bond en de landen vloeit voort dat artikel 80 lid 1 GG niet rechtstreeks toepasselijk is op delegatie van regelgevende bestuursbevoegdheid door 'Landesgesetze' aan de bestuursorganen van het betreffende Land. ${ }^{117}$ Desalniettemin gelden ó́k in deze verhoudingen de eisen die in artikel 80 lid 1 GG zijn neergelegd, hetzij op grond van analoge bepalingen in de 'Landesverfassungen', hetzij rechtstreeks op grond van het 'Rechtsstaatsprinzip' (artikel 20 lid 2 GG juncto artikel 28 lid $2 \mathrm{GG}) .{ }^{118}$ De rechtsstatelijke relevantie van het betreffende artikel is ook niet beperkt tot bevoegdheden met een typisch regelgevingskarakter. Hoewel de Grondwettelijke redactie formeel beperkt is tot 'Rechtsverordnungen' blijkt uit de jurisprudentie van het Bundesverfassungsgericht dat de inhoudelijke eisen die uit dit artikel voortvloeien in ieder geval ók relevant zijn voor 'Ermächtigungen der Exekutive zur Vornahme belastender Verwaltungsakte'. ${ }^{119}$ Tot deze conclusie kwam het Gericht an de hand van een uitvoerige analyse, welke hier - vanwege het belang ervan - integraal wordt weergegeven (de Romeinse nummers zijn toegevoegd door mij R.J.N.S.): ${ }^{120}$

(I) 'Das folgt insbesondere aus dem Grundsatz der Gesetzmaßigkeit der Verwaltung. Dieser Grundsatz fordert nicht nur irgendeine, sondern eine begrenzte und naher bestimmte Ermăchtigung der Exekutive

114. F. Mayer, Das Verfassungsrechtliche Gebot der gesetzlichen Ermăchtigung, in: Festschrif zum 75. Geburtstag von H. Nottarp, Karsruhe 1961, p. 190; Maunz/Durig/Herzog, Grundgesetz Kommentar, a.w., 80/19; K. Stern, Das Staatsrecht der Bundesrepublik Deutschland, Band I, Munchen 1984, p. 816.

115. Maunz/Durig/Herzog, Grundgesetz Kommentar, a.w., 80/9.

116. F. Mayer, Das Verfassungsrechtliche Gebot der gesetzlichen Ermachtigung, a.w., p. 190. Op dit punt is er dus een duidelijk verschil met art. 89 van de Nederlandse Grondwet dat in essentie aanknoopt bij de idee dat alleen 'Eingriffsverwaltung' een wettelijke basis behoef.

117. In dit kader dient voorts te worden opgemerkt dat op autonome 'Satzung' (de verordeningsbevoegdheid van decentrale publiekrechtelijke lichamen) het Gebot niet van toepassing is. Zie: A. Bleckmann, Staatsrecht I, Staatsorganisationsrecht, Koln/Berlin/Bonn/Munchen 1993, p. 239-240.

118. Maunz/Durig/Herzog, Grundgesetz Kommentar, a.w., 80/19.

119. Vgl. H. Maurer, Allgemeines Verwaltungsrecht, a.w., p. 110.

120. BVerfG 12 november 1958, BVerfGe 8, nr. 34 (Preisgesetz). 
zur Vornahme belastender Verwaitungsakte; er zielt darauf ab, der Eingriffe der offentliche Gewalt möglichst berechenbar zu machen. Das Gesetz muß die Tatigkeit der Verwaltung inhaltich normieren und darf sich nicht darauf beschranken, allgemein gehaltene Grundsatze auf zu stellen. Eine ,vage Generalklausel', die es dem Ermessen der exekutive uberlaßt, die Grenzen der Freiheit im einzelnen zu bestimmen, ist mit dem Grundsatz der GesatzmaBigkeit der Verwaltung nicht vereinbar (...)

(II) Das ergibt sich ferner aus dem Prinzip der Gewaltenteilung. Sind die Vollmachten der Exekutive nicht hinreichend bestimmt, so fuhrt sie nicht mehr das Gesetz aus und handelt nicht mehr nach den Richtlinien des Gesetzgebers, sondern entscheidet an dessen Stelle (...)

(III) Das folgt schließlich aus der Rechtsstaatlichen Forderung nach moglichst luckenlosem gerichtlichem Schutz gegen die Verletzung der Rechtssphare des Einzelnen durch Eingriffe der offentlichen Gewalt, wie durch Art. 19 Abs. 4 GG gewahrleistet ist. Der durch diese Vorschrift der Gerichten erteilte Rechtsschutzauftrag kann nur dann verwirklicht werden, wenn die Anwendung der norm durch die in die Rechtssphäre des Staatsburgers eingreifende Exekutive von den Gerichten nachprufbar ist. Die Eingriffsermächtigung muß auch aus diesen Grunde hinreichend bestimmt sein (...).'

Uit deze uitspraak blijkt dat aan het staatsrechtelijke legaliteitsbeginsel meer dan formele betekenis toekomt. Het 'Vorbehalt des Gesetzes' vereist nl. dat bevoegdheidsnormen, op grond waarvan het bestuur door de wetgever gemachtigd wordt tot het uitoefenen van (belastende) bestuursbevoegdheden, afdoende inhoudelijk begrensd dienen te worden met het oog op het democratische postulaat én in het belang van een adequate rechtsbescherming. ${ }^{121}$

Na deze algemene opmerkingen kan artikel 80 lid 1 GG nader worden beschouwd. De kern van de betreffende bepaling is neergelegd in de tweede volzin. Hierin zijn in algemene bewoordingen de Grondwettelijke criteria gecodificeerd waaraan een delegatiebepaling (Ermächtigungsnorm) dient te voldoen. Deze volzin luidt: 'Dabei müssen Inhalt, Zweck und Ausmaß der erteilten Ermächtigung im Gesetze bestimmt werden.' Op grond van deze bepaling rust op de wetgever de plicht om wettelijke bepalingen, waarin hij het bestuur machtigt tot het uitvaardigen van 'Rechtsverordnungen', naar onderwerp (Inhalt) en doel (Zweck) te begrenzen. Tevens dient de begrenzing van de gedelegeerde bevoegdheid op objectieve wijze uit de bepaling te blijken (de 'Ausmaß' dient bepaalbaar te zijn).

Voordat aan de hand van de jurisprudentie van het Bundesverfassungsgericht op de genoemde criteria wordt ingegaan, is het van belang de essentie van het Bestimmtheitsgebot dieper te doorgronden. Aan artikel 80 lid 1 GG, dat in de Duitse grondwet werd opgenomen als een reactie op de 'blanco-delegatie' praktijken tijdens de Weimar-periode en het Derde rijk ${ }^{122}$, ligt het principiële uitgangspunt ten grondslag dat in een democratische rechtsstaat de bevoegdheid tot énzijdige rechtsvorming (Normsetzung) door het bestuur slechts beperkt van omvang kan zijn en steeds op een duidelijk

121. Zie in dit kader ook paragraaf 4.6.3.

122. Zie: Denninger/Ridder/Simon/Stein, Kommentar zum Grundgesetz fur die Bundesrepublik Deutschland, Band 2, Neuwied und Darmstadt 1984, p. 746-747. 
omlijnde democratische machtiging behoort te steunen. ${ }^{123}$ Aldus beschouwd, staat het Bestimmtheitsgebot in het teken van de rechtsstatelijke scheiding van machten, ondersteunt het vanuit een democratisch perspectief het primaat van de wetgever en waakt het tegen ongeclausuleerde inperking of uitholling van grondrechten door het regelgevende en beschikkende bestuur. ${ }^{124}$ Het Gebot vervult met andere woorden een democratischrechtsstatelijke spilfunctie binnen de Duitse constitutie. ${ }^{125}$

\subsubsection{Bestimmtheitsgebot en specialiteitsbeginsel}

Mayer $^{126}$ legt in dit kader een verband tussen artikel 80 lid 1 GG en het constitutionele specialiteitsbeginsel (Spezialitätsprinzip). De verhouding tussen de wetgever in formele zin en het bestuur wordt, voorzover het de bevoegdheid tot éénzijdige rechtsvorming betreft beheerst door dit beginsel:

'Die Ermächtigung des Gesetzes muß nach Inhalt, Zweck und Ausmaß nicht nur im konkreten Falle bestimmbar, sondern von Anfang an bestimmt sein. Es gilt also der Grundsatz der Spezialität der Normsetzungsermächtigung. Die Anforderungen des Spezialitätsprinzips bemessen sich dabei nach dem konkreten Fall, "nach der Natur des in Frage kommenden Gesetzes" und vor allem auch nach dem Gesetzeszweck' (curs. R.J.N.S.).

Aan de verhouding tussen wetgever en bestuur ligt binnen het Duitse constitutionele bestel, toegespitst op het proces van éénzijdig gerichte rechtsvorming, het uitgangspunt van 'de speciale machtiging' ten grondslag. Deze grondregel steunt op een tweetal principes. Op de eerste plaats gaat deze regel ervan uit dat het primaat van rechtsvorming in een democratische rechtsstaat berust bij de wetgever, die beschikt over directe democratische legitimatie om éenzijdig rechtsnormen te vormen. Op de tweede plaats rust, als onmiddellijk uitvloeisel van deze primaire regel, op de wetgever de plicht om op een zorgvuldige wijze te waken over dit primaat. Ingevolge artikel 80 lid 1 GG staat de Grondwetgever de wetgever slechts onder een aantal stringente condities toe om het bestuur te machtigen om (gericht) nieuw recht te (doen) vormen. Artikel 80 lid 1 GG waakt, zoals vermeld, over de constitutionele machtenscheiding, en beoogt te voorkomen dat de wetgever substantiële

123. Vgl. Maunz/Durig/Herzog, Grundgesetz Kommentar, a.w., 80/5: 'In Art. 80 umschreibt der Verfassungsgeber die Grenzen der Rechtssetzungsbefugnis der Exekutive und fugt diese damit in das Vorstellungsbild des Grundgesetzes vom Rechtsstaat ein. Die darin zum Ausdruck kommende Auffassung von einer nur beschrankten Rechtssetzung durch die Exekutive entspricht dem Sinn und Zweck des Rechtsstaatsprinzips, wie es dem Grundgesetz zugrundeliegt.'

124. Zie: Denninger/Ridder/Simon/Stein, a.w., p. 751-753.

125. Ik wijs in dit verband op een recente uitvoerige studie van de hand van Papier en Möller, waarin de betekenis van het Bestimmtheitsgebot vanuit diverse rechtsstatelijke invalshoeken wordt belicht. H.-J. Papier en J. Moller, Das Bestimmtheitsgebot und seine Durchsetzung, Aor 1997 (122), i.h.b. p. 178-182.

126. F. Mayer, Das verfassungsrechtliche Gebot der Gesetzlichen Ermächtigung, a.w., p. 189. 
en/of wezenlijke delen van zijn bevoegdheid tot rechtsvorming overlaat aan het bestuur. ${ }^{127}$ Aan het bestuur komt derhalve enkel regelgevende bevoegdheid toe op grond van een speciale 'Normsetzungsermächtigung'. Het machtigen tot gerichte rechtsvorming impliceert tevens een Grondwettelijke plicht om deze machtiging inhoudelijk ${ }^{128}$ af te bakenen aan de hand van de genoemde criteria. Deze eis wordt in de literatuur ook wel aangeduid als het 'Konkretisierungs- und Spezialisierungsgebot'. ${ }^{129}$

\subsubsection{Jurisprudentie Bundesverfassungsgericht}

Het Bundesverfassungsgericht heeft een omvangrijke jurisprudentie over het 'Bestimmtheitsgebot' ontwikkeld, die nu nader wordt geanalyseerd. ${ }^{130}$

In 1951 deed het Bundesverfassungsgericht uitspraak inzake de Herindelingswet voor de landen Baden, Württemberg-Baden en Württemberg. ${ }^{131}$ In deze uitspraak overwoog het Bundesverfassungsgericht ten aanzien van artikel 80 lid 1 GG:

\footnotetext{
'In bewußter Abkehr von der Praxis Weimarer Zeit fordert Art. $80 \mathrm{GG}$ als Grundlage fur Rechtsverordnungen jeder Art eine gesetzliche Ermåchtigung, die nach Inhalt, Zweck und AusmaB genau umgrenzt ist. (..) Das Parlament soll sich seiner Verantwortung als gesetzgebende Korperschaft nicht dadurch entschlagen können, daß es einen Teil der Gesetzgebungsmacht der Regierung ubertragt, ohne genau die Grenzen dieser ubertragenen Kompetenzen bedacht und bestimmt zu haben. (..) Ob die Ermächtigung zum Erlaß von Verordnungen nach Inhalt, Zweck und Ausmaß hinreichend begrenzt ist, laßt sich nur von Fall zu Fall entscheiden. Jedenfalls fehlt es dann an der notigen Beschrănkung, wenn die Ermăchtigung so unbestimmt ist, daß nicht mehr verausgesehen werden kann, in welchem Fälen und mit welcher Tendenz von ihr Gebrauch gemacht werden wird und welchen Inhalt die auf Grund der Ermächtigung erlassen Verordnungen haben können.'
}

Het Bundesverfassungsgericht legde in deze uitspraak de nadruk op een belangrijk aspect van het rechtszekerheidsbeginsel: het voorzienbaarheidsvereiste. De wetgever dient steeds

127. Vgl. H. Hasskarl, Die Begrenzung exekutiver Rechtsetzungsbefugnis unter besonderer Beruchsicktigung der Bundesgezetsgebung, ein Beitrag zu Art. 80 Abs. 1 Satz 2 GG, Saarbricken 1969, p. 56 en 57 . Hier ligt een duidelijk verband met de door het Bundesverfassungsgericht ontwikkelde 'Wesentlichkeitstheorie'. Vgl. in dit kader ook: H. Dreier, Hierarchische Verwaltung im demokratischen Staat, a.w., p. 181, A. Bleckmann, Staatsrecht I, a.w., p. 235 en H.-J. Papier en J. Moller, Das Bestimmtheitsgebot und seine Durchsetzung, a.w., p. 180. In dit verband wijzen deze laatstgenoemde auteurs er nog op dat het Bestimmtheitsgebot beoogt te voorkomen dat enkel de rechter het bestuur nog kan controleren en sturen. Ook deze rechter is aan aspecten van het Bestimmtheitsgebot gebonden, $\mathrm{nl}$. het bieden van rechtszekerheid, maar hij mag het bestuur niet (doelgericht) 'programmeren'. Dit is de tak van de wetgever (a.w., o.m. p. 180 en 191).

128. Deze eis wordt in de Duitse literatuur treffend aangeduid als de 'materiellen Grundsatz der inhallichen Bestimmtheit der Ermächtigung'. R. Winckelmann, Die Rechtssprechung des Bundesverfassungsgerichtes zu Art. 80 Grundgesetz, NJW 1959, p. 962.

129. H. Hasskarl, a.w., p. 58.

130. Een gedeelte van deze analyse publiceerde ik reeds. Zie: R.J.N. Schlossels, Wederkerigheid en specialiteit in het bestuursrecht, in: Eenzijdig en wederkerig? (red. E.C.H.J. van der Linden en A.Q.C. Tak), Deventer 1995, p. 160-163.

131. BVerfG 23 oktober 1951, BVerfGe 1, nr. 10. 
vooraf duidelijkheid te verschaffen over de mogelijke inhoud van 'Rechtsverordnungen', zodat rechtssubjecten zich (in abstracte zin) een beeld kunnen vormen van hun rechten en plichten. Dit toetscriterium van het Bundesverfassungsgericht wordt ook wel aangeduid als de 'Vorhersehbarkeitsformel'. ${ }^{132}$

Uit latere uitspraken blijkt dat de specificeringsplicht direct is gefundeerd in de democratisch-rechtsstatelijke verhouding tussen wetgever en bestuur. Zo legt het Bundesverfassungsgericht een belangrijk verband tussen de taak van de wetgever, $\mathrm{nl}$. het verschaffen van democratische legitimatie aan het bestuur, en het 'Bestimmtheitsgebot'. ${ }^{133}$ Hierbij hanteert het Gericht de zogenoemde 'Selbstentscheidungsformel'. ${ }^{134}$ De wetgever zal zich steeds dienen te beraden over het doel van een regeling. Daarnaast dient de wetgever alle essentiële elementen van een regeling zelf vast te stellen. ${ }^{135}$

In een uitspraak over het 'Umsatzsteuergesetz' van 5 maart 1958 treedt een en ander nog duidelijker op de voorgrond. ${ }^{136}$ Hier overwoog het Gericht met het oog op artikel 80 GG: 'Diese erstmalig im Grundgesetz eingeführte Regel versucht, die Macht der Exekutive im Bereich der Rechtssetzung zu begrenzen und die Verantwortung der Legislative für den Inhalt der Rechtsordnung zu stärken. Artikel 80 GG soll den Gesetzgeber zwingen, die für die Ordnung eines Lebensbereichs entscheidenden Vorschriften selbst zu setzen und, soweit Einzelregelungen der Exekutive überlassen bleiben, sie nach Tendenz und Ausmaß soweit selbst zu bestimmen, daß der mögliche Inhalt der erlassenden Verordnungen voraussehbar ist.' Vervolgens overwoog het Gericht:

\footnotetext{
'Aus dem Rechtsstaatsprinzip ergibt sich, daß die Ermăchtigung so genau bestimmt sein muß, daß schon aus ihr und nicht aus der auf sie gestutzten Verordnung erkennbar und vorsehbar sein muB, was von dem Burger gefordert werden kann. Denn mit dem Rechtsstaatsprinzip verbindet sich die Vorstellung, daß das Gesetz dadurch, daß es nach eingehender Beratung im Parlament in einem grosseren Rechtswert verkorpert als eine Verordnung und in hőherem Maße auf Dauer angelegt ist als die von der Exekutive erlassen Verordnungen.'
}

Uit deze uitspraak blijkt dat het Bundesverfassungsgericht de 'rechtswaarde' van de wet in formele zin van groot belang acht gelet op het democratiebeginsel. Deze 'rechtswaarde' van de wet in formele zin is volgens het Gericht groter dan die van regelstelling door het bestuur. Centrale invalshoek is in dit kader de 'objectieve wil' van de wetgever die in de wet geacht wordt tot uitdrukking te komen. Alleen indien deze in een openbaar debat gevormde 'wil' uit de wettelijke regeling kan worden afgeleid is aan de eisen, welke voortvloeien uit het 'Bestimmtheitsgebot', voldaan: 'Maßgebend ist der in der Bestimmung zum Ausdruck kommende objektive Wille des Gesetzgebers, so wie er sich aus dem

132. H. Hasskarl, a.w., p. 63 .

133. BVerfG 12 juni 1956, BVerfGe, 5, nr. 12.

134. H. Hasskarl, a.w., p. 63.

135. Signaleer de relatie tussen de 'Selbstentscheidungsformel' en de 'Wesentlichkeitstheorie'. Vgl. BVerfG 8 januari 1981, BVerfGe, 56, nr. 1.

136. BVerG 5 maart 1958, BVerfGe 7, nr. 36. 
Wortlaut der Ermächtigungsnorm und dem Sinnzusammenhang ergibt, in den die Ermächtigung gestellt ist. (curs. R.J.N.S.) ${ }^{137}$

Afhankelijk van de aard van de uit te oefenen bestuursbevoegdheid, en de hierbij in het geding zijnde rechtsbelangen, stelt artikel 80 GG strengere eisen aan de specificiteit van de bevoegdheidsgrondslag. Van belang is dat ók dat in de sfeer van de 'Leistungsverwaltung' een duidelijke afgrenzing van de bevoegdheid wordt verlangd:

\footnotetext{
'Eine Ermachtigung muß aber die Grenzen enger ziehen und sachliche Grundsatze aufstellen an die sich der Verordnungsgeber zu halten hat. Wenn auch die Anforderungen des Art. 80 Abs. 1 Satz 2 GG bei Ermächtigungen zu belastenden Normen strenger sein mögen als bei Ermächtigungen zu begunstigenden Regelungen, so kann auch im letzteren Fall nicht darauf verzichtet werden, daß Inhalt, Zweck und Ausmaß der Ermächtigung hinreichend bestimmt sind. Art. 80 Abs. 1 Satz 2 GG dient nicht nur dem Schutz des Staatsburgers vor unvorhergesehen Belastungen seitens der Exekutive, sondern auch und in erster Linie der rechtsstaatlich gebotenen klaren Abgrenzung der Rechtssetzung durch Legislative und Exekutive'.138
}

Het Bundesverfassungsgericht scherpt de eisen die aan de 'Ermächtigungsnorm' worden gesteld in het bijzonder aan indien er grondrechten in het geding zijn (de 'Grundrechtsrelevanz' van de materie). In een uitspraak waarin een bevorderingsregeling inzake middelbare scholieren in het geding was, werd in dit verband overwogen:

\begin{abstract}
'Welche Bestimmtheitsanforderungen im einzelnen erfullt sein müssen, ist von der Besonderheiten des jeweiligen Regelungsgegenstandes sowie der Intensităt der Maßnahme abhăngig. (..) Die Bestimmtheit der Ermächtigungsnorm muß der Grundrechtsrelevanz der Regelung entsprechen, zu der Ermächtigt wird. Greift die Regelung erheblich in die Rechtsstellung des Betroffenen ein, so müsen höhere Anforderungen an den Bestimmtheitsgrad der Ermächtigung gestellt werden, als wenn es sich um einen Regelungsbereich handelt, der die Grundrechtsausubung weniger tangiert' (curs. R.J.N.S.). ${ }^{139}$
\end{abstract}

Ondanks de rechtsstatelijke eisen die aan bevoegdheidsnormen gesteld worden, heeft het Bundesverfassungsgericht naar een zekere balans gezocht tussen doelmatigheid en rechtsstatelijkheid. Het 'Bestimmtheitsgebot' eist, zo blijkt uit latere jurisprudentie, geen uitputtende en uiterst gedetailleerde wettelijke inkadering van een bestuursbevoegdheid. Artikel 80 lid 1 GG eist enkel een 'democratisch-programmatische' inkadering van de bevoegdheidsnorm op hoofdlijnen in het belang van de rechtszekerheid van de burger. Waar het in essentie om gaat is dat de reikwijdte van een 'Ermächtigungsnorm' op een objectieve wijze kan worden afgeleid uit de wettelijke context. ${ }^{140}$ Naarmate intensiever wordt ingegrepen in rechtsposities van burgers, gelden stringentere specificiteitseisen.

137. BVerfG 12 november 1958 , BVerfGe 8, nr. 34.

138. BVerfG 30 januari 1968, BVerfGe 23, nr. 6.

139. BVerG 20 oktober 1981, BVerfGe 58, nr. 19. Vgl. - toegespitst op art. 103 lid 2 GG - BVerfG 27 november 1990, BVerfGe 83, nr. 9 (p. 145) en in meer algemene zin BVerfG 3 juni 1992, BVerfGe 86, nr. 15 (p. 311).

140. Maunz/Durig/Herzog, Grundgesetz Kommentar, a.w., 80/13. Vgl. BVerfG 15 december 1983, BVerfGe 65 , nr 1. 
Binnen de objectieve grenzen die de wet stelt mag de verdere concretisering en uitwerking van een regeling aan het bestuur worden toevertrouwd. In dit kader mag aan dat bestuur, afhankelijk van de omstandigheden van het geval, een begrensde vrijheid van rechtshandelen toekomen. ${ }^{141}$ Hierbij houdt het Bundesverfassungsericht rekening met het gegeven dat ó́k het bestuur kan bogen op een indirecte democratische legitimatie. ${ }^{142}$ Uit de latere jurisprudentie van het Gericht blijkt dat eveneens bepaalde pragmatische aspecten mogen meewegen bij de toetsing van 'Ermächtigungsnormen' aan de eisen van artikel 80 lid 1 GG. Zo zal (technische) administratieve regelgeving zich soms snel aan de veranderende maatschappelijke gegevenheden moeten kunnen aanpassen. ${ }^{143}$

\subsubsection{Relevantie jurisprudentie Bundesverfassungsgericht}

Indien men de jurisprudentie van het Bundesverfassungsgericht over artikel 80 lid $1 \mathrm{GG}$ overziet dan kan worden geconstateerd dat de kwaliteit van bevoegdheidsnormen, die het bestuur machtigen tot éénzijdig rechtsvormend handelen de bijzondere aandacht van de wetgever behoeven. De Duitse jurisprudentie toont mijns inziens op een overtuigende wijze aan dat dit uitgangspunt óók - of wellicht juist - in de hedendaagse interventiestaat onverkort geldt. Deze aandacht dient zich in het bijzonder toe te spitsen op de materiële (d.w.z. inhoudelijke) inkadering van bevoegdheidsnormen. Uit het rechtszekerheidsbeginsel vloeit, via de eisen van voorzienbaarheid en voorspelbaarheid van overheidshandelen, voort dat het doel en de begrenzing van een bestuursbevoegdheid voor de burgers vooraf kenbaar dient te zijn. Het democratiebeginsel brengt met zich dat de wetgever in formele zin de wezenlijke elementen van een regeling zelf dient vast te stellen. Naarmate aan de in het geding zijnde rechtsbelangen van burgers een grotere rechtswaarde moet worden toegekend, zal ook de 'Ermächtigungsnorm' aan hogere eisen van specificiteit moeten voldoen (denk aan de Grundrechtsrelevanz).

In de Duitse literatuur wordt de jurisprudentie van het Gericht wel gekritiseerd vanwege het ontbreken van concrete toetsmaatstaven. Naar aanleiding van het vereiste van voorzienbaarheid, merkte Stein bijv. op: 'Man müßte aber schon hellseherische Fähigkeiten haben, um allein mit Hilfe einer Ermächtigungsnorm vorherzusehen, welchen Inhalt Verordnungen haben können, die künftig auf grund der Ermächtigung gehen. ${ }^{144}$ Ondanks dit soort kritiek kan de jurisprudentie van het Bundesverfassingsgericht naar mijn oordeel als bijzonder waardevol worden gekarakteriseerd, daar zij vanuit fundamentele rechtsstatelijke beginselen en principes een plicht construeert tot wettelijke inkadering van bestuursbevoegdheden. Dat het Bestimmtheitsgebot in dit verband meer een richtsnoer - een beginsel - vormt dan een gedetailleerd toetsingshandvat doet hier niet aan af. ${ }^{145}$

141. Vgl. BVerfG 24 april 1991, BVerfGe 84, nr. 9 (p. 149): 'Die Vorschriften brauchen nur so bestimmt zu sein, wie dies nach der Eigenart der zu regelnden Sachverhalte mit Rucksicht auf den Normzweck moglich ist.'

142. Vgl. BVerfG 4 februari 1975, BVerfGe 38, nr. 28.

143. Zie: BVerfG 20 oktober 1981 , BVerfGe 58, nr. 19.

144. E. Stein, Staatsrecht, 14. Auflage, Tubingen 1993, p. 162. 


\subsection{6 'Prescribed by law'}

Niet alleen het Duitse constitutionele recht biedt waardevolle aanknopingspunten om te komen tot een invulling van het specialiteitsbeginsel op 'wetgevingsniveau'. Eisen ten aanzien van de wettelijke grondslag van (bestuurs)bevoegdheden kunnen eveneens worden afgeleid uit de jurisprudentie van het Europese Hof voor de Rechten van de Mens (EHRM). Met name de jurisprudentie met betrekking tot het begrip 'prescribed by law'146 in het Europees Verdrag tot bescherming van de Rechten van de Mens en de fundamentele vrijheden (EVRM), is in dit kader relevant. In een serie arresten heeft het Hof invulling gegeven aan zijn visie inzake de 'rule of law' ${ }^{147}$

De basis voor deze jurisprudentie werd gelegd in het bekende 'Sunday Times'arrest. ${ }^{148}$ In casu stond de vraag centraal of de Engelse common-law inzake 'contempt of Court' (minachting van de rechterlijke macht) voldoende precies was geformuleerd om op grond van dit strafbaar feit een inbreuk op de vrijheid van meningsuiting (artikel 10 EVRM) toe te staan. Hiertoe overwoog het Hof ten aanzien van de 'wettelijke' grondslag:

'In the Court's opinion, the following are two of the requirements that flow from the expression "prescribed by law". Firstly, the law must be adequatly accessible: the citizen must be able to have an indication that is adequate in the circumstances of legal rules applicable to a given case. Secondly, a norm cannot be regarded as "law" unless it is formulated with sufficient precision to enable the citizen to regulate his conduct: he must be able - if need be with appropriate advice - to foresee, to a degree that is reasonable in the circumstances, the consequences which a given action may entail.'

Uit dit arrest blijkt dat het Hof - evenals het Bundesverfassungsgericht - grote waarde hecht aan het beginsel van rechtszekerheid. Indien de overheid inbreuk maakt op rechten van burgers, dient het voor deze burgers duidelijk te zijn op welke wettelijke bepalingen deze inbreuk wordt gebaseerd. Voorts dient de grondslag voor de inbreuk voldoende duidelijk te zijn geformuleerd. De betrokken burgers behoren zich steeds een beeld te kunnen vormen van hun (mogelijke) rechtspositie (voorzienbaarheid en voorspelbaarheid). Uit de 'rule of law' vloeit verder voort dat wettelijke bepalingen die discretionaire ruimte laten voor het uitoefenen van bevoegdheden, tevens op objectieve wijze de reikwijdte van

145. In dit verband verdient nog vermelding dat in de recente Duitse literatuur wordt gepleit voor een (verdere) opwaardering en operationalisering van het fundamentele Bestimmtheitsgebot. Het Bundesverfassungsgericht lijkt hier gevolg aan te geven. Vage bevoegdheidsredacties behoeven vanuit een grondrechtelijk perspectief een duidelijke motivering. Zie: H.-J. Papier en J. Moller, Das Bestimmtheitsgebot und seine Durchsetzung, a.w., i.h.b. p. 196 e.v.

146. Vgl. de artikelen 9, 10 en 11 EVRM.

147. Het legaliteitsprincipe wordt door het Hof aangeduid met de benaming 'rule of law'. Door deze term te hanteren zoekt het Hof geén aansluiting bij het Angelsaksische recht. Het gaat om een algemeen principe waaraan in beginsel geen onderscheid tussen 'common-law' stelsels en continentale rechtsstelsels ten grondslag ligt. Vgl. EHRM 26 april 1979, Series A, Vol. 30 (Sunday Times). Het Hof onderscheidt tussen het 'law'-vereiste sec en de 'quality of the law'. T.a.v. het 'law'-vereiste houdt het Hof wel rekening met de verschillen tussen continentale stelsels en 'common law'-stelsels.

148. EHRM 26 april 1979, Series A, Vol. 30 (Sunday Times); NJ 1980, 146, m.nt. EAA. 
deze bevoegdheid moeten aangeven. ${ }^{149}$ Hoe precies de wetgever de bevoegdheid dient af te bakenen, hangt af van de omstandigheden van het geval en de in het geding zijnde rechten en belangen. Uit de 'Malone'-zaak ${ }^{150}$ blijkt in ieder geval dat uit de wettelijke grondslag op een heldere wijze dient te blijken hoe de bevoegdheid, gelet op de legitieme (wettelijke) doelstelling, kan worden uitgeoefend:

'Consequently the law must indicate the scope of any such discretion conferred on the competent authorities and the manner of its exercise with sufficient clarity, having regard to the legitimate aim of the measure in question, to give the individual adequate protection against arbitrary interference.'

Het aangeven van de begrenzing van een bevoegdheid biedt tevens een garantie tegen willekeurig handelen door de overheid. Uit het 'Silver'-arrest blijkt dat helderheid en conditionering temeer is geboden indien de uitoefening van de bevoegdheid niet (direct) aan democratische controle onderworpen is. ${ }^{151}$

De jurisprudentie van het Hof, waarop in latere jurisprudentie consequent wordt voortgebouwd ${ }^{152}$, steunt - zoals Simon vaststelde - op het fundamentele beginsel van rechtszekerheid en het democratiebeginsel. ${ }^{153}$ In dit opzicht sluit deze jurisprudentie mijns inziens goed aan bij die van het Bundesverfassungsgericht. ${ }^{154}$

\subsection{Meer aandacht voor de inhoudelijke normering van bestuursbevoegdheid in Nederland}

Ook in Nederland is het besef dat er bijzondere aandacht dient uit te gaan naar de inhoudelijke normering van bestuursbevoegdheden doorgedrongen. ${ }^{155}$ In verschillende proefschriften uit de jaren negentig van de twintigste eeuw is an deze problematiek aandacht besteed. Opmerkelijk is dat deze aandacht, juist wanneer de rechtsstatelijke bevoegdheidsleer onder druk lijkt te staan ${ }^{156}$, manifester wordt. Van belang lijkt mij dat de roep om meer inhoudelijke normering van bestuursbevoegdheden niet alleen voortvloeit uit algemene rechtsstatelijke noties, maar mede steun vindt in empirisch onderzoek naar de

149. Zie: EHRM 25 maart 1983, Series A, Vol. 61 (Silver and others). Hierin overweegt het Hof: 'A law which confers a discretion must indicate the scope of that discretion.' Hierbij dient te worden aangetekend dat onder omstandigheden precisering op basis van jurisprudentie (case-law) 6́k afdoende kan zijn. Vgl. de rechtsoverwegingen in: EHRM 25 februari 1993, Series A, Vol. 256 (Funke vs. France).

150. EHRM 2 augustus 1984, Series A, Vol. 82 (Malone). Vgl. ook nog het recentere Goodwin-arrest. EHRM 27 maart 1996, Reports of judgements and decisions 1996 II (Goodwin vs. the United Kingdom).

151. EHRM 25 maart 1983, Series A, Vol. 61 (Silver and others).

152. Bijv.: EHRM 24 april 1990, Series A, Vol. 176 (Kruslin/Huvig); NJ 1991, 523, m.nt. EJD.

153. H.J. Simon, Publiekrecht of privaatrecht?, diss. VU, Zwolle 1993, p. 129.

154. Zie paragraaf 4.4 .4 van dit boek.

155. Vgl. De Haan/Drupsteen/Fernhout, Bestuursrecht in de sociale rechtsstaat I, a.w., p. 15. Deze auteurs interpreteren de toegenomen aandacht voor de inhoudelijke normering van bestuursbevoegdheid als een uitbreiding van het beginsel van wetmatigheid van bestuur.

156. Zie in dit kader hoofdstuk 2 van dit boek. 
juridische kwaliteit van bevoegdhedenstelsels in ons land. ${ }^{157}$ Ook door het parlement wordt het gevaar van te globale bevoegdheidstoedelingen onderkend. ${ }^{158}$

Eijlander heeft er in zijn dissertatie, mede naar aanleiding van de jurisprudentie van het Bundesverfassungsgericht, voor gepleit om meer aandacht te besteden aan de conditionering van bevoegdheden die door de wetgever aan lagere regelgevers en bestuursorganen worden toegekend. ${ }^{159}$ Hierbij zou de wetgever met name meer aandacht moeten besteden aan de materiële inkadering van deze bevoegdheden. Klap denkt in een soortgelijke richting. In situaties waarin het handelen van de overheid (d.w.z. een bevoegdheidsuitoefening) negatieve consequenties kan hebben voor burgers moet de wetgever volgens hem voorzichtig zijn met het stellen van vage normen. ${ }^{160}$ Op de wet- of regelgever rust een bewijslast om de noodzaak tot het stellen van vage normen aan te tonen. ${ }^{161} \mathrm{De}$ vaag geclausuleerde bevoegdheid is derhalve uitzondering en moet door de wetgever worden gemotiveerd. ${ }^{162}$

157. Ik wijs op het omvangrijke onderzoek van de Algemene Rekenkamer inzake 'Vergunningen' (TK 19951996, 24656, nrs. 1-2). Uit dit empirische onderzoek blijkt o.m. dat op Rijksniveau van de - bij wijze van steekproef onderzochte - 100 (discretionaire) vergunningstelsels 51 niet (5), dan wel uiterst globaal (46) naar doel waren begrensd (a.w., p. 20). De conclusie van de Rekenkamer was op dit punt zeer kritisch: 'De doelen van de vergunningstelsels bleken veelal zo abstract te zijn geformuleerd, dat het al dan niet bereiken van deze doelen nauwelijks vastgesteld kon worden. Daar waar de doelen van het vergunningstelsel en die van de overkoepelende wet- en regelgeving schriftelijk zijn vastgelegd, is de verhouding hiertussen vaak onduidelijk. (a.w., p. 22)' Meer aandacht voor de formulering van doelstellingen werd door de Algemene Rekenkamer aanbevolen (a.w., p. 59).

158. Ik wijs bijv. op de parlementaire commotie omtrent art. 174a van de Gemeentewet dat de burgemeester een ingrijpende bevoegdheid toekent om in bepaalde gevallen panden wegens (drugs)overlast te sluiten (de zgn. Wet Victoria). Zie hierover uitvoerig: J.G. Brouwer en A.E. Schilder, Art. 174a Gemeentewet: godin der overwinning?, NJB 1997/13, i.h.b. p. 573 en E.C.M. Jurgens, Van Victor, via Victoria en Damocles, naar Procrustes. Over ons wetgevend gehakkel bij de bestrijding van drugsoverlast vanuit woningen, NTB 1997/8, p. 293 e.v.

159. Ph. Eijlander, De wet stellen, a.w., p. 46.

160. A. Klap, Vage normen in het bestuursrecht, diss. RUL, Zwolle 1994, p. 33.

161. Vgl. aanwijzing 17 van de Aanwijzingen voor de regelgeving 1993 zoals laatstelijk gewijzigd bij besluit van de Minister-President d.d. 20 december 1995 (voor de doorlopende tekst wordt verwezen naar de Sduteksteditie van de Aanwijzingen, Den Haag 1996: 'Gereedschap voor de wetgevingspraktijk', deel vier). De aanwijzing luidt: ' 1 . Bij de toekenning van bestuursbevoegdheden wordt de uitoefening daarvan zoveel mogelijk genormeerd. 2. Met het oog hierop worden discretionaire bevoegdheden en bevoegdheden met vage toepassingscriteria niet toegekend, tenzij daarvoor goede gronden zijn.' Kritisch over (de redactie van) deze aanwijzing: B.W.N. De Waard, Samenwerkende machten. Wetgeving en rechtspraak, in dienst van het recht, oratie KUB, Zwolle 1994, p. 22-23.

162. De doelspecificering van de bevoegdheidsnorm in het lichaam van de wet dient goed onderscheiden te worden van de motivering van het doel van de wet (of bepaalde wetsartikelen) in de memorie van toelichting, dan wel het aanduiden van het doel van de wet in de considerans. Overigens dragen ók de laatstgenoemde adstructies reeds bij aan het kunnen vaststellen van het doel van een bepaalde bevoegdheid. Vgl. K. Waaldijk, Motiveringsplichten van de wetgever, diss. RL, Lelystad 1994, i.h.b. p. 182-183 en 207. 
Ook Van Ommeren ${ }^{163}$ pleit in zijn proefschrift voor een specifieke grondslag voor bestuursbevoegdheid. van Ommeren meent de eis van specificiteit te kunnen stellen omdat hij het legaliteitsbeginsel beperkt tot het stellen van de burgers bindende regels (verplichtingen). Specifieke bevoegdheid impliceert volgens Van Ommeren dat uit de wettelijke grondslag - voorzover mogelijk - het doel blijkt waartoe de betreffende bevoegdheid kan worden uitgeoefend. In algemene zin dienen de grenzen van een bevoegdheid uit de wet te blijken. van belang is nog dat deze auteur de wettelijke specificeringsplicht in verband brengt met het specialiteitsbeginsel.

Simon wijst in zijn proefschrift op de relatie tussen het specialiteitsbeginsel en de inhoudelijke kwaliteitseisen die aan de (formele) wettelijke bevoegdheidsgrondslag dienen te worden gesteld. Hij vestigt in het bijzonder de aandacht op de jurisprudentie van het Europese Hof voor de Rechten van de Mens inzake de 'rule of law' (in accordance with the law). ${ }^{164}$ Als principe van behoorlijke regel- of wetgeving is het specialiteitsbeginsel volgens Simon dienstbaar aan het beginsel van formele rechtszekerheid. Naarmate aan de in het geding zijnde belangen (van burgers) meer gewicht dient te worden toegekend, zullen ook de eisen die aan de kwaliteit van de bevoegdheidsgrondslag moeten worden gesteld hoger zijn. Interessant is dat Simon de eis om de formele bevoegdheidsgrondslag te specificeren fundeert in de idee dat de fictieve toestemming van burgers aan de overheid tot belangenaantasting, die besloten ligt in de legaliteitseis, zo beperkt mogelijk van omvang behoort te zijn. ${ }^{165}$

Zelfs Stout, die in haar proefschrift ${ }^{16}$ de grondslag van bestuursbevoegdheid vanuit een 'modern' open bevoegdheidsperspectief analyseerde, komt tot een verwante conclusie. In haar boek lijkt zij in belangrijke mate afstand te nemen van het beginsel van wetmatigheid van bestuur door sterk de nadruk te leggen op de wenselijkheid van een open bestuursbevoegdheid. Een dergelijke open bestuursbevoegdheid zou noodzakelijk zijn om de communicatieprocessen tussen overheid en samenleving goed te laten verlopen. ${ }^{167}$ Vervolgens werkt zij in paragraaf 10.4 haar visie inzake de wettelijke grondslag van bestuursbevoegdheid nader uit. Volgens Stout kan in beginsel alleen de wet (bestuurs)bevoegdheid verlenen en het orgaan aanduiden dat deze bevoegdheid mag uitoefenen. ${ }^{168}$ Dit formele aspect is evenwel niet voldoende. De wetgever dient voorts de 'politiek-principiële hoofdmomenten' van beleid vast te leggen. Hieronder begrijpt Stout in ieder geval

163. F.J. van Ommeren, De verplichting verankerd, a.w., p. 115.

164. H.J. Simon, Publiekrecht of privaatrecht?, a.w., p. 128. Zie ook zijn noot onder VzARRS 30 augustus 1990, AB 1991, 567 waar hij stelt: 'De 'rule of law', schrijft niet alleen voor dat de vrijheidsbeperking die een overheidsinterventie meebrengt op de wet berust, vereist is tevens dat de overheid de belangen ter bescherming waarvan hij intervenieert (bijv. via een verbods-annex vergunningstelsel), zo concreet en nauwkeurig mogelijk in de wet aangeeft.'

165. Vgl. H.J. Simon, Publiekrecht of privaatrecht?, a.w., p. 273.

166. H.D. Stout, De betekenissen van de wet, diss. RUL, Zwolle 1994.

167. H.D. Stout, De betekenissen van de wet, a.w., p. 229

168. H.D. Stout, De betekenissen van de wet, a.w., p. 230 en 240. 
het vaststellen van het doel van een bevoegdheid. ${ }^{169} \mathrm{Zij}$ lijkt in dit verband eveneens steun te zoeken bij het Duitse constitutionele recht en de jurisprudentie van het Bundesverfassungsgericht. ${ }^{170}$ Naast de materiële inkadering van de bestuursbevoegdheid pleit zij tevens voor een zorgvuldige procedurele inkadering van dergelijke bevoegdheid, zodat het concretiserende rechtsvormingsproces door het bestuur met voldoende waarborgen is omkleed. ${ }^{171}$

Tot slot wijs ik nog op de oratie van De Waard. Deze auteur gaat uit van de realiteit dat discretionaire bevoegdheden en vage termen in de hedendaagse wetgeving onvermijdelijk zijn ${ }^{172}$, maar hij is wél van mening dat bepaalde aanwijzingen voor de wetgever zinvol kunnen zijn. De Waard benadrukt dat in de wettelijke grondslag van een bevoegdheid het doel van die bevoegdheid duidelijk tot uitdrukking zou moeten komen. Het gaat hierbij niet zozeer om de motivering die aan het toekennen van een bepaalde bevoegdheid ten grondslag ligt, maar om het definiëren van de bevoegdheid zelf. ${ }^{173}$

\subsection{Vijf perspectieven}

Gelet op het voorafgaande behoeft de stelling, dat rechtsnormen die bestuursbevoegdheden in het leven roepen de bijzondere aandacht van de wetgever behoeven, mijns inziens géen betoog meer. Vanuit het denkraam van de democratische rechtsstaat, maar ook vanuit de bestuurlijke besluitvormingspraktijk kunnen vele argumenten worden aangedragen ter onderbouwing van deze stelling. In de laatste paragraaf van dit hoofdstuk zal ik de argumenten kort in kaart brengen en waar nodig nader toelichten. Het belang van 'specialiteit' van bestuursbevoegdheid kan vanuit een vijftal perspectieven worden verdedigd.

\subsubsection{Het democratisch perspectief}

Uit het voorafgaande blijkt dat het specialiteitsbeginsel kan worden opgevat als een rechtsstatelijk structuurbeginsel dat de wetgever dwingt om zich steeds te bezinnen over de reikwijdte van discretionaire bevoegdheden die hij aan het bestuur toedeelt. Bij hem rust binnen de democratische rechtsstaat het primaat inzake de éénzijdig gerichte publieke rechtsvorming binnen de staat. Door het vaag normeren van (bestuurs)bevoegdheden geeft de wetgever dit primaat gedeeltelijk uit handen. ${ }^{174}$ Doordat het specialiteitsbeginsel eist dat bestuursbevoegdheden door de wetgever enkel worden toebedeeld ter behartiging van specifieke publiekrechtelijke belangen (de eis van publieke doelbinding), ondersteunt dit

169. H.D. Stout, De betekenissen van de wet, a.w., p. 240.

170. Vgl. noot 38 op p. 240 van haar proefschrift.

171. H.D. Stout, De betekenissen van de wet, a.w., p. 241.

172. B.W.N. de Waard, Samenwerkende machten, a.w., p. 27.

173. B.W.N. de Waard, Samenwerkende machten, a.w., p. 31.

174. A. Klap, Vage normen in het bestuursrecht, a.w, p. 34. 
beginsel het democratisch postulaat. ${ }^{175}$ De wetgever zal bestuursbevoegdheden die hij toedeelt aan de bestuurlijke organisatie zo nauwkeurig als mogelijk inhoudelijk dienen af te bakenen. Op deze wijze kan er (ook) in de moderne interventiestaat een 'upgrading' van de staatsrechtelijke legaliteitseis worden bewerkstelligd. Van belang is dat de wetgever zich op dit inhoudelijke aspect van de bevoegdheidsgrondslag concentreert (onderwerp en doel) en niet volstaat met het louter procedureel inkaderen van bestuursbevoegdheden. ${ }^{176}$

\subsubsection{Het legitimatieperspectief in ruime zin}

De mate van specialiteit van een (wettelijke) bevoegdheidsnorm is mede bepalend voor de kenbaarheid, voorzienbaarheid en voorspelbaarheid van de publieke rechtsvorming voor de rechtssubjecten. Naarmate de toepassingscondities van een competentie concreter zijn omschreven kunnen rechtssubjecten zich een beter beeld vormen van hun rechtspositie zoals die kan ontstaan, of ontstaat, nadat bevoegdheidsuitoefening heeft plaatsgevonden. Aldus beschouwd, kan de conditionering en doelbinding van een bestuursbevoegdheid door de wetgever bijdragen aan de acceptatie van de statelijke machtsuitoefening. Hier is de juridische benadering van het legitimatievraagstuk in het geding, die er in essentie van uitgaat dat blote macht door binding aan het recht - en in het bijzonder de wet - tot gezag wordt getransformeerd. ${ }^{177}$ Voor de statelijke macht heeft dit volgens Donner de volgende consequentie: 'De macht van overheden moet tot bevoegdheid, d.w.z. tot rechtens omschreven, bepaalde en verplichtende macht worden, zodat er een beroep op kan worden gedaan en er verweer tegen kan worden gevoerd' (curs. R.J.N.S.). ${ }^{178}$ Deze opvatting klinkt ook door in het Handboek van het Nederlandse staatsrecht wanneer wordt benadrukt dat staatsen overheidsmacht uitsluitend ambtelijke macht impliceert die per definitie beperkt van aard en omvang is: 'Dat is de juridische benadering, die in staatsmacht meer ziet dan een feitelijk gegeven en haar slechts aanvaardt als rechtsmacht, uit te oefenen naar een rechtsregel, volgens rechtens genormeerde procedures en voor door het recht gestelde of erkende

175. Vgl. het gestelde in hoofdstuk 3 van dit boek over de relatie tussen het specialiteitsbeginsel en het democratisch postulaat.

176. Bijv. door middel van inspraak-, overleg-, en adviesbepalingen. Vgl. R. Fernhout, Instrument en norm, in: Rechtsvorming in de sociale rechtsstaat, Deventer 1989, p. 35. De wetgever zal bijgevolg op hoofdlijnen het inhoudelijke proces van rechtsvorming dat hij initieert moeten overzien. Zie: I.C. van der Vlies, Het legaliteitsbeginsel en kwaliteit van de wetgeving, Bestuur 1989/3, p. 68.

177. Volgens Donner kennelijk het enige aspect dat de aandacht van de jurist behoeft. Zie: A.M. Donner, Legitimiteit in de sociologie en rechtswetenschap, Beleid \& maatschappij, 1975/1, p. 34. Het gaat hier om wat Weber - in essentie - aanduidde als legitimiteit door 'Legale Herrschaft'. Zie o.m. M. Weber, 'Die drei reinen Typen der legitimen Herrschaft', als bijlage gepubliceerd in: J. Winckelmann, Legitimităt und Legalităt in Max Webers Herrschaftssoziologie, Tubingen 1952, p. 106 e.v. Vgl. voorts: E.M.H. Hirsch Ballin, Publiekrecht en beleid, Alphen aan den Rijn 1979, p. 65/71. Hirsch Ballin merkt in dit kader over staat, staatsgezag en recht op: 'Aldus constitueert hij zichzelf juist als wat hij wil zijn, nl. als drager van gezag, - niet slechts macht -, en stempelt hij zijn macht tot macht in dienst van het recht. Er constitueert zich een staat'.

178. A.M. Donner, Bestendig en wederkerig. Over het verband van staat en staatsrecht, oratie RUG, Zwolle 1979, p. 13. 
doeleinden. Deze benadering heeft oude papieren, ouder dan de moderne staat zelf, en zij is een belangrijke bijdrage om niet alleen de staatkundige betrekkingen, maar allerlei maatschappelijke betrekkingen en verschijnselen te stabiliseren en te reguleren. ${ }^{179}$

In dit kader kan worden gesteld dat de kenmerkende juridische bevoegdheidsstructuur binnen de democratische rechtsstaat, en de cultuurhistorisch bepaalde rechtsbeginselen die daaraan ten grondslag liggen ${ }^{180}$, bijdragen tot stabiliteit en bijgevolg tot acceptatie van staatsmacht. Daudt wijst hierbij op de relaties tussen 'structurele legitimiteit' en legaliteit. Vaste structuren binnen een rechtsstelsel kunnen een belangrijke bijdrage leveren aan de stabilisering ervan. ${ }^{181}$ Met name aan de structuur van (doelgebonden) bevoegdheden binnen een rechtsstelsel wordt een legitimerende en stabiliserende werking toegeschreven. Zo stelt Zippelius: ${ }^{182}$ 'Gewiss spielen auch Verfahrensstrukturen und Kompetenzen eine wichtige Rolle bei der herstellung einer verbindlichen Sozialordnung. Die Rechtsordnung hält Verfahren und Kompetenzen bereit, innerhalb deren Konflikte ausgetragen werden. Sie dient als Schema furr eine Kanalisierung und Koördination der in der Gemeinschaft vorhandenen Interessen und Einflüsse' (curs. R.J.N.S.). Deze opvatting sluit goed aan bij de idee dat binnen de publieke rechtsorde principieel verschillende rechtssferen elkaar ontmoeten en onder de regulerende werking van typische rechtsbeginselen, binnen de doelgebonden kaders van (discretionaire) bestuursbevoegdheden, met elkaar worden geharmoniseerd. ${ }^{183}$

\subsubsection{Het rechtsbeschermingsperspectief}

Naarmate bevoegdheidsnormen in een hogere mate inhoudelijk zijn gespecificeerd neemt de waarborgfunctie van deze normen toe. De bevoegdheidsnorm is immers het referentiekader waaraan de bevoegdheidsuitoefening primair op geldigheid getoetst dient te worden. De bevoegdheidsnorm vervult deze functie van toetsingsmaatstaf voor de (administratieve) rechter. Een bevoegdheid die onvoldoende geconditioneerd is kan deze functie niet op een adequate wijze vervullen. ${ }^{184}$ De toetsing aan algemene rechtsbeginselen en algemene beginselen van behoorlijk bestuur kan bij afwezigheid van een specifieke bevoegdheidsgrondslag naar mijn oordeel géen afdoende compensatie bieden. ${ }^{185}$ Zo bieden deze beginselen bijv. geen enkel aanknopingspunt voor de beantwoording van de vraag of een

179. Van der Pot/Donner, Handboek van het Nederlandse staatsrecht, a.w., p. 127.

180. Zie hoofdstuk 3 paragraaf 3.2.3.

181. H. Daudt, Legitimiteit en legitimatie, a.w., p. 9. Ook Couwenberg onderscheidt als legitimerende factor het in acht nemen van erkende procedures en structuren (zgn. procedurele of structurele legitimiteit). S.W. Couwenberg, Gezag en Vrijheid, Inleiding in de constitutionele rechts- en ontwikkelingstheorie, Zwolle, 1991, p. 10.

182. R. Zippelius, Legitimation im demokratischen Verfassungsstaat, in: Legitimation des modernen Staates, Wiesbaden 1981, p. 87.

183. Ik verwijs in dit kader naar de hoofdstukken 3 en 6 .

184. Vgl. J.M. Barendrecht, Recht als model van rechtvaardigheid, diss. KUB, Deventer 1992, p. 69.

185. Vgl. N. Verheij, Deuken in het ideaal, a.w., p. 238. Vgl. in dit verband de - m.i. - niet geheel onterechte klachten van bestuurlijk Nederland. Bestuur in geding, Rapport van de werkgroep Van Kemenade, Haarlem 1997, p. 8-9, 30 en 46. 
bestuursbevoegdheid voor een bepaald doel mag worden gebruikt en zo ja, voor welk doel. Toetsing aan ongeschreven recht kan de wetmatigheidstoetsing dan ook niet vervangen, doch slechts aanvullen. ${ }^{186}$ Cruciaal is in dit kader de opmerking van Ruiter: 'In veel recente wettelijke competentieregelingen in het bestuursrecht is een zorgwekkende nadruk gelegd op de functie "scenario voor competentie-uitoefening", terwijl aan de functie "grondslag voor identificatie van aanvechtbare competentie-uitoefening", niet of nauwelijks aandacht is besteed. Een overmaat aan wettelijke rechtsbeschermingsprocedures kan dit gebrek vervolgens niet compenseren' (curs. R.J.N.S.). ${ }^{187}$

De Duitse auteur Achterberg ${ }^{188}$ heeft de relatie tussen rechtsbescherming en de specificiteit van wetgeving treffend onder woorden gebracht door te stellen: 'In jedem Fall kann auch fur diesen Versuch (de ontwikkeling van de Wesentlichkeitstheorie R.J.N.S.) der Lösung des Vorbehaltsproblems nicht ausser Acht gelassen werden, daß es letzlich um den Rechtsschutz des Burgers geht. (...) Besteht hinsichtlich eines zu regelnden Gegenstands das Bedürfnis gerichtlicher Nachprufbarkeit, so ergibt sich hieraus die Wesentlichkeit der Materie und als Konsequenz hieraus das Erfordernis gesetzlicher Regelung als Judikativmaßtab. Je intensiver das Rechtsschutzbedürfnis, desto spezieller hat der Inhalt der gesetzlichen Regelung zu sein' (curs. R.J.N.S.). De wetgever dient zich daarom terdege bewust te zijn van de functie die iedere competentienorm met het oog op de rechterlijke toetsing vervult. Een zinvolle, legitimatieverschaffende, rechterlijke toetsing vereist steeds een afdoende mate van 'specialiteit' van de (bevoegdheids)norm waaraan getoetst moet worden. ${ }^{189}$

\subsubsection{Het organisatieperspectief}

De werking van het specialiteitsbeginsel vindt zijn neerslag ook in het bestuurlijke organisatierecht. Ieder bestuursorgaan heeft binnen de statelijke structuur van organen een eigen afgebakende werkkring waarbinnen het zijn bestuursactiviteit dient te ontplooien. ${ }^{190}$ Deze werkkring zal primair moeten worden afgeleid uit de context van de wet op grond

186. Vgl. de opvatting van Giacometti, paragraaf 4.2.6.

187. D.W.P. Ruiter, Bestuursrechtelijke wetgevingsleer, Assen/Maastricht, 1987, p. 246.

188. N. Achterberg, Allgemeines Verwaltungsrecht, 2. völlig neubearbeitete Auflage, Heidelberg 1986, p. 339.

189. Vgl. de visie van de Duitse auteur Fricke in zijn proefschrift: 'Gerichtliche Uberprufung ersetzt nicht Bestimmtheit, sondern erfordert Sie im Gegenteil. Jede andere betrachtungsweise ubersieht, daß ein belastender Einzelakt nur dann einer wirksamen gerichtlichen Kontrolle unterliegen kann, wenn die zugrunde liegende Ermăchtigungsnorm genugend ausdeutbare Substanz besitzt, um eine Prufung zu ermoglichen.' H.J. Fricke, Die (erheblichen) Belange der Bundesrepublik Deutschland im Auslandergesetz und das Bestimmtheitsgebot, diss. Münster, Münster 1973, p. 28 en 29. Vgl. ook J.M. Barendrecht, Recht als model van rechtvaardigheid, a.w., p. 69 en 70 . De toetsmaatstaven die de rechter hanteert bij afwezigheid van duidelijke en objectieve toetscriteria zijn volgens Barendrecht op zichzelf enkel 'verwijzingen naar inhoudsloze rechtvaardigheid'.

190. Vgl. het eerder omschreven Franse en Belgische 'principe de spécialité' (hoofdstuk 2, paragraaf 2.2.1) dat ziet op de afbakening van het werkterrein van gespecialiseerde overheidsinstellingen, alsmede van functionele en territoriale openbare lichamen in het publiekrecht. Zie: W. Konijnenbelt, Het specialiteitsbeginsel in het Nederlandse en het Franse administratieve recht, NTB 1994/10, p. 310 en 311. 
waarvan het betreffende bestuursorgaan in het leven is geroepen. ${ }^{191}$ Binnen de globaal bepaalde wettelijke werkkring zal een bestuursorgaan op basis van de toegekende bestuursbevoegdheden publiekrechtelijke belangen dienen te behartigen. Hier is een typisch publiekrechtelijke verantwoordelijkheid in het geding. ${ }^{192}$ Vanuit dit perspectief bezien kan het specialiteitsbeginsel worden opgevat als een funderend beginsel voor de bestuursorganisatie. ${ }^{193}$ Dombrowski stelt in dit kader: 'Jede Zuständigkeitsregel beabsichtigt eine Verteilung der Aufgaben des Staates unter seine verschiedene Organe. Insofern gibt die Kompetenz eine Antwort auf die Frage, welche unter mehreren Behörden eine bestimmte Art von Angelegenheiten zu erledigen hat. Kompetenz bedeutet Ermächtigung und Beschränkung zugleich, d.h. ausschließlich das kompetente Organ darf sich mit einer bestimmten Angelegenheit befassen und hat gleichseitig die Erfullung anderer als der ihm zugewiesenen Aufgaben zu unterlassen. ${ }^{194}$

Een duidelijke afbakening van bestuursverantwoordelijkheid (de ambtsplicht) vormt tevens een duidelijke instructie aan het bestuur om niet te treden in de behartiging van publiekrechtelijke belangen die door de wetgever aan andere onderdelen van de bestuursorganisatie zijn toevertrouwd. Stroink en De Waard voeren in dit verband het 'efficiencyaspect' ten tonele. Dit efficiency aspect wil dat dezelfde belangen zo min mogelijk dubbel worden afgewogen, liefst éénmaal en wel binnen het meest gerede kader. ${ }^{195}$ Dubbele belangenafweging legt $\mathrm{nl}$. een extra last op het functioneren van de bestuurlijke organisatie en werkt competentieconflicten in de hand. Het is derhalve vanuit een oogpunt van doelmatigheid van belang dat publiekrechtelijke belangen (zo mogelijk) steeds aan én specifiek bevoegdhedenkader kunnen worden toebedeeld.

\subsubsection{Het doelmatigheids- en besluitvormingsperspectief}

Het organisatieperspectiefvloeit over in het doelmatigheids- en besluitvormingsperspectief. Op het eerste gezicht lijkt de stelling dat de verwezenlijking van het specialiteitsbeginsel bijdraagt aan een doelmatige bestuurlijke besluitvorming ambivalent. In de literatuur is er immers op gewezen dat dit beginsel juist leidt tot een versnippering van bestuursbevoegdheden, een verbrokkeling van het bestuur en bijgevolg tot een opdeling van de rechtsverhouding tussen burger en overheid. ${ }^{196}$ Een burger heeft soms voor één en dezelfde activi-

191. Ruiter noemt bepalingen in een wet die de 'werkkring' globaal afbakenen 'competentievestigend'; ze dienen onderscheiden te worden van de specifieke bevoegdheidsscheppende bepalingen. D.W.P. Ruiter, Normscheppende bepalingen in bestuursrechtelijke wetten, Bestuurswetenschappen 1980/4, p. 270.

192. Vgl. D.W.P. Ruiter, Normscheppende bepalingen in bestuursrechtelijke wetten, a.w., p. 267.

193. Vgl. F.J. van Ommeren, De verplichting verankerd, p. 117 e.v.

194.. Dombrowski, Mißbrauch der Verwaltungsmacht, zum Problem der Kopplung verschiedener Verwaltungszwecke, Mainz 1967, p. 40 en 41.

195. F.A.M. Stroink en B.W.N. de Waard, Het specialiteitsbeginsel, in: Burger en overheid, 's-Gravenhage 1984, p. 244.

196. Zie bijv. M. Scheltema, Van rechtsbescherming naar een volwaardig bestuursrecht, a.w., p. 1359 en meer uitvoerig zijn afscheidsrede als hoogleraar bestuursrecht: $M$. Scheltema, De wondere wereld van het bestuursrecht, afscheidsrede RUG, Deventer 1997, i.h.b. p. 13-14. Vgl. ook W. Konijnenbelt, Rechtsverwer- 
teit diverse vergunningen nodig, hetgeen bezwaarlijk als 'doelmatig' kan worden aangemerkt. Ik kom hier nog op terug.

Voorop dient naar mijn oordeel te worden gesteld dat de bestuurlijke belangenafweging door de werking van het specialiteitsbeginsel wordt ingekaderd en gestructureerd. Doordat het bestuur deze 'afweging van rechtsbelangen' ${ }^{197}$ opzet vanuit de door de wetgever gedetermineerde speciale publiekrechtelijke belangen, wordt - zoals Damen ${ }^{198}$ signaleerde - voorkomen dat de administratie, die een bepaalde maatschappelijke activiteit wil tegenhouden, van argument naar argument kan verspringen. Dat is gunstig voor de burger. De publieke doelbinding beschermt echter ook de bestuursorganisatie voor overbelasting in de besluitvormingssfeer doordat de te behartigen publiekrechtelijke belangen vooraf door de wetgever zijn vastgesteld en niet meer in algemene zin tegen elkaar behoeven te worden afgewogen. De bestuurlijke afweging van belangen is bijgevolg gespecificeerd, doorzichtig en juist daarom doelmatig.

\subsubsection{Enige opmerkingen over coördinatie en integratie}

Niet ontkend kan echter worden dat de gefragmenteerde structuur van bestuursbevoegdheden voor de burger én het bestuur bepaalde ongemakken voor de besluitvorming met zich brengt. Deze ongemakken treden in het bijzonder op de voorgrond indien er sprake is van samenloop van verschillende vergunningstelsels op hetzelfde complex van feiten. In dit kader kunnen zich procedurele en/of inhoudelijke fricties voordoen. ${ }^{199}$ Vergunningprocedures kunnen bijv. in tijd asynchroon verlopen en er bestaat bij verwante vergunningstelsels het gevaar van het stellen van tegenstrijdige voorschriften. Evenmin is het uitgesloten dat een bepaalde vergunning wél, en een andere vergunning juist niet wordt verleend. Dit komt de rechtszekerheid en beleidsafstemming ${ }^{200}$ niet ten goede.

Dergelijke besluitvormingsproblemen dienen mijns inziens echter niet te worden ondervangen door het specialiteitsbeginsel te relativeren of zelfs helemaal over boord te zetten. Andere wegen, die vanuit rechtsstatelijk oogpunt minder bedenkelijk zijn, dienen in dit verband te worden bewandeld. ${ }^{201}$ Op deze plaats raakt het rechtsstatelijke leerstuk van het specialiteitsbeginsel de juridisch-technische discussies over de coördinatie en/of integratie van vergunningstelsels. In hoofdstuk 1 is aangegeven dat deze laatstgenoemde discussies in dit boek goeddeels buiten beschouwing blijven, omdat zij sterk verweven zijn met de complexe normatieve structuren binnen de afzonderlijke delen van het bijzondere

king door het bestuur: het vertrouwensbeginsel in het administratieve recht, Geschriften van de Vereniging voor Administratief Recht LXXIV, Groningen 1975, p. 70.

197. Zie over het proces van 'belangenafweging' meer uitvoerig hoofdstuk 6 van dit boek.

198. Zie zijn noot onder HR 18 december 1992 (Kuunders), Gst. 6970, p. 411.

199. Ik ontleen deze termen aan J. Struiksma, Verwant zonder verband. De coordinatie van de bouw- en milieuvergunning, Deventer 1993, p. 37.

200. Vgl. De Haan/Drupsteen/Fernhout, Bestuursrecht in de sociale rechtsstaat I, a.w., p. 96 .

201. Zie ook mijn noot onder Rb. Amsterdam 2 oktober 1996, JB 1996/263 (monumentenvergunning De Houtkoper), waar ik wees op de noodzaak om goed te onderscheiden tussen de rechtsstatelijke dimensie van het specialiteitsbeginsel en de besluitvormingstechnische implicaties ervan. 
bestuursrecht. Op deze plaats volsta ik daarom, vanuit een algemeen bestuursrechtelijke invalshoek, met enige opmerkingen.

In de literatuur is erop gewezen dat het enkele feit dat er voor één activiteit verschillende vergunningen benodigd zijn op zich nog geén reden vormt om tot coördinatie over te gaan. ${ }^{202}$ Eerst zal de juridische en bestuurlijke noodzaak van coordinatie aannemelijk moeten worden gemaakt. Deze noodzaak mag niet te snel worden aangenomen, daar vergaande coördinatie- en afstemmingsconstructies ook onbedoelde extra bestuurslasten met zich kunnen brengen. ${ }^{203}$ De door Ruiter ontwikkelde, en door Struiksma toegepaste samenlooptypologie, lijkt mij in dit kader een goed houvast te bieden. ${ }^{204}$ Coördinatie van vergunningverlening is volgens Ruiter aangewezen indien er sprake is van typische samenloop van vergunningstelsels. ${ }^{205}$ Van typische samenloop is volgens deze auteur in ieder geval sprake indien de samenloop logischerwijs noodzakelijk (en dus voorspelbaar) is gelet op de rechtsfeitomschrijvingen die aan de betreffende vergunningplichten ten grondslag liggen. Samenloop kan daarnaast ook typisch zijn indien de samenloop op basis van ervaringsregels veelvuldig in de praktijk is te verwachten.

Eerst na een positieve beantwoording van de noodzakelijkheidsvraag komt de vraag aan de orde naar de wijze van coördinatie. Deze coördinatie zal een wettelijke grondslag dienen te hebben; de wetgever die bestuursbevoegdheden toedeelt, is ook gehouden om na te gaan of bepaalde bevoegdheidsnormen met elkaar in verband dienen te worden gebracht, en zo ja in hoeverre. Hierbij dient naar mijn oordeel een principieel onderscheid te worden gemaakt tussen enerzijds de materiële integratie van bestuurs-bevoegdheden, en anderzijds de procedurele coördinatie van besluitvormings-procedures. Dit hoofdonderscheid wordt, in verfijnde en uitgewerkte vorm, ook in de literatuur gehanteerd. ${ }^{206}$

202. D.W.P. Ruiter, Organisatorische aspecten van vergunningstelsels, BR 1980, p. 102.

203. In dit kader kan nog eens worden gewezen op de relativerende visie van Donner in de laatste druk van zijn handboek wat betreft de bestuurlijke 'roep om coördinatie' A.M. Donner, Nederlands bestuursrecht, Algemeen deel, Alphen aan den Rijn 1987, vijfde herziene druk, p. 109. Het zou m.i. ook een volstrekte illusie zijn om te streven naar 'uitputtende' coordinatie gelet op de enorme complexiteit van de overheidsorganisatie. De nadruk dient te liggen op het oplossen van echte kneipunten, d.w.z. knelpunten die objectief vaststelbaar zijn en bovendien door de betrokkenen (burgers en/of bestuur) als last worden ervaren.

204. D.W.P. Ruiter, Organisatorische aspecten van vergunningstelsels, a.w., p. 102-103; J. Struiksma, Verwant zonder verband, a.w., p. 32-38.

205. Volgens Ruiter weer te onderscheiden in symmetrische en asymetrische samenloop. Bij symmetrische samenloop tussen twee vergunningstelsels is een bepaald gedragstype in alle voorstelbare concrete gevallen aan beide vergunningvereisten onderworpen. Bij asymmetrische noodzakelijke samenloop gaat het vergunningvereiste krachtens éen stelsel steeds gepaard met het vergunningvereiste krachtens het andere stelsel, maar is het omgekeerde niet het geval. D.W.P. Ruiter, Organisatorische aspecten van vergunningstelsels, a.w., p. 102-103.

206. Vgl. de gedetailleerde indeling die Van der Gun hanteert. V.E. van der Gun, De coördinatie van de bouwvergunning en de milieuvergunning. Vraagstuk op het raakvlak van ruimtelijke ordening en milieubeheer, RegelMaat 1990/1, p. 4-5. Van der Gun noemt nog, als - wellicht - afzonderlijk te onderscheiden categorie, het concentreren van verschillende bestuursbevoegdheden bij één bestuursorgaan. 
Integratie van vergunningstelsels gaat gepaard met het partieel of geheel in elkaar schuiven van de inhoudelijke kenmerken van de onderliggende bevoegdheidsnormen ${ }^{207}$ Deze vérstrekkende vorm van coördinatie (in ruime zin) acht Struiksma alleen aangewezen bij samenloop van verwante vergunningstelsels. ${ }^{208}$ Een voorbeeld biedt de 'integrale' milieuvergunning die in 1993 op basis van de Wet milieubeheer tot stand kwam door de integratie van verschillende sectorale milieuwetten. ${ }^{209}$ Terughoudendheid ten aanzien van integratie van bestuursbevoegdheden is mijns inziens met het oog op het specialiteitsbeginsel echter geboden. Bevoegdhedenintegratie leidt immers vaak tot een verruiming van het toetsingskader ${ }^{210}$ en bijgevolg tot uitholling van het specificiteitsgehalte van een bevoegdheid. Hierdoor kunnen weer afbakeningsproblemen met andere bestuurlijke wetgeving ontstaan. ${ }^{211}$ In dit verband dient vanuit rechtsstatelijk oogpunt gewaakt te worden voor excessieve en vooral diffuse belangbehartiging door de bestuursorganisatie. ${ }^{212}$ Ruiter ${ }^{213}$, die in beginsel voorstander is van verdergaande coördinatie, uitte met het oog hierop een mijns inziens belangrijke waarschuwing:

\begin{abstract}
'Hoewel dit klassieke principe in de huidige samenleving enigszins op de achtergrond dreigt te geraken, wil ik toch, tegen de stroom van onze tijd in, onder uw aandacht brengen dat een zekere "geslotenheid" van vergunningstelsels in het licht van het beginsel dat het bestuur gebonden dient te zijn aan de wetgeving, zeer gewenst kan zijn. Enige wederzijdse afscherming van vergunningstelsels lijkt een noodzakelijke voorwaarde om te bereiken dat elk stelsel ook werkelijk alleen wordt toegepast ter bescherming van de specifieke belangen om welke het vergunningvereiste is gesteld.'
\end{abstract}

207. Zie voor een analyse van de inhoudelijke kenmerken van bevoegdheids- of 'secundaire' normen hoofdstuk 2 van dit boek (paragraaf 2.3.2).

208. J. Struiksma, Verwant zonder verband, a.w., p. 37.

209. Hierover uitvoerig: H.J.A.M. van Geest, Integratie in de Wet milieubeheer: met name de milieuvergunning, Gst. 6987, p. 229-233 en Gst. 6988, p. 264-268.

210. Uiteraard kan een bevoegdhedenkader ook los van de integratie van reeds bestaande vergunningstelsels worden verruimd. Dit geschiedde bijv. met de belangenafwegingskaders van de Wet tot vaststelling van bepalingen betreffende 's Rijks waterstaatswerken en de Rivierenwet. Zie voor de beweegredenen hiertoe de memorie van toelichting bij het voorstel van wet: TK 1989-1990, 21721, 3, i.h.b. p. 1-3. Een andere optie is het verruimen van een beslissingsbevoegdheid in geval van bepaalde 'zware' besluiten. Ik wijs op de verruimde MER-beslissingsbevoegdheid op grond van de Wet milieubeheer (art. $7.35 \mathrm{Wm}$ ) Zie over de precieze relatie tussen het specialiteitsbeginsel en deze verruimde (materiele) beslissingsbevoegdheid: M.A. Heldeweg, Normstelling en expertise. Waarborgen voor technische deskundigheid i.h.b. bij vergunningverlening in het milieurecht, diss. RL, 's-Gravenhage 1993, p. 231 e.v.

211. Zie de kritische naschriften van Hennekens over de reikwijdte van het afwegingskader van de Wet milieubeheer onder ABRS 6 september 1994 (Gst. 7003, p. 74-75) en VzABRS 14 oktober 1994 (Gst. 7007, p. 203-204).

212. Vgl. in dit kader Damen die waarschuwde voor het 'tegen elkaar wegstrepen' van (publiekrechtelijke) belangen bij een geîntegreerde belangenafweging in het kader van een énnbesluitstelsel. L.J.A. Damen, De geheime directe van het bestuur. Mensbeeld, bestuursbeeld en legaliteitsbeginsel, in: In wederkerigheid (Scheltema-bundel), Deventer 1997, p. 42.

213. D.W.P. Ruiter, Organisatorische aspecten van vergunningstelsels, a.w., p. 102 en p. 105. 
Aan deze terechte waarschuwing kan mijns inziens nog worden toegevoegd dat de wetgever, gelet op het specialiteitsbeginsel, eveneens terughoudend dient te zijn met het tot stand brengen van bijzondere wetgeving die, in verband met de dringend noodzakelijke realisering van projecten, de bestaande structuur van bestuursbevoegdheden (gedeeltelijk) terzijde stelt (zgn. 'gelegenheidswetgeving') ${ }^{214}$ Besluitvorming op basis van dergelijke wetgeving werkt overigens onbevoegd bestuurshandelen in de hand. ${ }^{215}$ In dit kader kan worden gewezen op de Deltawet grote rivieren die weliswaar leidde tot een enorme tijdwinst ten aanzien van de procedures voor de kade- en dijkaanleg, maar tevens tot een wel érg vergaande versimpeling en integratie van de bestuurlijke materiële normstelling tengevolge van de volledige concentratie van bestuursbevoegdheden (de én besluitconstructie). ${ }^{216}$

Tegen de diverse vormen van procedurele coördinatie bestaat daarentegen vanuit specialiteitsoogpunt veel minder bezwaar. Procedurele coördinatie van besluitvormingsprocedures tast de bestaande structuur van doelgebonden bestuursbevoegdheden inhoudelijk niet aan, maar ondervangt wél bepaalde procedurele fricties. Ik ga op deze plaats niet in op de verschillende procedurele afstemmingsconstructies ${ }^{217}$, maar volsta met de opmerking dat een aantal constructies reeds in de wetgevingspraktijk is beproefd. ${ }^{218} \mathrm{De}$ (vierde tranche van de) Algemene wet bestuursrecht zal in dit verband wellicht meer eenheid brengen. ${ }^{219}$

214. Vgl. bijv. de Deltawet Grote Rivieren. Zie over deze wet o.m.: J.M. Polak, De Deltawet grote rivieren, NJB 1995/12, p. 453-454; A.A.J. de Gier en P.J.J. van Buuren, De Deltawet grote rivieren, een eenmalig experiment?, NTB 1995/6, p. 145-152 en de noot van Th. Drupsteen onder ABRS 18 juli 1995, BR 1996/1, p. 63-66. Ik wijs ook nog op de 'Vergunningwet Westerschelde'. Hierover: J.P. de Jong, wetgevingsrubriek NTB 1997/3, p. 123-124.

215. Vgl. ABRS 11 september 1995, AB 1995, 532, m.nt. AvH (ontoelaatbare bouwvoorschriften in dijkverbeteringsplan).

216. A.A.J. de Gier en P.P.J. Driessen, Van de nood een deugd? Verslag van een evaluatie-onderzoek naar de werking van de Deltawet grote rivieren, Gst. 7064, i.h.b. p. 625.

217. Zie in dit kader: V.E. van der Gun, De coordinatie van de bouwvergunning en de milieuvergunning, a.w., p. 4-5. Het gaat hier i.h.b. om synchronisatieregelingen, aanhoudingsregelingen, opschortende voorwaarden en koppeling van weigeringsgronden.

218. Ik wijs o.m. op: de artikelen 52, 53 en 54 van de Woningwet en de artikelen 8.28 e.v., alsmede de artikelen 14.1 e.v. van de Wet milieubeheer.

219. Door de commissie voor de Algemene Regels van Bestuursrecht (de commissie Scheltema) werd in dit kader reeds een eerste concept-cő̈rdinatieregeling ontworpen, die echter zeer kritisch werd ontvangen. Ik wijs in dit verband op het onderzoek 'Coordinatiebepaling in de Algemene wet bestuursrecht' van het Onderzoeks- en Adviesbureau van de Vereniging van Nederlandse Gemeenten (SGBO), uitgevoerd door A.J.H. Smallenbroek en R.J.G.M. Aerts, Den Haag 1996. Het concept-voorstel van de commissie strekt(e) tot het introduceren van een algemene informatieplicht van bestuursorganen alsmede tot een procedurele coठrdinatieplicht voor situaties waarin voor een bepaalde activiteit meer dan éen besluit van een bestuursorgaan kan worden aangevraagd (zie bijlage 1 bij genoemd rapport, p. 69-70). De belangrijkste kritiek van de zijde van de onderzoekers was dat de concept-regeling volgens hen gén oplossing biedt voor de oorzaak van de afstemmingsproblemen: nl. het feit dat regulering plaatsvindt vanuit het perspectief van de (deel)- belangen die behartigd moeten worden en niet vanuit het gezichtspunt van de burger die zich in een bepaalde hoedanigheid tot de overheid wendt (a.w., p. 65). Gepleit wordt voor meer geîntegreerde (gemeentelijke) besluitvorming toegespitst op besluitvormingsclusters (bijv. een cluster 


\subsubsection{De 'grote' projecten}

Op deze plaats dient nog in het kort de aandacht te worden gevestigd op de discussies inzake 'grote projecten' 220 die in de jaren negentig het middelpunt vormen van de beschouwingen over 'cőrdinatie' van bestuurlijke besluitvorming. ${ }^{221}$ In dit kader lijkt onverminderd de wettelijke bevoegdheidsstructuren, het specialiteitsbeginsel en andere eisen van rechtsstatelijkheid - als hardnekkig adagium te gelden dat er natuurlijk vóór alles wél bestuurd moet kunnen worden. ${ }^{222}$ De Wetenschappelijke Raad voor het Regeringsbeleid (WRR) wijst er in dit verband fijntjes op dat 'wil een relatief klein land als Nederland daadwerkelijk mee kunnen komen in de Europese (beleids)concurrentieslag, de besluitvorming over grootschalige infrastructurele projecten dient te voldoen aan minimum-eisen van voorspelbaarheid en betrouwbaarheid, ook wat betreft het tempo ervan'.

Het ligt in dit kader voor de hand dat de gefragmenteerde structuur van de bestuurswetgeving in het bijzonder als een bestuurslast en vertragingsfactor wordt ervaren. ${ }^{223} \mathrm{De}$ cumulatie van besluitvormings- en rechtsbeschermingsprocedures wordt gepositioneerd als een (wellicht terechte) formele juridische bedreiging voor nieuwe 'grote projecten'. Maar óók de ingevolge het specialiteitsbeginsel gedifferentieerde materiële besluitvorming moet het ontgelden. Dit komt goed tot uitdrukking op pagina 83 van het WRR-rapport inzake 'Besluiten over grote projecten' waar o.m. de volgende drie uitspraken worden aangetroffen:

'De verwezenlijking van een groot project is zodoende niet afhankelijk van de beslissing van én instantie, maar juist van een zeer groot aantal verschillende instanties. De besluitvorming geschiedt niet in het kader van één omvattende ordening, waarbinnen de verschillende aspecten onderling worden afgewogen, maar in het kader van een groot aantal sub-ordeningen, die ieder van uit andere belangen en gezichtspunten zijn ingericht. (..) Door de differentiatie van verantwoordelijkheden en bevoegdheden verwatert de verantwoordelijkheid voor het project als geheel, wat nog wordt bevorderd door de toenemende juridificatie. (..) De huidige ordening kent, kortom, aan middelpuntvliedende krachten van deelaspecten en belangentegen-

'evenementen' en 'het oprichten van een horecabedrijf). Aan het onderzoek ligt helaas géén rechtsstatelijk onderzoek naar de betekenis van het specialiteitsbeginsel ten grondslag.

220. Gedacht kan bijv. worden aan de aanleg van de Betuwespoorlijn, de uitbreiding van Schiphol en de realisatie van een Hoge Snelheidslijn (HSL) door het groene hart van de Randstad. Vgl. in dit kader uitvoerig het VAR-preadvies van Stroink dat in het voorjaar van 1998 verschijnt. F.A.M. Stroink, Complexe besluitvorming; een opgave voor burger, bestuur en rechter, VAR-reeks 120, Alphen aan den Rijn 1998.

221. Ik beperk mij in dit boek tot het rapport van de Wetenschappelijke Raad voor het Regeringsbeleid inzake 'Besluiten over grote projecten' (rapporten aan de Regering, 1994-46, Den Haag 1994). Vgl ook de voorstudie van Lambers, Lubach en Scheltema: Versnelling juridische procedures grote projecten, 1994V85, Den Haag 1994.

222. Vgl. L.J.A. Damen, De geheime directe van het bestuur: mensbeeld, bestuursbeeld en legaliteitsbeginsel, a.w., p. 36-37.

223. De 'versnipperde' administratieve wetgeving wordt door de WRR overigens zeker niet als de enige vertragingsfactor aangewezen. Het spectrum van factoren is zeer kleurrijk. Zie: Besluiten over grote projecten, a.w., p. 37-49. 
stellingen een zwaarder gewicht toe dan aan de samenhang en integratie die voor grote projecten moet worden gerealiseerd.'

De - overigens fraaie analyses - van de Wetenschappelijke Raad voor het Regeringsbeleid monden uiteindelijk uit in een voorstel voor een 'wet grote projecten'. Het is hier geenszins de plaats om in te gaan op de precieze inhoud en de wetgevingstechnische implicaties van dit voorstel. Waar het mij om gaat is het volgende. Geconcentreerde besluitvorming die (enkel) projectmatig (één project-besluit) én centralistisch is georiënteerd zal ongetwijfeld leiden tot het sneller doorhakken van bestuurlijke knopen. Ook is het denkbaar dat de vertegenwoordigende organen zich ten aanzien van het project als geheel een completer beeld kunnen vormen van het daaraan ten grondslag liggende noodzakelijke besluit.

Hier staat mijns inziens echter als groot nadeel tegenover dat de belangenafweging - en zeker de afweging van publieke belangen - noodzakelijkerwijs globaler en diffuser van aard wordt. De optimale behartiging van publiekrechtelijke belangen (het specialiteitsbeginsel) kan hierdoor op de achtergrond raken en ondergeschikt worden aan de noodzaak tot de realisering van een bepaald project (instrumentalisme). Hier is bijv. door Damen de aandacht op gevestigd. ${ }^{224}$ Het lijkt mij dan ook zeer verdedigbaar dat de Regering het voorstel van de Raad, wat betreft het tot stand brengen van een gehele nieuwe 'wet grote projecten', vooralsnog in de ijskast heeft gezet. ${ }^{225}$ Het is naar mijn oordeel nl. van groot belang dat de discussies over de realisering van 'grote projecten' én over verdere ingrijpende wijzigingen van de bestuurswetgeving - hoe gewenst ook - in dit kader eerst nauwkeuriger getoetst worden aan de rechtsstatelijke randvoorwaarden die o.m. het specialiteitsbeginsel stelt.

\subsubsection{Tot slot: een kwestie van bestuurscultuur?}

Ter afronding van deze slotparagraaf en daarmee van dit hoofdstuk dient erop te worden gewezen dat afstemming van vergunningverlening in het belang van de burger óok een kwestie is van bestuursmentaliteit. Verwacht mag worden dat het bestuur bijv. een vergunningaanvrager op een actieve wijze behulpzaam is bij de beantwoording van de vraag wel$k e$ vergunningen benodigd zijn en bij welk bestuursorgaan die dienen te worden aangevraagd. ${ }^{226}$ Een wettelijke informatieplicht zou deze cultuuromslag bij het bestuur overigens een handje kunnen helpen. ${ }^{227}$ In dit kader dienen ook de wettelijke doorzendplichten van de Awb (in het bijzonder artikel 2:3 Awb) te worden gepositioneerd. ${ }^{228}$

224. L.J.A. Damen, De geheime directe van het bestuur: mensbeeld, bestuursbeeld en legaliteitsbeginsel, a.w., p. 42.

225. Zie de brief van de minister van Volkshuisvesting, Ruimtelijke Ordening en Milieubeheer aan de Kamer: TK 1995-1996, 24690, nr. 1.

226. Konijnenbelt pleitte hier in 1975 reeds voor. Zie: W. Konijnenbelt, Rechtsverwerking door het bestuur: het vertrouwensbeginsel in het administratieve recht, a.w., p. 70. 
Het is primair een taak van de bestuursorganisatie om er zorg voor te dragen dat de burger zo weinig mogelijk last ondervindt van de bestuurlijke bevoegdheidsstructuren. Voor deze burger zou daarom 'het bestuur' als organisatorisch geheel aanspreekpunt ${ }^{229}$ moeten zijn; vervolgens is het dan aan dit bestuur om op een actieve wijze na te gaan welke bevoegdheden in het geding zijn en door wie deze bevoegdheden worden uitgeoefend. ${ }^{230}$ Het verbeteren van de interne bestuurlijke organisatie en het bevorderen van 'klant-gerichtheid' kan naar mijn oordeel uiteindelijk fors bijdragen aan het ondervangen van besluitvormingstechnische complicaties die het specialiteitsbeginsel voor de burger soms met zich brengt.

227. De commissie Scheltema formuleerde in dit verband reeds een voorstel, waarvan het eerste lid luidde: ' 1 . Een bestuursorgaan geeft op verzoek van een belanghebbende aan welke besluiten van dat bestuursorgaan nodig zijn om een bepaalde activiteit te mogen verrichten.' Overigens ondernemen de gemeenten ook zelf acties, bijv. door de introductie van de 'één-loket-gedachte'. Zie het onderzoek 'Coordinatiebepaling in de Algemene wet bestuursrecht', a.w., p. 61.

228. De noot van R.M. van Male onder ABRS 3 juni 1994, AB 1994, 602 (autocross Zuidwolde).

229. Ik erken onmiddelijk dat de realisering van een dergelijk bestuursorganisatorisch uitgangspunt uitermate complex is en veel nader onderzoek vereist. Voor de burger zou echter al iets gewonnen zijn indien de éénheid van het besluitende bestuur bijv. op respectievelijk gemeentelijk, provinciaal en Rijksniveau meer tot uitdrukking zou komen. Vgl. in dit kader de interessante suggestie van Stroink om besluiten van de gemeentelijke organen - vanuit het perspectief van de burger - aan de gemeente toe te rekenen. F.A.M. Stroink, Boekbespreking J.A.F. Peters. Publiekrechtelijke rechtspersonen, NTB 1997/6, p. 241.

230. Soms kan ook de wetgever via specifieke 'fictie-bepalingen' de burger behulpzaam zijn door te bepalen dat onder de aanvraag van een bepaald type besluit mede de aanvraag van een ander noodzakelijk besluit wordt begrepen. 


\section{Hoofdstuk 5}

\section{Het verbod van détournement de pouvoir}

\section{$5.1 \quad$ Inleiding}

In de literatuur wordt het specialiteitsbeginsel in verband gebracht met het 'klassieke' verbod van détournement de pouvoir.' Dit rechtsstatelijke verbod, dat voortvloeit uit het specialiteitsbeginsel ${ }^{2}$, richt zich als concrete gedragsregel tot het bestuur en eist dat een bestuursbevoegdheid niet wordt gebruikt voor een ander doel dan het doel waarvoor die bevoegdheid door de wetgever aan het bestuur is toegekend. ${ }^{3}$ Het verbod, dat is neergelegd in artikel 3:3 van de Algemene wet bestuursrecht, dwingt bestuursorganen met andere woorden om bestuursbevoegdheden doelconform uit te oefenen. Het kan worden opgevat als een operationalisering van het legaliteitsbeginsel. ${ }^{4}$ Tevens fungeert het verbod als toetsmaatstaf voor de rechter. Aan het verbod van détournement de pouvoir ligt een lange historie ten grondslag. Het leerstuk werd, zoals de naam reeds doet vermoeden, overgenomen uit het Franse recht. Dit geschiedde in het eerste kwart van de twintigste eeuw. ${ }^{5}$ In Frankrijk werd het verbod ruim vijftig jaar eerder door de Conseil d'Etat als beroepsgrond geïntroduceerd in het kader van het Franse rechtmatigheidsberoep (het 'recours pour excès de pouvoir').

Omdat het specialiteitsbeginsel en het verbod van détournement de pouvoir als wezenlijke ijkpunten voor de beperktheid van overheidsgezag in elkaars verlengde liggen, ligt het voor de hand om in dit boek aan de historische ontwikkeling van het verbod aandacht te besteden. Van belang is bovendien dat het verbod van détournement de pouvoir in de

1. Zo bespreken Van der Burg en Cartigny het specialiteitsbeginsel in het kader van hun beschouwingen over het verbod van détournement de pouvoir. Van der Burg/Cartigny/Overkleeft-Verburg, Rechtsbescherming tegen de overheid, vijfde druk, Nijmegen 1985, p. 109-110; Vgl. voorts: A.M. Donner, Nederlands bestuursrecht, Algemeen deel, vijfde herziene druk, Alphen aan den Rijn 1987, p. 109; F.A.M. Stroink, Algemeen bestuursrecht. Een inleiding, tweede druk, Zwolle 1996, p. 13; A.Q.C. Tak, Hoofdlijnen van het Nederlands bestuursprocesrecht, derde druk, Zwolle 1995, p. 177 en L.J.A. Damen, naschrift onder ARRS 15 december 1987, Gst. 6855, nr. 6, m.n. L.J.A. Damen (Publex-zaak).

2. Vgl. J.G. Steenbeek/F.A.M. Stroink, Wet administratieve rechtspraak overheidsbeschikkingen, vierde herziene druk, 's-Gravenhage 1988, p. 229. Alhoewel het specialiteitsbeginsel en het verbod van détournement de pouvoir aan elkaar verwant zijn verdient het aanbeveling om beide te onderscheiden. Het specialiteitsbeginsel is immers een algemeen staats- en bestuursrechtelijk principe (vgl. hoofdstuk 3 en 4), terwijl genoemd verbod hier slechts éen bepaalde uitwerking van is.

3. Vgl. bijv. Van Wijk/Konijnenbelt/Van Male, Hoofdstukken van administratief recht, tiende geheel herziene druk, 's-Gravenhage 1997, p. 366.

4. Vgl. Van Male die het verbod van détoumement de pouvoir in verband bracht met de rechtsstaatidee en het legaliteitsbeginsel. R.M. van Male, Rechter en bestuurswetgeving, diss. KUB, Zwolle 1988, p. 333.

5. Het verbod van détoumement de pouvoir werd in Nederland voor het eerst expliciet door de wetgever gepositiveerd in art. 8 lid 1 van de Distributie- en Crisiswet van 1918 (Stb. 1918, 494). 
Algemene wet bestuursrecht in verband wordt gebracht met de bestuurlijke belangenafwegingsplicht. Het verbod zou volgens de wetgever immers aan deze plicht complementair zijn. ${ }^{6}$ Ook dit is een reden voor een nadere verkenning.

In de pagrafen 5.2 tot en met $5.5 \mathrm{zal}$ de ontwikkeling en de betekenis van het verbod van détournement de pouvoir naar Frans administratief recht worden beschouwd. Hierbij zal o.m. aandacht worden besteed aan de vraag of aan het betreffende leerstuk in het hedendaagse Franse bestuursrecht nog veel betekenis wordt toegekend. Vervolgens zal in paragraaf 5.6 de aandacht op het Nederlandse recht worden gericht.

\subsection{Het Franse 'recours pour excès de pouvoir'}

Het verbod van détournement de pouvoir kwam in het Franse bestuursrecht als beroepsgrond tot ontwikkeling binnen het 'recours pour excès de pouvoir'. Het 'recours pour excès de pouvoir' kan worden omschreven als een algemene administratiefrechtelijke beroepsgang tegen 'actes administratifs unilatéraux décisoire' (besluiten) ${ }^{7}$ Binnen deze beroepsgang worden de aangevochten besluiten door de administratieve rechter op rechtmatigheid getoetst. Het betreft een toetsing aan alle geschreven en ongeschreven regels en beginselen van het objectieve publiekrecht recht ('recours objectif'). ${ }^{8}$ Zoals reeds uit de benaming van deze beroepsgang blijkt, ontwikkelde het rechtmatigheidsberoep zich in Frankrijk rondom het centrale begrip bestuursbevoegdheid (pouvoir/compétence).

De toetsingsgronden binnen deze beroepsgang worden traditioneel ingedeeld in een viertal (hoofd)categorieèn: (1) incompétence, (2) vice de forme, (3) détournement de pouvoir, en (4) violation de la loi. ${ }^{9}$ De verschillende gronden zijn verwant aan elkaar. Uiteindelijk zijn zij allen in belangrijke mate terug te voeren op 'violation de la loi'. ${ }^{10}$

Van origine wordt het 'recours pour excès de pouvoir' gezien als een controle op de aanwezigheid van bevoegdheid en de wetmatige uitoefening daarvan. Onbevoegdheid (in-

6. PG Awb I, MvT, p. 209.

7. Eenzijdige administratiefrechtelijke rechtshandelingen, in dit hoofdstuk verder te noemen 'besluiten' ('décisions'). Vgl. R. Chapus, Droit administratif général, tome I, 10e édition, Paris 1996, p. 460 e.v. Hieronder vallen zowel beschikkingen als algemeen verbindende voorschriften. Het verbod van détournement de pouvoir is derhalve voor alle 'actes administratifs (décisoire)' van betekenis. Vgl. Auby/Drago, Traité des recours en matière administrative, Paris 1992, p. 530.

8. Vgl. F.-P. Bénoit, Le droit administratif français, Paris 1968, p. 574. Zie voor een algemene karakterisering van het Franse 'recours pour excès de pouvoir' bijv. C.W.A. Timmermans, De administratieve rechter en beoordelingsvrijheden van bestuursorganen, diss. RUL, Leuven 1973, p. 7-11.

9. Het betreft hier een hoofdindeling die verschillende onderverdelingen kent. Deze verschillen vaak - op detailpunten - per auteur. Een uiterst gedetailleerde onderverdeling wordt aangetroffen bij Auby/Drago, Traité des recours en matière administrative, a.w., p. 332.

10. Vgl. De Laubadère/Venezia/Gaudemet, Traité de droit administratif, tome I, 13e édition, Paris 1994, p. 494 en R. Chapus, Droit administratif général, a.w., p. 928. Van belang is in dit verband dat 'violation de la loi' in het Franse administratieve recht ruim wordt uitgelegd. Hieronder wordt iedere schending van het 'principe de (a) légalité' gezien. Dit beginsel omspant zowel het geschreven als het ongeschreven (publiek)recht, waaronder de 'principes généraux du droit' (zie: De Laubadère/Venezia/Gaudemet, a.w., p. 553,585 e.v.; Chapus, a.w., p. 89 e.v.). 
compétence) en vormverzuim (vice de forme) zijn dan ook de oudste vernietigingsgronden. Het is dan ook evident dat de bevoegdheidsleer in het Franse bestuursrecht een centrale plaats inneemt. Bénoit merkt er het volgende over op:

'La compétence d'un agent administratif est une aptitude qui lui est conférée a faire certains actes juridiques au nom d'une collectivité administrative et sur un territoire déterminé. (..) La règle fondamentale qui domine le fonctionnement de notre administration est qu'aucun agent administratif ne peut faire un acte juridique au nom d'une collectivité administrative s'il n'est investi préablement de la compétence correspondante. (..) Cette règle, premier aspect du principe de la légalité qui régit toute l'action administrative, constitue la base de tout notre ordre administratif." ll

Ook De Laubadère c.s. benadrukken het belang van de wettelijke toekenning en verdeling van bestuursbevoegdheid: ' $L$ 'incompétence est, pour l'acte administratif, un vice radical parce que les pouvoirs des agents publics sont rigoureusement attribués et répartis par la loi; la notion de compétence est en effet la base de tout le droit public. ${ }^{12}$

In de tweede helft van de negentiende eeuw komt in de jurisprudentie van de Conseil d'Etat een nieuwe toetsingsgrond tot ontwikkeling die de administratieve rechter mogelijkheden biedt om een bepaald aspect van de bevoegdheidsuitoefening 'intern' ${ }^{13}$ te toetsen. Deze nieuwe toetsingsgrond, waarbij de bestuursbevoegdheid werd benaderd vanuit de idee van de doelgebondenheid, is bekend geworden onder de naam 'détournement de pouvoir'. Uitgangspunt van het leerstuk van de 'détournement de pouvoir' is dat iedere bestuursbevoegdheid door de wet aan een bestuursorgaan wordt toegekend ter behartiging van speciale aspecten van het algemeen belang. ${ }^{14}$ Vidal geeft duidelijk de relatie aan tussen de toetsing op détournement de pouvoir en het 'speciale' werkterrein van bestuursorganen:

'Certes, dès l'origine, le juge ne s'est pas borné à se demander si l'auteur de l'acte attaqué avait eu en vue l'intérêt général plus ou moins largement entendu, il est allé plus loin et a recherché si le but voulu par le législateur avait été effectivement poursuivi. En effet, la spécialité du but des actes est une conséquence de la spécialité des fonctions exercées par leurs auteurs, laquelle n'est elle-même qu'une règle de dicipline destinée à assurer le développement ordonné de l'action administrative, et concourant, par conséquent, à la poursuite de l'intérêt général." (cursivering R.J.N.S.) ${ }^{\text {15 }}$

11. F.-P. Bénoit, Le droit administratif français, a.w., p. 470.

12. De Laubadère/Venezia/Gaudemet, Traité de droit administratif, a.w., p. 496.

13. De Franse doctrine onderscheidt tussen 'illégalité externe' en 'illégalité interne' van een 'acte administratif'. Tot de eerste categorie gebreken worden de (formele) bevoegdheids- en procedurefouten gerekend (de 'incompétence' en de 'vice de forme'). Tot de laatste categorie behoren de meer materiële gebreken ta.v. de inhoud van het bestuursbesluit (de gebreken in de 'motifs' en de 'détoumement de pouvoir'). Zie: R. Chapus, Droit administratif général, a.w., p. 931.

14. Vgl. De Laubadère/Venezia/Gaudemet, Traité de droit administratif, a.w., p. 500: 'En outre, chaque compétence administrative n'est donnée à son titulaire qu'en vue de la poursuite d'un but particulier qui peut être du reste plus ou moins précis.'

15. R. Vidal, L'évolution du détournement de pouvoir dans la jurisprudence administrative, RDP 1952, p. 310 . 
Op een bestuursorgaan rust de plicht om zijn bevoegdheden steeds in het algemeen belang uit te oefenen, waarbij het verboden is om andere doeleinden dan de specifiek-wettelijke na te streven. ${ }^{16}$ Overtreding van dit verbod kan aanleiding geven tot vernietiging van het betreffende besluit (annulation).

\subsection{De ontwikkeling van het leerstuk van détournement de pouvoir door de Conseil d'Etat}

Het leerstuk van détournement de pouvoir maakt sinds de tweede helft van de negentiende eeuw deel uit van het positieve Franse administratieve recht. Om een helder beeld te krijgen van de historie van dit leerstuk, is het zinvol om kennis te nemen van enige vroege jurisprudentie van de Conseil d'Etat.

\subsubsection{Pariset en Laumonnier-Carriol}

Naar algemeen in de Franse literatuur wordt aangenomen, werd het verbod van détournement de pouvoir door de Conseil d'Etat in 1875 geïntroduceerd in de arresten Pariset en Laumonnier-Carriol. ${ }^{17}$ Aan beide arresten lag een vergelijkbare casuspositie ten grondslag. Ingevolge een nationaliseringswet dienden alle luciferfabrieken in Frankrijk onteigend te worden. De minister van financiën, die zich geconfronteerd zag met een extra belasting van de begroting, deed alle prefecten een circulaire toekomen waarin hij hen opdroeg om over te gaan tot de sluiting van alle fabrieken die in strijd met de wettelijke regelingen inzake 'établissements dangereux, incommodes et insalubres' in werking waren. ${ }^{18}$ Het was duidelijk dat de minister uitsluitend de kosten, welke voor de staat voortvloeiden uit de te verwachten onteigeningsprocedures, beoogde te beperken. Een tweetal eigenaren, die geconfronteerd werden met de sluiting van hun fabriek, stelde tegen de betreffende

16. Het bestuur is bijgevolg, in tegenstelling tot een burger, nooit vrij in zijn doelverwezenlijking. Rivero bracht dit helder onder woorden: 'L'administration, à la différence du particulier qui choisit librement le but de ses actes, se voit imposer la fin que son action doit poursuivre. De façon générale, elle ne doit jamais exercer ses compétences qu'en vue de la satisfaction de l'intérêt public, en vertu d'un principe général du droit. De façon plus particulière, les textes assignent à certaines compétences un but précis: les pouvoirs de police ont pour but d'assurer le maintien de l'ordre, la procédure d'alignement a pour but de fixer les limites d'une voie publique, etc.' J. Rivero, Droit administratif, onzième édition, Paris 1985, p. 263.

17. C.E. 26 november 1875, Rec. 934 (Pariset) en C.E. 26 november 1875, Rec. 936 (Laumonnier-Carriol). Deze arresten zijn ook gepubliceerd in: Long/Weil/Braibant, Les grand arrêts de la jurisprudence administrative, 10e édition 1993, p. 26 e.v. In de literatuur wordt het arrest 'Lesbats' uit 1864 gezien als een belangrijke voorloper van deze jurisprudentie; C.E. 25 februari 1864, Rec. 209, concl. L'Hopital (Lesbats). In casu had een prefect een verbod uitgevaardigd i.v.m. het parkeren van omnibussen voor het lokale station. Het verbod had enkel tot doel om de uitvoering van een overeenkomst tussen de spoorwegmaatschappij en een publieke busonderneming te waarborgen (anti-concurrentie). Van Male wijst er overigens op dat sommige Franse auteurs nog vroegere aanzetten voor het leerstuk van détournement de pouvoir in de jurisprudentie menen te hebben ontdekt. R.M. van Male, Rechter en bestuurswetgeving, a.w., p. 92.

18. Vgl. de voormalige Nederlandse Hinderwet. 
besluiten beroep in bij de Conseil d'Etat. Naar aanleiding van dit beroep kwam de Conseil tot het oordeel dat de prefect zijn bevoegdheid tot sluiting niet had uitgeoefend met het oog op de doelstelling van de wetgeving inzake gevaarlijke inrichtingen, maar uitsluitend in het financieel belang van de staat. Dit werd ontoelaatbaar geacht.

In deze standaardarresten treedt reeds op de voorgrond dat het Franse leerstuk van détournement de pouvoir op 'subjectieve' leest werd geschoeid. ${ }^{19}$ De Conseil d'Etat traceert de doelstellingen die bestuurders daadwerkelijk beogen na te streven bij de uitoefening van een bestuursbevoegdheid. Het betreft een zoektocht naar de drijfveren en intenties achter de bevoegdheidsuitoefening. Vervolgens toetst de Conseil d'Etat of deze subjectieve doelstellingen overeenstemmen met het objectieve doel dat door de wetgever ten grondslag is gelegd aan de betreffende bevoegdheid. ${ }^{20}$ Uit het arrest Pariset blijkt dat détournement de pouvoir óok dan aanwezig kan zijn indien de bevoegdheidsuitoefening naar objectieve maatstaven overeenkomstig de wet is.

De subjectieve benadering van de bevoegdheidsuitoefening, waarop de Conseil d'Etat de leer van de détournement de pouvoir fundeerde, werd in Nederland reeds in het begin van deze eeuw gekritiseerd. Zo wees Mulder ${ }^{21}$ in zijn proefschrift uit 1922 op enige zwakke plekken van het Franse leerstuk. Hij vestigde met name de aandacht op het feit dat onzuivere bestuursintenties niet steeds leiden tot handelen in strijd met het objectieve doel van de wet. ${ }^{22}$ Indien een besluit geheel in overeenstemming is met dit objectieve doel zullen subjectieve (bijkomende) doelstellingen niet snel aanleiding mogen geven tot een vernietiging wegens détournement de pouvoir. Enerzijds ligt er in dit soort situaties, zoals hierna zal blijken, een aanzienlijk bewijsprobleem, anderzijds kunnen er vraagtekens worden geplaatst bij de juridische relevantie van een vernietiging op grond van louter ongeoorloofde subjectieve motieven. Deze relevantie kan dan immers enkel gelegen zijn in een morele afstraffing van bestuurders.

\subsubsection{Objectivering}

Uit de vroege jurisprudentie van de Conseil d'Etat blijkt dat overtreding van het verbod van détournement de pouvoir in de rechtspraktijk vrijwel uitsluitend aanleiding gaf tot vernietiging indien het nastreven van ongeoorloofde subjectieve doelstellingen zich tevens uitte in handelen in strijd met het objectieve wettelijke doel van een bestuursbevoegdheid. In dit verband werd wel gesproken over de 'objectivering' van het leerstuk van détourne-

19. Vgl. J.J. Boasson, De rechter tegenover de vrijheid der administratie, diss. RUL, Groningen 1911, p. 313314. Voorzover ik kon nagaan analyseerde Boasson in Nederland voor het eerst uitvoerig de d.d.p.jurisprudentie van de Conseil d'Etat.

20. Vgl. R. M. van Male, Rechter en bestuurswetgeving, diss. KUB, Zwolle 1988, p. 93.

21. A.C.J. Mulder, De theorie van den détournement de pouvoir van den Franschen Conseil d'Etat, diss. UU, Utrecht 1922 . Het betreft hier bij mijn weten het enige Nederlandse proefschrift dat geheel aan het betreffende leerstuk werd gewijd.

22. A.C.J. Mulder, De theorie van den détoumement de pouvoir van den Franschen Conseil d'Etat, a.w., p. 38 . 
ment de pouvoir. ${ }^{23}$ Zoals nog zal blijken heeft met name deze objectivering ertoe bijgedragen dat de vernietiging op grond van détournement de pouvoir 'concurrentie' kreeg van objectief georiënteerde vernietigingsgronden, waaronder in het bijzonder het leerstuk van 'contrôle des motifs'.

Een goed voorbeeld waarbij ongeoorloofde subjectieve doelstellingen zich evident uitten in het handelen in strijd met het objectieve doel van een bevoegdheid biedt het Larbaud-arrest. ${ }^{24}$ In casu weigerde de minister van landbouw een vergunning voor de exploitatie van een minerale bron, alsmede voor de verkoop van het water uit de betreffende bron. Het wettelijke vergunningvereiste was exclusief gesteld in het belang van de openbare gezondheid. Uit de beschikking en uit de verklaringen van de zijde van de minister bleek echter dat de aanvrage niet (concreet) getoetst was aan de genoemde wettelijke doelstelling. Geenszins was gebleken dat de exploitatie van de bron een gevaar inhield voor de openbare gezondheid, zodat de vergunning, gelet op het objectieve doel van de vergunningbevoegdheid, verleend had behoren te worden. Uit het rechterlijk onderzoek bleek dat de weigering in werkelijkheid was ingegeven ter bescherming van een naburige bron (Vichy), welke door de staat werd geexploiteerd. Dit was voor de Conseil d'Etat aanleiding om op grond van détournement de pouvoir te vernietigen.

In de vroege jurisprudentie van de Conseil d'Etat treft men ook vele voorbeelden van vernietigingen aan waarbij de détournement de pouvoir niet door het bestuur werd verhuld. Zo werd in de Cestier-zaak ${ }^{25}$ een politieverordening van de burgemeester van Lyon, die het venten van koopwaren aan de openbare weg reglementeerde, wegens détournement de pouvoir vernietigd. De verordeningsbevoegdheid was aan de burgemeester toegekend o.m. in het belang van het (reguleren) van het verkeer. Doordat de considerans van de betreffende verordening echter niet inging op de noodzaak om het verkeer te reguleren, maar expliciet sprak over de noodzaak om de lokale detailhandel te beschermen, werd de objectieve doelstelling van de bevoegdheid hier volgens de Conseil d'Etat niet gediend, waarna een vernietiging volgde.

\subsubsection{Het Pagès-arrest: géén behartiging van private belangen}

Zoals Mulder terecht opmerkte rekende de Conseil d'Etat door de introductie van het verbod van détournement de pouvoir definitief af met de veronderstelling dat 'pouvoir discrétionnaire' gelijk staat aan 'pouvoir arbitraire' ${ }^{26}$ Indien de wetgever een discretionaire bestuursbevoegdheid aan een bestuursorgaan toekent, wordt het betreffende orgaan niet ontslagen van de plicht om deze bevoegdheid doelconform uit te oefenen, waarbij uitoefening 'in het algemeen belang' als minimum indicatie geldt. De behartiging van

23. Vgl. A.C.J. Mulder, De theorie van den détournement de pouvoir van den Franschen Conseil d'Etat, a.w., p. 100.

24. C.E. 6 december 1878, Rec. 973 (Larbaud).

25. C.E. 17 november 1899 , Rec. 645 (Cestier).

26. A.C.J. Mulder, De theorie van den détoumement de pouvoir van den Franschen Conseil d'Etat, a.w., p. 42. 
persoonlijke belangen, hetzij van bestuurders, hetzij van burgers, is in dit perspectief ontoelaatbaar.

Dit gegeven moest ertoe leiden dat de Conseil d'Etat ook een principieel standpunt innam ten aanzien van het behartigen van zuiver privaatrechtelijke belangen. In het belangrijke Pagès-arrest ${ }^{27}$ bleek de Conseil d'Etat zich uitdrukkelijk op het standpunt te stellen dat het bestuur bij de uitoefening van een bestuursbevoegdheid uitsluitend een bepaald aspect van het algemeen belang mag behartigen en gén private belangen van burgers. In casu stond een geschil tussen een tweetal eigenaren centraal inzake de opvang van (benedenstrooms) water van een onbevaarbare rivier. De Code Civil voorzag, ter regulering van dergelijke geschillen, in een uitvoerige regeling. Daarnaast was er een publiekrechtelijk vergunningstelsel van kracht. Nadat de prefect deze vergunning had geweigerd op grond van het gerezen eigendomsgeschil moest de Conseil d'Etat over de toelaatbaarheid van deze weigering oordelen.

Volgens de Conseil was er sprake van een evidente 'excès de pouvoir'. De prefect mocht de vergunningaanvraag enkel toetsen aan de doelstelling van de wettelijke regeling. $\mathrm{Bij}$ het ontbreken van een expliciete doelstelling diende de besluitvorming zich volgens de Conseil d'Etat te beperken tot gronden welke aan het algemeen belang ontleend konden worden, waarbij in casu o.m. gelet moest worden op de noodzaak overstromingen te voorkomen en de openbare gezondheid te verzekeren. De weigering van de betreffende vergunning op grond van een privaatrechtelijk geschil werd volstrekt ontoelaatbaar geacht.

\subsection{Het leerstuk van détournement de pouvoir in de Franse doctrine}

In de Franse literatuur is sinds de arresten Pariset, Laumonnier-Carriol en Pagès veel aandacht besteed aan het verbod van détournement de pouvoir. Een punt dat in de dogmatische discussies op de voorgrond trad zag op de theoretische onderbouwing van het verbod van détournement de pouvoir. In dit verband zijn de meningen in de Franse literatuur met name verdeeld over de vraag of een détournement de pouvoir vergelijkbaar is met een 'incompétence' dan wel handelen in strijd met de wet impliceert (violation de la loi). ${ }^{28}$

\subsubsection{Laferrière}

Laferrière, die de ontwikkeling van het leerstuk van détournement de pouvoir als vicePrésident van de Conseil d'Etat van dichtbij meemaakte, gaf een van de eerste aanzetten voor deze dogmatische discussie. Hij presenteerde de détournement de pouvoir als een onjuist gebruik van het bevoegdheidsmandaat dat het bestuur van de wetgever had ontvangen. Dit mandaat kon volgens Laferrière door het bestuur niet alleen overschreden worden door het letterlijk overtreden van de wet, maar óok door het nastreven van doel-

27. C.E. 22 maart 1901, Rec. 351 (Pagès).

28. Zie voor een uitvoerige bespreking van met name de oudere visies in de literatuur: $R$. Vidal, L'évolution du détournement de pouvoir dans la jurisprudence administrative, a.w., p. 275 e.v. 
stellingen die de wetgever niet voor ogen hadden gestaan. Laferrière zag dit gebrek als een vorm van 'incompétence':

'Le détournement de pouvoir constitue donc un abus du mandat que l'administrateur a reçu; celui qui le commet prend, sous une fausse apparence de légalité, des décisions qu'il ne lui appertient pas de prendre, et qui sont ainsi entachées d'une sorte d'incompétence, sinon par les prescriptions qu'elles édictent, du moins par le but qu'elles poursuivent. ${ }^{29}$

Laferrière vestigde er in dit verband de aandacht op dat de Conseil d'Etat het leerstuk van détournement de pouvoir bewust koppelde aan het recours pour excès de pouvoir. ${ }^{30}$ Door deze koppeling kon een détournement de pouvoir worden opgevat als een bepaald species van onbevoegdheid. Het verbod van détournement de pouvoir dwingt het bestuur om, indien de letter van de wet zwijgt, in ieder geval te handelen in het verlengde van de geest van de wet: ' $\mathrm{La}$ jurisprudence a trouvé moyen d'étendre aux actes faits par l'Administration en vertu de ses pouvoirs discrétionnaires, un contrôle de légalité auquel il semble difficile de les soumettre (..) Mais si la loi ne fixe pas d'avance la teneur de ces décisions, elle moins leur but général et l'esprit dans lequel elles doivent être prises (..) S'inspirant de cette vérité, la jurisprudence a admis que les actes discrétionnaires peuvent être annulés comme illégaux lorsqu'ils sont faits dans un but étranger à celui que la loi a eu en vue. ${ }^{31}$

\subsubsection{Het interbellum: Rolland, Hauriou en Duguit}

In navolging van Laferrière zagen diverse auteurs de détournement de pouvoir als een soort bevoegdheidsoverschrijding ${ }^{32}$ die niet zozeer bleek uit het handelen in strijd met de letterlijke tekst van de wet, maar uit het handelen in strijd met de bedoeling van de wetgever. Exemplarisch is bijv. Rolland die de détournement de pouvoir als volgt omschreef:

'C'est un cas d'incompétence, mais d'un genre un peu particulier. Il y a détournement de pouvoir quand un agent administratif use de ses pouvoirs en se conformant à la lettre de la loi, mais en poursuivant en réalité un but autre que celui en vue duquel ses pouvoirs lui ont été áttribués. ${ }^{33}$

Tijdens het interbellum distantieerde met name Hauriou ${ }^{34}$ zich van de opvatting dat de toetsing op détournement de pouvoir enkel een rechtmatigheidscontrole impliceerde.

29. E. Laferrière, Traité de la juridiction administrative et des recours contentieux, tome second, Paris 1888, p. 522 .

30. E. Laferrière, Traité de la juridiction administrative et des recours contentieux, a.w., p. 522.

31. E. Laferrière, aangehaald bij: R. Vidal, L'évolution du détoumement de pouvoir dans la jurisprudence administrative, a.w., p. 284.

32. Vgl. R. Vidal, L'évolution du détoumement de pouvoir dans la jurisprudence administrative, a.w., p. 278279. Vidal wijst er in dit verband op dat in de oudste literatuur, waarmee hij i.h.b. doelt op Aucoc, elke overeenkomst van de détoumement de pouvoir met onbevoegdheid werd bestreden.

33. L. Rolland, Précis de droit administratif, troisième édition, Paris 1930, p. 245.

34. M. Hauriou, Précis de droit administratif et de droit public, onzième édition, Paris 1927, p. 419 en 420. 
Volgens Hauriou was het noodzakelijk om een strikt onderscheid te maken tussen de 'légalité' en de 'moralité' welke ten grondslag ligt aan het bestuurshandelen. In de visie van Hauriou kon het legaliteitsbeginsel uitsluitend externe grenzen aan discretionaire bestuursbevoegdheden stellen. Binnen de sfeer van de discretie regeerde volgens hem niet de legaliteit maar de bestuurlijke moraliteit. Deze 'moralité administrative' was volgens Hauriou geenszins vergelijkbaar met de intentie van de wetgever. Auteurs die de moraliteit van het bestuur gelijk beoogden te stellen aan de wil van de wetgever werden door hem bestreden. ${ }^{35}$ Hauriou zag het leerstuk van détournement de pouvoir meer als een toetsingsgrond die de mogelijkheid opende om de uitoefening van discretionaire bestuursbevoegdheden te onderwerpen aan een vergaande controle op bestuurlijke 'zedelijkheid'. Aldus opgevat, impliceerde de controle op de afwezigheid van détournement de pouvoir volgens hem meer dan een formele toetsing op strijd met het doel van de wet. 'Il est évident que la moralité dépasse la légalité et, par conséquent, le détournement de pouvoir dépasse en profondeur d'action la violation de la loi. ${ }^{36}$

Duguit ${ }^{37}$ deelde de opvatting van Hauriou niet. Hij zocht naar een andere onderbouwing van de détournement de pouvoir. Hiertoe fundeerde hij dit leerstuk in zijn algemene theorie inzake de doelgerichtheid van 'actes juridiques' (rechtshandelingen). Duguit ging ervan uit dat iedere rechtshandeling wordt verricht met een speciaal doel. Het verbod van détournement de pouvoir vormde volgens hem slechts een speciale uitwerking van deze algemene theorie, toegespitst op de éenzijdige publiekrechtelijke rechtshandeling.

De doelgerichtheid vormt volgens Duguit wél een zeer wezenlijk element van 'actes publics':

'Le but déterminant joue une rôle extrêmement important dans l'activité juridique de l'administration. C'est en effet, d'après la légalité du but déterminant que s'apprécie très souvant la validité d'un acte public. ${ }^{38}$

35. 'Pour combattre la distinction que nous faisons ici entre la légalité et la moralité administrative, on objecte que la moralité administrative n'est pas autre chose que l'esprit général de la loi, et que, par conséquent, le détournement de pouvoir n'est pas autre chose que la violation de l'esprit de la loi, cas particulier de la violation de la loi. Mais il n'est pas vrai que l'esprit des lois administratives se confonde avec la moralité administrative, pa plus que l'esprit des lois civiles ne se confond avec la moralité individuelle. (..) l'esprit de la moralité, c'est la directive à imposer aux devoirs dans l'intérêt du bien; il y a un écart entre ce qui est juste et ce qui est bien.' M. Houriou, Précis de droit administratif et de droit public, a.w., p. 420. Deze opvatting van Hauriou werd in latere literatuur overigens treffend bestreden. Vgl. M. Waline, Droit administratif, 8e édition, Paris 1959, p. 452-453.

36. M. Hauriou, Précis de droit administratif et de droit public, a.w., p. 420. Welke bestuurlijke 'zedelijkheidsnormen' Hauriou precies voor ogen stonden wordt door hem niet expliciet uit de doeken gedaan. Uit zijn betoog kan echter worden afgeleid dat het hier gaat om de plicht van het bestuur om te handelen 'in het algemeen belang' en de bestuurlijke besluitvorming vrij te houden van persoonlijke en politieke belangen.

37. L. Duguit, Traité de droit constitutionnel, troisième édition, tome deuxième La théorie générale de l'état, Première partie Eléments, fonctions, et organes de l'état, Paris 1928.

38. L. Duguit, Traité de droit constitutionnel, a.w., p. 379. 
De aard van het na te streven doel is volgens Duguit bepalend voor het aannemen van een 'acte public'. Niet elke rechtshandeling welke afkomstig is van een 'agent public' kan worden aangemerkt als een 'acte public'. Hiervoor is tevens vereist dat er met deze handeling een publiek doel wordt nagestreefd: 'De même, l'acte fait par un agent public n'est pas un acte public parce qu'il émane d'un tel agent. Il n'est un acte public que lorsqu'il est déterminé par un but de service public. ${ }^{39}$ Welke de publieke doelstellingen zijn, staat niet ter beoordeling van het bestuur. Enkel de wetgever kan deze doelen determineren. Ook indien de wetgever aan een bestuursorgaan een discretionaire bevoegdheid toedeelt, kan het bestuur niet zelf bepalen welke doeleinden met deze bevoegdheid mogen worden nagestreefd. De 'ambtswil' van het bestuur wordt bijgevolg ingegeven door de wil van de wetgever. Alleen hij bepaalt de doelgerichtheid van het bestuurshandelen. Indien de doelstellingen van het bestuur niet overeenstemmen met het doel dat de wetgever heeft beoogd, gaat het bestuur zijn bevoegdheid te buiten:

'Si l'agent poursuit un autre but que celui-là, il voile la loi, il outrepasse sa compétence tout de même que lorsqu'il fait un acte qui par son objet est contraire à la loi. (..) Un acte public qui est déterminé par un but contraire à la loi est entaché de nullité tout comme celui dont l'objet est illégal. (..) Si l'agent public peut apprécier l'opportunité de l'acte, il ne peut jamais poursuivre un but qu'il déterminerait librement. Il ne peut jamais poursuivre que le but prévu par la loi. Sinon, son acte est entaché d'illégalité, illégalité qui apparait sous un aspect un peu particulier, illégalité qu'on appelle détournement de pouvoir, lequel est vraiment un excès de pouvoir comme l'illégalité a raison de l'objet. ${ }^{40}$

Dat een détournement de pouvoir in dit verband in wezen een bevoegdheidsgebrek is, leidde Duguit ook af uit de jurisprudentie van de Conseil d'Etat. ${ }^{41}$ Vidal, die zelf wél een onderscheid maakt tussen onbevoegd handelen en handelen dat mank gaat aan détournement de pouvoir wijst erop dat de visie van Duguit uiteindelijk voortvloeide uit diens strikte bevoegdheidsconceptie. ${ }^{42}$

\subsubsection{De naoorlogse Franse literatuur}

In de naoorlogse Franse bestuursrechtelijke literatuur lijkt het onderscheid tussen onbevoegdheid en détournement de pouvoir enigszins te vervagen. Zo wijst Bénoit ${ }^{43} \mathrm{er}$ bij de bespreking van de verschillende beroepsgronden van het 'recours pour excés de pouvoir' op dat de onderscheiding tussen deze gronden traditioneel van aard is. Volgens hem staat het bevoegdheidsaspect steeds centraal binnen het rechtmatigheidsberoep en kunnen alle

39. L. Duguit, Traité de droit constitutionnel, a.w., p. 381.

40. L. Duguit, Traité de droit constitutionnel, a.w., p. 391.

41. L. Duguit, Traité de droit constitutionnel, a.w., p. 387: 'Dans beaucoup des ces arrêts, le conseil d'Etat parle non pas de détournement de pouvoir, mais d'excès de pouvoir ou encore de fonctionnaire 'qui a fait de ses pouvoirs un usage non autorisé par la loi', ce qui motre bien que le détoumement de pouvoir est véritablement une violation de la loi de compétence.'

42. R. Vidal, L'évolution du détoumement de pouvoir dans la jurisprudence administrative, a.w., p. 282.

43. F.-P. Bénoit, Le droit administratif français, a.w. , p. 581 en 582. 
beroepsgronden - waaronder détournement de pouvoir - in essentie herleid worden tot deze bevoegdheidsvraag. Waline ${ }^{44}$ benadrukt in zijn handboek wél het fundamentele verschil tussen détournement de pouvoir en de andere vernietigingsgronden. De toetsing op afwezigheid van détournement de pouvoir zou meer zijn dan enkel een objectieve rechtmatigheidstoets omdat deze er (mede) op gericht is de intenties van het bestuursorgaan vast te stellen.

In de hedendaagse administratiefrechtelijke handboeken van Chapus ${ }^{45}$ en De Laubadère c.s. ${ }^{46}$ wordt de discussie over de aard van de détournement de pouvoir mijns inziens echter niet meer op het scherpst van de dogmatische snede gevoerd. De détournement de pouvoir lijkt enkel vanuit didactisch oogpunt onderscheiden te worden van de incompétence en de violation de la loi. Auby en Drago wijzen ook nog op het nut van de traditionele onderscheiding met het oog op de toetsingssystematiek van de administratieve rechter. ${ }^{47}$ Deze toetst het aangevochten besluit in een bepaalde volgorde aan de verschillende beroepsgronden. Hierbij gaat de toetsing op 'légalité externe' vooraf aan de toetsing op 'légalité interne'.

Juist ten aanzien van de rechterlijke controle onderscheidt de toetsing op détournement de pouvoir zich volgens de Franse auteurs van het hierna nog te bespreken onderzoek naar de 'motifs' van een besluit. Het onderzoek naar détournement de pouvoir is er uiteindelijk steeds op gericht om door te dringen tot de verborgen en subjectief bepaalde 'mobiles' achter de bevoegdheidsuitoefening. ${ }^{49}$ Deze behoren volgens Chapus ${ }^{50}$ tot de 'ordre psychologique' van de bestuursactiviteit.

\subsubsection{Soorten en gradaties van détournement de pouvoir}

In de Franse dogmatiek worden doorgaans drie hoofdvarianten van détournement de pouvoir onderscheiden: (1) het bestuurlijk handelen in strijd met het algemeen belang, (2) het nastreven van publiekrechtelijke belangen welke niet overeenstemmen met het specifieke belang dat door de wetgever ten grondslag is gelegd aan de betreffende bestuursbevoegdheid, en (3) de détournement de procedure. ${ }^{51}$

De eerste variant wordt als het meest 'ernstig' aangemerkt. ${ }^{52}$ Indien het bestuur door middel van de uitoefening van een bestuursbevoegdheid uitsluitend particuliere of politieke

44. M. Waline, Droit administratif, a.w., p. 443-444.

45. R. Chapus, Droit administratif général, a.w., p. 955 e.v.

46. De Laubadère/Venezia/Gaudemet, Traité de droit administratif, a.w., p. 498 e.v.

47. Auby/Drago, Traité des recours en matière administrative, a.w., p. 333.

48. Letterlijk: de 'drijfveren'; het gaat hier om de subjectieve intenties, de bedoelingen van het bestuur.

49. Vgl. De Laubadère/Venezia/Gaudemet, Traité de droit administratif, a.w., p. 499.

50. R. Chapus, Droit administratif général, a.w., p. 955.

51. Op dit punt wijkt het Nederlandse bestuursrecht niet af. Vgl. Van Wijk/Konijnenbelt/Van Male, Hoofdstukken van administratief recht, a.w., p. 366 (variant 1 en 2), en wat betreft de détournement de procedure p. 332. Vgl. in dit laatste verband reeds H.D. van Wijk, Détournement de pouvoir ou d'eau seulement?, opgenomen in: Besturen met recht, 's-Gravenhage 1974, p. 171 e.v.

52. R. Chapus, Droit administratif général, a.w., p. 956. 
belangen van bestuurders nastreeft, dan wel indien wordt beoogd om personen schade toe te brengen overtreedt het orgaan de belangrijkste regel van het besturen, nl. het nastreven van het algemeen belang. ${ }^{53}$ Deze regel wordt door de administratieve rechter met kracht gesanctioneerd. Het gaat hier niet om een 'vooroorlogs' rariteitenkabinet. Ook in de meer recente jurisprudentie van de Conseil d'Etat zijn er voorbeelden te vinden van nepotisme. Zo zag de burgemeester van Calacuccia ${ }^{54}$ zijn verkeersmaatregel, die in het bijzonder de belangen van een bepaalde eigenaar beoogde te dienen, vernietigd op grond van détournement de pouvoir.

De tweede hoofdvariant van détournement de pouvoir wordt gekenmerkt door het feit dat het bestuursorgaan wél een bepaald publiekrechtelijk belang nastreeft, maar niet het specifieke belang dat door de wetgever aan de betreffende bestuursbevoegdheid ten grondslag werd gelegd. Dit is wellicht de meest voorkomende vorm van détournement de pouvoir.

Berucht zijn in dit verband de financiële (bij)bedoelingen die vaak door middel van een bepaalde bestuursbevoegdheid worden nagestreefd. ${ }^{55}$ Overigens blijkt uit de jurisprudentie dat het zeer wel mogelijk is dat een bestuursorgaan, terwijl het meent in het algemeen belang te handelen, geheel te goeder trouw een détournement de pouvoir begaat. $\mathrm{Zo}$ had de gemeenteraad van Puteaux ${ }^{56}$ een verhoging van de onroerende zaakbelasting (taxe d'habitation) voor een bepaalde groep van belastingplichtigen (nl. bijstandsgerechtigden) gecompenseerd. Volgens de Conseil d'Etat diende in het kader van een bijstandsuitkering echter de persoonlijke behoefte centraal te staan. $\mathrm{Nu}$ de verhoging niet gerechtvaardigd werd door de behoefte in individuele gevallen werd het compensatiebesluit vernietigd op grond van détournement de pouvoir.

Een bijzondere categorie binnen de détournements de pouvoir wordt tot slot gevormd door de zgn. 'détournements de procédure'. ${ }^{57}$ Indien de wet een bepaalde procedure voorschrijft ter realisering van een bepaald doel, dan dient het bestuursorgaan deze speciale procedure ook daadwerkelijk te volgen. De speciale procedure biedt immers meestal bijzondere waarborgen die door de wetgever noodzakelijk zijn geoordeeld gelet op de bevoegdheidsuitoefening.

53. Vgl. A. De Laubadère, Traité de droit administratif, a.w., p. 499-500.

54. C.E. 11 mei 1984, RDP 1986, p. 275. (maire de Calacuccia).

55. Auby en Drago wijzen er expliciet op dat in vele gevallen van bewezen détournement de pouvoir er sprake is van financiele bijbedoelingen. Auby/Drago, Traité des recours en matière administrative, a.w., p. 537. Een klassiek standaardvoorbeeld biedt C.E. 4 juli 1924, Rec. 641 (Beaugé). In casu had de burgemeester van Biarritz op basis van zijn algemene politiebevoegdheid een verordening uitgevaardigd op grond waarvan het uitsluitend was toegestaan om zich op het strand te ontkleden in van gemeentewege geplaatste en beheerde badhokjes. De verordening beoogde volgens de Conseil d'Etat echter niet de openbare zedelijkheid te dienen maar juist het financiele belang van de gemeente.

56. C.E. 23 maart 1988, Rec. 130 (ville de Puteaux).

57. De Laubadère/Venezia/Gaudemet, Traité de droit administratif, a.w., p. 501; R. Chapus, Droit administratif général, a.w., p. 961. Ik wijs erop dat Chapus voor dit verbod géén zelfstandige betekenis ziet weggelegd. Het verbod zou volgens hem herleidbaar zijn tot ofwel 'erreur de droit, ofwel détournement de pouvoir. 


\subsection{De 'contrôle des motifs' (causa) en détournement de pouvoir (le but)}

Naast het verbod van détournement de pouvoir is in de loop van deze eeuw door de Conseil d'Etat een andere toetsingssystematiek tot ontwikkeling gebracht die door de rechter wordt toegepast om een besluit op 'interne' rechtmatigheid te beoordelen. Het betreft hier het leerstuk van de 'contrôle des motifs'. Enkele opmerkingen over dit leerstuk zijn op deze plaats van belang. ${ }^{58} \mathrm{De}$ opkomst van de 'contrôle des motifs' kan nl. verklaren waarom de toetsing aan het verbod van détourment de pouvoir enigszins aan betekenis heeft ingeboet.

\subsubsection{Enige kenmerken van de 'contrôle des motifs'}

De leer van 'contrôle des motifs' gaat uit van de veronderstelling dat iedere bevoegdheidsuitoefening (besluit) is gebaseerd op een bepaalde feitelijke en een juridische grondslag. Tot de 'motifs' van een bevoegdheidsuitoefening worden naar Frans recht de objectieve antecedenten ${ }^{59}$ gerekend op basis waarvan een bestuursorgaan besluit om een bepaalde bestuursbevoegdheid uit te oefenen (de causa). Deze objectieve antecedenten dienen naar Frans recht uitdrukkelijk onderscheiden te worden van de subjective 'mobiles' waaraan het verbod van détournement de pouvoir is gerelateerd. ${ }^{60}$ Auby en Drago omschrijven de 'motifs' van een besluit als volgt:

'Ces motifs sont constitués par les éléments de droit et de fait qui ont conduit l'Administration à agir. Lorsqu'il prend une décision, l'administrateur se fonde à la fois sur une règle de droit écrit ou un principe général du droit et sur une certain situation de fait. Sa décision sera le résultat de ces deux catégories de motifs. ${ }^{\prime 61}$

De leer van 'contrôle des motifs', die is terug te voeren op de bevoegdheids- en wetmatigheidsleer ${ }^{62}$, strekt ertoe om de rechter een (toets)instrument te verschaffen ter vaststelling

58. Voor een uitvoerige analyse van dit leerstuk - toegespitst op de intensiteit van de rechterlijke toetsing van beoordelingsruimte - kan worden verwezen naar het proefschrift van Klap. A. Klap, Vage normen in het bestuursrecht, diss. RUL, Zwolle 1994, p. 107 e.v. en (minder recent) C.W.A. Timmermans, De administratieve rechter en beoordelingsvrijheden van bestuursorganen, a.w., p. 37-45. Zie voorts: R. Chapus, Droit administratif général, a.w., p. 946-947 en p. 967-977. Tot slot wijs ik op de omvangrijke 'standaardstudie' van Pacteau die vrijwel geheel aan het leerstuk van 'contrôle des motifs' is gewijd: B. Pacteau, Le juge de l'excès de pouvoir et les motifs de l'acte administratif, Traveaux et recherches de la faculté de droit et de science politique de l'université de Clermont I, 1977.

59. Vgl. De Laubadère/Gaudemet/Venezia, Traité de droit administratif, a.w., p. 499. De term 'motif' kan in dit verband dan ook niet vertaald worden als 'motief'. De Nederlandse term 'motief' duidt immers op subjectiviteit (intentie/bedoeling).

60. Zie over dit onderscheid i.h.b.: R. Vidal, L'évolution du détournement de pouvoir dans la jurisprudence administrative, a.w., p. 287.

61. Auby/Drago, Traité des recours en matière administrative, a.w., p. 475.

62. Vgl. Bénoit die opmerkte: 'On voit ainsi que le problème des motifs peut lui aussi rattaché directement à la notion de compétence elle-même. (..) On voit par les analyses qui précèdent que tous les motifs, de fait ou de droit, sont fixés par les textes qui créent la compétence et en aménagent l'exercice.' F.-P. Bénoit, 
van de objectieve grenzen van een bestuursbevoegdheid. Hierbij geldt als uitgangspunt dat een geconditioneerde bestuursbevoegdheid uitsluitend op een rechtsgeldige wijze kan worden uitgeoefend indien de wettelijke normcondities door een bepaald complex van feiten worden vervuld.

De 'motifs' van een besluit kunnen bijgevolg onderscheiden worden in 'motifs de droit' (de juridische grondslagen) en 'motifs de fait (de feitelijke grondslagen). Een bestuursorgaan dat een bestuursbevoegdheid uitoefent zal zich eerst een nauwkeurig beeld dienen te vormen van de wettelijke normcondities. Deze zullen zonodig moeten worden geïnterpreteerd. Het orgaan mag in dit verband enerzijds de wettelijke begrenzing niet overschrijden, anderzijds moet het orgaan de ruimte binnen de wettelijke kaders wél volledig benutten. ${ }^{63}$ Vervolgens zal het orgaan, voordat het overgaat tot het uitoefenen van een bestuursbevoegdheid, de feiten waarop het zich baseert op juistheid dienen te toetsen. ${ }^{64}$ Tot slot zal nauwkeurig nagegaan dienen te worden of de wettelijke normcondities door de zorgvuldig vastgestelde feiten worden vervuld (de kwalificatie). ${ }^{65}$

\subsubsection{Concurrentie?}

De opkomst van de 'contrôle des motifs' is van invloed geweest op de toetsing aan het verbod van détournement de pouvoir. Deze invloed bestaat hieruit, dat handelen in strijd met genoemd verbod doorgaans óbk een gebrek in de 'motifs' van een besluit met zich brengt (violation de la loi). Strikt genomen vormt de 'contrôle des motifs' een hulpmiddel voor het onderzoek naar détournement de pouvoir. ${ }^{66}$ Bepaalde gebreken in de 'motifs'

Le droit administratif français, a.w., p. 546 en 547.

63. De wettelijke (doel)grenzen van een bevoegdheid worden in Frankrijk door de administratieve rechter nauwkeurig vastgesteld en gecontroleerd. Zie: B. Pacteau, Le juge de l'excès de pouvoir et les motifs de l'acte administratif, a.w., p. 170. Vgl. Auby/Drago, Traité des recours en matière administrative, a.w., p. 499. Hierbij zal de rechter, bij het interpreteren van de (functionele) reikwijdte van een bestuursbevoegdheid, zo mogelijk aansluiting zoeken bij de terminologie en de strekking (het doel) van de wet. Vgl. voor een fraai voorbeeld: C.E. 10 januari 1968, Rec. p. 24 (Daudens). Indien ook de strekking van de wet geen uitkomst biedt dan zal in ieder geval een begrenzing van de bestuursbevoegdheid worden gezocht in de algemene rechtsgrond voor alle overheidsactiviteit, nl. het dienen van het 'algemeen belang'. Pacteau (a.w., p. 173) wijst in dit verband op het eerder besproken Pagès-arrest (C.E. 22 maart 1901, Rec. 351 ), waarin het handelen 'in het algemeen belang' volgens hem duidelijk werd gepositioneerd als een algemene beperking waaraan iedere uitoefening van een bestuursbevoegdheid is onderworpen.

64. Voorzover het bestuursorgaan zich beroept op niet bestaande of onjuist vastgestelde feiten is er sprake van een 'erreur de fait'. De feitenvaststelling is nauw verbonden met het legaliteitsaspect. Indien de wet het bestaan van een bepaald feitencomplex eist als voorwaarde voor een bevoegdheidsuitoefening, dan is een rechtmatige bevoegdheidsuitoefening ook uitsluitend mogelijk indien hieraan is voldaan. Vgl. B. Pacteau, Le juge de l'excès de pouvoir et les motifs de l'acte administratif, a.w., p. 139 en 140.

65. Het zal duidelijk zijn dat het Franse leerstuk van de 'motifs', gelet op het voorafgaande, een raakvlak vertoont met het leerstuk van de motivering van bestuursbesluiten. De vaststelling van feiten en de (eventuele) uitleg van de wet zal immers door het bestuur deugdelijk en draagkrachtig moeten worden gemotiveerd. Vgl. o.m. R.M. van Male, Beredeneerd besluiten. Plaats, functie en betekenis van het motiveringsbeginsel in het Nederlandse bestuursrecht, NTB 1988/3, i.h.b., p. 77-78.

66. Vgl. R. Vidal, L'évolution du détournement de pouvoir dans la jurisprudence administrative, a.w., p. 295. 
van een bestuursbesluit vormen soms een duidelijke indicatie voor een verborgen détournement de pouvoir. ${ }^{67}$ Er bestaat bijv. een gerede kans dat een bestuursorgaan buitenwettelijke belangen behartigt, indien een bevoegdheidsuitoefening plaatsvindt zonder dat het speciale publiekrechtelijke belang dit vergt of hierdoor wordt gediend. ${ }^{68}$ Ook is het mogelijk dat een bestuursorgaan zich beroept op niet bestaande feiten om een détournement de pouvoir te verdoezelen (erreur de fait).

Het bewijs van détournement de pouvoir kan bijgevolg vaak geleverd worden nadat een gebrek in de feitelijke of juridische grondslagen van het besluit is vastgesteld. ${ }^{69} \mathrm{De}$ samenloop van een gebrek in de 'motifs' van een besluit en détournement de pouvoir heeft tot gevolg dat de rechter in deze situatie ook een keuze heeft uit twee vernietigingsgronden. Daar een gebrek in de 'motifs' zich op een objectief waarneembare wijze manifesteert, vormt een dergelijk gebrek vanuit bewijstechnisch oogpunt vaak een aantrekkelijker vernietigingsgrond dan de subjectief georiënteerde détournement de pouvoir. Dit vormt een eerste belangrijke verklaring voor het feit dat het aantal vernietigingen van besluiten op de laatstgenoemde grond is afgenomen. ${ }^{70}$

\subsubsection{Een 'déclin' van het verbod van détournement de pouvoir?}

In de Franse literatuur is bijgevolg wel gesproken over een 'déclin' van het verbod van détournement de pouvoir. Chapus spreekt dit echter uitdrukkelijk tegen. ${ }^{71}$ Weliswaar is het aantal vernietigingen wegens détournement de pouvoir afgenomen, maar dit zegt weinig over de relevantie van dit verbod zelf. Uit het geringe aantal vernietigingen kan niet worden afgeleid dat het verbod van detournement de pouvoir in mindere mate door het bestuur wordt overtreden.

Naast het grote aantal vernietigingen op grond van gebreken in de 'motifs' van bestuursbesluiten verdient op deze plaats bijzondere vermelding dat bewijstechnische problemen de détournement de pouvoir parten spelen. 'Le problème de la preuve est, sans aucun doute, le problème capital du détournement de pouvoir', verzuchtten Auby en Drago. ${ }^{72}$ Het bewijsprobleem wordt veroorzaakt doordat het bewijs van détournement de pouvoir vaak op een indirecte wijze geleverd moet worden. Het komt immers niet vaak

67. Vgl. R. Vidal, L'évolution du détournement de pouvoir dans la jurisprudence administrative, a.w., p. 296.

68. Zich manifesterend in een 'erreur de droit' of een onjuiste feitenkwalificatie.

69. Vidal heeft hier het volgende over opgemerkt: 'Toutefois, en pratique, le cas le plus fréquent est celui ou ces intentions sont appréciées à la lumière des faits préexistants, qui ont déterminé la mise en mouvement de la volonté de l'auteur de l'acte. Autrement dit, le but poursuivi est découvert à la lumière des motifs. Aussi, le détournement de pouvoir devait-il, quoique subjectif dans son principe, s'orienter fatalement sur le terrain si important de sa preuve vers une conception largement objective.' R. Vidal, L'évolution du détournement de pouvoir dans la jurisprudence administrative, a.w., p. 294.

70. De Laubadère/Venezia/Gaudemet, Traité de droit administratif, a.w., p. 503.; zic ook: Auby/Drago, Traité des recours en matiere administrative, a.w., p. 531 en C.W.A. Timmermans, De administratieve rechter en beoordelingsvrijheden van bestuursorganen, a.w., p. 75-76.

71. R. Chapus, Droit administratif général, a.w., p. 960.

72. Auby/Drago, Traité des recours en matière administrative, a.w., p. 538. 
voor dat een bestuurder uitdrukkelijk blijk geeft van verborgen bedoelingen die de aanleiding vormden voor het nemen van een bepaald besluit. Lemasurier ${ }^{73}$ heeft het proces van bewijsvoering in dit kader als volgt gekarakteriseerd:

'Ce qu'il faudra prouver ce n'est pas un élément concret, mais un élément intellectuel, psychologique, une intention...un sentiment même: le juge devra d'abord rechercher le mobile qui a inspiré l'auteur de l'acte, le résultat que celui-ci se proposait d'atteindre, puis confronter ensuite ce mobile avec le but voulu par le législateur, avec l'esprit de la loi, les fins d'intérêt général qui s'imposent à l'Administration.(.) A moins de circonstances exceptionnelles, le but poursuivi par l'Administration sera celui que voudra bien lui prêter le juge dans son intime conviction: la preuve du détournement de pouvoir résulte d'une conviction, non d'une constatation.'

De rechter kan de overtuiging krijgen dat er sprake is van détournement de pouvoir op basis van correspondentie, notities en adviezen die zich in het procesdossier bevinden. Voorts kan het bewijs worden geleverd op grond van niet weersproken beweringen van de appellant alsmede op grond van omstandigheden en feiten die zich na het nemen van het besluit (nog) hebben voorgedaan. ${ }^{74}$ Het vermoeden van détournement de pouvoir kan overigens voor de rechter aanleiding zijn om de toetsing aan de andere (interne) beroepsgronden aan te scherpen. ${ }^{75}$ Hiertoe is alle reden daar een (verborgen) détournement de pouvoir vaak samengaat met een objectieve schending van het wettelijke doel van een bevoegdheid. Het bewijs van détournement de pouvoir kan dan worden geobjectiveerd. ${ }^{76}$

Het bewijs van détournement de pouvoir wordt tot slot niet alleen bemoeilijkt door bewijsproblemen, maar ook door een problematiek die in de Franse literatuur bekend staat onder de benaming van 'pluralite de buts'. ${ }^{77}$ Dit probleem, dat ook in Nederland bekend is $^{78}$, doet zich voor indien een bestuursorgaan naast ongeoorloofde doelstellingen gelijktijdig óok het objectieve doel van de wet nastreeft. Uit de jurisprudentie van de Conseil d'Etat blijkt dat niet iedere nevendoelstelling die het bestuur nastreeft détournement de pouvoir oplevert. Nevendoelstellingen mogen de hoofddoelstelling echter geenszins overheersen en het algemeen belang mag nooit in het gedrang komen. ${ }^{79}$

73. J. Lemasurier, La preuve dans le détoumement de pouvoir, RDP 1959, p. 36 e.v.

74. Voor een uitvoerige bespreking van de jurisprudentie inzake het bewijs van détournement de pouvoir kan verwezen worden naar Auby/Drago, Traité des recours en matière administrative, a.w., p. $538 \mathrm{t} / \mathrm{m} 540$, en J. Lemasurier, La preuve dans le détournement de pouvoir, a.w., p. $57 \mathrm{t} / \mathrm{m} 66$.

75. Vgl. Auby/Drago, Traité des recours en matière administrative, a.w., p. 538.

76. Lemasurier merkt in dit verband op: 'La preuve du détournement de pouvoir est négative: il faut prouver que le but poursuivi est contraire au but légal ou à l'intérêt général. C'est là d'ailleurs un élément d'objectivité dans la recherche subjective du but poursuivi.' J. Lemasurier, La preuve dans le détournement de pouvoir, a.w., p. 45 .

77. Zie hierover bijv. Auby/Drago, Traité des recours en matière administrative, a.w., p. $532 \mathrm{t} / \mathrm{m} \mathrm{534}$. Vgl. De Laubadère/Venezia/Gaudemet, Traité de droit administratif, a.w., p. 502.

78. Zie mijn noot onder Pres. Rb. Assen 29 februari 1996, JB 1996/129 (parkeren Klazienaveen).

79. Vgl. R. Chapus, Droit administratif général, a.w., p. 960. Chapus wijst erop dat in situaties waarin 'le but principal' dat door het bestuur wordt nagestreefd overeenstemt met het doel van de wet, nevendoelstellingen niet (snel) zullen leiden tot een vernietiging wegens détournement de pouvoir. 


\subsection{Het leerstuk van détournement de pouvoir in het Nederlandse bestuursrecht}

Het verbod van détournement de pouvoir wordt ook binnen het Nederlandse bestuursrecht opgevat als een fundamentele gedragsregel voor het bestuur. ${ }^{80}$ Het leerstuk staat in ons land van oudsher bekend onder de Franse benaming, ofschoon ook andere aanduidingen zijn beproefd zoals misbruik van overheidsmacht ${ }^{81}$, misbruik van (bestuurs)bevoegdheid $^{82}$, machtsafwending ${ }^{83}$, of 'oneigenlijk' gebruik van bevoegdheid. ${ }^{84}$ Een door Wiar$\mathrm{da}^{85}$ beproefde typisch Nederlandse benaming - onzuiverheid van oogmerk - vond geen ingang in de rechtspraktijk.

\subsubsection{Franse origine}

'Tegenwoordig wordt onder het verbod van détournement de pouvoir verstaan de plicht van het bestuur om een bevoegdheid te gebruiken in overeenstemming met de bedoeling van de wetgever en om met zuivere oogmerken en motieven te handelen.' Zo wordt in het gezaghebbende rapport ABAR het verbod inzake misbruik van bestuursbevoegdheid naar Nederlands recht gedefinieerd. ${ }^{86}$

Naar men mag aannemen werd de Nederlandse theorievorming inzake het verbod van détournement de pouvoir gebaseerd op het Franse recht. ${ }^{87}$ Niet alleen de benaming wijst

80. Voor de formele wetgever heeft het leerstuk niet zoveel betekenis omdat diens bevoegdheid niet (specifiek) doelgebonden is. Vgl. Van Wijk/Konijnenbelt/Van Male, Hoofdstukken van administratief recht, a.w., p. 366-377; R. de Lange, Publiekrechtelijke rechtsvinding, diss. UvA, Zwolle 1991, p. 31.

81. Zie: N. Okma, Misbruik van recht, diss. VU, Wageningen 1945, p. 139. Okma vatte de détournement de pouvoir op als een bepaalde vorm van misbruik van overheidsmacht, $\mathrm{nl}$. het gebruik van een bevoegdheid buiten haar doel. Misbruik van overheidsmacht zag Okma weer als een species van 'misbruik van recht'. Volgens hem was er nagenoeg géén principieel verschil tussen de leer van misbruik van recht in het privaatrecht en détournement de pouvoir (N. Okma, a.w., p. 28-29).

82. Vgl. J.A. Steenbeek, Het beroep tegen administratieve beschikkingen, commentaar Wet Bab, 's-Gravenhage 1966, p. 117 e.v. en Steenbeek/Stroink, Wet administratieve rechtspraak overheidsbeschikkingen, a.w., p. 229.

83. Het betreft hier een van oorsprong Belgische aanduiding. Zie: A.M. Donner, Nederlands bestuursrecht, a.w., p. 107.

84. Zie: Van der Burg/Cartigny/Overkleeft-Verburg, Rechtsbescherming tegen de overheid, a.w., p. 109.

85. G.J. Wiarda, Algemene beginselen van behoorlijk bestuur (preadvies VAR), Geschriften van de Vereniging voor Administratief recht XXIV, Haarlem 1952, p. 61 en 62.

86. Rapport inzake Algemene Bepalingen van Administratief Recht (ABAR), vijfde geheel herziene druk, Alphen aan den Rijn 1984, p. 147.

87. Vgl. W.G. Vegting, Het algemeen Nederlands administratief recht I, Alphen aan den Rijn 1954, p. 240241. Volgens Vegting ging Nederland net als vele andere Westeuropese landen, wat betreft de détournement de pouvoir, in de leer bij de Franse rechtspraak en doctrine. Vgl. voorts het Rapport ABAR, a.w., p. 146-147. Ook in de memorie van toelichting bij art. 3:3 Awb wordt gewezen op de Franse oorsprong van het verbod. PG Awb I, MvT, p. 207. De Franse rechtsontwikkeling zal ook invloed hebben gehad op de Duitse doctrine, maar het leerstuk ontwikkelde zich in dit land op een meer autonome wijze. De détournement de pouvoir wordt in Duitsland aangemerkt als een bepaald type 'Ermessenfehler', en is bekend onder de benaming 'Ermessenmißbrauch'. Zie bijv. H. Maurer, Allgemeines Verwaltungsrecht, 11. Auflage, Munchen 1997, p. 127. Vgl. in dit kader $\S 40$ van het Verwaltungsverfahrensgesetz: 'Ist die 
in die richting, maar ook de periode waarin het verbod als toetsingsgrond voor bestuurshandelen in het Nederlandse bestuursrecht werd gepositiveerd. Dit geschiedde voor het eerst in de Distributie- en crisiswet van $1918 .^{88}$ Het verbod werd vervolgens, na een uitvoerige parlementaire behandeling, als toetsingsgrond opgenomen in de Ambtenarenwet 1929. ${ }^{89}$ Juist in deze periode - het interbellum - beleefde de toetsing aan détournement de pouvoir in Frankrijk zijn absolute hoogtepun $\mathrm{t}^{90}$ en de bekendheid van de jurisprudentie van de Conseil d'Etat reikte tot ver over de Franse landsgrenzen heen. In 1922 wijdde Mulder $^{91}$ in ons land zelfs een heel proefschrift aan de Franse jurisprudentie, nadat Boasson in 1911 reeds het nodige voorwerk had verricht. ${ }^{92}$

Tijdens de parlementaire behandeling van de Ambtenarenwet 1929 werd het d.d.p.verbod als toetsingsnorm, naast 'strijd met een wettelijk voorschrift', door de regering aanvaardbaar geacht. ${ }^{93}$ De mogelijkheid van toetsing aan het verbod maakte in ons land de weg vrij voor de ontwikkeling van toetsing van bestuurshandelingen aan ongeschreven rechtsbeginselen. Toetsing van discretionaire bevoegdheidsuitoefeningen aan het verbod van détournement de pouvoir werd overigens in deze beginjaren ruim uitgelegd. Zo vestigde Van der Meide er de aandacht op dat het verbod, zoals gecodificeerd in artikel 58, eerste lid van de Ambtenarenwet 1929 waarschijnlijk mede het specimen van de 'willekeurige' beslissing omvatte. ${ }^{94}$ In deze tijd werd het verbod verder sterk omgeven door de odeur van laakbaar en onbehoorlijk handelen van overheidsambten (machtsmisbruik).

\subsubsection{Toch Nederlands?}

De stelling dat het leerstuk van détournement de pouvoir integraal uit het Franse recht werd overgenomen, doet echter (te) weinig recht aan ontwikkelingen in ons land. Ofschoon het verbod van détournement de pouvoir pas na de Eerste Wereldoorlog als toetsingsgrond in Nederland werd gepositiveerd, waren er reeds eerder vele aanwijzingen waaruit kan worden afgeleid dat het doelgebonden en beperkte karakter van bestuursbevoegdheid een belangrijke plaats werd toebedacht in de Nederlandse rechtspraktijk en in de administratief-

Behठ̈rde ermăchtigt, nach ihrem Ermessen zu handeln, hat sie ihr Ermessen entsprechend dem Zweck der Ermächtigung auszuluben und die gesetzlichen Grenzen des Ermessens einzuhalten' (curs. R.J.N.S.).

88. In art. 8 lid 1 (Wet van 26 juli 1918, Stb. 494).

89. In art. 58 lid 1 van de genoemde wet.

90. Vgl. J.H. van der Meide, Ontwikkeling van de toetsingsnormen in de ambtenarenrechtspraak, NJB 1980/40, p. 1055.

91. A.C.J. Mulder, De theorie van den détoumement de pouvoir van den Franschen Conseil d'Etat, diss. UU, Utrecht 1922.

92. J.J. Boasson, De rechter tegenover de vrijheid der administratie, a.w., p. 313-330.

93. Zie voor een bespreking van deze parlementaire behandeling J.H. van der Meide, Ontwikkeling van de toetsingsnormen in de ambtenarenrechtspraak, a.w., p. 1054 en 1055. Zie voorts: M. Schreuder-Vlasblom. De macht der kritiek, diss. RUG, Zwolle 1987, p. 156 e.v.

94. J.H. van der Meide, Ontwikkeling van de toetsingsnormen in de ambtenarenrechtspraak, a.w., p. 1055. 
rechtelijke theorievorming. ${ }^{95}$ Donner heeft er in zijn proefschrift op gewezen dat de ontwikkeling van het leerstuk van détournement de pouvoir samenging met het ter behartiging toedelen van administratiefrechtelijke belangen aan takken van dienst. ${ }^{96}$ De ontwikkeling van het gefragmenteerde, of gedifferentieerde, stelsel van administratieve wetgeving ${ }^{97}$ leidde tot de ontwikkeling van de rechtsstatelijke (gedrags)regel dat uitsluitend de door de wetgever aan een bestuursorgaan toevertrouwde (publiekrechtelijke) belangen - hoe vaag deze ook zijn - door dat orgaan mogen worden behartigd. ${ }^{98}$

Enige 'spontane' vernietigings-KB's uit de tweede helft van de negentiende eeuw tonen in dit verband aan dat de theorievorming omtrent 'détournement de pouvoir' - zij het niet onder deze benaming - in het Nederlandse publiekrecht tot ontwikkeling kwam onafhankelijk van het Franse recht. Ik verwijs in dit kader kortheidshalve naar een fraaie analyse van Van der Net die hier terecht de aandacht op vestigde. ${ }^{99}$ Uit de door deze auteur besproken KB's blijkt dat de Kroon in overschrijding en misbruik van bestuursmacht, alsmede in het aanwenden van bestuursmacht voor andere dan toegestane doeleinden, reden zag om besluiten van gemeentelijke en provinciale bestuursorganen te vernietigen. Van der Net merkt in dit kader o.m. op:

'Het zakelijk meest belangwekkende (..) vind ik zelf, dat daarmede bewezen wordt, dat misbruik van macht en bevoegdheid wel degelijk ook in het oer-Hollandse rechtsbewustzijn als laakbaar leefde, en dat we benoeming van die laakbaarheid echt niet, althans in de grond van de zaak niet bij uitstek van de Fransen hebben behoeven te leren' (curs. R.J.N.S). ${ }^{100}$

Desalniettemin is de Franse theorievorming voor een belangrijk deel bepalend geweest voor de verdere ontwikkeling van het leerstuk van détournement de pouvoir in ons land.

\subsubsection{Literatuur}

In de Nederlandse administratiefrechtelijke literatuur is steeds fundamentele betekenis toegekend aan het verbod van détournement de pouvoir. ${ }^{101}$ In de oudere literatuur treft

95. Vgl. de uitvoerige analyse inzake de doelbinding van bestuursbevoegdheden door Boasson in zijn proefschrift. J.J. Boasson, De rechter tegenover de vrijheid der administratie, a.w., i.h.b. p. 367-374. Boasson was de mening toegedaan dat de erkenning van het uitgangspunt van doelbinding reeds rond de eeuwwisseling was verankerd in de jurisprudentie van de Hoge Raad (vgl. a.w., p. 119-121).

96. A.M. Donner, De rechtskracht van administratieve beschikkingen, diss. VU, Alphen aan den Rijn 1941, p. 75 .

97. Vgl. in dit verband ook: J.J. Boasson, De rechter tegenover de vrijheid der administratie, a.w., p. 371.

98. Vgl. de opmerkingen van Struycken, die dit uitgangspunt reeds in 1910 verwoordde. A.A.H. Struycken, Administratie of rechter, Arnhem 1910, p. 27.

99. B.J. van der Net, Détournement de pouvoir in het vernietigingsrecht. Tot uitsterven gedoemd?, TvO 1976/11, p. 216 e.v.

100. B.J. van der Net, Détournement de pouvoir in het vernietigingsrecht, a.w., p. 216.

101. Alleen lijkt te staan: R. de Winter, Oud zeer, in: Azen op tegenslag, Lelystad 1994, p. 14 e.v. De Winter acht het verbod van détournement de pouvoir niet meer van deze tijd, evenmin als het uitgangspunt van wetmatigheid van bestuur en de idee van beperktheid van overheidsbevoegdheid. 
men in dit kader nogal eens ferme uitspraken aan, waaruit kan worden afgeleid dat het verbod werd gezien als een fundament voor rechtsstatelijk bestuur. ${ }^{102}$ Exemplarisch is in dit verband een uitspraak die men aantreft in het handboek van Kranenburg/Vegting:

\begin{abstract}
'Men heeft begrepen, dat de speciale bevoegdheden, die aan een overheidsorgaan zijn gegeven, niet los in de lucht hangen, maar samenvallen met het speciale doel, dat men door de regeling heeft willen verwezenlijken. Wijkt het betreffende orgaan van dat doel af, gebruikt het m.a.w. een bevoegdheid tot een ander doel, dan waarvoor deze aan dit orgaan is toegekend, dan zaagt het de tak af, waarop het is gezeten' (curs. R.J.N.S.). ${ }^{103}$
\end{abstract}

Maar ook in meer recente literatuur wordt aan naleving van het verbod van détournement de pouvoir door het bestuur waarde gehecht. Stellinga ${ }^{104}$ ziet détournement de pouvoir als een euvel dat geweerd dient te worden, en Nicolai ${ }^{105}$ brengt het verbod in verband met het meer algemene verbod van misbruik van bevoegdheid dat hij ziet als een grondbeginsel van onze rechtsorde. De bespreking van het verbod van détournement de pouvoir heeft zich een vaste plaats in de Nederlandse handboeken algemeen bestuursrecht verworven. ${ }^{106}$

Konijnenbelt ${ }^{107}$ brak in 1984 , als voorzitter van de Vereniging voor Administratief recht, een lans voor het leerstuk. Volgens hem geeft het verbod extra reliëf aan het aloude wetmatigheidsbeginsel. Het verbod van détournement de pouvoir kan volgens Konijnenbelt in het hedendaagse bestuursrecht met name een belangrijke functie vervullen als interpretatiemaatstaf voor de wettelijke bevoegdheidsgrondslag. De wet kent bevoegdheden immers niet zonder meer toe, maar altijd uitsluitend om het algemeen belang te dienen, en bovendien met het oog op min of meer specifieke doeleinden. ${ }^{108}$ Ook Donner ${ }^{109}$ benadrukte in zijn Algemeen deel het belang van het verbod van détournement de pouvoir als centraal bestuursrechtelijk leerstuk. Ofschoon het verbod als beroepsgrond aan betekenis heeft inge-

102. Ik wijs op het 'vlammende' betoog van A.A.H. Struycken in zijn artikel over de administratieve rechtspraak in crisiszaken, o.m. opgenomen in: Nederlandsch administratief recht, Haarlem 1919, p. 634. Struycken pleitte voor betere (rechtsstatelijke) waarborgen binnen de bestuursorganisatie ter voorkoming van machtsmisbruik en willekeur.

103. Kranenburg/Vegting, Inleiding in het Nederlands administratiefrecht, Haarlem 1951, p. 53.

104. J.R. Stellinga, Grondtrekken van het Nederlands administratiefrecht, tweede herziene druk, Zwolle 1973, p. 128.

105. P. Nicolai,, Het tandvlees van het recht, in: Recht op scherp (Duk-bundel), Zwolle 1984, p. 25.

106. De Haan/Drupsteen/Fernhout, Bestuursrecht in de sociale rechtsstaat $\mathbb{I}$, vierde geheel herziene druk, Deventer 1996, p. 94 e.v.; Nicolai e.a., Bestuursrecht, zesde geheel herziene druk, Amsterdam 1997, p. 448 e.v.; H.J. Simon, Handboek bestuurs(proces)recht volgens de Awb, 's-Gravenhage 1997, p. 137138; J.B.J.M. ten Berge, Besturen door de overheid. Nederlands algemeen bestuursrecht 1, tweede druk, Deventer 1997, p. 301-302 en Van Wijk/Konijnenbelt/Van Male, Hoofdstukken van administratief recht, a.w., p. 366-368 en 404.

107. W. Konijnenbelt, De Assepoester onder de beginselen van behoorlijk bestuur. Over het verbod van machtsafwending, Geschriften van de Vereniging voor Administratief recht XCII (verslag), Alphen aan den Rijn 1984, p. 142 t/m 145.

108. W. Konijnenbelt, De Assepoester onder de beginselen van behoorlijk bestuur, a.w., p. 144 .

109. A.M. Donner, Nederlands bestuursrecht, a.w., p. 109. 
boet, blijft volgens hem het verwijt van détournement de pouvoir aan het adres van het bestuur één van de zwaarste en overtuigendste.

Wellicht vormt deze laatste constatering ook een reden voor de geringe 'populariteit' van het verbod als vernietigingsgrond. ${ }^{110}$ De détournement de pouvoir wordt mijns inziens te snel in de sfeer van het 'laakbare' bestuur getrokken. Ik wijs er in dit kader, in navolging van andere auteurs, op dat een bestuursorgaan ook geheel te 'goeder trouw' het verbod kan overtreden. "' Vaak is enkel de interpretatie van het (te) vaag geformuleerde objectieve doel van een bestuursbevoegdheid in het geding. Ik kom hier in paragraaf 5.6.6 nog op terug.

\subsubsection{De wetgeving}

Het verbod van détournement de pouvoir komt sedert lang tot uitdrukking in de Nederlandse wetgeving. Het verbod werd o.m. neergelegd in bepalingen die het stellen van vergunning- of ontheffingsvoorschriften door het bestuur exclusief relateerden aan de bescherming van speciale publiekrechtelijke belangen. Het bekendste voorbeeld biedt in dit kader artikel 18, eerste lid van de voormalige Keurenwet 1895 ingevolge welk artikellid aan een vergunning te verbinden voorwaarden uitsluitend mochten strekken tot bescherming van die belangen, om welke het vereiste van vergunning was gesteld. ${ }^{112}$

Via de Wet $\mathrm{Bab}$ en de Wet Arob $^{113}$, verkreeg het leerstuk van détournement de pouvoir uiteindelijk een prominente plaats in de Algemene wet bestuursrecht. De Awbwetgever heeft het verbod van détournement de pouvoir in de vorm van een algemene gedragsregel voor bestuursorganen in artikel 3:3 gecodificeerd. ${ }^{114}$ Deze gedragsregel is zowel van toepassing op bestuursbevoegdheden met een beschikkingskarakter als met een

110. Vgl. H.J. Simon, Handboek bestuurs(proces)recht volgens de Awb, a.w., p. 137.

111. In dit verband dient ook de verzuchting van De Goede en Van den Brink te worden geplaatst: 'En zo is het. Bestuurders met laakbare bedoelingen bestaan, maar zijn gelukkig schaars. Bestuurders die goede bedoelingen langs een verkeerde weg willen realiseren, zijn talrijker. Maar ook dan kan er sprake zijn van détournement de pouvoir.' De Goede/Van den Brink, Beeld van het Nederlands bestuursrecht, vijfde druk, 's-Gravenhage 1986, p. 184. Vgl. ook Steenbeek/Stroink, Wet administratieve rechtspraak overheidsbeschikkingen, a.w., p. 232-233.

112. Soortgelijke bepalingen worden ook in moderne bestuursrechtelijke wetgeving aangetroffen. Als voorbeeld kan gewezen worden op art. 6 lid 2 Woningwet dat luidt: 'Aan een vrijstelling als bedoeld in het eerste lid (van voorschriften uit het Bouwbesluit R.J.N.S.) mogen slechts voorwaarden worden verbonden ter bescherming van de belangen, waarop de voorschriften, waarvan vrijstelling wordt verleend, het oog hebben.' Vgl. bijv. ook: art. 15 lid 3 Wet op de Ruimtelijke Ordening en art. 8.11 lid 3 Wet milieubeheer.

113. Het verbod van détournement de pouvoir was in essentie als beroepsgrond neergelegd in art. 4 lid 1 sub b van de Wet Bab, respectievelijk in art. 8 lid 1 sub $b$ van de Wet Arob. De redactie was in beide wetten identiek en luidde dat voorziening/beroep o.m. mogelijk was terzake dat 'b. het administratieve orgaan bij het geven van de beschikking van zijn bevoegdheid kennelijk tot een ander doel gebruik heeft gemaakt dan tot de doeleinden, waartoc die bevoegdheid gegeven is; ...' (curs. R.J.N.S.). Vgl. ook nog art. 5 onder $b$ van de Wet Arbo.

114. Art. 3:3 Awb luidt: 'Het bestuursorgaan gebruikt de bevoegdheid tot het nemen van een besluit niet voor cen ander doel dan waarvoor die bevoegdheid is verleend.' 
regelgevingskarakter. ${ }^{115}$ Door de codificatie van het verbod van détournement de pouvoir in afdeling 3:2 van de Algemene wet bestuursrecht heeft de wetgever beoogd om de regel rechtstreeks als norm voor het 'besluitende' bestuur te formuleren. ${ }^{116}$ Van bijzonder belang is dat hierdoor expliciet tot uitdrukking wordt gebracht dat het verbod een centrale spil vormt binnen het proces van bestuurlijke belangenafweging. In hoofdstuk 6 , waar ik artikel 3:4 lid $1 \mathrm{Awb}$ bespreek, kom ik terug op de relatie tussen belangenafweging en het verbod van détournement de pouvoir.

\subsubsection{Jurisprudentie}

Het aantal uitspraken waarbij besluiten vernietigd werden op grond van détournement de pouvoir is, vanuit relatief oogpunt bezien, niet bijzonder groot. ${ }^{117}$ Verschillende verklaringen kunnen hiervoor worden gegeven. ${ }^{118}$ Het bewijsprobleem, dat in paragraaf 5.5.3 werd besproken, lijkt in ieder geval goede papieren te hebben. Hierbij dient wél te worden opgemerkt dat het aantal uitspraken dat met het leerstuk in verband kan worden gebracht omvangrijker is indien men rekening zou houden met vernietigingen op grond van strijd met de wet en het motiveringsbeginsel. ${ }^{119}$ Overigens lijkt het leerstuk sinds de

115. PG Awb I, MvT, p. 208. Zie over het verbod van détournement de pouvoir en 'bestuurswetgeving' i.h.b. - het proefschrift van Van Male. R.M. van Male, Rechter en bestuurswetgeving, diss. KUB, Zwolle 1988, p. 333 e.v. Overigens gaat strijd met het verbod van détournement de pouvoir hier in de regel schuil achter strijd met de wettelijke attributie- of delegatiegrondslag. Vgl. o.m. HR 1 juli 1983, AB 1984, 103, m.nt. FHvB, NJ 1984, 360, m.nt. M. Scheltema (prijzenbeschikking medisch specialisten); HR 6 mei 1983, AB 1984, 101, m.nt. H.K. Fernandes Mendes en FHvdB (Bullenbaaiheffing); HR 10 april 1984, NJ 1984, 612, m.nt. ' $t \mathrm{H}$ (jodiumhoudend broodzout) en HR 9 mei 1984, NJ 1985, 227, m.nt. J.P. Scheltens (schriktarief Zaanstad).

116. PG Awb I, MvT, p. 208.

117. Zie 0.m. HR 14 januari 1949, NJ 1949, 557 (woonruimtevordering Zandvoort); HR 9 april 1976, NJ 1976, 394, m.nt. W.F.P., AB 1976, 162, m.nt. J.R.St. (dansen in Katwijk); KB 28 juli 1960, AB 1960 p. 709, m.nt. St. (wachtverbod 's-Hertogenbosch); KB 17 maart 1980, AB 1980, 364, m.nt. V.d.V. (grondverkoop Havelte); KB 1 april 1988, AB 1988, 297 (verkeersmaatregel Gouda); KB 30 juni 1994, AB 1994, 638 (bestemmingsplan Meijel); ARRS 4 januari 1977, AB 1978, 10, m.nt. F.H.v.d.B (bejaardenoord Huize Clifford); ARRS 12 augustus 1977, AB 1978, 6, m.nt. v.d.V. (zomerwoning Terschelling); ARRS 20 augustus 1979, AB 1980, 298, m.nt v.d.V., tB/S III, nr. 136, m.a. tB/S (watergemaal Stroink); ARRS 1 april 1980, tB/S III, nr. 179, m.a. tB/S (singelhuis Utrecht); ARRS 8 september 1981, tB/S III, nr. 293, m.a. tB/S (zondagsrust Staphorst); ARRS 1 februari 1982, Gst. 1982, 6725 (leefbaarheidsverordening Kortgene); ARRS 22 februari 1982, tB/S III, nr. 329, m.a. M.C.B. (woonplaatsdispensatie notaris); ARRS 10 januari 1985, AB 1985, 501, m.nt. JHvdV (dansvergunning Kesteren); ARRS 15 december 1987, Gst. 1988, 6855, m.nt. L.J.A. Damen (Publex-zaak); CRvB 19 maart 1976, AB 1976, 219 (Herindelingswet Zaanstreek); CRvB 5 mei 1978, AB 1978, 498, m.nt. In 't V. (reorganisatie); CRvB 29 december 1978, AB 1979, 505, m.nt. E.H.N. (vermindering lesuren) en CRvB 29 september 1994, ABkort 1994, 924.

118. Damen noemt: (1) de hypothese dat détournement de pouvoir niet vaak voorkomt, (2) de concurrentie van vernietigingen op grond van strijd met de wet, en (3) het bewijstechnische probleem. L.J.A. Damen, naschrift onder ARRS 15 december 1987, Gst. 6855, nr. 6 (Publex-zaak).

119. Een (verborgen) détournement de pouvoir kan tot uitdrukking komen in een gebrekkige motivering van een besluit. De rechter kan in dit geval 'formeel' venietigen (vgl. bijv. ABRS 16 december 1996, JB 1997/23, m.nt. R.J.N.S. (bewonersorganisatie Franklin). Zie: Rapport ABAR, a.w., p. 150-151. Het afdoen 
inwerkingtreding van de Algemene wet bestuursrecht weer wat meer in de rechterlijke belangstelling te staan. ${ }^{120}$

Omdat de meeste jurisprudentie in de gangbare handboeken wordt besproken volsta ik hier met een illustratieve uitspraak van de (voormalige) Afdeling rechtspraak ${ }^{121}$ inzake het watergemaal Stroink. In casu had de gemeenteraad van Brederwiede - in voorziening overeenkomstig het eerdere besluit van burgemeester en wethouders, een bouwvergunning geweigerd voor de afbraak van de schoorsteen van genoemd watergemaal op grond van (cultuur)historische beweegredenen. Volgens de Afdeling rechtspraak van de Raad van State werden deze motieven echter niet gedekt door de welstandsbepaling in de vigerende bouwverordening die uitsluitend op belangen van esthetische aard zag. Vernietiging van de beschikking volgde op grond van détournement de pouvoir. Volgens de Afdeling had de raad verzuimd om te beoordelen of het watergemaal, nadat de schoorsteen was verwijderd, aan de welstandseisen bleef voldoen. Cultuurhistorische motieven mochten bij deze beoordeling geen rol spelen. Het streven van de gemeente om de schoorsteen - die (nog) niet als monument ingevolge de Monumentenwet was aangemerkt - via het vergunningstelsel van de Woningwet te beschermen strandde hierdoor.

\subsubsection{Een bevoegdheidsgebrek?}

De discussies inzake het rechtskarakter van détournement de pouvoir hebben, in navolging van de meningsverschillen in Frankrijk, óók geklonken in de Nederlandse literatuur. ${ }^{122}$ Zo is er gestreden over de vraag of een bestuursorgaan dat zich schuldig maakt aan détournement de pouvoir bevoegd of onbevoegd handelt. Nauw verbonden hiermee is de vraag of détournement de pouvoir onderscheiden moet worden van handelen in strijd met de wet en wat de relatie is tot het willekeurverbod. ${ }^{123}$ Hier klinkt soms de Franse leer door ${ }^{124}$ waarin, zoals bleek, de zgn. 'subjectieve' benadering van het verbod centraal staat.

van een détournement de pouvoir op grond van schending van het motiveringsbeginsel doet m.i. echter niet altijd afdoende recht aan de juridische ernst van dit gebrek. Vgl. mijn noot onder Rb. 's-Hertogenbosch 6 juli 1995, JB 1995/319 (speelstraat 's-Hertogenbosch). In meer algemene zin verschaft de motivering vaak direct of indirect aanwijzingen waaruit kan worden afgeleid welke belangen een bestuursorgaan daadwerkelijk beoogde te behartigen. Zie over de relatie tussen motivering en doelbehartiging voorts: Stroink/Steenbeek, Wet administratieve rechtspraak overheidsbeschikkingen, a.w., p. 231.

120. Naast de uitspraak die in de voorafgaande voetnoot werd vermeld kan worden gewezen op: Pres. Rb. Assen 17 oktober 1996, JB 1996/252; Pres. Rb. Zutphen 12 september 1996, JB 1996/238 en Pres. Rb. Assen 29 februari 1996, JB 1996/129, alledrie met noot R.J.N.S.

121. ARRS 20 augustus 1979, AB 1980, 298, m.n. v.d.V.; tB/S III, 136, m.a. tB/S. (stoomgemaal Stroink).

122. Zie voor een beknopt overzicht van de standpunten in de literatuur en de jurisprudentie in de vooroorlogse periode: A. Kleijn en J.V. Rijpperda Wierdsma, De rechtsgevolgen van formeel onjuiste of onbevoegd genomen (verrichte) besluiten en handelingen (prae-adviezen VAR), Geschriften van de VAR VI, Haarlem 1942 , p. 121-126.

123. Zie voor een fraaie theoretische verhandeling: J.R. Stellinga, Détournement de pouvoir, Bestuurswetenschappen 1952, p. 399 e.v.

124. Vgl. de relatie tussen het verbod van détournement de pouvoir (le but) en het leerstuk van de 'contrôle des motifs' (causa) als species van 'violation de la loi'. Zie paragraaf 5.5.2. 
Steenbeek en Stroink hebben deze 'subjectieve' benadering verdedigd. ${ }^{125}$ Volgens hen is er in geval van détournement de pouvoir wél sprake van bevoegdheid, alleen het gebruik van deze bevoegdheid is verkeerd. Typerend voor dit onjuiste gebruik zijn de (verkeerde) subjectieve intenties - een soort 'ambtelijke' kwade trouw - aan de zijde van het bestuur, welke niet overeenstemmen met het objectieve doel van de bevoegdheid. Exemplarisch voor een meer 'objectieve' benadering van het leerstuk is de opvatting van Vegting. Voor deze auteur impliceert handelen in strijd met het doel van een bevoegdheid primair handelen in strijd met de wet. ${ }^{126}$

Deze discussie, die door Donner ${ }^{127}$ mijns inziens terecht als 'een tamelijk steriel debat' werd omschreven, heeft uiteindelijk niet zoveel praktische betekenis. Ook de administratieve rechter heeft er nooit zo'n theoretisch punt van gemaakt. Ik neem het standpunt in dat détournement de pouvoir een onmiskenbaar bevoegdheidsgebrek is. Het gebrek staat naar mijn mening goeddeels gelijk aan handelen zonder een afdoende wettelijke bevoegdheidsgrondslag. Minder juist acht ik een standpunt dat het verbod van détournement de pouvoir op één lijn stelt met een algemeen beginsel van behoorlijk bestuur. ${ }^{128}$ Het verbod is immers ontwikkeld tegen de achtergrond van het rechtsstatelijke principe van wetmatigheid van bestuur. Waar algemene beginselen van behoorlijk bestuur de rechtmatige uitoefening van een reeds bestaande bestuursbevoegdheid waarborgen, daar is het verbod van détournement de pouvoir bepalend voor de bewaking van de objectieve publiekrechtelijke grenzen van die bevoegdheid zelf. Het rechtsstatelijke verbod bindt het bestuursorgaan in het kader van het (gerichte) rechtshandelen in concreto aan het functionele (doel)criterium van die bevoegdheid. ${ }^{129}$

Hierin schuilt ook het belang van het verbod van détournement de pouvoir voor het hedendaagse bestuursrecht. Juist wanneer wettelijke bevoegdheidsnormen open en vaag zijn dient het bestuur ingescherpt te worden dat het doelgebonden publieke rechtsvormingsproces, dat door de wetgever onvoltooid uit handen werd gegeven, desalniettemin conform de intenties van die wetgever behoort te worden voltooid. Als fundamentele instructienorm voor het bestuur behoudt het verbod dan ook volledig zijn waarde, ongeacht of er sprake is van 'Eingriffsverwaltung' of 'Leistungsverwaltung'. ${ }^{130}$ Steeds zal een bevoegdheidsuit-

125. Steenbeek/Stroink, Wet administratieve rechtspraak overheidsbeschikkingen, a.w., p. 230-232.

126. W.G. Vegting, Het algemeen Nederlands administratiefrecht I, a.w., p. 240.

127. A.M. Donner, Algemeen bestuursrecht, Algemeen deel, tweede ongewijzigde druk, Alphen aan den Rijn 1967, p. 276.

128. Vgl. De Haan/Drupsteen/Fernhout, Bestuursrecht in de sociale rechtsstaat I, a.w., p. 94.

129. Zie inzake de 'materiele' kenmerken van een bevoegdheidsnorm hoofdstuk 2 van dit boek (paragraaf 2.3.3). Vgl. voorts A.Q.C. Tak, Hoofdlijnen van het Nederlands bestuursprocesrecht, a.w., p. 177. Tak ziet het verbod van détournement de pouvoir als een vertaling van het legaliteits- en specialiteitsbeginsel naar de uitoefening van een bepaalde bestuursbevoegdheid in concreto.

130. Zie wat betreft de verwerping van dit onderscheid hoofdstuk 4. In dit verband is nog van belang dat in de derde tranche van de Awb het vereiste van doelbinding ook t.a.v. subsidiebevoegdheden in essentie tot uitdrukking wordt gebracht, waarbij tevens paal en perk wordt gesteld aan het verbinden van allerlei bijkomende voorschriften aan subsidiebeschikkingen welke zijn gelegen buiten dit doel (vgl. de artikelen 4:37 Awb e.v.). Zie hierover bijv. J.B.J.M. ten Berge, Besturen door de overheid, a.w., p. 338. 
oefening dienstig moeten zijn aan de optimalisering van een specifiek publiekrechtelijk doel. ${ }^{131}$ Het bestuursorgaan zal hiervan in de motivering die het besluit draagt blijk dienen te geven. De primaire indicator voor een (mogelijke) détournement de pouvoir is mijns inziens dan ook niet zozeer de aanwezigheid van ontoelaatbare 'subjectieve' intenties, maar het feit dat het publiekrechtelijke doel van een bevoegdheid niet, dan wel op een gebrekkige wijze, door de bevoegdheidsuitoefening wordt gediend. Dit kan uiteraard het gevolg zijn van ontoelaatbare bestuurlijke bedoelingen, maar de oorzaak kan óok zijn gelegen in het te goeder trouw onjuist interpreteren ${ }^{132}$ van de (functionele) grenzen van een bestuursbevoegdheid. Een en ander rechtvaardigt mijns inziens dat de rechter die een détournement de pouvoir vaststelt ${ }^{133}$ uiteindelijk vernietigt wegens strijd met de wet. ${ }^{134}$

\subsection{Conclusie}

Het leerstuk van détournement de pouvoir werd door de Conseil d'Etat in de tweede helft van de negentiende eeuw tot ontwikkeling gebracht. Dit geschiedde in het kader van het Franse rechtmatigheidsberoep (het 'recours pour excès de pouvoir'). Bij de ontwikkeling van het leerstuk, dat een meer adequate toetsing van discretionaire bestuursbevoegdheden moest waarborgen, baseerde de Conseil d'Etat zich op het gegeven dat iedere bestuursbevoegdheid door de wetgever met het oog op een speciaal doel aan een bestuursorgaan wordt toegekend.

Bijgevolg is het verbod van détournement de pouvoir gerelateerd aan het legaliteitsprinsipe. Overtreding van het verbod van détournement de pouvoir vindt plaats indien de subjectieve doelstellingen die bestuurders nastreven niet overeenstemmen met de objectieve doelstelling van de wet. Het verbod van détournement de pouvoir stelt bijgevolg grenzen aan de bestuurlijke belangenbehartiging. Het Nederlandse verbod van détournement de pouvoir werd in het begin van de twintigste eeuw goeddeels overgenomen uit het Franse

131. Met Nicolaï kan dan ook worden ingestemd voorzover hij zich op het standpunt stelt dat het verbod van détournement de pouvoir met name ziet op de beperking voor het bestuur om algemene (d.w.z. publiekrechtelijke) belangen te behartigen (in de zin van 'af te wegen'). Nicolar e.a., Bestuursrecht (1997), a.w., p. 449.

132. Het feit dat het vaststellen van het precieze doel van een bestuursbevoegdheid vaak complex is, vormt op zich reeds een reden voor de wetgever om dit afdoende in het lichaam van de wet te specificeren en om deze specificering voorts in de memorie van toelichting grondig te motiveren. Ik verwijs naar het gestelde in hoofdstuk 4 van dit boek (i.h.b. paragraaf 4.5 ).

133. Waarbij de rechter de gebruikelijke interpretatiemethoden mag hanteren om het objectieve doel van een bestuursbevoegdheid vast te stellen (m.n. teleologische, wetshistorische en systematische interpretatie). Zie over deze methoden de nog altijd gezaghebbende beschouwingen van Scholten. Asser-Scholten (Algemeen deel) 1974 , i.h.b. p. 41 e.v., p. 44 e.v. en p. 116 e.v.

134. Interessant is in dit verband dat bestuurlijk Nederland ondanks de forse kritiek op de voortschrijdende 'juridisering' van het openbare bestuur nog relatief vél vertrouwen stelt in het leerstuk van détournement de pouvoir. Vgl. het rapport van de werkgroep Van Kemenade 'Bestuur in geding', Haarlem 1997, i.h.b., p. 30 en 75. 
recht; het verbod sloot echter aan bij de notie van 'doelgebondenheid' van bestuursbevoegdheid die reeds in het Nederlandse bestuursrecht leefde.

Doordat het bewijs van détournement de pouvoir een nauwkeurig onderzoek naar de intenties van het bestuur vereist, zijn de bewijstechnische problemen aanzienlijk. In situaties waarin er sprake is van een 'verborgen' détournement de pouvoir zal dit evenwel vaak leiden tot een objectieve schending van de bevoegdheidsnorm. Naar Frans recht bestaat er in dit soort situaties voor de rechter de mogelijkheid om een besluit te vernietigen op grond van een gebrek in de 'motifs' (objectieve grondslagen). Naar Nederlands recht is hier sprake van 'strijd met de wet'. Doordat de rechter in geval van détournement de pouvoir kan vernietigen op grond van 'strijd met de wet', is het aantal vernietigingen op grond van het verbod niet bijzonder groot.

Dit doet niet af aan het feit dat het verbod als bestuurlijke gedragsregel niets aan betekenis heeft verloren. Dit beeld wordt bevestigd door de actuele literatuur en de jurisprudentie, zowel in Frankrijk als in Nederland. Het verbod waarborgt binnen de democratische rechtsstaat immers ten principale een doelconforme uitoefening van bestuursbevoegdheden. 


\section{Hoofdstuk 6}

\section{Het specialiteitsbeginsel en beleidsvrijheid}

\subsection{Inleiding}

In de voorafgaande hoofdstukken werd het specialiteitsbeginsel als een structuurprincipe van rechtsstatelijk bestuursrecht beschouwd. In dit kader bleek dat uit het specialiteitsbeginsel een constitutionele plicht voor de wetgever kan worden afgeleid om bestuursbevoegdheden inhoudelijk te normeren. De wetgever dient een bevoegdheid op een zodanige wijze af te bakenen dat voor rechtssubjecten in hoofdlijnen voorzienbaar is waartoe het bestuur deze bevoegdheid kan uitoefenen.

Deze wettelijke normering vormt natuurlijk niet het enige normatieve kader dat een bestuursbevoegdheid begrenst, maar het is wél het enige dat speciaal op de bevoegdheid is toegespitst. Het specialiteitsbeginsel bindt in dit verband, zoals Heldeweg het treffend uitdrukte, de bevoegdheidsuitoefening aan het primaat van de wetgever. ${ }^{1}$ De specifieke wettelijke begrenzing van een bevoegdheid wordt aangevuld door de normerende werking van de algemene rechtsbeginselen, de beginselen van behoorlijk bestuur en de grondrechten.

Een bestuursorgaan dat een (discretionaire) bestuursbevoegdheid uitoefent bouwt voort op het belangenafwegings- en rechtsvormingsproces dat door de wetgever 'in abstracto' werd geïnitieerd. ${ }^{2}$ Het orgaan dient hierbij, zoals Vegting stelde, de in de wet neergelegde abstracte wilsuiting van de wetgever om te zetten in een concrete rechtshandeling. ${ }^{3}$ Van belang is nu dat het specialiteitsbeginsel niet alleen de wetgever verplicht om een bestuursbevoegdheid afdoende te specificeren, maar dat het tevens het bestuur dwingt om deze specificering in concreto te respecteren. Het respecteren van de wettelijke grenzen van een bestuursbevoegdheid wordt met name op de proef gesteld wanneer er sprake is van bestuurlijke discretie. Het zal dan ook niet verbazen dat het specialiteitsbeginsel direct

1. M.A. Heldeweg, Beleidsregels: naar een nieuwe catechismus voor 'ambtelijke bijbels'?, NTB 1995/4, p. 85.

2. Vgl. in dit verband de treffende opmerkingen van Van $W_{i j k}$ over discretionaire beschikkingsbevoegdheden: 'Men kan dus toch wel volhouden dat de administratie, beschikkingen uitvaardigende, voortwerkt aan de vorming van de norm die de wet slechts in beginsel stelde. Men kan het ook zo stellen, dat de administratie het werk voortzet en ten einde brengt dat de wetgever wel onvoltooid uit handen moest geven.' H.D. van Wijk, Hoofdstukken van administratief recht, 's-Gravenhage 1968, p. 58. Ik wijs in dit verband ook op Heldeweg die bestuursbevoegdheden omschreef als 'kristallisatiepunten' binnen het proces van gelede normstelling. M.A. Heldeweg, Publiekrechtelijke autonomie, in: Eenzijdig en wederkerig? (red. E.C.H.J. van der Linden en A.Q.C. Tak), Deventer 1995, p. 131 en 134.

3. W.G. Vegting, Het algemeen Nederlands administratiefrecht, Deel I, Alphen aan den Rijn 1954, p. 312. 
in verband wordt gebracht met de begrenzing van het proces van bestuurlijke belangenafweging. ${ }^{4}$

Voordat het specialiteitsbeginsel met het oog hierop nader wordt geanalyseerd, zal in dit hoofdstuk eerst aandacht worden besteed aan de vraag wanneer de wetgever aan een bestuursorgaan ruimte heeft toegekend om 'belangen af te wegen'. Het betreft hier de vraag naar de echte 'discretie', de 'beleidsvrijheid' of het zogenoemde '(freies) Ermessen'. Deze 'vrijheid' tot belangenafweging zal worden afgebakend ten opzichte van andere vormen van 'bestuurlijke vrijheid' (paragraaf 6.2).

Dat 'belangen' in geval van beleidsvrijheid door het bestuur behoren te worden afgewogen wordt overigens sinds lang aanvaard in de bestuursrechtelijke theorie en praktijk. ${ }^{5}$ De plicht tot daadwerkelijke belangenafweging is momenteel neergelegd in artikel 3:4 lid 1 van de Algemene wet bestuursrecht (Awb). ${ }^{6}$ Onduidelijk is echter wat 'afwegen' van belangen nu precies impliceert. Welke grootheden dienen met andere woorden door een bestuursorgaan tegen elkaar te worden 'afgewogen' en wat is de ratio achter deze 'afweging'? Enigszins onduidelijk is ook wat, gelet op de materiële bestuurlijke besluitvorming, onder het begrip 'belang' dient te worden verstaan. Deze vragen komen in de paragrafen 6.3 en 6.4 aan bod. Eerst worden de vormen van bestuurlijke beslissingsruimte nader beschouwd (paragraaf 6.2).

\subsection{Beoordelingsruimte en beleidsruimte}

Tengevolge van de voortschrijdende 'materiële' terugtred van de wetgever' ontstaat er, binnen wettelijke kaders, beslisruimte voor het bestuur. Deze beslisruimte komt, toegespitst op bestuursbevoegdheid, op verschillende manieren tot uitdrukking in de bevoegdheidsnorm. Gelet op het onderwerp van dit boek is het van belang om na te gaan op welke wijze een bestuursorgaan, binnen de grenzen van een doelgebonden bevoegdheid, van zijn beslisruimte gebruik dient te maken. ${ }^{8}$ De aandacht wordt hierbij geconcentreerd op de implicaties van de bestuurlijke 'vrijheid' in de relatie wetgever-bestuur en niet op de 'vrijheid' van het bestuur ten opzichte van de toetsende rechter.'

4. Een uitvoerige bespreking van de relevante literatuur zal plaatsvinden in hoofdstuk 7. Een analyse van de relevante jurisprudentie vindt plaats in hoofdstuk 8 van dit boek.

5. Vgl. bijv. Nicolar die in zijn proefschrift deze belangenafwegingsplicht in verband brengt met het beginsel van 'deugdelijke besluitvorming'. P. Nicolaï, Beginselen van behoorlijk bestuur, diss. UvA, Deventer 1990 , m.n. p. 342 e.v.

6. De Algemene wet bestuursrecht concipieert (discretionaire) bestuurlijke besluitvorming als een gemotiveerde afweging van de belangen van het bestuur tegen de belangen van belanghebbenden. Vgl. R.M. van Male, Enkele aspecten van het begrip belanghebbende in de Algemene wet bestuursrecht, VARreeks 108, Alphen aan den Rijn 1992, p. 14.

7. Zie hoofdstuk 4 paragraaf 4.2.5.

8. Beslisruimte wordt in het kader van het publieke rechtsvormingsproces expliciet aan het bestuur toegekend en kan uitsluitend bestaan binnen de objectieve grenzen van een bestuursbevoegdheid. Vgl. G.H.L. Weesing, Beoordelingsvrijheid en beleidsvrijheid: Gegeven of te laten vrijheden?, in: In de sfeer van administratief recht (Konijnenbelt-bundel), Utrecht 1994, p. 436. 


\subsubsection{Objectieve beoordelingsruimte}

Indien de wetgever aan een bestuursorgaan beslisruimte toekent (of noodgedwongen laat) doet hij dit niet steeds op een uniforme wijze. Beslisruimte kan allereerst onderverdeeld worden in 'objectieve beoordelingsruimte"10 en 'subjectieve beoordelingsruimte'." Van 'objectieve' beoordelingsruimte is sprake indien de wetgever bij het formuleren van het toepasselijkheidsdomein ${ }^{12}$ van een bevoegdheid vage begrippen of termen hanteert die een objectieve strekking hebben. Hiermee wordt bedoeld dat deze begrippen de bestuursbevoegdheid in objectieve zin beogen af te bakenen en géén bestuurlijke beslisvrijheid creëren welke door de rechter behoort te worden gerespecteerd.

Het gaat hier veelal om vage begrippen die aan de natuurlijke spreektaal zijn ontleend en die door de wetgever niet nader gespecificeerd konden worden. Gedacht kan bijv. worden aan woorden als 'gebouw', 'woonruimte', 'inflatie' en 'afvalstoffen'. ${ }^{13}$ Deze woorden hebben in de spreektaal een min of meer vaste betekenis, maar kenmerken zich desalniettemin door een bepaalde mate van vaagheid. ${ }^{14}$ Het bestuursorgaan zal dergelijke begrippen, voorzover de wetgever een nadere definitie achterwege heeft gelaten, zonodig zelf moeten interpreteren. Dit interpretatieproces strekt ertoe om de objectieve strekking van de betreffende vage term vast te stellen. ${ }^{15}$ Uitgangspunt is dat praktische, subjectieve en politieke argumenten hierbij géén rol mogen spelen en dat de rechter de bestuurlijke inter-

9. Wat betreft de problematiek van de wettelijke 'vage termen' en het rechterlijk toetsingsrecht verwijs ik naar de rechtsvergelijkende studie van Klap. A. Klap, Vage normen in het bestuursrecht, diss. RUL, Zwolle 1994. Met Klap dient te worden gesignaleerd dat de vraag naar de vrijheid van het bestuur ten opzichte van de wetgever en andere vraag betreft dan de vraag naar de (mogelijke) vrijheid van dit bestuur ten opzichte van de toetsende bestuursrechter (a.w., p. 58-59). Zie, wat de toetsingsproblematiek betreft, ook het oudere rechtsvergelijkende proefschrift van Timmermans. C.W.A. Timmermans, De administratieve rechter en beoordelingsvrijheden van bestuursorganen, diss. RUL, Leuven 1973.

10. Ook wel aangeduid als 'gebonden beoordelingsruimte'. Vgl. J.H. van Kreveld, Beleidsregels in het recht, diss. RUG, Deventer 1983, p. 7.

11. Ook wel aangeduid als 'beoordelingsvrijheid'. J.H. Van Kreveld, Beleidsregels in het recht, a.w., p. 7. Er dient op gewezen te worden dat het begrip 'beoordelingsvrijheid'; zoals dit door Van Kreveld wordt gehanteerd, niet overeenstemt met het gelijknamige begrip dat van Duk afkomstig is (zie paragraaf 6.2.3).

12. Zie voor het begrip 'toepasselijkheidsdomein' hoofdstuk 2, paragraaf 2.3.3.

13. Vaak heeft de wetgever wél nog een poging ondernomen om dit soort vage termen in een zgn. "betekenisof begripsbepaling' nader te definiêren. Volledige duidelijkheid zal een dergelijke definitie vrijwel nooit verschaffen. Vgl. bijv. art. 1 lid 1 onder $c$ van de Woningwet waar het begrip 'gebouw' wordt gedefinieerd als: 'elk bouwwerk, dat een voor mensen toegankelijke overdekte geheel of gedeeltelijk met wanden omsloten ruimte vormt.'

14. Klap heeft gewezen op het feit dat vage normen gelet op de inherente vaagheid van de natuurlijke taal niet vermeden kunnen worden. Ook zal de wetgever een begrip vaak in een bepaalde mate willen 'abstraheren' zodat er verschillende feitelijke situaties onder kunnen worden begrepen. A. Klap, Vage normen in het bestuursrecht, a.w., p. 7. Vgl. ook R. de Lange, Publiekrechtelijke rechtsvinding, diss. UvA, Zwolle 1991, p. 50. Zie voor een kritische bespreking van deze laatstgenoemde dissertatie: A.R. Neerhof, Beleidswetenschap 1992/2, p. 186-188.

15. Vgl. Nicolar e.a., Bestuursrecht, zesde geheel herziene druk, Amsterdam 1997, p. 330 en 332-333. Vgl. tevens HR 26 maart 1976, NJ 1976, 375, m.nt. Prins (Ploegmakers/Geffen). De rechter dient bindend uit te maken hoe een wettelijke vage term moet worden geïnterpreteerd. 
pretatie uiteindelijk vol toetst. Vervolgens zal het bestuur aan de hand van de vastgestelde feiten in concreto moeten beoordelen of de vage normcondities door deze feiten worden vervuld. ${ }^{16}$

\subsubsection{Subjectieve beoordelingsruimte}

De 'subjectieve' variant van beoordelingsruimte is moeilijker te karakteriseren. Het 'subjectieve' schuilt volgens Van Kreveld ${ }^{17}$ in het feit dat dit type ruimte tot op zekere hoogte door de rechter dient te worden gerespecteerd. Van Kreveld noemt een drietal manieren waarop de wetgever dit type beoordelingsruimte kan creëren. Allereerst kan de wetgever beoordelingscriteria in de normcondities (van de bevoegdheid) opnemen die naar hun aard subjectief zijn, dan wel vragen om een inhoudsdeskundige uitleg. Gedacht kan worden aan begrippen als 'doelmatig', 'rechtvaardig' en 'redelijke eisen van welstand'. Ook kan de wetgever een subjectiverende formule opnemen in de bevoegdheidsnorm. Het standaard voorbeeld is in dit verband de zinsnede 'naar het oordeel van'. ${ }^{18}$ Tot slot kan de wetgever, volgens Van Kreveld, in de bevoegdheidsnorm tot uitdrukking brengen dat vage beoordelingscriteria nog geenszins aangeven hoe een bestuursbevoegdheid dient te worden gebruikt (de typische 'kan'-bepaling of 'facultatieve' bevoegdheid ${ }^{19}$ ).

Toegespitst op de relatie wetgever-bestuur verschilt de 'objectieve' beoordelingsruimte mijns inziens van de 'subjectieve' doordat de wetgever in dit laatste geval een uitdrukkelijk beroep doet op de ambtelijke expertise én de eigen staatsrechtelijke besluitvormingsverantwoordelijkheid van het bestuur. Subjectieve beoordelingsruimte dwingt het bestuur met andere woorden tot een zelfstandige bestuurlijke waardering van feiten en belangen.

Het valt overigens op dat Van Kreveld géen principieel onderscheid maakt tussen de door hem genoemde typen van 'subjectieve' beoordelingsruimte. Hij duidt alledrie de vormen aan met het verzamelbegrip 'beoordelingsvrijheid'. Dit begrip stemt volgens hem overeen met wat anderen aanduiden als discretionaire bevoegdheid, 'freies Ermessen' of beleidsvrijheid. Een en ander doet wat ongedifferentieerd aan. ${ }^{20}$ Van Kreveld geeft wél een helder inzicht in de redenen waarom de wetgever 'subjectieve' beslisruimte voor het

16. Zie voor het onderscheid tussen (1) feitenvaststelling, (2) norminterpretatie, en (3) feitenkwalificatie: A. Klap, Vage normen in het bestuursrecht, a.w., p. 254-256.

17. J.H. van Kreveld, Beleidsregels in het recht, a.w., p. 7. Benadrukt dient te worden dat 'subjectief in dit verband geenszins duidt op een 'eigen wil' van het bestuursorgaan. Zoals in hoofdstuk 2 werd gesteld heeft een bestuursorgaan enkel een 'objectieve', door de typische bestuursfunctie bepaalde en begrensde, ambtswil.

18. Deze, of soortgelijke formules, vormen voor de rechter een belangrijke indicatie om terughoudend te toetsen. Vgl. A. Klap, Vage normen in het bestuursrecht, a.w., p. 257.

19. Dit laatste begrip ontleen ik aan: C.W.A. Timmermans, De administratieve rechter en beoordelingsvrijheden van bestuursorganen, a.w., p. 4.

20. J.H. Van Kreveld, Beleidsregels in het recht, a.w., p. 7 en 8 . Vgl. de boekbespreking door Duk. W. Duk, RMTh. 1985/2, p. 178-179. Vgl ook Timmermans die 'beoordelingsvrijheid' als een verzamelbegrip hanteert voor verschillende typen van bestuurlijke vrijheid in het kader van een bestuursbevoegdheid. C.W.A. Timmermans, De administratieve rechter en beoordelingsvrijheden van bestuursorganen, a.w., p. 3-4. 
bestuur creëert. Het gaat hier volgens hem om (1) de noodzaak van maximale wettelijke doelverwezenlijking, (2) de noodzaak van maximale flexibiliteit van het overheidsoptreden, en (3) de optimale verwezenlijking van het uitgangspunt van 'de minste pijn' bij het bestuursoptreden. ${ }^{21}$

Op deze plaats verdient met name de eerste, door Van Kreveld aangevoerde reden, aandacht. Door het creëren van 'subjectieve' beslisruimte kan de wetgever bewerkstelligen dat het doel van een wettelijke regeling optimaal in het individuele geval wordt verwezenlijkt. Van Kreveld merkt hierover op:

'Door deze individualisering kan het doel van de wetgever, bijv. een doelmatige verdeling van woonruimte, wellicht beter gerealiseerd worden dan wanneer de bestuursinstantie wegens nauwe binding aan helder geformuleerde wettelijke voorschriften geen vrijheid van handelen in het individuele geval heeft. Kortom: individualisering - bij de uitoefening van een beoordelingsvrijheid (in de zin van Van Kreveld R.J.N.S.) kan leiden tot maximale effectiviteit, tot maximale verwezenlijking van het doel van de wetgever., ${ }^{22}$

Van Kreveld brengt een bepaald type 'beoordelingsvrijheid', in de door hem gehanteerde betekenis, derhalve in verband met het proces van 'individualiserende' rechtsvorming door het bestuur. Van belang is dat hij de mogelijkheid tot het stellen van (gedrags)voorschriften in concreto hierbij relateert aan het doeltreffend uitoefenen van een bestuursbevoegdheid. ${ }^{23}$ De bevoegdheid tot het stellen van voorschriften ziet Van Kreveld als een impliciete (rechtsvormende) bevoegdheid ${ }^{24}$, die - in beginsel ${ }^{25}$ - steeds erkend dient te worden in geval van discretie.

\subsubsection{Een gedifferentieerde 'subjectieve' beoordelingsruimte?}

Van Krevelds karakterisering van 'subjectieve beoordelingsruimte' is instructief, maar tegelijkertijd te weinig gedifferentieerd. In navolging van Duk is het in de Nederlandse bestuursrechtelijke theorie gebruikelijk om te onderscheiden tussen een tweetal hoofdtypen

21. J.H. van Kreveld, Beleidsregels in het recht, a.w., p. $4 \mathrm{I}$.

22. J.H. van Kreveld, Beleidsregels in het recht, a.w., p. 41. Van Kreveld verstaat onder het 'doeltreffend' uitoefenen van beoordelingsvrijheid bijgevolg het uitoefenen van deze vrijheid op een zodanige wijze dat de doeleinden waartoe de bevoegdheid is gegeven zo goed mogelijk worden bereikt (a.w., p. 46).

23. J.H. van Kreveld, Beleidsregels in het recht, a.w., p. 54.

24. Een cruciaal punt, waaruit wederom blijkt dat een bestuursorgaan uitsluitend binnen de grenzen van zijn bestuursbevoegdheid bindende voorschriften in concreto kan creerren. Van Kreveld merkt hierover op: 'Voorts worden - naar men wel moet aannemen - ook de omvang en precieze inhoud van de impliciete bevoegdheid begrensd door de omvang en het karakter van de expliciete bevoegdheid. Het gaat immers (o.a. het stellen van voorschriften R.J.N.S.) om een afgeleide bevoegdheid.' J.H. van Kreveld, Beleidsregels in het recht, a.w., p. 55.

25. Tenzij de wet of de aard van de bevoegdheid zich tegen het stellen van voorschriften verzet. J.H. van Kreveld, Beleidsregels in het recht, a.w., p. 55. Van Kreveld wijst in dit verband op bevoegdheden tot het geven van beschikkingen voor een eenmalige situatie en beschikkingen die een beoordeling naar de situatie op één tijdstip vergen maar daarna over een lange periode rechtsgevolgen hebben (a.w., p. 55 noot 128). 
van 'subjectieve' beoordelingsruimte (of beter 'beslisruimte'). Het betreft het bekende onderscheid tussen 'beleidsvrijheid' en 'beoordelingsvrijheid'. ${ }^{26}$

Volgens Duk is er tussen deze twee vrijheden een principieel verschil. Hij definieert de begrippen als volgt: 'Iemand - wie dan ook - heeft beoordelingsvrijheid voorzover het rechtens aan hem is overgelaten om zelfstandig, en in beginsel met uitsluiting van ieder ander, te beoordelen of de voorwaarden voor rechtmatige uitoefening van een van zijn rechten of bevoegdheden in concreto zijn vervuld. Hij heeft beleidsvrijheid voorzover het hem rechtens vrijstaat, van gebruik van recht of bevoegdheid af te zien in die gevallen waarin de voorwaarden voor rechtmatige uitoefening daarvan wel vervuld zijn. ${ }^{27} \mathrm{De}$ vrijheid van beoordeling ziet volgens Duk op de kwalificatie van de feiten en niet op de interpretatie van vage wettelijke normcondities. ${ }^{28}$ Evenmin ziet deze vrijheid op het vaststellen van de feiten. ${ }^{29}$ Duk vervolgt zijn betoog door het principiële verschil tussen beide 'vrijheden' als volgt te karakteriseren:

'Tussen beleids- en beoordelingsvrijheid bestaat onder andere dit markante verschil, dat ruimte voor het nemen van een beslissing naar eigen inzicht bij deze twee vrijheden (niet zozeer in omvang als wel) in dimensie uiteenloopt. Beoordelingsvrijheid is - zo zouden we het kunnen uitdrukken - tweedimensionaal, en

26. W. Duk, De zachte kern van het bestuursrecht, RMTh. 1978, p. 574 e.v. Dit onderscheid werd door Duk later nader uitgewerkt. Zie: W. Duk, Beoordelingsvrijheid en beleidsvrijheid, RMTh. 1988/4, p. 156 e.v. De onderscheiding tussen 'beleidsvrijheid' en 'beoordelingsvrijheid' is overigens nauw verwant aan het onderscheid dat in de Duitse bestuursrechttheorie wordt gemaakt tussen 'Ermessen' en 'Beurteilungsspielraum'. Met name Bachof stond aan de wieg van dit onderscheid. Zie: O. Bachof, Beurteilungspielraum, Ermessen und unbestimmter Rechtsbegriff im Verwaltungsrecht, JZ 1955/4, p. 97 e.v.; H. Maurer, Allgemeines Verwaitungsrecht, 1le Auflage, Munchen 1997, p. 119 e.v., i.h.b. p. 124 en p. 131. Ook Klap, die de Duitse literatuur op hoofdpunten bespreekt, heeft erop gewezen dat Duks theorie verwant is aan de Duitse theorievorming. A. Klap, Vage normen in het bestuursrecht, a.w., p. 61.

27. W. Duk, Beoordelingsvrijheid en beleidsvrijheid, a.w., p. 157.

28. Waarbij Duk ervan uitgaat dat het interpreteren van vage termen strikt te scheiden is van de vraag of de vastgestelde feiten de vage normcondities vervullen (de beoordelings- of kwalificatievraag). Op dit theoretische uitgangspunt is kritiek geuit. Vgl. met name Van der Burg die erop heeft gewezen dat feitenvaststelling, wetsinterpretatie en feitenkwalificatie (beoordeling) elkaar kunnen bel̈nvloeden. Zie: Van der Burg/Cartigny/Overkleeft-Verburg, Rechtsbescherming tegen de overheid, Nijmegen 1985, p. 163. Ook Nicolar en De Lange hebben erop gewezen dat de grenzen tussen 'feitenvaststelling', 'feitenkwalificatie' en 'norminterpretatie' in praktijk niet zelden vervagen en in elkaar overvloeien. P. Nicolaï, Beginselen van behoorlijk bestuur, a.w., p. 295; R. de Lange, Publiekrechtelijke rechtsvinding, a.w., p. 59 e.v.

29. Zie: W. Duk, Beoordelingsvrijheid en beleidsvrijheid, a.w., p. 161 en 163 . Vrijheid tot feitenvaststelling door het bestuur kan niet worden erkend, daar feiten en omstandigheden bestaan of niet. Een andere kwestie is of het bestuursorgaan wel in staat is om de bestaande feiten volledig (objectief) vast te stellen. Weten en kennen (ook van deskundigen) zijn immers begrensd. In een eerder artikel omschreef Duk beoordelingsvrijheid dan ook als volgt: ' $\mathrm{Er}$ is vrijheid van beoordeling, maar daarmee nog geen beleidsvrijheid, wanneer zich een van beiden voordoet: (1) de feiten - inclusief omstandigheden - op grond waarvan moet worden beslist, liggen niet zo duidelijk, dat verschil van mening daaromtrent tussen redelijke mensen uitgesloten zou zijn; (2) de 'toepasselijke' tekst van wet of administratief besluit laat ook waar de feiten volkomen duidelijk liggen - ruimte voor verschil van mening, tussen redelijke mensen, over wat nu precies op grond daarvan moet worden beslist. Niettemin: rechtens geldt slechts énn beslissing als de juiste.' W. Duk, De zachte kern van het bestuursrecht, RMTh, 1978, p. 575 (noot 26). 
beleidsvrijheid driedimensionaal. lemand met beleidsvrijheid kan en mag namelijk die vrijheid gebruiken voor het nastreven van bepaalde (zij het niet alle door hem beoogde) doeleinden, en daarvoor is in het platte vlak van de beoordelingsvrijheid geen ruimte. ${ }^{, 30}$

Deze nogal cryptische karakterisering van het verschil tussen beleidsvrijheid en beoordelingsvrijheid wordt in het vervolg van Duks betoog verduidelijkt. Indien uit een bevoegdheidsnorm voor een bestuursorgaan beoordelingsvrijheid voortvloeit dan kan, in theorie, slechts één beoordeling als juist worden aangemerkt. ${ }^{31}$ Het 'tweedimensionale' karakter van de vrijheid tot beoordeling zoekt Duk nl. in het uitgangspunt dat vage normcondities vervuld kunnen zijn of niet; andere varianten zijn in beginsel niet denkbaar. ${ }^{32} \mathrm{De}$ 'vrijheid' van beoordeling schuilt hierin dat de beoordeling door het bestuursorgaan als exclusief wordt aangemerkt. Deze beoordeling ${ }^{33}$ is, mits genomen binnen de kaders van wet en recht, de enige juiste die in principe door de rechter dient te worden gerespecteerd. Deze mag de bestuurlijke beoordeling enkel marginaal toetsen.

Het 'driedimensionale' karakter van beleidsvrijheid zoekt Duk vervolgens in het feit dat er bij beleidsvrije bevoegdheden verschillende rechtens als juist aan te merken bevoegdheidsuitoefeningen denkbaar zijn. Een bestuursorgaan dat beleidsvrijheid heeft beschikt derhalve over een keuzemogelijkheid om de door de wetgever gestelde publiekrechtelijke doelen te bereiken. ${ }^{34}$ Deze keuzemogelijkheid brengt Duk direct in verband met de plicht om belangen af te wegen. Deze belangenafweging, die op een consistente wijze behoort te worden volvoerd, dient er volgens Duk garant voor te staan dat het nagestreefde beleidsdoel in concreto wordt bereikt of benaderd.

Een plicht tot belangenafweging ontbreekt volgens Duk indien er sprake is van typische beoordelingsvrijheid. Het bestuursorgaan zal in dit soort 'beslisvrije' situaties enkel de vraag dienen te beantwoorden of de (vage) normcondities in concreto zijn vervuld of niet. Beoordeling is bijgevolg een activiteit die het bestuur in het tweedimensionale vlak, d.w.z. $z o n d e r$ belangen te waarderen en tegen elkaar af te wegen, uitoefent. Duk erkent overigens een theoretische uitzondering op deze hoofdregel in situaties waarin het 'overwicht' of 'onderwicht' van een bepaald belang, in vergelijking met andere rechtens te respecteren

30. W. Duk, Beoordelingsvrijheid en beleidsvrijheid, a.w., p. 160.

31. Vgl. de Duitse theorie inzake de 'eine richtige Entscheidung'. Deze theorie gaat ervan uit dat normcondities, als objectieve bestanddelen van een bevoegdheidsnorm, in beginsel slechts op én manier kunnen worden uitgelegd. Vgl. H. Maurer, Allgemeines Verwaltungsrecht, a.w., p. 130. Ik laat hier in het midden in hoeverre dat deze theoretische benaderingswijze als juist kan worden aangemerkt gelet op uiterst vage en gesubjectiveerde normcondities (bijv. 'naar het oordeel van'). Zie voor kritiek op deze theorie het proefschrift van Klap (A. Klap, Vage normen in het bestuursrecht, a.w.). Op bladzijde 130 komt deze auteur tot de navolgende conclusie: 'De theorie van de enig juiste beslissing, die in de Duitse discussie min of meer is uitgegroeid tot juridisch axioma, is dus op een logisch onhoudbaar fundament gegrond.'

32. W. Duk, Beoordelingsvrijheid en beleidsvrijheid, a.w., p. 161

33. Of beter: 'feitenkwalificatie'.

34. W. Duk, Beoordelingsvrijheid en beleidsvrijheid, a.w., p. 164. In het kader van de keuzevraag kunnen volgens Duk politieke doelstellingen en opvattingen, alsmede ethische of andere waarden een rol spelen. W. Duk, De zachte kem van het bestuursrecht, RMTh. 1978, p. 574. 
belangen, behoort tot de uitdrukkelijk gestelde (wettelijke) voorwaarden voor een rechtmatige uitoefening van een recht of bevoegdheid. ${ }^{35}$

\subsubsection{Variëren op Duk}

De denkbeelden van Duk hebben veel invloed gehad op de Nederlandse theorievorming inzake discretionaire bestuursbevoegdheden. ${ }^{36}$ De bestuursrechtelijke handboeken volg(d)en zijn onderscheid tussen beoordelings- en beleidsvrijheid meestal. ${ }^{37}$ Voorzover er in hoofdartikelen aandacht wordt besteed aan dit onderwerp, is er mijns inziens eveneens sprake van variaties op Duks denkbeelden. ${ }^{38}$

Heldeweg ${ }^{39}$ volgt Duk in het onderscheid tussen beoordelings- en beleidsvrijheid, maar hij baseert het verschil tussen beide 'beslisvrijheden' niet expliciet op het al dan niet afwegen van belangen. Het principiêle onderscheid tussen beide 'vrijheden' zoekt Heldeweg in het onderscheid tussen - wat hij noemt - feitenvaststelling en rechtsvaststelling. Kenmerkend voor 'echte' beleidsvrijheid is volgens Heldeweg dat het bestuursorgaan een keuzemogelijkheid heeft in de sfeer van de rechtsgevolgen. ${ }^{40} \mathrm{Bij}$ typische beoordelingsvrijheid ontbreekt daarentegen deze keuzemogelijkheid. Vrijheid van beoordeling kan zich

35. W. Duk, Beoordelingsvrijheid of beleidsvrijheid, a.w., p. 165. Volgens Duk vloeien in dit (volgens hem) hypothetische geval beoordelings- en beleidsvrijheid in elkaar over.

36. Hierbij teken ik aan dat aan Duk inderdaad de verdienste toekomt het onderscheid tussen 'beoordelingsvrijheid' en beleidsvrijheid' indringend in het bestuursrechtelijke debat aan de orde te hebben gesteld. Dit onderscheid was m.i. echter in de Nederlandse theorievorming reeds bekend. Vgl. in dit verband de enigszins in de vergetelheid geraakte beschouwingen van Vegting die, zij het niet onder deze benamingen, een uitgewerkt onderscheid presenteerde tussen (objectieve) beoordelingsruimte, beoordelingsvrijheid en beleidsvrijheid. W.G. Vegting, Het algemeen Nederlands administratiefrecht, a.w., p. 315-318. Vgl. voorts A.M. Donner, Nederlands bestuursrecht, Algemeen deel, vierde herziene druk, Alphen aan den Rijn 1974, p. 227-229 en, zij het minder expliciet, de krachtige beschouwingen door Van der Hoeven. J. van der Hoeven, De grenzen van de rechterlijke functie in de administratieve rechtspraak, RMTh. 1974, p. 672673.

37. Zie: A.M. Donner, Nederlands bestuursrecht, Algemeen deel, vijfde herziene druk, Alphen aan den Rijn 1987, p. 97; het Rapport van de commissie inzake Algemene Bepalingen van Administratief Recht (ABAR), vijfde geheel herziene druk, Alphen aan den Rijn 1984, p. 139 en 140 (noot 61); Nicolar e.a., Bestuursrecht, a.w., p. 328 e.v., i.h.b. p. 336-338; J.B.J.M. ten Berge, Besturen door de overheid, tweede druk, Deventer 1997, p. 243-245; Van Wijk/Konijnenbelt/Van Male, Hoofdstukken van administratief recht, tiende geheel herziene druk, 's-Gravenhage 1997, p. 173-179. In meer kritische zin: De Haan/Drupsteen/Fernhout, Bestuursrecht in de sociale rechtsstaat I, vierde geheel herziene druk, Deventer 1996, p. 78-79 en 247-248. De Haan c.s. zijn van oordeel dat het onderscheid niet te scherp moet worden aangezet omdat in de praktijk beoordelings- en beleidsvragen in elkaar over kunnen lopen. Eveneens in kritische zin A.Q.C. Tak, De nieuwe Van Wijk/Konijnenbelt, NTB 1994/6, p. 169. Volgens Tak is de onderscheiding verwarrend en overbodig, en zijn er geen bijzondere (rechts)gevolgen aan verbonden. Hij lijkt - i.v.m. de intensiteit van rechterlijke toetsing - uitsluitend te willen onderscheiden tussen 'objectieve vage termen' en 'beleidsvrijheid'.

38. Vgl. bijv. N. Verheij, Onrechtmatige overheidsdaad en beginselen van behoorlijk bestuur: de Hoge Raad toetst eindelijk rechtstreeks, NJB 1987/41, p. 1313.

39. M.A. Heldeweg, Beleidsregels: naar een nieuwe catechismus voor 'ambtelijke bijbels', NTB 1995/4, p. 89 en 90 . 
volgens Heldeweg uitsluitend voordoen in de sfeer van de feitenkwalificatie; deze vrijheid geldt echter niet ten aanzien van de interpretatie van vage toepassingscondities. Hier stelt Heldeweg zich op het standpunt dat toepassingscondities, als objectieve begrenzingen van een bestuursbevoegdheid, slechts op één manier kunnen worden uitgelegd, waarbij de rechter uiteindelijk dwingend uitmaakt welke manier dat is. ${ }^{41}$ Van belang voor de specialiteitsproblematiek is dat Heldeweg de mening is toegedaan dat bestuursbevoegdheden per definitie een objectieve strekking hebben, ongeacht of het bestuursorgaan beleids- of beoordelingsvrijheid toekomt. Deze objectieve strekking brengt met zich dat iedere uitoefening van de bevoegdheid steeds begrepen moet kunnen worden vanuit het publiekrechtelijke belang met het oog waarop de bevoegdheid is gegeven. ${ }^{42}$

Een meer normtheoretische benadering van het onderscheid tussen beleidsvrijheid en beoordelingsvrijheid wordt aangetroffen in een uitvoerige uiteenzetting van de hand van Jue. ${ }^{43}$ Jue stelt voorop dat ingevolge het legaliteitsbeginsel in de rechtsstaat overheidsbevoegdheden in wettelijke conditionele normen worden omschreven. Binnen de objectieve begrenzing van deze normen komt aan het bestuur soms een zekere vrijheid toe. ${ }^{44}$ Hierbij gaat Jue ervan uit dat deze 'vrijheid' zich kan manifesteren in de gedaante van twee (deel)bevoegdheden, nl. aanvullingsbevoegdheid en interpretatiebevoegdheid. ${ }^{45}$ Van aanvullingsbevoegdheid is volgens Jue sprake indien het verantwoordelijke bestuursorgaan op basis van een bevoegdheidsnorm zelfstandig de argumenten dient te selecteren die noodzakelijk zijn om tot een consistente en rechtsgeldige uitoefening van een bevoegdheid te komen. Uit het betoog van Jue blijkt dat hij het invullen van - wat hij noemt - 'argumentatieleemtes in de wet' vooral ziet als een proces van belangeninventarisatie, belangenselectie en belangenwaardering. Jue duidt bestuursbevoegdheden die worden gekenmerkt door een bevoegdheid tot aanvullende interpretatie aan als 'discretionair' ${ }^{46}$

Een 'argumentatieleemte' in de wet wordt volgens Jue veroorzaakt doordat de wetgever niet (volledig) in staat is geweest om een binnen het politieke besluitvormingsproces gedetermineerd 'doelprogramma' te vertalen in een uitputtende conditionele wettelijke norm. Onder 'doelprogramma' wordt verstaan een binnen het politiek-democratische proces afgebakende doelstelling die bereikt dient te worden om bepaalde maatschappelijke

40. 'Als gezegd vergt beleidsvrijheid dat het bestuur een norm stelt welke niet in abstracto, exclusief dwingend uit de bevoegdheid is af te leiden. Anders gezegd, het bestuur zou op basis van genoemde aanname verschillende rechtens aanvaardbare beslissingen kunnen nemen. In die zin staat beleidsvrijheid op énn lijn met het proces van rechtsvorming' (curs. R.J.N.S). M.A. Heldeweg, Beleidsregels: naar een nieuwe catechismus voor 'ambtelijke bijbels', a.w., p. 90.

41. M.A. Heldeweg, Beleidsregels: naar een nieuwe catechismus voor 'ambtelijke bijbels', a.w., p. 89. Vgl. ook de pittige stelling op bladzijde 90 van zijn NTB-bijdrage: 'Er is maar én interpretatie juist en alles wat daarvan afwijkt is eenvoudig in strijd met de wet.'

42. M.A. Heldeweg, Beleidsregels: naar een nieuwe catechismus voor 'ambtelijke bijbels', a.w., p. 89.

43. R.J. Jue, Rechterlijke terugtred bij de beoordeling van bestuurlijke beslissingen, a.w., p. 440 e.v.

44. R.J. Jue, Rechterlijke terugtred bij de beoordeling van bestuurlijke beslissingen, a.w., p. 447.

45. R.J. Jue, Rechterlijke terugtred bij de beoordeling van bestuurlijke beslissingen, a.w., p. 450.

46. R.J. Jue, Rechterlijke terugtred bij de beoordeling van bestuurlijke beslissingen, a.w., p. 459. Als voorbeeld wijst Jue op de veelvuldig in het bestuursrecht voorkomende 'kan'-bepalingen. 
problemen te keren, waarbij de wijze waarop dit precies dient te gebeuren nog niet is ingevuld. Het is dan aan het bestuur om de vertaling van het doelprogramma, binnen de kaders van de wettelijke norm, te voltooien. Ten aanzien van het rechtskarakter van dit omzettingsproces verschilt Jue kennelijk met Heldeweg van mening. Waar laatstgenoemde auteur benadrukt dat de objectieve strekking van een bevoegdheidsnorm de bevoegdheidsuitoefening beheerst, daar ziet Jue ruimte voor politieke voorkeuren. ${ }^{47}$

Jue onderscheidt de aanvullingsbevoegdheid scherp van (wat hij noemt) de interpretatiebevoegdheid. Deze laatstgenoemde bevoegdheid speelt een rol indien de betekenis van bepaalde wettelijke condities (termen) meerduidig is. Uit het betoog van Jue kan worden afgeleid dat 'interpretatiebevoegdheid' betrekking heeft op de bevoegdheid om te beoordelen of feitelijke situaties in concreto een bepaalde wettelijke normconditie vervullen. Volgens Jue dient een bestuursorgaan in het kader van deze interpretatiebevoegdheid primair aansluiting te zoeken bij het maatschappelijke gebruik van een bepaald begrip. Het taalgebruik vormt hierbij een belangrijk uitgangspunt. Interpretatie van een begrip aan de hand van het taalgebruik zal echter niet altijd de noodzakelijke duidelijkheid kunnen verschaffen, daar er in de praktijk verschillende (taalkundige) invullingen van een begrip denkbaar zijn. ${ }^{48}$ In dit soort situaties ziet Jue weer een duidelijke functie weggelegd voor de eigen verantwoordelijkheid van het bestuursorgaan om in het licht van de doelstelling en de strekking van de wet aanvullende argumenten te vinden om voor een bepaalde interpretatie te kiezen. De bestuurlijke interpretatie verkrijgt dan bijgevolg een 'doelgericht karakter'. ${ }^{49}$ De situatie waarin het bestuur dan verkeert is volgens Jue verwant aan situaties waarin een 'aanvullingsbevoegdheid' dient te worden aangenomen. Doelen in combinatie met feiten strekken dan tot richtsnoer voor een rechtsgeldige bevoegdheidsuitoefening. ${ }^{50}$

Tot slot verdient de opvatting van Weesing ${ }^{51}$ aandacht. Ook Weesing gaat ervan uit dat beleidsvrijheid betekent dat het bestuursorgaan gehouden is een afweging van belangen te verrichten. Om het onderscheid tussen beleids- en beoordelingsvrijheid duidelijk te markeren erkent hij bij de laatstgenoemde vrijheid géén ruimte voor belangenafweging. Waar Duk nog de theoretische mogelijkheid openhoudt dat beleids- en beoordelingsvrijheid in elkaar (kunnen) overlopen, daar verwerpt Weesing deze mogelijkheid met het oog op een heldere terminologie. Weesing stelt zich op het standpunt dat indien in het kader van een (ogenschijnlijke) beoordelingsvraag de wetgever expliciet of impliciet een afweging

47. R.J. Jue, Rechterlijke terugtred bij de beoordeling van bestuurlijke beslissingen, a.w., p. 452 .

48. Jue spreekt in dit verband over 'neutrale kandidaten'. R.J. Jue, Rechterlijke terugtred bij de beoordeling van bestuurlijke beslissingen, a.w., p. 458 .

49. R.J. Jue, Rechterlijke terugtred bij de beoordeling van bestuurlijke beslissingen, a.w., p. 459.

50. R.J. Jue, Rechterlijke terugtred bij de beoordeling van bestuurlijke beslissingen, a.w., p. $46 \mathrm{I}$. Hieruit leidt Jue af dat de rechter dan terughoudend dient te toetsen. Klap acht Jues opvatting discutabel, o.m. omdat Jue het onderscheid tussen norminterpretatie en feitenkwalificatie uit het oog zou verliezen. A. Klap, Vage normen in het bestuursrecht, a.w., p. 58-59.

51. G.H.L. Weesing, Beoordelingsvrijheid en beleidsvrijheid: Gegeven of te laten vrijheden?, in: In de sfeer van administratief recht (Konijnenbelt-bundel), Utrecht 1994, p. 429 e.v. 
van belangen veronderstelt er sprake is van beleidsvrijheid. Deze beleidsvrijheid kan leiden tot bestuurlijk/politieke prioritering. ${ }^{52}$

Weesing acht het onderscheid tussen de 'vrijheden' van het bestuur niet alleen van belang voor het toetsingsvraagstuk, maar ók voor de bestuurlijke besluitvorming. Voor het onderwerp van dit boek is dit van belang. Bij beleidsvrijheid is een bestuursorgaan volgens Weesing vrijer dan bij beoordelingsvrijheid. Beleidsvrijheid impliceert dat het bestuur door de wetgever gemachtigd is om naar eigen inzicht het gewicht van de betrokken belangen te bepalen ter bereiking van een bepaald beleidsdoel. Dit heeft volgens Weesing gevolgen voor het bestuurlijke besluitvormingsproces. Weesing wijst in dit kader op de aard en omvang van de inspraak die geboden dient te worden en op de vraag of, en zo ja welke, voorwaarden aan een besluit mogen worden verbonden..$^{53}$ In geval van beleidsvrijheid brengt een belangenafwegingsplicht in concreto voorts met zich dat, gelet op de betrokken belangen van burgers, soms afgeweken dient te worden van een vaste beleidslijn. Bij beoordelingsvrijheid zal een dergelijke afwijkingsmogelijkheid zich volgens Weesing niet vaak voordoen, daar dit snel zou leiden tot handelen in strijd met de betreffende wettelijke regeling. ${ }^{54}$

\subsection{Het rechtskarakter van beleidsvrijheid}

De essentie van beleidsvrijheid wordt, zo blijkt uit het voorafgaande literatuuroverzicht, primair gezocht in een (doelgebonden) keuzevrijheid voor het bestuur in de rechtsgevolgensfeer. Om tot een verantwoorde modaliteit van bevoegdheidsuitoefening te komen zal het verantwoordelijke bestuursorgaan een 'afweging' van de betrokken belangen dienen te verrichten. Uitgangspunt is hierbij dat verschillende rechtens juiste beslissingen denkbaar zijn..$^{55}$ Ook bestaat er brede overeenstemming over het feit dat 'beleidsvrijheid' steeds een door de wet toegekende én door het (on)geschreven recht ${ }^{56}$ begrensde vrijheid is.

52. G.H.L. Weesing, Beoordelingsvrijheid en beleidsvrijheid: Gegeven of te laten vrijheden?, a.w., p. 435 en 436 e.v.

53. G.H.L. Weesing, Beoordelingsvrijheid en beleidsvrijheid: Gegeven of te laten vrijheden?, a.w., p. 436. Hieruit blijkt dat Weesing beleidsvrijheid ziet als een 'vrije' rechtsvormingsruimte voor het bestuur. Binnen deze (doelgebonden) ruimte zal het bestuursorgaan, rekening houdend met (materiele) belangposities van andere rechtssubjecten, rechtsvormend maatwerk dienen te verrichten.

54. G.H.L. Weesing, Beoordelingsvrijheid en beleidsvrijheid: Gegeven of te laten vrijheden?, a.w., p. 437.

55. Vgl. A.M. Donner, Nederlands bestuursrecht, Algemeen deel, vierde herziene druk, Alphen aan den Rijn 1974, p. 227. Ik wijs er verder nog op dat ook in het Duitse en Franse bestuursrecht de keuzemogelijkheid in de rechtsgevolgensfeer als een essentiale van de beleidsvrijheid (Ermessen, pouvoir discrétionnaire) wordt aangemerkt. Vgl. H. Maurer, Allgemeines Verwaltungsrecht, a.w., p. 121 en R. Chapus, Droit administratif général, tome I, 10e édition, Paris 1996, p. 963.

56. Dat ók het ongeschreven recht het 'vrije goedvinden' van het bestuur begrenst werd in ons land reeds in 1911 door Boasson op een overtuigende wijze aangetoond. J.J. Boasson, De rechter tegenover de vrijheid der administratie, diss. RUL, Groningen 1911, i.h.b. p. 362 e.v. In Duitsland spreekt men het liefst over een 'plichtgemaßßes' of 'rechtlich gebundenes' Ermessen. Vgl. H. Maurer, Allgemeines Verwaltungsrecht, a.w., p. 125-126. 


\title{
6.3.1 Belangenafweging en rechtsvorming
}

Belangenafweging vormt blijkbaar een onmisbare stap in het proces van concretiserende rechtsvorming door het bestuur. Belangenafweging én rechtsvorming zijn, aldus beschouwd, aan elkaar gerelateerd. ${ }^{57}$ Van Male ${ }^{58}$ karakteriseert het (bestuurlijke) rechtsvormingsproces dan ook als volgt:

\begin{abstract}
'Het geldende recht is op zichzelf genomen geen belang, maar de uitkomst van een belangenafweging. Vastgesteld werd immers dat het bij de rechtsvorming gaat om het concretiseren van het algemeen belang, dat wil zeggen de algemene rechtvaardigheidsidee. Deze te concretiseren vergt het vaststellen, afwegen en prioriteren van rechtstreeks betrokken belangen, alsmede het kenbaar maken van de motieven die tot de onderlinge rangorde hebben geleid. Eenmaal gevormd zijnde komt recht in beginsel niet meer voor afweging tegen andere belangen in aanmerking.'
\end{abstract}

Op deze plaats is de vraag naar het rechtskarakter van beleidsvrijheid relevant. Dient een beleidsvrije bevoegdheidsuitoefening gezien te worden als een volledig door het objectieve publiekrecht beheerste rechtshandeling die enkel gericht is op de 'uitleg' van wat het speciale publiekrechtelijke doel, gelet op het relevante feiten- en belangensubstraat in concreto, vergt, of gaat het om een meer subjectief bepaalde (rechts)handeling waarbij het bestuursorgaan, weliswaar binnen objectieve wettelijke kaders, zélf belangen van rechtssubjecten naar politiek/bestuurlijk inzicht mag waarderen en prioriteren? Aan deze problematiek, die de kern van het vraagstuk van de beleidsvrijheid en bestuurlijke rechtsvorming raakt, wordt in de Nederlandse literatuur weinig aandacht besteed. ${ }^{59}$

\subsubsection{Drie visies inzake beleidsvrijheid}

Een blik op de Duitse theorievorming werkt hier verhelderend. $\mathrm{Koch}^{60}$ onderscheidt in zijn theoretisch-beschrijvende studie over de mate van gebondenheid van het bestuur aan de wet een drietal visies inzake beleidsvrijheid.

De eerste stroming ziet, volgens Koch, de echte beleidsvrijheid als een 'Wahl zwischen Zwecken'. Alleen indien het bestuur een werkelijke keuzevrijheid heeft om verschillende

57. Zie over de relatie tussen belangenafweging en rechtsvorming $0 . \mathrm{m}$. R. de Lange, Publiekrechtelijke rechtsvinding, a.w., p. 97. Met name het (bijzondere) bestuursrecht kan als typisch belangenafivegingsrecht' worden gekwalificeerd. Vgl. A.P. Klap en J.B.J.M. ten Berge, De derde als het stiefkind van het bestuursrecht, in: De derde in het recht, AAe 1997/5, p. 339.

58. R.M. van Male, Enkele aspecten van het begrip belanghebbende in de Algemene wet bestuursrecht, a.w., p. 22.

59. Vgl. Tak die erop heeft gewezen dat de vraag hoe een algemene (plicht tot) belangenafweging te verenigen is met het specifieke wettelijke kader van een bestuursbevoegdheid nog steeds niet bevredigend is opgelost. A.Q.C. Tak, Hoofdlijnen van het Nederlands bestuursprocesrecht, derde druk, Zwolle 1995, p. 111. De 'subjectieve' opvatting lijkt heersend. Vgl. bijv. Nicolaï, Bestuursrecht, a.w., p. 330 (noot 51).

60. H.J. Koch, Unbestimmte Rechtsbegriffe und Ermessenermăchtigungen im Verwaltungsrecht. Eine logische und semantische Studie zur Gesetzesbindung der Verwaltung, Frankfurt am Main 1979, p. 148 e.v. Ofschoon deze studie niet tot de meest recente kan worden gerekend, behoort zij m.i. tot de meest uitvoerige en verdiepende op dit gebied. In de Nederlandse literatuur trof ik geen vergelijkbaar werk aan. 
openbare belangen te behartigen, en op basis van politieke voorkeuren tot een prioriteitstelling kan komen, is er sprake van vrijheid van beleid. Het hoeft hier niet te gaan om een onbegrensde ruimte om doelstellingen na te streven. Essentieel is dat er binnen een wettelijke ruimte een subjectieve (politieke) vrijheid wordt erkend, waarbij de wet het nastreven van bepaalde doelstellingen kan uitsluiten. Zodra de wetgever een bevoegdheid echter aan één specifiek doel heeft gebonden zou er géén sprake meer zijn van echte beleidsvrijheid, daar er dan met het oog op de normvervolmaking slechts één juiste beslissing (nl. de meest optimale voor dát doel) mogelijk zou zijn. Koch kritiseert deze 'normtheoretische' opvatting. Binding van een bevoegdheid aan een bepaald doel zegt nog niets over de te kiezen middelen om dat doel te bereiken. Vaak is het, gelet op de vaagheid van een doel ${ }^{61}$, ook onmogelijk om vast te stellen welke beslissing in concreto optimaal is. In de regel zijn er verschillende gelijkwaardige alternatieven voor handen om een bepaald doel te bereiken. De keuze wordt dan volgens Koch beheerst door de eisen van noodzaak (Erforderlichkeit), proportionaliteit (Verhältnismäßigkeit) en geschiktheid (Geeignetheit).

De tweede hoofdstroming spreekt van beleidsvrijheid indien het bestuur een rechtsvormende activiteit verricht die gericht is op 'Ergänzung des Normzwecks'. ${ }^{62}$ Vanuit deze optiek vult het bestuur, gelet op zijn eigen verantwoordelijkheid en deskundigheid de door de wetgever gestelde doelen aan waarbij het zich laat leiden door de strekking van het wettelijke kader. De wet wordt hierbij niet als het enige (exclusieve) besliskader gezien, maar wél als een grensstellend kader waarbinnen het bestuur eigen aanvullende (d.w.z. subjectieve) beslismaatstaven mag ontwikkelen. Een zwak punt van deze visie acht Koch dat de discretionaire bevoegdheidsuitoefening enerzijds aan het doel van de wet wordt gebonden en dat anderzijds andere beslismaatstaven dan dit doel toch toelaatbaar worden geacht.

In dit verband schetst Koch een tweetal opties. In de eerste plaats zou men ervan uit kunnen gaan dat 'aanvullende' bestuurlijke beslismaatstaven op een gelijk niveau worden gesteld als het doel van de wet. In dit geval zou het bestuur dan een echt 'Wahlrecht' hebben. Aannemelijker is echter dat er een hiërarchische rangorde dient te worden erkend tussen de 'ratio legis' en de beslismaatstaven die het bestuur zelfstandig ontwikkelt. Eigen doelstellingen zouden door het bestuur uitsluitend nagestreefd mogen worden voorzover de verwezenlijking van het wettelijke doel niet in gevaar komt. ${ }^{63}$ Volgens Koch verschilt de tweede opvatting inzake beleidsvrijheid alleen van de eerste - nl. het echte recht tot 'Zweckwahl' - indien men de laatstgenoemde optie tot uitgangspunt neemt. De beslisvrijheid van het bestuur is in dit verband steeds ondergeschikt aan het verwezenlijken van

61. Koch spreekt hier over de 'mangelnde Orientierungskraft eines nur vage ausgedrückten Zwecks.' H.J. Koch, Unbestimmte Rechtsbegriffe und Ermessenermächtigungen im Verwaltungsrecht, a.w., p. 150 en 151.

62. H.J. Koch, Unbestimmte Rechtsbegriffe und Ermessenermächtigungen im Verwaltungsrecht, a.w., p. 154 e.v. Vgl. in dit kader de eerder in dit hoofdstuk besproken visie van Jue inzake de bevoegdheid van het bestuur tot 'wetsaanvullend argumenteren' (paragraaf 6.2.4).

63. H.J. Koch, Unbestimmte Rechtsbegriffe und Ermessenermachtigungen im Verwaltungsrecht, a.w., p. 155. 
het wettelijke doel. Een zwak punt blijft evenwel dat niet expliciet wordt gemaakt wanneer het bestuur zich 'loszingt' van het speciale wettelijke doel.

De derde en laatste hoofdstroming ziet het uitoefenen van een beleidsvrije bevoegdheid als een volledig 'Normzweckgebundene Entscheidung'. ${ }^{64}$ Binnen deze visie staat de binding van de discretionaire bevoegdheidsuitoefening aan de tekst én strekking van de wet centraal. Het primaat van de 'ratio legis' vormt het leidende uitgangspunt. Hierbij lijkt de rechtsvormende activiteit van het bestuur opgevat te worden als een soort 'interpretatieactiviteit'. Het bestuur dient enkel vast te stellen wat het doel van de bevoegdheid in concreto vereist. De bevoegdheidsuitoefening deelt bijgevolg volledig in het objectieve karakter van de wettelijke bevoegdheidsnorm; het wettelijke doel is bepalend voor de vraag in welke richting de bevoegdheidsuitoefening zich dient te bewegen. Beleidsvrijheid (of ruimte) wordt enkel gezien als een keuzemogelijkheid tussen verschillende doelgebonden handelingsalternatieven. De aanhangers van deze visie onderkennen volgens Koch eveneens - zij het noodgedwongen - dat er grenzen gelden voor de sturing van de bevoegdheidsuitoefening aan de hand van het doel van de wet. Indien uit het objectieve doel van de wet redelijkerwijs géén richting meer kan worden afgeleid waarin de bevoegdheidsuitoefening zich moet begeven, erkennen ook zij een 'subjectieve' restruimte voor het beslissende bestuursorgaan. Ter rechtvaardiging wordt dan een beroep gedaan op de complexiteit en de vaagheid van wettelijke doelen. Koch vraagt zich in dit verband terecht af, of binnen deze visie dan niet toch een beperkte 'Zweckwahl' wordt erkend. ${ }^{65}$

\subsubsection{Subjectief of objectief?}

De verschillende visies inzake het juridische karakter van beleidsvrijheid zijn terug te voeren op tegenstrijdige uitgangspunten die op het eerste gezicht moeilijk met elkaar verzoend lijken te kunnen worden. Veelzeggend is de volgende verzuchting van $\mathrm{Koch}^{66}$ :

'Der unterschied scheint also eher in der verfassungsrechtlichen Bewertung von Ermessensermàchtigungen als in der Beschreibung der durch solche Ermächtigungen eingerăumten Handlungsspielrăume zu liegen. Die Forderung einer strikten Bindung der Ermessensbetattigung an die Normzwecke geht auf diese rechtsstaatliche Position zuruck, die Anerkennung der begrenzten Entscheidungsfreiheit auf eine methodische Analyse der Möglichkeit einer Bindung an die Gesetzeszwecke. Dieser Dualismus scheint dafur verantwortlich zu sein, daß Ermessenermächtigungen gleichzeitig als Bindungen und Freistellungen bezeichnet werden.'

Vanuit een meer 'objectieve' visie zal het uitgangspunt zijn dat een bestuursorgaan zich bij de bevoegdheidsuitoefening exclusief dient te oriënteren op het wettelijke doel dat door de wetgever aan een bestuursbevoegdheid ten grondslag is gelegd. ${ }^{67}$ Optimale behartiging van dit objectieve en op democratische wijze gedetermineerde doel wordt bepalend geacht voor de bevoegdheidsuitoefening in concreto. Een 'objectieve' interpretatie van beleidsvrijheid

64. H.J. Koch, Unbestimmte Rechtsbegriffe und Ermessenermăchtigungen im Verwaltungsrecht, a.w., p. 157 e.v. Volgens Koch wint deze opvatting terrein.

65. H.J. Koch, Unbestimmte Rechtsbegriffe und Ermessenermachtigungen im Verwaltungsrecht, a.w., p. 163.

66. H.J. Koch, Unbestimmte Rechtsbegriffe und Ermessenermåchtigungen im Verwaltungsrecht, a.w., p. 163. 
brengt met zich dat de bevoegdheidsnorm wordt gezien als een norm die geconcretiseerd dient te worden gelet op de relevante omstandigheden van het geval. Dit proces van concretisering dient zich volstrekt los van iedere politiek/bestuurlijke prioriteitstelling te voltrekken. Met name Heldeweg heeft zich recentelijk in de richting van een 'objectieve' visie begeven. ${ }^{68}$

Ofschoon een dergelijke visie theoretisch sterk is, onderkent zij mijns inziens uiteindelijk in onvoldoende mate de problemen die samenhangen met de inherente vaagheid van wettelijke doelstellingen. Voor het bestuursorgaan zal het in de regel onmogelijk zijn om uit de verschillende keuze-alternatieven het ene 'optimale' te kiezen. In een realistische kijk op de sturende kracht van een beleidsvrije bevoegdheidsnorm erkent men dat de ambtsplicht van een bestuursorgaan enkel verplicht tot het streven naar een zo optimaal mogelijke doelverwezenlijking in concreto. Hierbij wordt van het orgaan niet verwacht dat het ene theoretische optimum daadwerkelijk wordt bereikt. De keuze behoeft enkel in redelijkheid verdedigbaar te zijn. ${ }^{69}$ Voorts wordt in een louter 'objectieve' benadering van beleidsvrijheid een bevoegdheidsnorm ${ }^{70}$ te zeer op een lijn gesteld met een reeds voltooide rechtsnorm. De bevoegdheidsnorm is naar mijn oordeel juist een (ver)bindende normatieve schakel tussen het democratische-politieke proces van belangenafweging in abstracto en de uiteindelijke in concreto gevormde gedragsnormen welke rechtssubjecten binden."

Een meer 'subjectief' georiënteerde benadering van beleidsvrijheid lijkt verdedigbaar. Een dergelijke benadering gaat ervan uit dat een beleidsvrije bevoegdheidsuitoefening niet volledig beheerst kan worden door de objectieve strekking van de wet. De wettelijke bevoegdheidsnorm wordt wél gezien als een cruciaal grensstellend kader, maar hieruit kan niet één rechtens juiste bevoegdheidsuitoefening worden afgeleid. Binnen het wettelijke kader wordt een bandbreedte erkend waarbinnen politiek/bestuurlijke opvattingen, alsmede ambtelijke inzichten, een rol kunnen spelen bij het bepalen van de meest optimale

67. In dit kader is de visie van Teunissen exemplarisch: 'Ook bij zgn. 'vrije' bevoegdheden kan m.i. worden volgehouden dat het overheidsorgaan slechts én beslissing kan nemen, nl. de beslissing die de wetgever zou hebben genomen wanneer hij zelf in staat was geweest de volledige belangenafweging te verrichten.' J.M.H.F. Teunissen, Strategisch concept voor nivellerende rechtswetenschap, in: Eenzijdig en wederkerig? (red. E.C.H.J. van der Linden en A.Q.C. Tak) Deventer 1995, p. 279 (noot 5).

68. M.A. Heldeweg, Publiekrechtelijke autonomie, a.w., p. 121 e.v. (zie i.h.b. p. 133 e.v.). De visie van Heldeweg komt in hoofdstuk 7 van dit boek meer uitvoerig aan bod.

69. Voor de rechter geldt hier de plicht om 'marginaal' te toetsen. Vgl. M.A. Heldeweg en R.J.N. Schlðssels, Willekeur getoetst; terug naar Doetinchem?, JB 1996/212, p. 906 e.v. Zie over 'marginale toetsing' verder: R. de Lange, Publiekrechtelijke rechtsvinding, a.w., p. 46-48.

70. Zie over de structuur kenmerken van de (publieke) bevoegdheidsnorm meer uitvoerig hoofdstuk 2 , paragraaf 2.3.2.

71. Vgl. de beschouwingen in hoofdstuk 4 van dit boek. Eerder steide ik met het oog hierop dat het bestuursorgaan in geval van beleidsvrijheid 'een normatieve vertaalslag' dient te maken. Zie: R.J.N. Schlossels, Een dakkapel te Edam: de wens van eenheid van recht?, in: Rechtspraak bestuursrecht. De annotaties 1995-1996, p. 69. 
modaliteit van bevoegdheidsuitoefening. ${ }^{72}$ Deze visie is helder verwoord door de sectie bestuursrecht van de Rijksuniversiteit Limburg:

\begin{abstract}
'In de individuele rechtsbedeling is besturen meer dan zuiver mechanische uitvoering. De wetgever laat daartoe dan ook welbewust ruimte. Waar de wet beleidsvrijheid laat, komt de politieke legitimatie van het bestuur het meest volledig tot zijn recht. (..) Dit brengt mee dat hun taakuitoefening (van de bestuursorganen R.J.N.S.) niet slechts objectief-juridisch maar ook subjectief-politiek is genormeerd en gelegitimeerd. Dit betekent dat voorop staat de bevoegdheid (en verplichting) van het bestuur om, bezien vanuit de ratio van de wettelijke regeling, gewicht toe te kennen aan de bijzondere omstandigheden van ieder voorliggend geval' (curs. R.J.N.S.). ${ }^{73}$
\end{abstract}

Ik benadruk dat een dergelijke opvatting geenszins impliceert dat persoonlijke intenties van ambtsdragers van invloed mogen zijn op de bevoegdheidsuitoefening. De rechtsstaatgedachte zelf brengt reeds met zich dat bestuursorganen ók in geval van beleidsvrijheid volledig gebonden zijn aan ongeschreven publieke rechtsnormen, dat zij de typische rechtsbelangen van rechtssubjecten overeenkomstig deze normen moeten respecteren en dat de bevoegdheidsuitoefening steeds door het algemeen belang moet worden ingegeven. ${ }^{74} \mathrm{Al}-$ dus beschouwd, erkent een 'subjectieve' opvatting dat een bestuursorgaan als rechtsvormend gemeenschapsorgaan volwaardig deel uitmaakt van de staatsorganisatie en dat het onder respectering van de gehele normenstructuur van het objectieve publiekrecht aan deze gemeenschapsfunctie invulling geeft. ${ }^{75}$

Mijns inziens dienen de verschillen in de denkbeelden over het rechtskarakter van beleidsvrijheid te worden gerelativeerd. Ofschoon een 'objectieve' en 'subjectieve' opvatting inzake beleidsvrijheid ver van elkaar lijken te staan, wordt in beide benaderingswijzen

72. Zie bijv. H.J. Simon, Handboek bestuurs(proces)recht volgens de Awb, 's-Gravenhage 1997, p. 142.

73. Sectie bestuursrecht Rijksuniversiteit Limburg, Beleidsregels: gebruiksaanwijzing van bestuursbevoegdheid, RegelMaat 1993/2, p. 56 en 57. Voor deze bijdrage tekenden: R.E. Bakker, J.M.E. Derks, M.A. Heldeweg, B.M.J. van der Meulen, E. Ramakers, H.J. Simon en A.Q.C. Tak.

74. Vgl. in dit verband de treffende karakterisering van beleidsvrijheid door de Duitse auteur Forsthoff, die over het karakter van beleidsvrijheid het volgende opmerkte: 'Wăhrend der Richter nach dem Gesetz judiziert, entnimmt der Verwaltungsbeambte die Maximen seines Tatigseins zum Teil dem Gesetz, zum Teil der eigenen Erfahrung und Einsicht. Soweit das letztere geschieht, spricht man vom Ermessen, das in Verbindung mit zahlreichen Adjektiven wie 'frei', 'pflichtmåßig', 'diskretionår', 'technisch' oder auch als 'Verwaltungsermessen' einen zentralen Begriff des Verwaltungsrechts bildet.' E. Forsthoff, Lehrbuch des Verwaltungsrecht, erster Band Allgemeiner Teil, achte neu bearbeitete Auflage, Munchen/Berlin 1961, p. 73 en 74. Het gaat hier om een 'Ineinandergreifen von Ermessen und normativer Gebundenheit' (a.w., p. 78). Het samengaan van deze sferen sluit volgens Forsthoff het 'pflichtgebunden' karakter van de beleidsvrijheid niet uit. Dit karakter wortelt in de rechtsstaatgedachte zelf: 'Die Plichtgebundenheit der Verwaltung ist mit dem Rechtsstaat selbstverstandlich gegeben. Sie bedeutet, daß die Verwaltung weder nach Belieben noch nach Willkür verfahren düre. Belieben bedeutet ein handeln, das ausschließlich subjektiven Erwagungen ohne Zusammenhang mit sachlichen Zwecken entspringt, wăhrend als Willkur ein Handeln aus sachfremden Motiven zu bezeichnen ist. (a.w., p. 85 en 86).'

75. De rechtsfiguur 'beleidsvrijheid' geef, aldus opgevat, uitdrukking aan de zelfstandige ambtelijke verantwoordelijkheid van het bestuur binnen de grenzen van de wet en het recht. Vgl. H. Maurer, Aligemeines Verwaltungsrecht, a.w., p. 124. 
erkend dat een bestuurlijke bevoegdheidsuitoefening steeds dienstig behoort te zijn aan de verwezenlijking van het speciale wettelijke doel dat aan de betreffende bevoegdheid ten grondslag ligt. ${ }^{76}$ Beide opvattingen erkennen ók dat een bestuursorgaan zich in het kader van een beleidsvrije bevoegdheidsuitoefening dient te oriënteren op alle relevante omstandigheden van het geval. Ingevolge de ambtsplicht dient het bestuursorgaan zijn bevoegdheid op een zodanige wijze uit te oefenen dat deze steeds dienstig is aan de 'ratio legis'.

\subsubsection{Wat valt er af te wegen?}

De plicht tot het 'afwegen van belangen' vormt, in geval van beleidsvrijheid, een bestuursrechtelijke vanzelfsprekendheid. ${ }^{77}$ Ook de Awb-wetgever heeft de 'belangenafwegingsplicht' een centrale plaats toebedacht in het bestuurlijke besluitvormingsproces. $^{78}$ Zo verplicht artikel 3:4 lid 1 Algemene wet bestuursrecht het bestuursorgaan (in beginsel) om 'de rechtstreeks bij een besluit betrokken belangen af te wegen'.

Het was de Hoge Raad die bij de introductie van zijn 'marginale willekeurs'-toetsing ${ }^{79}$ de belangenafwegingsplicht duidelijk onderstreepte door te overwegen dat: '...voor tussenkomst van den rechter reden zou kunnen zijn, indien de vordering als een daad van willekeur zou zijn aan te merken; dat deze figuur zich voordoet, als moet worden aangenomen, dat de vorderende autoriteit bij afweging van de in aanmerking komende belangen in redelijkheid niet tot een vordering heeft kunnen komen, en dus afweging van die belangen geacht moet worden niet te hebben plaats gehad; ...' (curs. R.J.N.S.) ${ }^{80}$ De overwegingen van de Hoge Raad stonden model voor de bekende 'c-grond' in artikel 8 lid 1 onder $\mathrm{c}$ van de voormalige Wet Arob. ${ }^{81}$ Ingevolge deze toetsingsgrond kon een beschikking worden vernietigd indien "het administratieve orgaan bij afweging van de betrokken belangen niet

76. Ik wijs op Vegting die er de aandacht op heeft gevestigd dat het nastreven van het (objectieve) wettelijke doel overeenkomstig rechtsnormen óbk ('subjectieve') doel-matigheid van de beslissing impliceert. W.G. Vegting, Het algemeen Nederlands administratief recht, a.w., p. 314. Vgl. in dit verband ook de fraaie beschouwingen van P.C.E. van Wijmen, Recht, belang en rechtsbescherming. Actie en belang, forum en toetsingsgrond; een dwarsdoorsnede van de rechtsbescherming tegen het overheidsbestuur, diss. UU, 's-Gravenhage, p. 478-479 en p. 490-491.

77. Vgl. de opvatting van Stroink. Hij acht de ruimte voor 'belangenafweging' een essentieel kenmerk van beleidsvrijheid. F.A.M. Stroink, Boekbeschouwing B.W.N. de Waard, Samenwerkende machten. Wetgeving en rechtspraak in dienst van het recht, RMTh. 1995/8, p. 373. Zie ook: P. Nicolar, Beginselen van behoorlijk bestuur, a.w., p. 345 en Nicolar e.a., Bestuursrecht, a.w., p. 338. In dit laatste werk spreekt Nicolar over de 'waardering' van belangen, hetgeen mij meer aanspreekt. J.B.J.M. ten Berge, Besturen door de overheid, a.w., p. 242.

78. Zie: R.M. van Male, Enkele aspecten van het begrip belanghebbende in de Algemene wet bestuursrecht, a.w., p. 14.

79. HR 25 februari 1949, NJ 1949, 558 (woonnimtevordering Doetinchem).

80. En in het kader van het bekende Landsmeer-arrest luidde het: '...dat voorop worde gesteld dat een overheidsorgaan dat gebruik maakt van een in hoofdzaak discretionaire bevoegdheid, als in art. 7 Woonruimtewet aan $\mathrm{B}$. en $\mathrm{W}$. is gegeven, bij de afweging van de daarbij in aanmerking komende belangen in beginsel vrij is naar eigen inzicht de rangorde dier belangen te bepalen en overeenkomstig dat inzicht te beslissen; ...' (curs. R.J.N.S.). HR 4 januari 1963, AB 1963, 603, m.nt. St. (Landsmeer). 
in redelijkheid tot de beschikking heeft kunnen komen'. De 'c-grond' heeft tot vél jurisprudentie van de Afdeling rechtspraak geleid, waarbij de marginale toetsing van de belangenafweging centraal stond. ${ }^{82}$

Nicolaï heeft de belangenafwegingsplicht in zijn proefschrift aangemerkt als een essentieel element van het door hem omschreven beginsel van 'deugdelijke besluitvorming ${ }^{33}$ Kritische geluiden, hoewel schaars, waren er echter ook. Zo uitte Stellinga meer dan eens kritiek op 'belangenafwegingen' waarbij financieel-economische belangen van particulieren prevaleerden boven bepaalde algemene belangen op het gebied van het milieu- en landschapsbehoud. Hierbij leek hij zich in het bijzonder te keren tegen het ogenschijnlijk 'onderhandelen' over de inhoud van het algemeen belang in concreto. ${ }^{84}$

De vraag dringt zich op wat precies onder het 'afwegen van belangen' dient te worden verstaan. Wellicht dat het begrip 'afwegen' als fysische analogie verwarrend is. $\mathrm{Bij}$ een discretionaire bevoegdheidsuitoefening kan er mijns inziens géén sprake zijn van een 'afwegen' van een tweetal grootheden in de letterlijke betekenis van dit werkwoord. Afwegen zou dan immers vóoronderstellen dat er een tweetal gelijksoortige grootheden aan de hand van één meetcriterium in balans kan worden gebracht. Dit is naar mijn mening een onzuivere voorstelling van zaken. In geval van beleidsvrijheid is er géén sprake van gelijksoortige grootheden die volstrekt met elkaar in balans kunnen worden gebracht. Een publiekrechtelijk belang wortelt immers in de publieke rechtsorde ${ }^{85}$ terwijl de rechtsbelangen van rechtssubjecten juist geworteld zijn in de privaatrechtelijke autonomie. Voorts dient gewezen te worden op het 'multipolaire' karakter van het bestuursrecht: het bestuur is in concreto vaak gehouden om met verschillende subjectgebonden rechtsbelangen rekening te houden. De kring van rechtssubjecten die betrokken kan zijn bij een bestuurlijke bevoegdheidsuitoefening verzet zich reeds hierom tegen een echte 'afweging', die immers naar haar aard enkel 'bi-polair' van aard zou kunnen zijn. ${ }^{86}$

\subsubsection{De grondregel van minimale belangenaantasting}

Het proces van bestuurlijke 'belangenafweging' dient bijgevolg vanuit een andere invalshoek te worden benaderd. Het proces, waarbij de publieke en private belangensferen elkaar

81. Zie: J.G. Steenbeek en F.A.M. Stroink, Wet administratieve rechtspraak overheidsbeschikkingen, vierde herziene druk, 's-Gravenhage 1988, p. 234. De formulering van deze 'c-grond' werd via art. 4 van de Wet Bab ontleend aan art. 5 Wet Arbo.

82. Voor een uitvoerige analyse van deze jurisprudentie kan verwezen worden naar Steenbeek/Stroink, Wet administratieve rechtspraak overheidsbeschikkingen, a.w., p. $234 \mathrm{t} / \mathrm{m} 249$.

83. P. Nicolar, Beginselen van behoorlijk bestuur, a.w., p. 342.

84. Zie over de visie van Stellinga uitvoerig hoofdstuk 7 van dit boek (paragraaf 7.2.1).

85. Vgl. in dit kader uitvoerig hoofdstuk 3 van dit boek.

86. Ik heb mij het bestuurlijke belangenafwegingsproces dan ook nooit zo goed kunnen voorstellen aan de hand van een weegschaal waarbij aan éen kant alle door een besluit bevoordeelde belangen en aan de andere kant alle door dat besluit benadeelde belangen worden gelegd. Vgl. A.Q.C. Tak, Overheidsbestuur en privaatrecht, Alphen aan den Rijn 1978, p. 118. Een dergelijke visualisatie doet m.i. weinig recht aan de complexiteit van de 'afweging'. 
ontmoeten, staat in zijn meest elementaire vorm in het teken van de (normatieve) spanning tussen een speciaal publiekrechtelijk belang enerzijds en de bij de bevoegdheidsuitoefening betrokken subjectgebonden rechtsbelangen van burgers anderzijds. ${ }^{87}$ Alleen het betrokken publiekrechtelijke belang kan doelgerichte énzijdige rechtsvorming door het bestuur legitimeren; particuliere belangen kunnen dit naar hun rechtsaard niet. $\mathrm{Zij}$ dienen als rechtens beschermde belangen in het proces van rechtsvorming wél zoveel mogelijk te worden ontzien. ${ }^{88}$ Dit vloeit uiteindelijk voort uit de scheiding tussen de publieke staat en de burgerlijke maatschappij en de hiermee verband houdende rechtsstaatgedachte. ${ }^{89}$

In dit verband dient naar mijn oordeel de tweede door Nicolai ${ }^{90}$ geformuleerde grondregel voor het bestuurlijke 'belangenafwegingsproces' te worden gepositioneerd. Op de overheid rust steeds de bewijslast om aan te tonen dat beperkingen ten aanzien van de positieve en negatieve vrijheid ${ }^{91}$ van rechtssubjecten noodzakelijk zijn: 'Voor de uitoefening van bevoegdheden en rechten door de administratie impliceert dat uitgangspunt de erkenning van de grondregel dat belangen van de burgers niet méér mogen worden aangetast dan strikt noodzakelijk is en dat het bestuur (dus) telkens naar een oplossing dient te zoeken waarbij de aantasting zo gering mogelijk is' (curs. P.N.). ${ }^{92}$

Naar mijn oordeel biedt deze grondregel een juiste basis om (de kern) van het 'belangenafwegingsproces' te karakteriseren. De bestuurlijke belangenafwegingsplicht, zoals neergelegd in artikel 3:4 Awb (met name lid 2), houdt een plicht in voor het bestuur om bij de uitoefening van een (beleidsvrije) bestuursbevoegdheid alle rechtstreeks betrokken belangposities van rechtssubjecten zoveel mogelijk te ontzien. De publiekrechtelijke belang-behartiging staat hierbij voortdurend onder de regulerende werking van het handelen 'in het algemeen belang' ${ }^{93}$ Dit leidende principe vereist het aantonen van noodzaak, zorgvuldigheid, evenwichtigheid, evenredigheid én proportionaliteit ten aanzien van de publiekrechtelijke belangbehartiging in concreto. ${ }^{94}$

87. Dit uitgangspunt is m.j. op een zeer fraaie wijze verwoord door Van der Hoeven. Zie: J. van der Hoeven, De grenzen van de rechterlijke functie in de administratieve rechtspraak, a.w., p. 673.

88. In hoofdstuk 9 (paragraaf 9.7) kom ik hier op terug.

89. Zie hierover hoofdstuk 3 paragraaf 3.2 De plicht voor de overheid om belangen van burgers zoveel mogelijk te ontzien zou volgens Konijnenbelt ók voortvloeien uit de democratische gedachte. Van Wijk/Konijnenbelt/Van Male, Hoofdstukken van administratief recht, a.w., p. 80.

90. P. Nicolali, Beginselen van behoorlijk bestuur, a.w., p. 420 e.v. Nicolar heeft in dit verband een drietal grondregels geformuleerd. De eerste betreft het verbod voor de overheid om private belangen te behartigen, de derde betreft het fundamentele verbod van misbruik van bevoegdheid (a.w. p. 418 e.v. en p. 423 e.v.).

91. Hier is de private autonomie in het geding die in de sociale rechtsstaat door overheidsinterventie ók kan worden verruimd (bijv. het verlenen van uitkeringen).

92. P. Nicolail, Beginselen van behoorlijk bestuur, a.w., p. 420. Vgl. A.Q.C. Tak, Overheidsbestuur en privaatrecht, a.w., p. 118. Dit uitgangspunt van 'minimale belangenaantasting' werd in onze bestuursrechttheorie overigens geïntroduceerd door J.J. Boasson, De rechter tegenover de vrijheid der administratie, a.w., p. 381-383. Konijnenbelt bespreekt zijn beginsel van 'de minste pijn', dat m.i. een iets beperktere strekking heef, als onderdeel van het materiele zorgvuldigheidsbeginsel. Daarnaast onderscheidt hij als elementen van dit laatstgenoemde beginsel het evenredigheidsbeginsel (in enge zin) en de égaliténorm. Van Wijk/Konijnenbele/Van Male, Hoofdstukken van administratief recht, a.w., p. 368 e.v. 


\subsubsection{Beoordelingsvrijheid en beleidsvrijheid}

Het 'afwegen' van (rechts)belangen mag dus geenszins worden opgevat als een soort onderhandelingsproces tussen enerzijds rechtssubjecten en anderzijds het bestuur over de invulling van een speciaal publiekrechtelijk belang in concreto. Voorop staat dat de behartiging van het publiekrechtelijke belang behoort tot de verantwoordelijkheid van de overheid. Het 'afwegen' van belangen kan mijns inziens dan ook enkel worden uitgelegd als 'rekening houden met'. Hierin vindt naar mijn oordeel het onderscheid tussen beoordelingsvrijheid en beleidsruimte, wat betreft de inrichting van de bestuurlijke besluitvorming, zijn zin. Hierbij teken ik aan dat dit onderscheid niet als een waterdicht schot kan worden aangemerkt. ${ }^{95}$ Het gaat meer om de onderscheiding van bepaalde typerende fasen in het bestuurlijke besluitvormingsproces.

In geval van beoordelingsvrijheid dient het bestuur, gelet op zijn bijzondere expertise en verantwoordelijkheid, de vraag te beantwoorden of een specifieke bevoegdheid mag worden uitgeoefend. Hierbij staat de vraag centraal of een bepaald complex van feiten de wettelijke toepassingscondities van de bestuursbevoegdheid vervult. Deze vraag is toegespitst op de activering van de bevoegdheidsnorm sec. Het bestuursorgaan dient zich in de beoordelingsfase primair rekenschap te geven van de rechtsnormen die een juridisch correcte beoordeling waarborgen. Met name het formele zorgvuldigheidsbeginsel vervult in dit kader een belangrijke functie (vgl. artikel 3:2 Awb).

93. Zie hierover meer uitvoerig hoofdstuk 3 paragraaf 3.3. Van Eikema Hommes heeft de harmoniserende functie van het recht in dit verband als volgt gekarakteriseerd: 'Ook op publiekrechtelijk terrein worden rechtsbelangen geharmoniseerd, maar nu in het licht van typisch publiekrechtelijke beginselen, die de verschillende publieke rechtsgebieden beheersen. Daar is allereerst het administratieve recht met zijn harmonisering van publieke bestuursbelangen onderling en met private rechtsbelangen van private personen en groepen. Al deze gecompliceerde harmoniseringen op het gebied van onderwijs, vervoer, huisvesting etc. etc. staan onder leiding van het typisch publiekrechtelijke beginsel van het algemeen staatsbelang (salus publica) ' (curs. E.H.). H.J. van Eikema Hommes, De elementaire grondbegrippen der rechtswetenschap, a.w., p. 478.

94. Deze 'behartiging' manifesteert zich door de concretisering - het 'materialiseren' - van de in abstracto geformuleerde bevoegdheidsnorm. Vgl. in dit verband M.A. Heldeweg, Publiekrechtelijke autonomie, a.w., p. 142 .

95. Allereerst is in dit kader van belang dat de wetgever soms steken laat vallen en het bestuur niet duidelijk instrueert wat voor soort 'vrijheid' in het geding is. Vgl. B.W.N. de Waard, Samenwerkende machten. Wetgeving en rechtspraak in dienst van het recht (oratie), Zwolle 1994, p. 23. Gevolg hiervan is dat de rechter soms - maar niet vaak - genoodzaakt is om de beoordelingsactiviteit en de typische belangenafiveging in elkaar te laten overvloeien. Vgl. ARRS 22 juli 1977, AB 1977, 420 m.nt. v.d.V. (welstandoordeel Baarderadeel) en CBb 24 januari 1992, AB 1992, 253, m.nt. RMvM (Promet 50 DS). Vgl. in dit verband ook: CBb 26 maart 1974, AB 1974, 193 (Vapona-strip) en CBb 31 mei 1977, AB 1977, 349 (Vlodolex-band). Tot slot heeft De Lange, die van mening is dat beoordelings- en beleidsvrijheid vloeiend in elkaar overlopen (R. de Lange, Publiekrechtelijke rechtsvinding, a.w., p. 66), er terecht de aandacht op gevestigd dat de norminterpretatie meestal plaatsvindt in het licht van de beoordeling van de feiten. Deze beoordeling kan, afhankelijk van de aard van de vage term, soms een afweging van belangen impliceren. 
In geval van beleidsvrijheid staat vervolgens de vraag centraal op welke wijze de publiekrechtelijke belangensfeerkan worden geharmoniseerd met de sfeer van de subjectgebonden rechtsbelangen. Het samenstel van rechtsnormen dat in deze 'beleidsvrije' fase wordt geactiveerd is beduidend complexer dan in de beoordelings(vrije) fase. Eerst nu zal het bestuursorgaan zich immers ók volledig rekenschap moeten geven van de rechtsnormen die de (rechts)belangen van de rechtssubjecten naar hun inhoud beschermen. Hierbij kan gedacht worden aan de grond-, mensen- en typische vermogensrechten. Bovendien worden in deze beleidsvrije fase de specifieke rechtsnormen geactiveerd die zijn toegespitst op het harmoniseren van de eerder bedoelde belangensferen. Ik wijs o.m. op het typische evenredigheidsbeginsel de eis van de égalité devant les charges publiques' en het vertrouwensbeginsel. Resumerend kan men stellen dat de beoordelingsactiviteit is toegespitst op de vraag of bestuurlijk rechtshandelen mogelijk is (de toepasselijkheid van de bevoegdheidsnorm), terwijl tijdens de 'beleidsvrije' fase van een bestuurlijk besluitvormingsproces de modaliteitskeuze van het publieke rechtshandelen en de aanvaardbaarheid van het overheidshandelen in concreto centraal staat.

\subsubsection{Een tweetal 'belangenafwegings'-karakteristieken}

Ofschoon aan het onderscheid tussen 'regelgevende' en typische 'beschikkings'-bevoegdheden van het bestuur in dit boek geen bijzondere aandacht wordt besteed, dient er op deze plaats wél op te worden gewezen dat de belangenafwegings-karakteristiek (zo er sprake is van een relevante afwegingsruimte) ten aanzien van deze bevoegdheidstypen verschilt. Het algemene uitgangspunt dat belangposities van burgers zoveel mogelijk door het bestuur dienen te worden ontzien geldt zowel voor bestuursbevoegdheden met een 'regelgevings-' als met een 'beschikkingskarakter' ${ }^{96}$ Een kenmerkend verschil is echter hierin gelegen dat individuele belangposities voor het bestuur bij de vaststelling van algemene regels vaak minder duidelijk zijn. De regelgever zal daarom slechts zelden kunnen voorzien welke gevolgen een bevoegdheidsuitoefening precies heeft voor één individualiseerbaar rechtssubject.

Daarentegen kan het verantwoordelijke bestuursorgaan vaak wél de consequenties van een regeling inschatten voor een (abstracte) groep van rechtssubjecten. Met de belangen van deze groepen zal het bestuur dan - op straffe van overtreding van het verbod van

96. Over de structuur van de belangenafweging - waarbij gedacht kan worden aan het verbod van willekeur bij de uitoefening van regelgevende (bestuurs)bevoegdheden bestaat gén overvloedige literatuur. Dit houdt misschien verband met het feit dat een rechtstreeks beroep tegen algemeen verbindende voorschriften (avv's) ingevolge de Awb (nog) is uitgesloten (vgl. art. 8:2 aanhef en onder a Awb). Wél bestaat er interessante jurisprudentie van de burgerlijke rechter op grond van art. 6:162 BW (1401 BW oud). In dit verband kan gewezen worden op A.J. Bok, Zorgvuldige en afgewogen regelgeving in het licht van de Algemene wet bestuursrecht, NTB 1993/3; enige algemene beschouwingen en opmerkingen treft men verder aan in de proefschriften van Van Male en Bok. R.M. van Male, Rechter en bestuurswetgeving, diss. KUB, Zwolle 1988, m.n. hoofdstuk 25 (het verbod van willekeur) en A.J. Bok, Rechterlijke toetsing van regelgeving, diss. RUG, Deventer 1991, p. 89 e.v.; m.n. p. 97 e.v. waar Bok het Landbouwspuitvliegers-arrest bespreekt. 
willekeur - zoveel mogelijk rekening dienen te houden. Dit bleek duidelijk in het bekende 'Landbouwspuitvliegers'-arrest ${ }^{77}$ waarin de Hoge Raad een bepaling uit het Besluit luchtvaarttoepassingen bestrijdingsmiddelen ( 29 mei 1984, Stb. 233), en de daarop gebaseerde uitvoeringsregeling, op rechtmatigheid jegens de betrokken landbouwluchtvaartbedrijven toetste via de sluis van de 'marginale' willekeurstoets. In casu dreigden de betreffende bedrijven aanzienlijke schade te ondervinden door nieuwe regels inzake het gebruik van bestrijdingsmiddelen vanuit de lucht. De Hoge Raad was van oordeel dat bij de vaststelling van de betreffende AMvB de rechtsbelangen van de betrokken bedrijven in ieder geval 'afgewogen' dienden te worden tegen de speciale publiekrechtelijke belangen welke de Bestrijdingsmiddelenwet (1962) beoogde te beschermen.

Hierbij benadrukte de Hoge Raad dat de 'wetgevende functie"98 met zich brengt dat de rechter zich in het kader van de belangenwaardering én belangenafweging, die ten grondslag ligt aan algemeen verbindende voorschriften, terughoudend dient op te stellen. Van Buuren zoekt de reden hiervoor (o.m.) in de aard van deze belangenafweging: 'Zinvol lijkt mij daarin te lezen dat het bij wetgeving meer nog dan bij uitvoering door middel van beschikkingen gaat om het afwegen van belangen van algemene aard in een relatief abstract kader. Het afwegen van belangen van meer algemene aard is een zaak waarin het primaat onomstreden aan de politiek is. ${ }^{, 99}$ Scheltema, die het arrest eveneens annoteerde, legde niet zozeer de nadruk op het politieke karakter van deze afweging maar op het feit dat het bestuur bij de afweging niet met alle bijzondere omstandigheden in concreto rekening hoeft te houden. ${ }^{100}$ Dit laatste standpunt lijkt mij, toegespitst op 'bestuurs-wetgeving', juister. ${ }^{101}$

97. HR 16 mei 1986, AB 1986, 574, m.nt. PvB en MS; NJ 1987, 251 (landbouwspuitvliegers). Ook gepubliceerd in AB Klassiek, derde druk, Deventer 1997, p. 170 e.v. m.nt. R.M. van Male. Een ander voorbeeld biedt het bekende arrest inzake de tolkentarieven. In casu had de gemeente Den Haag de vergoedingen voor tolkwerkzaamheden verlaagd zonder voorafgaand overleg met de betrokkenen en hun belangenorganisatie. Overigens dient te worden opgemerkt dat het in casu ging om de wijziging van een beleidsregel, en niet om regelgeving in materielle zin. HR 27 juni 1986, NJ 1987, 726, m.nt. MS (tolkentarieven).

98. In dit verband wordt gedoeld op wetgeving in materiële zin door de Kroon bij AMvB. Ik spreek overigens liever over 'bestuursregelgeving', d.w.z. regels die op basis van een specifieke bestuursbevoegdheid tot stand worden gebracht.

99. Zie zijn noot onder het 'Landbouwspuitvliegers'-arrest, AB 1986, 574. Vgl. voorts de annotatie van Van Male onder dit arrest in AB Klassiek (derde druk, Deventer 1997, p. 176-177) en A.Q.C. Tak, Repliek op een reactie, NTB 1994/7, p. 202 (naar aanleiding van B.W.N. de Waard, Niet terecht opmerkelijk, NTB 1994/7, p. 201-202).

100. Zie zijn noot onder het 'Landbouwspuitvliegers'-arrest, AB 1986, 574: 'Omdat het om een regeling gaat, waarbij slechts in algemene zin belangen kunnen worden afgewogen, behoeft ook niet naar de feitelijke situatie in een concreet geval te worden gekeken.'

101. Overigens blijkt uit het bekende arrest 'Leffers' dat het bestuur $66 \mathrm{k}$ bij de vaststelling van regels wél steeds oog dient te hebben voor (plotselinge en onverwachte) inbreuken op rechtsposities van bepaalde - of zelfs specifieke - rechtssubjecten die in vergelijking tot andere rechtssubjecten op een onevenredige wijze door de (vast te stellen) regeling (kunnen) worden benadeeld. Het aanbieden van nadeelcompensatie kan soms noodzakelijk blijken. Zie: HR 18 januari 1991, AB 1991, 241, m.nt. F.H. van der Burg; NJ 1992, 638, m.nt. C.J.H. Brunner. Ook gepubliceerd in AB Klassiek, derde druk, Deventer 1997, p. 245 
Naast het meer abstracte karakter van de belangenafweging bij regelgevende bestuursbevoegdheden, is er nog een tweede typerend verschil tussen deze bevoegdheden en typische beschikkingsbevoegdheden. Het betreft hier het verschijnsel van de 'derdebelanghebbenden'. De (procedurele) onderscheiding van de rechtstreeks bij een bevoegdheidsuitoefening betrokken rechtssubjecten in 'direct-belanghebbende(n)' en 'derden' is kenmerkend voor beschikkingsbevoegdheden. Doordat bestuursorganen op basis van beschikkingsbevoegdheden positief recht vormen ten aanzien van (de activiteiten van) een specifiek rechtssubject lijkt het zinvol om een onderscheid te maken tussen dit subject, dat immers rechtstreeks in rechtsvaststellende zin door de bevoegdheidsuitoefening wordt getroffen, en andere (particuliere) rechtssubjecten. De rechtspositie van deze laatstgenoemden lijkt niet door de bevoegdheidsuitoefening als rechtshandeling te worden gewijzigd. ${ }^{102}$ Juist de vraag in hoeverre een bestuursorgaan, gelet op het specialiteitsbeginsel, met rechtstreeks betrokken belangen van derden rekening mag (en moet) houden, verdeelt de meningen in de bestuursrechtelijke literatuur. ${ }^{103}$ Het betreft hier een complexe problematiek die in de volgende twee hoofdstukken aan de hand van een nadere literatuur- en jurisprudentie-analyse uitvoerig aan de orde zal komen. Dit verklaart waarom mijn aandacht in het vervolg van dit boek met name uitgaat naar beschikkingsbevoegdheden.

\subsection{Rechtsbelang en belangenafweging in concreto}

$\mathrm{Nu}$ is vastgesteld dat het kenmerk van beleidsvrijheid (mede) is gelegen in een bestuurlijke plicht om 'belangen af te wegen' (in de zin van 'rekening houden met'), dient te worden nagegaan welke deze 'belangen' dan zijn.

\subsubsection{Het begrip 'belang'}

Op deze plaats zal géén poging worden ondernomen om te komen tot een sluitende definiëring van het nogal ongrijpbare begrip 'belang'. Reeds verschillende auteurs hebben pogingen ondernomen om dit abstracte begrip te omschrijven zonder dat - naar mijn idee - een heldere definitie tot stand kwam. ${ }^{104}$ Diverse beschouwingen over het 'belang'begrip vangen aan met een verwijzing naar het proefschrift van Okma die opmerkte dat met het woord 'belang' één van de meest gebruikte en tevens een van de meest vluchtige

e.v., m.nt. P.J.J. van Buuren. Ik wijs - ter vergelijking - ook op HR 21 oktober 1994, NJ 1996, 231, m.nt. MS (Krijco Amusement BV).

102. Vgl. M.A. Heldeweg, Publiekrechtelijke autonomie, a.w., p. 142.

103. Zie: R.J.N. Schlösels, Het specialiteitsbeginsel en derde-belangen: een frisse benadering of rechtsstatelijk drijfzand?, NTB 1996/3, i.h.b. p. 83-84.

104. Voor enige fundamentele beschouwingen over dit begrip kan verwezen worden naar J. van Baars, Point d'intérêt, point d'action, diss. VU, Amsterdam 1971, m.n. hoofdstuk 2; H.J. van Eikema Hommes, De elementaire grondbegrippen der rechtswetenschap, Deventer 1972, p. $461 \mathrm{t} / \mathrm{m}$ 463. P.C.E. van Wijmen, Recht, belang en rechtsbescherming, a.w., p. $116 \mathrm{t} / \mathrm{m} 125$ en C.A. Groenendijk, Bundeling van belangen bij de burgerlijke rechter, diss. KUN, Zwolle 1981, m.n. hoofdstuk 2. Vgl. ook nog P. van Dijk, Toetsing van overheidshandelen door de nationale en internationale rechter en het vereiste van een procesbelang, 'sGravenhage 1976, i.h.b. p. 19-24. 
en kameleontische begrippen wordt aangeroerd waar de rechtswetenschap zich van bedient. ${ }^{105}$ Van Wijmen heeft erop gewezen dat het begrip belang door juristen 'axiomatisch' wordt gebruikt; er wordt gemeenschappelijk uitgegaan van een vóóronderstelde begripsinhoud, die zelf niet bewezen kan of behoeft te worden. ${ }^{106}$ En Van Baars wees er reeds op dat het begrip 'belang' zich praktisch en theoretisch aan een enigszins scherpe definiëring onttrekt. ${ }^{107}$

Daar iedere beoefenaar van het bestuursrecht een zekere voorstelling heeft van het 'belang'-begrip, lijkt een theoretische beschouwing in dit boek overbodig. Enige indicatieve opmerkingen zijn wel op zijn plaats. Allereerst dient het (feitelijke) begrip 'belang' onderscheiden te worden van (objectief) 'recht'. Het recht tracht, zoals Van Baars ${ }^{108}$ opmerkt, de samenleving te ordenen door het geven van regels voor belangenverhoudingen. Feitelijke belangenverhoudingen worden uiteraard niet volledig beheerst door het recht. Volgens Van Baars zou het leven, gelet op de grote diversiteit van door rechtssubjecten als zodanig ervaren belangen, dan onleefbaar worden. ${ }^{109}$ Slechts bepaalde belangen zijn binnen de normatieve kaders van een rechtsstelsel relevant. A fortiori kan gesteld worden dat rechtsnormen derhalve slechts bepaalde belangen beschermen. Binnen de context van het recht kan dan ook beter worden gesproken over rechtsbelangen. Dit begrip zal ik in de volgende paragraaf nader toelichten.

Op deze plaats dient er nog op te worden gewezen dat het 'belang'-begrip naar zijn aard een relationeel begrip ${ }^{110}$ is. Het begrip dient tegen de achtergrond van een subject-object relatie te worden geprojecteerd. ${ }^{11}$ De betekenis van een belang voor een bepaald (rechts)subject, de drager, wordt eerst in volle omvang duidelijk indien het al dan niet intreden van een bepaalde gebeurtenis leidt - of zal leiden - tot een wijziging of aantasting van de materiële of immateriële belangen van dat subject. De bedoelde wijziging, ook wel aan te duiden als het verschil, kan overigens voor- of nadelig van aard zijn. ${ }^{112}$

105. N. Okma, Misbruik van recht, diss. VU, Amsterdam 1945, p. 43.

106. P.C.E. van Wijmen, Recht, belang en rechtsbescherming, a.w., p. 119.

107. J. van Baars, Point d'intérêt, point d'action, a.w., p. 43.

108. J. van Baars, Point d'intérét, point d'action, a.w., p. 40.

109. J. van Baars, Point d'intérêt, point d'action, a.w., p. 40.

110. Vgl. P.C.E. van Wijmen, Recht, belang en rechtsbescherming, a.w., p. 122.

111. Zo definieerde Okma 'belang' in zijn proefschrift als 'de geobjectiveerde gevoelsrelatie tusschen een subject en een object'. N. Okma, Misbruik van recht, a.w., p. 196.

112. Vgl. in dit verband Van Baars die de oorspronkelijke kern van het 'belang'-begrip zocht in het aanwezig (kunnen) zijn van verschil voor iemand ten gevolge van gebeurtenissen met betrekking tot zijn situatie. J. van Baars, Point d'intérêt, point d'action, a.w., p. 44. Van Wijmen heeft er naar mijn oordeel terecht op gewezen dat dit 'verschil' niet gelijk kan worden gesteld aan 'het belang'. Het verschil vormt wêl een parameter aan de hand waarvan het hebben van belang kan worden vastgesteld. Zie: P.C.E. van Wijmen, Recht, belang en rechtsbescherming, a.w. p. 122. 


\subsubsection{Iets over subjectgebonden rechtsbelangen}

Het in de vorige paragraaf bedoelde verschilmoment wordt in het bestuursrecht voor een rechtssubject (de belanghebbende) vaak veroorzaakt door de uitoefening van een bestuursbevoegdheid. ${ }^{113}$ Deze bevoegdheidsuitoefening vindt, als publiekrechtelijke rechtshandeling, haar neerslag in een besluit (artikel 1:3 lid 1 Awb).

Wat is nu, naar mijn mening, een typisch rechtsbelang? Voordat ik hier een antwoord op formuleer ${ }^{1 / 4}$, wijs ik erop dat ik het begrip rechtsbelang tot één bepaalde groep normatief-relevante belangen beperk. Ik hanteer het begrip in dit boek bovendien in een specifieke betekenis die afwijkt van de gangbare in het bestuurs(proces)recht. ${ }^{115}$ Van de rechtsbelangen onderscheid ik allereerst de publiekrechtelijke belangen. ${ }^{116}$ Deze publiekrechtelijke belangen sturen, zoals in hoofdstuk 3 bleek $^{117}$, op een exclusieve wijze het gerichte bestuurlijke rechtsvormingsproces. Hierdoor zijn zij, hoewel vanuit normatief oogpunt cruciaal, onvergelijkbaar met de subjectgebonden rechtsbelangen. Omdat publiekrechtelijke belangen - toegespitst op de bevoegdheidsuitoefening - gepositioneerd dienen te worden aan de normzijde van het recht kan een rechtssubject, d.w.z. een natuurlijke persoon of een rechtspersoon, mijns inziens in de regel niet fungeren als (zelfstandige) drager en behartiger van dit soort gemeenschapsbelangen.

113. Het feitelijke en het 'privaatrechtelijke' handelen door het bestuur laat ik buiten beschouwing.

114. Voor een meer uitvoerige beschouwing verwijs ik naar R.J.N. Schlossels, Belang als prismabeeld. Over rechtsfeiten, gerichte rechtsvorming en belangenpluriformiteit in het bestuursrecht, in: Spectraal recht? De bevoegdheidsuitoefening door de overheid als rechtsfeit (red. E.C.H.J. van der Linden, R.J.N. Schlossels, R.J.G.H. Seerden), Den Haag 1998, p. 97 e.v. Ik beoog in het bestuursrecht een pluriform 'belang'-begrip te hanteren, waarbij in ieder geval een onderscheid wordt gemaakt tussen: (1) typisch subjectgebonden rechtsbelangen (naar mijn mening de vermogensrechten in ruime zin en de erkende grond- en mensenrechten), (2) publiekrechtelijke belangen van de overheid, en (3) typisch 'statutaire' belangen die krachtens intern organisatierecht van een rechtspersoon worden vastgesteld.

115. Ik wijs erop dat het begrip 'rechtsbelang' of 'materieel belang' in de bestuurs(proces)rechtelijke literatuur, toegespitst op de administratieve rechtsbescherming, ook in een andere betekenis wordt opgevat, $\mathrm{nl}$. als aspect van de procestechnische ontvankelijkheidseis. Vgl. B.W.N. de Waard, Beginselen van behoorlijke rechtspleging, diss. UU, Zwolle 1987, p. 199 e.v. Het 'materiele belang' wordt in dit verband afgezet tegen het 'procesbelang', d.w.z. het belang dat moet bestaan bij het volgen van de betreffende rechtsbeschermingsprocedure. Zie bijv. H.J. Simon, Handboek bestuurs(proces)recht, 's-Gravenhage 1997, p. 3536. Ik vat het 'materielle' ontvankelijkheidsaspect echter onder het 'belanghebbende'-begrip dat ik vervolgens als procestechnisch begrip afzet tegen het begrip 'rechtsbelang' (paragraaf 6.4.3).

116. Tak heeft gewezen op de noodzaak om een onderscheid te maken tussen publiekrechtelijke belangen en rechtsbelangen door op te merken: "Immers, het "besluit" is in de Awb gedefinieerd als "rechtshandeling" (vgl. art. 1:3 lid 1). Het wordt o.m. beheerst door het publiekrechtelijke specialiteitsbeginsel, dat inhoudt dat alteen de bijzondere door de wet (waarop de bevoegdheidsuitoefening rust) beoogde belangen een rol mogen spelen (vgl. art. 3:3 Awb). Derhalve moeten wij bij besluiten onderscheiden tussen belangen, waarvan de behartiging beoogd werd bij het nemen ervan (dat kunnen alleen de door de betreffende wet beoogde belangen zijn), en alle andere belangen (vgl. ook de omschrijving in het oude art. 2 Wet Arob: "gericht op rechtsgevolg"). Deze laatste belangen zijn niet te relateren aan het besluit als "rechtshandeling"' (curs. R.J.N.S.). A.Q.C. Tak, Hoofdlijnen van het Nederlands bestuursprocesrecht, a.w., p. 90.

117. Zie i.h.b. de paragrafen 3.2 .4 en 3.4.1. 
Kenmerkend voor een typisch rechtsbelang is naar mijn oordeel allereerst het gegeven dat de drager van een dergelijk belang (het rechtssubject) zelf ${ }^{118}$ géen invloed heeft op het bestempelen van dit belang als zijnde rechtens relevant. Het rechtssubject kan met andere woorden zijn rechtsbelangen, naar hun aard en inhoud beschouwd ${ }^{119}$, niet autonoom 'genereren'. ${ }^{120}$ Evenmin kan een rechtssubject rechtsplichten creëren om met zijn belangen in het rechtsverkeer rekening te houden. Dat zou strijdig zijn met de aard van het rechtsbelang en de grondstructuur van het recht. Uitsluitend de objectieve rechtsorde kan, bepaalde 'feitelijke' belangen van rechtssubjecten naar hun inhoud, dus materieel, erkennen als zijnde rechtens relevant. ${ }^{121}$ Hierbij dient erop te worden gewezen dat de vaststelling van de aard, inhoud en omvang van rechtsbelangen bij voortduring afhankelijk is van de interpretatie van de materiële rechtsnormen die bepaalde 'feitelijke' belangen als rechtswaarde beschermen (bijv. de grondrechten). De rechtsbelangen hebben bijgevolg een objectief karakter. ${ }^{122}$ Hierdoor zijn zij voor mederechtssubjecten steeds kenbaar en wordt jegens deze medesubjecten tevens de rechtswaarde van het betreffende belang gelegitimeerd. Een belang wordt vervolgens tot volwaardig rechtsbelang indien het rechtssubject zijn belangpositie in rechte door een actie kan bestendigen. ${ }^{123}$

Het voorafgaande brengt mijns inziens met zich dat 'belangen' die uitsluitend in de subjectief bepaalde gedachtenwereld van subjecten leven, of enkel ethisch of politiek kunnen worden gefundeerd, niet als rechtsbelang kunnen worden aangemerkt. ${ }^{124}$ Verwant

118. Of in geval van een rechtspersoon de organen van het rechtssubject.

119. Het begrip 'rechts'-belang vat ik derhalve op als materieel/inhoudelijk. Een rechtsbelang vertegenwoordigt een door het objectieve recht erkende rechtswaarde. Ik wijs, ter vergelijking, op Van Eikema Hommes' definitie van het begrip rechtsbelang: 'We kunnen rechtsbelang in deze zin misschien het beste omschrijven als rechtsgoed, d.i. al wat rechtens bescherming verkrijgt ten dienste van rechtssubjecten. Het gaat hier om concrete goederen met economische (in geld uit te drukken) of idecle (niet in geld uit te drukken) waarde, naar hun rechtsaspect (cursivering E.H.).' H.J. van Eikema Hommes, De elementaire grondbegrippen der rechtswetenschap, Deventer 1972, p. 463. Belangrijkste functie van het recht, als normenstelsel, is in dit kader het stabiliseren van de wereld van de rechtsbelangen (a.w., p. 221). Cruciaal lijkt mij in dit verband dat Van Eikema Hommes benadrukt dat het rechtsbelang niet aan de normzijde van het recht fungeert, maar aan de feitelijke subjectszijde (a.w., p. 461).

120. Natuurlijk kunnen rechtssubjecten bijv. onderling de inhoud van een obligatoire overeenkomst bepalen - en bijgevolg afdwingbare vorderingsrechten in het leven roepen -, maar dit kan enkel omdat het objectieve recht deze mogelijkheid, binnen bepaalde grenzen, erkent.

121. Ik spreek bewust over de 'erkenning' van rechtsbelangen door het objectieve recht. Hiermee geef ik aan dat het (subjectgebonden) rechtsbelang in mijn optiek uiteindelijk is geworteld in de autonomie van de rechtssubjecten. Rechtsbelangen worden m.a.w. niet door de staatsorganisatie verleend.

122. Vgl. bijv. de objectiverende rechtsoverwegingen in ABRS 1 april 1996, JB 1996/155 m.nt. R.J.N.S. (duivenhok Velp).

123. Vgl. Van Wijmen die in zijn definitie van 'belang' dit vereiste van 'actie in rechte' incorporeert. P.C.E. van Wijmen, Recht, belang en rechtsbescherming, a.w., p. 124.

124. Bepaalde belangen kunnen naar hun aard niet worden aangemerkt als rechtsbelang. Dit kan zo zijn omdat zij uitsluitend in de sfeer van de ethiek zijn gelegen, dan wel omdat aantasting - in de regel - door het recht ongesanctioneerd blijft (denk bijv. aan typische concurrentiebelangen). Interessant is in dit verband het overzicht naar Duits recht dat Hufen geeft. Zie: F. Hufen, Verwaltungsprozeßrecht, 2. Auflage, Müchen 1996, p. 284-286. 
hieraan is het vereiste dat het rechtsbelang daadwerkelijk dient te bestaan; louter 'toekomstige' belangen kunnen mijns inziens géén subjectgebonden rechtsbelang zijn. ${ }^{125}$ In mijn optiek is tot slot essentieel dat ten aanzien van een typisch rechtsbelang, in theorie, één rechtssubject als autonome drager moet kunnen fungeren. ${ }^{126}$ Het rechtsbelang, in de door mij omschreven zin, kan zich derhalve aan individualiseerbare rechtssubjecten hechten. Belangen die van betekenis zijn voor iedereen en bijgevolg nooit aan éen rechtssubject kunnen worden toegerekend, voldoen in beginsel niet aan dit criterium. ${ }^{127}$ Hier zijn met name de ideële belangen en de algemene fundamentele rechtswaarden in het geding. Van Wijmen stelt ten aanzien van dit soort belangen: 'Niemand kan pretenderen een dergelijk belang voor zichzelf te hebben, te behartigen: het leent er zich niet voor, als exclusief behandeld te worden; het laat zich niet verbinden aan de (rechts)persoon van de aanlegger, met uitsluiting van anderen. ${ }^{128}$ Een louter ideëel belang hecht zich mijns inziens niet direct aan rechtssubjecten omdat het naar zijn aard uiteindelijk géén rechtsbelang is. ${ }^{129}$ Van belang is in dit verband dat dit soort fundamentele belangen veelal ook tot uitdrukking komen in meer concrete en erkende grond- en mensenrechten. Vele van deze laatstbedoelde rechten, die mijns inziens ruim geïnterpreteerd dienen te worden, vormen zoals nog zal blijken wél typisch subjectgebonden rechtsbelangen.

Ik merk in dit verband vervolgens op dat statutaire belangen van rechtspersonen - die van ideële aard kunnen zijn -, gelet op de geschetste kenmerken, naar mijn oordeel niet als typisch rechtsbelang kunnen worden aangemerkt. Ten aanzien van deze belangen kan in het externe rechtsverkeer immers géen rechtssubject als geïndividualiseerde drager worden aangewezen. ${ }^{130}$ Statutaire belangen vervullen weliswaar een belangrijke normatieve functie binnen de rechtsorde, maar zij verschillen naar hun rechtsaard principieel van subjectgebonden rechtsbelangen. Statutaire belangen zijn $\mathrm{nl}$. primair bepalend voor de

125. Uiteraard kunnen rechtsbelangen van 'toekomstige' generaties door het recht veilig worden gesteld, maar dit dient naar mijn mening dan te geschieden in de vorm van publiekrechtelijke belangen. De erkenning van een rechtsbelang (bijv. een mensenrecht) kan wél met zich brengen dat bij wijze van 'reflex' ook belangen van toekomstige (natuurlijke) rechtssubjecten worden beschermd (denk bijv. aan het m.i. fundamentele recht van ieder mens om in vrijheid nakomelingen te verwekken).

126. Ik zou de individualistische rechtssubjecttheorie centraal willen stellen. Zie over de verschillende rechtssubjecttheorieèn G. Radbruch, Rechtsphilosophie, funfte auflage, Stuttgart 1956, p. 232.

127. Deze eis sluit uiteraard geenszins uit dat rechtssubjecten hun rechtsbelangen collectief, in een bepaald verband, kunnen behartigen (zie voor een mooi voorbeeld: HR 2 december 1994, NJ 1996, 246, (Coopag Finance BV)). In dit kader kan dan worden gesproken over 'collectieve' rechtsbelangen.

128. P.C.E. van Wijmen, Recht, belang en rechtsbescherming, a.w., p. 229.

129. Vgl. Van Wijmen die deze belangen 'ethisch' fundeert (dit type belang verdient bescherming 'om des zelfs wille ). P.C.E. Van Wijmen, Recht, belang en rechtsbescherming, a.w., p. 227.

130. Anders bijv.: N. Frenk, Kollektieve akties in het privaatrecht, diss. UU, Deventer 1994, p. 40. Frenk is de - m.i. onjuiste - mening toegedaan dat de erkenning van een rechtspersoon als rechtssubject noodzakelijkerwijs met zich brengt dat de statutaire belangen van deze persoon moeten worden aangemerkt als eigen rechtsbelangen. De rechtsbelangen van een rechtspersoon dienen goed te worden onderscheiden van de interne (statutaire) doelstellingen van die persoon. 
doelverwezenlijking van een (private) rechtspersoon. ${ }^{131}$ Als zodanig normeren zij vanuit een intern perspectief het functioneren van de organen van die persoon en begrenzen diens activiteiten. ${ }^{132}$

Van belang is in dit verband dat de inhoud van 'statutaire' belangen concreet wordt omlijnd ingevolge intern organisatierecht van de rechtspersoon. ${ }^{133}$ Dit heeft tot gevolg dat de organen van de rechtspersoon invloed kunnen uitoefenen op de invulling van deze belangen naar hun inhoud. Reeds hierom kan men zich afvragen of dit soort 'interne' belangen op gelijke voet als typische rechtsbelangen door een rechtspersoon in rechte kunnen worden behartigd. ${ }^{134}$ In het verlengde hiervan kan men de principiële vraag stellen in hoeverre deze belangen een zelfstandige rol mogen spelen in een bestuurlijk besluiten rechtsvormingsproces (zie paragraaf 6.4.6). Ik neem in ieder geval het standpunt in dat aan deze belangen enkel in samenhang met de echte rechtsbelangen van een rechtspersoon, dan wel in samenhang met de rechtsbelangen van de rechtssubjecten die deze persoon in het leven riepen, betekenis toekomt.

Ik wijs op dat het feit de statutaire belangen van een rechtspersoon van de (externe) rechtsbelangen van deze persoon dienen te worden onderscheiden. ${ }^{135}$ Deze laatstbedoelde belangen (bijv. vermogensrechten) fungeren uiteraard (wel) als materiële rechtswaarde in het rechtsverkeer met andere subjecten. Tot slot dienen de statutaire belangen uiteraard ók van de typisch publiekrechtelijke belangen te worden onderscheiden. ${ }^{136}$

131. Daarnaast vervullen dit soort belangen naar positief Nederlands recht een functie bij de beantwoording van de vraag of een rechtspersoon kan worden aangemerkt als 'belanghebbende' in het bestuurs(proces)recht. Vgl. art. 1:2 lid 3 Awb. Een rechtspersoon met een voldoende specifiek statutair belang kan nl. als 'belanghebbende' een besluit in rechte aanvechten (zie bijv. ABRS 26 mei 1997, AB 1997, 336, m.nt. FM (crematoriumvergunning Doom)). Hieruit kan naar mijn oordeel echter geenszins worden afgeleid dat dergelijke statutaire belangen bijv. een zelfstandige rol mogen spelen in het proces van bestuurlijke belangenafweging. Veelzeggend is in dit verband het feit dat het niet is uitgesloten dat een rechtspersoon in rechte wordt ontvangen indien deze eerst $n a$ het besluit in primo is opgericht. Ik wijs op: ABRS 16 december 1996, JB 1997/23, m.nt. R.J.N.S. (bewonersorganisatie Franklin).

132. De rechtspersoon met ideële doelstellingen zal zijn standpunten zeer wel via politiek-democratische kanalen (inspraak, publicitaire pressie, betoging) kunnen uitdragen. Volgens mij is dat ook de primair aangewezen weg. Anders kennelijk: P.J. Boukema, Democratie en rechtsbescherming, NTB 1996/4, p. 144-145.

133. Dit gegeven staat m.i. op gespannen voet met het 'rechtsbelang'-begrip. Als men nl. aanvaardt dat 'interne' belangen van bijv. belangenorganisaties op gelijke voet staan met typische rechtsbelangen dan zal men naar mijn oordeel bijgevolg oók ten principale moeten aanvaarden dat een dergelijke organisatie statutaire belangen zelfstandig binnen het beschermingsbereik van bepaalde rechtsnormen kan manoeuvreren. Vgl. bijv. Frenk, Kollektieve akties in het privaatrecht, a.w., p. 57-58.

134. Naar positief Nederlands recht lijkt dit uitgangspunt inmiddels wel in belangrijke mate te zijn aanvaard. Vgl. HR 18 december 1992, NJ 1994, 139, m.nt. MS en CJHB (Kuunders) en art. 3:305a lid I BW. Vgl. in dit verband de fundamentele kritiek van J.M.H.F. Teunissen, Het burgerlijk kleed van de staat. Beschouwingen over de tweewegenleer, diss. RL, Zwolle 1996, p. 303-306.

135. Een onderscheid dat m.i. óbk de Awb-wetgever onderkende. Vgl. PG Awb I, MvT , p. 148.

136. Vgl. Tak die in dit verband een waarschuwing deed uitgaan voor het gevaar van het ontstaan van - wat hij noemt - 'surrogaat-overheden' die statutaire belangen (van algemene of ideele aard), als zouden dit echte publiekrechtelijke belangen zijn, in civilibus behartigen. A.Q.C. Tak, De overheid in het burgerlijk 


\subsubsection{Rechtsbelang en belanghebbende}

Voordat ik het begrip 'rechtsbelang' handen en voeten geef dient eerst nog iets te worden opgemerkt over het 'belanghebbende'-begrip. Voor een helder beeld van de materiële bestuurlijke besluitvorming is het van belang om dit laatstbedoelde begrip goed van het 'rechtsbelang'- begrip te onderscheiden. Het 'belanghebbende'-begrip, zoals neergelegd in artikel 1:2 lid $1 \mathrm{Awb}$, vervult nl. primair een procestechnische functie. Het begrip is binnen het Nederlandse bestuursprocesrecht bepalend voor de beantwoording van de vraag of een rechtssubject ontvangen kan worden bij de administratieve rechter. Binnen het Nederlandse stelsel van administratieve rechtsbescherming is dit 'belanghebbende'-begrip gekoppeld aan een 'recours objectif'. ${ }^{137}$ De bevoegdheid van de administratieve rechter wordt immers onder de Algemene wet bestuursrecht bepaald door het 'besluit'-begrip (artikel 1:3 lid $1 \mathrm{Awb}$ ). In beginsel verkrijgt elke 'belanghebbende', ongeacht of hij door een besluit in zijn (subjectieve) rechten is aangetast én ongeacht of zijn belangen door het bestuur zijn meegewogen in het kader van de besluitvorming, toegang tot de rechter.

Aan het vereiste van 'belanghebbendheid' wordt in het kader van het bezwaar- en beroepsrecht enkel een beperking van feitelijke aard ${ }^{138}$ gesteld om te voorkomen dat een onbepaalde kring van rechtssubjecten toegang verkrijgt tot de rechter. Het gaat hier om een kwantitatieve afbakening van de kring van bezwaar- en beroepsgerechtigden (het keren van een 'actio popularis'). Een 'belanghebbende' heeft toegang tot de rechter zodra zijn belangpositie zich in objectieve zin voldoende onderscheidt van die van andere subjecten; alleen zijn 'feitelijke' belangen dienen afdoende bij een bevoegdheidsuitoefening (besluit) te zijn betrokken. ${ }^{139}$ Onder belang kan in dit verband worden verstaan elk feitelijk gegeven dat door een besluit wordt (of kan worden) beïnvloed voorzover dit gegeven bepaalbaar, actueel, rechtstreeks én persoonlijk aan een specifiek - d.w.z. individualiseerbaar - rechtssubject is gerelateerd. ${ }^{140}$ Een door het objectieve recht inhoudelijk be-

recht, 's-Gravenhage 1997, p. 218. Dit staat op gespannen voet met de eis van (algemene) democratische legitimatie van publiekrechtelijke belangen. Natuurlijk kunnen statutaire belangen van rechtspersonen wel 'samenvallen' met publiekrechtelijke belangen (vgl. het statutaire belang van een milieuvereniging dat gedeeltelijk samenvalt met het publiekrechtelijke belang dat ten grondslag ligt aan de Wet milieubeheer).

137. Het bezwaar- en beroepstelsel ingevolge de Algemene wet bestuursrecht kan (nog steeds) in belangrijke mate als een 'recours objectif' worden aangemerkt, zij het dat het 'belanghebbende-begrip' een subjectief kenmerk vormt. Ook stelde de Awb-wetgever de rechtsbeschermingsfunctie centraal en bijgevolg de binding van de omvang van het geschil aan de inhoud van het beroepschrift (vgl. 8:69 lid 1 Awb). Tak spreekt in dit verband over een 'onmogelijke' relatie tussen (objectieve) controle en (subjectieve) rechtsbescherming. Zie: A.Q.C. Tak, Hoofdlijnen van het Nederlands bestuursprocesrecht, a.w., p. 91. Voor een meer diepgaande studie naar de verschillen tussen een 'recours subjectif' en een 'recours objectif' kan verwezen worden naar het proefschrift van Banda. Op bladzijde 158 e.v. vat hij de kenmerken samen. P.H. Banda, Administratief procesrecht in vergelijkend perspectief, Zwolle 1989, i.h.b. p. 158 en 159.

138. Vgl. H.J. Simon, Handboek bestuurs(proces)recht volgens de Awb, a.w., p. 29 en 32.

139. ABRS 27 juni 1997, JB 1997/191, m.nt. R.J.N.S. (NV Texels Eigen Stoomboot Onderneming).

140. Zie voor een beschrijving van de vereisten voor 'belanghebbendheid' o.m. A.Q.C. Tak, Hoofdlijnen van het Nederlands bestuursprocesrecht, a.w., p. $105 \mathrm{~V} / \mathrm{m} 109$. 
schermd belang is naar Nederlands bestuursprocesrecht, anders dan in een 'recours subjectif', gén voorwaarde voor toegang tot de administratieve rechter. ${ }^{141}$

Overigens zou in dit verband een andere opvatting, vanuit het perspectief van het specialiteitsbeginsel, verdedigbaar zijn geweest. Tak heeft erop gewezen dat het 'besluit'begrip in de Algemene wet bestuursrecht is gedefinieerd als een rechtshandeling. Van een besluit kan uitsluitend sprake zijn indien met de beslissing het behartigen van bepaalde belangen is beoogd. Het gaat om een gerichte handeling met bepaalde beoogde publieke rechtsgevolgen. Kenmerkend voor het publiekrecht is volgens Tak dat het specialiteitsbeginsel grenzen stelt aan de kring van belangen waarvan de behartiging (door het bestuur) 'mag worden beoogd'. Volgens hem zou daarom in theorie verdedigbaar zijn dat een beroepsrecht enkel toekomt aan de rechtssubjecten die door de beoogde - en tot hen gerichte - rechtshandeling in hun belangen worden geraakt. ${ }^{142}$

Een koppeling van de ontvankelijkheidsproblematiek aan de beperkende werking van het specialiteitsbeginsel zou dan voor de hand liggen, in die zin dat een rechtssubject uitsluitend ontvankelijk zou zijn bij de administratieve rechter voorzover de wettelijke regeling waarop het besluit is gebaseerd de gelaedeerde belangen beoogt te beschermen. ${ }^{143}$ Hiermee zou dan de 'Schutznormleer' een rol zijn gaan spelen bij de beantwoording van de ontvankelijkheidsvraag. De 'Schutznormleer' - d.w.z. het toepassen van het publiekrechtelijke specialiteitsbeginsel in het kader van de ontvankelijkheidstoets - werd in dit verband door de Awb-wetgever echter uitdrukkelijk verworpen. ${ }^{144}$

141. Vgl. op dit punt het Duitse bestuursrecht. De aanwezigheid van een 'subjektives offentliches Recht' aan de zijde van de klager vormt hier in de regel een voorwaarde voor de gang naar de administratieve rechter (vgl. de Anfechtungs- en Verpflichtungsklage). Van een dergelijk recht is (in beginsel), in ieder geval wat betreft de 'Anfechtungsklage' door derden (niet-adressaten), slechts sprake indien een dwingend publiekrechtelijk voorschrift mede het belang van een individueel rechtssubject beoogt te beschermen (Schutznormtheorie). Soms kan een dergelijk 'subjectief' recht ók rechtstreeks uit een grondrecht worden afgeleid. In hoofdstuk 9, paragraaf 9.4.3 zal ik nader aandacht besteden aan dit 'Schutznorm'-denken. Ik verwijs naar H. Maurer, Allgemeines Verwaltungsrecht, 11. Auflage, München 1997, p. 152-153; p. 156 en F. Hufen, Verwaltungsprozeßrecht, a.w., p. 289-290.

142. Vgl. A.Q.C. Tak, Hoofdlijnen van het Nederlands bestuursprocesrecht, a.w., p. 91 en 111.

143. Tak lijkt de mening te zijn toegedaan dat het specialiteitsbeginsel met zich zou kunnen brengen dat een appellant in beroep alleen gronden mag aanvoeren die een relatie hebben met het door de bijzondere wet beoogde belang. Vgl. A.Q.C. Tak, Hoofdlijnen van het Nederlands bestuursprocesrecht, a.w., p. 162. Een dergelijk standpunt heeft in de Nederlandse literatuur echter nooit op veel bijval kunnen rekenen. Door Van Buuren werd deze visie verworpen. P.J.J. van Buuren, Kringen van belanghebbenden, i.h.b. in procedures tegen de overheid, diss. RUG, Deventer 1978, p. 84. Vgl. ook de bijdrage van Dorhout aan de 'Non ex regula'-bundel (Liber amicorum Mr. J. van der Hoeven). Dorhout beantwoordt de vraag of de relativiteitsleer (Schutznormleer) bruikbaar is als 'ontvankelijkheidsdrempel' in het administratieve procesrecht negatief. L. Dorhout, Relativiteit van onrechtmatigheid, ook iets voor de administratieve rechter?, in: Non ex regula, Deventer 1985, p. 37 e.v. Vgl. echter W. Konijnenbelt, Eenkleurige belanghebbenden, NTB $1997 / 8$, p. 320-321.

144. In de Nota naar aanleiding van het Eindverslag werd door de regering nl. opgemerkt: 'Ter zake van de toepassing van het "specialiteitsbeginsel" stellen wij ons op het standpunt, dat de vraag of de belangen waarin de appellant beschermd wil worden deel uitmaken van de belangen die bij het besluit waartegen hij opkomt moeten worden afgewogen, geen rol behoort te spelen bij de beoordeling van de vraag of iemand 


\subsubsection{Een monochrome opvatting?}

Binnen het stelsel van de Algemene wet bestuursrecht werd het procestechnische 'belanghebbende'-begrip getransplanteerd naar het materiële bestuursrecht en de (non-contentieuze) bestuurlijke besluitvormingsfase. Het werd hierdoor in ons land in algemene zin bepalend voor de vraag wiens belangen zodanig bij een besluit zijn betrokken, dat daaraan bij de voorbereiding én besluitvorming een bijzondere positie moet worden toegekend. ${ }^{145}$

Volgens Van Male is bijgevolg binnen de structuur van de Algemene wet bestuursrecht het 'belanghebbende'-begrip bepalend voor de vraag wiens belangen rechtstreeks bij een besluit zijn betrokken. ${ }^{146}$ Het 'belang'-begrip dient volgens hem in dit verband analoog aan het 'belanghebbende'-begrip te worden geïnterpreteerd. Deze opvatting behoeft mijns inziens echter nuancering, daar de Algemene wet bestuursrecht méér is dan een rechtsbeschermingswet. Zij normeert immers óok de uitoefening van de (bestaande) bestuursbevoegdheden. Een 'monochrome' opvatting, zoals blijkbaar voorgestaan door Van Male, die het 'belanghebbende'-begrip beoogt te doen samenvallen met het begrip 'rechtsbelang' doet, toegespitst op de materièle bestuurlijke besluitvorming, te weinig recht aan dit laatstgenoemde begrip. De vraag welke 'belangen' in het proces van bestuurlijke belangenafweging betrokken mogen (en moeten) worden kan mijns inziens uiteindelijk niet bevredigend worden beantwoord aan de hand van een louter procestechnisch, pragmatisch, (ontvankelijkheids)begrip. ${ }^{147}$

De betekenis die aan het begrip 'rechtsbelang' toekomt binnen het proces van bestuurlijke belangenafweging dient te worden geanalyseerd tegen de achtergrond van het proces van doelgebonden concretiserende rechtsvorming door het bestuur (de bevoegdheidsuitoefening). Van belang is in dit kader dat artikel 3:4 lid $1 \mathrm{Awb}$ in de literatuur en

belanghebbende is. Voldoende voor de ontvankelijkheid is dat iemand feitelijk, voldoende onderscheiden van anderen, in een eigen persoonlijk belang wordt getroffen' (curs. R.J.N.S.). PG Awb I (NEV), p. 153. Deze visie was niet nieuw, maar sloot naadloos aan bij de interpretatie van het 'belanghebbende-begrip' in de zin van de Wet Arob. Vgl. ARRS 27 november 1976, AB 1979, 70. Zie voorts: R.M. van Male, Enkele aspecten van het begrip belanghebbende in de Algemene wet bestuursrecht, a.w., p. 75. De 'relativiteitsleer' zou volgens Van Male bovendien niet in het systeem van de Algemene wet bestuursrecht passen. Zie voor een uitdrukkelijke verwerping van de Schutznormleer: ABRS 30 januari 1997, JB 1997/114, m.nt. HJS. Vgl, ook ABRS 4 november 1997, JB 1997//285, m.nt. R.J.N.S. Zie ook: H.J. Simon, Handboek bestuurs(proces)recht volgens de Awb, a.w., p. 29.

145. Vgl. PG Awb I, MvT, p. 147.

146. R.M. van Male, Enkele aspecten van het begrip belanghebbende in de Algemene wet bestuursrecht, a.w., p. 76. Van Male gaat ervan uit dat al deze 'rechtstreeks betrokken belangen' in beginsel een rol mogen spelen bij de besluitvorming.

147. Vgl. de principiele interventie van Damen bij het preadvies van Van Male, Enkele aspecten van het begrip belanghebbende in de Algemene wet bestuursrecht, VAR-reeks 109 (verslag), Alphen aan den Rijn 1993, p. $25 \mathrm{t} / \mathrm{m}$ 28. Damen plaatste emstige vraagtekens bij de 'monochrome' benadering van Van Male. Volgens Damen dient het bestuurlijke besluitvormingsproces opgezet te worden vanuit het 'belang'-begrip. In dit verband moet er volgens hem veel meer aandacht worden besteed aan het specialiteitsbeginsel (a.w., p. 26). Opvallend mag worden genoemd dat Van Male in reactie op deze interventie gén fundamenteel verweer voerde. Hij beriep zich met name op het nogal 'procedurele' karakter van het bestuurstecht in Nederland (Verslag, a.w., p. 47.). 
in de jurisprudentie in verband wordt gebracht met het specialiteitsbeginsel. ${ }^{148}$ Aannemelijk is dan ook de veronderstelling dat het specialiteitsbeginsel naar Nederlands recht weliswaar géén functie vervult in het bestuursprocesrecht (de ontvankelijkheidstoets), maar daarentegen wél in het kader van het bestuurlijke belangenafwegingsproces.

Binnen het Nederlandse bestuurs(proces)recht bestaat bijgevolg een nogal hybride ${ }^{149}$ situatie waarbij het verkrijgen van toegang tot de administratieve rechter niet automatisch met zich brengt dat het bestuursorgaan, toegespitst op de (discretionaire) bevoegdheidsuitoefening, met de ingebrachte belangen rekening behoeft te houden. Indien de administratieve rechter vaststelt dat bepaalde (materiële) rechtsbelangen van belanghebbenden géén rol mogen spelen in de besluitvorming dan dient hij de belanghebbende wél ontvankelijk te verklaren, maar de bezwaren die betrekking hebben op de gestelde belangaantasting in zoverre ongegrond te verklaren. ${ }^{150}$ Onjuist lijkt mij in dit verband de opvatting dat alle belangen van een belanghebbende die toegang geven tot de rechter per definitie óók belangen zijn die door het bestuur ingevolge artikel 3:4 lid 1 Awb bij de materiële besluitvorming - in rechtsvormende zin - dienen te worden afgewogen.

Een belanghebbende kan, gelet op de karakteristieken van het Awb-bestuursprocesrecht, in beginse ${ }^{151}$, nadat hij is ontvangen door de rechter, een in alle opzichten rechtmatig besluit verlangen, zowel wat de wijze van totstandkoming als wat de inhoud betreft. ${ }^{152}$ De belanghebbende kan mijns inziens op grond van zijn procestechnische kwaliteit echter gén aanspraak maken op het - in materiële zin - 'rekening houden' met zijn belangen. Wél kan een belanghebbende in beroep uiteraard de vraag aan de administratieve rechter voorleggen of het bestuur terecht bepaalde (veronderstelde) rechtsbelangen buiten de besluitvorming heeft gehouden. Deze vraag zal de rechter naar mijn oordeel echter niet bevestigend of ontkennend mogen beantwoorden door simpelweg te verwijzen naar artikel

148. Art. 3:4 lid 1 Awb wordt in paragraaf 6.5.2 van dit hoofdstuk besproken.

149. Ten Berge en Tak wezen hier in 1983 reeds op. Ten Berge/Tak, Nederlands administratief procesrecht, deel 1, Zwolle 1983, p. 194. De scheiding tussen 'formeel belang' (belanghebbendheid) en '(rechts)belang' wordt in het Nederlandse bestuurs(proces)recht overigens reeds lang onderkend. Zo scheidde Van Buuren in zijn proefschrift de 'ontvankelijkheidsproblematiek' van de 'materiele besluitvorming' door het bestuur. P.J.J. van Buuren, Kringen van belanghebbenden, a.w., p. 83. Zie ook: B.W.N. de Waard, Beginselen van behoorlijke rechtspleging, a.w., p. 204-207.

150. Dit ging bijv. fout in de bekende uitspraak inzake de 'Prijzenbeschikking verblijfsrecreatiebedrijven'. ARRS 27 november 1979, tB/S IV, nr. 42 m.a. J.S. en tB/S. Zie: Steenbeek/Stroink, Wet administratieve rechtspraak overheidsbeschikkingen, vierde herziene druk, 's-Gravenhage, p. 213 en F.A.M. Stroink, Kern van de bestuursrechtspraak, 's-Gravenhage 1997, p. 94. Ik kom op deze uitspraak in hoofdstuk 8 bij de bespreking van de Arob-jurisprudentie terug.

151. In de literatuur is wel gepleit voor het hanteren van een 'congruentie-regel'. Ingevolge een dergelijke regel zou een belanghebbende alleen bezwaren mogen aanvoeren die samenhangen met zijn bijzondere belang-positie (die hem toegang tot de rechter verschafte). Zie hierover: P.J.J. van Buuren, Kringen van belanghebbenden, a.w., p. $88 \mathrm{t} / \mathrm{m}$ 90. Een dergelijke congruentie-regel kan echter niet als geldend recht worden aangemerkt.

152. Vgl. de noot van Stroink/Steenbeek onder de 'Prijzenwetuitspraak' (ARRS 27 november 1979, tB/S IV, nr. 42 m.a. tB/S). Zie ook: H.J. Simon, Handboek bestuurs(proces)recht, a.w., p. 29. 
1:2 Awb. Een nadere bezinning inzake de betrokken rechtsbelangen van de belanghebbende is in dit verband noodzakelijk (vgl. paragraaf 6.4.3).

\subsubsection{Complicaties voor de bestuurspraktijk}

In dit verband dient erop te worden gewezen dat door de procestechnische interpretatie van het 'belanghebbende'-begrip voor het bestuur in de praktijk wél een zekere druk ontstaat om alle feitelijke belangen die toegang geven tot de administratieve rechter ook maar in de bestuurlijke besluitvorming te betrekken ofschoon dit strikt genomen niet in overeenstemming is met het specialiteitsbeginsel. ${ }^{153}$ Deze problematiek mag zeker niet onderschat worden. Zo wees Schreuder-Vlasblom er - indirect - op dat met name de rechtspositie van de direct-belanghebbende niet gebaat is bij een afweging van alle betrokken (feitelijke) derde-belangen. ${ }^{154}$ Deze kan immers ten onrechte worden geconfronteerd met de 'normatieve' vertaling van dergelijke belangen door het bestuur in de vorm van beperkende voorschriften. Ook is er in de literatuur op gewezen dat het procestechnische 'belanghebbende'-begrip in het teken staat van de rechtsbescherming en door de rechter 'strategisch', en bijgevolg casuïstisch, wordt geïnterpreteerd. ${ }^{155}$ Reeds hierom biedt dit begrip géén optimale waarborg voor het inrichten van de materiële bestuurlijke besluitvorming. Hieraan kan tot slot nog worden toegevoegd dat de bestuurlijke rechtsvorming ook niet gediend is bij een 'integrale' (materiële) afweging van alle (feitelijke) belangen van belanghebbenden. De overzichtelijkheid én doelmatigheid van de besluitvorming, dreigt er onder te lijden. Binnen de bestuurlijke besluitvorming dient mijns inziens reeds hierom meer aandacht uit te gaan naar de materiële rechtsbelangen van rechtsubjecten die door een besluit (kunnen) worden getroffen.

\subsubsection{De materiële bestuurlijke besluitvorming}

Wat schieten we nu op met de voorafgaande karakterisering van het begrip 'rechtsbelang' en de onderscheiding van dit begrip ten opzichte van het 'belanghebbende'-begrip? Ik zal een en ander kort toelichten.

In de literatuur is er terecht op gewezen dat het voor de hand ligt om de bestuurlijke 'belangenafweging' op te zetten vanuit de vraagstelling met welke materiële rechtsbelangen van rechtssubjecten een bestuursorgaan rekening moet houden. ${ }^{156}$ Helaas komt de beantwoording van deze vraag onder de vigeur van de Algemene wet bestuursrecht nogal slecht uit de verf. In het (hedendaagse) Nederlandse bestuurs(proces)recht is nl. de aandacht (nog

153. Vgl. Van Wijk/KonijnenbeltVan Male, Hoofdstukken van administratief recht, a.w., p. 336.

154. M. Schreuder-Vlasblom, Herorięntatie bestuursrechtspraak, VAR-reeks 112, Alphen aan den Rijn 1994, p. 48 en 49.

155. Vgl. A.P. Klap en J.B.J.M. ten Berge, De derde als het stiefkind van het bestuursrecht, a.w., p. 76-77. Volgens deze auteurs kan dit begrip dan ook enkel fungeren als referentiepunt bij het verrichten van de bestuurlijke belangenafweging (a.w., p. 78). Vgl. wat betreft de 'kneedbaarheid' van het feitelijke 'belanghebbende'-begrip J.L. Boxum, De kneedbaarheid van de belanghebbende, in: In wederkerigheid (Scheltema-bundel), Deventer 1997, p. 85 e.v. 
steeds) te veel gefixeerd op het procestechnische 'belanghebbende'-begrip. Het 'rechtsbelang'-begrip is daardoor slechts gebrekkig geoperationaliseerd. ${ }^{157}$ De Nederlandse bestuursrechtheorie geeft bijgevolg géén helder antwoord op de vraag met welke belangen van rechtssubjecten het bestuur bij de besluitvorming in materiële zin rekening dient te houden. Een zelfstandige operationalisering van het begrip 'rechtsbelang' is naar mijn oordeel een primaire voorwaarde om het bestuurlijke rechtsvormingsproces beter te kunnen begrijpen. Tevens leidt een adequate onderscheiding tussen publiekrechtelijke belangen en subjectgebonden rechtsbelangen tot een beter begrip van de werking van het specialiteitsbeginsel.

In dit boek zal ik het begrip 'rechtsbelang' overigens niet aan een uitputtende analyse onderwerpen. Voor een goed begrip van de werking van het specialiteitsbeginsel is dit geenszins noodzakelijk. Ik wijs erop dat in het Nederlandse (bestuurs)recht reeds alle elementen aanwezig zijn om het begrip 'rechtsbelang', los van het procestechnische 'belanghebbende'-begrip, beter te operationaliseren. De typische rechtsbelangen zijn naar mijn oordeel nl. steeds te herleiden tot enerzijds subjectieve vermogenrechten (in ruime $\mathrm{zin}^{158}$ ) en anderzijds grond- en mensenrechten. De bestuurlijke rechtsvorming, op basis van een beleidsvrije bestuursbevoegdheid, dient mijns inziens tegen deze achtergrond verder te worden geoperationaliseerd; zij dient te worden opgezet vanuit enerzijds de democratisch gelegitimeerde publiekrechtelijke belangen en anderzijds vanuit de rechtstreeks betrokken materiële rechtsbelangen van rechtssubjecten. Dit standpunt zal ik in hoofdstuk 9 nader toelichten.

\subsection{Het specialiteitsbeginsel en bestuurlijke belangenafweging}

In hoofdstuk 1 van dit boek werd erop gewezen dat het specialiteitsbeginsel in de literatuur in verband wordt gebracht met de begrenzing van de bestuurlijke plicht om in het kader van een discretionaire bevoegdheidsuitoefening de (rechtsreeks) betrokken belangen af te wegen.

\subsubsection{De veronderstelde selectiefunctie}

Aangenomen wordt dat het specialiteitsbeginsel met zich brengt dat het bestuur niet alle rechtstreeks betrokken (rechts)belangen in de 'afweging' meeneemt. Indien dit wél het geval zou zijn, dan zou aan het doelgebonden karakter van bestuursbevoegdheden onvoldoende recht worden gedaan. Men zou kunnen stellen dat aan het specialiteitsbeginsel met

156. Zie: L.J.A. Damen, interventie bij het VAR-preadvies van Van Male 'De belanghebbende, enkele aspecten van het begrip belanghebbende in de Algemene wet bestuursrecht', VAR-reeks 109 (verslag), Alphen aan den Rijn 1993, p. 25 t/m 28, i.h.b. p. 26.

157. Door art. 1:2 Awb, dat op procestechnische gronden drie categorieen van 'belanghebbenden' onderscheidt, te relateren aan art. 3:4 lid 1 Awb lijken - toegespitst op de bestuurlijke belangenafweging - de typische rechtsbelangen, publiekrechtelijke belangen en statutaire belangen van rechtspersonen 'op een hoop' te worden gegooid. Dit is het ultieme gevolg van een monochroom 'belanghebbende'-begrip.

158. Ik zal aansluiting zoeken bij het 'civil rights'-begrip van art. 6 EVRM (zie: hoofdstuk 9, paragraaf 9.6.3). 
het oog op de bestuurlijke belangenafwegingsplicht een selectiefunctie wordt toebedacht. Op deze plaats is (nog) niet van belang welke belangen door de werking van het specialiteitsbeginsel van 'afweging' worden uitgezonderd, maar wél de notie dat er bepaalde belangen zijn uitgezonderd. In dit verband kan gewezen worden op de drie fundamentele regels die Donner naar aanleiding van het bekende Doetinchem-arrest formuleerde ten aanzien van de aard en omvang van de bestuurlijke belangenafwegingsplicht: ${ }^{159}$

'Aldus wordt in negatieve formulering naar de norm verwezen, dat aan iedere beslissing een afweging van alle in aanmerking komende belangen ten grondslag moet liggen, dat die belangen overeenkomstig hun aard en gewicht behoren mee te wegen en dat geen belangen, die niet in aanmerking behoren te komen, gewicht mogen hebben' (curs. R.J.N.S.).

Ter afsluiting van dit hoofdstuk zal nu nagegaan worden of, en zo ja in hoeverre, de Awbwetgever aan het specialiteitsbeginsel inderdaad een 'selecterende' rol heeft toebedacht wat betreft de omvang van de bestuurlijke belangenafweging.

\subsubsection{Artikel 3:4 lid 1 Awb en het specialiteitsbeginsel}

De Awb-wetgever heeft getracht om in artikel 3:4 lid $1 \mathrm{Awb}$ de kern van het bestuurlijke belangenafwegingsproces te codificeren. ${ }^{160}$ of deze codificatiepoging gelet op het specialiteitsbeginsel geslaagd is, mag worden betwijfeld. ${ }^{161}$ In de literatuur is erop gewezen dat deze Awb-bepaling meer vragen oproept dan ze beantwoordt. ${ }^{162}$

Allereerst is het opmerkelijk dat de problematiek inzake het specialiteitsbeginsel en de omvang van de bestuurlijke belangenafwegingsplicht in de memorie van toelichting bij artikel 3:4 lid $1 \mathrm{Awb}$ niet aan de orde komt. ${ }^{163}$ Zo wordt aan de slepende discussies in de literatuur, die op het moment van de vaststelling van de eerste tranche van de $A w b^{164}$ reeds meer dan tien jaar duurden, géén aandacht besteed. Desalniettemin wordt genoemd artikel in de literatuur ${ }^{165}$ en in de jurisprudentie ${ }^{166}$ met het specialiteitsbeginsel in verband gebracht.

De tekortkoming in de memorie van toelichting kan op een tweetal manieren worden verklaard. Ofwel de Awb-wetgever heeft de problematiek simpelweg over het hoofd gezien, ofwel een principiële discussie is bewust vermeden zodat het specialiteitsbeginsel

159. A.M. Donner, Nederlands bestuursrecht, Algemeen deel, vierde herziene druk, Alphen aan den Rijn 1974, p. 97.

160. De bepaling luidt: ' 1 . Het bestuursorgaan weegt de rechtstreeks bij het besluit betrokken belangen af, voorzover niet uit een wettelijk voorschrift of uit de aard van de uit te oefenen bevoegdheid een beperking voortvloeit.'

161. Zie reeds de fundamentele kritiek van de vakgroep publiekrecht van de Rijksuniversiteit Utrecht uit 1987. Algemene wet bestuursrecht, NJB 1987/28, p. 880.

162. Th. G. Drupsteen, En de gemeenteraad maar belangen afwegen, in: In de sfeer van administratief recht (Konijnenbelt-bundel), Utrecht 1994, p. 71.

163. Vgl. PG Awb I, MvT, p. $208 \mathrm{Vm}$ 210. Volgens Simon is in art. 3:4 Awb aan het specialiteitsbeginsel dan ook geen plaats toebedacht. H.J. Simon, Handboek bestuurs(proces)recht volgens de Awb, a.w., p. 139.

164. Wet van 4 juni 1993, Stbl. 315. Zie voor de verschillende visies in de literatuur hoofdstuk 7. 
verder in de literatuur en de jurisprudentie kon uitkristalliseren. Welke verklaring ook juist is, aangenomen moet worden dat de 'specialiteits'-problematiek wél bij de wetgever bekend was. ${ }^{167}$

Ofschoon de wetgever géen expliciete aandacht aan het specialiteitsbeginsel heeft besteed, is het toch zinvol om na te gaan of er (impliciet) uit artikel 3:4 lid 1 Awb indicaties inzake de omvang van de belangenafwegingsplicht kunnen worden afgeleid. ${ }^{168}$ In dit kader is allereerst van belang dat volgens de memorie van toelichting genoemd artikellid complementair is aan artikel 3:3 van de Awb. De memorie van toelichting stelt voorop dat waar het verbod van détournement de pouvoir ${ }^{169}$ verbiedt om een beslissingsbevoegdheid te gebruiken voor het dienen van andere doeleinden of belangen dan waarvoor de bevoegdheid geschapen is, artikel 3:4 lid 1 Awb het bestuur verplicht om, binnen de ruimte die de wet hiervoor laat, alle relevante belangen die door de te nemen beslissing zullen worden geraakt af te wegen. ${ }^{170}$ Dit artikellid codificeert derhalve enkel de (materiële) zorgvuldigheidsplicht die met zich brengt dat relevante belangen ook daadwerkelijk dienen te worden afgewogen binnen de wettelijke beslissingsruimte. ${ }^{171}$ Voor een belangenafweging bestaat volgens de wetgever alleen dan géén ruimte indien reeds uit de wet zelf de inhoud van een besluit voortvloeit, dan wel bij sterk gebonden beschikkingsbevoegdheden.

Hieruit kan worden afgeleid dat de belangenafwegingsplicht in het stelsel van de Algemene wet bestuursrecht wordt begrensd door het bevoegdheidsbeginsel. Dit beginsel wordt niet in deze wet gepositiveerd, maar wordt wél als gegeven beschouwd. De Algemene wet bestuursrecht geeft immers uniforme regels voor de uitoefening van bestaande bestuursbevoegdheden. De afwegingsplicht van artikel 3:4 lid 1 Awb kan bijgevolg nooit als een zelfstandige bevoegdheidsbasis fungeren, doch heeft slechts betekenis binnen de doelgebonden kaders van een reeds bestaande bestuursbevoegdheid. ${ }^{172}$

165. Zie bijv. W. Konijnenbelt, Het specialiteitsbeginsel in het Nederlandse en het Franse administratieve recht, NTB 1994/10, p. 309 en 310; Van Wijk/Konijnenbelt/Van Male, Hoofdstukken van administratief recht, a.w., p. 112 en H.J. Simon, De kleine revolutie: Eén jaar besturen onder de Awb I, JB 1995/2, p. 100.

166. Het specialiteitsbeginsel wordt zelden expliciet vermeld in rechterlijke uitspraken. Dit gebeurde bijv. wél in Pres. Rb. Maastricht 24 februari 1995, JB 1995/111, m.nt. R. Schlossels.

167. Door de regering werd het specialiteitsbeginsel immers als 'ontvankelijkheidsdrempel' uitdrukkelijk verworpen. Zie: PG Awb I EV en NEV, p. 152 en 153. Zie verder paragraaf 6.4.3.

168. Vgl. A.J.C. de Moor-van Vugh, Commentaar algemene wet bestuursrecht (losbladig), E 3.2.3-4/E 3.2.3-5. De Moor-van Vugt zoekt ook naar dergelijke indicaties en trekt de (voorzichtige) conclusie dat de Awbwetgever zich in de richting van de 'beleidscontexttheorie' heeft begeven. Zie over deze theorie paragraaf 7.2.4 van dit boek. Zelf ben ik op dit punt wat voorzichtiger.

169. Zie over dit verbod uitvoerig hoofdstuk 5 van dit boek.

170. PG Awb I, MvT, p. 209.

171. Vgl. in dit kader Van Buuren die erop heeft gewezen dat het niet aannemelijk is dat de Awb-wetgever door middel van art. 3:4 lid 1 Awb de betekenis van het legaliteitsbeginsel en het doelgebonden karakter van bestuursbevoegdheden heeft willen beperken zonder daarover ook maar een opmerking te maken. $P$. van Buuren, Belangen afwegen en het specialiteitsbeginsel (Awb-notities 11), NJB 1995/12, p. 460. 
Het geheel van de in de afweging te betrekken belangen wordt volgens de memorie van toelichting op twee manieren beperkt. ${ }^{173}$ Op de eerste plaats mogen alleen rechtstreeks betrokken belangen worden meegewogen. Belangen die in een (ver)verwijderd verband staan tot het te nemen besluit dienen bijgevolg buiten het afwegingsproces te blijven. Op deze wijze wordt het proces van belangenafweging enigszins 'overzichtelijk' gehouden. Een 'eliminatie' van bepaalde belangen naar hun rechtsaard wordt er niet mee beoogd.

Van groter belang in verband met het specialiteitsbeginsel is de tweede beperking. Deze kan voortvloeien uit een wettelijk voorschrift, of uit de strekking (de aard) van de uit te oefenen bestuursbevoegdheid. De memorie van toelichting stelt in dit kader uitdrukkelijk: 'Artikel 3.2.3 (het huidige artikel 3:4 Awb R.J.N.S.) verplicht complementair tot een volledige belangenafweging, waarbij echter belangen die geen rol beogen te spelen, buiten beschouwing moeten worden gelaten. ${ }^{174}$ Hiermee erkent de Awb-wetgever een belangrijk aspect van het specialiteitsbeginsel, door bepaalde belangen, vanwege hun aard, uit te sluiten van het belangenafwegings- en/of rechtsvormingsproces. De vraag of een bepaald belang een rol mag spelen is volgens de memorie van toelichting een zaak van interpretatie van de wettelijke regeling in kwestie of (bij het ontbreken van een wettelijke regeling) van de aard en de strekking van de bevoegdheid zelf. Indien de wettelijke regeling expliciet een algemeen belang noemt op grond waarvan de vergunning mag worden geweigerd, dan mogen géén andere belangen aan een dergelijke weigering ten grondslag worden gelegd. Ook indien de wettelijke regeling op dit punt onduidelijk is, kan uit de strekking van de regeling of uit de verhouding tot andere regelingen desalniettemin een beperking voortvloeien om bepaalde belangen in de afweging te betrekken. ${ }^{175}$

6. Resumerend kan worden vastgesteld dat de grenzen welke gelden voor de bestuurlijke 'belangenafweging' en rechtsvorming onder de vigeur van de Algemene wet bestuursrecht in ieder geval (mede) voortvloeien uit de aard en de (wettelijke) structuur van de bestuursbevoegdheden, en bijgevolg uit het specialiteitsbeginsel. In hoofdstuk 8 zal dit ook blijken uit de geanalyseerde jurisprudentie.

172. Vgl. in dit verband H.J. Simon, Financiële voorwaarden en voorschriften. Een blik vanuit de theorie op de praktijk, NTB 1994/6, p. 153 . Onjuist is naar mijn oordeel dan ook de visie van Konijnenbelt die betoogde dat art. 3:4 lid 1 Awb 'met één machtwoord' een einde heeft gemaakt aan de specialiteitsproblematick. Konijnenbelt lijkt hierbij over het hoofd te zien dat de omvang van de belangenafwegingsplicht steeds door een specifieke bestuursbevoegdheid wordt begrensd. W. Konijnenbelt, Het specialiteitsbeginsel in het Nederlandse en het Franse administratieve recht, a.w., p. 309. Wellicht zuiverder is de visie in Van Wijk/ Konijnenbelt/Van Male, Hoofdstukken van administratief recht, a.w., p. 333. Hier wordt art. 3:4 lid 1 Awb als een bepaling met een 'procedureel karakter' omschreven.

173. PG Awb I, MvT, p. 209.

174. PG Awb I, MvT, p. 209.

175. Dit lijkt ook te gelden voor bepaalde belangen van rechtssubjecten. In dit verband kan gewezen worden op het feit dat in de memorie van toelichting de aandacht wordt gevestigd op de (oude) Kroonjurisprudentie inzake de Hinderwet. Op grond van deze jurisprudentie mocht aan waardedalingen van onroerend goed in de omgeving van een inrichting bij het al dan niet verlenen van Hinderwetvergunningen géén betekenis worden toegekend. De juistheid van deze jurisprudentie wordt in de MvT onderschreven. PG Awb I, MvT, p. 209. 


\subsection{Conclusie}

In dit hoofdstuk werd de rechtsfiguur 'beleidsvrijheid' verkend en afgebakend ten opzichte van objectieve beoordelingsruimte en beoordelingsvrijheid. Beleidsvrijheid impliceert, naar algemeen wordt aangenomen, een plicht voor het verantwoordelijke bestuursorgaan om bij het uitoefenen van zijn bevoegdheid alle rechtstreeks betrokken (rechts)belangen daadwerkelijk af te wegen. Intussen roept deze 'belangenafwegingsplicht' vragen op. Is het wel mogelijk om publiekrechtelijke belangen 'af te wegen' tegen rechtsbelangen van rechtssubjecten? En mogen bestuurlijk-politieke oordelen, gelet op het objectieve (wettelijke) doel van een bestuursbevoegdheid, hierbij gewicht in de schaal leggen?

Vastgesteld werd dat 'belangenafweging' dient te worden uitgelegd als een plicht voor het bestuur om enerzijds speciale publiekrechtelijke belangen te behartigen en anderzijds met de betrokken rechtsbelangen van rechtssubjecten rekening te houden. Een bestuursorgaan kan - toegespitst op het publieke rechtshandelen - met 'subjectgebonden' rechtsbelangen rekening houden doordat op basis van een typische beleidsvrije bevoegdheidsnorm verschillende rechtens juiste beslissingen kunnen worden genomen. Een essentiële norm die deze keuzevrijheid normeert is het beginsel van 'minimale belangenaantasting'.

Voor een goed begrip van de materiële bestuurlijke besluitvorming is het van belang om goed te onderscheiden tussen publiekrechtelijke belangen en (subjectgebonden) rechtsbelangen. Waar de eerstgenoemde belangen het bestuurlijke rechtsvormingsproces exclusief sturen, daar dient met de laatstgenoemde belangen rekening te worden gehouden. Cruciaal is in dit verband dat het begrip 'rechtsbelang' in het bestuursrecht los van het procestechnische 'belanghebbende'-begrip dient te worden geoperationaliseerd. Hierbij werd het (voorlopige) standpunt ingenomen dat rechtsbelangen steeds herleidbaar zijn tot (subjectieve) vermogensrechten en grond- en mensenrechten. De publiekrechtelijke belangen en de intern-statutaire belangen van rechtspersonen werden, hoewel vanuit normatief oogpunt uiterst relevant, niet als typisch rechtsbelang aangemerkt.

Tot slot werd in dit hoofdstuk artikel 3:4 lid 1 Awb geanalyseerd. Dit artikel wordt in de literatuur en in de jurisprudentie in verband gebracht met het specialiteitsbeginsel. Ofschoon de wetgever aan dit beginsel geen bijzondere aandacht heeft besteed, lijkt de essentie ervan wél in genoemd artikel, gelezen in samenhang met artikel 3:3 Awb (het verbod van détournement de pouvoir), tot uitdrukking te komen. 


\section{Hoofdstuk 7}

\section{De meningen in de literatuur}

\subsection{Inleiding}

In dit hoofdstuk worden de verschillende visies besproken die in de literatuur worden aangetroffen over het bestuursrechtelijke specialiteitsbeginsel. ${ }^{1}$ Hierbij wordt als kanttekening geplaatst dat er géén literatuur wordt besproken van vóór $1976{ }^{2}$ Reden hiervoor is dat het begrip 'specialiteitsbeginsel' vóór dit tijdstip niet in de literatuur wordt aangetroffen ${ }^{3}$, terwijl de fundamentele discussies omtrent de implicaties van dit beginsel voor het proces van bestuurlijke belangenafweging eerst in de jaren tachtig en negentig van deze eeuw de volle aandacht trekken. Een en ander wil niet zeggen dat het specialiteitsbeginsel pas in de afgelopen twintig jaar betekenis heeft gekregen. Integendeel, in de voorafgaande hoofdstukken (m.n. hoofdstuk 3, 4 en 5) bleek dat het beginsel tot de fundamenten van de democratische rechtsstaat kan worden gerekend. In de literatuur heeft het beginsel echter geruime tijd een sluimerend bestaan geleid, hetgeen waarschijnlijk samenhangt met de vanzelfsprekendheid waarmee de notie van 'beperktheid' en 'doelgebondenheid' van bestuursbevoegdheid werd benaderd.

Naarmate het spanningsveld tussen de fundamenten van de democratische rechtsstaat (denk aan de 'wetmatigheid van bestuur') en de toekenning van discretionaire bevoegdheden aan het bestuur groeide, bleek er kennelijk behoefte te bestaan om aan de problematiek van de begrenzing van bestuurlijke belangenafweging aandacht te besteden. Het 'specialiteitsbeginsel' voorzag deze - overigens weinig doorzichtige - discussie in ons land van een herkenbaar etiket. ${ }^{4}$

$\mathrm{Bij}$ de beschrijving van de standpunten zal in dit hoofdstuk met name de aandacht uitgaan naar de vraag hoe de verschillende auteurs het ogenschijnlijke spanningsveld tussen het specialiteitsbeginsel en de bestuurlijke belangenafwegingsplicht (artikel 3:4 lid $1 \mathrm{Awb}$ ) benaderen. De visies zullen zoveel mogelijk in chronologische volgorde worden besproken. Op deze wijze kan wellicht een ontwikkeling in de theorievorming worden waargenomen. Als uitgangspunt is er voor gekozen om de visie(s) van één bepaalde auteur in én paragraaf te bespreken. Waar wenselijk zal in de betreffende paragraaf een kort commentaar op

1. Hoewel hierbij volledigheid is nagestreefd, worden niet alle auteurs die aandacht hebben besteed aan het specialiteitsbeginsel besproken. Enkel aan auteurs die een substantiłle bijdrage hebben geleverd aan de discussies wordt aandacht besteed.

2. Uitgezonderd een noot van Stellinga onder KB 13 juni 1973, AB 1973, 263 (zie paragraaf 7.3).

3. Waarschijnlijk is het begrip 'specialiteitsbeginsel' geintroduceerd door Van der Burg. Voorzover ik heb kunnen nagaan hanteerde hij dit begrip voor het eerst in een noot onder ARRS 30 juni 1977, AB 1977, 392.

4. De 'specialiteitsdiscussie' leidde in de Nederlandse bestuursrechtelijke literatuur, zoals Simon opmerkte, tot een kakofonie van meningen. Zie zijn noot onder ARRS 5 juni 1991, AB 1992, 444 (woonschip 'Goede verwachting'). 
de betreffende visie worden gegeven. Op basis van de inzichten die ontleend kunnen worden aan de literatuur, alsmede aan de jurisprudentie-analyse (hoofdstuk 8), zal in hoofdstuk 9 een eigen visie inzake de 'speciliateitsproblematiek' worden gegeven.

\section{2 'Preciezen', 'rekkelijken' en 'gematigden'}

In navolging van benamingen die door Helder en Jue werden geïntroduceerd, is het gebruikelijk om de auteurs die gepubliceerd hebben over het specialiteitsbeginsel in te delen in 'rekkelijken' en 'preciezen'. ${ }^{5}$ Tot de 'rekkelijke'stroming worden gerekend de auteurs die het proces van belangenafweging zo veel mogelijk 'open' willen houden. $\mathrm{Zij}$ erkennen een ruime mogelijkheid tot het meewegen van alle (rechtstreeks) bij een besluitvormingsproces betrokken belangen, voorzover de wet geen tegenindicatie bevat. De 'rekkelijke' auteurs zetten zich af tegen strikt sectorale besluitvorming waarbij - naar hun oordeel - in onvoldoende mate over de grenzen van een specifiek bevoegdhedenkader wordt gekeken. Men spreekt in dit verband wel over 'belangeneliminatie'. Zij pleiten ervoor dat een bestuursorgaan bijv. in het kader van een vergunningverlening niet alleen rekening houdt met het speciale publiekrechtelijke belang dat ten grondslag ligt aan de in het geding zijnde bestuursbevoegdheid, maar zo mogelijk ook met aanverwante publiekrechtelijke belangen.

De 'precieze' of 'orthodoxe' stroming staat juist een beperkte belangenafweging voor. In de visie van de preciezen dient de afweging 'in abstracto', zoals deze door de wetgever reeds is verricht, door een bestuursorgaan gerespecteerd te worden. De preciezen hechten bijgevolg veel waarde aan het uitgangspunt van wetmatigheid van bestuur. ${ }^{7}$ Het staatsrechtelijke legaliteitsbeginsel, en het daarmee samenhangende verbod van détournement de pouvoir, impliceren dat de mogelijkheden om met vreemde publiekrechtelijke belangen rekening te houden voor een bestuursorgaan beperkt zijn. De hoofdregel is volgens de preciezen dat een bestuursorgaan uitsluitend het speciale publiekrechtelijke belang dat ten grondslag ligt aan een bepaalde bestuursbevoegdheid in de afweging mag betrekken,

5. E. Helder en R.J. Jue, Belangenafweging in het bestuursrecht, Bestuurswetenschappen 1987/1, p. 25 e.v. VIg. ook: E.M. Messer en M.A. Heldeweg, Bestuurscompensatie en het specialiteitsbeginsel. Een beschouwing over juridische spraakverwaring, rekkelijk versus preciezen en enkele cryptische wetsartikelen, RMTh. 1990/4, p. 147 e.v.; J.E. Goldschmidt, Positieve discriminatie (staats- en bestuursrechtelijke aspecten van positieve actie), Preadvies Nederlandse Juristen Vereniging (NJV), Zwolle 1989, p. 105; S. Borger en K.F. Schuiling, De Awb getoetst door de rechter: voorbereiding van besluiten, Openbaar bestuur 1995/10, p. 25; A.P. Klap en J.B.J.M. ten Berge, De derde als stiefkind van het bestuursrecht, in: De derde in het recht, AAe (special), 1997/5, p. 78-79 en R.J.N. Schlossels, Het specialiteitsbeginsel en derde-belangen: Een frisse benadering of rechtsstatelijk drijfzand?, NTB 1996/3, p. $83 \mathrm{~V} / \mathrm{m} 85$ (paragraaf 2 'Precieze dogmatiek en rekkelijk pragmatisme'). Tot slot wijs ik op een fraaie analyse van beide hoofdstromingen waarvoor Heldeweg in 1995 tekende. Zie: M.A. Heldeweg, Het specialiteitsbeginsel: bel voor de laatste ronde?, in: Rechtspraak bestuursrecht, De annotaties, 's-Gravenhage 1995, i.h.b. p. 179 e.v.

6. Vgl. Konijnenbelt die sprak over 'orthodox' georiënteerden. Van Wijk/Konijnenbelt/Van Male, Hoofdstukken van administratief recht, negende druk, Utrecht 1994, p. 425.

7. Vgl. S. Borger en K.F. Schuiling, De Awb getoetst door de rechter: voorbereiding van besluiten, a.w., p. 25. 
waarna dit belang dient te worden afgewogen tegen de betrokken private belangen van de direct-belanghebbende. Particuliere belangen van derden worden in een precieze opvatting uitgesloten van het belangenafwegingsproces, voorzover zij niet samenvallen met het eerdergenoemde speciale publiekrechtelijke belang.

Overigens duiden de termen 'rekkelijk' en 'precies' op uitersten. Diverse auteurs nemen een gematigd standpunt in, waarbij zij vanuit een rechtspolitiek of louter pragmatisch oogpunt concessies doen aan het standpunt van de preciezen. Deze concessies zien met name op de positie van de particuliere belangen binnen het belangenafwegingsproces. Op verschillende manieren is getracht om theorievorming te ontwikkelen op basis waarvan er ruimere mogelijkheden ontstaan om met de verschillende rechtsbelangen van bijv. derden rekening te houden in situaties waarin deze niet samenvallen met de speciale publiekrechtelijke belangen die door het bestuur dienen te worden behartigd. Auteurs die een dergelijke tussenvisie hebben ontwikkeld worden wel aangeduid als de 'gematigden'.

\subsubsection{Stellinga}

Stellinga wordt in de literatuur gerekend tot de stroming van de 'preciezen'. Binnen deze stroming zou hij een extreem standpunt hebben ingenomen. ${ }^{8}$ De visie van Stellinga over 'het specialiteitsbeginsel' - een begrip dat hij zelf overigens niet hanteert - is neergelegd in diverse noten onder Koninklijke Besluiten uit de periode tussen 1972 en $1985 .{ }^{9}$ Het overgrote deel van deze Koninklijke Besluiten heeft betrekking op ontheffingen van provinciale verordeningen op het terrein van landschaps- en natuurschoon (plassen-, caravan-, ligschepen- en tentenverordeningen, alsmede verordeningen tegen landschapsontsiering).

Stellinga's notie van het specialiteitsbeginsel klinkt duidelijk door in een noot onder een Koninklijk Besluit uit $1973 .{ }^{10}$ In casu hadden burgemeester en wethouders van Oostvoorne een aanvraag om een Hinderwetvergunning ingevolge artikel 6 van de toenmalige Hinderwet niet-ontvankelijk verklaard. De aanvraag was volgens het college in strijd met het vigerende uitbreidingsplan. De Kroon vernietigde dit besluit omdat bezwaren van planologische aard bij de toepassing van de Hinderwet geen rol mochten spelen. Volgens de Kroon diende het college een aanvraag om Hinderwetvergunning uitsluitend te toetsen

8. Vgl. bijv. E.M. Messer en M.A. Heldeweg, Bestuurscompensatie en het specialiteitsbeginsel, a.w., p. $156 / 157$.

9. Zie zijn annotaties onder: KB 13 juni 1973, AB 1973, 263; KB 18 oktober 1976, AB 1977, 79; KB 5 december 1977, AB 1978, 62; KB 1 april 1977, AB 1977, 333; KB 26 oktober 1978, AB 1979, 138; KB 19 oktober 1978, AB 1979, 89; KB 24 maart 1981, AB 1981, 397; KB 25 juli 1981, AB 1982, 15 ; KB 2 februari 1982, AB 1982, 228; KB 13 mei 1982, AB 1982, 379; KB 4 juni 1982, AB 1982, 465; KB 19 mei 1982, AB 1982, 514; KB 9 juli 1982, AB 1983, 22; KB 26 januari 1983, AB 1983, 195 en KB 11 oktober 1984, AB 1985, 165.

10. KB 13 juni 1973, AB 1973, 263 m.nt. J.R. Stellinga. Zie voor een vergelijkbare casus KB 26 oktober 1978, AB 1979, 138 m.nt. J.R. Stellinga. In casu beriep het college van de gemeente Schijndel zich op de noodzaak van 'efficiënt bestuur' om een weigering van een Hinderwetvergunning wegens strijd met het bestemmingsplan te rechtvaardigen. 
aan de bepalingen van deze wet. In zijn noot onder dit Koninklijk Besluit merkt Stellinga op:

'Het is namelijk zaak bij de toepassing van administratieve wetten elke zodanige wet geheel op zichzelf te beschouwen. Op het eerste gezicht heeft dit de schijn tegen zich, maar toch is het de enige mogelijkheid. Gaat men twee of meer wetten "dooreenmengen", dan is allerlei moeilijkheid te verwachten, vooral wanneer krachtens zulke wetten ook nog beroep kan worden ingesteld, soms bij verschillende instanties.'

Ook een annotatie onder een Koninklijk Besluit van 13 mei $1982^{\prime \prime}$ bevat een vingerwijzing in de richting van het specialiteitsbeginsel: 'Anders dan bij het burgerlijk en strafrecht heeft men bij het administratief recht niet te doen met een codificatie, maar is dat recht alleen te vinden in afzonderlijke wetten of groepen van wetten. Elk dezer wetten heeft steeds een eigen grondslag, structuur, stelsel etc. Daarbij komt, dat de wettelijke regelingen hier zo omvangrijk en ingrijpend zijn, dat zij elkaar wel eens zeer dichtbij raken' (curs. R.J.N.S.).

Uit Stellinga's impliciete visie over het specialiteitsbeginsel vloeide een - op het eerste gezicht - nogal radicaal standpunt voort ten aanzien van het proces van bestuurlijke belangenafweging. Naar het oordeel van Stellinga mocht in het kader van een ontheffing ${ }^{12}$ uitsluitend gelet worden op het speciale publiekrechtelijke belang dat was neergelegd in de betreffende wettelijke regeling. Dit betekende dat aantasting van dit belang, voorzover deze aantasting niet door voorschriften kon worden ondervangen, diende te leiden tot een weigering. Uit den boze achtte Stellinga het 'meewegen' van de bijzondere belangen van de aanvrager, welke o.m. van economische, financiële of sociale aard kunnen zijn. Op grond van deze belangen mochten volgens Stellinga géén concessies aan de behartiging van het speciale publiekrechtelijke belang worden gedaan. De Kroonjurisprudentie waarin dit wel gebeurde is door Stellinga, soms in felle bewoordingen, veroordeeld. ${ }^{13}$

Het lijkt erop of Stellinga in zijn noten géén afweging tussen het speciale publiekrechtelijke belang en de particuliere belangen van de aanvrager (direct-belanghebbende) duldt. ${ }^{14}$ In een noot onder een Koninklijk Besluit van 5 december 1977 stelt hij zelfs zonder veel

11. KB 13 mei 1982, AB 1982, 379.

12. Niet duidelijk is of Stellinga t.a.v. vergunningbevoegdheden een ander standpunt huldigde. Uit zijn noot onder KB 5 december 1977, AB 1978, 62 zou kunnen worden afgeleid dat hij cen 'belangenafweging' alleen ontkent bij ontheffingsbevoegdheden (de figuur van de 'dispensatie').

13. Stellinga sprak in dit kader over 'een onjuiste belangenafweging'. Zie i.h.b. zijn noten onder: $\mathrm{KB} I$ april 1977, AB 1977, 333; KB 19 oktober 1978, AB 1979, 89; KB 24 maart 1981, AB 1981, 397 en KB 2 februari 1982, AB 1982, 228. In zijn noot onder het $\mathrm{KB}$ van 1 april 1977 laat hij zich de volgende bekende uitspraak ontvallen: 'Men stelle het zich al voor, dat bij het verlenen van een vergunning voor een kerncentrale ten nadele van de omgeving zou gerekend worden met de financiele belangen van de onderneming!'

14. Bijgevolg wordt de opvatting van Stellinga in de literatuur als achterhaald beschouwd. Zie bijv. Th. Drupsteen, En de gemeenteraad maar belangen afwegen, in: In de sfeer van administratief recht (Konijnenbeltbundel), Utrecht 1994, p. 75.; W. Konijnenbelt, Het specialiteitsbeginsel in het Nederlandse en het Franse administratieve recht, NTB 1994/10, p. 306; M.A. Heldeweg, Het specialiteitsbeginsel: bel voor de laatste ronde?, a.w., p. 182 en E. Helder en R.J. Jue, Belangenafweging in het bestuursrecht, a.w., p. 32. 
omhalen: 'Het eigen belang van degene, die om "vergunning" vraagt speelt geen rol.' En in een noot onder een Konininklijk Besluit van 11 oktober $1984^{15}$, waarin de Kroon in het kader van een ontheffing van bepalingen van een provinciale Plassenverordening rekening hield met de gezondheidsbelangen van een 71 -jarige appellant, merkte Stellinga in klare bewoordingen op:

'Deze motivering om i.c. ondanks de niet te ontkennen stoornis de ontheffing te verlenen is wel uiterst zwak. Er kunnen in het administratieve recht gevallen zijn, waarin met de belangen van bepaalde personen rekening gehouden moet worden, maar in de regel zal het algemeen belang moeten voorgaan. I.c. is dit belang het in stand houden van het zeer fraaie Loet-gebied en het weren van storende bouwsels. Daarop mag geen inbreuk gemaakt worden door het verlenen van een ontheffing aan de appellant wegens zijn uiteraard te betreuren gezondheidstoestand.'

De essentie van Stellinga's visie is naar mijn oordeel niet gelegen in het volledig ontkennen van iedere vorm van 'belangenafweging', maar in het benadrukken van de bijzondere positie die aan het speciale publiekrechtelijke belang in het kader van een discretionaire bevoegdheidsuitoefening toekomt. Volgens Stellinga dient het bestuursorgaan zich bij het proces van concretiserende rechtsvorming exclusief door dit speciale wettelijke belang te laten leiden. Dit vloeit voort uit de ambtsplicht van het betreffende bestuursorgaan. Deze plicht verzet zich tegen een 'belangenafweging' die gekarakteriseerd kan worden als "onderhandelen"16 over hetgeen een bepaald publiekrechtelijk belang in concreto eist. Indien ik de visie van Stellinga juist interpreteer, dan heeft hij uitsluitend beoogd aan te geven dat hetgeen een speciaal publiekrechtelijk belang vergt niet door het bestuursorgaan ter discussie kan worden gesteld.

\subsubsection{Tonnaer}

In zijn Utrechtse proefschrift 'Wikken en beschikken' ontwikkelde Tonnaer ${ }^{17}$ in het begin van de jaren tachtig zijn 'integraliteitsbeginsel'. Tonnaers betoog, dat o.m. een reactie is op de opvatting van Stellinga, vangt aan met een kritische beschouwing van het verschijnsel dat hij aanduidt als 'bestuurlijke belangeneliminatie'. Uitgaande van een aantal Koninklijke Besluiten inzake ontgrondingenvergunningen signaleert Tonnaer dat bepaalde openbare belangen (lees: 'publiekrechtelijke' belangen) niet in de besluitvorming worden betrokken omdat deze reeds in het kader van andere wettelijke regelingen worden beschermd. Vanuit een bestuurskundige optiek uit Tonnaer kritiek op deze 'positiefrechtelijke' praktijk die verband houdt met het specialiteitsbeginsel. Zonder dit beginsel als zodanig te noemen geeft hij er wél een globale omschrijving van:

15. KB 11 oktober 1984, AB 1985, 165.

16. Vgl. de opvatting van Heldeweg die in dit verband heeft gesproken over 'sjoemelen'. M.A. Heldeweg, Publiekrechtelijke autonomie. Over exclusieve behartiging van het algemeen belang en de wederzijdse onvrijheid van burger en overheidsbestuur, in: Eenzijdig en wederkerig?, Deventer 1995, p. 140.

17. F.P.C.L. Tonnaer, Wikken en beschikken, diss. UU, Zwolle 1982. 
'Administratiefrechtelijke regelingen beogen te voorzien in bescherming van specifieke belangen waarbij elk vakdepartement als hoeder van het zich binnen de portefeuille van iedere vakminister bevindende gedeelte van de overheidszorg opwerpt, terwijl die regelingen op bepaalde deelprocessen en -belangen zijn toegespitst en daarom eigen procedures en karakteristieken bezitten en aan eigen regels gehoorzamen. ${ }^{18}$

Op grond van een aantal overwegingen verdedigt Tonnaer vervolgens het meewegen van bepaalde openbare belangen in de bestuurlijke besluitvorming, óok indien die buiten het specifieke kader van de betreffende wettelijke regeling zijn gelegen. ${ }^{19}$

De mogelijkheid om andere openbare belangen in de afweging te betrekken vloeit volgens Tonnaer voort uit het feit dat overheidsorganen naast speciale bestuursbevoegdheden ook 'overheidsmacht' ontlenen aan de Grondwet én aan de daarop gebaseerde organieke wetgeving (bijv. de Gemeentewet en de Provinciewet).$^{20}$ De openbare belangen die behoren tot de huishouding van een publiekrechtelijk lichaam zouden in beginsel in het bestuurlijke proces van belangenafweging mogen worden betrokken. Een en ander impliceert niet dat Tonnaer géén grenzen erkent aan het belangenafwegingsproces. Deze grenzen zoekt hij in (1) de intentie van de bijzondere wettelijke regeling, (2) de verhouding tot andere regelingen en (3) de bevoegdheidstoerusting van het overheidsorgaan uit anderen hoofde dan vanuit die bijzondere regelingen. ${ }^{21}$

Op diverse plaatsen in zijn proefschrift komt Tonnaer tot stellingen over de (gewenste) omvang van het proces van belangenafweging. Zo stelt hij bijv. ten aanzien van dit proces: 'De veelheid van belangen welke bij de afweging mogen worden betrokken is recht evenredig aan de grootte van de beleidsvrijheid welke aan de beleidsvoerders wordt gelaten. ${ }^{.22}$ Enige pagina's verder merkt hij op: 'De omvang van die ruimte is recht evenredig aan de veelheid van belangen die in de afweging betrokken kunnen of mogen worden. ${ }^{23}$ Waarna hij tot de volgende slotsom komt: 'De afweging is perfect indien het met afwegen belaste of tot afwegen bevoegde bestuursorgaan in staat wordt gesteld alle voor het nemen van de beslissing relevante belangen in volledige objectiviteit in de afweging te betrekken. ${ }^{24}$

Deze uitspraken duiden er mijns inziens op dat Tonnaer moeite heeft met het uit elkaar houden van de juridische en bestuurskundige benadering van belangenafwegingsprocessen. Enerzijds lijkt hij ervan uit te gaan dat de ruimte die een bepaald bevoegdhedenkader biedt voor belangenafweging volledig benut dient te worden. Hiermee erkent hij een dergelijk bevoegdhedenkader als juridische grens. In dit verband doet het overigens vreemd aan dat

18. F.P.C.L. Tonnaer, Wikken en beschikken, a.w., p. 25 en 26.

19. Ik wijs in dit kader ook op het latere proefschrift van Backes. Backes heeft - vanuit een sectoraal/instrumenteel perspectief - eveneens een afzwakking van het specialiteitsbeginsel bepleit om waar nodig rekening te kunnen houden met ecologische en milieubelangen. $\mathrm{Ch}$. W. Backes, Juridische bescherming van ecologisch waardevolle gebieden, diss. UU, Zwolle 1993, m.n. p. 526 e.v.

20. F.P.C.L. Tonnaer, Wikken en beschikken, a.w., m.n. p. $185 \mathrm{t} / \mathrm{m} 187$.

21. F.P.C.L. Tonnaer, Wikken en beschikken, a.w., p. 35.

22. F.P.C.L. Tonnaer, Wikken en beschikken, a.w., p. 198.

23. F.P.C.L. Tonnaer, Wikken en beschikken, a.w., p. 200.

24. F.P.C.L. Tonnaer, Wikken en beschikken, a.w., p. 232. 
hij het 'mogen' meewegen in een adem noemt met het 'kunnen' meewegen. Anderzijds stelt hij zich met de bevoegdheidsgrens niet tevreden, gelet op zijn definitie van een 'perfecte' belangenafweging. Tonnaer acht een belangenafweging slechts perfect indien een bestuursorgaan ook (in bepaalde situaties) rekening kan houden met 'vreemde' openbare belangen. Hoe hij een dergelijke 'perfecte' afweging juridisch verantwoordt, blijft onduidelijk, temeer daar hij als een belangrijk grensstellend criterium voor het belangenafwegingsproces het verbod van détournement de pouvoir opvoert. ${ }^{25}$

In zijn preadvies voor de Vereniging voor Administratief Recht (VAR) ${ }^{26}$, bouwt Tonnaer voort op zijn theorie inzake het beginsel van 'materiële integraliteit'. Vanuit een 'bestuurskundige' optiek analyseert Tonnaer wederom de vraag welke openbare belangen door een bestuursorgaan in het kader van een bestuurlijk besluitvormingsproces dienen te worden meegenomen. Uitgangspunt van Tonnaer vormt de stelling dat in een proces van bestuurlijke belangenafweging, dat vooraf gaat aan een vergunningverlening, naast de belangen van de aanvrager én van derden, óók vreemde openbare belangen een rol spelen. ${ }^{27}$ Uit het betoog kan worden afgeleid dat Tonnaer niet uitsluitend een feitelijke situatie beschrijft, maar ervan uitgaat dat het bestuur ook vanuit juridische optiek met dergelijke belangen rekening mag houden. Het feit dat wettelijke regelingen het kader van vergunningbevoegdheden meestal negatief formuleren ('de vergunning wordt slechts geweigerd op grond van...') impliceert volgens Tonnaer dat vreemde openbare belangen wel degelijk - naast speciale - van belang kunnen zijn.

Tonnaer kent aan het speciale openbare belang (c.q. de speciale openbare belangen) dat (die) ten grondslag ligt (liggen) aan de betreffende bestuursbevoegdheid wél een centrale positie toe. Openbare belangen die de meest hechte band hebben met het speciale openbare belang krijgen in zijn visie a priori een waarde mee die groter is dan die van 'vreemde' openbare belangen. Vervolgens stelt Tonnaer vast dat bestuursorganen steeds geneigd zijn om in het kader van een vergunningverlening alle relevante openbare belangen, die behoren tot de huishouding van het publiekrechtelijke lichaam waartoe het orgaan behoort, in de beoordeling van een vergunning te betrekken ${ }^{28}$ Dit leidt volgens Tonnaer tot een geoorloofde vermenging van de openbare belangen die beschermd worden in een bepaald medebewindskader en alle belangen die behoren tot de autonome huishouding van de

25. F.P.C.L. Tonnaer, Wikken en beschikken, a.w., p. 171.

26. F.P.C.L. Tonnaer/Chr. Kooij, Vergunningverlening in stroomversnelling, Geschriften van de vereniging voor administratief recht XCII, Alphen aan den Rijn 1984, p. 77 e.v. (m.n. p. 106 t/m 119). Zie over dit preadvies ook: Th.G. Drupsteen, Algemene vergadering Vereniging voor Administratief Recht (verslag), NJB 1984/24, p. 724-725.

27. F.P.C.L. Tonnaet/Chr. Kooij, Vergunningverlening in stroomversnelling, a.w., p. 106. Het standpunt van Tonnaer leidde tijdens de VAR-vergadering tot pittige interventies (VAR-reeks XCII, verslag, p. 157, 177 en 178). Vgl. o.m. de visies van Nicolar, Drupsteen en Gonggrijp-van Mourik. Die kritiek spitste zich o.m. toe op de gesuggereerde afzwakking van het specialiteitsbeginsel. Breed werd de opvatting gedragen dat een vergunning enkel op grond van specifiek-wettelijke belangen mag worden geweigerd. De visie van Stroink bespreek ik in paragraaf 7.2 .3 afzonderlijk.

28. F.P.C.L. Tonnaer/Chr. Kooij, Vergunningverlening in stroomversnelling, a.w., p. 109. 
rechtspersoon waartoe het orgaan behoort. ${ }^{29}$ De verwezenlijking van een dergelijk besluitvormingsproces, brengt Tonnaer in verband met het beginsel van 'materiele integraliteit':

\footnotetext{
'Het beginsel van materiêle integraliteit komt bij de vergunningverlening erop neer dat in elke afweging impliciet wordt rekening gehouden met de verschillende belangen waarvan het bestuursorgaan vindt dat ze tot de huishouding van het openbaar lichaam behoren' (curs. R.J.N.S.).
}

Ik kan hier niets anders in lezen dan dat Tonnaer het specialiteitsbeginsel ter zijde schuift. Dubieus acht ik bovendien de 'subjectivering' die in deze definitie besloten ligt: een bestuursorgaan kan in beginsel immers - binnen marges - zelf bepalen wat tot de huishouding van het betreffende lichaam wordt gerekend.

De verwezenlijking van het 'integraliteitsbeginsel' leidt volgens Tonnaer tot een kwalitatief betere besluitvorming. Hij vergelijkt de werking van dit beginsel met een hologram: het totaalbeeld is steeds aanwezig, maar er lichten steeds andere facetten op. Overigens ziet Tonnaer het integraliteitsbeginsel niet als een absoluut beginsel. Beperkingen vloeien volgens hem o.m. voort uit:

- de decentralisatie van het bestuur (beleidsdoelstellingen worden vaak op verschillende overheidsniveau's - binnen verschillende huishoudingen - behartigd);

- specialiteit van administratieve wetgeving (Tonnaer voert het specialiteitsbeginsel bijgevolg op als een beginsel dat inbreuk kan maken op het algemenere 'integraliteitsbeginsel');

- planmatigheid van het beleid (hoe hij in het plan een beperking ziet voor de belangenafweging is niet geheel duidelijk. Deze kan gelegen zijn in het sectorale karakter van een bepaald plan);

- functionaliteit van het bestuur (diverse bestuursbevoegdheden worden door functionele lichamen of zelfstandige bestuursorganen uitgeoefend. Het integraliteitsbeginsel komt hierdoor niet volledig tot zijn recht).

Volgens Tonnaer zelf - en dit mag mijns inziens opmerkelijk worden genoemd - bestaat er géén spanning tussen het integraliteitsbeginsel en het specialiteitsbeginsel. ${ }^{30} \mathrm{De}$ onderbouwing van deze stelling is nogal cryptisch. Lees ik het goed, dan stelt Tonnaer dat bij 'integraal' bestuur niet in strijd met het specialiteitsbeginsel wordt gehandeld zolang voldoende recht wordt gedaan aan de betrokken specifieke openbare belangen.

\subsubsection{Stroink en De Waard}

In hun bijdrage aan de Steenbeek-bundel nemen Stroink en De Waard ${ }^{31}$ een precies standpunt in ten aanzien van het specialiteitsbeginsel. Van belang is dat deze auteurs het

29. Deze opvatting is door Stroink en De Waard overigens bestreden. Zie: F.A.M. Stroink en B.W.N. De waard, Het specialiteitsbeginsel, in: Burger en overheid (Steenbeek-bundel), 's-Gravenhage 1984, p. 248 (zie paragraaf 7.2.3 van dit hoofdstuk).

30. F.P.C.L. Tonnaer/Chr. Kooij, Vergunningverlening in stroomversnelling, a.w., p. 113. 
specialiteitsbeginsel in een duidelijke rechtsstatelijke context plaatsen. Uitgangspunt dient volgens hen te zijn het gegeven dat bestuursbevoegdheden in een rechtsstaat steeds (naar doel) beperkt zijn. De wetgever dient de grenzen van een bestuursbevoegdheid aan te geven. Het wettelijke kader begrenst bijgevolg het door het bestuur te volvoeren proces van belangenafweging.

De auteurs zijn van mening dat handelen in strijd met het specialiteitsbeginsel zich voordoet in situaties waarin een bestuursorgaan wél een bevoegdheid bezit, maar hiervan een onjuist gebruik maakt. ${ }^{32}$ Schending van het specialiteitsbeginsel leidt snel tot détournement de pouvoir. Als - voorlopig - antwoord op de vraag welke belangen een bestuursorgaan wél, en welke het niet mag meewegen bij de uitoefening van een bestuursbevoegdheid stellen Stroink en De Waard:

'...dat aspect van het algemeen belang dat (of: die aspecten ... die) de betreffende regeling beoogt te beschermen, tegenover de belangen van de aanvrager; een en ander voorzover de wet niet anders bepaalt. ${ }^{33}$

De auteurs stellen in beginsel géén beperkingen aan het meewegen van de particuliere belangen van de betrokken direct-belanghebbende (de aanvrager). Het uitoefenen van een vergunningbevoegdheid is er immers op gericht om tot een beoordeling in concreto te komen.

Stroink en De Waard maken in het kader van de belangenafweging een onderscheid tussen een 'negatieve' en 'positieve' beslissing. Een negatieve beslissing mag uitsluitend zijn grondslag vinden in het speciale algemene (lees: publiekrechtelijke) belang dat ten grondslag ligt aan een bestuursbevoegdheid, terwijl bij een positieve beslissing óók met de belangen van de aanvrager rekening dient te worden gehouden. Deze laatstbedoelde belangen kunnen daarom steeds een rol spelen: '...de beschikking moet altijd berusten op een afweging van de speciale (in de betreffende regeling beschermde) belangen tegen die (alle) belangen van de aanvrager'. ${ }^{34}$

Een andere vraag is of er in een concreet geval veel ruimte bestaat om met de betrokken belangen van de aanvrager daadwerkelijk rekening te houden. Naarmate een bepaald publiekrechtelijk (deel)belang, dat ten grondslag ligt aan een bestuursbevoegdheid, zwaarder weegt en naarmate dit belang nauwkeuriger naar objectieve maatstaven bepaalbaar is, zal de ruimte voor het rekening houden met de belangen van de directbelanghebbende afnemen. Zo zijn er volgens Stroink en De Waard situaties denkbaar waarin de belangen van de aanvrager géen, of bijna geen invloed kunnen hebben op de besluitvorming. Ter illustratie bespreken zij in dit kader een door Stellinga genoemd

31. Stroink/De Waard, Het specialiteitsbeginsel, a.w., p. 231 e.v.

32. Stroink/De Waard, Het specialiteitsbeginsel, a.w., p. 235.

33. Stroink/De Waard, Het specialiteitsbeginsel, a.w., p. 236. Dit standpunt klinkt ook door in het werk 'Nieuw bestuursprocesrecht', waaraan Stroink en De Waard meewerkten. Nieuw bestuursprocesrecht, onder redactie van J.B.J.M. ten Berge e.a., Nijmegen 1994, p. 118.

34. Stroink/De Waard, Het specialiteitsbeginsel, a.w., p. 238. 
voorbeeld met betrekking tot een vergunning ten behoeve van een kerncentrale. ${ }^{35}$ Ook in een dergelijke situatie waarin het speciale publiekrechtelijke belang vrij nauwkeurig bepaalbaar is, kunnen de belangen van de aanvrager echter een rol spelen ofschoon de ruimte om met deze belangen rekening te houden klein zal zijn. ${ }^{36}$

Stroink en De Waard achten - zo blijkt uit de strekking van hun betoog - steeds een beperking aanwezig ten aanzien van het meewegen van particuliere belangen van derden. Vaak gaat het hier nl. om belangen die in een ander wettelijk afwegingskader thuishoren. Daarom is het steeds van belang de positie van een publiekrechtelijke regeling in relatie tot andere regelingen te analyseren. Deze andere wettelijke regelingen kunnen tot gevolg hebben dat het afwegingskader van een bepaalde bevoegdheid - hoewel ruim geformuleerd impliciet wordt beperkt. ${ }^{37}$ Stroink en De Waard stellen dat als uitgangspunt kan gelden, dat zoveel mogelijk getracht moet worden om te voorkomen dat bij het geven van beschikkingen een interferentie van regelingen ontstaat door vermenging van belangen. Ter onderbouwing van dit standpunt beroepen zij zich niet alleen op het rechtsstatelijke aspect van het specialiteitsbeginsel, maar ook op het 'efficiency'-aspect, het rechtsbeschermingsaspect en het rechtszekerheidsbeginsel. ${ }^{38}$ Dubbele afweging van bepaalde belangen dient te worden voorkomen, terwijl eenmaal afgewogen belangen in een andere procedure niet meer ter discussie behoren te worden gesteld. Om dit resultaat te bereiken stellen de auteurs zich op het volgende standpunt:

'Terugkerend op het specialiteitsbeginsel kan in ieder geval als hoofdregel worden aangemerkt, dat belangen, die hun uitdrukkelijke bescherming hebben gevonden in een andere wettelijke regeling niet mogen worden meegewogen. ${ }^{39}$

In hun opstel bestrijden Stroink en De Waard de opvatting van Tonnaer inzake het meewegen van alle belangen die tot de huishouding van een publiekrechtelijk lichaam behoren. Deze opvatting van Tonnaer berust volgens hen op een 'fundamenteel misverstand' ${ }^{40}$ Een bestuursorgaan dat een specifieke (medebewindsbevoegdheid) bezit dient deze bevoegdheid uit te oefenen met het oog op de aan die bevoegdheid ten grondslag liggende publiekrechtelijke belangen. Zonder een bijzondere (autonome) aanvullende bevoegdheidsregeling mag het orgaan géén rekening houden met de belangen die tot de gehele huishouding van het betreffende lichaam behoren. Zou dit wél toelaatbaar zijn, dan zou dit een ongebreidelde bevoegdheidstoeneming impliceren van dat orgaan.

In vervolg op de bijdrage aan de Steenbeek-bundel intervenieerde Stroink tijdens de VAR-vergadering van 12 april 1984 bij de behandeling van het eerder besproken preadvies

35. Zie Stellinga's noot onder: KB 1 april 1977, AB 1977, 333.

36. Stroink/De Waard, Het specialiteitsbeginsel, a.w., p. 239.

37. Stroink/De Waard, Het specialiteitsbeginsel, a.w., p. 244.

38. Stroink/De Waard, Het specialiteitsbeginsel, a.w., p. 244 en 245.

39. Stroink/De Waard, Het specialiteitsbeginsel, a.w., p. 245.

40. Stroink/De Waard, Het specialiteitsbeginsel, a.w., p. 248. 
van Tonnaer. Stroink distantieerde zich in dit kader van Tonnaers visie inzake het specialiteitsbeginsel. Over dit beginsel merkte Stroink op:

'Ik ken daaraan een absoluter karakter toe dan Tonnaer. Het beginsel is een operationalisering van de rechtsstaatgedachte en houdt in dat een overheidsbevoegdheid per definitie beperkt is en alleen mag worden uitgeoefend om bepaalde doeleinden te bereiken. ${ }^{, 4}$

Het meningsverschil met Tonnaer spitste zich in het bijzonder toe op de vraag welke publiekrechtelijke belangen in de afweging dienen te worden meegewogen. Stroink bestreed de theorie van Tonnaer die ervan uitgaat dat alle openbare belangen, die binnen de autonome sfeer van een lichaam vallen, in de afweging mogen worden betrokken. Stroink stelde hiertoe de rechtsstatelijke bevoegdheidsleer centraal:

\begin{abstract}
'Samenvattend kan ik mijn standpunt als volgt formuleren. Ik hecht waarde aan de benadering van het specialiteitsbeginsel, ook al omdat het waarborgen inhoudt. Het voorkomt dat de bestuurlijke overheden zich, zoals vroeger in de politiestaat, met alles kunnen gaan bezighouden en het geeft de burger de waarborg dat dat niet zomaar zal gebeuren., ${ }^{42}$
\end{abstract}

Ook in latere publicaties hebben zowel Stroink als De Waard mijns inziens blijk gegeven van een 'precieze' visie inzake het specialiteitsbeginsel. ${ }^{43}$

\title{
7.2.4 Helder en Jue
}

In hun opstel 'Belangenafweging in het bestuursrecht' nemen Helder en Jue in $1987^{44}$ de draad van de specialiteitsdiscussie weer op en trachten een nieuwe visie te ontwikkelen inzake de omvang van het proces van bestuurlijke belangenafweging. $\mathrm{Zij}$ beogen een antwoord te geven op de vraag welke (materiële) rechtsbelangen wél, en welke niet door een bestuursorgaan mogen worden meegewogen in een besluitvormingsproces. In hun visie staat het begrip 'beleidscontext' centraal. Allereerst constateren de auteurs dat de dogmatiek verdeeld is over de belangenafwegingskwestie. Deze verdeeldheid trachten zij te

41. Interventie bij het preadvies van Tonnaer. F.P.C.L. Tonnaer/Chr. Kooij, Vergunningverlening in stroomversnelling a.w. (verslag), p. 150.

42. Interventie bij het preadvies van Tonnaer. F.P.C.L. Tonnaer/Chr. Kooij, Vergunningverlening in stroomversnelling, Geschriften voor de vereniging voor administratief recht XCII, Alphen aan den Rijn 1984 (verslag), p. 151.

43. Stroink heeft er in 1995 blijk van gegeven op rechtsstatelijke gronden aan zijn precieze visie inzake het specialiteitsbeginsel vast te houden. Zie: F.A.M. Stroink, Reflecties op verschillende bevoegdheden, in: Recht in het water. De juridische aspecten van watersnood, Antwerpen/Apeldoorn 1995, p. $123 \mathrm{Vm} 125$. $\mathrm{Hij}$ merkte in dit verband $0 . \mathrm{m}$. op: 'Het specialiteitsbeginsel geeft een belangrijke waarborg voor de vrijheid van de burger. Zou dit beginsel losgelaten worden en zou de overheid in principe altijd bevoegd zijn alle belangen af te wegen dan zouden wij al gauw in een totalitaire maatschappij terecht komen. Ik ben het dan ook niet eens met schrijvers die het specialiteitsbeginsel willen versoepelen of zelfs verlaten.' (a.w., p. 124). Voor een meer recente beschouwing van De Waard over het specialiteitsbeginsel verwijs ik naar zijn aantekening onder ABRS 10 mei 1995, RAwb 1995, nr. 72 (telefooncel Buttervliet).

44. E. Helder en R.J. Jue, Belangenafweging in het bestuursrecht, Bestuurswetenschappen 1987/1, p. 25 e.v. 
relativeren door te stellen dat 'preciezen' en 'rekkelijken' op verschillende fronten strijden. Tonnaer c.s. zouden hun aandacht met name richten op de mee te wegen openbare belangen, terwijl Stroink c.s. met name aandacht zouden hebben voor de positie van bepaalde particuliere belangen (derden).

Helder en Jue zijn van mening dan beide stromingen een wetgevings- en een beschikkingsprobleem verwarren. De wetgever zal nooit in staat zijn om exact aan te geven welke belangen in een besluitvormingsproces een rol mogen spelen, zodat het bestuur steeds aanvullend moet opereren. Het specialiteitsbeginsel is dan ook met name een rechtsstatelijk beginsel dat zich richt tot de wetgever en het kan niet worden aangemerkt als een beginsel van behoorlijk bestuur dat direct toepasbaar is op een beschikkingshandeling. Helder en Jue stellen in dit verband voorop dat het vraagstuk van de belangenafweging niet zwart-wit benaderd dient te worden: '...naar onze mening gaat het bij nauwkeurige beschouwing vooral ook om de vraag op welke wijze en in welke mate aan bepaalde belangen enig gewicht kan worden toegekend' ${ }^{45}$ Gelet op dit uitgangspunt ontwikkelen de auteurs hun 'beleidscontext'-theorie. Onder 'beleidscontext' verstaan zij:

'De met de wettelijke doelstelling verbonden ruimte voor belangenafweging, waarbinnen rechtmatig kan worden beschikt. De beleidscontext bestaat uit de optelsom van aan de ene kant de wettelijke doelstelling(en) en de vertaling daarvan in de wettelijke en bestuurlijke beslisregels plus aan de andere kant de daarmee verbonden openbare belangen en belangen van burgers. ${ }^{, 46}$

Het verbod van détournement de pouvoir interpreteren zij in het verlengde van deze definitie als 'het beschikken buiten de beleidscontext'. Centraal binnen de 'beleidscontext' staan de wettelijke doelstellingen; deze domineren de context. Helder en Jue analyseren nu de positie van een drietal belangen-groepen: (1) de particuliere belangen, die binnen de beleidscontext vallen. Welke dit zijn wordt niet nader uitgewerkt; naar men mag aannemen zijn dit in ieder geval alle belangen van de aanvrager alsmede belangen van derden, voorzover deze gerelateerd zijn aan de wettelijke doelstellingen. (2) de elders wettelijk geregelde of vastgelegde beleidsdoelstellingen (d.w.z. de zgn. vreemde publiekrechtelijke belangen), en (3) de aan de beleidscontext geheel vreemde 'andere' belangen.

Particuliere belangen dienen volgens Helder en Jue te worden meegewogen, doch zij mogen binnen de 'beleidscontext' nooit ten principale als doelstelling gaan fungeren. $\mathrm{Zij}$ dienen steeds ondergeschikt te zijn aan de wettelijke doelstelling die centraal staat. Een vergunning kan daarom niet uitsluitend worden verleend of geweigerd op grond van particuliere belangen. Evenmin mogen voorschriften worden gesteld die alleen deze particuliere belangen beogen te dienen.

Voor een bestuursorgaan is het vervolgens niet zonder meer ongeoorloofd om een blik te werpen op beleidsdoelstellingen die bescherming hebben gevonden in andere wettelijke regelingen. Vreemde beleidsdoelstellingen dienen echter primair binnen hun eigen kader te

45. Helder/Jue, Belangenafweging in het bestuursrecht, a.w., p. 34.

46. Helder/Jue, Belangenafweging in het bestuursrecht, a.w., p. 35. 
worden verwezenlijkt en mogen niet in een ander kader worden gedupliceerd. Evenmin mag een vreemde beleidsdoelstelling getransformeerd worden tot een zelfstandige doelstelling. Dit zou misbruik van bevoegdheid opleveren. Aan de 'beleidscontext' geheel vreemde belangen vallen in ieder geval buiten de boot, indien het meewegen het genereren van een zelfstandige beleidscontext impliceert.

De theorie van Helder en Jue zoekt het antwoord op de vraag naar de omvang van de belangenafweging niet in juridisch-dogmatische criteria, maar in de eisen van de praktijk. De 'beleidscontext'-theorie biedt mijns inziens géen helder antwoord op de vraag in hoeverre vanuit juridisch oogpunt grenzen aan het proces van bestuurlijke belangenafweging dienen te worden gesteld. De oplossing die door Helder en Jue wordt aangedragen gaat sterk uit van de omstandigheden van het geval, en is naar mijn oordeel primair bestuurskundig van aard. Vanuit juridisch oogpunt biedt zij (te) weinig houvast. ${ }^{47}$

\subsubsection{Vakgroep staats- en bestuursrecht UU}

Vanaf 1987 belanden de discussies over het specialiteitsbeginsel in een stroomversnelling. Een verklaring hiervoor kan gevonden worden in de totstandkoming van de Algemene wet bestuursrecht (eerste tranche), waarin o.m. bepalingen worden opgenomen inzake het proces van bestuurlijke belangenafweging. ${ }^{48}$

In een commentaar op het voorontwerp van de eerste tranche oefende de vakgroep staats- en bestuursrecht van de Rijksuniversiteit Utrecht in 1987 principiële kritiek uit op de redactie van het huidige artikel 3:4 lid 1 Awb (artikel 3.2.3 lid 1 Voorontwerp). ${ }^{49}$ In dit artikellid heeft de Awb-wetgever de hoofdregel van het proces van bestuurlijke belangenafweging willen codificeren (de belangenafwegingsplicht). Volgens de vakgroep doet de formulering van genoemd lid het specialiteitsbeginsel tekort. De auteurs spreken het vermoeden uit dat de Commissie wetgeving algemene regels van bestuursrecht onder voorzitterschap van Scheltema het specialiteitsbeginsel (en de betekenis daarvan) onvoldoende heeft onderkend. $\mathrm{Zij}$ benadrukken expliciet dat een bevoegdheid van het openbaar bestuur altijd beperkt is.

De visie van de vakgroep sluit aan bij de opvattingen van Stroink en De Waard. Van belang is dat door de vakgroep een duidelijk verband werd gelegd tussen artikel 3:4 lid 1 Awb en het specialiteitsbeginsel. Dit verband is door de Awb-wetgever kennelijk onvoldoende onderkend, hetgeen ondermeer blijkt uit het feit dat in de memorie van toelichting bij dit artikel geen enkele beschouwing aan het specialiteitsbeginsel is gewijd. ${ }^{50}$ Van

47. Vgl. de opmerkingen van Drupsteen die het begrip 'beleidscontext' niet erg scherp acht. Th. G. Drupsteen, En de gemeenteraad maar belangen afwegen, a.w., p. 77.

48. Vgl. afdeling 3:2 'zorgvuldigheid en belangenafweging'.

49. Vakgroep staats- en bestuursrecht UU, Algemene wet bestuursrecht, NJB 1987/28, p. 880. Voor de tekst van deze bijdrage tekenden J.B.J.M. ten Berge, C.J.A. Crasborn, G.F.M. Grotendorst, M.J. Sluijs, R.F.R.M. Sommer, B.W.N. de Waard en R.J.G.M. Widdershoven.

50. Zie: PG Awb I, MvT, p. $208 \mathrm{t} / \mathrm{m}$ 211.Ik verwijs naar de beschouwingen in hoofdstuk 6 van dit boek, waar art. 3:4 lid 1 Awb is geanalyseerd. Zie ook: R.J.N. Schlossels, Het specialiteitsbeginsel en derde-belangen: Een frisse benadering of rechtsstatelijk drijfzand, NTB 1996/3, p. 85/86. 
belang is voorts dat de Utrechtse vakgroep steeds een beperking aanwezig acht ten aanzien van het meewegen van belangen van derden. Deze opvatting, die later door Simon in een reactie $^{51}$ is bestreden, werd door de vakgroep geëxpliciteerd in een naschrift. In dit naschrift vestigden Crasborn en De Waard namens de auteurs er de aandacht op dat derdebelangen in de regel 'veralgemeniseerbaar' zijn. Concrete belangen van derden manifesteren zich vaak als een aspect van een bepaald algemeen (lees: publiekrechtelijk) belang. Crasborn en De Waard delen de visie van Simon dan ook niet voorzover deze het zonder meer toelaatbaar acht dat derde-belangen aanleiding kunnen geven tot het stellen van voorschriften, dan wel een weigering kunnen rechtvaardigen. Uit het betoog van beide auteurs kan worden afgeleid dat dit slechts zo kan zijn indien deze derde-belangen samenvallen met het speciale publiekrechtelijke belang dat de betreffende wettelijke regeling beoogt te beschermen.

\subsubsection{Simon}

Simon heeft sinds 1987 in vele publicaties aandacht besteed aan het specialiteitsbeginsel. $^{52} \mathrm{Hij}$ is een van de weinige auteurs die diverse aspecten van dit beginsel heeft belicht. Simon analyseerde het specialiteitsbeginsel als beginsel van behoorlijke wetgeving en bracht in dit verband de relaties tussen het specialiteitsbeginsel en de 'rule of law' - zoals neergelegd in het Europees Verdrag tot bescherming van de Rechten van de Mens (EVRM) - in kaart. Tevens besteedde hij aandacht aan de relaties tussen het specialiteitsen democratiebeginsel. ${ }^{53}$ Voordat ik Simons standpunten over de (omvang) van de bestuurlijke belangenafwegingsplicht en het specialiteitsbeginsel schets, is het zinvol om in vogelvlucht enige opmerkingen te maken over zijn theoretische - rechtseconomische denkraam.

Volgens Simon komt aan de overheid, die hij plaatst in de principiële rol van maximalisator van maatschappelijk nut ${ }^{54}$, slechts in een tweetal situaties een rechtsgrond toe om (rechts)handelend op te treden..$^{55}$ De overheid reageert in de eerste plaats naar aanleiding van materiële (vrijheids)tekorten in de maatschappelijke rechtsrelaties tussen burgers

51. H.J. Simon, Algemene wet bestuursrecht (reactie), NJB 1987/43, p. 1392. De opvatting van Simon komt uitvoerig in de volgende paragraaf aan bod.

52. Simon heeft zijn denkbeelden over het specialiteitsbeginsel o.m. uiteengezet in een aantal noten onder: VZARRS 27 mei 1986, AB 1987, 267; VzARRS 26 februari 1990, AB 1991, 566; VzARRS 2 juli 1990, AB 1991, 278 (tB/S 1990, 72); Rb. Amsterdam, 15 maart 1990, AB 1991, 58; VzARRS 30 augustus 1990, AB 1991, 567; ARRS 5 juni 1991, AB 1992, 444. Zie verder zijn proefschrift: H.J. Simon, Publiekrecht of privaatrecht?, diss. VU, Zwolle 1993, p. 119 e.v, 127 e.v. en 271 e.v. Zie voorts: H.J. Simon, Algemene wet bestuursrecht (reactie), NJB 1987/43, p. 1392; H.J. Simon, Financiele voorwaarden en voorschriften, NTB 94/6, p. 149 e.v.; H.J. Simon, Het 'nieuwe vreemdelingenrecht'. Een analyse vanuit het algemene staats- en bestuursrecht, Sociaal Recht 1994/3, p. 72 en H.J. Simon, Handboek bestuurs(proces)recht volgens de Awb, 's-Gravenhage 1997, p. 139-141.

53. Ik verwijs naar hoofdstuk 3 van dit boek waar op verschillende plaatsen aandacht is besteed aan Simons visie over het specialiteitsbeginsel.

54. H.J. Simon, Publiekrecht of privaatrecht?, a.w., p. 51.

55. H.J. Simon, Publiekrecht of privaatrecht?, a.w., o.a. p. 110 e.v. 
onderling; d.w.z. naar aanleiding van tekorten binnen - wat Simon aanduidt - als het 'meta-privaatrecht'. ${ }^{56} \mathrm{De}$ overheid heeft in dit verband een dienende functie. Haar handelen behoort gericht te zijn op nutsmaximalisatie in die zin dat door interventies de materiële vrijheid van rechtssubjecten wordt gemaximaliseerd. Voor overheidsinterventie is, bezien vanuit het 'meta-privaatrecht', alleen plaats indien er aan het noodzakelijkheidsvereiste is voldaan. ${ }^{57}$ Vast moet staan dát er een meta-privaatrechtelijk tekort is, zodat de rechtsgrond voor het overheidshandelen op dit tekort kan worden gefundeerd. Voorts dient vast te staan dat de overheid het meest is aangewezen om het betreffende tekort op te heffen. ${ }^{58}$

Van belang is nu, dat volgens Simon overheidsinterventies die hun rechtsgrond vinden in een meta-privaatrechtelijk tekort in principe zijn gericht op het handhaven van de wederkerige autonomie tussen rechtssubjecten in horizontale rechtsrelaties. ${ }^{59}$ Dit inzicht is essentieel daar hieruit voortvloeit dat de inhoudelijke normen voor deze interventies primair worden aangereikt door het meta-privaatrecht. Het '(meta)'-publiekrecht staat hierbij enkel garant voor de vormgeving en sanctionering van een overheidsinterventie, die slechts tot doel kan hebben de (private) automie - binnen de grenzen van een gegeven verdeling van nutswaarden - te realiseren. Kenmerkend voor nutsmaximalisatieprocessen naar aanleiding van 'meta-privaatrechtelijke' tekorten is nu dat deze zich vaak voltrekken binnen een typische 'driehoeksrelatie' tussen overheid, direct-belanghebbende en derden. ${ }^{60}$ Zoals hierna zal blijken fundeert Simon op deze conceptie een ruime plicht voor het bestuur om rechtsbelangen van rechtssubjecten in de besluitvorming te betrekken.

Een rechtsgrond voor overheidshandelen kan volgens Simon echter niet enkel in een 'meta-privaatrechtelijk tekort' worden gefundeerd, maar soms ook direct in het 'meta-publiekrecht'. Een 'meta-publiekrechtelijke' rechtsgrond voor overheidshandelen is aanwezig indien autonomietekorten van rechtssubjecten door de overheid worden opgeheven boven het niveau waartoe het meta-privaatrecht mogelijkheden biedt. In dit verband kan bijv. gedacht worden aan de noodzakelijke zorg voor boven-individuele belangen en de herverdeling van inkomsten voortvloeiend uit de gegeven verdeling van nutswaarden. Inherent hieraan is óók de verzorging en de instandhouding van het overheidsapparaat

56. H.J. Simon, Publiekrecht of privaatrecht?, a.w., p. 92/93. Van een 'meta-privaatrechtelijk' tekort is volgens Simon sprake indien horizontale (rechts)relaties bezien vanuit de doelstelling van de samenleving (nl. de maximalisering van maatschappelijk nut) structureel niet tot nutsmaximale uitkomsten leiden. De overheid behoort hier dan volgens Simon 'corrigerend' op te treden. Van belang is overigens om erop te wijzen dat 'horizontale' rechtsrelaties tussen private rechtssubjecten onderling worden vermoed nutsmaximaliserend te zijn (zie bijv. a.w., p. 117 en 173). Zie voor de door Simon gehanteerde analyseniveau's (meta, meso en micro) a.w. p. 84.

57. H.J. Simon, Publiekrecht of privaatrecht?, a.w., p. 117.

58. H.J. Simon, Publiekrecht of privaatrecht?, a.w., p. 110.

59. H.J. Simon, Publiekrecht of privaatrecht?, a.w., p. 150.

60. H.J. Simon, Publiekrecht of privaatrecht?, a.w., p. 149. Vgl. over deze typerende driehoeksrelatie R.J.N. Schlossels, Het specialiteitsbeginsel en derde-belangen: Een frisse benadering of rechtsstatelijk drijfzand?, a.w., p. $89 \mathrm{t} / \mathrm{m} 91$. 
alsmede de oplegging van financiële lasten in dat kader (bijv. belastingheffing) ${ }^{61}$ Handelt de overheid op basis van een rechtsgrond die gelegen is in het 'meta-publiekrecht' dan plaatst zij zich in principe in een verticale relatie tot de betrokken rechtssubjecten. Doel van het overheidshandelen is dan niet langer gericht op het realiseren van wederkerige autonomie in horizontale rechtsrelaties, maar op het maximaliseren van de individuele private autonomie boven het niveau van de bestaande nutswaarden. ${ }^{62}$ Is de overheidsinterventie direct gebaseerd op het 'meta-publiekrecht' dan speelt de nutsmaximalisatie in de horizontale relaties tussen rechtssubjecten niet direct. Begrijp ik Simon goed, dan zullen in dit verband enkel belangentegenstellingen tussen de overheid en het betreffende rechtssubject aan de orde (kunnen) zijn.

Indien er een materiële rechtsgrond voor overheidshandelen kan worden aangewezen, dan komt in de theorievorming van Simon vervolgens de bevoegdheidsvraag aan de orde. Deze heeft volgens Simon een formele en een materiële component. ${ }^{63}$ Simon stelt de materiële bevoegdheidscomponent gelijk aan het vereiste van evenwichtigheid of evenredigheid van het besluitvormingsproces. ${ }^{64}$ Leidende beginselen voor het overheidshandelen zijn in dit verband de noodzakelijkheid, de proportionaliteit en de subsidiariteit. De evenwichtigheidstoets komt overigens eerst aan de orde nadat de betrokken (subjectieve) rechten en belangen zijn geïnventariseerd. In dit kader wijst Simon erop dat niet alle belangen behoeven te worden afgewogen. Grenzen aan het afwegingsproces kunnen voortvloeien uit de wet (d.w.z. uit het specialiteitsbeginsel), maar ook uit utiliteitsoverwegingen en uit de aard van de betreffende belangen. ${ }^{65}$ In het kader van de evenwichtigheidstoets stelt Simon het uitgangspunt van 'minimale belangenaantasting' van particuliere belangen centraal. Dit uitgangspunt kan het beste door het bestuur in concreto worden geoperationaliseerd. ${ }^{66}$ Van belang is tot slot dat Simon - in het licht van de materiële bevoegdheidsvraag - de mogelijke aantasting van rechtsbelangen sec onderscheidt van de mogelijke aantasting van de vermogenswaarde van deze belangen. Indien de aantasting van een belang - dat in de belangenafweging diende te worden betrokken - is toegestaan (eerste toets), kan bestuurscompensatie gelet op het evenwichtigheidsbeginsel desalniettemenin geboden zijn (tweede toets). ${ }^{67}$

$\mathrm{Na}$ deze inleidende opmerkingen over Simons theorievorming kan de aandacht worden gericht op zijn specifieke bijdrage(n) aan de specialiteitsdiscussie. De eerste bijdragen van

61. H.J. Simon, Publiekrecht of privaatrecht?, a.w., p. 111, 113 en 117.

62. H.J. Simon, Publiekrecht of privaatrecht?, a.w., p. 151. Welke publieke belangen hier in het geding zijn wordt volgens Simon bepaald in het publieke besluitvormingsproces (a.w., p. 111).

63. De formele component, die hier niet verder wordt besproken, ziet op de wetmatigheid van bestuur. Aan de formele bevoegdheidsgrondslag stelt Simon - gelet op de jurisprudentie van het EHRM - de eis van specificiteit. Zie hierover uitvoerig hoofdstuk 4 van dit boek.

64. H.J. Simon, Publiekrecht of privaatrecht?, a.w., p. 119.

65. H.J. Simon, Publiekrecht of privaatrecht?, a.w., p. 119/120. Simon wijst erop dat bijv. met concurrenticbelangen in de regel geen rekening behoeft te worden gehouden.

66. H.J. Simon, Publiekrecht of privaatrecht?, a.w., p. 68.

67. H.J. Simon, Publiekrecht of privaatrecht?, a.w., p. 122-124. Vgl. de benadering in Simons handboek. H.J. Simon, Handboek bestuurs(proces)recht volgens de Awb, a.w., p. 143-144. 
Simon aan deze discussie dateren uit de periode tussen 1987 tot 1993. In 1987 verwoordt hij in een noot voor het eerst zijn standpunt. ${ }^{68}$ Volgens Simon blijkt uit de Arob-jurisprudentie dat de administratieve rechter met name let op de vraag in hoeverre een bestuursbevoegdheid aan een bepaald algemeen belang is gebonden. Bij een gebonden bevoegdheid kan alleen het speciale algemene belang leiden tot weigering en/of het verbinden van voorschriften aan een vergunning. Indien een speciaal algemeen belang niet uitdrukkelijk aan de bestuursbevoegdheid ten grondslag is gelegd, kunnen volgens Simon vreemde algemene belangen of belangen van particulieren (waaronder óok derden) mede een rol spelen. Indien er sprake is van een discretionaire bevoegdheid dan dienen in beginsel alle beïnvloede belangen in de belangenafweging een rol te spelen. Hierbij dient, gelet op het gelijkheidsbeginsel, géen onderscheid gemaakt te worden tussen de particuliere belangen van de direct-belanghebbendeen van derden. Het specialiteitsbeginsel opereert volgens Simon met name op het niveau van de openbare/algemene belangen. Vreemde openbare belangen mogen in ieder geval géén aanleiding geven tot een weigering en/of het stellen van voorschriften. Indien een bestuursbevoegdheid niet aan een specifiek belang is gebonden is het volgens Simon denkbaar dat belangen van derden die worden aangetast kunnen leiden tot een weigering of het stellen van voorschriften. Hierbij plaatst hij wél expliciet als kanttekening dat (vreemde) particuliere belangen de 'originaire belangencontext' niet mogen gaan domineren. ${ }^{69}$ In een reactie op het commentaar van de vakgroep staats- en bestuursrecht van de Rijksuniversiteit Utrecht inzake artikel 3:4 lid 1 Awb (artikel 3.2.3 lid 1 Voorontwerp) herhaalt Simon in essentie dit standpunt. ${ }^{70}$

In 1991 werkt Simon ${ }^{71}$ zijn visie nader uit, waarbij hij de theoretische onderbouwing van zijn standpunt enigszins wijzigt. Het meewegen van belangen van derden wordt nu door hem verdedigd op grond van de 'raison d'être' van bestuursorganen, nl. zorg te dragen voor het algemeen belang. Volgens Simon vloeit de verplichting van een bestuursorgaan om ook met 'vreemde' belangen van derden rekening te houden voort uit de algemene taak van de overheid om het algemeen belang te maximaliseren. Hierbij lijkt hij vooruit te lopen op de rechtseconomische analyses in zijn proefschrift. Op grond van een maximalisatieplicht dient het bestuur de belangenafweging zoveel mogelijk 'open te houden'. Opvallend is wél dat Simon nu vaststelt dat de posities van derden en van een direct-belanghebbende binnen het proces van belangenafweging niet geheel vergelijkbaar zijn. Een vergunningstelsel creëert voor de laatstgenoemde nl. een onvrijheid. De directbelanghebbende heeft recht op herstel van zijn oorspronkelijke vrijheid, voorzover het aan de betreffende regeling neergelegde algemene (lees: publiekrechtelijke) belang zich daar niet tegen verzet. De plicht tot een afweging tussen het (speciale) publiekrechtelijke belang en de belangen van de direct-belanghebbende is daarmee gegeven. Daarnaast dient het bestuursorgaan de afwegingsruimte die een wettelijke regeling kent volledig te benutten.

68. Zie zijn noot onder VzARRS 27 mei 1986, AB 1987, 267.

69. Vgl. de 'beleidscontext'-theorie van Helder en Jue die in paragraaf 7.6 werd besproken.

70. H.J. Simon, Algemene wet bestuursrecht (reactie), NJB 1987/43, p. 1392.

71. Zie zijn noot onder: Rb. Amsterdam, 15 maart 1990, AB 1991, 58. 
Dit impliceert volgens Simon dat ook aan de (rechtstreeks) betrokken belangen van derden recht dient te worden gedaan, voorzover dit niet leidt tot een aantasting van de materiële vrijheid van de direct-belanghebbende. In dit verband dient het bestuur te bezien of de belangen van de betrokken rechtssubjecten kunnen worden verzoend, of er wellicht alternatieven bestaan en of een onredelijke dan wel onbillijke belangenafweging kan worden voorkomen. In het belang van derden kunnen volgens Simon ook voorschriften aan een vergunning worden verbonden, mits een dergelijk voorschrift een afspiegeling is van een juiste toedeling van gewichten van de in geding zijnde belangen.

In het zelfde jaar handhaaft Simon samen met Gieske ${ }^{72}$ het uitgangspunt dat het specialiteitsbeginsel in hoofdzaak ziet op het buitensluiten van vreemde publiekrechtelijke belangen. Beide auteurs verdedigen in hun noot de stelling dat in het kader van een - wat zij noemen - 'secundaire' belangenafweging ook vreemde publieke belangen (waaronder financiële) een rol kunnen spelen. Een dergelijke 'secundaire' belangenafweging zou door het bestuursorgaan kunnen worden verricht indien het speciale publiekrechtelijke belang, dat ten grondslag ligt aan een bepaalde bestuursbevoegdheid, zich niet tegen vergunningverlening verzet. Dit zou zich kunnen voordoen indien in een Algemene Plaatselijke Verordening de verdeling van standplaatsvergunningen aan een zgn. 'maximumstelsel' is gekoppeld. De betrokken speciale publiekrechtelijke belangen (bijv. het belang van de openbare orde en de verkeersveiligheid) worden binnen een dergelijk stelsel beschermd door het aantal te verlenen vergunningen vooraf aan een maximum te binden. Ten aanzien van de verdeling sec zou het bestuursorgaan volgens Simon en Gieske, indien op grond van het specifieke publieke belang géen keuzemogelijkheid is, uit andere publiekrechtelijke belangen verdelingscriteria kunnen afleiden. Hierbij wordt bijv. gedacht aan het realiseren van de grondrechtelijke materiële gelijkheid.

In 1992 mengt Simon zich nogmaals in de 'specialiteits'-discussie. In een noot onder een uitspraak van de Afdeling rechtspraak van de Raad van State van 5 juni $1991^{73}$ inzake een vergunning ingevolge artikel 56 van het Algemeen Reglement van Politie voor rivieren en Rijkskanalen, positioneert hij zichzelf nu in een middenpositie tussen 'preciezen' en 'rekkelijken'. Simon signaleert dat het verschil van mening tussen beide hoofdstromingen zich toespitst op het meewegen van particuliere belangen van derden. Volgens de 'preciezen' zouden deze belangen niet in de belangenafweging mogen worden betrokken, tenzij deze samenvallen met het speciale algemene (lees: publiekrechtelijke) belang dat ten grondslag ligt aan de betreffende bestuursbevoegdheid. Volgens Simon verplicht artikel 3:4 lid $1 \mathrm{Awb}$ in principe tot het meewegen van alle rechtstreeks betrokken belangen, dus óok van derden. Indien 'vreemde' belangen van derden niet door de wetgever van afweging zijn uitgesloten, impliceert dit volgens Simon overigens niet dat deze 'de originaire belangencontext' mogen gaan domineren. Wel kan er, afhankelijk van de aard van het vreemde

72. Zie hun noot onder: VzARRS 2 juli 1990, AB 1991, 278. Vgl. i.v.m. Simons visie inzake 'secundaire belangenafweging' ook de noot onder $\mathrm{Rb}$. Amsterdam 15 maart 1990, AB 1991, 58.

73. ARRS 5 juni 1991, AB 1992, 444 (woonschip 'Goede verwachting'). 
belang, een 'minimaal gewicht' aan worden toegekend. Veel helderheid biedt deze laatste opmerking helaas niet.

In zijn proefschrift uit $1993^{74}$ en in latere publicaties geeft Simon ervan blijk voorstander te zijn van een 'ruime' afweging van belangen van derden (in 'horizontale' relaties). In zijn opstel 'Financiële voorwaarden en voorschriften' ${ }^{75}$ aanvaardt hij op grond van - o.m. - doelmatigheidsoverwegingen het meewegen van deze belangen, voorzover er sprake is van een bestuursbevoegdheid die een bepaalde afwegingsruimte kent (discretie). Het meewegen van (vreemde) belangen van derden is volgens Simon evenwel alleen toegestaan indien dit voortvloeit uit de rechtsnormen die de horizontale relaties tussen belanghebbenden beheersen. Dit standpunt houdt verband met Simons visie inzake de taak die op de overheid rust, nl. het opheffen van 'meta-privaatrechtelijke'-tekorten (zie hiervoor). Uiteindelijk blijkt dit uitgangspunt dus vérgaande gevolgen te kunnen hebben: 'Dit zou wel kunnen betekenen dat, anders dan naar heersende opvatting, (bijv.) een vergunning kan worden geweigerd op grond van belangen die liggen buiten de betreffende regeling. ${ }^{76}$

De consequenties van deze laatste uitspraak mogen niet onderschat worden. Door zich op dit standpunt te stellen relativeert Simon naar mijn oordeel de scheiding tussen de specifieke (beginsel-gefundeerde) rechtssferen van het publiek- en het privaatrecht in belangrijke mate. Door hem wordt gesuggereerd om in het kader van de publiekrechtelijke bevoegdheidsuitoefening rechtsnormen van materieel privaatrecht te hanteren om de rechtsrelaties tussen de betrokken rechtssubjecten te harmoniseren (de opheffing van het 'meta privaatrechtelijk'-tekort). De privaatrechtelijke (zorgvuldigheids)normen, die de horizontale relatie tussen de direct-belanghebbende en derden van origine beheersen, kunnen volgens Simon met andere woorden onder omstandigheden óbk énzijdige rechtsvorming door een bestuursorgaan legitimeren. Dit standpunt heeft tot gevolg dat de specifieke wettelijke bevoegdheidsgrondslag voor het bestuur - buiten het legaliteitsbeginsel om - wordt opgerekt.

Resumerend kan dan ook worden gesteld dat Simon zich in een nogal 'rekkelijke' positie manoeuvreert, die weliswaar theoretisch onderbouwd is (de nutsmaximalisatietheorie), maar daarnaast ook door pragmatische overwegingen wordt ingegeven. ${ }^{77}$ In hoeverre Simon de opvatting van de 'preciezen' inzake het specialiteitsbeginsel in dit verband als onjuist verwerpt wordt mijns inziens niet geheel duidelijk. ${ }^{78}$

74. Zie bijv. H.J. Simon, Publiekrecht of privaatrecht?, a.w., p. 143, 174 en 277-278.

75. H.J. Simon, Financi\&le voorwaarden en voorschriften. Een blik vanuit de theorie op de praktijk, NTB $94 / 6$, p. 149 e.v.

76. H.J. Simon, Financiele voorwaarden en voorschriften, a.w., p. 153. In dit verband valt het op dat Simon in zijn handboek de huidige jurisprudentie over het specialiteitsbeginsel als 'uitermate rekkelijk' karakteriseert, hetgeen goed bij een dergelijk uitgangspunt aansluit. H.J. Simon, Handboek bestuurs(proces)recht volgens de Awb, a.w., p. 140. In hoofdstuk 8 meen ik tot een meer genuanceerd oordeel over de jurisprudentie te moeten komen.

77. Nl. o.m. op grond van het feit dat belanghebbenden een 'dubbele' gang naar de rechter wordt bespaard. Ik kom hier in hoofdstuk 9 op terug (paragraaf 9.5.5). 


\subsubsection{Stout}

In haar opstel in de Groningse bundel 'De rechtsstaat herdacht' heeft Stout ${ }^{79}$ een visie inzake het specialiteitsbeginsel uiteen gezet. Gelet op de noodzaak van doelmatig overheidsoptreden, waarbij het bestuursrecht instrumenteel wordt benaderd, tracht zij de betekenis van het legaliteits- en specialiteitsbeginsel te relativeren.

Stout stelt in haar betoog het spanningsveld tussen rechtsstaat en doelmatigheid centraal. Allereerst maakt zij een onderscheid tussen het specialiteitsidee enerzijds, en het specialiteits- en legaliteitsbeginsel anderzijds. Het specialiteitsidee is volgens Stout het globaal geformuleerde uitgangspunt dat de overheid zich alleen mag bezighouden met taken die haar zijn opgedragen of die binnen haar taken passen. ${ }^{80}$ Het specialiteitsbeginsel is een concretisering en operationalisering van dit ruimere specialiteitsidee. Het legaliteitsbeginsel en het specialiteitsbeginsel vereisen een overheid die handelt op basis van uitdrukkelijk toegekende en afgebakende bevoegdheden. Beide beginselen richten zich primair tot de wetgever. ${ }^{81}$ Deze dient zorg te dragen voor een bevoegdhedentoedeling die mede recht doet aan het doelmatigheidsaspect.

Stout stelt vast dat het bestuur op verschillende beleidsterreinen gehinderd wordt in zijn taakvervulling. De klassieke uitleg van het specialiteitsbeginsel is hier volgens haar debet aan:

'De conclusie lijkt te worden gerechtvaardigd dat de klassieke uitleg van het specialiteitsbeginsel nog al eens aan cen uit een oogpunt van beleidsmatigheid en effectiviteit wenselijke integrale belangenafweging in de weg staat. ${ }^{, 82}$

Vervolgens stelt zij tegen deze achtergrond de rechtsstatelijkheidsnotie van het specialiteitsbeginsel ter discussie. Volgens Stout is de klassieke waarborgfunctie van de wet in belangrijke mate verloren gegaan. ${ }^{83}$ Het klassieke specialiteitsbeginsel kwam tot bloei in een periode waarin de overheid slechts een gering aantal doelstellingen had. Vanuit een oogpunt van democratische controle lag toen voor de hand dat deze doelstellingen in speci-

78. Vgl. H.J. Simon, Het 'nieuwe' vreemdelingenrecht. Een analyse vanuit het algemene staats- en bestuursrecht, Sociaal recht 1994/3, p. 72, waar hij opmerkt: 'In het bestuursrecht geldt als onderdeel van het legaliteitsbeginsel, het specialiteitsbeginsel. Dit beginsel brengt o.m. mee dat de voorwaarden, beperkingen, voorschriften en dergelijke te verbinden aan een overheidsbesluit, alleen dan geoorloofd zijn indien deze noodzakelijk moeten worden geacht met het oog op de realisering van het materiele doel dat aan de betreffende publiekrechtelijke regeling ten grondslag ligt' (curs. R.J.N.S.). Simon heeft hier waarschijnlijk de 'verticale' relatie tussen het bestuur en de burger op het oog.

79. H.D. Stout, Doelmatige bestuurlijke belangenafweging: een speciaal terrein, in: De rechtsstaat herdacht, Zwolle 1989, p. 237 e.v.

80. H.D. Stout, Doelmatige bestuurlijke belangenafweging, a.w., p. 237.

81. H.D. Stout, Doelmatige bestuurlijke belangenafweging, a.w., p. 239.

82. H.D. Stout, Doelmatige bestuurlijke belangenafweging, a.w., p. 241.

83. Vgl. in dit verband haar proefschrift. H.D. Stout, De betekenissen van de wet. Theoretisch-kritische beschouwingen over het principe van wetmatigheid van bestuur, diss. RUL, Zwolle 1994. Zie met name p. 82. 
fieke bevoegdhedenkaders werden beschermd. Ook de doelmatigheid was hiermee gediend (nl. géén dubbele belangenafweging). Wetgeving is echter ingrijpend veranderd doordat de wetgever niet meer in staat is om de inhoudelijke norm in de wet zelf te codificeren. ${ }^{84}$ Dit leidde volgens Stout tot ruimere bevoegdhedenkaders, die niet exclusief genormeerd worden door het specialiteitsbeginsel, maar ook door de beginselen van behoorlijk bestuur. De absolute betekenis van wetgeving, en bijgevolg van het specialiteitsbeginsel, dient volgens Stout gerelativeerd te worden. Zij positioneert dit rechtsstatelijke beginsel in een spanningsveld met beginselen van behoorlijk bestuur. Volgens haar mag genoemd beginsel niet uitsluitend in verband worden gebracht met het verbod van détournement de pouvoir. De betekenis van het specialiteitsbeginsel ligt volgens haar niet zozeer in de waarde die aan de betrokken particuliere belangen van direct of derde-belanghebbenden dient te worden toegekend, maar vooral in de keuze en in het relatieve gewicht van de verschillende beleidsdoelen. Voor het meewegen van particuliere belangen zijn de algemene beginselen van behoorlijk bestuur volgens haar de aangewezen maatstaven. ${ }^{85}$ Alle bij de bestuurlijke besluitvorming betrokken particuliere belangen kunnen en moeten worden meegewogen. Dit meewegen mag echter niet leiden tot het nastreven van een zelfstandige beleidsdoelstelling. Volgens Stout kunnen belangen van derden onder omstandigheden leiden tot de weigering van een vergunning. ${ }^{86}$ Bovendien kunnen deze belangen het stellen van voorschriften rechtvaardigen.

Aan het slot van haar betoog maakt Stout nog een onderscheid tussen 'primaire' en 'secundaire' weigeringsgronden in een - wat zij noemt - 'positieve' en 'negatieve' context. Waar het om gaat is het volgende. Volgens Stout mag het bestuur naast het speciale publiekrechtelijke belang dat ten grondslag ligt aan een bestuursbevoegdheid ook andere verwante publiekrechtelijke belangen in de besluitvorming betrekken. Het primaat ligt echter bij de primaire doelstelling van de wettelijke regeling. Alleen op grond van het speciale publiekrechtelijke belang mag het bestuur tot een weigering komen, terwijl datzelfde speciale belang zich anderzijds niet mag verzetten tegen een verlening. Secundaire doelstellingen (d.w.z. verwante publiekrechtelijke belangen) kunnen, zo begrijp ik Stout, wél aanleiding geven tot het stellen van voorschriften. ${ }^{87}$

\subsubsection{Goldschmidt}

Goldschmidt heeft in haar preadvies voor de Nederlandse Juristen Vereniging ${ }^{88}$ inzake positieve discriminatie aandacht besteed aan het specialiteitsbeginsel. In dit preadvies wordt in het bijzonder ingegaan op de vraag of het specialiteitsbeginsel een belemmering

84. H.D. Stout, Doelmatige bestuurlijke belangenafweging, a.w., p. 245.

85. H.D. Stout, Doelmatige bestuurlijke belangenafweging, a.w., p. 246.

86. H.D. Stout, Doelmatige bestuurlijke belangenafweging, a.w., p. 247.

87. Vgl. het schematische 'afwegingsmodel' van Stout. H.D. Stout, Doelmatige bestuurlijke belangenafweging, a.w., p. 251.

88. J.E. Goldschmidt, Positieve discriminatie (staats- en bestuursrechtelijke aspecten van positieve actie), Preadvies Nederlandse Juristen Vereniging (NJV), Zwolle 1989, p. 59 e.v. (zie met name p. 100 e.v.). 
vormt om in het kader van subsidieverlening voorschriften aan een beschikking te verbinden die discriminatie beogen tegen te gaan, dan wel achterstanden beogen weg te werken (positieve discriminatie). In vervolg hierop analyseert Goldschmidt een en ander óók voor het verlenen van vergunningen.

Goldschmidt relativeert het specialiteitsbeginsel. Dit beginsel kan volgens haar bij een te starre interpretatie met zich brengen dat (bepaalde) grondrechten buiten beschouwing moeten blijven bij een regeling die niet expliciet ziet op de verwezenlijking van een of meer grondrechten. ${ }^{89}$ Dit uitgangspunt acht zij niet aanvaardbaar. Het specialiteitsbeginsel kent weliswaar aan het speciale publiekrechtelijke belang een zekere hardheid toe, maar dit mag niet leiden tot een beknelling van andere zwaarwegende belangen waaronder bepaalde grondrechten.

Daarom verdedigt zij de stelling dat de regelgever en het bestuur in elk geval met het gelijkheidsbeginsel rekening dienen te houden bij het verlenen van subsidies of vergunningen. In dit verband denkt Goldschmidt ook aan het stellen van voorwaarden en voorschriften. Ongeacht de aard van de subsidieregeling acht zij toelaatbaar dat op grond van het Grondwettelijke gelijkheidsbeginsel voorschriften worden opgelegd ter voorkoming van discriminatie c.q. voorschriften die positief discriminerend zijn. Het specialiteitsbeginsel verzet zich in haar visie daar niet tegen. ${ }^{90}$ Enige beleidsvrijheid is wél noodzakelijk. ${ }^{91}$ Volgens Goldschmidt stelt het gelijkheidsbeginsel de werking van het specialiteitsbeginsel - in concreto - ter zijde.

Mij lijkt een dergelijke gedachtengang niet juist. ${ }^{92}$ Het specialiteitsbeginsel determineert immers exclusief de reikwijdte van de publiekrechtelijkerechtshandeling (de gerichte bevoegdheidsuitoefening) door te eisen dat hieraan een specifiek publiekrechtelijk belang ten grondslag ligt. Dit belang geeft exclusief richting aan het bestuurlijke rechtsvormingsproces, en kán wellicht een nadere invulling geven aan bijv. een sociaal grondrecht. ${ }^{93}$ Grondrechten sec, en in het bijzonder de klassieke vrijheids- en gelijkheidsrechten, zijn echter typisch subjectgebonden rechten. Dit brengt met zich dat zij door private rechtssubjecten vaak als 'afweerrecht' ingebracht kunnen worden in het bestuurlijke belangenafwegingsproces. ${ }^{94} \mathrm{Zij}$ kunnen mijns inziens evenwel niet zelfstandig doelgericht richting geven aan de publiekrechtelijke rechtsvorming. Zou dit uitgangspunt wél worden

89. J.E. Goldschmidt, Positieve discriminatie, a.w., p. 105.

90. J.E. Goldschmidt, Positieve discriminatie, a.w., p. 113.

91. Vgl. de opvatting van Simon zoals verwoord in zijn noot onder Rb. Amsterdam, 15 maart 1990, AB 1991, 58. Beleidsvrijheid sec acht hij niet voldoende. Als randvoorwaarde geldt volgens Simon dat het publieke belang bij een voorkeursbeleid het belang dat in het vergunningstelsel bescherming heeft gevonden niet geheel en al opzij kan zetten. Dit zou détournement de pouvoir opleveren.

92. Vgl. A.K. Koekkoek, Grenzen aan grondrechten. Aantekeningen bij het voorstel voor een Algemene wet gelijke behandeling, in: Gelijk behandelen. Commentaren op het voorstel Algemene wet gelijke behandeling (Publicaties van de Staatsrechtkring), Zwolle 1991, p. 50.

93. Zo kan bijv. het vergunningstelsel van de Wet milieubeheer gerelateerd worden aan art. 21 van de Grondwet dat de overheid o.m. de zorg opdraagt tot verbetering en bescherming van het leefmilieu.

94. In hoofdstuk 9 van dit boek waar ik de bestuurlijke bevoegdheidsuitoefening als rechtsfeit analyseer kom ik hier meer uitvoerig op terug. 
aanvaard dan zou dat bijv. met zich brengen dat aan een milieuvergunning ter behartiging van diverse klassieke en sociale grondrechten voorschriften zouden mogen worden verbonden. Dit zou het specialiteitsbeginsel ernstig ondermijnen.

\subsubsection{De Planque}

In zijn VAR-preadvies ${ }^{95}$ gaat De Planque uitvoerig in op het proces van bestuurlijke belangenafweging. Ter beantwoording van de vraag welke belangen wél, en welke niet in de belangenafweging mogen worden betrokken heeft De Planque uitvoerig de jurisprudentie geanalyseerd. Allereerst dient volgens hem het algemene deelbelang (lees: het speciale publiekrechtelijke belang) ter bescherming waarvan het vergunningstelsel in het leven is geroepen in de belangenafweging te worden betrokken. De Planque erkent dat het vaak niet eenvoudig is om de precieze inhoud van dit deelbelang vast te stellen. Nauwkeurige raadpleging van tekst en wetsgeschiedenis van een regeling is in dit verband noodzakelijk. Soms kan er sprake zijn van een groep van deelbelangen. In dit geval dient dan te worden nagegaan in hoeverre er een bijzondere regeling bestaat waarbinnen een bepaald facet van het deelbelang op speciale wijze wordt beschermd. Een zekere 'aantasting' van het betreffende algemene deelbelang kan, onder bepaalde voorwaarden, door middel van 'bestuurdencompensatie ${ }^{96}$ worden gecompenseerd. Dit kan uiteraard alleen indien de aantasting op geld waardeerbaar is. Vreemde algemene belangen mogen volgens De Planque niet in de belangenafweging worden betrokken. Dit zou détournement de pouvoir opleveren. ${ }^{97}$

Concrete belangen van derden mogen alleen worden meegewogen voorzover deze belangen (mede) beschermd worden door het speciale algemene belang. ${ }^{98}$ Hieruit volgt dat andere concrete belangen van derden, die niet zijn terug te voeren tot dit belang - in beginsel - buiten beschouwing behoren te blijven. Hierbij kan het zo zijn dat bepaalde concrete belangen in het kader van een andere regeling worden beschermd. Belangrijkste relativering van dit standpunt vloeit volgens De Planque voort uit een aantal uitspraken van de Afdeling rechtspraak, waarin expliciet wordt overwogen dat een bestuursorgaan waar mogelijk rekening dient te houden met alle concrete belangen van derden. ${ }^{99}$ Volgens De Planque mogen deze Afdelingsuitspraken niet worden onderschat. De gevolgen zijn vergaand en moeilijk in te passen in een 'precieze' specialiteitsvisie. De Planque vraagt zich daarom af, of de Afdeling met deze jurisprudentie de deur heeft opengezet voor het

95. J.H.W. de Planque, De mogelijkheden van administratieve rechters en de Kroon om het bestuur tot schadevergoeding te veroordelen, VAR-reeks 102, Alphen aan den Rijn 1989, p. 11-49.

96. Van 'bestuurdencompensatie' is sprake indien een rechtssubject (burger) 'de overheid' in het kader van een positief besluit compenseert. Deze compensatie komt dan ten ten goede aan de behartiging van het betrokken publiekrechtelijke belang (Vgl. bijv, de storting van een bedrag in een 'parkeerfonds' onder gelijktijdige ontheffing van een verplichting om voldoende parkeergelegenheid bij een nieuwbouw te realiseren).

97. De Planque, VAR-reeks 102, a.w., p. 19.

98. De Planque, VAR-reeks 102, a.w., p. 21.

99. Vgl. ARRS 21 augustus 1984, AB 1984, 542 (m.nt. Van Wijmen). Zie voor een uitvoerige bespreking van deze jurisprudentie hoofdstuk 8. 
(volledig) meewegen van civielrechtelijke belangen in het kader van de uitoefening van een bestuursbevoegdheid. Volgens De Planque zou dit een onjuiste gang van zaken zijn. ${ }^{100}$

In dit verband dienen volgens hem vraagtekens te worden geplaatst bij het feit dat het bestuur en de administratieve rechter zich inlaten met het beoordelen van civielrechtelijke geschillen. De opmerkingen die De Planque in dit kader maakt zijn mijns inziens van aanzienlijk belang. Hij merkt o.m. op:

\begin{abstract}
'Zou die opvatting zo ver behoren te gaan dat ook expliciet in het burgerlijke recht beschermde belangen (curs. J.dP) van derden bij de vergunningverlening zouden kunnen worden meegewogen? Bijv. in die zin, dat vergunningverlening kan afstoten op de omstandigheid dat door verlening van de vergunning een erfdienstbaarheid zou worden geschonden of wanprestatie onvermijdelijk wordt? Ik zou menen van niet. Met het vergunningvereiste wordt immers niet de naleving van het civiele recht beoogd; daarvoor bestaan eigen middelen. Het zou ook ongerijmd zijn dat het administratieve recht wel een specialiteitsbeginsel aanvaardt dat specifieke bestuursrechtelijke regelingen een eigen plaats gunt, doch het civiele recht "even meeneemt" bij de beoordelingen van allerlei beslissingen' (curs. R.J.N.S.). ${ }^{101}$
\end{abstract}

De Planque wijst er mijns inziens terecht op dat het zonder meer meewegen van typisch 'civiele geschilpunten' in het bestuurlijke besluitvormingsproces gevolgen kan hebben voor het overheidsaansprakelijkheidsrecht. Indien men immers aanvaardt dat een bestuursorgaan met alle civiele rechtsbelangen van de betrokken rechtsgenoten rekening behoort te houden, dan zal het bestuur er snel op aangesproken kunnen worden dat in concreto bepaalde belangen ten onrechte niet zijn meegewogen. Ook zou de situatie zich kunnen voordoen dat een bestuursorgaan het meewegen van een bepaald belang onder gelijktijdige aanbieding van compensatie afkoopt:

\footnotetext{
'Waar een privaatrechtelijk belang een weigeringsgrond voor verlening van een vergunning kan vormen, zou in omstandigheden ook door het bestuur geoordeeld kunnen worden dat ingeval de aantasting van dat private belang bij wijze van nadeelcompensatic wordt vergoed, de vergunning wel verleend kan worden. Naar mijn oordeel moeten wij die weg niet opgaan - of beter gezegd: zo snel mogelijk verlaten - en privaatrechtelijke geschillen laten waar zij horen: in de relatie tussen de civiele partijen zelf en zonodig bij de burgerlijke rechter. ${ }^{102}$
}

De Planque heeft onderkend dat aan het meenemen van 'privaatrechtelijke' geschilpunten tussen rechtssubjecten in het publiekrechtelijke besluitvormingsproces diverse haken en ogen zitten. Zo worden de privaatrechtelijke en publiekrechtelijke rechtsnormen die de rechtsrelaties tussen de betrokken burgers beheersen op een ondoorzichtige wijze verweven

100. De Planque, VAR-reeks 102, a.w., p. 22 en 23 . De Planque beoogt in dit verband echter geenszins tegen te spreken dat het bestuur rekening behoort te houden met de belangen van private rechtssubjecten indien een (discretionaire) bestuursbevoegdheid wordt uitgeoefend. Uit de gehele context van zijn betoog blijkt $\mathrm{nl}$. dat hij enkel doelt op de geschillen tussen rechtssubjecten onderling die beheerst worden door rechtsnormen van objectief (materieel) privaatrecht.

101. De Planque, VAR-reeks 102, a.w., p. 22 en 23.

102. De Planque, VAR-reeks 102, a.w. p. 26-27. 
met als gevolg dat het toch al complexe bestuurlijke besluitvormingsproces verder aan helderheid verliest. Voorts verliest de rechtsstatelijke functie van het specialiteitsbeginsel sterk aan betekenis indien men eenmaal aanvaardt dat ób civielrechtelijke belangen (doelbestemd) richting kunnen geven aan het (gerichte) publiekrechtelijke rechtsvormingsproces.

\subsubsection{Messer en Heldeweg}

In een opstel over het specialiteitsbeginsel en bestuurscompensatie ${ }^{103}$, ontwikkelden Messer en Heldeweg in 1990 een theorie inzake het meewegen van vreemde bijzondere (lees: particuliere) belangen van derden. $\mathrm{Na}$ een algemene analyse van het leerstuk van de bestuurscompensatie, waarbij de compensatieplicht bezien wordt vanuit het belangenafwegingsproces zelf ${ }^{104}$, menen de auteurs vast te kunnen stellen dat het specialiteitsbeginsel en het beginsel van 'égalité devant les charges publiques' op gespannen voet met elkaar staan. Indien immers uitgegaan wordt van een 'precieze' visie inzake het specialiteitsbeginsel dan zal er weinig ruimte zijn om belangen van derden, die niet verdisconteerd zijn in het betreffende algemene (lees: publiekrechtelijke) belang waarop de wettelijke regeling ziet, mee te wegen. Compensatie voor onevenredig nadeel is dan evenmin aan de orde. ${ }^{105}$ Derhalve is de interpretatie van het specialiteitsbeginsel volgens hen bepalend voor de reikwijdte van de op het bestuur rustende plicht om onevenredig benadeelde belangen van derden te compenseren. $\mathrm{Bij}$ een strikte (precieze) interpretatie van genoemd beginsel zullen vreemde belangen van derden aangewezen zijn op de bescherming die zij aan privaatrechtelijke rechtsnormen kunnen ontlenen. ${ }^{106}$

Om toch in zekere mate tegemoet te komen aan rechtstreeks betrokken belangen van derden nemen Messer en Heldeweg een gematigd standpunt in. Centrale invalshoek is het openhouden van compensatiemogelijkheden, zodat optimaal recht kan worden gedaan aan het égalité-beginsel. Gelet op dit uitgangspunt interpreteren de auteurs het proces van belangenafweging als een proces van eliminatie. ${ }^{107}$ Het specialiteitsbeginsel sluit op het niveau van de wettelijke regeling vreemde algemene (lees: publiekrechtelijke) belangen uit. Deze mogen niet in de afweging worden betrokken. Vervolgens dient op beschikkingsniveau onderzocht te worden of bepaalde vreemde-bijzondere belangen expliciet of impliciet worden uitgesloten. Hierbij dient naar de tekst van de wet en de bijbehorende memorie van toelichting te worden gekeken. Uitsluiting dient in ieder geval te geschieden indien deze belangen bescherming genieten binnen een ander wettelijk kader. De resterende

103. E.M. Messer en M.A. Heldeweg, Bestuurscompensatie en het specialiteitsbeginsel. Een beschouwing over juridische spraakverwarring, rekkelijk versus preciezen en enkele cryptische wetsartikelen, RMTh. 1990/4, p. 147 e.v.

104. Messer/Heldeweg, Bestuurscompensatie en het specialiteitsbeginsel, a.w., p. 151.

105. In hoofdstuk 9 zal blijken dat een dergelijke conclusie, ook al huldigt men een 'precieze' opvatting, m.i. niet noodzakelijkerwijs behoeft te worden gedeeld.

106. Vgl. Messer/Heldeweg, Bestuurscompensatic en het specialiteitsbeginsel, a.w., p. 158.

107. Messer/Heldeweg, Bestuurscompensatie en het specialiteitsbeginsel, a.w., p. 161. 
vreemde bijzondere belangen mogen worden meegewogen en kunnen in geval van onevenredige benadeling door de overheid worden gecompenseerd.

Dit systeem leidt volgens Messer en Heldeweg tot een verschuiving van het risico voor aansprakelijkheid van de vergunninghouder naar de overheid, die bijgevolg een hoge(re) prijs betaalt om de haar toebedeelde publiekrechtelijke belangen te kunnen beschermen. Hier staat tegenover dat indien de wetgever een compensatieplicht voor het bestuur niet wenselijk acht, hij vreemde derde-belangen in een regeling expliciet van afweging kan uitsluiten. Volgens Messer en Heldeweg wordt dan langs democratische weg uitgemaakt of compensatie van onevenredig nadeel in concreto een privaatrechtelijke zaak is of dat daarin een taak voor het bestuur ligt. ${ }^{108}$

\subsubsection{Van den Berk}

Van den Berk heeft in haar proefschrift ${ }^{109}$ - in het licht van het specialiteitsbeginsel enige gedachten ontwikkeld over de relatie tussen de (omvang van de) bestuurlijke belangenafweging en de mogelijke plicht tot nadeelcompensatie. In artikel 3:4, lid 1 Awb (artikel 3.2.3, lid 1 voorstel van wet) leest zij een ruime belangenafwegingsplicht op basis waarvan het bestuur alle rechtstreeks betrokken belangen dient af te wegen. Van den Berk gaat ervan uit dat dit Awb-artikel er niet aan in de weg staat dat het bestuur ook belangen in de afweging betrekt welke niet door de specifieke wettelijke regeling worden beschermd. Hierbij maakt zij géén onderscheid tussen belangen van (de) direct-belanghebbende(n) en van derden. Van den Berk pleit vervolgens voor een 'tweetrapsconstructie' in de besluitvorming. ${ }^{110}$ De 'primaire besluitvorming' wordt beheerst door het evenredigheidsbeginsel. Besluitvorming kan alleen maar rechtmatig zijn indien alle met het besluit te dienen belangen zwaarder wegen dan de door het besluit te benadelen belangen. In dit kader dient het bestuur steeds te onderzoeken welk alternatief het minst bezwarend is voor potentiële gelaedeerden.

Interessant is nu dat Van den Berk de mogelijke plicht tot nadeelcompensatie afplitst van de 'primaire besluitvorming'. Een rechtmatige 'primaire besluitvorming' sluit in de visie van Van den Berk niet uit dat er tengevolge van (de uitvoering van) het besluit belangen benadeeld (kunnen) worden. Gelet op het égalité-beginsel kan compensatie dan toch noodzakelijk zijn. De compensatievraag is echter niet (meer) van invloed op het rechtmatige besluit, maar dient in de 'secundaire besluitvorming' aan de orde te komen. In de visie van Van den Berk dient de beoordeling van de rechtmatigheid van het schadeveroorzakende overheidshandelen sec en de beoordeling van de schadevraag derhalve gescheiden plaats te vinden. Bijgevolg wordt een compensatiemogelijkheid ten aanzien van gelaedeerde particuliere belangen geopend in situaties waarin deze belangen géén

108. Messer/Heldeweg, Bestuurscompensatie en het specialiteitsbeginsel, a.w., p. 162.

109. J.A.M. van den Berk, Schadevergoeding voor rechtmatig toegebrachte schade door de overheid, diss. UU, Zwolle 1991, i.h.b. p. $45 \mathrm{tm} 49$ en p. 154 e.v.

110. J.A.M. van den Berk, Schadevergoeding voor rechtmatig toegebrachte schade door de overheid, p. 48 en 49. 
overwegend gewicht in de 'primaire' besluitvormingschaal konden leggen. Jammer is, dat Van den Berk niet aangeeft of, en zo ja in hoeverre het meewegen van (vreemde) derdebelangen kan leiden tot het verbinden van voorschriften aan bijv. een vergunning. Haar theorie geeft wél een indicatie hoe met gelaedeerde particuliere belangen rekening kan worden gehouden zonder dat deze van invloed zijn op de (speciale) bevoegdheidsuitoefening (d.w.z. de publiekrechtelijke rechtshandeling) sec.

\subsubsection{Heldeweg}

In 1995 mengt Heldeweg zich weer in de discussies. ${ }^{11}$ In zijn bijdrage aan de bundel 'Eenzijdig en wederkerig?' analyseert hij het begrip 'publiekrechtelijke autonomie'. ${ }^{112}$ In dit verband doet hij ook uitspraken over het proces van bestuurlijke belangenafweging en de positie van particuliere belangen daarbinnen. Allereerst determineert hij de plaats van de (discretionaire) bevoegdheidsnorm binnen een rechtsstelsel. Dergelijke normen zijn volgens hem de resultante van een exclusief proces van democratische belangenafweging. Binnen dit proces worden algemene (d.w.z. abstracte) normen geformuleerd die het doel van een bevoegdheid uitdragen. De algemene norm welke door de wetgever aan een specifieke bevoegdheid ten grondslag wordt gelegd bepaalt de rechtspositie van een onbepaalde groep individuele burgers ten overstaan van de overheid. Publiekrechtelijke bevoegdheden vormen als het ware de kristallisatiepunten in het proces van gelede normstelling. ${ }^{113}$ Het proces van éenzijdige rechtsvorming door een bestuursorgaan vat Heldeweg vervolgens op als het behartigen van het 'in abstracto' gedetermineerde algemene (lees: publiekrechtelijke) belang enerzijds en het zich rekenschap geven van bijzondere belangen van burgers. Het onderscheid tussen 'behartigen' en 'rekenschap geven' is cruciaal, daar alleen het speciale algemene belang een basis voor overheidsinterventie mag vormen. Het gegeven dat een bestuursorgaan zich rekenschap dient te geven van bijzondere belangen van burgers impliceert in de visie van Heldeweg dat het doel van de abstracte (algemene) norm in concreto wordt bereikt met zo min mogelijk last voor elke burger (égalité). ${ }^{114}$

111. Ik wijs er volledigheidshalve op dat Heldeweg ook in zijn proefschrift uit 1993 nog enige opmerkingen maakte over het specialiteitsbeginsel, die echter niet afzonderlijk besproken behoeven te worden. Van belang is dat Heldeweg het specialiteitsbeginsel ziet als een juridische waarborg die de (bestuurlijke) machtsuitoefening aan het democratisch-politieke primaat bindt. Zie: M.A. Heldeweg, Normstelling en expertise. Waarborgen voor technische deskundigheid i.h.b. bij vergunningverlening in het milieurecht, diss. RL, 's-Gravenhage 1993, p. 133.

112. M.A. Heldeweg, Publiekrechtelijke autonomie. Over exclusieve behartiging van het algemeen belang en de wederzijdse onvrijheid van burger en overheidsbestuur, in: Eenzijdig en wederkerig?, Deventer 1995, p. 121 e.v. In dit zelfde jaar verschijnt van zijn hand de uitvoerige annotatie 'Het specialiteitsbeginsel: bel voor de laatste ronde?, in: Rechtspraak bestuursrecht, De annotaties, 's-Gravenhage 1995, p. 175 e.v. Deze annotatie, waarop in dit hoofdstuk niet zal worden ingegaan, geeft een overzicht van de verschillende visies in de literatuur, maar omvat daarnaast een fraaie theoretische analyse van de 'rekkelijke' en 'precieze' tendenties.

113. M.A. Heldeweg, Publiekrechtelijke autonomie, m.n. p. $127 \mathrm{t} / \mathrm{m} 136$.

114. M.A. Heldeweg, Publiekrechtelijke autonomie, biz.136 en 137. 
Welke gevolgen heeft dit geschetste uitgangspunt nu voor het proces van rechtsvorming in concreto? Heldeweg werkt zijn theorie uit aan de hand van het voorbeeld van een (discretionaire) vergunningbevoegdheid. Aan een dergelijk vergunningstelsel ligt steeds een materiële norm - hoe vaag ook - in de vorm van een algemeen belang ten grondslag. De formele verbodsnorm stelt het bestuursorgaan in staat om deze abstracte materiële norm verder te concretiseren. ${ }^{115}$ Het bestuursorgaan stelt eerst vast hoe de algemene norm in het concrete geval luidt. Aan deze concretiserende vaststelling gaat géén 'belangenafweging' in de traditionele zin van het woord vooraf. Het betreft, indien ik Heldeweg goed begrijp, een éénzijdige interpretatie-handeling door het bestuur. Vervolgens rijst de vraag hoe de geconcretiseerde materielle norm in concreto dient te worden doorgevoerd. Eerst nu gaat het effect van de norm op bijzondere belangen een rol spelen. Het bestuursorgaan onderzoekt, binnen de grenzen van het wettelijke kader, hoe doorvoering kan plaatsvinden zonder dat aan betrokkenen onnodige of onevenredige lasten worden opgelegd. De materiële norm kan in dit verband niet (meer) ter discussie worden gesteld, daar dit ontegenzeggelijk ertoe leidt dat het bestuur 'wetgever in eigen zaak' wordt. ${ }^{116}$

Voor de positie van de belangen van burgers heeft het stelsel van Heldeweg een aantal gevolgen. Daar waarborging van bijzondere rechtsbelangen niet het oogmerk is van de materiële publiekrechtelijke norm, wordt het standpunt ingenomen dat noch de belangen van de aanvrager noch die van derden door deze norm worden beschermd. Tussen de positie van derde-belanghebbenden en de aanvrager is er evenwel één punt van verschil. Door de bevoegdheidsuitoefening vindt er een essentiële nadere determinatie plaats van de rechtspositie van laatstgenoemde. De rechtspositie van derden wordt volgens Heldeweg niet nader bepaald. ${ }^{117}$ Bijgevolg relativeert Heldeweg in vergaande mate de invloed van rechtsbelangen van derden op rechtsvormingsniveau 'in concreto'. Ook het égalité-beginsel kan volgens hem in dit verband in beginsel niet van betekenis zijn omdat rechtsposities reeds in algemene zin (in abstracto) waren bepaald. Bovendien beoogt de materiële norm géén herschikking in de onderlinge verhouding van burgers, gemeten naar hun individuele belang-posities. Slechts in situaties waarin de algemene norm in abstracto dermate vaag is geformuleerd, zou het denkbaar zijn dat eerst in concreto blijkt dat derden door deze norm onevenredig worden getroffen. Met het oog hierop lijkt Heldeweg een compensatiemogelijkheid door het bestuur in concreto open te willen houden. ${ }^{118}$

\subsubsection{Damen}

In zijn interventie ${ }^{119}$ bij het eerder besproken VAR-preadvies van De Planque (zie paragraaf 7.11) geeft Damen - zij het indirect - een uiteenzetting van zijn visie over het specialiteitsbeginsel. Naar mijn oordeel gaat het om een belangrijke interventie die in de literatuur helaas onvoldoende aandacht heeft gekregen. De beschouwing van Damen vangt

115. M.A. Heldeweg, Publiekrechtelijke autonomie, p. 141.

116. M.A. Heldeweg, Publiekrechtelijke autonomie, p. 140.

117. M.A. Heldeweg, Publiekrechtelijke autonomie, p. 142.

118. M.A. Heldeweg, Publiekrechtelijke autonomie, p. 145. 
aan met enige opmerkingen over het verschijnsel nadeelcompensatie. Damen onderscheidt een drietal soorten compensatie, die hij toetst aan de legaliteitsidee: (1) de 'echte' bestuurscompensatie, (2) de 'bestuurdencompensatie' en (3) de 'burgercompensatie'.

Volgens Damen wordt - indien ik hem juist interpreteer - een plicht strekkende tot bestuurscompensatie ingegeven door het algemeen belang. Deze visie sluit aan bij de 'égalité-gedachte'. Kenmerkend voor bestuurscompensatie is een compensatiestroom welke loopt van dit algemeen belang naar een bepaald privé-belang. Het legaliteitsbeginsel verzet zich niet tegen een dergelijke compensatiestroom. Er worden immers niet éénzijdig door het bestuur aan burgers plichten opgelegd.

Van bestuurscompensatie dient de bestuurdencompensatie onderscheiden te worden. Van bestuurdencompensatie is sprake indien een individuele burger - in de vorm van een voorwaarde ${ }^{120}$ - verplicht wordt om aan het bestuur een bedrag te voldoen ter verkrijging van een gunstig besluit. Damen plaatst bij deze gang van zaken vanuit legaliteitsoogpunt reeds meer vraagtekens. Onder bepaalde voorwaarden zou 'bestuurdencompensatie' toelaatbaar kunnen worden geacht. Gedacht kan worden aan de connexiteit tussen de doelstelling van de bevoegdheid en het geldbedrag, het proportionaliteitsvereiste, en de afwezigheid van een andere wettelijke verhaalsmogelijkheid.

Uiterst bedenkelijk acht Damen de burgercompensatie. Hiervan is volgens hem sprake indien een bestuursorgaan aan de direct-belanghebbende, bij wijze van voorwaarde of voorschrift, een plicht oplegt om bepaalde nadelen van derden te vergoeden. Dergelijke burgercompensatie ziet dus op een geldstroom in een horizontale verhouding tussen burgers onderling. Vanuit legaliteitsoogpunt kunnen bij dergelijke constructies volgens Damen serieuze vraagtekens worden geplaatst. Overigens heeft de Afdeling rechtspraak in principe de burgercompensatie in de Paul-Krugerbrug uitspraken aanvaard. ${ }^{121}$

Damen vraagt zich in dit verband af in hoeverre een weigering van een vergunning gebaseerd kan worden op een weigering van de direct-belanghebbende om burgercompensatie aan te bieden. Uit de reeds eerder genoemde uitspraken van de ARRS van 21 augustus 1984, AB 542 en VzARRS 27 mei 1986, AB 1987, 267 blijkt volgens Damen dat de Afdeling deze optie openhoudt. Simon heeft in dit kader betoogd ${ }^{122}$ dat de belangen van derden ingevolge het gelijkheidsbeginsel op gelijke voet als de belangen van de directbelanghebbende dienen te worden meegewogen. Volgens Damen spreekt deze 'instructieve

119. L.J.A. Damen, Interventie bij het VAR-preadvies van J.H.W. de Planque, De mogelijkheden van administratieve rechters en de Kroon om het bestuur tot schadevergoeding te veroordelen, VAR-reeks 103 (verslag), p. 54 e.v.

120. De 'bestuurdencompensatie' komt ook wel voor in de vorm van de bevoegdhedenovereenkomst. Vgl. HR 13 april 1962, NJ 1964, 366, m.nt. HB (Kruseman). In dit verband dient men uiteraard uiterst alert te zijn op overheidshandelen in strijd met het verbod van détournement de pouvoir.

121. Vgl. de kritische analyse van deze rechtspraak door Van Male (paragraaf 7.2.15 van dit hoofdstuk) R.M. van Male, Marionette. Over het afwentelen van nadeelcompensatie bij beschikkingsvoorschrif, in: In de sfeer van administratief recht (Konijnenbelt-bundel), Utrecht 1994, p. $295 \mathrm{t} / \mathrm{m} 313$.

122. Zie zijn noot onder: VzARRS 27 mei 1986, AB 1987, 267. Simon is hier overigens later op terug gekomen. Vgl. zijn noot onder: Rb. Amsterdam, 15 maart 1990, AB 1991, 58. 
uitleg' op het eerste gezicht wel aan, maar er bestaat een groot risico dat het specialiteitsbeginsel te ver wordt opgerekt. Met name in gevallen waarin het betreffende privébelang geen enkel verband houdt met het algemene deelbelang dat aan de bevoegdheid ten grondslag ligt, moet 'burgercompensatie' dubieus worden geacht. Damen verzet zich tegen argumenten die pleiten voor 'burgercompensatie'. Zijn oordeel luidt: 'Ook de Afdeling rechtspraak is aan het legaliteitsbeginsel gebonden en kan niet buitenwettelijk plichten voor burgers scheppen.'

Ik vestig hier óók nog de aandacht op een andere 'VAR-interventie' van Damen die van belang is in het licht van het specialiteitsbeginsel. Het betreft de interventie bij het preadvies van Van Male uit 1992. ${ }^{123}$ In deze interventie pleit Damen ervoor om in het kader van het materiële besluitvormingsproces dat vooraf gaat aan een discretionaire bevoegdheidsuitoefening meer aandacht te besteden aan het 'belang'-begrip. Dit begrip dreigt volgens hem door het procestechnische 'belanghebbende'-begrip steeds verder onder te sneeuwen. Doordat de aandacht teveel gericht wordt op dit laatste begrip wordt volgens Damen te weinig aandacht besteed aan de verschillende nuances die de bestuurlijke besluitvorming inhoudelijk zouden moeten kenmerken. In dit kader benadrukte hij ook het belang van het specialiteitsbeginsel:

\begin{abstract}
'Zou de diversiteit van belangen niet veel meer centraal moeten staan en aldus niet ook een rol moeten spelen in de besluitvorming in de eerste fase? Het bestuursorgaan moet volgens de artikelen 3.2.1 en 3.2.3 Awb (de huidige art. 3:2 en 3:4 Awb R.J.N.S.) omtrent de relevante belangen de nodige kennis verzamelen en moet de rechtstreeks betrokken belangen in het algemeen tegen elkaar afwegen. Dit betekent dat het bestuursorgaan moet nagaan welke belangen relevant kunnen zijn en welke van die belangen kunnen en moeten worden meegewogen. Een en ander leidt er mijns inziens toe dat we veel meer aandacht zouden moeten besteden aan het specialiteitsbeginsel, dat Van Male eigenlijk maar betrekkelijk kort behandelt. Allerlei belangen die geen rol bij de besluitvorming mogen spelen, hoeven niet te worden gerepresenteerd, noch in de non-contentieuze, noch in de contentieuze fase' (curs. R.J.N.S.).
\end{abstract}

\title{
7.2.14 Nicolaï
}

Nicolaï heeft in verschillende publicaties ${ }^{124}$ een eigen theorie over het specialiteitsbeginsel en het proces van bestuurlijke belangenafweging ontwikkeld. Deze theorie, die een rechtspolitieke brug probeert te slaan tussen de 'precieze' en de 'rekkelijke' stroming, heeft o.m. invloed gehad op de denkbeelden van Konijnenbelt en van Van Male die hierna zullen worden besproken.

123. L.J.A. Damen, Interventie bij het VAR-preadvies van R.M. van Male, Enkele aspecten van het begrip belanghebbende in de Algemene wet bestuursrecht, VAR-reeks 108 (verslag), p. $25 \mathrm{t} / \mathrm{m} / 28$.

124. I.h.b. dient gewezen te worden op zijn 'kronieken abbb' in het Nederlands Tijdschrift voor Bestuursrecht. In deze kronieken besteedde Nicolar meer dan eens aandacht aan het specialiteitsbeginsel. Zie: NTB 1987, p. 95 t/m 96; NTB 1992/2, p. 63 t/m 65; NTB 1992/7 $241 \mathrm{t} / \mathrm{m}$ 243; NTB 1994/6, p. 186 en NTB 1995/4, p. $98 \mathrm{v} / \mathrm{m}$ 99. Verder kan worden gewezen op zijn proefschrift: P. Nicolaĭ, Beginselen van behoorlijk bestuur, diss. UvA, Deventer 1990, p. 350 en 351 en op: Nicolaï e.a., Bestuursrecht, vijfde herziene druk, Amsterdam 1994, p. 285-286 en Nicolaï e.a., Bestuursrecht, zesde geheel herziene druk, Amsterdam 1997, p. $443-446$. 
In zijn proefschrift ${ }^{125}$ vangt Nicolaï zijn bespreking van het specialiteitsbeginsel aan met een korte interpretatie van het verbod van détournement de pouvoir. 'Uit het verbod van d.d.p. vloeit voort, dat het bestuursorgaan zijn bevoegdheid niet mag aanwenden ter bescherming van andere algemene belangen dan die waarvan de behartiging aan hem is opgedragen. Een deugdelijke besluitvorming vereist dus, dat het orgaan nagaat welke algemene belangen ter behartiging zijn opgedragen en dat het deze - en geen andere - daadwerkelijk in de afweging betrekt.' Verder dient het bestuursorgaan vast te stellen welke bijzondere (lees: particuliere) belangen in het besluitvormingsproces dienen te worden betrokken. Ten aanzien van de belangen van de direct-belanghebbende gaat Nicolaï uit van het principe dat deze volledig dienen te worden meegewogen. Ook belangen van derden dienen in beginsel in de belangenafweging te worden betrokken. In dit verband onderscheidt hij een tweetal situaties. Allereerst is er de situatie waarin het belang van een derde 'opgaat' in het algemene (lees: publiekrechtelijke) belang dat de overheid in het gegeven geval (mede) heeft te beschermen. ${ }^{126}$ In deze situatie kunnen en moeten de bijzondere belangen van derden volledig worden meegewogen. Nicolaï wijkt hier niet af van de 'precieze' opvatting. Daarnaast is er de situatie waarin de opgedragen belangenbehartiging door de wetgever aan het bestuur niet mede in abstracto alle betrokken belangen van derden omvat. Nicolaï stelt vast dat het in dit verband van belang is hoe 'streng' men het specialiteitsbeginsel interpreteert.

In zijn 'Kroniek algemene beginselen van behoorlijk bestuur' in het Nederlands Tijdschrift voor Bestuursrecht ${ }^{127}$ komt Nicolaï in 1992 tot een eigen visie ten aanzien van het meewegen van (vreemde) belangen van derden. Nicolaï leidt uit de jurisprudentie van de Afdeling rechtspraak en de Afdeling geschillen van bestuur af dat het verbod van détournement de pouvoir en het specialiteitsbeginsel niet meebrengen dat concrete particuliere belangen van derden bij de besluitvorming geheel buiten beschouwing mogen worden gelaten. ${ }^{128}$ Deze belangen kunnen volgens hem niet buiten de besluitvorming worden gehouden, omdat het meewegen ervan een noodzakelijke stap is in het stelsel van nadeelcompensatie zoals dat door de Afdeling rechtspraak werd ontwikkeld. Op een bestuursorgaan rust nl. steeds de rechtsplicht om op eigen initiatief na te gaan in hoeverre belangen van derden worden geschaad en in hoeverre daaraan door compensatie tegemoet kan worden gekomen. ${ }^{129}$

In een latere Kroniek in hetzelfde jaar ${ }^{130}$ gaat hij een stap verder. Volgens Nicolaï kan alleen een aangepaste theorie tot een doorbreking van - wat hij noemt - de specialiteitsim-

125. P. Nicolaï, Beginselen van behoorlijk bestuur, a.w., p. 350 en 351.

126. Vgl. ook Nicolar e.a., Bestuursrecht (1994), a.w., p. 283.

127. P. Nicolai, Kronieken abbb, NTB 1992/7, p. 241 e.v.

128. P. Nicolaï, Kronieken abbb, NTB 1992/2, p. 64. In dit verband wijst hij i.h.b. op AGRS 28 mei 1991, AB 1991, 691 m.nt. JJIV. Zie voorts: ARRS 12 januari 1982, AB 1982, 299 m.nt. P.C.E. van Wijmen; ARRS 21 augustus 1984, AB 1984, 542 m.nt. P.C.E. van Wijmen; VzARRS 27 mei 1986, AB 1987, 267 m.nt. H.J. Simon. Deze uitspraken komen in hoofdstuk 8 uitvoerig aan bod.

129. P. Nicolar, Kronieken abbb, NTB 1992/2, p. 65.

130. P. Nicolar, Kronieken abbb, NTB 1992/7 241 Um 243. 
passe leiden. Nicolaï stelt voorop dat men alleen uit deze impasse kan geraken indien er een verzoening wordt bereikt tussen enerzijds het specialiteitsbeginsel en anderzijds de rechtsplicht van het bestuur om rekening te houden met bijzondere belangen van derdebelanghebbenden. Nicolaï legt resoluut de vinger op de zere plek. Ten aanzien van de positie van belangen van derden dient volgens hem gekozen te worden: of voor het specialiteitsbeginsel, of voor het uitgangspunt van integrale belangenafweging, d.w.z. voor het meewegen van alle particuliere belangen die geraakt worden door een besluit. Beide visies zijn volgens hem onverenigbaar, tenzij er concessies worden gedaan. Nicolaï kiest voor een concessie. Hij leest hiertoe in een bestuursbevoegdheid een tweetal 'deelbevoegdheden'. ${ }^{131}$ Op de eerste plaats is er de bevoegdheid tot het weigeren of verlenen (dan wel intrekken), die uitsluitend mag worden aangewend ter behartiging van de algemene (lees: publiekrechtelijke) belangen met het oog waarop een bevoegdheid is toegekend. Daarnaast dient een impliciete bevoegdheid tot het stellen van voorschriften te worden onderscheiden. Deze bevoegdheid moet geacht worden mede te zijn toegekend met het oog op de bescherming van de bijzondere belangen van particulieren. De impliciete bevoegdheid tot het stellen van voorschriften mag alleen niet worden uitgeoefend indien de wetgever op dit punt uitdrukkelijk beperkingen heeft gesteld. Door het inlezen van een impliciete bevoegdheid tot het stellen van voorschriften ter bescherming van belangen van particulieren (waaronder derden) wordt het spanningsveld tussen het meewegen van deze belangen en het verbod van détournement de pouvoir opgeheven.

Het afwegingsmodel van Nicolaï ziet er nu als volgt uit. Het bestuursorgaan gaat eerst na welke andere particuliere belangen dan die van de aanvrager rechtstreeks door een besluit (zullen) worden geraakt. Vervolgens gaat het bestuursorgaan na in hoeverre deze belangen worden geschaad, en komt zo mogelijk aan die belangen tegemoet door een alternatief besluit. Als onaanvaardbare schade aan de belangen van derden voorzienbaar is en daaraan tegemoet kan worden gekomen door het verbinden van voorschriften aan de vergunning die betrekking hebben op de wijze waarop de vergunde activiteit wordt verricht (gedragsvoorschriften), mag het bestuursorgaan deze voorschriften aan de vergunning verbinden. In dit verband geldt een tweetal randvoorwaarden. Zo dient er steeds voldoende gewicht te worden toegekend aan de belangen van de aanvrager (directbelanghebbende). Bovendien mogen de gedragsvoorschriften niet van zodanige aard zijn, dat deze in feite een verkapte weigering inhouden. Indien aan de gerechtvaardigde belangen van derden niet door middel van voorschriften tegemoet kan worden gekomen, dan dient het bestuursorgaan het aanbieden van bestuurscompensatie te overwegen voorzover de schade van de derde redelijkerwijze niet voor diens rekening behoort te blijven. ${ }^{132}$ Deze compensatieplicht wordt dan door het bestuur gedragen, en mag niet bij

131. Reeds eerder heb ik mij afgevraagd of het wel mogelijk is om - gelet op het legaliteitsbeginsel - een bestuursbevoegdheid 'te splitsen' zoals Nicolaĩ voorstaat. Zie: R.J.N. Schlossels, Wederkerigheid en specialiteit in het bestuursrecht, in: Eenzijdig en wederkerig?, Deventer 1995, p. 179.

132. Dit afwegingsmodel wordt ook verwoord in het handboek 'Bestuursrecht'. Nicolaï e.a., Bestuursrecht (1994), a.w., p. 285 en 286 en Nicolaï e.a., Bestuursrecht (1997), a.w., p. 445-446. 
vergunningvoorschrift op de vergunninghouder worden afgewenteld. Dit zou immers strijd met het legaliteitsbeginsel impliceren. ${ }^{133}$

Het handboek 'Bestuursrecht' ${ }^{134}$ plaatst de theorie van Nicolaï in een breder kader. Tevens wordt in de vijfde druk van dit boek nog eens verantwoord waarom Nicolail de keuze maakte voor een tussenstandpunt. De belangrijkste reden hiervoor is de eerdergenoemde jurisprudentie van de voormalige Afdeling rechtspraak van de Raad van State, waaruit blijkt dat op een bestuursorgaan steeds de plicht rust om bij de belangenafweging waar redelijkerwijs mogelijk óók de vraag te betrekken hoe kan worden voorkomen dat aan particuliere belangen van derden schade wordt toegebracht. ${ }^{135}$ Uit deze jurisprudentie volgt naar het oordeel van Nicolaï dat het verbod van détournement de pouvoir (en bijgevolg het specialiteitsbeginsel) niet zo streng mag worden uitgelegd dat in het geheel geen aandacht wordt besteed aan de betrokken belangen van derden, tenzij deze belangen in het kader van andere regelingen afdoende worden beschermd dan wel de wetgever ze (bewust) buiten de afweging heeft willen houden. Aan vreemde belangen van derden kan een bepaald gewicht worden toegekend door te aanvaarden dat deze belangen aanleiding kunnen geven tot het stellen van gedragsvoorschriften. Ofschoon zich in dit verband een spanningveld aftekent met het legaliteitsbeginsel, moet het stellen van voorschriften ter bescherming van vreemde derde-belangen worden aanvaard daar anders het meewegen van deze belangen - althans volgens Nicolaï - tot een dode letter zou worden. ${ }^{136}$

In 1995 voegt Nicolaï nog een verrassende dimensie toe aan zijn visie. Na geconstateerd te hebben dat Konijnenbelt op eenzelfde lijn zit stelt hij vast dat 'dit uitgangspunt in de literatuur brede ondersteuning vindt'. ${ }^{137}$ Kennelijk gesterkt door deze 'brede' ondersteuning zet hij een volgende stap. Nicolaï acht het nu niet langer uitgesloten dat - in de toekomst - de regeling van de 'horizontale' (privaatrechtelijke) verhouding tussen een vergunninghouder en derde-belanghebbenden geheel geacht kan worden te zijn besloten in de afweging door het bestuursorgaan. Hierdoor zou de vergunning, zo begrijp ik Nicolaï, volledig kunnen vrijwaren tegen separate acties van derden op grond van bijv. onrechtmatige daad of misbruik van recht. De taak om de verhouding tussen de vergunninghouder en derden juridisch af te bakenen zou dan volledig verschuiven naar het bestuursorgaan en de administratieve rechter. Het bestuursorgaan zou zich volgens Nicolaï dan kunnen ontwikke-

133. Zie ook: Nicolar e.a., Bestuursrecht (1994), a.w., p. 285 (noot 140) en Nicolar e.a, Bestuursrecht (1997), a.w., p. 444 (noot 1995). Vgl. Nicolals 'Kroniek abbb': NTB 1994/6, p. 186. Nicolar nadert op dit punt de visie van Messer en Heldeweg (zie paragraaf 7.2.10 van dit hoofdstuk) die de mogelijkheid van nadeelcompensatie i.v.m. vreemde derde-belangen openhouden, mits deze last door 'het algemeen belang' wordt gedragen.

134. Nicolar e.a., Bestuursrecht (1994), a.w., m.n. p. 282 t/m 285 en Nicolair e.a., Bestuursrecht (1997), a.w., p. $443-446$.

135. Zie o.m.: ARRS 12 januar: 1982, AB 1982, 299 m.nt. P.C.E. van Wijmen; ARRS 21 augustus 1984, AB 1984, 542 m.nt. P.C.E. van Wijmen en VzARRS 27 mei 1986, AB 1987, 267 m.nt. H.J. Simon. Deze jurisprudentie komt in hoofdstuk 8 nader aan de orde.

136. Nicolair e.a., Bestuursrecht (1997), a.w., p. 445.

137. P. Nicolar, Kroniek abbb, NTB 1995/4, p. 98 t/m 99. 
len tot een 'bemiddelaar', hetgeen hij een geheel nieuwe en verfrissende benadering acht. ${ }^{138}$

\subsubsection{Van Male}

Van Male heeft zijn visie over het specialiteitsbeginsel o.m. uiteen gezet in een preadvies voor de Verening voor Administratief Recht. ${ }^{139} \mathrm{Hij}$ benadert de vraag of bepaalde (particuliere) belangen rechtens beschermd zijn vanuit: (1) de grenzen van het afwegingskader van een bestuursbevoegdheid (legaliteit/specialiteit)en (2) de 'Schutznormleer'. De beantwoording van de vraag welke belangen het bestuur mag behartigen wordt volgens hem beheerst door het legaliteitsbeginsel. Aan de hand van de wettelijke regeling, de strekking van de bevoegdheid en andere wettelijke regelingen zal genoemde vraag dienen te worden beantwoord.

Het specialiteitsbeginsel stelt volgens Van Male geen grenzen aan het meewegen van de belangen van een direct-belanghebbende. Deze belangen zijn in de regel tegengesteld aan de algemene (lees: publiekrechtelijke) belangen van het bestuur. ${ }^{140} \mathrm{De}$ vraag in hoeverre rechtsbelangen van derden mogen worden meegewogen dient volgens Van Male te worden beantwoord aan de hand van de ruimte welke wordt gelaten door het wettelijke voorschrift waarop de bevoegdheid is gebaseerd. Geen bezwaar bestaat er volgens Van Male tegen het meewegen van zgn. 'parallelle' belangen van derden. Hiermee doelt Van Male op belangen van derden die gebaat zijn bij eenzelfde uitkomst van het besluitvormingsproces als het bestuur voor ogen staat. ${ }^{141}$ Indien de belangen van een derde buiten de wettelijke ruimte van een bevoegdheid vallen kunnen deze, zo begrijp ik Van Male, niet leiden tot een beperking van de vrijheid van de direct-belanghebbende. Dit vloeit echter niet direct voort uit het specialiteitsbeginsel. Dit beginsel richt zich immers primair op het buitensluiten van vreemde algemene belangen:

'De essentie van het specialiteitsbeginsel is derhalve dat het zich primair richt tot het bestuur, met dien verstande dat dit beperkt wordt in zijn bevoegdheid om belangen te beschermen. Het bestuur mag slechts dat aspect van het algemeen belang behartigen dat de desbetreffende wettelijke regeling beoogt te beschermen. ${ }^{142}$

Tot zover is de visie van Van Male helder. Vervolgens doet hij echter, geïnspireerd door de theorie van Nicolaï, enige concessies aan deze duidelijkheid. Van Male maakt nl. een onderscheid tussen het weigeren van een vergunning/ontheffing enerzijds, en het verlenen

138. Deze Kroniek vormde voor mij de aanleiding om vanuit rechtsstatelijk perspectief te reageren op deze gedachtenvorming. Zie: R.J.N. Schlossels, Het specialiteitsbeginsel en derde-belangen: Een frisse benadering of rechtsstatelijk drijfzand?, NTB 1996/3, p. 81 e.v. Zie verder hoofdstuk 9 van dit boek.

139. R.M. van Male, Enkele aspecten van het begrip belanghebbende in de Algemene wet bestuursrecht, VARreeks 108, Alphen aan den Rijn 1992, p. m.n. 76 e.v.

140. Van Male, VAR-reeks 108, a.w., p. 77.

141. Van Male, VAR-reeks 108, a.w., p. 77.

142. Van Male, VAR-reeks 108, a.w., p. 78. 
hiervan onder voorschriften en beperkingen anderzijds. In de situatie waarin een aanvraag wordt gehonoreerd zou het bestuur óók rekening mogen houden met de belangen van derden welke buiten het wettelijke kader vallen. De plicht om rekening te houden met de belangen van derden wordt door hem gebaseerd op het evenredigheidsbeginsel. Indien nadeelcompensatie gelet op bepaalde belangen van derden geïndiceerd is, kan dit leiden tot een compensatievoorschrift of een andere wijze van uitoefening van de bevoegdheid. Het probleem van het verbod van détournement de pouvoir lost Van Male praktisch op. Volgens Van Male is er nl. pas sprake van een rechtens relevante détournement de pouvoir indien het 'rekening houden met' de belangen van derden zou resulteren in een verkapte weigering. ${ }^{143}$ Het feit dat bepaalde belangen rechtens niet beschermd zijn kan volgens Van Male tenslotte óbk voortvloeien uit de 'Schutznorm- of relativiteitsleer'. Niet duidelijk wordt waarom Van Male deze situatie onderscheidt naast de werking van het specialiteitsbeginsel. ${ }^{144}$

In de Konijnenbelt-bundel ${ }^{145}$ wijdt Van Male vervolgens enkele fundamentele beschouwingen aan de positiefrechtelijke praktijk waarbij (in het kader van een vergunningverlening) nadeelcompensatieplichten door middel van 'compensatievoorschriften' op de direct-belanghebbende worden afgewenteld. Op grond van de zaak Nederlandse Spoorwegen/GS van Friesland ${ }^{146}$ en de bekende Paul Krugerbrug-jurisprudentie, stelt Van Male vast dat volgens geldend Nederlands bestuursrecht afwenteling van schadevergoeding door een bestuursorgaan op een direct-belanghebbende bij wijze van compensatievoorschrift geoorloofd is. ${ }^{147}$

Van Male stelt deze Afdelingsjurisprudentie vanuit een rechtsstatelijk oogpunt ter discussie. Allereerst fundeert hij de plicht tot het meewegen van particuliere belangen op het evenredigheidsbeginsel (artikel 3:4 lid $2 \mathrm{Awb}$ ). Ingevolge dit beginsel bestaat er, behoudens een contra-indicatie, een plicht om deze belangen in de bestuurlijke afweging te betrekken. Gelaedeerde derde-belangen, zo begrijp ik Van Male, mogen echter niet leiden tot een weigering van een vergunning of ontheffing, maar dienen onder omstandigheden wél op een adequate wijze te worden gecompenseerd. In dit verband kan gedacht worden aan passende overgangsmaatregelen, het onderzoeken van alternatieven of het toekennen van een schadevergoeding. ${ }^{148}$ Een compensatieplicht berust (in beginsel) exclusief op het verantwoordelijke bestuursorgaan. ${ }^{149}$ Indien er, gelet op de belangen van een derde, een

143. Van Male, VAR-reeks 108, a.w., p. 79.

144. Van Male bespreekt in dit verband de uitspraak van de Voorzitter van de Afdeling rechtspraak inzake EDAH-Brummen. VzARRS 29 december 1982, AB 1983, 305, m.nt. CLR (EDAH Brummen). Deze uitspraak zal in hoofdstuk 8 nog aan de orde komen.

145. R.M. van Male, Marionette. Over het afwentelen van nadeelcompensatie bij beschikkingsvoorschrift, in: In de sfeer van administratief recht (Konijnenbelt-bundel), Utrecht 1994, p. $295 \mathrm{t} / \mathrm{m} 313$.

146. Zie: VzARRS 29 oktober 1992, AB 1993, 183, m.nt. RMvM. Zie in dit kader ook paragraaf 8.4.5 van dit boek.

147. R.M. van Male, Marionette, a.w., p. 296. Zie in dit verband ook zijn oratie. R.M. van Male, Onvoltooid recht. Over rechtsbetrekking, bestuursrecht en bestuursprocesrecht, oratie EUR, Zwolle 1993, p. 18-21.

148. R.M. van Male, Marionette, a.w., p. 299.

149. R.M. van Male, Marionette, a.w., p. 300. 
compensatieplicht dient te worden aangenomen dan mag deze compensatielast niet zonder meer worden 'afgewenteld' op de direct-belanghebbende. Het legaliteitsbeginsel staat hieraan volgens Van Male nl. in de weg. De enkele omstandigheid dat derde-belangen in de afweging mogen (of moeten) worden betrokken, brengt bijgevolg nog niet met zich dat het bestuursorgaan (zonder wettelijke basis) aan het besluit belastende voorschriften voor de direct-belanghebbende mag verbinden. Buitenwettelijke compensatievoorschriften zijn volgens Van Male in strijd met artikel 104 van de Grondwet. ${ }^{150}$ De eerdergenoemde jurisprudentie lijkt de grenzen van hetgeen gelet op het legaliteitsbeginsel toelaatbaar moet worden geacht te overschrijden. De 'compensatie'- jurisprudentie is volgens Van Male temeer bedenkelijk indien deze wordt vergeleken met de standaardjurisprudentie van de Afdeling rechtspraak inzake het verbinden van financiële voorschriften aan beschikkingen. ${ }^{151}$ Financiële voorschriften zijn ingevolge deze jurisprudentie slechts toelaatbaar indien het voorschrift verband houdt met de doelstelling van de wettelijke bepaling, in het algemeen belang noodzakelijk is, en er géén andere (met meer waarborgen omklede) weg is waarlangs een tegemoetkoming of compensatie kan worden verlangd. ${ }^{152}$ Financiële voorschriften welke ertoe strekken om derde-belangen te compenseren zullen volgens Van Male meestal geen rechtstreeks verband houden met het doel van de wettelijke regeling en derhalve op gespannen voet staan met het verbod van détournement de pouvoir. ${ }^{153}$

Dit standpunt van Van Male is belangwekkend. In de eerste plaats wordt de vinger op de zere plek van de 'Paul Krugerbrug'-jurisprudentie gelegd. Van Male schetst op een heldere wijze het rechtsstatelijke spanningsveld tussen het legaliteitsbeginsel, het verbod van détournement de pouvoir en het rechtszekerheidsbeginsel enerzijds, en de praktijk van het afdwingen van 'onzuivere schadecompensatie' bij beschikkingsvoorschrift anderzijds.

Vervolgens lijkt Van Male een onderscheid te maken tussen het meewegen van vreemde derde-belangen $\mathrm{sec}$, en het vertalen van dergelijke belangen in belastende voorschriften voor de direct-belanghebbende. Ofschoon Van Male uitsluitend kritiek uit op 'compensatievoorschriften' is zijn visie naar mijn oordeel ook van belang voor andere belastende voorschriften die vreemde belangen van derden beogen te beschermen. Het lijkt niet meer dan logisch om ook ten aanzien van dergelijke voorschriften tot een spanningsveld met het legaliteitsbeginsel (en specialiteitsbeginsel) te concluderen. Dat zou dan kunnen impliceren dat gelaedeerde derde-belangen welke niet samenvallen met het speciale algemene belang

150. R.M. van Male, Marionette, a.w., p. 301.

151. Ik wijs erop dat deze vergelijking door Van Male m.i. niet geheel opgaat. De jurisprudentie inzake financiele voorwaarden van de Afdeling (bestuurs)rechtspraak zag (ziet) primair op de relatie burgerbestuur (bestuurdencompensatie), terwijl de 'afwentelingsproblematiek' ziet op de relatie burger-burger (burgercompensatic).

152. Vgl. R.M. van Male, Marionette, a.w., p. 302. Een standaarduitspraak in deze is ARRS 30 augustus 1985, AB 1986, 243, m.nt. D.A. Lubach. Zie voor verdere jurisprudentie inzake 'financiêle voorschriften' hoofdstuk 8. Overigens wijst Van Male erop dat deze standaardjurisprudentie slechts ten dele leidraad kan zijn met het oog op de onderhavige problematiek. Deze jurisprudentie ziet immers op de relatie bestuursorgaan-burger en niet op de relatie burger-burger. Vgl. in dit verband ook de eerderbesproken visie van Damen over het verschijnsel 'burgercompensatie' (paragraaf 7.2.13).

153. R.M. van Male, Marionette, a.w., p. 303. 
van een regeling wél door het bestuursorgaan zouden kunnen worden gecompenseerd, maar géén aanleiding kunnen vormen voor het verbinden van belastende voorschriften aan een beschikking.

\subsubsection{Drupsteen}

Drupsteen besteedt in de Konijnenbelt-bundel ${ }^{154}$ aandacht aan de betekenis van artikel 3:4 lid $1 \mathrm{Awb}$. Na in algemene zin kritiek te hebben geuit op de snelle totstandkoming van de Algemene wet bestuursrecht en het oppervlakkige karakter van de memorie van toelichting, richt hij zijn pijlen op het genoemde artikel. Ofschoon het eerste lid van artikel 3:4 Awb er op het eerste gezicht vanzelfsprekend en weinig problematisch uitziet, roept het artikel volgens Drupsteen meer vragen op dan het beantwoordt. ${ }^{155}$ Dit artikellid bevat volgens hem $\mathrm{nl}$. een geheel eigen problematiek, die in de memorie van toelichting vrijwel niet aan bod komt en tijdens de parlementaire behandeling niet aan de orde is gesteld. ${ }^{156}$ Uit de verdere inhoud van zijn betoog blijkt dat Drupsteen hier doelt op de problematiek inzake het specialiteitsbeginsel. ${ }^{157}$

Eerst loopt hij de verschillende visies in de literatuur nog eens langs. Hierbij stelt hij vast dat de opvatting van Stellinga geen steun heeft gevonden en niet het positieve recht weergeeft. Of het pleidooi van Stroink en De Waard door artikel 3:4 lid 1 Awb achterhaald is laat Drupsteen in het midden, maar hij stelt wél vast dat men er met het doel van de regeling alleen niet komt. Een ruimere benadering is noodzakelijk. ${ }^{158}$ In dit verband lijkt hij zich niet te willen aansluiten bij bijv. de opvattingen van Tonnaer, omdat hij betwijfelt of de Awb-wetgever in artikel 3:4 lid 1 het specialiteitsbeginsel heeft willen doorbreken en bijgevolg een keuze maakte voor het beginsel van materiële integraliteit. ${ }^{159}$ Ook de visie van Nicolaï kan hem niet echt bekoren. Ofschoon deze visie volgens Drupsteen verhelderend werkt kan zij onvoldoende verklaren waarom ingevolge de jurisprudentie (vreemde) derde-belangen soms wél en soms niet in de belangenafweging dienen te worden betrokken. Bovendien biedt de theorie van Nicolaï volgens Drupsteen geen oplossing indien een belang van een derde zeer zwaarwegend van aard is. Volgens Nicolaï mag (en moet) een dergelijk belang immers in de afweging worden betrokken, maar mag dit niet leiden tot een weigering. Derhalve kan een zodanig belang niet het gewicht krijgen dat het verdient. Een overtuigend voorbeeld van een dergelijke situatie kan Drupsteen echter moeilijk bedenken.

154. Th. G. Drupsteen, En de gemeenteraad maar belangen afwegen, in: In de sfeer van administratief recht (Konijnenbelt-bundel), Utrecht 1994, p. 69 t/m 82.

155. Th. G. Drupsteen, En de gemeenteraad maar belangen afwegen, a.w., p. 71.

156. In dit verband benadrukt Drupsteen dat het hier niet uitsluitend om een interessante academische discussie gaat. De vraag in hoeverre belangen van derden in een afweging dienen te worden betrokken, hangt volgens hem direct samen met de verplichting om hetzij in natura, hetzij in geld bestuurscompensatie aan te bieden. Th. G. Drupsteen, En de gemeenteraad maar belangen afwegen, a.w., p. 82.

157. Th. G. Drupsteen, En de gemeenteraad maar belangen afwegen, a.w., p. 74 e.v.

158. Th. G. Drupsteen, En de gemeenteraad maar belangen afwegen, a.w., p. 77.

159. Th. G. Drupsteen, En de gemeenteraad maar belangen afwegen, a.w., p. 79. 
Drupsteen houdt het uiteindelijk maar op een visie, die een soort 'mix' is van de reeds bestaande opvattingen. Zijn opvatting houdt in dat alle belangen van de aanvrager in de belangenafweging dienen te worden betrokken. Belangen van derden die door de besluitvorming in de knel komen moeten eveneens in de belangenafweging worden betrokken, tenzij (1) deze belangen uitdrukkelijk worden beschermd in andere regelingen, (2) de betreffende regeling wat doel of strekking betreft een duidelijk houvast biedt waarom derde-belangen niet deel uit behoeven of mogen maken van de afweging, of (3) deze belangen voor de overheid niet beschermenswaardig zijn. Het feit dat een belang in de afweging mag worden betrokken impliceert overigens nog niet dat op grond van een dergelijk belang ook mag worden geweigerd. Tot slot stelt Drupsteen zich terughoudend op ten aanzien van het meewegen van vreemde algemene (lees: publiekrechtelijke) belangen. Het is volgens Drupsteen kennelijk (exclusief) aan de wetgever om te bepalen welke algemene belangen in de afweging mogen (en moeten) worden betrokken. ${ }^{160}$

\subsubsection{Konijnenbelt}

Konijnenbelt ${ }^{161}$ heeft, zo lijkt het, aansluiting gezocht bij de visie van Nicolaï. Indien de regeling weigeringsgronden aangeeft of expliciet aangeeft welke voorschriften aan een vergunning mogen worden verbonden, dan dient het bestuursorgaan zich daaraan te houden. De wetgever kan het afwegingskader van een bestuursbevoegdheid ruim stellen of juist beperken. De 'id quod'-vraag ziet in dit kader op het weigeren of verlenen ten principale. Bij deze vraag mogen volgens Konijnenbelt uitsluitend het algemene belang waar de regeling op ziet (d.w.z. het speciale publiekrechtelijke belang) en de belangen van de direct-belanghebbende tegen elkaar worden afgewogen. De 'id quod' vraag spitst zich primair toe op de vraag of $f$ het gevraagde vergund kan worden.

Indien deze 'id quod'-vraag positief kan worden beantwoord dient vervolgens de 'modus quo'-vraag te worden beantwoord. Het betreft hier de vraag naar de randvoorwaarden voor het vergunde handelen. Hierbij dient volgens Konijnenbelt een afweging plaats te vinden tussen de belangen van de direct-belanghebbende tegenover de rechtstreeks betrokken belangen van andere belanghebbenden, tenzij uit de wettelijke regeling uiteraard iets anders voortvloeit. In dit kader mogen met het oog op belangen van derden in beginsel ó́k voorschriften en beperkingen ten laste van de direct-belanghebbende worden opgelegd. Dit is slechts anders indien het betreffende belang reeds in een andere wettelijke regeling bescherming heeft gevonden. In de meest recente druk van Van Wijk/Konijnenbelt wordt het standpunt ingenomen dat de hiervoor geschetste benadering in de lijn ligt van artikel 3:4 lid 1 Awb en de jurisprudentie. ${ }^{162}$

160. Th. G. Drupsteen, En de gemeenteraad maar belangen afwegen, a.w., p. 82.

161. Van Wijk/Konijnenbelt/Van Male, Hoofdstukken van administratief recht, negende druk, Utrecht 1994, p. $424 \mathrm{t} / \mathrm{m}$ 427. In de tiende druk van dit handboek is de benadering nagenoeg identiek. Van Wijk/Konijnenbelt/Van Male, Hoofdstukken van administratief recht, tiende geheel herziene druk, 's-Gravenhage 1997, p. 334-335.

162. Van Wijk/Konijnenbelt/Van Male, Hoofdstukken van administratief recht (1997), p. 335-336. 
In zijn afscheidsrede als hoogleraar bestuursrecht aan de Universiteit van Amsterdam heeft Konijnenbelt nog enige interessante aanvullende beschouwingen gewijd aan het specialiteitsbeginsel. Ofschoon deze beschouwingen niet hebben geleid tot nieuwe theorievorming kunnen zij hier niet onvermeld blijven. ${ }^{163}$ Aan de hand van een gefingeerde casus $^{164}$, waarbij een vergunningverlening ingevolge het Algemeen reglement van politie voor rivieren en Rijkskanalen in het geding is, wordt de specialiteitsproblematiek door hem op een originele wijze in kaart gebracht. Na eerst een beeld te hebben geschetst van de verschillende belangen die bij een vergunningverlening betrokken kunnen zijn, worden deze door hem ingedeeld in een drietal hoofdgroepen: (1) belangen die de kans op vergunningverlening kunnen vergroten, (2) belangen die de kans op een weigering vergroten en (3) belangen die invloed hebben op de voorschriften waaronder vergunningverlening plaatsvindt.

De vraag naar de betekenis van het specialiteitsbeginsel formuleert Konijnenbelt vervolgens tegen de achtergrond van het bestuursbevoegdheidsbegrip en het legaliteitsbeginsel. Een wettelijke regeling die een vergunningstelsel in het leven roept, doet dat - uitdrukkelijk of impliciet - altijd om daarmee speciale belangen te beschermen. De vraag naar de betekenis van het specialiteitsbeginsel ziet nu volgens Konijnenbelt op de vraag hoe exclusief de vergunningbevoegdheid aan deze belangen (d.w.z. het doel van de regeling) is gebonden. Dit doel is bepalend voor de vraag in hoeverre door het bestuur inbreuk mag worden gemaakt op de vrijheid van rechtssubjecten. Hoe strikter het specialiteitsbeginsel wordt opgevat, des te sterker is de doorwerking van het legaliteitsbeginsel. ${ }^{165}$ Deze (klassieke) legaliteitsopvatting brengt volgens Konijnenbelt met zich dat het specialiteitsbeginsel zich niet verzet tegen het meewegen van belangen die de kans op vergunningverlening vergroten. Door vergunningverlening wordt immers de oorspronkelijke vrijheid van de aanvrager hersteld. Uit de context van Konijnenbelts betoog kan worden afgeleid dat hij in dit verband primair particuliere belangen van de aanvrager op het oog heeft, en géén algemene belangen die buiten het kader van de betreffende wettelijke regeling zijn gelegen.

Vervolgens concentreert Konijnenbelt zich op de vraag in hoeverre het bestuur rekening kan houden met belangen die buiten de betreffende wettelijke regeling zijn gelegen, en bovendien voor de aanvrager de kans op een weigering vergroten. In dit verband hanteert hij een matrix aan de hand waarvan hij belangen indeelt. De meest interessante onderscheiding die hij hierbij maakt is die tussen belangen: (1) die in geen enkele administratiefrechtelijke regeling worden beschermd, (2) die in een wettelijke regeling worden beschermd welke door een ander bestuursorgaan wordt uitgevoerd, en (3) die in een andere wettelijke

163. Deze rede is in bewerkte vorm gepubliceerd in het Nederlands Tijdschrift voor Bestuursrecht. W. Konijnenbelt, Het specialiteitsbeginsel in het Nederlandse en het Franse administratieve recht, NTB $1994 / 10$, p. 305 e.v.

164. Geïnspireerd door VzARRS 27 mei 1986, AB 1987, 267 m.nt. H.J. Simon en ARRS 5 juni 1991, AB 1992, 444, m.nt. H.J. Simon.

165. W. Konijnenbelt, Het specialiteitsbeginsel in het Nederlandse en het Franse administratieve recht, a.w., p. 306. 
regeling worden beschermd die wél door het zelfde bestuursorgaan wordt uitgevoerd. Deze onderverdeling loopt dwars door de indeling in algemene en particuliere belangen. Tegen het meewegen van belangen uit alledrie de categorieën kunnen volgens Konijnenbelt vanuit theoretisch oogpunt steekhoudende bezwaren worden ingebracht. ${ }^{166}$ In de eerste situatie zou het bestuur belangen in de afweging betrekken die op geen enkele wijze aan het bestuur zijn toevertrouwd. De vergunningbevoegdheid zou dan volgens Konijnenbelt slechts een willekeurig aangrijpingspunt zijn om inbreuk te maken op de vrijheid van de aanvrager. In de tweede situatie zal het laten meewegen van het belang met zich brengen dat het bestuursorgaan zich begeeft op het exclusieve bevoegdheidsterrein van een ander bestuursorgaan. Er zou derhalve sprake zijn van een niet toelaatbare doorkruising van de wettelijke bevoegdhedenstructuur. Ook in het laatste geval kunnen zich problemen voordoen, die volgens Konijnenbelt tot détournement de procedure kunnen leiden. Iedere bestuursbevoegdheid is immers ingekaderd in zijn eigen procedurele structuur.

Al deze bezwaren steunen de visie van de 'preciezen' of 'orthodoxen'. Desalniettemin lijkt Konijnenbelt vanuit het oogpunt van de burger niet voor deze opvatting te willen kiezen. Belangrijkste bezwaar tegen de 'precieze' opvatting is volgens hem nl. dat dit standpunt leidt tot situaties die voor de niet-jurist niet te vatten zijn. Voor de burger is het immers onduidelijk waarom bepaalde belangen wél mogen worden meegewogen en andere juist niet. Konijnenbelt laat zich in dit verband de volgende, veelzeggende, uitspraak ontvallen:

'Samenvattend kun je zeggen dat het vasthouden aan een orthodoxe opvatting van het specialiteitsbeginsel maatschappelijk moeilijk verkoopbaar is. (..) Daarom zijn er theoriečn ontwikkeld die een middenkoers bepleiten, waarmee de scherpe kantjes van het specialiteitsbeginsel worden afgeslepen zonder dat èrg fundamenteel wordt gezondigd tegen het legaliteitsbeginsel. Laveren tussen Scylla en Charybdis. ${ }^{167}$

Konijnenbelt doelt in dit verband op de eerder besproken theorieën van Helder en Jue, Nicolaï en Simon. Al deze visies gaan volgens hem mank aan een zekere inbreuk op het legaliteitsbeginsel. Maar hier staat volgens Konijnenbelt een tweetal belangrijke winstpunten tegenover. In de eerste plaats worden voor de burger 'niet uit te leggen beslissingen' vermeden. In de tweede plaats kan door middel van een tussenstandpunt een mogelijkheid worden opengehouden voor nadeelcompensatie-uitspraken in de sfeer van de Paul Krugerbrug-jurisprudentie. ${ }^{168}$ Vanuit een 'precieze' optiek is deze jurisprudentie - volgens Konijnenbelt - nu eenmaal moeilijk te verklaren.

166. W. Konijnenbelt, Het specialiteitsbeginsel in het Nederlandse en het Franse administratieve recht, a.w., p. 308.

167. W. Konijnenbelt, Het specialiteitsbeginsel in het Nederlandse en het Franse administratieve recht, a.w., p. 308.

168. Vgl. ARRS 12 januari 1982, AB 1982, 299, m.nt. Van Wijmen. Deze jurisprudentie zal in hoofdstuk 8 aan de orde komen. 


\subsubsection{Van Buuren}

Dat de theoretische discussies over het specialiteitsbeginsel ook na de inwerkingtreding van artikel 3:4 lid 1 Awb werden voortgezet blijkt uit een 'Awb-notitie' van Van Buuren in het Nederlands Juristenblad. ${ }^{169}$ Van Buuren opent deze Awb-notitie met de opmerking dat het specialiteitsbeginsel één van de meest omstreden beginselen is binnen het bestuursrecht. De strijd spitst zich met name toe op de positie van (vreemde) derde-belangen binnen het proces van bestuurlijke belangenafweging. Doordat de rechtspraak ten aanzien van de betekenis van genoemd beginsel niet vast is, blijven de auteurs verdeeld in 'rekkelijke' en 'precieze' stromingen. Volgens Van Buuren kan uit artikel 3:4 lid 1 Awb, anders dan Konijnenbelt betoogde, géén verwerping van de precieze visie worden afgeleid. Verwerping van de precieze visie impliceert in wezen niets minder dan een (gedeeltelijke) verwerping van het legaliteitsbeginsel en dat heeft de Awb-wetgever volgens Van Buuren niet beoogd. Hij wijst er in dit kader op dat in de parlementaire geschiedenis van artikel 3:4 lid $1 \mathrm{Awb}$ het woord 'specialiteitsbeginsel' niet is gevallen. Van Buuren acht bijgevolg de 'precieze' visie ook onder de vigeur van de Algemene wet bestuursrecht goed verdedigbaar:

'Zelf neig ik eigenlijk tot die opvatting. De preciezen hebben namelijk het legaliteitsbeginsel (waaruit voortvloeit dat iedere bestuursbevoegdheid doelgebonden is) aan hun zijde en het is niet zonder meer aannemelijk dat de Awb-wetgever daarop een beperking heeft willen aanbrengen zonder daarover ook maar een opmerking te maken.'

De betekenis die aan artikel 3:4 lid $1 \mathrm{Awb}$ dient te worden toegekend is volgens hem de volgende. Allereerst benadrukt het betreffende artikel dat het bestuursorgaan met alle belangen van de direct-belanghebbende rekening dient te houden. Daarnaast scherpt het artikel het bestuursorgaan in, rekening te houden met die belangen van derden die niet buiten de 'range' van te beschermen belangen vallen.

\subsubsection{Tak}

Tak heeft in een aantal publicaties direct ${ }^{170}-$ dan wel indirect ${ }^{171}-$ zijn visie ten aanzien van bestuursbevoegdheid, bestuurlijke besluitvorming en het specialiteitsbeginsel verwoord. In zijn handboek over het Nederlandse bestuursprocesrecht belicht Tak dit beginsel op een aantal plaatsen. Tak stelt de doelgebonden bestuursbevoegdheid centraal en verbindt hieraan de consequentie dat een bestuursorgaan op basis van een dergelijke bevoegdheid enkel beoogde rechtsgevolgen in het leven kan roepen. Hierbij maakt Tak géén principieel onderscheid tussen 'Eingriffs-' en 'Leistungsverwaltung'. ${ }^{172}$ Al het overheidshandelen dient doelgebonden van aard te zijn alsmede dienstig aan het algemeen belang. Tak positioneert in dit kader publieke bevoegdheid scherp ten opzichte van privaatrechtelijke bevoegdheid:

169. P. van Buuren, Awb-notities (11), Belangen afwegen en het specialiteitsbeginsel, NJB 1995/12, p. 460 en 461. 
'Hiertegenover (staat R.J.N.S.) het publiekrecht als gesloten, specifiek-wettelijk bevoegdhedenarsenaal, onvrij en ongelijk, immers uiteindelijk, na horen en inspraak, altijd eenzijdig uit te oefenen door de overheid en daarbij steeds gedetermineerd door de doelstelling van het algemeen belang dat met de specifieke bevoegdheidstoekenning is beoogd te behartigen. $\mathrm{Zo}_{0}$ is de publiekrechtelijke bevoegdheid altijd door het specialiteitsbeginsel en het verbod van détoumement de pouvoir ingesnoerd in het specifieke wettelijke keurslijf, met als kompas dus de "richtige" uitvoering van de wet. ${ }^{173}$

De vraag welke gevolgen 'mogen worden beoogd' dient volgens Tak exclusief beantwoord te worden in het licht van het specialiteitsbeginsel, dat inhoudt dat enkel de door de specifieke wet beoogde publiekrechtelijke belangen een rol mogen spelen. ${ }^{174}$ Aan dit uitgangspunt verbindt Tak een aantal gevolgen. Belangen dienen volgens hem allereerst onderscheiden te worden in belangen die door het bestuur mogen worden behartigd en andere bij een publieke bevoegdheidsuitoefening betrokken belangen. Uitsluitend de eerste - nl. de door de specifieke wet beschermde belangen - zijn gerelateerd aan het besluit als rechtshandeling. Doordat de publieke bevoegdheidsuitoefening zich nu primair manifesteert in de gedaante van een publiekrechtelijke rechtshandeling (besluit) kan dit volgens Tak, bij een strikte uitleg van het specialiteitsbeginsel, ertoe leiden dat door het bestuur én de rechter niet met alle reële gevolgen van de bevoegdheidsuitoefening rekening kan worden gehouden. ${ }^{175}$ Particuliere belangen die vreemd zijn aan deze bevoegdheidsuitoefening - d.w.z. de belangen die niet door de speciale wet worden beschermd - zouden tengevolge hiervan enkel bescherming vinden in het privaatrecht. ${ }^{176}$ In het licht van deze 'precies' gekleurde opvatting, waarbij de bevoegdheidsleer centraal staat, is het begrijpelijk dat Tak vraagtekens plaatst bij het 'afwegen' van het speciale publiekrechtelijke belang tegen de betrokken particuliere belangen.

Indien echter wordt aangenomen dat uitsluitend de speciale publiekrechtelijke belangen door het bestuur mogen worden behartigd, resteert de vraag in hoeverre andere belangen nog een rol mogen spelen in de bestuurlijke besluitvorming. Verdedigbaar acht Tak een

170. Zie: A.Q.C. Tak, Hoofdlijnen van het Nederlands bestuursprocesrecht, derde druk, Zwolle 1995, o.m. p. 91, 11, 127, 156, 162, 177, 188 en 419; A.Q.C. Tak, De overheid in het burgerlijk recht, 's-Gravenhage 1997, o.m. p. 26-27, 104 en 111; A.Q.C. Tak, Het moment X, TvO 1990/6, p. 135; A.Q.C. Tak, Terugtocht van twee wegen, NTB 1989/9/10, i.h.b. p. 304 V/m 305; Zie ook A.Q.C. Tak, Overheid en Burgerlijk Wetboek. Naar een invullende rechtsleer, Recht en kritiek 1993/3, p. 180 en de publicatie samen met Simon: Het BW als 'zwart gat'. De onttakeling van het publiekrecht door een 'gemene' rechter, NTBR 1994/8, i.h.b. p. 178.

171. Zie over het karakter van het bestuurlijke besluitvormingsproces: A.Q.C. Tak, De ongewenste discussie, in: Nieuw bestuursprocesrecht (red. J.B.J.M. ten Berge, F.A.M. Stroink, A.Q.C. Tak, B.W.N. de Waard en R.J.G.M. Widdershoven), Deventer 1992, i.h.b. p. 72 e.v. Zie over de visie van Tak inzake overheidsbevoegdheid ook de NJB-bijdrage die hij samen met Teunissen publiceerde: J.M.H.F. Teunissen en A.Q.C. Tak, Recht ist was der Umwelt nutzt?, NJB 1994/18, i.h.b. p. 610 en 613.

172. A.Q.C. Tak, De overheid in het burgerlijk recht, a.w., p. 26.

173. A.Q.C. Tak, De overheid in het burgerlijk recht, a.w., p. 111.

174. A.Q.C. Tak, Hoofdlijnen van het Nederlands bestuursprocesrecht, a.w., p. 90.

175. A.Q.C. Tak, Hoofdlijnen van het Nederlands bestuursprocesrecht, a.w., p. 91.

176. A.Q.C. Tak, Hoofdlijnen van het Nederlands bestuursprocesrecht, a.w., p. 162. 
opvatting waarbij het bestuur met deze laatstgenoemde 'kruisende' belangen rekening mag en moet houden in die zin dat deze zoveel mogelijk worden ontzien. Hiermee acht Tak evenwel het probleem van de verenigbaarheid van een algemene belangenafweging met een specifieke bevoegdheid vanuit theoretisch oogpunt niet bevredigend opgelost. ${ }^{177}$

Wel geeft hij een hint in de richting van een nadere onderbouwing. Van belang is $\mathrm{nl}$. dat Tak benadrukt dat het specialiteitsbeginsel uitsluitend relevant is ten aanzien van de uitoefening van een bestuursbevoegdheid als publiekrechtelijke rechtshandeling (het rechtsvormingsaspect). Het rechtshandelen van het bestuur heeft als rechtsfeit evenwel niet enkel beoogde rechtsgevolgen, maar ók niet beoogde (rechts)gevolgen. De consequenties die Tak hieraan verbindt dienen gepositioneerd te worden tegen de achtergrond van zijn denkbeelden over de grondslag van bestuursbevoegdheid en bestuurlijke besluitvorming. Zoals in hoofdstuk 4 werd aangegeven fundeert Tak bestuursbevoegdheid in een pré-wettelijke grondslag of rechtsgrond. Het rechtsstatelijk legaliteitsvereiste ziet hij bijgevolg als een belangrijk hulpmiddel - doch niet als een noodzakelijk vereiste - om publieke bevoegdheid te 'legaliseren'. ${ }^{178}$ De legitimatie van specifieke overheidsmacht, d.w.z. macht in de vorm van specifieke bevoegdheden ${ }^{179}$, zoekt Tak primair in het democratisch postulaat én in het rechtszekerheidsbeginsel. Het specialiteitsbeginsel bewaakt volgens hem - als zelfstandig beginsel - de gezagslijn tussen de volkswil en de bestuurlijke machtsuitoefening. Het beginsel brengt met zich dat aan de burger uitsluitend lasten mogen worden opgelegd die in het kader van de democratische bevoegdheidstoekenning werden beoogd, en géén andere. ${ }^{180}$ De gebondenheid van het bestuur aan specifieke bevoegdheidsgrondslagen geldt met het oog op het rechtsvormingsaspect (het publieke rechtshandelen). Deze gebondenheid ontslaat een overheidsorgaan er volgens Tak echter niet van om zich ook steeds rekenschap te geven van de algemene 'bevoegdheden' en plichten die inherent zijn aan de ambtsfunctie. Hiermee doelt hij in het bijzonder op de materiële rechtsgrond voor alle overheidsactiviteit, $\mathrm{nl}$. het handelen in het algemeen belang van de publieke rechtsgemeenschap. ${ }^{181} \mathrm{Zie}$ ik het goed, dan regeren hier volgens Tak in ieder geval de eisen die voortvloeien uit het evenredigheidsbeginsel, het égalité-beginsel en het verbod van willekeur. ${ }^{182}$ Tak leidt uit deze 'materiële bevoegdheid' de plicht voor het bestuur af om zich tijdens het bestuurlijke besluitvormingsproces (waar mogelijk) daadwerkelijk rekenschap te geven van alle betrokken belangen. Om deze plicht te kunnen vervullen is

177. A.Q.C. Tak, Hoofdlijnen van het Nederlands bestuursprocesrecht, a.w., p. 111 .

178. Zie bijv. A.Q.C. Tak, Het moment X, a.w., p. 134.

179. Teunissen en Tak omschrijven specifieke overheidsmacht als de macht die krachtens het objectieve recht aan de overheid toekomt om op grond van verleende publiekrechtelijke bevoegdheden openbare belangen te behartigen. Voorzover de openbare belangbehartiging met zich brengt dat aan burgers lasten kunnen worden opgelegd, is vereist dat de machtsuitoefening plaatsvindt krachtens door het objectieve recht (en meer i.h.b. door de wet) begrensde specifieke competenties; daarmee wordt voldaan aan het rechtszekerheidsbeginsel, aan het gelijkheidsbeginsel en - als het goed is - ook aan de democratische legitimatie-eis. Zie: J.M.F.H. Teunissen en A.Q.C. Tak, Recht ist was der Umwelt nutzt?, NJB 1994/18, p. 610 en 613.

180. A.Q.C. Tak, Het moment X, a.w., 1990/6, p. 135.

181. A.Q.C. Tak, Het moment X, a.w., 1990/6, p. 135.

182. Zie: A.Q.C. Tak, De overheid in het burgerlijk recht, a.w., p. 438-439. 
vereist dat het bestuursorgaan de (rechtstreeks) betrokken belangposities tijdens de bestuurlijke besluitvormingsfase nauwkeurig in beeld brengt. ${ }^{183}$ Alhoewel 'bevoegdheidsvreemde' belangen in het kader van de objectieve bevoegdheidsuitoefening niet door het bestuur mogen worden behartigd, stelt Tak zich op het standpunt dat desalniettemin financiële compensatie van belangen door het bestuur soms aangewezen kan zijn om 'relatieve (of geïndividualiseerde) onrechtmatigheid' ${ }^{184}$ ten opzichte van rechtssubjecten te voorkomen. Een compensatieplicht komt in zicht indien de betrokken belangposities door de feitelijke gevolgen van besluitvorming onevenredig en onder schending van de égalité-norm benadeeld dreigen te worden. ${ }^{185}$ Tak relateert bijgevolg de plicht tot bestuurscompensatie niet aan het specialiteitsbeginsel. ${ }^{186}$

\subsubsection{Van Hall}

In de omvangrijke oratie van Van Hall ${ }^{187}$ uit 1995 staat het spanningsveld tussen integraal waterbeheer door waterschappen (het doelmatigheidsaspect) en het specialiteitsbeginsel (rechtsstatelijkheid) centraal. Na de veranderende functie van wetgeving in de twintigste eeuw te hebben belicht, schetst Van Hall de beperkingen die het specialiteitsbeginsel met zich brengt gelet op de functionele taakstelling van waterschappen. Het belangenafwegingsproces vindt daarom in ieder geval zijn grenzen in de taakstelling van het waterschap. ${ }^{188}$ Alleen belangen die behoren tot de huishouding van een openbaar lichaam mogen door de bestuursorganen van dat lichaam worden behartigd. Voor een waterschap - een doelcorporatie - komen deze grenzen snel in beeld. ${ }^{189}$ Van Hall gaat ervan uit dat het specialiteitsbeginsel (in enge zin) verband houdt met het doelgebonden karakter van bestuursbevoegdheden. In het waterschapsrecht vloeien deze bevoegdheden voort uit de bijzondere beheerswetgeving. Het specialiteitsbeginsel stelt grenzen aan het proces van belangenafweging dat het bestuur binnen de kaders van zijn doelgebonden bestuursbevoegdheden verricht. ${ }^{190}$

Ten aanzien van de publiekrechtelijke belangen legt Van Hall het primaat bij de wetgever. In beginsel kan alleen de wetgever bepalen hoe wijd de kring van belangen is

183. Zie A.Q.C. Tak, De ongewenste discussie, in: Nieuw bestuursprocesrecht, a.w., p. 72 en 73; A.Q.C. Tak, Het moment X, a.w., p. 135.

184. Vgl. J.M.H.F. Teunissen, Schadevergoeding wegens relatief onrechtmatige overheidsdaad, NJB 1994/5, p. 163/164. Tak prefereert de term 'geïndividualiseerde onrechtmatigheid' die hij afzet tegen de (eventuele) objectieve onrechtmatigheid van het publieke rechtshandelen (het besluit). Zie hierover uitvoerig: A.Q.C. Tak, De overheid in het burgerlijk recht, a.w., p. 364-372.

185. Zie: A.Q.C. Tak, De ongewenste discussie, in: Nieuw bestuursprocesrecht, a.w., i.h.b. 77 en 78 ; vgl. ook A.Q.C. Tak, Het moment X, a.w., p. 136.

186. Vgl. A.Q.C. Tak, De overheid in het burgerlijk recht, a.w., p. 370.

187. A. van Hall, Het specialiteitsbeginsel in het waterstaatsrecht. Over kringen van belangen, oratie UU, Zwolle 1995. Besproken door J.H.A. Teulings in RMTh. 1997/3, p. 116-117.

188. Hier is de 'ruime' betekenis van het specialiteitsbeginsel in het geding zoals wij die kennen uit het Franse en het Belgische administratieve recht (vgl. hoofdstuk 2 van dit boek, paragraaf 2.2.1).

189. Van Hall, Het specialiteitsbeginsel in het waterstaatsrecht, a.w., p. 16.

190. Van Hall, Het specialiteitsbeginsel in het waterstaatsrecht, a.w., p. 24. 
die bij het verlenen van een vergunning een rol mogen spelen. ${ }^{191}$ Het zijn uitsluitend de door de wetgever gedetermineerde belangen die behartigd mogen worden; met andere belangen dient, waar mogelijk, wél rekening te worden gehouden. ${ }^{192}$ Van Halls oratie straalt relativering uit. Zo stelt hij zich de vraag of met de komst van de moderne staat en zijn eigensoortige ordeningswetgeving het specialiteitsbeginsel niet een bijgestelde betekenis heeft gekregen. ${ }^{193}$ In het hedendaagse waterschapsrecht, waarbinnen het integrale waterbeheer centraal staat, gaat bijv. de aandacht uit naar vele algemene (lees: publiekrechtelijke) belangen die onderling de nodige verwantschap vertonen, met elkaar verweven zijn of juist conflicteren. ${ }^{194} \mathrm{Om}$ een optimale belangenbehartiging mogelijk te maken, lijkt Van Hall bereid te zijn om het specialiteitsbeginsel te relativeren. Hierbij neemt hij het standpunt in dat de wettelijke bevoegdheidsgrondslag (in de beheerswetgeving) niet alleen aan de hand van de letter van de wet moet worden beschouwd, maar vooral ook aan de hand van de parlementaire geschiedenis. Ten aanzien van het functionele waterschap geldt dat de algemene belangen die in de afweging worden betrokken in ieder geval verband dienen te houden met de waterstaatkundige zorg zoals deze tot uitdrukking komt in de taakopdracht ingevolge artikel 56 lid 1 Waterschapswet. Grenzen aan de belangbehartiging komen volgens Van Hall ook in zicht zodra de competentiesfeer van mede-overheden wordt betreden:

'Die belangen kunnen niet worden meegewogen al was het alleen maar omdat de democratische controlestructuur op een dergelijke grensoverschrijding niet is toegesneden, nog afgezien van de bezwaren die in het legaliteits- en specialiteitsbeginsel kunnen liggen. ${ }^{195}$

Ondanks een voorzichtige relativering van het specialiteitsbeginsel, pleit Van Hall ervoor dat de wetgever duidelijkheid verschaft omtrent de vraag welke (algemene) belangen behoren te worden afgewogen. ${ }^{196}$ Hiertoe doet hij een aantal aanbevelingen, die er in hoofdlijnen op neerkomen dat de wetgever, maar ook andere regelgevers, de belangenkaders van bevoegdheden op het gebied van de waterstaats- en waterschapswetgeving expliciteren. ${ }^{197}$ Ook dienen de juridische relaties met andere overheden, met name ten aanzien van de afbakening van bevoegdheden, goed in het oog te worden gehouden. ${ }^{198}$ Coördinatie en inte-

191. Van Hall, Het specialiteitsbeginsel in het waterstaatsrecht, a.w., o.m. p. 15, 22 en 53.

192. Van Hall, Het specialiteitsbeginsel in het waterstaatsrecht, a.w., 25.

193. Van Hall, Het specialiteitsbeginsel in het waterstaatsrecht, a.w., p. 19.

194. Naast de traditionele waterschapsbelangen (waterkwantiteitsbeheer) kan gedacht worden aan milieubelangen, ecologische belangen, agrarische belangen en economische belangen.

195. Van Hall, Het specialiteitsbeginsel in het waterstaatsrecht, a.w., p. 36.

196. In dit kader dient erop gewezen te worden dat Van Hall expliciet afstand neemt van de opvattingen van Tonnaer en Stout (a.w. p. 31). Aan het einde van zijn oratie benadrukt Van Hall de verantwoordelijkheid van de wetgever: 'De eerste verantwoordelijkheid voor het afbakenen van bestuurlijke bevoegdheden in relatie tot het belangenafwegingsproces - en met name welke belangen daarbij behoren te worden betrokken - ligt bij de wetgever.' (a.w. p. 83).

197. A. van Hall, Het specialiteitsbeginsel in het waterstaatsrecht, a.w., p. 57. Vgl. over de constitutionele specificeringsplicht t.a.v. bestuursbevoegdheden hoofdstuk 4 van dit boek. 
gratie van vergunningstelsels vormen daarom volgens Van Hall de aangewezen instrumenten om grensproblemen en onduidelijke situaties voor burgers te minimaliseren:

'Om te voorkomen dat bij de vergunningverlening een uit rechtsstatelijk oogpunt ongewenste oprekking van het specialiteitsbeginsel plaatsvindt onder de druk van de toenemende behoefte aan integrale - en dus steeds - diffusere belangenafwegingen zal de integrale afweging mogelijk moeten worden gemaakt door de wetgever via harmoniseren, coördineren of integreren van wetgeving of vergunningstelsels. ${ }^{199}$

Ten aanzien van het meewegen van particuliere belangen spitst Van Hall zijn aandacht met name toe op de positie van belangen van derden binnen het afwegingsproces. ${ }^{200} \mathrm{Na}$ vastgesteld te hebben dat hieromtrent in de literatuur de meeste meningsverschillen bestaan, formuleert hij het kader waarbinnen op zoek wordt gegaan naar een standpuntbepaling:

'Bij het zoeken van de grens rond het al of niet mogen betrekken van vreemde derde-belangen bij vergunningverlening speelt onder andere mee hoe eisen door de beginselen van de rechtsstaat gesteld gerelateerd worden aan op zich even verdedigbare eisen van doelmatigheid en doeltreffendheid van het bestuuriijk handelen. ${ }^{201}$

Van Hall gaat ervan uit dat de grenzen die het specialiteitsbeginsel stelt aan het meewegen van belangen van derden moeilijk in algemene zin zijn vast te stellen. Deze grenzen zullen volgens hem vaag blijven vanwege de subtiele weging van rechtsstatelijke eisen en eisen van doelmatigheid. ${ }^{202}$ In dit kader vraagt hij zich af, of het onderscheid tussen de diverse visies binnen het spectrum - variërend van 'beperkt rekkelijk' tot 'meer rekkelijk' - niet flinterdun is. Alle visies hebben volgens Van Hall nl. als uitgangspunt dat belangen van derden niet onnodig mogen worden geschaad en dat het bestuursorgaan dat deze belangen meeweegt gelijkertijd de belangen van de aanvrager niet dermate in de knel mag brengen dat er sprake is van een 'pseudo'-weigering. ${ }^{203}$ Deze aanname brengt Van Hall tot het volgende standpunt. Belangen van derden, die niet samenvallen met het speciale publiekrechtelijke belang, kunnen in beperkte mate een rol spelen bij de invulling van de voorschriften van een vergunning. Voorwaarde is dan wel dat deze belangen niet reeds in het kader van andere vergunningstelsels worden beschermd. In dit verband dient tevens aan de navolgende randvoorwaarden ${ }^{204}$ te zijn voldaan: (1) particuliere belangen mogen

198. A. van Hall, Het specialiteitsbeginsel in het waterstaatsrecht, a.w., p. 56.

199. A. van Hall, Het specialiteitsbeginsel in het waterstaatsrecht, a.w., p. 57.

200. Van Hall gaat ervan uit dat alle belangen van de direct-belanghebbende (de aanvrager) in de afweging mogen en moeten worden betrokken (a.w. p. 75). Ik wijs erop dat de visie van Van Hall over het specialiteitsbeginsel van invloed is geweest op de opvatting van Ten Berge. Zie: J.B.J.M. ten Berge, Besturen door de overheid, tweede druk, Deventer 1997, p. 324. Ten Berge volgt evenwel niet alle nuances die Van Hall aanbrengt (vgl. a.w., p. 326).

201. A. van Hall, Het specialiteitsbeginsel in het waterstaatsrecht, a.w., p. 39.

202. A. van Hall, Het specialiteitsbeginsel in het waterstaatsrecht, a.w., p. 50.

203. A. van Hall, Het specialiteitsbeginsel in het waterstaatsrecht, a.w., p. 46.

204. A. van Hall, Het specialiteitsbeginsel in het waterstaatsrecht, a.w., p. 49. 
tegenover de (speciale) algemene belangen niet de overhand krijgen (2) de rechten van de aanvrager mogen er niet (substantieel) door worden aangetast (3) voor andere belanghebbenden mag de vergunning geen als onaanvaardbaar aan te merken gevolgen hebben en (4) de derde-belangen moeten een relatie hebben met de belangen die de regeling beoogt te beschermen. Géén acht hoeft te worden geslagen op belangen die slechts in een meer verwijderd verband door de te nemen beslissing kunnen worden geschaad.

Van Hall zoekt aansluiting bij de 'methode-Nicolaï'. In Van Halls standpunt worden echter ó́k elementen aangetroffen die ontleend lijken aan de visies van Helder en Jue ('beleidscontexttheorie') en Simon (respecteren materiële vrijheid direct-belanghebbende). De vierde voorwaarde doet een meer 'precieze' invloed vermoeden. ${ }^{205}$ Weliswaar erkent Van Hall een beperkte speelruimte om met (vreemde) belangen van derden in normatieve zin rekening te houden, maar dan dienen deze belangen wél verband te houden met de wettelijke regeling waarop een vergunningstelsel berust. Uiteindelijk krijg ik echter de indruk dat Van Hall 'de kool en de geit' wil sparen, door enerzijds op grond van rechtspolitieke overwegingen de scherpe kantjes van het specialiteitsbeginsel af te zwakken, maar anderzijds de rechtsstatelijke waarborgen die uit dit beginsel voortvloeien te benadrukken.

\subsection{Conclusies}

$\mathrm{Na}$ deze bespreking van de verschillende opvattingen over het specialiteitsbeginsel is het zinvol om de standpunten te ordenen. Ik benadruk in dit kader dat ik door het hanteren van de navolgende drie-indeling, nl. publiekrechtelijke belangen, (rechts)belangen van de direct-belanghebbende en (rechts)belangen van derden, nog géén uitspraak beoog te doen over de juistheid van een dergelijke indeling. De indeling wordt - vooralsnog - gehanteerd omdat diverse auteurs er betekenis aan lijken toe te kennen. ${ }^{206} \mathrm{Ik}$ kom hier in hoofdstuk 9 op terug.

\subsubsection{Publiekrechtelijke belangen}

Door vrijwel alle auteurs wordt aangenomen dat aan het speciale publiekrechtelijke belang (ook wel aangeduid als speciaal 'algemeen' of 'openbaar' belang) een bijzondere positie toekomt binnen het proces van bestuurlijke belangenafweging. Dit publiekrechtelijke belang, dat door de wetgever aan een specifieke bestuursbevoegdheid ten grondslag is gelegd, kan een weigering rechtvaardigen. Voorts kunnen met het oog op dit speciale publiekrechtelijke belang voorschriften worden gesteld. Indien een bestuursorgaan vreemde publiekrechtelijke belangen behartigt in het kader van een (discretionaire) bevoegdheidsuitoefening zal er al snel sprake zijn van een schending van het verbod van détournement de pouvoir. Sommige auteurs kennen aan het speciale publiekrechtelijke belang - met uitsluiting van alle andere publiekrechtelijke én particuliere belangen - zelfs een exclusieve positie toe

205. Vgl. ook p. 76 van zijn oratie waar een meer 'precieze' ondertoon doorklinkt.

206. Vgl. recentelijk het handboek van Ten Berge: J.B.J.M. ten Berge, Besturen door de overheid, a.w., p. 324326. 
binnen het proces van 'belangenafweging' [Stellinga, Heldeweg, Tak]. Een aantal bestuurskundig georiënteerde auteurs pleit er daarentegen voor om ook aanverwante publiekrechtelijke belangen in de afweging te betrekken. Zij willen het specialiteitsbeginsel niet al te strikt opvatten [Tonnaer, Helder en Jue, Stout]. Toch wordt ook in bepaalde sectoraal/functioneel georiënteerde publicaties het rechtsstatelijke belang van het specialiteitsbeginsel centraal gesteld [Van Hall]. Het meewegen van aanverwante publiekrechtelijke belangen wordt wel verdedigd op grond van de 'beleidscontext'-theorie [Helder en Jue] en het beginsel van 'materiële integraliteit' van de administratieve wetgeving [Tonnaer].

\subsubsection{Belangen van de direct-belanghebbende}

Het meewegen van de belangen van de direct-belanghebbende is weinig omstreden in de literatuur. Hiertoe bestaat volgens vrijwel alle auteurs een plicht. Slechts een beperkt aantal auteurs lijkt hier anders over te denken [Stellinga, Heldeweg, Tak]. Volgens hen kunnen er aan hetgeen het speciale publiekrechtelijke belang in concreto vergt géén concessies worden gedaan in verband met particuliere belangen. Deze laatstgenoemde belangen mogen in ieder geval niet door het bestuur worden behartigd. Derhalve kan er géén sprake zijn van een echte 'afweging' van belangen. Met particuliere belangen dient het bestuursorgaan wel zoveel mogelijk rekening te houden [Heldeweg, Tak]. Het meewegen van alle betrokken belangen van de direct-belanghebbende wordt vanuit theoretisch oogpunt o.m. verdedigd op grond van het beginsel van individuele rechtsbedeling [o.a. Nicolaï, Simon], het uitgangspunt van de minste pijn [o.a. Nicolai, Simon, Heldeweg, Konijnenbelt, De Planque], het evenredigheids- of evenwichtigheidsbeginsel [o.a. De Planque, Van Male] en de nutsmaximalisatieplicht van de overheid [Simon]. Het meewegen lijkt voorts te worden beschouwd als inherent aan het proces van concretiserende rechtsvorming door het bestuur [Stroink en De Waard]. Deze theoretische onderbouwingen zijn mijns inziens verwant aan elkaar. Volgens sommige auteurs vloeit in meer algemene zin uit het specialiteitsbeginsel géén beperking voort voor het meewegen van particuliere belangen. Dit beginsel beoogt nl. uitsluitend vreemde publiekrechtelijke belangen buiten de afweging te houden [Stout, Simon, Helder en Jue, Van Male].

\subsubsection{Belangen van derden}

Het meewegen van belangen van derden is in de literatuur omstreden. Volgens de 'precieze' school mogen belangen van derden uitsluitend in de belangenafweging worden betrokken voorzover zij 'samenvallen' met het speciale publiekrechtelijke belang dat ten grondslag ligt aan de betreffende bestuursbevoegdheid [Stroink, De Waard]. Verschillende auteurs neigen in die richting [De Planque, Damen, Van Buuren]. Sommige auteurs stellen zich, gelet op de gebondenheid van de publiekrechtelijke rechtshandeling aan het specialiteitsbeginsel, terughoudend op ten aanzien van het meewegen van derde-belangen [Tak, Heldeweg]. Zij houden wél een mogelijkheid van nadeelcompensatie open (égalitébeginsel). 
Diverse auteurs accepteren daarentegen een ruimere mogelijkheid om belangen van derden in de afweging te betrekken [Simon, Nicolai, Konijnenbelt, Van Male, Drupsteen, Van Hall, Ten Berge]. Overigens zijn deze auteurs het er over eens dat derde-belangen alleen maar mogen worden meegewogen voorzover deze niet in het kader van een andere administratiefrechtelijke regeling bescherming hebben gevonden. Meewegen is niet toegestaan indien de wettelijke regeling dit op ondubbelzinnige wijze uitsluit [Ten Berge]. Het meewegen van derde-belangen wordt door sommige auteurs, in geval van een discretionaire bevoegdheid, vanuit theoretisch oogpunt verdedigd op grond van het gelijkheidsbeginsel en de nutsmaximalisatieplicht van de overheid [Simon]. Anderen zoeken aansluiting bij de jurisprudentie [o.a. Nicolai, Van Male] of menen in de artikel 3:4 lid $1 \mathrm{Awb}$ een ruime afwegingsplicht te ontwaren [o.a. Konijnenbelt]. Ook zijn er auteurs die door het meewegen van (bepaalde) belangen van derden willen voorkomen dat deze 'derden' een extra gang naar de civiele rechter dienen te maken [Simon, Van Hall]. $\mathrm{Zij}$ relativeren bijgevolg de werking van het specialiteitsbeginsel, en de binding van het bestuursorgaan aan dit beginsel, voor zover het bestuur beoogt te interveniëren in typisch 'horizontale' relaties tussen burgers onderling op basis van materieel privaatrecht.

De auteurs die het meewegen van (vreemde) belangen van derden mogelijk - en zelfs verplicht - achten, verschillen onderling overigens van mening over de vraag op welke wijze dan aan deze belangen tegemoet kan (of moet) worden gekomen. In het uiterste geval zou een 'vreemd' particulier belang - mits van voldoende gewicht - een weigering kunnen rechtvaardigen [Simon, Stout, Ten Berge]. De meeste auteurs beperken zich echter tot het accepteren van een mogelijkheid tot het stellen van gedragsvoorschriften [Nicolai,, Konijnenbelt, Van Male]. Indien er voorschriften worden gesteld dient er wél voldoende gewicht te worden toegekend aan de rechtspositie van de direct-belanghebbende [Nicolai]; zijn materiële vrijheid mag niet op een onevenredige wijze worden aangetast [Simon]. Bovendien mogen particuliere belangen nooit gaan fungeren als een zelfstandige beleidsdoelstelling [Stout, Helder en Jue]. Evenmin mogen zij de 'beleidscontext' domineren [Helder en Jue]. Tot slot is er voor gewaarschuwd dat gedragsvoorschriften niet mogen leiden tot een verkapte weigering of een rechtens relevante détournement de pouvoir [Konijnenbelt, Nicolai, Van Male]. Overigens zijn niet alle auteurs de mening toegedaan dat in de rechtsvormende (voorschriften)sfeer aan de betrokken belangen van derden tegemoet gekomen mag worden. In dit verband dient ook de aandacht uit te gaan naar een alternatieve uitoefening van de bevoegdheid of het aanbieden van nadeelcompensatie [Simon, Messer en Heldeweg, Nicolai, Van Male]. Hierbij dient opgemerkt te worden dat een aantal auteurs de vraag naar het 'meewegen' van de belangen expliciet loskoppelt van de vraag of deze belangen gevolgen in de rechtsvormende sfeer kunnen rechtvaardigen (voorschriften, weigering). Aan derde-belangen kan (zoals gesteld) ók recht worden gedaan door het toekennen van nadeelcompensatie in geval van onevenredige benadeling [Messer en Heldeweg, De Planque]. Andere auteurs lijken (soms) in deze richting te willen gaan [Simon en Van Male]. Afwenteling van een compensatieplicht dient dan volgens sommigen, gelet op het legaliteitsbeginsel (in beginsel), te worden verworpen [ Van Male, Damen]. 



\section{Hoofdstuk 8}

\section{Het specialiteitsbeginsel in de jurisprudentie}

\subsection{Inleiding}

Nadat in het voorafgaande hoofdstuk de meningen over het specialiteitsbeginsel in de literatuur zijn geanalyseerd, zal in dit hoofdstuk de aandacht uitgaan naar de jurisprudentie. Analyse van 'het' specialiteitsbeginsel in de jurisprudentie brengt een aantal problemen met zich die vooraf toelichting behoeven. Voorop dient te worden gesteld dat in de jurisprudentie zelden expliciet aan dit beginsel wordt gerefereerd. ' Hoe een rechterlijk college het ongeschreven specialiteitsbeginsel interpreteert, blijkt meestal op een indirecte wijze. In dit verband kan bijv. gedacht worden aan de mate waarin, en de wijze waarop, het meewegen van (vreemde) publiekrechtelijke belangen en (norm)vreemde derdebelangen toelaatbaar wordt geacht. Verband hiermee houdt de vraag in hoeverre, met het oog op dergelijke belangen, het stellen van (gedrags)voorschriften door een rechterlijk college geoorloofd wordt geacht (het rechtsvormingsaspect). Ook het aannemen van plichten tot nadeelcompensatie kan indicatief zijn. ${ }^{2}$ Tot slot is de wijze waarop een rechterlijk college het gefragmenteerde karakter van de administratieve wetgeving benadert van belang. Relevant is bijv. in hoeverre een college de ingebrachte bezwaren - gelet op hun aard en inhoud - toedeelt aan een specifiek wettelijk bevoegdhedenkader of juist buiten beschouwing laat.

Er deden zich ook praktische analyse-beperkingen voor. Een probleem vormde het feit dat het trefwoord 'specialiteitsbeginsel' via de reguliere registers van de jurisprudentietijdschriften $^{3}$ en CD-rom slechts een beperkt aantal treffers opleverde. Het ging dan met

1. Een voorbeeld van een impliciete verwijzing naar het beginsel biedt bijv. ARRS 24 mei 1983, tB/S III, nr. 443, m.a. tB/S (lichtreclame Heemstede). Ik trof in de jurisprudentie slechts drie expliciete vermeldingen aan van het specialiteitsbeginsel. Het betrof hier een uitspraak van de Maastrichtse rechtbankpresident (Pres. Rb. Maastricht 24 februari 1995, JB 1995/111, m.nt. R. Schlossels), een arrest van het Gerechtshof 's-Hertogenbosch (Hof 's-Hertogenbosch 1 september 1991, NJ 1992, 548) en ABRS 14 maart 1996, BR 1996/11, p. 906 e.v., m.nt. H.J. de Vries (achtergevelrooilijn Ambt Montfort).

2. In de literatuur is - zo bleek in hoofdstuk 7 - de aandacht gevestigd op de relaties tussen het specialiteitsbeginsel en (de omvang van) nadeelcompensatieplichten. Zie bijv. Th. G. Drupsteen, En de gemeenteraad maar belangen afwegen, in: In de sfeer van administratief recht (Konijnenbelt-bundel), Utrecht 1994, p. 82 en E.M. Messer en M.A. Heldeweg, Bestuurscompensatic en het specialiteitsbeginsel. Een beschouwing over juridische spraakverwarring, rekkelijken versus preciezen en enkele cryptische wetsartikelen, RMTh. 1990/4, p. 147 e.v.

3. Voor de analyse werd primair gebruik gemaakt van de jurisprudentie zoals gepubliceerd in Administratiefrechtelijke beslissingen (AB), Jurisprudentie bestuursrecht (JB), de losbladige editie van Ten Berge/Stroink $(\mathrm{tB} / \mathrm{S})$, de losbladige editie Rechtspraak Algemene wet bestuursrecht (RAwb) en de Gemeentestem (Gst.). Aanvullend materiaal kwam uit Nederlandse Jurisprudentie (NJ), Milieu en Recht (M\&R), Bouwrecht 
name om jurisprudentie van na 1990 . Om meer relevante jurisprudentie te achterhalen was het noodzakelijk om handmatig via diverse (indirecte) trefwoorden 'specialiteitsproblemen' te traceren. Ingangen die in dit kader werden gehanteerd waren o.m.: 'belangenafweging', 'derde-belangen', 'détournement de pouvoir', 'nadeelcompensatie', 'bestuurscompensatie' en '(ontoelaatbaar) voorschrift(en)'. Bruikbare jurisprudentie werd bók achterhaald door te zoeken op specifieke vergunningtypen, zoals 'standplaatsvergunning', 'ontgrondingsvergunning', 'milieuvergunning' en 'rivierenwetvergunning'.

\subsection{Een nadere onderzoeksverantwoording}

$\mathrm{Bij}$ de inventarisatie gold als uitgangspunt relevante jurisprudentie te verzamelen van alle hoogste nationale ${ }^{4}$ rechterlijke colleges die vanaf $1976^{5}$ werden - en worden - geconfronteerd met de toetsing van (de uitoefening van) doelgebonden bestuursbevoegdheden, en in het bijzonder beschikkingsbevoegdheden. Tijdens de inventarisatie bleek dat er weliswaar een grote hoeveelheid relevante jurisprudentie kon worden getraceerd, maar dat deze niet evenwichtig over de verschillende (rechterlijke) colleges was verdeeld. Verreweg het grootste gedeelte van het bruikbare materiaal bleek afkomstig te zijn van de Kroon uit de 'pre-Benthem' periode, de voormalige rechtsprekende Afdelingen van de Raad van State (ARRS en AGRS) en van de huidige Afdeling bestuursrechtspraak (ABRS). Slechts een beperkt aantal relevante uitspraken werd aangetroffen in de jurisprudentie van het College van Beroep voor het bedrijfsleven ( $\mathrm{CBb}$ ). De inventarisatie van de jurisprudentie van de Centrale Raad van Beroep (CRvB) leverde - afgezien van enige uitspraken over détournement de pouvoir ${ }^{6}$ - géén noemenswaardige jurisprudentie over het specialiteitsbeginsel op.

In de jurisprudentie van de burgerlijke rechter (m.n. de Hoge Raad en de Gerechtshoven) werden tenslotte enkele uitspraken aangetroffen die aandacht verdienen. Hierbij dient te worden opgemerkt dat de burgerlijke rechter sedert de invoering van de Wet Arob in 1976, slechts zelden de uitoefening van discretionaire (beschikkings)bevoegdheden toetst(e). De burgerrechtelijke jurisprudentie is echter anderszins relevant. In dit kader dient te worden gewezen op de jurisprudentie van de Hoge Raad inzake de vrijwarende

(BR), kort geding (KG), Nieuwsbrief Algemene wet bestuursrecht (NA), Administratiefrechtelijke beslissingen kort (ABkort), Sociaal Economische Wetgeving (SEW) en de bundels Uitspraken College van beroep voor het Bedrijfsleven (UCB).

4. In hoofdstuk 1 is het aspect van de beperkte rechtsvergelijking verantwoord, evenals het achterwege laten van een analyse van de jurisprudentie van het Europese Hof van Justitie (HvJ). Enkele 'hoogste' rechterlijke instanties zijn buiten beschouwing gelaten; ik wijs in dit kader i.h.b. op het College van Beroep voor de studiefinanciering (CvBSf) en de Hoge Raad in belastingzaken.

5. Dit jaartal is enerzijds gekozen vanwege het feit dat vanaf dit tijdstip Arob-jurisprudentie van de Afdeling rechtspraak voor handen was (de Wet Arob van 1 mei 1975 - Stb. 284 - trad in werking op 1 juli 1976), en anderzijds vanwege de temporele aansluiting bij de literatuur-analyse in hoofdstuk 7 . Enige relevante Kroonjurisprudentie van vóór genoemd tijdstip wordt overigens wél besproken, evenals enige oudere jurisprudentie van de burgerlijke rechter.

6. Zie in dit kader hoofdstuk 5 van dit boek. 
werking van vergunningen. Uit deze jurisprudentie blijkt $\mathrm{nl}$. - zij het op een indirecte wijze - dat de Hoge Raad ervan uit gaat dat in het kader van een discretionaire bevoegdheidsuitoefening in beginsel niet alle (rechts)belangen van (particuliere) rechtssubjecten worden afgewogen (zie paragraaf 8.8.4 e.v.).

Voor de 'oververtegenwoordiging' van de jurisprudentie van de rechtsprekende Afdelingen van de Raad van State in dit hoofdstuk kan een aantal verklaringen worden gegeven. In de eerste plaats waren - en zijn - deze Afdeling(en) actief op een breed terrein van het bijzondere bestuursrecht. Bovendien namen (neemt) zij een belangrijk deel van de rechtsbescherming op het terrein van het ruimtelijke- en milieuhygiënische bestuursrecht voor hun (haar) rekening. Juist deze delen van het bijzondere bestuursrecht worden gekenmerkt door diverse wetten met elkaar overlappende, dan wel verwante bestuursbevoegdheden. Gedacht kan bijv. worden aan de bekende 'grensconflicten' tussen de Wet op de Ruimtelijke Ordening (WRO) enerzijds, en de Wet milieubeheer (Wm) en de Ontgrondingenwet anderzijds.

Een andere verklaring voor het grote aantal relevante uitspraken van de ARRS, AGRS en ABRS is gelegen in het feit dat zich op het werkterrein van deze administratieve rechters veel complexe belangenconflicten voordoen (voordeden), zowel wat betreft conflicterende publiekrechtelijke belangen ${ }^{7}$ als wat betreft botsende particuliere rechtsbelangen. $Z_{0}$ is de 'derde-belanghebbende' met name een frequente appellant op het (huidige) werkterrein van de Afdeling bestuursrechtspraak. Het administratieve geschil manifesteert zich in dit verband vaak als een (indirect) juridisch geschil tussen een directbelanghebbende en (een kring van) derden die opkomen voor hun rechtsbelangen. ${ }^{8}$ Doordat deze derden vaak belangen inbrengen in het bestuurlijke proces van belangenafweging die tegengesteld zijn aan die van de direct-belanghebbende, wordt voor de rechter de vraag actueel in hoeverre het bestuur met deze belangen, gelet op het specialiteitsbeginsel, rekening mag houden.

Uit het voorafgaande vloeit tevens een verklaring voort voor de 'ondervertegenwoordiging' van de Centrale Raad van Beroep (CRvB). Het werkgebied van de CRvB wordt immers, in tegenstelling tot dat van de Afdeling bestuursrechtspraak, gekenmerkt door

7. Zie voor een fraai voorbeeld van een complexe 'afweging' van publiekrechtelijke belangen bijv.: ABRS 7 december 1995, AB 1996, 64, m.nt. AvH (peilbesluit IJsselmeer).

8. Zie o.m. A.Q.C. Tak, Hoofdlijnen van het Nederlands bestuursprocesrecht, derde druk, Zwolle 1995, p. 93. Ook Scheltema wees in het recente verleden expliciet op het feit dat bestuursrechtelijke 'conflictbeheersing' niet zelden in het teken staat van een belangentegenstelling tussen burgers onderling. M. Scheltema, Van rechtsbescherming naar een volwaardig bestuursrecht, NJB 1996/33, p. 1356 . Vgl. bijv. VzARRS 19 november 1993, Gst. 6990, nr. 4, m.n. HH; ARRS 8 augustus 1989, AB 1991, 142 en ARRS 22 maart 1985, AB 1985, 471 (vereniging 'Mazzo'). In de laatstgenoemde uitspraak stond de verlening van een nachtvergunning voor een discotheek ter discussie, waartegen omwonenden bezwaar maakten. De Afdeling overwoog i.v.m. de belangenafweging: 'Tegenover hun belangen (van omwonenden R.J.N.S.), die er voor pleitten de onderhavige nachtvergunning niet te verlenen, stonden evenwel de belangen van de vereniging 'Mazzo', die de inrichting ten tijde van het besluit van verweerder van 20 juni 1983 al ongeveer 3 jaar in exploitatie had. Ook met de belangen aan die zijde had verweerder emstig rekening te houden.' 
besluiten en handelingen op grond van de ambtenarenwetgeving en de wetgeving op het gebied van de sociale zekerheid. Belangenconflicten op deze terreinen beperken zich in de regel tot de rechtsrelatie tussen het verantwoordelijke bestuursorgaan en de directbelanghebbende (bi-polair). De bevoegdheden, die hun grondslag vinden in bijv. de sociale zekerheidswetgeving vertonen bovendien weinig belang-interferentie met andere stelsels. Meestal wordt de kern van sociale zekerheidswetten nl. niet gevormd door discretionaire (in de zin van beleidsvrije) bevoegdhedenstelsels, maar door gedetailleerde stelsels waaruit belanghebbenden in de regel hun rechtspositie duidelijk kunnen afleiden. ${ }^{9}$ Tegengestelde belangen van derden spelen hier doorgaans géén rol. ${ }^{10}$

Gelet op het voorafgaande is besloten om de jurisprudentie-analyse in dit boek te 'beperken' tot relevante beslissingen van de Kroon, en de uitspraken van de Afdeling rechtspraak van de Raad van State (ARRS), de Afdeling Geschillen van bestuur van de Raad van State (AGRS), de Afdeling bestuursrechtspraak van de Raad van State $(A B R S)^{11}$, het College van Beroep voor het bedrijfsleven $(\mathrm{CBb})$ en de burgerlijke rechter.

Ook de analyse-methode behoeft enige toelichting. Gekozen is voor een analyse van de 'specialiteitsproblematiek' rond een aantal deelthema's. Deze aanpak biedt mijns inziens een mogelijkheid om een goed inzicht te krijgen in de relevante jurisprudentie. De betreffende thema's zijn geselecteerd aan de hand van de in hoofdstuk 7 gesignaleerde meningsverschillen in de literatuur. Het betreft de volgende onderwerpen:

(a) de positie van (speciale) pubiekrechtelijke belangen in het proces van bestuurlijke belangenafweging;

(b) het gefragmenteerde karakter van de administratieve wetgeving en de gevolgen voor het bestuurlijke belangenafwegingsproces. Het toedelen van 'bezwaren' aan specifieke afwegingskaders;

(c) de positie van (norm)vreemde (derde-)belangen van particulieren in het proces van bestuurlijke belangenafweging;

(d) Het meewegen van 'privaatrechtelijke' belangen - en in het bijzonder geschilpunten tussen burgers - die géén bescherming vinden in specifieke (van toepassing zijnde) bevoegdhedenstelsels;

(e) de mogelijkheid tot het stellen van (gedrags)voorschriften ter bescherming van (1) publiekrechtelijke belangen, en (2) particuliere rechtsbelangen.

Bij de bespreking van de uitspraken zullen per rechterlijk college - zo mogelijk - deze deelthema's aan de orde komen. Vermelding verdient nog dat er géén chronologische bespreking van de jurisprudentie plaatsvindt. Dit hangt samen met het feit dat in de jurisprudentie meestal gén ontwikkeling in 'chronologische' zin kan worden waargenomen. In dit verband dient er overigens op te worden gewezen dat er voor gewaakt moet

9. Vgl. in dit kader Van der Burg/Cartigny/Overkleeft-Verburg, Rechtsbescherming tegen de overheid, vijfde druk, Nijmegen 1985, p. 162.

10. Vgl. de noot van Stroink onder Rb. Roermond 6 februari 1996, JB 1996/70.

11. In paragraaf 8.5 , waar de jurisprudentie van de ABRS ter sprake komt, zal ook (in noten) aandacht worden besteed aan relevante uitspraken van de sectoren bestuursrecht van de arrondissementsrechtbanken. 
worden een jurisprudentie-analyse in een al te strak 'empirisch' onderzoeksregime te dringen. Strak empirisch onderzoek, gevolgd door systematische ordening, kan immers leiden tot (te) vergaande gevolgtrekkingen. ${ }^{2}$ Het centrale uitgangspunt in dit hoofdstuk is het verkennen van bepaalde lijnen en ontwikkelingen in vaak tegenstrijdige en soms uiterst casuistische jurisprudentie.

\subsection{De Kroon}

De 'jurisprudentie'13 van de Kroon - in het bijzonder uit de pre-Benthem periode - die relevant is voor het onderwerp van dit boek is omvangrijk. Het is bepaald niet eenvoudig om uit enige honderden Koninklijke Besluiten een selectie te maken en die vervolgens in enige pagina's te bespreken. Keuzes en beperkingen waren dan ook onvermijdelijk. Toch is getracht om een zo representatief mogelijk beeld te schetsen van de rijke Kroonjurisprudentie, die veel invloed heeft gehad op de (latere) jurisprudentie van de rechtsprekende afdelingen van de Raad van State.

\subsubsection{Speciale publiekrechtelijke belangen}

De Kroon heeft steeds erkend dat de speciale publiekrechtelijke belangen die in administratieve wetgeving bescherming hebben gevonden - in geval van beleidsvrijheid - afgewogen kunnen (en ook moeten) worden tegen de rechtstreeks betrokken particuliere rechtsbelangen. ${ }^{14} \mathrm{Zo}$ ging de Kroon ervan uit dat het algemene landschapsbelang in het kader van een ontheffing van bepalingen uit een provinciale Plassenverordening diende te worden afgewogen tegen de bijzondere gezondheidsbelangen van een appellant. ${ }^{15} \mathrm{En}$ in een andere zaak, waarbij een keur-vergunning in het geding was, werden de bedrijfsbelangen van een appellant afgewogen tegen het algemene dijkbelang en het belang van de verkeersveiligheid. ${ }^{16}$ Duidelijk is ook een overweging uit een Koninklijk Besluit van 31 augustus 1987, waarin de weigering van een gemeentelijke kapvergunning centraal stond. ${ }^{17}$

12. Wetenschappers hebben nogal eens de neiging om uit bepaalde jurisprudentie mér af te leiden dan het betreffende rechterlijke college voor ogen stond. Vgl. in dit kader de relativerende opmerkingen die Schipper in 1995 maakte tijdens de jaarvergadering van de Nederlandse Vereniging voor Rechtspraak. W.H. Schipper, De rechterlijke macht en wetgever, Trema 1996/1, p. 4 e.v.

13. Ik zal steeds over Kroon-jurisprudentie spreken, ofschoon de Kroon uiteraard niet als een administratieve rechter kan worden aangemerkt. De begrippen 'Kroon-jurisprudentie' en 'bestemmingsplan-jurisprudentie' zijn echter ingeburgerd in het Nederlandse bestuursrecht. In dit verband dient er ók op te worden gewezen dat 'het' Kroonberoep in feite niet bestond. De diverse beslissingen van de Kroon ondervonden $\mathrm{nl}$. invloed van de verschillende departementsculturen. Zie: Van Buuren/Bolt/Scheltema, Kroonberoep en Arob-beroep, Rapport van de vakgroep bestuursrecht en bestuurskunde Groningen naar de verschillen tussen Kroonberoep en Arob-beroep, Deventer 1981, p. 15-16.

14. Zie bijv. KB 10 april 1973, AB 1973, 215 (Sleeuwijkse dijk); KB 22 december 1978, AB 1979, 270 (boorput Enschede); KB 6 april 1987, AB 1987, 295 (kapvergunning Aarle-Rixtel) en KB 20 juni 1991, AB 1991, 611 (verkeersmaatregel Hellevoetsluis).

15. KB 11 oktober 1984, AB 1985, 165, m.nt. J.R.St. (Loet-gebied).

16. KB 28 augustus 1984, AB 1986, 31 (oprit Lekdijk). 
In casu overwoog de Kroon: '...doch bij afweging van de betrokken belangen bestaat er naar Ons oordeel aanleiding aan het belang dat appellant heeft bij velling van de iepeboom voorrang toe te kennen boven het belang van het stadsschoon dat met de handhaving van de boom is gediend' (curs. R.J.N.S.).

Onverminderd de erkenning van een plicht tot daadwerkelijke belangenafweging in concreto, heeft de Kroon er in de regel nauwkeurig op toe gezien dat een bevoegdheidsuitoefening - in het bijzonder een weigering - steeds haar rechtvaardiging vond in het speciale publiekrechtelijke belang dat aan de betreffende administratieve regeling ten grondslag lag. ${ }^{18}$ Dit ondervond bijv. de gemeenteraad van Enschede ${ }^{19}$ die ingevolge de Wegenwet enige verbindingen tussen een aantal 'brinken' met het oog op typische verkeersveiligheidsbelangen aan het openbare verkeer onttrok, maar deze verbindingen gelijktijdig bestemde tot voet- en fietspad. Volgens de Kroon maakte de raad ten onrechte gebruik van zijn Wegenwet-bevoegdheid. De veiligheid op de weg moest via de Wegenverkeerswetgeving worden behartigd en niet op basis van de Wegenwet. Fraai is in dit kader ook een Koninklijk besluit van 17 augustus 1984 waarin de Kroon het begrip 'openbaar rivier en stroombelang' ingevolge de Rivierenwet (oud) interpreteert. ${ }^{20}$ In casu had de hoofdingenieur-directeur van de Rijkswaterstaat in de Directie Benedenrivieren het verzoek van een watersportvereniging, strekkende tot vergunning ingevolge de Rivierenwet voor het plaatsen van een dertigtal meerpalen in de Beneden-Merwede, geweigerd. Deze weigering was in het bijzonder gebaseerd op de veronderstelling dat het slaan van palen een eerste aanzet zou vormen voor de aanleg van een jachthaven, hetgeen uit nautische overwegingen door de hoofdingenieur-directeur onwenselijk werd geacht. Volgens de Kroon bood het bevoegdhedenkader van de Rivierenwet echter géen afdoende weigeringsgrond ter bescherming van de (toekomstige) scheepvaartbelangen sec: '...dat naar Ons oordeel uit de wetsgeschiedenis kan worden afgeleid, dat onder openbaar rivier of stroombelang mede het scheepvaartbelang moet worden verstaan in de zin van het belang, dat de scheepvaart erbij heeft, dat zich in de voorname rivieren en stromen geen obstakels bevinden, die de afvoer van het water en daardoor de scheepvaart kunnen hinderen; dat Wij echter geen aanleiding kunnen vinden voor een zo ruime uitleg van het begrip scheepvaartbelang, dat ter bescherming van dat belang de vergunning voor het slaan van die 30 meerpalen zou kunnen worden geweigerd' (curs. R.J.N.S.).

Het meewegen van vreemde publiekrechtelijke belangen vormde overigens niet zonder meer een reden om een besluit resoluut te vernietigen. Zo overwoog de Kroon in een zaak waarin het Goudse college ${ }^{21}$ met het oog op (o.m.) milieuhygiënische belangen - nl. het

17. KB 31 augustus 1987, AB 1987, 542 (kapvergunning Venlo).

18. Vgl. voor een door de Kroon 'getraceerde' zuivere détournement de pouvoir KB 30 juni 1994, BR 1995/7, p. 576 e.v., m.nt. H.J. de Vries (Meijel).

19. KB 22 januari 1982, AB 1982, 229 (wegonttrekking Enschede).

20. KB 17 augustus 1984, AB 1986, 20, m.nt. JTvdB (watersportvereniging Sliedrecht).

21. KB 1 april 1988, AB 1988, 297 (verkeersmaatregel Gouda). Overigens werd in casu het bestreden besluit desalniettemin door de Kroon vernietigd omdat de maatregel niet in het algemeen verkeersbelang werd geacht. 
‘...Volgens het stelsel en de strekking van het RVV (het Reglement Verkeerstekens en Verkeersregels R.J.N.S.), kan tot vaststelling van een verkeersmaatregel slechts worden overgegaan, indien zulks in het algemeen verkeersbelang nodig is. Blijkens de overwegingen van het bestreden besluit hebben $B$ en $W$ de in geding zijnde verkeersmaatregel voomamelijk vastgesteld ten einde lawaai, trillingen en stank, veroorzaakt door vrachtverkeer, tegen te gaan. Deze doelstelling kan, gelet op het stelsel en de strekking van het RVV, niet worden aangemerkt als een tot het algemeen verkeersbelang te rekenen omstandigheid, ten behoeve waarvan een dergelijke maatregel kan worden getroffen. Uit het bestreden besluit en het verhandelde in de openbare vergadering van de Afd., voornoemd, kan echter worden opgemaakt dat B en W, die vreesden dat na de opening van de Steve Bikobrug de intensiteit van het vrachtverkeer ter plaatse nog verder zou toenemen, deze verkeersmaatregel mede hebben getroffen met het oog op de veiligheid van met name het langzame verkeer' (curs. R.J.N.S.).

\subsubsection{Een 'Schutznorm'-theorie?}

De Kroon heeft er in diverse Koninklijke Besluiten blijk van gegeven een soort 'Schutznorm'-theorie toe te passen om bepaalde bezwaren van (derde-)belanghebbenden buiten specifieke afwegingskaders te houden. In dit verband kan allereerst worden gewezen op de uitvoerige Kroonjurisprudentie die werd gevormd op basis van de (voormalige) Hinderwet. Uit deze jurisprudentie, die hier niet uitvoerig zal worden besproken, blijkt dat de Kroon allerlei bezwaren die gelet op het speciale toepassingskader van de Hinderwet niet relevant waren, resoluut buiten de belangenafweging hield. ${ }^{22}$ Dit gold o.m. ten aanzien van bezwaren van landschappelijke, natuurwetenschappelijke en recreatieve aard. ${ }^{23}$ Ook bezwaren van louter planologische aard werden als niet relevant aangemerkt ${ }^{24}$, evenals bezwaren die verband hielden met uitsluitend de visuele hinder welke veroorzaakt werd door een inrichting. ${ }^{25}$ Soms werd met belangen die de persoonlijke omstandigheden van een appellant betroffen geen rekening gehouden. ${ }^{26}$

Ook in het kader van diverse andere administratieve regelingen werd wel een 'Schutznorm'-benadering toegepast. Dit ondervond bijv. het bestuur van het waterschap GrootWilnis-Vinkeveen ${ }^{27}$ dat bezwaar maakte tegen de verlening van een provinciale lozings-

22. Vgl. voor een treffend voorbeeld: KB 12 juni 1963, AB 1963, 899 (mengsmeerpomp Amsterdam).

23. KB 5 januari 1973, AB 1973, 94, m.nt. J.R. St.

24. Zie bijv. KB 27 juni 1972, AB 1972, 201, m.nt. J.R.St. In casu voerde appellant o.m. aan dat de betreffende inrichting (een rioolwaterzuiveringsinstallatie) niet in een woonwijk thuishoorde. Zie ook: KB 31 mei 1972, AB 1972, 226.

25. KB 8 december 1982, AB 1983, 231, m.nt. FO.

26. Zie bijv. KB 17 november 1976, AB 1977, 164. In casu werd de gezondheidstoestand van een bepaalde omwonende niet relevant geacht gelet op de besluitvorming ingevolge de Hinderwet. Merkwaardig genoeg kende de Kroon in het kader van andere regelingen wél betekenis toe aan specifieke gezondheidsbelangen. Ik wijs op het hiervoor besproken KB 11 oktober 1984, AB 1985, 165, m.nt. J.R. St (Loet-gebied).

27. KB 5 september 1972, AB 1973, 89 (De Put en de Gagel). Vgl. KB 4 juni 1982, AB 1982, 465, m.nt. J.R. St. (Milieugroep Gorssel). In casu werden bezwaren van appellante die i.h.b. betrekking hadden op het transport en slordig storten van materialen buiten het specifieke afwegingskader van de Wet 
ontheffing op grond van het feit dat hierdoor de belangen van o.m. de sportvisserij en de waterrecreatie in het gedrang zouden komen. De Kroon overwoog: '... dat de door appellant aangevoerde omstandigheid, dat het betrokken bedrijf in een landbouwgebied gelegen is, alwaar tevens verpozing wordt gezocht, buiten beschouwing moet blijven, in verband met de thans uitsluitend aan de orde zijnde vraag of, gelet op de belangen, welke de Verordening waterverontreiniging Utrecht beoogt te beschermen, een ontheffing van het in die verordening vervatte verbod tot lozing, als hier in het geding, kan worden verleend' (curs. R.J.N.S.). In een Koninklijk Besluit van 12 april 1976 treedt een dergelijke benadering eveneens duidelijk op de voorgrond. Burgemeester en wethouders van Eindhoven, hadden - mede op planologische gronden - géén vrijstelling verleend van enige technische voorschriften uit de plaatselijke Bouwverordening ten behoeve van de verbouwing van een woning tot café. Ten onrechte volgens de Kroon. Uit artikel 12 van de toenmalige Woningwet leidde deze nl. af '...dat uit het vorengaande volgt, dat burgemeester en wethouders - en in beroep de raad - bij het nemen van een beslissing omtrent de vraag, of van een voorschrift der bouwverordening al dan niet vrijstelling moet worden verleend, bij hun overwegingen alleen die belangen mogen betrekken, welke bedoeld voorschrift beoogt te beschermen' (curs. R.J.N.S.). ${ }^{28}$

Ook in de jaren tachtig kunnen voorbeelden van de 'Schutznorm'-benadering worden aangetroffen in Koninklijke Besluiten die betrekking hebben op verkeersmaatregelen ingevolge de Wegenverkeerswet. ${ }^{29}$ In een Middelburgse zaak $^{30}$, waarin burgemeester en wethouders ten aanzien van een (formeel) binnen de bebouwde kom gelegen weggedeelte de maximumsnelheid op $70 \mathrm{~km}$ p/u hadden gesteld, maakte een bewoner bezwaar met het oog op te verwachten extra geluidsoverlast die volgens hem het gevolg zou zijn van het verhogen van de maximumsnelheid ter plaatse. Dit bezwaar werd echter door de Kroon resoluut buiten de bestuurlijke besluitvorming gehouden: ' $\ldots$ dat overigens de door appellant in beroep aangevoerde bezwaren, voorzover deze betrekking hebben op de - verwachte - geluidsoverlast, wat daar verder ook van zij, te dezen buiten behandeling moeten blijven, aangezien het RVV andere belangen dan de hier door appellant bedoelde beoogt te beschermen; ...' (curs. R.J.N.S.).

\subsubsection{De scheiding van publiek- en privaatrecht}

De Kroon is steeds uitgegaan van een strikte scheiding tussen publiek- en privaatrecht, in die zin dat (de aantasting van) rechtsbelangen van burgers die expliciet bescherming vonden (vond) in het burgerlijke recht in principe ${ }^{31}$ buiten de bestuurlijke besluitvorming werden (werd) gehouden. ${ }^{32}$ Zo overwoog de Kroon in een Koninklijk Besluit van 27 december 1972 dat in het kader van de Hinderwet een erfdienstbaarheid, die zich in casu

verontreiniging oppervlaktewateren gehouden.

28. KB 12 april 1976, BR 1976, p. 386-387.

29. Ik wijs o.m. op KB 8 februari 1988, AB 1988, 266 (busbaan Someren) en op KB 10 juli 1989, AB 1990, 172 (oogstfeest Raaite).

30. KB 13 mei 1982, AB 1982, 379, m.nt. J.R.St. (Laan der Verenigde Naties). 
verzette tegen de vestiging van een Hinderwetplichtig bedrijf, gén weigeringsgrond voor de vergunningverlening kon opleveren. ${ }^{33}$ In een andere Hinderwet-zaak maakte een appellant o.m. bezwaar tegen een vergunning op grond van het feit dat hij overlast vreesde, veroorzaakt door afstromend hemelwater naar zijn lagergelegen perceel. Volgens de Kroon diende echter ook dit bezwaar buiten beschouwing te blijven omdat het géen betrekking had op gevaar schade of hinder als bedoeld in vermeld artikel 13 Hinderwet. ${ }^{34}$ Stellige rechtsoverwegingen worden in dit verband aangetroffen in een Koninklijk Besluit uit $1982 .{ }^{35}$ In casu hadden gedeputeerde staten van Zuid-Holland ingevolge de provinciale Wegenverordening ontheffing verleend aan een waterschap om een aantal plaatselijke wegaansluitingen te verbreden. In het verband met deze verbredingswerkzaamheden werd zonder toestemming van een rechthebbende een strook grond bij de weg getrokken. Het bezwaar van appellant (de rechthebbende) spitste zich op deze problematiek toe. Nadat de Kroon had vastgesteld dat de verbreding in het belang van de instandhouding van de betreffende weg moest worden geacht - en de ontheffing derhalve terecht was verleend -, werd ten aanzien van de bezwaren overwogen dat '...voorts artikel 25 tweede lid van de meervermelde verordening niet medebrengt, dat een ontheffing achterwege dient te blijven als door de uitvoering van de ingevolge die ontheffing geoorloofde werkzaamheden inbreuk zou worden gemaakt op de rechten van derden, doch dat deze bepaling slechts beoogt aan te geven, dat een ontheffing de rechten van derden onverlet laat; dat echter de vraag of, en $z o$ ja in hoeverre, rechten door de bedoelde werkzaamheden zouden zijn geschonden niet door Ons, maar door de burgerlijke rechter kan worden beantwoord; ...' (curs. R.J.N.S.). Uit dit Koninklijk Besluit blijkt overduidelijk dat de Kroon rechtsgeschillen naar burgerlijk recht in het kader van de bestuurlijke besluitvorming buiten beschouwing liet. ${ }^{36}$

\subsubsection{De verhouding tussen de administratieve regelingen}

De Kroon is er in de regel alert op geweest om de verschillende besluitvormingskaders van sectorale administratieve wetten te scheiden. Dit blijkt o.m. uit de wijze waarop de Kroon bezwaren van appellanten, die in het kader van andere vergunningprocedures aan de orde

31. In principe, omdat uitzonderingen altijd de regel bevestigen. Zie bijv. KB 23 oktober 1976, AB 1977, 147. In dit Koninklijk Besluit besliste de Kroon dat een gemeentelijke kapvergunning voor een boom niet mocht worden geweigerd met voorbij gaan aan de artikelen 713 en 714 BW (oud). Vgl. ook het oudere KB 11 september 1964, AB 1965, p. 167 e.v.

32. Ik wijs erop dat ik hier doel op het weren van 'private rechtsbelangen' uit het materiële bestuurlijke besluitvormingsproces. De Kroon heeft daarentegen wél aanvaard dat bijv. een vergunningaanvraag nietontvankelijk kan worden verklaard indien onomstotelijk vaststaat dat de potentiěle vergunninghouder tengevolge van privaatrechtelijke belemmeringen geen daadwerkelijk gebruik van zijn vergunning zou kunnen maken. De redenering is dan niet dat de vergunning gelet op de toepasselijke regels van burgerlijk recht, en de betrokken rechten van bijv. derden, dient te worden geweigerd, maar dat de aanvrager onvoldoende belang heeft bij de vergunningverlening. Zie bijv. KB 30 oktober 1981, AB 1982, 46, m.nt. J.R. St.

33. KB 27 december 1972, AB 1973, 119, m.nt. J.R. St.

34. KB 24 juni 1977, AB $1977,344$.

35. KB 19 mei 1982, AB 1982, 514, m.nt. J.R. St. (wegverbreding Leidschendam). 
konden komen, buiten de specifieke afweging hield. Zo dienden bijv. de belangen die bescherming vonden in de (voormalige) Afvalstoffenwet en de Wet verontreiniging oppervlaktewateren bij de belangenafweging ingevolge de Ontgrondingenwet buiten beschouwing te blijven. ${ }^{37}$ Evenmin achtte de Kroon het toelaatbaar dat aan een ontgrondingenvergunning voorwaarden (bijv. ter voorkoming van hinder) werden verbonden waarvan de wenselijkheid krachtens andere wetten of verordeningen diende te worden beoordeeld. ${ }^{38}$ Ook onderscheidde de Kroon nauwkeurig de verschillende doelstellingen van afwegingskaders. In een Koninklijk Besluit van 6 april $1982^{39}$ deed de Kroon bijv. aan het college van burgemeester en wethouders van Zoeterwoude haarfijn de verhouding tussen de Wet chemische afvalstoffen en de Hinderwet uit de doeken. Hierbij nam de Kroon afstand van de opvatting van genoemd college inhoudende dat de vergunde inhoud van een vergunning ingevolge de eerstgenoemde wet afgestemd diende te worden op de vigerende Hinderwetvergunningen:

'...dat echter een vergunning krachtens het in art. 8 Wet chemische afvalstoffen genoemde vergunningstelsel niet in de plaats treedt van of uitbreiding geeft aan een op grond van de Hinderwet verleende vergunning; dat immers de doelstelling van de Wet chemische afvalstoffen is het verschaffen van een organisatorisch kader voor het op doelmatige wijze bewaren, bewerken, verwerken of vernietigen van chemische afvalstoffen'.

De Kroon heeft zich overigens wél gevoelig getoond voor de nadelen die een (te) strakke scheiding van de verschillende administratieve besluitvormingskaders met zich bracht. Een tweetal Koninklijke Besluiten, waarbij verschillende administratiefrechtelijke regelingen met elkaar in verband werden gebracht, verdient hier aandacht. Allereerst is er het opmerkelijke Koninklijk Besluit van 9 juli 1982 inzake de aanlegsteiger in de Dieperpoel te Warmond. ${ }^{40}$ In casu hadden gedeputeerde staten van Zuid-Holland ontheffing van de provinciale Plassenverordening geweigerd voor het aanwezig hebben (en uitbreiden) van een aanlegsteiger. Enige jaren eerder was deze steiger in zijn oorspronkelijke vorm echter gebouwd ingevolge een bouwvergunning. Bovendien was ten behoeve van deze bouwvergunning een anticipatieprocedure gevoerd, die geresulteerd had in het verlenen van een verklaring van geen bezwaar door het eerder genoemde provinciale college. De Kroon vond een provinciale afbraakeis, in het licht van deze voorgeschiedenis, té verstrekkend en overwoog: '...dat weliswaar de aanwezigheid van een steiger van $5 \times 5 \mathrm{~m}$ reeds een zekere storing en ontsiering van het watergebied vormt; dat evenwel mede in aanmerking dient te worden genomen, dat GS in 1973 een verklaring van geen bezwaar op grond van artikel

36. KB 28 februari 1991, AB 1991, 313 (bestemmingsplan Tuinbouwgebied Sloten). Vgl. nog ABRS 25 april 1994, AB 1994, 579 (bestemmingsplanwijziging Ermelo).

37. KB 11 september 1987, AB 1988, 186, m.nt. PJS. Vgl. ook KB 29 december 1976, AB 1977, 206 (inzake de verhouding Ontgrondingenwet en Hinderwet) en KB 20 december 1982, AB 1983, 232, m. nt. FO. In dit laatste $\mathrm{KB}$ speelde de relatie tussen de Hinderwet en de Bestrijdingsmiddelenwet.

38. KB 26 januari 1983, AB 1983, 195, m.nt. J.R. St.

39. KB 6 april 1982, AB 1982, 374, m.nt. F.O.

40. KB 9 juli 1982, AB 1983, 22, m.nt. J.R. St. (steiger Dieperpoel). 
19 Wet op de Ruimtelijke Ordening en artikel 50 achtste lid Woningwet hebben verleend met betrekking tot een bouwvergunning voor zulk een steiger; dat onder deze omstandigheden de redelijkheid gebiedt, dat, zij het onder voorschriften, alsnog ontheffing wordt verleend van een steiger van $5 \times 5 \mathrm{~m} ;$...' (curs. R.J.N.S.). Volgens annotator Stellinga was de handelwijze van de Kroon in deze 'zonder meer fout'. Ten onrechte werden volgens hem twee geheel op zichzelf staande voorschriftencomplexen door een beroep op 'de redelijkheid' met elkaar in verband gebracht, hetgeen hij in strijd met de wet achtte. ${ }^{41}$

Minder vergaand was daarentegen een koppeling die de Kroon in een Koninklijk Besluit van 7 maart $1988^{42}$ tot stand bracht tussen een ontgrondingenvergunning en een vergunningverlening ingevolge de Afvalstoffenwet. In casu maakten appellanten in de procedure op basis van de Ontgrondingenwet bezwaar tegen het feit dat ten behoeve van de afvalstorting - die na de ontgronding zou volgen - nog geen vergunning ingevolge de (voormalige) Afvalstoffenwet was verleend. De Kroon deelde dit bezwaar, en overwoog: 'In verband hiermede komt het Ons noodzakelijk voor dat aan de onderwerpelijke vergunning alsnog een voorwaarde wordt verbonden die inhoudt, dat met de ontgrondingswerkzaamheden eerst een aanvang mag worden gemaakt nadat en voorzover de ingevolge andere wetten voor het ter plaatse storten van afvalstoffen vereiste vergunningen zijn verleend en onherroepelijk zijn geworden.' Het valt op dat de Kroon hier in feite een niet bij de wet voorziene procedureel-temporele koppeling ${ }^{43}$ tussen twee afzonderlijke vergunningstelsels tot stand bracht door middel van een vergunningvoorschrift. De inhoudelijke belangenafweging werd echter strikt gescheiden gehouden, zodat het specialiteitsbeginsel niet in het gedrang kwam.

\subsubsection{Bestemmingsplan en milieuwetgeving}

Het is zinvol om afzonderlijk aandacht te besteden aan de omvangrijke bestemmingsplanjurisprudentie van de Kroon. De bevoegdheden ingevolge de Wet op de Ruimtelijke Ordening (WRO), en in het bijzonder de bestemmingsplanbevoegdheid (artikel 10 WRO), kennen nl. een bijzonder ruim (facetmatig)afwegingskaderdat zich uitstrekt over alle ruimtelijk relevante belangen. Dit ruime afwegingskader brengt met zich dat de WRO-bevoegdheden veel interferentie vertonen met bevoegdheden ingevolge sectorale wetgeving die (eveneens) betrekking heeft op het gebruik, de inrichting en het beheer van de ruimte. Gelet op deze interferentie komen 'specialiteitsproblemen' in het ruimtelijke bestuursrecht veelvuldig voor.

Met name de relaties tussen de sectorale milieuwetgeving en het bestemmingsplan zijn complex. ${ }^{44}$ Waar in het kader van de milieuwetgeving de bescherming van het fysieke milieu door middel van specifieke - op inrichtingen toegespitste - normstelling op de voorgrond staat, daar neemt binnen de planologische besluitvormingskaders de optimale

41. Hierbij dient echter wel te worden aangetekend dat in casu een 'discretionaire' handhavingsvraag aan de orde was.

42. KB 7 maart 1988, $A B$ 1988, 306, m.nt. P.J.S. (ontgronding Hoogland).

43. Zie in dit verband hoofdstuk 4 (paragraaf 4.6.6). 
ruimtelijke scheiding van de verschillende gebruiksfuncties van grond en opstallen een centrale plaats in. Milieubelangen en ruimtelijke belangen raken elkaar in die zin dat de behartiging van de eerstgenoemde belangen voor een deel langs het facetmatige ruimtelijke beleidsspoor kan worden gerealiseerd. Milieunormen kunnen immers niet zelden in ruimtelijke relevante afstandsnormen worden vertaald. Dit gegeven ligt ten grondslag aan het ruimtelijke instrument van de zonering. De noodzaak van zonering komt bijv. goed tot uitdrukking in de casus die ten grondslag lag aan het Koninklijk Besluit Geldermalsen van 18 januari $1991 .^{45}$ In casu hadden gedeputeerde staten van Gelderland partie̋le goedkeuring onthouden aan een bestemmingsplangedeelte waarin woningen en een speelweide volgens genoemd college te dicht in de nabijheid van een boomgaard waren geprojecteerd. In de boomgaard vond regelmatig bespuiting plaats met bestrijdingsmiddelen. De Kroon deelde de opvatting van gedeputeerde staten en was van oordeel dat de toepasselijkheid van de Bestrijdingsmiddelenwet niets afdeed aan de noodzaak van ruimtelijke zonering: 'Voorop moet worden gesteld dat in het kader van een bestemmingsplan een afweging van alle bij het gebruik van de gronden betrokken belangen dient plaats te vinden, het milieubelang niet uitgezonderd. De toepasselijkheid in casu van de Bestrijdingsmiddelenwet en daarop gebaseerde regelgeving staat hieraan niet in de weg, aangezien deze regels enerzijds en de Wet op de Ruimtelijke Ordening anderzijds elk een eigen werkingssfeer hebben. Voorts komt het streven van gedeputeerde staten om milieubelastende functies ruimtelijk te scheiden van milieugevoelige functies Ons juist voor' (curs. R.J.N.S.).

Zonering van ruimte is, zo blijkt uit het bovenstaande Koninklijk Besluit, gericht op de scheiding van elkaar (vanuit milieu-oogpunt) 'bijtende' gebruiksfuncties. In het bestemmingsplan kan deze ruimtelijke zonering bij uitstek haar normatieve beslag krijgen doordat de ruimtelijke scheiding van de verschillende bestemmingen hierin bindend wordt vastgesteld. Gelet op het vorenstaande kan worden gesteld dat binnen de planologische besluitvormingskaders en de milieuhygiennische besluitvormingskaders (bijv. ingevolge de Wet milieubeheer) verwante publiekrechtelijke belangen worden behartigd. ${ }^{46}$ Toch zullen de regulerende functies van de Wet op de Ruimtelijke Ordening en de milieuwetgeving gescheiden dienen te blijven; het publiekrechtelijke belang van een goede ruimtelijke ordening valt immers niet samen met het publiekrechtelijke belang van de bescherming van het fysieke milieu. ${ }^{47}$ Tegen deze achtergrond heeft de Kroon een omvangrijke jurisprudentie ontwikkeld.

44. Vgl. het oudere - doch zér uitvoerige - onderzoek van Otten. F.P.J.M. Otten, Ruimtelijke Ordening en Milieubeheer. De bescherming van het leefmilieu via het instrumentarium van de Wet op de Ruimtelijke Ordening, 's-Gravenhage 1980, i.h.b. hoofdstuk 3.

45. KB 18 januari 1991, AB 1991, 478, m.nt. AKW (Geldermalsen).

46. De verwantschap tussen de milieuhygienische en planologische besluitvormingskaders is door Struiksma in zijn dissertatie haarfijn uit de doeken gedaan. Zie: J. Struiksma, Verwant zonder verband. De courdinatie van de bouw- en milieuvergunning, Deventer 1993 (i.h.b. de hoofdstukken 4 en 5).

47. Ik wijs in dit kader op het Koninklijk Besluit Bolsward (KB 10 november 1993, AB 1994, 267), waarin de Kroon expliciet overwoog dat '...een bestemmingsplan en de milieuwetgeving verschillende, op zich zelf staande toetsingskaders zijn.' Vgl. bijv. ook: KB 20 april 1989, AB 1989, 304, m.nt. JHvdV (Driebergen). 
Uit de Koninklijke Besluiten inzake de Rotterdamse Maasvlakte ${ }^{48}$ en Hefshuizen ${ }^{49}$ blijkt allereerst dat het niet is toegestaan om typisch milieuhygiënische normen (bijv. emissie- en immissienormen) als rechtstreeks toetsingskader, d.w.z. in de vorm van voorschriften, in een bestemmingsplan op te nemen. ${ }^{50}$ Evenmin mogen in een bestemmingsplan voorschriften worden opgenomen die betrekking hebben op de toegepaste productiewijze van een bedrijf. Daarentegen is het wél toelaatbaar om een bepaald type bedrijf van vestiging in een specifiek gebied uit te sluiten indien het - gelet op de milieuhygienische aard van dat bedrijfstype - vanuit ruimtelijk oogpunt bij voorbaat vaststaat dat vestiging niet verantwoord is. Indien de vestiging van bepaalde bedrijven (bijv. intensieve veehouderijen) vanuit ruimtelijk oogpunt bedenkelijk is, en de vanuit ruimtelijk oogpunt aanmerkelijke nadelen door de milieuwetgeving niet afdoende kunnen worden ondervangen ${ }^{51}$, is het óok toelaatbaar om een wijzigingsbevoegdheid in het bestemmingsplan op te nemen. Hierdoor kunnen dan per geval de ruimtelijke consequenties van een bedrijfsvestiging in een bepaald gebied worden beoordeeld. ${ }^{\text {s2 }}$

Uit de Kroonjurisprudentie blijkt dat het bestemmingsplan zich dient te richten op een eerste (globale) ruimtelijke scheiding van gebruiksfuncties en dat de milieuwetgeving - als een soort tweede zeef - in concreto (dus binnen een gegeven bestemming) de kwaliteit van het fysieke leefmilieu dient te waarborgen. ${ }^{53}$ Dit brengt $0 . m$. met zich dat in een bestem-

48. KB 19 september 1986, AB 1987, 221, m.nt. AWK (Maasvlakte II). Zie ook reeds KB 10 maart 1979, BR p. 419 (Maasvlakte I).

49. KB 17 december 1987, AB 1988, 388, m.nt. AWK (Hefshuizen). Vgl. in dit verband ook de Koninklijke Besluiten Halsteren (KB 5 december 1986, AB 1987, 222), Ulestraten (KB 27 oktober 1981, AB 1982, 54, m.nt.V.d.N.) en Helmond (KB 27 november 1984, AB 1985, 232). In het laatstgenoemde Koninklijke Besluit onthield de Kroon goedkeuring aan een bestemmingsplan dat voorschriften bevatte inzake de maximale geluidsbelasting op gevels van woningen, alsmede het geluidsniveau binnen woningen. Volgens de Kroon waren deze voorschriften nl. in strijd met de Wet geluidhinder.

50. Uit het Koninklijk Besluit Opsterland (KB 6 augustus 1993, AB 1995, 54) blijkt dat dit niet alleen geldt voor bestemmingsplanvoorschriften in 'enge' zin, maar bijv. ook voor een beschrijving van hoofdlijnen (b.i.h.). Milieuhygienische doelstellingen (opgenomen in de b.i.h.) mogen bijv. niet dienen als rechtstreeks toetsingskader voor planologische vrijstellingen en aanlegvergunningen.

51. Wat betreft de veehouderij zou men kunnen denken aan beperking van de te gunnen veestapel en specifieke voorschriften ter voorkoming van stank en hinder.

52. Zie: KB 22 april 1988, AB 1988, 402 (Leerdam).

53. Deze benadering is bijv. duidelijk neergelegd in een Koninklijk Besluit van 8 december 1987 (AB 1988, 532). T.a.v. de toelaatbaarheid van intensieve veehouderij in een plangebied overwoog de Kroon met het oog op de relatie tussen bestemmingsplan en milieuwetgeving: 'Uit hoofde van de Wet op de Ruimtelijke Ordening moeten alle bij het gebruik van de bodem betrokken belangen in een bestemmingsplan worden gecoordineerd om tot een doelmatige indeling en een verantwoord gebruik van de grond en de opstallen te komen. (..) In verband hiermee is het streven van het gemeentebestuur om uit planologisch oogpunt beperkingen aan te brengen t.a.v. agrarische bedrijven met intensieve veehouderij-activiteiten in beginsel aanvaardbaar. Hieraan doet niet af dat eveneens in het kader van de milieuwetgeving regels zijn te stellen t.a.v. intensieve veehouderij, daar deze regels slechts betrekking hebben op de milieuhygiénische effecten afkomstig van een bedrijf dat ingevolge een bestemmingsplan op een bepaalde plaats toelaatbaar is' (curs. R.J.N.S.). Vgl. ook: KB 16 maart 1987, AB 1987, 371 (Tilburg) en KB 23 december 1987, AB 1988, 265 (Amsterdam). Ik wijs er in dit verband ook nog op dat in gevallen waarin de milieuwetgeving génn 
mingsplan de vestiging van een bepaald bedrijfstype, dat vanuit milieuhygiënisch oogpunt op een bepaalde locatie toelaatbaar is, niet reeds geheel mag uitsluiten. Dit uitgangspunt is door de Kroon o.m. neergelegd in het bekende Koninklijk Besluit 'Spijkenisse' ${ }^{54}$ In dit Koninklijk Besluit overwoog de Kroon nl. dat (wat de milieubelasting betreft) in het kader van de hantering van een zgn. Staat van Inrichtingen ${ }^{55}$ - ter zonering van de bedrijfsvestiging in een plangebied - niet mocht worden uitgegaan van het 'gemiddelde type bedrijf' binnen een bedrijfsgroep. Zou dit immers wél het uitgangspunt zijn, dan zouden aan bijv. 'moderne' milieuvriendelijke bedrijven systematisch te hoge (afstands)eisen worden gesteld. Met het oog op dit gegeven heeft de Kroon ook steeds het standpunt gehuldigd dat een bestemmingsplan, dat een Staat van Inrichtingen omvat, dient te voorzien in vrijstellings- en/of wijzigingsbevoegdheden.

\subsubsection{Bestemmingsplan en andere 'grensconflicten'}

Het normatieve planologische regime kan conflicteren met diverse andere administratieve regelingen en met beleidsdoelstellingen die buiten de ruimtelijke ordening sec zijn gelegen. Zo zijn bijv. de raakvlakken tussen 'welstandsbeleid' en 'planologisch/stedenbouwkundig beleid' diffuus. Ingevolge vaste Kroonjurisprudentie mogen in een bestemmingsplan gén specifieke welstandscriteria worden opgenomen. Het welstandsbeleid vindt zijn juridische grondslag immers in artikel 12 van de Woningwet en niet in artikel 10 van de Wet op de Ruimtelijke Ordening. Gelet op het bepaalde in artikel 8 lid 6 van de Woningwet is de plaatselijke Bouwverordening de aangewezen regeling om dit beleid normatief te concretiseren. Een voorschrift in het (ontwerp)bestemmingsplan 'Kapelaansdijk' van de gemeente Veldhoven ${ }^{56}$, waarin aan burgemeester en wethouders de bevoegdheid was toegekend om met inachtneming van de beschrijving in hoofdlijnen nadere eisen te stellen aan de situering, de bouwmassa, de vormgeving en de toegepaste materialen voor wat betreft bouwwerken op een bedrijventerrein, kon dan ook niet de goedkeuring van de Kroon verkrijgen. ${ }^{57}$

afdoende bescherming aan de planologische waarde van een gebied biedt, het bestemmingsplan - in beginsel - een aanvullende functie in dit kader kan vervullen. Zo accepteerde de Kroon bijv. een (planologisch) aanlegvergunningenstelsel dat het gebruik van meststoffen in een natuur- en bosgebied beoogde te reguleren. Zie: KB 30 maart 1987, AB 1987, 443 (Melick en Herkenbosch).

54. KB 10 juli 1989, AB 1990, 92, m.nt. AWK (Spijkenisse).

55. Een Staat van Inrichtingen maakt onderdeel uit van de bestemmingsplanvoorschriften en omvat een indeling (in abstracto) van de in een bepaald plangebied toelaatbare bedrijven naar hun ruimtelijk relevante milieubelasting. Naarmate een bedrijf, wat betreft milieubelasting, 'hoger scoort' zal het in een bedrijvencategorie worden ingedeeld die qua afstand verder van andere gevoelige gebruiksfuncties (bijv. een woonwijk) dient te worden gesitueerd. Het voert in het kader van dit boek te ver om de verschillende bedrijfsindelingssystemen en de in dat kader gehanteerde milieuparameters te bespreken. In dit verband dient wél nog te worden opgemerkt dat ingevolge de Kroonjurisprudentie een Staat van Inrichtingen en het bijbehorende indelingssysteem dient te worden toegespitst op de specifieke kenmerken van een plangebied. Zie bijv. KB 5 augustus 1994, AB 1995, 22 (Nieuwegein).

56. KB I december 1993, AB 1994, 462, m.nt. AWK (Veldhoven). 
Het voeren van een typisch (financieel) volkshuisvestings- of bedrijvenbeleid ingevolge een bestemmingsplan is eveneens, voorzover dit ruimtelijk niet relevant is, ontoelaatbaar. Zo onthield de Kroon goedkeuring aan zogenoemde 'sociale bepalingen' welke door de Amsterdamse gemeenteraad waren opgenomen in het bestemmingsplan 'Wilhelmina Gasthuisterrein' ${ }^{58}$ Ontoelaatbaar achtte de Kroon eveneens een 'planologische' bedrijvenregeling die door de gemeenteraad van Alkemade was neergelegd in de voorschriften van het bestemmingsplan 'De Lasso Zuid'. ${ }^{59}$ De betreffende bedrijvenregeling beoogde te bewerkstelligen dat zich op een lokaal bedrijventerrein uitsluitend lokale bedrijven, dan wel bedrijven met een lokale binding zouden vestigen. De Kroon maakte met deze bepaling korte metten en stelde vast dat de WRO gén grondslag bood voor een regeling die enkel betrekking had op een specifieke groep van bedrijven 'die zich in niets anders onderscheidt van soortgelijke, andere bedrijven dan in hun herkomst'.

Ook de verhouding tussen de Wet op de Ruimtelijke Ordening (WRO) en de Ontgrondingenwet is veelvuldig in de Kroonjurisprudentie aan de orde gesteld. ${ }^{60}$ De verhouding tussen beide wetten is complex omdat zowel de WRO, als de Ontgrondingenwet een ruim belangenafwegingskader kennen. Waar het besluitvormingskader van de Wet op de Ruimtelijke Ordening zich richt op de afweging van alle ruimtelijk relevante belangen, daar ziet het afwegingskader van de Ontgrondingenwet op het afwegen van (alle) bij de ontgronding betrokken belangen. ${ }^{61} \mathrm{De}$ vraag of een vergunning ingevolge de Ontgrondingenwet in strijd met het vigerende bestemmingsplan kan worden verleend vormt een rode draad in de relevante Koninklijke Besluiten. Het valt op dat de Kroon steeds voorop stelde dat de WRO en de Ontgrondingenwet twee zelfstandige, d.w.z. naast elkaar staande regelingen zijn met een eigen toetsingskader. Dit brengt met zich dat het gegeven, dat de uitvoering van een ontgronding in strijd is met het vigerende bestemmingsplan, géén zelfstandige reden is om een ontgrondingsvergunning te weigeren. Wél zal in het kader van de belangenafweging, die aan het verlenen van de ontgrondingsvergunning ten grondslag ligt, de bestemming van het betreffende gebied in ogenschouw moeten worden genomen. Het publieke belang van een goede ruimtelijke ordening, zoals gespecificeerd in het bestem-

57. Vgl. ook KB 15 november 1984, AB 1985, 491 (Nieuwkoop). Daarentegen had de Kroon weer géen bezwaar tegen een verwant voorschrift in het (ontwerp-) bestemmingsplan 'Ansen' van de gemeente Ruinen KB 17 januari 1984, AB 1984, 396 (Ansen). Dit voorschrift beoogde overigens uitsluitend de uitwendige hoofdvorm van de bebouwing in het gave dorpsbeeld van het brinkdorp wat betreft goothoogte, nokhoogte en dakvorm te conserveren. Volgens de Kroon was dit voorschrift aanvaardbaar omdat het een betere mogelijkheid bood om het dorpsbeeld te beschermen dan het welstandstoezicht.

58. KB 17 oktober 1988, AB 1989, 75, m.nt. AKW (Amsterdam).

59. KB 21 februari 1995, AB 1995, 477, m.nt. AKW; BR 1995/7, p. 578, m.nt. H.J. De Vries. (Alkemade).

60. Zie o.m. het contrair KB 25 juli 1981, AB 1982, 15, m.nt. J.R. St; KB 20 januari 1983, AB 1983, 300 en het contrair KB 23 oktober 1984, AB 1985, 166, m.nt. F.P.C.L. Tonnaer en KB 24 mei 1985, AB 1985, 475. Ik verwijs voorts op de bespreking van de jurisprudentie van de Afdeling geschillen van Bestuur ingevolge de Tijdelijke Wet Kroongeschillen die in het vervolg van dit hoofdstuk aan de orde zal komen.

61. Dit kan een uiterst breed spectrum van (publiekrechtelijke) belangen betreffen, waaronder bijv. o.m. de belangen van natuur- en landschapsschoon, landbouw, recreatie, woon- en leefmilieu, verkeer, drinkwatervoorziening en werkgelegenheid. 
mingsplan, zal dan afgewogen dienen te worden tegen alle andere bij de ontgronding betrokken (publiekrechtelijke) belangen. Hierbij staat niet bij voorbaat vast welk belang zal prevaleren. ${ }^{62}$ Een factor van betekenis is in dit kader bijv. het gegeven of een ontgronding - op termijn - ook daadwerkelijk planologisch kan worden ingepast.

Ik rond af met nog enige andere veel voorkomende 'grensconflicten' in het ruimtelijk bestuursrecht. ${ }^{63} \mathrm{De}$ relatie tussen het beschermingsregime van de Natuurbeschermingswet en het bestemmingsplan is vaak in de Kroonjurisprudentie aan de orde geweest. ${ }^{64} \mathrm{Uit}$ de relevante Koninklijke Besluiten blijkt dat de Natuurbeschermingswet een specifieke functie vervult naast het planologische regime van het bestemmingsplan, ók indien in dit plan de betreffende gronden reeds tot natuurgebied waren bestemd. De aanwijzing van een gebied als natuurmonument brengt $\mathrm{nl}$. verdergaande (positieve) beheersmogelijkheden met zich dan de mogelijkheden die het bestemmingsplan en de Wet op de Ruimtelijke Ordening kunnen bieden. Omgekeerd heeft de Kroon echter ook aanvaard dat bijv. aanlegvergunningstelsels vanuit planologisch oogpunt wenselijk en toelaatbaar kunnen zijn naast specifieke vergunningstelsels ingevolge sectorale wetgeving. Dit geldt ób indien zij op dezelfde activiteit betrekking hebben. Een mooi voorbeeld biedt in dit verband een Koninklijk Besluit van 22 augustus $1983 .{ }^{65}$ In casu had de gemeenteraad van Wijhe in het bestemmingsplan 'Buitengebied' (onder uitzondering van enige categorieën van gewassen) het vellen, rooien en beschadigen van houtgewas - anders dan bij wijze van verzorging in het winterbed van de IJssel aan een aanlegvergunningstelsel gebonden. De hoofdinge-

62. Deze gedachtegang is bijv. uitvoerig verwoord in het contrair Koninklijk Besluit inzake de mergelwinning te Berg en Terblijt (KB 23 oktober 1984, AB 1985, 166, m.nt. F.P.C.L. Tonnaer). Ik citeer de centrale overwegingen van de Kroon: '...dat de Ontgrondingenwet, mede gelet op de geschiedenis van de totstandkoming daarvan, de toepasselijkheid van de Wet op de Ruimtelijke Ordening niet uitsluit; dat de afweging van de in art. 10 vijfde lid Ontgrondingenwet bedoelde belangen mede inhoudt, dat met de bestemmingen van het gebied, dat in de aanvraag om vergunning is begrepen, voldoende rekening wordt gehouden; dat de feitelijke uitvoering van de onderwerpelijke ontgronding tot het resultaat zal leiden dat deze terreinen, voorzover in het 'Algemeen Bestemmingsplan' der voormalige gem. Berg en Terblijt aangewezen voor 'Agrarisch gebied met landschappelijke waarde', blijvend aan deze bestemming zullen worden onttrokken, doch dat zulks, mede gelet op de daarmee te dienen belangen, op zichzelf niet zonder meer aan het verlenen van een vergunning, als hier in het geding, in de weg behoeft te staan; dat derhalve o.m. het belang van handhaving van deze bestemming ter plaatse moet worden afgewogen tegen de met de ontgronding te dienen belangen; ...' (curs. R.J.N.S.).

63. De navolgende grensconflicten trof ik frequent aan in de Kroonjurisprudentie: WRO/Natuurbeschermingswet; WRO/Ontgrondingenwet; WRO/Rivierenwet; WRO/Boswet; WRO/Luchtvaartwet; WRO/Wegenverkeerswet; WRO/Waterstaatswet 1900; WRO/Bestrijdingsmiddelenwet en WRO/Grondwaterwet.

64. Zie o.m. KB 15 maart 1982, AB 1982, 417, m.nt. CLR (de 'Blanke Slikken'); KB 3 februari 1983, AB 1983, 279, m.nt. CLR (Kievietsbloementerreinen); KB 18 mei 1983, AB 1983, 416, m.nt. CLR (de Dommelbeemden); KB 17 december 1984, AB 1985, 262, m.nt. BJvdN (Kop van Schouwen I) en KB 14 maart 1986, AB 1986, 484 (Markiezaatsmeer-Zuid).

65. KB 22 augustus 1983, AB 1984, 340 (Wijhe). Ik wijs in dit kader ook op KB 15 maart 1984, AB 1984, 397 (Helvoirt) en KB 23 mei 1984, AB 1985, 104, m.nt. AWK (Ohé en Laak) die in een zelfde richting wijzen. In de betreffende zaken waren respectievelijk vergunningstelsels ingevolge de Boswet en de Ontgrondingenwet naast een aanlegvergunningstelsel in het geding. Zie voorts nog: KB 24 mei 1985, AB 1985, 475 (Schaijk). 
nieur-Directeur van de Rijkswaterstaat in de Directie Overijssel maakte hiertegen bezwaar omdat naar zijn oordeel naast de waarborgen die de Rivierenwet bood geen behoefte bestond aan een separaat planologisch vergunningstelsel. De Kroon deelde deze opvatting echter niet, en was - kort gezegd - van oordeel dat de Rivierenwet (oud) géén landschappelijke, cultuurhistorische en natuurwetenschappelijke waarden veilig kon stellen. Deze belangen konden daarentegen wél adequaat door middel van het aanlegvergunningenstelsel worden beschermd.

Een aantal interessante 'grens'-conflicten deed zich tot slot voor in de relaties tussen WRO/Wegenverkeerswet, WRO/Grondwaterwet en WRO/Waterstaatswet 1900. Uit een Koninklijk Besluit van 4 januari $1995^{66}$ blijkt dat ingevolge een bestemmingsplan géén verkeerstechnisch beleid mag worden gevoerd. Dit ondervond een aantal inwoners van Baarn die van oordeel waren dat het (ontwerp-)bestemmingsplan 'Lage Vuursche 1992' in een bepaalde straat de parkeerdruk onvoldoende reguleerde. De Kroon overwoog ten aanzien van hun bezwaren o.m.: 'Het kan niet worden ontkend dat het regelen van parkeergelegenheid aan de zuidkant van de dorpskern uit een oogpunt van goede ruimtelijke ordening van belang is. Dit houdt echter niet in dat het plan uit dien hoofde op gedetailleerde wijze de parkeermogelijkheden langs de Koudelaan zou dienen vast te leggen. Naar Ons oordeel is de wegenverkeerswetgeving het meest geëigende instrument om door middel van bewegwijzering het verkeer naar de minst bezwarende parkeergelegenheden te verwijzen.' De bezwaren dienden derhalve, voorzover zij het parkeerbeleid sec betroffen, buiten het typisch planologische besluitvormingskader te blijven. In een Koninklijk Besluit van oudere datum ${ }^{67}$ hield de Kroon bezwaren van het bestuur van het waterschap Geleen- en Molenbeek buiten de planologische afweging omdat de Waterstaatswet 1900 de bezwaren afdoende kon ondervangen. Het genoemde waterschapsbestuur maakte in casu bezwaar tegen een (ontwerp)bestemmingsplan van de gemeente Susteren waarin volgens het bestuur ten onrechte aan een strook grond langs een openbare waterloop de bestemming 'Tuin' was gegeven. Volgens het waterschapsbestuur zou dit gevolgen hebben voor de mogelijkheden om de oever machinaal te onderhouden. De Kroon deelde deze opvatting niet: '...dat, voorzover nodig, het Waterschap met gebruikmaking van de hem krachtens de Waterstaatswet 1900 toegekende bevoegdheden maatregelen kan nemen tot aanleg en verbetering van noodzakelijk geachte werken; dat onder deze omstandigheden de belangen van de rechthebbenden op de tuinen dienen te prevaleren boven het belang van de appellant om dit oevergedeelte machinaal te onderhouden; ...'.

Ter afsluiting van deze paragraaf kan nog gewezen worden op een Koninklijk Besluit waarin planologische bezwaren van een appellant buiten een specifiek sectoraal afwegingskader werden gehouden. ${ }^{68}$ In casu maakte een kwekerij bezwaar tegen een wijzigingsvergunning ingevolge de Grondwaterwet, waarin het de NV Waterleiding Maatschappij

66. KB 4 januari 1995, AB 1995, 337, m.nt. AKW (Baarn). Vgl. ABRS 16 april 1996, BR 1996/10, p. 815 e.v. m.nt. H.J. de Vries (Haarlemmermeer).

67. KB 19 november 1981, AB 1982, 75, m.nt. v.d.N. (Susteren).

68. KB 7 november 1981, AB 1982, 47 (Gilze en Reijen). 
'Noord-West-Brabant' - kort gezegd - werd vergund om een waterwinning in de richting van de bedrijfspercelen van appellant te verplaatsen. Deze laatste was van oordeel dat de vergunningverlening ingevolge de Grondwaterwet de planologische belangenafweging in het kader van een toekomstige wijziging van het bestemmingsplan geheel illusoir zou maken. Desalniettemin liet de Kroon de bezwaren van appellant, die in het bijzonder betrekking hadden op een te projecteren beschermingszone, buiten beschouwing: '.. dat dit bezwaar buiten beschouwing moet blijven, aangezien het niet betreft de wateronttrekking als zodanig; dat immers - zoals ook uit de geschiedenis van de totstandkoming van de Grondwater Waterleidingbedrijven blijkt - tegen het algemeen belang van de drinkwatervoorziening slechts dienen te worden afgewogen andere algemene belangen, welke met de onttrekking van water zijn gemoeid; ...'.

\subsubsection{Tussenconclusie}

Overziet men de omvangrijke Kroonjurisprudentie dan kan worden vastgesteld dat de Kroon strak de hand hield aan het specialiteitsbeginsel. Dit blijkt in het bijzonder uit het feit dat de Kroon het bestuurlijke belangenafwegingsproces, alsmede de publiekrechtelijke bevoegdheidsuitoefening in zijn algemeenheid, sterk benaderde vanuit de specifieke publiekrechtelijke belangen die in een administratieve regeling bescherming hadden gevonden. Om 'vreemde' belangen van (derde-)belanghebbenden buiten de belangenafweging te houden paste de Kroon meer dan eens een soort 'Schutznorm'-leer toe. Ook was de Kroon zich terdege bewust van de gefragmenteerde structuur van de administratieve wetgeving. De Kroon onderzocht in de regel nauwkeurig aan welk specifiek besluitvormingskader een bepaald bezwaar van een appellant diende te worden toegedeeld.

\subsection{De Afdeling rechtspraak van de Raad van State (ARRS)}

Tijdens het relatief korte bestaan van de Afdeling rechtspraak, heeft dit college op grond van de voormalige Wet Arob een enorme hoeveelheid jurisprudentie op bestuursrechtelijk terrein geproduceerd. Deze jurisprudentie - die betrekking heeft op vele delen van het bijzondere bestuursrecht ${ }^{69}$ - wordt in hoofdlijnen voortgezet door de huidige Afdeling bestuursrechtspraak. Zeventien jaar Arob-jurisprudentie heeft veel uitspraken opgeleverd die relevant zijn voor het in dit boek besproken onderwerp. ${ }^{70}$ Het belang van de Arobjurisprudentie wordt extra onderstreept door het feit dat bepaalde uitspraken duidelijk doorklinken in de huidige jurisprudentie van de Afdeling bestuursrechtspraak.

69. Stroink heeft in dit kader gesproken over de belangrijkste Nederlandse administratieve rechter, in die zin dat de Arob-rechter over een algemene aanvullende competentie beschikte voorzover er 'beschikkingen' in het geding waren. Zie: F.A.M. Stroink, Rechterlijke organisatie en rechtspraak in beweging, Zwolle 1993, p. 115.

70. Voor een analyse van de Arob-jurisprudentie en het specialiteitsbeginsel in de periode 1977 tot 1984 wordt de aandacht gevestigd op de analyse van Stroink en De Waard in de Steenbeek-bundel. F.A.M. Stroink en B.W.N. de Waard, Het specialiteitsbeginsel, in: Burger en overheid, 's-Gravenhage 1984, i.h.b. p. $236 \mathrm{t} / \mathrm{m} 246$. 


\subsubsection{Belangenafweging en doelgebondenheid}

Uit de jurisprudentie van de Afdeling rechtspraak blijkt dat dit college steeds is uitgegaan van een bestuurlijke plicht om in het kader van een discretionaire beschikkingsbevoegdheid het speciale publiekrechtelijke belang 'af te wegen' tegen alle betrokken belangen van de direct-belanghebbende. De uitspraken waaruit dit blijkt zijn talrijk en behoeven niet uitvoerig te worden besproken. ${ }^{71}$ Vermeldenswaardig is dat de Afdeling 6́6k economische en typische bedrijfsbelangen van particulieren in de afweging betrok. ${ }^{72}$ Dit gold eveneens voor diverse belangen van niet-materiêle aard. ${ }^{73}$ Opvattingen à la Stellinga, waarbij een afwegingsplicht leek te worden ontkend ${ }^{74}$, zijn door de Afdeling steeds verworpen. Dit blijkt bijv. duidelijk uit de uitspraak inzake het Recreatieschap Vinkeveense Plassen. ${ }^{75}$ In casu stelde het genoemde recreatieschap zich, in het kader van een ontheffingsprocedure ingevolge de Verordening Vinkeveense Plassen 1977, op het standpunt dat met de door de direct-belanghebbende aangevoerde belangen geen rekening kon worden gehouden gelet op de beperkte taakomschrijving van het schap (nl. de behartiging van de belangen van recreatie, natuur- en landschapsbescherming). Het belang van de direct-belanghebbende was hierin gelegen dat hij met zijn (nieuwe en grotere) woonboot ligplaats kon innemen. De Afdeling overwoog:

'Het argument dat deze zwaarwegende belangen van appellant gelet op de taakomschrijving van het recreatieschap geen aanleiding kunnen zijn tot het verlenen van de ontheffing acht de Afdeling niet gegrond. Die taakomschrijving laat onverlet dat het dagelijks bestuur en verweerster zijn gehouden bij het verlenen van een ontheffing alle relevante belangen van de aanvrager van een ontheffing in aanmerking te nemen' (curs. R.J.N.S.).

Uit de jurisprudentie kan worden afgeleid dat de Afdeling het belangenafwegingsproces zag als een proces dat gericht is op het bereiken van een zekere balans ${ }^{76}$ tussen het

71. Een chronologische greep uit deze rijke jurisprudentie: ARRS 26 augustus 1977, tB/S (beroepsgronden), p. 93, m.a. tB/S; ARRS 13 december 1979, AB 1980, 368, m.nt. CLR, eveneens gepubliceerd in BR 1980, p. 452; ARRS 21 februari 1984, AB 1984, 300, m.nt. CLR; ARRS 8 december 1987, AB 1988, 398, m.nt. JHvdV; ARRS 14 december 1987, AB 1988, 441; ARRS 31 maart 1988, AB 1989, 6, m.nt. JHvdV; ARRS 27 april 1989, AB 1990, 216; ARRS 14 juni 1990, AB 1991, 280; ARRS 19 februari 1993, AB 1993, 540, m.nt. RMvM; ARRS 15 oktober 1993, AB 1994, 181.

72. Zie bijv. ARRS 15 augustus 1980, Gst. 6652, nr. 5, m.n. J.M.K. (gasopslag Borssele) en ARRS 8 augustus 1989, AB 1991, 142 (shoarmazaak Apeldoorn). Een van de centrale overwegingen in de laatstgenoemde uitspraak luidde: 'Naar het oordeel van de Afd. kan niet met recht worden gezegd dat verweerder bij afweging van het financiële belang van appellant bij latere sluitingstijden in en rond het weekend tegen het belang van omwonenden bij een ongestoorde nachtrust in dit geval niet in redelijkheid aan dit laatste belang overwegende betekenis heeft kunnen toekennen' (curs. R.J.N.S.).

73. Zie bijv. ARRS 18 februari 1993, AB 1993, 289, m.nt. PJS en ARRS 15 februari 1993, AB 1993, 488, m.nt. L.J.J. Rogier (nadeelcompensatie en immateriele schade).

74. Zie voor een bespreking van de opvatting van Stellinga inzake de bestuurlijke belangenafwegingsplicht hoofdstuk 7 (paragraaf 7.2.1).

75. ARRS 13 juli 1981, tB/S III, nr. 275, m.a. tB/S. (recreatieschap Vinkeveense plassen).

76. Vgl. art. 3:4 lid 2 Awb. 
speciale publiekrechtelijke belang dat aan een bevoegdheid ten grondslag ligt en de betrokken particuliere belangen. Dit verklaart waarom volgens de Afdeling verwacht mag worden dat nadeelcompensatie aan de direct-belanghebbende wordt aangeboden, indien diens gerechtvaardigde belangen noodzakelijkerwijs moeten wijken voor het speciale publiekrechtelijke belang. ${ }^{77}$ Illustratief is in dit kader een centrale rechtsoverweging in de Afdelingsuitspraak over de verplaatsing van het benzinestation aan de Rijksweg 16, waarin werd overwogen: 'De Afdeling rechtspraak is voorts van oordeel dat verweerder in redelijkheid onder gelijktijdige toekenning van nadeelcompensatie aan appellante, een groter gewicht heeft kunnen toekennen aan de algemene belangen van de verkeersveiligheid en van een goede infrastructuur ter plaatse dan aan het belang van appellante bij handhaving van haar benzinestation aldaar' (curs. R.J.N.S.). ${ }^{78}$

Dat de Afdeling 'gecharmeerd' was van een ruime belangenafwegingsplicht blijkt wel uit de wijze waarop in diverse uitspraken deze plicht in erg algemene (en wellicht te ruime) bewoordingen werd geformuleerd. ${ }^{79}$ Met name bepaalde Voorzittersuitspraken zijn exemplarisch. Men treft in dit verband o.m. overwegingen aan dat '...alle daarvoor in aanmerking komende belangen ${ }^{\mathrm{BO}}$ in overweging dienen te worden genomen of dat '...alle daarbij betrokken belangen ${ }^{181}$ dienen te worden afgewogen. Uit dergelijke (Voorzitters)uitspraken mag naar mijn oordeel echter niet te snel de conclusie worden getrokken dat de Afdeling een ruime - integrale - belangenafweging voorstond. In dit verband is het noodzakelijk om na te gaan welke betekenis door de Afdeling werd toegekend aan het doelgebonden karakter van bestuursbevoegdheden. Hierbij is het zinvol om na te gaan hoe de Afdeling het speciale publiekrechtelijke belang (of het samenstel van speciale publiekrechtelijke belangen) positioneerde binnen het proces van bestuurlijke belangenafweging.

Een aantal uitspraken inzake APV-vergunningen illustreert allereerst dat de Afdeling niet erg consequent was in het kiezen van haar overwegingen. In een uitspraak van 17 november $1981^{82}$ betreffende een vergunning tot het planten van een heg, overwoog de Afdeling ten aanzien van het belang van het natuurschoon en uiterlijk aanzien van de gemeente dat '...bij de afweging van belangen, die aan een beslissing op een verzoek om vergunning ter opheffing van dit verbod vooraf dient te gaan, in ieder geval het evengenoemde belang dient te worden betrokken en dat een weigering van een dergelijke

77. Vgl. bijv. ARRS 8 februari 1989, AB 1990, 152, m.nt. P.C.E. van Wijmen (woonschip 'De Blijheid') en ARRS 8 juli 1992, AB 1993, 248, m.nt. C. Riezebos (kapverordening Oldenzaal).

78. ARRS 9 maart 1993, AB 1994, 83 (benzinestation Rijksweg 16).

79. Het betreft hier i.h.b. uitspraken welke betrekking hebben op planologische en microstedenbouwkundige vrijstellingen. Zie bijv. ARRS 21 oktober 1977, BR 1978, p. 118 (Leeuwarden). Hier overwoog de Afdeling dat het verantwoordelijke bestuursorgaan alle belangen in zijn overwegingen kon betrekken, '... welke door het verlenen van de vrijstelling worden gediend of geschaad.' Vgl. ook ARRS 9 februari 1978, AB 1978, 478, m.nt. v.d.V.

80. Zie bijv. VzARRS 21 januari 1987, AB 1988, 55 inzake een vrijstelling ingevolge art. 18a WRO (oud).

81. Zie bijv. VzARRS 4 september 1987, AB 1988, 204, m.nt. PvB inzake een ligplaatsvergunning ingevolge de Amsterdamse APV. Vgl. ook: VzARRS 19 november 1993, Gst. 6990, p. 328, m.n. H.H. inzake de vaststelling van de sluitingstijd voor een Horeca-gelegenheid ingevolge de Zoetermeerse APV.

82. ARRS 17 november 1981, AB 1982, 107, m.nt. v.d.V. (Wassenaarse heg). 
vergunning ten minste mede hierin haar grondslag moet kunnen vinden, dat dit belang door deze beslissing wordt gediend' (curs. R.J.N.S.). ${ }^{83}$ In een tweetal uitspraken inzake het folkloristische Limburgse 'gansslaan' of 'gansrijden' kwam de Afdeling ten aanzien van het betrokken 'openbare orde'-belang tot overwegingen die onderling aanzienlijk verschillen. In de zaak Born ${ }^{84}$ overwoog de Afdeling: 'Met artikel 45 (van de APV R.J.N.S.) is dan ook beoogd de belangen van de openbare orde te beschermen, hetgeen betekent dat bij het al dan niet verlenen van een vergunning met name belangen ontleend aan de openbare orde in aanmerking dienen te worden genomen' (curs. R.J.N.S.). In de zaak Eijsden ${ }^{85}$ luidde het daarentegen: 'Dit brengt met zich dat bij de afweging van belangen die aan een besluit op een verzoek om een vergunning als bedoeld in dat artikel vooraf dient te gaan, in ieder geval het belang van de openbare orde moet worden betrokken' (curs. R.J.N.S.). Tot slot kan in dit verband nog de aandacht worden gevestigd op een formulering die o.m. kan worden aangetroffen in de uitspraak over een geweigerde standplaatsvergunning te Urk. ${ }^{86}$ In deze uitspraak overwoog de Afdeling dat '...bij de afweging van belangen die aan een beslissing op een verzoek om vergunning tot het innemen van standplaats vooraf dient te gaan, in ieder geval het belang van de openbare orde dient te worden betrokken, en dat bij afwezigheid van ieder gevaar voor aantasting van dat belang, andersoortige belangen niet kunnen leiden tot weigering van de vergunning' (curs. R.J.N.S.). ${ }^{87}$ Deze citaten tonen reeds aan dat detail-analyse van de jurisprudentie van de Afdeling complex is. De indruk bestaat dat de Afdeling niet altijd op de consequenties van bepaalde overwegingen alert was, en evenmin consequent in het gebruik van haar woordkeus. Daarom is het zinvoller om te zoeken naar meer algemene lijnen in de jurisprudentie.

83. Vgl. in dit kader de overwegingen in ARRS 6 december 1988, AB 1989, 139, m.nt. JHvdV (standplaatsvergunning Giethoorn). Inzake een geweigerde standplaatsvergunning werd hier overwogen: 'Art. Cl APV is opgenomen in hoofdstuk C, waarvan de titel luidt 'Openbare Orde'. Dit brengt met zich dat bij afweging van de belangen die aan een beslissing op een verzoek om vergunning vooraf dient te gaan, in ieder geval het belang van de openbare orde moet worden betrokken en dat bij de afwezigheid van gevaar voor aantasting van dat belang, de bescherming van andersoortige belangen geen grond mag vormen voor weigering van de vergunning' (curs. R.J.N.S.).

84. ARRS 22 december 1986, AB 1987, 395, m.nt. JHvdV ('gawstrekke' Bom).

85. ARRS 26 augustus 1987, AB 1988, 263 ('gansslaan' Eijsden). Dat de formuleringen in de diverse uitspraken inzake APV-vergunningen weinig constant waren blijkt indien men de betreffende overweging in de Eijsdense uitspraak plaatst naast bijv. een centrale overweging uit ARRS 27 januari 1979, AB 1980, 81 (standplaatsvergunning De Bilt). Hier luidde het o.m.: 'Nu de desbetreffende bepaling van de APV is opgenomen onder de voorschriften strekkende tot bescherming van het belang van de openbare orde, dienen $\mathrm{B}$ en $\mathrm{W}$, een verzoek om ontheffing te toetsen aan de specifiek onder openbare orde te vervatten belangen' (curs. R.J.N.S.).

86. ARRS 24 september 1992, AB 1993, 61, m.nt. RMvM (standplaatsvergunning Urk).

87. Stroink en De Waard wezen reeds op de mogelijke gevolgen van een dergelijke (taalkundig) verstrekkende overweging. Indien het belang van de openbare orde ook maar enigszins in het geding zou zijn, wordt de deur geopend voor het meewegen van andere (algemene) belangen. Of de Afdeling zich bewust was van deze consequentie is onduidelijk. Zie: F.A.M. Stroink en B.W.N. De Waard, Het specialiteitsbeginsel, a.w., p. 242. 
In dit kader zijn er talrijke uitspraken voorhanden waaruit blijkt dat de Afdeling, met het oog op de bevoegdheidsuitoefening, aan het speciale publiekrechtelijke belang een bijzondere positie toekende. Het gehele discretionaire besluitvormingsproces diende, zo kan uit vele uitspraken worden afgeleid, begrepen te kunnen worden vanuit het speciale belang dat een regeling (primair) beoogt te beschermen. ${ }^{88}$ Dit impliceert dat een belangenafweging zich volgens de Afdeling diende te voltrekken binnen een specifiek wettelijk toetsingska$\mathrm{der}^{89}$ en dat het proces van concretiserende rechtsvorming (primair) hierin zijn grondslag diende te vinden. ${ }^{90}$ Een fraai voorbeeld biedt mijns inziens een uitspraak inzake een associatievergunning ingevolge artikel 6 lid 5 van de Wet op de Geneesmiddelenvoorziening. ${ }^{9 l}$ In casu had de Commissie voor gebiedsaanwijzing in de provincie Overijssel (verweerder) vergunning verleend aan een huisarts die wenste te associèren met een apotheekhoudend arts. Hiertegen maakte een concurrerende apotheker bezwaar. Uit do uitspraak blijkt dat de Afdeling van oordeel was dat verweerder al te zeer de wenselijkheid van een assiociatievergunning centraal had gesteld in de besluitvorming. Volgens de Afdeling diende daarentegen het speciale wettelijke belang van de geneesmiddelenvoorziening centraal te staan:

88. Vgl. ARRS 14 mei 1984, AB 1985, 220, m.nt. JHvdV (kermis Lichtenvoorde). Hiermee is overigens nog weinig gezegd over de wijze waarop de Afdeling de inhoud en omvang van een dergelijk speciaal publiekrechtelijk belang vaststelde. In het kader van APV-bevoegdheden paste de Afdeling veelvuldig de bekende 'Rubrica est lex' methode toe. Uit de plaats van de betreffende bevoegdheid in de verordening leidde de Afdeling de strekking ervan af. Zie bijv. ARRS 27 november 1978, AB 1979, 476, m.nt. v.d.V.; ARRS 22 december 1986, AB 1987, 395, m.nt. JHvdV en ARRS 23 januari 1988, AB 1989, 101. Uit de jurisprudentie blijkt dat de paraplu van sommige APV-bepalingen volgens de Afdeling nogal ruim was. Vérstrekkend is bijv. VzARRS 22 juli 1993, AB 1994, 136 (autocross Mill en St. Hubert) met kritische noot van Van Male. Hier rekende de Voorzitter het algemene milieubeschermingsbelang tot de belangen die de APV beoogde te beschermen (in casu de belangen van openbare orde, veiligheid en gezondheid). Ook het aansluiting zoeken bij andere bepalingen uit een wet en het rekening houden met de (gewijzigde) reikwijdte van de wet zelf, werd toegepast. Vgl. VzARRS 27 augustus 1992, AB 1993, 34, eveneens met kritische noot van Van Male; $\mathrm{tB} / \mathrm{S}$ 1992, nr. 105 m.a. FM (wedstrijdverbod Roosendaal en Nispen).

89. Dit blijkt expliciet uit een Voorzittersuitspraak van 2 maart 1989, AB 1990, 30. In casu stond een besluit ingevolge de Wet geluidhinder centraal waarbij door gedeputeerde staten van Zuid-Holland op planologische gronden was geweigerd om een hogere grenswaarde voor verkeerslawaai vast te stellen. De Voorzitter, die onmiddellijk uitspraak deed in de hoofdzaak, vernietigde op grond van détournement de pouvoir en overwoog: 'Wij stellen vast dat vorenweergegeven motivering geen blijk geeft van een beoordeling van het verzoek die zich beweegt in het relevante toetsingskader, nl. de Wet geluidhinder, meer i.h.b. de art. 83-85 van die wet' (curs. R.J.N.S.). Zie bijv. ook: ARRS 5 april 1993, Gst. 6999, p. 595, m.n. HH (uitwegvergunning Moergestel).

90. Uit verschillende uitspraken blijkt overigens dat de Afdeling aan (beleids)factoren die slechts op een meer indirecte wijze verband hielden met het speciale publiekrechtelijke belang dat de regeling beoogde te beschermen wél enige betekenis toekende. Vgl. bijv. ARRS 6 januari 1986, AB 1986, 230 inzake een geweigerde exploitatievergunning voor een amusementshal: 'De Afd. stelt voorop dat, gezien doel en strekking van de Wet op de kansspelen, bij de beoordeling van een verzoek om vergunning als het onderhavige de vraag of er uit een oogpunt van marktontwikkelingen behoefte bestaat aan een speelautomatenhal op zichzelf geen rol kan spelen' (curs. R.J.N.S.).

91. ARRS 27 januari 1993, AB 1993, 376, m.nt. AFMB (associatievergunning Tubbergen). 
'Integendeel, zij (de bepaling op grond waarvan vergunning werd verleend R.J.N.S.) biedt ruimte om naast en tegenover vorenbedoelde wenselijkheid andere belangen, betrekking hebbende op de geneesmiddelenvoorziening, in de afweging te betrekken. Met name in het onderhavige geval mag het belang van de geneesmiddelenvoorziening niet veronachtzaamd worden, aangezien het gaat om gezamenlijke praktijkuitoefening met een arts, die zijn bevoegdheid ter zake van de geneesmiddelenvoorziening ontleent aan art. 34 eerste lid.(.) Naar het oordeel van de Afdeling rechtspraak blijkt uit het bestreden besluit onvoldoende dat verweerster een belangenafweging, als hiervoor weergegeven heeft gemaakt. Met name blijkt niet dat verweerster aandacht heeft besteed aan de vraag of de geneesmiddelenvoorziening voldoende is gewaarborgd vanuit de dichtstbijzijnde apotheek (apotheken) in het betrokken gebied' (curs. R.J.N.S.).

Duidelijk is ook een uitspraak van de Afdeling inzake de intrekking van een tweetal terrasvergunningen welke verleend waren aan een Amsterdamse horeca-exploitant. ${ }^{92}$ Deze intrekking bleek primair te zijn ingegeven om de terugkeer van de plaatselijke markt ter plaatse te bewerkstelligen. Burgemeester en wethouders miskenden hierdoor volgens de Afdeling het speciale belang van de openbare orde: 'Niet in geschil is dat de in dit hoofdstuk (van de APV R.J.N.S.) opgenomen artikelen strekken ter bescherming van de openbare orde. De Afdeling stelt dan ook vast dat, gelet op het bepaalde in artikel 6 eerste lid van de verordening onderhavige vergunningen slechts kunnen worden ingetrokken op grond van belangen aan de openbare orde ontleend.(..) Naar het oordeel van de Afdeling is de terugkeer van de markt naar het Waterlooplein en de daarmee in verband staande behoefte aan extra ruimte voor het plaatsen van marktkramen wellicht in het belang van de betrokken kooplieden, maar daarmee valt een dergelijke doelstelling nog niet aan te merken als een belang van openbare orde in de zin van de betreffende bepaling van de verordening.'

In dit verband dient ook de aandacht te worden gevestigd op de jurisprudentie van de Afdeling inzake de toelaatbaarheid van het hanteren van zgn. 'maximumstelsels' bij het verlenen van standplaats- en ventvergunningen. ${ }^{93}$ Uit de Afdelingsjurisprudentie blijkt mijns inziens dat dergelijke stelsels hun grondslag dienen te vinden in de speciale publiekrechtelijke belangen die de betreffende bepalingen in de Algemene Plaatselijke verordening beogen te beschermen. ${ }^{94}$ Alleen dit belang (of deze belangen) kan (kunnen)

92. ARRS 13 mei 1991, AB 1992, 110 (terrasvergunning Zwanenburgwai). Uit deze uitspraak blijkt dat het meewegen van 'vreemde' belangen reeds snel leidt tot détournement de pouvoir.

93. Deze 'maximumstelsels' zijn in de regel neergelegd in een beleidsregel en zijn gericht op een beperking van het aantal te verlenen standplaatsvergunningen naar aantal en branche.

94. Zie bijv. ARRS 29 oktober 1985, AB 1986, 515, m.nt. JHvdV; VzARRS 2 juli 1990, AB 1991, 278, m.nt.

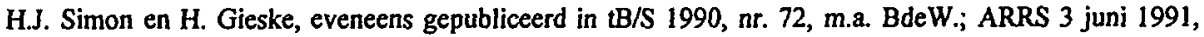
AB 1992, 264 en ARRS 24 september 1992, AB 1993, 61, m.nt. RMvM. Aandacht verdient in dit verband $66 \mathrm{k}$ de omvangrijke jurisprudentie van de Afdeling inzake de bescherming van het plaatselijke (detailhandels)voorzieningenniveau. De Afdeling achtte het niet toelaatbaar dat via APV-vergunningstelsels enkel op basis van het 'openbare orde' of 'verkeersveiligheids'-belang een vestigingsbeleid werd gevoerd (vgl. ARRS 27 januari 1979, AB 1980, 81 en ARRS 25 maart 1980, AB 1980, 585). Ook gemeentelijke vergunningstelsels die het behoefte-element centraal stelden werden in strijd met de landelijke vestigingswetgeving geacht (ARRS 31 juli 1984, AB 1985, 236, m.nt. JHvdV). Toelaatbaar werden wél geacht stelsels die (expliciet) tot doel hadden te voorkomen dat in (kleine) kemen het lokale voorzieningenniveau in gevaar zou komen (vgl. ARRS 9 februari 1984, AB 1984, 514, m.nt. JHvdV (Melick en Herkenbosch), 
uiteindelijk een weigering dragen. Van belang is verder dat de Afdeling het in de regel ontoelaatbaar achtte dat een specifiek publiekrechtelijk standplaatsvergunningenstelsel op 'privaatrechtelijke' gronden werd 'uitgehold', doordat bijv. het daadwerkelijk innemen van een standplaats (mede) afhankelijk werd gesteld van een gemeentelijke toestemming ${ }^{95}$ ten behoeve van het gebruik van de gemeentegrond. Ook hier eiste de Afdeling dat de publiekrechtelijke vergunningverlening primair aan de specifiek in de APV beschermde belangen diende te worden getoetst. ${ }^{96}$ De Afdeling ging hierbij zelfs zover dat zij een 'privaatrechtelijke' weigering opvatte als een impliciete weigering om een standplaatsvergunning te verlenen en bijgevolg het toestemmingsvereiste 'oploste' in de publiekrechtelijke rechtshandeling. ${ }^{97}$ Uit deze jurisprudentie blijkt mijns inziens dat de Afdeling alert was op de overheidsplicht om in het kader van een standplaatsvergunningenbeleid uitsluitend publiekrechtelijke belangen te behartigen. In deze context kunnen tot slot $660 \mathrm{k}$ uitspraken worden geplaatst waaruit blijkt dat 'privaatrechtelijke' overeenkomsten met derden in beginsel géén reden mogen vormen om een publiekrechtelijke (APV-)vergunning te weigeren. ${ }^{98}$

\subsubsection{De verhouding tussen administratieve regelingen}

In het algemeen kan worden gesteld dat de Afdeling rechtspraak zich steeds bewust is geweest van het gefragmenteerde karakter van administratieve wetgeving. De verhouding tussen de verschillende specifieke administratieve regimes kwam veelvuldig in haar jurisprudentie aan de orde. De hoeveelheid relevante uitspraken is dermate omvangrijk, dat hier volstaan moet worden met een algemene schets en een aantal verwijzingen. Uit de

ARRS 18 juni 1985, AB 1986, 543, m.nt. JHvdV (Veere) en ARRS 5 mei 1986, AB 1986, 544, m.nt. JHvdV (Eersel)). Zie meer uitvoerig over deze problematiek: J.C. Schroot, Van plaatselijke protectie tot bescherming van consumentenbelangen, Gst. 6760, p. 17 e.v.

95. Een populaire constructie betrof met name het verpachten of verhuren van standplaatsen aan de meest biedende. Zie bijv. VzARRS 19 februari 1985, AB 1985, 565, m.nt. P.J.J. van Buuren (Weert); VzARRS 17 februari 1986, tB/S, 1986, nr. 34, m.a. F.A.M.S. (Elburg) en VzARRS 12 april 1989, AB 1990, 46, JHvdV (Abcoude).

96. Helder zijn de overwegingen van de Voorzitter in de zaak Weert: 'Dienaangaande overwegen Wij dat verweerders sub 2 (het college van burgemeester en wethouders R.J.N.S.), gelet op de hun bij of krachtens de gemeentewet toevertrouwde publiekrechtelijke taken en bevoegdheden, in een bijzondere positie als administratief orgaan met de daarbij behorende verantwoordelijkheden zijn geplaatst. In verband hiermede dienen verweerders sub 2 naar ons aanvankelijk oordeel in beginsel los van het verpachten van een verkoopstandplaats - daargelaten of zij tot die verpachting bevoegd zijn - te bezien aan wie voor het innemen van die standplaats met toepassing van de betreffende publiekrechtelijke regelen en beginselen een vergunning zou dienen te worden verleend' (curs. R.J.N.S.). In gelijke bewoordingen: VzARRS 17 februari 1986, tB/S, 1986, nr. 34, m.a. F.A.M.S. (Elburg).

97. Zie: VzARRS 3 november 1983, AB 1985, 65 (Emmen) en VzARRS 29 mei 1984, AB 1985, 66 (Mijdrecht). In ARRS 7 mei 1987, tB/S, 1987, nr. 73 m.a. F.A.M.S. (Emmen) loste de Afdeling een door de gemeente gestelde 'overeenkomst' geheel op in de vergunningverlening en interpreteerde deze als een financiele vergunningvoorwaarde.

98. Zie bijv. ARRS 15 december 1987, Gst. 6855, nr. 6, m.n. L.J.A. Damen (Publex) en VzARRS 16 augustus 1989, AB 1990, 205 (standplaatsvergunning Venhuizen). 
relevante jurisprudentie blijkt dat de Afdeling in de regel zorgvuldig naging hoe verschillende administratieve regelingen zich tot elkaar verhielden. Hierbij trachtte de Afdeling specifieke bevoegdhedenkaders - en de daarin beschermde publiekrechtelijke belangen - zoveel mogelijk te scheiden en bezwaren aan de juiste kaders toe de delen. ${ }^{99}$ Dat deze 'scheiding', mede bezien vanuit het oogpunt van de betrokken burgers, niet steeds een gemakkelijke opgave was, tonen diverse uitspraken aan. Reeds in 1977 werd de Afdeling in de zaak 'De Ark' ${ }^{100}$ geconfronteerd met een casus die met het oog op het specialiteitsbeginsel van principieel belang is. In casu maakten appellanten bezwaar tegen de overlast die volgens hen werd veroorzaakt door het in een (voormalig) kerkgebouw gevestigde restaurant/recreatiecentrum 'De Ark' te Renesse. Volgens appellanten dienden burgemeester en wethouders hiertegen ofwel door politiedwang ${ }^{101}$, ofwel door weigering van een ontheffing ingevolge de Drank- en Horecawetverordening op te treden. Interessant is dat in dit kader expliciet een beroep werd gedaan op een (verondersteld) beginsel van 'eenheid van openbaar bestuur'. Dit beginsel bracht volgens appellanten mee dat burgemeester en wethouders, ook al waren aan de Drank- en Horecawet geen bezwaren te

99. Een greep uit de vele interessante uitspraken over 'grensconflicten' tussen verschillende (wettelijke) regelingen: Verhouding bestemmingsplan/Wegenwet (ARRS 9 september 1982, AB 1983, 269, m.nt. P.C.E. van Wijmen) Onttrekking weg aan het openbare verkeer ingevolge de Wegenwet is mogelijk ook al gaat het vigerende bestemmingsplan uit van handhaving van deze weg; Verhouding Drank-en Horecawet/ Hinderwet (ARRS 18 maart 1986, AB 1987, 91, m.nt. JHvdV) Overlastaspecten verband houdende met de openbare orde kunnen onverminderd de toepasselijkheid van de Hinderwet bij de verlening van een dansvergunning worden betrokken. Vgl. ook VzARRS 4 juni 1987, AB 1988, 63; Verhouding Wet verontreiniging oppervlaktewateren/bestemmingsplan (ARRS 22 december 1987, AB 1988, 489, m.nt. PvB) Het lozen van huishoudelijk afvalwater kan niet via gebruiksbepalingen in bestemmingsplan worden gereguleerd; Verhouding plaatselijke overlast- of leefmilieuverordening/Wet geluidhinder (ARRS 23 januari 1988, AB 1989, 101; ARRS 4 maart 1988, AB 1988, 416, m.nt. JHvV) Regulering van overlast op grond van een plaatselijke verordening is mogelijk onverminderd het toepassingsgebied van de Wet geluidhinder. Vgl. verhouding plaatselijke (overlast)verordening/Hinderwet (VzARRS 4 juni 1987, SEW 1988, p. 738 en ARRS 8 augustus 1989, AB 1991, 142) Bepalingen uit een gemeentelijke overlastverordening zijn overigens niet van toepassing voorzover een AMvB krachtens de Hinderwet van toepassing is, zie: VzARRS 10 september 1993, AB 1994, 250. Verhouding Marktverordening/Wegenverkeerswet (ARRS 21 december 1992, 287) Uit een Marktverordening voortvloeiend 'parkeerverbod' kan bestaan naast regime Wegenverkeerswet; Verhouding APV/Woningwet/bestemmingsplan (VzARRS 19 oktober 1990, 79, m.nt. PvB) Stelsel van terrasvergunningen kan bouwvergunningplicht en bestemmingsplan niet terzijde stellen; Verhouding Woonwagenwet/bestemmingsplan (ARRS 24 mei 1983, tB/S III, 444, m.a. $\mathrm{tB} / \mathrm{S}) \mathrm{Bij}$ de uitoefening van bevoegdheden op basis van de Woonwagenwet mogen planologische belangen geen rol spelen; Verhouding Wet op de Ruimtelijke Ordening/Lager Onderwijswet en Wet op het basisonderwijs (ARRS 10 april 1986, tB/S, 1986, nr. 75 m.a. BdeW) De stichting van een bijzondere lagere school kan ingevolge het spoor van het bestemmingsplan niet in een gehele woonkern worden geweerd indien op grond van de onderwijswetgeving medewerking dient te worden verleend; en tot slot een bijzonder voorbeeld: Verhouding Dellawe//Woningwet (ARRS 20 januari 1984, AB 1984, 193, m.nt. CLR) Deltawet stelt bouwvergunningplicht ingevolge Woningwet niet terzijde.

100. ARRS 30 juni 1977, AB 1977, 392, m.nt. G.J.M. Cartigny (recreatiecentrum 'de Ark') In de noot onder deze uitspraak wordt, voorzover ik heb kunnen nagaan, voor de eerste keer melding gemaakt van 'het specialiteitsbeginsel'.

101. Wegens vermeende overtreding van art. 352 lid 1 van de plaatselijke Bouwverordening. 
ontlenen, toch gén vergunning ingevolge deze wet behoorden te verlenen voor een inrichting in een gebouw, waarvan de planologische bestemming een andere was dan drank- en horecavestiging. Doordat artikel 352 lid 1 van de plaatselijke Bouwverordening in casu evenwel niet van toepassing was, kwam de Afdeling niet aan de beantwoording van deze 'heikele' vraag toe. De Afdeling was wél van oordeel dat de ontheffing van de Drank- en Horecaverordening terecht was, en dat optreden tegen de 'gewraakte geluidshinder' via (andere) bepalingen uit de plaatselijke verordening tot de mogelijkheden behoorde. Uit deze uitspraak bleek reeds dat met name uit de samenloop van (facetmatige) planologische regelingen en (sectorale) bevoegdhedenkaders complexe afwegingsproblemen konden voortvloeien. ${ }^{102}$

In de zaak IJsselmuiden ${ }^{103}$ diende de Afdeling expliciet in te gaan op de relatie tussen de Wet op de Ruimtelijke Ordening en een APV-ontheffingstelsel dat o.m. het plaatsen of laten liggen van recreatievoer- en vaartuigen vanuit esthetisch oogpunt beoogde te reguleren. Volgens appellant werd - kort samengevat - via dit stelsel ten onrechte planologisch beleid gevoerd. De Afdeling overwoog evenwel:

\begin{abstract}
'De genoemde artikelen van de APV zijn blijkens het hoofdstuk waarin ze zijn geplaatst alsmede hun formulering vastgesteld in het belang van het uiterlijk aanzien van de gemeente, welk esthetisch motief voor de gehele gemeente geldt en dan ook naar zijn aard geenszins afhankelijk is van een bijzondere, planologische bestemming. Voorzover met genoemde artikel mede is beoogd om recreatieve ontwikkelingen aan beperkingen te onderwerpen, merkt de Afd. op, dat het hierbij gaat om slechts een van de vele aspecten, die bij de ordening van de ruimte een rol (kunnen) spelen. De Wet op de Ruimtelijke Ordening is, anders dan de onderhavige artikelen, ook niet gericht op de behartiging van een enkel belang, doch juist op de corrdinatie van alle belangen, waarvoor het gebruik van de ruimte relevant is.'
\end{abstract}

In de zaak Enkhuizen ${ }^{104}$ was de Afdeling minder helder over de precieze relatie tussen het bestemmingsplan en een sectorale verordening. In casu hadden burgemeester en wethouders van Enkhuizen appellant aangeschreven om zijn woonschip te verplaatsen naar een andere havenlocatie. Reden hiervoor was dat op de bestaande locatie geen vergunning op grond van de Havenverordening Enkhuizen zou worden verleend, omdat ingevolge het planologische beleid van de gemeente woonschepen binnen een bepaald havengebied geconcentreerd dienden te worden. Hiertoe waren bij bestemmingsplan bepaalde ligplaatsen aangewezen. $\mathrm{Na}$ te hebben vastgesteld dat de Havenverordening het belang van de orde en

102. En soms voor de betrokken burgers vreemde situaties. Zie bijv. ARRS 6 december 1988, AB 1989, 140, m.nt. JHvdV (kiosk Brederwiede). In casu hadden burgemeester en wethouders van Brederwiede in bezwaar - overigens geheel in de lijn van het specialiteitsbeginsel - een standplaatsvergunning voor een kiosk verleend, maar tegelijkertijd aan belanghebbende meegedeeld dat van de vergunning in praktijk geen gebruik gemaakt kon worden omdat er tevens een bouwvergunning vereist was. Deze laatste vergunning kon gelet op het vigerende bestemmingsplan niet worden verleend. De Afdeling zag in deze bestuurlijke mededeling (m.i. terecht) gén verkapte weigering van de standplaatsvergunning.

103. ARRS 27 november 1978, AB 1979, 476, m.nt. v.d.V. (IJsselmuiden).

104. ARRS 18 november 1985, tB/S III, nr. 660, m.a. F.A.M.S. (Havenverordening Enkhuizen). 
veiligheid in de havens en openbare wateren in de gemeente beoogde te beschermen, overwoog de Afdeling:

'De Afdeling is van oordeel dat de strekking van de verordening niet eraan in de weg staat dat bij een beslissing op een verzoek tot het innemen van ligplaats mede wordt bezien of de gewenste lokatie uit een oogpunt van ruimtelijke ordening voor dat doel aanvaardbaar is, aangezien de ruimtelijke ordening van de gemeentelijke wateren en wijze waarop de orde in deze wateren wordt gehandhaafd, overeenkomsten en parallellen kunnen vertonen. Dat brengt evenwel niet mede dat enkel voor in het bestemmingsplan aangewezen lokaties een vergunning zou kunnen worden verleend' (curs. R.J.N.S.).

Omdat er gelet op het geldende overgangsrecht géen planologische belemmering op de bestaande liglocatie aanwezig was, moest er naar het oordeel van de Afdeling vanuit worden gegaan dat '...in de planologische situatie niet zonder meer reden tot weigering van de vergunning gelegen is.' Uit deze uitspraak zou men kunnen afleiden dat de Afdeling het toelaatbaar achtte dat het planologische afwegingskader in zekere mate verweven werd met het speciale afwegingskader van de Havenverordening. Dit zou dan niet in overeenstemming zijn met een 'precieze' interpretatie van het specialiteitsbeginsel. Overigens mag men aan een dergelijke uitspraak géén verstrekkende betekenis toekennen, getuige de vele 'precieze' uitspraken van de Afdeling. Illustratief is bijv. de kwestie inzake de grondverkoop Liempde. ${ }^{105}$ In casu had de gemeente Liempde een perceel grond verkocht aan een particulier voor de bouw van een motel nabij rijksweg 264. Deze grondverkoop was in het kader van het preventieve toezicht goedgekeurd door gedeputeerde staten van NoordBrabant. Vervolgens weigerden gedeputeerde staten echter in het kader van de planologische vrijstellings- en anticipatieprocedure de benodigde verklaring van geen bezwaar. Bijgevolg werd de Afdeling geconfronteerd met de vraag hoe de procedure ex. artikel 228 Gemeentewet zich verhield tot de procedure ingevolge artikel 19 WRO en artikel 50 lid 8 van de Woningwet (oud):

'Ook de omstandigheid, dat verweerders de verkoop van het perceel "De Roode Bleek" aan appellante sub 1 in het kader van de toetsing op grond van artikel 228 van de gemeentewet hebben goedgekeurd, kan naar het oordeel van de Afdeling niet als een zodanige omstandigheid worden aangemerkt, dat verweerders niet in redelijkheid de gevraagde medewerking hadden kunnen weigeren. De toetsing op grond van artikel 228 immers houdi geen enkel oordeel in over de planologische aanvaardbaarheid van een op de grond geprojecteerde bouw' (curs. R.J.N.S.).

Uit deze uitspraak blijkt op een heldere wijze dat de Afdeling géén algemeen beginsel van 'eenheid van openbaar bestuur' erkende, en in principe strikt de hand hield aan de scheiding van de verschillende administratieve bevoegdhedenstelsels ${ }^{106}$, de in dat kader aan de orde zijnde belangenafwegingen ${ }^{107}$, en bijgevolg het specialiteitsbeginsel.

105. ARRS 5 augustus 1983, tB/S III, nr. 466, m.a. tB/S (grondverkoop Liempde). Ten Berge en Stroink duidden deze uitspraak in hun aantekening aan als een 'gaaf voorbeeld van het zogenaamde specialiteitsbeginsel'. 


\subsubsection{Belangen van derden}

Vrij snel na de invoering van de Arob-rechtspraak leek de Afdeling, wellicht geïnspireerd door bepaalde beslissingen van de Kroon ${ }^{108}$, ten aanzien van het meewegen van derdebelangen een publiekrechtelijke variant van de civielrechtelijke 'Schutznorm- of relativiteitsleer' te willen introduceren. ${ }^{109}$ Deze leer zou dan, toegespitst op de bestuurlijke belangenafweging, met zich brengen dat derde-belangen enkel (in rechtsvormende zin) in de afweging mogen worden betrokken voorzover ze beschermd worden door de wettelijke regeling waarop de in het geding zijnde bestuursbevoegdheid is gebaseerd. Hierbij leek de Afdeling aanvankelijk te twijfelen omtrent de beantwoording van de vraag of een dergelijke Schutznormleer toegepast zou moeten worden in verband met de omvang van de bestuurlijke belangenafwegingsplicht, of ook met het oog op de ontvankelijkheid. In de bekende en gekritiseerde Prijzenwet-uitspraak ${ }^{110}$, werd deze vraag in de laatstbedoelde zin beantwoord. Het feit dat belangen van derden géen rol mochten spelen in de bestuurlijke besluitvorming ingevolge de Prijzenwet, vertaalde de Afdeling in een nietontvankelijkverklaring van de betreffende appellanten:

'De Afdeling stelt dienaangaande voorop dat de aanvullende rechtsbescherming van de Wet administratieve rechtspraak overheidsbeschikkingen op zichzelf niet de strekking kan hebben wijzigingen te brengen in de aard van de belangen, waarmee bij het nemen van een besluit rekening dient te worden gehouden.(.) $\mathrm{Zij}$ is van oordeel dat, gelet op de opzet en de strekking van de Prijzenbeschikking en het systeem van artikel 3 van de Prijzenwet, voor verweerders geen ruimte bestaat om bij het beoordelen van verzoeken tot het

106. Ook hier geldt dat uitzonderingen de regel bevestigen. Vgl. bijv. VzARRS 21 augustus 1992, AB 1993, 103 (Rotterdam) inzake de 'samenloop' van een geweigerde overlastvergunning en een verleende planologische vrijstelling. In casu was het horecabeleid in de laatstgenoemde procedure uitdrukkelijk aan de orde geweest. In het kader van de procedure inzake de overlastvergunning werd echter desalniettemin negatief beslist. De Voorzitter overwoog hiertoe: 'Dit in aanmerking nemende is Ons op grond van de stukken en het verhandelde ter zitting vooralsnog onvoldoende duidelijk waarom de belangenafweging bij het onderhavige besluit tot een andere uitkomst heeft geleid dan in het geval van het besluit inzake vrijstelling.'

107. Vgl. voor een minder heldere uitspraak bv VzARRS 19 juli 1992, tB/S, nr 78, m.a. G.H.A. inzake de relatie tussen de intrekking van een APV-ontheffing en de Hinderwet.

108. Vgl. bijv. het eerder besproken KB 12 april 1976, BR 1976, p. 386 (Eindhoven).

109. De vraag of de schutznorm-leer een functie kan vervullen met het oog op de bestuurlijke belangenafweging, zal in hoofdstuk 9 aan de orde komen. Zie hierover in kritische zin: H. Frantzen, Schutznorm, congruentie en relativiteit bij vrijstellingen t.b.v. de bouwvergunning, BR 1986, p. 578 e.v. Vgl. verder hoofdstuk 6 (paragraaf 6.4.3 en 6.4.4).

110. ARRS 27 november 1979, tB/S IV, nr. 42, m.a. tB/S (prijzenwet beschikking). Een verklaring voor de Prijzenwet-uitspraak zou gelegen kunnen zijn in het feit dat de Afdeling rechtspraak niet wilde treden in de competentiesfeer van het College van Beroep voor het bedrijfsleven (CBb) dat ingevolge art. 7 van de Prijzenwet kennis nam van beroepen, ingesteld door de aanvrager of de houder van een ontheffing. Hierdoor werd echter het algemene (aanvullende) beroepsrecht van belanghebbenden ingevolge de (toenmalige) Wet Arob onvoldoende onderkend. Een positieve beantwoording van de vraag of belangen van belanghebbenden mochten worden afgewogen, was in het licht van de rechtsbeschermingsstructuur van de Wet Arob niet vereist voor het erkennen van een beroepsrecht. Zie: F.A.M. Stroink, Bevoegdheid Afdeling rechtspraak/ bijzondere administratieve rechters/Kroon, TvO 1980/10, p. 219. 
verlenen van een ontheffing van het daarin gestelde verbod rekening te houden met de belangen van degenen met wie de verzoeker overeenkomsten van dienstverlening aangaat of kan aangaan.(.) Het vorenstaande voert de Afdeling tot de slotsom dat noch van appellante sub 1 noch van andere appellanten kan worden gezegd dat zij door het bestreden besluit rechtstreeks in hun belangen zijn getroffen.'

Deze uitspraak, die strikt genomen de ontvankelijkheidsproblematiek verwarde met de vraag naar de omvang van het materiële bestuurlijke belangenafwegingsproces, vond géén navolging en in 1985 werd door de Afdeling rechtspraak expliciet afstand genomen van de Schutznormleer als ontvankelijkheidsdrempel. ${ }^{11}$ Dit uitgangspunt geldt ook onder de Algemene wet bestuursrecht. ${ }^{112}$

Ofschoon toepassing van de Schutznormleer als ontvankelijkheidsdrempel werd verworpen, bleven sporen van deze leer een functie vervullen in verband met de vraag in hoeverre bepaalde belangen van derden bescherming vonden binnen een specifiek bevoegdheidsstelsel. In het geschil omtrent een para-commerciële horeca-inrichting (sportkantine) te Haarlem ${ }^{113}$ overwoog de Afdeling bijv., naar aanleiding van de bezwaren van horecaexploitanten die terug te voeren waren op concurrentiemotieven, het volgende:

'Het in het geding zijnde verbod, dat gebaseerd is op genoemd art. 18 Drank- en Horecawet, kan, naar het oordeel van de Afd., niet geacht worden te strekken tot bescherming van de commerciele horecabedrijven, maar om te voorkomen dat alcohol wordt geschonken in inrichtingen welke daarvoor niet in de eerste plaats bestemd zijn en waarvan het - meest jeugdige - publiek met een ander oogmerk dan het gebruik van

111. Zie: ARRS 15 november 1985, AB 1986, 321, m.nt. PvB (verklaring van geen bezwaar woonwagenlocatie). In de noot onder deze uitspraak stelt Van Buuren dat de Afdeling rechtspraak niet wil weten van congruentie-regels of relativiteitsvereisten. Wijzend op een bijdrage van L. Dorhout aan de Van der Hoeven bundel (Relativiteit van de onrechtmatigheid, ook iets voor de administratieve rechter?, in: Non ex regula, Deventer 1985 , p. $33 \mathrm{t} / \mathrm{m} 43$ ) neemt ook hij vervolgens afstand van de relativiteitsleer. Zie ook: ARRS 3 april 1991, AB 1992, 140. Vgl. ook reeds ARRS 22 april 1983, AB 1984, 212, m.nt C.L.R. en ARRS 23 april 1982, AB 1982, 460 m.nt. C.L.R. (bouwvergunning Nieuwerkerk aan de IJssel). In het Nederlandse bestuursprocesrecht geldt dus als uitgangspunt dat het feit dat er een beroepsrecht bestaat niet automatisch met zich brengt dat het bestuur met de belangen van de appellant in materielle zin rekening behoeft te gehouden. T.a.v. de bezwaren die een belanghebbende in rechte mag aanvoeren geldt gén beperking. Zie ook nog de aantekeningen van Ten Berge en Stroink onder ARRS 27 november 1979, tB/S IV, nr. 42 m.a. tB/S (Prijzenwet) en VzARRS 5 februari 1981, tB/S VII, nr. 131, m.a. tB/S (sluitingsverlof Enschede). Koetser vestigde er overigens, onder verwijzing naar een aantal niet-gepubliceerde uitspraken, de aandacht op dat de schutznorm-leer in de jurisprudentie van de Afdeling geschillen van bestuur (AGRS) ook na dit tijdstip nog een rol bleef vervullen. Zie: M.B. Koetser, 'Belanghebbende' volgens de rechtsprekende Afdelingen van de Raad van State, VAR-reeks 108, p. 114-115.

112. Zie: PG Awb I, NEV, p. 153. Vgl. ABRS 30 januari 1997, JB 1997/114, m.nt. HJS (V.o.f. Van Eijk en $\mathrm{Zn)}$.

113. ARRS 18 april 1980, AB 1981, 86, m.nt. v.d.V (sportkantine Haarlem). Ook in eerdere uitspraken kunnen aanzetten voor een soortgelijke schutznorm-benadering worden aangetroffen. Zie bijv. ARRS 7 augustus 1978, BR 1978, p. 757 (Amsterdam). I.v.m. een vrijstelling van een bepaling uit de gemeentelijke bouwverordening overwoog de Afdeling: ' $\mathrm{Bij}$ de beoordeling van de vraag of een vrijstelling ex. art. 48 MBV kan worden verleend, mocht de gemeenteraad zich niet laten leiden door andere motieven, dan die welke verband houden met de belangen met het oog waarop het voorschrift waarvan vrijstelling was verzocht is gegeven.' 
alcohol aanwezig is. De Afdeling is dan ook van mening, dat de belangen welke volgens appellante zijn geschaad, namelijk de financielle en economische belangen van horeca-exploitanten die hinder ondervonden van de zogenaamde paracommerciele horeca-inrichtingen, zoals sportverenigingen, niet de belangen zijn waarop art. 8 verordening betrekking heeft, zodat niet met vrucht gesteld kan worden dat verweerders bij het verlenen van bedoelde ontheffing deze belangen ten onrechte niet in hun overwegingen hebben betrokken' (curs. R.J.N.S.).

Een soortgelijke overweging paste de Voorzitter van de Afdeling toe in de zaak EDAHBrummen. ${ }^{114}$ Bezwaren van detailhandelaren tegen de (nieuw)bouw van een EDAH-vestiging werden hier buiten de belangenafweging gehouden op basis van de overweging dat verzoekers niet werden getroffen in belangen welke de (stedenbouwkundige) bepalingen, waarvan krachtens de gemeentelijke Bouwverordening vrijstelling was verleend, beoogden te beschermen. Deze Schutznorm-overweging kon ook in de bodemprocedure rekenen op de instemming van de Afdeling. ${ }^{115}$ In een uitspraak van 24 mei 1983 lijkt het alsof de Afdeling de Schutznormleer in verband brengt met het specialiteitsbeginsel. ${ }^{116}$ In casu maakten omwonenden bezwaar tegen een krachtens de Algemene Plaatselijke Verordening verleende ontheffing voor het aanbrengen van een lichtreclame. Deze bezwaren hielden primair verband met de vrees voor (licht)overlast. Naar aanleiding van deze bezwaren overwoog de Afdeling:

\begin{abstract}
'De bezwaren van appellanten, woonachtig in de naaste omgeving, houden in dat door lichtuitstraling van deze reclamevoering inbreuk op hun woongenot wordt gemaakt.(.) De Afdeling overweegt dat artikel 153, eerste lid, in de Algemene Plaatselijke Verordening is opgenomen onder het hoofdstuk 'Bescherming van natuurschoon en zorg voor het uiterlijk van de gemeente'. Dit brengt mee, dat een verzoek om een ontheffing van het in artikel 153, eerste lid, vervatte verbod uitsluitend kan worden afgewezen, indien daarvoor gronden kunnen worden ontleend aan evenbedoelde, op het vlak van de esthetica gelegen belangen. Voorts mogen, indien een ontheffing wordt verleend, daaraan krachtens een algemeen beginsel van administratief recht, slechts voorschriften worden verbonden die dienen ter bescherming van de belangen, met het oog waarop het desbetreffende verbod in het leven is geroepen, in casu de belangen van de bescherming van natuurschoon en de zorg voor het uiterlijk van de gemeente.(.) Daargelaten of kan worden aangenomen dat verweerster bevoegd was alsnog voorschriften bij de ontheffing op te nemen, als door haar gedaan, kan voorts naar het oordeel van de Afdeling in elk geval niet worden staande gehouden, dat verweerster ten onrechte er niet toe is overgegaan om in verband met de bezwaren van appellanten, welke immers veeleer voortkomen uit ondervonden hinder dan uit zorg voor het uiterlijk aanzien van de gemeente, voorschriften van een stringenter karakter vast te stellen' (curs. R.J.N.S).
\end{abstract}

114. VZARRS 29 december 1982, AB 1983, 305, m.nt. CLR (EDAH Brummen). Eveneens gepubliceerd in Gst. 6755, nr. 10, m.a. J.M.K. Vgl. ook VzARRS 5 februari 1981, tB/S VII, nr. 131, m.a. tB/S (sluitingsverlof Enschede).

115. Zie: ARRS 27 september 1984, Gst. 6778, nr. 7 m.n. J.M.K. (EDAH Brummen). J.M. Kan merkt in zijn naschrift onder deze uitspraak op dat gezien de omstandigheid dat deze zaak in een enkelvoudige kamer werd behandeld, aangenomen mag worden dat binnen de Afdeling over de - met betrekking tot dit vraagstuk - te volgen gedragslijn eenstemmig werd gedacht.

116. ARRS 24 mei 1983, tB/s III, nr. 443, m.a. tB/S (lichtreclame Heemstede). 
Uit deze uitspraak kan worden afgeleid dat de Afdeling in casu onderzocht of bepaalde belangen van derden beschermd werden door de van toepassing zijnde APV-bepaling. Gesteld kan worden dat de betreffende bepaling door de Afdeling - zij het impliciet blijkbaar werd aangemerkt als een publiekrechtelijke 'Schutznorm' die mede bepaalde particuliere belangen (van derden) beoogde te beschermen, voorzover deze belangen samenvielen (of verband hielden) met het speciale publiekrechtelijke belang dat aan de bevoegdheid ten grondslag lag. In een verwante uitspraak over een vergunningplichtige lichtreclame te Leiderdorp ${ }^{117}$, stelde de Afdeling in nog duidelijker bewoordingen dat bepaalde belangen van een derde-belanghebbende niet door het betreffende APVvergunningstelsel werden beschermd:

'Zoals hiervoor reeds vermeld betreffen de bezwaren van appellant de inbreuk op zijn woongenot door het licht van voornoemde lichtreclame.(.) Artikel 42 is in de Algemene Politieverordening opgenomen onder het hoofdstuk "Van maatregelen ter bevordering van de openbare veiligheid". Naar het oordeel van de Afdeling kan het belang met het oog waarop appellant nadere voorwaarden wenst niet aangemerkt worden als een belang dat valt onder de bevordering van de openbare veiligheid.'

Ook in latere jurisprudentie worden onmiskenbare sporen van een Schutznorm-benadering aangetroffen. ${ }^{118}$ In dit verband kan gewezen worden op voorzittersuitspraken inzake de Valkenburgse opticiën ${ }^{119}$ en de Borgerse drogisterij ${ }^{120}$, waarin eveneens concurrentiebelangen in het kader van planologische vrijstellings- en anticipatieproceduresniet relevant werden geacht. Interessant is vervolgens een Afdelingsuitspraak over de intrekking van een APV-vergunning tot het aanbrengen van een verwijzingsbord naar een benzineverkooppunt aan een publieke lichtmast. ${ }^{121}$ Deze intrekking vond plaats omdat een concurrerend benzinestation door deze verwijzing nadeel stelde te ondervinden:

'Verweerder is van mening dat, nu destijds met het verlenen van de onderhavige vergunning de belangen of rechten van een derde zijn geschaad, daarin grond is gelegen voor intrekking van die vergunning. Naar het oordeel van de Afdeling heeft de gehanteerde reden voor intrekking van de aan appellante verleende vergunning uitsluitend betrekking op het commercikle belang van een met appellante concurrerend bedrijf.

117. ARRS 8 maart 1983, tB/S III, nr. 423, m.a. BdeW (lichtreclame Leiderdorp).

118. Zie: VzARRS 28 november 1988, AB 1989, 469. De Voorzitter hield in deze uitspraak bepaalde bezwaren van een derde tegen een uitwegvergunning resoluut buiten de afweging: 'Gezien de plaats die art. 24 in de APV inneemt kan een aanvraag om een vergunning als bedoeld in deze bepaling slechts worden beoordeeld aan de hand van de vraag of het belang van de openbare orde zich al dan niet tegen het verlenen van de vergunning verzet. Andere belangen spelen daarbij geen rol.' Vgl. ook: VzARRS 21 augustus 1992, AB 1993, 149 en VzARRS 2 juli 1993, AB 1994, 206, m.nt. RMvM.

119. VZARRS 19 januari 1987, SEW 1988, p. 736 e.v.

120. VzARRS 6 maart 1990, AB 1991, 139. In deze uitspraak overwoog de Voorzitter: 'Wij onderkennen dat de vestiging van de onderhavige winkel nadeel kan opleveren voor andere in Borger gevestigde drogisterijen. Zulks is evenwel op zichzelf onvoldoende om medewerking aan zodanige vestiging te onthouden. Tot het reguleren van concurrentieverhoudingen zijn verweerders in het kader van de hun door de Wet op de Ruimtelijke Ordening opgedragen taak niet geroepen.'

121. ARRS 24 juni 1991, AB 1992, 25, m.nt. JHvdV (benzineverkooppunt Bruinisse). 
Deze intrekkingsgrond kan niet worden teruggevoerd op het ten aanzien van art. 13 van de verordening toepasselijke criterium van de openbare orde' (curs. R.J.N.S.).

In een Afdelingsuitspraak van 30 december 1986 was de derde-belanghebbende een bestuursorgaan. ${ }^{122}$ Burgemeester en wethouders van Cromstrijen hadden op financieeleconomische, volksgezondheids- én milieuhygiënische gronden bezwaar tegen de verlening van een ontheffing ingevolge de Plassenverordening Zuid-Holland door gedeputeerde staten ten behoeve van het storten van specie en grond in het Hollandsch Diep. Zij achtten de ontheffing o.m. nadelig voor de plaatselijke watersportrecreatie. De betreffende ontheffingsbevoegdheid was gebonden aan een aantal specifieke weigeringsgronden. Aan deze gronden lagen in ieder geval de publiekrechtelijke belangen van landschapsbehoud, natuurbescherming, ecologie en bruikbaarheid van het water ten grondslag. De door de burgemeester en wethouders aangevoerde bezwaren werden door de Afdeling met het oog hierop buiten de belangenafweging gehouden. Hun 'derde-belangen' bleven overigens niet alleen buiten beschouwing omdat het betreffende ontheffingstelsel ze niet beoogde te beschermen, maar óok vanwege het feit dat bepaalde belangen in het kader van een andere administratieve wet (in het bijzonder de Wet verontreiniging oppervlaktewateren) bescherming hadden gevonden.

Relevant is in dit kader ook nog de uitspraak van de Afdeling inzake het woonschip de 'Goede Verwachting' te Breukelen. ${ }^{123}$ Ook hier was de 'derde-belanghebbende' een bestuursorgaan. Burgemeester en wethouders van Breukelen maakten nl. op planologische gronden bezwaar tegen de verlening van een ligplaatsvergunning ingevolge artikel 56 van het Algemeen Reglement van Politie voor Rivieren en Rijkskanalen voor het behouden van ligplaats met een woonschip. De Afdeling diende in beroep een oordeel te geven omtrent de vraag welk gewicht het planologische bezwaar van de gemeente in de weegschaal kon leggen. In dit kader werd eerst vastgesteld dat verweerder (de hoofdingenieur-directeurvan de Rijkswaterstaat in de directie Utrecht) zich primair had laten leiden door het speciale belang dat aan artikel 56 van genoemd reglement ten grondslag lag. De Afdeling toonde hiervoor begrip en overwoog:

\footnotetext{
'Het standpunt van verweerder dat het waterstaatkundig belang waarop het reglement is gericht, zich niet verzet tegen verlening van de in geding zijnde vergunning acht de Afdeling alleszins aannemelijk. (..) De Afdeling is voorts van oordeel, gezien doel en strekking van het reglement, dat verweerder niet ten onrechte aan de omstandigheid dat het waterstaatkundig belang zich niet verzet tegen het verlenen van de vergunning, doorslaggevende betekenis heeft toegekend. Wat er verder zij van de toezegging van verweerder om met de gemeente overleg te voeren over de verlening van vergunningen, verweerder kon er, gelet op de aard van de door appellanten naar voren gebrachte bezwaren, redelijkerwijs vanuit gaan dat het door appellanten gewenste overleg uit waterstaatkundig oogpunt geen nieuwe gezichtspunten zou opleveren' (curs. R.J.N.S.).
}

122. ARRS 30 december 1986, AB 1988, 34.

123. ARRS 5 juni 1991, AB 1992, 444, m.nt. H.J. Simon (woonschip de 'Goede Verwachting'). Simon trekt in zijn instructieve noot onder deze uitspraak de voorzichtige conclusie dat de Afdeling de belangenafweging 'precies' benaderde. 
Uit deze overwegingen kan mijns inziens worden afgeleid dat de aard van de door een 'belanghebbende' ingebrachte bezwaren met zich kan brengen dat deze belangen gén of slechts een beperkte rol ${ }^{124}$ mogen spelen in een specifiek belangenafwegingsproces. Dit zal met name het geval zijn indien deze belangen vreemd zijn aan het betreffende bevoegdheidsstelsel.

In een uitspraak van de Afdeling over een terrasvergunning, eveneens uit 1991, ${ }^{125}$ treedt deze benadering wederom op de voorgrond. Aan de betreffende vergunning waren ter voorkoming van (geluids)overlast voor omwonenden voorschriften verbonden. De centrale overwegingen waren nu de volgende:

'De Afdeling verwerpt allereerst het standpunt van verweerders dat bij het verlenen van een vergunning op grond van artikel 64, eerste lid, ook overlast-aspecten als door verweerders bedoeld een rol kunnen spelen. Dit artikellid moet geacht worden te zijn gegeven ter bescherming van een onbelemmerd gebruik van de openbare weg en met het oog op de verkeersveiligheid.(.) Dit betekent dat met betrekking tot de vraag of een vergunning op grond van artikel 64, eerste lid, voornoemd geweigerd of onder beperkingen verleend behoort te worden, andere belangen dan bovenbedoelde buiten beschouwing gelaten moeten worden.(.) $\mathrm{De}$ Afdeling stelt vast dat de klachten van omwonenden, waaraan verweerders met de in geding zijnde beperking van de sluitingstijd hebben beoogd tegemoet te komen, in hoofdzaak zien op geluidsoverlast en niet op de belemmering of de veiligheid van het verkeer op de weg.(.) Uit het voorgaande volgt dat verweerders, nu zij bij de vergunningverlening op grond van artikel 64 , eerste lid, andere dan genoemde aspecten betreffende de belemmering en de veiligheid van het verkeer hebben betrokken, de grenzen van hun bevoegdheid op grond van dit artikellid hebben overschreden en mitsdien een onjuiste toepassing aan dit voorschrift hebben gegeven' (curs. R.J.N.S.).

Uit de voorafgaande jurisprudentie kan mijns inziens worden afgeleid dat Afdeling meer dan eens expliciet onderzocht of bepaalde belangen van derden werden beschermd in het kader van een specifiek vergunning- of ontheffingstelsel ${ }^{126}$, dan wel of deze belangen voldoende verband hielden met de het besluit dat ter discussie stond. ${ }^{127}$

124. Simon spreekt in zijn noot onder de betreffende uitspraak over 'een minimaal gewicht'.

125. ARRS 24 juni 1991, tB/S 1991, nr. 86, m.a. BdeW (cafe 'De Eland').

126. Vgl. in dit kader ook nog ARRS 10 juli 1987, AB 1988, 68, m.nt. JHvdV (uitwegvergunning Stad Delden) en ARRS 22 juni 1987, AB 1988, 103 (camping Vredenburg BV). In de laatstgenoemde uitspraak maakten omwonenden bezwaar tegen een vergunning ingevolge de Kampeerverordening Noord-Brabant. De bezwaren spitsten zich toe op het gebruik en onderhoud van de toegangsweg tot de camping. De Afdeling overwoog: 'De bezwaren van appellanten zijn gericht tegen het gebruik en de onderhoudstoestand van de weg Vredenburg, waaraan appellanten wonen en waaraan zij grond hebben liggen en welke weg de toegangsweg vormt tot de camping Vredenburg. De weg Vredenburg maakt echter geen onderdeel uit van de kampeerplaats en van de verleende vergunning. Voorwaarden, zoals appellanten wensen, kunnen dan ook niet gesteld worden in het kader van het verlenen van een kampeervergunning en bezwaren in verband daarmede zijn dan ook niet gericht op enig onderdeel van de vergunning.'

127. Ik wijs ook nog op ARRS 21 maart 1985, AB 1986, 319, m.nt. JHvdV (fietspad Zoetermeer): 'De bezwaren van appellanten richten zich blijkens de stukken en het verhandelde ter zitting niet zozeer tegen de aanleg van het pad op zichzelf als wel tegen het feit dat dit pad opengesteld zal worden voor bromfietsen. De Afd. meent dat appellanten na de aanleg van het fietspad de mogelijkheid hebben om in dit verband aan $B$ en $W$ te verzoeken om op grond van het RVV een maatregel te nemen tot wering van bromfietsen.' Vgl. tot slot VzARRS 7 juni 1990, AB 1991, 226, m.nt. JHvdV (lichtreclame Hengelo) en 


\subsubsection{Toch een ruime afwegingsplicht?}

Naast de hierboven besproken uitspraken, waaraan een soort 'Schutznorm'-leer ten grondslag lijkt te liggen, kan er een tegenovergestelde lijn in de jurisprudentie van de Afdeling rechtspraak worden waargenomen, waarin meer de nadruk werd gelegd op een integrale plicht van het bestuur om waar mogelijk rekening te houden met alle rechtstreeks betrokken belangen van derden. De lijn wordt duidelijk gemarkeerd door de standaarduitspraak inzake de 'oeverbeschoeiing Vecht'. ${ }^{128}$ In casu had de hoofdingenieur-directeur van de Rijkswaterstaat in de directie Noord-Holland (verweerder) ingevolge het Algemeen reglement van politie voor rivieren en Rijkskanalen aan een direct-belanghebbende vergunning verleend voor het aanbrengen van een nieuwe oeverbeschoeiing voor diens perceel, bestaande uit een damwand. De eigenaar van een belendend perceel stelde in beroep tengevolge van deze nieuwe damwand schade te lijden omdat hij gedwongen was zijn eigen oeververdediging aan te passen teneinde ophoping van vuil zoals wrakhout en dode vissen in een ontstane hoek tegen te gaan. Door verweerder werd echter in beroep betoogd dat de betreffende beschoeiing niet strijdig was met de belangen waarvoor het vereiste van vergunning was gesteld. Het betrof hier in het bijzonder de belangen welke betrokken waren bij de verzekering van een veilig en doelmatig gebruik van Rijkswaterstaatswerken. Volgens verweerder kon alleen met deze belangen bij vergunningverlening rekening worden gehouden. De Afdeling nam in een uitvoerige overweging uitdrukkelijk afstand van deze opvatting:

\footnotetext{
'Immers noch uit de strekking noch uit de bewoordingen der wet valt af te leiden dat verweerder bij het verlenen van een vergunning als de onderhavige alleen zou rekening hebben te houden met de belangen waarvoor het vereiste van vergunning tot het uitvoeren van een werk als het onderhavige is gesteld, zijnde de belangen betrokken bij de verzekering van een veilig en doelmatig gebruik van de rijkswaterstaatswerken en de bescherming daarvan. Integendeel, het ligt op de weg van de overheid bij de afweging waar rede-? lijkerwijs mogelijk te betrekken de vraag hoe kan worden voorkomen dat de belangen van derdenbelanghebbenden ten gevolge van de uitvoering van een dergelijk werk worden geschaad' (curs. R.J.N.S.).
}

Naar aanleiding van deze uitspraak kan men zich afvragen in hoeverre de Afdeling beoogde om een integrale plicht tot het afwegen van alle rechtstreeks betrokken derdebelangen te introduceren en of deze belangen ook bijv. het stellen van gedragsvoorschriften konden legitimeren. In dit verband is het interessant om kennis te nemen van de - contrasterende - visies van Van Wijmen en De Waard die beiden de uitspraak annoteerden. Beide annotatoren zijn het erover eens dat de betreffende uitspraak van belang is voor het stelsel

ARRS 8 december 1983, AB 1984, 146, m.nt. CLR. (Utrechtse veiligheidsdienst BV). In de laatstgenoemde uitspraak waren burgemeester en wethouders van De Bilt van oordeel dat hinder- en overlastaspecten niet in het kader van een planologische vrijstelling ingevolge art. 352 lid $4 \mathrm{MBV}$ (oud) mochten worden meegewogen. De Afdeling deelde deze opvatting overigens in casu niet.

128. ARRS 21 augustus 1984, AB 1984, 542, m.nt. P.C.E. van Wijmen (oeverbeschoeiing Vecht). Eveneens gepubliceerd in tB/S III, nr. 555, m.a. BdeW. Vgl. ook VzARRS 27 mei 1986, AB 1987, 267, m.nt. H.J. Simon. In deze laatstgenoemde Voorzittersuitspraak worden identieke overwegingen aangetroffen. 
van bestuurscompensatie, zoals dat door de Afdeling rechtspraak reeds in de bekende Paul Krugerbrug-uitspraken ${ }^{129}$ begin jaren tachtig werd geintroduceerd. Daarna scheiden evenwel de wegen van Van Wijmen en De Waard. Van Wijmen stelt zich niet de vraag of het betreffende derde-belang in casu wel in de bestuurlijke belangenafweging mocht worden betrokken. Na vastgesteld te hebben dat het hart van het bestuurscompensatiestelsel wordt gevormd door een (zoals Van Wijmen stelt) 'richtige' belangenafweging, constateert hij dat de Afdeling 'korte metten' maakt met de relativiteitsleer. Van Wijmen merkt over het meewegen van het betreffende derde-belang slechts op dat '...het een postulaat van zorgvuldigheid is, dat hun belang mede in aanmerking wordt genomen'. De Waard positioneert daarentegen deze 'zorgvuldigheidsplicht' tegen de achtergrond van het specialiteitsbeginsel. Hij acht het denkbaar '...dat de Afdeling niet méér bedoelde te zeggen dan dat het bestuursorgaan de belangen van derden in een zaak als de onderhavige niet volstrekt mag negeren, en moet bezien in hoeverre, binnen de beperkte mogelijkheden die het afwegingskader biedt, aan de bezwaren van derden tegemoet gekomen kan worden.' De uitspraak zou dan ook een reactie van de Afdeling kunnen zijn op een al te resolute verwijzing van het conflict tussen de direct-belanghebbende en de derde naar het privaatrecht. De Waard concludeert bijgevolg dat in deze uitspraak géén belangrijke relativering van het specialiteitsbeginsel behoeft te worden gelezen. Bij deze - mijns inziens juiste conclusie zou ik willen aansluiten. Zoals hierna nog zal blijken werd met de uitspraak inzake de 'oeverbeschoeiing Vecht' door de Afdeling rechtspraak wél - misschien onbedoeld - een lijn ingezet die in de jaren negentig zou leiden tot uitspraken die mijns inziens op gespannen voet staan met het specialiteitsbeginsel.

\subsubsection{De 'onzuivere' schadebeschikking}

De ruimere aandacht van de Afdeling rechtspraak voor de positie van belangen van derden hield naar mijn oordeel verband met de introductie van het leerstuk van de 'onzuivere schadebeschikking' in de bekende Paul Krugerbrug-uitspraken. ${ }^{130}$ Deze jurisprudentie is, ofschoon de aandacht hier doorgaans niet op gericht is, van grote betekenis voor de interpretatie van het specialiteitsbeginsel. De schakel tussen het leerstuk van de 'onzuivere schadebeschikking' en het specialiteitsbeginsel wordt gevormd door de belangenafwegingsplicht die in het kader van een discretionaire bevoegdheidsuitoefening op het bestuur rust. Genoemde belangenafwegingsplicht vormt het theoretische hart van de Paul Krugerbrug-constructie. Een eventuele nadeelcompensatieplicht kan uiteraard uitsluitend aan de orde zijn indien een bepaald particulier belang in de betreffende afweging behoorde te worden betrokken. Het verdient in dit verband aanbeveling om de bekende Paul Krugerbrug-casus nog eens in herinnering te roepen. Centraal stond de verlening van een

129. Deze uitspraken komen in paragraaf 8.4 .5 aan bod.

130. ARRS 12 januari 1982, AB 1982, 299, m.nt. P.C.E. van Wijmen (Paul Krugerbrug I) en ARRS 22 november 1983, AB 1984, 154, m.nt. J.H.W. De Planque (Paul Krugerbrug II). Vgl. ook de eerdere 'Baalderbrug'-uitspraak die reeds op een soortgelijke theoretische leest was geschoeid (ARRS 15 december 1981, AB 1982, 298). 
vergunning ingevolge artikel 87 van het Algemeen reglement van politie voor Rivieren en Rijkskanalen door de hoofdingenieur-directeur van Rijkswaterstaat in de directie Utrecht aan de gemeente Utrecht. ${ }^{131}$ Ingevolge deze vergunning was het de gemeente toegestaan om de oude beweegbare Paul Krugerbrug over het Merwedekanaal te vervangen door een vaste verbinding. Als gevolg van de vervanging van de beweegbare brug door een vaste verbinding zouden enige bedrijven, waaronder scheepswerf 'De Liesbosch' aanzienlijk nadeel ondervinden omdat zij juist aangewezen waren op het scheepvaartverkeer door het genoemde kanaal. Aan de betreffende vergunning werd nu een zgn. 'compensatievoorschrift' verbonden, dat de houder van de vergunning (o.m.) verplichtte om de redelijkerwijs mogelijke maatregelen te nemen ten einde te voorkomen dat derden ten gevolge van het gebruik van de vergunning schade zouden lijden.

In casu was o.m. de vraag relevant in hoeverre het verantwoordelijke bestuursorgaan met de belangen van de benadeelde derde-belanghebbenden rekening behoorde te houden. ${ }^{132}$ Interessant is dat Van Wijmen in zijn noot onder Paul Krugerbrug I opmerkte dat de verweerder in dit verband een poging ondernam 'twee paarden tegelijk te berijden, hetgeen echter tot mislukken was gedoemd omdat de beesten twee verschillende richtingen uitgingen'. Deze twee paarden waren volgens hem enerzijds het beroep op de relativiteitsleer (derhalve een beroep op de beperkte strekking van het vergunningstelsel) en anderzijds het erkennen van een plicht om een adequate voorziening te treffen voor de schade die de derde-belanghebbenden zouden lijden als gevolg van de aanleg van een vaste brug. Van Wijmen raakte hier de kern van de 'onzuivere' compensatieproblematiek. Een van de breekpunten vormde in de 'Paul Krugerbrug'-casus nl. - impliciet - de beantwoording van de principiële vraag of de schade voor de scheepswerven werd veroorzaakt door de vergunningverlening (de publiekrechtelijke rechtshandeling) of door de feitelijke bouw van de brug die in het kader van het vergunningstelsel naar publiekrechtelijke maatstaven werd gereguleerd.

Verweerder had in dit verband de relativiteitsleer in stelling gebracht door nauwkeurig te analyseren welke belangen in het kader van het betreffende vergunningstelsel werden beschermd (lees: gereguleerd). Het betrof hier de uitleg van hetgeen onder '....de bescherming van Rijkswaterstaatswerken, alsmede ter verzekering van het doelmatig en veilig gebruik van dier werken ${ }^{133}$ diende te worden verstaan. De Afdeling gaf de visie van

131. Het feit dat de direct-belanghebbende in casu een publiekrechtelijk lichaam was, vertroebeld de casus enigszins. Desalniettemin dient goed voor ogen te worden gehouden dat de hoofdingenieur-directeur van Rijkswaterstaat in de directie Utrecht publiekrechtelijk verantwoordelijk was voor de bevoegdheidsuitoefening, en niet de gemeente Utrecht als vergunningaanvrager. De gemeente was wél verantwoordelijk voor de feitelijke bouw van de brug.

132. Beantwoording van deze vraag hangt samen met de m.i. juiste veronderstelling dat een publiekrechtelijk vergunningstelsel nooit alle (private) rechtsbelangen van rechtssubjecten kan beschermen. Zoals in paragraaf 8.8.4 e.v. van dit hoofdstuk zal blijken, zijn in dit verband nl. het civielrechtelijke leerstuk van de vrijwarende werking van vergunningen en het specialiteitsbeginsel aan elkaar gerelateerd.

133. Kortom de 'doelbinding' van het betreffende vergunningstelsel ingevolge art. 87 van het Algemeen reglement van politie voor rivieren en Rijkskanalen. 
verweerder op dit punt als volgt weer: 'Met deze opsomming heeft verweerder, naar hij stelt, willen aangeven wat in het kader van het Algemeen reglement van politie voor rivieren en Rijkskanalen onder bepalingen "ter bescherming van 's-Rijks waterstaatswerken, alsmede ter verzekering van het doelmatig en veilig gebruik dier werken" moet worden verstaan. Volgens verweerder zal een weigering van een vergunning haar grondslag moeten vinden in de belangen die de wet beoogt te beschermen.(.) Door het vervangen van de thans beweegbare brug door een vaste wordt - aldus verweerder - noch schade toegebracht aan het Merwedekanaal, noch het doelmatig en veilig gebruik van vorengenoemd kanaal aangetast.'

Doordat verweerder echter gelijktijdig met dit betoog erkende dat desalniettemin nadeelcompensatie was aangewezen, richtte de Afdeling haar volledige aandacht vervolgens op de vraag naar de omvang van deze vergoeding en de in casu toe te passen berekeningssystematiek. Hierdoor werd de principiële beantwoording van de opgeworpen relativiteitsvraag (onbewust) omzeild. ${ }^{134}$ Impliciet kan uit de Paul Krugerbrug-jurisprudentie worden afgeleid dat de Afdeling rechtspraak een mogelijkheid tot nadeelcompensatie creěerde zonder te eisen dat de gelaedeerde belangen specifiek door het betreffende vergunningstelsel werden beschermd. ${ }^{135}$ Ofschoon dergelijke oplossing vanuit pragmatisch oogpunt aantrekkelijk was (en is), gaat zij - op het eerste gezicht - mank aan het ontbreken van een duidelijk theoretisch fundament voor de compensatieaansprakelijkheid met name wat betreft de verdeling van de draaglast tussen het betrokken bestuursorgaan en de directbelanghebbende (vergunninghouder) ${ }^{136}$ De Paul Krugerbrug-uitspraken, en de uitspraken die daarop later zijn gebaseerd, geven nl. gén handvat voor de beantwoording van de vraag welk nadeel (of welke schade) veroorzaakt werd (wordt) door de publiekrechtelijke bevoegdheidsuitoefening en welke schade het gevolg was (is) van de feitelijke activiteit die

134. Bijgevolg werd de Afdeling in latere jurisprudentie weer met deze vraag geconfronteerd. Zie de hiervoor besproken uitspraak inzake de 'oeverbeschoeiing Vecht'. ARRS 21 augustus 1984, AB 1984, 542, m.nt. P.C.E. van Wijmen (oeverbeschoeiing Vecht). Eveneens gepubliceerd in tB/S III, nr. 555, m.a. BdeW.

135. Ik laat hier de beantwoording van de vraag in het midden of de gelaedeerde belangen in casu door het betreffende vergunningstelsel werden beschermd. Dit standpunt lijkt mij overigens verdedigbaar. Zie: R.J.N. Schlössels, Wederkerigheid en specialiteit in het bestuursrecht, in: Eenzijdig en wederkerig? (red. E.C.H.J. van der Linden en A.Q.C. Tak), Deventer 1995, p. 185 (noot 115). Dat de consequenties van de 'Paul Krugerbrug'-constructie verstrekkend waren, blijkt op heldere wijze indien men deze leer vergelijkt met de overwegingen van de Hoge Raad in het bekende EZH/Bailey-arrest, dat ongeveer twintig jaar eerder werd gewezen (HR 14 juni 1963, NJ 1965, 82, m.nt. J.H.B.). De Hoge Raad huldigde in dit arrest - waaraan een vergelijkbare casuspositic ten grondslag lag - in essentie nl. de opvatting dat er in beginsel géen ruimte was voor vergoeding van schade indien door de vergunninghouder gehandeld werd ingevolge een vergunning waaraan een afweging van de betrokken publiekrechtelijke en bijzondere belangen ten grondslag lag.

136. Van belang is dat in de Paul-Krugerbrug casus zich (naar de vorm genomen) het verschijnsel van de 'burgercompensatie' voordeed. Van Male is van mening dat in casu afwenteling van compensatielasten bij vergunningvoorschrif - zonder een wettelijke grondslag - eerder aanvaardbaar was omdat de vergunninghouder een publiekrechtelijke rechtspersoon was met een eigen belastinggebied. R.M. van Male, Onvoltooid recht. Over rechtsbetrekking, bestuursrecht en bestuursprocesrecht (oratie EUR), Zwolle 1993, p. 21 . 
in dat verband wordt gereguleerd. Een gevolg van het ontbreken van een duidelijke bezinning ten aanzien van bijv. het causaliteits- en relativiteitsaspect heeft er mijns inziens in dit kader toe bijgedragen dat de Afdeling in latere jurisprudentie (te) vergaande mogelijkheden accepteerde tot het verbinden van 'compensatie- of afwentelingsvoorschriften' aan vergunningen. ${ }^{137}$

In dit verband is de Voorzittersuitspraak inzake Nederlandse Spoorwegen NV/gedeputeerde staten van Friesland van belang. ${ }^{138}$ In casu stond een ontheffing ingevolge het Waterreglement Friesland en de Vaarwegenverordening Friesland - strekkende tot het dempen van een onderdoorgang van het water 'De Welle' in de spoorlijn Leeuwarden/ Heerenveen - ter discussie. Een tankstation voor recreatievaart en een jachthaven stelden tengevolge van deze demping, die volgens de Nederlandse Spoorwegen NV noodzakelijk was in verband met de vernieuwing van het spoor, een omzetverlies te ondervinden. In het kader van de voorlopige voorzieningprocedure ${ }^{139}$ werd de Voorzitter o.m. geconfronteerd met de stelling van de Nederlandse Spoorwegen NV dat niet zij, maar de overheid eventueel nadeel van de betreffende derde-belanghebbenden diende te compenseren (de verdeling van de draaglast!). ${ }^{140}$ De Voorzitter, die onmiddellijk uitspraak deed in de hoofdzaak, deelde deze opvatting geenszins en overwoog: 'Overigens heeft appellante ter zitting ten onrechte de stelling betrokken dat in een geval als het onderhavige niet zij als. aanvraagster van de ontheffingen door de uitvoering waarvan derden worden benadeeld gehouden is tot schadevergoeding, doch de ontheffing verlenende overheid. Met verweerders moet worden geoordeeld dat een zodanige plicht veeleer op appellante als direct belanghebbende bij de ontheffing rust.' Vervolgens oordeelde de Voorzitter dat ter, bescherming van de gelaedeerde derde-belangen een compensatievoorschrift aan de verleende ontheffing verbonden had kunnen worden.

De vraag welke belangen door het ontheffingstelsel en de daaraan ten grondslag liggende regelingen werden beschermd speelde blijkbaar géén rol in de overwegingen van de Voorzitter. De Voorzitter concentreerde zich blijkbaar op de vraag of door de voorgenomen (feitelijke) demping van De Welle (onaanvaardbaar) nadeel ontstond voor de betrokken derde-belanghebbenden. Voor deze demping kon de NS primair verantwoordelijk worden gehouden. Hieruit zou men impliciet kunnen afleiden dat de Voorzitter ervan uitging dat eventueel nadeel niet door de bevoegdheidsuitoefening sec - de ontheffing -

137. Uiteindelijk resulterend in de hierna nog te bespreken Buttervliet-uitspraak van de Afdeling bestuursrechtspraak (ABRS 10 mei 1995, RAwb 1995, nr. 72, m.a. BdW).

138. VzARRS 29 oktober 1992, AB 1993, 183, m.nt. RMvM (demping De Welle). Deze uitspraak is ook besproken door B.W.N. de Waard, Wie van de drie? Toerekening van onderzoekskosten naar mogelijke schade als gevolg van een ontheffing, in: Het actuele recht, Lelystad 1993, p. 239-242 en door R.M. van Male, Marionette. Over het afwentelen van nadeelcompensatie bij beschikkingsvoorschrift, in: In de sfeer van administratief recht (Konijnenbelt-bundel), Utrecht 1994, p. 295 e.v.

139. Gedeputeerde staten die de ontheffingen hadden verleend, kwamen in de bezwarenfase toch tot een weigering, waarna de NS om cen voorlopige voorziening vroegen.

140. In casu was oók de vraag an de orde of de NS verplicht konden worden de kosten van een onderzoek naar eventuele schade/nadeel op zich te nemen. 
werd veroorzaakt, maar door de feitelijke activiteit die in het kader van het ontheffingstelsel vanuit publiekrechtelijk oogpunt werd gereguleerd. Dit zou bijgevolg kunnen verklaren waarom volgens de Voorzitter niet het verantwoordelijke bestuursorgaan, maar de directbelanghebbende een compensatielast diende te dragen. Gaat men hiervan uit dan resteert echter de vraag waarom het bestuursorgaan zich in het kader van de specifieke (doelgebonden) bevoegdheidsuitoefening (de publiekrechtelijke rechtshandeling) dan diende te mengen in het schade-aspect. Was hier immers niet sprake van een privaatrechtelijk geschil tussen de NS en de derde-belanghebbenden? Hiermee is tevens de vraag gegeven of gedeputeerde staten van Friesland, gelet op het legaliteits- en specialiteitsbeginsel, wel bevoegd waren om een compensatievoorschrift aan de ontheffing te verbinden, overeenkomstig de opvatting van de Voorzitter. ${ }^{141}$ Een dergelijk compensatievoorschrift zou immers in casu niet zijn rechtsgrond in de aantasting van een publiekrechtelijk belang, dan wel in de aantasting van een privaat rechtsbelang door de behartiging van een publiekrechtelijk belang vinden, maar in handelen van de direct-belanghebbende dat wellicht jegens derden naar civielrechtelijke maatstaven onrechtmatig was.

Weliswaar kon niet op voorhand worden uitgesloten dat de publiekrechtelijke belangen, die aan het betreffende bevoegdheidsstelsel ten grondslag lagen, tevens de belangen van de derden beoogden te beschermen - en dat hierin een grondslag was gelegen voor nadeelcompensatie door de overheid -, maar dit kwam niet expliciet in de casus aan de orde. Evenmin kwam de vraag aan de orde of tengevolge van de bevoegdheidsuitoefening het égalité- en/of evenredigheidsbeginsel wellicht werden geschonden. Gerechtvaardigd is dan ook de vraag of - en zo ja in hoeverre - de rechtsrelatie tussen de Nederlandse Spoorwegen NV en de betreffende derde-belanghebbenden voor wat betreft het schadeaspect wel ter discussie stond binnen de kaders van het publiekrechtelijke bevoegdheidsstelsel. In hoofdstuk 9 kom ik op deze problematiek, die de scheiding van publiek- en privaatrecht in essentie raakt, nog terug.

\subsubsection{Het meewegen van 'privaatrechtelijke' belangen}

In de lijn van de hiervoor belichte jurisprudentie ligt de problematiek van het 'meewegen' van in het privaatrecht beschermde belangen. Wellicht duidelijker is de volgende formulering: In hoeverre mag het bestuur in het kader van de uitoefening van een specifieke bestuursbevoegdheid treden in typisch privaatrechtelijke geschilpunten? Mag bijv. een planologische vrijstelling geweigerd worden op grond van het feit dat een erfdienstbaarheid of een bepaling van burenrecht ${ }^{142}$ zich hiertegen verzet? Met De Planque kan goeddeels worden ingestemd, wanneer hij opmerkt dat in de relevante jurisprudentie van de Afdeling op dit punt géén consistente benadering kan worden ontwaard. ${ }^{143} \mathrm{Zo}$ is door de Afdeling bij herhaling uitgesproken dat aan civielrechtelijke belemmeringen in principe géen

141. Vgl. in kritische zin R.M. van Male, Onvoltooid recht, a.w., p. 21.

142. Vgl. in dit kader R.J.N. Schlossels, Een dakkapel te Edam: de wens van eenheid van recht?, in: Rechtspraak bestuursrecht 1995-1996. De annotaties. 's-Gravenhage 1997, p. 65 e.v. 
betekenis toekomt in het kader van de verlening van een bouwvergunning. ${ }^{144}$ Aan bepalingen van burenrecht, eigendomsrecht en andere zakelijke rechten van derden kwam daarentegen wél weer betekenis toe indien er tevens planologische vrijstellingen of vrijstellingen van bebouwingsvoorschriften noodzakelijk waren om het bouwplan te kunnen realiseren. ${ }^{145}$ Ook aan het burenrecht kwam in het kader van de verlening van een kapvergunning betekenis toe. ${ }^{146}$ Ofschoon de Afdelingsjurisprudentie niet consequent van aard is, kan er wél een globale lijn in worden ontwaard. Uit de geanalyseerde uitspraken blijkt $\mathrm{nl}$. dat naarmate een bevoegdheid 'beleidsvrijer' was, volgens de Afdeling aan typisch civielrechtelijke aspecten meer aandacht diende te worden besteed.

\subsubsection{Toelaatbaarheid van voorschriften}

Tot slot zal aandacht worden besteed aan de vraag in hoeverre volgens de Afdeling rechtspraak aan een vergunning of ontheffing (gedrags)voorschriften ${ }^{147}$ mochten worden verbonden. Ook in dit verband kan slechts in hoofdlijnen bij de omvangrijke jurisprudentie worden stilgestaan. De Afdeling werd veelvuldig geconfronteerd met de vraag of bepaalde voorschriften toelaatbaar waren. De variatie aan casusposities die de revue passeerden toont aan dat de bestuurlijke praktijk op dit punt uiterst inventief is, en het voorschrift aanwendt als een populair normatief middel om bepaalde (geoorloofde of ongeoorloofde) beleidsdoelstellingen te realiseren. Voorop kan worden gesteld dat de Afdeling in principe strikt de hand hield aan het uitgangspunt dat voorschriften uitsluitend aan een vergunning of ontheffing mogen worden verbonden ter bescherming van de speciale publiekrechtelijke belangen welke het betreffende bevoegdheidsstelsel beoogt te beschermen. ${ }^{148}$ Dat de

143. Zie: J.H.W. de Planque, De mogelijkheden van administratieve rechters en de Kroon om het bestuur tot schadevergoeding te veroordelen, VAR-reeks 102, Alphen aan den Rijn, p. 126. Graag verwijs ik ook naar de uitvoerige jurisprudentie-analyse van De Planque die betrekking heeft op het 'meewegen van civielrechtelijke aspecten' (p. $22 \mathrm{t} / \mathrm{m}$ 27). Deze uitvoerige analyse zal hier niet worden herhaald. Op de toelaatbaarheid van het beslechten van 'privaatrechtelijke' geschilpunten door het bestuur zal eveneens in hoofdstuk 9 worden ingegaan.

144. Vgl. bijv. ARRS 23 april 1982, AB 1982, 460, m.nt. C.L.R. (bouwvergunning Nieuwerkerk aan de IJssel) en ARRS 9 maart 1984, AB 1984, 351, m.nt. C.L.R.

145. Vgl. bijv. VzARRS 14 september 1977, AB 1978, 166, m.nt. v.d.V. (Castricum) ARRS 12 juni 1980, tB/S III, nr. 197, m.a. J.S. (Amstelveen); ARRS 9 maart 1984, AB 1984, 351, m.nt. C.L.R. (Schijndel) en ARRS 10 januari 1986, tB/S, 1986, nr. 5, m.a. BdeW (Haarlem).

146. Zie: VzARRS 31 mei 1991, AB 1992, 17, m.nt. JHvdV (kapvergunning Epe). In casu was er sprake van mede-eigendom van een beuk op een perceelgrens. De Voorzitter overwoog, na te hebben vastgesteld dat één mede-eigenaar tot kappen bevoegd kon zijn: 'Dit laat echter onverlet dat verweerders bij het beoordelen van de vraag of de vergunning verleend kan worden, naast de gronden die in art. 5 van de verordening uitdrukkelijk zijn opgenomen, ook de belangen van deze mede-zakelijk gerechtigde dienen mee te wegen.'

147. In de jurisprudentie werd (wordt) in plaats van over 'voorschrift' ook wel over 'voorwaarde' gesproken.

148. Zie o.m.: ARRS 5 juni 1979, tB/S III, nr. 126, m.a. tB/S (sloopvoorwaarde Loosdrecht); VzARRS 30 juli 1985, tB/S VII, nr. 271, m.a. tB (kweeknetten); ARRS 18 november 1985, tB/S III, nr. 661, m.a. tB (horeca-ontheffing Domburg); ARRS 14 mei 1987, AB 1989, 4, m.nt. L. Bomhof (Afvalstoffenverordening Leimuiden); VzARRS 30 augustus 1990, AB 1991, 567, m.nt. H.J. Simon (kokkelvisserij), eveneens 
Afdeling in dit kader een tamelijk precieze opvatting huldigde blijkt duidelijk uit de zaak betreffende de stortheuvel te Mierlo. ${ }^{149}$ In casu kwam o.m. de vraag aan de orde of het toelaatbaar was om aan een aanlegvergunning - die verleend was ten behoeve van een stortheuvel - een voorwaarde van milieuhygiënische aard te verbinden ter voorkoming van overlast. Volgens appellant (een derde-belanghebbende) zou artikel 44, tweede lid van de Wet op de Ruimtelijke Ordening (WRO) hier géen beletsel voor vormen omdat er een nauwe relatie bestond tussen belangen van ruimtelijke aard en algemene milieuhygiënische belangen. De Afdeling deelde deze opvatting echter niet:

'De Wet op de Ruimtelijke ordening beoogt een algemeen kader te bieden, waarbinnen zich de coordinatie voltrekt van alle bij het gebruik van de bodem betrokken belangen met het oog op een zo doelmatig mogelijke indeling van de bodem. (..) De door appellant gewenste voorwaarde beoogt een bepaald belang in het bijzonder te behartigen, te weten het voorkomen of beperken van milieuhinderlijke gevolgen voor de omgeving van het in werking zijn van de betrokken afvalverwerkingsinrichting. Dit belang valt naar het oordeel van de Afd. buiten het bereik van de belangen die in het betrokken aanlegvergunningenstelsel bescherming vinden' (curs. R.J.N.S.).

Tevens achtte de Afdeling voorwaarden waarbij de gemeente zich vrijwaarde van aansprakelijkheid jegens derden niet toelaatbaar. Evenmin werd het toelaatbaar geacht dat voorschriften of voorwaarden aan een vergunning werden verbonden welke uitsluitend beoogden te voorkomen dat in strijd met privaatrechtelijke belemmeringen werd gehandeld. ${ }^{150}$ Bijzonder doelmatig en inventief - maar eveneens in strijd met het specialiteitsbeginsel - handelde het college van Oosterhout ${ }^{151}$ toen het aan een vergunning voor het gebruik van een gemeentelijke loswal de voorwaarde verbond dat niet ten behoeve van derden mocht worden gelost of overgeladen. Door middel van dit voorschrift beoogde het college kennelijk het financiële belang van de gemeente te behartigen. De Afdeling vernietigde echter op grond van détournement de pouvoir:

'De Afd. is van oordeel dat de zorg voor een rendabele exploitatie van genoemd openbaar gedeelte van de loswal, zijnde een belang van bedrijfseconomische aard, niet kan worden gerekend tot vorenomschreven doelstellingen (nl. de instandhouding, bruikbaarheid, vrijheid en veiligheid van de loswal R.J.N.S.) van de

gepubliceerd in $\mathrm{tB} / \mathrm{S} 1990$, nr. 89 , m.a. $\mathrm{tB}$. Ten Berge duidt deze beschikking aan als een 'mooi voorbeeld' van de toepassing van het specialiteitsbeginsel; ARRS 8 maart 1991, AB 1992, 149 (supermarkt Reuver) en ARRS 24 juli 1991, tB/S 1991, nr. 103, m.a. BdeW (Horecavergunning Almelo). In deze laatste uitspraak was het college van Almelo wel fors over de schreef gegaan door aan een vergunning op grond van de Drank- en Horecawet voorschriften te verbinden die de tewerkstelling van illegaal in Nederland verblijvende vreemdelingen beoogden tegen te gaan.

149. ARRS 2 december 1986, AB 1988, 67, m.nt. PvB (stortheuvel Mierlo). Zie ook de Voorzittersuitspraak: VZARRS 19 maart 1985, verkort gepubliceerd in de aantekening onder VzARRS 13 maart 1985, tB/S VII, nr. 261. Vgl. ARRS 23 januari 1988, AB 1989, 101 (fietscrossterrein Zelhem). In casu werd een voorschrift aan een APV-vergunning dat geluidsoverlast beoogde tegen te gaan ontoelaatbaar geacht. Het betreffende voorschrift was niet gesteld in het belang van de openbare orde.

150. Vgl. VzARRS 18 oktober 1993, Gst. 7002, p. 41, m.n. B. (standplaatsvergunning Reeuwijk).

151. ARRS 8 mei 1981, AB 1981, 524, m.nt. v.d.V. (loswal Oosterhout). 
onderhavige - publiekrechtelijke - verordening, waarmede kennelijk is beoogd het algemeen belang van het waarborgen van bovengenoemde kwaliteiten met betrekking tot de loswal in zijn geheel te behartigen.'

- Deze uitspraak houdt verband met de jurisprudentie van de Afdeling inzake het verbinden van financiele voorschriften en/of voorwaarden aan vergunningen en ontheffingen. $O_{p}$ dit type voorwaarden en voorschriften was de Afdeling steeds bijzonder alert met het oog op détournement de pouvoir en détournement de procedure. Uit de standaarduitspraak inzake de bouw van de Rabobank Zoeterwoude ${ }^{152}$ blijkt dat de Afdeling naast het algemene vereiste dat financiële voorwaarden hun grondslag dienen te vinden in de doelstelling van de regeling ${ }^{153}$ waarop de bevoegdheidsuitoefening is gebaseerd (en aan de verwezenlijking van deze doelstelling een rechtstreekse bijdrage dienen te leveren), een tweetal aanvullende eisen formuleerde. Zo stelde de Afdeling dat de verlening van een vergunning of vrijstelling in het algemeen belang tot het heffen van een geldbedrag dient te nopen, en dat ....de stellige noodzaak om een financiële voorwaarde op te leggen ook hieruit moet blijken, dat niet een andere, uit hoofde van rechtsbescherming meer aanvaardbare mogelijkheid aanwezig is om een tegemoetkoming of compensatie te verlangen'. Tegen deze achtergrond bezien is het uiteraard niet onbegrijpelijk dat de Afdeling in haar jurisprudentie bijv. de mogelijkheden tot kostenverhaal voor gemeenten in het kader van de exploitatie van bestemmingsplannen en bestemmingsplanwijzigingen resoluut aan banden legde. ${ }^{154}$ Tevens was de Afdeling steeds alert op vormen van 'verkapte' belastingen in de vorm van financiële voorschriften (détournement de procedure). ${ }^{155}$

\subsubsection{Tussenconclusie}

In algemene zin kan worden geconcludeerd dat door de Arob-rechter de essentie van het specialiteitsbeginsel werd erkend. De jurisprudentie van de voormalige Afdeling rechtspraak van de Raad van State beantwoordt voor een deel aan de uitgangspunten van een 'precieze' visie inzake het specialiteitsbeginsel(aandacht voor de bevoegdheidsleer, het

152. ARRS 30 augustus 1985, AB 1986, 243, m.nt. D.A. Lubach (Rabobank Zoeterwoude). In casu was er sprake van een voorwaarde verbonden aan een vrijstelling ingevolge art. 258 van de plaatselijke bouwverordening ten behoeve van de aanleg van 13 parkeerplaatsen.

153. Vgl. ARRS 13 oktober 1979, AB 1980, 466 (woningonttrekking Rotterdam); ARRS 20 juni 1983, AB 1984, 75, m.nt. JHvdV (ontsluiting tuinbouwgebied 'Nieuwland') en ARRS 10 augustus 1988, AB 1988, 541 , m.nt. PvB (verbreding Van Brienenoordbrug).

154. Ik wijs in dit kader o.m. op ARRS 13 oktober 1983, AB 1984, 30, m.nt. C.L.R. (Deurne) en ARRS 4 oktober 1985, AB 1986, 242, m.nt. Lubach (camping de Pluimpot). Tevens kan gewezen worden op de jurisprudentie van de Afdeling inzake de diverse uitwegvergunningenstelsels. Vgl. o.m. ARRS 1 september 1977, AB 1977, 366, m.nt. Van der Veen (Maastricht I) en ARRS 8 mei 1981, AB 1981, 391, m.nt. Borman (Nuth II).

155. Vgl. ARRS 25 juli 1983, tB/S III, 459, m.a. tB/S (recreatieschap 'De Merwelanden'). In casu werd het heffen van een bijdrage voor administratie- en toezichtkosten ta.v. ligplaatsen voor recreatievaartuigen door middel van een voorwaarde in beginsel ontoelaatbaar geacht met het oog op de doelstelling van de betreffende Vaartuigenverordening (nl. bescherming van landschap en natuur, alsmede het verzekeren van rust in het natuurgebied). 
legaliteitsbeginsel en de doelgebondenheid van bestuursbevoegdheid). Soms worden echter meer 'rekkelijke' uitspraken aangetroffen. Dit kan wellicht verklaard worden door het feit dat de Afdeling enerzijds de hand wilde houden aan het specialiteitsbeginsel, en anderzijds toch zoveel mogelijk recht wilde doen aan alle particuliere belangen van rechtstreeks belanghebbenden (denk aan nadeelcompensatie).

\subsection{De Afdeling geschillen van bestuur van de Raad van State (AGRS)}

De Afdeling geschillen van bestuur heeft gedurende de korte periode dat zij als administratieve rechter krachtens de Tijdelijke wet Kroongeschillen (TwK) ${ }^{156}$ recht sprak een aanzienlijke hoeveelheid jurisprudentie gevormd die van belang is voor de interpretatie van het specialiteitsbeginsel. De jurisprudentie-analyse betreft de periode van 1 januari 1988 tot 1 januari 1994.

\subsubsection{De verhouding tussen administratieve regelingen}

De problematiek inzake de verhouding tussen de verschillende administratieve wetten is in de jurisprudentie van de Afdeling geschillen van bestuur veelvuldig aan de orde gesteld. Evenals bij de bespreking van de uitspraken van de Afdeling rechtspraak en de beslissingen van de Kroon wordt hier volstaan met het schetsen van hoofdlijnen. Over de samenloop van verschillende (voormalige) milieuwetten, waaronder de Wet verontreiniging oppervlaktewateren, de Afvalstoffenwet, de Hinderwet en de Wet chemische afvalstoffen heeft de Afdeling regelmatig uitspraken gedaan. Hierbij toonde de Afdeling zich uiterst precies in het afgrenzen van de werkingssfeer van de verschillende vergunningstelsels, die vaak gelijktijdig op een bepaalde activiteit/inrichting van toepassing zijn. ${ }^{157}$ Bijzondere vermelding verdient in dit kader de jurisprudentie over de verhouding tussen het bestemmingsplan (Wet op de Ruimtelijke Ordening) en de Ontgrondingenwet. Uit deze jurisprudentie blijkt dat een vergunningverlening ingevolge de Ontgrondingenwet - welke wet een zéér ruim belangenafwegingskader kent ${ }^{158}$ - in beginsel bók mogelijk is indien het vigerende bestemmingsplan zich daartegen verzet. Voorwaarde is dan wel dat de planologische inpasbaarheid van de ontgronding niet definitief onmogelijk mag zijn. ${ }^{159}$

156. De Tijdelijke wet Kroongeschillen (TwK) betrof de Wet van 18 juni 1987, Stb. 317.

157. Ik wijs o.m. op: AGRS 14 november 1990, AB 1991, 231 (zandexploitatiemaatschappij Tilburg BV) inzake de samenloop Wvo/Afvalstoffenwet; AGRS 9 november 1990, AB 1992, 92 (Eijsden Gifvrij) inzake de samenloop Afvalstoffenwet/Wca; AGRS 8 februari 1991, AB 1991, 519, m.nt. Chr. Backes (Morton Thiokol BV) inzake (o.m.) de samenloop Wvo/Hinderwet; VzAGRS 1 maart 1991, AB 1991, 558 (Hoogovensgroep BV) eveneens inzake de samenloop Wvo/Hinderwet en AGRS 14 januari 1994, Gst. 6995, p. 490, m.n. R. Uylenburg (boomkwekerij St. Oedenrode) inzake de verhouding Bestrijdingsmiddelenwet/ Hinderwet.

158. Zie bijv. AGRS 11 september 1991, AB 1991, 654 en AGRS 12 september 1991, AB 1991, 653, m.nt. PJS.

159. Vgl. AGRS 18 april 1991, AB 1991, 477 (recreatieoord 'De Kriekel'); AGRS 20 juni 1991, AB 1991, 560, m.nt. PJS (ontgronding Ewijk) en AGRS 16 maart 1992, AB 1992, 306, m.nt. PJS (woonark Vinkeveen). 
Ook wat betreft de vergunningverlening ingevolge de (voormalige) Afvalstoffenwet bleek de Afdeling bezwaren van planologische aard goeddeels buiten de afweging te houden. ${ }^{160}$

De relatie bestemmingsplan/sectorale wetgeving kwam ook in andere Afdelingsuitspraken aan de orde. In het kader van een onttrekkingsprocedure ingevolge de Wegenwet ten behoeve van het Themapark Vervoer (Autotron) in de gemeenten Nuland en Rosmalen stelde de Afdeling zich op het standpunt dat de planologische inpasbaarheid van dit park, en de uitkomst van de planologische procedures, een specifieke afweging binnen het kader van de Wegenwet niet overbodig maken: 'De Afd. is van oordeel dat indien een wegonttrekking noodzakelijk dan wel gewenst is ter realisering van een bestemmingsplan, dit op zich onvoldoende reden is om tot onttrekking van die weg over te gaan. Aan het besluit tot onttrekking aan het openbaar verkeer dient een zelfstandige belangenafweging ten grondslag te liggen, waarbij dit belang een van de mee te wegen belangen is en een gewichtige reden kan zijn om tot onttrekking over te gaan. Daartegenover dient echter het belang van het gebruik van de weg in aanmerking te worden genomen' (curs. R.J.N.S.). In eenzelfde lijn ligt een uitspraak van de Afdeling waarin wordt benadrukt dat het afwegingskader van een gemeentelijke kapverordening los staat van het ter plaatse vigerende bestemmingsplan. ${ }^{161}$

In dit verband dient ook de aandacht te worden gevestigd op een fraaie casus inzake de samenloop van de Ontgrondingenwet en de Boswet. ${ }^{162}$ Gedeputeerde staten van Utrecht hadden aan appellant vergunning ingevolge de Ontgrondingenwet verleend o.m. onder de voorwaarde dat - kort weergegeven - in het belang van het landschapsschoon en de landschapsecologische waarden er $n a$ ontgronding op een gedeelte van het terrein beplanting diende te worden aangebracht. Appellant kon zich niet met deze verplichting verenigen omdat hem reeds ingevolge de Boswet een herplantplicht werd opgelegd door Staatsbosbeheer. Na de doelstellingen van zowel de Ontgrondingenwet als de Boswet nauwkeurig te hebben geanalyseerd overwoog de Afdeling:

'De Afd. stelt mitsdien vast dat de Ontgrondingenwet en de op de Utrechtse ontgrondingenverordening gebaseerde verplichting een ander oogmerk dient dan de uit de Boswet voortvloeiende herplantplicht en concludeert dat de regeling van de Boswet de bevoegdheid van verweerders om aan een ontgrondingsvergunning de voorwaarde te verbinden dat op een door hen aan te wijzen perceel compenserende beplanting moet worden aangebracht, onverlet laat' (curs. R.J.N.S.).

Deze uitspraak ligt ook in de lijn van de latere Regge en Dinkel-uitspraak, waarin de Afdeling geschillen van bestuur strak de hand hield aan het doelgebonden karakter van bestuursbevoegdheid. In deze casus achtte de Afdeling geschillen het nl. ontoelaatbaar dat

160. Zie bijv.: AGRS 29 mei 1991, AB 1991, 631 m.nt. ThGD en VzAGRS 7 augustus 1990, AB 1991, 626, m.nt. ThGD.

161. AGRS 8 maart 1989, AB 1989, 197, m.nt. PJS (Groesbeek). De Afdeling overwoog letterlijk: 'De kapverordening is een op zichzelf staande gemeentelijke regeling met een eigen toepassingsgebied, die in beginsel losstaat van andere gemeentelijke verordeningen en regelingen zoals het bestemmingsplan' (curs. R.J.N.S.).

162. AGRS 7 februari 1991, AB 1991, 307 (Loosdrecht). 
een waterschap weigerde om op grond van landschappelijke en biologische belangen keurontheffing te verlenen van een vaarverbod op de Dinkel. Deze belangen mochten, gelet op de reglementaire taak van het waterschap, niet worden behartigd. ${ }^{163}$

\subsubsection{Belangen van derden}

Evenals in de Arob-jurisprudentie en in de Kroonjurisprudentie, treft men in de TwKjurisprudentie uitspraken aan waarin de Afdeling geschillen van bestuur, die overigens een belangenafwegingsplicht tussen publieke en private belangen ten principale erkende ${ }^{164}$, desalniettemin bepaalde derde-belangen ingevolge een soort 'Schutznorm'-benadering buiten het belangenafwegingsproces hield. ${ }^{165}$ Illustratief is een uitspraak van de Voorzitter van 12 september $1991 .{ }^{166}$ In casu had de minister van Verkeer en Waterstaat, in afwijking van de aanvraag die strekte tot vergunning voor onbepaalde tijd, een vergunning ingevolge artikel 4 van de Rivierenwet verleend voor bepaalde tijd ten behoeve van het storten en weer opbaggeren van zand in het zomerbed van de Nieuwe waterweg. De beperking in tijd was in het bijzonder ingegeven door financiele belangen van de Dienst der Domeinen die de betreffende zandput in de toekonst door middel van openbare inschrijving wilde gaan gunnen. De Voorzitter overwoog in dit kader: 'Met appellante/verzoekster is de voorzitter van oordeel dat bij het verlenen van vergunning als de onderhavige uitsluitend rekening kan worden gehouden met belangen ontleend aan het openbaar rivier- en stroombelang, zodat bij de beoordeling van een aanvraag voor een zodanige vergunning aan de financielle belangen van derden - zoals in dit geval de Dienst der Domeinen - voorbij moet worden gegaan' (curs. R.J.N.S.).

163. AGRS 24 mei 1993, Wb 1993, p. 574, m.a. I. Poortvliet. Vgl. Pres. Rb. Almelo 21 april 1994, Awbkatern $(A B), 75$. Van belang is dat uit deze laatste uitspraak blijkt dat nota's en plannen de strekking (d.w.z. het wettelijke doel) van een bestuursbevoegdheid niet kunnen wijzigen. Zie voor een uitvoerige bespreking van de gehele Dinkel-kwestie(s): A. van Hall, Het specialiteitsbeginsel in het waterstaatsrecht. Over kringen van belangen, oratie UU, Zwolle 1995, , p. 66-69. Van Hall bespreekt in dit kader ook nog (latere) jurisprudentie die interessant is. In de Dinkel-zaak vorderde - en verkreeg - de Staat der Nederlanden in kort geding nl. als eigenaar van een gedeelte van het betreffende water een (tijdelijk) kanoverbod ter bescherming van de natuurwaarden! In feite werd hierdoor de beschermende werking van het specialiteitsbeginsel door toepassing van de 'twee-wegenleer' ondergraven (Pres. Rb. Almelo 2 augustus 1994, JB 1994/230, m.nt. F.A.M.S.). Vgl. wat betreft deze problematiek, verder hoofdstuk 2 (paragraaf 2.5.3).

164. Zie voor een treffend voorbeeld AGRS 10 januari 1991, AB 1991, 180, m.nt. PJS (houtopstand Venray).

165. Ik wijs erop dat uit - niet gepubliceerde -, maar door Koetser geanalyseerde jurisprudentie van de Afdeling blijkt dat de Schutznorm-benadering ook wel leidde tot niet-ontvankelijk verklaringen. Zie: M.B. Koetser, VAR-reeks 108, a.w., p. 114-115.

166. VzAGRS 12 september 1991, AB 1992, 350 (Amsterdamse Ballast Bagger en Grond BV). Vgl. in dit kader VzAGRS 22 september 1992, AB 1993, 8 (V.o.f. Combinatie Zeeland Haringvliet). In deze laatstgenoemde uitspraak kende de Voorzitter wél met het oog op de verlening van een ontgrondingsvergunning betekenis toe aan de belangen van de Dienst der Domeinen. Dit kan samenhangen met het feit dat het afwegingskader van de Rivierenwet - ook na verruiming bij wet van 13 mei 1991, Stb. 1991, 277 beperkter is dan dat van de Ontgrondingenwet. 
In een uitspraak van 28 november $1991^{167}$ geeft de Afdeling zelf duidelijk blijk van het uitsluiten van bepaalde particuliere (derde-)belangen. Het college van gedeputeerde staten van Zuid-Holland had op grond van artikel 16 tweede lid van de Wet op de lijkbezorging aan het college van burgemeester en wethouders van Barendrecht, onder voorwaarden, toestemming verleend voor het uitbreiden van een algemene begraafplaats. In de voorwaarden was in het belang van omwonenden bepaald dat een tien meter brede groenstrook diende te worden aangelegd. De Afdeling achtte deze voorwaarde gelet op de strekking van het betreffende bevoegdheidsstelsel - dat de verontreiniging van bodem, water en lucht beoogde tegen te gaan - niet toelaatbaar:

'Uit de overwegingen van het bestreden besluit blijkt, dat verweerders de in geding zijnde voorwaarden in het besluit hebben opgenomen ten einde tegemoet te komen aan bij de omwonenden levende bezwaren van psycho-hygienische aard. De Afdeling stelt vast, dat artikel 16 tweede lid derde volzin hiertoe geen ruimte biedt. Immers de belangen met het oog waarop de gewraakte voorwaarden zijn gesteld, te weten belangen betreffende de geestelijke gezondheid en het geestelijk welbevinden, kunnen niet worden gerekend tot de belangen van de volksgezondheid welke art. tweede lid der wet beoogt te beschermen' (curs. R.J.N.S.).

\subsubsection{Een vérstrekkende uitspraak?}

Naast deze 'precies' aandoende uitspraken, worden er in de Afdelingsjurisprudentie ook uitspraken aangetroffen die blijk geven van ruimere mogelijkheden om met (vreemde) 'derde-belangen' rekening te houden. Deze jurisprudentie ligt in de lijn van de in paragraaf 8.4.4 besproken uitspraken van de Afdeling rechtspraak inzake 'Paul Krugerbrug I en II' en 'Oeverbeschoeiing Vecht'. Van bijzonder belang is in dit verband de Afdelingsuitspraak van 28 mei $1991^{168}$ inzake de ontheffing van een waterschapskeur ten behoeve van het dempen van een aantal watergangen in de gemeente Zijpe. Een derde-belanghebbende stelde tegen de betreffende ontheffing, na eerst - zonder succes - ingevolge artikel 22 Waterstaatswet 1900 (oud) GS van Noord-Holland verzocht te hebben het besluit te vernietigen, beroep in bij de Kroon. Gelet op de Tijdelijke wet Kroongeschillen diende de Afdeling geschillen te beoordelen of het waterschapsbestuurmet de belangen van appellant rekening had dienen te houden in het kader van de keurontheffing. In casu waren de bezwaren van appellant met name van verkeerskundige aard; hij vreesde nl. op zijn woonlokatie ernstige overlast van zware vrachtauto's met zand. Gedeputeerde staten hadden zich op het standpunt gesteld dat het dagelijks bestuur van het waterschap zich bij de besluitvorming terecht had beperkt tot de belangen welke samenhingen met de in het reglement van het waterschap neergelegde functionele taakstelling van het schap, alsmede tot de belangen die beschermd werden door de in de keur opgenomen verbodsbepalingen.

De Afdeling stelde eerst de publiekrechtelijke belangen, die aan de ontheffingsbevoegdheid ten grondslag lagen, vast. Ofschoon de bevoegdheid niet expliciet aan enig te beharti-

167. AGRS 28 november 1991, AB 1992, 142, m.nt. PJS (algemene begraafplaats Barendrecht).

168. AGRS 28 mei 1991, AB 1991, 691, m.nt. JJIV (keurontheffing Zijpe). Zie over de positie van belangen van derden ook: AGRS 21 februari 1989, AB 1989, 181 (invalidenparkeerplaats Steenbergen) en AGRS 16 oktober 1990, AB 1991, 92, m.nt. PJS (invalidenparkeerplaats L.). 
gen openbaar belang was gebonden, stelde de Afdeling zich op het standpunt dat uit de tekst en strekking van de keurbepaling kon worden afgeleid dat deze met name het belang van de waterbeheersing beoogde te beschermen. Hieruit volgde naar het oordeel van de Afdeling: '...dat algemene, openbare belangen die vreemd zijn aan het belang dat deze verbodsbepaling beoogt te beschermen, een bestuursorgaan geen aanleiding kunnen geven om een ontheffing van die bepaling te weigeren, zoals ook verweerders hebben overwogen'. Na vervolgens te hebben vastgesteld dat aan bepaalde bezwaren van appellant (nl. de overtreding van de maximum snelheid en beschadiging van het wegdek) ingevolge andere wettelijke regelingen tegemoet kon worden gekomen, overwoog de Afdeling in algemene bewoordingen:

\begin{abstract}
'Anders dan verweerders, gelet op de inhoud van het bestreden besluit, het verweerschrift en tijdens de openbare vergadering van de Afdeling, voornoemd, gegeven toelichting daarop, kennelijk veronderstellen kan uit de voren geciteerde keurbepalingen echter niet worden afgeleid, dat concrete particuliere belangen van derden bij de besluitvorming geheel buiten beschouwing zouden kunnen worden gelaten. Integendeel, het ligt op de weg van de overheid bij de afweging waar redelijkerwijs mogelijk te betrekken de vraag hoe $k a n$ worden voorkomen dat de belangen van derden, i.c. ingevolge de verlening van een ontheffing van keurbepalingen, onnodig worden geschaad. Algemeen aanvaard is ook het uitgangspunt, dat een besluit geen als onaanvaardbaar aan te merken nadelige gevolgen voor een of meer belanghebbenden mag hebben. Het standpunt van verweerders dat zij dit aspect gelet op het doel en strekking van de van toepassing zijnde keurbepalingen geheel buiten beschouwing konden laten, geeft blijk van een onjuiste rechtsopvatting' (curs. R.J.N.S.).
\end{abstract}

Deze krasse rechtsoverwegingen, werden gevolgd door enige relativerende opmerkingen: 'Van het waterschap mag worden verwacht', aldus de Afdeling, '...dat bij de besluitvorming rekening wordt gehouden met particuliere belangen die rechtstreeks door een besluit zouden kunnen worden getroffen. Het waterschap behoeft evenwel geen acht te slaan op belangen die slechts in een meer verwijderd verband door de te nemen beslissing kunnen worden geschaad' (curs. R.J.N.S.).

\title{
8.5.4 Toedeling van bezwaren aan de juiste bevoegdhedenkaders
}

De gefragmenteerde structuur van de administratiefrechtelijke wetgeving brengt - zoals reeds diverse malen werd gesteld - met zich dat de belangen van burgers binnen verschillende bevoegdhedenkaders bescherming kunnen vinden. Het is dan, mede uit een oogpunt van besluitvormingsefficiency, noodzaak om bezwaren aan de meest geëigende kaders toe te delen. ${ }^{169}$ Hierbij kan blijken dat de plicht om rekening te houden met

169. Voor burgers en belangengroepen die met de 'gedeelde' overheid worden geconfronteerd zal dit niet altijd begrijpelijk zijn. Vgl. voor een fraai voorbeeld van 'bezwaar-eliminatie' bijv. AGRS 8 februari 1991, AB 1991, 519, m.nt. Chr. Backes (Morton Thiokol BV). T.a.v. de ingebrachte bezwaren tegen een Hinderwetvergunning overwoog de Afdeling: 'De bezwaren van appellante, voorzover zij planologische aspecten betreffen, zijn geen bezwaren met betrekking tot gevaar, schade of hinder in de zin van de Hinderwet en kunnen dan ook niet bij de beoordeling van de in geding zijnde beschikking tot vergunningverlening worden betrokken. Sinds de gewijzigde redactie van art. 13 Hinderwet moeten onder gevaar, schade of 
bepaalde particuliere belangen - ondanks de ruimte die het afwegingskader biedt (impliciet) wordt beperkt door andere wettelijke regelingen. Illustratief is een uitspraak van de Afdeling inzake de gedeeltelijke onttrekking van de Amsterdamse Van Nijenrodeweg aan het openbare verkeer ten behoeve van woningbouw. ${ }^{170}$ Ten aanzien van de vele bezwaren van bewoners, die o.m. van planologische, verkeerstechnische en milieuhygiennische aard waren, overwoog de Afdeling eerst dat de opvatting van appellanten, welke erop neerkwam dat de onderwerpelijke wegonttrekking prematuur zou zijn (daar de planologische procedures nog niet waren afgerond), niet kon worden gedeeld:

'Immers, noch in de Wegenwet, noch in enige andere wettelijke regeling kan steun worden gevonden voor de opvatting dat vooruitlopend op het onherroepelijk worden van een bestemmingsplan niet mag worden begonnen met de procedure tot onttrekking aan het openbaar verkeer van een binnen het plan gelegen weg of weggedeelte. De Afd. merkt voorts op dat voor het verrichten van werkzaamheden ten behoeve van de ter plaatse geprojecteerde woningen inmiddels conform alle daarvoor in de Wet op de Ruimtelijke Ordening, de Woningwet, de Ontgrondingenwet alsmede de kapverordening der gemeente Amsterdam, voorgeschreven procedures zijn c.q. worden gevolgd. Bezwaren van appellanten die belangen betreffen welke door middel van genoemde regelingen moeten worden beschermd, dienen dan ook in het kader van de onderwerpelijke beroepen op grond van de Wegenwet buiten beschouwing te blijven' (curs. R.J.N.S.).

De Afdeling heeft ook aanvaard - wellicht niet geheel in overeenstemming met het specialiteitsbeginsel - dat bepaalde particuliere belangen buiten beschouwing kunnen blijven indien afdoende vaststaat dat een andere wettelijke procedure bepalend is voor de vraag of van een aangevraagde vergunning daadwerkelijk gebruik kan worden gemaakt. Dat ondervond de V.o.f. 'Camping Zuiderduin' ${ }^{171}$ toen zij beroep instelde tegen de weigering van gedeputeerde staten om ingevolge de provinciale Beplantingsverordening een kapvergunning te verlenen. Deze vergunning was aangevraagd om een stuk bos te kunnen kappen ten behoeve van de uitbreiding van de camping. De Afdeling deelde het standpunt van GS, dat erop neer kwam dat aan de belangen van appellanten voorbij kon worden gegaan omdat de beoogde uitbreiding van de camping (nog) in het kader van de planologische procedures aan de orde diende te worden gesteld. Zolang het vigerende bestemmingsplan niet was gewijzigd gold ter plaatse de bestemming 'Natuurgebied'. Ingevolge het aanlegvergunningenstelsel dat ten aanzien van deze bestemming van kracht was, kon gén vergunning voor het kappen worden verleend. Kennelijk hadden appellanten volgens de Afdeling bijgevolg óok geen belang bij een kapvergunning.

hinder in de zin van de Hinderwet mede worden begrepen bezwaren van milieuhygienische aard in ruime zin, echter voorzover daar niet middels andere wetgeving in wordt voorzien. Zo is het bezwaar van appellante, dat de verlening van de Hinderwetvergunning niet bijdraagt tot vermindering van de waterverontreiniging, gelet op art. 38a eerste lid Hinderwet, geen bezwaar dat de Hinderwet beoogt te weren, maar een bezwaar dat moet worden beoordeeld in het kader van de Wet verontreiniging oppervlaktewateren.'

170. AGRS 31 oktober 1988, AB 1989, 54 (onttrekking Van Nijenrodeweg).

171. AGRS 21 november 1989, AB 1990, 96 (camping Zuiderduin). 


\subsubsection{Het meewegen van 'privaatrechtelijke' belangen}

De Afdelingsjurisprudentie inzake het 'meewegen' van in het burgerlijke recht beschermde belangen is, evenals de jurisprudentie van de Afdeling rechtspraak, niet steeds eenduidig geweest. In verband met de onttrekking van wegen aan het openbare verkeer ingevolge de Wegenwet werd de Afdeling bij herhaling met deze problematiek geconfronteerd.

Inzake het verzoek tot de gedeeltelijke onttrekking van de Maarnse Vinkenbuurtweg ${ }^{172}$ (ten behoeve van een kampeer- en bungalowterrein) stelde de Afdeling uitdrukkelijk dat '...noch in de tekst van de Wegenwet, noch in de geschiedenis van de totstandkoming van de wet aanknopingspunten kunnen worden gevonden voor de juistheid van de veronderstelling van verweerders, dat bepaalde redenen voor of belangen bij een wegonttrekking bij de besluitvorming dienaangaande geen rol zouden mogen spelen. Dit betekent naar het oordeel van de Afd. dat ook particuliere belangen op zichzelf beschouwd als een gewichtige reden voor onttrekking aan het openbare verkeer kunnen worden aangemerkt' (curs. R.J.N.S.). In een andere 'onttrekkingszaak' bleek dat de voorgenomen verkoop van een stuk grond echter géén (zelfstandige) reden mag vormen om een weggedeelte aan het openbare verkeer te onttrekken. Van belang is ook dat de Afdeling erop wees dat bezwaren van een derde, welke gericht waren tegen de verkoop sec, buiten het kader van de Wegenwet vallen. ${ }^{173}$

In de zaak 'V.o.f. Combinatie Zeeland Haringvliet' werd de Voorzitter van de Afdeling geschillen van bestuur om een voorlopige voorziening/schorsing gevraagd inzake het besluit van de minister van Verkeer en Waterstaat waarbij deze een aanvraag om toestemming tot ontgronding niet-ontvankelijk had verklaard. Deze niet-ontvankelijk verklaring hield verband met het feit dat de aanvrager (nog) niet beschikte over de 'privaatrechtelijke' toestemming van de Staat (Dienst der Domeinen) om ontzilt zeezand in het betreffende onderwaterdepot op te slaan. De Voorzitter ging ervan uit dat aan het ontbreken van deze benodigde toestemming niet voorbij kon worden gegaan en trof géen voorlopige voorziening.

De Afdeling zélf heeft daarentegen meer dan eens uitgesproken dat privaatrechtelijke geschilpunten in het kader van een vergunningverlening ingevolge de Ontgrondingenwet niet aan de orde kunnen komen. Zeer duidelijk was het standpunt van de Afdeling inzake de uitbreiding van de zandwinning in het recreatieproject 'Het Hambroek' te Borculo. ${ }^{174}$ In casu werd door het college van Borculo en het dagelijks bestuur van het recreatieschap Oost-Gelderland in beroep bezwaar gemaakt tegen een verleende ontgrondingsvergunning op grond van het feit dat er geen afdoende (financiêle) overeenstemming bestond tussen de eigenaren en het recreatieschap inzake de overdracht van de percelen na voltooiing van de ontgronding. De Afdeling overwoog:

172. AGRS 9 oktober 1990, AB 1991, 49, m.nt. PJS (recreatiemaatschappij 'Lage Kanje' BV). Vgl. ook AGRS 18 mei 1989, AB 1989, 323, m.nt. PJS en AGRS 20 juli 1989, AB 1989, 433.

173. AGRS 8 april 1993, Gst. 6988, p. 272, m.n. HH (wegonttrekking Voorst).

174. AGRS 6 februari 1991, AB 1991, 297 m.nt. PJS (recreatieschap Oost-Gelderland). Vgl. ook AGRS 31 januari 1991, AB 1991, 234 m.nt. PJS. 
'Naar het oordeel van de Afd. is hier sprake van een geschil tussen de bij het recreatieproject betrokken overheden en de eigenaar van de bedoelde percelen tot de voorwaarden waaronder die percelen aan het recreatieschap zullen worden overgedragen.(.) Nog afgezien van het feit dat dit geschil eerst is ontstaan nadat verweerders hun besluit tot vergunningverlening hadden genomen en nadat verweerders aan de aanvankelijk door appellanten in beroep aangevoerde bezwaren tegemoet waren gekomen, betreft het hier een geschil van privaatrechtelijke aard waarover de Afd. zich niet kan uitspreken. Voorzover appellanten beogen dat in de vergunningvoorwaarden alsnog een financiele regeling wordt voorgeschreven met betrekking tot o.m. de beoogde overdracht van percelen aan het recreatieschap, overweegt de Afd. dat voor het opnemen van dergelijke voorwaarden van privaatrechtelijke aard, die ook niet strekken ter bescherming van de bij de uitvoering van de ontgronding betrokken belangen, in de Ontgrondingenwet geen steun kan worden gevonden' (curs. R.J.N.S.).

Tot slot verdient de schorsingszaak inzake Oliehandel Keizer Karel BV aandacht. ${ }^{175}$ In casu liet de Voorzitter privaatrechtelijke eigendomsbelemmeringen, die zich (kennelijk) tegen een vergunning ingevolge de Rivierenwet verzetten, uitdrukkelijk buiten beschouwing. Na te hebben vastgesteld welke publiekrechtelijke belangen in het kader van de Rivierenwet - na verruiming van het afwegingskader bij wet van 13 mei 1991 (Stb. 1991, 277) - werden beschermd, overwoog de Voorzitter $\mathrm{nl}$. dat 'Uit het vorenstaande moet worden afgeleid dat met de wetswijziging is beoogd ruimte te bieden voor afweging van aanverwante openbare belangen. De voorzitter heeft vooralsnog geen aanknopingspunten kunnen vinden voor de juistheid van de stelling van verweerder, dat een vergunning thans ook zou kunnen worden geweigerd of ingetrokken ter bescherming van (eigendoms)rechten van particulieren' (curs. R.J.N.S.).

Annotator Verburg wees er in zijn noot onder deze uitspraak mijns inziens terecht op dat het feit dat het particuliere geschil tussen de vergunninghouder en de derde binnen het verruimde afwegingskader van de Rivierenwet geen rol mag spelen, niet uitsluit dat met (anverwante) openbare belangen, die de Rivierenwet beoogt te beschermen, tevens belangen van particuliere aard kunnen zijn gemoeid. Als voorbeeld wees hij erop dat het belang van een niet afkalvende oever primair particulier (privaatrechtelijk) van aard is, maar daarnaast het verlies van natuurwaarden meebrengt. Hier is dan een soort 'reflexwerking ${ }^{176}$ van de objectieve bevoegdheidsnorm in het geding.

\subsubsection{Toelaatbaarheid van voorschriften}

Beschikkingsvoorschriften dienden volgens de Afdeling geschillen van bestuur hun grondslag te vinden in het specifieke wettelijke afwegingskader op basis waarvan een besluit werd genomen. Het palet van regelingen en voorschriften is dermate kleurrijk dat slechts aan enkele voorbeelden aandacht kan worden besteed. Zo bleek bijv. een voorschrift dat verbonden was aan een vergunning ingevolge de Afvalstoffenwet niet toelaatbaar, daar dit betrekking had op een activiteit die ingevolge de Wet verontreiniging oppervlaktewateren

175. VzAGRS 6 februari 1992, AB 1992, 674, m.nt. JJIV (oliehandel Keizer Karel BV) In deze zaak werd in gelijke zin beslist door de Afdeling bestuursrechtspraak. Zie ABRS 29 juli 1994, ABkort 1994, 737.

176. Vgl. in dit verband hoofdstuk 9 (paragraaf 9.4.3). 
werd gereguleerd. ${ }^{177}$ Toelaatbaar was daarentegen een voorschrift dat werd verbonden aan de verlening van gezinsbijstand en dat appellante verplichte om een bepaling in een echtscheidingsconvenant (betreffende het vermogen van een minderjarige zoon) te wijzigen. Volgens de Afdeling geschillen was dit voorschrift verenigbaar met artikel 3 lid 2 van de Algemene Bijstandswet dat voorwaarden toeliet welke strekken tot vermindering of beěindiging van de bijstand. ${ }^{178}$

Interessant zijn in dit verband ook nog enige beroepszaken over 'meerwaardeclausules' en 'vrijwaringsvoorwaarden', verbonden aan keurontheffingen en/of vergunningen. In een uitspraak van 19 december 1990 sprak de Afdeling zich o.m. uit over de toelaatbaarheid van een zgn. 'meerwaardeclausule' welke door Dijkgraaf en hoogheemraden van het (voormalig) hoogheemraadschap van Groot-Alblasserwaard aan een tweetal keurvergunningen was verbonden. ${ }^{179}$ De vergunningen waren (in het verleden) verleend voor het aanpassen van een te Hardinxveld-Giessendam, in de steunberm van de Merwededijk, gelegen woning. De betreffende clausules strekten ertoe om te voorkomen dat de eventuele meerwaarde van de woning, welke het gevolg zou zijn van de verbouwingen, in geval van latere zetting of amovering tengevolge van dijkversterkingswerken financieel gecompenseerd diende te worden. De Afdeling achtte dit soort compensatiebeperkende voorwaarden niet toelaatbaar: 'Zoals de Afd. hiervoor reeds heeft overwogen, zijn te dezen toepasselijke bepalingen van de verordening, waarin o.m. - zakelijk weergegeven - wordt voorgeschreven dat het zonder vergunning verboden is op de dijk een gebouw te plaatsen of een bestaand gebouw uit te breiden dan wel te verbouwen, in het leven geroepen ter bescherming van het dijksbelang, meer in het bijzonder het belang van instandhouding van de dijk in voortdurende waterkerende staat. Gelet op de tekst van de in geding zijnde voorwaarde, alsmede de door appellanten gegeven toelichting daarop, staat vast dat deze voorwaarde aan de betreffende vergunning is verbonden ten einde een - toekomstig financieel nadeel voor het hoogheemraadschap uit te sluiten. Naar het oordeel van de Afd. strekt deze voorwaarde niet tot bescherming van de belangen waarvoor het vereiste van vergunning is gesteld. ${ }^{180}$

\subsubsection{Tussenconclusie}

Indien men de jurisprudentie van de Afdeling geschillen van bestuur van de Raad van State overziet, dan kan vastgesteld worden dat deze in het algemeen recht deed aan het

177. AGRS 28 februari 1992, AB 1993, 598, m.nt. ThGD (autowrakken Odijk).

178. AGRS 9 september 1993, AB 1994, 521.

179. AGRS 19 december 1990, AB 1991, 362, m.nt. JJIV. Vgl. ook AGRS 15 november 1989, AB 1990, 323, m.nt. JJIV.

180. Een zelfde lot was tot slot een 'vrijwaringsvoorwaarde' beschoren welke door het bestuur van het waterschap 'De Middelsékrite' was verbonden aan een ontheffing ingevolge het Algemeen reglement volmachtenboezemwaterschappen en de politieverordening van het schap ten behoeve van de verbreding van een dam. AGRS 7 oktober 1991, AB 1992, 410, m.nt. JJIV (waterschap De Middelsékrite). Ik wijs erop dat de Afdeling bestuursrechtspraak op dit punt blijkbaar een ruimere visie huldigt. Vgl. ABRS 31 juli 1996, AB 1996, 480, m.nt. AvH (brug Oegstgeesterkanaal). 
specialiteitsbeginsel. Ofschoon de jurisprudentie op bepaalde punten aansluit bij de jurisprudentie van de Afdeling rechtspraak, moet worden geconstateerd dat de Afdeling geschillen het beginsel meer 'precies' benaderde. Op dit punt sluit de lijn die de Afdeling volgde mijns inziens aan bij de (oudere) Kroonjurisprudentie.

\subsection{De Afdeling bestuursrechtspraak van de Raad van State (ABRS)}

Doordat artikel 3:4 lid 1 Awb de rechter weinig houvast biedt wat betreft de interpretatie van het specialiteitsbeginsel ${ }^{181}$, kon worden aangenomen dat de jurisprudentie van de 'nieuwe' Afdeling bestuursrechtspraak niet (geheel) consistent zou zijn. Naar verwachting zou de Afdeling op pragmatische wijze voortborduren op de wisselvallige Arob-jurisprudentie. Een eerste verkenning van de relevante uitspraken bevestigde deze veronderstelling. Hierbij dient men voor ogen te houden dat aan de uitspraken van de Afdeling bestuursrechtspraak in de periode (direct) na het in werking treden van de eerste tranche van de Awb (1 januari 1994) nog bestuurlijke besluitvorming van vóór dit tijdstip ten grondslag lag. Toch heeft de Afdeling bestuursrechtspraak (als appélrechter ${ }^{182}$ ) onder de vigeur van de Awb reeds enige uitspraken gedaan die - zij het naar mijn mening niet op geheel bevredigende wijze - richting geven aan de interpretatie van het specialiteitsbeginsel.

\subsubsection{Belangenafweging en doelgebondenheid}

De Afdeling bestuursrechtspraak ziet er - grosso modo - op toe dat doelgebonden bestuursbevoegdheden worden aangewend ter behartiging van de publiekrechtelijke belangen die de wetgever voor ogen stonden bij de toekenning van de betreffende bevoegdheid. ${ }^{183}$ Zo hield het openbare orde belang sec onvoldoende verband met het

181. Dit artikellid, dat in de literatuur en jurisprudentie in verband wordt gebracht met het specialiteitsbeginsel, is in hoofdstuk 6 van dit boek besproken (paragraaf 6.5.2).

182. Waar zinvol zal in deze paragraaf (in de noten) ook aandacht worden besteed aan de relevante uitspraken van de sectoren bestuursrecht van de Arrondissementsrechtbanken.

183. Vgl. ABRS 5 augustus 1996, AB 1996, 426, m.nt. PJS (sluipverkeer Vianen). Dit geldt ook voor zgn. 'indirecte' bestuursbevoegdheden, waaronder bijv. goedkeuringsbevoegdheden. Zie bijv. ABRS 2 mei 1995, Gst. 7017, p. 503 e.v., m.n. B. (veemarkt Zwolle). Deze uitspraak is illustratief voor de problemen die het vaststellen van het specifieke doel van een bepaalde bestuursbevoegdheid vaak met zich brengt. De Afdeling was in casu van mening dat de bevoegdheid van gedeputeerde staten ex art. 229 Gemeentewet (oud), om de instelling van weekmarkten goed te keuren ten dienste stond van de openbare orde. Bijgevolg oordeelde de Afdeling dat aan concurrentie-aspecten, die waren ingebracht door het college van burgemeester en wethouders van een naburige gemeente, gén overwegende betekenis kon worden toegekend. Annotator Brederveld is van mening dat de Afdeling in deze uitspraak - wat betreft het doel van de goedkeuringsbevoegdheid - de plank volledig misslaat. Volgens hem bleek uit de (parlementaire) geschiedenis van de goedkeuringsbevoegdheid dat deze juist aan GS was toegekend met het oog op het belang van de handelsomvang (het algemene economische belang). Ik wijs tot slot nog op ABRS 17 mei 1994, ABkort 1994, 526 (sluiten spoorwegovergang) en ABRS 26 mei 1997, AB 1997, 336, m.nt. FM (crematoriumvergunning Doorn). De laatstgenoemde uitspraak is interessant omdat de Afdeling hier werd geconfronteerd met een bestuursbevoegdheid die niet aan een specifieke weigeringsgrond was gebonden. 
publiekrechtelijke belang van de bescherming van het milieu. In het kader van de verlening van een milieuvergunning mocht dit belang nl. géén zelfstandige rol spelen in de belangenafweging. ${ }^{184}$ Een ander voorbeeld biedt een Afdelingsuitspraak van 1 december $1994 .^{185}$ Een standplaatsvergunning, waaraan het belang van de openbare orde ten grondslag lag, mocht niet worden geweigerd op religieuze motieven. Overigens is die openbare orde-'paraplu', in de optiek van de Afdeling, ruim. ${ }^{186}$ In dit verband kan er ook op worden gewezen dat de Afdeling bestuursbevoegdheden in de stedenbouwkundige sfeer soms nogal ruim interpreteert. Vermeldenswaardig is een uitspraak van 14 maart 1996. In deze uitspraak kwam de vraag aan de orde of belangen van algemeen planologische aard gewicht in de schaal mochten leggen in het kader van een micro-stedenbouwkundige vrijstelling. ${ }^{187}$ De rechtbank had deze vraag in de aangevallen uitspraak, gelet op het specialiteitsbeginsel, uitdrukkelijk ontkennend beantwoord. De Afdeling deelde deze opvatting echter geenszins. Volgens haar dienden nl. 'alle belangen in de overwegingen te worden betrokken, welke door het verlenen van de vrijstelling zouden worden gediend of geschaad'.

Het feit dat speciale publiekrechtelijke belangen de uitoefening van een bestuursbevoegdheid sturen en richting geven, sluit niet uit dat ook andere belangen een rol mogen 1 (en soms moeten) spelen bij de besluitvorming. De Afdeling acht het toelaatbaar dat een bepaalde inbreuk op het te behartigen publiekrechtelijke belang moet worden geaccepteerd, om zo afdoende aan de rechtstreeks betrokken belangen van particulieren tegemoet te kunnen komen. ${ }^{188}$ Ook sluit de Afdeling niet uit dat bepaalde secundaire (beleids)doelstellingen binnen de belangenafweging een rol mogen spelen, op voorwaarde dat bijv. een weigering in overwegende mate door het speciale publiekrechtelijke belang wordt gedragen. ${ }^{189}$

Weinig helder is in dit kader een uitspraak van 14 december 1995 inzake de onttrekking van een weg aan het openbare verkeer door de raad van de gemeente Hilvarenbeek. ${ }^{190}$

De Afdeling zag zich genoodzaakt, gelet op de bedoeling van de wetgever, met kunst en vliegwerk het afwegingskader globaal af te bakenen.

184. ABRS 5 januari 1996, Gst. 7041, p. 562 e.v.; ABkort 1996, 116 (milieuvergunning de 'S-tapperij'). Ook algemene belangen betreffende de natuur en het landschap, alsmede de vraag of een bedrijfsmatige activiteit economisch exploitabel is, dienen in het kader van de Wet milieubeheer (in de regel) buiten beschouwing te blijven. Vgl. VzABRS 24 april 1995, AB 1995, 515 (sportcomplex Vietnamweide).

185. ABRS 1 december 1994, AB 1995, 211, m.nt. RMvM (standplaatsvergunning Montfoort).

186. Vgl. bijv. ABRS 7 oktober 1996, Gst. 7050, p. 162 e.v. (uitstalvergunning Groningen) en ABRS 10 oktober 1996, Gst. 7055, p. 326 e.v. (standplaatsvergunning winkelcentrum Leidschenhage).

187. ABRS 14 maart 1996, BR 1996/11, p. 906 e.v. m.nt. H.J. De Vries (achtergevelrooilijn Ambt Montfort). $\mathrm{Vgl}$. in dit verband de m.i. meer genuanceerde uitspraak inzake het 'Velpse duivenhok' die in paragraaf 8.6.4 uitvoerig zal worden besproken.

188. Vgl. ABRS 23 augustus 1994, AB 1994, 592 (kapvergunning Enschede).

189. Zie bijv. ABRS 26 juni 1995, NA 1995, 235 (nachtvergunning Amhem). In casu had de burgemeester van Arnhem in het kader van zijn weigering om een nachtvergunning voor een horeca-gelegenheid te verlenen mede met een beleidsmatig doelgroepencriterium rekening gehouden (in casu was er sprake van een maximumstelsel).

190. ABRS 14 december 1995, AB 1996, 86 (wegonttrekking Hilvarenbeek). 
De raad wenste tot deze onttrekking over te gaan omdat de betreffende weg binnen de wegenstructuur geen noodzakelijke functie meer vervulde voor het openbaar verkeer, én omdat de gemeente een gedeelte van deze weg wilde verkopen aan particulieren voor de bouw van een carport. Derde-belangenhebbenden - allen gebruikers van de weg - maakten tegen de onttrekking bezwaar en voerden o.m. aan dat het besluit (tegen de achtergrond van de voorgenomen verkoop aan particulieren) niet het algemeen belang diende. De Afdeling deelde dit standpunt echter niet een overwoog:

'...dat de belangen van deze bewoners bij het kunnen aankopen van grond zonder de aanwezigheid van een openbaar pad en de belangen van verweerder bij de verkoop van deze grond wel dienen te worden meegewogen bij het beoordelen van de belangen die zijn gediend met dan wel die zich verzetten tegen het onttrekken van de openbaarheid van de weg'.

De Afdeling leek van oordeel dat - ofschoon de onttrekkingsbevoegdheid haar grondslag vond in de Wegenwet en gebonden was aan de publiekrechtelijke belangen die deze wet beoogt te behartigen - desalniettemin vermogensrechtelijke belangen de wegonttrekking (mede) konden legitimeren. Een dergelijke opvatting, voorzover juist weergeven, is uiteraard moeilijk verenigbaar met de essentie van het specialiteitsbeginsel, dat nl. eist dat enkel speciale publiekrechtelijke belangen de bevoegdheidsuitoefening mogen sturen en legitimeren. ${ }^{191}$

\subsubsection{De verhouding tussen administratieve regelingen}

Dat de complexe verhouding tussen de verschillende bevoegdhedenstelsels in de administratieve wetgeving garant staat voor een rijke jurisprudentie bleek reeds in dit hoofdstuk. Het heeft op deze plaats weinig toegevoegde waarde om alle jurisprudentie gedetailleerd in kaart te brengen, daar deze voortbouwt op de reeds besproken Arob-en TwK-jurisprudentie. Ik schets daarom slechts enige hoofdlijnen.

Uit de jurisprudentie kan als hoofdregel worden afgeleid dat iedere bestuursbevoegdheid een eigen specifiek afwegingskader ${ }^{192}$ kent waaraan, naast andere toepasselijke kaders,

191. Dat de Afdeling betekenis toekent aan het (in rechtsvormende zin) 'meewegen' van typisch vermogensrechtelijke belangen in een doelgebonden publieke context blijkt ook op een duidelijke wijze uit VzABRS 9 juli 1996, KG 1996, 361 (overdracht ammoniakrechten) en ABRS 9 februari 1996, JB 1996/82, m.nt. R. Schlössels (dakkapel Edam). In de laatstgenoemde uitspraak kende de Afdeling betekenis toe aan bepalingen van burenrecht met het oog op een planologische vrijstelling.

192. Vgl. bijv. ABRS 14 juni 1995, AB 1996, 3, m.nt. ChB (hogere grenswaarden Wet geluidhinder Giessenlanden). In casu kwam o.m. de verhouding bestemmingsplanprocedure/grenswaardenprocedure Wet geluidhinder aan de orde. Vgl. verder - wat betreft de verhouding tussen het afwegingskader van een keurvergunning en de Wet verontreiniging oppervlaktewateren - ook nog ABRS 23 september 1997, AB 1997, 435, m.nt. AvH (waterschap Meer en Woude). Uit deze uitspraak blijkt duidelijk dat het specialiteitsbeginsel er voor waakt dat bestuursorganen niet hun onderlinge competentiegebieden betreden (het bestuursorganisatorische aspect van het beginsel). 
steeds een zelfstandige betekenis toekomt. ${ }^{193}$ Deze hoofdregel sluit niet uit dat verschillende afwegingskaders elkaar kunnen beïnvloeden. In een uitspraak van 27 mei $1994^{194}$ overwoog de Afdeling ten aanzien van de Ontgrondingenwet bijv. nog eens expliciet dat deze wet weliswaar een algemeen afwegingskader biedt voor bij de ontgronding betrokken belangen, maar dat deze wet dient terug te treden 'voor zover in de bescherming van bij de ontgronding betrokken belangen wordt voorzien door specifieke wettelijke regelingen'. Uit een Afdelingsuitspraak van 12 januari 1994, waarin de verhouding tussen de Woonwagenwet (oud) en de Wet op de Ruimtelijke Ordening aan de orde kwam $^{195}$, bleek dat een ontheffing ingevolge artikel 10 van de eerstgenoemde wet, strekkende tot het innemen van standplaats buiten een regulier centrum, niet onmogelijk was in geval van strijd met het bestemmingsplan. Aan een met het planologische regime strijdige situatie komt echter well in het kader van de belangenafweging (enige) betekenis toe. ${ }^{196}$ Onder omstandigheden kan het innemen van een standplaats nl. een zodanige inbreuk op de door het bestemmingsplan beschermde belangen betekenen, dat redelijkerwijze niet tot verlening van een ontheffing kan worden besloten, aldus de Afdeling.

193. Vgl. bijv. ABRS 3 januari 1995, ABkort 1995, 36. Het feit dat een bouwwerk planologisch niet is toegestaan, staat er niet aan in de weg dat er in het kader van de Wet milieubeheer een zelfstandig onderzoek naar specifiek milieuhygiënische aspecten dient plaats te vinden; Het feit dat een bouwvergunning is verleend impliceert niet dat er (automatisch) óok een inritvergunning ingevolge de APV wordt verleend. ABRS 19 juni 1996, Gst. 7049, p. 147 e.v., m.n. J.M.H.F. Teunissen (Hengelo). Duidelijk is in dit kader ook: Rb. Amsterdam 2 oktober 1996, JB 1996/263, m.nt. R.J.N.S. (monumentenvergunning De Houtkoper). Het specialiteitsbeginsel verzet zich volgens de Afdeling overigens niet tegen procedureelinhoudelijke afstemmingsconstructies tussen wettelijke regimes op basis van bijv. een gemeentelijke verordening, mits de afzonderlijke eindverantwoordelijkheid van de betrokken bestuursorganen hierdoor niet wordt aangetast én de (onderliggende) wetgeving hierdoor niet wordt doorkruist. Vgl. ABRS 24 maart 1997, AB 1997, 201; Gst. 7058, p. 442 e.v. m.n. HH (horeca-exploitatievergunning Amsterdam) en ABRS 16 mei 1997, JB 1997/155, m.nt. R.J.N.S. (garagevergunning Amsterdam). Ik wijs er tot slot op dat de Afdeling er zorgvuldig op toe ziet dat de juiste bestuursbevoegdheden en procedures worden gehanteerd, ook wanneer het gaat om verwante APV-bevoegdheden. Zie bijv. ABRS 22 mei 1997, AB 1997, 306, m.nt. FM (cafésluiting Venlo). Vgl. ook: ABRS 2 juni 1994, AB 1994, 648, m.nt. PvB (Middenschouwen). In casu stond de verhouding tussen een 'binnenplanse' vrijstellingsprocedure en de wettelijke procedure voor bestemmingsplanwijziging centraal.

194. ABRS 27 mei 1994, AB 1994, 451, m.nt. PJS (ontgronding Heteren).

195. ABRS 12 januari 1994, Gst. 6986, p. 220 e.y., m.n. C.P.J. Goorden (standplaatsontheffing Amsterdam).

196. Vgl. in dit kader Pres. Rb. Maastricht 24 februari 1995, JB 1995/111, m.nt. R. Schlठssels (exploitatievergunning Meers). In deze uitspraak van de Maastrichtse president kwam de vraag aan de orde in hoeverre in het kader van de verlening van een gemeentelijke exploitatievergunning voor een cafébedrijf het gebruiksregime van het ter plaatse vigerende bestemmingsplan in de besluitvorming diende te worden betrokken. De president was - gelet op het specialiteitsbeginsel - van oordeel dat het planologische aspect door verweerder niet in de besluitvorming behoefde te worden betrokken en dat hij hieraan bijgevolg evenmin doorslaggevende betekenis behoefde toe te kennen. Alleen het belang of de belangen die in de betreffende regeling bescherming hadden gevonden en de direct bij de toepassing van de regeling betrokken particuliere belangen mochten een - beslissende - rol spelen. Deze 'precieze' benadering, die wellicht niet door de Afdeling bestuursrechtspraak zou worden gedeeld, is over het algemeen positief ontvangen in de literatuur. Vgl. bijv. de noot van H.J. de Vries onder KB 1 september 1995, BR 1995/12, p. 1008. 
In dit verband kan ook de aandacht worden gevestigd op het feit dat door de verruiming van het afwegingskader van een bepaalde administratieve wet de mogelijkheid tot afweging van belangen (en normstelling) binnen een ander kader - ofschoon aanvankelijk toelaatbaar - wordt beperkt. In een zaak waarin het college van burgemeester en wethouders van Weesp ${ }^{197}$ had geweigerd om ingevolge artikel 8.24 lid 1 Wet milieubeheer een milieuvergunningvoorschrift op verzoek van de vergunninghouder in te trekken, kwam de Afdeling tot het oordeel dat het betreffende voorschrift - dat o.m. bepaalde dat parkeren buiten de parkeerhavens niet was toegestaan - niet langer aanvaardbaar was gelet op de nieuwe wegenverkeerswetgeving die sinds 1 november 1991 van kracht was. Deze wetgeving had sedert die datum niet alleen betrekking op het belang van de vrijheid en veiligheid op de weg, maar ób́k op het beperken van overlast, hinder en schade doo: het verkeer. Doordat de parkeerproblematiek sedert het genoemde tijdstip afdoende door de specifieke wegenverkeerswetgeving kon worden ondervangen, was er kennelijk géén ruimte (meer) om deze problematiek ook nog via vergunningvoorschriften ingevolge de Wet milieubeheer te reguleren. ${ }^{198}$

De samenloop van verschillende wettelijke regimes kan complexe (interpretatie)problemen tot gevolg hebben. ${ }^{199}$ Een fraai - en voor het specialiteitsbeginsel om verschillende redenen relevant - voorbeeld biedt de Afdelingsuitspraak over het autocrossen te Zuidwolde. ${ }^{200}$ In casu had een derde-belanghebbende twee achtereenvolgende jaren (nl. in 1991 en 1992) bezwaar gemaakt én beroep ingesteld tegen besluiten van de burgemeester van Zuidwolde, waarbij deze naar aanleiding van een kennisgeving ingevolge artikel 2.2.3 van de Algemene Plaatselijke Verordening (APV) voorschriften had gegeven voor het houden van een autocrossevenement. De beide zaken werden door de Afdeling bestuursrechtspraak gevoegd behandeld. In dit kader diende de Afdeling zich eerst te buigen over de samenloop van twee bevoegdhedenstelsels ingevolge de APV. ${ }^{201}$ Appellant had nl. aangevoerd (althans de Afdeling interpreteerde één en ander zo) dat het stelsel op basis waarvan de burgemeester voorschriften had gesteld in casu terzijde werd gesteld door een aantal andere bepalingen uit de APV op grond waarvan het college van burgemeester en wethouders - kort gezegd - bevoegdheden toekwamen om terreinen aan te wijzen waar wedstrijden met motorvoertuigen juist wel (onder bepaalde voorwaarden), of juist niet (behoudens ontheffing) toelaatbaar waren. De Afdeling deelde deze opvatting

197. Zie ABRS 6 september 1994, Gst. 7003, p. 73 e.v., m.n. HH (parkeervoorschrift Weesp).

198. Overigens was het betreffende voorschrift volgens annotator Hennekens ook vóór de betreffende wetswijziging reeds in strijd met de Wegenverkeerswet (oud) omdat het volgens hem toen evenzeer een verkeersmaatregel betrof.

199. Vgl. de 'worsteling' van de Voorzitter van de Afdeling in VzABRS 14 oktober 1994, Gst. 7007, p. 201 e.v., m.n. HH (cafe Thijssen). In casu stond de verhouding tussen een gemeentelijke terrasvergunning en een terrasvoorschrift uit de AMvB Horeca-bedrijven Wet milieubeheer centraal.

200. ABRS 3 juni 1994, AB 1994, 602, m.nt. RMvM (autocross Zuidwolde), eveneens gepubliceerd in Gst. 7006 , p. 170 e.v., m.n. B.

201. Een ander voorbeeld van een complexe verhouding tussen twee bevoegdhedenstelsels ingevolge plaatselijke verordeningen biedt: ABRS 9 juni 1994, AB 1994, 664 (lichtreclame Zeeman Goes). 
van appellant niet, en achtte het mogelijk dat de beide bevoegdhedenstelsels afzonderlijk van elkaar op het autocrossen van toepassing waren:

'Zoals ook blijkt uit de verschillen in bevoegdheidstoedeling - enerzijds aan de burgemeester, anderzijds aan burgemeester en wethouders - is hier sprake van twee afzonderlijke stelsels. Er is geen reden om aan te nemen dat de toepasselijkheid van het ene stelsel de toepasselijkheid van het andere uitsluit.'

Maar de Afdeling, en dit is van bijzonder belang, toonde wél begrip voor de onduidelijkheid die een en ander voor de burger kon meebrengen:

'In dit verband verdient overigens opmerking dat het op de weg van verweerder ligt om, indien bij hem een niet nader gespecificeerd verzoek om toestemming voor een autocross wordt ingediend, te onderzoeken of naast de art. 2.2 .2 e.v. ook nog andere gemeentelijke regelingen van toepassing zijn.'

In dit kader mocht volgens de Afdeling bestuursrechtspraak van de burgemeester worden verwacht dat hij het verzoek van de autocrossclub ook aan burgemeester en wethouders zou hebben voorgelegd (quod non). $\mathrm{Nu}$ in casu de aangevochten besluiten van de burgemeester onmiskenbaar op het betreffende artikel 2.2.2 APV waren gebaseerd, spitste de toetsing door de Afdeling zich hierop toe. In dit kader interpreteerde de Afdeling het beroep van appellant, die exploitant was van een nabij het crossterrein gelegen natuurcamping, als een beroep tegen het ten onrechte niet verbieden van het evenement door de burgemeester. Vervolgens analyseerde de Afdeling op grond van welke publiekrechtelijke belangen de burgemeester tot een verbod kon overgaan. Het betrof hier in de visie van de Afdeling het belang van de openbare orde de belangen van veiligheid, zedelijkheid en gezondheid. Andere belangen dan de genoemde, aldus de Afdeling, konden bij de toepassing van de artikel 2.2.2 e.v. 'geen zelfstandige rol spelen'.

$\mathrm{Nu}$ appellant in casu primair klaagde over geluidsoverlast, deed zich een bijkomend probleem voor. Nadat verweerder nl. het eerste primaire besluit (op $16 \mathrm{mei} 1991$ ) had genomen, waarbij het geluidhinderaspect kennelijk werd betrokken, was in de gemeente Zuidwolde een specifieke Verordening geluidhinder van kracht geworden (op 1 oktober 1991), gebaseerd op de Wet geluidhinder. Ingevolge deze verordening was het college, en niet de burgemeester bevoegd, tot vergunningverlening. Een en ander bracht naar het oordeel van de Afdeling met zich dat verweerder ten tijde van het tweede primaire besluit (d.d. 19 mei 1992) géén rekening meer mocht houden met geluidsoverlast die ter plaatse van het evenement werd voortgebracht. Hier deed zich de bekende situatie voor waarbij een afwegingskader (impliciet) wordt beperkt door een speciale administratieve regeling van latere datum. In casu had verweerder dit overigens nog tijdens de bestuurlijke heroverweging onderkend en alsnog het geluidhinderaspect buiten beschouwing gelaten. ${ }^{202}$ Bijgevolg kwam de Afdeling tot het eindoordeel dat verweerder in redelijkheid tot zijn besluit had kunnen komen. 


\subsubsection{Belangen van derden}

De jurisprudentie van de Afdeling bestuursrechtspraak inzake het 'meewegen' van belangen van derden in de bestuurlijke besluitvorming is bij eerste beschouwing niet eenduidig. Enerzijds worden 'precieze' uitspraken aangetroffen waarin de Afdeling de beproefde 'Schutznorm'-benadering lijkt toe te passen, anderzijds heeft de Afdeling meer dan eens benadrukt dat het bestuur steeds met alle (rechtstreeks) betrokken belangen van particulieren (en bijgevolg ook van derden) rekening dient te houden. Dit, op het eerste gezicht wisselvallige jurisprudentiebeeld, doet denken aan de jurisprudentie van de voormalige rechtsprekende Afdelingen van de Raad van State.

Wat betreft de 'precieze' uitspraken, kan allereerst de aandacht worden gevestigd op de uitspraak inzake de camping in het winterbed van de Maas. ${ }^{203}$ In casu stond de vraag centraal of in het kader van een vergunningverlening ten behoeve van deze camping ingevolge de Rivierenwet - zoals deze van kracht was vóor 1 augustus 1991 - betekenis mocht worden toegekend aan de bezwaren van omwonenden die zich toespitsten op de verloedering van hun woonomgeving door de exploitatie van bedoelde camping. Appellanten hadden in dit verband betoogd dat het toetsingskader van de Rivierenwet door de wijziging van deze wet per 13 mei 1991 (Stb. 1991, 277) was verruimd, zodat niet uitsluitend met het openbaar rivier-en stroombelang rekening diende te worden gehouden, maar ook met de daarmee verbonden belangen van andere dan waterstaatkundige aard. Hiermee beoogden zij aan te geven dat hun belangen in het kader van de vergunningverlening behoorden te worden beschermd. ${ }^{204}$ Uit de relevante rechtsoverwegingen van de Afdeling kan worden afgeleid dat de vraag óf belangen van particulieren binnen de 'range' van een wettelijk kader vallen inderdaad een relevante besluitvormingsfactor is. In casu kwam de Afdeling evenwel niet toe aan de beantwoording van deze vraag omdat het omstreden besluit genomen was vóór de inwerkingtreding van de betreffende wetswijziging. Het betoog van appellanten trof 'mitsdien' geen doel, zodat aan hun bezwaren in dit verband geen gewicht kon toekomen.

De vraag of bezwaren van een derde (voldoende) verband hielden met de ingevolge een vergunningstelsel te behartigen publiekrechtelijke belangen speelde ook in de Afdelings-

202. Vermeldenswaardig is dat verweerder het verzoek van de autocrossclub tijdens de heroverwegingsfase alsnog in handen van het college stelde met het oog op vergunningverlening. Deze vergunning werd inderdaad verleend. De Afdeling die ervan uitging dat het beroep mede tegen deze vergunning was gericht, stelde het beroep in zoverre alsnog in handen van het college van Zuidwolde ter behandeling als bezwaarschrift.

203. ABRS 12 augustus 1994, AB 1994, 607, m.nt. RMvM (camping in winterbed). Vgl. over het afwegingskader van de Rivierenwet ook: ABRS 29 april 1994, ABkort, 524. (watersportvereniging 'De Prins').

204. Met annotator Van Male (noot onder uitspraak in AB 1994,607) ben ik overigens van mening dat in casu verdedigbaar was dat de belangen van de appellanten binnen het nieuwe verruimde toetsingskader van de Rivierenwet vielen. Tot 'aan de rivier of stroom verbonden belangen' kunnen blijkens de MvT o.m. worden gerekend: de belangen van de scheepvaartafwikkeling, natuur, en landschap. Onder het landschapsbelang valt m.i. oók het belang van een aanvaardbare visueel-ruimtelijke kwaliteit van de omstreden camping. 
uitspraak inzake States Express Touringcars BV. ${ }^{205}$ In deze zaak deelde de Afdeling het standpunt van gedeputeerde staten van Zuid-Holland dat planologische en verkeerstechnische bezwaren van een derde tegen een waterschapsvergunning - strekkende tot een slootdemping - door het bestuur buiten beschouwing konden worden gelaten en dat de vergunningaanvraag door verweerders terecht primair was beoordeeld met het oog op de waterstaatkundige belangen. Voorzover de bezwaren van appellant wél verband hielden met waterstaatkundige belangen (appellant stelde $\mathrm{nl}$. wateroverlast te ondervinden tengevolge van een slechte waterbeheersing in zijn woongebied) toetste de Afdeling of de ondervonden overlast min of meer direct verband hield met het verlenen van de omstreden vergunning. Volgens de Afdeling was hiervan géén sprake, zodat verweerders in redelijkheid hun positieve besluit hadden kunnen nemen.

Tot slot kan de aandacht worden gevestigd op een héél 'precieze' uitspraak van de Afdeling van 1 maart $1996 .{ }^{206}$ In casu maakte een buurman bezwaar tegen het verlenen van een uitwegvergunning aan de eigenaar van een aangrenzend agrarisch bedrijf. Hij stelde door de aanleg van de betreffende uitrit op diverse manieren in zijn woongenot te worden aangetast (o.m. inkijk en geluidshinder). De Afdeling hield deze bezwaren echter resoluut buiten de besluitvorming, gelet op de plaats die het vergunningstelsel innam in de Lopikse APV ('rubrica est lex'). In dit verband werd overwogen:

\footnotetext{
'Gezien deze plaats van het artikel in de APV kan de aanvraag voor de in dat artikel bedoelde vergunning naar het oordeel van de Afd. slechts worden beoordeeld aan de hand van de vraag of het belang van de veiligheid op de weg zich al dan niet tegen het verlenen van de vergunning verzet. Andere belangen, zoals die van omwonenden, alsmede de vraag of een nieuwe uitrit, gelet op de situering van reeds bestaande uitritten in de omgeving, wel als noodzakelijk moet worden beschouwd, kunnen in dit kader niet aan de orde komen. De grieven van appellant kunnen derhalve geen van alle doel treffen' (curs. R.J.N.S.).
}

Michiels stelt in zijn noot onder deze uitspraak vast dat de Afdeling in casu het specialiteitsbeginsel strikt hanteert, daar waar de 'rekkelijken' - Michiels noemt geen auteurs $^{207}$ - het tenminste toelaatbaar zouden achten dat in de sfeer van de vergunningvoorschriften zoveel mogelijk tegemoet wordt gekomen aan de niet door de wettelijke regeling behartigde belangen van derden. Voorts vraagt hij zich af, hoe het nu zit met de in artikel 3:4 Awb neergelegde plicht om alle relevante belangen af te wegen. Michiels houdt het erop dat in casu weinig ruimte was voor het bestuur; het stellen van voorschrif-

205. ABRS 30 november 1995, AB 1996, 23, m.nt. AvH (States Express Touringcars BV)

206. ABRS 1 maart 1996, AB 1996, 359, m.nt. FM (uitwegvergunning Lopik). Een ander - maar toch minder helder voorbeeld - van de toepassing van een 'precieze' interpretatie van het specialiteitsbeginsel biedt m.i. nog ABRS 5 januari 1996, AB 1996, 97, m.nt. AvH (waterwinplaats Hammerflier). In casu hield de Afdeling belangen van een appellant buiten het specifieke afwegingskader van art. 14 lid 1 van de Grondwaterwet (vergunning tot wateronttrekking) omdat deze belangen niet konden worden aangemerkt als bij het grondwaterbeheer betrokken belangen. Appellant stelde in casu overlast te ondervinden van de plaatsing van pompputten (op zijn grond) en hij vreesde waardevermindering van de betrokken landerijen.

207. Het ligt voor de hand dat Michiels met name doelt op de denkbeelden van Nicolar, Konijnenbelt, Van Male en Simon (zie de literatuurbespreking in hoofdstuk 7 van dit boek). 
ten of het aanbieden van bestuurscompensatie waren niet aan de orde, terwijl de exacte vormgeving van de uitweg niet bijster veel ter zake deed. Met andere woorden: volgens Michiels had het bestuur in casu slechts weinig mogelijkheden om aan de belangen van de buurman tegemoet te komen.

Naast deze 'precieze' uitspraken van de Afdeling staat jurisprudentie die op het eerste gezicht nogal 'rekkelijk' oogt. Ik wijs o.m. op de uitspraken van de Afdeling inzake de dam te Dirksland en de slootdemping te Landsmeer. In de casus Dirksland ${ }^{208}$ hadden dijkgraaf en heemraden van het waterschap Goeree-Overflakkee aan de gemeente Dirksland ontheffing verleend van een verbodsbepaling ingevolge het Algemeen Polderreglement ten behoeve van - kort gezegd - het verwijderen en (op een andere plaats) weer aanleggen van een dam in een watergang. Uit de stukken bleek dat het waterschapsbestuur tot verlening van de ontheffing was overgegaan omdat de waterbeheersingsbelangen zich er niet tegen verzetten en andersoortige belangen gén rol zouden mogen spelen in de besluitvorming. Een derde-belanghebbende, eigenaar van een perceel landbouwgrond waartoe de dam toegang verschafte, verzocht ingevolge artikel 22 Waterstaatswet 1900 (oud) aan gedeputeerde staten van Zuid-Holland om vernietiging van het betreffende besluit. Hij stelde in dit verband schade te ondervinden door de verplaatsing van de genoemde dam. Gedeputeerde staten, die overigens van oordeel waren dat de belangen van derden op redelijke wijze in de belangenafweging behoorden te worden betrokken, wezen het verzoek desalniettemin af omdat appellant niet alleen nadelen maar ook voordelen ondervond. Dit besluit van gedeputeerde staten stond vervolgens ter discussie bij de Afdeling bestuursrechtspraak.

Nadat de Afdeling had vastgesteld dat een ontheffing uitsluitend mocht worden geweigerd in het belang van de waterhuishouding, de kwaliteit van het water en de vaargelegenheid, spitste zij haar rechtsoverwegingen toe op de vraag of dit gegeven nu tevens met zich bracht dat de nadelige gevolgen die appellant door de ontheffing ondervond terecht buiten de besluitvorming waren gehouden. De Afdeling stelde in dit verband voorop dat uit de betreffende (doelgebonden) keurbepalingen niet kon worden afgeleid dat particuliere belangen van derden bij de besluitvorming geheel buiten beschouwing zouden kunnen worden gelaten, waarna de bekende 'Integendeel...' rechtsoverweging uit de 'Vecht'-uitspraak ${ }^{209}$ van de voormalige Afdeling rechtspraak volgde. Hierna volgden vervolgens rechtsoverwegingen, die dit algemene uitgangspunt kennelijk nader beoogden uit te werken:

\footnotetext{
'Algemeen aanvaard is ook het uitgangspunt dat een besluit geen als onaanvaardbaar aan te merken nadelige gevolgen voor een of meer belanghebbenden mag hebben. Blijkens de stukken en het verhandelde in de openbare vergadering van de Afdeling bestuursrechtspraak zijn dijkgraaf en heemraden van opvatting dat
}

208. ABRS 16 december 1994, AB 1995, 305, m.nt. AvH (Dirksland).

209. ARRS 21 augustus 1984, AB 1984, 542, m.nt. P.C.E. van Wijmen (oeverbeschoeiing Vecht). Eveneens gepubliceerd in $\mathrm{tB} / \mathrm{S}$ III, nr. 555, m.a. BdeW. Deze uitspraak is eerder in dit hoofdstuk uitvoerig besproken (zie paragraaf 8.4.4). Vgl. AGRS 28 mei 1991, AB 1991, 691, m.nt. JJIV (keurontheffing Zijpe). 
uitsluitend waterstaatkundige belangen in de afweging konden worden betrokken en dat de bezwaren van appellant, zijnde van civielrechtelijke aard, niet in acht genomen konden worden. Voorzover verweerders zich op het standpunt hebben gesteld dat zij de juistheid van deze opvatting van dijkgraaf en heemraden buiten beschouwing konden laten, hebben zij blijk gegeven van een onjuiste rechtsopvatting.(.) Van het waterschapsbestuur mag worden verwacht dat bij de besluitvorming rekening wordt gehouden met particuliere belangen van derden die rechtstreeks door een besluit zouden kunnen worden getroffen. Dijkgraaf en heemraden hadden naar het oordeel van de Afdeling bestuursrechtspraak bij het nemen van hun besluit dan ook niet kunnen volstaan met het beoordelen van de vraag of verlening van de ontheffing uit een oogpunt van waterbeheersing aanvaardbaar was, doch het college had tevens de belangen van appellant, van de gemeente en van eventuele andere derden bij zijn besluitvorming moeten betrekken. Dit betekent dat dijkgraaf en heemraden, voorafgaande aan het nemen van hun besluit, ten onrechte niet hebben onderzocht of appellant tengevolge van het verlenen van bedoelde ontheffing schade zou kunnen leiden die redelijkerwijs niet te zijnen laste behoorde te komen' (curs. R.J.N.S.).

In een overweging ten overvloede wees de Afdeling er tot slot nog op dat het feit dat aan een ontheffing de verplichting wordt verbonden om de 'redelijkerwijs mogelijke maatregelen te nemen' teneinde te voorkomen dat derden tengevolge van het gebruik van de ontheffing schade ondervinden, het verantwoordelijke bestuursorgaan niet ontslaat van de verplichting om een zelfstandig onderzoek in te stellen naar de mogelijk nadelige gevolgen van het besluit voor derden.

In het verlengde van deze uitspraak ligt de uitspraak van de Afdeling inzake de slootdemping te Landsmeer. ${ }^{210}$ In casu - ik zet de casuspositie en de procedurele voorgeschiedenis iets uitvoeriger uiteen - hadden dijkgraaf en heemraden van het waterschap De Waterlanden geweigerd om aan twee burgers ontheffing van de vigerende waterschapskeur te verlenen ten behoeve van het dempen van een tussen hun percelen gelegen sloot. Tevens had het waterschapsbestuur hen aangeschreven om een reeds geplaatste houten en metalen constructie uit de sloot te verwijderen. De reden voor de weigering en de aanschrijving was gelegen in het feit dat een derde-belanghebbendestelde door deze demping vrije doorvaart te verliezen. Bovendien stelde deze belanghebbende een inbreuk op haar eigendomsrecht én economische waardedaling van haar huis. De aanvragers van de ontheffing ${ }^{211}$ konden $z i c h$ met het voor hen negatieve besluit niet verenigen en verzochten gedeputeerde staten van Noord-Holland om vernietiging van het besluit. Het college van gedeputeerde staten, dat het besluit inderdaad vernietigde, stelde zich op het standpunt dat van een waterschap 'in het algemeen' mag worden verwacht om in de besluitvorming rekening te houden met de door de keurbepalingen beschermde belangen en met belangen van particulieren die rechtstreeks door een besluit worden getroffen. Ten aanzien van de belangen van de derde had dit volgens genoemd college de volgende implicaties. Met het gestelde vaarbelang mocht in beginsel - daar dit kennelijk

210. ABRS 6 februari 1996, AB 1996, 131, m.nt. AvH (slootdemping Landsmeer). Evenals in de casus van de dam te Dirksland betrof het een procedure ex artikel 22 Waterstaatswet 1900 (oud). In dit verband wijs ik ook nog op ABRS 11 april 1996, AB 1996, 286, m.nt. AvH (Baas Gouda BV).

211. Hun belangen betroffen i.h.b. het kunnen vergroten van hun erf, de betere bereikbaarheid van hun woning(en) en het bexindigen van een (illegale) situatie van achterstallig onderhoud. 
door de keurbepalingen werd beschermd - rekening worden gehouden. ${ }^{212} \mathrm{De}$ andere belangen waarop de derde zich beriep werden door gedeputeerde staten beschouwd als 'belangen die slechts in een meer verwijderd verband door het besluit kunnen worden geschaad'. Het waterschap behoefde daar blijkbaar géen acht op te slaan.

De zaak belandde vervolgens bij de Afdeling bestuursrechtspraak doordat de derdebelanghebbende beroep instelde. $\mathrm{Zij}$ achtte het niet begrijpelijk dat verweerders (GS) wél met de particuliere belangen van de aanvragers, maar niet met haar belangen rekening hielden. De Afdeling benaderde de problematiek van de derde-belangen in een tweetal stappen. Eerst werd de doelstelling van het betreffende bevoegdheidsstelsel in kaart gebracht. In dit verband waardeerde de Afdeling eerst - zo lijkt het - de belangen van de derde in het licht van de speciale publiekrechtelijke belangen. Zo viel in casu het belang van de derde, voorzover dit betrof een ongehinderde doorvaart, samen met de publiekrechtelijke belangen die in de betreffende keurbepalingen bescherming vonden (o.m. het algemeen vaarbelang). De Afdeling kende aan dit belang van appellante daarom in het licht van genoemde bepalingen en de taakstelling van het waterschap een betekenis toe, waarbij niet van (doorslaggevend) belang werd geacht of dit belang in casu ook nog bescherming vond in een planologische vaarbestemming of in een privaatrechtelijk (zakelijk) gebruiksrecht. Als tweede stap ging de Afdeling vervolgens na of de particuliere belangen (in casu van appellante) anderszins ten gevolge van het verlenen van de gevraagde ontheffing nadeel zouden kunnen ondervinden die redelijkerwijs niet te haren laste behoorde te komen.'

Uit de rechtsoverwegingen die volgden kan mijns inziens worden afgeleid dat de Afdeling steeds de optie van nadeelcompensatie wenst open te houden. ${ }^{213}$ De Afdeling ziet in dit verband géén noodzaak om een onderscheid te maken tussen de belangen van derden en de belangen van direct-belanghebbenden.

\subsubsection{Het Velpse Duivenhok}

Waar in de bovenstaande Afdelingsuitspraken de jurisprudentie van de voormalige rechtsprekende Afdelingen van de Raad van State duidelijk doorklinkt, daar biedt mijns inziens de uitspraak van de Afdeling inzake het Velpse duivenhok ${ }^{214}$ een voorbeeld van een nieuwe bezinning van de Afdeling op de specialiteitsproblematiek. In casu hadden burgemeester en wethouders van Rheden ten behoeve van het vergroten van een garage tot

212. In casu achtten gedeputeerde staten dit belang echter niet reeel, aangezien uit het (na de primaire besluitvorming in werking getreden plaatselijke bestemmingsplan) bleek dat slootdemping behoudens aanlegvergunning mogelijk was.

213. Dit ligt anders indien de door het betreffende besluit (onevenredig) benadeelde rechtsbelangen ingevolge een 'zuivere' nadeelcompensatieregeling gecompenseerd kunnen worden. In dit geval kan het nadeelaspect in het kader van de specifieke bevoegdheidsuitoefening buiten beschouwing blijven. Vgl. ABRS 31 juli 1996, AB 1996, 433, m.nt. AvH (peilbesiuit St. Philipsland).

214. ABRS 1 april 1996, JB 1996/155, m.nt. R.J.N.S.; ABkort 1996, 234; BR 1996/11, p. 908 e.v. m.nt. H.J. de Vries. (Velpse duivenhok). Voorzover ik kon nagaan is dit ook de eerste uitspraak van de Afdeling bestuursrechtspraak als appèlrechter over het specialiteitsbeginsel. 
een duivenhok/garage, onder gelijktijdige vrijstelling van een goothoogtevoorschrift uit de vigerende plaatselijke bouwverordening, bouwvergunning verleend. Een tweetal derdebelanghebbenden maakte bezwaar tegen deze besluiten en de zaak belandde in hoger beroep bij de Afdeling. Hier spitsten zich de rechtsvragen toe op de belangenafweging die aan het verlenen van de vrijstelling ten grondslag diende te liggen. Appellanten stelden dat zij zich niet met de (stedenbouwkundige) vrijstelling konden verenigen, omdat zij tengevolge van het houden van de duiven gezondheidsproblemen ondervonden. Voorts maakten zij bezwaar op grond van het feit dat de duiven volgens hen geluidshinder en hinder door uitwerpselen veroorzaakten. Nadat de Afdeling voorop had gesteld dat bij het verlenen van een dergelijke vrijstelling alle daarbij betrokken belangen van omwonenden in aanmerking dienen te worden genomen en dat géén belangen op voorhand buiten beschouwing mochten blijven, volgde een aantal nuancerende rechtsoverwegingen:

'Het vorenstaande neemt echter niet weg, dat het gewicht dat aan de belangen kan worden toegekend van geval tot geval kan verschillen. In dit verband komt betekenis toe aan de aard van de afwijking van de voorschriften die door de vrijstelling mogelijk wordt gemaakt en, meer in het bijzonder, aan de mate waarin de belangen van de omwonenden bij die afwijking zijn betrokken' (curs. R.J.N.S.).

Nadat de Afdeling vervolgens nauwkeurig had onderzocht welke invloed de goothoogtevrijstelling daadwerkelijk ${ }^{215}$ had op de belangen van appellanten, werd overwogen:

'Een en ander brengt met zich dat de volgens appellanten geschade belangen - van hoeveel gewicht die op zichzelf beschouwd ook mogen zijn - slechts in een verwijderd verband staan tot de in geding zijnde afwijking van de wettelijke voorschriften. Daarbij komt dat de tegen de vrijstelling ingebrachte bezwaren in overwegende mate voortvloeien uit omstandigheden die appellanten persoonlijk betreffen. Als zodanig liggen zij in een ander vlak dan de stedebouwkundige en (micro) planologische ordening - op basis van min of meer te objectiveren maatstaven - welke wordt beoogd met de voorschriften van de Bouwverordening op grond waarvan de vrijstelling is verleend. De toepassing van de Bouwverordening is dan ook niet bij uitstek het kader waarin de specifieke gezondheidsbelangen van appellanten tegenover de belangen van Meuwissen tot gelding dienen te worden gebracht' (curs. R.J.N.S.).

Ook vestigde de Afdeling er de aandacht op dat burgemeester en wethouders in geval van concrete hinder ingevolge de bepalingen van de Algemene Plaatselijke Verordening (APV) konden optreden.

De relevante rechtsoverwegingen in de 'duivenhok'-uitspraak lijken geïnspireerd door verschillende visies in de literatuur. ${ }^{216} \mathrm{De}$ hoofdregel, bekend uit eerdere uitspraken, die de Afdeling hanteert is de volgende: in het kader van een discretionaire bevoegdheidsuitoefening dienen in beginsel alle daarbij betrokken belangen van belanghebbenden in

215. Van belang was in casu dat de bezwaren van appellanten in essentie gerelateerd waren aan de gebruiksfunctie van het duivenhok. Op deze gebruiksfunctie sec had de goothoogtevrijstelling echter géen (bepalende) invloed. De Afdeling constateerde terecht dat het in casu ook zonder deze vrijstelling mogelijk was om het duivenhok op de betreffende plaats op te richten, zij het met een geringere hoogte.

216. De hierna volgende bespreking van de uitspraak komt goeddeels overeen met een gedeelte uit mijn annotatie onder de betreffende Afdelingsuitspraak in Jurisprudentie Bestuursrecht (JB 1996/155). 
aanmerking te worden genomen. Hierbij mogen bepaalde belangen niet op voorhand buiten beschouwing blijven. Deze hoofdregel lijkt bij eerste beschouwing blijk te geven van een nogal 'rekkelijke' visie inzake het belangenafwegingsproces. Maar deze conclusie mag niet te snel worden getrokken. Uit de hoofdregel vloeit nl. enkel voort dat met alle betrokken particuliere belangen waar mogelijk rekening dient te worden gehouden. Hiermee is mijns inziens nog niet gezegd dat ter bescherming van deze belangen bijv. ook zonder meer voorschriften mogen worden gesteld of dat particuliere belangen een weigering om de bevoegdheid uit te oefenen kunnen rechtvaardigen (het 'rechtsvormingsaspect'). Dát particuliere belangen niet 'op voorhand' door het bestuur mogen worden uitgesloten ('geellimineerd') vloeit voort uit het feit dat eerst tijdens het bestuurlijke besluitvormingsproces kan worden vastgesteld of bepaalde belangen voldoende bij een besluit 'betrokken' zijn. Indien een bestuursorgaan 'op voorhand' bepaalde belangen buiten beschouwing laat, zou dit immers in strijd zijn met het bepaalde in artikel 3:2 Awb. Juist om een zorgvuldig besluitvormingsproces te kunnen voltooien, zal eerst 'de nodige kennis omtrent de relevante feiten en de af te wegen belangen' dienen te worden vergaard.

$\mathrm{Na}$ deze formele inventarisatiefase, volgt pas de belangenselectie- en waarderingsfase. In deze fase dient, gelet op het specialiteitsbeginsel, te worden vastgesteld welke particuliere belangen gewicht in de schaal van het publieke (gerichte) rechtsvormingsproces mogen leggen, en met welke belangen anderszins in de besluitvorming rekening behoort te worden gehouden. Met het oog op deze belangenselectie wordt de 'hoofdregel' door de Afdeling trapsgewijs verfijnd, waarbij kennelijk een 'graduele' (meer pragmatische) visie het uitgangspunt vormt. Het 'gewicht' dat aan de onderscheiden particuliere belangen in het licht van de toepasselijke administratiefrechtelijke voorschriften moet worden toegekend kan immers volgens de Afdeling van geval tot geval verschillen. Door de Afdeling wordt in dit verband zowel aan de aard van de betrokken particuliere belangen betekenis toegekend (is het een zuiver persoonlijk belang dat specifiek deze appellant betreft?), als aan de mate waarin de bevoegdheidsuitoefening - in het licht van de onderliggende publiekrechtelijke regelingen - de betrokken belangposities daadwerkelijk beïnvloedt (het 'causaliteitsaspect').

Allereerst is vereist dat de belangen waarmee rekening wordt gehouden in een voldoende verband staan tot het betreffende wettelijke bevoegdheidsstelsel en de daarop gebaseerde bevoegdheidsuitoefening. In casu is dat volgens de Afdeling kennelijk niet het geval. Het al dan niet verlenen van de omstreden goothoogtevrijstelling is blijkbaar niet van bepalende invloed op het ondervonden nadeel door omwonenden (nl. het gezondheidsen overlastaspect). In de terminologie van artikel 3:4 lid 1 Awb zijn de betreffende belangen derhalve niet 'rechtstreeks' bij het besluit betrokken. ${ }^{217}$

Een volgende verfijning (mijns inziens cumulatief) vloeit voort uit het feit dat de Afdeling in essentie erkent dat een publiekrechtelijk bevoegdheidsstelsel niet alle rechtstreeks betrokken particuliere belangen kán beschermen. Een doelgebonden publiekrechtelijk bevoegdheidsstelsel 'beschermt' burgers slechts relatief, en biedt geen willekeurig aankno-

217. Art. 3:4 lid 1 Awb is in hoofdstuk 6 besproken (paragraaf 6.5.2). 
pingspunt om allerlei belangenconflicten tussen private rechtssubjecten onderling te 'reguleren'. Als verfijning geldt hier een soort 'relativiteits- of Schutznormleer', welke leer naar mijn oordeel verband houdt met de in artikel 3:4 lid 1 Awb neergelegde eis dat de belangenafwegingsplicht slechts geldt 'voor zover niet uit een wettelijk voorschrift of uit de aard van de uit te oefenen bevoegdheid een beperking voortvloeit'. De Afdeling overweegt in dit verband terecht dat de bouwverordening niet bij uitstek het kader is waarin de specifieke gezondheidsbelangen van appellanten tegenover de belangen van de aanvrager tot gelding dienen te worden gebracht. Let wel, deze verfijning is mijns inziens slechts relevant voorzover het rechtsvormingsaspect (nl. het stellen van voorschriften of een weigering) in het geding is. ${ }^{218}$ Indien bepaalde betrokken particuliere belangen niet 'samenvallen' met de speciale publiekrechtelijke belangen die aan het bevoegdheidsstelsel ten grondslag liggen, blijft onverkort de plicht voor het bestuur gelden om het evenredigheids- en égalité-beginsel te respecteren. Als derhalve vaststaat dat bepaalde particuliere belangen onevenredig worden getroffen door de bevoegdheidsuitoefening als rechtsfeit dan kan nadeelcompensatie door het bestuur alsnog geïndiceerd zijn. ${ }^{219}$ Dit blijkt mijns inziens ó́k uit de hiervoor besproken uitspraken van de Afdeling inzake de dam te Dirksland en de slootdemping te Landsmeer.

Tot slot geldt steeds als negatieve voorwaarde dat de betrokken derde-belangen niet in het kader van een andere publiekrechtelijke regeling worden beschermd. Zo werd het overlastaspect (het vlieggeluid en de uitwerpselen van de duiven) in casu mede binnen de normatieve kaders van de APV gereguleerd. Dit is wellicht een meer geêigend besluitvormingskader om de gelaedeerde belangen - althans vanuit publiekrechtelijk oogpunt tot gelding te brengen. Concluderend kan worden gesteld dat de Afdeling in de 'duivenhok'-uitspraak een genuanceerd-rechtspolitieke interpretatie van het specialiteitsbeginsel beproefde. ${ }^{220}$ Hierbij kan men zich niet aan de indruk onttrekken dat de Afdeling blijkbaar een brug wilde bouwen tussen de 'precieze' en 'rekkelijke' visies in de literatuur. ${ }^{221}$

218. Vgl. ABRS 28 april 1997, AB 1997, 262, m.nt. A.vH. (dam Schouwsloot).

219. Ik kom hier in het afsluitende hoofdstuk 9 op terug, waarbij ik de bestuurlijke bevoegdheidsuitoefening als doelgebonden 'rechtshandeling', maar ook - in ruimere zin - als 'rechtsfeit' beschouw.

220. Ik wijs erop dat deze uitspraak direct in de rechtbankjurisprudentie werd 'opgepikt'. Vgl. Rb. Roermond 27 september 1996, JB 1996/225, m.nt. R.J.N.S. en in mindere mate ook Rb. Maastricht 14 augustus 1996, JB 1996/196, m.nt. R.J.N.S. Vgl. echter ook de 'precieze' benadering in Rb. Almelo 1 oktober 1996, AB 1997, 69, m.nt. AvH. (houtwal Lonneker) In casu overwoog de Almelose rechtbank, naar aanleiding van een grief van een derde inzake een keurontheffing o.m. dat 'T.a.v. de grief betreffende de schaduwwerking valt op te merken dat het verbod op het hebben van beplanting in het leven is geroepen om te verzekeren dat er langs watergangen steeds ruimte blijft die verweerder nodig heeft voor het mechanisch onderhoud. Wanneer dat belang in het gedrang zou komen is dat een reden de gevraagde ontheffing te weigeren; andere belangen zoals eventuele groeischade ten gevolge van schaduw kunnen geen grond opleveren voor het weigeren van een ontheffing.' In gelijke zin ABRS 10 september 1997, AB 1997, 409, m.nt. AvH (houtwal Weerselo). Vgl. tot slot voor een meer precieze 'Schutznormbenadering' Pres. Rb. 's-Hertogenbosch 5 december 1996, Awb-katern 1997, 64. 


\subsubsection{De Buttervliet-uitspraak: een anomalie?}

Haaks op de genuanceerde rechtsoverwegingen in de 'Velpse'-uitspraak lijken (in ieder geval wat betreft derde-belangen) de overwegingen in de uitspraak van de Afdeling inzake de telefooncel op de verzorgingsplaats Buttervliet te staan. ${ }^{22}$ Deze uitspraak werd een klein jaar vóór de 'duivenhok'-uitspraak gedaan. Ofschoon men zich kan afvragen of hier sprake is van een anomalie in het algemene jurisprudentiebeeld ${ }^{223}$, verdient de uitspraak op deze plaats, gelet op de nogal vérstrekkende implicaties die de centrale rechtsoverwegingen met zich brengen, afzonderlijk aandacht.

In casu had de hoofdingenieur-directeur van de Rijkswaterstaat in de directie ZuidHolland aan PTT Telecom een vergunning ingevolge het Rijkswegenreglement verleend ten behoeve van de plaatsing van een telefooncel op de verzorgingsplaats Buttervliet langs de A29. Aan de vergunning was een compensatievoorschrift verbonden dat er in het bijzonder toe strekte om te voorkomen dat een exploitant van een nabij de verzorgingsplaats gelegen benzinestation schade zou ondervinden doordat zijn inkomsten - die hij ontving uit het gebruik van een door hem (verplicht) geplaatste telefoon - zouden verminderen tengevolge van de plaatsing van de nieuwe PTT-telefooncel. Dit compensatievoorschrift vormde de inzet van de beroepszaak. Volgens PTT telecom mocht een dergelijk voorschrift niet aan de vergunning worden verbonden (er werd o.m. een beroep gedaan op het verbod van détournement de pouvoir). De Afdeling deelde deze opvatting echter niet. $\mathrm{Na}$ te hebben vastgesteld dat het vergunningvereiste weliswaar was gesteld in het waterstaatkundige belang, en de daaraan verwante openbare belangen van o.m. natuur, landschap en milieu, overwoog de Afdeling in algemene, niet nader genuanceerde, bewoordingen dat dit 'uiteraard' niet afdoet:

‘...aan het uitgangspunt dat - behoudens in gevallen waarin de bevoegdheid tot vergunningverlening exclusief is gebonden aan bepaalde specifieke belangen - het vergunningverlenend orgaan alle bij de beslissing betrokken belangen van derden dient te betrekken in zijn afweging. Belangen van derden kunnen ook aan vergunningverlening in de weg staan, dan wel aanleiding zijn tot het aan de vergunning verbinden van voorwaarden. (..) Een redelijke afweging van de belangen van derden staat er naar het oordeel van de Afdeling voorts niet aan in de weg dat aan een vergunning voor het plaatsen van een telefooncel de voorwaarde wordt verbonden dat de nadelen die derden daarvan kunnen ondervinden door de vergunninghouder dienen te worden gecompenseerd' (curs. R.J.N.S.).

221. De Vries, die de 'duivenhok'-uitspraak in Bouwrecht heeft besproken, vroeg zich terecht af, of de Afdeling eigenlijk niet een beetje op twee gedachten hinkt, nl. enerzijds de 'precieze' en anderzijds de 'rekkelijke'. H.J. de Vries, BR 1996/11, p. 912.

222. ABRS 10 mei 1995, RAwb 1995, nr. 72, m.a. BdW (telefooncel Buttervliet). Ik besprak deze uitspraak reeds eerder in. Zie: R.J.N. Schlossels, Het specialiteitsbeginsel en derde-belangen: een frisse benadering of rechtsstatelijk drijfzand?, NTB 1996/3, p. 93-94 en R.J.N. Schlossels, Een dakkapel te Edam: de wens van eenheid van recht?, in: Rechtspraak bestuursrecht 1995-1996. De annotaties, 's-Gravenhage 1997, p. 75-76.

223. Volgens De Vries past de uitspraak in ieder geval wel in de jurisprudentielijn van de Afdeling. H.J. de Vries, BR 1996/11, p. 912 (noot onder ABRS 1 april 1996). 
Deze pragmatische rechtsoverwegingen stralen - ik kan er niets anders in lezen - een sfeer uit van een volledig open belangenharmonisatie in het publiekrecht op basis van een vage redelijkheidsnotie. Deze redelijkheidsnotie legitimeert volgens de Afdeling blijkbaar het stellen van voorschriften in het belang van derden, ook al houden deze voorschriften geen enkel verband met het doel van de bevoegdheid. De Afdeling heeft er ogenschijnlijk geen probleem mee dat het bestuur zich loszingt van zijn specifieke bestuursbevoegdheid. De geconditioneerde tussenvoeging in de bovenstaande rechtsoverwegingen ("behoudens in de gevallen waarin...') doet daarom nogal geforceerd aan, vooral indien men in aanmerking neemt dat in casu juist sprake was van een bestuursbevoegdheid die aan duidelijk omlijnde publiekrechtelijke belangen was gebonden. Het betrof hier, zoals de Afdeling n.b. zélf vaststelde, belangen van waterstaatkundige aard, alsmede belangen van natuur, landschap en milieu. Annotator De Waard, bij wie de geciteerde rechtsoverwegingen blijkbaar ook bedenkingen opriepen, vraagt zich in zijn naschrift in het bijzonder af wanneer er dan sprake is van een 'exclusieve binding' als zelfs een expliciet aangegeven kader voor belangenafweging, waarvan in de onderhavige wetgeving toch sprake is, dergelijke binding volgens de Afdeling blijkbaar niet bewerkstelligt.

Het, vanuit rechtsstatelijk oogpunt kwestieuze, verschijnsel van 'burgercompensatie' en de 'afwentelingsvoorschriften' lijken met de bovenstaande uitspraak door de Afdeling bestuursrechtspraak ten principale, zonder een adequate theoretische onderbouwing, te zijn aanvaard. ${ }^{224}$ De Afdeling gaat er immers in essentie vanuit dat een bestuursorgaan ook compensatieplichten kan vaststellen tussen burgers onderling in situaties waarin het nadeel geenszins het gevolg is van de (gerichte) behartiging van speciale publieke belangen door de overheid. Over de implicaties van een en ander lijkt de Afdeling zich, ondanks kritische geluiden in de literatuur, nauwelijks te bekommeren. ${ }^{225}$ In feite is de Afdeling met deze uitspraak mijns inziens niet ver verwijderd van een situatie waarin simpelweg wordt aanvaard dat het bestuur goeddeels naar eigen inzicht, op basis van zijn discretionaire bestuursbevoegdheden, in de vorm van vergunningvoorschriften rechtsverhoudingen tussen burgers onderling kan vaststellen. Een dergelijke ('wederkerige') ontwikkeling, die wellicht erg 'handig' is voor het bestuur, roept vanuit democratisch-rechtsstatelijk oogpunt toch serieuze bedenkingen op. Ik kom hier in hoofdstuk 9 op terug.

224. Het begrip 'burgercompensatie' wordt ontleend aan Damen. Zie zijn interventie bij het VAR-preadvies van De Planque (VAR-reeks 103). Damen onderscheidt hier de 'burgercompensatie' uitdrukkelijk van de 'bestuurscompensatie' (compensatiestroom burger-bestuurde) en de 'bestuurdencompensatie (compensatiestroom burger-bestuur). Aanzetten voor de constructie van 'burgercompensatie' treft men reeds aan in de jurisprudentie van de voormalige Afdeling rechtspraak. Ik wijs bijv. op: VzARRS 29 oktober 1992, AB 1993, 183, m.nt. RMvM (NS/GS Friesland). Uiteindelijk voert de 'burgercompensatie' terug op de Paul Krugerbrug-jurisprudentie. Zie: ARRS 12 januari 1982, AB 1982, 299, m.nt. P.C.E. van Wijmen (Paul Krugerbrug I).

225. Ik wijs op: R.M. van Male, Marionette. Over het afwentelen van nadeelcompensatie bij beschikkingsvoorschrif, in: In de sfeer van administratief recht, Utrecht 1994, i.h.b. p. 301-303 en 313. Zie verder, i.h.b. wat betreft kritiek op de Buttervliet-uitspraak: G.A. van der Veen, Openbare zaken. Betekenis van het aloude publiek domein na vestiging van het primaat van het publiekrecht, diss. UU, Utrecht 1997 , p. $459-460$. 


\subsubsection{Toelaatbaarheid van voorschriften}

Wat betreft de toelaatbaarheid van het verbinden van voorschriften aan vergunningen en ontheffingen heeft de jurisprudentie van de Afdeling bestuursrechtspraak - behoudens de uitzonderlijke Buttervliet-uitspraak - weinig nieuws gebracht ten opzichte van de voormalige Arob- en TwK-jurisprudentie. Voorschriften dienen hun grondslag tenminste mede in de speciale publiekrechtelijke belangen te vinden die aan een bevoegdheidsstelsel ten grondslag liggen. ${ }^{226}$ Een strikte binding aan het specifieke doel van een bevoegdheidsstelsel eist de Afdeling in het bijzonder wat betreft financiele voorwaarden (betalingsverplichtingen). ${ }^{227}$ Voorschriften en voorwaarden van privaatrechtelijke aard mogen in beginsel niet aan een publiekrechtelijke vergunning of ontheffing worden verbon$\operatorname{den}^{228}$

Een fraai - en precies - voorbeeld biedt in dit kader de Afdelingsuitspraak inzake de Marktverordening van de gemeente Moergestel. ${ }^{229}$ In casu had het college van Moergestel ontheffing verleend van de ingevolge de plaatselijke Marktverordening geldende verplichting voor marktlieden om gebruik te maken van marktkramen die werden verhuurd door een vanwege het college aangewezen exploitant. Aan de betreffende ontheffing was de voorwaarde verbonden om aan de bedoelde exploitant een vergoeding te betalen. Deze verplichting hield verband met de contractuele afspraken die de gemeente met deze marktkramenexploitant had gemaakt. De vraag was nu of de betreffende voorwaarde toelaatbaar was. De Afdeling was van oordeel dat dit niet het geval was. Zij stelde voorop dat aan een ontheffing - als bedoeld - geén voorwaarden mochten worden verbonden welke dienen 'ter bescherming van andere belangen dan waarvoor het vereiste van de ontheffing is gesteld'. In casu lag volgens de Afdeling aan het ontheffingsstelsel het belang van een ordelijk verloop van de markt ten grondslag. De omstreden voorwaarde was kennelijk niet herleidbaar tot dit publiekrechtelijke belang: ${ }^{230}$

'Met het garanderen van een aantrekkelijke exploitatie van de marktkramen worden echter in het bijzonder de belangen van de marktkooplieden gediend. Hun belangen zijn echter geenszins als openbare belangen te

226. Vgl. bijv. ABRS 18 april 1995, ABkort 1995, 343; ABRS 29 februari 1996, Gst. 7041, p. 571 e.v., m.nt. C.P.J. Goorden (dwangsom Callantsoog) en ABRS 30 oktober 1996, Gst. 7056, p. 383 e.v. (voorwaarde tropisch hardhout). Wat betreft deze laatste uitspraak dient ter vergelijking ook nog te worden gewezen op: ABRS 4 juli 1994, Gst. 6997, p. 543 e.v. (voorwaarde financielle compensatie) en VzABRS 3 maart 1994 , Gst. 6988, p. 282 e.v. (sloopvergunning Mariaschool).

227. ABRS 1 februari 1995, Gst. 7013, p. 393 e.v., m.nt. C.P.J. Goorden (kapvergunning Bussum). Vgl. echter ook: ABRS 31 juli 1996, AB 1996, 480, m.nt. AvH (brug Oegstgeesterkanaal). De Afdeling 'leest' in deze uitspraak een financieel belang voor een hoogheemraadschap in het algemene waterstaatkundige 'keurbelang' in. Dit alles doet nogal 'rekkelijk' aan.

228. ABRS 11 januari 1996, ABkort 1996, 94.

229. ABRS 16 juni 1995, Gst. 7035, p. 361 e.v., m.n. B. (Moergestel).

230. Annotator Brederveld vraagt zich af, of de Afdeling hier niet wat te kort door de bocht gaat, daar ook het (huishoudelijk) belang van de gemeente bij het instandhouden van de markt verweven is met de belangen van de kramenexploitant en de belangen van andere kooplieden. 
beschouwen, ter bescherming waarvan voorwaarden, als waarvan te dezen sprake is, kunnen worden gesteld.'

\subsubsection{Tussenconclusie}

De jurisprudentie van de Afdeling bestuursrechtspraak bouwt voort op de jurisprudentie van de voormalige rechtsprekende Afdelingen van de Raad van State. De jurisprudentie van zowel de Afdeling rechtspraak (het open houden van de nadeelcompensatie-optie) als de jurisprudentie van de Afdeling geschillen van bestuur (een meer precieze benadering) zijn van invloed op de jurisprudentie van de Afdeling bestuursrechtspraak. Dit levert een wisselvallig jurisprudentiebeeld op. Als Awb-appèlrechter lijkt de Afdeling, zo blijkt mijns inziens uit de uitspraak over het Velpse Duivenhok, een genuanceerde rechtspolitieke benadering van het specialiteitsbeginsel voor te staan. Een 'graduele' aanpak van de problematiek, waarbij wordt nagegaan of bepaalde belangen wel in een afdoende verband staan tot de bevoegdheidsuitoefening, vormt de rode draad. Al met al levert dit een jurisprudentiebeeld op dat zich in een meer 'rekkelijke' richting begeeft. ${ }^{231}$ Opmerkelijk is in dit verband overigens dat de sectoren bestuursrecht soms juist neigen naar een meer 'precieze' benadering van het specialiteitsbeginsel.

\subsection{Het College van beroep voor het bedrijfsleven ( $\mathrm{CBb}$ )}

In de inleiding van dit hoofdstuk is reeds aangegeven dat de inventarisatie van de uitspraken van het College van Beroep voor het bedrijfsleven $(\mathrm{CBb})$ - wat betreft het onderwerp van dit boek - géén grote hoeveelheid relevante jurisprudentie heeft opgeleverd. Gedeeltelijk hangt dit mijns inziens, evenals bij de jurisprudentie van de Centrale Raad van Beroep, samen met het feit dat de 'derde-belanghebbende' op het werkgebied van het College niet zo'n prominente plaats inneemt. In het economische bestuursrecht staat $\mathrm{nl}$. vaak de rechtsrelatie tussen bestuursorgaan en direct-belanghebbende (de aanvrager) centraal. Bovendien zijn de bestuursbevoegdheden in de economische ordeningswetgeving vaak in detail genormeerd en komen discretionaire belangenafwegingsprocessen - waarbij er sprake is van 'echte' beleidsvrijheid (dus géén beoordelingsvrijheid) en complexe belangenafwegingen - minder vaak voor.

\subsubsection{Doelbinding bestuursbevoegdheid}

Dat het College van Beroep voor het bedrijfsleven toeziet op een doelconforme uitoefening van bestuursbevoegdheden blijkt duidelijk uit een uitspraak van 13 april $1988 .{ }^{232}$ In casu had de directeur van Staatsbosbeheer te Utrecht aan appellante geweigerd toestemming te verlenen om een gerooid bosareaal op elders gesitueerde grond te herplanten. Deze wei-

231. Vgl. de mening van H.J. de Vries onder ABRS 1 april 1996, BR 1996/11, p. 912 . In stelliger bewoordingen H.J. Simon: 'Uit de rechtspraak kan geen andere conclusie worden getrokken dan dat naar 'huidige rechtsopvatting' een uitermate 'rekkelijke' visie heerst. H.J. Simon, Handboek bestuurs(proces)recht, 'sGravenhage 1997, p. 140. 
gering hield verband met het feit dat de directeur (verweerder) van oordeel was dat de voorgestelde herplantlocatie een bijzondere natuurwetenschappelijke waarde had. Verweerder was voorts van oordeel dat de Boswet (mede) tot doel had om houtopstanden vanuit een oogpunt van natuurbehoud te bewaren. Het College deelde deze opvatting niet, en concludeerde dat er sprake was van détournement de pouvoir:

\begin{abstract}
'De Boswet heeft ten doel de instandhouding van bosareaal in kwantitatieve en kwalitatieve zin, zie MvA II, p. 5. Voorop staat daarbij dat geen bos verloren gaat. Het belang van het behoud van bos op een bepaalde plaats kan, voorzover instrumenten daartoe reiken, gehandhaafd worden met in de Boswet neergelegde bevoegdheden, zoals een kapverbod of het weigeren om toestemming te verlenen tot vervulling van de herplantplicht op andere, kwalitatief niet gelijkwaardige, grond. Met het bestreden besluit heeft verweerder evenwel beoogd aantasting van belangrijke naturwetenschappelijke waarden van een gebied, waarop de Boswet als zodanig niet van toepassing is, te voorkomen, terwijl de belangen die de Boswet beoogt te dienen, met name de instandhouding van een bosareaal, bij het verlenen van de gevraagde toestemming niet in het gedrang komen.'
\end{abstract}

Doelgebondenheid van bestuursbevoegdheden sluit een belangenafweging 'in concreto' geenszins uit. Het College ziet er consequent op toe dat alle (rechtstreeks) betrokken belangen van (direct-)belangenhebbenden, waaronder ók bedrijfseconomische belangen, daadwerkelijk in de afweging worden betrokken. ${ }^{233}$ In dit kader wordt niet uitgesloten dat bijv. een te behartigen milieubelang in concreto - gelet op de omstandigheden van het geval - moet wijken voor economische belangen van ondernemers. ${ }^{234}$

\title{
8.7.2 Het meewegen van 'privaatrechtelijke' belangen
}

Uit de Voorzittersuitspraak inzake de aanbesteding van groepsvervoer aan Javo BV door burgemeester en wethouders van Smallingerland ingevolge de Wet Autovervoer personen, blijkt dat geschilpunten van typisch 'privaatrechtelijke' aard volgens het College niet ter beoordeling staan van de administratieve rechter. ${ }^{235}$ In casu had de gemeente, alvorens

232. CBb 13 april 1988, AB 1988, 311 (herplantplicht Baarle-Nassau). Een duidelijke toetsing aan het doel van een wettelijke regeling biedt voorts: CBb 23 mei 1995, AB 1995, 403, m.nt. JHvdV(stichting Bevordering Werkgelegenheid Roermond). Tot slot wijs ik op CBb 14 juli 1993, AB 1994, 245 (NV SEP). Volgens Van den Berk, die deze uitspraak bespreekt in haar studiepocket 'bestuursschaderecht', zou hieruit blijken dat het College 'expliciet aandacht schenkt aan de problemen rondom het specialiteitsbeginsel'. (zie: J.A.M. van den Berk, Bestuursschaderecht, Deventer 1997, p. 98). Zelf acht ik deze uitspraak overigens minder helder. In het verlengde van het toezien op een doelconforme uitoefening van bevoegdheden ligt de controle op détournement de procedure en op de verhouding tussen de verschillende administratieve regelingen. Zie bijv. over de verhouding Bestrijdingsmiddelenwetwet bodembescherming: CBb 28 februari 1992, AB 1992, 343, m.nt. RMvM. Het spreekt in dit kader voor zich dat een belangenafweging zich binnen het wettelijke kader dient te begeven. Vgl. CBb 25 juni 1997, AB 1997, 406 m.nt. JHvdV.

233. Vgl. bijv. CBb 19 januari 1994, AB 1995, 281 (Gammaster BV).

234. Zie: VzCBb 29 januari 1990, AB 1990, 359 (toelating bestrijdingsmiddelen met mecoprop). Vgl. echter CBb 5 december 1994, AB 1995, 169, m.nt. JHvdV (herplantplicht 'Kloostermolen'). In casu kende het College een zwaar gewicht toe aan de in de Boswet beschermde belangen.

235. VzCBb 30 november 1987, AB 1989, 187, m.nt. H.J. Simon (Javo BV). 
tot vergunningverlening ingevolge de genoemde wet over te gaan, een overeenkomst over het te verzorgen groepsvervoer gesloten met het bedrijf dat óók de vergunning zou krijgen. Een concurrent maakte tegen deze handelwijze bezwaar en vroeg om een voorlopige voorziening. Hoewel de Voorzitter het verband tussen de overeenkomst en de vergunningverlening erkende bracht dit naar zijn oordeel echter niet met zich dat

'...een beoordeling van de rechtmatigheid van die (burgerrechtelijke) overeenkomst en van hetgeen in de precontractuele fase tussen pp. is geschied aan de orde kan komen bij de toetsing van de bestreden beschikking door de administratieve rechter'.

Annotator Simon, die in zijn noot onder deze uitspraak ingaat op het specialiteitsbeginsel, stelt vast dat de Voorzitter het privaatrechtelijke aspect hier wat te resoluut buiten beschouwing laat. Het specialiteitsbeginsel verzet zich er volgens hem nl. niet tegen dat in het kader van de belangenafweging ók civielrechtelijke belangen en aspecten een rol kunnen spelen. ${ }^{236}$ In casu speelde dit temeer, daar de gemeente zelf bij de overeenkomst was betrokken, zodat men alert diende te zijn op détournement de pouvoir. Deze opvatting van Simon kan worden gedeeld, daar hij in zijn noot tevens benadrukt dat 'elke afweging zal moeten voldoen aan de randvoorwaarde dat daarmee geen afbreuk wordt gedaan aan het algemeen vervoerbelang (het doel van de regeling)'. Met andere woorden: het speciale publiekrechtelijke belang moet worden behartigd, maar met andere belangen mag (en moet) rekening worden gehouden.

\subsubsection{Belangen van derden}

Hoe het College aankijkt tegen de positie van (vreemde) belangen van derden in het belangenafwegingsproces, is niet met zekerheid vast te stellen. De jurisprudentie biedt mijns inziens slechts weinig aanknopingspunten. Uit een uitspraak van 30 september $1992^{237}$ blijkt allereerst dat het feit dat bepaalde particuliere belangen niet bij de bestuurlijke besluitvorming mogen worden meegewogen, nog geenszins met zich brengt dat aan de betreffende belanghebbende geen beroepsrecht toekomt. Het College verwerpt derhalve, in de lijn van de eerder besproken Afdelingsjurisprudentie, de 'Schutznorm'-leer in het kader van de ontvankelijkheidstoets. In de betreffende uitspraak stelde een belanghebbende beroep in tegen een ontheffing ingevolge de Winkelsluitingswet ten behoeve van de exploitatie van een avondwinkel. Interessant is dat deze belanghebbende, als bewoner van een woonruimte boven de betreffende winkel, in het bijzonder bezwaar maakte tegen de ontheffing omdat hij meende aanzienlijke geluidhinder te zullen ondervinden. De exploitant van de avondwinkel voerde in beroep een verweer inhoudende dat de belangen waarin belanghebbende stelde te zijn getroffen géén belangen waren die bij de besluitvorming ingevolge de Winkelsluitingswet waren betrokken. Het College plaatste dit verweer, zoals gesteld, in de ontvankelijkheidscontext en overwoog dat noch in

236. Zie uitvoerig over Simons interpretatie van het specialiteitsbeginsel hoofdstuk 7 (paragraaf 7.2.6).

237. CBb 30 september 1992, AB 1992, 638, m.nt. JHvdV (avondwinkel Abo Seada). 
de bewoordingen van artikel 12 lid 1 Winkelsluitingswet (in casu het beroepsrecht verlenende artikel R.J.N.S.) noch in de geschiedenis omtrent zijn totstandkoming steun valt te vinden 'voor de opvatting dat deze bepaling slechts beroep openstelt voor degenen die zijn getroffen in de belangen die de wet primair beoogt te dienen of te beschermen en die in het bijzonder betrokken moeten worden in de besluitvorming betreffende de in deze bepaling onderscheiden appellabele besluiten.' Het College kwam vervolgens helaas niet meer toe aan de beantwoording van de vraag of de belangen van de appellant een rol mochten spelen in de materielle bestuurlijke besluitvorming. Uit de geciteerde rechtsoverweging kan mijns inziens wél worden afgeleid dat het College de vraag of bepaalde belangen - naar hun aard - 'in het bijzonder' betrokken moeten worden bij de besluitvorming kennelijk een relevante rechtsvraag acht.

Een aanwijzing - maar zeker niet meer - dat de betrokken belangen verband moeten houden met het speciale publiekrechtelijke belang dat een wettelijke regeling beoogt te dienen, kan naar mijn oordeel worden gelezen in een uitspraak over het vervoer van gegranuleerde hoogovenslakken. ${ }^{238}$ In casu maakte een tweetal - onafhankelijke - schippers bezwaar tegen een vergunning ingevolge de (voormalige) Wet Goederenvervoer Binnenscheepvaart (WGB) welke door de Commissie Vervoersvergunningen aan een derde was verleend ten behoeve van ongeregeld vervoer buiten de schippersbeurs om. Volgens appellanten had de vergunningverlenende instantie zich gebaseerd op economische motieven aan de zijde van de verlader die niets hadden uit te staan met de doelmatigheid van de vervoervoorziening en de hoofddoelstelling van de WGB, t.w. het bereiken en bevorderen van gezonde verhoudingen binnen de vervoerstak. Het College deelde deze opvatting echter niet, en overwoog:

\footnotetext{
'Niet kan worden geoordeeld dat aan economische belangen aan de zijde van de verlader geen gewicht mag worden toegekend bij de afweging van de bij de onderhavige vergunningverlening betrokken belangen. Integendeel, ingevolge het bepaalde bij art. 1 lid 1 onder $\mathrm{j}$ WGB, is onder het te dezen bepalende algemeen vervoersbelang, onder meer te begrijpen een evenwichtige behartiging der onderscheidene bij het vervoer van goederen betrokken belangen. Tot de af te wegen belangen zijn derhalve mede te rekenen de belangen van de verlader' (curs. R.J.N.S.).
}

Overigens bestaat de indruk dat het College 'specialiteitsproblemen' soms omzeilt door belanghebbenden die '(norm)vreemde' belangen in de besluitvormingsprocedure willen inbrengen, waar mogelijk niet aan te merken als 'rechtstreeks belanghebbend' (resulterend in een niet-ontvankelijk verklaring). In dit kader kan de aandacht worden gevestigd op een uitspraak van 23 januari 1996, welke betrekking had op een beroep tegen de goedkeuring van dienstregelingen van busvervoer. ${ }^{239}$ In casu had appellant bezwaar tegen de goedkeu-

238. CBb 23 februari 1994, AB 1994, 340, m.nt. JHvdV (cementfabriek Rozenburg BV).

239. CBb 23 januari 1996, AB 1996, 182, m.nt. JHvdV; ABkort 1996, 101; JB 1996/75 (goedkeuringsbesluiten dienstregeling). Ik wijs in dit verband - ter vergelijking - ook nog op CBb 31 juli 1996, ABkort, 675. Indien een appellant eenmaal als 'belanghebbende' kan worden aangemerkt, kent het College blijkbaar niet meer zoveel betekenis toe aan de vraag of bepaalde particuliere belangen wel door een administratieve regeling worden beschermd. Vgl. CBb 7 juli 1993, UCB 1993, 51 (speelautomatenhallen Rotterdam). 
ring op grond van het feit dat hij - extra - overlast in de vorm van geluid, trilling en stank meende te (gaan) ondervinden. Het College verklaarde hem echter niet-ontvankelijk, daar niet was gesteld dat de overlast door de dienstregelingen in doorslaggevende mate was toegenomen. Deze benadering doet denken aan de benadering die de Afdeling bestuursrechtspraak volgde in de eerder besproken uitspraak over het Velpse Duivenhok, zij het dat de Afdeling de omwonenden in casu wél aanmerkte als belanghebbende, maar in het kader van de materiële besluitvorming hun belangen 'op afstand' hield.

\subsection{De burgerlijke rechter}

Aan het slot van dit hoofdstuk zal enige aandacht worden besteed aan de jurisprudentie van de burgerlijke rechter. ${ }^{240}$ Zoals in de inleiding van dit hoofdstuk werd vermeld toetste de burgerlijke rechter, zeker sedert de komst van de voormalige Wet Arob, slechts zelden de uitoefening van (discretionaire) beschikkingsbevoegdheden. ${ }^{241}$ Uit enkele arresten van de Hoge Raad kan desalniettemin worden afgeleid hoe dit college denkt over de bestuurlijke plicht tot belangenafweging. Ook kan uit deze jurisprudentie worden afgeleid dat de Hoge Raad zich terdege bewust is van de gefragmenteerde structuur van de administratieve wetgeving, alsmede van de doelbinding van bestuursbevoegdheden. ${ }^{242}$

\subsubsection{De Waalbrug te Ewijk}

Interessante rechtsoverwegingen over de aard en de omvang van een discretionair belangenafwegingsproces worden aangetroffen in het (oudere) arrest inzake De Hoop/Staat der Nederlanden. ${ }^{243}$ In casu had scheepswerf De Hoop, samen met een andere werf, een kort geding aangespannen tegen de Staat der Nederlanden dat er - kort gezegd - toe strekte om de Staat te verbieden de bouw van de Waalbrug te Ewijk voort te zetten omdat deze bouw onrechtmatig zou zijn jegens de betreffende werven. Eisers stelden nl. schade te ondervinden tengevolge van een geringere doorvaarthoogte. Zo zou het transport van grote objecten en/of zeeschepen naar Rotterdam en de Noordzee onmogelijk, dan wel ernstig

240. Zie ook hoofdstuk 2 (paragraaf 2.5.3).

241. De burgerlijke rechter toetst wel - als algemene 'restrechter' - wetgeving in materiłle zin ('bestuurswetgeving'). In dit kader kwam ook wel de vraag aan de orde of een regelgever niet het doel van zijn regelgevende bevoegdheid had miskend (de vraag naar de regelgevende détoumement de pouvoir). Vgl. bijv. HR 1 juli 1983, NJ 1984, 360, m.nt. MS (LSV/prijzenbeschikking), HR 10 april 1984, NJ 1984, 612, m.nt. ' $t \mathrm{H}$ (Jodiumhoudend broodzout) en de beoordeling van het middel in het incidentele beroep in HR 16 mei 1986, AB 1986, 574, m.nt. PvB (Landbouwspuitvliegen). Op deze jurisprudentie zal ik hier niet nader ingaan. Zie in dit verband R.M. van Male, Rechter en bestuurswetgeving, diss. KUB, Zwolle 1988, p. 333 e.v. Vgl. ook A.J. Bok, Rechterlijke toetsing van regelgeving, diss. RUG, Deventer 1991, p. 153155.

242. Ik zal in deze paragraaf gén arresten van de Hoge Raad bespreken die betrekking hebben op het leerstuk van détournement de pouvoir (d.d.p). Ik wijs op het jurisprudentieoverzicht in hoofdstuk 5 . Het verbod van d.d.p. wordt sinds lang als fundamentele rechtsregel door de Hoge Raad erkend. Vgl. het standaardarrest HR 14 januari 1949, NJ 1949, 557 (Zandvoortse woonruimtevordering).

243. HR 21 juni 1974, NJ 1974, 439 (scheepswerf De Hoop/Staat der Nederlanden). 
bemoeilijkt worden. Van belang was dat er in casu géén vergunningplicht bestond ingevolge de Rivierenwet omdat de bouw uitging van de minister van Verkeer en Waterstaat (het Rijk). Een van de cassatiemiddelen, althans enige onderdelen daarvan, betoogde desalniettemin dat de minister met het oog op de besluitvorming zou moeten handelen alsof er wél een vergunningplicht ingevolge de Rivierenwet bestond. De Hoge Raad ging in dit kader uitvoerig in op de aard van het belangenafwegingsproces ingevolge de Rivierenwet. Van belang is dat het cassatiemiddel in dit verband betoogde dat '...de Minister, voor de vraag of voor het onderhavige werk een vergunning volgens de Rivierenwet zou kunnen worden verleend, slechts het openbaar rivier- en stroombelang als richtsnoer had moeten nemen, doch geen rekening had mogen houden met belangen, betrokken bij de bouw en instandhouding van de geprojecteerde brug, alsmede dat hij, nu tegenover de benadeling van de scheepvaartbelangen van de werven met de bouw van de brug geen openbaar rivier- of stroombelang is gediend, een vergunning zou hebben moeten weigeren'.

De Hoge Raad deelde deze opvatting inzake de te volvoeren belangenafweging evenwel niet. Ik citeer de relevante rechtsoverwegingen volledig:

'...dat de stelling dat de Minister het openbaar rivier- en stroombelang als richtsnoer behoort te nemen, in zoverre juist is dat de Minister heeft te beoordelen of weigering van de vergunning op gronden, ontleend aan het openbaar rivier- of stroombelang, nodig is (art. 8 paragraaf 2); dat echter de stelling dat de Minister de vergunning moet weigeren indien door het werk, kortgezegd, enig scheepvaartbelang wordt benadeeld (zonder dat daartegenover staat dat het openbaar rivier- of stroombelang in ander opzicht door het werk wordt gediend), in zijn algemeenheid niet kan worden aanvaard; dat het onderhavige geval dáárdoor wordt gekenmerkt dat het scheepvaartbelang door de bouw van de brug in het algemeen niet wordt geschaad, maar dat de bouw nadeel oplevert voor het bijzonder belang dat de werven hebben in verband met de vaart naar zee van de door hen gebouwde zeeschepen; dat een redelijke hantering van het in de Rivierenwet neergelegde vergunningstelsel meebrengt dat de Minister in zodanig geval, voor de vraag of weigering van de vergunning "nodig" is, mede betekenis toekent aan de bij de totstandkoming van het werk betrokken belangen en deze afweegt tegen het belang dat door het werk wordt geschaad; dat toch bedoeld vergunningstelsel strekt tot verzekering van de goede staat van de voorname rivieren; dat deze strekking meebrengt dat, naar mate de goede staat van de rivier mér wordt aangetast, de bij het werk betrokken belangen minder betekenis zullen krijgen, doch dat omgekeerd met gemelde strekking alleszins verenigbaar is dat, naar mate de goede staat van de rivier minder wordt aangetast, meer betekenis wordt toegekend aan het belang van het werk, in dier voege dat, als het belang groot is, een beperkte aantasting van het rivier- of stroombelang eerder kan worden aanvaard; dat derhalve de stelling dat de Minister bij de onderhavige belangenafweging de belangen betrokken bij de bouw van de geprojecteerde brug, niet in de belangenafweging had mogen betrokken, niet als juist kan worden aanvaard;...' (curs. R.J.N.S.)

Deze rechtsoverwegingen van de Hoge Raad bevatten mijns inziens een schat aan informatie. Allereerst is van belang dat de Hoge Raad het doel van een discretionaire bestuursbevoegdheid centraal stelt. Het belangenafwegingsprocesmoet vanuit het wettelijke doel kunnen worden begrepen. Dit doel kan mede strekken ter bescherming van belangen van particulieren (in casu de werven). ${ }^{244}$ Echter, het enkele feit dat een particulier (beschermd) belang wordt benadeeld - zonder dat het wettelijke belang anderszins wordt gediend - kan de bevoegdheidsuitoefening (nl. de vergunningverlening) niet verhinderen, voorzover tenminste niet ók het speciale publiekrechtelijk belang ten principale (of zoals 
de Hoge Raad het uitdrukt 'in het algemeen') wordt geschaad. ${ }^{245}$ Doet zich dit laatste niet voor, dan is er volgens de Raad alle reden om tot een afweging van belangen in concreto te komen. In het kader van deze 'belangenafweging' dienen dan de belangen die gediend zijn bij de bouw, gesteld te worden tegenover de te benadelen (particuliere) belangen. Ook met het oog op de alsdan te verrichten afweging van belangen blijft het speciale wettelijke belang echter richtsnoer. Naarmate dit belang meer wordt aangetast - welke mogelijkheid de Raad rechtens expliciet aanvaardt - zal er minder ruimte zijn om andere belangen te honoreren.

\subsubsection{Het gefragmenteerde karakter van administratieve regelingen}

Ook de burgerlijke rechter werd, zoals uit het voorafgaande blijkt, geconfronteerd met het doelgebonden karakter van administratieve wetgeving. De burgerlijke rechter werd eveneens geconfronteerd met de gefragmenteerde structuur van deze wetgeving. Een arrest van het Arnhemse gerechtshof $\mathrm{f}^{26}$ biedt in dit kader een aardig voorbeeld. Aan dit arrest lag een hoog opgelopen geschil omtrent de plaatsing van een patates friteskraam ten grondslag. In casu was de betreffende kraam, met toestemming van de gemeente - onder verlening van een standplaatsvergunning en rioolvergunning - op een gemeentelijke groenstrook vóór een woning geplaatst. De eigenaar van deze woning vorderde vervolgens op grond van onrechtmatige daad de verwijdering van de volgens hem als bouwwerk aan te merken (en in strijd met het vigerende bestemmingsplan gebouwde) kraam. De rechtbank wees deze vordering in essentie toe. In appel spitste de houder van de patates frites-kraam zijn grieven o.a. toe op het feit dat de kraam in overleg met de gemeente op de bewuste locatie was geplaatst, en dat voorts krachtens toestemming (o.m. standplaatsvergunning) van burgemeester en wethouders werd gehandeld. Nadat het Hof had overwogen dat een bestemmingsplan niet alleen het algemeen belang dient, doch ook strekt tot de bescherming van privé-belangen werd vastgesteld dat in casu de belangen van de woningeigenaar ingevolge het bestemmingsplan als (daardoor) beschermd konden worden beschouwd. Van belang voor het onderwerp van dit boek is dat het Hof expliciet de

244. Ik kan mij in dit verband goed vinden in de opvatting van Vos, die naar aanleiding van het EZH/Bailyarrest (HR 14 juni 1963, NJ 1965, 82, m.nt. J.H.B) opmerkte dat de Hoge Raad de Rivierenwet - wat betreft de betrokken scheepvaartbelangen - opvatte als een 'Schutznorm'. A.T. Vos, Overheidsvergunning en onrechtmatige daad, in: Op de grenzen van komend recht (Beekhuis-bundel), Deventer/Zwolle 1969, p. 308.

245. Het valt op dat de Hoge Raad hier de speciale publiekrechtelijke belangen goed weet te onderscheiden van de bijzondere belangen die door dit belang wellicht bij wijze van 'reflex' worden beschermd. Het feit dat bijzondere belangen worden benadeeld is kennelijk op zichzelf onvoldoende reden om de vergunning te weigeren. De Hoge Raad is hier overigens niet ver verwijderd van de vraag of deze benadeelde bijzondere belangen dan door de overheid behoren te worden gecompenseerd. Helaas waren de cassatiemiddelen niet op een dergelijke rechtsvraag toegesneden. Hierbij zij opgemerkt dat de onderhavige casus vrijwel identiek was aan de - hiervoor in het kader van de Arob-jurisprudentie besproken - Paul Krugerbrug casus (vgl. paragraaf 8.4.5).

246. Gerechtshof Amhem 21 april 1976, NJ 1977, 77. 
implicaties van de gemeentelijke besluitvorming (de vergunningverlening) in ogenschouw nam en overwoog dat in het besluit niet tevens een planologische vrijstelling kon worden gelezen:

'Overwegende dat - wat er overigens ook van het karakter van de in vermeld besluit vervatte vergunning moge zijn - dat besluit in elk geval niet inhield een vrijstelling tot gebruik van bedoelde grond in afwijking van de daaraan in het bestemmingsplan gegeven bestemming (t.w. die van "openbaar groen"), zoals evenmin het geval is met het besluit van B. en W. der gemeente d.d. 3 april 1973, waarbij B.A. Rave vergunning werd verleend voor een aansluiting van de kraam op de gemeentelijke riolering; ...'

Uit deze rechtsoverwegingen blijkt dat de verlening van de ene vergunning door de gemeente geenszins afdoet aan het feit dat ook ingevolge andere - verwante regelingen vergunningen en/of vrijstellingen benodigd kunnen zijn. De eigenaar van de kraam werd in casu op een onaangename wijze geconfronteerd met de 'gedeelde' overheid.

Bijzondere aandacht verdient in dit verband het Kuunders-arrest. ${ }^{247}$ In casu werd boer Kuunders - door Damen vergeleken met een 'pingpongballetje' dat heen en weer wordt geslagen door overheidsinstanties ${ }^{248}$ - op een wel zeer onaangename wijze geconfronteerd met het 'gedeelde' bestuur. Een aantal milieu-organisaties vorderde en verkreeg in casu een civielrechtelijk verbod jegens boer Kuunders om een varkensstal te gebruiken zolang hij niet zou beschikken over een geldige vergunning op grond van artikel 12, eerste lid van de Natuurbeschermingswet. Met het oog op het specialiteitsbeginsel is in het bijzonder rechtsoverweging 4.3 .4 van het arrest van belang. In deze rechtsoverweging positioneerde de Hoge Raad, in navolging van het Gerechtshof 's-Hertogenbosch de werkingssfeer van de Hinderwet expliciet ten opzichte van de Natuurbeschermingswet. De rechtsvraag die in dit kader aan de orde kwam was of een vergunning ingevolge de eerstgenoemde wet afdeed aan de vergunningplicht ingevolge de laatstgenoemde wet. Ik citeer de relevante rechtsoverwegingen van de Raad:

\footnotetext{
'Het hof heeft voorts met juistheid overwogen dat het feit dat de onderhavige ammoniak-emissie wordt gedekt door een daartoe aan Kuunders verleende hinderwetvergunning, niet meebrengt dat deze daarvoor, nu die emissie valt aan te merken als een handeling als in art. 12 Natbw. bedoeld, niet tevens een vergunning als in dit voorschrift bedoeld, zou behoeven. De Hinderwet beschermt andere belangen dan de Natuurbeschermingswet.(.) Voorts is van belang dat, zoals het hof heeft aangestipt, een hinderwetvergunning wordt
}

247. HR 18 december 1992, AB 1994, 396; NJ 1994, 139 m.nt. MS en CJHB; AB Klassiek, derde druk, Deventer 1997, p. 285 e.v. m.nt. Th. G. Drupsteen (Kuunders). Het Kuunders-arrest geniet met name bekendheid gelet op de rechtsoverwegingen van de Hoge Raad inzake het (collectieve) vorderingsrecht van belangenorganisaties (vgl. het huidige art. 3:305a BW), en de mogelijkheden voor deze organisaties om naast bestuursdwangverzoeken ook civiele acties te entameren ter handhaving van de (milieu)wetgeving. Dat het arrest echter ob́k van belang is voor het specialiteitsbeginsel is in de literatuur nauwelijks gesignaleerd. Damen, en in mindere mate Drupsteen, pikten de specialiteitsproblematiek overigens wél op. Zie respectievelijk hun naschrift (Gst. 6770, p. 410 e.v.) en noot (AAe 1993/9, m.n. p. 670/671) onder het arrest. Ik veronderstel de onderliggende casuspositie en het procesverloop goeddeels als bekend en concentreer mij op de voor dit boek relevante rechtsoverwegingen uit het arrest.

248. Zie punt 9 van zijn naschrift onder het arrest (Gst. 6770). 
verleend door een ander bestuursorgaan dan een vergunning ingevolge art. 12 Natbw., zodat reeds daardoor niet is verzekerd dat bij die verlening, ook wanneer daarbij, zoals te dezen, milieubelangen worden meegewogen, aan de door de Natuurbeschermingswet gediende ecologische belangen het in het kader van laatstgenoemde wet vereiste gewicht wordt toegekend' (curs. R.J.N.S.). ${ }^{249}$

Van belang is dat de Hoge Raad niet alleen de typische werkingssfeer van twee speciale administratieve wetten naar hun doelstelling begrensde, maar impliciet óók de bestuursorganisatorische implicaties van het specialiteitsbeginsel belichtte. ${ }^{250}$ In casu was nl. het college van burgemeester en wethouders van Deurne verantwoordelijk voor de uitvoering van de Hinderwet en de minister Landbouw, Natuurbeheer en Visserij voor de uitvoering van de Natuurbeschermingswet. Om een goede behartiging van publiekrechtelijke belangen te bewerkstelligen zal ieder orgaan binnen zijn typische werkgebied dienen te blijven. Dit is soms onaangenaam voor de burger, maar zoals Damen terecht in zijn naschrift onder het Kuunders-arrest opmerkte, zijn er ób́k wel redenen aan te voeren om juist blij te zijn met deze gedeelde overheid: het bevordert nl. 'checks and balances' en de overheid kan bij de beoordeling van de aanvaardbaarheid van een bepaalde activiteit, gelet op de doelbinding van de wetgeving, niet van argument naar argument springen. ${ }^{251}$

\subsubsection{Het specialiteitsbeginsel in stelling tegen de overheid?}

Soms biedt de gefragmenteerde structuur van de administratieve wetgeving de burger - in plaats van een last - ook een handvat om de overheid zélf in het complexe net van bestuursbevoegdheden te vangen en op afstand te houden. Een verdienstelijke - doch niet succesvolle - poging hiertoe wordt aangetroffen in het arrest Lodewikus Bouw/provincie Noord-Brabant. ${ }^{252}$ Ik schets kort de nogal ingewikkelde casus. Inzet van het geschil vormde de rechtmatigheid van een bestuursdwangaanzegging uitgaande van gedeputeerde staten van Noord-Brabant en gericht tot Lodewikus Bouw Maatschappij BV (hierna: Lodewikus). De aanschrijving strekte tot het opnieuw aanleggen van een dam in het Sluizegat, zijnde een arm van de rivier de Donge. Deze dam (de 'waterschapsdam') had Lodewikus op grond van een verkregen waterschapsvergunning verwijderd om zo een door hem aangelegde jachthaven te verbinden met de Donge. Gedeputeerde staten van Noord-

249. Drupsteen wees er overigens op dat de overweging van de Hoge Raad dat beide wetten verschillende belangen beschermen - zo gesteld - niet juist is. In zijn noot onder het Kuunders-arrest in Ars Aequi (a.w. punt 4) vestigt hij er de aandacht op dat sedert de verruiming van de werkingssfeer van de (voormalige) Hinderwet in 1981 deze wet (mede) betrekking had op natuurbeschermingsbelangen. Desalniettemin zou men m.i. kunnen stellen dat deze ruimere Hinderwet impliciet werd beperkt door de 'speciale' Natuurbeschermingswet waarin de behartiging van het publiekrechtelijke natuurbeschermingsbelang centraal stond. Vgl. de conclusie van A.G. Koopmans die opmerkte: 'In verhouding tot de Hinderwet, die een algemeen karakter heeft, strekt de Natuurbeschermingswet tot bescherming van een specifiek, bijzonder beschermenswaardig geacht, belang.'

250. Zie hoofdstuk 4 (paragraaf 4.6.4).

251. Zie punt 8 van zijn naschrift onder het arrest (Gst. 6770).

252. HR 19 mei 1978, NJ 1979, 545 (Lodewikus Bouw/provincie Noord-Brabant). Het betreft een arrest uit het 'pre-Arob' tijdperk. 
Brabant hadden echter op planologische gronden bezwaar tegen de verbinding van de haven met de Donge. Deze bezwaren betroffen het daadwerkelijke gebruik van de haven als jachthaven vooruitlopend op (nadere) ruimtelijke besluitvorming. Gedeputeerde staten schreven echter aan op grond van de Ontgrondingenwet: de waterschapsdam zou zonder de benodigde ontgrondingsvergunning zijn afgegraven. Uiteindelijk werd de Hoge Raad vanwege Lodewikus Bouw geconfronteerd met een aantal spitsvondige cassatiemiddelen die verband hielden met het specialiteitsbeginsel. Kort samengevat kwamen deze middelen op het volgende neer: (1) de Ontgrondingenwet zou niet op de afgraving van toepassing zijn, maar de Rivierenwet omdat de werkzaamheden in het zomerbed van de Donge waren uitgevoerd, (2) de verleende waterschapsvergunning ingevolge het Reglement op de waterkering in Noord-Brabant 1905 zou aan bestuursdwang ingevolge overtreding van de Ontgrondingenwet in de weg staan, (3) gedeputeerde staten zouden de Ontgrondingenwet ten onrechte aanwenden om ruimtelijke beleidsdoeleinden na te streven, en (4) gedeputeerde staten zouden niet door middel van bestuursdwang tot het herstel van de dam mogen overgaan omdat zij zelf niet beschikten over een Rivierenwetvergunning.

Geen van deze middelen trof volgens de Hoge Raad echter doel. Het eerste middel niet omdat het Hof volgens de Raad het begrip 'winterbed' op een juiste wijze had geïnterpreteerd. Het tweede middel werd terzijde gesteld door vast te stellen dat een waterschapsvergunning niet uitsloot dat $66 \mathrm{k}$ nog een ontgrondingsvergunning voor de werkzaamheden was vereist. Ten aanzien van het derde middel overwoog de Hoge Raad dat een ruimtelijk belang niet een belang is dat buiten de doeleinden van de Ontgrondingenwet lag. Tot slot trof ook het beroep op de afwezigheid van een Rivierenwetvergunning geen doel. De Hoge Raad paste in dit kader de Schutznormtheorie toe, door te stellen dat de betreffende bepalingen uit de Rivierenwet niet strekten tot bescherming van de belangen van Lodewikus.

\subsubsection{Het leerstuk van de vrijwarende werking van vergunningen}

Het leerstuk van de vrijwarende werking van vergunningen ${ }^{253}$, dat verband houdt met de civielrechtelijke 'Schutznorm'-benadering, kan een helder licht werpen op de betekenis van het publiekrechtelijke specialiteitsbeginsel. Het verband tussen het specialiteitsbeginsel, de vraag of een overheidsvergunning kan vrijwaren tegen aansprakelijkheid op grond van onrechtmatige daad (artikel 6:162 BW) én de genoemde Schutznormtheorie is wellicht op het eerste gezicht niet geheel duidelijk. Hierin is waarschijnlijk de reden gelegen waarom dit verband in de literatuur slechts door weinig auteurs is gesignaleerd. ${ }^{254}$ 


\subsubsection{De relativiteits- of 'Schutznorm'-leer (artikel 6:163 BW)}

De civielrechtelijke relativiteits- of Schutznormleer vervult in het kader van het leerstuk van de onrechtmatige daad een (beperkende) functie met het oog op het vaststellen van de onrechtmatigheid, en wel in het bijzonder voorzover de onrechtmatigheid gebaseerd wordt op een normschending. Om in geval van overtreding van een (geschreven of ongeschreven) rechtsnorm onrechtmatigheid jegens een gelaedeerde te kunnen aannemen is normovertreding sec niet voldoende, maar dient tevens te worden vastgesteld dat de overtreden norm (mede) het gelaedeerde belang beoogt te beschermen. ${ }^{255}$ Dit vereiste is neergelegd in artikel 6:163 BW. De relativiteitsleer verplicht de burgerlijke rechter in geval van een gestelde normschending derhalve om zorgvuldig na te gaan welke belangen de betreffende rechtsnorm, waarop een beroep wordt gedaan, beoogt te beschermen. Of anders uitgedrukt: de rechter zal dienen na te gaan welke rechtens relevante belangen (door de wetgever) in de betreffende norm zijn verdisconteerd.

In het kader van dit boek is van belang dat de civiele rechter veelvuldig is geconfronteerd met de vraag of - en zo ja in hoeverre - administratieve wetgeving, alsmede de daarin opgenomen bevoegdhedenstelsels, de rechtsbelangen van rechtssubjecten beoogde te beschermen. Bekend is bijv. het arrest van de Hoge Raad inzake de Tilburgse tandartsen. ${ }^{256}$ In casu besliste de Raad dat het uitoefenen van het tandartsberoep zonder een

253. Het leerstuk van de vrijwarende werking van vergunningen is in de literatuur veelvuldig aan de orde gesteld. Ik wijs o.m. op: A.T. Vos, Overheidsvergunning en onrechtmatige daad. Enkele beschouwingen over de vraag, welke plaats de overheidsvergunning in het leerstuk der onrechtmatige daad inneemt, in: Op de grenzen van komend recht (Beekhuis-bundel), Deventer/Zwolle 1969, p. 297 e.v.; H.A. Groen, Overheidsvergunning en onrechtmatige daad, diss. RUL, Deventer 1977, i.h.b. p. 25-43; S.C.J.J. Kortmann, Vergunning voor onrechtmatig handelen?, in: Goed en trouw (Van der Grinten-bundel), Zwolle 1984, p. 461 e.v.; S.C.J.J. Kortmann, annotatie onder HR 23 september 1988 (Franse Kalimijnen), AAe 1989/10, i.h.b. p. 882 e.v.; W.G. Huijgen, Publiekrechtelijke vergunning en privaatrechtelijke aansprakelijkheid, in: Quod Licet (Kleijn-bundel), Deventer 1992, p. 135 e.v.; H.J. Simon, Publiekrecht of privaatrecht?, diss. VU, Zwolle 1993, p. 342 e.v.; W.G. Huijgen, Reflexwerking van vergunningen, in: De derde in het recht, AAe $1997 / 5$ (special), p. 330 e.v.; H.J. de Ru, annotatie onder HR 10 maart 1972 (Vermeulen/Lekkerkerker), in: AB Klassiek, derde druk, Deventer 1997, p. 102 e.v.; R.J.G.H. Seerden, De vrijwarende werking van milieuvergunningen, in: Eenzijdig en wederkerig?, Deventer 1995, p. 249 e.v. en G.T.J.M. Jurgens, Bestuurlijk gedogen. Aanvaardbaarheid en gevolgen van bestuurlijk gedogen in het milieurecht en het ruimtelijk recht, diss. UU, Zwolle 1996, p. 173 e.v.

254. Deze 'link' werd wél waargenomen door Damen en Seerden. Zie: L.J.A. Damen, naschrift onder HR 18 december 1992 (Kuunders) in Gst. 6970, p. 410-411. en R.J.G.H. Seerden, De vrijwarende werking van milieuvergunningen, p. 262-266. Vgl. ook A.Q.C. Tak, De overheid in het burgerlijk recht, 's-Gravenhage 1997, p. 397.

255. Zie over deze, aan het Duitse recht ontleende, leer o.m. Asser-Hartkamp 4-III, negende druk, Zwolle 1994, p. 92-93. Ik wijs ook op het Leidse proefschrift van Lankhorst die de relativiteitsleer (mede in historisch perspectief) uitvoerig analyseerde. G.H. Lankhorst, De relativiteit van de onrechtmatige daad, diss. RUL, Deventer 1992, i.h.b. hoofdstuk 2. Zie ook: G.E. van Maanen, Onrechtmatige daad. Aspekten van de ontwikkeling van een omstreden leerstuk, diss. RUG, Deventer 1986, p. 196-199.

256. HR 17 januari 1958, NJ 1961, 568 (Tilburgse tandartsen). 
vereiste wettelijke toelating in beginsel niet $^{257}$ onrechtmatig was ten opzichte van bevoegde tandartsen, omdat de wet op de Tandheelkunst - die in casu was overtreden - er niet toe strekte om hun (concurrentie-)belangen te beschermen. De betreffende wet diende slechts het (publiekrechtelijke) belang van de volksgezondheid. Dit was anders in het Bonthandel-arrest. ${ }^{258}$ In dit arrest nam de Hoge Raad nl. aan dat het vergunningstelsel ingevolge de Vestigingswet bedrijven 1954 wél de belangen van concurrenten beschermde.

Dát administratieve vergunningstelsels volgens de Hoge Raad particuliere belangen kunnen beschermen, blijkt mijns inziens ook op een duidelijke wijze uit het bekende arrest Van Dam/ Beukeboom. ${ }^{259}$ In casu overwoog de Hoge Raad dat aan voorwaarden welke rechtsgeldig verbonden waren aan een Hinderwetvergunning een soortgelijke betekenis dient te worden toegekend als aan gedragsvoorschriften van de centrale of decentrale wetgever, waarvan de schending in beginsel een onrechtmatige daad oplevert jegens degenen te wier bescherming die normen zijn gesteld. Met het oog hierop is van bijzonder belang dat de Hoge Raad ervan uitging dat aan het stellen van beschermende vergunningvoorwaarden een gerichte belangenafweging door de overheid vooraf gaat. Uit het arrest Claas/Van Tongeren ${ }^{260}$ blijkt voorts dat bijv. ók bepalingen uit een bouwverordening (mede) kunnen strekken ter bescherming van de belangen van omwonenden. Dit geldt eveneens voor een bestemmingsplan en de daarbij behorende (gebruiks)voorschriften. ${ }^{261}$ Tot slot kan in dit verband de aandacht worden gevestigd op het arrest inzake de Stichting Werkpool te Utrecht. ${ }^{262}$ In casu kwam de vraag aan de orde of de genoemde stichting door te handelen in strijd met de vergunningplicht ingevolge de Wet op het ter beschikking stellen van arbeidskrachten jegens een concurrent onrechtmatig had gehandeld. Volgens de Hoge Raad was dit niet het geval daar de strekking van de wet, en het daarop gestoelde besluit, niet (mede) de bescherming van vergunninghouders tegen niet-vergunninghouders omvatte, doch slechts de goede verhoudingen op de arbeidsmarkt beoogde te reguleren (zijnde een specifiek publiekrechtelijk belang).

Uit deze jurisprudentie kan mijns inziens worden afgeleid dat de Hoge Raad er vanuit gaat dat typisch administratiefrechtelijke wetgeving, die primair publiekrechtelijke belangen beoogt te behartigen, alsmede de publieke normstelling krachtens deze wetgeving, in beginsel oók geacht kan worden bepaalde belangen van particulieren te beschermen. Voorwaarde is dan wél dat de betreffende administratieve wet de relativiteits- of 'Schutznorm'-toets doorstaat. De wet, en de op basis van deze wet (in concreto) gevormde

257. In casu werd overigens wél tot onrechtmatig handelen geconcludeerd omdat het overtreden van de wet desalniëttemin maatschappelijk onzorgvuldig werd geacht jegens de tandartsen. Men spreekt in de 'civiele' literatuur in dit verband over de 'correctie Langemijer'. Zie hierover: G.H. Lankhorts, De relativiteit van de onrechtmatige daad, a.w., p. 25 e.v.

258. HR 30 oktober 1959, NJ 1961, 574 (bonthandel).

259. HR 9 januari 1981, NJ 1981, 227, m.nt. C.J.H.B. (Van Dam/Beukeboom).

260. HR 28 juni 1985, NJ 1986, 356, m.nt. MS (Claas/Van Tongeren).

261. Vgl. bijv. in het verlengde van het Claas/Van Tongeren-arrest: Gerechtshof Amhem 6 januari 1987, NJ $1988,288$.

262. HR 19 juni 1987, NJ 1988, 91 (stichting Werkpool). 
gedragsvoorschriften, dienen er in ieder geval mede toe te strekken particuliere belangen te beschermen. ${ }^{263}$

\subsubsection{Specialiteitsbeginsel en relativiteitsleer}

Het leerstuk van de vrijwarende werking van vergunningen houdt verband met de relativiteitsleer. Dit leerstuk stelt de vraag centraal in hoeverre een handelen overeenkomstig een geldige vergunning naar civielrechtelijke maatstaven onrechtmatig kan zijn. Jurgens signaleert terecht dat het antwoord op deze vraag eigenlijk simpel zou kunnen zijn. ${ }^{264}$ Artikel 6:162 BW noemt in lid 2 immers drie onrechtmatigheidscategorieën: inbreuk maken op een (subjectief) recht, een doen of nalaten in strijd met een wettelijke plicht en handelen in strijd met hetgeen volgens ongeschreven recht in het maatschappelijk verkeer betaamt. Een vergunningverlening kan in beginsel uitsluitend van invloed zijn op de tweede onrechtmatigheidsgrond. Een vergunningstelsel beoogt immers een bepaalde feitelijke activiteit met het oog op een speciaal publiekrechtelijk belang te reguleren. Indien een vergunning door een bevoegd bestuursorgaan wordt verleend, dan brengt dit enkel met zich dat het uitoefenen van de vergunde activiteit niet langer in strijd is met de specifieke administratieve wet. Het zal echter duidelijk zijn dat een dergelijke wet niet alle beginselen en regels omvat die de betreffende (vergunningplichtige) activiteit normeren als rechtsfeit. Vaak zal er in de normensfeer (de 'normzijde' van het recht) ${ }^{265}$ ten aanzien van deze activiteit sprake zijn van een samenloop van geschreven en ongeschreven privaatrechtelijke, publiekrechtelijke én strafrechtelijke rechtsnormen. Om een voorbeeld te noemen: het feit dat er ingevolge de Wet milieubeheer een vergunning wordt verleend voor een tuindersbedrijf, geeft nog géén strafrechtelijke vrijbrief om in de kassen van dat bedrijf, in strijd met de Opiumwet, hennepplanten te kweken. ${ }^{266}$ Evenmin legitimeert de exploitatie van een dergelijke inrichting overeenkomstig een vergunning tot het maken van inbreuken op bijv. bepalingen van burenrecht. Tot slot sluit, zoals in dit hoofdstuk bij herhaling is gebleken, een vergunningverlening ingevolge de ene administratieve wet geenszins uit dat er daarnaast óók nog andere vergunningen zijn vereist.

Het voorafgaande lijkt vanzelfsprekend. Het is mijns inziens dan ook geen vergaande gevolgtrekking dat een specifieke publiekrechtelijke toestemming (een 'vergunningverlening'), gebaseerd op een doelgebonden bestuursbevoegdheid, slechts relatief van aard kan zijn. Relatief in die zin dat strijd met 'de' wet slechts partieel, nl. met het oog op de speciale publiekrechtelijke belangen die de betreffende wet beoogt te beschermen, wordt opgeheven. De publiekrechtelijke vergunningverlening heeft daarom in beginsel géén

263. De vraag of dit het geval is, zal vaak aanleiding geven tot moeilijke interpretatiekwesties. Ik laat dit hier verder rusten. Op deze plaats is van belang de vaststelling dat administratieve rechtsnormen - toegespitst op subjectgebonden (particuliere) belangen - als 'Schutznormen' kunnen fungeren.

264. G.T.J.M. Jurgens, Bestuurlijk gedogen, a.w., p. 173.

265. Vgl. paragraaf 3.2 .4 van dit boek.

266. Zie hierover: R.J.N. Schlossels, Stek \& Co (reactie 3) een geval van kruisbestuiving?, Gst. 7036, p. 391393. 
invloed op de rechtsgevolgen die ten aanzien van hetzelfde feitencomplex als rechtsfeit voortvloeien uit andere normenstelsels. ${ }^{267}$ Hiermee hangt samen dat het niet aannemelijk is dat een doelgebonden publiekrechtelijke vergunningverlening ooit volledig kan vrijwaren tegen civielrechtelijke aansprakelijkheid. ${ }^{268}$

Het is echter te simpel om, in het kader van een onrechtmatige daadsactie, aan de aanwezigheid van een geldige vergunning geen enkele betekenis toe te kennen. De vraag in hoeverre een vergunning 'vrijwaart', en derhalve wordt geacht (mede) particuliere belangen te beschermen, dient op een genuanceerde wijze beoordeeld te worden tegen de achtergrond van het doel van het betreffende vergunningstelsel, alsmede tegen de achtergrond van de belangen die de wetgever met dat stelsel beoogt te beschermen en de omstandigheden van het geval. ${ }^{269}$ Dit was ook de benadering van de Hoge Raad in het standaardarrest Vermeulen/Lekkerkerker. ${ }^{270}$ In dit (oudere) arrest overwoog de Hoge Raad dat $\mathrm{nl}$. '...het antwoord op de vraag of, en in hoeverre, een door de overheid verleende vergunning invloed heeft op de beoordeling van de aansprakelijkheid uit onrechtmatige daad van degene die overeenkomstig de vergunning handelt, doch daarbij toch schade en/of hinder toebrengt aan derden, afhangt van de aard van de vergunning en het belang dat wordt nagestreefd met de regeling waarop de vergunning berust, zulks in verband met de omstandigheden van het geval' (curs. R.J.N.S.). De Hoge Raad concludeerde dat het vergunningstelsel ingevolge de Hinderwet niet met zich bracht dat eigenaren van naburige percelen een vorm van hinder, die normaliter jegens hen onrechtmatig was, zouden moeten dulden omdat er een hinderwetvergunning in het spel was. Met andere woorden, het vergunningstelsel ingevolge de Hinderwet boogde volgens de Hoge Raad geenszins de inbreuken op het subjectieve eigendomsrecht van de aangrenzende eigenaar te legitimeren. Of nóg anders gezegd: de (aangetaste) rechtsbelangen van de eigenaar van de aangrenzende grond waren volgens de Hoge Raad niet (volledig) verdisconteerd in de

267. In deze zin ook: A.T. Vos, Overheidsvergunning en onrechtmatige daad, a.w., p. 304. Fraai acht ik in dit verband Vos' karakterisering van publiekrechtelijke vergunningstelsels (a.w., p. 303-304).

268. Vgl. de scherpzinnige analyse van De Ru die vaststelde dat aan de publieke vergunningverlening en aan een civiele onrechtmatige daadsactie verschillende belangenafwegingen én normenstelsels ten grondslag liggen: 'één waarbij het algemeen belang de boventoon voert, en één waarbij private belangen voorop staan,...' H.J. de Ru, AB Klassiek, a.w., p. 107. Hierbij neemt hij m.i. terecht afstand van bepaalde opvattingen uit civielrechtelijke hoek waar de 'rechtseenheid' alsmede de gelijkschakeling van private en publieke normstelling soms (te veel) lijkt te worden verheerlijkt. Vgl. recentelijk: W.G. Huijgen, Reflexwerking van vergunningen, a.w., i.h.b. p. 336. Huijgen betoogt dat de leer 'Vermeulen/Lekkerkerker' thans - gelet op de integrale milieuvergunning - enigszins verouderd is.

269. Het is dus - tenzij de regeling expliciet is inzake de beantwoording van de vrijwaringskwestie - een kwestie van 'meer-of-minder vrijwaring' en niet een kwestie van 'wel-of-géén vrijwaring', waarbij de structuur en het doel van het vergunningstelsel nauwkeurig moeten worden geanalyseerd. Factoren als discretionair/gebonden, alsmede specifieke/algemene doelbinding kunnen een rol spelen bij de beantwoording van de vrijwaringsvraag.

270. HR 10 maart 1972, NJ 1972, 278, m.nt. G.J.S. (Vermeulen/Lekkerkerker). Vgl. ook HR 23 september 1988, NJ 1989, 743; AAe 1989, p. 874 e.v. m.nt. S.C.J.J. Kortmann (Franse Kalimijnen). Ik verwijs voorts naar de jurisprudentiebespreking door Seerden. R.J.G.H. Seerden, De vrijwarende werking van milieuvergunningen, a.w., p. 249 e.v. 
normstelling ingevolge de Hinderwet. Hier treedt wederom de relatieve dimensie van (administratieve) rechtsnormen op de voorgrond. Deze normen beschermen slechts bepaalde rechtsbelangen. Dit geldt evenzeer voor de vergunning zelf die, zoals Vos reeds terecht opmerkte, niet losstaat van de (wettelijke) norm maar functioneert binnen het stelsel van die norm zelf. 271

Complexer - doch mijns inziens niet principieel anders ${ }^{272}$ - ligt de situatie indien een onrechtmatige daadsactie niet wordt geconstrueerd als een inbreuk op een subjectief recht, maar als een schending van een ongeschreven maatschappelijke zorgvuldigheidsnorm. In dit verband dringt zich echter uitdrukkelijker de vraag op in hoeverre civielrechtelijke belangen - die door de maatschappelijke zorgvuldigheidsnorm(en) worden beschermd tevens zijn verdisconteerd in de publiekrechtelijke normstelling. In het verlengde hiervan ligt vervolgens de vraag of aan de ongeschreven zorgvuldigheidsnormen dan naast de expliciete publieke normstelling nog zelfstandige betekenis toekomt met het oog op het vaststellen van onrechtmatigheid. In dit verband dient voorop te worden gesteld dat handelen overeenkomstig specifieke publieke normstelling volgens de Hoge Raad van invloed kan zijn op de vraag of er in strijd met de maatschappelijke zorgvuldigheid wordt gehandeld. In het EZH/Bailey-arrest ${ }^{273}$ besliste de Raad nl. dat een op strijd met 'de in het maatschappelijk verkeer betamende zorgvuldigheid' gebaseerde onrechtmatige daadsactie niet los van een betrokken publiekrechtelijke vergunning kan worden beoordeeld. Dit standpunt vloeide kennelijk voort uit het feit dat publieke normstelling vaak (mede) de rechtsrelaties tussen burgers onderling beoogt te reguleren. ${ }^{274}$ Maar dit betreft dan slechts een gedeeltelijke ('partielle') regulering, want niet kan worden uitgesloten dat maatschappelijke zorgvuldigheidsnormen of andere regels van burgerlijk recht, een verdergaande bescherming bieden aan rechtssubjecten dan de specifieke publieke normstelling. ${ }^{275}$

271. A.T. Vos, Overheidsvergunning en onrechtmatige daad, a.w., p. 309.

272. In de literatuur is wel verdedigd dat het al dan niet vrijwaren van publiekrechtelijke vergunningen mede afhangt van de aard van de gestelde onrechtmatigheidsgrond (nl. rechtsinbreuk of handelen in strijd met de maatschappelijke zorgvuldigheid). In dit verband werd het standpunt ingenomen dat een vergunning in principe (tenzij de wet dit uitdrukkelijk bepaalt) niet vrijwaart indien er sprake is van een inbreuk op een subjectief recht. Vgl. i.h.b. H.A. Groen, Overheidsvergunning en onrechtmatige daad, a.w., p. 35. Met Kortmann (Vergunning voor onrechtmatig handelen, a.w., p. 469-470) en Jurgens (Bestuurlijk gedogen, a.w., p. 175-176) ben ik van mening dat een onderscheid naar de aard van de gestelde onrechtmatigheidsgrond te kunstmatig is. Het maakt m.i. voor de beantwoording van de vraag of een vergunning vrijwaart in principe niet uit of de gelaedeerde rechtsbelangen van burgers bescherming genieten in de vorm van een subjectief (privaat)recht of worden beschermd door een maatschappelijke zorgvuldigheidsnorm.

273. HR 14 juni 1963, NJ 1965, 82, m.nt. J.H.B. (EZH/Bailey).

274. Ik wijs er overigens op dat Simon in dit verband kennelijk uitgaat van een fundamenteel verschil tussen de arresten Vermeulen/Lekkerkerker en EZH/Bailey. Hij wijst er nl. op dat in het eerste arrest een vergunningstelsel centraal stond dat 'meta-privaatrechtelijke tekorten' beoogde op te heffen (de Hinderwetvergunning beoogt immers - op een aanvullende wijze - de belangen van burgers onderling te beschermen), terwijl het bij het vergunningstelsel ingevolge de Rivierenwet juist ging om de behartiging van het 'bovenindividuele' openbare vaarbelang (waaraan reeds een uitputtende belangenafweging ten grondslag lag). In de Vermeulen/Lekkerkerker situaties zou volgens Simon in de regel géén vrijwarende werking kunnen worden aangenomen. H.J. Simon, Publiekrecht of privaatrecht?, a.w., p. 344-346. 
Kortmann heeft er in dit verband op gewezen dat vergunningvoorwaarden een leidraad kunnen zijn bij de invulling van open zorgvuldigheidsnormen die de intersubjectieve relaties in het maatschappelijke rechtsverkeer beheersen. ${ }^{276}$ Vergunningvoorwaarden kunnen volgens deze auteur, afhankelijk van de aard en inhoud van de vergunning - alsmede de regeling waarop deze berust - 'reflexwerking' hebben. ${ }^{277}$ 'Reflexwerking' van vergunningvoorwaarden brengt met zich, zo begrijp ik Kortmann, dat deze dan geacht worden (mede) de rechtsposities van particulieren te beschermen en onderling te normeren (Schutznormgedachte). Deze bescherming kan echter niet verder reiken dan de relativiteit van de betreffende publieke normstelling. Steeds zal daarom dienen te worden nagegaan welke rechtsbelangen van burgers in het publieke normstellingsproces zijn 'verdisconteerd' ${ }^{278}$ Voorts zal nagegaan dienen te worden of aan deze belangen in het belangenafwegingsproces, dat aan de normstelling vooraf ging, het juiste gewicht is toege$\operatorname{kend}^{279}$, en of de publieke normstelling nog afdoende actueel is. ${ }^{280}$ De principiële divergentie tussen private en publieke rechtsnormen vormt hierbij mijns inziens het uitgangspunt.

Overigens dient erop te worden gewezen dat de Hoge Raad deze divergentie lijkt te hebben gerelativeerd. In het arrest Bal/'t Laaksche Hoogh ${ }^{281}$ aanvaardde de Raad nl. dat de civiele rechter in kort-geding zijn onrechtmatigheidsoordeel in het kader van een hinderactie, gelet op de bijzondere omstandigheden van het geval, mocht afstemmen op

275. Vgl. A.T. Vos, Overheidsvergunning en onrechtmatige daad, a.w., p. 306-307 die in dit kader sprak over 'zelfstandige normen' die hun grondslag kunnen vinden in het ongeschreven recht of in subjectieve rechten. In dit kader blijkt wederom dat privaatrecht en publiekrecht zelfstandige, in beginsel van elkaar divergerende normenstelsels omvatten. De jurisprudentie van de Hoge Raad biedt in dit kader heldere voorbeelden waaruit blijkt dat de rechtsrelaties tussen private rechtssubjecten onderling - onverminderd de regulering door specifieke publieke normen - obk beheerst worden door regels en beginselen van burgerlijk recht. Ik wijs o.m. op HR 26 november 1993, NJ 1995, 322, m.nt. CJHB (Zaadnoorddijk c.s./Staat der Nederlanden), inzake de verhouding tussen het vergoedingstelsel ingevolge art. 26 van de Luchtvaartwet en een onrechtmatige daadsactie. Ook kan nog gewezen worden op HR 15 maart 1996, JB 1996/120, m.nt. HJS/RJNS; NJ 1997, 3, m.nt. E.J.H. Schrage (Van der Tuuk Adriani/Batelaan), inzake de verhouding tussen (het ontbreken) van een bestuurscompensatieregeling in de Wet op de Geneesmiddelenvoorziening en een civiele actie op grond van ongerechtvaardigde verrijking. Zie hierover: H.C.F. Schoordijk, Een vordering uit ongerechtvaardigde verrijking wegens het profiteren door apotheker van intrekking vergunning apotheekhoudend arts, NTBR 1996/10, p. 247 e.v.

276. S.C.J.J. Kortmann, Vergunning voor onrechtmatig handelen?, a.w., p. 472-473.

277. S.C.J.J. Kortmann, Vergunning voor onrechtmatig handelen?, a.w., p. 474.

278. Dat dit, met name voor de vergunninghouder, geen gemakkelijke opgave is heeft Groen gesignaleerd. H.A. Groen, Overheidsvergunning en onrechtmatige daad, a.w., p. 39-40.

279. Het belangenafwegingsproces mag, zo blijkt uit het aangehaalde EZH/Bailey-arrest, niet kennelijk onredelijk zijn. Vgl. G.T.J.M. Jurgens, Bestuurlijk gedogen, a.w., p. 177-178.

280. Ik wijs erop dat het maatschappelijke rechtsverkeer voortdurend in beweging is, en dat publieke normstelling - bijv. in het kader van een vergunning - verouderd. Dit brengt reeds met zich dat ongeschreven maatschappelijke zorgvuldigheidsnormen moeilijk in publieke vergunningvoorschriften kunnen worden gecodificeerd. Vgl. J.A.M. van Angeren, De gewone rechter en de administratieve rechtsgangen, diss. RUL, Deventer 1968, p. 131.

281. Zie: HR 15 december 1995, AB 1996, 302, m.nt. G.A. van der Veen (Bal/'t Laaksche Hoogh). 
- door het bevoegde gezag noodzakelijk geachte - vergunningvoorschriften die nog gén (formele) rechtskracht hadden. De leer van de vrijwarende werking van vergunningen werd in dit arrest mijns inziens door de Hoge Raad geenszins verlaten. ${ }^{282}$ Dit laatste kan naar mijn oordeel tot slot evenmin worden afgeleid uit het belangrijke arrest inzake de Kernenergiewetvergunning van Covra NV. ${ }^{283}$ In casu poogde o.m. de 'Stichting Miljoenen zijn tegen' via de burgerlijke rechter in aanvulling op de specifieke vergunning ingevolge de Kernergiewet - tegen welke vergunning (nog) beroep aanhangig was - op basis van een verklaring voor recht, alsmede op basis van gebods- en verbodsacties, extra en andere regels en voorschriften af te dwingen ten aanzien van een semi-permanente opslag van radio-actief afval te Borsele. In cassatie kwam o.a. de vraag aan de orde of zodanige vorderingen, mede tegen de achtergrond van de rechtsmachtverdeling tussen de burgerlijke rechter en de bestuursrechter, toewijsbaar waren. De Hoge Raad stelt in het arrest vóór alles vast dat er géén sprake is van vorderingen strekkende 'tot vergoeding van geleden of te lijden schade of tot vaststelling van aansprakelijkheid van Covra ter zake van de aantasting van concrete belangen van een bepaalde groep burgers...' (curs. R.J.N.S.). $\mathrm{Na}$ vervolgens - kort gezegd - te hebben benadrukt dat de burgerlijke rechter niet de competentie van de bestuursrechter mag betreden, overweegt de Hoge Raad in het arrest ten aanzien van de toewijsbaarheid van de vorderingen:

'Daarbij heeft te gelden dat de vergunninghouder zich in beginsel op het standpunt mag stellen dat de vergunning overeenkomstig de wet is verleend en de overeenkomstig de wet in aanmerking te nemen. belangen door de vergunningverlenende instantie volledig en op de juiste wijze zijn afgewogen, en dat geen plaats is voor voorzieningen als in dit geding gevorderd, zolang hij overeenkomstig de vergunning handelt, maar dat dit anders zal kunnen zijn op grond van bijzondere omstandigheden, waarvan in het onderhavige geval evenwel niet is gebleken. Dit uitgangspunt brengt mee dat de Stichting, die bij de bestuursrechter tegen de vergunning beroep heeft ingesteld, in de procedure voor de burgerlijke rechter haar vorderingen ter zake van voormelde voorzieningen niet kan doen steunen op gronden die in de beroepsprocedure aan de orde zijn gesteld of hadden kunnen worden gesteld. In het bijzonder kan zij in dit geding voor de burgerlijke rechter zich niet erop beroepen dat de overeenkomslig de wet in aanmerking komende belangen op onjuiste wijze zijn afgewogen. (curs. R.J.N.S.)'

Deze rechtsoverwegingen houden mijns inziens verband met de leer van formele rechtskracht. ${ }^{284} \mathrm{De}$ burgerlijke rechter dient niet over identieke rechtsgeschillen te oordelen als de bestuursrechter. Daarom zal in civilibus (de inhoud van) het publiekrechte-

282. Annotator Van der Veen merkt over de door de Hoge Raad voorgestane afstemming het volgende op: 'Met deze afstemming ademt het arrest de sfeer van rechtseenheid. Rechtseenheid is een groot goed, zodat het streven gericht zou moeten zijn op een verdergaande integratie van het zgn. publiek-en privaatrechtelijke burenrecht' (curs. R.J.N.S.). In dit kader mag men echter niet uit het oog verliezen dat in het arrest $\mathrm{Bal} /$ 't Laaksche Hoogh een kort-geding het vertrekpunt was, en niet een bodemprocedure. M.i. aanvaardde de Hoge Raad mede op gronden van processuele efficiency-gronden dat de rechter in kort-geding zijn rechtmatigheidsoordeel mocht afstemmen op de bestuurlijke besluitvorming (vgl. R.O. 3.3.).

283. HR 17 januari 1997, RvdW 1997/24C (Covra NV)

284. Zie paragraaf 9.5 .5 van dit boek. Vgl. op deze plaats i.h.b. HR 8 september 1995, JB 1995/249 (gebruiksvergunning gemeente Utrecht). 
lijke besluit - de vergunning - in de regel gerespecteerd dienen te worden. Het is ook geenszins aan de burgerlijke rechter om in aanvulling op de 'normstelling' krachtens een administratieve wet zelfstandig een soort aanvullende 'vergunning'-voorschriften te gaan stellen. Dit zou leiden tot een ernstige uitholling van het (door het specialiteitsbeginsel gebonden) primaat van het bestuur, hetgeen de Hoge Raad impliciet ook wel onderkent. De burgerlijke rechter zal echter wél steeds kunnen oordelen over de aansprakelijkheid voor daadwerkelijke schade welke ontstaat (of dreigt te ontstaan) door een vergunningplichtige activiteit. De aantasting van concrete (rechts)belangen was in de Covra-zaak echter niet aan de orde.

De relatie tussen het specialiteitsbeginsel, de relativiteitsleer én het leerstuk van de vrijwarende werking van publiekrechtelijke vergunningen wordt nu, gelet op het voorafgaande, in volle omvang duidelijk. Een vergunning kan uitsluitend vrijwaren tegen aansprakelijkheid indien de regeling waarop het vergunningstelsel is gebaseerd - alsmede de aan een vergunning (rechtsgeldig) verbonden voorwaarden (of beter voorschriften) - mede de betrokken gelaedeerde particuliere belangen beogen te beschermen. Dergelijke beschermende werking gaat enkel uit van publiekrechtelijke normstelling voorzover de betreffende particuliere belangposities mede in deze normstelling, na een proces van belangenafweging, zijn verdisconteerd. Of bepaalde particuliere belangen mogen worden betrokken in de bestuurlijke belangenafweging, en bijgevolg in de normstelling verdisconteerd kunnen worden, hangt weer af van de grenzen die het specialiteitsbeginsel stelt aan het proces van bestuurlijke belangenafweging en rechtsvorming. Toegespitst op het bestuurlijke rechtsvormingsproces zou men kunnen stellen dat het specialiteitsbeginsel bepaalt in hoeverre particuliere belangen op het niveau van de rechtsvaststelling door het bestuur kunnen (en mogen) worden beschermd, terwijl de relativiteitsleer deze beschermende werking op het niveau van de normschending (d.w.z. in het 'intersubjectieve' rechtsverkeer) bewaakt. ${ }^{285}$ Jurgens heeft dit als volgt verwoord:

\footnotetext{
'Mijns inziens kan de vraag naar de vrijwarende werking van een vergunning niet los worden gezien van het belang waarop in de onrechtmatige daadsactic een beroep wordt gedaan. Alleen wanneer dit belang, gelet op het wettelijk kader waarop de vergunning is gebaseerd, mocht meewegen bij de besluitvorming die tot de vergunning heeft geleid, kan er überhaupt sprake zijn van een mogelijk vrijwarende werking van de vergunning. In wezen is dit een omgekeerde toepassing van de relativiteitseis: als een bepaald belang niet onder het beschermingsbereik van een norm valt, kan het handelen conform die norm ook nooit meebrengen dat men voor een inbreuk op dat belang niet aansprakelijk is' (curs. R.J.N.S.). ${ }^{286}$
}

Ook Damen heeft het leerstuk van de vrijwarende werking van vergunningen in verband gebracht met het specialiteitsbeginsel, en bijgevolg met de (omvang van de) bestuurlijke belangenafwegingsplicht. Alleen voorzover belangen van burgers zijn (of hadden kunnen worden meegewogen) in de bestuursrechtelijke procedure, verleent de vergunning

285. Vgl. ook R.J.N. Schlossels, Het specialiteitsbeginsel en derde-belangen: een frisse benadering of rechtsstatelijk drijfzand?, NTB 1996/3, p. 92.

286. G.T.J.M. Jurgens, Bestuurlijk gedogen, a.w., p. 177. 
- mogelijk - immuniteit voor civielrechtelijke aansprakelijkheid. Van een 'volledige' verdiscontering van de private rechtssfeer - en de daaraan inherente belangenconflicten in de publieke normstelling zal echter niet gauw sprake zijn. Strikt genomen is dat ook een weinig aantrekkelijk, zelfs onaantrekkelijk, perspectief. Hij merkte in dit kader op:

'Met een dergelijke integrale belangenafweging zou de private sfeer wel in hoge mate worden "gepubliciseerd". Daarmee zou een ongespecificeerde belangenafweging in handen van de administratie komen te liggen, waarmee in hoge mate afbreuk wordt gedaan aan het legaliteitsbeginsel en de in casu van toepassing zijnde variant hiervan, het specialiteitsbeginsel (curs. R.J.N.S.). ${ }^{287}$

Resumerend kan men stellen dat het specialiteitsbeginsel ervoor waakt dat een bestuursorgaan binnen de grenzen van een toegekende discretionaire bestuursbevoegdheid slechts een gespecificeerde afweging van belangen verricht. De specificiteit van de te volvoeren afweging is door de wetgever reeds in abstracto bepaald. Het feit dat een bestuurlijke afweging van belangen gespecificeerd van aard is brengt met zich dat de normstelling op basis van het te verrichten belangenafwegingsproces eveneens specifiek is, in die zin dat slechts bepaalde belangen hierdoor worden beschermd. In de jurisprudentie van de Hoge Raad komt dit (vooralsnog) tot uitdrukking in het leerstuk van de vrijwarende werking van vergunningen. Dit leerstuk is mijns inziens strikt genomen niets meer, en niets minder, dan de civielrechtelijke erkenning door de Hoge Raad van het publiekrechtelijke specialiteitsbeginsel.

\subsection{Enige conclusies}

Indien men de grote hoeveelheid aan jurisprudentie, die relevant is voor de interpretatie van het specialiteitsbeginsel, overziet dan kunnen de navolgende algemene conclusies worden getrokken. Ik teken hierbij aan dat deze conclusies uiteraard nooit volledig recht kunnen doen aan alle nuances in de geanalyseerde uitspraken.

1. In de geanalyseerde jurisprudentie van de verschillende rechterlijke colleges en de Kroon komt de aandacht voor het doelgebonden karakter van bestuursbevoegdheden goed tot uitdrukking. Dit geldt evenzeer voor de gefragmenteerde structuur van de administratieve wetgeving, en de in het kader van deze wetgeving specifiek te reguleren belangenconflicten. Aan bestuursbevoegdheden liggen speciale publiekrechtelijke belangen ten grondslag die door het verantwoordelijke bestuursorgaan dienen te worden behartigd. Welke de betrokken speciale belangen zijn, zal uit de wettelijke bevoegdheidsgrondslag dienen te blijken, dan wel uit de parlementaire geschiedenis van de betreffende wet, of uit de verhouding van deze wet tot andere administratieve wetten. Het behartigen van vreemde publiekrechtelijke belangen leidt snel - maar niet altijd - tot détournement de pouvoir.

2. De uitoefening van een doelgebonden discretionaire bestuursbevoegdheid verplicht in beginsel tot het afwegen in concreto van alle (rechtstreeks) betrokken particuliere belangen tegen de genoemde speciale publiekrechtelijke belangen. Particuliere belangen mogen niet

287. L.J.A. Damen, naschrift onder HR 18 december 1992 (Kuunders), Gst. 6970, p. 410-411. 
'op voorhand' door het bestuur buiten beschouwing worden gelaten, en waar mogelijk dient het bestuursorgaan aan deze belangen tegemoet te komen door een alternatieve wijze van bevoegdheidsuitoefening (beginsel van de 'minste pijn'). Bijkomende voorwaarde is wél dat de betrokken particuliere belangen niet in een te (ver) verwijderd verband tot de bevoegdheidsuitoefening mogen staan (er geldt een causaliteitseis).

3. Indien eenmaal vaststaat dát bepaalde particuliere belangen op een onevenredige (en in vergelijking tot andere rechtssubjecten ongelijke) wijze door een specifieke bevoegdheidsuitoefening worden benadeeld, dan is nadeelcompensatie door het bestuur geboden, voorzover het nadeel redelijkerwijs niet geheel of ten dele ten laste van de betreffende belanghebbende behoort te blijven. De jurisprudentie lijkt ervan uit te gaan dat de plicht tot nadeelcompensatie los staat van de (beperkende) werking van het specialiteitsbeginsel. Er geldt met andere woorden niet de eis dat de belangen door het specifieke bevoegdheidsstelsel worden beschermd. Dit verklaart mijns inziens ten dele de 'rekkelijke' nuances in diverse uitspraken.

4. De uitoefening van een specifieke bestuursbevoegdheid wordt gestuurd door de speciale publiekrechtelijke belangen die aan de betreffende bevoegdheid ten grondslag liggen. Een weigering om een bevoegdheid uit te oefenen zal ten minste mede in deze speciale belangen zijn grondslag dienen te vinden (wederom op straffe van détournement de pouvoir). Voorzover de bevoegdheidsuitoefening is gericht op nadere publieke normstelling (bijv. in de vorm van vergunningvoorschriften), zal deze normstelling in de regel eveneens zijn grondslag in de bedoelde speciale publiekrechtelijke belangen dienen te vinden. Dat het verantwoordelijke bestuursorgaan door middel van gedragsvoorschriften naar eigen inzicht rechtsrelaties tussen particulieren onderling kan reguleren, kan mijns inziens niet uit de jurisprudentie worden afgeleid. De jurisprudentie toont zich wat betreft de voorschriftenproblematiek in hoofdzaak 'precies'. Met het oog op financièle voorschriften is de jurisprudentie in het bijzonder alert op détournement de procedure. Opmerkelijk is in dit kader wél de door de Afdeling bestuursrechtspraak geaccepteerde praktijk van 'burgercompensatie' en 'compensatievoorschriften'. Hier kunnen vanuit rechtsstatelijk oogpunt serieuze vraagtekens bij worden geplaatst. Het betreft hier kennelijk een instrumentalistische rechtsfiguur die de (bestuurlijke) praktijk tevreden stelt. Een nieuwe theoretische bezinning is in dit verband echter wenselijk.

5. Het doelgebonden karakter van bestuursbevoegdheden stelt, onverminderd het feit dat met alle rechtstreeks betrokken belangen van particulieren rekening dient te worden gehouden (in de vorm van een alternatieve wijze van bevoegdheidsuitoefening of nadeelcompensatie), bepaalde grenzen aan het - in rechtsvormende zin - meewegen van particuliere belangen. Sommige belangen lijken naar hun aard en inhoud van afweging te zijn uitgesloten. De jurisprudentie is op dit punt echter - ók onder de Algemene wet bestuursrecht - niet eenduidig. Belangen van rechtssubjecten worden soms buiten de afweging gehouden indien ze in het kader van een andere publiekrechtelijke regeling bescherming vinden. Hier lijkt, mede vanuit een oogpunt van besluitvormingsdoelmatigheid, als uitgangspunt te gelden dat deze belangen in het meest geëigende publiekrechtelijke besluitvormingskader dienen te worden afgewogen. Onduidelijker is de positie van 
particuliere belangen die niet in het kader van andere discretionaire bevoegdhedenkaders kunnen worden meegewogen. Voorzover deze belangen niet samenvallen met de speciale te behartigen publiekrechtelijke belangen ('reflexweking'), lijken zij in jurisprudentie niet zelden op grond van een soort 'Schutznorm'-benadering buiten de afweging te worden gehouden. De redenering is dan, dat de betreffende administratieve wetgeving deze belangen niet beoogt te beschermen. Particuliere belangen werden in dit kader ook wel eens buiten de afweging gehouden omdat zij de appellant 'persoonlijk' betroffen, of omdat zij in een te ver verwijderd verband stonden tot de bevoegdheidsuitoefening (zie onder punt 2). Voorzover 'normvreemde' belangen van particulieren al niet geheel buiten de afweging dienen te blijven, mag aan deze belangen volgens de jurisprudentie géén doorslaggevende of beslissende betekenis in het kader van de (gerichte) publieke rechtsvorming toekomen. Overigens lijkt de Schutznormbenadering geleidelijk aan belang in te boeten, daar de Afdeling bestuursrechtspraak zich nogal 'rekkelijk' opstelt.

6. De jurisprudentie getuigt mijns inziens tot slot van een scheiding tussen de door het specialiteitsbeginsel beheerste publieke normenstelsels enerzijds, en private normenstelsels anderzijds. Uit de (administratieve) jurisprudentie blijkt mijns inziens dat een doelgebonden bestuursbevoegdheid niet legitimeert om door het privaatrecht beheerste rechtsgeschillen tussen belanghebbenden 'mee te nemen' in de publieke besluitvorming en normstelling. Deze constatering wordt - zij het 'in spiegelbeeld' - bevestigd door de civielrechtelijke jurisprudentie van de Hoge Raad inzake de vrijwarende werking van publiekrechtelijke vergunningen. 



\section{Hoofdstuk 9}

\section{Het specialiteitsbeginsel: een rechtspolitiek dilemma?}

\subsection{Inleiding}

In het laatste hoofdstuk van dit boek zal ik op basis van de inzichten die ontleend kunnen worden aan enerzijds de literatuuranalyse en het jurisprudentie-onderzoek ${ }^{1}$, en anderzijds aan de meer algemene beschouwingen in de hoofdstukken 2 tot en met 6 een eigen visie inzake de 'specialiteitsproblematiek' uiteen zetten. Ik concentreer mij hierbij op de beantwoording van de vraag welke grenzen het specialiteitsbeginsel stelt, of (wellicht beter) behoort te stellen, aan het proces van belangenafweging door het bestuur in het kader van de uitoefening van een discretionaire beschikkingsbevoegdheid. ${ }^{2}$ Wat betreft de beantwoording van deze vraag bestaan in de bestuursrechtelijke literatuur, zoals in hoofdstuk 7 bleek, aanzienlijke verschillen van mening.

De gedachtenvorming in dit afsluitende hoofdstuk is (mede) gebaseerd op standpunten die ik reeds in enkele voorpublicaties en noten uiteen heb gezet ${ }^{3}$, waarbij ik opmerk dat naarmate het schrijven van dit boek vorderde er uiteraard bijstellingen hebben plaatsgevonden. Voorts zijn de denkbeelden, waar nodig, verder uitgewerkt en op een aantal punten - mede naar aanleiding van reacties in de literatuur - nader onderbouwd, danwel verfijnd.

\subsection{Enkele uitgangspunten vooraf}

Aan mijn standpunt over het specialiteitsbeginsel liggen enkele uitgangspunten ten grondslag die ik in herinnering roep. In dit boek is allereerst uitgegaan van een principiële scheiding tussen enerzijds publiekrechtelijke belangen en anderzijds subjectgebonden rechtsbelangen. Toegespitst op het publieke recht kan worden gesteld dat enkel de publiekrechtelijke belangen ten grondslag liggen aan (specifieke) bestuursbevoegdheden. Deze

1. Zie respectievelijk de hoofdstukken 7 en 8 van dit boek.

2. Vgl. de tweede probleemstelling zoals verwoord in hoofdstuk 1.

3. Zie: R.J.N. Schløssels, Wederkerigheid en specialiteit in het bestuursrecht, in: Eenzijdig en wederkerig? (red. E.C.H.J. van der Linden en A.Q.C. Tak), Deventer 1995, p. 153-190; R.J.N. Schlठssels, Het specialiteitsbeginsel en derde-belangen: een frisse benadering of rechtsstatelijk drijfzand?, NTB 1996/3, p. 81-96; R.J.N. Schlठssels, Een dakkapel te Edam: de wens van eenheid van recht?, in: Rechtspraak bestuursrecht 1995-1996. De annotaties, 's-Gravenhage 1997, p. 65 e.v. en R.J.N. Schlossels, Stek \& Co (reactie 3). Een geval van kruisbestuiving?, Gst. 1996/7036, p. 391-393. Zie verder mijn noten onder: Pres. Rb. Maastricht 24 februari 1995, JB 1995/111, m.nt. R. Schlðssels (cafébedrijf Meers); ABRS 9 februari 1996, JB 1996/82, m.nt. R. Schlossels (dakkapel Edam); ABRS 1 april 1996, JB 1996/155, m.nt. R.J.N.S. (duivenhok Velp); Rb. Utrecht 12 april 1996, JB 1996/150 (opslagloods IJsselstein); Rb. Maastricht 14 augustus 1996, JB 1996/196 (schuur Mechelen); Rb Roermond 27 september 1996, JB 1996/225 (herplantplicht Nederweert) en Rb. Amsterdam 2 oktober 1996, JB 1996/263 (de Houtkoper). 
belangen, die in de regel expliciet ingevolge constitutionele procedures op een democratische wijze worden vastgesteld, sturen het gerichte bestuurlijke rechtsvormingsproces binnen de publieke rechtsgemeenschap. ${ }^{4}$ Het zijn deze belangen, en gén andere, die door de verantwoordelijke bestuursorganen op basis van een gedifferentieerde bevoegdhedenstructuur worden behartigd in het algemeen belang van de leden-rechtssubjecten van het staatsverband.

Het specialiteitsbeginsel brengt als rechtsstatelijk beginsel met zich dat de wetgever de bevoegdheden van het bestuur vóoraf bindt aan specifieke publiekrechtelijke belangen. In hoofdstuk 4 zijn in dit kader verschillende argumenten aangedragen ter adstructie van een dergelijke constitutionele specificeringsplicht. In dit verband is het standpunt ingenomen dat het staatsrechtelijke legaliteits- 'beginsel', toegespitst op de grondslag van bestuursbevoegdheid, enkel een ondersteunend staatsrechtelijk principe is dat dienstig is aan enerzijds de operationalisering van het democratisch postulaat en anderzijds aan het specialiteitsbeginsel. ${ }^{5}$ Dit laatste beginsel geeft ten principale invulling aan de grondstructuur van de bestuursorganisatie binnen de democratische-rechtsstaat, alsmede aan de aan deze staatsconceptie inherente scheiding tussen een publieke statelijke sfeer en een vrije, gedifferentieerde, burgerrechtelijke sfeer (de maatschappij). Voor het rechtsstatelijke bestuur geldt derhalve steeds het uitgangspunt van taak- én bevoegdheidsspecificiteit. ${ }^{6}$ Hiermee is een antwoord geformuleerd op de eerste probleemstelling van dit boek, die luidde:

'Welke betekenis moet aan het specialiteitsbeginsel als - verondersteld - rechtsstatelijk beginsel worden toegekend?'

Binnen de publieke rechtsorde komen twee - naar hun rechtsaard - verschillende sferen van normatief-relevante belangen met elkaar in aanraking. Naast de publiekrechtelijke belangen zijn dat de typische rechtsbelangen van (private) rechtssubjecten. ${ }^{7}$ Op deze

4. Onder gerichte bestuurlijke rechtsvorming versta ik de door de statelijke bestuursorganen gernitieerde rechtsvorming op basis van specifieke doelgebonden bestuursbevoegdheden. Deze bevoegdheden kunnen een beschikkings- of regelgevingskarakter hebben. Ik wijs er - wellicht ten overvloede - op dat $66 \mathrm{k}$ de rechter in het licht van zijn statelijke functies recht vormt, maar deze rechtsvorming is niet doelgerichtregulerend maar primair geschilbeslechtend van aard. Uiteraard formuleert de rechter, in het kader van de uitoefening van zijn geschilbeslechtende functie, soms scherpe - meer algemene - 'regels' maar deze beogen niet het gedrag van rechtssubjecten gericht te reguleren. $\mathrm{Zij}$ kunnen wel een 'kenbron van recht zijn'. Vanuit dit perspectief bezien is de rechtspraak van de bestuursrechter ten opzichte van het bestuur, dat steeds het rechtsvormings-initiatief neemt, juridisch sturend van aard. In dit verband dient tot slot wel te worden gewezen op de feitelijke precedentwerking van rechterlijke uitspraken. Vgl. de studie van A.R. Neerhof, Het geschil voorbij. Een studie naar de bruikbaarheid van bestuursrechtelijke jurisprudentie als kenbron van recht, diss. RUG, Deventer 1995.

5. En in ruimere zin $66 \mathbf{k}$ aan algemene rechtsbeginselen waaronder i.h.b. het rechtszekerheidsbeginsel, het verbod van willekeur (het consistentiebeginsel) en het gelijkheidsbeginsel.

6. Vgl. hoofdstuk 4 waar werd geconcludeerd dat aan de constitutionele specificiteitseis, afhankelijk van de in het geding zijnde rechtsbelangen van burgers en de (ingrijpende) aard van een bestuursbevoegdheid, hogere of lagere eisen dienen te worden gesteld (vgl. m.n. paragraaf 4.5). 
plaats dient in herinnering te worden geroepen dat het gerichte bestuurlijke proces van rechtsvorming gerelateerd is aan de verschillende rechtsbelangen van de onderscheiden rechtssubjecten. Doelgerichte publieke rechtsvorming beoogt immers per definitie vanuit een bovenindividueel perspectief de wereld van de subjectieve rechtsbelangen te reguleren, waar nodig te ordenen en in ruime zin te harmoniseren. Dit fundamentele uitgangspunt brengt met zich dat in het kader van de uitoefening van een (discretionaire) bestuursbevoegdheid steeds met de rechtstreeks betrokken rechtsbelangen van rechtssubjecten rekening behoort te worden gehouden. ${ }^{8}$

\subsection{De betekenis van het specialiteitsbeginsel voor de bestuurlijke rechtshandeling}

Welke betekenis komt nu ten principale toe aan het specialiteitsbeginsel? Het antwoord op deze vraag moet mijns inziens gezocht worden in de aard van de bestuurlijke bevoegdheidsuitoefening en in de (gelaagde) structuur van de gerichte publieke rechtsvorming in ruimere zin. De bevoegdheidsuitoefening in het bestuursrecht is vóór alles een rechtens relevante én krachtens ambtswil beoogde handeling die gericht is op specifiekerechtsgevolgen. ${ }^{9}$ Als doelgebonden rechtshandeling vindt zij haar causa exclusief in de rechtswil van een competent bestuursorgaan. Het betreft een publiekrechtelijkerechtshandeling, omdat de bevoegdheidsuitoefening begrensd én genormeerd wordt door de regels en beginselen van het objectieve publiekrecht. De publieke rechtshandeling, die geïmmuniseerd is tegen de psychologische wil van de ambtsdrager ${ }^{10}$, deelt in dit objectiefrechtelijke karakter. $\mathrm{Zij}$ is nl. altijd gericht op de vorming van nieuw objectief publiekrecht. ${ }^{.1}$

Het specialiteitsbeginsel is vanuit dit perspectief bezien als structuurbeginsel van bestuursbevoegdheid in belangrijke mate bepalend voor de (mogelijke) inhoud van het publiekrechtelijke rechtshandelen. ${ }^{12}$ Nieuw door een bestuursorgaan te vormen rechtsvoorschriften dienen nl., op straffe van détournement de pouvoir ${ }^{13}$, herleidbaar te zijn tot het doel van de betreffende competentienorm. Tegen deze achtergrond brengt het specialiteitsbeginsel de volstrekte afwezigheid van originaire autonomie ${ }^{14}$ aan de zijde van de bestuursorganisatie tot uitdrukking. In dit kader is tevens het inzicht van belang dat de bestuurlijke bevoegdheidsuitoefening als beoogde rechtens relevante handeling (d.w.z.

7. Vgl, hoofdstuk 3 en 6 (i.h.b. de paragrafen 3.5.1 en 6.4.2).

8. Vgl. hoofdstuk 6, paragraaf 6.3.5.

9. Vgl. hoofdstuk 2 (i.h.b. paragraaf 2.4).

10. Vgl. HR 26 juni $1964, \mathrm{AB} 1965$ p. 647 e.v. Uit dit arrest blijkt dat een - achteraf - door de ambtsdrager aan een publieke rechtshandeling (vergunning) gegeven uitleg, niet bepalend is voor de inhoud daarvan.

11. Het kan hier gaan om de vorming van nieuwe publiekrechtelijke normen (in abstracto) of om het geven van voorschriften en rechtsvaststelling 'in concreto'.

12. Ik verwijs naar hoofdstuk 2 van dit boek waar werd gesteld dat het specialiteitsbeginsel tot uitdrukking komt in het 'functionele' kenmerk (d.w.z. het doel) van een publieke bevoegdheidsnorm. De inhoud van het bestuurlijke rechtshandelen wordt, afgezien van het doel, bijv. ók begrensd door het onderwerp van de bevoegdheidsnorm.

13. Zie hoofdstuk 5.

14. Vgl. hoofdstuk 2, paragraaf 2.5.1. 
rechtshandeling) enkel rechtsgevolgen mag bewerkstelligen die herleidbaar zijn tot de procedureel én materieel (door de wetgever) geconditioneerde bevoegdheidsnorm. Dit uitgangspunt geeft invulling aan het democratisch-rechtsstatelijke primaat van de wetgever, die de bestuurlijke rechtsvorming op hoofdlijnen aanstuurt en legitimeert. ${ }^{15} \mathrm{Hierna}^{16} \mathrm{zal}$ ik er overigens nog expliciet de aandacht op vestigen dat de rechtsgevolgen van een bestuurlijke bevoegdheidsuitoefening niet alleen voortvloeien uit de betreffende doelgebonden bevoegdheid, maar natuurlijk ók uit ongeschreven beginselrecht (bijv. de algemene beginselen van behoorlijk bestuur). Op deze plaats laat ik dit nog even rusten. Van belang is in dit verband dat het specialiteitsbeginsel ten grondslag ligt aan het specifieke rechtshandelen door een bestuursorgaan. Dit specifieke rechtshandelen, dat in de regel gebaseerd is op een expliciete wettelijke bevoegdheidsgrondslag, is 'ingebed' in een ruimere publiekrechtelijke rechtsgrond, waaraan het bestuursorgaan eveneens gebonden is (denk aan het 'handelen in het algemeen belang en aan de publieke beginselnormen).

De rechtsvormende functie van een bestuursorgaan komt tot uitdrukking in een objectiefrechtelijke conditionele bevoegdheidsnorm. De orgaanfunctie zelf is bijgevolg onlosmakelijk verbonden met de normzijde van het publieke recht. ${ }^{17}$ Deze functie brengt mijns inziens met zich dat een bestuursorgaan niet als partij participeert aan het rechtsverkeer tussen rechtssubjecten onderling. Ook kan het orgaan niet worden aangemerkt als een participant aan een 'wederkerige' rechtsbetrekking. ${ }^{18}$ Het orgaan reguleert het rechtsverkeer tussen rechtssubjecten immers vanuit een bovendindividueel en onpartijdig perspectief in dienst van de bestemmingsfunctie van de staat. ${ }^{19}$ Aan een bestuursorgaan komt bijgevolg binnen het rechtsverkeer géén - passieve - rechtssubjectiviteit toe, zodat participatie als subject aan rechtsbetrekkingen met rechtssubjecten op basis van gelijkheid is uitgesloten. Een bestuursorgaan fungeert met andere woorden niet als een zelfstandige drager van 'eigen' rechten, en typische rechtsbelangen. ${ }^{20}$

\subsection{Bestuurlijke bevoegdheidsstelsels nader beschouwd}

Om door te dringen tot de betekenis van het specialiteitsbeginsel voor het bestuurlijke 'rechts'-handelen, is het zinvol om de karakteristieken van bestuurlijke bevoegdheidsstelsels met een typisch beschikkingskarakter nader te analyseren.

15. Vgl. hoofdstuk 4, paragraaf 4.3 .

16. Zie: paragraaf 9.6 .

17. Vgl. hoofdstuk 3, paragraaf 3.2.4.

18. Zie: paragraaf 2.5.6.

19. Anders bijv. Foqué die de overheid uitdrukkelijk heeft gepositioneerd als een actor die 'te midden van een pluraliteit van burgers en belangen in de publieke ruimte handelt'. Zie: R. Foqué, De ruimte van het recht, oratie EUR, Arnhem 1992, p. 36. Vgl. in dit kader meer uitvoerig hoofdstuk 2 van dit boek waar ik afstand nam van de idee van een 'wederkerige' rechtsbetrekking in het bestuursrecht tussen bestuursorgaan en rechtssubjecten (vgl. paragraaf 2.5 .4 e.v.).

20. Vgl. Nicolar e.a., Bestuursrecht, zesde geheel herziene druk, Amsterdam 1997, p. 7. 


\subsection{De karakteristiek van een (discretionair) bevoegdheidsstelsel}

Bevoegdheidsstelsels waaraan een bestuursorgaan een discretionaire beschikkingsbevoegdheid ontleent kunnen (globaal) onderverdeeld worden in een drietal hoofdtypen. ${ }^{21}$ Allereerst is er het type waarbij een voorafgaande verbodsnorm een bepaalde feitelijke activiteit (van een rechtssubject) verbiedt. Dit verbod kan door het bestuursorgaan, al dan niet onder een bepaald regime van voorschriften, worden opgeheven (vergunning- en ontheffingstelsel). ${ }^{22}$ Vervolgens zijn er stelsels die een bestuursorgaan de bevoegdheid verlenen tot het geven van bepaalde ge- of verboden, het opleggen van bepaalde verplichtingen of het vaststellen van een aspect van een rechtspositie (status), zonder dat er sprake is van een voorafgaande verbodsnorm. Tot slot zijn er stelsels op basis waarvan een bepaalde feitelijke activiteit financieel kan worden 'begunstigd'. Hier zijn de typische subsidie- en uitkeringsstelsels in het geding. Ook financiële 'begunstiging' kan vaak plaatsvinden onder een bepaald regime van voorschriften.

Typerend voor alledrie de stelsels is het gegeven dat een bepaalde 'feitelijke' activiteit (nl. het rechtsfeit dat de bevoegdheidsuitoefening activeert) in het licht van een speciaal publiekrechtelijk belang wordt gereguleerd. ${ }^{23}$ Dit is $\mathrm{nl}$. de essentie van ieder bestuurlijk bevoegdheidsstelsel. Deze regulering vindt primair plaats door gerichte publieke rechtsvorming in concreto. Hierbij kan gedacht worden aan het opheffen van een verbod (onder voorschriften), dan wel het bindend vaststellen van een status of een (geldelijke) aanspraak. Steeds is er sprake van beoogde publieke rechtsgevolgen.

Ten aanzien van het eerste type bevoegdheidsstelsel (het vergunning- en ontheffingstelsel) dient te worden vastgesteld dat de verbodsnorm hier slechts kan worden aangemerkt als een ondersteunende norm die het mogelijk maakt om de inhoudelijke - nog onvoltooide - (doelgebonden) bevoegdheidsnorm te vertalen in voorschriften in concreto. Een dergelijke norm bevat slechts een relatief verbod. De in beginse ${ }^{24}$ vrije activiteit van een rechtssubject kan $\mathrm{nl}$. vanuit publiekrechtelijk perspectief enkel definitief worden verboden of beperkt met het oog op het speciale (samengestelde) publiekrechtelijke belang dat beslo-

21. Andere - meer gedetailleerde - onderverdelingen zijn uiteraard denkbaar. Vgl. bijv. J.B.J.M. ten Berge, Besturen door de overheid, Nederlands algemeen bestuursrecht 1, tweede druk, Deventer 1997, p. 156158. Ik laat de zgn. 'indirecte' bestuursbevoegdheden, d.w.z. de bestuursbevoegdheden die de uitoefening van andere bestuursbevoegdheden tot onderwerp van regulering hebben, hier buiten beschouwing.

22. In dit verband wordt er vanuit gegaan dat een vergunningstelsel niet ten principale verschilt van een ontheffingstelsel of een vrijstellingsstelsel. Het enige verschil zou men kunnen samenvatten als: 'vergunning' is regel, en 'ontheffing' is uitzondering. Voor de theoretische benadering maakt dit op deze plaats weinig verschil. Zie over de relativering van het onderscheid tussen 'vergunning' en 'ontheffing' o.m. H.D. van Wijk, Hoofdstukken van administratief recht, eerste druk, 's-Gravenhage 1968, p. 64-65.

23. Zie hierover: G.H. Addink en J.D.M. Steenbergen, Beperkingen van bevoegdheden: Een onderzoek van administratieve wetgeving, Bestuurswetenschappen 1985/7, p. 438 e.v.

24. In beginsel, omdat de activiteiten van rechtssubjecten in het 'intersubjectieve' rechtsverkeer onverminderd de toepasselijkheid van een publiekrechtelijk vergunningstelsel worden gereguleerd door de private (burgerrechtelijke) rechtsnormen. Vgi. hoofdstuk 8 (paragraaf 8.8 .4 wat betreft de leer van de vrijwarende werking van vergunningen). 
ten ligt in de doelstelling van de bevoegdheid. ${ }^{25}$ De ondersteunende verbodsnorm strekt er bijgevolg enkel toe om de te reguleren 'feitelijke' activiteit te 'blokkeren' totdat een publiekrechtelijk voorschriftenregime in concreto door het bestuursorgaan tot stand is gebracht. Vergunningverlening impliceert bijgevolg géen echte begunstiging ${ }^{26}$, doch slechts een (gedeeltelijk) herstel van de originaire - of materie̋le (private) - vrijheid van een rechtssubject zoals deze reeds bestond, voordat het publieke vergunningstelsel door de wetgever in het algemeen belang tot stand werd gebracht.

Een vergelijkbaar uitgangspunt geldt voor het tweede type bevoegdheidsstelsel. Het enige verschil met het typische vergunning- of vrijstellingsstelsel is gelegen in het feit dat een ondersteunende verbodsnorm in dit type stelsel ontbreekt. Rechtsvorming in concreto is binnen dit stelsel echter eveneens gebonden aan het doel van de betreffende bestuursbevoegdheid. Ook hier geldt weer dat concretiserende (gerichte) rechtsvorming exclusief in het teken behoort te staan van de behartiging van een speciaal publiekrechtelijk belang. Zo zal een aanschrijving tot het treffen van voorzieningen ten aanzien van een woning op grond van artikel 14 lid 1 van de Woningwet ten dienste moeten staan van de publiekrechtelijke belangen die ingevolge artikel 2 van de Woningwet (mogen) worden behartigd (woningbouwtechnische en veiligheidsbelangen).

Bij het derde type bevoegdheidsstelsel kan tenslotte de materiele vrijheid van een rechtssubject worden 'verruimd' in die zin dat de (financiele) randvoorwaarden voor de te verrichten feitelijke activiteit aan de hand van objectieve publiekrechtelijke maatstaven worden geoptimaliseerd. Ook hier treedt de democratisch gelegitimeerde publieke regulering op de voorgrond. Een bevoegdheidsuitoefening in positieve en negatieve zin is binnen dit stelsel legitiem voorzover de (bevoegdheids)norm zich daartegen niet verzet. Uitsluitend het speciale publiekrechtelijke belang dat in deze norm ligt besloten kan verhinderen dat 'begunstiging' (vrijheidsverruiming) plaatsvindt. Dit belang legitimeert mijns inziens $666 \mathrm{k}$ in positieve zin de rechtsvorming in concreto. Zo zal de toekenning van een subsidie steeds dienstig moeten zijn aan het publiekrechtelijke doel dat met het subsidiestelsel wordt nagestreefd. ${ }^{27}$

\subsubsection{Bindende (gedrags)voorschriften en voorwaarden}

Van belang is het inzicht dat een 'secundaire' publieke bevoegdheidsnorm binnen een discretionair bevoegdheidsstelsel de exclusieve basis biedt voor de specifieke (gerichte)

25. Zie: R.J.N. Schlössels, Het specialiteitsbeginsel en derde-belangen: een frisse benadering of rechtsstatelijk drijfzand?, a.w., p. 88. Vgl. in gelijke zin A.Q.C. Tak, De overheid in het burgerlijk recht, 's-Gravenhage 1997, p. 392.

26. Vaak wordt in de literatuur de vergunning aangeduid onder de m.i. weinig gelukkige aanduiding 'begunstigende beschikking'. Vgl. bijv. H.D. van Wijk, Hoofdstukken van administratief recht, eerste druk, a.w., p. 64 .

27. Vgl. 4:23 Awb (derde tranche). Ook de subsidiebevoegdheid is immers door de wetgever goeddeels binnen de werkingssfeer van het legaliteitsbeginsel gebracht. 
rechtsvormende activiteit van het bestuur. ${ }^{28}$ Deze norm is naar haar aard echter niet direct toepasbaar in de concrete situatie. Zij dient nader geconcretiseerd te worden gelet op alle relevante omstandigheden van het geval. In dit verband dient het verantwoordelijke bestuursorgaan, nadat is vastgesteld dat de toepassingscondities van een bevoegdheid door het feitencomplex in concreto zijn vervuld ${ }^{29}$, de verschillende rechtstreeks betrokken rechtsbelangen van rechtssubjecten in kaart te brengen. Met deze belangen dient het bestuursorgaan rekening te houden voorzover de (secundaire) bevoegdheidsnorm zich daar niet tegen verzet.

In dit verband lijkt mij allereerst van belang dat subjectgebonden (private) rechtsbelangen de gerichte rechtsvorming niet kunnen legitimeren. Deze belangen kunnen derhalve geén zelfstandige grondslag vormen voor de weigering een bevoegdheid uit te oefenen, het uitoefenen van de bevoegdheid, dan wel het stellen van bindende voorschriften in het kader van de bevoegdheidsuitoefening. Zou dit wél worden aanvaard dan zou dit tevens impliceren dat de scheiding tussen typisch publieke en private rechtsvorming wordt losgelaten en dat er bijgevolg rechtsonzekerheid ontstaat over de omvang van de specifieke bestuursbevoegdheid. De doelgebonden bestuursbevoegdheid zou met andere woorden worden gedenatureerd. Met De Planque ${ }^{30}$ ben ik in dit kader van mening dat het ook gén staatsrechtelijke taak van het bestuur is om typisch private rechtsgeschillen, die voortvloeien uit private rechtsnormen welke gelden tussen rechtssubjecten onderling, op basis van een bestuursbevoegdheid te beslechten door bindende (gedrags) voorschriften te stellen. In paragraaf 9.5.3 e.v. zal ik hier op terugkomen.

Rechtsvorming in concreto door een bestuursorgaan, d.w.z. het stellen van bindende voorschriften ten aanzien van een rechtssubject wiens activiteiten worden gereguleerd, kan mijns inziens enkel plaatsvinden op basis van een doelgebonden bevoegdheidsnorm die haar materiële rechtsgrond vindt in de bestemmingsfunctie van de publieke rechtsgemeenschap en haar formele grondslag - in verband met de rechtszekerheid - bij voorkeur in de wet. Bindende voorschriften die door een bestuursorgaan in dit kader worden gesteld ontlenen hun bindende en éénzijdig afdwingbare rechtskarakter enkel aan deze (discretionaire) bevoegdheidsnorm. ${ }^{31}$ In deze norm ligt $\mathrm{nl}$. een zelfstandige, doch vooraf

28. In hoofdstuk 2 is het normtheoretische begrip 'secundaire norm' besproken. Uiteraard blijft de overheid - naast de binding aan deze specifieke bevoegdheidsgrondslag - tevens gebonden aan de algemene (materiele) rechtsgrond voor overheidsactiviteit. Deze omvat in ieder geval de plicht om algemene rechtsbeginselen, algemene beginselen van behoorlijk bestuur en grondrechten in acht te nemen, alsmede het legitimerende publiekrechtelijke principe van 'handelen in het algemeen belang'. Vgl. A.Q.C. Tak, Het moment X, TrO 1990/6, p. 135.

29. Vgl. het gestelde over 'beoordelingsruimte' en 'beoordelingsvrijheid' in hoofdstuk 6.

30. Zie: hoofdstuk 7, paragraaf 7.2.9.

31. Anders: F.J. van Ommeren, De verplichting verankerd. De reikwijdte van het legaliteitsbeginsel en het materiele wetsbegrip, diss. VU, Deventer 1996, i.h.b. p. 342-351. Van Ommeren, die m.i. de betekenis van het (formele) legaliteitsbeginsel op dit punt enigszins verabsoluteert, verdedigt het standpunt dat verplichtende voorwaarden hun bindende werking - bij het ontbreken van een specifieke wettelijke machtiging - ontlenen aan een 'eenzijdige overeenkomst' (wilsovereenstemming) tussen bestuur en burger (a.w., p. 351). Opvallend is in dit kader dat Van Ommeren - in navolging van Vegting - de éénzijdige 
begrensde (de vrijheid tot!), rechtsvormende statelijke orgaancompetentie besloten. Tenzij de wettelijke bevoegdheidsgrondslag het stellen van voorschriften expliciet uitsluit, dient er daarom vanuit te worden gegaan dat de aanwezigheid van beleidsvrijheid het bestuursorgaan in beginsel ${ }^{32}$ machtigt tot rechtsvorming in concreto op voorwaarde dat de te stellen voorschriften niet in strijd zijn met het doel van de betreffende bestuursbevoegdheid én de overige materiële normkenmerken. ${ }^{33}$ Uit de jurisprudentie-analyse in hoofdstuk 8 van dit boek blijkt mijns inziens dat dit uitgangspunt in essentie breed door de administratieve rechters wordt gedeeld.

In dit verband kan men zich afvragen in hoeverre het bestuur door het specialiteitsbeginsel wordt beperkt in zijn mogelijkheden tot het stellen van voorwaarden, die niet kunnen worden aangemerkt als bindende (en afdwingbare) gedragsvoorschriften. Onder 'voorwaarden' versta ik in dit kader de door een bestuursorgaan ${ }^{34}$ te stellen condities waarvan de uitoefening van een specifieke bestuursbevoegdheid (vooraf) afhankelijk wordt gesteld. Een mooi voorbeeld bieden in dit kader de in praktijk nogal eens voorkomende 'voorwaarden' die verbonden worden aan een bestuurlijke gedoogverklaring. De voorwaarden waaronder een dergelijke gedoogverklaring soms wordt afgegeven lijken verdacht veel op echte 'vergunningvoorschriften' maar dienen hiervan, gelet op hun rechtskarakter, goed te worden onderscheiden. ${ }^{35}$ De bevoegdheid tot gedogen ligt nl., naar

beschikkingshandeling loskoppelt van de aanvaarding van de (inhoud van de) beschikking door de rechtssubjecten. Dit impliciete 'wederkerigheidsdenken' doet m.i. te weinig recht aan het machtskritische aspect van de bevoegdheidsuitoefening, alsmede aan de 'erga omnes'-functie van de publiekrechtelijke belangbehartiging. In hoeverre kán een rechtssubject zijn wil ten opzichte van het bestuur immers in 'vrijheid' bepalen? Vgl. in dit verband ook de bespreking van het proefschrift van Van Ommeren door M.B. Nijhof, NTB 1997/10, i.h.b. p. 395. Nijhof wijst er m.i. terecht op dat aan beschikkingen met een wettelijke grondslag (steeds) door het bestuur verplichtende voorwaarden gekoppeld mogen worden indien deze binnen de strekking en het doel van de wet vallen. Een extra wettelijke machtiging is hiervoor niet vereist.

32. Tenzij de aard van de betreffende bevoegdheid (bijv. bij een strikt gebonden bevoegdheid) zich daartegen verzet ofwel de wet uitputtend (limitatief) voorschrijft welke voorschriften toelaatbaar zijn.

33. Ik hanteer het verbod van détournement de pouvoir hier dus strikt. Ik kan mij bijgevolg goed vinden in de duidelijke stellingname van Van Wijk. Zie: H.D. van Wijk, Hoofdstukken van administratief recht, eerste druk, a.w., p. 82. Overigens betreft het hier nog steeds een algemeen aanvaard bestuursrechtelijk uitgangspunt. Vgl. o.m. J.B.J.M. ten Berge, Besturen door de overheid, a.w., p. 162; P. Nicolar c.s., Bestuursrecht, zesde geheel herziene druk, Amsterdam 1997, p. 197-198. Van Wijk/Konijnenbelt/Van Male, Hoofdstukken van administratief recht, tiende druk, 's-Gravenhage 1997, p. 231. De vraag naar de toelaatbaarheid van het verbinden van voorschriften aan een beschikking wordt in het Duitse bestuursrecht in soortgelijke zin beantwoord. Zie: H. Maurer, Allgemeines Verwaltungsrecht, 11. Auflage, Munchen 1997, p. 317-319 en 323-324. Van bijzonder belang is dat het Duitse Verwaltungsverfahrensgesetz (VwVfG) uitdrukkelijk bepaalt dat een voorschrift ('Auflage') niet in strijd mag zijn met het doel van een Verwaltungsakt ( $\$ 36.3 \mathrm{VwVfG}$ ).

34. Doordat voorwaarden 'door' het bestuursorgaan worden gesteld voorafgaande aan de eigenlijke bevoegdheidsuitoefening dienen deze - voorzover de wet ze niet toestaat - vanuit rechtsstatelijk oogpunt steeds uiterst kritisch te worden benaderd.

35. Zie: G.T.J.M. Jurgens, Bestuurlijk gedogen. Aanvaardbaarheid en gevolgen van bestuurlijk gedogen in het milieurecht en het ruimtelijk bestuursrecht, diss. UU, Zwolle 1996, p. 158-159. 
algemeen wordt aangenomen, besloten in de (discretionaire) bestuursbevoegdheid tot handhaven. ${ }^{36}$ Indien het bestuur besluit om onder voorwaarden af te zien van handhaving (en dus te gedogen), dan zijn deze voorwaarden - zoals Jurgens signaleert - géén nieuwe bindende en op zelfstandige wijze afdwingbare normen die in de plaats komen van de te handhaven (wettelijke) voorschriften. ${ }^{37}$ Naleving van deze voorwaarden is niet verplicht en voorkomt enkel dat tot handhaving wordt overgegaan. Gelet op het onderwerp van dit boek is het de vraag in hoeverre het stellen van dit soort 'voorwaarden' door het specialiteitsbeginsel wordt beperkt.

Jurgens komt in haar proefschrift niet tot een stellig antwoord. $Z \mathrm{ij}$ ziet de handhavingsbevoegdheid als een vrije bevoegdheid die ruimte biedt om alle belangen die gebaat zijn bij handhaving af te wegen tegen de belangen die hiermee niet gebaat zijn. Wél is zij de mening toegedaan dat eventuele gedoogvoorwaarden ertoe moeten strekken om de belangen die met handhaving zouden zijn gebaat alsnog zo goed mogelijk tot hun recht te laten komen. ${ }^{38}$ Dit lijkt mij in ieder geval een belangrijke aanzet in de juiste richting. Zoals ik eerder betoogde ${ }^{39}$ dient het verbod van détournement de pouvoir mijns inziens ten aanzien van deze voorwaarden analoog te worden toegepast, in die zin dat bijv. ók gedoogvoorwaarden steeds moeten strekken tot bescherming van de (publiekrechtelijke) belangen die door het onderliggende (overtreden) wettelijke voorschrift worden beschermd. Op deze wijze wordt $\mathrm{nl}$. voorkomen dat het handhavende bestuur 'de facto' vreemde beleidsdoeleinden gaat nastreven (onder de 'dreiging' van handhaving) en daarmee de handhavingsbevoegdheid denatureert. Dit standpunt neem ik eveneens in ten aanzien van andere voorwaarden. ${ }^{40}$

\subsubsection{Publiekrechtelijke regulering en 'reflex'-rechten}

Tegen de hiervoor geschetste achtergrond kan de positie van rechtssubjecten in relatie tot het bestuurlijke 'rechts'-handelen nader worden bepaald. Hiervoor is het noodzakelijk om de (discretionaire) bevoegdheidsnorm duidelijk te positioneren binnen de 'rechtsverhouding' die binnen het objectieve publiekrecht bestaat tussen een bestuursorgaan en een (eventuele) kring van rechtstreeks bij een bevoegdheidsuitoefening betrokken rechtssubjecten.

Deze relatie kan, toegespitst op beschikkingsbevoegdheid, vaak worden vergeleken met een driehoek. ${ }^{41}$ Met het oog hierop is het inzicht van belang dat de 'horizontale' rechtsrelaties tussen de betrokken - particuliere - rechtssubjecten (de 'basis' van de driehoek) van origine beheerst worden door rechtsnormen die hun materiële rechtsgrond vinden in

36. Vgl. bijv. P.J.J. van Buuren, Gedogend besturen, oratie UU, Deventer 1988, p. 11.

37. G.T.J.M. Jurgens, Bestuurlijk gedogen, a.w., p. 32.

38. G.T.J.M. Jurgens, Bestuurlijk gedogen, a.w., p. 32.

39. Zie mijn noot onder Rb. Amsterdam 28 januari 1997, JB 1997/61 (gedoogbeschikkingen raamprostitutiebedrijven Amsterdam).

40. Vgl. het standpunt in de jurisprudentie t.a.v. 'financiele voorwaarden' (bijv. paragraaf 8.4.7 wat betreft de Arob-rechter). 
het privaatrecht. Op deze - vaak algemene en open - rechtsnormen kunnen rechtssubjecten over en weer een beroep doen ter bescherming van hun autonome belangposities. ${ }^{42}$ Zodra een bepaalde, door een rechtssubject ontplooide activiteit, voorwerp van publiekrechtelijke regulering wordt binnen een bevoegdheidsstelsel, kan dit van invloed zijn op de oorspronkelijke (private) rechtsrelaties tussen de betrokken rechtssubjecten. Tengevolge van de toepasselijkheid van een bevoegdheidsstelsel worden nl. aspecten van deze rechtsrelaties, die oorspronkelijk nog geheel door het materiele privaatrecht werden beheerst, nu 'partieel' beheerst door een specifieke (aanvullende) publiekrechtelijke normering. ${ }^{43}$ In dit verband kan men zich afvragen of de betrokken rechtssubjecten onder deze omstandigheden dan geen (publieke) 'aanspraak' hebben op een bepaalde modaliteit van bestuurlijk rechtshandelen. Hierbij kan bijv. gedacht worden aan een 'aanspraak' op bepaalde voorschriften die specifiek ter bescherming van hun rechtsbelangen dienen te worden gesteld. Deze vraag is niet eenvoudig te beantwoorden.

\subsubsection{Relevante ontwikkelingen en theorievorming in Duitsland}

Een blik in de richting van het Duitse 'Verwaltungs(prozeß)recht', dat een traditie kent wat betreft het denken in termen van publieke 'subjectieve rechten' en Schutznormen, is in dit kader nuttig. In Duitsland is bovendien diepgravend onderzoek gedaan naar de publiekrechtelijke regulering van belangenconflicten tussen (private) rechtssubjecten onderling in een bestuursrechtelijke (bevoegdheids)context. In dit verband wordt de regulerende functie van bestuurlijke bevoegdheidsstelsels o.m. tegen een grondrechtelijke en constitutionele achtergrond gepositioneerd.

Gelet op het onderwerp van dit boek is bijv. het omvangrijke Habilitationsschrift van Schmidt-Preuß interessant. ${ }^{44}$ Volgens Schmidt-Preuß is de reden voor een (gedeeltelijke) 'publicisering' van (private) belangenconflicten tussen rechtssubjecten onderling gelegen in een door de wetgever noodzakelijk geachte conflictoplossing ('Konfliktschlichtung') tussen

41. Vgl. H.J. Simon, Financielle voorwaarden en voorschriften. Een blik vanuit de theorie op de praktijk, NTB 94/6, p. 152; A. Klap en G. ten Berge, De derde als het stiefkind van het bestuursrecht, in: De derde in het recht, AAe (special) 1997/5, p. 337 en R.J.G.M. Widdershoven, Naar een bestuurs(proces)rechtelijk Ius Commune in Europa, VAR-reeks 116, Alphen aan den Rijn 1996, p. 126-127. Strikt genomen zou overigens het beeld van een 'kegel' een nog betere visualisatie zijn, aangezien er in het publiekrecht sprake kan zijn van een kring van 'belanghebbende' rechtssubjecten. I.v.m. de helderheid van de theorievorming wordt hier één snijvlak - in de vorm van een driehoek - uitgehaald (nl. de situatie welke uitgaat van de direct-belanghebbende, het bestuursorgaan en én derde-belanghebbende).

42. Vgl. over het autonomie-beginsel in privaatrechtelijke verhoudingen het gestelde in hoofdstuk 2, paragraaf 2.5.1.

43. Vgl. het leerstuk van de 'vrijwarende' werking van vergunningen dat ik in hoofdstuk 8 - in het licht van het specialiteitsbeginsel - heb besproken.

44. M. Schmidt-Preuß, Kollidierende Privatinteressen im Verwaltungsrecht. Das subjektive offentliche Recht im multipolaren Verwaltungsrechtsverhaltnis, Hab. Univ. Bayreuth, Berlin 1992. 
particulieren aan de hand van publiekrechtelijke maatstaven.$^{45}$ Een dergelijke conflictoplossing kan noodzakelijk zijn om bijv. de materiële (grondrechtelijk gewaarborgde) vrijheid van de betrokken rechtssubjecten te maximaliseren ${ }^{46}$ De wetgever ontleent hiertoe een 'mandaat' tot publiekrechtelijke conflictoplossing, namens deze rechtssubjecten, aan het democratiebeginsel. ${ }^{47}$

Van belang is dat de publieke conflictoplossing door een bestuursorgaan volgens Schmidt-Preuß steeds plaatsvindt aan de hand van een normatief 'Konfliktschlichtungsprogramm' dat een rechtstreekse afgeleide is van een objectieve publiekrechtelijke 'Ordnungsnorm'. Deze 'Ordnungsnorm' wordt door de wetgever vastgesteld. ${ }^{48}$ Belangrijkste functie van een dergelijke publieke rechtsnorm is het vóraf in abstracto ordenen, begrenzen, én waarderen van de betrokken - grondrechtelijke $e^{49}$ - belangen van (private) rechtssubjecten. Op basis van deze ordening en waardering kan het verantwoordelijke bestuursorgaan vervolgens de norm in concreto vertalen. Essentieel is volgens Schmidt-Preuß dat rechtssubjecten aan dezelfde publiekrechtelijke norm een 'aanspraak' kunnen ontlenen. Het gaat hier echter niet om een rechtstreekse (wederzijdse) 'aanspraak', maar om een indirecte die herleidbaar is tot de onvoltooide publiekrechtelijke norm binnen het bevoegdheidsstelsel. Bijgevolg bestaat er, althans volgens Schmidt-Preuß, een door de publieke 'Ordnungsnorm' beheerste rechtsrelatie tussen de betrokken rechtssubjecten. ${ }^{50}$ Het gegeven dat deze bevoegdheidsnorm het belangrijkste referentiepunt vormt voor de publieke conflictregulering dient de rechtszekerheid. ${ }^{51}$

45. Vgl. M. Schmidt-Preuß, Kollidierende Privatinteressen im Verwaltungsrecht, a.w., p. 38 noot 7. Dit brengt met zich dat de overheid derhalve de noodzaak van haar aanwezigheid in het rechtsverkeer tussen private rechtssubjecten steeds dient te rechtvaardigen (te legitimeren). Vgl. bijv. H.J. Simon, Publiekrecht of privaatrecht?, diss. VU, Zwolle 1993, p. 113.

46. Vgl. M. Schmidt-PreuB, Kollidierende Privatinteressen im Verwaltungsrecht, a.w., p. 426.

47. M. Schmidt-Preuß, Kollidierende Privatinteressen im Verwaltungsrecht, a.w., p. 38.

48. De inhoud van een 'Konfliktschlichtungsprogramm' dient in eerste instantie te worden vastgesteld door interpretatie van de 'Ordnungsnorm' zelf, eventueel in relatie tot andere (publieke) 'Ordnungsnormen' (denk aan de verhouding tussen de verschillende bestuurlijke bevoegdheidsstelsels). Hierbij is i.h.b. het doel van de wet en de totstandkomingsgeschiedenis van belang. Ook beleidsregels, wetsinterpreterende regels en richtlijnen zijn van betekenis. De vraag of een 'Ordnungsnorm' verenigbaar is met andere normen (bijv. grondrechten of algemene rechtsbeginselen) staat primair ter beoordeling van de wetgever, maar 'grondrechtconforme' uitleg in concreto wordt niet uitgesloten.

49. In het Duitse bestuursrecht valt overigens, zoals hiema nog zal blijken, een tendens te bespeuren waarbij de publiekrechtelijke (wettelijke) 'regulering' steeds herleid wordt tot haar grondrechtelijke fundamenten (der 'Verfassungsbezug'). De wetgever reguleert nl. steeds tegen de achtergrond van grondrechtelijke belangentegenstellingen (rechts)conflicten tussen rechtssubjecten. Vgl. ook: H. Maurer. Allgemeines Verwaltungsrecht, a.w., p. 156; zie voorts: Hain/Schlette/Schmitz, Ermessen und Ermessensreduktion - ein Problem im Schnittpunkt von Verfassungs- und Verwaltungsrecht, AOR 1997 (122), p. 48-49.

50. M. Schmidt-Preuß, Kollidierende Privatinteressen im Verwaltungsrecht, a.w., p. 135 en 139. De 'aanspraak' is gericht tegen de staat die in dit kader wordt aangemerkt als 'Pflichtsubjekt'. De 'Ordnungsnorm' is gelijktijdig bevoegdheidsgrondslag voor het bestuur èn grensstellende norm ta.v. de vrijheid van de betrokken particuliere rechtssubjecten binnen het publiekrechtelijke normenstelsel. 
Een discretionaire bevoegdheidsnorm (Ermessens- of 'Ordnungsnorm') stuurt het bestuurlijke rechtshandelen op een doelgerichte wijze (vgl. $\S 40 \mathrm{VwVfG})^{52}$ Hierbij wordt, evenals in het Nederlandse recht, een keuzevrijheid in de rechtsgevolgensfeer erkend. ${ }^{53}$ Van belang is in dit verband de vraag met welke (subjectgebonden) rechtsbelangen een bestuursorgaan, indien het een specifieke (discretionaire) bestuursbevoegdheid uitoefent, rekening dient te houden. Deze vraag kan naar Duits bestuurs(proces)recht, toegespitst op beschikkingsbevoegdheid, voor een belangrijk deel beantwoord worden aan de hand van $\S 42.2$ Jo. § 113.1 van de Verwaltungsgerichtsordnung (VwGO). Naar Duits recht kan een rechtssubject nl. in beginsel alleen bij de bestuursrechter worden ontvangen in een beroep tegen een 'Verwaltungsakt' indien, en voor zover, aannemelijk kan worden gemaakt dat hierdoor zijn of haar (subjectieve) rechten worden aangetast. ${ }^{54}$ Voorwaarde voor de gegrondverklaring van een dergelijk beroep is vervolgens o.m. dat deze (mogelijke) rechtsaantasting door de rechter daadwerkelijk wordt vastgesteld (die Begründetheit; $\S 113.1 \mathrm{VwGO}$ ). Deze benaderingswijze, waarin belangrijke kenmerken van een 'recours subjectif' worden herkend ${ }^{55}$, brengt met zich dat het besluitende bestuur uit de ontvankelijkheidsjurisprudentie van de bestuursrechter bruikbare aanknopingspunten kan destilleren voor de beantwoording van de vraag aan welke belangen van rechtssubjecten, gelet op de bevoegdheidsuitoefening, in het bijzonder gewicht behoort toe te komen. Anders uitgedrukt: binnen het Duitse Verwaltungs(prozeß)recht treedt de discrepantie tussen het procestechnische 'belanghebbende'-begrip en de materiële rechtsbelangen van de 'belanghebbende' minder op de voorgrond dan in het Nederlandse administratieve recht omdat de

51. Ik wijs op de relaties tussen het algemene rechtszekerheidsbeginsel en het Duitse constitutionele ' $B e$ stimmtheitsgebot' dat in hoofdstuk 4 (paragraaf 4.4.2 e.v.) werd geanalyseerd. Dit Bestimmtheitsgebot geldt uiteraard $66 \mathrm{k}$ t.a.v. een bestuurlijke 'Ordungsnorm'.

52. Vgl. Hain/Schlette/Schmitz, Ermessen und Ermessensreduktion, a.w., p. 43.

53. Zie bijv. H. Maurer, Allgemeines Verwaltungsrecht, a.w., p. 121; Hain/Schlette/Schmitz, Ermessen und Ermessensreduktion, a.w., p. 37.

54. Het Duitse stelsel van administratieve rechtsbescherming vindt zijn grondslag in art. 19.4 van het Grundgesetz (GG). Dit artikel garandeert 'Individualrechtsschutz' voor rechtssubjecten die door handelingen van het bestuur (die offentliche Gewalt) in hun rechten worden aangetast. De 'Verwaltungsgerichtsordnung' (vgl. o.m. \$ 40.1 VwGO) werkt deze gegarandeerde rechtsbescherming nader uit. Zie o.m. W. Schmitt Glaeser, Verwaltungsprozeßrecht, 11. neubearbeitete Auflage, Stuttgart/Munchen/Hannover/Berlin 1992, p. 34 e.v. Ik beperk mij in dit verband i.h.b. tot de 'Anfechtungsklage' en de 'Verpflichtungsklage' ( $\$ 42$ VwGO). Deze 'Klagen' zien op het beroep tegen 'Verwaltungsakte', alsmede op het beroep tegen de afwijzing daarvan dan wel de weigering te beschikken. De rechtsfiguur 'Verwaltungsakt' komt goeddeels overeen met het Nederlandse beschikkingsbegrip (vgl. \& 35 VwVfG). Het Duitse bestuurs(proces)recht kent overigens 66 k de algemene (objectieve) 'Normenkontrolle' met betrekking tot algemeen verbindende voorschriften (vgl. \$47 VwGO). In het kader van deze 'rechtsgang' die door een verzoek, en dus niet door een 'Klage', wordt ingeleid behoeft de schending van een subjectief recht niet aannemelijk te worden gemaakt. Hier volstaat het aantonen van een minder strikt 'belang' (Nachteil). Vgl. F. Hufen, Verwaltungsprozeßrecht, 2. Auflage, Munchen 1996, p. 396 e.v.

55. Vgl. bijv. E. Gurlit, Die Klagebefugnis des Adressaten im VerwaltungsprozeB, Die Verwaltung 1995 (28), p. 455 . 
vraag naar de 'Rechtsverletzung' centraal staat. ${ }^{56}$ Naar Duits recht impliceert de vaststelling van 'belanghebbendheid' bijgevolg tevens een (voorlopige ${ }^{57}$ ) positieve beantwoording van de vraag of de betrokken rechtsbelangen van een rechtssubject door de bestuurlijke bevoegdheidsuitoefening worden geraakt.

Omdat in hoofdstuk 8 van dit boek bleek dat de Nederlandse bestuursrechter, gelet op het specialiteitsbeginsel, nogal heeft geworsteld (en worstelt) met de Schutznormleer is het nuttig om in het kort na te gaan welke functie deze leer nu precies binnen het Duitse bestuurs(proces)recht vervult. Van belang is dat de Schutznormleer in het Verwaltungs(prozeß)recht een functie vervult bij de beantwoording van de vraag of er sprake is van een (beschermd) subjectgebonden 'recht'. Voordat de beantwoording van de vraag naar de 'Rechtsverletzung' door de rechter ter hand kan worden genomen, dient er eerst nagegaan te worden of het belang van de klager, ten aanzien waarvan deze stelt dat het is aangetast, door een (publiekrechtelijke) Schutznorm wordt beschermd. Hierbij valt het op dat dit Schutznormvereiste wordt toegespitst op de rechtspositie van derden. Deze worden aangeduid als 'Nichtadressaten' of 'Drittbetroffenen'. Waar ten aanzien van een rechtssubject tot wie een (belastende) Verwaltungsakt rechtstreeks is gericht op grond van de zgn. 'Adressatentheorie's8 nagenoeg automatisch wordt aangenomen dat diens subjectieve rechten in het geding (kunnen) zijn, daar moeten deze 'derden' $\mathrm{nl}$. in de regel een beroep kunnen doen op een publiekrechtelijke Schutznorm. Als Schutznorm wordt in dit verband aangemerkt een rechtsnorm die niet alleen het algemene publieke belang dient maar tevens individualiseerbare private belangen beschermt. ${ }^{59}$

De strikte hantering van de Schutznormleer heeft er mijns inziens toe geleid dat in het Duitse Verwaltungs(prozeß)recht aan de rechtsbelangen van derden, toegespitst op de bestuurlijke rechtsvorming, minder snel betekenis wordt toegekend dan aan de rechtsbelangen van een direct-belanghebbende. Ik wijs in dit verband op de opmerkelijke relatie met de problematiek die in de Nederlandse bestuursrechtelijke literatuur wordt waargeno-

56. Zie over het onderscheid tussen het procestechnische 'belanghebbende'-begrip en het begrip 'rechtsbelang hoofdstuk 6, paragraaf 6.4.4.

57. Voorlopig, daar een 'Rechtsverletzung' uiteraard definitief ten gronde moet worden vastgesteld. In het kader van de ontvankelijkheid is de zgn. 'Moglichkeitstheorie' heersend. Deze theorie houdt in dat de klager alleen afdoende aannemelijk moet maken dat een 'Verwaltungsakt' zijn subjectieve rechten kan aantasten. Vgl. E. Gurlit, Die Klagebefugnis des Adressaten im VerwaltungsprozeB, a.w., p. 457; W. Schmitt Glaeser, VerwaltungsprozeBrecht, a.w., p. 96.

58. Zie over deze theorie o.m.: E. Gurlit, Die Klagebefugnis des Adressaten im Verwaltungsprozeß, a.w., p. 451 e.v.; F. Hufen, VerwaltungsprozeBrecht, a.w., p. 282-283. Ik wijs erop dat deze 'Adressatentheorie' alleen wordt toegepast bij de 'Anfechtungsklage' en wel wat betreft de belastende Verwaltungsakt.

59. Over de Schutznormleer is in Duitsland overvloedig gepubliceerd. Ik wijs i.h.b. op het indrukwekkende overzichtsartikel van H. Bauer, Altes und Neues zur Schutznormtheorie, AoR 113 (1988), p. 582 e.v. Zie voorts de bekende handboeken: F. Hufen, Verwaltungsprozeßrecht, a.w., p. 289 e.v.; W. Schmitt Glaeser, VerwaltungsprozeBrecht, a.w., p. 98 e.v. en H. Maurer, Allgemeines Verwaltungsrecht, a.w., p. 152. Maurer wijst erop dat voor de beantwoording van de vraag of er sprake is van een 'subjectief (publiek)recht' van een rechtssubject de 'gesetzlich bezweckte Interessenschutz' (van het voorschrift waarop een beroep wordt gedaan) in eerste instantie bepalend is. 
men. Ook in ons land wordt immers, gelet op het specialiteitsbeginsel, vaak een onderscheid gemaakt tussen het 'meewegen' van de belangen van de direct-belanghebbende en de belangen van derden. De centrale vraag is echter in hoeverre deze benadering als juist kan worden aangemerkt. In ons land zijn de meningen op dit punt, zoals in hoofdstuk 7 bleek $^{60}$, nogal verdeeld. Hier staan de 'preciezen' immers tegenover de 'gematigden' en de 'rekkelijken'.

In dit verband is van belang dat de onderscheiding tussen 'Adressaten' en 'Nichtadressaten' momenteel in de Duitse literatuur wordt gekritiseerd. ${ }^{61}$ De Schutznormbenadering, die nog steeds heersend is, staat in dit verband onder druk. Een belangrijk bezwaar dat tegen de Schutznormleer wordt ingebracht is het gegeven dat het buitengewoon lastig is om vast te stellen wanneer een publieke rechtsnorm mede private rechtsbelangen beschermt en in welke gevallen de norm uitsluitend het algemene publieke belang dient. ${ }^{62}$ Daar publieke rechtsnormen bij wijze van 'reflex' vrijwel altijd de belangen van rechtssubjecten beschermen, is het soms zelfs onmogelijk om na te gaan of een rechtsnorm bepaalde belangen in het bijzonder beschermt. Van groter belang is echter dat een onverkorte en té strikte toepassing van de Schutznormleer kan leiden tot een ongelijke behandeling van de verschillende, bij de bestuurlijke bevoegdheidsuitoefening betrokken, rechtssubjecten. Met name vanuit grondrechtelijk perspectief wordt in Duitsland op dit gegeven kritiek geuit.

Dit heeft geleid tot tendensen in de literatuur en de jurisprudentie die de vaststelling van een 'Rechtsverletzung' door een Verwaltungsakt op een meer directe wijze in het teken van de bescherming van de grondrechten lijken te willen stellen. ${ }^{63}$ De hieraan ten grondslag liggende gedachte is dat de uitoefening van een beschikkingsbevoegdheid als gerichte rechtshandeling weliswaar in eerste instantie de direct-belanghebbenderaakt, maar dat hierdoor géénszins kan worden uitgesloten dat deze bevoegdheidsuitoefening gelijktijdig (indirecte) feitelijke gevolgen heeft voor andere betrokken rechtssubjecten. ${ }^{64}$ Ook van een mogelijke aantasting van hun (grond)rechten zal het bestuur zich daarom terdege rekenschap dienen te geven. In dit kader ziet dat bestuur zich overigens gesteld voor de complexe opgave ervoor te waken dat het 'rekening houden met' de rechtsbelangen van 'derden' (Nichtadressaten) niet leidt tot een te vergaande aantasting van de materiële rechtspositie van de direct-belanghebbende. ${ }^{65}$ Voorop blijft daarom staan het uitgangspunt

60. Zie de conclusies (paragraaf 7.3).

61. Vgl. bijv. E. Gurlit, Die Klagebefugnis des Adressaten im VerwaltungsprozeB, a.w., i.h.b. p. 479.

62. Zie voor een overzicht van de kritische literatuur op dit punt: H. Bauer, Altes und Neues zur Schutznormtheorie, a.w., p. 594-596.

63. Zie o.m. H. Maurer, Allgemeines Verwaltungsrecht, a.w., p. 155-156; F. Hufen, Verwaltungsprozeßrecht, a.w., p. 298 e.v. Hufen wijst er in dit verband op dat achter de Schutznormtheorie steeds de grondrechten staan (a.w., p. 298).

64. Vgl. H. Maurer, Allgemeines Verwaltungsrecht, a.w., p. 156: 'Die Grundrechten bilden unbestritten Abwehrrechte gegen staatliche Maßnahmen, und zwar nicht nur gegen gezielte Eingriffe, sondern ggf. auch gegen sonstige, mehr beilaufige Beeinträchtigungen von Freiheit und Eigentum durch staatliches Verhalten' (curs. R.J.N.S.).

65. Vgl. E. Gurlit, Die Klagebefugnis des Adressaten im VerwaltungsprozeB, a.w., p. 469. Vgl. de 'worstelingen' in de Nederlandse bestuursrechtelijke literatuur op dit punt (de visies van de 'gematigden'). 
dat primair de wet, in de vorm van een duidelijke én begrensde (d.w.z. 'Bestimmte') publieke bevoegdheidsnorm, de grondrechtposities van rechtssubjecten onderling afgrenst. ${ }^{66}$ Opvallend is desalniettemin dat het 'rechtsbelang'-begrip in het Duitse bestuursrecht uiteindelijk in belangrijke mate via de grondrechten, waaronder het eigendomsrecht, blijkt te worden ingevuld. Hierdoor wordt het bestuurlijke rechtsvormingsproces onmiskenbaar in het teken gesteld van de spanning tussen publiekrechtelijke belangen enerzijds en grondrechten anderzijds. Deze constatering lijkt mij óok van belang voor het Nederlandse bestuursrecht en met name voor de materielle bestuurlijke besluitvorming. De Duitse theorievorming blijkt immers in het bestuursrecht op een meer geexpliciteerde wijze invulling te geven aan het begrip 'rechtsbelang' dan de Nederlandse. ${ }^{67}$ Ik kom hier op terug (paragraaf 9.6.1 e.v.).

\subsubsection{Een 'subjectief recht' op een bepaalde modaliteit van bevoegdheidsuitoefening?}

De Duitse theorievorming werpt mijns inziens een interessant licht op de specialiteitsdiscussie in Nederland. Soms wordt $\mathrm{nl}$. uit het oog verloren dat de belangbehartiging binnen de publieke rechtsgemeenschap volledig ten dienste staat, althans behoort te staan, van de leden-rechtssubjecten. Dit zijn de dragers van typische (grondrechtelijke) rechtsbelangen. De publiekrechtelijke belangbehartiging is in dit verband vóor alles gericht op de vorming van nieuw objectief recht dat deze belangen van rechtssubjecten vanuit een publiek gemeenschapsperspectief reguleert. Vanuit dit perspectief bezien, heeft ieder - bij een bevoegdheidsuitoefening betrokken - rechtssubject ook 'recht' op een optimale behartiging van de publiekrechtelijke belangen. Doelgerichte publieke rechtsvorming strekt er immers toe om in concreto randvoorwaarden te creëren waaronder de rechtsbelangen van de rechtssubjecten optimaal door hen kunnen worden behartigd onder gelijktijdige respectering van de rechtsbelangen van medesubjecten.

Het voorafgaande kan wellicht verklaren waarom in de Nederlandse literatuur over het specialiteitsbeginsel het 'meewegen' van belangen van derde-belanghebbenden in het algemeen niet problematisch wordt geacht voorzover deze 'samenvallen' met het speciale - door het bestuursorgaan te behartigen - publiekrechtelijke belang. ${ }^{68}$ In dit verband kan immers als juist worden aanvaard dat door de uitoefening van een specifieke bestuursbevoegdheid bij wijze van 'reflex' óók belangen van rechtssubjecten (feitelijk) worden be-

66. Vgl. W. Schmitt Glaeser, VerwaltungsprozeBrecht, a.w., p. 102-103. Deze auteur wijst erop dat met name in 'mehrpolige Verwaltungsverhaltmisse' (d.w.z. bestuursrechtelijke verhoudingen waarbij derden betrokken zijn) de wettelijke bevoegdheidsnormen, die de belangenconflicten tussen burgers begrenzen, niet gemist kunnen worden omdat de grondrechtsnormen sec te vaag zijn (a.w. p. 102).

67. De 'doordenking' van de bestuursrechtelijke theorievorming vanuit het perspectief van de grondrechten lijkt mij in dit kader nog veel vruchten te kunnen afwerpen. Ik wijs in deze context - ter illustratie - op: F.M.C. Vlemminx, Bestuurscompensatie en grondrechten, NTB 1994/7, p. 193 e.v.

68. Zie over dit 'samenvallen' bijv. Nicolar e.a., Bestuursrecht, a.w., p. 441 . Men zou kunnen stellen, zoals Nicolar doet, dat de (rechts)belangen van derden als het ware in 'geabstraheerde' vorm in de belangenafweging worden betrokken. 
schermd. ${ }^{69}$ Dit zal in het 'multipolaire' bestuursrecht vaak het geval blijken te zijn. Hierbij kan nog worden opgemerkt dat (voltooide) materiele rechtsvoorschriften in het bestuursrecht kunnen fungeren als voorschriften die de belangen van rechtssubjecten beschermen. De strekking van dergelijke voorschriften is vaak niet zozeer gelegen in het beschermen van rechtssubjecten tegen de overheid, maar juist in het verschaffen van (extra) materiële publiekrechtelijke bescherming aan rechtssubjecten jegens hun mederechtssubjecten. ${ }^{70} \mathrm{De}$ regulerende functie van het publieke recht treedt hier duidelijk op de voorgrond.

Doordat de publieke belangbehartiging in dit verband (mede) is gerelateerd aan de belangen van rechtssubjecten lijkt bij sommige auteurs, misschien onder invloed van Duitse denkbeelden ${ }^{71}$, de idee te hebben postgevat dat rechtssubjecten aan bestuursrechtelijke (bevoegdheids)normen, onder omstandigheden, 'subjectieve bestuursrechtelijke rechten' (kunnen) ontlenen. ${ }^{72}$ Deze rechten of aanspraken zouden dan binnen een publieke rechtsbetrekking jegens het bestuur tot gelding kunnen worden gebracht. Hiermee verband houdt de vraag of bijv. een bepaalde modaliteit van bevoegdheidsuitoefening zou kunnen worden afgedwongen. ${ }^{73}$ Deze 'subjectiveringstendens' in het bestuursrecht ten aanzien van bestuursbevoegdheid leidt naar mijn oordeel niet tot een zuivere voorstelling van zaken. ${ }^{74}$ Zoals reeds eerder werd gesteld kan naar mijn oordeel een bestuursorgaan nl. niet worden aangemerkt als een rechtssubject dat binnen de publieke rechtsgemeenschap in een

69. Vgl. over het begrip 'rechtsreflex' R.J.B. Bergamin, Rechten jegens de overheid. Het begrip publiekrechtelijke subjectieve rechten, diss. UvA, Nijmegen 1995, p. 74.

70. Vgl. bijv. HR 17 september 1982, NJ 1983, 278 m.nt. MS (Zegwaard/Knijnenburg) en HR 28 juni 1985, NJ 1986, 356, m.nt. MS (Claas/van Tongeren). Deze visie meen ik ook te bespeuren in de jurisprudentie van het Europese Hof voor de Rechten van de Mens. Vgl. bijv. EHRM 25 november 1993, Series A, Vol. 279 (Zander vs. Sweden). Zie voorts paragraaf 9.6.3. Vgl. in dit kader ook mijn NTB-artikel 'Het specialiteitsbeginsel en derde-belangen: een frisse benadering of rechtsstatelijk drijfzand?, a.w., i.h.b. p. 98-91.

71. Naar Duits bestuursrecht wordt wel aanvaard dat een rechtssubject (onder voorwaarden) een subjectieve én afdwingbare aanspraak op een 'fehlerfreie Ermessensentscheidung' heeft. De betreffende discretionaire bevoegdheidsnorm moet dan wél (mede) 'individualschutzend' van aard zijn. Een besluit met een bepaalde inhoud $k$ an in rechte enkel worden afgedwongen indien er sprake is van een 'Ermessensreduktion auf Null', hetgeen wil zeggen dat het bestuursorgaan rechtens nog maar éen juiste beslissing kan nemen. Zie bijv. H. Maurer, Allgemeines Verwaltungsrecht, a.w., p. 158-159 en Hain/Schlette/Schmitz, Ermessen und Ermessensreduktion, a.w., p. 39. Deze laatste auteurs zijn op dit punt echter kritisch en wijzen erop dat uit een 'Ermessensnorm' (een discretionaire bevoegdheidsnorm) niet zonder meer 'subjectieve aanspraken' kunnen worden afgeleid. Voorzover er onder omstandigheden al 'aanspraken' uit voortvloeien zullen deze (mede) op grondrechten moeten worden gebaseerd (a.w. p. 48-49).

72. Zie uitvoerig het proefschrift van Bergamin. R.J.B. Bergamin, Rechten jegens de overheid, a.w., hoofdstuk 4. Bergamin spreekt over een 'bestuursrechtelijk subjectief recht' (als species van het ruimere 'publiekrechtelijke subjectieve recht' waaronder hij $66 \mathbf{k}$ de grondrechten rekent) indien op een '...bestuursorgaan ten behoeve van het particuliere belang een ondubbelzinnige verplichting rust en daarbij de mogelijkheid is gegeven dat de rechter een uitspraak doet waarin deze verplichting wordt gehandhaafd'(a.w., p. 221). Vgl. voorts: F.J. van Ommeren, De verplichting verankerd, a.w., p. 275-278.

73. In die zin dat een rechtssubject bijv. een bepaald regime van regulerende voorschriften zou kunnen afdwingen. Bergamin komt in ieder geval tot een ontkenning van 'bestuursrechtelijke subjectieve rechten' in geval van beleids- en beoordelingsvrijheid. R.J.B. Bergamin, Rechten jegens de overheid, a.w., p. 226. 
- wederkerige - rechtsbetrekking staat tot de 'echte' rechtssubjecten (de zelfstandige dragers van rechten en plichten). ${ }^{75}$ De functie van een orgaan, welke tot uitdrukking komt in de uitoefening van een ambtelijke bevoegdheid, kan naar zijn aard gén object zijn van een subjectief (vorderings)recht waarop een afdwingbare 'aanspraak' van rechtssubjecten bestaat. Dit zal zeker het geval zijn voorzover er sprake is van een discretionaire bevoegdheid. De bevoegdheidsuitoefening - ten aanzien waarvan het bestuursorgaan exclusieve verantwoordelijkheid draagt - leidt tot de vorming van nieuw objectief publiekrecht. Als rechtsfeit wordt de bevoegdheidsuitoefening door datzelfde objectieve publieke recht genormeerd. ${ }^{76}$

\subsection{Rekkelijken, preciezen én rechtspolitiek?}

Nadat in het voorafgaande in essentie het standpunt is ingenomen dat het gerichte publieke rechtshandelen door een bestuursorgaan op exclusieve wijze wordt aangestuurd door $p u$ bliekrechtelijke belangen, is het tijd om de meningsverschillen in de (Nederlandse) literatuur omtrent het specialiteitsbeginsel te verklaren. In hoofdstuk 7 van dit boek zijn de verschillende visies over het specialiteitsbeginsel uitvoerig analyseerd. Tegen deze achtergrond én in het licht van de algemene opmerkingen uit de voorafgaande hoofdstukken over de rechtsverhouding tussen bestuursorgaan en burgers, de aard van bestuursbevoegdheid en het rechtskarakter van beleidsvrijheid kan naar mijn oordeel worden gesteld dat de interpretatie van het specialiteitsbeginsel afhankelijk is van rechtspolitieke tendenties. ${ }^{77}$

Uiteindelijk zijn naar mijn mening de verschillen in opvatting, zoals ik in hoofdstuk 2 van dit boek suggereerde, terug te voeren op verschillende concepties omtrent de aard en de

74. Uiteraard kan men zich op het standpunt stellen dat hier een definitieprobleem in het geding is. Indien ik echter de uiteindelijke omschrijving lees die bijv. Bergamin geeft van een 'bestuursrechtelijk subjectief recht' dan lijkt mij hier, zoals ik reeds in hoofdstuk 2 stelde, niets anders in het geding dan de werking van de algemene beginselen van behoorlijk bestuur en derhalve het objectieve publiekrecht. R.B. Bergamin, Rechten jegens de overheid, a.w., p. 268 . Zie wat betreft een kritische stellingname tegen 'subjectieve bestuursrechten' ook: A.Q.C. Tak, De overheid in het burgerlijk recht, a.w., p. 110. Tak ziet gén enkele ruimte voor 'subjectieve' private aanspraken op het algemeen belang, de behartiging van publieke taken of belangen, gelet op het legitimiteits- én specialiteitsbeginsel. De burger kan de overheid wél op basis van de regels en beginselen van het objectieve publiekrecht aanspreken op een correcte taakvervulling.

75. Vgl. de fundamentele kritiek van Teunissen. J.M.H.F. Teunissen, De 'wederkerige rechtsbetrekking' als strategisch concept voor nivellerende rechtswetenschap?, in: Eenzijdig en wederkerig? (red. E.C.H.J. van der Linden en A.Q.C. Tak), Deventer 1995, p. 303 e.v. Teunissen baseert zijn kritiek in belangrijke mate op Giacometti. Z. Giacometti, Allgemeine Lehren des rechtsstaatlichen Verwaltungsrecht, Zurich 1960, i.h.b. p. 302-310.

76. Dit doet er uiteraard niet aan af dat de burger binnen het publieke rechtsverband als volwaardig rechtssubject (d.w.z. als drager van typische vermogens- en grondrechten) wordt erkend. Zie voor kritiek op het 'publieke subjectieve recht' ook hoofdstuk 2 (paragraaf 2.5.6.).

77. Vgl. de analyse van Heldeweg. M.A. Heldeweg, Het specialiteitsbeginsel: bel voor de laatste ronde?, in Rechtspraak bestuursrecht 1994-1995. De annotaties, 's-Gravenhage 1995, p. 191-196. 
grondslagen van het rechtsstatelijke bestuursrecht en, in het verlengde hiervan, de aard van de rechtsverhouding tussen bestuursorgaan en burger(s). Afhankelijk van de visie die men onderschrijft, zal de betekenis die wordt toegekend aan het specialiteitsbeginsel (aanzienlijk) verschillen. Naar mijn idee staat een tweetal hoofdstromingen, die ik zou willen aanduiden als 'klassiek-precies' en '(post)modern-rekkelijk', tegenover elkaar. Ik zal de kenmerken van beide stromingen schetsen zodat de diepere achtergrond van de meningsverschillen over het specialiteitsbeginsel goed zichtbaar wordt.

\subsubsection{De 'klassiek-precieze'stroming}

In de 'klassiek-precieze' stroming neemt de doelgebonden bestuursbevoegdheid een centrale plaats in. De nadruk wordt gelegd op de democratische fundering van deze bevoegdheid, het primaat van de wetgever (het legaliteitsaspect) en de beperkte rechtsvormende potenties van bestuursorganen (het 'Bestimmtheitsgebot'). Inherent aan deze stroming is mijns inziens de idee van een principiële, in materiële rechtsbeginselen gefundeerde én cultuurhistorisch bepaalde, scheiding tussen publieke en private rechtsvorming (de principiële aanname van rechtspluriformiteit). ${ }^{78}$ De publieke rechtsvorming die het bestuur bewerkstelligt is volgens de 'klassiek-precieze' stroming per definitie doelgebonden van aard; andere belangen dan 'publiekrechtelijke' mogen deze rechtsvorming niet in normatieve zin sturen. Aan het verbod van détournement de pouvoir wordt veel waarde gehecht. De publieke rechtsvorming, welke zich ter bevordering van de structurele legitimiteit dient te voltrekken op basis van een verfijnde en gedifferentieerde bevoegdhedenstructuur, staat volledig in dienst van de bestemmingsfunctie van de publieke rechtsorde. Interventies in de vrije rechtsrelaties tussen burgers onderling (en hun georganiseerde verbanden) behoeven bijgevolg steeds een specifieke legitimatie die zijn uiteindelijke rechtsgrond vindt in het op exclusieve wijze dienen van het algemeen belang onder respectering van de rechtsbelangen van rechtssubjecten. De noodzaak van specifieke democratische legitimatie wordt met het oog hierop (mede) gefundeerd in de principielle verschillen tussen de bevoegdheden van het bestuur en de rechten en plichten van de burgers-rechtssubjecten (de autonomie gedachte).

Beschouwt men de 'klassiek-precieze' stroming nader, dan blijkt er véél aandacht uit te gaan naar het 'machtskritische' aspect (overheidsmacht én overheidsinterventies zijn niet vanzelfsprekend) alsmede naar een duidelijke scheiding van de verantwoordelijkheden van de publieke staat enerzijds en de vrije burgerrechtelijke 'maatschappij' anderzijds. Tegen deze achtergrond geeft het specialiteitsbeginsel, als fundamenteel rechtsstatelijk principe, mede in een grondrechtelijke context, principieel invulling aan deze scheiding. Hierbij lijkt mij tot slot van belang dat de 'klassieke' referentiekaders (bijv. de legaliteits- en bevoegdheidseis) ó́k in de hedendaagse interventiestaat centraal worden gesteld.

78. Dit uitgangspunt leidt tot verzet tegen zgn. 'nivellerende' rechtsvisies die juist de materiêle éénheid van het recht als normenstelsel benadrukken. Vgl. J.M.H.F. Teunissen, Strategisch concept voor nivellerende rechtswetenschap?, a.w., p. 318 e.v. 


\subsubsection{De 'postmodern-rekkelijke'stroming(en)}

De 'postmodern-rekkelijke' stromingen ${ }^{79}$ kiezen mijns inziens voor andere, meer pragmatische, vertrekpunten. Toegespitst op de bestuursfunctie wordt niet langer de specifieke bestuursbevoegdheid centraal gesteld. Het bestuursorgaan wordt daarentegen als een zelfstandig 'rechtssubject' en drager van (rechts)belangen gepositioneerd. Deze 'subjectiveringstendens', waaraan mijns inziens géén geexxpliciteerd theoretisch uitgangspunt ten grondslag ligt, neemt binnen deze stromingen een belangrijke plaats in. ${ }^{80}$ Publieke belangen dienen vanuit het overheidsperspectief vooral effectief en doelmatig te worden behartigd (instrumentalistische tendens). Dit leidt vaak tot een sterke relativering van het uitgangspunt van wetmatigheid van bestuur en een afzwakking van het belang van het bevoegdheidsbeginsel. De aanwezigheid van de intervenierrende overheid in het vrije maatschappelijke leven wordt a priori geaccepteerd. De wetmatigheidseis lost op in een bredere - maar minder specifieke - rechtmatigheidseis waarover primair door de rechter dient te worden gewaakt. Zodra de overheid, en in het bijzonder het bestuur, als een vanzelfsprekende en altijd aanwezige actor in het rechtsverkeer wordt gepositioneerd én geaccepteerd, vermindert vanzelfsprekend óok de behoefte aan voorafgaande (abstracte) democratische legitimatie van overheidsactiviteit. De ogenschijnlijk 'veilige' idee dat bestuur en burger in beginsel op gelijke wijze zijn gebonden aan algemene ongeschreven rechtsnormen én de grondrechten doet de behoefte aan binding van de overheidsmacht aan specifieke bevoegdheden als sneeuw voor de zon verdwijnen. ${ }^{81}$ Binnen sommige '(post)modern-rekkelijke' stromingen denkt men bijgevolg zonder veel bezwaar te kunnen kiezen voor 'horizontaal', onderhandelend en compromiszoekend-bestuur waarbij aan het bestuursorgaan uiteindelijk óók de rol van 'bindende bemiddelaar' in private rechtsconflicten tussen burgers wordt

79. Anders dan bij de 'klassiek-precieze' stroming is hier het generaliseren een hachelijker aangelegenheid. Het juridisch 'postmodernisme' en de sceptische rechtswetenschap hebben immers niet veel op met 'principes' en 'dogmatiek'. Hier treft men - complex verweven - o.m. 'instrumentalistische', 'pragmatische', 'sceptische', 'rechtseenheid-' en 'rechtsrelativerende' visies aan. Desalniettemin meen ik bepaalde gemeenschappelijke tendenties te bespeuren. Voor een treffende schets van het 'postmodernisme', toegespitst op de rechtswetenschap, verwijs ik naar de fraaie tekst van Smits. J. Smits, Privaatrecht en postmodernisme. Over recht en tijdsgeest, toegelicht aan de hand van enige civielrechtelijke fenomenen, Recht en kritiek, 1997/2, p. 155 e.v. Tot de kenmerken van postmodernistische stromingen kunnen o.m. worden gerekend (1) een afkeer van dogmatiek, ideologie en intellectualisme, (2) simplificatie en pragmatisme (3) (en neiging tot) normen- en waardenrelativisme, alsmede het stellen van vorm boven inhoud (veel waarde toekennen aan procedures en het bewerkstelligen van procedurele legitimiteit) en (4) een sceptische benadering van ieder aspect van het recht. Zie over de relatie tussen postmodemisme en sceptische rechtstheorie ook: K. Rozemond, De toekomst van de kritische rechtstheorie (redactioneel), Recht en kritiek, 1997/3, p. 202. Volgens Rozemond is het typerend voor de 'postmoderne' jurist dat hij of zij, los van diepere gerechtigheidsidealen 'met behulp van zijn gereedschapskist van altijd voorlopige meningen en overtuigingen sleutelt aan de juridische problemen van zijn specialisme.' (a.w., p. 202).

80. Vgl. in dit kader hoofdstuk 2 (paragraaf 2.5 .5 en 2.5.6) van dit boek, waar het concept van de 'wederkerige rechtsbetrekking' in het bestuursrecht is geanalyseerd.

81. Vgl. bijv. R. de Winter, Oud zeer, in: Azen op tegenslag, Lelystad 1994, p. 17-18. Hierbij realiseert men zich m.i. onvoldoende dat het voor de burger vaak véél gemakkelijker is om aan te tonen dat 'de overheid' de wet overtreedt, dan dat een bepaald grondrecht wordt aangetast. 
toebedacht. De materiële verschillen tussen publiek- en privaatrecht worden in dit verband soms vergaand gerelativeerd (rechtseenheidsvisies). ${ }^{82}$

Het zal duidelijk zijn dat vanuit deze optiek voor een al te strikte uitleg van het specialiteitsbeginsel weinig ruimte is. Het bestuur heeft nl. behoefte aan een (relatief) vrije en algemene bevoegdheid om in de rechtsverhoudingen tussen rechtssubjecten bindend te kunnen interveniëren door middel van het stellen van gedrags- en compensatievoorschriften. Van de mogelijkheid tot binding van rechtssubjecten door het bestuur doen de '(post)modern-rekkelijke' stromingen echter géén afstand. Deze stromingen beogen mijns inziens daarom per saldo enkel de mogelijkheden tot éénzijdige binding door het bestuur te verruimen door een afzwakking van het legaliteits- en specialiteitsbeginsel te bepleiten. Reeds eerder stelde ik dat deze visies (ook de meer 'gematigden'), hoe sympathiek ook, steeds op het scherpst van de wetmatigheidssnede balanceren. ${ }^{83}$

\subsubsection{Bindende bemiddeling door het bestuursorgaan?}

Overziet men de geschetste stromingen ${ }^{84}$ dan blijkt mijns inziens dat, wat betreft het specialiteitsbeginsel, de schoen in het bijzonder wringt in situaties waarin de rechtsbelangen van een rechtssubject, wiens activiteiten door een bepaald bevoegdheidsstelsel worden gereguleerd, conflicteren met die van mederechtssubjecten.$^{85}$ Hiervan zal op vele terreinen van het bestuursrecht snel sprake zijn. ${ }^{86}$ In dit verband zullen rechtssubjecten de neiging hebben om hun gehele belangenconflict, ongeacht de materieelrechtelijke aard daarvan, op het bordje van het bestuur te presenteren. Dit is een gegeven dat in de bestuurs(recht)praktijk gemakkelijk valt te onderkennen en dat bovendien vanuit de nietjuridische belevingswereld van burgers geenszins onbegrijpelijk is.

Voor zover rechtssubjecten evenwel buiten het kader van een specifieke bestuursbevoegdheid aansturen op bindende beïnvloeding van de activiteiten van hun mederechtssubject(en), door tussenkomst van het bestuur, manifesteren zich rechtsstatelijke complicaties. Deze complicaties, in het bijzonder de spanning met het uitgangspunt van wetmatigheid van bestuur, zijn in de literatuur door sommige auteurs op pragmatische wijze opgelost. Zo

82. Ik teken hierbij aan dat ik geén bezwaar heb tegen het traceren van 'gemeenschappelijke' rechtsbeginselen. Ik wordt echter argwanend indien over bestuursrechtelijke rechtsverhoudingen 'bi-polair' wordt gedacht, er 'aanspraken' op vergunningen worden erkend en het onderscheid tussen publiek- en privaatrecht wordt gereduceerd tot een 'subtiliteit'. Zie: J.H. Nieuwenhuis, Op gespannen voet. Een evenwichtstheorie over de betrekkingen tussen het publieke en het burgerlijke recht, NJB 1998/1, p. 12 en 17.

83. R.J.N. Schlossels, Het specialiteitsbeginsel en derde-belangen: een frisse benadering of rechtsstatelijk drijfzand?, a.w., p. 84.

84. Delen van de tekst in deze en de navolgende paragraaf werden reeds eerder door mij gepubliceerd. Zie: R.J.N. Schlossels, Een dakkapel te Edam: de wens van eenheid van recht?, in: Rechtspraak bestuursrecht 1995-1996. De annotaties, 's-Gravenhage 1997, i.h.b. p. 71-81.

85. Indien de belangen van een derde parallel lopen aan die van de direct-belanghebbende zal er vanuit legaliteitsoogpunt weinig bezwaar bestaan om deze belangen in de afweging te betrekken. In de sfeer van de 'Leistungsverwaltung' spelen conflicten met derden minder frequent.

86. Vgl. de inleidende opmerkingen in hoofdstuk 8 over de 'derde-belanghebbende' (paragraaf 8.2). 
introduceerde Nicolaï de idee van een 'gedeelde' bestuursbevoegdheid op basis waarvan het stellen van voorschriften ter bescherming van 'derde'-belangen in beginsel steeds toelaatbaar wordt geacht. Konijnenbelt, Van Male en - in zekere zin ook - Van Hall volgden deze weg. ${ }^{87}$ Ook de Afdeling bestuursrechtspraak van de Raad van State lijkt van deze 'rechtspolitieke' oplossing gecharmeerd te zijn. De theoretische onderbouwingen van deze visies zijn echter, in het licht van de grondslagen van de democratische-rechtsstaat, weinig geëxpliciteerd. Duidelijk is wél de impliciete wens om het legaliteits- en specialiteitsbeginsel te relativeren.

Minder verhullend is de visie van Scheltema. Volgens hem zal het bestuursrecht zich ten principale dienen te orienteren op de bestuursrechtelijke (wederkerige) rechtsbetrekking, waarbinnen de belangentegenstelling tussen private rechtssubjecten onderling vaak een centrale plaats inneemt:

\footnotetext{
'Daar neemt het bestuur vaak een tussenpositie in tussen burgers met verschillende belangen. De conceptie van het bestuursrecht als bescherming tegen de overheid is dan duidelijk inadequaat: men wil niet zozeer het optreden van de overheid, maar dat van een mede-burger bestrijden. ${ }^{88}$
}

Binnen deze bestuursrechtelijke rechtsbetrekking zullen de betrokken partijen elkaars belangen op basis van wederkerigheid dienen te respecteren: rechten én plichten dienen duidelijk te zijn.

In het verlengde hiervan dient het recht de participanten aan de hiervoor bedoelde rechtsbetrekking - waaronder het bestuur - de instrumenten te verschaffen om hun belangposities te beschermen. Beleidsvrijheid wordt in dit kader mijns inziens niet langer opgevat als een doelgebonden vrijheid, maar als een meer oorspronkelijke vrijheid van het bestuur. De belangen 'van' het bestuur worden als het ware in een publieke ruimte ${ }^{89}$ tussen een veelheid van andere (private) rechtsbelangen behartigd. Het bestuursorgaan staat bijgevolg niet langer als publiek rechtsorgaan boven de partijen, maar wordt zélf partij in een 'maatschappelijke' belangenstrijd. Het bestuursorgaan vervreemdt hierdoor geleidelijk van zijn publieke orgaanfunctie en wordt een actor in een netwerk van rechtsbetrekkingen. Bestuursbevoegdheden vormen binnen deze rechtsbetrekkingen slechts aanknopingspunten voor bemiddelend en onderhandelend bestuur (de zgn. 'discours'-gedachte).

Het (materiële) recht, niet langer principieel onderscheiden naar zijn publieke en private oorsprong, vult dan de 'lege huls' van het 'rechtsbetrekking'-concept. De binnen de democratische rechtsstaat te onderscheiden rechtsrelaties tussen bestuur-burger(s) en burger-burger vloeien samen en er resteert uiteindelijk één ongedifferentieerde 'rechtsbetrekking' die niet alleen beheerst wordt door publiekrecht (nl. door een 'open' bestuursbevoegdheid) maar óók door maatschappelijke zorgvuldigheidsnormen, normen van buren-

87. Hun visies zijn uitvoerig in hoofdstuk 7 van dit boek besproken.

88. M. Scheltema, Van rechtsbescherming naar een volwaardig bestuursrecht, NJB 1996/33, p. 1356.

89. Vgl. R. Foqué, De ruimte van het recht, oratie EUR, Arnhem 1992, p. 31 e.v. 
recht en de privaatrechtelijke eisen van redelijkheid en billijkheid. ${ }^{90}$ Een dergelijk beeld treedt mijns inziens bijv. duidelijk op de voorgrond in de oratie van Foqué die de 'algemene beginselen van behoorlijkheid' bij het concretiseren van 'publieke rechtsbetrekkingen' centraal wil stellen: 'Naast de algemene beginselen van behoorlijk bestuur, betreft het hier ook de evolutie van de zorgvuldigheid welke in het maatschappelijke verkeer betaamt, via het leerstuk van de ongeschreven regels van de goede trouw naar de maatstaven van redelijkheid en billijkheid in het nieuwe B.W.' (curs. R.F.). ${ }^{91}$ In een dergelijke benadering past naar mijn oordeel ob́k de principiële aanvaarding van het uitgangspunt dat rechtsgeschillen over rechtsbelangen van burgers, die materieel bescherming vinden in het civielrecht, ten principale in de weg kunnen staan aan een bevoegdheidsuitoefening in het publiekrecht. Ook zouden dergelijke belangen éenzijdige normstelling door het bestuur in de vorm van (compensatie)voorschriften kunnen legitimeren. ${ }^{92}$

\subsubsection{Kater Napoleon en nogmaals Buttervliet}

Het heeft er alle schijn van dat het doordringen van private rechtsnormen en rechtsbeginselen in de typisch bestuurlijke besluitvorming door de administratieve rechter wordt gesanctioneerd. Van het bestuur wordt soms een actieve opstelling verwacht wat betreft het interveniëren in rechtsconflicten tussen civiele partijen onderling, waarbij de doelgebonden bestuursbevoegdheid niet het ankerpunt vormt. In dit verband kan bijv. gewezen worden op de uitspraak van de Afdeling bestuursrechtspraak van de Raad van State inzake de 'telefooncel Buttervliet ${ }^{\text {} 3}$ en de uitspraak van de Voorzitter van de (voormalige) Afdeling rechtspraak inzake 'kater Napoleon'. ${ }^{94}$

In de laatstgenoemde zaak hadden burgemeester en wethouders van Wassenaar de eigenaar van een kater ingevolge de plaatselijke APV een plicht opgelegd inhoudende dat hij het betreffende huisdier uitsluitend op het afgesloten erf van zijn woning mocht houden. Na te hebben vastgesteld dat de betreffende APV-bepaling openbare belangen (nl. de openbare orde en de volksgezondheid) kon dienen - en derhalve verbindend was stelde de Voorzitter vast dat de betreffende aanschrijving, gelet op het gedrag van de kater, een afdoende basis vond in het bedoelde APV-voorschrift. Hiermee was de kous echter niet af. De Voorzitter bleek nl. op andere gronden bedenkingen tegen het besluit van het Wassenaarse college te hebben. Hij stelde zich nl. op het standpunt dat onder de gegeven omstandigheden van verweerders had mogen worden verwacht

90. Vgl. HR 20 mei 1994, NJ 1995, 691, m.nt. CJHB (De Negende van Oma). Kritisch in dit kader: A.Q.C. Tak, De overheid in het burgerlijk recht, a.w., p. 105 en p. 287-288.

91. R. Foqué, De ruimte van het recht, a.w., p. 38.

92. Denkbeelden in deze richting zijn ontwikkeld door Simon en Nicolar. Vgl. P. Nicolaï, Kroniek Algemene beginselen van behoorlijk bestuur, NTB 1995/4, p. 98 en H.J. Simon, Financiele voorwaarden en voorschriften. Een blik vanuit de theorie op de praktijk, NTB 1994/6, p. 152-153.

93. ABRS 10 mei 1995, RAwb 1995, nr. 72, m.a. BdW (telefooncel Buttervliet).

94. VZARRS 28 juni 1993, AB 1994, 422 (kater Napoleon). 
'.dat zij, aivorens te besluiten tot de in geding zijnde aanschrijving, zouden hebben onderzocht of aan de klachten van omwonenden niet in belangrijke mate doelmatig tegemoet zou kunnen worden gekomen door bemiddeling bij het treffen van een - minder verstrekkende - regeling tussen appellanten en betrokken omwonenden, waarbij enerzijds verzoekers ervoor zorgdragen dat kater Napoleon slechts op gezette tijden gedurende een bepaalde periode buiten de woning van verzoekers verblijft en anderzijds betrokken omwonenden zodanige maatregelen nemen dat wordt voorkomen dat kater Napoleon hun woning gedurende die periode kan binnendringen' (curs. R.J.N.S).

Met andere woorden, de Voorzitter, die overigens onmiddellijk uitspraak deed in de hoofdzaak en het besluit vernietigde ${ }^{95}$, verlangde een actieve bemiddelende houding van het bestuur welke zou dienen te resulteren in een regeling van het burengeschil.

In de Buttervliet-uitspraak, die uitvoerig in hoofdstuk 8 van dit boek is besproken ${ }^{96}$, werd de rechtsfiguur van de 'burgercompensatie' in verstrekkende vorm door de Afdeling bestuursrechtspraak omarmd. ${ }^{97}$ De Afdeling aanvaardde immers in deze uitspraak dat een bestuursorgaan bindende compensatieverplichtingen kan vaststellen tussen burgers onderling in situaties waarin het nadeel geenszins het (directe) gevolg is van de behartiging van publiekrechtelijke belangen door het bestuur. Over de rechtsstatelijke implicaties van een en ander leek (en lijkt) de Afdeling zich, ondanks kritische geluiden in de literatuur, niet te bekommeren. ${ }^{98}$ Deze kritische geluiden zijn recentelijk enkel toegenomen. Zo merken Nicolaï c.s.9 in hun handboek over het verschijnsel 'compensatievoorschrift', in de lijn van de visie van Damen, het volgende op:

'Als voor het stellen van zo'n voorschrift geen wettelijke grondslag bestaat, moet zo'n voorschrift in strijd worden geoordeeld met art. 3:3 Awb (omdat het immers niet strekt ter bescherming van de algemene belangen die bij de vergunningverlening in acht moeten worden genomen) en verdraagt het zich niet met het legaliteitsbeginsel tenzij men het specialiteitsbeginsel (in onze ogen onaanvaardbaar) zou oprekken. (curs. R.J.N.S.)'

Ook Tak heeft kritisch stelling genomen tegen de figuur van de compensatievoorwaarde die hij niet alleen in strijd acht met het specialiteitsbeginsel, maar ook overbodig. ${ }^{100} \mathrm{De}$ forse kritiek is begrijpelijk. In feite is de Afdeling met haar 'rekkelijke' jurisprudentie nagenoeg beland in een situatie waarin ten principale wordt aanvaard dat het bestuur ook los van zijn doelgebonden bestuursbevoegdheid door middel van (vergunning)voorschriften rechtsposities van burgers onderling bindend kan vaststellen.

95. De rechtsoverwegingen kunnen m.i. dan ook niet worden verklaard door enkel te wijzen op het feit dat er sprake was van een voorlopige voorziening.

96. Zie paragraaf 8.6.5.

97. Het begrip 'burgercompensatie' is ontleend aan Damen (zie paragraaf 7.2.13).

98. Zie o.m. R.M. van Male, Marionette. Over het afwentelen van nadeelcompensatie bij beschikkingsvoorschrif, in: In de sfeer van administratief recht (Konijnenbelt-bundel), Utrecht 1994, i.h.b. p. $301 \mathrm{t} / \mathrm{m}$ 303. Zie ók paragraaf 8.4.5.

99. Nicolar e.a., Bestuursrecht, a.w., p. 199.

100. A.Q.C. Tak, De overheid in het burgerlijk recht, a.w., p. 394. Overbodig omdat het civiele aansprakelijkheidsrecht volgens hem reeds voorziet in een regeling (nl. art. 6:162 BW). 


\subsubsection{Een aantrekkelijk perspectief?}

Is deze ontwikkeling in de jurisprudentie en de bestuursrechttheorie, die de publieke en private 'conflictbeslechting' beoogt samen te trekken, nu werkelijk aantrekkelijk? Ik zou menen van niet. Het bestuurlijke besluitvormingsproces, dat gestuurd wordt door het specialiteitsbeginsel, is naar zijn aard niet gericht op het harmoniseren van typisch private rechtsgeschillen tussen civiele partijen onderling. ${ }^{101}$ Dat is primair het terrein van het civiele recht. Evenmin is dit proces erop gericht private rechtsposities van burgers onderling in volle omvang bindend vast te stellen. Private belangenconflicten worden $\mathrm{nl}$. enkel vanuit een publiekrechtelijk oogpunt gereguleerd. De 'rechtsrelatie' tussen burgers onderling wordt, in het kader van bijv. een vergunningstelsel, dan ook hooguit ten dele publiekrechtelijk ingevuld.

De bezwaren die geuit zijn tegen het (in vergaande mate) verweven van privaat- en publiekrecht in het kader van de bestuurlijke bevoegdheidsuitoefening zijn niet uitsluitend van academische aard. ${ }^{102}$ Het 'meewegen' van expliciet in het civiele recht gereguleerde rechtsconflicten tussen burgers door het bestuur leidt immers tot diverse complicaties voor de rechtspraktijk en verdient reeds daarom géen aanbeveling. Ik zal in vogelvlucht een drietal complicaties de revue laten passeren. Een eerste complicatie schuilt in de aard van het bestuurlijke besluitvormingsproces. Dit proces is primair gericht op de vorming van nieuw objectief publiekrecht, en niet op het (bindend) vaststellen van rechtsposities van rechtssubjecten (naar privaatrecht). Ook het belangenafwegingsproces, dat vooraf gaat aan het nemen van een discretionair besluit, vormt een onlosmakelijk onderdeel van het doelgebonden proces van publieke rechtsvorming. ${ }^{103}$

Een besluit, dat het eindresultaat is van dit publieke rechtsvormingsproces, zal na het ongebruikt verstrijken van de bezwaar- of beroepstermijnen van de Awb formele rechts-

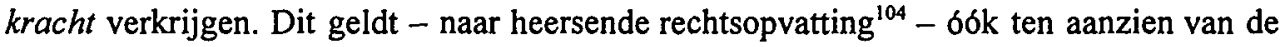
in dat besluit opgenomen (beschikkings)voorschriften. In geval van bezwaar- en beroep zal de formele rechtskracht intreden nadat hierover door de competente bestuurs- of rechterlijke beroepsinstantie onherroepelijk is beslist. Deze formele rechtskracht brengt de onaantastbaarheid van het betreffende bestuursbesluit met zich, welke onaantastbaarheid in principe óók door de civiele rechter dient te worden gerespecteerd. ${ }^{105}$

101. In het kader van een vergunningstelsel vindt - zoais gesteld - well een publiekrechtelijke regulering van 'gepubliciseerde' geschillen tussen burgers plaats (vgl. paragraaf 9.4.4 en 9.4.5).

102. Vgl. i.h.b. de in hoofdstuk 7 van dit boek besproken opvattingen van De Planque en Damen.

103. Vgl. over de samenhang tussen rechtsvorming, belangenafweging en belang R.M. van Male, Enkele aspecten van het begrip belanghebbende in de Algemene wet bestuursrecht, VAR-reeks 108, Alphen aan den Rijn 1992, p. 18-22.

104. Anders: A.Q.C. Tak, De overheid in het burgerlijk recht, a.w., o.m. p. 150 e.v. (i.h.b. p. 162). Tak koppelt de formele rechtskracht aan de publieke rechtshandeling, d.w.z. de vaststelling van het besluit, maar niet noodzakelijkerwijs aan de rechtsnormen die bij dat besluit in het leven zijn geroepen.

105. Zie voor de hoofdregel van de leer van formele rechtskracht HR 16 mei 1986, AB 1986, 573, m.nt. FHvdB; NJ 1986, 723, m.nt. MS (Heesch/Van de Akker). Voor een uitvoerige bespreking van deze leer, en verdere literatuurverwijzingen, verwijs ik naar: E.C.H.J. van der Linden, Rechtskracht en de 
Indien nu een bestuursorgaan bij wijze van vergunningvoorschrift bijv. burenrechtelijke rechtsposities van civiele partijen zou determineren, kunnen zich tegen de achtergrond van het leerstuk van formele rechtskracht van besluiten problemen voordoen. Stel dat een partij uiteindelijk toch een civiele vordering instelt. Hoe zal de burgerlijke rechter zich dan dienen op te stellen tegenover een besluit dat vergunningvoorschriften bevat die de rechtspositie van civiele partijen beogen te regelen ${ }^{106}$ terwijl ze in strijd zijn met bepalingen uit het Burgerlijk Wetboek? Zal hij ook in deze gevallen uit dienen te gaan van de onaantastbaarheid van deze voorschriften, of zal hij een uitzondering op de 'hoofdregel' van formele rechtskracht dienen aan te nemen? Dit laatste lijkt mij met het oog op een juiste interpretatie van het burgerlijke recht onontkoombaar. ${ }^{107}$ Voor de vergunninghouder, die vertrouwde op de juistheid van de 'vergunningvoorschriften', leidt dit dan tot extra onzekerheid. Deze vragen tonen reeds aan dat het 'meewegen' van in het burgerlijke recht gereguleerde rechtsconflicten in de bestuurlijke besluitvorming ertoe zal leiden dat er complexe competentieconflicten tussen het bestuur en de administratieve rechter enerzijds, en de civiele rechter anderzijds kunnen ontstaan. ${ }^{108}$

Een tweede complicatie schuilt in de principiële verschillen tussen privaatrechtelijke normen en publiekrechtelijke (bevoegdheids)normen. Ik wees daar reeds eerder op. ${ }^{109}$ Publiekrechtelijke normen die aan specifieke bestuursbevoegdheden ten grondslag liggen, zijn doelgebonden en toepasselijk op vooraf welomschreven handelingen (rechtsfeiten); zij hebben een uitgesproken - door de wetgever gedetermineerd - conditioneel karakter. Privaatrechtelijke normen, waaronder in het bijzonder de (ongeschreven) maatschappelijke zorgvuldigheidsnormen, zijn daarentegen vaak open en flexibel van aard. Zij zijn toegespitst op het kleurrijke spectrum van rechtsconflicten tussen burgers onderling. Zo biedt bijv. artikel 6:162 BW (onrechtmatige daad) een voorbeeld van een flexibel normenstelsel dat ten dienste staat van de typisch burgerrechtelijke conflictbeslechting. Het verschil in rechtskarakter van de bedoelde normen brengt o.m. met zich dat een begrip als 'maatschappelijke' onzorgvuldigheid moeilijk in vergunningvoorschriften onder woorden kan worden gebracht. ${ }^{110}$ Bovendien is de vergunningverlening, toegespitst op typische

publiekrechtelijke wederkerige rechtsbetrekking, in: Eenzijdig en wederkerig? (red. E.C.H.J. van der Linden en A.Q.C. Tak), Deventer 1995, p. 191 e.v. alsmede naar M.R. Mok en R.P.J.L. Tjittes, Formele rechtskracht en overheidsaansprakelijkheid, RMTh. 1995, p. 383 e.v.

106. Ik wijs in dit kader ook op de spanning met art. $107 \mathrm{Gw}$ waar in lid 1 o.m. is bepaald dat de wet (met delegatie-mogelijkheid) het burgerlijk recht in algemene wetboeken regelt.

107. Strikt genomen kan de burgerlijke rechter uiteraard het besluit in een dergelijke civiele procedure 'negeren', en de rechtspositie van de betrokken civiele partijen naar burgerlijk recht vaststellen (vgl. HR 2 februari 1990, AB 1990, 223, m.nt. G.P. Kleijn (Bolsius)). Problematisch is echter dat er dan naast het BW een ander soort 'privaat'-recht in de vorm van vergunningvoorschriften blijft bestaan dat hiermee in strijd is.

108. Hier is ook door De Planque op gewezen. Zie: J.H.W. de Planque, De mogelijkheden van administratieve rechters en de Kroon om het bestuur tot schadevergoeding te veroordelen, VAR-reeks 102, Alphen aan den Rijn 1989, p. 23.

109. Zie: R.J.N. Schlठssels, Het specialiteitsbeginsel en derde-belangen, a.w., i.h.b. p. 89-93.

110. Vgl. J.A.M. van Angeren, De gewone rechter en de administratieve rechtsgangen, Deventer 1968, p. 131. 
duurvergunningen, slechts een momentopname die de (privaatrechtelijke) werkelijkheid natuurlijk niet kan 'bevriezen'. Daarom zal er in het rechtsverkeer tussen burgers, onverminderd de aanwezigheid van een geldige publiekrechtelijke vergunning en/of regulering, steeds een (aanvullend) beroep op privaatrechtelijke rechtsnormen moeten kunnen worden gedaan ter bescherming van private rechtsbelangen. Dit komt mijns inziens o.m. tot uitdrukking in de leer van de Hoge Raad inzake de vrijwarende werking van vergunningen. ${ }^{111}$

Een derde en laatste complicatie die het meewegen van 'private' rechtsgeschillen door het bestuur met zich brengt is van praktische aard. Naar mijn oordeel is het simpelweg niet verantwoord om bestuursorganen, die binnen de organisatie van de staat een typische bestuursfunctie vervullen, te belasten met de interpretatie én eerstelijns handhaving van burgerlijk recht. Het bestuur is hiervoor niet geequipeerd. De handhaving van het burgerlijke recht is van oudsher toevertrouwd aan de rechtsgenoten onderling die hierbij een beroep kunnen doen op de burgerlijke rechter. Een plicht voor het bestuur om ten principale met privaatrechtelijke normen en rechtsconflicten tussen burgers onderling rekening te houden zou bovendien geenszins bijdragen aan een doelmatig, doorzichtig en dáárdoor rechtszeker bestuurlijk besluitvormingsproces. De complexe bestuurlijke plicht om rechtsbelangen van burgers te harmoniseren in het licht van speciale publiekrechtelijke belangen wordt immers nog complexer indien de beslechting van private rechtsconflicten tussen burgers onderling een bijkomende doelstelling wordt van de bestuurlijke besluitvorming. Het samen laten vloeien van de typisch publieke en private normensfeer zou bovendien, zoals Damen terecht signaleerde, een ongespecificeerde belangenafwegingsplicht in de handen van het bestuur leggen.

Door Van Hall'112 is in dit verband tegengeworpen dat een 'te strakke' uitleg van het specialiteitsbeginsel ertoe zal leiden dat burgers snel verwezen worden naar het civiele recht, hetgeen hij blijkbaar onwenselijk acht. Een soortgelijke opvatting bespeur ik bij Simon die met het oog op een doelmatige rechtsbedeling in dit verband gewicht toekent aan de toegankelijkheid van de rechter. ${ }^{113}$ Hoe sympathiek deze standpunten ook zijn, ik lees er géén overtuigend juridisch argument in om de betekenis van het specialiteitsbeginsel, als structuurprincipe van bestuursbevoegdheid, te relativeren. Indien rechtssubjecten immers de bescherming die het materiêle privaatrecht hen biedt in rechte moeizaam kunnen afdwingen dan dient deze problematiek naar mijn oordeel te worden ondervangen door het vereenvoudigen van het burgerlijke rechtsvorderingsrecht en niet door een 'rechtsbeschermingsvlucht' - via het bestuurlijke besluitvormingsproces - naar de administratieve rechter. ${ }^{14}$

111. Zie over deze jurisprudentie hoofdstuk 8 van dit boek, paragraaf 8.8.4 e.v.

112. A. van Hall, Het specialiteitsbeginsel in het waterstaatsrecht. Over kringen van belangen, oratie UU, Zwolle 1995, p. 78.

113. Zie voor de opvatting van Simon uitvoerig hoofdstuk 7. Zie o.m.: H.J. Simon, Handboek bestuurs(proces)recht volgens de Awb, 's-Gravenhage 1997, p. 140. Vgl. ook H.J. Simon, Publiekrecht of privaatrecht?, diss. VU, Zwolle 1993, p. 342. 
Overziet men de diverse complicaties, dan ben ik van oordeel dat het standpunt dat De Planque in 1989 in zijn VAR-preadvies innam nog steeds hout snijdt. Hij kwam, kort gezegd, tot de conclusie dat het (in rechtsvormende zin) meewegen van uitdrukkelijk in het privaatrecht beschermde belangen, en het reguleren van intersubjectieve rechtsgeschillen tussen burgers door het bestuur - los van een specifieke bevoegdheid -, een weg is die niet opgegaan moet worden dan wel zo snel mogelijk dient te worden verlaten. ${ }^{115}$ Meer in algemene zin zou ik hieraan nog willen toevoegen dat er op het eerste gezicht wellicht een aantrekkelijke weg in het geding lijkt, maar dat deze weg onvoldoende is doordacht vanuit de typische structuurgrondslagen van het publiek- en privaatrecht.

\subsection{De rechtsgevolgen van een bevoegdheidsuitoefening}

De bestuurlijke bevoegdheidsuitoefening fungeert binnen de (publieke) rechtsorde niet uitsluitend als een doelgerichte rechtshandeling met beoogde rechtsgevolgen, maar in ruimere zin óó als rechtsfeit. Het objectieve (publiek)recht kan immers aan een bepaalde bevoegdheidsuitoefening rechtsgevolgen verbinden die niet direct voortvloeien uit de specifieke bevoegdheidsnorm maar uit andere (ongeschreven) rechtsnormen. Dit klinkt in eerste instantie misschien wat vreemd, hetgeen verband houdt met het feit dat deze vanzelfsprekende stelling impliciet ten grondslag ligt aan ons denken over de bestuurlijke bevoegdheidsuitoefening. ${ }^{116}$ Het is mijns inziens ook niet zo'n verrassende stelling, maar zij kan wél verklaren waarom bepaalde rechtsgevolgen van een bestuurlijke bevoegdheidsuitoefening volledig beheerst worden door het specialiteitsbeginsel en andere niet. Wat dit laatste betreft wijs ik in het bijzonder op de plicht tot nadeelcompensatie die door verschillende auteurs, onder omstandigheden, óok dan wordt aangenomen indien een bepaald belang van een rechtssubject géen rol mag spelen in de bestuurlijke belangenafweging (d.w.z. in de doelgerichte rechtsvorming). Ik kom hier op terug in paragraaf 9.6.2. Waar het op deze plaats om gaat is de notie dat een bevoegdheidsuitoefening als

114. Overigens heb ik reeds eerder aangegeven dat het wellicht wél een aantrekkelijke optie is om in de toekomst de administratieve rechter gelijktijdig met de toetsing van een bestuursbesluit kennis te laten nemen van (eenvoudige) civiele rechtsvorderingen die in relatie staan tot dat besluit. Zie: R.J.N. Schløssels, Een dakkapel te Edam: de wens van eenheid van recht?, a.w., p. 81-82.

115. J.H.W. de Planque, VAR-recks 102, a.w., p. 27.

116. Steenbeek wees er reeds op in de inleiding bij zijn proefschrift, toen hij er de aandacht op vestigde dat de rechtsgevolgen van een beschikking niet enkel uit de beoogde rechtshandeling voortvloeien maar soms óok uit de beschikking als rechtsfeit. Dit aspect viel echter buiten zijn onderzoeksterrein: 'Onder rechtsgevolgen worden dan in dit verband slechts verstaan de rechtsgevolgen welke rechtstreeks voortvloeien uit de rechtshandeling, en derhalve niet de rechtsgevolgen welke indirecte zouden kunnen worden genoemd, omdat zij voortvloeien uit het enkele geschieden van de rechtshandeling als rechtsfeit, zoals bijv. het geval is wanneer een overheidsbeschikking tevens oplevert een onrechtmatige daad' (curs. R.J.N.S.). Zie: J.G. Steenbeek, Rechtshandeling en rechtsgevolg in het staats- en administratief recht, Assen/Arnhem 1958 , p. 9. Ik vestig de aandacht op de Maastrichtse bundel met opstellen die geheel in het teken staat van de bevoegdheidsuitoefening door de overheid als rechtsfeit, getiteld: Spectraal recht? De bevoegdheidsuitoefening door de overheid als rechtsfeit (red. E.C.H.J. van der Linden, R.J.N. Schlossels en R.J.G.H. Seerden), Den Haag 1998. 
rechtshandeling is gebaseerd op een specifieke bestuursbevoegdheid (een expliciete bevoegdheidsnorm), en dat deze bevoegdheidsuitoefening tegelijkertijd als rechtsfeit wordt genormeerd door de (ongeschreven) regels en beginselen van het objectieve publiekrecht. De inhoud van een besluit wordt daarom uiteindelijk enerzijds bepaald door de specifieke bevoegdheid (het specialiteitsbeginsel)en anderzijds door meer algemene publiekrechtelijke rechtsnormen. Dit uitgangspunt lijkt mij in het bestuursrecht algemeen te worden gedeeld.

Door de wettelijke definiëring van een besluit als een publiekrechtelijke rechtshandeling (vgl. artikel 1:3 Awb) wordt echter het gegeven dat 'de' rechtsgevolgen van 'de' bevoegdheidsuitoefening niet enkel uit een specifieke bevoegdheidsnorm voortvloeien maar óok uit andere publieke rechtsnormen soms uit het oog verloren. Dit heeft er naar mijn mening in de discussies over de interpretatie van het specialiteitsbeginsel bijv. toe geleid dat wel verdedigd wordt dat rechtsbelangen van rechtssubjecten geheel buiten de 'belangenafweging' dienen te blijven voorzover zij niet 'samenvallen' met het publiekrechtelijke belang dat ten grondslag ligt aan de specifieke bevoegdheidsnorm. Hier is mijns inziens sprake van een ongewenste verabsolutering van de 'Schutznormgedachte'.

Huldigt men een dergelijk standpunt, dan verliest men immers uit het oog dat het specialiteitsbeginsel alleen met zich brengt dat (private) rechtsbelangen niet van invloed mogen zijn op het gerichte publieke rechtshandelen. Het beginsel brengt echter géenszins met zich dat het bestuur met de rechtstreeks betrokken belangen van rechtssubjecten géen rekening behoeft te houden. De bestuurlijke bevoegdheidsuitoefening, die 'erga omnes' werkt, kan immers relevante gevolgen hebben ten aanzien van een vooraf nog onbepaalde groep van rechtssubjecten. Doordat de bevoegdheidsuitoefening binnen het recht fungeert als een zelfstandig rechtsfeit, kan het (geschreven én ongeschreven) publiekrecht, zoals gesteld, rechtsgevolgen aan deze bevoegdheidsuitoefening verbinden welke niet herleidbaar zijn tot de specifieke bevoegdheidsnorm. Reeds hieruit vloeit voort dat het bestuur met bepaalde (rechts)belangen rekening moet houden ook al worden deze belangen niet expliciet 'beschermd' door de (secundaire) publieke bevoegdheidsnorm.

\subsubsection{Rechtsbelangen: twee hoofdgroepen?}

In dit hoofdstuk resteert de vraag met welke subjectgebonden rechtsbelangen een bestuursorgaan in het kader van de uitoefening van zijn (discretionaire) bestuursbevoegdheid in het bijzonder rekening behoort te houden. Ik zou mij in dit verband, in het verlengde van de opmerkingen die ik in hoofdstuk 6 maakte over het begrip 'rechts'-belang, op het standpunt willen stellen dat er binnen de (publieke) rechtsorde twee belang-typen kunnen worden onderscheiden die als zelfstandig subjectgebonden rechtsbelang fungeren. Het betreft hier: (1) de subjectieve vermogensrechten, en (2) de grond- en mensenrechten. Deze twee hoofdgroepen, die ruim moeten worden opgevat en zeker niet strikt van elkaar gescheiden behoeven te worden, kunnen nader worden onderverdeeld. Een gedetailleerde uitsplitsing zal ik in dit boek echter achterwege laten. Waar het mij om gaat is het volgende. Om het bestuurlijke proces van belangenafweging-en rechtsvorming in concreto vanuit een juridisch oogpunt beter te kunnen doorgronden zal men naar mijn oordeel een materiële invulling aan het begrip 'rechtsbelang' moeten geven. In hoofdstuk 6 is door mij 
het standpunt ingenomen dat het rechtsbelang een species is van een grotere groep rechtens relevante belangen. I $k$ duidde al deze belangen aan onder het verzamelbegrip 'normatieve belangen'. Naast het typische 'rechtsbelang', ten aanzien waarvan rechtssubjecten (natuurlijke personen en rechtspersonen ${ }^{117}$ ) als drager fungeren, heb ik de publiekrechtelijke belangen en de 'intern' statutaire belangen (van rechtspersonen) als hoofdgroepen onderscheiden. Ik neem in dit boek het standpunt in dat een bestuursorgaan bij de uitoefening van een discretionaire bestuursbevoegdheid in het bijzonder rekening dient te houden met de typische rechtsbelangen van rechtssubjecten (d.w.z. de vermogensrechten in ruime zin én de erkende grond- en mensenrechten). Dit standpunt sluit volgens mij nl. goed aan bij de jurisprudentie van het Europese Hof voor de Rechten van de Mens (EHRM), maar bijv. ó́k bij de eerder besproken Duitse theorievorming. ${ }^{118} \mathrm{Ik}$ zal nu bij beide typen subjectgebonden 'rechtsbelangen', toegespitst op de bevoegdheidsuitoefening en het specialiteitsbeginsel, kort stilstaan.

\subsubsection{Het specialiteitsbeginsel en nadeelcompensatie}

Subjectieve vermogensrechten - persoonlijke en absolute - vormen binnen het private recht(sverkeer) het voorbeeld bij uitstek van typisch subjectgebonden rechtsbelangen. Kenmerkend voor het vermogensrecht is dat de aldaar beschermde belangen in de regel naar hun aard op geld waardeerbaar zijn. ${ }^{119}$ Omdat de doelstelling van het gerichte bestuurlijke rechtsvormingsproces in de democratische rechtsstaat is gelegen in het harmoniseren en reguleren van alle materißle rechtssferen in het licht van typisch publiekrechtelijke belangen, zal aan de subjectieve vermogensrechten van natuurlijke én rechtspersonen in het kader van de bestuurlijke bevoegdheidsuitoefening bijzondere betekenis dienen toe te komen. De respectering van de vermogensrechtelijke sfeer van de vrije burgerlijke maatschappij door de statelijke (bestuurs)organen is hier nl. in het geding.

In dit kader dient te worden vastgesteld dat een vermogensrecht in geval van een rechtmatige aantasting door een bestuurlijke bevoegdheidsuitoefening naar zijn aard in financiële zin kan worden gecompenseerd. Hiertoe bestaat, mits aan een aantal compensatievoorwaarden is voldaan ${ }^{120}$, naar Nederlands bestuursrecht ook een plicht. Een dergelijke nadeelcompensatieplicht kan, zoals door Vucsán in een reactie op een eerdere publicatie van mijn hand werd gesignaleerd, bestaan onafhankelijk van de werking van het

117. En naast natuuriijke en rechtspersonen soms ook collectiviteiten van rechtssubjecten die niet de (burgerrechtelijke) status van rechtspersoon hebben.

118. Vgl. paragraaf 9.4.4.

119.) Zie bijv. Pitlo/Gerver e.a., Het systeem van het Nederlandse privaatrecht, elfde druk, Amhem 1995, p. 109.

120. Zie voor een bespreking van deze criteria (waaronder-het begrip_normaal maatschappelijk risico') bijy. mijn noot onder ABRS 26 oktober 1995, JB 1996/13 (NV Regionale Energiemaatschappij Utrecht). 
specialiteitsbeginsel. ${ }^{121}$ Dit beginsel stuurt immers, zoals gesteld, enkel de bevoegdheidsuitoefening als rechtshandeling, maar beperkt niet de plicht voor het bestuur om bijv. in geval van een schending van de 'égalité devant les charges publiques' ${ }^{122}$ financiele compensatie aan te bieden. ${ }^{123}$ Een plicht tot nadeelcompensatie vloeit naar mijn oordeel dan ook niet voort uit de specifieke (secundaire) bevoegdheidsnorm maar uit de rechtsnormen die de bevoegdheidsuitoefening als rechtsfeit (mede) normeren. ${ }^{124}$ Het loskoppelen van de nadeelcompensatieproblematieken het specialiteitsbeginsel is in de literatuur, zo bleek in hoofdstuk 7, reeds door verschillende auteurs verdedigd. ${ }^{125}$ Dit uitgangspunt lijkt mij juist én verenigbaar met het specialiteitsbeginsel.

Ik wijs er in dit verband nog op dat de ruime(re) erkenning in het bestuursrecht van de mogelijkheid voor een rechtssubject om 'zelfstandige schade- en compensatiebesluiten' ${ }^{126}$

121. R.L. Vucsán, Het kind van de rekening: nadeelcompensatie en de afwenteling in de algemene wet bestuursrecht, in: In wederkerigheid (Scheltema-bundel), Deventer 1997, p. 301. In mijn NTB-artikel over het specialiteitsbeginsel, waar Vucsán op reageerde, heb ik de relatie tussen dit beginsel en een eventuele compensatieplicht tegen de achtergrond van de behartiging van het speciale publiekrechtelijke belang benadrukt. Ik sloot echter niet uit dat ook los van het specialiteitsbeginsel compensatieplichten denkbaar zijn. R.J.N. Schlðssels, Het specialiteitsbeginsel en derde-belangen: een frisse benadering of rechtsstatelijk drijfzand?, a.w., p. 95.

122. Welk beginsel expliciet in de Nederlandse jurisprudentie is erkend. Zie: ABRS 18 februari 1997, AB 1997, 143, m.nt. PvB; JB 1997/47, m.nt. HJS (grondwaterbeschermingsgebied Vierlingsbeek) en ABRS 6 mei 1997, AB 1997, 229, m.nt. PvB; JB 1997/118, m.nt. HJS (Van Vlodrop BV). Zie over dit beginsel bijv.: B.J. Schueler, Schadevergoeding onder de Algemene wet bestuursrecht (Mon. Awb B7), Deventer 1997, p. 107; J.A.M. van den Berk, Bestuursschaderecht, Deventer 1997, p. 17-19 en H.J. Simon, Handboek bestuurs(proces)recht volgens de Awb, a.w., p. 144-145. Zie ook: PG Awb I, MvA II, p. 212. Het égalité-beginsel, dat uit het Franse bestuursrecht afkomstig is, was echter al lang in ons land bekend. Vgl. de uitvoerige studie van Konijnenbelt. W. Konijnenbelt, De égalité devant les charges publiques in het Franse administratieve recht, Bestuurswetenschappen 1971/5, p. 265 e.v.

123. Anders: J.A.M. van den Berk, Bestuursschaderecht, a.w., p. 94. Van den Berk lijkt ervan uit te gaan dat de werking van het specialiteitsbeginsel de nadeelcompensatieplicht ingevolge het égalité-beginsel kan belinvloeden.

124. De 'bevoegdheidsuitoefening' geldt uiteraard wél als causa. Wat betreft de compensatieplicht kan ik met Van Burren instemmen wanneer hij signaleert dat een rechtsgevolg van een besluit niet (direct) voortvloeit uit een rechtsbeginsel (vgl. de égalité-norm). Zie: P.J.J. van Buuren, Grenscorrectie tussen bestuursrecht en privaatrecht via het zelfstandig schadebesluit, NJB 1997/17, p. 763. Ik acht het minder juist om op een beginselnorm een separate bevoegdheid van het bestuur te baseren op basis waarvan kan worden vastgesteld of er een compensatieplicht bestaat. M.i. vloeit een compensatieplicht nl. voort uit het objectieve publiekrecht bij een bepaalde modaliteit van bevoegdheidsuitoefening (als rechtsfeit). Het bestuurs-'besluit' omtrent compensatie zie ik in dit verband mér als een 'declaratoir'. Het gaat hier nl. om de vaststelling van een (ongeschreven) rechtsplicht die uit een publiek rechtsbeginsel voortvloeit. Vgl. Th. G. Drupsteen, Het zelfstandig schadebesluit en de ondragelijke lichtheid van de Nederlandse Grondwet (reacties), NJB 1997/34, p. 1597.

125. Ik wijs i.h.b. op de visies van Simon, Tak, Messer/Heldeweg en Van den Berk.

126. De literatuur hierover is welhaast niet meer te overzien. Ik wijs op de jurisprudentiebesprekingen door B.J. Schueler, Schadevergoeding onder de Algemene wet bestuursrecht, a.w., i.h.b. hoofdstuk 2; H.J. Simon en R.J.N. Schlossels, Het zelfstandig schadebesluit; nieuwe kansen?, JB 1996/255, p. 1119 e.v;; B.P.M. van Ravels, De Afdeling bestuursrechtspraak en het zuivere schadebesluit: geen schoonheidsprijs, NTB 1997/2, p. 55 e.v.; P.J.J. van Buuren, Grenscorrecties tussen bestuursrecht en privaatrecht via het zelfstandig 
uit te lokken, uiteindelijk een positieve uitwerking kan hebben op een precieze interpretatie van het specialiteitsbeginsel. Uit de jurisprudentie-analyse kan $\mathrm{nl}$. worden afgeleid dat de gesignaleerde 'rekkelijke' tendensen in de (Afdelings)rechtspraak voor een deel toegeschreven kunnen worden aan de wens om steeds een - procedurele - mogelijkheid voor nadeelcompensatie open te houden. Dit leidde in de jaren tachtig van de twintigste eeuw o.m. tot de ontwikkeling van de figuur van het 'onzuiver schadebesluit ${ }^{127}$, waarbij de nadeelcompensatievraag de bestuurlijke besluitvorming ten principale ging beheersen. Uiteindelijk heeft deze jurisprudentie er naar mijn oordeel toe bijgedragen dat de administratieve rechter de gekritiseerde praktijk van de 'burgercompensatie' en 'afwentelingsvoorschriften' aanvaardde. Doordat de nadeelcompensatieproblematiek momenteel via de weg van een 'zelfstandig besluit' tamelijk eenvoudig kan worden afgesplitst van de besluitvorming ten principale, zal deze in rustiger vaarwater kunnen worden afgewikkeld. ${ }^{128}$ Met het oog hierop zal dan mijns inziens wél dienen te worden aanvaard dat het 'uitlokken' van een zelfstandig 'compensatie'-besluit óók dan mogelijk is indien het connexe (rechtmatige) 'hoofdbesluit' reeds formele rechtskracht heeft. ${ }^{129}$

\subsubsection{Civil rights and obligations: een bredere invalshoek}

lk zou er overigens voor willen pleiten om het begrip 'vermogensrecht' in een bestuursrechtelijke context, mede gelet op het 'Europese recht' niet beperkt, d.w.z. in de zin van het Burgerlijk Wetboek (BW), uit te leggen. Om meer inzicht te verkrijgen in een benade-

schadebesluit, a.w., p. 759 e.v.; T. Knoop, De Afdeling bestuursrechtspraak gooit het roer om. Het zelfstandig schadebesluit. Hooge Raad, let op uw seack, Gst. 7054, p. 286 e.v. en I.C. van der Vlies, Zelfstandige schadebesluiten, AAe 1997/9, p. 602 e.v.

127. Vgl. de in hoofdstuk 8 besproken Paul-Krugerbrug jurisprudentie.

128. Vgl. W. Konijnenbelt, De administratieve rechter als schadevergoedingsrechter (preadvies voor de vereniging voor burgerlijk recht), Lelystad 1996, p. 19-20. Een wettelijke regeling van het 'zelfstandig schade- en/of nadeelcompensatiebesluit' in de Awb is, gelet op de rechtszekerheid, in dit verband wenselijk maar m.i. niet absoluut noodzakelijk. Vgl. J.M. Polak, Het zelfstandig schadebesluit (opinie), NJB 1997/29, p. 1326. Anders Kortmann die zelfs Grondwettelijke bezwaren meent te ontwaren wat betreft de praktijk van het 'zelfstandig schadebesluit'. Zie: C.A.J.M. Kortmann, De Grondwet en de jurisprudentie inzake het zelfstandig schadebesluit, NJB 1997/29, p. 1327 e.v. Deze kritiek wordt m.i. treffend ontzenuwd door Th. G. Drupsteen, Het zelfstandig schadebesluit en de ondragelijke lichtheid van de Nederlandse Grondwet (reacties), a.w. p. 1596 e.v. Een voorstel voor een Awb-regeling betreffende zelfstandige nadeelcompensatiebesluiten treft men aan bij: P.J.J. van Buuren, Nadeelcompensatie in de Algemene wet bestuursrecht, in: Aantrekkelijke gedachten. Beschouwingen over de Algemene wet bestuursrecht (red. Boxum/Damen e.a.), Deventer 1993, p. 91 e.v. (i.h.b. p. 102 e.v.).

129. Welke mogelijkheid ik aanvaard door te onderscheiden tussen de bevoegdheidsuitoefening als (beoogde) rechtshandeling en (in ruimere zin) als rechtsfeit, alsmede op basis van een differentiatie tussen absolute en relatieve onrechtmatigheid van een bevoegdheidsuitoefening (vgl. wat dit laatste betreft paragraaf 9.7), Deze opvatting is (nog) niet algemeen aanvaard. Vgl. bijv.: B.J. Schueler, Schadevergoeding onder de Algemene wet bestuursrecht, a.w., p. 113-114. Schueler plaatst vraagtekens bij een zelfstandig schadebesluit indien het connexe hoofdbesluit reeds formele rechtskracht heeft. Ik zie niet zoveel problemen indien een langere termijn voor het uitlokken van een zelfstandig schade- of compensatiebesluit wordt erkend die bijv. aansluit bij de civielrechtelijke verjaringstermijnen. 
ring van het bestuurlijke rechtsvormingsproces vanuit de wereld van de daarbij betrokken subjectgebonden (vermogens)belangen, is het instructief om een blik te werpen op de jurisprudentie van het Europese Hof voor de Rechten van de Mens (EHRM). In deze jurisprudentie is, in het licht van artikel $6 \mathrm{EVRM}^{130}$, nl. veelvuldig de vraag aan de orde gesteld of bepaalde bestuurlijke besluitvorming bepalend is voor de vaststelling van de 'civil rights and obligations' van rechtssubjecten. Ofschoon artikel 6 EVRM uiteraard primair de toegang tot een onafhankelijke en onpartijdige rechter garandeert is het in dit verband mijns inziens eveneens van belang voor de bestuurlijke besluitvorming. Omdat genoemd artikel $\mathrm{nl}$. de toegang tot de rechter óbk veilig stelt indien door bestuurshandelen 'civil rights' worden gedetermineerd, wordt door de toepassing van deze bepaling op een indirecte wijze een antwoord gegeven op de vraag in welke gevallen een bestuurlijke bevoegdheidsuitoefening de (rechts)belangen van burgers raakt ('determineert'). Er vanuit gaande dat artikel 6 EVRM door het Hof bovendien autonoom, d.w.z. onafhankelijk van nationale kwalificaties, wordt uitgelegd, kan de jurisprudentie op basis van deze verdragsbepaling dus belangrijke aanwijzingen bevatten voor de beantwoording van de vraag welke belangen van rechtssubjecten volgens het Hof als zelfstandig rechtsbelang dienen te worden aangemerkt.

Overziet men de jurisprudentie op basis van artikel 6 EVRM, dan valt allereerst op dat het Hof zich bij de uitleg van het 'civil right'-begrip in eerste instantie concentreerde op de klassieke vermogensrechten en in het bijzonder op het eigendomsrecht. ${ }^{131}$ Een oriëntering op de 'burgerlijke' rechtsstaatgedachte zal in dit verband een belangrijke rol hebben gespeeld. ${ }^{132}$ Deze benadering bracht met zich dat het Hof publieke besluitvormingsprocedures, die (mede) gericht zijn op concrete of algemene normstelling en die de vrije uitoefening van het eigendomsrecht beïnvloeden, beslissend acht voor de vaststelling van 'civil rights and obligations'. ${ }^{133}$ Ook bestuurlijke besluitvorming (bijv. vergunningverlening) die van invloed is op rechten welke als een afgeleide van het (economische) eigendomsrecht kunnen worden aangemerkt, zijn door het Hof op deze wijze binnen de wer-

130. Voor een uitvoerige analyse van de relevante jurisprudentie verwijs ik naar M.L.W.M. Viering, Het toepassingsgebied van art. 6 EVRM, diss. UU, Zwolle 1994, m.n. hoofdstuk 4.

131. Vgl. voor een bevestiging van het belang van het eigendomsrecht: EHRM 28 september 1995, Series A, Vol. 326 (Procola vs. Luxembourg). Zie m.n. rechtsoverweging 39 van dit arrest. Het recht op eigendom (in meer beperkte zin) is verankerd in art. 1 van het eerste Protocol behorende bij het EVRM. Zie hierover: J.G.C. Schokkenbroek, Toetsing aan de vrijheidsrechten van het Europees verdrag tot bescherming van de rechten van de mens, diss. RUL, Zwolle 1996, p. 53-57. Van belang is dat het eigendomsbegrip in de EVRM-context in relatie tot het begrip 'civil right' ruim wordt uitgelegd in die zin dat er bijv. 6ók opgebouwde pensioenaanspraken, het (persoonlijke) gebruik van een zaak, alsmede ondernemers-'goodwill' onder kunnen vallen. Ik wijs - ter vergelijking - 6ók op de vier fundamentele 'vrijheden' van het EG-verdrag die m.i. eveneens een afgeleide zijn van het (economische) eigendomsrecht (t.w. het vrije verkeer van goederen, werknemers, diensten en kapitaal). Voorzover ik het eigendomsrecht in deze bijdrage als typisch rechtsbelang positioneer doel ik op een dergelijke ruime betekenis en niet op de beperkte zakenrechtelijke betekenis zoals bedoeld in art. 5:1 BW.

132. Vgl. E.M.H. Hirsch Ballin, Het grondrecht op behoorlijke rechtspraak in het Nederlandse administratieve recht, Handelingen NJV deel 1, tweede stuk, Zwolle 1983, p. 94. 
kingssfeer van artikel 6 EVRM gebracht. Gedacht kan bijv. worden aan het 'economische' - en derhalve op geld te waarderen - 'recht' op een vrije bedrijfs- en beroepsuitoefening. ${ }^{134}$

In dit kader is van bijzonder belang dat 'civil rights' in de optiek van het Hof niet alleen kunnen worden gedetermineerd door een tot een bepaald rechtssubject gerichte bevoegdheidsuitoefening (d.w.z. het publieke 'rechtshandelen'). Uit verschillende arresten, waaronder in het bijzonder de Ortenberg- en Zander-cases ${ }^{135}$, blijkt $\mathrm{nl}$. dat een publieke bevoegdheidsuitoefening als rechtsfeit van bepalende invloed kan zijn op 'civil rights and obligations' van bijv. derden. ${ }^{136}$ Met name uit de Zander-case (r.o. 25/26) blijkt dat publieke vergunningverlening, ók indien deze gebaseerd is op een discretionaire bestuursbevoegdheid ${ }^{137}$, van bepalende invloed kan zijn op de 'civil rights' van omwonenden (derden). Hieraan doet niet af het feit dat de aantasting van burgerlijke rechten eventueel in een separate schadevergoedingsprocedure aan de orde kan worden gesteld. Gelet op de Nederlandse specialiteitsdiscussie is met name van belang dat het Straatburgse Hof het onderscheid tussen 'direct-belanghebbende' en 'derden' in dit verband niet lijkt te maken. Uitgangspunt is steeds dat rechtssubjecten, ongeacht tot wie het publieke rechtshandelen is gericht, door een bevoegdheidsuitoefening in hun 'civil rights' kunnen worden geraakt. Een rechtsbeschermingsprocedure die aan de eisen van artikel 6 EVRM voldoet moet dan toegankelijk zijn.

Naast de jurisprudentie van het Hof over artikel 6 EVRM, die rechtstreeks of meer indirect steunt op het (klassieke) eigendomsrecht, staan uitspraken waarin ook los van dit recht 'civil rights and obligations' in de vermogensrechtelijke sfeer worden erkend. Hierbij dient gedacht te worden aan verschillende soorten uitkeringen op grond van de sociale zekerheidswetgeving. Of een bepaald recht in dit kader een 'civil' karakter vertoont is

133. Zie de 'Jacobsson-cases' waarin de relatie tussen een publiekrechtelijk bouwverbod en het eigendomsrecht aan de orde kwam (EHRM 25 oktober 1989, Series A, Vol. 163 en EHRM 28 juni 1990, Series A, Vol. $180 \mathrm{~A}$ ). Zie voorts de zaak Oerlemans waarin de relatie tussen een aanwijzing ingevolge de Nederlandse Natuurbeschermingswet en het eigendomsrecht centraal stond (EHRM 27 november 1991, Series A, Vol. 219).

134. In dit kader dient uiteraard op het bekende Benthem-arrest te worden gewezen (EHRM 23 oktober 1985, Series A, Vol. 97, m.n. rechtsoverweging 36). Vgl, voorts EHRM 7 juli 1989, Series A, Vol. 159 (Tre Traktorer $\mathrm{AB}$ ). In deze - uitvoerig gemotiveerde zaak - stond de intrekking van een drank- (en Horeca)vergunning ingevolge de Zweedse wetgeving centraal. Deze vergunning werd bepalend geacht voor de exploitatie van een restaurant.

135. EHRM 25 november 1994, Series A, Vol. 295 B (Ortenberg vs. Austria) en EHRM 25 november 1993, Series A, Vol. 279 B (Zander vs. Sweden).

136. Het Hof gaat er dus vanuit dat een bestuurlijke (of soms rechterlijke) bevoegdheidsuitoefening beslissend kan zijn voor de 'determination of civil rights' als het betreffende 'right' hierdoor enkel feitelijk (en dus niet bindend-juridisch) wordt geraakt. Zie in dit kader ook: R.J.N. Schlossels, Hoe hard mag een appelverbod zijn? Enige opmerkingen over de uitsluiting van hoger beroep tegen voorlopige voorzieningen ex art. 8:84 Awb, JB 1997/166, p. 748.

137. Discretie sluit uiteraard niet uit dat 'civil rights' kunnen worden gedetermineerd op een rechtens bindende wijze. Discretie wordt immers steeds genormeerd door het recht. Vgl. in dit verband EHRM 21 september 1993, Series A, Vol. 268 A (Zumtobel vs. Austria). 
volgens het Hof afhankelijk van diverse criteria die in een flexibel analysemodel zijn neergelegd. In dit kader is de formele kwalificatie van een bepaalde zekerheids-'aanspraak' naar nationaal recht slechts indicatief. Doorslaggevend acht het Hof het materiële rechtskarakter van de 'aanspraak', waarbij bijv. o.m. wordt gelet op de samenhang met traditionele privaatrechtelijke rechtsfiguren zoals de arbeidsovereenkomst en de verzekeringsovereenkomst. Medebepalend acht het Hof ók of een bepaalde 'aanspraak' kan worden gekarakteriseerd als een typisch 'personal, economic and individual right'.

In de sfeer van de sociale zekerheids-uitkeringen is het Hof in de arresten Feldbrugge en Schuler-Zgraggen ${ }^{138}$, alsmede in het arrest Salesi ${ }^{139}$, gekomen tot een meer algemene en ruimere erkenning van 'civil rights'. Uit het arrest Schouten-Meldrum ${ }^{140}$ blijkt dat bij de verplichting tot premieheffing volgens het Hof óok sprake kan zijn van de 'determination of civil rights and obligations'. Uit deze 'jongere' jurisprudentie van het EHRM kan mijns inziens worden afgeleid dat het Straatburgse Hof - onder bepaalde voorwaarden 'civil rights' erkent (en derhalve zelfstandige, geïndividualiseerde rechtsbelangen van burgers) buiten de sfeer van de klassieke vermogensrechten. Het 'civil rights'-begrip wordt hierdoor gepositioneerd in een hedendaagse sociaal-rechtsstatelijk context. Een directe fundering van 'civil rights' in bepaalde mensenrechten komt bijgevolg in zicht. Dit is niet verwonderlijk daar de 'civil rights' binnen de context van het EVRM uiteindelijk verband houden met de individuele materielle vrijheid van de mens. ${ }^{141}$ Deze vrijheid komt binnen de sociale-rechtsstaat niet alleen tot uitdrukking in het respecteren van de formele vrijheid van het individu, maar eveneens in het garanderen van een bepaalde mate van materiele individuele bestaanszekerheid. Het vaststellen van deze zekerheid door de overheid (bijv. door het toekennen van een uitkering aan een rechtssubject) impliceert in deze context het determineren van 'civil rights'. Een vastgestelde uitkering staat mijns inziens dan ook goeddeels gelijk aan een vermogensrecht. Deze typische 'hedendaagse' vermogensrechten én de mensenrechten, waarin zij uiteindelijk zijn gefundeerd, vloeien in elkaar over. Dit brengt mij bij de tweede hoofdgroep binnen de subjectgebonden rechtsbelangen: de erkende grond- en mensenrechten.

138. EHRM 29 mei 1986, Series A, Vol. 99 (Feldbrugge) en EHRM 24 juni 1993, Series A, Vol. 257-E (Schuler-Zgraggen vs. Switzerland).

139. EHRM 26 februari 1993, Series A, Vol. 99 (Salesi vs. Italy).

140. EHRM 9 december 1994, Series A, Vol. 304 (Schouten en Meldrum vs. The Netherlands). Zie voor een vitvoerige bespreking van dit arest: A.W. Heringa, De redelijke termijn in het bestuursproces, Rechtspraak bestuursrecht. De annotaties 1994-1995, 's-Gravenhage 1995, p. 121 e.v.

141. Vgl. reeds de visie van de commissie in de Benthem-zaak. Conclusies ECRM d.d. 22 mei 1984, Series A, Vol. 97, p. 24. 


\subsubsection{Het specialiteitsbeginsel en de grond- en verdragsrechten}

Grond- en mensenrechten kunnen in algemene zin worden gekwalificeerd als binnen de publieke rechtsorde jegens de overheid ${ }^{142}$ erkende en beschermde rechtsbelangen van fundamentele aard. Grondrechten zijn ook wel omschreven als (gepositiveerde) 'aanspraken' van mensen op de bescherming van hun elementaire belangen of rechten.${ }^{143}$ Elementair in die zin dat zij binnen de publieke rechtssfeer voor alles de autonomie van de natuurlijke persoon, de mens ${ }^{144}$ als rechtssubject, tot uitdrukking brengen ten opzichte van de publieke rechtsgemeenschap. In zekere zin manifesteren de grondrechten zich hierbij als de 'immateriële' tegenhanger, maar tevens als een onmisbaar complement, van de typische vermogensrechten. Soms valt het onderscheid tussen beide groepen rechtsbelangen dan ook moeilijk te maken. ${ }^{145}$ De persoonlijke autonomie manifesteert zich in het bijzonder in de gedaanten van de menselijke vrijheid en waardigheid, de eigen persoonlijkheid, het zelfbeschikkingsrecht, de gelijkheid en een materieel recht op een kwalitatief aanvaardbaar bestaan.

De 'klassieke' grond- en mensenrechten vormen in een publiekrechtelijke context subjectgebonden rechtsbelangen bij uitstek. ${ }^{146} \mathrm{Het}$ spreekt voor zich dat aan deze fundamentele mensenrechten in het kader van de uitoefening van een bestuursbevoegdheid steeds bijzondere betekenis dient toe te komen. In dit verband moet allereerst worden vastgesteld dat uit het specialiteitsbeginsel - naar mijn oordeel - géén beperkingen voortvloeien om een

142. Het leerstuk van de 'horizontale' of 'derden'-werking van grondrechten laat ik hier buiten beschouwing. Naar mijn oordeel werken de grondrechten niet rechtstreeks in de rechtsrelaties tussen de rechtssubjecten onderling, maar enkel naar analogie waarbij de materiele inhoud van fundamentele rechten in typisch privaatrechtelijke rechtsnormen tot uitdrukking kan komen. Zo vinden m.i. diverse persoonlijkheidsrechten hun privaatrechtelijke uitwerking in het personen- en familierecht, het respect voor de eigendom in het zakenrecht en de autonomie van kerkgenootschappen en verenigingen in het rechtspersonenrecht. Vgl. wat betreft deze 'indirecte' benadering: A.K. Koekkoek, Grenzen aan grondrechten, in: Gelijk behandelen. Commentaren op het voorstel Algemene wet gelijke behandeling (publ. Staatrechtkring) Zwolle 1991, p. 30 en 34. Zie over de problematiek van de horizontale werking in algemene zin o.m. C.A.J.M. Kortmann, Constitutioneel recht, derde druk, Deventer 1997, p. 352 e.v. Opvallend is dat Kortmann enkel wenst te spreken over echte horizontale werking van grondrechten voorzover er in private relaties sprake is van éénzijdige gezagsuitoefening (a.w., p. 353). Ook in Duitsland wordt - zelfs vanuit privaatrechtelijke hoek - kritiek geuit op het erkennen van 'derden'-werking van grondrechten. Vgl. voor principiěle kritiek op het leerstuk van de 'Drittwirkung' van grondrechten in private rechtsbetrekkingen bijv. W. Flume, Allgemeiner Teil des Burgerlichen Rechts, zweiter Band, Das Rechtsgeschaff, vierte unverănderte Auflage, Berlin/Heidelberg 1992, p. 20-22.

143. Vgl. Hofman/Sap/Sewandono, Grondrechten in evenwicht, Deventer 1995, p. 17 en Van der Pot/ Donner/ Prakke, Handboek van het Nederlandse staatsrecht, dertiende druk, Zwolle 1995, p. 205. Het gaat hier om een ruim verzamelbegrip van (prepositieve) mensenrechten, gecodificeerde grondrechten en verdragsrechten.

144. Ook de rechtspersoon (en soms andere collectiviteiten) kan (kunnen), als rechtssubject, drager zijn van (andere) fundamentele rechten. Deze nogal heikele problematiek laat ik hier verder rusten. Zie o.m. A.L.J. van Strien, Rechtspersonen en mensenrechten. De gelding van mensenrechten voor rechtspersonen in het strafproces, RMTh. 1996/1, p. 3 e.v. en C.A.J.M. Kortmann, Constitutioneel recht, a.w., p. 348-349. Overigens dient men in dit verband goed te onderscheiden tussen de 'rechten' van de rechtspersoon en de (collectieve) fundamentele 'rechten' van de individuele rechtssubjecten die deze persoon oprichtten. 
grondwettelijk of verdragsrechtelijk beschermd belang van een rechtssubject in de bestuurlijke 'belangenafweging' te betrekken voorzover dit rechtssubject een (bepaalde modaliteit van) bestuurlijke bevoegdheidsuitoefening wil afweren. Integendeel, hiertoe bestaat binnen de democratische rechtsstaat steeds een plicht. ${ }^{147}$ Deze plicht houdt direct verband met de erkenning én respectering van de autonomie van de rechtssubjecten. Zwemstra ${ }^{148}$, die de problematiek van de bescherming van grondrechten in relatie tot de discretionaire bevoegdheidsuitoefening analyseerde, merkte in dit verband het volgende op over het specialiteitsbeginsel:

\begin{abstract}
'Het is daarom temeer van belang dat de bescherming van grondrechten vereist dat de grondrechtelijke belangen van de aanvrager van een hem begunstigende overheidshandeling in beginsel altijd in de afweging betrokken worden, ook als een regeling een beperkt doel heeft, en ongeacht de mate van beoordelingsvrijheid in de besluitvorming. Dit vloeit rechtstreeks voort uit de gebondenheid van overheidsorganen aan grondrechten uit hoofde van de verticale werking van grondrechten. Het specialiteitsbeginsel dient hiervoor geen inperking te betekenen.'
\end{abstract}

Met deze opvatting van Zwemstra, die eigenlijk erg voor de hand ligt ${ }^{149}$, kan volledig worden ingestemd. Zijn visie sluit ook goed aan bij de rechtsstatelijke context waarbinnen zowel het specialiteitsbeginsel als de (klassieke) grondrechten functioneren. Beiden strekken er binnen de democratische rechtsstaat (o.m.) toe om een (al te) opdringerige overheid op afstand te houden. Zoals in hoofdstuk 3 van dit boek werd betoogd ligt het specialiteitsbeginsel met het oog hierop ten grondslag aan de scheiding tussen de publieke staatsorganisatie en een vrije burgerlijke maatschappij. Het beginsel waarborgt in dit verband dat de overheidsorganisatie enkel de aan haar opgedragen publiekrechtelijke belangen behartigt. Aldus beschouwd, ondersteunt dit cultuurhistorisch bepaalde beginsel, ók in

145. Vgl. het eigendomsrecht dat (in essentie) wordt gewaarborgd in art. $14 \mathrm{Gw}$ alsmede in art. I van het eerste Protocol behorende bij het EVRM. In dit verband dient er ook op te worden gewezen dat 'klassieke' grondrechten vaak eerst in volle omvang kunnen worden uitgeoefend indien de staat hiertoe vermogensrechtelijke randvoorwaarden realiseert en waarborgt (denk bijv. aan subsidies en uitkeringen). Vgl. in dit kader de relativering van het onderscheid tussen 'klassieke' en 'sociale' grondrechten. Prakke c.s. brengen dit m.i. goed onder woorden indien zij de grondrechten in hun algemeenheid positioneren tegen de achtergrond van het gegeven dat de staat als rechtsgemeenschap 'geborgenheid' voor de mens beoogt te creëren. Van der Pot/Donner/Prakke, Handboek van het Nederlandse staatsrecht, a.w., p. 207.

146. Vaak wordt in dit kader aan deze rechtsbelangen de status van 'subjectief publiekrecht' toegekend. Hiertegen bestaat m.i. geen bezwaar zolang men zich realiseert dat deze 'rechten' niet in alle opzichten vergelijkbaar zijn met de subjectieve vermogensrechten. Vgl. R.J.B. Bergamin, Rechten jegens de overheid, a.w., i.h.b. hoofdstuk 3. Enigszins kritisch: C.A.J.M. Kortmann, Constitutioneel recht, a.w., p. $345-346$.

147. Vgl. in dit verband: H.J. Simon, Publiekrecht of privaatrecht?, a.w., p. 121.

148. S. Zwemstra, Bescherming van uitingsrechten door administratieve rechters, diss. KUB, Zwolle 1992, p. 80.

149. Men zou immers ook 'simpelweg' kunnen stellen dat een (wettelijke) bevoegdheidsnorm vanuit positiefrechtelijk oogpunt hiërarchisch ondergeschikt is aan een grondrechtsnorm. Bij strijd zal reeds daarom de bevoegdheidsnorm moeten wijken ten gunste van het grondrecht dat in een rechtsnorm van hogere orde is neergelegd. 
de hedendaagse interventiestaat, het streven naar een heldere scheiding tussen enerzijds publieke en anderzijds private verantwoordelijkheden.

Waar het specialiteitsbeginsel er vanuit een publiekrechtelijk gemeenschapsoogpunt toe strekt de publieke belangbehartiging te begrenzen en in positieve zin te bestemmen, daar stellen met name de 'klassieke' grondrechten vanuit het perspectief van de rechtssubjecten en hun private verbanden grenzen aan deze belangbehartiging. Grondrechten, en met name de typische vrijheidsrechten, strekken er nl. toe om de overheidsorganisatie 'op afstand' te houden; zij vormen integrerende elementen van de democratische rechtsstaatgedachte. Het specialiteitsbeginsel en de 'klassieke' grondrechten zijn - vanuit deze invalshoek bezien elkaars complement.

Dit geldt echter niet voor alle fundamentele 'rechten'. Er zijn immers bepaalde grondrechtelijke en/of verdragsrechtelijke belangen die er juist (primair) toe strekken om de overheidsorganisatie aan te sporen tot publieke belangbehartiging (de zgn. 'sociale' grondrechten). Deze groep van fundamentele belangen kan men mijns inziens het beste beschouwen als zwaarwegende publiekrechtelijke belangen ${ }^{150}$ die nog verder door de wetgever dienen te worden gespecificeerd en waarvan de inhoud ingevolge een gericht rechtsvormingsproces, dat beheerst wordt door het specialiteitsbeginsel, behoort te worden verwezenlijkt. Een helder voorbeeld biedt artikel 21 van de Grondwet dat o.m. de zorg voor het leefmilieu tot $z$ waarwegende taak van de overheid bestempelt. Deze taakopdracht vindt zijn uitwerking én operationalisering in de publiekrechtelijke belangen die aan de verschillende milieuwetten ten grondslag liggen. Deze belangen sturen nl. het gerichte bestuurlijke rechtsvormingsproces aan.

Voor zover bepaalde sociale grondrechten strekken tot het waarborgen van een materiële bestaanszekerheid van individuele rechtssubjecten is het evenwel denkbaar dat, bij wijze van uitzondering, uit deze 'rechten' subjectgebonden rechtsbelangen voortvloeien (vgl. artikel 20 lid 3 Grondwet). ${ }^{151}$

\subsubsection{Fricties tussen grondrechten en publiekrechtelijke belangen}

Ofschoon de grondrechten en het specialiteitsbeginsel, zoals gesteld, gedeeltelijk elkaars complement zijn, zullen in het bestuursrecht de (speciale) publiekrechtelijke belangen, in het kader van een discretionaire bevoegdheidsuitoefening, niet zelden tegenover grondwettelijk beschermde belangen staan. Ook de grondwetgever heeft dit voorzien en erkend dat onder omstandigheden grondrechten voor andere zwaarwegende (publiekrechtelijke)

150. Dit boek is niet de plaats om het rechtskarakter van de sociale grondrechten uitvoerig te analyseren. Ik sluit aan bij de gangbare opvatting dat deze 'rechten' meestal opdrachten aan de overheid inhouden en niet door burgers direct afdwingbaar zijn. Zie voor een uitvoerig onderzoek naar het rechtskarakter van de sociale grondrechten: A.W. Heringa, Sociale grondrechten, diss. RUL, 's-Gravenhage 1989, i.h.b. hoofdstuk III.

151. Ook t.a.v. dit 'recht' op bijstand geldt echter dat dit op basis van de wet wordt geconcretiseerd. Verdedigbaar is dat er pas sprake kan zijn van een (vermogensrechtelijk) rechtsbelang van een rechtssubject nadat een uitkering in concreto is vastgesteld, en 'onderdeel' is gaan vormen van het vermogen van het betrokken rechtssubject. 
belangen moeten wijken. ${ }^{152}$ De beantwoording van de vraag in welke gevallen een grond- (of verdrags)recht in concreto voor een publiekrechtelijk belang moet wijken is afhankelijk van een aantal factoren. Het ligt buiten het bestek van dit boek om deze vraag uitputtend te behandelen. Op deze plaats wordt daarom volstaan met enkele meer algemene opmerkingen.

Beperking van een grond- of verdragsrecht door de uitoefening van een (discretionaire) bestuursbevoegdheid kan pas aan de orde zijn nadat is vastgesteld of het betreffende fundamentele recht daadwerkelijk in het geding is. Hierbij speelt de problematiek van de redelijke interpretatie. Van een redelijke interpretatie is sprake indien een grondrecht op een zodanige (restrictieve) wijze wordt uitgelegd dat er géén formele strijd meer bestaat met de regeling (of de bevoegdheidsuitoefening) waarvan de (ogenschijnlijke) beperking uitgaat. ${ }^{153} \mathrm{De}$ betreffende regeling wordt dan geacht het grondrecht niet te raken. ${ }^{154}$ Eerst nadat de omvang van een bepaald grondrecht is vastgesteld, komt de toelaatbaarheid van een eventuele beperking aan bod. Hierbij geldt, toegespitst op de Nederlandse Grondwet ${ }^{155}$, als hoofdregel dat een grondrechtsnorm die het grondrecht erkent tevens aangeeft of, door wie en (eventueel) ter behartiging van welke publiekrechtelijke belangen, dit grondrecht kan worden beperkt. Aan deze hoofdregel ligt de zgn. leer van de bijzondere beperkingen ten grondslag. ${ }^{156}$ Ingevolge deze leer zijn, kort gezegd, alleen door de Grondwetgever uitdrukkelijk voorziene beperkingen van grondrechten toelaatbaar.

Het strakke Grondwettelijke systeem van de bijzondere beperkingen bleek echter, gelet op de zeer ruime werkingssfeer van grondrechten en de complexe structuur van bestuursbevoegdheden, in de praktijk aanleiding te geven tot problemen. ${ }^{157}$ Een extra complicerende factor vormde het discretionaire karakter van vele bestuursbevoegdheden. Deze factor werd door de Grondwetgever wellicht wat te licht gewogen. Uit de memorie van toelichting bij de Grondwet van $1983 \mathrm{kan}$ nl. worden afgeleid dat bijv. niet aan de beperkingsclausule 'behoudens ieders verantwoordelijkheid volgens de wet' wordt voldaan

152. TK 1975-1976, 13872, nr. 3 (MvT), p. 11.

153. Vgl. bijv. ARRS 2 juli 1984, AB 1985, 273 m.nt. R. Fernhout en J.A. Hofman (verblijfsvergunning imam). Deze uitspraak lijkt geYnspireerd door HR 13 april 1960, NJ 1960, 436 (AOW I).

154. Zie: B.P. Vermeulen, Algemene beperkingen, redelijke uitleg en redelijke toepassing van grondrechten, RegelMaat 1990/4, p. 84.

155. Op de beperkingssystematiek van de diverse verdragen ga ik niet nader in. Zie, wat betreft het EVRM-verdrag, o.m. het omvangrijke proefschrift van Schokkenbroek. J.G.C. Schokkenbroek, Toetsing aan de vrijheidsrechten van het Europees verdrag tot bescherming van de rechten van de mens, a.w., i.h.b. p. 177 e.v.

156. TK 1976-1977, 13872, nr. 7 (MvA), p. 12. Deze leer staat tegenover de leer van de 'algemene beperkingen'. Hieronder worden beperkingen verstaan die niet herleidbaar zijn tot een specifieke Grondwettelijke beperkingsclausule. Algemene beperkingen kunnen als neveneffect voortvloeien uit regelgeving die niet primair op (bepaalde) grondrechten betrekking heeft. Vgl. Heringa/Zwart, De Nederlandse Grondwet, derde herziene druk, Zwolle 1991, p. 26; zie voorts: P.W.C. Akkermans, Redelijke grondwetinterpretatie, AAe 1990/6, p. 399 en S.C. den Dekker-Van Bijsterveld, Gemeenten en algemene beperkingen van klassieke grondrechten, Gst. 1991, 6925, p. 382 e.v.

157. Vgl. B.P. Vermeulen, Algemene beperkingen, redelijke uitleg en redelijke toepassing van grondrechten, a.w., p. 82 en 83. 
indien de wetgever aan een bestuursorgaan een vergunningbevoegdheid verleent, voorzover deze bevoegdheid niet volstrekt gebonden is. ${ }^{158}$

Ofschoon de beperkingssystematiek van de Grondwet nogal star is, heeft de Grondwetgever desalniettemin voorzien in een aantal algemene 'hardheidsclausules' dat het systeem iets relativeert. ${ }^{159}$ Toegespitst op het onderwerp van dit boek is in het bijzonder de figuur van de 'redelijke toepassing' van een grondrecht van belang. ${ }^{160}$ Deze 'redelijke toepassing' impliceert dat in bepaalde (uitzonderlijke) situaties een grondrecht, of een daaraan connex recht, na een zorgvuldige afweging van de betrokken belangen een beperking mag ondergaan indien een (te) strikte bescherming van dat grondrecht in concreto tot een evidente onredelijkheid zou leiden. In de literatuur is er terecht op gewezen dat de Grondwetgever bijgevolg door de achterdeur toch de leer van de algemene beperkingen introduceerde. ${ }^{161}$

De rechter heeft de handreiking van de Grondwetgever echter aangenomen en zijdelings beperkingen van grondrechten toelaatbaar geacht, alhoewel deze beperkingen strikt genomen niet herleidbaar waren tot een grondwettelijke beperkingsclausule. ${ }^{162}$ Soms gebeurde dit door een 'connex' recht af te splitsen van het eigenlijke (kern)grondrecht, waardoor een beperkend resultaat kon worden bereikt. ${ }^{163}$ Gelet op het specialiteitsbeginsel is in dit verband bijv. de uitspraak van de Afdeling bestuursrechtspraak inzake het kerkgebouw te Purmerend illustratief. ${ }^{164}$ In casu kwam o.m. de vraag aan de orde in hoeverre het luiden van een kerkklok beschermd werd door de vrijheid van godsdienst en in hoeverre ten aanzien van dit luiden krachtens de milieuwetgeving een (niet door de Grondwet voorziene) beperking mocht worden gesteld. Uit de uitspraak blijkt met het oog hierop dat een 'zijdelingse' beperking van een grondrecht ook dan toelaatbaar kan zijn indien op basis van de Grondwet specifieke beperkende wetgeving tot stand is (of kan worden) gebracht. Onverminderd de regulering krachtens de Wet openbare manifestaties (Wom) achtte de Afdeling nl. een beperking van het klokgelui bij vergunningvoorschrift

158. TK 1975-1976, 13872, nr. 3 (MvT), p. 23.

159. Een aan de literatuur. ontleend begrip. Zie: P.W.C. Akkermans, Redelijke grondwetinterpretatie, a.w., p. 400 . Vgl. voorts: B.P. Vermeulen, Algemene beperkingen, redelijke uitleg en redelijke toepassing van grondrechten, a.w., p. 78 en 79.

160. Naast de figuur van de 'redelijke toepassing' heeft de Grondwetgever hardheidsclausules gefundeerd in 'evoluerende rechtsopvattingen' en (nieuwe) 'breed aanvaarde rechtsinstellingen'. Zie: TK 1975-1976, 13872, nr. 3 (MvT), p. 21 en 22.

161. Heringa/Zwart, De Nederlandse Grondwet, a.w., p. 27.

162. Zie bijv. VzARRS 16 februari 1989, AB 1990, 9 m.nt. P.J. Boon (Evangeliesatiegemeente De Deur). Deze uitspraak is eveneens gepubliceerd in AAe 1990/6, p. 398 e.v. m.nt van P.W.C. Akkermans en in de Gemeentestem (6883, nr 11 m.nt. J.M.H.F. Teunissen). De indruk lijkt gerechtvaardigd dat de rechter in dit verband nogal pragmatisch te werk gaat. Vgl. Van der Pot/Donner/Prakke, Handboek van het Nederlandse staatsrecht, a.w., p. 226.

163. Zie voor een fraai voorbeeld: ABRS 5 januari 1996, AB 1996, 179, m.nt. J.A. Hofman (Evangelisatiegemeente De Deur). In casu werd een beperking van het aan het recht op belijden en betogen connexe recht van 'geluidsversterking' in het kader van een op een Algemene Plaatselijke Verordening gebaseerd bevoegdheidsstelsel in beginsel toelaatbaar geacht ter voorkoming van geluidsoverlast.

164. ABRS 27 oktober 1994, Gst. 7005, nr. 5 met naschrift B. (kerkgebouw Purmerend). 
ingevolge de Hinderwet toelaatbaar. Na te hebben vastgesteld dat de regeling van artikel 10 Wom de belangen welke genoemd worden in artikel 6 , lid $2 \mathrm{Gw}$ beoogt te beschermen, overwoog de Afdeling in dit verband dat

'...deze belangen niet te vereenzelvigen zijn met het belang van het voorkomen of beperken van gevaar, schade of hinder in de zin van de artikelen 13 en 17 van de Hinderwet. Dit betekent dat, anders dan verweerders menen, de Wet openbare manifestaties er niet aan in de weg staat dat in het kader van de toepassing van de Hinderwet aan een vergunning voorschriften worden verbonden met betrekking tot het door de, tot die inrichting behorende, kerkklok voortgebrachte geluid'.

In de literatuur is deze rechterlijke praktijk waarbij (aspecten van) grondrechten soms op basis van een concrete belangenafweging buiten de grondwettelijke beperkingssystematiek om worden beperkt gematigd positief ontvangen. ${ }^{165}$ Hierbij lijkt mij de vraag of deze praktijk toelaatbaar is ondergeschikt ${ }^{166}$ aan de vraag onder welke voorwaarden dit mag geschieden. Naar mijn oordeel dient te worden aanvaard dat zich binnen een complex rechtsstelsel, dat gekenmerkt wordt door een uitgebreide en gedifferentieerde structuur van doelgebonden bestuursbevoegdheden, zich noodzakelijkerwijs - door de (Grond)wetgever niet voorziene - conflicten kunnen voordoen tussen grondrechten en publiekrechtelijke belangen. Een 'gekwalificeerde' belangenafweging ${ }^{167}$ biedt mijns inziens dan de beste waarborg om beide zwaarwegende belangen, die van een andere normatieve aard zijn, met elkaar te harmoniseren. Dit is óok de strekking van de opvattingen van diverse andere

165. Sommige auteurs gaan er zonder meer vanuit dat de leer van de 'algemene beperkingen' toch is aanvaard. Vgl, de noten van Boon onder VzARRS 16 februari 1989, AB 1990, 9 en onder VzARRS 17 augustus 1990, AB 1991, 44; zie voorts: B.P. Vermeulen, Algemene beperkingen, redelijke uitleg en redelijke toepassing van grondrechten, a.w., p. 83. Anderen zijn van oordeel dat de rechter zich binnen de kaders van de Grondwettelijke 'hardheidsclausules' begeeft. Vgl. S.C. den Dekker-Van Bijsterveld, Gemeenten en algemene beperkingen van klassieke grondrechten, a.w., p. 385 en 386. Tot slot is er de opvatting dat de rechter differentieert tussen 'kernrechten' en 'connexe rechten', waarbij bepaalde randaspecten van ingeroepen grondrechten een geringere bescherming genieten dan het eigenlijke recht. Vgl. de noot van J.A. Hofman onder ABRS 5 januari 1996, AB 1996, 179.

166. Vgl. de relativerende opmerking van Boon in zijn noot onder VzARRS 17 augustus 1990, AB 1991, 44: 'Aanvaarding van een uitlaatklep in enigerlei gedaante is nu eenmaal onvermijdelijk, gezien de tamelijk dogmatische benadering die op het punt van de grondrechten bij de Grondwetsherziening van 1983 is gevolgd. Of men in dit verband wil spreken van 'algemene beperkingen van grondrechten', 'een redelijke grondwetsinterpretatie' of 'een hardheidsclausule voor uitzonderingsgevallen' is m.i. niet veel meer dan een kwestie van smaak.'

167. D.w.z. een 'afweging' die afdoende recht doet aan het zwaarwegende karakter van grondrechten. Vgl. S.C. den Dekker-Van Bijsterveld, Gemeenten en algemene beperkingen van klassieke grondrechten, a.w., p. 386. Zie ook TK 1975-1976, 13872, nr. 3 (MvT), p. 22. Vgl. in dit verband het betoog van Vermeulen die de leer van de algemene beperkingen slechts toelaatbaar acht indien er (door de rechter) 'materiele afwegingscriteria' worden gehanteerd. Hierbij denkt hij aan het proportionaliteitsbeginsel, de kernrechtgedachte (een grondrecht mag niet in de kern worden aangetast), het onderscheid tussen inhoud en vorm én de voorwaarde dat gebruik van enige betekenis van het grondrecht overblijft. B.P. Vermeulen, Algemene beperkingen, redelijke uitleg en redelijke toepassing van grondrechten, a.w., p. 83 en 84 . 
auteurs. ${ }^{168}$ Als voordeel van een dergelijke belangenafweging, die volgens mij verenigbaar is met het specialiteitsbeginsel, kan o.m. worden gezien de mogelijkheid om tot een afweging 'in concreto' te komen, waarbij - gelet op alle relevante omstandigheden van het geval - recht wordt gedaan aan het betrokken grondrecht. ${ }^{169}$ Nauw verwant hieraan is de opvatting dat aan de grondrechten binnen het complexe stelsel van bestuursrechtelijke regelingen en discretionaire bevoegdheden alleen op basis van een proces van belangenafweging een adequate invulling kan worden gegeven. ${ }^{130}$ Tot slot is er in de literatuur op gewezen dat een dergelijke belangenafweging 'in concreto' ook goed aansluit bij de beperkingssystematiek van het Europees Verdrag tot bescherming van de Rechten van de Mens (EVRM). ${ }^{171}$

Voorop dient evenwel steeds te blijven staan dat de wetgever die discretionaire bestuursbevoegdheden in het leven roept vooraf nagaat welke grondrechten door de uitoefening van deze bevoegdheden in concreto kunnen worden geraakt. Hierbij dient de wetgever reeds in abstracto te beoordelen in hoeverre deze beperkingen verenigbaar zijn met de van toepassing zijnde beperkingssystematieken.

\subsection{Het specialiteitsbeginsel en belangenafweging: eigen visie}

Aan het einde van dit boek zal ik, toegespitst op de uitoefening van een discretionaire beschikkingsbevoegdheid ${ }^{172}$, mijn visie inzake de betekenis van het specialiteitsbeginsel geven. Ik wijs erop dat ik reeds op diverse plaatsen in andere hoofdstukken impliciet en expliciet standpunten heb ingenomen, die ik hier niet uitputtend zal herhalen. ${ }^{173} \mathrm{Ik}$ beperk mij op deze plaats tot het formuleren van een antwoord op de tweede probleemstelling van dit boek. Deze probleemstelling luidde:

'Welke grenzen stelt het specialiteitsbeginsel aan het proces van belangenafweging door het bestuur in het kader van een discretionaire bevoegdheidsuitoefening?'

In de literatuur is er terecht op gewezen dat de meningsverschillen over de interpretatie van het specialiteitsbeginsel, en de omvang van de bestuurlijke belangenafweging in concreto, uiteindelijk verband houden met de vraag op welke wijze de eis van doelgebonden bestuurlijk rechtshandelen verenigd kan worden met het uitgangspunt van individuele rechtsbedeling. ${ }^{174}$ Met andere woorden: hoe kan het uitgangspunt van doelgebonden

168. Zie o.m.: F.H. Kistenkas, Naar een grondrechtelijke evenredigheidstoetsing, Gst. 1991 nr. 6925 , p. 377 e.v.; Zie ook: S. Zwemstra, Bescherming van uitingsrechten door administratieve rechters, a.w., p. 536.

169. S.C. den Dekker-Van Bijsterveld, Gemeenten en algemene beperkingen van klassieke grondrechten, a.w., p. 384 en 385.

170. Vgl. S. Zwemstra, Bescherming van uitingsrechten door administratieve rechters, a.w., p. 535.

171. Zie bijv.: F.H. Kistenkas, Naar een grondrechtelijke evenredigheidstoetsing, a.w., p. 378.

172. Het navolgende is evenwel in essentie ook toepasbaar op 'regelgevende' bestuursbevoegdheid.

173. Zie het resumé in paragraaf 9.2 van dit hoofdstuk.

174. Vgl. A.Q.C. Tak, Hoofdlijnen van het Nederlands bestuursprocesrecht, derde druk, Zwolle 1995, p. 111. 
(gerichte) rechtsvorming in het bestuursrecht verenigd worden met het optimaal respecteren van de - bij een bevoegdheidsuitoefening betrokken - subjectgebonden rechtsbelangen. Ik zou deze vraag in een drietal stappen ${ }^{175}$ willen beantwoorden. Voorop (stap 1) stel ik als uitgangspunt dat individuele rechtsbedeling géenszins met zich brengt dat door een bestuursorgaan ter 'behartiging' van private rechtsbelangen bijv. bindende (gedrags)voorschriften mogen worden gesteld. Het bestuur mag op straffe van détournement de pouvoir nooit private rechtsbelangen behartigen. ${ }^{176}$ Identificatie van het bestuur met de rechtsbelangen van rechtssubjecten zou bovendien de onpartijdigheid van dit bestuur kunnen schaden (vgl. artikel 2:4 Awb). Temeer omdat er in het bestuursrecht vaak sprake is van een 'kring' van belanghebbenden (denk aan de 'derden') dient zich dan het gevaar van ongelijke behandeling snel aan. Wat betreft de bevoegdheidsuitoefening als rechtshandeling interpreteer ik het specialiteitsbeginsel derhalve precies, waarbij ik afstand neem van de standpunten van 'de gematigden' ${ }^{177}$ Met name de idee van een 'gedeelde' bestuursbevoegdheid, waarbij het stellen van voorschriften wordt losgekoppeld van het specifieke doel van een bevoegdheid, acht ik op rechtsstatelijke gronden bedenkelijk. Het rechtshandelen (d.w.z. het bewerkstelligen van beoogde rechtsgevolgen) door het bestuur dient, zoals ik in dit boek bij herhaling betoogde, exclusief gelegitimeerd te worden door de 'bovenindividuele' publiekrechtelijke belangen die aan de betreffende bestuursbevoegdheid ten grondslag liggen. Deze belangen, en géén andere, zijn de normatieve belangen die inhoudelijk invulling geven aan de bestemmingsfunctie van de publieke rechtsorde. De vraag welke belangen als 'publiekrechtelijk' kunnen worden aangemerkt dient, ingevolge het democratisch postulaat, in de regel uitdrukkelijk door de wetgever te worden beantwoord (het 'Bestimmtheitsgebot'). Dit dient de rechtszekerheid en werkt bovendien een duidelijke, heldere én doelmatige taakverdeling binnen de bestuurlijke organisatie in de hand.

Het voorafgaande 'precieze' standpunt sluit niet uit dat subjectgebonden rechtsbelangen door het bestuurlijke rechtsvormingsproces in concreto worden beschermd. Dit proces is immers, zoals gesteld ${ }^{178}$, vaak dienstig aan de regulering van belangenconflicten tussen de rechtssubjecten onderling. Hierdoor lijkt er soms geen strikte scheiding te bestaan tussen publiekrechtelijke en private rechtsbelangen (het bekende 'samenvallen' van belangen). Het feit dat de bestuurlijke normstelling de subjectgebonden rechtsbelangen vanuit een publiekrechtelijk oogpunt beschermt brengt echter niet met zich dat deze laatstgenoemde belangen door het bestuur mogen worden behartigd. ${ }^{179}$ Evenmin sluit het geformuleerde

175. Vgl. mijn noot onder Rb. Roermond 27 september 1996, JB 1996/225 (herplantplicht Nederweert).

176. Het spreekt voor zich dat een bestuursorgaan aan de weigering om een beschikkingsbevoegdheid uit te oefenen evenmin private rechtsbelangen van burgers (derden) ten grondslag mag leggen.

177. Ik denk i.h.b. aan Nicolar, Konijnenbelt, Van Male en Van Hall. Zie in dit kader hoofdstuk 7 van dit boek.

178. Zoals eerder werd gesteld staat de bestuurlijke rechtsvorming uiteraard wél ten dienste van de rechtssubjecten. Vgl. paragraaf 9.4.5.

179. De behartiging van belangen impliceert - anders dan het 'rekening houden met' - een identificatie met deze belangen. Het bestuur mag zich, zoals gesteld, nooit met private belangen van burgers identificeren. 
'precieze' uitgangspunt uit dat voltooide publieke rechtsnormen in het rechtsverkeer tussen rechtssubjecten onderling als een 'Schutznorm' kunnen fungeren. Er bestaat mijns inziens echter aan de zijde van de rechtssubjecten, nooit een afdwingbaar 'subjectief recht' op een bepaalde modaliteit van een (discretionaire) bevoegdheidsuitoefening. Rechtssubjecten hebben met andere woorden gén afdwingbare subjectieve aanspraak op gerichte of ("beoogde') bestuurlijke rechtsvorming. De bevoegdheidsuitoefening wordt nl. volledig beheerst door de regels en beginselen van het objectieve publiekrecht. Een 'precies' standpunt sluit mijns inziens wél uit dat een rechtssubject wordt geconfronteerd met bindende gedragsvoorschriften die hun grondslag (én legitimatie) niet vinden in het speciale publiekrechtelijke belang dat aan de betreffende bestuursbevoegdheid ten grondslag ligt, maar enkel in private rechtsbelangen van zijn mederechtssubjecten.

Ik erken vervolgens (stap 2) dat een bestuursorgaan op basis van een beleidsvrije bestuursbevoegdheid verschillende als rechtens juist aan te merken beslissingen kan nemen. In theorie kan weliswaar worden verdedigd dat een beleidsvrije bestuursbevoegdheid enkel op één (rechtens) juiste wijze kan worden uitgoefend, maar dit uitgangspunt berust op een aantal premissen die mijns inziens in concreto nagenoeg nooit verwezenlijkt zullen zijn. ${ }^{180}$ Bijgevolg zal een bestuursorgaan in geval van beleidsvrijheid - gelet op de bevoegdheidsnorm - steeds over een normatieve bandbreedte beschikken waarbinnen het rechtens kan handelen (de rechtsvormingsalternatieven). Met het oog hierop is het orgaan ervoor verantwoordelijk om de meest optimale modaliteit van bevoegdheidsuitoefening te kiezen, d.w.z. diè modaliteit die leidt tot de meest optimale behartiging van het (de) betrokken publiekrechtelijke belang(en) onder een gelijktijdige minimale aantasting van de rechtstreeks betrokken (rechts)belangen van de rechtssubjecten. Hier is de fundamentele evenredigheidsnorm in het geding (vgl. artikel 3:4 lid 2 Awb). Deze basisregel van bestuurlijke besluitvorming scherpt het bestuur in dat doelgebonden bestuurlijk rechtshandelen steeds gevolgen kan hebben voor de (feitelijke) belangen van de in concreto betrokken rechtssubjecten. De met het besluit te dienen doelen (d.w.z. de behartiging van de publiekrechtelijke belangen) dient daarom steeds in een evenredige verhouding te staan tot een eventuele aantasting van de betrokken rechtsbelangen. Als algemene bestuurlijke besluitvormingsregel, die tevens het vereiste van noodzakelijkheid van het publieke rechtshandelen incorporeert, dient de evenredigheidsnorm mijns inziens altijd in acht te worden genomen. Schending van deze norm, die het hart van de bestuurlijke belangenafwegingsplicht raakt, leidt tot onrechtmatigheid van het doelgebonden publieke rechtshandelen ten principale. ${ }^{181}$

180. De belangrijkste premisse is dat alle in concreto betrokken rechtsbelangen van rechtssubjecten volledig (d.w.z. uitputtend) in kaart zijn gebracht en dat het bestuursorgaan op basis van deze informatie precies kan vaststellen welk besluit het objectieve recht - in dit ene geval - voorschrijft. Naar mijn mening is dit een juridische utopie. Vgl. voorts hoofdstuk 6, paragraaf 6.3.3.

181. Vgl. de benaderingswijze van Simon. H.J. Simon, Handboek bestuurs(proces)recht, 's-Gravenhage 1997, p. 144. 
Gelet op de 'keuzevrijheid' ten aanzien van het rechtshandelen, gaat primair de aandacht uit naar de materiële vrijheid van het rechtssubject wiens activiteiten onderwerp van de publiekrechtelijke regulering zijn binnen een bevoegdheidsstelsel (de zgn. 'directbelanghebbende'). Het publieke rechtshandelen is immers in eerste instantie - ter beinvloeding - op zijn activiteiten gericht. Onjuist is mijns inziens echter het standpunt dat een bestuursorgaan vervolgens géen, dan wel op een andere wijze, rekening zou moeten houden met de rechtsbelangen van 'derden'. Het onderscheid tussen 'direct-belanghebbende' en 'derde-belanghebbenden' heeft met name een processuele achtergrond. Vanuit het perspectief van het bestuur als besluitvormend orgaan verkeren mijns inziens echter alle rechtssubjecten, toegespitst op de bevoegdheidsuitoefening, in een vergelijkbare positie. ${ }^{182}$ In gelijke gevallen zullen deze rechtssubjecten dan ook gelijk door het bestuur moeten worden behandeld, waarbij de status van 'direct-belanghebbende' een bijzondere positie (bijv. wat betreft nadeelcompensatie) niet rechtvaardigt. Het bestuursorgaan zal steeds dienen na te gaan wiens belangen door een bepaalde bevoegdheidsuitoefening worden geraakt en op welke wijze. Op basis van deze informatie zal vervolgens de meest wenselijke modaliteit van bevoegdheidsuitoefening moeten worden bepaald.

Staat eenmaal vast dát een bepaalde modaliteit van bevoegdheidsuitoefening ten principale toelaatbaar is (in 'abstracte' zin evenredig), dan zal (stap 3) door het bestuur nauwkeurig nagegaan dienen te worden of de (beginsel)normen van het publiekrecht wellicht nog ten aanzien van bepaalde rechtssubjecten rechtsgevolgen verbinden aan de (gekozen modaliteit van) bevoegdheidsuitoefening die niet direct uit de specifieke bevoegdheidsnorm voortvloeien. Hierbij zal in het bijzonder gelet moeten worden op de rechtstreeks betrokken rechtsbelangen van rechtssubjecten. Deze rechtsbelangen onderscheiden zich op basis van een aantal normatieve criteria van de feitelijke belangen van subjecten. ${ }^{183}$ Tot deze rechtsbelangen reken $\mathrm{ik}$, zoals gesteld, de vermogensrechtelijke belangen (in ruime zin) én alle erkende grond- en mensenrechten. ${ }^{184}$ Door deze globale, maar desalniettemin afgebakende, invulling van het 'rechtsbelang'-begrip krijgt het bestuur mijns inziens een bruikbaar handvat aangereikt voor de beantwoording van de vraag welke belangen van rechtssubjecten in het bijzonder dienen te worden ontzien in het kader van de besluitvorming in concreto. De invulling die ik aan het begrip 'rechtsbelang' beoog te geven sluit naar mijn mening goed aan bij de jurisprudentie van het Europese Hof voor de Rechten van de Mens (EHRM), maar bijv. óók bij het Duitse bestuursrecht.

De aard van het betreffende subjectgebonden rechtsbelang is overigens bepalend voor de wijze waarop het bestuur in voorkomende gevallen aan dit belang tegemoet kan (moet) komen. Allereerst is het mogelijk dat een rechtsbelang een duidelijke, en derhalve op geld waardeerbare, vermogenskern heeft. Is dit het geval, dan zal in het bijzonder aan de hand

182. Uiteraard zullen een 'direct-belanghebbende' en 'derden' (met tegengestelde belangen) trachten om de gerichte publieke rechtsvorming vanuit hun eigen belang-perspectief te beinvloeden. Het bestuur dient zich in dit kader echter exclusief door de speciale publiekrechtelijke belangen te laten leiden.

183. Vgl. hoofdstuk 6, paragraaf 6.4.2.

184. Zie: de paragrafen $9.6 .2 \mathrm{t} / \mathrm{m} 9.6 .3$ 
van de maatstaven van de égaliténorm, en zonodig aan de hand van andere materiële beginselnormen ${ }^{185}$, nagegaan dienen te worden of nadeelcompensatie in concreto geboden is. Door het aanbieden van financiële compensatie kan mijns inziens de (relatieve of subjectieve) onrechtmatigheid van publiek rechtshandelen jegens een bepaald rechtssubject worden opgeheven. ${ }^{186}$ Het specialiteitsbeginsel beperkt deze nadeelcompensatieplicht, zoals gesteld, niet. ${ }^{187}$

Daarnaast is het denkbaar dat een bepaald rechtsbelang een immaterielle (meer fundamentele) rechtswaarde vertegenwoordigt die, in geval van aantasting, niet in vermogens-

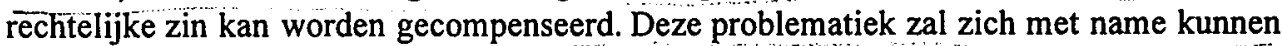
voordoen in de sfeer van de grond- en mensenrechten. Zoals in paragraaf 9.6.5 werd gesteld is het primair aan de (Grond)wetgever, dan wel aan de verdragspartijen, om (eventuele) conflicten tussen (speciale) publiekrechtelijke belangen enerzijds en grond- en mensenrechten anderzijds vooraf op een adequate wijze te ondervangen (denk aan de verschillende beperkingssystematieken). Er zijn echter situaties denkbaar waarin deze beperkingssystematieken een onvoldoende soelaas bieden. In dit soort situaties acht ik een 'gekwalificeerde' belangenafweging in concreto toelaatbaar. ${ }^{188}$ Hierbij zal dan primair de fundamentele evenredigheidsnorm als maatstaf dienen te fungeren. De uitkomst van een 'gekwalificeerde' belangenafweging kan mijns inziens met zich brengen dat het publieke rechtshandelen (alsnog) ten principale onrechtmatig blijkt te zijn (zie stap 2). Ook is het denkbaar dat het rechtshandelen jegens een bepaald rechtssubject in concreto geheel of gedeeltelijk gén rechtsgevolgen kan resorteren, maar deze rechtsfiguur is in het Nederlandse bestuursrecht (nog) niet ontwikkeld. ${ }^{189}$

185. Ik denk bijv. aan het vertrouwensbeginsel, voorzover de schending van deze beginselnorm niet reeds leidt tot onrechtmatigheid van het bestuurlijke rechtshandelen ten principale.

186. Vgl. H.Th.J.F. van Maarseveen, Een opmerking over de onrechtmatige overheidsdaad, NJB 1954, p. 918. In diens lijn J.M.H.F. Teunissen, Schadevergoeding wegens relatief onrechtmatige overheidsdaad, NJB 1994/5, p. 163 e.v. alsmede A.Q.C. Tak, De overheid in het burgerlijke recht, a.w:, p. 369 e.v. Vgl. HR 18 januari 1991, AB 1991, 241 m.nt. FHvdB (Leffers/Staat).

187. Vgl. de opmerkingen in paragraaf 9.6.2. Men kan in dit verband stellen dat het in acht nemen van het specialiteitsbeginsel vóór alles bepalend is voor de objectieve rechtmatigheid van de bevoegdheidsuitoefening (als rechtshandeling).

188. Vgl. paragraaf 9.6 .5 .

189. In dit verband is in de literatuur de vraag aan de orde gesteld of het publieke rechtshandelen (het besluit) wel 'relatief' onrechtmatig kan zijn. Ik wijs op de kennelijke controverse tussen Stroink en Tak. F.A.M. Stroink, Kern van de bestuursrechtspraak, 's-Gravenhage 1997, p. 21-22 en A.Q.C. Tak, De overheid in het burgerlijk recht, a.w., i.h.b. p. 366 . Tak en Stroink zijn het er overigens over eens dat relatieve onrechtmatigheid als rechtsfiguur bij besluiten van algemene strekking kan worden erkend. T.a.v. 'beschikkingen' verschillen echter de standpunten. Vanuit een (subjectief) grondrechtperspectief zou ik in theorie niet op voorhand willen uitsluiten dat bók een beschikking, die immers 'erga omnes' werkt, in concreto jegens een bepaald rechtssubject (bijv. een derde) geheel of gedeeltelijk gén rechtsgevolg kan resorteren (d.w.z. 'relatief' onrechtmatig is). De praktische betekenis van een dergelijke theorie zal echter uitermate gering zijn, mede gelet op de rechtsbeschermingsstructuur van de Awb die is afgestemd op een vernietiging van een besluit als geheel. 
Gelet op het voorafgaande (stap 2 en 3 ) zal overigens steeds nauwkeurig nagegaan dienen te worden of een bepaalde bevoegdheidsuitoefening (dan wel de weigering daartoe) bepaalde - feitelijke - gevolgen heeft voor de belangen van rechtssubjecten (het causaliteitsvereiste). Pas daarna dient te worden nagegaan of het objectieve recht aan deze (feitelijke) gevolgen vervolgens rechtsgevolgen verbindt. Het bestuur hoeft daarom slechts met de belangen van rechtssubjecten rekening te houden indien deze door de bevoegdheidsuitoefening worden geraakt. Een 'conditio sine qua non'-toets kan in dit verband als uitgangspunt dienst doen. Hierbij zal mijns inziens goed moeten worden onderscheiden tussen de gevolgen die door de publieke bevoegdheidsuitoefening worden veroorzaakt en de gevolgen die hun oorzaak vinden in het (rechts)feit dat deze bevoegdheidsuitoefening activeert. ${ }^{190}$ Dit is overigens een moeilijke opgave waarbij een 'conditio sine qua non' benadering tekortkomingen kan vertonen. Een voorbeeld kan dit verduidelijken. Indien bijv. een bedrijf ten behoeve waarvan een milieuvergunning wordt verleend hinder bewerkstelligt, kan men zich afvragen of deze hinder een gevolg is van de vergunningverlening (nl. het publieke rechtshandelen waarbij een verbod wordt opgeheven) of van de vergunningplichtige activiteit? Aan dit aspect van de 'publieke' causaliteitsproblematiek, nl. het toerekenen van gevolgen aan twee (of meer) 'rechtsfeiten', is in het Nederlandse bestuursrecht (nog) nauwelijks aandacht besteed. Ook ik laat deze problematiek, die vraagt om een gedetailleerd theoretisch onderzoek naar de verschillende causaliteitstheorieën en de bruikbaarheid daarvan in het bestuursrecht, in dit boek rusten.

In eerdere publicaties heb ik mij wél reeds op het standpunt gesteld dat bepaalde gevolgen van een vergunningplichtige activiteit niet al te snel aan het gerichte publieke rechtshandelen dienen te worden toegerekend. Dit zou immers leiden tot een vrijwel automatische (en te vergaande) aansprakelijkheid ten laste van het algemeen belang. De benadering dat in het geschetste voorbeeld de hinder nu eenmaal het gevolg is van het feit dat door de vergunningverlening een verbod tot het uitoefenen van de activiteit wordt opgeheven lijkt mij te simpel. Om een tè vergaande toerekening van bepaalde gevolgen aan het publieke rechtshandelen als causa te voorkomen, zal naar mijn oordeel bijgevolg aan de hand van corrigerende causaliteitstheorieën (de voorzienbaarheidsleer en de toerekening naar redelijkheid) een nuancering dienen plaats te vinden. ${ }^{191}$ Hiermee wordt dan tevens voorkomen dat zich aan de zijde van het bestuur (te snel) de behoefte doet voelen om compensatielasten bij beschikkingsvoorschrift af te wentelen op de betrokken direct-belanghebbende.

190. Vgl. over deze problematiek: A.Q.C. Tak, De overheid in het burgerlijk recht, a.w., p. 392-394. Nadeel of schade kan in dit verband m.i. drie oorzaken hebben: (1) het gerichte bestuurlijke rechtshandelen, (2) de bestuurlijke bevoegdheidsuitoefening als rechtsfeit - denk aan de niet-beoogde (feitelijke) gevolgen waaraan het objectieve recht rechtsgevolgen verbindt -, en (3) het onderliggende (rechts)feit dat de bevoegdheidsnorm activeert.

191. Vgl. in dit kader o.m. mijn noot onder Rb. Roermond 27 september 1996, JB 1996/225 en R.J.N. Schløssels, Het specialiteitsbeginsel en derde-belangen: een frisse benadering of rechtsstatelijk drijfzand?, NTB 1996/3, i.h.b. p. 89 e.v. 


\subsection{Slotopmerkingen: een confronterend beginsel...}

Ik kom nu tot een afronding van dit laatste hoofdstuk en daarmee van dit boek. Soeteman heeft gesteld: 'Het enige wat we hebben om beginselen te funderen zijn argumenten. ${ }^{192}$ Deze simpele en relativerende uitspraak, die als opdracht aan dit proefschrift is meegegeven, geldt mijns inziens zeker voor het specialiteits-beginsel. De argumenten die kunnen worden aangedragen om het belang van dit beginsel te adstrueren zijn van normtheoretische, rechtsstatelijke, democratische, cultuurhistorische en bestuursorganisatorische aard. In dit boek is, naar mijn mening, in de verschillende hoofdstukken ruim aandacht besteed aan de verschillende argumenten. Tevens is in dit slothoofdstuk, toegespitst op de (omvang van) de bestuurlijke belangenafweging, een visie omtrent het specialiteitsbeginsel uiteen gezet. Hiermee is getracht een antwoord te gegeven op de onderzoeksvragen die in hoofdstuk 1 werden geformuleerd.

$D e ́$ uitleg of interpretatie van het specialiteitsbeginsel treft de lezer in dit boek echter niet aan. Dat kan ook niet. Met Vranken moet worden beaamd dat een rechtsbeginsel naar zijn aard 'confronterend' is. ${ }^{193} \mathrm{Zo}$ is $66 \mathrm{k}$ de betekenis die men uiteindelijk aan het specialiteitsbeginsel wenst toe te kennen o.m. afhankelijk van de visie die men huldigt ten aanzien van de algemene grondslagen van het democratisch-rechtsstatelijke bestuursrecht, het verschijnsel beleidsvrijheid en de scheiding tussen een publieke en een private rechtssfeer. ${ }^{194}$ Tevens is de interpretatie sterk afhankelijk van de betekenis die men (nog) toekent aan de bevoegdheidsleer in het hedendaagse bestuursrecht. ${ }^{195}$ Aanvaardt men met andere woorden de aanwezigheid van 'het bestuur' in de maatschappelijke structuren als een vanzelfsprekendheid of eist men hiervoor steeds een voorafgaande specifieke én legitimerende grondslag in de vorm van een duidelijke (democratisch gefundeerde) bevoegdheid? Anders gezegd: is de 'de' overheid altijd bevoegd tenzij het tegendeel blijkt, of is er in principe alleen afdoende publieke bevoegdheid indien deze is toegekend overeenkomstig kenbare constitutionele procedures?

Ik heb in dit boek in essentie betoogd dat het specialiteitsbeginsel een cultuurhistorisch bepaald basisbeginsel is van de democratische rechtsstaat (een 'structuurbeginsel'). Het beginsel is naar mijn oordeel bijgevolg een historisch bepaalde realiteit die niet ontkend kan worden zonder gelijktijdig óok de basisstructuur van deze staatsconceptie te

192. A. Soeteman, Hercules aan het werk. Over de rol van rechtsbeginselen in het recht, in: Rechtsbeginselen, AAe (special) 1991, p. 37.

193. Zie: Asser-Vranken, Algemeen deel, Zwolle 1995, p. 92.

194. Hier is toch wel wat mér in het geding dan de simpele vraag of men 'een aanhanger' is van het specialiteitsbeginsel. Vgl. R. de Lange, Publiekrechtelijke rechtsvinding, diss. UvA, Zwolle 1991, p. 30.

195. De betekenis van de bevoegdheidsleer en het legaliteitsbeginsel wordt in het 'moderne' bestuursrecht helaas nogal eens onderschat. Vgl. de pittige stellingname van Rozemond in zijn redactioneel commentaar waarin de opheffing van het tijdschrift 'Recht en kritiek' werd aangekondigd: 'Het is verontrustend om te zien dat kwaliteitseisen als het martelverbod, het recht op een eerlijk proces en het legaliteitsbeginsel heel gemakkelijk opzij kunnen worden gezet in moderne rechtssystemen als het Britse en het Nederlandse' (curs. R.J.N.S.). K. Rozemond, De toekomst van de kritische rechtstheorie, a.w., p. 201. 
ontkennen, dan wel in belangrijke mate af te zwakken. ${ }^{196}$ Door de opkomst van de (sociale) interventiestaat, die ik zie als een ontwikkeling van het oorspronkelijke democratisch-rechtsstatelijke basisconcept, is de werking van het specialiteitsbeginsel weliswaar onder druk komen te staan maar dit impliceert nog niet dat dit beginsel tengevolge hiervan zijn betekenis zou hebben verloren. Juist in deze 'interventiestaat' is er meer dan ooit behoefte aan een duidelijke scheiding tussen publiekrechtelijke en private (maatschappelijke) verantwoordelijkheden en werkzaamheden. ${ }^{197}$ De erkenning én respectering van het specialiteitsbeginsel is mijns inziens dienstig aan de realisering van deze behoefte. ${ }^{198}$

Veel zal echter afhangen van de bereidheid binnen de hedendaagse rechtswetenschap en rechtspraktijk om het belang van genoemd beginsel te (blijven) onderschrijven en te positioneren als een ankerpunt voor ons rechtsstatelijke bestuursrecht. Welke benadering men in dit verband ook kiest, men zal zich steeds terdege rekenschap dienen te geven van de juridische consequenties hiervan. Het relativeren, afzwakken of ontkennen van een cultuurhistorisch bepaald rechtsbeginsel op grond van pragmatische, instrumentalistische en doelmatigheidsargumenten schiet mijns inziens in ieder geval tekort. De waarde en betekenis van een 'rechts'-beginsel dient naar mijn overtuiging steeds op basis van een geëxpliciteerde materiële rechtsvisie te worden vastgesteld. Hieraan kunnen óok de beoefenaren van het 'positieve' staats- en bestuursrecht zich uiteindelijk niet onttrekken op straffe van verschraling van de rechtswetenschap. De eisen die gesteld dienen te worden aan de beoefening van het bestuursrecht behoren met het oog hierop in ieder geval niet éenzijdig te worden gevoed door de eisen van de bestuurspraktijk. ${ }^{199}$

196. Waarbij ik 'nieuwe' argumenten niet op voorhand terzijde beoog te schuiven. De kwaliteit van 'nieuwe' argumenten zal m.i. echter steeds vanuit een theoretisch-juridisch perspectief moeten worden bevestigd. Vgl. J. Smits, De vergissing der XII Tafelen. Een enkele gedachte bij het thema van autoriteit en kwaliteit in het burgerlijk recht, Recht en kritiek 1996/4, p. 402-403.

197. Ik citeer Simon die tegen de achtergrond van de interventiestaatgedachte de vanzelfsprekendheid van overheidsoptreden juist afwijst: 'Een belangrijk kenmerk van het no-nonsense-tijdperk, is dat interventie van de overheid in de samenleving niet meer als vanzelfsprekend wordt aanvaard. Overheidsinterventie dient te worden getoetst op noodzakelijkheid, subsidiariteit en proportionaliteit.' H.J. Simon, Handboek bestuurs(proces)recht, a.w., p. 181.

198. Anders blijkbaar: R. de Winter, Oud zeer, in: Azen op tegenslag, Lelystad 1994, p. 15-16.

199. Uiteraard kan ook in dit verband worden ingestemd met Vranken wanneer hij stelt dat rechtsbeginselen '...te belangrijk zijn om alleen aan rechtsfilosofen over te laten.' Asser-Vranken, a.w, p. 91. Constateren is éen, realiseren is echter twee... 


\section{Summary}

This dissertation deals with the purpose-specific principle (specialiteitsbeginsel) in Dutch constitutional and administrative law. Practitioners of Dutch public law are familiar with this principle. In short, the purpose-specific principle implies that a rule of administrative law may only be applied within its own well-defined scope and, as a result, may not be used to achieve objectives outside that scope (mixed motives). In addition, the administrative authority laid down in the legislative instrument in question may not be exercised for a purpose other than that which the legislature envisaged when attributing the authority (improper purposes). This is known as the prohibition against détournement de pouvoir. Furthermore, the general constitutional purpose-specific principle requires of the legislature that it sufficiently specify the authority conferred on the administration by providing substantive norms. In this context, the purpose-specific principle ties administrative authority to the, democratically legitimized, legislature's prerogative to legislate. This aspect of the Dutch purpose-specific principle relates to the German constitutional Bestimmtheitsgebot.

In contemporary Dutch administrative law, the Dutch purpose-specific principle is a controversial notion. First of all, it has led to a divided or compartmentalized administration. One single activity may in some instances require several licenses, which is most inconvenient first of all to the public, but also to the administration. There are conflicting views in the literature and case law as to the extent to which the purpose-specific principle limits the administration's discretionary freedom in weighing the interests involved, in cases where such freedom has been granted. The on-going disagreements between the various authors have resulted in a clash between two schools of thought. There is a 'liberal' and a 'strict' school. Those adhering to the liberal view prefer to render the purpose-specific principle and legality of administration in a less absolute form: the administration must be able to act effectively. For this reason, they favour a broad weighing of the interests involved. The followers of the strict school, however, emphasize the purpose-specific nature of administrative authority. In their view, the administration may only promote those interests for which the legislature has granted it authority, whereas other interests will be at best taken into consideration. The differences of opinion in the literature and case law have been the major reason for writing this dissertation. The research on which this dissertation reports will provide answers to the following two questions:

1. What importance must be attached to the Dutch purpose-specific principle as a fundamental principle of public law?

2. What limits are set by this principle to the administration's weighing of the interests in cases where it has been granted discretionary freedom? 
The subject of Chapter 2 is the concept of 'administrative authority', since administrative authority is based on the purpose-specific principle. It is logical therefore to first analyze the features of administrative authority. By virtue of their authority, administrative bodies are able unilaterally to alter or establish the legal position of the party/ies involved. Essential features of administrative authority are limitedness and specificity. Authority arising from public law, and consequently administrative authority, must be strictly distinguished from powers granted under private law. It must be kept in mind that publiclaw and private-law powers have disparate substantive roots. Public-law authority stems from the special character of the public-law system. Such authority must always be exercised in the public interest (res publica), whereas, in substantive terms, private-law powers serve to protect the interests of the parties proper. It is worth noting that privatelaw powers are not governed by the purpose-specific principle. Administrative authority, not to be confused with administrative duties, is attributed to administrative bodies that are specifically created under a legal system. In legal relations governed by administrative law, administrative bodies are the 'opposite number' of the party involved. The central component of this administrative-law relationship is the authority vested in the administrative body, and consequently the purpose-specific principle. For this reason, administrative bodies and the interested parties can in no instance shape these legal relations of their own accord. Nor are these relations reciprocal; the unilateral exercise of administrative authority takes precedence. The interested party's specific permission is not required. Naturally, the relationship between the administration and the party in question is fully governed by law.

Chapter 3 places the purpose-specific principle in a broader historico-theoretical perspective. The author investigates the development of the system of purpose-specific administrative authority in Western democratic states under the rule of law (rechtsstaat). This development resulted in a fundamental separation between the public state, which promotes public interest, and private civil society, which enjoys party autonomy under contract law. In such a society, private parties pursue their own interests within the constraints imposed by public law. The author subsequently discusses the process of the formation of law within the state, i.e. the public legal community. This process of the formation of law is placed against the backdrop of general principles of public law. It shows that the area of tension between the administration's promotion of public-law interests and that same administration's respect for private-law interests is at the core of that process of law formation. The Chapter ends with a study of the relation between the legal purpose-specific principle and other public-law principles, with special emphasis on the democratic postulate and the principle of legality. The author concludes that the purpose-specific principle must not be identified with the principle of legality (of administration), since the former, together with the democratic postulate, constitutes the foundation of the legality principle, where administrative authority is concerned. Consequently, the purpose-specific principle sets requirements of a qualitative nature for the legal basis of administrative authority.

The legal basis of administrative authority is the subject of Chapter 4 . On the basis of research in the literature, the author determines the extent to which, under Dutch 
constitutional law, administrative authority must have a basis in statutory law. Since the Dutch Constitution of 1887 , it has been generally accepted that in particular administrative authority which imposes obligations on the party, should have a basis in statutory law. This is expressed by the German concept of Eingriffsverwaltung (administrative infringement upon people's rights and freedoms). After the Second World War, partly as a result of theoretical development in Germany, the idea gained ground that the legality requirement could not automatically be made contingent on the distinction between authority to impose obligations and authority to confer rights. During the 1980s, one of the doctrines advocated in the Netherlands was the German Wesentlichkeitstheorie (the doctrine of the essential). The basic assumption of this theory is that the legislature, in view of its democratically legitimized prerogative to legislate, should take all far-reaching, essential administrative decisions. For this reason, according to the Wesentlichkeitstheorie, the legality requirement derives directly from the separation of powers (Trias Politica). Partly as a result of this theory, the author argues that all administrative powers resulting in infringement, restriction or determination of the (constitutional) legal position of a party should be governed by statute. This requirement of a statutory basis particularly enhances legal certainty. In the second part of Chapter 4 , the author investigates the extent to which administrative authority should be subject to substantive norms set by the legislature. To answer this question, the case law of the German Constitutional Court (Bundesverfassungsgericht) on the Bestimmtheitsgebot (specificity requirement) (Art. 80 (1) German Constitution [Grundgesetz]) as well as the ECHR case law on the 'rule of law' are analyzed. On the basis of this analysis, the author concludes that the legislature should formulate precise substantive norms as to content and purpose of administrative authority. Parties involved should be able to get an idea, from such substantive law, of the possible scope of the administrative authority (foreseeability). Chapter 4 concludes with an inventory of the arguments which may be put forward to underpin the necessity of the purpose-specificity of administrative authority. Purpose-specificity serves the legislature's prerogative to legislate, legitimizes administrative authority and provides a guideline to the judiciary when testing the legality of administrative action. In addition, it enhances the transparency of administrative organization and the effectiveness of the decision-making process; thus each administrative body knows which public-law interests it must protect and which not.

Chapter 5 centres on the prohibition against détournement de pouvoir (improper purposes). Within democratic states under the rule of law, it is a generally accepted principle that administrative bodies may not exercise their administrative authority for purposes other than for which the legislature envisaged that authority when attributing it. This principle has been codified and laid down in Article 3:3 of the Dutch General Administrative Code (Awb). The doctrine of détournement de pouvoir was developed in the nineteenth century by the French Council of State (Conseil d'Etat). In the beginning of this century, it was received into Dutch administrative law. Although administrative tribunals seldom quash an administrative decision on the grounds of détournement de pouvoir, the author concludes that the prohibition still constitutes a fundamental constitu- 
tional rule of conduct for public authorities in today's democratic states under the rule of law.

The 'problem of purpose-specificity' only comes into full view, where a specific administrative authority allows for discretionary freedom. This relates to the second question: what interests must the administrative body take into account in this process of discretionary law-forming? To answer this question, the legal character of discretionary freedom is analyzed in Chapter 6. The general assumption is that discretionary freedom imposes a duty on the administrative body to weigh the interests involved. The author concludes that the weighing of interests must be construed as the administrative body's duty to promote specific public-law interests, while at the same time taking into account the interests of the party/ies involved. The public-law interests exclusively direct the process of administrative law-forming. The main reason why the interests of the party/ies involved can be taken into account in case of discretionary freedom, is that the administrative body is in a position to take a number of different, legally correct, decisions. Discretionary freedom implies therefore a freedom of choice for the administrative body as to the legal effects of their action. Such 'freedom' is in all cases limited, however, by the purpose for which the authority was granted. Thus, the purpose-specific principle delimits the process of interests weighing by the administration. (cf. Article 3:4, s. 1 in conjunction with Article 3:3 Awb).

In Chapters 7 and 8 the author studies the limits imposed by the purpose-specific principle on the administrative body's duty to weigh all interests involved on the basis of a detailed analysis of Dutch scholarly writing on administrative law and relevant case law. This analysis confirms that there are different schools of thought on the subject: a 'liberal' and a 'strict' school. In particular there is no consensus on the extent to which the administrative body must take the interests of third parties into account with regard to the administration's power of decision, for instance, in granting licenses. There is a movement for the application of the Schutznorm theory (theory of relevant interests), application of which would entail the administration's only taking into account third-party interests, if those interests enjoy protection within the scope of the administrative authority in question. The other school of thought is that the administration should take into account those interests of the party/ies involved, which will be affected by the decision. In Dutch case law this is expressed in particular by the doctrine of administrative compensation (bestuurscompensatie). The courts have ruled that the interests affected need not enjoy the protection of the specific administrative authority in order to assume an administrative duty to compensate the party affected.

In the final Chapter, the author presents his own view on the 'specificity problem', based on the preceding chapters. The point of departure here is an analysis of the exercise of administrative authority from the perspective of the administration creating intended legal effects and the perspective of legal effects ensuing by operation of law. The author investigates the way in which the exercise of administrative authority affects the sphere of interest of the party/parties involved. In the author's view, these interests include in particular individual property rights, contractual and extracontractual rights and constitu- 
tional and human rights. Against the backdrop of the set of principles underlying public law, the author subsequently establishes the way in which administrative bodies should take into account the various interests of the party/ies involved. On the basis of the author's analysis of recent theory formation in Germany about the Schutznorm as applied in administrative law and of Article 6 ECHR (determination of civil rights), the author concludes that, without exception, the administration must take all interests of the party/ies in question into account. This premise does not in the least imply that such interests legitimize unilateral law-forming by the administration, since such law-forming is always contingent on the specific purpose for which the authority has been granted. This entails, among other things, that administrative bodies can never by virtue of their public-law authority bind parties in their legal relations under private law; this is prevented by the division between public and private law. It also entails that only such specific public-law interest which is the legal basis for the administrative authority, can, for instance, legitimize the administration's law-making with regard to the issuing of licences. In conclusion, the administrative body may only refuse to exercise a specific authority on the grounds of public-law interest. The purpose-specific principle does not impose limits on the doctrine of administrative compensation, however. If a party's interest is disproportionately adversely affected by the lawful exercise of administrative authority, the administration in question is obliged, in principle, to offer that party (financial) compensation. Generally speaking, the administrative body is to exercise a discretionary administrative power in a manner which has the least adverse effect on the party/ies involved. This follows from the principle of proportionality (cf. Article 3:4, s. 2 Awb).

In conclusion, Chapter 9 contains a number of comments aimed at putting the purposespecific principle somewhat in perspective: the interpretation of the purpose-specific principle will not be found in this book. It is impossible to define it conclusively. The author agrees with Vranken that legal principles are 'confrontational' by definition.' The meaning one wishes to attach to the purpose-specific principle depends on how one views the general principles of administrative law in democratic states under the rule of law, the phenomenon of discretionary freedom and the division between the public and private legal sphere. Interpretation of this concept also very much depends on how much weight is attached to the theory of legality of administrative action in present-day administrative law. In other words, is the presence of an administration in societal structures viewed as a matter of course on grounds of policy effectiveness, or is a prior specific statutory basis in the form of a democratic and purpose-specific administrative authority required? The author answers this question involving the politics of law in the latter sense.

1. Asser-Vranken, Algemeen deel (Asser serie), Zwolle (1995), at 92. 



\section{Literatuurlijst}

Achterberg, N.,

Allgemeines Verwaltungsrecht, 2. vőllig neubearbeitete und erweiterte Auflage, Heidelberg 1986. Ackermans-Wijn, J.C.E.,

Contracten met de overheid. Een onderzoek naar de contractsvrijheid van publiekrechtelijke rechtspersonen en het toepasselijke materielle recht, diss. KUN, Deventer 1989.

Addink, G.H./Steenbergen, J.D.M.,

Beperking van bevoegdheden: Een onderzoek van administratieve wetgeving, Bestuurswetenschappen 1985/7, p. 430 e.v.

Akkermans, P.W.C.,

Redelijke grondwetinterpretatie, AAe 1990/6, p. 398 e.v.

Angeren, J.A.M. van,

De gewone rechter en de administratieve rechtsgangen, diss. RUL, Deventer 1968.

Asser/Hartkamp 4-III,

negende druk, Zwolle 1994.

Asser/Scholten,

Algemeen deel, Zwolle 1974.

Asser/Vranken,

Algemeen deel, Zwolle 1995.

Auby/Drago,

Traité des recours en matière administrative, Paris 1992.

Baars, J. van,

Point d'intérêt, point d'action, diss. VU, Amsterdam 1971.

Bachof, O.,

Beurteilungsspielraum, Ermessen und unbestimmter Rechtsbegriff im Verwaltungsrecht JZ 1955/4, p. 97 e.v.

Backes, Ch.W.,

Juridische bescherming van ecologisch waardevolle gebieden, diss. UU, Zwolle 1993.

Banda, P.H.,

Administratief procesrecht in vergelijkend perspectief: een rechtsvergelijkende studie naar de invloed van de functie van het beroep op de rechter bij de regeling van het administratieve procesrecht, diss. KUB, Zwolle 1989.

Barendrecht, J.M.,

Recht als model van rechtvaardigheid, diss. KUB, Deventer 1992.

Barents, R.,

De communautaire rechter tegenover burocratie en politiek. De interactie tussen algemene rechtsbeginselen en discretionaire bevoegdheden, RMTh. 1995/5, p. 219 e.v. 
Barents, R.,

Milieu en interne markt. Enkele opmerkingen over de betekenis en de gevolgen van het rechtsbasisvereiste in het communautaire recht, SEW 1993/1, p. 5 e.v.

Bauer, H.,

Altes und Neues zur Schutznormtheorie, AøR 1988 (113), p. 582 e.v.

Bénoit, F.-P.,

Le droit administratif français, Paris 1968.

Bense, M./Zijlstra, S,

Het begrip bestuursorgaan. Betekenis en strekking van artikel 1:1, eerste lid, Algemene wet bestuursrecht, NTB 1994/9, p. 253 e.v.

Bergamin, R.,

Rechten jegens de overheid. Het begrip publiekrechtelijke subjectieve rechten, diss. UvA, Nijmegen 1995.

Berge, J.B.J.M. ten,

Besturen door de overheid, Nederlands Algemeen bestuursrecht 1, tweede druk, Deventer 1997.

Berge, ten/Tak,

Nederlands administratief procesrecht, deel 1, Zwolle 1983.

Berge, J.B.J.M. ten, e.a. (red.),

Nieuw bestuursprocesrecht, Nijmegen 1994.

Bergh, C.C.J.J. van den,

Iets over publiek- en privaatrecht, in: Ter recognitie (Van der Linden-bundel, red. C. Streefkerk en S. Faber), Hilversum 1987, p. 9 e.v.

Berk, J.A.M. van den, Bestuursschaderecht, Deventer 1997.

Berk, J.A.M. van den, Schadevergoeding voor rechtmatig toegebrachte schade door de overheid, diss. UU, Zwolle 1991.

Besluiten over grote projecten,

Rapporten aan de regering, 1994/46, Wetenschappelijke Raad voor het Regeringsbeleid, Den Haag 1994.

Bestuur in geding,

Rapport van de werkgroep inzake terugdringing van de juridisering van het openbare bestuur (rapport Van Kemenade), Haarlem 1997.

Beurskens, W.J.J., Hoeveel toekomst heeft de 'doorkruisingsleer'?, NTBR 1997/9, p 276 e.v.

Bleckmann, A.,

Staatsrecht I, Staatsorganisationsrecht, Köln/Berlin/Bonn/Munchen 1993.

Bloembergen, A.R.,

De eenheid van privaatrecht en administratief recht, WPNR 5372 (p. 1 e.v.), 5373 (p. 17 e.v.), 5374 (p. 33 e.v.) en 5375 (p. 49 e.v.)

Bloembergen, A.R.,

Overheidsprivaatrecht: schets van een algemeen deel, WPNR 6074, p. 950 e.v.

Bloembergen A.R/Lubach D.A.,

Burgerlijk recht en administratief recht: twee gelijkwaardige rechtsgebieden, open verbonden in één rechtsorde, WPNR 5885, p. 446 e.v. 
Boasson, J.J.,

De rechter tegenover de vrijheid der administratie, diss. RUL, Groningen 1911.

Bobkenforde, E.-W,

Entstehung und Wandel des Rechtsstaatsbegriffs, in: Staat, Gesellschaft, Freiheit, Studien zur

Staatstheorie und zum Verfassungsrecht, erste Auflage, Frankfurt am main 1976, p. 65 e.v.

Böckenforde, E.-W.,

Die bedeutung der Unterscheidung von Staat und Gesellschaft im Demokratischen Sozialstaat der

Gegenwart, in: Staat, Gesellschaft, Freiheit, Studien zur Staatstheorie und zum Verfassungsrecht, erste Auflage, Frankfurt am main 1976, p. 185 e.v.

Böckenforde, E.-W.,

Die Entstehung des Staates als Vorgang der Säkularisation, in: Staat, Gesellschaft, Freiheit, Studien zur Staatstheorie und zum Verfassungsrecht, erste Auflage, Frankfurt am Main 1976, p. 42 e.v.

Böckenforde, E.-W.,

Gesetz und gesetzgebende Gewalt. Von den Anfängen der deutschen Staatsrechtslehre bis zur Höhe des staatsrechtlichen positivismus (Hab.), zweite Auflage, Berlin 1981.

Böckenförde, E.-W.,

Verfassungsfragen der demokratie, in: Staat, Verfassung, Demokratie, Studien zur Verfassungstheorie und zum Verfassungsrecht, Frankfurt am Main 1991, p. 289 e.v.

Boer, M.M. den,

Zelfstandige bestuursorganen uit de zelfkant van de democratie?, VAR-reeks 118, Alphen aan den Rijn 1997.

Bohtlingk F.R.,

De rechtsstaat Nederland (oratie), Utrecht 1958.

Böhtlingk F.R./Logemann J.H.A.,

Het wetsbegrip in Nederland, Alphen aan den Rijn 1966.

Bok, A.J.,

Rechterlijke toetsing van regelgeving, diss. RUG, Deventer 1991.

Bok, A.J.,

Zorgvuldige en afgewogen regelgeving in het licht van de algemene wet bestuursrecht, NTB 1993/3, p. 117 e.v.

Borger, S./Schuiling, K.F.,

De Awb getoetst door de rechter: voorbereiding van besluiten, Openbaar bestuur 1995/10, p. 24 e.v.

Bosch-Kemper, J. de,

Handleiding tot de kennis van het Nederlandsche staatsregt en staatsbestuur, Amsterdam 1853.

Boukema, P.J.,

Democratie en rechtsbescherming, NTB 1996/4, p. 144 e.v.

Boxum, J.L.,

De kneedbaarheid van de belanghebbende, in: In wederkerigheid (Scheltema-bundel), p. 85. e.v.

Brenninkmeijer, A.F.M.,

Een leerstellig cliché, in: In de sfeer van administratief recht (Konijnenbelt-bundel), Utrecht 1994, p. 13 e.v.

Brouwer, J.G./Schilder, A.E.,

Artikel 174a Gemeentewet: godin der overwinning?, NJB 1997/13, p. 571 e.v. 
Brouwer, P.W.,

Rechtsbeginselen en rechtspositivisme, in: Rechtsbeginselen, AAe 1991/10, p. 757 e.v.

Burg, F.H. van der, annotatie onder het Meerenberg arrest in AB Klassiek, derde druk, Deventer 1997, p. 7 e.v.

Burg, F.H. van der, Is het wenselijk dat de overheid maatregelen neemt tot ordening en publicatie van bestaande subsidievoorwaarden?, preadvies NJV 1977, deel I, tweede stuk, Zwolle 1977.

Burg, van der/Cartigny,

Rechtsbescherming tegen de overheid, Utrecht 1979.

Burg, van der/Cartigny/Overkleeft-Verburg,

Rechtsbescherming tegen de overheid, vijfde druk, Nijmegen 1985.

Burg, W. van der,

Het democratisch perspectief, diss. UU, Arnhem 1991.

Burkens/Kummeling/Vermeulen/Widdershoven,

Beginselen van de democratische rechtsstaat, vierde druk, Deventer 1997.

Burkens, M.C./Stroink, F.A.M.,

Sociale verzorgingsstaat en consensuele besluitvorming, NJB 1980/29, p. 743 e.v.

Buuren, P.J.J. van,

Belangen afwegen en het specialiteitsbeginsel, Awb-notities (11), NJB 1995/12, p. 460 e.v.

Buuren, P.J.J. van,

Gedogend besturen, oratie UU, Deventer 1988.

Buuren, P.J.J. van,

Grenscorrectie tussen bestuursrecht en privaatrecht via het zelfstandig schadebesluit, NJB 1997/17, p. 759 e.v.

Buuren, P.J.J. van,

Kringen van belanghebbenden, in het bijzonder in procedures tegen de overheid, diss. RUG, Deventer 1978.

Buuren, P.J.J. van,

Nadeelcompensatie, Awb-notities (16), NJB 1995/17, p. 637 e.v.

Buuren, P.J.J. van,

Nadeelcompensatie in de algemene wet bestuursrecht, in: Aantrekkelijke gedachten. Beschouwingen over de Algemene wet bestuursrecht (red. Boxum/Damen e.a.), Deventer 1993, p. 91 e.v.

Buuren van/Bolt/Scheltema,

Kroonberoep en Arob-beroep, Rapport van de vakgroep bestuursrecht en bestuurskunde Groningen naar de verschillen tussen Kroonberoep en Arob-beroep, Deventer 1981.

Buijs, J.T.,

De Grondwet, Toelichting en kritiek, eerste deel, Arnhem 1883.

Caenegem, R.C. van,

Geschiedkundige inleiding tot het publiekrecht, uitg. E. Story-Scientia 1985.

Chapus, R.

Droit administratif général, tome 1, 10e édition, Paris 1996.

Cliteur, P.B.,

Conservatisme en cultuurrecht. Over de fundering van recht in rechtsbeginselen, diss. RUL, Amsterdam 1989. 
Cliteur, P.B., What developments can we expect in the field of human rights for the coming decades?, Rechtstheorie (Dunker \& Humblot, Berlin), 1996 (2), p. 177 e.v.

Colenbrander, H.T., Ontstaan der Grondwet (Bronnenverzameling), tweede deel 1815, 's-Gravenhage 1909.

Couwenberg, S.W., Gezag en vrijheid, Inleiding in de constitutionele rechts- en ontwikkelingstheorie, Zwolle 1991. Couwenberg, S.W., Modern constitutioneel recht en emancipatie van de mens, deel III, Constitutionele ontwikkelingsmodellen, Assen 1984.

Crasborn, C.J.A/Waard B.W.N. de, Naschrift bij reactie H.J. Simon Algemene wet bestuursrecht, NJB 1987/43, p. 1393.

Damen, L.J.A., Bestaat de Awb-mens?, in: Aantrekkelijke gedachten, beschouwingen over de Algemene wet bestuursrecht, Deventer 1993, p. 109 e.v.

Damen, L.J.A., Boekbespreking M. Kobussen 'De vrijheid van de overheid', RMTh. 1992/10, p. 465 e.v.

Damen, L.J.A., De assistent-kampbeheerder die graag ambtenaar had willen zijn, AAe 1995/4, p. 290 e.v.

Damen, L.J.A., (interventie), De belanghebbende, VAR-reeks 109 (verslag), Alphen aan den Rijn 1993, p. 25 e.v. Damen, L.J.A., De geheime directe van het bestuur: mensbeeld, bestuursbeeld en legaliteitsbeginsel, in: In wederkerigheid (Scheltema-bundel), Deventer 1997, p. 35 e.v.

Damen, L.J.A., Ongeregeld en ondoorzichtig bestuur, diss. RUG, Deventer 1987.

Damen, L.J.A., (interventie), Overheidsaansprakelijkheid administratieve en burgerlijke rechter, VAR-reeks 103 (verslag), Alphen aan den Rijn 1990, p. 54 e.v.

Dashwood, A., The limits of the European community powers, E.L. Review, 1996/21, p. 113 e.v.

Daudt, H., Legitimiteit en legitimatie, Beleid \& Maatschappij 1975/1, p. 5 e.v.

Dekker-van Bijsterveld, S.C. den, Gemeenten en algemene beperkingen van klassieke grondrechten, Gst. 1991, 6925, p. 382 e.v. Denninger/Ridder/Simon/Stein, Kommentar zum Grundgesetz für die Bundesrepublik Deutschland, Band 2, Neuwied/Darmstadt 1984.

Derks, J.M.E., De grondwet en delegatie. Het delegatievraagstuk in constitutioneel perspectief, diss. RL, Maastricht 1995.

Dijk, P. van, Toetsing van overheidshandelen door de nationale en internationale rechter en het vereiste van procesbelang, diss. RUL, 's-Gravenhage 1976. 
Dombrowski, H., Mißbrauch der Verwaltungsmacht. Zum Problem der Kopplung verschiedener Verwaltungszwecke, Mainz 1967.

Donner, A.M.,

Bestendig en wederkerig. Over het verband van staat en staatsrecht, oratie RUG, Zwolle 1979.

Donner, A.M.,

De rechtskracht van administratieve beschikkingen, diss. VU, Alphen aan den Rijn 1941.

Donner, A.M.,

Iets over kiesstelsels, Amsterdam 1967.

Donner, A.M.,

Legitimiteit in sociologie en rechtswetenschap, Beleid \& Maatschappij, 1975/1, p. 33 e.v.

Donner, A.M.,

Nederlands bestuursrecht, Algemeen deel, tweede ongewijzigde druk, Alphen aan den Rijn 1967.

Donner, A.M.,

Nederlands bestuursrecht, Algemeen deel, vierde herziene druk, Alphen aan den Rijn 1974.

Donner, A.M.,

Nederlands bestuursrecht, Algemeen deel, vijfde herziene druk, Alphen aan den Rijn 1987.

Dorhout, L.,

Relativiteit van onrechtmatigheid, ook iets voor de administratieve rechter? (Liber amicorum mr.

J. van der Hoeven), in: Non ex regula, Deventer 1985, p. 33 e.v.

Dreier, $\mathrm{H}$.,

Hierarchische Verwaltung im demokratischen Staat, Genese, aktuelle Bedeutung und funktionelle Grenzen eines Bauprinzips der Exekutive, Tübingen 1991.

Drupsteen, Th.G.,

Algemene vergadering Vereniging voor Administratief Recht (verslag), NJB 1984,/24, p. 724 e.v.

Drupsteen, Th. G.,

En de gemeenteraad maar belangen afwegen, in: In de sfeer van administratief recht (Konijnenbelt-bundel), Utrecht 1994, p. 69 e.v.

Drupsteen, Th. G.,

Het zelfstandig schadebesluit en de ondragelijke lichtheid van de Nederlandse Grondwet (reacties), NJB 1997/34, p. 1596 e.v.

Duguit, L.,

Traité de droit constitutionnel, troisième édition, tome deuxième, La théorie générale de l'état, Première partie Eléments, fonctions et organes de l'état, Paris 1928.

Duk, W.,

Beoordelingsvrijheid en beleidsvrijheid, RMTh. 1988/4, p. 156 e.v.

Duk, W.,

Boekbespreking J.H. van Kreveld, Beleidsregels in het recht, diss. RUG, RMTh. 1985/2, p. 174 e.v.

Duk, W.,

De zachte kern van het bestuursrecht, RMTh 1978, p. 574 e.v.

Dworkin, R.,

Taking rights seriously, zesde druk, Cambridge/Massachusetts 1979. 
Eikema Hommes, H.J. van,

De elementaire grondbeginselen der rechtswetenschap, Een juridische methodologie, Deventer 1972.

Eikema Hommes, H.J. van,

De rechtsbeginselen volgens de transcendentaal-empirische methode, in: Rechtsbeginselen, Zwolle 1980 , p. 33 e.v.

Eikema Hommes, H.J. van,

De samengestelde grondbegrippen der rechtswetenschap, Een juridische methodologie, Zwolle 1976.

Eikema Hommes, H.J. van,

De wijsgerige grondslagen van de rechtssociologie, Deventer/Zwolle 1986.

Eikema Hommes, H.J. van,

Hoofdlijnen der rechtssociologie en de materielle indelingen van het publiek- en privaatrecht, Zwolle 1975.

Elzinga, D.J./Warmeling, H.G.,

Het Nederlandse parlementaire stelsel, Nijmegen 1993.

Erp, H. van,

Het politiek belang. Over de politieke orde in een pluralistische samenleving, Amsterdam 1994.

Eijlander, Ph.,

De wet stellen. Beschouwingen over onderwerpen van wetgeving, diss. KUB, Zwolle 1993.

Fernhout, R.,

Instrument en norm, in: Rechtsvorming in de sociale rechtsstaat (De Haan-bundel), Deventer 1989, p. 23 e.v.

Florijn, N.,

Rechtsvergelijking in de bestudering van het publiekrecht. Een stilistische benadering, Preadvies voor de Nederlandse vereniging voor rechtsvergelijking nr. 53, Deventer 1996, 83 e.v.

Flume, W.,

Allgemeiner Teil des Bürgerlichen Rechts, zweiter Band, Das Rechtsgeschăft, vierte unveränderte Auflage, Berlin/Heidelberg 1992.

Foqué, R.,

De ruimte van het recht (oratie), Arnhem 1992.

Forsthoff, E.,

Lehrbuch des Verwaltungsrechts, erster Band Allgemeiner Teil, achte neubearbeitete Auflage, München/Berlin 1961.

Frantzen, H.,

Schutznorm, congruentie en relativiteit bij vrijstellingen t.b.v. de bouwvergunning, BR 1986, p. 578 e.v.

Frenk, N.,

Kollektieve akties in het privaatrecht, diss. UU, Deventer 1994.

Fricke, H.J.,

Die (erhebliche) Belange der Bundesrepublik Deutschland im Auslandergesetz und das Bestimmtheitsgebot, diss. Münster 1973.

Geest, H.J.A.M. van,

Integratie in de Wet milieubeheer: met name de milieuvergunning, Gst. 6987, p. 229 e.v. 
Gier, A.A.J. de/Buuren P.J.J. van,

De Deltawet grote rivieren, een eenmalig experiment?, NTB 1995/6, p. 145 e.v.

Gier, A.A.J. de/Driessen, P.P.J.,

Van de nood een deugd? Verslag van een evaluatie-onderzoek naar de werking van de Deltawet grote rivieren, Gst. 7064, p. 621 e.v.

Giacometti, Z.,

Allgemeine Lehren des rechtsstaatlichen Verwaltungsrechts, 1. Band, Zürich 1960.

Gierke, O. von,

Das deutsche Genossenschaftsrecht I-IV, Berlin 1913.

Goede, de/Brink, van den,

Beeld van het Nederlands bestuursrecht, vijfde druk, 's-Gravenhage 1986.

Goldschmidt, J.E.,

Positieve discriminatie (staats- en bestuursrechtelijke aspecten van positieve actie), Preadvies NJV, Zwolle 1989.

Goorden, C.P.J.,

Rechtsbevoegdheid in het bestuursrecht, diss. KUB, Zwolle 1990.

Goorden, C.P.J.,

Verzelfstandiging: naar een doorzichtig en geregeld bestuur, VAR-reeks 118, Alphen aan den Rijn 1997.

Gribnau, J.L.M.,

De wederkerige rechtsbetrekking als nieuw paradigma, R\&R, 1993, p. 87 e.v.

Groen, H.A.,

Overheidsvergunning en onrechtmatige daad, diss. RUL, Deventer 1977.

Groenendijk, C.A.,

Bundeling van belangen bij de burgerlijke rechter, diss. KUN, Zwolle 1981.

Gun, V.E. van der,

De coördinatie van de bouwvergunning en de milieuvergunning. Vraagstuk op het raakvlak van ruimtelijke ordening en milieubeheer, RegelMaat 1990/1, p. 2 e.v.

Gurlit, E.,

Die Klagebefugnis des Adressaten im Verwaltungsprozeß, Die Verwaltung 1995 (28), p. 449 e.v.

Haan, de/Drupsteen/Fernhout,

Bestuursrecht in de sociale rechtsstaat I, Ontwikkeling, Organisatie, Instrumentarium, derde geheel herziene druk, Deventer 1986.

Haan, de/Drupsteen/Fernhout,

Bestuursrecht in de sociale rechtsstaat I, Ontwikkeling, Organisatie, Instrumentarium, vierde geheel herziene druk, Deventer 1996.

Habermas, J.,

Faktizităt und Geltung, Beitrage zur Diskurstheorie und des demokratischen Rechtsstaats, Frankfurt am Main 1992.

Hain/Schlette/Schmitz,

Ermessen und Ermessensreduktion - ein Problem im Schnittpunkt von Verfassungs- und Verwaltungsrecht, Aor 1997 (122), p. 33 e.v.

Hall, A. van,

Het specialiteitsbeginsel in het waterstaatsrecht. Over kringen van belangen (oratie), Zwolle 1995. 
Hall, A. van,

Landbouw en water. Beleidsmatige en juridische aspecten van waterbeheer. Preadvies voor de vereniging voor agrarisch recht, Agrarisch Recht, 1995/4, p. 175 e.v.

Hart, H.L.J.,

The concept of law, tiende druk, Oxford 1992.

Hasskarl, H.,

Die begrenzung exekutiver Rechtsetzungsbefugnis unter besonderer Berlcksichtigung der Bundesgesetzgebung, ein Beitrag zu Art. 80. Abs. 1 Satz 2 GG., Saarbrücken 1969.

Hauriou, M.,

Précis de droit administratif et de droit public, onzième édition, Paris 1927.

Haverkate, G.,

Rechtsfragen des Leistungsstaats, Verhăltnismäßigkeitsgebot und Freiheitsschutz im leistenden Staatshandeln, Hab. Tübingen 1983.

Helder, E./Jue, R.J.,

Belangenafweging in het bestuursrecht, Bestuurswetenschappen 1987/1, p. 25 e.v.

Heldeweg, M.A.,

Beleidsregels: naar een nieuwe catechismus voor 'ambtelijke bijbels'?, NTB 1995/4, p. 81 e.v.

Heldeweg, M.A./van der Linden, E.C.H.J.,

Een volwaardig bestuursrechtelijk debat, of rechtsbescherming tegen de burger als juridisch tekort?, NJB 1996/43, p. 1818 e.v.

Heldeweg, M.A.,

Het specialiteitsbeginsel: bel voor de laatste ronde?, in: Rechtspraak bestuursrecht. De annotaties 1994/1995, p. 175 e.v.

Heldeweg, M.A., Normstelling en expertise. Waarborgen voor technische deskundigheid in het bijzonder bij de vergunningverlening in het milieurecht, diss. RL, 's-Gravenhage 1993.

Heldeweg, M.A.,

Publiekrechtelijke autonomie. Over exclusieve behartiging van het algemeen belang en de wederzijdse onvrijheid van burger en overheidsbestuur, in: Eenzijdig en wederkerig? (red. E.C.H.J. van der Linden en A.Q.C. Tak), p. 121 e.v.

Heldeweg, M.A./Schlossels, R.J.N., Willekeur getoetst; terug naar Doetinchem?, JB 1996/212, p. 906 e.v.

Heringa, A.W.,

De redelijke termijn in het bestuursproces, Rechtspraak bestuursrecht. De annotaties 1994-1995, 's-Gravenhage 1995, p. 121 e.v.

Heringa, A.W.,

Sociale grondrechten, diss. RUL, 's-Gravenhage 1989.

Heringa/Zwart,

De Nederlandse Grondwet, derde herziene druk, Zwolle 1991.

Hirsch Ballin, E.H.M.,

Het grondrecht op behoorlijke rechtspraak in het Nederlandse administratieve recht, Handelingen

NJV deel 1, tweede stuk, Zwolle 1983.

Hirsch Ballin, E.H.M.,

Publiekrecht en beleid, diss. UvA, Alphen aan den Rijn 1979. 
Hirsch Ballin, E.H.M.,

Rechtsstatelijke subsidieverhoudingen, preadvies VAR, Geschriften van de Vereniging voor Administratief Recht XCIX, Alphen aan den Rijn 1988.

Hirsch Ballin, E.H.M./Verheij, N.,

Rechtsvergelijking in het bestuursrecht, in: Rechtsvergelijking AAe 1994/5 (special), p. 371 e.v. Hirsch Ballin, E.M.H.,

Wederkerig bestuursrecht, RMTh. 1989/1, p. 1 e.v.

Hoekema, A.J.,

Het rechtskarakter van doelmatig onderhandelend bestuur, in: Recht, rechtvaardigheid en doelmatigheid (red. Maris/Bos/Hoekema/van Peijpe), Arnhem 1990, p. 101 e.v.

Hoekema, A.J.,

Onderhandelend bestuur, Recht der Werkelijkheid, 1994/1, p. 97 e.v.

Hoeven, J. van der,

De drie dimensies van het bestuursrecht, VAR-reeks 100, Alphen aan den Rijn 1989.

Hoeven, J. van der,

De grenzen van de rechterlijke functie in de administratieve rechtspraak, RMTh. 1974, p. 658 e.v. Hoeven, J. van der,

De magische lijn. Verkenningen op de grens van publiek en privaatrecht, in: Honderd jaar rechtsleven, Zwolle 1970, p. 201 e.v.

Hoeven, J. van der,

Publiek- en privaatrecht, in: Osmose tussen publiek en privaatrecht, AAe 1987/5, p. 277 e.v.

Hofman/Sap/Sewandono,

Grondrechten in evenwicht, Deventer 1995.

Huart, F.J.A.,

Misbruik van burgerlijk recht door de administratie, in: Verspreide geschriften, Alphen aan den Rijn 1949, p. 13 e.v.

Hufen, F.,

Verwaltungsprozeßrecht, 2. Auflage, München 1996.

Huijgen, W.G.,

Publiekrechtelijke vergunning en privaatrechtelijke aansprakelijkheid, in Quod Licet (Kleijnbundel), Deventer 1992, p. 135 e.v.

Huijgen, W.G.,

Reflexwerking van vergunningen, in: De derde in het recht, AAe 1997/5 (special), p. 330 e.v.

Imboden, $\mathrm{M}$.,

Das Gesetz als Garantie rechtsstaatlicher Verwaltung, Basel/Stuttgart 1954.

Jèze, G.,

Les principes généraux du droit administratif, deuxième édition, Paris 1914.

Jong, J.P. de,

Bestuursrecht van vreemde herkomst: een onderzoek naar de bronnen en grondslagen van een drietal centrale elementen van de Nederlandse bestuursrechttheorie, diss. KUB, Zwolle 1988.

Jong, J.P. de,

Wetgevingsrubriek NTB 1997/3, p. 123 e.v, inzake de 'Vergunningwet Westerschelde'.

Jue, R.J.,

Grondbeginselen van het recht, Groningen 1990. 
Jue, R.J.,

Rechterlijke terugtred bij de beoordeling van bestuurlijke beslissingen, RMTh. 1985/5, p. 440 e.v. Jue, R.J.,

Vrijheid van besturen, R\&R, 1986/15, p. 141 e.v.

Jurgens, E.C.M.,

De mythe van Meerenberg. Over de betrekkelijke legitimatie die uitgaat van medewetgeving door de Staten-Generaal, NJB 1993/39 (Themanummer Zorgen om wetgeving), p. 1381 e.v.

Jurgens, E.C.M.,

Van Victor, via Victoria en Damocles, naar Procrustes. Over ons wetgevend gehakkel bij de bestrijding van drugsoverlast vanuit woningen, NTB 1997/8, p. 293 e.v.

Jurgens, G.T.J.M.,

Bestuurlijk gedogen in het milieurecht en het ruimtelijk recht, diss. UU, Zwolle 1996.

Kelsen, H.,

Allgemeine Theorie der Normen, Im Auftrag des Hans-Kelsen-Instituts aus dem Nachlaß herausgegeben von: K. Ringhofer und R. Walter, Wien 1979.

Kelsen, H.,

Reine Rechtslehre, zweite vollstăndig neubearbeitete Auflage, Wien 1960.

Kistenkas, F.H.,

Naar een grondrechtelijke evenredigheidstoetsing, Gst. 1991, 6925, p. 377 e.v.

Klap, A.P.,

Vage normen in het bestuursrecht, diss. RUL, Zwolle 1994.

Klap, A.P./Berge, J.B.J.M. ten,

De derde als het stiefkind van het bestuursrecht, in: De derde in het recht, AAe 1997/5, p. 75 e.v.

Kleijn, A./Rijpperda Wierdsma, J.V.,

De rechtsgevolgen van formeel onjuiste of onbevoegd genomen (verrichte) besluiten en handelingen (prae-adviezen VAR), Geschriften van de Vereniging voor Administratief recht, Haarlem 1942.

Knoop, T.,

De Afdeling bestuursrechtspraak gooit het roer om. Het zelfstandig schadebesluit. Hooge Raad, let op uw seack, Gst. 7074, p. 286 e.v.

Kobussen, M.H.,

De vrijheid van de overheid, diss. KUB, Zwolle 1991.

Kobussen, M.H.,

Een privaatrechtelijke legaliteitseis? De wissel(werking) tussen het legaliteitsbeginsel en het ongeschreven recht bij privaatrechtelijk overheidshandelen, NTB 1989/4, p. 97 e.v.

Koch, H.J.,

Unbestimmte Rechtsbegriffe und Ermessenermächtigungen im Verwaltungsrecht. Eine logische und semantische Studie zur Gesetzesbindung der Verwaltung, Frankfurt am Main 1979.

Koekkoek, A.K.,

Grenzen aan grondrechten. Aantekeningen bij het voorstel voor een Algemene wet gelijke behandeling, in: Gelijk behandelen. Commentaren op het voorstel Algemene wet gelijke behandeling (Publicaties van de staatsrechtkring), Zwolle 1991, p. 29 e.v.

Koetser, M.B.,

'Belanghebbende' volgens de rechtsprekende Afdelingen van de Raad van State, preadvies, VARreeks 108, Alphen aan den Rijn 1992. 
Koning, H., Directe democratie in Nederland, diss. RL, Maastricht/Den Haag 1995.

Konijnenbelt, W.,

De administratieve rechter als schadevergoedingsrechter, preadvies voor de vereniging voor burgerlijk recht, Lelystad 1996.

Konijnenbelt, W.,

De assepoester onder de beginselen van behoorlijk bestuur. Over het verbod van machtsafwending, Geschriften van de Vereniging voor Administratief recht XCII (verslag), Alphen aan den Rijn, p. 142 e.v.

Konijnenbelt, W.,

De égalité devant les charges publiques in het Franse administratieve recht, Bestuurswetenschappen $1971 / 5$, p. 265 e.v.

Konijnenbelt, W.,

Eenkleurige belanghebbenden, NTB 1997/8, p. 320 e.v.

Konijnenbelt, W.,

Het specialiteitsbeginsel in het Nederlandse en het Franse administratieve recht, NTB 1994/10, p. 305 e.v.

Konijnenbelt, W,

Rechtsverwerking door het bestuur: het vertrouwensbeginsel in het administratieve recht, Geschriften van de VAR LXXIV, Groningen 1975.

Koopmans' Compendium van het staatsrecht, bew. door Th. L. Bellekom e.a., zevende druk, Zwolle 1994.

Koopmans, T.,

De rol van de wetgever, in: Honderd jaar rechtsleven, Zwolle 1970, p. 221 e.v.

Kortmann, C.A.J.M.,

Constitutioneel recht, geheel herziene derde druk, Deventer 1997.

Kortmann, C.A.J.M.,

De Grondwet en de jurisprudentie inzake het zelfstandig schadebesluit, NJB 1997/29, p. 1327 e.v.

Kortmann, C.A.J.M.,

Het eeuwfeest van Meerenberg, NJB 1974/40, p. 1277 e.v.

Kortmann, C.A.J.M.,

Positivisme, soevereiniteit en recht, NJB 1997/11, p. 482 e.v.

Kortmann, S.C.J.J.,

Vergunning voor onrechtmatig handelen?, in: Goed en trouw (Van der Grinten-bundel), Zwolle 1984, p. 461 e.v.

Kranenburg, R.,

Het Nederlandsch staatsrecht, eerste deel, zesde druk, Haarlem 1947.

Kranenburg/Vegting,

Inleiding in het Nederlands administratiefrecht, Haarlem 1951.

Kreveld, J.H. van,

Beleidsregels in het recht, diss. RUG, Deventer 1983.

Kreveld, van/Scheltema,

Parlementaire geschiedenis van de Wet Arob, Groningen 1976. 


\section{Laferrière,}

Traité de la juridiction administrative et des recours contentieux, tome second, Paris 1888 .

Lambers, $\mathrm{C}$,

De én-loket-gedachte: ofwel het wieltje van de rolstoel, in: In wederkerigheid (Scheltemabundel), Deventer 1997, p. 307 e.v.

Lange, R. de,

Publiekrechtelijke rechtsvinding, diss. UvA, Zwolle 1991.

Lankhorst, G.A.,

De relativiteit van de onrechtmatige daad, diss. RUL, Deventer 1992.

Laubadère, de/Venezia/Gaudemet,

Droit administratif, tome 1, 13e édition, Paris 1994.

Lemasurier, J.,

La preuve dans le détournement de pouvoir, RDP 1959, p. 36 e.v.

Linden, E.C.H.J. van der,

Rechtskracht en de publiekrechtelijke wederkerige rechtsbetrekking, in: Eenzijdig en wederkerig?

(red. E.C.H.J. van der Linden en A.Q.C. Tak), Deventer 1995, p. 191 e.v.

Lubach, D.A.,

Beleidsovereenkomsten. Een onderzoek naar de juridische aspecten van het gebruik van de overeenkomst als beleidsinstrument door de overheid, diss. RUG, Deventer 1986.

Lubach, D.A.,

De verhouding privaat-publiekrecht in het licht van het NBW, Geschriften voor de vereniging voor administratief recht XCIV, Alphen aan den Rijn 1986.

Maanen, G.E. van,

Onrechtmatige daad. Aspekten van de ontwikkeling van een omstreden leerstuk, diss. RUG, Deventer 1986.

Maanen, G.E. van,

Van de vogelen des hemels en de stranden der zee. Publiek domein en andere overheidseigendom, WPNR 6074, p. 970 e.v.

Maarseveen, $H$. van,

Bevoegdheid, in: Algemene begrippen staatsrecht, derde geheel herziene druk, Zwolle 1991, p. 63 e.v.

Maarseveen, H. Th.J.F. van,

Een opmerking over de onrechtmatige overheidsdaad, NJB 1954, p. 914 e.v.

Male, R.M. van,

Beredeneerd besluiten. Plaats, functie en betekenis van het motiveringsbeginsel in het Nederlandse bestuursrecht, NTB 1988/3, p. 73 e.v.

Male, R.M. van,

Enkele aspecten van het begrip belanghebbende in de Algemene wet bestuursrecht, VAR-reeks 108, Alphen aan den Rijn 1992.

Male, R.M. van,

Marionette. Over het afwentelen van nadeelcompensatie bij beschikkingsvoorschrift, in: In de sfeer van administratief recht (Konijnenbelt-bundel), Utrecht 1994, p. 295 e.v.

Male, R.M. van,

Onvoltooid recht. Over rechtsbetrekking, bestuursrecht en bestuursprocesrecht (oratie), Zwolle 1993. 
Male, R.M. van,

Rechter en bestuurswetgeving, diss. KUB, Zwolle 1988.

Mast/Dujardin,

Overzicht van het Belgisch administratief recht, dertiende geheel opnieuw bewerkte en aangevulde uitgave, Brussel 1994.

Maunz/Dürig/Herzog,

Grundgesetz Kommentar (losbladig).

Maurer, $\mathrm{H}$.,

Allgemeines Verwaltungsrecht, 11. Auflage, München 1997.

Mayer, F.,

Das Verfassungsrechtliche Gebot der gesetzlichen ermächtigung, in: Festschrift zum 75. Geburtstag von Hermann Nottarp, Karlsruhe 1961.

Mayer, O.,

Deutsches Verwaltungsrecht, dritte Auflage, erster Band, München/Leipzig, 1924.

Meide, J.H. van der,

Ontwikkeling van de toetsingsnormen in de ambtenarenrechtspraak, NJB 1980/40, p. 1053 e.v.

Messer, E.A./Heldeweg, M.A.,

Bestuurscompensatie en het specialiteitsbeginsel. Een beschouwing over juridische spraakverwarring, rekkelijk versus preciezen en enkele cryptische wetsartikelen, RMTh. 1990/4, p. 147 e.v.

Meulen, B. van der,

De normering van het feitelijk handelen der overheid, NTB 1991/9, p. 267 e.v.

Michiels, F.C.M.A.,

De Arob-beschikking, diss. KUN, Nijmegen 1987.

Moor-van Vugt, A. de,

Commentaar Algemene wet bestuursrecht (losbladig), E 3.2.3.-4/E 3.2.3.-5.

Moor-van Vugt, A. de,

Maten en gewichten. Het evenredigheidsbeginsel in Europees perspectief, diss. KUB, Zwolle 1995.

Mortelmans, K.J.M.,

Gekke koeien: in dubio pro sanitate, AAe 1996/11, p. 712 e.v.

Mulder, A.C.J.,

De theorie van den détournement de pouvoir van den Franschen Conseil d'Etat, diss. UU, Utrecht 1922.

Münch, von/Ehlers,

Verwaltung und Verwaltungsrecht im demokratischen und sozialen Rechtsstaat, in: Allgemeines Verwaltungsrecht, 9. Auflage, Berlin/New York 1992.

Neerhof, A.R.,

Boekbespreking R. de Lange, Publiekrechtelijke rechtsvinding, diss. UvA, Beleidswetenschap 1992/2, p. 186-188.

Neerhof, A.R.,

Het geschil voorbij. Een studie naar de bruikbaarheid van bestuursrechtelijke jurisprudentie als kenbron van recht, diss. RUG, Deventer 1995.

Net, B.J. van der,

Détournement de pouvoir in het vernietigingsrecht. Tot uitsterven gedoemd?, TvO 1976/11, p. 216 e.v. 
Nicolaii, P.,

Beginselen van behoorlijk bestuur, diss. UvA, Deventer 1990.

Nicolaï e.a.,

Bestuursrecht, vijfde herziene druk, Amsterdam 1994.

Nicolaï e.a.,

Bestuursrecht, zesde geheel herziene druk, Amsterdam 1997.

Nicolaï, $P$,

De stiekeme citoyen, in: De Awb-mens: boeman of underdog? (Damen-bundel), Nijmegen 1996, p. 179 e.v.

Nicolaï, P.,

Het tandvlees van het recht, in: Recht op scherp. Beschouwingen over handhaving van publiekrecht (Duk-bundel), Zwolle 1984, p. 3 e.v.

Nicolaï, P.,

Kroniek algemene beginselen van behoorlijk bestuur, NTB 1987/3, p. 91 e.v.

Nicolaï, P.,

Kroniek algemene beginselen van behoorlijk bestuur, NTB 1992/2, p. 56 e.v.

Nicolaii, P.,

Kroniek algemene beginselen van behoorlijk bestuur, NTB 1992/7, p. 234 e.v.

Nicolaï, P.,

Kroniek algemene beginselen van behoorlijk bestuur, NTB 1994/6, p. 179 e.v.

Nicolaï, P.,

Kroniek algemene beginselen van behoorlijk bestuur, 1995/4, p. 95 e.v.

Nieuwenhuis, J.H.,

Op gespannen voet. Een evenwichtstheorie over de betrekkingen tussen het publieke en het burgerlijke recht, NJB 1998/1, p. 9. e.v.

Nieuwenhuis, J.H.,

Vechten met de beer? De strijd om het legaliteitsbeginsel, RMTh. 1997/9, p. 351 e.v.

Nijhof, M.B.,

Boekbespreking. F.J. van Ommeren. De verplichting verankerd: De reikwijdte van het legaliteitsbeginsel en het materiele wetsbegrip, NTB 1997/10, p. 392 e.v.

Nijholt, $H$.,

Op weg naar een bestuursrechtelijke normering van het gemeentelijk aanbestedingsbeleid in de bouw, diss. RL, Maastricht 1996.

Okma, N.,

Misbruik van recht, diss. VU, Wageningen 1945.

Ommeren, F.J. van,

De verplichting verankerd. De reikwijdte van het legaliteitsbeginsel en het materiële wetsbegrip, diss. VU, Deventer 1996.

Ommeren, F.J. van,

Kroniek 'bestuurshandelingen', NTB 1995/5, p. 125 e.v.

Ommeren, F.J. van,

Kroniek 'bestuurshandelingen', NTB 1996/2, p. 70 e.v.

Orde in de regelgeving,

Eindrapport van de commissie wetgevingsvraagstukken (commissie Polak), 's-Gravenhage 1985. 
Otten, F.P.J.M.,

Ruimtelijke ordening en milieubeheer. De bescherming van het leefmilieu via het instrumentarium van de Wet op de Ruimtelijke Ordening, diss. UU, 's-Gravenhage 1980.

Oud, P.J.,

Het constitutioneel recht van het Koninkrijk der Nederlanden II, tweede druk, Zwolle 1970.

Pacteau, B.,

Le juge de l'excès de pouvoir et les motifs de l'acte administratif, Traveaux et recherches de la faculté de droit et science politique de l'université de Clermont I, 1977.

Papier, H-.J.Möller, J.,

Das Bestimmtheitsgebot und seine Durchsetzung, Aor 1997 (122), p. 178 e.v.

Pessers, D.,

Wederkerigheid: het rechtsbeginsel van de informatiesamenleving?, NJB 1996/22, p. 836 e.v.

Peters, J.A.F.,

Bestuursorgaan in de Awb. Kanttekeningen bij een opmerkelijke inhoud, JB 1995/297, p. 1067

e.v.

Peters, J.A.F.,

Publiekrechtelijke rechtspersonen, diss. KUB, Deventer 1997.

Peters, J.A.F.,

Zbo's, verzelfstandiging en privatisering. Een korte beschouwing over de VAR-preadviezen 1997, NTB 1997/4, p. 139 e.v.

Pitlo/Gerver e.a.,

Het systeem van het Nederlandse privaatrecht, elfde druk, Arnhem 1995.

Planque, J.H.W. de,

De mogelijkheden van administratieve rechters en de Kroon om het bestuur tot schadevergoeding te veroordelen, VAR-reeks 102, Alphen aan den Rijn 1989.

Polak, C.H.F.,

Het begrip 'algemeen belang' in de verschillende onderdelen van het administratieve recht, Geschriften van de VAR XIX, Haarlem 1950.

Polak, J.M.,

De Deltawet grote rivieren, NJB 1995/12, p. 453 e.v.

Polak, J.M.,

Het zelfstandig schadebesluit (opinie), NJB 1997/29, p. 1326.

Poortinga, E.,

De scheiding tussen publiek- en privaatrecht bij Johan Rudolph Thorbecke (1798-1872). Theorie en toepassing, diss. UU, Nijmegen 1987.

Pot, C.W. van der,

De vormen van het besturen, in: Nederlandsch bestuursrecht, Alphen aan den Rijn 1932, p. 201 e.v.

Pot, van der/Donner,

Handboek van het Nederlandse staatsrecht, dertiende druk, Zwolle 1995.

Radbruch, G.,

Rechtsphilosophie, funfte Auflage, Stuttgart 1956.

Rapport inzake Algemene Bepalingen van Administratief Recht (ABAR), vijfde geheel herziene druk, Alphen aan den Rijn 1984. 
Ravels, B.P.M. van,

De Afdeling bestuursrechtspraak en het zuiver schadebesluit: geen schoonheidsprijs, NTB 1997/2, p. 55 e.v.

Rivero, J.,

Droit administratif, onzième édition, Paris 1985.

Rolland, L.,

Précis de droit administratif, troisième édition, Paris 1930.

Roos, N.H.M.,

Enige opmerkingen over de grondslagenproblematiek in de rechtsfilosofie van H.J. van Eikema Hommes, R\&R 1980, p. 26 e.v.

Ross, A.,

Directives and norms, London 1968.

Rozemond, K.,

De toekomst van de kritische rechtstheorie (redactioneel), Recht en kritiek 1997/3, p. 197 e.v.

Ruiter, D.W.P., Bestuursrechtelijke wetgevingsleer, Assen/Maastricht 1987.

Ruiter, D.W.P., Normscheppende bepalingen in bestuursrechtelijke wetten, Bestuurswetenschappen 1980/4, p. 260 e.v.

Ruiter, D.W.P,

Organisatorische aspecten van vergunningstelsels, BR 1980, p. 97 e.v.

Scheltema, M.,

Bestuursrecht: Is het bestuur wetgever in eigen zaak?, in: Problemen van wetgeving, Deventer 1982, p. 131 e.v.

Scheltema, M.,

De rechtsstaat, in: De rechtsstaat herdacht (red. J.W.M. Engels e.a.), Zwolle 1989, p. 11 e.v.

Scheltema, M.,

De wondere wereld van het bestuursrecht (afscheidsrede), Deventer 1997.

Scheltema, M.,

Gebondenheid van overheid en burger aan eigen voorafgaand handelen (rechtsverwerking), Geschriften van de vereniging voor administratief recht LXXIV, Groningen 1975.

Scheltema, M.,

Van rechtsbescherming naar een volwaardig bestuursrecht, NJB 1996/33, p. 1355 e.v.

Schendelen, M.C.P.M. van,

Terugtred van de wetgever, Alphen aan den Rijn 1987.

Schipper, W.H.,

De rechterlijke macht en wetgever, Trema 1996/1, p. 4 e.v.

Schlossels, R.J.N.,

Belang als prismabeeld. Over rechtsfeiten, gerichte rechtsvorming en belangenpluriformiteit in het bestuursrecht, in: Spectraal recht? (red. E.C.H.J. van der Linden, R.J.N. Schlossels, R.J.G.H. Seerden), Den Haag 1998, p. 97 e.v.

Schlossels, R.J.N.,

Een dakkapel te Edam: de wens van eenheid van recht?, in: Rechtspraak bestuursrecht. De annotaties 1995-1996, p. 65 e.v. 
Schlossels, R.J.N.,

Het specialiteitsbeginsel en derde-belangen: een frisse benadering of rechtsstatelijk drijfzand?, NTB 1996/3, p. 81 e.v.

Schlossels, R.J.N.,

Hoe hard mag een appelverbod zijn? Enige opmerkingen over de uitsluiting van hoger beroep tegen voorlopige voorzieningen ex art. 8:84 Awb, JB 1997/166, p. 743 e.v.

Schlössels, R.J.N.,

Stek \& Co: een geval van kruisbestuiving? (reactie 3), Gst. 7036, p. 391 e.v.

Schlössels, R.J.N.,

Wederkerigheid en specialiteit in het bestuursrecht, in: Eenzijdig en wederkerig? (red. E.C.H.J. van der Linden en A.Q.C. Tak), Deventer 1995, p. 153 e.v.

Schlössels, R.J.N.,

Wettelijk onrecht en bovenwettelijk recht: een reactie, Anti Nomoi, RegelMaat 1997/2, p. 80 e.v.

Schmidt-Preuß,

Kollidierende Privatinteressen im Verwaltungsrecht. Das subjektive offentliche Recht im multipolaren Verwaltungsrechtsverhältnis, Hab. Univ. Bayreuth, Berlin 1992.

Schmitt Glaeser,

Verwaltungsprozeßrecht, 11. neubearbeitete Auflage, Stuttgart/Munchen/Hannover/Berlin, 1992.

Schokkenbroek, J.G.C.,

Toetsing aan de vrijheidsrechten van het Europees verdrag tot bescherming van de rechten van de mens, diss. RUL, Zwolle 1996.

Schoordijk, H.C.F.,

Bestuursrecht en privaatrecht. Een interne rechtsvergelijking, in: Verspreid werk van prof. mr. H.C.F. Schoordijk, Deventer 1991, p. 463 e.v.

Schoordijk, H.C.F.,

Een vordering uit ongerechtvaardigde verrijking wegens het profiteren door apotheker van intrekking vergunning apotheekhoudend arts, NTBR 1996/10, p. 247 e.v.

Schreuder, C.A.,

Publiekrechtelijke taken, private rechtspersonen, diss. RUG, Deventer 1994.

Schreuder-Vlasblom, M.,

De macht der kritiek, De gedachtenvorming over aard en zin van rechterlijke beoordeling van bestuursoptreden sedert omstreeks 1815, diss. RUG, Zwolle 1987.

Schreuder-Vlasblom, M.,

Heroriëntatie bestuursrechtspraak, VAR-reeks 112, Alphen aan den Rijn 1994.

Schreuder-Vlasblom, M.,

Het nieuwe bestuursprocesrecht, VAR-reeks 113 (Verslag), Alphen aan den Rijn 1995, p. 55 e.v.

Schroot, J.C.,

Van plaatselijke protectie tot bescherming van consumentenbelangen, Gst. 6760, p. 17 e.v.

Schueler, B.J.,

Schadevergoeding onder de algemene wet bestuursrecht, Deventer 1997.

Schueler, B.J.,

Vernietigen en opnieuw voorzien. Over het vernietigen van besluiten en beslechten van geschillen, diss. UU, Zwolle 1994.

Schuiling K.F./Winter H.B.,

De pretenties van de wetgever, Openbaar Bestuur 1992/1, p. 2 e.v. 
Sectie bestuursrecht Rijksuniversiteit Limburg,

Beleidsregels: gebruiksaanwijzing van bestuursbevoegdheid, RegelMaat 1993/2, p. 54 e.v.

Seerden, R.J.G.H.,

De vrijwarende werking van milieuvergunningen, in: Eenzijdig en wederkerig? (red. E.C.H.J. van der Linden en A.Q.C. Tak), Deventer 1995, p. 249 e.v.

Simon, H.J.,

Algemene wet bestuursrecht (reactie), NJB 1987/43, p. 1392.

Simon, H.J.,

Autonomie en 'verbintenis'in het publiekrecht: een intern rechtsvergelijkende analyse, in: Eenzijdig en wederkerig? (red. E.C.H.J. van der Linden en A.Q.C. Tak), Deventer 1995, p. 61 e.v.

Simon, H.J.,

De directe toetsing getoetst, over publieke normen in het privaatrecht, BR 1988, p. 2 e.v.

Simon, H.J.,

De kleine revolutie: Eén jaar besturen onder de Awb I, JB 1995/30, p. 91 e.v.

Simon, H.J.,

Financiële voorwaarden en voorschriften. Een blik vanuit de theorie op de praktijk, NTB 1994/6, p. 149 e.v.

Simon, H.J.,

Handboek bestuurs(proces)recht volgens de Awb, 's-Gravenhage 1997.

Simon, H.J.,

Het 'nieuwe vreemdelingenrecht'. Een analyse vanuit het staats- en bestuursrecht, Sociaal Recht $1994 / 3$, p. 68 e.v.

Simon, H.J.,

Publiekrecht en burgerlijk recht. Het arrest Staat/Kabayel, WPNR 1994/6, p. 753 e.v.

Simon, H.J.,

Publiekrecht of privaatrecht? Een geschiktheidsonderzoek aan de hand van het nutsmaximalisatiebeginsel toegespitst op het gebruik van het privaatrecht door het bestuur, diss. VU, Zwolle 1993.

Simon, H.J./Schlössels, R.J.N.,

Het zelfstandig schadebesluit; nieuwe kansen?, JB 1996/255, p. 1119 e.v.

Simon, H.J./Tak, A.Q.C.,

Het BW als 'Zwart gat'. De onttakeling van het publiekrecht door een 'gemene' rechter, NTBR $1994 / 8$, p. 173 e.v.

Smallenbroek, A.J.H./Aerts, R.J.G.M.,

Coordinatiebepaling in de Algemene wet bestuursrecht, Onderzoek door het Onderzoeks- en Adviesbureau van de Vereniging van Nederlandse Gemeenten (SGBO), Den Haag 1996.

Smits, J.,

De vergissing der XII tafelen. Een enkele gedachte bij het thema van autoriteit en kwaliteit in het burgerlijk recht, Recht en kritiek 1996/4, p. 395.

Smits, J.,

Privaatrecht en postmodernisme. Over recht en tijdsgeest, toegelicht aan de hand van enige civielrechtelijke fenomenen, Recht en kritiek 1997/2, p. 155 e.v.

Soeteman, A.,

Hercules aan het werk. Over de rol van rechtsbeginselen in het recht, In rechtsbeginselen, AAe 1991/10, p. 744 e.v. 
Spill F.W. ter, en A.Q.C. Tak,

Onwetmatig bestuur, Geschriften van de VAR nr. 86, Alphen aan den Rijn 1981.

Steenbeek, J.G.,

Het beroep tegen administratieve beschikkingen, commentaar wet Bab, 's-Gravenhage 1966.

Steenbeek, J.G.,

Rechtshandeling en rechtsgevolg in het staats- en bestuursrecht, diss. UU, Arnhem 1958.

Steenbeek, J.G./Stroink F.A.M.,

Wet administratieve rechtspraak overheidsbeschikkingen, vierde herziene druk, 's-Gravenhage 1988.

Stein, E.,

Staatsrecht, 14. Auflage Tübingen 1993.

Stellinga, J.R.,

Détournement de pouvoir, Bestuurswetenschappen 1952, p. 399 e.v.

Stellinga, J.R.,

Grondtrekken van het Nederlands administratiefrecht, tweede herziene druk, Zwolle 1973.

Stern, K.,

Das Staatsrecht der Bundesrepublik Deutschland, band I, München 1984.

Stout, H.D.,

De betekenissen van de wet. Theoretisch-kritische beschouwingen over het principe van wetmatigheid van bestuur, diss. RUL, Zwolle 1994.

Stout, H.D.,

Doelmatige bestuurlijke belangenafweging: een speciaal terrein, in: De rechtsstaat herdacht (red.

J.W.M. Engels e.a.), Zwolle 1989, p. 237 e.v.

Strien, A.L.J van,

Rechtspersonen en mensenrechten. De gelding van mensenrechten voor rechtspersonen in het strafproces, RMTh. 1996/1, p. 3 e.v.

Stroink, F.A.M.,

Algemeen bestuursrecht. Een inleiding, tweede druk, Zwolle 1996.

Stroink, F.A.M.,

Beginsel van wetmatigheid van bestuur en het begrip uitvoering, Afd. RRvS contra HR?, TvO 1983/9, p. 204 e.v.

Stroink, F.A.M.,

Bevoegdheid Afdeling rechtspraak/bijzondere administratieve rechters/Kroon, TvO 1980/10, p. 218 e.v.

Stroink, F.A.M.,

Boekbespreking J.A.F. Peters Publiekrechtelijke rechtspersonen, NTB 1997/6, p. 239 e.v.

Stroink, F.A.M.,

Boekbeschouwing B.W.N. de Waard, Samenwerkende machten. Wetgeving en rechtspraak in dienst van het recht (oratie), RMTh. 1995/8, p. 373 e.v.

Stroink, F.A.M.,

De Algemene wet bestuursrecht en het sociale zekerheidsrecht, Tijdschrift voor Sociaal Recht, $1989 / 10$, p. 256 e.v.

Stroink, F.A.M.

De schaduwzijden van de algemene wet bestuursrecht, JB 1995/147, p. 546 e.v.

Stroink, F.A.M.,

Het leerstuk der deconcentratie, diss. UU, 's-Gravenhage 1978. 


\section{Stroink, F.A.M.,}

Interventie bij het VAR-preadvies van Tonnaer 'Vergunningverlening in stroomversnelling', Geschriften van de VAR XCII (verslag), Alphen aan den Rijn, p. 150 e.v.

Stroink, F.A.M.,

Kern van de bestuursrechtspraak, 's-Gravenhage 1997.

Stroink, F.A.M., Rechterlijke organisatie en rechtspraak in beweging, Zwolle 1993.

Stroink, F.A.M.,

Reflecties op verschillende bevoegdheden, in: Recht in het water. De juridische aspecten van watersnood, Antwerpen/Apeldoorn 1995.

Stroink, F.A.M./Steenbeek, J.G.,

Inleiding in het staats- en administratief recht, vierde herziene druk, Alphen aan den Rijn 1989.

Stroink, F.A.M./de Waard, B.W.N.,

Het specialiteitsbeginsel, in: Burger en overheid (Steenbeek bundel), 's-Gravenhage 1984, p. 231 e.v.

Stroink/Tak/Teunissen,

Een analyse van één jaar TwK-jurisprudentie, NJB 1989/8, p. 253 e.v.

Struiksma, J.,

Verwant zonder verband. De coördinatie van de bouw- en milieuvergunning, Deventer 1993.

Struycken, A.A.H.,

Administratie of rechter. Beschouwingen over de moderne rechtstaatsgedachte, Arnhem 1910.

Struycken, A.A.H.,

Administratieve rechtspraak in crisiszaken, opgenomen in: Nederlandsch administratief recht, Haarlem 1919, p. 633 e.v.

Tak, A.Q.C.,

Boekbespreking F.J. van Ommeren, De verplichting verankerd. De reikwijdte van het legaliteitsbeginsel en het materiele wetsbegrip RMTh. 1997/6, p. 254 e.v.

Tak, A.Q.C.,

De nieuwe Van Wijk/Konijnenbelt, NTB 1994/6, p. 165 e.v.

Tak, A.Q.C.,

De ongewenste discussie, in: Nieuw bestuursprocesrecht (red. J.B.J.M. ten Berge, F.A.M. Stroink e.a.), Deventer 1992, p. 67 e.v.

Tak, A.Q.C.,

De overheid in het burgerlijk recht, 's-Gravenhage 1997.

Tak, A.Q.C.,

Een volwaardig bestuursrecht (reactie), NTB 1996/9, p. 299 e.v.

Tak, A.Q.C.,

Het moment X, TvO 1990/6, p. 134 e.v.

Tak, A.Q.C.,

Inleiding bundel 'Eenzijdig en wederkerig?' (red. E.C.H.J. van der Linden en A.Q.C. Tak), Deventer 1995, p. 1 e.v.

Tak, A.Q.C.,

Overheid en burgerlijk wetboek. Naar een invullende rechtsleer, Recht en kritiek 1993/2, p. 174 e.v. 
Tak, A.Q.C.,

Overheidsbestuur en privaatrecht, Alphen aan den Rijn 1978.

Tak, A.Q.C.,

Repliek op een reactie. Reactie op B.W.N. de Waard, Niet terecht opmerkelijk, NTB 1994/7, p. 202.

Tak, A.Q.C.,

Terugtocht van twee wegen, NTB 1989/9/10, p. 297 e.v.

Tak, A.Q.C./Bakker, R.E.,

De centrale rol van het willekeurverbod bij de toetsing van overheidshandelen, in: Publiekrechtelijke bewegingen (red. Heringa/Verheij), Deventer 1990, p. 205 e.v.

Tak, A.Q.C./Teunissen, J.M.H.F.,

Wie zorgt er voor de rechtsstaat? Een voortgezet debat, Recht en kritiek 1994/4, p. 340 e.v.

Teulings, J.H.A.,

Boekbespreking A. van Hall, Het specialiteitsbeginsel in het waterstaatsrecht (oratie), RMTh. $1997 / 3$, p. 116 e.v.

Teunissen, J.M.H.F,

Afrekening met de gemene rechtsleer en de tweewegenleer (1), Gst. 7048, p. 85 e.v.

Teunissen, J.M.H.F.,

Het burgerlijk kleed van de staat. Beschouwingen over de tweewegenleer, diss. RL, Zwolle 1996.

Teunissen, J.M.H.F./Tak, A.Q.C.,

Recht ist was der Umwelt nutzt? Over zorgplichtbepalingen, civiele acties en tweewegenleer. Een overdenking n.a.v. de opneming van een zorgplichtbepaling in de Wet milieubeheer, NJB $1994 / 18$, p. 605 e.v.

Teunissen, J.M.H.F.,

Schadevergoeding wegens relatief onrechtmatige overheidsdaad, NJB 1994/5, p. 163 e.v.

Teunissen, J.M.H.F.,

Strategisch concept voor nivellerende rechtswetenschap?, in: Eenzijdig en wederkerig? (red.

E.C.H.J. van der Linden en A.Q.C. Tak), Deventer 1995, p. 277 e.v.

Thorbecke, J.R.,

Aanteekening op de Grondwet, tweede uitgave, eerste deel, 's-Gravenhage 1906.

Thorbecke, J.R.,

Bijdrage tot herziening van de Grondwet, 1848 , tweede druk 1948.

Tieman, J.R.C.,

Wederkerige rechtsbetrekking en bestuursdwang, NTB 1997/6, p. 226 e.v.

Timmermans, C.W.A.,

De administratieve rechter en beoordelingsvrijheden van bestuursorganen, diss. RUL, Leuven 1973.

Tjittes, R.P.J.L.,

Herbezinning op de grondslagen van de overheidsaansprakelijkheid, Preadvies voor de vereniging voor burgerlijk recht, Lelystad 1996.

Tjittes, R.P.J.L./Mok, M.R.,

Formele rechtskracht en overheidsaansprakelijkheid, RMTh. $1995 / 9$, p. 383 e.v.

Tonnaer, F.P.C.L.,

Legaal besturen; het legaliteitsbeginsel toetssteen of struikelblok?, in: Bestuur en norm (Crince Le

Roy-bundel), Deventer 1986, p. 265 e.v. 
Tonnaer, F.P.C.L.,

Wikken en beschikken. Een onderzoek naar verbeteringsmogelijkheden in de samenhang van de besluitvorming, in het bijzonder op het terrein van het ruimtelijk bestuursrecht, diss. UU, Zwolle 1982.

Tonnaer, F.P.C.L./Kooij Chr., Vergunningverlening in stroomversnelling, preadvies VAR, Geschriften van de vereniging voor administratief recht XCII, Alphen aan den Rijn 1984.

Vakgroep publiekrecht Rijksuniversiteit Utrecht 1987, Algemene wet bestuursrecht, NJB 1987/28, p. 877 e.v.

Veen, G.A. van der, Openbare zaken. Betekenis van het aloude publiek domein na vestiging van het primaat van het publiekrecht, diss. UU, Deventer 1997.

Veen, G.A. van der, Primaat van het publiekrecht en grondrechtelijke beperkingen op de contractsvrijheid, NTBR $1996 / 8$, p. 197 e.v.

Vegting, W.G.,

Het algemeen Nederlands administratief recht, eerste deel, Alphen aan den Rijn 1954.

Vergunningen,

Rapport Algemene Rekenkamer (TK 1995-1996, 24656, nrs. 1-2).

Verheij, N.,

De lijn. Alleen de wet heerscht over ons. Over wetmatigheid van bestuur I, Publiek Domein, p. 188 e.v.

Verheij, N.,

De lijn. Deuken in het ideaal. Over wetmatigheid van bestuur II, Publiek Domein 1989, p. 237 e.v.

Verheij, N.,

Onrechtmatige overheidsdaad en beginselen van behoorlijk bestuur: de Hoge Raad toetst eindelijk rechtstreeks, NJB 1987/41, p. 1309 e.v.

Verheij, N.,

Publiekrecht en privaatrecht in Engeland: singin' the continental blues, NTB 1990/1, p. 1 e.v.

Vermeulen, B.P.,

Algemene beperkingen, redelijke uitleg en redelijke toepassing van grondrechten, RegelMaat 1990/4, p. 78 e.v.

Versnelling juridische procedures grote projecten (door: Lambers, Lubach, Scheltema), Voorstudies en achtergronden, 1994/v85, Wetenschappelijke Raad voor het Regeringsbeleid, Den Haag 1994.

Vidal, R.,

L'évolution du détournement de pouvoir dans la jurisprudence administrative, RDP 1952, p. 275 e.v.

Viering, M.L.W.M.,

Het toepassingsgebied van artikel 6 EVRM, diss. UU, Zwolle 1994.

Vlemminx, F.M.C.,

Bestuurscompensatie en grondrechten, NTB 1994/7, p. 193 e.v.

Vlies, I.C. van der,

Handboek wetgeving, tweede herziene druk, Zwolle 1991. 
Vlies, I.C. van der,

Het legaliteitsbeginsel en de kwaliteit van de wetgeving, Bestuur 1989/3, p. 67 e.v.

Vlies, I.C. van der,

Het wetsbegrip en de beginselen van behoorlijke regelgeving, diss. UvA, 's-Gravenhage 1984.

Vlies, I.C., van der,

Zelfstandige schadebesluiten, AAe 1997/9, p. 602 e.v.

Vos, A.T.,

Overheidsvergunning en onrechtmatige daad, in: Op de grenzen van komend recht (Beekhuisbundel), Deventer/Zwolle 1969, p. 297 e.v.

Vucsán, R.L.,

Het kind van de rekening: nadeelcompensatie en de afwenteling in de algemene wet bestuursrecht, in: In wederkerigheid (Scheltema-bundel, Deventer 1997, p. 295 e.v.

Waaldijk, K.,

Motiveringsplichten van de wetgever, diss. RL, Lelystad 1994.

Waard, B.W.N. de,

Beginselen van behoorlijke rechtspleging, met name in het administratief procesrecht, diss. UU, Zwolle 1987.

Waard, B.W.N. de,

Niet terecht opmerkelijk. Reactie op A.Q.C. Tak, De nieuwe Van Wijk/Konijnenbelt, NTB 1994/7, p. 201 e.v.

Waard, B.W.N. de,

Samenwerkende machten. Wetgeving en rechtspraak in dienst van het recht, oratie KUB, Zwolle 1994.

Waard, B.W.N. de,

Wie van de drie? Toerekening van onderzoekskosten naar mogelijke schade als gevolg van een ontheffing, in: Het actuele recht, Lelystad 1993, p. 239 e.v.

Waline, M.,

Droit administratif, 8e édition, Paris 1959.

Walzer, M.,

Spheres of justice. A defense of pluralism and equality, New York 1983.

Weesing, G.H.L.,

Beoordelingsvrijheid en beleidsvrijheid: gegeven of te laten vrijheden?, in: In de sfeer van administratief recht (Konijnenbelt-bundel), Utrecht 1994, p. 429 e.v.

Wiarda, G.J.,

Algemene beginselen van behoorlijk bestuur (preadvies VAR), Geschriften van de Vereniging voor Administratief Recht XXIV, Haarlem 1952.

Widdershoven, R.J.G.M.,

Naar een bestuurs(proces)rechtelijk Ius Commune in Europa, VAR-reeks 116, p. 97 e.v.

Willemse, J.A.C.J.M.,

Hoe kan, in het licht van het specialiteitsbeginsel, bij een samenloop van wettelijke regelingen gekomen worden tot een inhoudelijk gecoördineerd bestuurlijk optreden?, doctoraalscriptie KUB, Dongen 1997.

Winkelmann, R.,

Die Rechtssprechung des Bundesverfassungsgerichtes zu Art. 80 Grundgesetz, NJW 1959, p. 961 e.v. 
Winckelmann, J.,

Legitimităt und Legalităt in Max Webers Herrschaftssoziologie, Tubingen 1952.

Winter, R.E. de,

Oud zeer, in: Azen op tegenslag, Lelystad 1994, p. 14 e.v.

Wijk, H.D. van,

Détournement de pouvoir ou d'eau seulement?, opgenomen in: Besturen met recht, 's-Gravenhage 1974 , p. 171 e.v.

Wijk, H.D. van,

Hoofdstukken van administratief recht, 's-Gravenhage 1968.

Wijk, H.D. van,

Hoofdstukken van administratief recht, 's-Gravenhage 1976.

Wijk, H.D. van,

Voortgaande terugtred (1959), opgenomen in: Besturen met recht, 's-Gravenhage 1974, p. 99 e.v.

Wijk, van/Konijnenbelt/van Male,

Hoofdstukken van administratief recht, negende druk, Utrecht 1994.

Wijk, van/Konijnenbelt/van Male,

Hoofdstukken van administratief recht, tiende geheel herziene druk, 's-Gravenhage 1997.

Wijmen, P.C.E. van,

Recht, belang en rechtsbescherming. Actie en belang, forum en toetsingsgrond; een dwarsdoorsnede van de rechtsbescherming tegen overheidsbestuur, diss. UU, 's-Gravenhage 1981.

Zippelius, R.,

Legitimation im demokratischen Verfassungsstaat, in: Legitimation des modernen Staates, Wiesbaden 1981.

Zwemstra, S.,

Bescherming van uitingsrechten door administratieve rechters, diss. KUB, Zwolle 1992. 


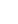




\section{Jurisprudentie}

\section{Europees Hof voor de Rechten van de Mens}

EHRM 26 april 1979, Series A, Vol. 30; NJ 1980, 146, m.nt. EAA

EHRM 25 maart 1983, Series A, Vol. 61

EHRM 2 augustus 1984, Series A, Vol. 82

EHRM 23 oktober 1985,

Series A, Vol. 97; NJ 1986, 102; AB 1986, 1, m.nt. E.M.H. Hirsch Ballin

46,375

EHRM 29 mei 1986, Series A, Vol. 99

376

EHRM 7 juli 1989, Series A, Vol. 159

EHRM 24 april 1990, Series A, Vol. 176; NJ 1991, 523, m.nt. EJD

124

EHRM 28 juni 1990, Series A, Vol. 180 A

EHRM 27 november 1991, Series A, Vol. 219

EHRM 25 februari 1993, Series A, Vol. 256

EHRM 26 februari 1993, Series A, Vol. 99

EHRM 24 juni 1993, Series A, Vol. 257-E

EHRM 21 september 1993, Series A, Vol. 268 A

EHRM 25 november 1993, Series A, Vol. 279

EHRM 25 november 1994, Series A, Vol. 295 B

EHRM 9 december 1994, Series A, Vol. 304

EHRM 28 september 1995, Series A, Vol. 326

\section{Hof van Justitie EG}

HvJ 20 september 1988, Jur. 1988, 4635

\section{Hoge Raad}

HR 13 januari 1879 , W4330

HR 10 juni 1919 , NJ 1919, p. 650

HR 12 januari 1923, NJ 1923, p. 307

HR 25 januari 1926, NJ 1926, p. 246, m.nt. L. Besier

HR 14 januari 1949, NJ 1949, 557

HR 4 maart 1952, NJ 1952, 365, m.nt. B.V.A.R.

HR 8 mei 1953, NJ 1953, 614

HR 7 mei 1957, NJ 1957, 516

HR 17 januari 1958, NJ 1961, 568

HR 26 november 1957, NJ 1958, 53

HR 30 oktober 1959, NJ 1961, 574

HR 13 april 1960, NJ 1960, 436

HR 24 oktober 1961, NJ 1962, 86 
HR 14 juni 1963, NJ 1965, 82, m.nt. J.H.B.

289,335

HR 26 juni 1964, AB 1965 p. 647 e.v.

30,345

HR 10 maart 1972, NJ 1972, 278, m.nt. G.J.S.

331,334

HR 22 juni 1973, NJ 1973, 386, m.nt. A.R.B.

94,110

HR 21 juni 1974, NJ 1974, 439

HR 26 maart 1976, NJ 1976, 375, m.nt. Prins

HR 9 april 1976, NJ 1976, 394, m.nt. W.F.P., AB 1976, 162, m.nt. J.R.St.

HR 11 januari 1977, NJ 1977, 467

HR 22 februari 1977, NJ 1977, 288, m.nt. Th. W. van Veen

51

HR 19 mei 1978, NJ 1979, 545

HR 9 januari 1981, NJ 1981, 227, m.nt. C.J.H.B.

HR 17 september 1982, NJ 1983, 278 m.nt. MS

HR 6 mei 1983, AB 1984, 101, m.nt. H.K. Fernandes Mendes en FHvdB

160

HR 1 juli 1983, AB 1984, 103, m.nt. FHvdB, NJ 1984, 360, m.nt. MS

160,325

HR 10 april 1984, NJ 1984, 612, m.nt. 't $\mathrm{H}$

160,325

HR 28 juni 1985, NJ 1986, 356, m.nt. MS

332,358

HR 9 mei 1984, NJ 1985, 227, m.nt. J.P. Scheltens

160

HR 16 mei 1986, AB 1986, 573, m.nt. FHvdB

366

HR 16 mei 1986, AB 1986, 574, m.nt. PvB en MS; NJ 1987, 251

186,325

HR 27 juni 1986, NJ 1987, 726, m.nt. MS

186

HR 27 juni 1986, NJ 1987, 898, m.nt. MS

HR 27 juni 1986, AB 1987, 241, m.nt. FHvdB

94

HR 27 juni 1986, NJ 1987, 743

HR 14 oktober 1986, NJ 1988, 511, m.nt. Th. W. van Veen

HR 27 maart 1987, NJ 1987, 727, m.nt. MS; AB 1987, 273 m.nt. FHvdB

HR 19 juni 1987, NJ 1988, 91

HR 23 september 1988, NJ 1989, 743

HR 14 april 1989, AB 1989, 207, m.nt. FHvdB

HR 26 januari 1990, AB 1990, 408, m.nt. G.P. Kleijn

HR 2 februari 1990, AB 1990, 223, m.nt. G.P. Kleijn

HR 9 juli 1990, AB 1990, 547, m.nt. G.P. Kleijn

HR 18 januari 1991, AB 1991, 241 m.nt. FHvdB; NJ 1992, 638, m.nt. C.J.H. Brunner 186, 387

HR 8 juli 1991, AB 1991, 659, m.nt. FHvdB

HR 24 april 1992, NJ 1993, 323, m.nt. MS; AB 1992, 542

HR 11 december 1992, NJ 1993, 301

HR 18 december 1992,

NJ 1994, 139, m.nt. MS en CJHB; Gst. 6970, 5; AB 1994, 396 2, 5, 60, 132, 192, 331, 339

HR 8 oktober 1993, AB 1994, 299, m.nt. FHvdB

HR 22 oktober 1993, AB 1994, 1, m.nt. G.A. van der Veen

HR 26 november 1993, NJ 1995, 322, m.nt. CJHB

HR 18 februari 1994, AB 1994, 415 m.nt. G.A. van der Veen

HR 20 mei 1994, NJ 1995, 691, m.nt. CJHB

$38,72,363$

HR 21 oktober 1994, NJ 1996, 231, m.nt. MS

HR 2 december 1994, NJ 1996, 246

HR 8 september 1995, JB 1995/249 
HR 16 februari 1996, JB 1996/87, m.nt. HJS/RJNS

HR 15 maart 1996, JB 1996/120, m.nt. HJS/RJNS

HR 26 april 1996, JB 1996, 159, m.nt. HJS

HR 17 januari 1997, RvdW 1997/24C

HR 16 mei 1997, JB 1997/148, m.nt. HJS

\section{Gerechtshof}

Gerechtshof Arnhem 21 april 1976, NJ 1977, 77

\section{Arrondissementsrechtbank}

Rb. Amsterdam, 15 maart 1990, AB 1991, 58

$216,219,224,231$

Rb. Roermond 18 april 1995, JB 1995/135

Rb. Maastricht 21 april 1995, JB 1995/116, m.nt. F.A.M.S.

Rb. 's-Hertogenbosch 6 juli 1995, JB 1995/319

Rb. 's-Gravenhage 21 augustus 1995, JB 1996/89

Rb. Roermond 6 februari 1996, JB 1996/70

Rb. Utrecht 12 april 1996, JB 1996/150

Rb. Maastricht 14 augustus 1996, JB 1996/196, m.nt. R.J.N.S.

Rb. Amsterdam 2 oktober 1996, JB 1996/263, m.nt. R.J.N.S.

Rb. Roermond 27 september 1996, JB 1996/225, m.nt. R.J.N.S. $317,383,388$

Rb. Almelo 1 oktober 1996, AB 1997, 69, m.nt. AvH

Rb. Amsterdam 2 oktober 1996, JB 1996/263

Rb. Amsterdam 28 januari 1997, JB 1997/61

\section{President Arrondissementsrechtbank}

Pres. Rb. Amsterdam 13 april 1994

Pres. Rb. Almelo 21 april 1994, Awb-katern (AB), 75

Pres. Rb. Maastricht 13 mei 1994,

Gst. 7002, 5, m.nt. B, RAwb 1995, 17, m.a. G.A. van der Veen

Pres. Rb. Almelo 2 augustus 1994, JB 1994/230, m.nt. F.A.M.S.

Pres. Rb. Maastricht 24 februari 1955, JB 1995/111, m.nt. R. Schlossels 42, 200, 253, 307, 343

Pres. Rb. Breda 26 april 1995, JB 1995/168, m.nt. R. Schlössels

Pres. Rb. 's-Gravenhage 8 december 1995, JB 1996/5

Pres. Rb. Zutphen 22 december 1995, JB 1996/65 m.nt. R.J.N.S./HJS

Pres. Rb. Assen 29 februari 1996, JB 1996/129

Pres. Rb. Zutphen 12 september 1996, JB 1996/238

Pres. Rb. Assen 17 oktober 1996, JB 1996/252

Pres. Rb. 's-Hertogenbosch 5 december 1996, Awb-katern 1997, 64

Pres. Rb. Utrecht 9 oktober 1997, JB 1997/287

Afdeling rechtspraak van de Raad van State

ARRS 27 november 1976, AB 1979, 70 
ARRS 30 juni 1977, AB 1977, 392, m.nt. G.J.M. Cartigny

ARRS 22 juli 1977, $A B$ 1977, 420 m.nt. v.d.V.

$86,203,277$

ARRS 12 augustus 1977, $A B$ 1978, 6, m.nt. v.d.V.

ARRS 1 september 1977, AB 1977, 366, m.nt. van der Veen 294

ARRS 21 oktober 1977, BR 1978, p. 118

ARRS 1 december 1977, AB 1978, 208, m.nt. M. Scheltema

ARRS 9 februari 1978, AB 1978, 478, m.nt. v.d.V.

ARRS 7 augustus 1978, BR 1978, p. 757

ARRS 27 november 1978, AB 1979, 476, m.nt. v.d.V.

274,278

ARRS 27 januari 1979, AB 1980, 81

ARRS 5 juni 1979, tB/S III, nr. 126, m.a. tB/S

ARRS 20 augustus 1979, AB 1980, 298, m.nt. v.d.V., tB/S III, nr. 136, m.a. tB/S

ARRS 13 oktober 1979, AB 1980, 466

ARRS 27 november 1979, tB/S IV, nr. 42 m.a. J.S. en tB/S

196,280

ARRS 13 december 1979, AB 1980, 368, m.nt. CLR

271

ARRS 25 maart 1980, AB 1980, 585

ARRS 1 april 1980, tB/S III, nr. 179, m.a. tB/S

ARRS 18 april 1980, AB 1981, 86, m.nt. v.d.V

ARRS 12 juni 1980, tB/S III, nr. 197, m.a. J.S.

ARRS 20 juni 1980, AB 1980, 567

ARRS 15 augustus 1980, Gst. 6652, 5, m.n. J.M.K.

271

ARRS 8 mei 1981, AB 1981, 524, m.nt. v.d.V.

ARRS 8 mei 1981, AB 1981, 391, m.nt. Borman

294

ARRS 13 juli 1981, tB/S III, nr. 275, m.a. tB/S

ARRS 8 september 1981, tB/S III, nr. 293, m.a. tB/S

ARRS 17 november 1981, $A B$ 1982, 107, m.nt. v.d.V.

ARRS 15 december 1981, AB 1982, 298

ARRS 12 januari 1982, AB 1982, 299 m.nt. P.C.E. van Wijmen

ARRS 1 februari 1982, Gst. 1982, 6725, 3

$233,235,287,319$

ARRS 11 februari 1982, AB 1983, 317, m.nt. JHvdV

ARRS 22 februari 1982, tB/S III, nr. 329, m.a. M.C.B.

ARRS 23 april 1982, AB 1982, 460, m.nt. CLR

ARRS 9 september 1982, AB 1983, 269, m.nt. P.C.E. van Wijmen

ARRS 8 maart 1983, tB/S III, nr. 423, m.a. BdeW

277

ARRS 22 april 1983, AB 1984, 212, m.nt CLR

ARRS 24 mei 1983, tB/S III, nr. 443, m.a. tB/S

ARRS 20 juni 1983, AB 1984, 75, m.nt. JHvdV

ARRS 25 juli 1983, tB/S III, nr. 459, m.a. tB/S

ARRS 5 augustus 1983, tB/S III, nr. 466, m.a. tB/S

ARRS 13 oktober 1983, AB 1984, 30, m.nt. CLR

ARRS 4 november 1983, AB 1984, 64

ARRS 22 november 1983, AB 1984, 154, m.nt. J.H.W. de Planque 287

ARRS 8 december 1983, AB 1984, 146, m.nt. CLR 286

ARRS 20 januari 1984, AB 1984, 193, m.nt. CLR 277

ARRS 24 januari 1984, AB 1984, 239, m.nt. CLR 50

ARRS 9 februari 1984, AB 1984, 514, m.nt. JHvdV 275 
ARRS 21 februari 1984, AB 1984, 300, m.nt. CLR

ARRS 9 maart 1984, AB 1984, 351, m.nt. CLR

ARRS 14 mei 1984, AB 1985, 220, m.nt. JHvdV

ARRS 2 juli 1984, AB 1985, 273, m.nt. R. Fernhout en J.A. Hofman

ARRS 21 augustus 1984, AB 1984, 542, m.nt. P.C.E. van Wijmen

ARRS 27 september 1984, Gst. 6778, 7, m.n. J.M.K.

$286,289,312$

ARRS 10 januari 1985, AB 1985, 501, m.nt. JHvdV

282

160

ARRS 31 januari 1985, AB 1986, 280, m.nt. JHvdV

ARRS 21 maart 1985, AB 1986, 319, m.nt. JHvdV

285

ARRS 22 maart 1985, AB 1985, 471

ARRS 18 juni 1985, AB 1986, 543, m.nt. JHvdV

ARRS 27 augustus 1985, AB 1987, 74, m.nt. JHvdV

ARRS 30 augustus 1985, AB 1986, 243, m.nt. D.A. Lubach

238,294

ARRS 4 oktober 1985, AB 1986, 242, m.nt. D.A. Lubach

294

ARRS 29 oktober 1985, AB 1986, 515, m.nt. JHvdV

275

ARRS 15 november 1985, AB 1986, 321, m.nt. PvB

281

ARRS 18 november 1985, tB/S III, nr. 660, m.a. F.A.M.S.

278

ARRS 18 november 1985 , tB/S III, nr. 661, m.a. tB

292

ARRS 6 januari 1986, AB 1986, 230

274

ARRS 10 januari 1986, tB/S, 1986, nr. 5, m.a. BdeW

292

ARRS 18 maart 1986, AB 1987, 91, m.nt. JHvdV

ARRS 10 april 1986, tB/S, 1986, nr. 75 m.a. BdeW

ARRS 5 mei 1986, AB 1986, 544, m.nt. JHrdV

ARRS 2 december 1986, AB 1988, 67, m.nt. PvB

293

ARRS 22 december 1986, AB 1987, 395, m.nt. JHvdV

273,274

ARRS 30 december 1986, AB 1988, 34

284

ARRS 7 mei 1987, tB/S, 1987, nr. 73 m.a. F.A.M.S.

276

ARRS 14 mei 1987, AB 1989, 4, m.nt. L. Bomhof

292

ARRS 22 juni 1987, $A B$ 1988, 103

285

ARRS 10 juli 1987, AB 1988, 68, m.nt. JHvdV

285

ARRS 26 augustus 1987, $A B$ 1988, 263

273

ARRS 8 december 1987, AB 1988, 398, m.nt. JHvdV

271

271

ARRS 14 december 1987, $\mathrm{AB}$ 1988, 441

276

ARRS 15 december 1987, Gst. 6855, 6, m.n. L.J.A. Damen

139, 160, 276

ARRS 22 december 1987, AB 1988, 489, m.nt. PvB

ARRS 23 januari 1988, AB 1989, 101

ARRS 4 maart 1988, AB 1988, 416, m.nt. JHvV

274, 277, 293

277

271

ARRS 31 maart 1988, AB 1989, 6, m.nt. JHvdV

294

ARRS 10 augustus 1988, AB 1988, 541, m.nt. PvB

273

278

ARRS 6 december 1988, AB 1989, 140, m.nt. JHvdV

272

ARRS 8 februari 1989, AB 1990, 152, m.nt. P.C.E. van Wijmen

ARRS 22 april 1989, Gst. 6887, p. 447

271

ARRS 27 april 1989, AB 1990, 216

$255,271,277$

ARRS 8 augustus 1989, AB 1991, 142 
ARRS 3 april 1991, AB 1992, 140

ARRS 13 mei 1991, AB 1992, 110

ARRS 3 juni 1991, AB 1992, 264

ARRS 5 juni 1991, AB 1992, 444, m.nt. H.J. Simon

ARRS 24 juni 1991, AB 1992, 25, m.nt. JHvdV

ARRS 24 juni 1991, tB/S 1991, nr. 86, m.a. BdeW

ARRS 24 juli 1991, tB/S, 1991, nr. 103, m.a. BdeW

ARRS 8 juli 1992, AB 1993, 248, m.nt. C. Riezebos

ARRS 24 september 1992, AB 1993, 61, m.nt. RMvM

ARRS 21 december 1992, AB 1993, 287

\section{Voorzitter Afdeling rechtspraak van de Raad van State}

VzARRS 14 september 1977, AB 1978, 166, m.nt. v.d.V.

VzARRS 19 maart 1981, AB 1982, 411

VzARRS 29 december 1982, AB 1983, 305, m.nt. CLR

VZARRS 3 november 1983, AB 1985, 65

VZARRS 29 mei 1984, AB 1985, 66 
VzARRS 2 juli 1990, AB 1991, 278, m.nt. H.J. Simon en H. Gieske

VzARRS 17 augustus 1990, AB 1991, 44

VzARRS 30 augustus 1990, AB 1991, 567, m.nt. H.J. Simon

$126,216,292$

VzARRS 19 oktober 1990, 79, m.nt. PvB

VzARRS 6 mei 1991, AB 1992, 414, m.nt. H.J. Simon

VzARRS 31 mei 1991, AB 1992, 17, m.nt. JHvdV

VzARRS 8 augustus 1991, AB 1992, 354, m.nt. R. Kluin

VzARRS 17 januari 1992, tB/S 1992, nr. 9

VzARRS 19 juli 1992, tB/S, nr 78, m.a. G.H.A.

VzARRS 21 augustus 1992, AB 1993, 103

280

VzARRS 21 augustus 1992, AB 1993, 149

283

VzARRS 27 augustus 1992, AB 1993, 34

VZARRS 29 oktober 1992, AB 1993, 183, m.nt. RMvM 319

VZARRS 18 mei 1993, Gst. 6971, p. 431

VzARRS 28 juni 1993, AB 1994, 422

VzARRS 2 juli 1993, AB 1994, 206, m.nt. RMvM

283

VzARRS 22 juli 1993, AB 1994, 136

274

VzARRS 26 augustus 1993, AB 1994, 199, m.nt. van Male

VzARRS 10 september 1993, AB 1994, 250

VzARRS 18 oktober 1993, Gst. 7002, p. 41, m.n. B.

VzARRS 19 november 1993, Gst. 6990, 4, m.n. HH

\section{Afdeling geschillen van bestuur van de Raad van State}

AGRS 28 mei 1991, AB 1991, 691 m.nt. JJIV

AGRS 31 oktober 1988, AB 1989, 54

AGRS 21 februari 1989, AB 1989, 181

AGRS 8 maart 1989, AB 1989, 197, m.nt. PJS 296

AGRS 18 mei 1989, AB 1989, 323, m.nt. PJS

AGRS 20 juli 1989, AB 1989, 433

AGRS 15 november 1989, AB 1990, 323, m.nt. JJIV

AGRS 21 november 1989, AB 1990, 96

AGRS 19 december 1990, AB 1991, 362, m.nt. JJIV

AGRS 9 oktober 1990, AB 1991, 49, m.nt. PJS

AGRS 16 oktober 1990, AB 1991, 92, m.nt. PJS

AGRS 9 november 1990, AB 1992, 92

AGRS 14 november 1990, AB 1991, 231

AGRS 10 januari 1991, AB 1991, 180, m.nt. PJS

AGRS 31 januari 1991, AB 1991, 234 m.nt. PJS 
AGRS 11 september 1991, AB 1991, 654

AGRS 12 september 1991, AB 1991, 653, m.nt. PJS

AGRS 7 oktober 1991, AB 1992, 410, m.nt. JJIV

AGRS 28 november 1991, AB 1992, 142, m.nt. PJS

AGRS 28 februari 1992, AB 1993, 598, m.nt. ThGD

AGRS 16 maart 1992, AB 1992, 306, m.nt. PJS

AGRS 8 april 1993, Gst. 6988, p. 272, m.n. HH

AGRS 24 mei 1993, Wb 1993, p. 574, m.a. I. Poortvliet 297

AGRS 9 september 1993, AB 1994, 521

AGRS 14 januari 1994, Gst. 6995, p. 490, m.n. R. Uylenburg

Voorzitter Afdeling geschillen van bestuur van de Raad van State

VzAGRS 7 augustus 1990, AB 1991, 626, m.nt. ThGD

VzAGRS 1 maart 1991, AB 1991, 558

VzAGRS 12 september 1991, AB 1992, 350

297

VzAGRS 6 februari 1992, AB 1992, 674, m.nt. JJIV

302

VzAGRS 22 september 1992, AB 1993, 8

Afdeling bestuursrechtspraak van de Raad van State

ABRS 12 januari 1994, Gst. 6986, p. 220 e.v., m.n. C.J.P. Goorden

ABRS 25 april 1994, AB 1994, 579

ABRS 29 april 1994, ABkort, 524

310

ABRS 17 mei 1994, ABkort 1994, 526

304

ABRS 27 mei 1994, AB 1994, 451, m.nt. PJS

307

ABRS 2 juni 1994, AB 1994, 648, m.nt. PvB

307

ABRS 3 juni 1994, AB 1994, 602, m.nt. RMvM

138,308

ABRS 9 juni 1994, AB 1994, 664

308

ABRS 4 juli 1994, Gst. 6997, p. 543 e.v.

320

ABRS 29 juli 1994, ABkort 1994, 737

302

ABRS 12 augustus 1994, AB 1994, 607, m.nt. RMvM

ABRS 23 augustus 1994, AB 1994, 592

ABRS 6 september 1994, Gst. 7003, p. 73 e.v., m.n. HH

134,308

ABRS 7 oktober 1994, AB 1995, 12

23

381

ABRS 27 oktober 1994, Gst. 7005, 5

ABRS 1 november 1994, AB 1995, 437, m.nt. E. Steyger

ABRS 16 december 1994, AB 1995, 305, m.nt. AvH

ABRS 3 januari 1995, ABkort 1995, 36

ABRS 1 februari 1995, Gst. 7013, p. 393 e.v., m.nt. C.P.J. Goorden

ABRS 10 april 1995, AB 1995, 498, m.nt. G.A. van der Veen

$52,53,54$

ABRS 18 april 1995, ABkort 1995, 343

320

304

ABRS 2 mei 1995, Gst. 7017, p. 503 e.v., m.n. B.

ABRS 10 mei 1995, RAwb 1995, nr. 72, m.a. BdeW

ABRS 14 juni 1995, AB 1996, 3, m.nt. ChB

$45,213,290,318,364$

ABRS 16 juni 1995, Gst. 7035, p. 361, e.v., m.n. B. 
ABRS 26 juni 1995, NA 1995, 235

ABRS 11 september 1995, AB 1995, 532, m.nt. AvH

ABRS 26 oktober 1995, JB 1996/13

ABRS 30 november 1995, JB 1995/337, m.nt. F.A.M.S.

16,53

ABRS 30 november 1995, AB 1996, 23, m.nt. AvH

ABRS 7 december 1995, AB 1996, 64, m.nt. AvH

ABRS 14 december 1995, AB 1996, 86

ABRS 5 januari 1996, Gst. 7041, p. 562 e.v.; ABkort 1996, 116

305

ABRS 5 januari 1996, AB 1996, 97, m.nt. AvH

311

ABRS 5 januari 1996, AB 1996, 179, m.nt. J.A. Hofman

381,382

320

313

ABRS 6 februari 1996, AB 1996, 131, m.nt. AvH

306,343

ABRS 9 februari 1996, JB 1996/82, m.nt. R. Schlossels

ABRS 29 februari 1996, Gst. 7041, p. 571 e.v., m.nt. C.J.P. Goorden

320

ABRS 1 maart 1996, AB 1996, 359, m.nt. FM

ABRS 14 maart 1996, BR 1996/11, p. 906 e.v., m.nt. H.J. de Vries

ABRS 1 april 1996, BR 1996, 11, p. 912; JB 1996/155 m.nt. R.J.N.S.

ABRS 11 april 1996, AB 1996, 286, m.nt. AvH

343

313

269

ABRS 16 april 1996, BR 1996/10, p. 815 e.v. m.nt. H.J. de Vries

307

ABRS 19 juni 1996, Gst. 7049, p. 147 e.v., m.n. J.M.H.F. Teunissen

314

ABRS 31 juli 1996, AB 1996, 433, m.nt. AvH

ABRS 31 juli 1996, AB 1996, 480, m.nt. AvH

ABRS 5 augustus 1996, AB 1996, 426, m.nt. PJS

303,320

304

15

305

ABRS 7 oktober 1996, Gst. 7050, p. 162 e.v.

ABRS 10 oktober 1996, Gst. 7055, p. 326 e.v.

39,52

ABRS 21 oktober 1996, JB 1996/232, m.nt. HJS

320

ABRS 30 oktober 1996, Gst. 7056, p. 383 e.v.

160,192

ABRS 16 december 1996, JB 1997/23, m.nt. R.J.N.S.

ABRS 21 januari 1997,

AB 1997, 136, m.nt. ChB; Gst. 7052, p. 243, m.n. J.M.H.F. Teunissen

ABRS 18 februari 1997, AB 1997, 143, m.nt. PvB; JB 1997/47, m.nt. HJS

52,372

ABRS 13 maart 1997, JB 1997/88, m.nt. R.J.N.S.

$\begin{array}{lr}\text { ABRS } 24 \text { maart 1997, AB 1997, 201; Gst. 7058, p. } 442 \text { e.v. m.n. HH } & 307 \\ \text { ABRS } 28 \text { april 1997, AB 1997, 262, m.nt. AvH. } & 317\end{array}$

ABRS 6 mei 1997, AB 1997, 229, m.nt. PvB; JB 1997/118, m.nt. HJS 52,372

ABRS 16 mei 1997, JB 1997/155, m.nt. R.J.N.S.

307

ABRS 22 mei 1997, AB 1997, 306, m.nt. FM

307

ABRS 26 mei 1997, AB 1997, 336, m.nt. FM

192,304

ABRS 27 juni 1997, JB 1997/191, m.nt. R.J.N.S.

193

317

$\begin{array}{lr}\text { ABRS } 23 \text { september 1997, AB 1997, 435, m.nt. AvH } & 306 \\ \text { ABRS } 4 \text { november 1997, JB 1997/285, m.nt. R.J.N.S. } & 195\end{array}$ 
Voorzitter Afdeling bestuursrechtspraak van de Raad van State

VzABRS 3 maart 1994, Gst. 6988, p. 282 e.v.

VZABRS 14 oktober 1994, Gst. 7007, p. 201 e.v., m.n. HH 308

VzABRS 24 april 1995, AB 1995, 515

VzABRS 9 juli 1996, KG 1996, 361

Centrale Raad van Beroep

CRvB 19 maart 1976, AB 1976, 219

CRvB 5 mei 1978, AB 1978, 498, m.nt. In 't V.

CRvB 29 december 1978, AB 1979, 505, m.nt. E.H.N.

160

CRvB 29 september 1994, ABkort 1994, 924

\section{College van Beroep voor het bedrijfsleven}

CBb 26 maart 1974, AB 1974, 193

CBb 31 mei 1977, AB 1977, 349

$\mathrm{CBb} 13$ april 1988, $\mathrm{AB} 1988,311$

CBb 24 januari 1992, AB 1992, 253, m.nt. RMvM

CBb 28 februari 1992, AB 1992, 343, m.nt. RMvM

CBb 30 september 1992, AB 1992, 638, m.nt. JHvdV

CBb 7 juli 1993, UCB 1993, 51

CBb 14 juli 1993, AB 1994, 245

$\mathrm{CBb} 19$ januari 1994, AB 1995, 281

CBb 23 februari 1994, AB 1994, 340, m.nt. JHvdV

$\mathrm{CBb} 5$ december 1994, AB 1995, 169, m.nt. JHvdV

CBb 23 mei 1995, AB 1995, 403

CBb 23 januari 1996, AB 1996, 182, m.nt. JHvdV

$\mathrm{CBb} 31$ juli 1996, ABkort, 675

$\mathrm{CBb} 25$ juni 1997, AB 1997, 406, m.nt. JHvdV

Voorzitter College van Beroep voor het bedrijfsleven

$\mathrm{VzCBb} 30$ november 1987, AB 1989, 187, m.nt. H.J. Simon

\section{Kroon}

KB 28 juli 1960, AB 1960 p. 709, m.nt. St.

KB 12 juni 1963, AB 1963, 899

KB 11 september 1964, $A B$ 1965, p. 167 e.v.

KB 31 mei 1972, AB 1972, 226

KB 27 juni 1972, AB 1972, 201, m.nt. J.R.St.

KB 5 september 1972, AB 1973,89 259

KB 27 december 1972, AB 1973, 119, m.nt. J.R. St.

KB 5 januari 1973, AB 1973, 94, m.nt. J.R. St.

KB 10 april 1973, AB 1973, 215

KB 13 juni 1973, AB 1973, 263 m.nt. J.R. St. 
KB 18 oktober 1976, AB 1977, 79

KB 23 oktober 1976, AB 1977, 147

147, 261

KB 17 november 1976, AB 1977, 164

KB 29 december 1976, AB 1977, 206

KB 1 april 1977, AB 1977, 333

$\mathrm{KB} 24$ juni 1977, AB 1977, 344

$205,206,212$

KB 5 december 1977, AB 1978, 62

KB 19 oktober 1978, AB 1979, 89

205,206

KB 26 oktober 1978, AB 1979, 138 m.nt. J.R. St.

205,206

KB 22 december 1978, AB 1979, 270

205

257

KB 10 maart 1979, BR p. 419

KB 17 maart 1980, AB 1980, 364, m.nt. V.d.V.

KB 24 maart 1981, AB 1981, 397

KB 25 juli 1981, AB 1982, 15, m.nt. J.R. St.

KB 30 oktober 1981, AB 1982, 46, m.nt. J.R. St.

205,267

261

KB 7 november 1981, AB 1982, 47

269

KB 19 november 1981, AB 1982, 75, m.nt. v.d.N.

KB 22 januari 1982, AB 1982, 229

258

KB 2 februari 1982, AB 1982, 228

205,206

KB 6 april 1982, AB 1982, 374, m.nt. FO

262

KB 15 maart 1982, AB 1982, 417, m.nt. CLR

268

KB 13 mei 1982, AB 1982, 379, m.nt. J.R.St.

KB 19 mei 1982, AB 1982, 514, m.nt. J.R.St.

KB 4 juni 1982, AB 1982, 465, m.nt. J.R. St.

KB 19 mei 1982, AB 1982, 514

$205,206,260$

205,261

205,259

KB 9 juli 1982, AB 1983, 22, m.nt. J.R. St.

KB 8 december 1982, AB 1983, 231, m.nt. FO

KB 20 december 1982, AB 1983, 232, m. nt. FO

262

267

KB 20 januari 1983, AB 1983, 300

205,262

KB 26 januari 1983, $A B$ 1983, 195, m.nt. J.R. St.

KB 3 februari 1983, AB 1983, 279, m.nt. CLR

KB 18 mei 1983, AB 1983, 416, m.nt. CLR

$\begin{array}{ll}\text { KB } 22 \text { augustus 1983, AB 1984, } 340 & 268 \\ \text { KB } 17 \text { januari } 1984, A B 1984,396 & 267\end{array}$

KB 23 mei 1984, AB 1985, 104, m.nt. AWK 268

KB 17 augustus 1984, $A B$ 1986, 20, m.nt. JTvdB 258

KB 28 augustus 1984, $\mathrm{AB} 1986,31$

KB 11 oktober 1984, AB 1985, 165, m.nt. J.R.St.

KB 23 oktober 1984, AB 1985, 166, m.nt. F.P.C.L. Tonnaer

$205,207,257,259$

KB 15 november 1984, AB 1985, 491

267,268

267

265

KB 27 november 1984, AB 1985, 232

268

KB 17 december 1984, AB 1985, 262, m.nt. BJvdN

267,268

$\mathrm{KB} 24$ mei 1985, AB 1985, 475

KB 14 maart 1986, AB 1986, 484

265

KB 19 september 1986, AB 1987, 221, m.nt. AWK 
KB 5 december 1986, AB 1987, 222

KB 16 maart 1987, AB 1987, 371

KB 30 maart 1987, AB 1987, 443

KB 6 april 1987, AB 1987, 295

$\mathrm{KB} 31$ augustus $1987, \mathrm{AB} 1987,542$

KB 11 september 1987, AB 1988, 186, m.nt. PJS

KB 8 december 1987, AB 1988, 532

KB 17 december 1987, AB 1988, 388, m.nt. AWK 265

KB 23 december 1987, AB 1988, 265

KB 8 februari 1988, AB 1988, $266 \quad 260$

KB 7 maart 1988, AB 1988, 306, m.nt. PJS 263

$\mathrm{KB} 1$ april 1988, $\mathrm{AB} 1988,297$

160,258

KB 22 april 1988, $A B$ 1988, 402

KB 17 oktober 1988, AB 1989, 75, m.nt. AKW 267

KB 20 april 1989, AB 1989, 304, m.nt. JHvdV 264

KB 10 juli 1989, AB 1990, $172 \quad 260$

KB 10 juli 1989, AB 1990, 92, m.nt. AWK $\quad 266$

KB 18 januari 1991, AB 1991, 478, m.nt. AKW 264

KB 28 februari 1991, AB 1991, 313

KB 20 juni 1991, AB 1991, 611 257

KB 6 augustus 1993, AB 1995, 54

KB 10 november 1993, AB 1994, 267

KB 1 december 1993, AB 1994, 462, m.nt. AWK 266

KB 30 juni 1994, AB 1994, $638 \quad 160$

KB 30 juni 1994, BR 1995/7, p. 576 e.v., m.nt. H.J. de Vries 258

KB 21 februari 1995, AB 1995, 477, m.nt. AKW; BR 1995/7, p. 578, m.nt. H.J. de Vries 267

KB 5 augustus 1994, AB 1995, $22 \quad 266$

KB 4 januari 1995, AB 1995, 337, m.nt. AKW 269

KB 1 september 1995, BR 1995/12, p. 1008

\section{Bundesverfassungsgericht}

BVerfG 23 oktober 1951, BVerfGe 1, nr. $10 \quad 119$

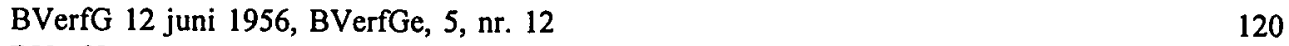

BVerfG 5 maart 1958, BVerfGe 7, nr. $36 \quad 120$

BVerfG 12 november 1958, BVerfGe 8, nr. $34 \quad 116,121$

BVerfG 30 januari 1968, BVerfGe 23, nr. $6 \quad 121$

BVerfG 4 februari 1975, BVerfGe 38, nr. $28 \quad 122$

BVerfG 28 oktober 1975, BVerfGe 40, nr. $22 \quad 109$

BVerfG 21 december 1977, BVerfGe 47, nr. $2 \quad 109$

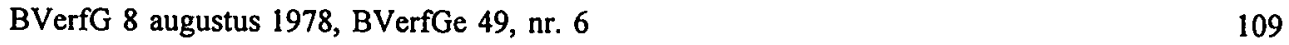

BVerfG 8 januari 1981, BVerfGe, 56, nr. $1 \quad 120$

BVerfG 20 oktober 1981, BVerfGe 58, nr. $19 \quad 122$

$\begin{array}{ll}\text { BVerfG } 15 \text { december 1983, BVerfGe 65, nr. } 1 & 121\end{array}$

BVerfG 18 december 1984, BVerfGe 68, nr. $1 \quad 112$

BVerfG 31 oktober 1984, BVerfGe 68, nr. $6 \quad 30$

BVerfG 27 november 1990, BVerfGe 83, nr. 9 
BVerfG 24 april 1991, BVerfGe 84, nr. 9

BVerfG 3 juni 1992, BVerfGe 86, nr. 15

\section{Conseil d'Etat}

C.E. 25 februari 1864, Rec. 209

142

C.E. 26 november 1875, Rec. 934

142

C.E. 26 november 1875 , Rec. 936

142

C.E. 6 december 1878, Rec. 973

144

C.E. 17 november 1899 , Rec. 645

144

C.E. 22 maart 1901, Rec. 351

145,152

C.E. 4 juli 1924, Rec. 641

150

C.E. 10 januari 1968 , Rec. p. 24

152

C.E. 11 mei 1984 , RDP 1986 , p. 275

150

C.E. 23 maart 1988, Rec. 130 



\section{Trefwoordenregister}

(de onderstaande nummers verwijzen naar de paragraafnummers in dit boek)

administratieve wetgeving, verhouding tussen

afwentelingsvoorschrift

algemeen belang

$8.3 .4,8.4 .2,8.5 .1,8.6 .2,8.8 .2$

$7.2 .13,7.2 .15,8.6 .5$

$2.5 .2,3.2 .1,3.3$

algemeenheidspostulaat

4.2.4

algemene maatregel van bestuur, zelfstandige

ambtsdragers

autonomie, privaatrechtelijke

beheersbevoegdheid, publieke

belang

6.4 .1

belang, subjectgebonden

6.4 .2

belangen, derde-

$8.3 .2,8.4 .3,8.5 .2,8.6 .3,8.7 .3$
$2.5 .3,3.5 .1$

belangen, publiekrechtelijke

belangen, vermogens-

9.6.2, 9.6.3

belangenafweging,

belangenafweging, secundair

$6.3 .1,6.3 .4,6.3 .7$

belangeneliminatie

7.2 .6

belanghebbende

7.2 .2

beleidsafstemming

6.4 .3

beleidscontexttheorie

4.6 .6

beleidsregels

7.2 .4

beleidsruimte

2.5.2

beleidsvrijheid

bemiddeling, bestuurlijke

$6.3,6.3 .6$

beoordelingsruimte,

beoordelingsruimte, subjectieve

6.2 .2

beoordelingsvrijheid

$6.2 .3,6.3 .6$

beperking, grondrechten

9.6.5

bestemmingsfunctie, publieke

2.5.3

bestemmingsplan, en milieuwetgeving

8.3 .5

bestemmingsplan, en sectorale wetgeving

8.3 .6

bestimmtheitsgebot

4.4.1, 4.4.2

bestuursbevoegdheid, definitie

bestuursbevoegdheid, indirecte

bestuurscompensatie, zie nadeelcompensatie

4.6 .8

bestuurscultuur

2.2 .2

bestuursorgaan

bestuurstaak 
bevoegdheid, formele

bevoegdheid, materièle

bevoegdheidsnorm

bevoegdheidsstelsel

blanco-delegatie

burgerplichten

civielrechtelijke, geschilpunten

civil rights

competentienorm

2.3.2

contrôle des motifs

5.5.1, 5.5.2, 5.5.3

coördinatie

4.6.6

cultuurrecht

delegatie

democratiebeginsel

détournement de pouvoir, objectivering

détournement de pouvoir, ontwikkeling Frans leerstuk

détournement de pouvoir, subjectieve benadering

5.3 .1

détournement de procedure

5.4 .5

discourstheorie

3.5 .2

discriminatie, positieve

7.2 .8

doelbinding, publieke macht

3.2 .2

doelmatigheidsaspect

7.2.7

doelstellingsprimaat wetgever

doorkruisingsdoctrine

2.5 .3

doorzendplichten

éénheid van openbaar bestuur, beginsel van

énzijdigheidsaspect publieke bevoegdheid

2.5.4

efficiency-aspect

$4.6 .4,7.2 .3$

égalité-beginsel

eingriffsverwaltung

feitelijke zijde recht

feitenkwalificatie

$6.2 .3,6.2 .4$

feitenvaststelling

$6.2 .3,6.2 .4$

formele rechtskracht

8.8.6, 9.5 .5

gedragsnorm

gelegenheidswetgeving

gematigden

gemeenschapsverhouding

gemengde rechtsleer 
grondrechten, en specialiteitsbeginsel

ingrijpende besluiten

kommunikative Macht

maatschappij, burgerlijke

machtsafwending

nadeelcompensatie, $\quad 7.2 .10,7.2 .11,7.2 .12,7.2 .13,7.2 .15,7.2 .19,8.4 .4,8.5 .3,8.6 .5,9.6 .2,9.7$

norm, primaire

norm, secundaire

normcondities

norminterpretatie

$6.2 .3,6.2 .4$

normstufenbau

2.3.2

3.2 .4

normzijde recht
nutsmaximalisatietheorie

$3.3 .2,7.2 .6$

onderhandelend bestuur

ontvankelijkheidstoets

onzuivere, schadebeschikking

onzuiverheid van oogmerk

ordnungsnorm

organisatie, bestuurlijke 
parlementaire democratie

politiestaat

preciezen

$7.2,7.2 .17,7.2 .18,9.5,9.5 .1$

prescribed by law

4.4.6

principe de (la) specialité

publiek domein

publieke taak-criterium

rechtsbeginsel, consitutief

rechtsbeginsel, typisch

rechtsbeginsel, modaal

rechtsbeginsel, regulatief

rechtsbeginselen, materiěle

rechtsbelangen, private, subjectieve

$3.2 .7,3.2 .8,4.3$

rechtsbevoegdheid

2.3.1

rechtspluriformiteit

rechtspositivisme

rechtsregel

rechtsstaat, democratische

rechtsstaat, liberale

rechtsstaat, sociale

rechtssubject

rechtsverband

rechtsvorming

recours objectif

recours pour excès de pouvoir

recours subjectif

redelijke interpretatie, grondrechten

reflex-rechten

rekkelijken

relativiteitsleer, zie schutznormleer

rule of law

samenloop, bevoegdheden

schutznorm(leer)

secularisatieproces

6.4.3, 7.2.15, 8.3.2, 8.4.3, 8.5.2, 8.6.3, 8.7.3, 8.8.5, 8.8.6, 9.4.4, 9.7

selbstentscheidungsformel

soeverein

structuurkenmerken bevoegdheid

subjectief publiek recht

subjectiveringstendens

subsidiebevoegdheid

taak, publiekrechtelijke

taakstelling 
toepasselijkheidsdomein

tweewegenleer

uitvoeringsbevoegdheid

uitvoeringshandeling

vertrouwensregel

3.2 .2

verzorgingsstaat

4.2 .5

voorschriften,

7.2.14, 8.4.7, 8.5.6, 8.6.6, 9.4.1, 9.4.2

voorwaarden,

9.4 .2

vorhersehbarkeitsformel

4.4.4

vrijwarende werking, vergunningen

8.8.6

wederkerige rechtsbetrekking

2.5.5, 2.5.6, 9.5.3

weigering, pseudo-

7.2 .20

weigeringsgrond, primair

7.2 .7

weigeringsgrond, secundaire

7.2 .7

wesentlichkeitstheorie

$4.2 .6,4.2 .7$

wetsbegrip

4.2

wetsbegrip, formele

4.2 .1

wetsbegrip, materiële

4.2.2

zwangsmonopol

3.2 .1 


$$
\text { . }
$$




\section{Curriculum Vitae}

Raymond Schlössels werd op 2 juli 1968 geboren te Nieuwstadt. In 1986 behaalde hij zijn diploma gymnasium-alfa aan het Serviam Lyceum te Sittard. Vervolgens studeerde hij Nederlands recht aan de Rijksuniversiteit Limburg (de huidige Universiteit Maastricht). Hier studeerde hij in 1991 af (cum laude). Van juli 1991 tot september 1992 vervulde hij zijn militaire dienstplicht als Reserve Officier Academisch Gevormde (ROAG) bij de Koninklijke Landmacht. Hij was werkzaam als waarnemend griffier bij de Militaire Kamer van de arrondissementsrechtbank te Arnhem en bij de Afdeling Internationale en Juridische Beleidsaangelegenheden (IJB), Directie Juridische Zaken (DJZ) van het Ministerie van Defensie te Den Haag. Na zijn diensttijd werkte hij een jaar als juridisch beleidsmedewerker ruimtelijke ordening en milieurecht bij de gemeente Beesel. Van 1993 tot 1996 was hij werkzaam als AIO bij de vakgroep publiekrecht van de Universiteit Maastricht. Bij diezelfde vakgroep is hij sinds september 1996 universitair docent staats- en bestuursrecht. 
In dit boek staat het bestuursrechtelijke specialiteitsbeginsel

centraal. Dit beginsel brengt met zich dat een administratieve wet enkel op haar eigen - naar doel begrensde - terrein mag worden toegepast.

Het specialiteitsbeginsel is in het hedendaagse Nederlandse bestuursrecht een uiterst omstreden beginsel. Met name de vraag welke belangen een bestuursorgaan in het kader van een discretionaire bevoegdheidsuitoefening mag (en moet) afwegen wordt verschillend in de literatuur beantwoord. Dient er voorrang te worden gegeven aan doelmatig 'integraal' bestuur of vormt de principiële beperktheid en doelgebondenheid van bestuursbevoegdheid nog steeds het uitgangspunt?

Genoemd beginsel wordt uitvoerig verkend en in verband gebracht met verschillende bestuursrechtelijke leerstukken: het begrip bestuursbevoegdheid, de bestuurlijke rechtsbetrekking, de wetmatigheid van bestuur, het verbod van détournement de pouvoir en het verschijnsel van beleidsvrijheid. Vervolgens wordt de relevante literatuur en de jurisprudentie gedetailleerd geanalyseerd.

Tot slot wordt getracht een 'precieze' visie inzake het specialiteitsbeginsel te verenigen met de bestuurlijke plicht om met alle relevante belangen van burgers rekening te houden (vgl. artikel 3:4 lid $1 \mathrm{Awb}$ ).

Raymond Schlössels (1968) is als universitair docent staatsen bestuursrecht verbonden aan de vakgroep Publiekrecht van de Universiteit Maastricht. Hij annoteert onder meer voor Jurisprudentie Bestuursrecht (JB). 